\title{
Ondernemende autoriteiten? Een onderzoek naar de handhaving van het Nederlandse en communautaire kartelrecht
}

Citation for published version (APA):

Quaedvlieg, H. M. J. (2001). Ondernemende autoriteiten? Een onderzoek naar de handhaving van het Nederlandse en communautaire kartelrecht. [Doctoral Thesis, Maastricht University]. Kluwer. https://doi.org/10.26481/dis.20011214hq

Document status and date:

Published: 01/01/2001

DOI:

10.26481/dis.20011214hq

Document Version:

Publisher's PDF, also known as Version of record

Please check the document version of this publication:

- A submitted manuscript is the version of the article upon submission and before peer-review. There can be important differences between the submitted version and the official published version of record.

People interested in the research are advised to contact the author for the final version of the publication, or visit the DOI to the publisher's website.

- The final author version and the galley proof are versions of the publication after peer review.

- The final published version features the final layout of the paper including the volume, issue and page numbers.

Link to publication

\footnotetext{
General rights rights.

- You may freely distribute the URL identifying the publication in the public portal. please follow below link for the End User Agreement:

www.umlib.nl/taverne-license

Take down policy

If you believe that this document breaches copyright please contact us at:

repository@maastrichtuniversity.nl

providing details and we will investigate your claim.
}

Copyright and moral rights for the publications made accessible in the public portal are retained by the authors and/or other copyright owners and it is a condition of accessing publications that users recognise and abide by the legal requirements associated with these

- Users may download and print one copy of any publication from the public portal for the purpose of private study or research.

- You may not further distribute the material or use it for any profit-making activity or commercial gain

If the publication is distributed under the terms of Article $25 \mathrm{fa}$ of the Dutch Copyright Act, indicated by the "Taverne" license above, 


\section{Ondernemende autoriteiten?}

"Een onderzoek naar de handhaving van het Nederlandse en communautaire kartelrecht" 



\section{Ondernemende autoriteiten?}

"Een onderzoek naar de handhaving van het Nederlandse en communautaire kartelrecht"

\section{Proefschrift}

ter verkrijging van de graad van doctor aan

de Universiteit Maastricht,

op gezag van de Rector Magnificus, Prof.dr. A.C. Nieuwenhuijzen Kruseman volgens het besluit van het College van Decanen,

in het openbaar te verdedigen

op vrijdag 14 december 2001 om 12.00 uur

door

Harald Mathias Johannes Quaedvlieg 
Promotores:

Prof.dr. G.A.A.J. van den Heuvel

Prof.mr. Th.A. de Roos (Universiteit Leiden)

\author{
Beoordelingscommissie: \\ Prof.dr. M.G. Faure (voorzitter) \\ Prof.mr. R. Barents \\ Prof.mr. H. de Doelder (Erasmus Universiteit Rotterdam) \\ Prof.mr. G.P.M.F. Mols \\ Prof.mr. F.A.M. Stroink
}


voor hem 



\section{Inhoudsopgave}

Lijst van afkortingen

Inleiding

Deel I

Het nationale en communautaire kartelrecht

Hoofdstuk 1. Het Nederlandse kartelrecht tot 1998

De oorsprong en ontwikkeling van de Nederlandse kartelwetgeving tot 1998

De kenmerken van het Nederlandse kartelrecht tot 1998

Aanmelding

Het algemeen belang als criterium voor overheidsinterventic

'De overheid'

Conclusie 
2.4.1 Verboden gedragingen van artikel 81 EG

Handhaving van het communautaire kartelverbod

Korte schets van de procedure

Het inwinnen van inlichtingen

De inhoud van het verzoek en de beschikking om inlichtingen

Onjuiste inlichtingen

Het verrichten van verificaties

De geadresseerden

De opdracht en de beschikking tot verificatie

De inhoud van de verificatiebeslissing

Bestuursrechtelijke handhaving en de Nederlandse

Mededingingsautoriteit 


\section{Deel II}

\section{De boetepraktijk en rechtsbescherming}

\section{Hoofdstuk 4. De boetepraktijk}

Competentie en het rechtskarakter van de boete

Het rechtskarakter van de boete

Schuld: opzet en onachtzaamheid

$\mathrm{Ne}$ bis in idem en non-cumulatie

Discretionaire bevoegdheid

De zwaarte van de inbreuk

I De ernst van de gedraging 266

II De gevolgen van het kartel 268

a) De aard en het belang van het betrokken product

b) Marktdekking

c) De naleving van het kartel

d) De marktsituatie

a) De mate van schuld

b) De omzet en marktpositie van de onderneming

c) Recidive en strafcumulatie

d) De rol van de ondernemingen

e) Het behaalde voordeel

f) De financiële positie van de ondernemingen

g) Geheimhouding

h) Onderzoek en onderneming

II Omstandigheden die niet direct verband houden met de onderneming

a) De economische situatie op de markt

b) Precedenten

c) Overheidsmaatregelen en onderzoeksvoortgang 
4.5 Het communautaire boetebeleid sinds 1998

Hoofdstuk 5. De rechtswaarborgen in het kartelrecht

Mensenrechten, ondernemingen en criminal charge

Berechting binnen een redelijke termijn: het EHRM en de Hoge Raad

Berechting binnen een redelijke termijn: het communautaire perspectief

Rechtsbijstand en verschoningsrecht

Kennisneming van stukken en geheimhouding

Informatie die naar haar aard onder de geheimhoudingsplicht valt 
Bijlage

Jurisprudentie en beschikkingen

Curriculum vitae 



\section{Lijst van afkortingen}

\begin{tabular}{|c|c|}
\hline AA & Ars Aequi \\
\hline Adv.bl. & Advocatenblad \\
\hline Awb & Algemene wet bestuursrecht \\
\hline $\mathrm{Bb}$ & Bedrijfsjuridische berichten \\
\hline BIE & Bijblad bij de Industrięle Eigendom \\
\hline BNB & Beslissingen in belastingzaken \\
\hline CMLR & Common Market Law Review \\
\hline DD & Delikt en Delinkwent. Tijdschrift voor Strafrecht \\
\hline $\begin{array}{l}\mathrm{d}-\mathrm{g} \mathrm{NMa} \\
\text { diss. }\end{array}$ & $\begin{array}{l}\text { directeur-generaal van de Nederlandse Mededingingsautoriteit } \\
\text { dissertatie }\end{array}$ \\
\hline EBLR & European Business Law Review \\
\hline ECD & Economische Controledienst \\
\hline ECLR & European competition law review \\
\hline ECRM & Europese Commissie voor de Rechten van de Mens \\
\hline EHRM & Europees Hof voor de Rechten van de Mens \\
\hline EVRM & $\begin{array}{l}\text { Europees Verdrag tot bescherming van de rechten van de mens en de } \\
\text { fundamentele vrijheden }\end{array}$ \\
\hline ELR & European Law Review \\
\hline ESB & Economisch-statistische berichten \\
\hline EPL & European Public Law \\
\hline EuZW & Europäische Zeitschrift für Wirtschaftsrecht \\
\hline FED & Fiscaal Weekblad FED \\
\hline GST & De Gemeentestem \\
\hline GvEA & Gerecht van Eerste Aanleg \\
\hline $\mathrm{HvJ} / \mathrm{Hof}$ & Hof van Justitie \\
\hline HR & Hoge Raad \\
\hline Int.Spect. & International Spectator \\
\hline Jur. & officiële jurisprudentieverzameling $\mathrm{HvJ}$ \\
\hline JV & Justitiële Verkenningen \\
\hline LIEI & Legal Issues of Economic Integration \\
\hline$M \& M$ & Markt en Mededinging \\
\hline M\&R & Milieu en Recht \\
\hline m.nt. & met noot \\
\hline MvT & Memorie van Toelichting \\
\hline Mw & Mededingingswet \\
\hline NJ & Nederlandse Jurisprudentie \\
\hline NJB & Nederlands Juristenblad \\
\hline NJCM-Bulletin & Nederlands Tijdschrift voor de Mensenrechten \\
\hline NJW & Neue Juristische Wochenschrift \\
\hline $\mathrm{NMa}$ & Nederlandse Mededingingsautoriteit \\
\hline NTB & Nederlands Tijdschrift voor Bestuursrecht \\
\hline NTER & Nederlands tijdschrift voor Europees Recht \\
\hline NV & De Naamlooze Vennootschap \\
\hline
\end{tabular}




\begin{tabular}{|c|c|}
\hline pag. & pagina('s) \\
\hline $\mathrm{Pb}$ & Publicatieblad van de Europese Gemeenschappen \\
\hline red. & redactie \\
\hline RIW & Recht der internationalen Wirtschaft \\
\hline RM Themis & Rechtsgeleerd Magazijn Themis. Tijdschrift voor publiek- en privaatre \\
\hline RW & Rechtskundig Weekblad \\
\hline SEW & $\begin{array}{l}\text { Sociaal-economische wetgeving. Tijdschrift voor Europees en econ, } \\
\text { misch recht }\end{array}$ \\
\hline Stb. & Staatsblad \\
\hline Stcrt. & Staatscourant \\
\hline TK & Tweede Kamer \\
\hline Trb. & Tractatenblad \\
\hline Trema & Tijdschrift voor de rechterlijke macht \\
\hline TVVS & Tijdschrift voor Vennootschappen, Verenigingen en Stichtingen \\
\hline $\mathrm{V} \& \mathrm{O}$ & Vennootschap \& Onderneming \\
\hline Vo & Verordening \\
\hline WED & Wet op de Economische Delicten \\
\hline Wem & Wet economische mededinging \\
\hline WFR & Weekblad voor Fiscaal Recht \\
\hline WvSr & Wetboek van Strafrecht \\
\hline WvSv & Wetboek van Strafvordering \\
\hline$W n W$ & 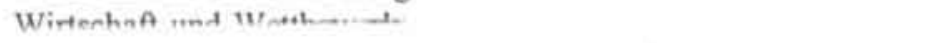 \\
\hline
\end{tabular}






\section{Inleiding}

\section{Algemeen}

In dit boek staat de handhaving van het Nederlandse en communautaire kartelrecht centraal. Deze handhavingszijde pleegt minder pennen in beweging te brengen dan het materiele kartelrecht. Geheel terecht is dat mijns inziens niet, aangezien er ook bij de handhaving grote belangen op het spel staan, zowel waar het de effectuering van het materiele recht als waar het de rechtspositie van de van overtreding verdachte onderneming betreft. Tegen de achtergrond van deze belangen wordt de handhaving in deze studie besproken: wordt er een bevredigend evenwicht bereikt tussen handhavingsdoelmatigheid en rechtsbescherming van de justitiabelen? Deze vraag is voor het Nederlandse kartelrecht te meer interessant en relevant omdat met de inwerkingtreding van de Mededingingswet' op 1 januari 1998 afstand werd genomen van de tot dan toe geldende strafrechtelijke handhaving van de nationale kartelwetgeving, ten gunste van handhaving via het in Nederland nog in zijn kinderschoenen staande (maar wel naar spoedige volwassenheid strevende) bestuurlijke boeterecht. Dit aspect brengt met zich dat de beantwoording van vorengestelde vraag ook buiten het kartelrecht relevant is.

\section{De omslag van het Nederlandse kartelrecht}

Intensivering en convergentie: met deze begrippen kan kernachtig het Nederlandse mededingingsbeleid sinds 1991 worden getypeerd. ${ }^{2}$ Intensivering staat daarbij synoniem voor een strenger en meer op vrije mededinging gericht beleid; of -met andere woorden- een repressiever en formeler anti-kartelbeleid dan voordien -en zeker voor $1987^{3}$ - in Nederland werd gevoerd. ${ }^{4}$ Convergentie geeft het streven weer naar aansluiting van het Nederlandse mededingingsbeleid -en in het verlengde daarvan de mededingingswetgeving- bij het mededingingsbeleid (en de regelgeving op dit terrein) van de Europese Gemeenschap

1 Wet van 22 mei 1997, houdende nieuwe regels omtrent de economische mededinging, Stb. 1997, 242.

2 TK 1990-1991, 22 093, nr. 1 (Brief van de staatssecretaris van Economische Zaken inzake het mededingingsbeleid). Toenmalig staatssecretarisvan Economische Zaken Van Rooy maakte (als eerste) het mededingingsbeleidtot eenvan de belangrijkstespeerpuntenvan het Nederlandseeconomischebeleid (hoewel aanvankelijk, aldus Mok (1992 I), pag. 46, ook haar beleid nog wel wat te wensen overliet). Weliswaar had reeds haar voorganger Evenhuis in 1987 met zijn Activiteitenplan (TK 1986-1987, 19700 hfdst. XIII, nr. 118) het mededingingsbeleidop de politieke agenda geplaatst, maar concrete, tastbare resultaten leverde dat in de praktijk nauwelijks op.

3 Het jaar waarin het hiervoor genoemde Activiteitenplan het licht zag.

4 Alhoewel intensivering volgens Van Rooy (1992), pag. 6, nog niet "het inferno van de redeloze concurrentie" zou inluiden. Zie over de door Van Rooy gedane voorstellen Mok (1992 V), pag. 266 e.v.. 
en van enkele (andere) EG-lidstaten. ${ }^{5}$ De redenen voor het streven naar deze 'Europese' convergentie laat ik hier in het midden -zij zullen in hoofdstuk 3 aan de orde worden gesteld-. Hier is van belang te concluderen dat zij heeft geleid tot omarming van het sinds de inwerkingtreding van het EEG-Verdrag ${ }^{6}$ in 1958 op de leest van een verbodstelsel (met als uitgangspunt het verbod op kartellering ${ }^{7}$ ) geschoeide ${ }^{8}$ - communautaire kartelstelsel. En aangezien het Nederlandse kartelrecht sinds zijn oorsprong in 1935 was gebaseerd op het zogenoemde misbruikstelsel (met als uitgangspunt de geldigheid van kartellering') en het kartelbeleid van oudsher (en tot 1991) werd gekenmerkt door een welwillende houding tegenover kartelinitiatieven, stonden intensivering en convergentie gelijk aan niet minder dan een principięle breuk met het verleden: aan het -overigens naar mijn mening niet (geheel) terechte ${ }^{10}$ - stigma van Nederland als kartelland of zelfs kartelparadijs ${ }^{\prime \prime}$, moest een einde komen. De welwillendheid maakte geleidelijk plaats voor een meer kritische en zelfs ten principale negatieve houding tegenover kartels, de aandacht voor de mededingingsproblematiek bij de centrale overheid groeide, de op dat moment geldende kartelregelgeving - de Wet economische mededinging (Wem) ${ }^{12}$ - werd strikter en op cen voor de buitenwereld meer zichtbare wijze toegepast en gehandhaafd, de Wem werd aangepast en aangescherpt teneinde een effectiever mededingingsbeleid te kunnen realiseren en ten slotte werd de Wem in 1998 door de Mededingingswet vervangen." Aldus kan met recht worden gesproken van een 'omslag', waarmee de wetgever de veranderde houding van de Nederlandse overheid ten aanzien van kartels ook wettelijk gestalte heeft gegeven en die een geheel andere benadering van kartels symboliseert.

Nederland is dan ook niet het enige land dat zijn nationaal kartelrecht aan de communautaire regelgeving -zonder daartoe overigens door enige communautairemaatregeldaadwerkelijk verplicht te zijnheeft aangepast. Onder meer België, lerland, Italië en Griekenland zijn Nederland daarin reeds voorgegaan. Voor een bespreking van de Belgische kartelwetgeving zie Ham (1992 II), pag. 803 e.v., Swennen (1993), pag. 510 e.v., Vandermeerseh(1994), Steenbergen(1996), pag. 324 e.v. alsmedeSteenbergen (1999), pag. 358 e.v.. Rijnsbergen (1993), pag, 641 e.v. bespreekt de lerse wetgeving. Over de Italiaanse en Griekse wetgeving zie Ham (1992 1), pag. 611 e.v..

6 Verdrag van 25 maart 1957 tot oprichting van de Europese Economische Gemeenschap, Trb. 1957, 91.

7 Het verbodstelsel komt in de hoofdstukken 2 en 3 aan bod.

8 Voor een bespreking van de redenen van de Europese keuze voor een verbodstelsel zij verwezen naar hoofdstuk 2.

9 Zie daarover nader hoofdstuk 1.

10 Dit beeld is om verschillende redenen niet adequaat. Ten eerste had Nederland geen -om in de sfeer van het mededingingsrecht te blijven- monopolie op kartellering. Kartels kwamen (en komen) evenzeer in andere landen en ook in de andere lid-staten voor, hetgeenalleenal uit het optreden van de communautaire instellingen uit hoofde van de artikelen 81 en 82 EG blijkt. Ten tweede was Nederland-zoals Van Rooy terecht stelde-geen eiland in Europa en evenmin een vrijhaven voor kartelpraktijken. Door de rechtstreekse werking van het communautaire kartelrecht binnen de Nederlandse rechtsorde kon kartellering op de Nederlandse markt door de communautaire instellingen worden aangepakt, althans in die gevallen waarin het kartel communautaire dimensies had. Het paradijs -als daarvan al sprake was- bestond derhalve in feite alleen voor kartels die niet onder de reikwijdte van de communautaire kartelregels vielen. En tegen deze kartels kon door de Nederiandse overheid worden opgetreden (hetgeen ook gebeurde, zij het zelden met harde hand), indien het algemeen belang in het geding was.

11 Bos (1994), pag. 906; Mok (1993 I), pag. 116.

12 Wet van 28 juni 1956 houdende regelen omtrent de economische mededinging, Stb. 1958, 413.

13. Op deze ontwikkeling wordt nader ingegaan in hoofdstukken 1 en 3. 
Het voorgaande moge reeds aanduiden dat de intensivering en convergentie op het terrein van het Nederlandse mededingingsrecht en de daaraan inherente overstap van het misbruiknaar het verbodstelsel een verdergaande betekenis hebben dan slechts een wijziging van beleid en wetgeving; zij duiden op een cultuuromslag, een proces dat nog allerminst is afgerond. Kartels waren namelijk volgens lange tijd heersende mening (zeker bij marktpartijen, maar ook op centraal overheidsniveau) iets vanzelfsprekends op de Nederlandse markt; overleg tussen marktpartijen, ook tussen concurrenten, over de te bepalen marktstrategie, over prijzen of over bescherming van gebieden vloeide -paradoxaal genoeg ${ }^{14}$ niet alleen voort uit de economische en de contractsvrijheid, maar werd bovendien als iets natuurlijks beschouwd en werd volstrekt aanvaardbaar gevonden. ${ }^{13}$ Als kartellering volgens de marktpartijen gelet op de economische omstandigheden de beste optie was, dan moest deze keuze worden gerespecteerd: marktpartijen zelf zouden immers het beste in staat zijn om te bepalen welk marktbeleid voor hen de beste uitkomsten zou opleveren. En de voordelen van kartellering waren in potentie legio: voorkoming van overmatige of zelfs moordende concurrentic onderling, bescherming van de positie van kartellerende ondernemingen tegen afnemers of buitenlandse concurrenten, meer stabiliteit door garantie van marktaandeel en prijzen, betere kwaliteit van producten en diensten, waarborging van gevarieerd aanbod voor afnemers door behoud van productie. Kortom: meer zekerheid voor de deelnemers aan een kartel maar ook -ondanks een veelal hogere prijs voor producten en diensten ${ }^{16}$ - voordelen voor afnemers in de vorm van onder meer een gegarandeerd aanbod en hogere kwaliteit.

De potentiële voordelen die aan kartels werden toegedicht, vormen één verklaring voor de welwillende houding tegenover kartels tot 1991. Een tweede en zeker niet minder belangrijke verklaring ligt in de lange Nederlandse traditie van overlegeconomie, corporatisme en zelfregulering; onderling overleg zou het draagvlak van het marktbeleid vergroten, mede omdat met een verscheidenheid aan belangen rekening zou worden gehouden, zou de kans op conflicten 'achteraf' kunnen verminderen en zou tot goede (economische) resultaten leiden. De rol van de overheid in deze was er een op afstand: als bewaker van het algemeen belang, die optrad in gevallen waarin de vrijheid door partijen werd misbruikt en hun handelen indruiste tegen dat algemeen belang. ${ }^{17}$ De Wet economische mededinging en haar voorlopers pasten zeer goed in deze traditie en vormden onmiskenbaar cen wettelijke vertaling van bedoelde visie. De Wem ging uit van het primaat van de markt: de vrijheid tot kartellering stond voorop, de overheid kon in beginsel pas bij gebleken strijd

14 Paradoxaal omdat de contractsvrijheid door kartels aan banden wordt gelegd. Met andere woorden: door gebruikmaking van de contractsvrijheid wordt deze tegelijkertijd beperkt.

15 Dit verklaart mede de relatieve openheid die er in Nederland ten aanzien van verschillende kartels bestond; kartels bijvoorbeeld binnen de boeken- en de fietsenbranche waren een publiek geheim.

16 Maar ook de hogere kartelprijs bleef meestal binnen de marges, aldus de voorstanders van kartellering. Een onredelijk hoge prijs zou niet mogelijk zijn gelet op de (dreiging van) buitenlandse concurrentie; bovendien zou tijdens de bepaling van de marktprijs rekening worden gehouden met de afnemers. Tekenend in dit verband was de (overigens vergeefse) verdediging van de deelnemers aan het Nederlandse bouwkartel in het kader van een communautaire kartelprocedure: ondanks de kartelafspraken lag de prijs van de bouwondernemers aanzienlijk lager dan in omringende landen, hetgeen volgens de betrokken ondernemers antoonde dat het kartel geen schade berokkende aan afnemers c.q. opdrachtgevers.

17 Van den Heuvel (1994), pag. 9-26. 
met het algemeen belang haar veto over het betreffende kartel uitspreken. ${ }^{18} \mathrm{Het}$ kartelbeleid lag in het verlengde hiervan: zelfs als er sprake was van strijd met het algemeen belang, werd in beginsel overleg met de betrokkenen bij het kartel en aanpassing ervan geprefereerd boven een repressief en punitief optreden.

De eerdergenoemde cultuuromslag is hierin gelegen dat marktgedrag dat lange tijd als volstrekt legitiem en zelfs positief gold, nu naar zijn aard als onaanvaardbaar en strijdig met het economische belang wordt aangemerkt en verboden is. In ieder geval vanuit de optiek van de overheid behoort de vanzelfsprekendheid van overleg over en afstemming van marktgedrag door ondernemingen tot het verleden. De Mededingingswet en meer algemeen de intensivering van het mededingingsbeleid zijn een uitvloeisel van de cultuuromslag op het niveau van de overheid. De omslag heeft vergaande betekenis voor het toekomstige mededingingsbeleid. Om enkele voorbeelden te noemen: ondernemers zijn voor zover het kartelrecht betreft niet langer in de eerste plaats gesprekspartners van het ministerie van Economische Zaken, maar (potentiële) verdachten van kartelinbreuken, het beleid zal zich niet primair kunnen blijven richten op het weghalen van de scherpe kanten van een kartel, maar zal verboden kartels volledig van de markt moeten doen verdwijnen en het beleid zal actiever en repressiever zijn. Dat dit voor ondernemers de nodige gevolgen meebrengt, moge duidelijk zijn. Bij hun zal er dientengevolge eveneens een cultuuromslag moeten plaatshebben, zeker waar het ondernemers uit het middenen kleinbedrijf betreft ('grotere' ondernemers en zeker multinationals moesten hun beleid immers al afstemmen op het communautaire kartelverbod, waarmee het Nederlandse verbod in grote lijnen convergeert). 'Ingeburgerd' marktgedrag zal door hen drastisch moeten worden herzien, zij zullen moeten 'wennen' aan meer mededinging alsmede aan een geheel andere benadering door de overheid en zij moeten gaan inzien dat mededinging uiteindelijk meer oplevert dan kartellering. Gelet op het voorgaande hoeft het niet te verbazen dat de wets- en beleidswijziging op kartelgebied, door ondernemingen lang niet altijd even positief is ontvangen. ${ }^{19}$

Hierboven is aangegeven dat de grondvesten van de Nederlandse kartelfilosofie volledig zijn vernieuwd. Die omslag moet leiden tot meer mededinging op de Nederlandse markt en dus tot een strikt(er) anti-kartelbeleid van de overheid. Of een dergelijk beleid ook in de praktijk zal worden gevoerd, hangt in belangrijke mate samen met twee factoren: een adequate regelgeving en de (politieke) wil om deze toe te passen. Deze wil mag aanwezig worden geacht, gelet op de veranderde houding op het niveau van de overheid ten aanzien van kartellering, temeer daar een gespecialiseerd orgaan, de Nederlandse Mededingingsautoriteit, met de toepassing van de Mededingingswet is belast. De -hoewel nog relatief prille-praktijk wijst inderdaad in die richting. De eerste factor eist wetgeving waarmee de uitvoerende instantie uit de voeten kan: de wetgeving moet effectief beleid (effectief in die zin dat de beleidsdoeleinden daadwerkelijk en zonder 'wezensvreemde' hindernissen verwezenlijkt kunnen worden) ook mogelijk maken. Omdat er grote twijfels bestonden omtrent de vraag of de Wem een dergelijke wet zou kunnen zijn, is ervoor

18 Zie over het misbruikstelsel en de historische achtergrond hiervan in Nederland hoofdstuk 1

19 Zo kopten het NRC Handelsblad op 21 mei 1996 'Kartelwet onaanvaardbaar. Hevig verzet detailhandel tegen Wijers' en Het FinancieeleDagblad op 18 januari 1997 'Detaillisten: nieuwe mededingingswet ontaardt in oligopolie' alsmede op 23 januari 'Werkgevers vinden geen gehoor bij Wijers' 
gekozen om deze wet te vervangen door de Mededingingswet die aan de genoemde voorwaarden wel zou moeten voldoen. De twijfels werden gevoed door de omstandigheid dat van enig restrictief anti-kartelbeleid op grond van de Wem in de bijna veertig jaar van haar bestaan geen sprake was geweest. Verschillende factoren zouden bovendien een opleving verhinderen of onwenselijk maken. Een eerste factor betrof het misbruikstelsel zelf: hoewel een strikt anti-kartelbeleid in theorie op grond van de Wem gevoerd zou kunnen worden (de Wem bood namelijk de mogelijkheid om categorieën gedragingen te verbieden ${ }^{20}$ ), zou cen dergelijk beleid de facto indruisen tegen de aard en ratio van deze wet. Daarenboven zou cen wet, gestoeld op een verbodstelsel naar Europees voorbeeld, meer recht doen aan de veranderde inzichten omtrent kartellering in Nederland en deze verandering ook kracht bijzetten. Een tweede factor betrof de handhaving, waarmee hier wordt gedoeld op het (punitief) overheidsoptreden tegen overtreders. ${ }^{21}$ Het vrijwel geheel ontbreken van deze handhaving werd voor een belangrijk deel geweten aan de omstandigheid dat de Wem strafrechtelijk, namelijk via de Wet op de cconomische delicten $(\text { WED })^{2}$ werd gehandhaafd. ${ }^{23}$ De Wem was slechts een van de talrijke ordeningsrechtelijke wetten waarvan de handhaving via de WED liep; de per definitie beperkte (handhavings)capaciteit dwongen het Openbaar Ministerie dan ook om de aandacht en voorhanden middelen over tal van wetten te verdelen, waarbij in de praktijk de Wem een allerminst vooraanstaande positie bleek toe te komen. Gevreesd werd dat een nieuwe wet uiteindelijk hetzelfde lot beschoren zou zijn als de Wem: het lot van het ontbreken van een -met het oog op de nieuwe doelstellingen van het kartelbeleid- redelijk geachte mate van formele en punitieve handhaving. Met andere woorden: de horden die op het van het mededingingsbeleid gescheiden strafrechtelijk traject lagen, zouden hoe dan ook te hoog en te talrijk zijn om een effectieve handhaving van de Mededingingswet te realiseren. Om enkele horden te noemen: de handhaving zou bij het strafrecht over (te) veel schijven lopen (opsporing, vervolging en rechterlijke beoordeling) met betrokkenheid van (te) veel verschillende instanties (het opsporingsapparaat, meer in het bijzonder de Economische Controledienst, het Openbaar Ministerie, eventueel de rechter-commissaris en de zittingsrechter), bij deze instanties zou de vereiste deskundigheid en affiniteit ontbreken en het risico van vanuit mededingingsperspectief bezien verkeerde prioriteiten, hetgeen gelet op de mogelijk geringe deskundigheid en de bewijsproblemen bij kartelinbreuken niet denkbeeldig zou zijn, als gevolg waarvan het niet tot strafrechtelijke vervolgingen, maar hooguit tot transacties zou komen. Omdat een dergelijk scenario niet paste in het beeld dat de centrale overheid bij de nieuwe Nederlandse kartelwet voor ogen stond, moest

20 Zie over dit verbodaspect van de Wem nader hoofdstuk 1.

21 Ook de civielrechtelijke handhavingsmogelijkheden van de Wem werden bekritiseerd. De weg naar de burgerlijke rechter was voor een belangrijk deel afgesloten, hetgeen verband hield met het misbruikstelsel. Op deze problematiek zal in hoofdstuk 1 worden ingegaan.

22 Wet van 22 juni 1950 , Stb. K 258 , houdende vaststelling van regelen voor de opsporing, de vervolging en de berechting van economische delicten.

23 Het kan inderdaadniet met recht ontkend worden dat er betrekkelijk weinig formele (strafrechtelijke) beslissingen tegen kartels zijn genomen en dat het strafrechtelijk traject in de praktijk nauwelijks werd gevolgd. Centraal in het kartelbeleid stond sturing van ondememersgedrag. Dit beleid was primair informeel van aard en toonde een aanzienlijk grotere activiteit bij het ministerie van Economische Zaken. Om van een handhavingstekort te spreken, zou mijns inziens dan ook te ver gaan. 
niet alleen het materiële recht worden aangepast (van misbruik- naar verbodstelsel ${ }^{24}$ ), maar diende tevens een andere koers te worden gevaren op handhavingsgebied. ${ }^{25}$ Daarom werd afscheid genomen van het strafrechtelijk traject en werd de handhaving overgeheveld naar het bestuursrecht: een wijziging ten opzichte van de Wem die in belang en ingrijpendheid niet onderdoet voor de overschakeling van misbruik- naar verbodstelsel.

Bestuursrechtelijke handhaving van de Mededingingswet derhalve en meer in het bijzonder (opnieuw vergelijkbaar met het communautaire recht): handhaving via de bestuurlijke boete. Met deze handhaving werd een nieuw bestuursorgaan belast: de Directeur-Generaal van de Nederlandse Mededingingsautoriteit. Deze beslist over ontheffingen, controleert de naleving van de Mededingingswet, spoort overtredingen en overtreders op en legt aan deze in voorkomende gevallen boetes op. Een dergelijke handhaving-in-één-hand voldoet in alles aan het streven naar doelmatigheid: deskundigheid -zo mag toch worden aangenomen- is gewaarborgd, snellere reacties op misstanden (door 'kortere lijnen') zijn waarschijnlijk en het risico van prioritering van handhaving van andere wetgeving boven die van de mededingingswetgeving is tot nul gereduceerd. ${ }^{26}$ De randvoorwaarden voor intensivering van het beleid (hier met name het handhavingsaspect) zijn dan ook gunstig. Maar doelmatigheid is slechts één zijde van de medaille waar het om overheidsoptreden gaat, zeker als dit kan leiden tot sanctie-oplegging. Met deze doelmatigheid is onlosmakelijk de rechtmatigheid van overheidsoptreden verbonden: de één kan niet zonder de ander. En juist op dat punt knelt mogelijk de schoen. Met het verlaten van de strafrechtelijke weg wordt tegelijk bekend terrein verlaten. Aan het formele strafrecht en zeker aan het wetboek van Strafvordering ligt de gedachte ten grondslag dat rechtmatigheid en doelmatigheid hand in hand gaan (of toch tenminste zouden moeten gaan), hetgeen zijn weerslag vindt in de uitgebreidheid van de procedurele rechten die in een strafrechtelijke procedure aan een verdachte toekomen. ${ }^{27}$ Deze vanzelfsprekendheid ontbreekt bij de handhaving via de bestuurlijke boete, door mij in navolging van Hartmann en Van Russen Groen aangeduid als 'bestuursstrafrecht'. ${ }^{28}$ Het betreft een nog relatief onontgonnen (rechts)gebied dat door de Mededingingswet is betreden, het heeft nauwelijks enige historie, kent geen overkoepelende codificatie van algemene uitgangspunten ${ }^{29}$ en is met name in het leven geroepen vanuit overwegingen van doelmatigheid ${ }^{30}$ Het is dus nog geenszins

24 Interessant in dit verband is dat bij de totstandkoming van de Mededingingswet op dit punt van de zijde van ondernemers ook de meeste kritiek is geuit. De gevolgen van de invoering van een verbodstelsel zou in hun ogen onaanvaardbare gevolgen hebben; met name 'kleinere' ondememingen zouden moeten vrezen voor hun voortbestaan.

25 Het enkele feit dat in een verbodstelsel in beginsel ieder kartel van meet af aan verboden en nietig is, heeft al belangrijke voordelen voor de handhaving via de burgerlijke rechter. De redenen hiervoor zullen in hoofdstuk 1 uiteen worden gezet.

26 Met dien verstande dat het kartelrecht binnen de Nederlandse Mededingingsautoriteit wel moet concurreren met de controle op fusies.

27 Vergelijk de MvT TK 1912-1913, 286, nr. 3.

28 Hartmann en Van Russen Groen (1994 II) en (1998), pag. 74. Wat hieronder moet worden verstaan, zal in hoofdstuk 5 worden besproken.

29 Wel zal naar verwachting de Vierde tranche van de Algemene wet bestuursrecht hierin voorzien. Vergelijk het Voorontwerp vierde tranche Awb, waarop in hoofdstuk 5 nader zal worden ingegaan.

30 Vergelijk bijvoorbeeld Handhaving door bestuurlijke boeten (1994). Een parallel kan worden getrokken met het economisch strafrecht. Voor dit rechtsgebied wordt reeds betoogd dat gelet op de aard van de overtredingen de doelmatigheid meer kan worden benadrukt (dit ten nadele van de rechtsbescher- 
een gegeven dat de rechtsbescherming in het bestuursstrafrecht voldoende tot zijn recht komt. De wetgever ziet in ieder geval op dit punt geen bezwaren: het EVRM ${ }^{31}$ is, in ieder geval waar het de punitieve procedure van de Mededingingswet betreft, van toepas$\operatorname{sing}^{32}$ en in de Mededingingswet zelf zijn verschillende waarborgen die het strafrecht eigen zijn (zoals het zwijgrecht voor de verdachte) overgenomen, waardoor van veronachtzaming van de rechten van degene die in een kartelprocedure is betrokken, geen sprake zou zijn. Hoewel het positief is dat bepaalde rechten ook binnen het bestuursstrafrecht worden beschermd, vermag het standpunt van de wetgever nog niet geheel gerust te stellen. Het feit dat het EVRM slechts minimumwaarborgen (hoe cruciaal deze ook zijn) bevat en dat lang niet alle nationale strafrechtelijke regels die dienen ter bescherming van de verdachte een pendant in de Mededingingswet kennen, doet de vraag rijzen of de stelligheid van de wetgever wel gerechtvaardigd is. Met andere woorden: komt de rechtspositie van de verdachte onderneming inderdaad niet in het gedrang door de handhaving via het bestuursstrafrecht?

\section{Probleemstelling en reikwijdte van het onderzoek}

Dit onderzoek richt zich op de (punitieve) handhaving van het Nederlandse en communautaire kartelrecht. Centraal staat de volgende vraag: in hoeverre bieden het Nederlandse en het communautaire recht voldoende rechtsbescherming aan ondernemingen die verdacht worden van een inbreuk op het materiële kartelrecht? Teneinde deze vraag te beantwoorden, zal worden ingegaan op de volgende sub-vragen:

1. hoe hebben het Nederlandse en communautaire kartelrecht en -beleid zich sinds hun ontstaan ontwikkeld?;

2. met welke bevoegdheden kunnen ondernemingen in het kader van een kartelonderzoek worden geconfronteerd?;

3. welke rechtsbeschermende normen gelden er in het Nederlandse en communautaire kartelrecht?, en

4. welke factoren spelen bij het sluitstuk van de handhaving, de straftoemeting, in de praktijk een rol?

In dit onderzoek gaat het om de handhaving van kartelrecht. De vraag die dan rijst is wat onder kartels moet worden verstaan. Voor zover het dit onderzoek betreft is het antwoord op deze vraag: ondernemersgedrag dat de mededinging beperkt. Deze definitie sluit aan bij de artikelen 81 en 82 EG alsmede de artikelen 6 en $24 \mathrm{Mw}$ en omvat derhalve zowel horizontaal als verticaal gedrag alsmede misbruik van machtspositie. In zoverre hanteer ik een ruime definitie. Uitdrukkelijk uitgesloten zijn echter de oneerlijke mededin-

ming) dan in het commune strafrecht het geval is. Als met name doelmatigheidsoverwegingen ten grondslag liggen aan de overheveling van het economische strafrecht naar het bestuursstrafrecht, dan is de vrees gerechtvaardigd dat daar het rechtmatigheidsaspect nog verder ondergesneeuwd raakt.

31 Europees Verdrag tot bescherming van de Rechten van de Mens en de Fundamentele Vrijheden, 4 november 1950, Trb. 1951, 154.

32 Voor de bespreking van het belang van het EVRM voor het bestuurstecht zie hoofdstuk 5. Daar komt ook aan de orde of rechtspersonen wel aanspraak kunnen doen gelden op bescherming van het EVRM. 
ging ${ }^{33}$ alsmede de concentratieproblematiek. ${ }^{34}$ De reden hiervoor is dat zij zich -niet in de laatste plaats op handhavingsgebied- wezenlijk van het kartelrecht in de zin zoals hier bedoeld onderscheiden. ${ }^{35}$

Uit de probleemstelling blijkt dat de nadruk in dit onderzoek bij de handhaving van het kartelrecht, bij het formele recht derhalve, ligt. Hierbij moeten echter twee kanttekeningen worden geplaatst. De eerste betreft de oplegging van sancties die een van de kernpunten van het onderzoek vormt: zij wordt in de (strafrechtelijke) doctrine van oudsher gerekend tot het materięle recht. De tweede kanttekening houdt verband met de nauwe relatie tussen materieel en formeel recht. Aangezien het te handhaven recht primair het materiële recht is, is de materięle norm in belangrijke mate bepalend voor de (effectiviteit van) de handhaving. Kennis van de uitgangspunten van het materiële recht is dan ook van belang voor een goed begrip van het formele recht en de toepassing hiervan. De aandacht voor het materiële recht (afgezien van de oplegging van sancties) moet in dit licht worden gezien: volstaan zal worden met een bespreking op hoofdlijnen; voor detailkwesties ten aanzien van het materiële recht wordt verwezen naar andere werken. ${ }^{36}$

Maar ook de handhaving wordt niet van a tot $\mathrm{z}$ (van toezicht tot en met het geven van een boetebesluit) besproken: er ontbreekt een 'hap'. De contradictoire fase van de procedure, volgend op het rapport (waar het de Mededingingswet betreft) respectievelijk de punten van bezwaar (voor het communautaire recht), blijft namelijk grotendeels onbehandeld. Hiervoor is gekozen omdat het kartelrecht hier niet iets wezenlijk nieuws biedt. Het bijzondere (en nieuwe, zeker waar het het Nederlandse recht betreft) van de handhaving van de kartelregelgeving ligt nu juist in het boete-aspect ervan: de regels omtrent toezicht en onderzoek, respectievelijk inzage en verificatie alsmede in de ruime discretionaire bevoegdheid van het bestuursorgaan waar het de boete-oplegging betreft. De effectiviteitsargumenten die hierbij een rol spelen, kunnen zeer wel de aandacht voor de rechtsbescherming op de achtergrond doen belanden. Strikt genomen zou wellicht de straftoemeting tegen de achtergrond van de probleemstelling ook buiten beschouwing kunnen worden gelaten. Toch is er voor geopteerd om hieraan wel uitgebreid aandacht te besteden. De redenen hiervoor zijn de volgende. Het opleggen van een bestuurlijke boete van overtreders vormt een wezenlijk (onder)deel van de handhaving én, zoals gezegd, (voor het Nederland-

33 Duk en Limperg (1985), pag. 178, typeren het verschil tussen het kartelrecht en het recht inzake de ongeoorloofde mededinging als volgt: "Het recht inzake de ongeoorloofde mededinging heeft niet tot taak de vrijheid van mededinging zeker te stellen, doch veeleer om het functioneren van de mededinging te normeren en, waar nodig, te reguleren".

34 In zoverre gebruik ik een beperkter begrip dan Mok (1998), pag. 1, die eveneens de concentraties als object van het kartelrecht beschouwt. De Mededingingswet kent -overigens in tegenstelling tot de Wem of enige andere Nederlandse wetgeving tot 1998- wel regels omtrent concentratietoezicht, die eveneens nauw aansluiten bij het communautaire recht op dit punt.

35 Dit wordt ook weerspiegeld in de organisatie van de NMa. Deze is met betrekking tot de Mededingingswet gesplitst in een afdeling Concentratiecontrole en een afdeling Onderzoek, Toericht en Ontheffingen (die zich bezig houdt met het kartelrecht zoals dat in dit onderzock centraal staat). Daarnaast is er de afdeling Beschikkingen, Bezwaar en Beroep, die, voorzover in dit verband relevant, de sanctiebeschikkingen maakt.

36 Onder andere Mok (1995) en Akyũrek-Kievits, Feenstra en Van der Woude I (met betrekking tot de Wem), Mok (1998) en Akyürek-Kievits, Feenstra en Van der Woude II (aangaande de Mededingingswet), Zăch (1994), Bellamy en Child (1993) alsmede Bellamy en Child (1996), Van Gerven e. a. (1997), Kerse (1998), Goyder (1998), Von der Groeben, Thiesing en Ehlermann (1999) en Korah (2000) (over het communautaire recht). 
se recht) het meest vernieuwende aspect ervan. Het opleggen van punitieve saneties door bestuursorganen is nog geen gemeengoed (ook al is de bestuurlijke boete sterk in opkomst $^{37}$ ) en zeker niet in de vorm waarin het kartelrecht deze kent, met zijn zeer substanticle boetes ${ }^{38}$ en grote discretionaire bevoegdheid van het bestuursorgaan waar het de straftoemeting betreft. De toepassing van deze bevoegdheid in de praktijk is van dermate groot belang voor de rechtspositie van de onderneming, dat een uitgebreide bespreking daarom reeds gerechtvaardigd is. Daar komt nog bij dat de hoogte van de boetes, die ook uit de praktijk blijkt, de noodzaak van een goede rechtsbescherming van de onderneming alleen maar versterkt.

Naast het nationale recht komt het communautaire kartelrecht uitgebreid aan bod. Hieraan liggen de volgende redenen ten grondslag. Ten eerste heeft het convergentiestreven ertoe geleid dat de Mededingingswet volledig op Europese leest is geschoeid. In de memorie van toelichting bij de Mededingingswet ${ }^{19}$ is uitdrukkelijk vastgelegd dat het Nederlandse beleid niet strenger maar ook niet milder mag zijn dan het EG-recht: expliciete convergentie van het Nederlandse recht en beleid met het communautaire derhalve. Weliswaar heeft dit uitgangspunt primair betrekking op het materiële recht, maar van daadwerkelijke convergentie zal weinig terecht komen indien de handhaving wezenlijk milder of strenger is op nationaal dan op communautair niveau. Kennis van het communautaire recht en beleid is dan ook essentieel voor een goed begrip van de Mededingingswet. Ten tweede heeft het Hof van Justitie in het kader van kartelprocedures uitdrukkelijk enkele verdedigingsrechten erkend. Deze rechten dienen in elke communautaire procedure te worden gewaarborgd. Mede tegen de achtergrond van convergentie zullen deze verdedigingsrechten ook in Nederlandse kartelprocedures volledig tot hun recht moeten komen. Ten derde is aandacht voor het communautaire kartelrecht onmisbaar met het oog op de beboeting van ondernemingen. De boeteregeling in de Mededingingswet is vrijwel identiek aan haar communautaire voorbeeld van artikel 15 Vo 17: in feite zijn slechts de rekeneenheden in beide regelingen afwijkend, een verschil dat met de invoering van de Euro tot het verleden zal behoren. Ten aanzien van de strafmaatbepaling komt de NMa een grote discretionaire bevoegdheid toe; dus zal zij op dit punt een beleid moeten gaan ontwikkelen. Dit beleid zal -wederom vanuit de gedachte dat nationaal recht op het communautaire recht moet zijn afgestemd- het straftoemetingsbeleid van de communautaire instellingen moeten volgen. Het inmiddels aanzienlijke aantal communautaire boetebeschikkingen (en rechterlijke beslissingen die veelal op dergelijke beschikkingen volgen) vormen derhalve een belangrijke bron voor de $\mathrm{NMa}$ bij de ontwikkeling van haar beleid, waarmee het belang van een kritische analyse van deze beschikkingen en beslissingen is gegeven.

Dit boek bestaat uit twee delen. In het eerste deel (hoofdstukken 1-3) worden de nationale en communautaire kartelregels onder de loep genomen. Bezien wordt met welke (materieelen formeelrechtelijke) regels ondernemingen op kartelgebied geconfronteerd worden en welke middelen de handhavende autoriteiten ter beschikking staan om naleving van de

37 Zie daarover hoofdstuk 5 .

38 In hoofdstukken 2 en 3 zal blijken dat de boete kan oplopen tot $10 \%$ van de wereldwijde omzet van de betrokken onderneming.

39 TK 1995-1996, 24707 , nr. 3. 
kartelregelgeving te controleren. Hoofdstuk 1 staat in het teken van de Nederlandse kartelregelgeving tot 1998. In hoofdstuk 2 staat het communautaire recht centraal. De Mededingingswet wordt in hoofdstuk 3 besproken. Het tweede deel (hoofdstukken 4 en 5) behandelt de strafmaatfactoren waarmee in de communautaire praktijk rekening wordt gehouden (hoofdstuk 4) en de rechten van een onderneming in het kader van een kartelprocedure, voorzover deze procedure mogelijk leidt tot oplegging van een punitieve sanctie (hoofdstuk 5). In de conclusie tenslotte zullen de probleemstelling en de daarmee samenhangende vragen worden beantwoord.

Deze studie is afgerond op 1 juli 2001. 


\section{Deel I Het nationale en communautaire kartelrecht}

Zoals elke geniale zakenman leerde hij al gauw dat vrije concurrentie verspillend werkte en dat een monopolie kosten bespaarde. Mario Puzo, De peetvader, De Boekerij, Amsterdam 1988, pag. 260. 



\section{Het Nederlandse kartelrecht tot 1998}

Nederiand had de naam een kartelparadijs te zijn. Afspraken tussen ondernemers waarbij bijvoorbeeld prijzen werden vastgesteld of markten onderling werden verdeeld, zouden aan de orde van de dag zijn.' En de Nederlandse overheid zou dit gedogen of er zelfs welwillend tegenover staan, getuige zowel de hantering van een misbruikstelsel als het milde optreden tegen kartels. Een schriller contrast met onder meer het communautaire recht zou nauwelijks denkbaar zijn. Dit contrast alsmede het gebrek aan een streng en doortastend optreden tegen kartels werden met name in de laatste jaren van de Wem als zeer problematisch ervaren, hetgeen de belangrijkste verklaring vormt voor het streven naar intensivering en convergentie. Tegen deze achtergrond rijst echter de vraag waarom het misbruikstelsel en het als (klaarblijkelijk te) mild ervaren Nederlandse kartelbeleid zo lang hebben kunnen standhouden. Bovendien is het de vraag of het hiervoor geschetste beeld over het Nederlandse kartelbeleid tot 1998 wel geheel zuiver is.

Deze vragen zullen in dit hoofdstuk aan de orde worden gesteld. Daartoe zal in de eerste paragraaf worden besproken waarom de Nederlandse kartelwetgeving sinds haar ontstaan gebaseerd is geweest op het misbruikstelsel en hoe deze wetgeving zich in de loop der tijd heeft ontwikkeld. In paragraaf 2 worden de belangrijkste kenmerken van de Wem en haar voorgangsters aan de orde gesteld, waarbij met name aandacht wordt besteed aan de maatregelen die de Nederlandse overheid tegen kartels kon nemen en aan het kartelbeleid zoals dat tot 1998 is gevoerd. In paragraaf drie staat de strafrechtelijke handhaving centraal. Daarbij zal de vraag worden beantwoord waarom voor strafrechtelijke handhaving van het Nederlandse kartelrecht is geopteerd. Tenslotte komen de strafbare gedragingen, de handhavingsbevoegdheden en de mogelijke sancties aan bod.

\section{De oorsprong en ontwikkeling van de Nederlandse kartelwetgeving tot 1998}

De oorsprong van de Nederlandse kartelwetgeving ligt in het begin van de jaren dertig van deze eeuw. ${ }^{2}$ De non-interventie in het economisch leven tot die tijd lag in de lijn van het klassieke economisch liberalisme. Deze economische theorie -ik volsta met het aanstippen van enkele belangrijke aspecten, omdat een grondigere bespreking hier te ver zou voeren- gaat ervan uit dat het nastreven van maximalisering van het eigen belang door alle individuele deelnemers aan het economisch proces leidt tot een optimaal welvaartsniveau: individueel belang en algemeen belang zijn in deze theorie onlosmakelijk met elkaar verbonden. Cruciaal voor de werking van dit mechanisme is dat de prijs voor de marktdeelnemers een gegeven is, tot stand gekomen door het vrije spel van vraag en aanbod en dus door vrije concurrentie tussen marktpartijen die onafhankelijk van elkaar hun marktbeleid bepalen en die geen wezenlijke invloed kunnen uitoefenen op het verloop

1 Dankert (1993), pag. 2, sprak van een "voor en door het eigen bedrijfsleven zeer geordend land".

2 In vergelijking tot de Verenigde Staten is dit relatieflaat; daar zag reeds in 1890 een kartelwetgeving. de Sherman Act, het licht. 
van het marktproces. Het optimale resultaat kan slechts worden bereikt indien men de markt zijn gang laat gaan. De markt is zodoende zelf-ordenend en zelf-regulerend zolang er sprake is van volledige, onbelemmerde concurrentie; verstoring van de vrije concurrentic betekent vrijwel automatisch verstoring van de zelf-regulerende werking van de markt, en dus het niet-bereiken van het optimale welvaartsresultaat. Iedere overheidsinterventie in het economische proces impliceert in feite een aantasting van de concurrentievrijheid. Maar ook marktpartijen kunnen in het economisch proces ingrijpen. Dit is het geval indien zij niet langer één van de vele partijen zijn voor welke de prijs een datum is, maar op de markt een (machts)positie innemen die hun in staat stelt om het spel van vraag en aanbod naar hun hand te zetten en om de prijs binnen bepaalde marges zelf te bepalen of althans te beïnvloeden. Economische machtsposities, met als meest verstrekkende vorm het monopolie, en kartelafspraken stellen marktpartijen in staat een invloed zoals hiervoor geschetst uit te oefenen; beide passen dan ook niet in de theorie van het klassieke liberalisme.

Zoals gezegd waren de non-interventie van de Nederlandse overheid tot de jaren dertig en de daarmee verweven contractsvrijheid van marktpartijen in overeenstemming met het gedachtegoed van het klassiek economisch liberalisme. Contractsvrijheid impliceerde echter tevens de mogelijkheid voor ondernemingen om ter bescherming van de eigen positie over te gaan tot kartellering. Van deze mogelijkheid werd in de Nederlandse praktijk inderdaad gebruik gemaakt, zij het -aldus VerLoren van Themaat ${ }^{3}$ - op relatief beperkte schaal. Als redenen hiervoor noemt deze schrijver de relatief late industrialisatic, de Nederlandse vrijhandelspolitiek en "het individualisme en de daarmee gepaard gaande "competitionmindedness" van de Nederlandse ondernemer". De juistheid van de laatstgenoemde reden kan in twijfel worden getrokken. Dat het met de "competitionmindedness" ook toen ${ }^{4}$ wel meeviel, blijkt wel uit de -ook door VerLoren van Themaat geconstateerdeaanwezigheid van kartels op markten die in grote mate waren afgeschermd van concurrentie uit het buitenland én uit het bestaan van deelnames aan internationale kartels. De reden voor afwezigheid van kartellering op grote schaal hing naar mijn mening dan ook met name samen met de openheid van de Nederlandse economie en de daarmee samenhangende buitenlandse concurrentie. Deze concurrentie makte het -ongeacht de wil van de Nederlandse ondernemers- zeer moeilijk om tot kartellering over te gaan.

Hoe dit ook zij, er bestond wel degelijk enige mate van kartellering, waartegen de Nederlandse overheid echter -tot op zekere hoogte in strijd met het economisch liberalis$\mathrm{me}^{5}$ - niet wenste op te treden: "Ingrijpen in de vrije regeling der onderlinge verhoudingen van ondernemers ten opzichte van productie en afzet" werd (nog) niet wenselijk geacht. ${ }^{6}$ De Nederlandse overheid duldde kartellering om tenminste twee redenen. De eerste reden was gelegen in de open, op export gerichte Nederlandse economie. Deze droeg er niet alleen zorg voor dat het aantal kartels relatief beperkt bleef, maar bovendien dat de wel aanwezige kartelafspraken de consumentenbelangen niet ernstig schaadden. De invloed van kartellering op de markt(werking) in Nederland werd zodoende als gering beoordeeld;

3 VerLoren van Themaat (1952 I), pag. 129.

4 In het recente verleden ontbrak in ieder geval bij veel Nederlandse ondernemingen de grote wil om in competitie te treden met concurrenten: onderlinge afspraken betreffende de mededinging genoten veelal de voorkeur.

5 Overigens zou een dergelijk verbod wel hebben ingedruist tegen de contractsvrijheid en tegen de non-interventiegedachte van het klassiek economisch liberalisme. 
vertrouwd werd op de zelf-regulerende werking van de markt. De tweede reden -en deze was wellicht nog belangrijker- was dat kartellering door de overheid tot op zekere hoogte als positief werd beoordeeld waar deze de Nederlandse ondernemingen in staat stelde hun concurrentiepositie ten opzichte van buitenlandse ondernemingen te versterken. Kartelmatig gedrag werd met andere woorden getolereerd omdat het Nederlandse ondernemingen beschermde tegen concurrentie uit het buitenland -hetgeen de Nederlandse economie ten goede zou komen-, terwijl nadelige effecten vrijwel afwezig waren dankzij de aanwezigheid van buitenlandse concurrentie op de Nederlandse markt.

De economische crisis van begin jaren dertig maakte een einde aan het uitgangspunt van non-interventie. Omdat veel (Europese) landen overgingen tot marktafschermende maatregelen teneinde zo de pijn van de crisis binnen hun landsgrenzen te verlichten, zagen de Nederlandse ondernemingen zich geconfronteerd met een aanzienlijke afname van hun exportmogelijkheden. ${ }^{7}$ Maar ook de afzet op de Nederiandse markt liep drastisch (om niet te zeggen dramatisch) terug, terwijl het aanbod gestaag groeide door toename van de productiecapaciteit, als gevolg van industrialisatie en rationalisatie. "De discrepantic tussen vraag en aanbod veroorzaakte een mate van concurrentie die bepaald ongezond was te noemen: de prijzen daalden tot een niveau, waarop produceren onrendabel werd en vele ondernemers hun werkzaamheden noodgedwongen moesten belindigen. De drang naar kartellering nam bij ondernemingen toe, omdat zij van mening waren dat slechts met bundeling van krachten en afspraken over (verkoop)prijzen de crisis het hoofd geboden kon worden. De ondernemingen wisten zich gesteund door de centrale overheid, waarbinnen ook de behoefte werd gevoeld "naar regeling der onderlinge concurrentie, b.v. door het brengen van eenige uniformiteit in de verkoopsvoorwaarden, het voorschrijven van minimum qualiteiten, het invoeren van een zekere arbeidsverdeeling in productic en distributie, het tegengaan van prijsbederf en van overmatige investaties" 9 . Kartellering derhalve als impuls voor de economie: kartels zouden concurrentie terugdringen, prijzen stabiliseren, productie in stand houden en zodoende werkgelegenheid en omvang van lonen garanderen of zelfs doen toenemen. ${ }^{10}$ De crisis versterkte zodoende de overtuiging

7 Snijders (1960), pag. 436.

8 Bovendien was er aanvankelijk sprake van een aanzienlijke groei van de import, mede te wijten aan de hoge waarde van de gulden, aldus Schaffmeister (1978), pag. 22.

9 MvT TK 1933-1934, 460, nr. 3, pag. 2. Terecht stelt Van der Woude (1995), pag. 199: "Van cen onvoorwaardelijk geloof in de werking van het marktmechanisme was geen sprake. De wetgever was eerder van mening dat ondernemersovereenkomsten een nuttige functie konden vervullen om de onvolkomenheden van dit mechanisme op te vangen".

10 Vanuit klassiek liberaal oogpunt, waarin zoals gezegd de afkeer van kartels (dus van marktmacht) een centrale plaats inneemt, is deze visie niet houdbaar. De economische werkelijkheid kwam echter niet (langer) overeen met de economische theoric. Concurrentie leverde geen resultaten op die aanvaardbaar waren (van -een acceptabele-zelf-regulering van de markt was begin jaren dertig geen sprake). Bovendien was er een onmiskenbare tendens van concentratie van macht bij de marktparticipanten, waardoor één van de uitgangspunten in de klassiek liberale theorie -de spreiding van macht op de markt zodat door de marktpartijen geen invloed kon worden uitgeoefend- was weggevallen en dus een optimaal resultaat van de marktwerking niet langer verzekerd was. De Nederiandse overheid had ervoor kunnen opteren om de vrije marktwerking alsnog een kans te geven, maar verwachtte hiervan -niet verbazend gelet op de wereldwijde crisis en op het vrijwel geheel ontbreken van afzetmarkten voor Nederlandse producten-geen heil. Zij was echter van oordeel dat de Nederlandse samenleving meer gebaat was bij de pogingen van marktpartijen om de krachten te bundelen en de verstoorde 
bij de Nederlandse overheid dat kartels positieve effecten hadden. "Tegelijk echter bracht de crisis de risico's van kartellering versterkt aan het licht. Zoals gezegd was een van de redenen voor de nationale overheid om kartellering te dulden gelegen in de omstandigheid dat buitenlandse concurrentie verhinderde dat Nederlandse ondernemingen te ver zouden gaan in hun kartelmatig gedrag: de gedachte was dat Nederlandse ondernemingen het zich niet konden permitteren misbruik te maken van onderlinge afspraken (bijvoorbeeld in de vorm van extreem hoge minimumprijzen) omdat in dat geval de consument zou uitwijken naar buitenlandse substituut-producten. Deze 'natuurlijke' bescherming tegen misbruik, die ervoor zorg droeg dat kartelafspraken voor (eind)afnemers weinig tot geen merkbare nadelige gevolgen meebrachten, was echter in de crisisjaren vrijwel geheel afwezig. Op de van het buitenland afgeschermde markt was dan ook de dreiging van misbruik van de kartelvrijheid door ondernemingen aanmerkelijk groter dan voordien.

Tegen de achtergrond van de economische crisis en de (zowel positieve als ook negatieve) gevolgen van kartellering in die tijd voldeed de terughoudende opstelling van de wetgever niet langer ${ }^{12}$ : de voordelen van kartels moesten ten volle worden benut, zo nodig door stimulerend ingrijpen van overheidswege, terwijl eventueel misbruik van de vrijheid tot kartellering aan banden moest worden gelegd en door overheidsingrijpen moest kunnen worden betindigd. Dit noopte de overheid tot het creêren van een wettelijke regeling op kartelgebied ${ }^{13}$, waarbij met zowel de positieve alsmede de negatieve aspecten

marktverhoudingen via kartels te ordenen. Daar kwam nog bij dat, zoals aangestipt, de Nederlandse overheid reeds voor de crisis -in strijd met het klassiek liberalisme- ervan overtuigd dat kartels óók positieve effecten met zich brachten. Deze genuanceerde houding ten aanzien van kartels ligt overigens in de lijn van het concept van de effectieve mededinging, waarop hiema nog kort zal worden ingegaan. Vergelijk over de achtergronden van de keuze van de Nederlandse overheid ook Schouten (1970), pag. 15 e.v. en dezelfde schrijver in 1973, pag. 12 e.v..

11 Voor een algemene kritiek op crisiskartels en hun 'waarde' bij het bestrijden van de crisis, zie men onder meer Aarts (1980), pag. 16-31.

12 Schouten (1970), pag. 22, stelt in dit verband: "waar concurrentie- en contractsvrijheid in hun ordenende kracht falen, vragen overwegingen van economische politiek én van rechtspolitiek een bewuste ordening van de betrekkingen op de markt". Volgens Schouten kan ingrijpen in de contractsvrijheid leiden tot meer vrijheid. Contractsvrijheid impliceert de vrijheid tot kartellering: door middel van kartellering kan echter de (contracts)vrijheid van de kartelleden alsmede van derden danig worden beperkt. In dit licht betekent een beperking door de overheid van de vrijheid om kartelovereenkomsten aan te gaan, tegelijk een verruiming van de (contracts)vrijheid. Vergelijk hierover ook Borst (1954), pag. 6-7. Mok (1975), pag. 158 stelt "dat een bijzondere karaktertrek van de verhouding kartelrecht-contractsvrijheid is dat, hoewel het kartelrechtde contractsvrijheidveelal sterk beperkt, het tegelijkertijd ertoe strekt de vrijheid te bevorderen". Volgens deze schrijver moet in het algemeenaan de "materiêle economischevrijheid en de maatschappelijkevrijheid' de voorkeur worden gegevenvoor 'de formele contractsvrijheid".

13 Kartelwetgeving was overigens slechts één van de vele wetgevingen op (sociaal-)economischterrein waarmee de Nederlandse overheid de crisis het hoofd trachtte te bieden. Met name op landbouwen vestigingsgebied liet de wetgever zich niet onbetuigd, zij het dat de op die (en andere ordenings-) gebieden tot stand gebrachte wetgeving van tijdelijke aard was: voorzien was dat zij expireerdezodra de economische situatie dat toeliet. Benadrukt moet hier worden dat dit niet gold ten aanzien van de kartelwetgeving: de wetgever overwoog uitdrukkelijk dat deze wetgeving geen crisismaatregel was, maar dat het een structurele maatregel betrof (vergelijk MvA TK 1934-1935, 64, nr. 1, pag. 5). Zie over de ordeningswetgeving in de crisistijd in het algemeen-naast zeer beknopt hierna $\$ 1.2$ uitgebreid Schaffmeister (1978), pag. 22 e.v. en Mulder (1950), pag. 104 c.v. 
van kartellering rekening moest worden gehouden. ${ }^{14}$ Het in 1934 gelanceerde ontwerp van de Wet op de verbindende kracht van ondernemersovereenkomsten en de hierop gebaseerde en in 1935 in werking getreden Wet tot het algemeen verbindend en onverbindend verklaren van ondernemersovereenkomsten (hierna: Ondernemersovereenkomstenwet 1935) deden recht aan dit uitgangspunt: de Nederlandse overheid kon zowel kartelbevorderende maatregelen (algemeen verbindendverklaring) alsmede maatregelen ter beteugeling of bestrijding van kartels (onverbindendverklaring) nemen. ${ }^{15}$ Hierbij dient een belangrijke aantekening te worden gemaakt. Uit de behandeling van het wetsontwerp (en uit de toepassing van de Ondernemersovereenkomstenwet 1935) bleek onmiskenbaar dat het zwaartepunt volledig bij de kartelbevorderende maatregel lag en dat de onverbindendverklaring slechts van secundair belang was; overigens is dit niet verbazend gelet op de tijd waarin en de omstandigheden waaronder de wet is ontstaan en het belang dat de Nederlandse overheid hechtte aan kartellering in die tijd. ${ }^{16}$

De omstandigheden tijdens de crisisjaren hebben derhalve niet alleen het totstandkomen van een wettelijke kartelregeling bevorderd, maar zij hebben tevens (samen met de reeds voordien heersende positieve houding tegenover kartels) in belangrijke mate de aard en inhoud van de wetgeving bepaald, een aard en inhoud die tot aan de inwerkingtreding van de Mededingingswet in 1998 de Nederlandse kartelwetgeving hebben gekenmerkt. De genoemde uitgangspunten van de Ondernemersovereenkomstenwet 1935 verklaren tevens de keuze voor het misbruikstelsel. Een dergelijk stelsel gaat uit van de geldigheid en legitimiteit van kartelmatig gedrag en staat derhalve neutraal -of zelfs uitgesproken positief- tegenover kartellering. Het eventueel ontbreken van enig positief nut van een kartel staat de geldigheid daarvan niet in de weg. De overheid treedt slechts dan tegen een kartel op indien het algemeen belang in het geding is. Pas indien ondernemingen misbruik ${ }^{17}$ maken van hun kartelvrijheid (vandaar de naam 'misbruikstelsel'), kan de

14 De aandacht voor zowel de positieve als de negatieve aspecten van kartellering werden door Colijn MvT TK 1933-1934, 460, nr. 3, pag. 2 als volgt verwoord: "In vele gevallen is het oogmerk (van kartellering, HQ) bestrijding van misbruiken in den concurrentiestrijd of het inperken der vrije mededinging. In zooverre kan het zoowel moreel als economisch wenschelijk zijn. In andere gevallen daarentegen gaat het streven in de richting van particuliere monopolievorming, waardoor het een gevaar kan opleverenvoor deneconomischenvooruitgang en voor het consumentenbelang. A angeziende nuttige werking er van licht in een schadelijke kan overgaan, is het moeilijk in het algemeen te zeggen of hierbedoelde streven bevorderd dan wel beperkt dient te worden. Slechts in concreto, wanneer de bijzondere omstandighedenvan het geval in aanmerking kunnen worden genomen, schijnt dezevraag voor beantwoording vatbaar". In dezelfde zin Schouten (1970), pag. 24. In zekere zin impliceerde dit dat de Nederlandsekartelwetgevingneutraal tegenover kartelleringstond (vergelijk Schaffmeister (1978), pag. 122). Duidelijk was in ieder geval dat de kartelwetgeving en -praktijk in Nederland allerminst onwelwillend tegenover kartels stond.

15 Deze aandacht voor zowel kartelbevorderende als ook kartelbestrijdende maatregelen toont, aldus Schouten (1973), pag. 14, aan dat het niet louter een crisiswetgeving betrof en dat op evenwichtige wijze rekening werd gehouden met het uitgangspunt dat kartels zowel positieve als negatieve gevolgen konden hebben.

16 Deze maatregelen zullen nader worden besproken in $\$ 2$.

17 Over de term 'misbruik' zie Mok (1998), pag. 15: deze term "moet niet opgevat worden in morele zin, doch als een aanduiding van datgene wat op grond van bepaaldecriteria ongewenst wordt geacht. Die criteria kunnen mede morele normen omvatten, maar zij zullen in de eerste plaats betrekking hebben op desiderata van economische politiek". Volgens Borst (1954), pag. 25 daarentegen wordt met deze term "onmiskenbaar iets laakbaars (...) aangegevenen dat is een ethisch-juridisch begrip". 
overheid overgaan tot het verbieden van het kartel of tot het ombuigen ervan tot een afspraak die niet in strijd is met het algemeen belang. ${ }^{18}$ Het optreden van de overheid in een misbruikstelsel is dientengevolge zeer casuïstisch van aard en komt in grote lijnen neer op de bestrijding van excessen. ${ }^{19}$ Een verbodstelsel -de 'klassieke' tegenhanger van het misbruikstelsel- daarentegen gaat, zoals de benaming reeds aangeeft, uit van een generiek verbod op kartellering. Het komt er in feite op neer dat in een verbodstelsel kartels als zodanig in strijd met het algemeen belang worden geacht. Wel kent een verbodstelsel over het algemeen een mogelijkheid van ontheffing van het verbod indien kan worden aangetoond dat het kartel een positief nut heeft dat niet zonder het kartel zou kunnen worden bereikt en dat bovendien de negatieve aspecten overstijgt. Gelet op de negatieve houding tegenover kartels in een verbodstelsel, zal een ontheffing eerder uitzondering dan regel zijn. ${ }^{20}$ Hoewel zowel voor het misbruikstelsel als ook voor het verbodstelsel geldt dat zij in meerdere of mindere mate 'streng in de leer' kunnen zijn ${ }^{21}$, moge uit het vorenstaande blijken dat een misbruikstelsel aanzienlijk beter bij het toenmalige uitgangspunt van de Nederlandse overheid -namelijk dat kartels in beginsel nuttig én in het algemeen belang zijn en dus in de regel geoorloofd dienden te zijn- aansloot dan een verbodstelsel, zoals dat onder meer aan het communautaire kartelrecht en de huidige Mededingingswet ten grondslag ligt. De keuze voor het misbruikstelsel sloot dan ook goed aan bij wat wel genoemd werd 'de Nederlandse kartelfilosofie'. En de duidelijke voordelen die kartels werden toegedicht -zeker in de crisistijd- leidden zelfs ertoe dat de Ondernemersovereenkomstenwet 1935 een relatief strikt misbruikstelsel kende ${ }^{22}$ en dat het beleid dat op grond van deze wet werd gevoerd onmiskenbaar 'pro-kartel' was: terwijl er verschillende algemeen verbindendverklaringen zijn geweest, werd de onverbindendverklaring nooit toegepast. ${ }^{23}$

18 Mogelijk blijft ook in een misbruikstelsel dat een kartelafspraakop andere gronden in strijd met het recht is. Te denken valt aan schending van de goede zeden of de openbare orde. Art. 3:40 lid 1 BW bepaalt immers dat overeenkomsten van rechtswege nietig zijn voorzover deze door inhoud of strekking in strijd zijn met de goede zeden of de openbare orde.

19 Uitermark(1986 I), pag. 108 e.v., acht deze typering overigens niet juist, hetgeen volgens Mok (1986 1), pag. 115 , ten onrechte is.

20 VerLoren van Themaat (1952 II), pag. 205, stelt in zijn naschrift op De Rooy dan ook dat een verbodstelsel slechts in bet leven kan worden geroepen indien vast staat dat de voordelen van kartels en dus de geldigheid grote uitzondering is.

21 Op het niveau van de wet, maar met name in de praktijk kunnen beide stelsels elkaar zeer dicht naderen. Dit is met name het geval indien in een misbruikstelsel het beleid er in belangrijke mate op is gericht om met het algemeen belang strijdig kartelgedrag aan te pakken, terwijl in het verbodstelsel veel ruimte wordt gecreěerd voor ontheffingen. De uitkomsten van het kartelbeleid verschillen dan niet wezenlijk van elkaar. Veel hangt af van de geldende -economische en politieke- inzichten bij de uitvoerende instanties.

22 Hierin bracht een wetswijziging in 1939 ook geen verandering. Inzet van de wijziging was het afwentelen van de kosten van algemeenverbindendverklaringen(voortvloeienduit de plicht tot controle door de Commissie van Toezicht op de naleving van deze maatregel) op degenen die het meest van deze maatregelen profiteerden, teneinde zo de schatkist te sparen. Bedoelde mogelijkheid was overigens reeds bij de wet van 1935 beoogd en in HR 11 november 1938, NJ 1938, 1116 erkend. Toch was de wet niet overbodig omdat de juistheid van het genoemde arrest in twijfel werd getrokken. Zie Scholten in zijn noot onder dit arrest en Kauffmann (1939), pag. 109.

23 Overigens geldt dat het slechts in een gering aantal gevallen is gekomen tot een formeel optreden op grond van de Ondernemersovereenkomstenwet 1935. Patijn (1942), pag. 13 e.v., noemt hiervoor een aantal redenen. De belangrijkste redenen lagen zijns inziens in de restricties die in de wet waren 
De Ondernemersovereenkomstenwet 1935 werd in 1941 opgevolgd door het Kartelbesluit. ${ }^{24}$ Ook deze onder Duitse bezetting geïntroduceerde kartelwetgeving beruste op het misbruikstelsel: de economische situatie was ten gevolge van de Tweede Wereldoorlog volledig verstoord en de mogelijkheden tot interventie in en sturing van het economische leven die het misbruikstelsel bood, lagen in de lijn van de (economische) politiek van de bezetter. De uitgangspunten veranderden dan ook niet ten opzichte van de Ondernemersovereenkomstenwet 1935; de invulling daarentegen wel. De interventiemogelijkheden van de overheid werden aanmerkelijk verruimd en de waarborgen tegen overheidsmisbruik aanzienlijk beperkt. ${ }^{25}$ Hoewel achtergrond en gedachtegoed van de bezetter ongetwijfeld enige invloed hebben uitgeoefend op deze aanscherping van de wettelijke regeling ${ }^{26}$. ligt daarin toch niet de meest voorname reden voor de aanscherping. De schaarste en (andere) economische problemen tijdens de oorlog maakten de mogelijkheid tot effectief en vérstrekkend optreden door de overheid veelal noodzakelijk. ${ }^{27}$ Dat het inderdaad geen "verfoeilijk stukje bezettingsrecht" dat het Kartelbesluit na de bezetting is gehandhaafd ${ }^{29}$ en tot eind $1958^{30}$ (in nauwelijks gewijzigde vorm) als kartelwetgeving dienst heeft gedaan. Hoe groot de invloed van de bezetter op de inhoud van het Kartelbesluit is geweest, is overigens van niet meer dan theoretisch belang, aangezien ten tijde van de bezetting het Kartelbesluit nooit (formeel)

opgenomen, in het gebrek aan overleg van de kartelleden met derden (waardoor de voordelen van de kartels vaak uitsluitend aan éen zijde lagen en dus algemeenverbindendverklaring niet voor de hand lag) en in de omstandigheid dat de overheid niet tot algemeenverbindendverklaring besloot, indien niet was gebleken dat van de maatregel een sanerende invloed op de bedrijfstak zou uitgaan. Het ontbreken van onverbindendverklaringen is met name te verklaren tegen de achtergrond van de economische situatie en de houding van de overheid tegenover kartels. Vergelijk ook VerLoren van Themaat (1952 I), pag. 130.

24 Besluit van 5 november 1941 van de Secretarissen-Generaal van de Departementen van Handel, Nijverheid en Scheepvaarten van Landbouw en Visscherij betreffende het kartelwezen, Stb. S.614 en Verordeningenblad 1941, 208; gewijzigd bij Besluit van 12 november 1942, Verordeningenblad 1943, 23. De Ondernemersovereenkomstenwet 1935 werd bij dit Besluit buiten werking gesteld.

25 Onder het Kartelbesluit werd een belangrijke beperkende voorwaarde voor overheidsinterventie geschrapt, te weten het vereiste dat de overheid pas kon overgaan tot algemeenverbindendverklaring indien er reeds een kartel was opgericht. In artikel 4 Kartelbesluit werd bepaald dat de overheid de bevoegdheid had om zelfstandig algemeenverbindende bedrijfsregelingen vast te stellen. De ordeningsmogelijkheden waren aldus voor de overheid compleetnu zij voor verbindendverklaringenniet meer afhankelijk was van het bestaan van kartels en zij dus dwangkartels in het leven kon roepen. Aldus ook de officieuze memorie van toelichting bij het Kartelbesluit (Het Kartelbesluit (1941), pag. 1679 e.v.). Voor een kritisch commentaar Maitland (1946), pag. 50. Patijn (1942), pag. 14-15, nuanceert overigens sterk de betekenis van de restricties uit de Ondernemersovereenkomstenwet 1935 voor de praktijk. Op de bedoelde restricties zal later nog worden ingegaan.

26 Mulder (1950), pag. 131, spreekt van het Kartelbesluit als behorende tot de regelingen "welke het net van overheidsbeheersing hebben dicht getrokken".

27 De aanpassingen waren in hoofdzaak bedoeld de slecht functionerende economie te stimuleren. Het is niet denkbeeldig dat een andere (niet onder Duitse invloed staande) regering in bet belang van de economie en het algemeen welzijn vergelijkbare maatregelen zou hebben moeten nemen.

28 Mok (1995), pag. 21

29 Besluit van 17 september 1944, houdende vaststelling van het besluit bezettingsmaatregelen, Stb. E93 (Besluit Bezettingsmaatregelen).

30 Op 14 november 1958 is het Kartelbesluit vervallen. Ook de Ondernemersovereenkomstenwet1935 werd op die dag pas officieel ingetrokken daar zij door het Kartelbesluit slechts buiten werking was gesteld. 
is toegepast. ${ }^{31}$ In de na-oorlogse jaren is het Kartelbesluit daarentegen wel verschillende malen formeel toepast. Ten aanzien van deze toepassing kunnen enkele belangrijke constateringen worden gemaakt. De eerste is dat de Nederlandse overheid -in absolute getallenniet op grote schaal van de haar geboden mogelijkheden gebruik heeft gemaakt: 18 formele beschikkingen hebben op grond van het Kartelbesluit het licht gezien. Op een enkele uitzondering na (te weten 3 schorsingen en één aanwijzing aan een economische machtspositie) betrof het steeds onverbindendverklaringen. Daarmee kom ik bij een tweede constatering: in de na-oorlogse jaren verschoof het accent van het Nederlandse kartelbeleid onmiskenbaar naar controle op en beteugeling van kartels. Deze ontwikkeling naar een meer op beperking van kartellering gericht beleid hield onder meer verband met de economische situatie en de goederenvoorziening. Deze verbeterden in de jaren na de oorlog, waardoor de dreiging van desastreuze mededinging vrijwel was verdwenen en waardoor in het verlengde daarvan er niet of nauwelijks enige noodzaak tot algemeen verbindendverklaring meer bestond. In tegendeel: het economisch herstel eiste veeleer een mededinging die vrij was van overheidsinterventie of onderlinge afspraken tussen ondernemingen. En juist deze onderlinge afspraken betreffende de mededinging -kartels derhalve- waren zeer in trek geraakt bij ondernemers. Zij waren in de crisis- en oorlogsjaren geconfronteerd met overheidsmaatregelen die de mededinging aan banden legden en zij hadden de smaak te pakken gekregen. Toen de overheid bedoelde maatregelen geleidelijk afschafte, werden deze door ondernemingen vervangen door regelingen die vergelijkbare resultaten bereikten. Om de mededinging een kans te geven en de terugtred van de overheid niet zinloos te doen zijn, was deze wel gedwongen om handelend tegen kartels op te treden. ${ }^{32}$ Zoals VerLoren van Themaat terecht stelde: "De inkrimping van de gedetailleerde overheidsbemoeiing was dan ook aanleiding tot een intensivering van het toezicht op ondernemersafspraken, ten einde zo nodig door onverbindendverklaring te voorkomen, dat ondernemers zich (...) zouden trachten te vrijwaren tegen onwelkome, maar als prikkel tot eigen verantwoordelijkheid en grotere efficiency waardevolle concurrentie". ${ }^{33}$

Een derde constatering is dat het Nederlandse misbruikstelsel de basis kon zijn voor een strikt beleid tegen (bepaalde vormen van) kartels. De overheid stond met name zeer huiverig tegenover exclusief verkeersregelingen, als gevolg waarvan zij zeer strenge eisen stelde voor toelaatbaarheid van deze kartelvorm. ${ }^{34}$ Deze eisen leidden zelfs tot een vorm van omkering van de bewijslast: in beginsel werd een regeling van bedoelde vorm in strijd geacht met het algemeen belang, maar de ondernemers hadden de mogelijkheid om aan te tonen dat de voordelen de nadelen overtroffen, in welk geval er geen onverbin-

31 Als reden hiervoor noemt Schouten (1973), pag. 83, dat de overheid als gevolg van de algemene schaarstetijdens en direct na de Tweede Wereldoorlog een strenge prijs-en distributiepolitiek voerde. Hierdoor was een apart kartelbeleid niet meer noodzakelijk en was ook de ruimte voor kartellering gering. VerLoren van Themaat (1952 1), pag. 131, voegt hieraan toe dat ook algemeen verbindend verklaringen niet voor de hand lagen aangezien door de schaarste van producten er geen desastreuze mededinging dreigde. De marktmacht lag reeds bij de producenten en hoefde dus niet door een kartel of een algemeen verbindend verklaring daarvan te worden gecreễerd.

32 Zie hierover ook Schouten (1973), pag. 17.

33 VerLoren van Themaat (1952 I), pag. 131.

34 Schouten (1976), pag. 11 wees erop dat de overheid slechts objectieve (kwaliteits- en inhoudelijke) gronden tot beperking van de toegang tot de markt aanvaardde. De facto dienden de kartelleden dezelfde waarborgen -waaronder bijvoorbeeld het getijkheidsbeginsel- in acht te nemen die ook door de overheid moesten worden gehonoreerd bij regeling van de mededinging. 
dendverklaring zou volgen. ${ }^{35}$ Hoewel met recht vraagtekens bij de rechtmatigheid van een dergelijk beleid konden worden gezet ${ }^{36}$, betekende dit cen intensief (anti-)kartelbeleid en werd de facto de situatie van een verbodstelsel met ontheffingsmogelijkheid ${ }^{37}$ of die van de in de Wem geìntroduceerde generieke onverbindendverklaring benaderd.

Duidelijk was dus dat bij de totstandkoming van de Wet economische mededinging $(W e m)^{38}$ de ideeèn omtrent de richting van het kartelbeleid (kartelbevorderend of kartelbeperkend) aanmerkelijk waren gewijzigd. De belangrijkste maatregel was niet langer de algemeen verbindendverklaring; niet langer was het de hoofdtaak van de overheid om stimulerend op te treden. Dat het tegendeel het geval was, kan echter ook niet met recht gesteld worden. De houding van de Nederlandse overheid tegenover kartels was nog steeds neutraal, met dien verstande dat zij tot de overtuiging was gekomen dat áls optreden noodzakelijk was, dit onder de gegeven economische omstandigheden ${ }^{39}$ primair de vorm zou moeten hebben van kartelbeperkende maatregelen. De neutrale houding -en daarmee de Nederlandse kartelfilosofie die zowel de positieve alsmede de negatieve aspecten van kartels in ogenschouw neemt- impliceerde dat de Nederlandse overheid zich geenszins geroepen voelde om kartels geheel van de Nederlandse markt te weren. Dus ook eind jaren vijftig heerste bij de centrale overheid onverminderd de visie dat kartels slechts dan zouden moeten worden aangepakt indien zij het algemeen belang schade zouden berokkenen. In dit licht verbaast het niet dat de wetgever ook aan de Wem het misbruikstelsel ten grondslag heeft gelegd en dat hij niet heeft geopteerd voor een verbodstelsel.

De traditie leefde dus voort in de Wem, hetgeen ook de handhaving van de in de Ondernemersovereenkomstenwet 1935 geïntroduceerde en in het Kartelbesluit gecontinueerde maatregelen aantoonde: zowel de algemeen verbindendverklaring als de onverbindendverklaring vonden hun weg naar de Wem. ${ }^{40}$ Maar de Wem kende daarenboven een geheel

35 Zie hieromtrent de discussie tussen De Rooy (1952 I) en VerLoren van Themaat (1952 II).

36 De Rooy (1952 II), pag. 241 e.v. achtte niet zonder grond een dergelijke gang van zaken niet zonder voorafgaande wettelijke regeling toelaatbaar.

$37 \mathrm{Zij}$ het dat in dit stelsel kartellering zonder ontheffing verboden en veelal van meet af aan nietig is.

38 Wet van 28 juni 1956 houdende regelen omtrent de economische mededinging, Stb. 1958, 413. Zie over deze wet algemeenVan der Meer Mohr-Soons (1996), Mok (1995) en Akyürek-Kievits, Feenstra en Van der Woude I. Aanvankelijk diende de Wem op grond van de Wet van 5 december 1957 , Stb. 1957, 528 (vervallen bij de Wet van 2 december 1965, Stb. 1965, 565) nog een ander belang. te weten het vervullen van artikel 88 EG-Verdrag (toen nog EEG-Verdrag) om gedurende cen overgangsperiode in overeenstemmingmet artikel 85 EG-Verdrag (thans artikel 81 EG) te beslissen over de toelaatbaarheid van kartelafspraken. Aldus heeft, in de woorden van Guldenmund (1992), pag. 112 , de Wem "gediend als grondslag voor de uitvoering van het kartelbeleid van de EEG".

39 In TK 1960-1961, 6348, werd het belang van de economischetoestand voor het Nederlandsekartelbeleid nog eens uitdrukkelijk onderstreept: "De ontwikkeling, welke het mededingingsbeleid voor en na de oorlog heeft doorgemaakt, stelt in het licht, dat binnen het raam van het principieel tweezijdig karakter van het mededingingsbeleid de feitelijke oriēntering ervan in overwegende mate beinvloed wordt door de actuele economische situatie",

40 Overigens stond primair de Ondernemersovereenkomstenwet 1935 model voor de Wem, met name op het terrein van de (in het Kartelbesluit geschrapte) rechtswaarborgen tegen overheidsoptreden. Toch bleek ook de invloed van het Kartelbesluit, onder meer door de handhaving van de in dit besluit gecreèerde aanmeldingsplicht voor kartels. 
nieuwe maatregel, die de Nederlandse kartelwetgeving verrijkte met een verbocelement ${ }^{41}$ en waardoor de Wem zich principieel van haar voorgangsters onderscheidde. Jet betrof de bevoegdheid tot generieke onverbindendverklaring van kartels. In tegenselling tot hetgeen het geval was bij de onverbindendverklaring, betrof het hier geen cisuistisch optreden tegen een bepaald kartel na geconstateerd misbruik, maar een 'verboc bij voorbaat' op kartelgedrag van een bepaalde aard of strekking: strijd met het algemen belang was in dat geval het uitgangspunt, ontheffing -en dus geldigheid- de uitzonderng. Voor de Nederlandse kartelwetgeving -het na-oorlogse beleid onder het Kartelbesluitwas zoals geconstateerd reeds ten dele in deze richting gegaan- was dit een novum, dat bij bepassing op ruime schaal de aard van het Nederlandse kartelrecht fundamenteel zou hebben gewijzigd. Dan immers zou het Nederlandse kartelstelsel in de praktijk naar een vertodstelsel zijn geèvolueerd. Tot een dergelijke invloed is het lange tijd niet gekomen. Op twee voor de praktijk minder relevante uitzonderingen -ten aanzien van kartelrechtspraak en nssendiscriminatie- na hebben tot 1993 slechts twee generieke maatregelen het licht geien. De eerste en meest belangrijke was de in 1964 tot stand gekomen generieke onverbirdendverklaring van (bepaalde vormen van) verticale prijsbinding ${ }^{42}$; de tweede uit 1986 daterende maatregel had betrekking op mededingingsregelingen in de bouwsector. In het kader van de intensivering van het mededingingsbeleid, die het beleid van voormalig staatsecretaris Van Rooy kenmerkte, volgden in 1993 en 1994 drie generieke maatregelen, respetievelijk met betrekking tot horizontale prijsafspraken, marktverdelingen en aanbestedingen (deze

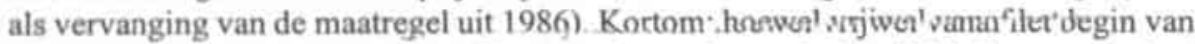
de Wem op het (overigens belangrijke) terrein van de verticale prijsbinding een verbod gold, heeft het verbodelement in het Nederlandse kartelrecht pas in 1994 -dus vrijwel aan het einde van de Wem- de overhand gekregen. Dit toont aan dat het misbruikstelsel en zijn uitgangspunten gedurende het gros van de jaren waarin de Wem het Nederlandse kartelrecht heeft bepaald, hebben kunnen overleven. Het toont evenzeer aan dat dankzij de intensivering van het kartelbeleid sinds begin jaren negentig, de overstap in 1998 naar het verbodstelsel dat de Mededingingswet kenmerkt niet zeer groot was.

Conclusie van het voorgaande moet zijn dat in Nederland sinds het begin van de nationale kartelwetgeving in 1935 tot zeker 1993 het misbruikstelsel de boventoon heeft gevoerd. Daarbij zijn er wel duidelijke verschillen tussen de vooroorlogse en de na-oorlogse toepassing (tijdens de oorlog is er geen sprake geweest van een -formeel- kartelbeleid): tijdens de eerste periode stonden -voornamelijk ten gevolge van de economische situatie- kartelbevorderende maatregelen op de voorgrond; in de na-oorlogse periode was het beleid meer gericht op beteugeling van de kartellering. Vanaf 1994 kreeg de Wem, dankzij verschillende generieke onverbindendverklaringen, in belangrijke mate een verbodkarakter, als gevolg waarvan de overstap naar het verbodstelsel van de Mededingingswet een geleidelijke was.

41 Men vergelijke onder meer Barents in: Steenbergen en Barents (1986), pag. 20; Van den Oosterkamp (1995), pag. 337 en Plompen (1996), pag. 158.

42 Zie daarover Van Eijkern (1964), pag. 198-200. Verticale prijsbinding wordt door Mok (1995), pag. 170 , omschreven als "de verplichting voor handelaren (...) goederen te verkopen tegen prijzen, die zijn vastgesteld door de leverancier van die goederen, of door voorafgaunde leveranciers". In vergelijkbare zin de Nota van Toelichting bij het Besluit houdende onverbindendverklaring van bepalingen betreffende verticale prijsbinding in mededingingsregelingen, Stb. 1964, 110 en De nieuwe kijk op vrij concurreren (ministerie van Economische Zaken) pag. 1:8. 
In de volgende paragrafen zal een aantal kenmerkende aspecten van de voormalige Nederlandse kartelwetgeving nader worden belicht. Zoals reeds eerder gesteld, zal niet worden gestreefd naar een volledige analyse van het Nederlands kartelrecht. Volstaan wordt met een bespreking van die aspecten, die voor beantwoording van de vraag omtrent de effectiviteit van de strafrechtelijke handhaving en de rechtsbescherming van de justitiabelen bij die handhavingsvorm relevantie hebben.

\section{De kenmerken van het Nederlandse kartelrecht tot 1998}

\subsection{Aanmelding, algemeen belang en 'de overheid'}

Het is hierboven verschillende malen benadrukt: het meest kenmerkend voor het Nederlandse kartelrecht tot aan de inwerkingtreding van de Mededingingswet in 1998 -of toch in ieder geval tot de generieke maatregelen van 1994 was het misbruikstelsel. Kartellering was geoorloofd, gebleken misbruik kon leiden tot onverbindendverklaring. Misbruik -op zich, zoals gezegd, een waardeneutrale term- stond daarbij gelijk aan schending van het algemeen belang. Dit algemeen belang speelde ook een rol bij de algemeen verbindendverklaring en de generieke onverbindendverklaring. Het was aan 'de overheid' dit algemeen belang te beschermen, hetzij via kartelbevorderende maatregelen, hetzij via maatregelen die misbruik zouden voorkomen of bestrijden. Om deze taak goed te kunnen vervullen, was zicht op kartellering op de Nederlandse markt voor de overheid van groot belang. Mede daarom bestond er voor ondernemers de verplichting om (vrijwel) ieder kartelinitiatief (maar niet een economische machtspositie) aan te melden.

\subsubsection{Aanmelding}

Misbruikstelsel en verbodstelsel gaan van principieel verschillende uitgangspunten uit. De taken van kartelinstanties verschillen in beide stelsels in niet mindere mate. In een verbodstelsel zijn de inspanningen vooral gericht op het doen naleven van het verbod en dus op het controleren óf het verbod wordt nageleefd ${ }^{43}$; in een misbruikstelsel daarentegen ligt de nadruk op de toetsing van de aanwezige kartels aan het algemeen belang, welke toetsing eventueel tot verbod of liever nog -gelet op het uitgangspunt van de wenselijkheid van kartels in dit stelsel- tot een aanpassing van het kartelgedrag kan leiden. In beide gevallen is het essentieel dat de kartelinstantie beschikt over betrouwbare en zo volledig mogelijke informatie over de aanwezigheid en reikwijdte van kartelafspraken. Zonder deze informatie kan het algemeen belang niet goed beschermd worden. In een verbodstelsel blijven er dan te veel kartels onontdekt; in een misbruikstelsel dreigt de aanwezigheid van met het algemeen belang strijdige kartels, zonder dat de overheid in

43 Daarnaast kan een belangrijk deel van de werkzaamheden liggen in de beoordeling omtrent het al dan niet verlenen van ontheffingen. Hierbij is overigens het voordeel dat het initiatief tot ontheffing van degenen dient uit te gaan die ontheffing van het verbod verlangen. Aan hen is het ook om aan te tonen dat hun afspraak het algemeen belang dient. 
staat is de betrokken ondernemingen in de door haar gewenste richting te sturen. ${ }^{44} \mathrm{Be}$ scherming van het algemeen belang en het voeren van een effectief beleid vergen derhalve informatie. Nu ligt het voor de hand dat deze informatie op tal van wijzen door de overheid kan worden verkregen -met name via klachten van mogelijk gedupeerden, klikbrieven van 'karteldissidenten' en ambtshalve gestart onderzoek-, maar het lijkt op het eerste gezicht onwaarschijnlijk dat deze door de leden van het kartel zelf zal worden verstrekt, of het zou onbedoeld moeten zijn, bijvoorbeeld - voorzover het een verbodstelsel betreftbij een vergeefs verzoek tot ontheffing. Toch was in de Wem, in navolging van het Kartelbesluit, een verplichting tot aanmelding -of officieel: mededeling-van in beginsel ${ }^{\text {ts }}$ iedere kartelactiviteit opgenomen. ${ }^{46}$ De voordelen hiervan spraken welhaast voor zich. Omdat bij de aanmelding alle relevante gegevens over de voorgenomen kartelafspraak gevoegd dienden te worden, leidde de aanmeldingsplicht -mits goed nageleefd- ertoe dat de Nederlandse overheid, en meer concreet het ministerie van Economische Zaken, een zeer waarheidsgetrouw beeld van de kartelsituatie op de Nederlandse markt zou verkrijgen. De informatie zou afkomstig zijn van degenen die over de meeste en meest betrouwbare informatie beschikten -de kartelleden zelf-, zonder de noodzaak van capaciteitsrovend ambtshalve onderzoek. Met deze informatie in de hand zouden de kartelontwikkelingen binnen Nederland goed gevolgd kunnen worden, zou het algemene kartelbeleid beter gevoerd kunnen worden en zou waar nodig sturend opgetreden kunnen worden. ${ }^{47}$ Het belang dat werd gehecht aan een correct kartelregister (zijnde de verzameling van alle aanmeldingen) werd weerspiegeld in de pogingen van de wetgever om zoveel mogelijk obstakels die aan aanmelding in de weg zouden kunnen staan, te slechten. Met name in dit licht diende het geheime karakter van het kartelregister te worden gezien. Omdat ervan kon worden uitgegaan dat ondernemers geen informatie zouden prijsgeven die bij derden, voornamelijk concurrenten en afnemers, bekend zou kunnen worden, werd uitdrukkelijk in de Wem bepaald dat derden geen recht op inzage van het kartelregister hadden.

44 Hiermee is niet gezegd dat marktpartijen in het ontbreken van adequaat overheidstoezicht een stimulans zien voor het opzettelijk inbreuk maken op het algemeen belang. Het is veeleer zo dat marktpartijen zich bij hun gedrag laten leiden door eigen voordeel en niet of tenminste minder door hetgeen al dan niet gunstig is voor het algemeen belang. Nu zal het vaak zo zijn dat algemeen en individueel belang parallellopen, maar zeker ook bij kartellering bestaat het gevaarvan een divergentie van beide belangen. Met afspraken die groot (financieel) voordeel -bijvoorbeeld dankzij een vaste, hoge minimum verkoopprijs- voor de kartelleden opleveren, is het algemeen belang meestal niet gediend. Als de overheid niet als controlerende en corrigerende instantie optreedt, ontbreekt de noodzakelijke rem op het handelen van marktpartijen in hun streven naar meer eigen voordeel.

45 Behoudens de uitzonderingsgevallen van artikel $4 \mathrm{Wem}$, waarin was voorzien in een mogelijkheid tot verkrijging van ontheffing van de aanmeldingsplicht en tot verlening van vrijstelling hiervan. De individuele ontheffing kon door de minister van Economische Zaken na een daartoe strekkend verzoek worden verleend. De vrijstelling had een algemeen karakter en zag op niet-aanmelding voor nader aangeduide groepen of soorten mededingingsregelingen. De criteria waaraan deze moesten voldoen alvorens in aanmerking te komen voor vrijstelling werden spoedig na het inwerkingtreden van de Wem vastgelegd in de beschikking van 3 juni 1960 (Stert. 1960, 107) tot uitvoering van artikel 4, eerste lid, zoals gewijzigd bij besluit van 14 mei 1987 (Stert. 1987, 92).

46 Denden -bijvoorbeeld concurrenten, afhemers of consumenten(organisaties)- zullen voor zover benadeeld veelal ook zonder wettelijke regeling een (vermeende) kartelactiviteit onder de aandacht van de overheid brengen. Dit mag niet verwacht worden van kartellerende ondernemingen.

47 Men vergelijkeSchaffmeister(1978), pag. 123: "Das Gesetz bezweckt, durcheine allgemeine Anmeldepflicht für sămtliche (rechtsverbindliche) Absprachen (...) eine amtliche Kontrolle auszuüben". 
De verstrekte informatie werd gereserveerd voor intern gebruik. ${ }^{48}$ Ook verder bestond er weinig gevaar voor ondernemers om tot aanmelding over te gaan. De aanmeldingsplicht was als gezegd voomamelijk bedoeld om een beeld te krijgen van de algemene karteltendens in Nederland en niet om tegen de aanmelder te kunnen optreden ingeval deze het algemeen belang had geschaad. Indien een misbruiksituatie desalniettemin werd geconstateerd, dan leidde dit in de praktijk niet tot een onmiddellijke onverbindendverklaring maar in beginsel hoogstens tot een aanpassing van het kartel, zodat het wel binnen de grenzen van het toelaatbare zou vallen. Een (strafrechtelijke) sanctie wegens gepleegd misbruik behoorde in het geheel niet tot de mogelijkheden. Dit gevoegd bij de omstandigheid dat tegen niet-aanmelding strafrechtelijk kon worden opgetreden ${ }^{49}$, maakt duidelijk dat het toch niet zo onwaarschijnlijk is dat -tenminste in een misbruikstelsel- de kartellerende ondernemingen zelf, en tot op zekere hoogte vrijwillig, informatie over hun gedragingen verschaffen aan de instantie die moet beoordelen of deze gedragingen de toets van het algemeen belang kunnen doorstaan. Dit was anders indien op voorhand reeds vaststond dat het ministerie van Economische Zaken over het betreffende kartel het onaanvaardbaar zou uitspreken of indien het kartel onder een generiek verbod viel. ${ }^{50}$ Er mag van worden uitgegaan dat in die situaties ondernemingen afzagen van aanmelding."1

Uit de jaarverslagen over de toepassing van de Wem kan worden afgeleid dat het kartelregister tot op zekere hoogte zijn taak heeft vervuld. Weliswaar werden niet alle kartelinitiatieven gemeld en bleven aan de andere kant kartels aangemeld die niet meer bestonden, toch toonde het kartelregister enkele tendensen in de kartelontwikkeling, zowel wat betreft de aard van de kartels als wat betreft hun aantallen.

48 De niet-openbaarheid van het kartelregister is veelvuldig ter discussie gesteld. Voorstanders wezen op de preventieve werking van mogelijke openbaarmaking van gegevens en de daarmee gepaard gaande negatieve publiciteit, op het recht van consumenten kennis te nemen van afspraken die wellicht in hun nadeei zijn (met als gevolg dat zij via de rechter of de overheid stappen zouden kunnen ondernemen tegen het kartel), op de verruiming van de mogelijkheden tot bewaking van het algemeen belang door niet-overheidsorganen(bijvoorbeeld consumentenorganisaties, zie hierover Mok (1969 II), pag. 136) en -wel zeer idealistisch-op een toename van het begrip voor kartelactiviteitenomdat ook de voordelen duidelijker naar voren zouden komen. Hiertegenkan worden ingebracht dat (nog afgezien van de reeds gememoreerde voordelen van een gesioten kartelregister) preventieve werking niet in het misbruikstelsel paste, waarin de geldigheid van kartels voorop staat. En waarom zou voorkomen moeten worden dat een geldige en niet zonder meer schadelijke overeenkomst tot stand komt? Bovendien zou openbaarmaking zeker als een sanctie worden gevoeld (bedacht moet worden dat in de mogelijkheid tot openbaarmakingvan gegevens in de Wem is voorzien en wel als sanetie in die gevallen, waarin een kartel in strijd met het algemeen belang is gebleken), terwijl kartellering als zodanig niet verboden was. Een voorstel in 1981 tot wijziging van de Wem op dit punt (Wetsvoorstel inzake Wijziging van de Wet economische mededinging (invoering van een openbaar kartelregister), 16 555 ), welk voorstel onder meer voorzag in vrije toegang tot het kartelregister voor een ieder, behoudens in gevallen waarin zwaarwegende belangen zich hiertegen zouden verzetten, heeft ternauwernood de eindstreep niet gehaald omdat het door de Eerste Kamer werd verworpen. Dat de openbaarheid van het kartelregister vervolgens in de koelkast belandde, werd door Mok (1987 III), pag. 72-73. betreurd.

49 De praktijk was echter dat dit niet gebeurde. Volstaan werd met een aansporing om alsnog tot aanmelding over te gaan. Vergelijk Mok (1983), pag. 670-671.

50 In deze zin ook Mulder in zijn noot bij HR 2 juni 1953, SEW (1953), pag. 470.

51 Het moge duidelijk zijn dat een aanmeldingsplicht zoals de Wem die kende geen functie zal kunnen hebben in een verbodstelsel. Zij zou evenveel effect hebben als een aan daders van een strafbaar feit op te leggen verplichting om zelf bij de politic aangifte te doen. 


\subsubsection{Het algemeen belang als criterium voor overheidsinterventie}

De toepassing van overheidswege van de in de Wem voorziene maatregelen -algemeen verbindendverklaring, generieke- en individuele onverbindendverklaring en aanwijzingen aan economische machtsposities- was gekoppeld aan het algemeen belang-criterium 5 . Dit begrip werd in de wet niet nader gedefinieerd, hetgeen ook niet goed denkbaar zou zijn geweest. 'Het' algemeen belang werd (en wordt) vormgegeven door tal van (niet limitatief op te sommen) aspecten, waarvan, gelet op de doelstelling van kartelwetgeving, in zijn algemeenheid slechts kan worden gezegd dat zij primair -maar niet exclusiefeconomisch getint waren. ${ }^{53}$ Bovendien lag 'het' algemeen belang ook niet vast in de tijd: een maatregel die in de jaren dertig in het algemeen belang was, was dit niet zonder meer in de na-oorlogse jaren. Aan dit criterium kon dan ook een zekere vaagheid niet worden ontzegd en dat was ook de opzet van de wetgever. Door het criterium voor overheidsinterventie rekbaar te houden, werd gerealiseerd dat de uitvoerende instantie met veranderende economische (niet in de laatste plaats conjuncturele) ontwikkelingen én met veranderende (beleids)inzichten rekening zou kunnen houden. Terecht stelde Schouten dat de vaagheid van het algemeen belang-begrip voortvloeide uit de materie en de 'tweezijdigheid' (kartelstimulering en kartelbeperking) van de wet. Juist omdat de houding tegenover kartels neutraal was (en dus het uitgangspunt was dat kartellering zowel in het algemeen belang als daarmee in strijd kon zijn), was in zijn algemeenheid niet aan te geven hoe economische orde en mededinging er uit moesten zien en dus evenmin hoe de overheid zou moeten optreden. ${ }^{54}$ Het vage begrip 'algemeen belang' stelde de overheid in staat op een bepaald moment, in een bepaalde situatie met inachtneming van alle door haar relevant geachte aspecten een beslissing te nemen. Deze flexibiliteit vindt men, zoals in paragraaf 1 reeds bleek, ook in de praktijk terug. In de crisisjaren voor de Tweede Wereldoorlog was het algemeen belang volgens de toenmalige bewindslieden gediend

52 Dit was reeds het geval in de Ondernemersovereenkomstenwet 1935. In het Kartelbesluit ontbrak dit vereiste teneinde een sneller en meer doeltreffend optreden mogelijk te maken. Dit zou volgens Het Kartelbesluit (1941) niet leiden tot eenaanzienlijkeintensivering van het overheidsoptredennoch tot overmatig optreden omdat de overheid hoe dan ook niet zou ingrijpen als het algemeen belang hierbij niet uitdrukkelijk gebaat zou zijn. Kritisch hierover Maitland (1946), pag. 52. Achteraf kan geconcludeerd worden dat het schrappen van het algemeen belang-criterium geen nadelige invloed heeft gehad; zoals reeds gemeld is gedurende de bezetting het Kartelbesluit nooit formeel toegepast en in de na-oorlogse jaren heeft de Nederlandse overheid in de praktijk steeds met het criterium rekening gehouden.

53 "Onder het algemeen belang vallen zowel niet-economische factoren als structurele factoren van economische aard"; deze stelling werd weliswaar verdedigd bij de openbare behandeling van het ontwerp Prijzenwet (Handelingen 15 november 1960, pag. 3127), maar zij gold evenzeer voor de Wem. Bij de beraadslagingen van het ontwerp van de Ondernemersovereenkomstenwet 1935, Handelingen 1934 1935, pag. 1507, voerde Joekes (Vrijzinnig-democratische Bond) vier facetten aan die volgens hem deel uitmaakten van het begrip algemeen belang: ten eerste de economische interessen (door Van den Tempel, Sociaal-DemocratischeArbeiderspartij, toegespitst op het concurrentievermogenop de wereldmarkt); ten tweede sociale factoren, met name bestaande uit de belangen van werknemers; ten derde de respectering van het persoonlijk initiatief en van persoonlijke energie (het vrije ondernemerschap als uitgangspunt van het economisch denken) en ten vierde het verbruikersbelang, dat niet onevenredig zou mogen worden geschaad. Niet noodzakelijk was een voordeel voor de hele gemeenschap; voldoende was een objectieve positieve bijdrage van de te nemen maatregel aan het algemeen belang (VV TK 1938-1939, 446 nr. 4, pag. 4).

Schouten (1970), pag. 25-26. 
bij een afscherming van de markt door kartels, hetgeen zelfs leidde tot verschillende algemeen verbindendverklaringen. In het eerste decennium na de Tweede Wereldoorlog werd met name uit economische overwegingen relatief streng door middel van onverbindendverklaringen tegen verschillende kartelvormen opgetreden. In de jaren negentig veranderden de beleidsinzichten dusdanig dat de meest belangrijke vormen van kartellering als zodanig in strijd met het algemeen belang werden geacht, hetgeen leidde tot een aantal generieke maatregelen en een toenadering tot het verbodstelsel.

Het probleem van vage begrippen in een wet is echter wel dat er voor de justitiabelen weinig rechtszekerheid bestaat. Dat was ook hier het geval: het was voor ondernemers nauwelijks mogelijk om -behoudens in die gevallen waarin bepaald gedrag generiek onverbindend was verklaard of waarin ook zonder een dergelijke maatregel de visie van de overheid voldoende vaststond- te voorspellen of hun mededingingsregeling al dan niet tegen het algemeen belang indruiste. ${ }^{55}$ Dit impliceerde tevens dat er van deze regeling weinig preventieve werking uitging. Ondernemers die niet konden inschatten of hun gedraging binnen de grenzen van het toelaatbare bleef, waagden, gelet op de voordelen die kartellering hun zou brengen, de gok. Een echte gok was het eigenlijk niet eens, aangezien het enige gevaar voor de ondernemers bestond in een (in de praktijk slechts zelden toegepaste ${ }^{56}$ ) onverbindendverklaring van de kartelafspraak. Hierbij dient overigens te worden aangetekend dat een streven naar preventieve werking. dus naar voorkoming van kartellering, in de Wem ook niet werd beoogd, behalve in de gevallen waarin een generieke maatregel was afgekondigd.

\subsection{3 'De overheid'}

In het bovenstaande is verschillende malen gerefereerd aan 'de overheid': 'de overheid' nam kartelmaatregelen, kartels moesten worden aangemeld bij 'de overheid', 'de overheid' beoordeelde of het algemeen belang al dan niet was geschonden etc. Wat hieronder in dit kader moest worden verstaan, werd nog in het midden gelaten. Het belang van bedoeld begrip vergt hier enige aandacht. De wetgever van 1935 opteerde voor het attribueren van kartelbevoegdheden aan de minister van Economische Zaken, en verwierp daarmee de toepassing van de wet door een onafhankelijk bestuursorgaan of door een rechterlijke instantie. Van deze keuze is in het Kartelbesluit ${ }^{57}$ noch in de Wem ten gronde afgeweken, met dien verstande dat in de Wem de minister van Economische Zaken slechts samen met de minister "wie de zaak mede aangaat" ${ }^{n 58}$ bevoegd was en de regering (naast de

55 Tot op zekere hoogte bood het algemeen belang-criterium voor de ondernemers wel bescherming tegen onevenredigoverheidsoptreden. De nadelenvoor de samenlevingmoesten immers aantoonbaar en objectief zijn. Dit bracht tevens met zich dat de bewijslast op de overheid nustte. Dat dit laatste ten onrechte niet steeds in de praktijk werd gebracht, bleek reeds in paragraaf 1 . Zie hierover eveneens kritisch Mok (1995), pag. 95 e.v..

56 Zie hierover paragraaf 2.2 .2 .

57 Bij de totstandkoming was dit de Secretaris-Generaal van het Departement van Handel, Nijverheid en Scheepvaart. Na de bezetting werd weer de minister van Economische Zaken bevoegd.

58 De minister van Economische Zaken diende, zodra een bepaalde maatregel mogelijke gevolgen voor het beleidsterrein van een collega-minister had, dexe in het besluitvormingsproces te betrekken, hetgeen inhield, dat "optreden ter bevordering van de marktwerking niet mogelijk is zonder het consent van bewindslieden die, terecht of ten onrechte, geacht worden het specifieke belang van de betrokken 
wetgever in formele zin) de tot generieke onverbindendverklaring bevoegdeinstantie was. Deze keuze was een juiste. De Ondernemersovereenkomstenwet 1935 en has opvolgsters waren onmiskenbaar species van het genus ordeningswetgeving, 'instrumpten van economisch beleid'. ${ }^{59}$ Het kartelbeleid, of zo men wil het mededingingsbeleic maakte integraal deel uit van het gehele economische beleid van de overheid. Een crgelijke wetgeving, met daaraan inherente vage toepassingsnormen -in casu het algemee belangen grote discretionaire bevoegdheden ${ }^{6}$, en de aard van de te nemen maatregen (met name de algemeen verbindendverklaring en de -voorzover het de Wem betrof-gnerieke onverbindendverklaring) leenden zich niet voor toepassing door een rechterlijp instantie. ${ }^{61}$ Integendeel: toepassing door de rechter van bijvoorbeeld de onverbindendvrklaring zou het economische beleid van de overheid kunnen doorkruisen. Bij de behndeling van het ontwerp van de Ondernemersovereenkomstenwet 1935 werd daarenpven de expertise bij de rechterlijke macht met betrekking tot de voor die wet relevante enomische vraagstukken in twijfel getrokken. ${ }^{62}$ De optie van een zelfstandig bestuusorgaan in plaats van de minister van Economische Zaken als bevoegde kartelinstantie wrd afgewezen omdat ook die optie tot gevolg zou hebben dat het kartelbeleid zou wordengescheiden van het overige economische beleid. De mogelijkheid voor de minister van Fonomische Zaken om het kartelbeleid te sturen, zou in dat geval zich niet uitstrekke tot het geven van aanwijzingen voor het concrete geval. In het verlengde daarvan zo ook de ministeriële verantwoordelijkheid voor het beleid afnemen en dus de controle loor het parlement op het beleid. Gelet op de vrees in het parlement van te veroaand igrijpen door de overheid in het economische leven, lag een dergelijke optie nog minder voor de hand. Daar kwam nog bij dat het verspilling van capaciteit werd geacht om een nieuw orgaan te belasten met taken, waarvoor het ministerie van Economische Zaken de benodigde expertise reeds in huis had. ${ }^{63}$

De keuze viel dus uiteindelijk terecht op de minister van Economische Zaken, maar zij had wel heel wat voeten in aarde gehad. Met name ${ }^{64}$ de concentratie van bevoegdheden bij één bewindsman (met het gevaar voor misbruik), alsmede de -uit de grote discretionaire

sector te behartigen", aldus Van As (1986) pag. 835.

59 Braakman (1997 II), pag. 196, die dit ten aanzien van de Wem stelt.

60 Zie hierover ook de opmerkingen van Braakman (1997 II), pag. 196.

61 Anders: Borst (1954) die zich (althans waar het de onverbindendverklaring betrof) juist een vurig pleitbezorger voor controle door de rechter toonde. Hij stelde dan ook (op pag, 25): "Beleid, d.i. een bepaalde, op de toekomst gerichte doelstelling, past uitstekend op de vervolging van kartels, dat is typisch een taak voor het bestuur, maar het oordeel over de maatschappelijke betamelijkheid, het onderscheiden tussen goed en kwaad, kan men beter aan een rechter overlaten". Zeer kritisch over deze opvatting is Samkalden (1954), pag. 273 e.v..

62 Opmerkelijk genoeg werden tijdens de behandeling van het wetsontwerp inzake de Ondernemersovereenkomstenwet 1935 tevens vraagtekens gezet bij de op het departement van Economische Zaken aanwezigeexpertise. De twijfels golden met name de expertise ten aanzienvan de positic en belangen van de arbeiders en consumenten.

63 Bij de behandeling van het wetsvoorstel Mededingingswet is er een discussie ontstaan over de mate vanzelfstandigheid van het orgaan dat met de uitvoering van de Mededingingswetzou worden belast. In dit geval achtte echter de Tweede Kamer een onafhankelijke positie ten opzichte van de minister van Economische Zaken raadzaam.

64 Gewezen werd bijvoorbeeld ook op de grote werkdruk waarmee (ook toen reeds) de minister te kampen had. 
bevoegdheid van de minister voortvloeiende- beperkte mogelijkheden voor de Eerste en Tweede Kamer om adequaat toezicht op het handelen van de bewindsman uit te oefe$n^{6}{ }^{65}$, leidden tot de invoering van een aantal extra voorwaarden die misbruik moesten voorkomen, een objectieve afweging van belangen moesten garanderen en de controlemogelijkheden van het pariement moesten vergroten. ${ }^{\infty}$ Een in het kader van de besluitvorming belangrijke aanvulling was de verplichting van het inwinnen van -een overigens niet bindend- advies vooraleer mocht worden overgegaan tot het treffen van een kartelmaatregel. ${ }^{67}$ In de Ondernemersovereenkomstenwet 1935 werd een vaste commissie uit de Economische Raad als adviesorgaan aangewezen. Hierin waren de belangrijkste marktpartijen vertegenwoordigd -naast leden van de Economische Raad ook leden van de Middenstandsraad, de Nijverheidsraad en vertegenwoordigers van de arbeidersorganisaties ${ }^{68}$. teneinde een goed beeld te krijgen van alle relevante facetten van het algemeen belang. Zoals gold voor veel van de waarborgen uit de wet van 1935, werd verplichting tot adviesinwinning niet in het Kartelbesluit overgenomen ${ }^{69}$ : er resteerde op grond van artikel

65 Zo merkte Rutgers van Rozenburg tijdens de Algemene Beraadslaging, Handelingen 1934-1935, pag. 1498, op dat "wij in dit wetsontwerp aan den Minister een blanco volmacht geven om in deze uiterst ingewikkelde materie te schalten und walten zoo goed en zoo kwaad als hij kan". "Zulk een volledige machtsoverdracht aan de Regeering mag niet ad infinitum zijn, de Kamer mag op dit terrein niet voor goed abdiceeren", Hoe gevoelig de kwestie lag, bleek nogmaals in 1939 bij de behandeling van het wijzigingswetsvoorstel. Eèn van de voorstellen zag op de aanscherping van de tekst van de wet teneinde te verduidelijken dat rechters zich niet in beleidskwesties mochten mengen (MvA TK 1939-1940, 68, nr. 1, pag. 2). Beide Kamers echter vreesden dat de regering de rol van de rechter (zie bijvoorbeeld Blomjous, Handelingen 1939-1940, pag. 78), van de Economische raad (VV TK 1938-1939, 446. 4, pag. 3) en van de volksvertegenwoordiging (Onder meer Blomjous, Handelingen 1939-1940, 68, pag. 77) wilde terugdringen.

66 Hieronder vielen onder meer de motiveringsplicht, opgenomen dankzij het amendement Smeenk/Terpstra (beiden Anti-Revolutionaire Partij), TK 1934-35, 64, nr. 7 en de halfjaarlijkserapportageverplichting van de minister aan de Staten-Generaal over de toepassing van de wet. Beperkingen die specifiek op de door de minister te nemen maatregelen betrekking hadden, komen bij de bespreking van die maatregelennog aan de orde. Hier zij reeds onderstreept dat men in ieder geval niet zover ging om zoals Van Oven (1934), pag. 540 had voorgesteld- de toepassing van een maatregel afhankelijk te maken van parlementaire goedkeuring.

67 De Ondernemersovereenkomstenwet 1935 volgde overigens een enigszins vreemde constructie. De minister was bevoegd (dus niet verplicht) om advies in te winnen alvorens een beslissing te nemen omtrent algemeen verbindend verklaring of onverbindend verklaring. Aangezien deze maatregelen telkens onder bij AMvB te stellen voorwaarden dienden te worden genomen, en voor deze AMvB wel advisering wettelijk verplicht was, werd in iedere zaak geadviseerd. Desalnietternin was de bescherming hierdoor niet optimaal. Zie hieromtrent Maitland (1946), pag. 18. De commissie was verplicht belanghebbendenen (voor zover die niet tot de belanghebbendengerekendkonden worden) vertegen. woordigers van werkgevers en werknemers uit betreffende bedrijfstak, te horen. De combinatie van adviesinwinning -zij het dat dezeniet optimaal was geregeld-en hoorplicht van de commissie leverde, aldus Patijn (1942), pag. 15, inzicht in de problemen van een bedrijfstak en was aldus een belangrijk onderdee! van de kartelprocedure.

68 Consumenten waren niet vertegenwoordigd, hoewel zij een onmiskenbaar belang hadden bij de uitkomst van de besluitvorming. Reden voor hun afwezigheid was met name gelegen in de omstandigheid dat zij niet georganiseerd waren.

69 Als reden hiervoor werd door Het Kartelbesluit (1941), pag. 1682, genoemd: "De oude procedure, voornamelijk beoogende te waarborgen, dat alle betrokken belangen in aanmerking zouden worden genomen, maakte een snel ingrijpen, waaraan onder de huidige omstandigheden zoozeer behoefte kan bestaan, moeilijk". 
8 lid 3 Kartelbesluit slechts een bevoegdheid voor de Secretaris-Generaal om tlanghebbenden of anderen te horen. In de na-oorlogse praktijk werd overigens steds advies ingewonnen, vanaf 1949 bij een weer in het leven geroepen vaste commisie van de Economische Raad, in 1950 opgevolgd door de Commissie bedrijfsregelingen. i de Wem werd de adviseringsplicht weer in ere hersteld. ${ }^{70}$ Met advisering werd de ommissie economische mededinging belast, samengesteld uit leden die een bijzondere desindigheid hadden op het gebied van de mededinging en het mededingingsrecht. ${ }^{71}$ Med gelet op deze deskundigheid en onafhankelijkheid ${ }^{72}$ van deze uit tenminste twaalfgewone $e^{73}$ leden bestaande commissie heeft zij een belangrijke rol gespeeld in het formel kartelbeleid. $^{74}$

In het voorgaande is ingegaan op de rol van het algemeen belang bij het nmen van kartelmaatregelen door 'de Nederlandse overheid'. In het volgende zullen de veichillende maatregelen 'tegen' kartels nader worden besproken. Allereerst zal echter worderingegaan op het object van de maatregelen: de mededingingsregeling.

\subsection{Mededingingsregelingen}

In de Wem stond -naast de economische machtspositie, die in paragraaf 2.4 aan od komt, het begrip mededingingsregeling centraal. ${ }^{75}$ Dit begrip werd in artikel 1 lid 1 geefinieerd ais:

70 De plicht werd overigens in 1995 beperkt op grond van de Wet afschaffing adviesverplichtingen, Stb. 1995, 355 .

71 Voor de wijze waarop het advies tot stand kwam, zie men Besluit van 11 november 1958, houdende regelen omtrent de werkwijze der Commissie economische mededinging, bedoeld in artikel 28 van de Wet economische mededinging, Stb. 1958, 489, zoals gewijzigd bij Besluiten van 2 april 1987. Stb. 1987, 109 en 7 september 1993, Stb. 500. Zie over deze commissie kort Van der Wal (1995). pag. 734 .

72 De adviescommissie was onafhankelijk en uitdrukkelijk niet gelieerd aan de Sociaal Economische Raad. De onafhankelijkheid bleek mede hieruit dat zij geen verantwoording verschuldigd waren aan een achterban (te denken valt aan consumenten, werknemers of werkgevers); zij maakten geen deel uit van de commissie als vertegenwoordigers van een bepaald belang, maar werden zoals gezegd geselecteerd op grond van hun expertise.

73 Op grond van artikel 28 lid 2 Wem konden tevens buitengewone leden, experts op bepaaldegebieden, worden benoemd. Overigens kon op grond van artikel 31 lid 3 Wem van eventuele dissenting opinions in het advies melding gemaakt worden.

74 In het informele kartelbeleid -op welk deel van het Nederlandse beleid in de praktijk duidelijk de nadruk lag-was er daarentegen geen rol voor de Commissie economische mededinging weggelegd. Bij de totstandkoming van de Mededingingswet heeft de Commissie economische mededinging overigens eveneens een advies kunnen uitbrengen.

75 DeOndernemersovereenkomstenwet1935 en het Kartelbesluit bezigden respectievelijkde begrippen ondememersovereenkomst ("afzonderlijke bedingen en besluiten, economische verhoudingen betreffende, welke verplichtingen inhouden, wijzigen of doen te niet gaan tussen personen, die cen bedrijf uitoefenen in enige tak van handel of nijverheid in de ruimste zin, of die daarbij betrokken zijn, alsmede tussen bovengenoemde personen en hun organisaties") en bedrijfsregeling ("bepalingen ter regeling van de mededinging, financieele verplichtingen daaronder begrepen, tusschen personen, die een bedrijf uitoefenen in cenigen tak van handel of nijverheid in den ruimsten zin"). 
een overeenkomst of burgerrechtelijk besluit, waarbij de economische mededinging tussen ondernemers wordt geregeld

Geheel in lijn met het misbruikstelsel behelsde deze definitic geen waardeoordeel ten aanzien van kartels. Ook de inhoudelijke eis van de regeling van de economische mededinging $^{76}$ gaf geen negatieve kwalificatie: het was niet relevant of de regeling een negatieve dan wel een positieve uitwerking op de mededinging had. Bedoelde eis beperkte slechts de reikwijdte van de Wem tot de categorie afspraken waarvoor deze bedoeld was, te weten afspraken betreffende de concurrentiepositie van ondernemers". De wet richtte zich uitsluitend tegen gedragingen van ondernemers. ${ }^{7 *}$ Hieronder moest op grond van het eerste lid van artikel 1 worden verstaan:

een natuurlijke persoon, die door het uitoefenen van een beroep of bedrif, anders dan in loondienst, en een rechtspersoon, die met als doel de uitoefening van een beroep of bedrijf, aan het economisch verkeer deelneemt, met of zonder winstoogmerk

Door de verwijzing in deze definitie naar het begrip 'rechtspersoon' en de daaraan inherente aansluiting bij Boek $2 \mathrm{BW}$, werd er voor een juridische invulling van het ondernemersbegrip gekozen. Dit betekende een afwijking van het communautair recht, waarin een ruimere- economische benadering van het ondernemingsbegrip wordt gehanteerd"; in de praktijk was het verschil met het communautaire recht overigens marginaal. ${ }^{30}$ Ook ten aanzien van de begrippen 'overeenkomst' en 'burgerrechtelijk besluit' werd het civiele pad bewandeld. Voor beide was de juridische binding kenmerkend ${ }^{81}$. De overeenkomst

76 Door Mok (1995), pag. 2, kernachtig getypeerd als 'strijd om klanten'.

77 De expliciete verwijzing naar economischemededinging moest uitsluiten dat de Wem zich uitstrekte over concurrentie op de arbeidsmarkt. Deze beperking gold reeds in de wet van 1935. Zie MVT TK 1933-1934, 460, nr. 3, pag. 3: "Voor bedingen en besluiten, waarvan het doel ligt in de sociale verhoudingen van den betreffenden bedrijfstak, gelden de bepalingen van dit wetsontwerp niet. Uiteraard treedt het dus ook niet op het terrein van het vraagstuk van de verbindendverklaring van collectieve arbeidsovereenkomsten". In de MvA TK 1934-1935, 64, nr. 1, pag. 4, werd onderstreept dat de wet wel zag op kartels waarin de sociale verhoudingen werden geregeld, zolang deze regeling maar niet het doel van het kartel was.

78 Het ondernemersbegrip werd overigens pas in 1994 in de Wem geïntroduceerd. Tot deze introductie werden de termen onderneming en (uitoefenaren van) vrije beroepen gehanteerd. Deze laatste categorie viel op haar beurt sinds 1987 (Wet van 21 april 1987, houdende vaststelling van de Wet inkomens vrije-beroepsbeoefenaren, Stb. 1987, 186) onder de reikwijdte van de Wem.

79 Zie hierover hoofdstuk 2.

80 Dit hing hiermeesamendatoverige samenwerkingsverbanden-vennootschaponder firma, maatschap en commanditaire vennootschap-als collectiviteit van natuurlijke personen gekwalificeerd konden worden en zodoende toch binnen de definitie vielen. Zie hierover Mok (1995), pag. 76. Het antwoord op de vraag in hoeverre delen van een concern als afzonderlijke ondernemers konden worden gezien (van belang voor de vraag of een coneerninterne afspraak als een overeenkomst tussen ondernemers kon worden aangemerkt) was -evenals het geval is in het kader van artikel 81 EG- afhankelijk van de mate van zelfstandigheid die aan de verschillende concerndelen toekwam.

81 In afwijking hiervan was het voor de bindende werking van een bedrijfsregeling in het Kartelbesluit niet noodzakelijk dat de regeling ook juridisch bindend was. Voldoende was, aldus de Hoge Raad in een op 2 juni 1953 gewezen arrest (SEW (1953), pag. 465 m.nt. A.M.), dat naleving van de regeling via -economische-druk kon worden afgedwongen. Hierin week het Kartelbesluit af van de Ondernemersovereenkomstenwet 1935. Dit verschil was voigens Mulder in zijn noot bij genoemd arrest terug te voeren op de veranderde economische realiteit. Als eerste aspect hiervan noemde Mulder het volgen- 
en het besluit hadden beide een obligatoir, verbintenisscheppend karakter en konden worden aangemerkt als civielrechtelijke rechtshandelingen. ${ }^{82}$ Ook hier week de Wem af van het communautaire recht waar het kartelbegrip wel verschillende vormen van nietbindende afstemming omvat. Historisch gezien is deze beperking van de omvang van het kartelbegrip voornamelijk te verklaren uit de te nemen maatregelen, die juridische binding voorop stellen. Niet bindende regelingen konden immers niet algemeen verbindend dan wel (generiek) onverbindend worden verklaard. Bij de aanscherping van het beleid in de jaren negentig zijn -met behoud van de verplichte bindendheid van mededingingsregelingen- de mogelijkheden om ook tegen niet-bindend gedrag op te treden verruimd. Dat overigens ook voor die tijd niet-bindend gedrag niet geheel buiten schot viel, zal hierna nog blijken.

\subsection{Maatregelen tegen mededingingsregelingen}

In het voorgaande is reeds verschillende malen gerefereerd aan de maatregelen die in het kader van de Wem en haar voorgangsters tegen mededingingsregelingen konden worden genomen: algemeen verbindendverklaring, onverbindendverklaring en generieke onverbindendverklaring. De volgorde wordt hierna bij de bespreking aangehouden omdat deze volgorde de ontwikkeling in het Nederlandse kartelrecht sinds zijn ontstaan weerspiegelt.

\subsubsection{De algemeen verbindendverklaring}

Zoals reeds in het historisch overzicht is aangegeven, is het met name het ontbreken van kartelbevorderende bevoegdheden geweest dat heeft geleid tot de totstandkoming van de eerste Nederlandse kartelwet, de Ondernemersovereenkomstenwet 1935. Kartels zouden de (verkoop)prijzen op een rendabel en aanvaardbaar niveau kunnen houden danwel brengen en aldus een bijdrage kunnen leveren aan instandhouding van productie en werkgelegenheid. Kartels die dit konden bewerkstelligen waren in het algemeen belang; onderne-

de. Onder de wet van 1935 was er sprake van een machtspositie aan de zijde van de afnemers, die ervoor zorgde dat afspraken van ondernemers (aan de aanbodzijde) innerlijk zwak waren, tenzij er sprake was van juridische afdwingbaarheid; onder het Kartelbesluit (althans na de Tweede Wereldoorlog) was de binding van kartelleden hechter en hun positie ten opzichte van de vraagzijde sterker: juridische gebondenheid maakte in veel gevallen plaats voor vrijwillige gebondenheid. Het tweede hiermee samenhangende- aspect van de ontwikkeling van de economische realiteit betrof het oprukken van de onverbindend verklaring ten koste van de algemeen verbindend verklaring. Zowel het eerste aspect (een toegenomen aantal kartels kende geen juridische binding) als het tweede aspect (beetindiging van een kartel vereiste in tegenstelling tot algemeen verbindend verklaring hiervan niet zonder meet juridische binding) maaktendat optreden tegenregelingenzonder bedoelde binding in belang toenam. Toch keerde de Wem-aanvankelijk-terug naar het systeem van de Ondernemersovereenkomstenwet 1935, mede omdat het Kartelbesluit ook op dit punt als te vérgaand werd beschouwd.

82 Ten aanzienvan de overeenkomst kon worden aangesloten bij artikel 6:213 BW; "Een overeenkomst (...) is een meerzijdige rechtshandeling, waarbij een of meer partijen jegens een of meer andere een verbintenis aangaan". Voor besluiten gold dat zij "verbintenisscheppende rechtshandelingen van rechtspersonen of andere samenwerkingsverbanden", aldus Mok (1995), pag. 47. In tegenstelling tot de overeenkomst was het besluit een eenzijdige rechtshandeling afkomstig van een overkoepelende organisatie of een samenwerkingsbureau waardoor de aangesloten ondernemers worden gebonden. 
mers die zich om welke reden dan ook aan deze kartellering onttrokken, lapten in die visie in feite het algemeen belang aan hun laars. Immers kon de weigering van enkelen om in een kartel te participeren, de werking van de gehele kartelafspraak ondermijnen. ${ }^{3}$ Voor die gevallen waarin de bestaande vrijheid tot kartellering geen bevredigende uitkomst bood, moest de overheid, overtuigd van het belang van kartels, handelend kunnen optreden. Daarvoor werd de bevoegdheid tot algemeen verbindendverklaring in het leven geroepen. Deze maatregel bewerkstelligde wat de naam reeds aangeeft: de kartelafspraak -of een deel hiervan ${ }^{34}$ - werd door deze maatregel voor alle ondernemers in een bepaalde bedrijfstak verbindend, dus met name ook voor die ondernemers die hadden geweigerd vrijwillig aan een kartel deel te nemen. ${ }^{85}$ Door de algemeen verbindendverklaringen ontstonden er verbintenissen voor alle getroffen ondernemingen, die mitsdien gehouden waren om de kartelafspraken na te leven. ${ }^{86}$

De maatregel greep diep in in de contractsvrijheid van ondernemers en in hun vrijheid om zelf het marktgedrag te bepalen. Het betrof, zoals Mok terecht stelde ${ }^{57}$, een ordeningspolitiek-wapen. Begin jaren dertig was een dergelijk vergaande overheidsinterventie in het marktproces en in de vrijheid van ondernemers een nog betrekkelijk onbekend fenomeen in Nederland. En hoewel over de noodzaak van deze interventiemogelijkheid relatief weinig discussie bestond, werden in het parlement wel bedenkingen geuit tegen macht waarover de overheid en meer in het bijzonder de minister van Economische Zaken zou komen te beschikken. Er werd zelfs -het kwam hierboven reeds ter sprake-gevreesd voor misbruik van macht. Gelet hierop was het niet verwonderlijk dat tijdens de parlementaire behandeling met name aandacht werd besteed aan het aan banden leggen van de macht van de minister, door de algemeen verbindendverklaring aan verschillende voorwaarden te binden. Belangrijke beperkingen vonden hun weg ook naar de wet ${ }^{\mathrm{st}}$ en zijn overgeno-

83 Bij de behandeling van het wetsvoorstel van 1934, MvT TK 1933-1934, 460, nr. 3, pag. 2, verwoordde de minister van Economische Zaken het standpunt van de regering als volgt: "Bij herhaling doet zich (...) het verschijnsel voor, dat het tot stand komen of ten uitvoer leggen van overeenkomsten, als bovenbedoeld, afstuit op den onwil van enkelen, die, van bet nut van samenwerking niet overtuigd, niet tot het prijsgeven van eenige vrijheid bereid zijn. Bij de bemoeiingen, die het Departement van EconomischeZaken doorloopend met tal van bedrijfstakken heeft, kon meer dan eens worden vastgesteld, dat voor een dergelijk afzijdig blijven elke redelijke grond ontbrak, of althans, dat de bezwaren, tegen toetreding ingebracht niet onoverkomelijk waren". Zie hierover ook Schouten (1973), pag. 12-13 en Mulder (1950), pag. 111.

84 Voor de Ondernemersovereenkomstenwetwerd in MvT bij artikel 2, TK 1933-1934, 460, nr. 3, pag. 3 gesteld dat het wenselijk was "de verbindendverklaring, in voorkomend geval, te beperken tot afzonderlijke bedingen van een kartelcontract, respectievelijk afzonderlijke besluiten van een syndicaat". In de praktijk kwam een dergelijke beperking niet of nauwelijks voor; zie Snijders (1960), pag. 581.

85 Tabingh Suermondt (1937), pag. 231, benadrukte terecht ook "voor de personen, die oorspronkelijk uit boofde van de overeenkomst gebonden waren, bovendien een gebondenheid uit hoofde van de ministerieele verbindendverklaring ontstaat op dezelfde wijze als voor de buitenstaanders, en dat deze gebondenheidblijft voortduren gedurende den tijd, dien de Minister daarvoor heeft vastgesteld, onafhankelijk van bet voortbestaan van de oorspronkelijke overeenkomst",

86 Zie over deze maatregel onder meer Schouten (1976), pag. 64 e.v..

87 Mok (1964 I), pag. 117.

88 Verschillende beperkingen werden overigens niet aanvaard. Zo bijvoorbeeld het voorstel om iedere algemeen verbindend verklaring bij afzonderlijke wet in formele zin te regelen (Rutgers van Rozenburg. Handelingen 1934-1935, pag. 1498. Hiervan werd afgerien om redenen van duur van de wetgevingsprocedure, inflexibiliteit van wetgeving bij gewijzigde ormstandigheden en -voor ondernemingen onwenselijke- openbaarheidvan de parlementaire behandeling van de betreffende wet; zie MvA TK 1934-1935, 
men in de Wem; in het Kartelbesluit daarentegen waren de meeste waarborgen uit doelmatigheidsoverwegingen geschrapt. Een eerste voorwaarde die in de Ondernemersovereenkomstenwet 1935 tegen overheidsmisbruik werd opgenomen, was dat slechts een bestaand kartel $^{19}$ algemeen verbindend kon worden verklaard. De aanwezigheid van enige mate van privaatrechtelijke ordening was vereist, waardoor de minister van Economische Zaken niet zelfstandig kartels in het leven kon roepen, om deze vervolgens algemeen verbindend te verklaren. ${ }^{90}$ Niet alleen was de minister van Economische Zaken ${ }^{91}$ afhankelijk van het bestaan van een kartel, hij mocht zelfs pas overgaan tot algemeen verbindendverklaring na een daartoe strekkend verzoek van de kartellerende ondernemers. ${ }^{92}$ Ook hierin kan duidelijk het streven naar beperking van de macht van de minister worden gezien ${ }^{93}$. zonder initiatief van de kartelleden stond hij immers machteloos. ${ }^{94}$ Een derde voorwaarde beperkte de mogelijkheid tot algemeen verbindendverklaring tot die gevallen waanin het kartel een overwegende betekenis had binnen de betreffende bedrijfstak, in de Wem geconcretiseerd tot de voorwaarde dat de in het kartel participerende ondernemers qua emzet en/of qua aantal derde (onafhankelijke) ondernemers overtroffen. ${ }^{95}$ Een vierde eis kwam

64, nt. 1, pag. 2. Aangezien het voorstel mede was bedoeld om het vermeend tekort aan deskundigheid bij de minister van Economische Zaken te ondervangen, kan daaraan nog worden tocgevoezd dat de vraag gerechtvaardigd lijkt of de deskundigheid bij de leden van de Staten-Generaal zoveelgroter was dan bij het departement van Economische Zaken.

89. Zoais hierna nog zal worden besproken, werden in 1994 de mogelijkheden vernuimd om tegen nietbindend gedrag op te treden. Voor de algemeen verbindend verklaring bleef echter de eis van juridische binding steeds een vereiste.

90 Deze op het eerste gezicht vanzelfsprekende voorwaarde (een niet bestaand kartel kan immers niet algemeen verbindend worden verklaard) is minder evident indien men bedenkt dat het Kartelbesluit deze voorwaarde niet kende. Hier bestond derhalve wel de mogelijkheid van dwangkartels.

91 In de Wem was bovendien de voorwaarde van voorafgaandoverleg met de minister van Binnenlandse Zaken opgenomen; zie Besluit van 11 november 1958 tot uitvoering van artikel 40, tweede lid, van de Wet economische mededinging, Stb. 490.

92 Een dergelijk vereiste ontbrak ten aanzien van de onverbindend verklaring. Dit lag ook voor de hand: in beginsel mocht niet verwacht worden dat bij kartelleden de wens leefde hun kartel onverbindend te laten verklaren zolang het hen profijt opleverde. Omdat de onverbindend verklaring in bet leven was geroepen om eventuele excessen met betrekking tot kartellering tegen te gaan, was het de taak van de overheid zelf om kartelafspraken te controleren en om in te grijpen als naar haar mening een bepaalde afspraak niet door de beugel kon. Eigen initiatief van de kant van de overheid was hier, in tegenstelling tot hetgeen het geval was bij de algemeen verbindend verklaring, geboden.

93 Het oorspronkelijke wetsontwerp voorzag niet in deze voorwaarde. Zij werd geĩntroduceerd bij het amendement van leden van de Christelijk Historische Unie (Rutgers van Rozenburg, Weitkamp, Katz, Tilanus en Snoeck Henkemans). Deze wensten zelfs dat algemeen verbindend verklaring geen doorgang zou vinden indien een 'belangrijke minderheid' (gedacht werd aan éen derde van de kartelleden) zich hiertegen verzette. Dit laatste voorstel werd echter niet aangenomen.

94 In het Kartelbesluit ontbrak deze voorwarde. Zie Het Kartelbesluit (1941), pag. 1681: "Deze wijziging ligt geheel in de lijn van de huidige meer actieve rol, die de overheid in het economische leven speelt en brengt met zich, dat de overheid, ook als het ondernemersbelang niet tot het aanvragen van een verbindendverklaring heeft geleid, de kartels kan gebruiken voor bepaalde overheidsdoeleinden ten aanzien van den geheelen bedrijfstak".

95 Het mes sneed hier aan twee kanten. Door deze eis werd zowel misbruik van ondernemerszijde voorkomen (een minderheid kon niet het beleid voor de meerderheid bepalen), alsmede een te grote invloed van de minister van Economische Zaken. In tegenstelling tot hetgeen het geval was in het Kartelbesluit kon de minister immers niet overgaan tot algemeen verbindend verklaring van een -gelet op de deelnemende ondernemers- relatief onbeduidende afspraak. 
reeds in paragraaf 2.1.2 aan bod: het algemeen belang moest de maatregel eisen. ${ }^{\circ 6} \mathrm{Nood}$ zakelijk hiervoor was dat het kartel aantoonbaar gunstig effect voor de samenleving had, dat het effect waarschijnlijk zonder kartel zou uitblijven en dat de niet-deelname aan het kartel door bepaalde ondernemers een goed functioneren van het kartel frustreerde. ${ }^{97}$

Beziet men de praktijk van de algemeen verbindendverklaring, dan kan men tot verschillende conclusies komen. De eerste is dat de minister van Economische Zaken, wellicht mede dankzij de hiervoor genoemde beperkingen, inderdaad geen misbruik van zijn bevoegdheid heeft gemaakt. Tot de maatregel werd uitsluitend besloten indien er van het kartel een sanerende invloed zou uitgaan en indien het kartel niet zou leiden tot een verstarring die de economische ontwikkeling zou schaden. De tweede conclusie kan zijn dat het ontbreken van belangrijke waarborgen in het Kartelbesluit, evenmin tot misbruik heeft geleid. Op basis van het Kartelbesluit is namelijk geen enkele algemeen verbindendverklaring genomen. Dit brengt ons bij de derde conclusie, namelijk dat in de voor-oorlogse periode er nog wel sprake was van een gebruik op redelijke schaal van de onderhavige maatregel, maar dat zij na de Tweede Wereldoorlog nauwelijks enig belang heeft gehad. ${ }^{\text {.s }}$ Voor dit laatste kunnen zeker drie redenen worden aangevoerd. De eerste heeft betrekking op de economische situatie in Nederland sinds de inwerkingtreding van de Wem in 1958. De crisis van de jaren dertig rechtvaardigde wellicht nog algemeen verbindendverklaring: na de Tweede Wereldoorlog deed zich een dergelijk slechte economische situatie echter niet meer voor en lag toepassing van de maatregel ook niet meer voor de hand. De tweede reden ligt in het communautaire recht. De Wem en het EG-Verdrag zijn in hetzelfde jaar in werking getreden. Zoals in hoofdstuk 2 zal blijken, is de invloed van het communautaire recht, ook op ogenschijnlijk nationale kartels, groot: afscherming van een nationale markt druist in principe in tegen het communautaire verbod op kartellering, hetgeen nietigheid van het betreffende kartel impliceert. Hieruit blijkt wel dat de ruimte voor algemeen verbindendverklaring beperkt was: de maatregel leidde in veel gevallen -behalve bij regionale of plaatselijk kartels- tot marktafscherming. In dat geval zou het kartel, hoewel algemeen verbindend verklaard -of liever: juist hierdoor ${ }^{90}{ }^{-}$, automatisch nietig

96 Bij de behandeling van het voorstel tot wetswijziging in 1939 werd voorgesteld om verbindendverkla. ring mogelijk te maken tenzij deze maatregel in strijd zou zijn met het algemeen belang. De minister ging niet inhoudelijk in op dit voorstel dat een aanzienlijke vemuiming van de bevoegdheden impliceerde.

97 In de Wem werd de werking van een algemeen verbindend verklaring overigens nog beperkt door een maximaal geoorloofde looptijd van drie jaar. Mocht er behoefte bestaan aan een verlenging, dan diende er een nieuw besluit genomen te worden, met alle waarborgen van dien. Tegen deze niet in de Ondernemersovereenkomstenwet 1935 voorkomende termijn bestond aanvankelijkoverigens wel bezwaar. Zie bijvoorbeeld Samkalden (1953), pag. 649.

98 Zie voor algemeenverbindendverklaringen Stcrt. 1 november 1937, 210 (Nederlandse Japonnenconventie), Stcrt. 9 augustus 1938, 153 (Regeling Schoenindustrie), Stert. 18 juli 1938, 137 (Regeling Lederindustrie), Ster. 9 augustus 1938, 153 (Wollenstoffenconventie), Stert. 13 jumi 1938, 112 (Zoutconventie), Stert. 19 april 1939, 77 (Groentenconservenindustrie), Stert. 2 februari 1938, 23 (Bakkersbedrijf Amsterdam), Stert. 2 februari 1939, 24 (Bakkersbedrijf Amsterdam), Stert. 30 januari 1975, 21 (Witte kristalsuiker), Stert. 13 januari 1984, 10 (Broodbakkersbedrijf).

99 De algemeen verbindend verklaring kon er immers juist toe leiden dat aan de ontheffingsvereisten van het derde lid van artikel 85 EG-Verdrag (thans 81 EG) niet (langer) voldaan was. Zie over de mogelijkheid van ontheffing in het communautaire recht het volgende hoofdstuk. 
zijn. ${ }^{100}$ De algemeen verbindendverklaring zou aldus niet alleen haar doel niet lunnen bereiken, maar bovendien zou de Nederlandse regering in feite in strijd handelen met het communautaire recht en het beginsel van 'gemeenschapstrouw'. Een derd $\mathrm{reden}$ ligt in de veranderde visie op kartellering en mededinging. Reeds in de behandeling van het ontwerp-Wem werd duidelijk gemaakt dat het beleid zou verschuiven naar kartebeperking. Maar met name sinds eind jaren tachtig is bij de Nederlandse overheid de overuiging gegroeid dat mededinging meer voordelen oplevert dan beperking hiervan door rivaat initiatief. Bij een dergelijk inzicht past de algemeen verbindendverklaring niet meer Waar de algemeen verbindendverklaring in een strikt misbruikstelsel nog wel plaats heff ${ }^{101}$, daar past zij niet bij de uitgangspunten van een verbodstelsel. ${ }^{102}$

\subsubsection{De onverbindendverklaring}

De onverbindendverklaring van kartelafspraken werd in de Ondememersovereenkomsenwet 1935 uitsluitend opgenomen om de wettelijke regeling te completeren. ${ }^{103}$ De crisisstuatie verlangde naar de stellige overtuiging van de toenmalige Nederlandse overheid welswaar slechts optreden dat de werking van kartels bevorderde, maar het feit dat met de Oniernemersovereenkomstenwet 1935 de tot stand brenging van een structurele wet werd boogd, eiste dat ook in een maatregel ter bestrijding van onwenselijk kartelgedrag werd voczien. Zoals reeds eerder gesteld, zag de Nederlandse overheid namelijk wel degelijk ok de (soterntilit)' gevaren van kartellering en besefte zij dat -in betere economische tijdenhet kartelbeleid een ander zwaartepunt zou kunnen krijgen dan in een periode van crisis. Dit standpunt zou overigens in de praktijk worden bewaarheid: tot en met de oorlogsjaren is geen enkele maatregel tot onverbindendverklaring getroffen ${ }^{104}$; na die tijd daarentegen heeft de onverbindendverklaring een belangrijkere rol (dan voorheen, maar ook dan de algemeen verbindendverklaring) vervuld.

Onverbindendverklaring vormde bij uitstek een maatregel die in een misbruikstelsel en (dus) bij de tweezijdigheid van de Nederlandse kartelvisie paste. Onverbindendverklaring betekende namelijk geen verbod op kartellering als zodanig; de vrijheid hiertoe werd

100 Mok (1978), pag. 751, wijst op de onmogelijkheid om protectionistische maatregelen aan de binnengrenzen te nemen.

101 Onontbeerlijk is zij echter in een dergelijk stelsel niet. Een misbruikstelsel wordt gekenmerkt door de neutrale houding tegenover kartellering. Deze houding betekent niet dat de overheid ook daadwerkelijk kartellering moet stimuleren of bevorderen.

102 Hoewel zij niet per definitie is uitgesloten in een dergelijk stelsel. Aldus ook Mok (1982 III), pag. 249. Gelet op de nieuwe kartelvisie van de Nederlandse overheid is het desalniettemin opmerkelijk dat bij de adviesaanvraagvan de Mededingingswet de mogelijkheid werd geopperd om de algemeen verbindend verklaring te handhaven. Een voorstel van die strekking kwam -na negatieve adviezen van de Commissie economische mededinging en de Sociaal Economische Raad-echter niet meer voor in het ontwerp-Mededingingswet.

103 Vergelijk Westerman (Verbond voor Nationaal Herstel), Handelingen 1934-1935, 64, pag. 1496.

104 Niet moet worden uitgesloten dat de onverbindend verklaring toch enige rol van betekenis heeft gespeeld, namelijk binnen een vorm van informeel beleid. Een dergelijk informeel beleid, dat zoals nog zal blijken de hoofdmoot van het beleid onder de Wem heeft gevormd, zou gericht kunnen zijn geweest op aanpassing van kartels, opdat en zodat deze alsnog binnen de grenzen van het algemeen belang zouden vallen. Gegevens over het al dan niet bestaan van een dergelijk informeel beleid zijn mij echter niet bekend. 
niet aangetast. Onverbindendverklaring was steeds gericht op een concrete kartelafspraak: werd door ondernemers van hun vrijheid tot kartellering misbruik gemaakt, werd met andere woorden het algemeen belang geschonden, dan -en pas dan-kon door de minister van Economische Zaken -de rechter kwam deze bevoegdheid niet toe- de bindende kracht aan het kartel in kwestie worden ontnomen. Hieruit volgt wel dat het beleid op dit punt zeer casuilstisch van aard was en het karakter had van excessenbestrijding: niet kartellering werd aangepakt, maar slechts kartellering die aantoonbaar de grenzen van het toelaatbare had overschreden. Indien door de minister van Economische Zaken door middel van een onverbindendverklaring tegen een kartel was opgetreden, betekende dit het einde van dit kartel: er was geen juridische binding meer, naleving kon niet meer (in rechte) worden afgedwongen. In feite gold vanaf het moment waarop de maatregel van kracht werd op de betreffende gedraging een verbod.

Vergelijkbaar met de ontbinding van wederkerige overeenkomsten in het civiele recht ontbeerde de onverbindendverklaring terugwerkende kracht. ${ }^{105}$ Deze ex nunc-werking had enkele belangrijke nadelen voor de positie van gedupeerden en de effectiviteit van de maatregel: schade ontstaan in de periode voorafgaand aan de onverbindendverklaring kon niet of nauwelijks op de kartelleden verhaald worden, waardoor het risico van vergaande kartellering voor ondernemers vrijwel afwezig was, te meer omdat wegens het misbruik in de bedoelde periode ook geen punitieve overheidssanctie kon worden opgelegd. ${ }^{106}$ Daar staat tegenover dat een keuze voor terugwerkende kracht niet goed in het Nederlandse systeem zou hebben gepast. De dreiging van een onverbindendverklaring met ex tuncwerking zou waarschijnlijk een remmende werking op kartellering als zodanig hebben gehad, hetgeen niet in overeenstemming zou zijn geweest met de neutrale houding ten opzichte van kartels. Terugwerkende kracht zou voorts voor aanzienlijke rechtsonzekerheid kunnen zorgen. Ondernemers zouden steeds moeten vrezen dat hun afspraken zouden worden vernietigd en dat hetgeen gepresteerd was, als onverschuldigd betaald, zou moeten worden teruggedraaid; zowel voor de betrokken ondernemers als voor derden zou zo een zeer onzekere situatie ontstaan. Dit klemde te meer omdat het voor de betrokkenen veelal niet zou zijn te voorspellen of 'naar het oordeel van de minister' het algemeen belang -toch een voor velerlei interpretatie vatbaar en van veel factoren afhankelijk begripzou zijn geschaad. ${ }^{107}$ In een dergelijke situatie ligt het niet in de rede om de ondernemers de risico's van onder meer aanzienlijke schadeclaims te laten dragen. ${ }^{108}$

De voorwaarden voor onverbindendverklaring waren minder talrijk dan het geval was bij de algemeen verbindendverklaring ${ }^{109}$ : het algemeen belang moest de maatregel eisen

105 Van den Oosterkamp (1995), pag. 337, spreckt van een optreden ad hoc en ex nunc.

106 Hierop zal nog in paragraaf 3.2 worden teruggekomen.

107 Nog afgezien van het zeer onzekere antwoord op de vraag of de minister zou ingrijpen indien hij strijd met algemeen belang zou constateren.

108 De wetgeverzag overigens ook de positic van bepaalde derden bij terugwerkendekracht in het geding komen. Indien ondernemers schadevergoeding zouden moeten betalen an afnemers of andere benadeelden, dan zou dit hun financiê le positie kunnen ondermijnen, waardoor eventuelecrediteurenvan deze ondernemers op hun beurt zouden worden gedupeerd. Dit werd als cen onaanvaardbaar risico van terugwerkende kracht ervaren.

109 Zo ontbraken bijvoorbeeld de eis dat om de maatregel verzocht moest worden en de voorwaarde dat het kartel een overwegende betekenis had. De laatste voorwaarde was wel in het oorspronkelijk ontwerp van de Ondernemersovereenkomstenwet 1935 opgenomen. De minister van Economische 
en zij kon -aanvankelijk- slechts worden toegepast op juridisch bindend gedrag. In het Kartelbesluit werd de eerste voorwaarde niet meer gesteld ${ }^{110}$, terwijl zij in de Wem in enigszins afgezwakte vorm (onverbindendverklaring indien gedraging in strijd met het algemeen belang) haar herintrede deed. ${ }^{11}$ De tweede voorwaarde die de Ondernemersovereenkomstenwet 1935 stelde -de noodzaak van juridische binding- deed de bevoegdheid tot onverbindendverklaring aanmerkelijk aan kracht inboeten. Hoewel kartels, gelet op de zekerheid voor de betrokkenen niet zelden in de vorm van een civielrechtelijke overeenkomst worden gegoten, is een dergelijke overeenkomst geenszins noodzakelijk voor een goede werking van een kartel. In het verlengde daarvan kan worden gesteld dat een niet-bindende regeling het algemeen belang even veel schade kan berokkenen als een overeenkomst. Toch bleef niet-bindend gedrag in de wet van 1935 buiten schot: onverbindendverklaring kon slechts bindende regelingen treffen. Ook hier gold dat het Kartelbesluit afweek van haar voorgangster (hetgeen overigens door de Hoge Raad pas in 1953 definitief werd vastgesteld ${ }^{112}$ ) en dat de Wem de Ondernemersovereenkomstenwet 1935 volgde. Ten dele kan deze restrictie verklaard worden uit de pogingen om de invloed van de overheid op het marktgedrag te beperken: bij de totstandkoming van de wet van 1935 was dit, zoals gezien, een belangrijk item; in de Wem moest dit mede als reactic op het op vele punten verdergaande kartelbesluit worden gezien. Voorts lag -het kwam bij de behandeling van de mededingingsregeling reeds ter sprake- een onverbindendverklaring van niet-bindend gedrag niet voor de hand: wat niet bindt, kan ook niet onverbindend worden verklaard. Gevolg van een en ander was dat de maatregel aan effectiviteit inboette: ondernemers die een 'onaantastbaar' kartel wensten, kozen de weg van onderlinge afspraken die geen juridische binding kenden. Hoewel dit probleem voor de hand lag, werd er binnen de Nederlandse overheid lange tijd geen noodzaak tot wijziging gevoeld. Gezien bedoelde problemen en gezien het op dit punt (zoals op zovele punten) veel strengere communautaire recht, mag dit verbazen. De geringe toepassing van de Wem en het gegeven dat kartelbeleid niet hoog op de Nederlandse politieke agenda stond, nemen

Zaken kwam hier reeds bij de MvA op terug en schrapte de betreffendepassage. Dit gebeurde tegen de achtergrond van het arbeiders- en verbruikersbelang, hetwelk een belangrijke in het algemeen belang rol werd toegedicht: druiste het kartel tegen deze belangen in, dan moest het van het economische toneel verdwijnen. De economischerelevantie van het kartel was in dat geval van ondergeschikt belang. Bovendien werd de interessante stelling verdedigd dat "naarmate bedingen of besluiten van minder beteekenis zijn voor de economische verhoudingen in den betreffenden bedrijfstak, (...) er ook minder bezwaartegen onverbindendverklaring (is), indien het algemeen belang dit vordert" (VV TK 1933-1934, 460, nr. 4, pag. 10.

110 VerLoren van Themaat (1952 I), pag. 148, constateerdenaar aanleiding van de na-oorlogse praktijk op grond van het Kartelbesluit dat niet alleen het algemeen belang-criterium als maatstaf werd gebruikt, maar dat bovendien enkele strijdigheid met het algemeen belang niet leidde tot onverbindend verklaring: daarvoor was noodzakelijk dat het algemeen belang de maatregel vereiste. In zoverre sloot de praktijk aan bij hetgeen de Ondememersovereenkomstenwet 1935 eiste. Overigens zou men hier ook van een kartelrechtelijk opportuniteitsbeginsel kunnen spreken, omdat slechts in zeet ernstige gevallen tot de maatregel werd overgegaan.

111 De Wem bood bij gebleken strijd met het algemeen belang ook de mogelijkheid tot publicatie van gegevensvan de mededingingsregeling of het niet-bindend gedrag. Dezevoor betrokken ondernemers ingrijpende maatregel is echter nooit toegepast, waardoor de verwachting van Samkalden (1954), pag. 2 dat zij "wellicht (zal) blijken een van de beste bestrijdingsmiddelen van met het algemeen belang onverenigbare verhoudingen in het bedrijfsleven te zijn" niet is bewaarheid.

112 Arrest van 2 juni 1953, SEW (1953), pag. 465 m.nt. A.M. 
de meeste verbazing echter weer weg. Een kleine opleving van de aandacht voor het kartelrecht medio jaren zeventig ${ }^{113}$ en begin jaren tachtig leidde onder meer tot cen niet aangenomen- voorstel om voor de toepassing van enkele artikelen van de Wem gentlemen's agreements als mededingingsregelingen aan te merken. ${ }^{114}$ Het probleem van het optreden tegen niet-bindend kartelgedrag deed zich in alle hevigheid gevoelen bij de pogingen van de Nederlandse overheid eind jaren tachtig en begin jaren negentig om het kartelbeleid te intensiveren. Weliswaar bleek dat in de praktijk tegen niet-bindend gedrag (in de vorm van onderling afgestemde feitelijke gedragingen) kon worden én werd opgetreden, maar de daarvoor bewandelde juridische omweg -via de collectieve machtspositic- werd niet fraai en effectief bevonden. ${ }^{15}$ Ditmaal leidden de voorstellen wel tot een ingrijpende wijziging van de Wem. ${ }^{116}$ Hieronder was ook een wijziging van de regeling van de onverbindendverklaring, die vanaf de inwerkingtreding van de wettelijke regeling als 'strijd met het algemeen belang-verklaring' door het leven ging. Artikel 19 lid 1 Wem luidde voor zover hier van belang:

Onze Ministers kunnen, indien naar hun oordeel een mededingingsregeling dan wel een rechtens niet bindende afspraak of rechtens niet bindend besluit, waarby de economische mededinging tussen ondernemers wordt geregeld, geheel of voor een gedeelte in strijd is met het algemeen belang of op een met dat belang strijdige wijze wordt toegepast: (..)

b. die regeling, die afspraak of dat besluit, geheel of voor dat gedeelte, al dan niet onvoorwaardelijk. in strud met bet algemeen belang verklaren.

Ten aanzien van mededingingsregelingen veranderde er niets: juridische binding bleef een constitutief vereiste en door toepassing van de maatregel werd op grond van het gewijzigde artikel 19 lid 3 Wem de regeling onverbindend. Voor rechtens niet-bindende afspraken en besluiten daarentegen gold dat vanaf het moment van inwerkingtreding van de wetswijziging ook zij bij gebleken strijd met het algemeen belang door een verbod getroffen konden worden. Wellicht ten overvloede zij vermeld dat de rechtsgevolgen voor al dan niet bindend gedrag pas door de 'in strijd met het algemeen belang verklaring' ${ }^{117}$ in werking traden; tot deze verklaring stond het ondernemers onverminderd vrij om kartelmatig gedrag te ontplooien.

113 Zie hierover onder meer Duk (1973), pag. 453, en VerLoren van Themaat (1978), pag. 185.

114 Wetsvoorstel tot invoering van een openbaar kartelregister (16 555). Dit voorstel werd echter in de Eerste Kamer verworpen.

115 Zie de opmerkingen van voormalig staatssecretarisvan Economische Zaken Van Rooy (1992), pag. 5: "Beter, duidelijker en Europeser (dan via de tot dan toe bewandelde juridische omweg, HQ) is het om dit afgestemde gedrag rechtstreeks aan te pakken als kartelmatig gedrag. Dat gaan we nu mogelijk maken". Ottervanger (1994), pag. 236, wijst op het belang van het 'afgestemd gedrag' voot een effectief mededingingsbeleid.

116 Wet van 2 november 1994 tot wijziging van de Wet economische mededinging (vergroting van de effectiviteit), Stb. 1994, 801. Deze wet trad op 1 september 1995 in werking en wel op grond van artikel VI van het Besluit van 19 mei 1995, houdende wijziging van enige algemene maatregelen van bestuur tot asnpassing aan de wet van 2 november 1994 (Stb. 801) tot wijziging van de Wet economische mededinging (vergroting van de effectiviteit), Stb. 1995, 287. Zie over bedoelde wet Ottervanger en Nijhuis (1994), pag. 481-491.

117 Deze enigszins omslachtige term -in plaats van de ingeburgerde term 'onverbindend verklaring'werd noodzakelijk door de uitbreiding van de reikwijdte van de maatregel tot niet-bindend gedrag. Zoals reeds gesteld, kan niet-bindend gedrag niet onverbindend worden verklaard. 
Naast de onverbindendverklaring kende de Wem een maatregel die daaraan connex was: de schorsing. ${ }^{118}$ In spoedeisende gevallen kon de minister van Economische Zaken in afwachting van een onverbindendverklaring een mededingingsregeling op grond van artikel $23 \mathrm{Wem}$ schorsen. De connexiteit met de onverbindendverklaring vloeide voort uit de procedurele eis dat slechts tot schorsing mocht worden overgegaan indien de procedure tot onverbindendverklaring reeds was gestart door indiening van een verzoek om advies omtrent onverbindendverklaring bij de Commissie economische mededinging. Doel van de tijdelijke maatregel-de maximaal toegestane duur van de schorsing bedroeg één jaar- was het voorkomen of beperken van de schadelijke effecten van een mededingingsregeling gedurende de periode waarin de onverbindendverklaringsprocedure aanhangig was.

Concluderend kan gesteld worden dat de onverbindendverklaring -of later de in strijd met het algemeen verbindendverklaring- de mogelijkheid bood om met het algemeen belang strijdig kartelgedrag per geval aan te pakken. Het beleid kon niet anders dan casuïstisch zijn en had het karakter van excessenbestrijding. De maatregel was dan ook in feite het karakteristieke kenmerk van het Nederlandse misbruikstelsel en een wettelijke vertaling van de daaraan ten grondslag liggende idee, namelijk dat ondernemers de ruimte moesten krijgen om mededingingsbeïnvloedend gedrag te ontplooien en dat overheidsinterventie beperkt zou moeten blijven tot de gevallen waarin ondernemers het algemeen belang hadden geschaad.

Rest de vraag naar de toepassing van de onverbindendverklaring in de praktijk. Tot en met de Tweede Wereldoorlog is er geen enkele maatregel van die strekking genomen: de economische situatie en de strikte overheidsregulering tijdens de bezetting maakten onverbindendverklaring niet wenselijk of noodzakelijk. Het na-oorlogse kartelbeleid toonde een ander beeld. Onder het regime van het Kartelbesluit werd een relatief strikt formeel 'anti-kartel-beleid' gevoerd: tussen 1945 en 1958 werden 13 onverbindendverklaringen uitgesproken, gemiddeld 1 per jaar. ${ }^{119}$ Dit beleid leek een vervolg te krijgen onder het regime van de Wem door de onverbindendverklaring van de Abtsweg-regeling in 1959. ${ }^{120}$ Deze onverbindendverklaring verwierf bekendheid, echter niet zozeer op grond van haar inhoud, of de ernst van het kartel, maar veeleer door de twijfelachtige eer dat zij tot 1986 de enige onverbindendverklaring op grond van de Wem is geweest! Dus gedurende zo'n 27 jaar is er geen formele maatregel tegen kartels genomen. Vanaf 1986 tot de inwer-

118 Ook onder het regime van het Kartelbesluit was schorsing mogelijk. Aanvankelijk kon snel worden ingegrepen omdat vertragende procedurevoorschriften-met name adviesinwinning-ontbraken. $\mathrm{Na}$ de herintrede van de adviesverplichting werd voorzien in een aparte wettelijke schorsingsregeling: de Wet schorsing bedrijfsregelingen.

119 Stcrt. 3 januari 1946, 2 (Bovag Limburg), Stert. 25 januari 1946, 39 (Bovag Twente), Stert. 16 november 1948, 222 (Electrotechnische sector), Stert. 24 maart 1950, 60 (CBR), Stert. 24 maart 1950, 60 (Haarden- en Kachelregeling), Stert. 17 november 1950, 225 (VBBB), Stert. 3 juli 1951, 126 (Slagerijen), Stcrt. 1 augustus 1952, 148 (Medische instrumenten), Stert. 10 mant 1952, 49 (Schilderswerken). Stert. 2 maart 1955, 43 (Melkdetailhandel), Stert. 20 januari 1956, 15 (Radiosector), Stert. 22 november 1955, 227 (Pharmaceutische sector), Stert. 12 december 1957, 242 (Electrotechnisch installatiemateriaal). Zie over dit beleid en het nadien 'laten vieren van de teugels' Mok, (1964 I), pag. 117 e.v. en -voor de periode 1955-1956- Van Rij (1956), pag. 161 e.v..

120 Stert. 6 april 1959, 65. 
kingtreding van de Mededingingswet op 1 januari 1998 werd het oude gemiddelde van 1 per jaar weer gehaald. ${ }^{121}$ Totaal werden er dus in de ongeveer 40 jaar dat de Wem dienst heeft gedaan als basis van het Nederlandse kartelbeleid welgeteld 13 beslissingen tot onverbindendverklaring genomen; in de hele historie van de onverbindendverklaring was dat het dubbele aantal. ${ }^{122}$ Met name het eerste aantal was niet van dien aard dat men van cen levendig gebruik van de mogelijkheid tot onverbindendverklaring kon spreken. Een belangrijk deel van de kritiek op de Wem richtte zich dan ook juist tegen het uitblijven van onverbindendverklaringen; VerLoren van Themaat verzuchtte bijvoorbeeld reeds in 1978 dat er sprake was van een "in gebreke blijvende nationale mededingingspolitiek" en een "al jaren durende impasse in het Nederlandse kartelbeleid", ${ }^{125}$ Deze kritiek was niet onbegrijpelijk, hoewel zij naar mijn mening niet geheel recht deed aan het Nederlandse kartelbeleid (ik kom hierop in paragraaf 2.5 nog terug). Wat er ook van deze kritiek zij, feit was dat de minister van Economische Zaken met grote terughoudendheid gebruik maakte van zijn bevoegdheid om kartels onverbindend te verklaren. De redenen voor deze geringe toepassing zullen in paragraaf 2.5 aan de orde komen. Eèn van deze redenen, door Mok al in 1964 genoemd als mogelijke oorzaak van een minder restrictief casuistisch optreden ${ }^{124}$, noem ik toch reeds op deze plaats, omdat zij aansluit bij de hierna te bespreken derde kartelmaatregel die de Wem kende: de totstandkoming van generieke onverbindendverklaringen.

\subsubsection{De generieke onverbindendverklaring}

De bevoegdheid tot generieke onverbindendverklaring was een novum in de Wem. Met haar werd een verbodelement in het Nederlandse kartelrecht geïntroduceerd ${ }^{125}$ en het pad van de casuïstische benadering van kartels -kenmerkend voor de 'individuele' onverbindendverklaring- verlaten. ${ }^{126}$ Niet een concrete mededingingsregeling ${ }^{127}$ werd door

121 Stert. 11 juli 1986, 134 (Bovag), Stert. 21 november 1986, 228 (Bodemspecie)-zie hierover Mok (1986 II), pag. 307-, Stcrt. 12 januari 1987, 9 (De Passage) -besproken door Mok (1987 I), pag. 48-49-. Stert. 17 februari 1989, 37 (ACI), Stert. 10 juli 1992, 132 en Stcrt. 10 juh 1992, 138 (beide CBR), Stert. 10 juli 1992, 135 (Trefcenter), Stert. 2 december 1992, 238 (Potplantenkarren), Stert. 13 mei 1993, 96 (Vereniging van Notarissen), Stcrt. 28 februari 1996, 43 (Bruna), Stert. 17 december 1996, 247 (Kabeltelevisie) en Stert. 10 december 1997, 243 (Middenwaard).

122 Het auntal schotsingen was - gelet op de strekking van de maatregel niet verbazend- nog geringer. Onder regime van bet Kartelbesluit respectievelijk de Wet schorsing bedrijfsregelingen werden drie maatregelen tot schorsing genomen: Stert. 3 juni 1954, 165 (Melksector); Stert. 9 maart 1955, 48 (Slagers) en Stert. 16 maart 1955, 63 (Radiohandelaren). De Wem kende welgeteld één schorsing: Stert. 4 februari 1992, 24 (Potplantenkarren). Zie over deze schorsing nader Mok (I992 II), pag. 67 e.v, en over de afwijzing van het verzoekom schorsing van de (schorsings) beschikking Mok (1993 II), pag. 24-25.

123 Verloren van Themaat (1978), pag. 191 en 192.

124 Mok (1964 I), pag. 117 e.v..

125 Vergelijk Van den Oosterkamp (1995), pag. 337, Barents in: Steenbergen en Barents (1986), pag. 20 en Plompen (1996), pag. 158. Ook Schouten (1960), pag. 163 e.v., een fel tegenstander van een verbodstelsel, erkende de invoering van een verbodelement maar pleitte voor een toepassing van de generiekemaatregel die zoveelmogelijk recht zou doen aan het (misbruik)uitgangspunt van de Wem.

126 Vergelijk ook Schouten (1960), pag. 161. 
een generieke onverbindendverklaring getroffen, maar een bepaalde soort (artikel 10 Wem sprak van aard of strekking) mededingingsregelingen. Het betrof, zoals Mok ${ }^{12 s}$ terecht stelde, een daad van (materielle) wetgeving ${ }^{129}$, waarbij gedrag van de bij de maatregel aangewezen aard of strekking werd verboden en die dat gedrag juridisch onmogelijk maakte. ${ }^{100}$ De gevolgen van de maatregel strekten zich uit over ten tijde van haar inwerkingtreding bestaand gedrag én over 'toekomstig' gedrag: bestaand gedrag was vanaf een in de maatregel vermeld tijdstip onverbindend; toekomstig gedrag van de aangewezen soort zou nooit juridische binding kunnen krijgen en was derhalve van rechtswege nietig. ${ }^{131}$ Met de generieke maatregel had de Nederlandse overheid een instrument in handen gekregen waarmee zij in één klap alle mededingingsregelingen kon aanpakken die (in de visie van de overheid althans) reeds door hun aard of strekking in strijd met het algemeen belang waren. Ten dele betekende een generieke onverbindendverklaring aldus een verlichting van de taak van de overheid, en wel in die zin dat niet langer casuïstisch behoefde te worden opgetreden tegen mededingingsregelingen waarvan, door de aard en strekking van het in het geding zijnde kartelgedrag, op voorhand reeds duidelijk was dat zij niet door de overheid geaccepteerd zouden worden. Zeker indien de maatregel niet meer was dan het in een wettelijke regeling vertalen van een reeds in het casuïstisch beleid uitgekristalliseerd oordeel over mededingingsregelingen van de betreffende soort, dan vormde zij louter een maatregel van doelmatigheid, die tal van procedures tot 'individuele' onverbindendverklaring, waarvan de uitkomst de facto reeds vooraf vaststond, voorkwam. In zoverre betekende de introductie van de generieke onverbindend verklaring geen inbreuk op het misbruikstelsel. ${ }^{132}$ Maar de reikwijdte van de generieke maatregel ging verder: ook gedrag dat zich tot dan toe nog nooit binnen Nederland had gemanifesteerd, maar dat toch gezien zijn aard en strekking van de Nederlandse markt moest worden

127 Ook na de wetswijziging van 1994 was het subject van de maatregel steeds een mededingingsregeling. dus een juridisch bindend kartel.

128 Mok (1995), pag. 149.

129 Een generieke onverbindendverklaring kon in de Wemzelf worden opgenomen of bij AMvB worden geintroduceerd. In dat laatste geval gold op grond van artikel $10 \mathrm{lid} 4 \mathrm{Wem}$ de maatregel voor een periode van maximaal vijf jaar, "tenzij bij nadere wet anders wordt bepaald". Dat naar aanleiding van deze bepaling vanuit wetstechnisch optiek onwenselijke situaties konden ontstaan, bleek uit de gang van zaken met betrekking tot de verlenging van de generieke onverbindendverklaring van verticale prijsbinding. In dit verband zagen enkele 'nadere wetten', waarin de werking van het Koninklijk Besluit van 1964 werd verlengd, het licht: Wetten van 11 mei 1969, Stb. 1969, 218; 31 mei 1972 , Stb. 1972, 1; 29 mei 1974, Stb. 1974, 316; 2 juni 1976, Stb. 1976, 313; 30 mei 1979, Stb. 1979. Stb. 1979, 291; 14 mei 1981, Stb. 1981, 285; 5 mei 1984, Stb. 1984, 240 en de Wet van 27 mei 1987, Stb. 1987, 269. Zie tevens de kritiek van Evenhuis, Handelingen I, 1986-1987, pag. $1456 \mathrm{en}$ MvT bij Wijziging van de Wet economische mededinging, TK 1988-1989, 21 105, nr. 3, pag. 1.

130 Behoudens in het geval van een ontheffing. In de mogelijkheid hiertoe was overigens in het oorspronkelijke wetsvoorstel niet voorzien. Wellicht de meeste bekendheid heeft de ontheffing inzake het boekenkartel gekregen. Zie Mok (1986 III), pag. 307-308 en kritisch over de argumenten voor deze ontheffing Uitermark (1986 II), pag. 4 e.v..

131 Vergelijk Barents in: Steenbergen en Barents (1986), pag. 22. Terecht stelde Mok (1995), pag. 152, dat het in feite een dubbele nietigheid betrof, zowel op grond van de Wem zelf als op grond van

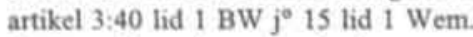

132 Zoals reeds eerder ter sprake kwam werd in de praktijk van het Kartelbesluit door een omkering van de bewijslast een met het resultaat van een generieke onverbindend verklaring vergelijkbaar resultaat bereikt. Nogmaals zij verwezen naar opmerkingen van De Rooy (1952 I) en VerLoren van Themaat (1952 II). 
geweerd, kon door haar worden getroffen. In die situatie was het optreden op grond van de Wem geen reactie meer op een misstand, maar een voorkomen hiervan. Zeker indien concurrentiepolitieke gronden aan de maatregel ten grondslag lagen, werd ten aanzien van het betreffende soort gedrag een verbodsysteem dicht genaderd. ${ }^{133}$ Voor verstokte aanhangers (zoals Schouten ${ }^{1 / 4}$ ) van een misbruikstelsel en een casuistische benadering van kartels was met name de dreiging van een ontwikkeling richting verbodstelsel een doorn in het oog. ${ }^{135}$ Juist omdat het volgens Schouten typerend voor kartels was dat zij positieve én negatieve gevolgen konden hebben, zou het niet mogelijk en evenmin wenselijk zijn om op ruime schaal kartels te verbieden. Deze kritiek ten spijt werd door de Nederlandse overheid de bevoegdheid tot generieke onverbindendverklaring in ruime zin geïnterpreteerd en werd uiteindelijk onder het regime van de Wem op belangrijke punten een verbodstelsel zeer dicht genaderd. ${ }^{136}$ Uiteindelijk, want lange tijd bleef de invloed van de maatregel relatief beperkt, namelijk tot rechtspraakregelingen ${ }^{137}$, verticale prijsbinding ${ }^{138}$ en regelingen inhoudende rassendiscriminatie ${ }^{139}$, waarbij het belang van de maatregel tegen verticale prijsbinding mededingingstechnisch het grootst was. Pas in 1986 zag een vierde generieke onverbindendverklaring het licht, en wel die betreffende kartels in de bouwsector. ${ }^{140}$ De kloof tussen het misbruikstelsel van de Wem

133 Zie hierover eveneens Mok (1998), pag. 39.

134 Zie voor zijn visie met name: Schouten (1960), pag. 163 alsmede Schouten (1970), (1973) en (1976).

135 Aanvaardbaar was de eerste ontwikkeling omdat daar de generieke maatregel in het verlengde van de 'individuele' onverbindend verklaring lag. Vergelijk Schouten (1960), pag. 161 e.v.

136 Hoofdzakelijk werden de generieke maatregelen in de vorm van een AMvB gegoten. De vraag was gerechtvaardigd of het voorkeur verdiende om dergelijk verstrekkende maatregelendoor het bestuur in plaats van door de formele wetgever-te laten nemen. Hier lag een van de bezwarentegen intensivering van het kartelbeleid op grond van de Wem. Het creëren van een situatie die vrijwel gelijk was aan die in een verbodstelsel was op grond van de Wem heel goed mogelijk en bovendien relatief eenvoudig te bewerkstelligen aangezien hiertoe een $\mathrm{AMvB}$ voldoende was. Dit impliceerde echter wel een gebrek aan legitimatic, die wel van een door de formele wetgever aanvaarde regeling zou uitgaan. Vanuit deze optick en vanuit het misbruikuitgangspunt van de Wemverdiende de principiele keuze voor een verbodstelsel de voorkeur.

137 Wet van 24 juli 1962, Stb. 307; verlengd bij wet van 21 februari 1968, Stb. 62 en in de Wem opgenomen in de artikelen $9 \mathrm{~b}-9 \mathrm{~d}$ bij de wetvan 15 december 1971, Stb. 774. Zie over dezegeneriekemaatregel Schouten (1976), pag. 28 e.v..

138 Besluit van 1 april 1964, houdende onverbindendverklaring van bepalingen betreffende verticale prijsbinding in mededingingsregelingen, Stb. 110, 1964, gewijzigd bij Besluiten van 31 augustus 1964, Stb. 352, 1964 en 18 januari 1973, Stb. 15, 1973 en aangevuld bij Besluit van 31 augustus 1964, Stb. 353, 1964. Zie voor een bespreking van het besluit van 1964 Van Eijkern (1964), pag. 198 e. $v_{.}$. Verankering van het verbod op verticale prijsbinding is gerealiseerd bij de Wet van is november 1989 tot wijziging van de Wet economischemededinging (voorzieningen met betrekking tot verticale prijsbinding), Stb. 1990, 6, nadatenkele cerdere pogingen waren gestrand: Wetsvoorstel inzake Wijziging van de Wet economische mededinging (Voorzieningen met betrekking tot prijsbinding en minimumprijzen), TK 1977-1978, 1978-1979, 1980-1981, 14886 (ingetrokken); Voorstel van wet inzake Wijziging van de Wet economische mededinging (voorzieningen met betrekking tot verticale prijsbinding), TK 1985-1986, 19361 (verworpen door de Eerste Kamer).

139 Wet van 18 februari 1971, Stb. 96, welke wet de generieke onverbindendverklaring van regelingen inhoudende rassendiscriminatie in artikel $9 \mathrm{a}$ Wem introduceerde. Overigens was op overtreding van dit artikel in de Wem geen straf gesteld.

140 Besluit van 29 december 1986 tot onverbindendverklaring van een aantal bepalingen in mededingingsregelingen aangaande het aannemersoverieg in de bouwsector, Stb. 1986, 676, besproken door Mok (1987 1), pag, 46-48. 
en een verbodstelsel werd echter pas in 1993 en 1994 -in het kader van de inensivering van het kartelbeleid- in grote mate gedicht door de inwerkingtreding van generike maatregelen inzake horizontale prijsbinding ${ }^{14 !}$, marktverdeling ${ }^{142}$ en -in mindere mte- aanbestedingsregelingen ${ }^{143}$.

\subsection{De maatregelen tegen economische machtsposities}

In het voorgaande is uitgebreid aandacht besteed aan de mededingingsregaing en de interventiemogelijkheden die de overheid hieromtrent ter beschikking stonde. De Wem kende nog een ander belangrijk begrip, waaraan -in navolging van het Kartbesluit ${ }^{14}$. verschillende maatregelen gekoppeld waren, namelijk de economische mantspositie. Deze werd in artikel 1 Wem gedefinieerd als:

cen feitelijke verhouding of rechtsverhouding op cen markt, die een overwegende invlod van een of meer ondememers op die markt voor goederen of diensten in Nederland medebrengt.

Uit deze definitie moge blijken dat voor een economische machtspositie, in teenstelling tot hetgeen het geval was voor een mededingingsregeling, geen juridisch bindnde kracht vereist was: een feitelijke machtspositie (bijvoorbeeld in de vorm van een Ionopolie, een gentlemen's agreement, onderling afgestemd feitelijk gedrag, waaraan gea overeenkomst ten grondslag lag of zelfs parallel marktgedrag van ondernemers ${ }^{145}$ ) op een bepaalde markt was voldoende. Omdat artikel 24 Wem aan de minister van Economische Zaken enkele maatregelen attribueerde om op te treden tegen een economische machtspositie

141 Besluit van 4 februari 1993, tot onverbindendverklaring van bepalingen in mededingingsregelingen inzake horizontale prijsbinding, Stb. 1993, 80. Zie hierover Biesheuvel(1993), pag. 845 e.v. en Ham (1993), pag. 626 e.v.. Dat horizontale prijsbinding in Nederland geen incident was moge blijken ut het aantal ontheffingsaanvragendie het ministerie van Economische Zaken tot augustus 1993 hadden bereikt: 49, waarvan ongeveer de helft bij het ministerie nog onbekend was. Zie hierover Noordhoff (1993) en Van Alphen (1993).

142 Besluit marktverdelingsregelingenKB 19 januari 1994, Stb. 56. Zie Van der Wal (1994 I), pag. 702 c.v..

143 Besluit mededingingsregelingen aanbestedingen KB 19 januari 1994, Stb. 55. Dit besluit verving het besluit van 29 december 1986. Reden hiervoor was de gevoelige beslissing van de Commissie inzake het Nederlandse bouwkartel: $\mathrm{Pb} 1992$ L $92 / 1$ (Bouwnijverheid in Nederland). Zie voor commentaar op deze beschikking Mok (1992 IV), pag. 125 e.v.. Voor een bespreking van bedoelde generieke maatregel en van de maatregelmet betrekking tot marktverdelingsregelingenzie: Mok (1994 I), pag. 467 e.v. alsmede Mok (1994 II), pag. 74-75.

144 De bevoegdheid tot het geven van aanwijzingen aan 'economische machtsposities' werd pas door een wijziging in 1943 (Verordeningenblad 1943, 23) in het Kartelbesluit opgenomen. De Ondernemersovereenkomstenwet 1935 kende deze bevoegdheid in het geheel niet.

145 Zie bijvoorbeeld KB 5 juni 1974, ur. 76, SEW (1975), pag. 556 e.v. m.nt. Van Houten. Hier bleek het Nederlandse kartelrecht ruimer dan het communautaire, omdat in het Nederlandse recht niet vereist was dat de ondernemers er zich van bewust waren dat zij parallel handelden en aldus een collectieve machtspositie vormden. Terecht stelt Mok (1995), pag. 72, dat dit verschil voortvloeide uit de afwijkende consequenties die aan het bestaan van een machtspositie verbonden zijn. In het Europese recht behoort eenaanzienlijkesanctie voor de gepleegdeinbreuktot de mogelijkheden, terwijl in het Nederlandse recht slechts in de oplegging van bepaalde verplichtingen (aanwijzingen) voor de toekomst was voorzien. Kritisch omtrent de uitbreiding van het begrip economische machtspositie tot nietafgestemd gedrag: Snijders (1982), pag. 270 e.v. 
die met het algemeen belang strijdige gevolgen had, kon derhalve vanaf de inwerkingtreding van de Wem mede tegen niet-bindend gedrag worden geageerd.

Bij de beoordeling door de minister van Economische Zaken van de eventuele aanwezigheid van een economische machtspositie moesten twee belangrijke vragen worden beantwoord: wat is in casu de relevante goederen- of diensten markt ${ }^{146} \mathrm{en}^{\text {is }}$ er sprake van een overwegende invloed? Voor de beantwoording van beide vragen maakte de minister van mutatis mutandis dezelfde criteria gebruik als de Europese Commissie op grond van artikel 86 EG-Verdrag (thans artikel $82 \mathrm{EG}){ }^{147}$ Voor een bespreking van deze criteria verwijs ik naar het tweede hoofdstuk, maar hier zij reeds vermeld dat het (gezamenlijke) marktaandeel van de betrokken ondernemer(s) een belangrijke rol speelde. $^{148}$

Indien de minister de aanwezigheid van een economische machtspositie had geconstateerd en deze volgens hem schade berokkende aan het algemeen belang ${ }^{149}$, dan kon hij tegen deze machtspositie een aantal maatregelen nemen die (ten dele) wezenlijk verschilden van de maatregelen tegen mededingingsregelingen. Artikel 24 Wem somde (limitatief) de volgende maatregelen op:

openbaarmaking van gegevens omtrent de machtspositie;

oplegging van de verplichting zich te onthouden van bepaalde gedragingen;

oplegging van een leveringsverplichting respectievelijk van een verplichting tot het verrichten van bepaaide diensten;

- het geven van voorschriften met betrekking tot prijzen van bepaalde goederen of diensten, en

- het geven van voorschriften met betrekking tot de voorwaarden voor levering van goederen, de verlening van diensten en de betaling daarvan.

Wat betreft de maatregelen tegen een economische machtspositie verschilde de Wem aanzienlijk van het communautaire recht. Dit laatste verbiedt misbruik van een machtspositie, waaruit (waar mogelijk) een -niet in het communautaire recht vastgelegde- nietigheid volgt; overtreding van het verbod kan tot hoge boetes aanleiding geven. In de Wem kon slechts -afgezien van de openbaarmaking- bij strijd met het algemeen belang door middel van de zogenoemde aanwijzingen sturend worden opgetreden, opdat misstanden zouden verdwijnen. ${ }^{150}$ Aangezien in tegenstelling tot hetgeen het geval was bij mededingingsregelingen, kende de Wem ten aanzien van economische machtsposities geen verbodelement;

146 Waarbij gold: hoe kleiner de markt, des te groter de kans op een machtspositic.

147 In dezelfde zin Mok (1995), pag. 65 e.v..

148 In de Hoffmann-La Roche-zaak is door de betrokken ministers geoordeeld dat een marktandeel van $34 \%$, in combinatie met enkele andere factoren, voldoende was voor het bestaan van een machtspositie. Door het College van Beroep voor het Bedrijfsleven is deze beschikking vemietigd, omdat de ministers niet in redelijkheid tot dit oordeel hadden kunnen komen: het marktaandeel was te laag (op de andere factoren werd door het CBB niet ingegaan). Voor een kritische bespreking van deze uitspraak, zie Mok in zijn noot bij bedoelde uitspraak, SEW (1980), pag. 135 e.v.. In de praktijk kwam het overigens voor dat uit het gevolg van ondernemersgedraghet bestaan van een economische machtspositie werd afgeleid, zonder dat aan marktaandelen en dergelijke aandacht werd besteed. Zie hierover Snijders (1982), pag. 272.

149 Waarbij het aldus Mok (1988), pag. 155, alleen ging om "gevolgen in de sfeer van marktgedrag. niet van marktstructuur". Concentratiecontrole was derhalve via deze weg niet mogelijk.

150 In spoedeisende gevallen zonodig via de voorlopige aanwijzing van artikel 27 Wem. 
in zoverre kwam dan ook het misbruikkarakter van de Wem bij de economische machtspositie het meest tot zijn recht.

De praktijk van de bevoegdheid van artikel 24 Wem was vergelijkbaar met de praktijk van de onverbindendverklaring: van toepassing op ruime schaal was geen sprake. In veertig jaar Wem ${ }^{151}$ zijn in totaal zes aanwijzingen ${ }^{152}$ en even zovele voorlopige aanwijzingen gegeven. ${ }^{153}$

\section{$2.5 \mathrm{Het}$ Nederlandse kartelbeleid onder de Wem}

Wat kan nu uit het voorgaande worden afgeleid? De uitgangspunten van de Wem -evenals die van haar voorgangsters- waren onmiskenbaar die van een misbruikwetgeving. Kartellering was geoorloofd tot het moment waarop ondernemers misbruik van hun kartelleringsvrijheid maakten en door de overheid - primair in de persoon van de minister van Economische Zaken- onverbindend werden verklaard. Onder omstandigheden kon tevens tot een kartelbevorderende maatregel in de vorm van de algemeen verbindendverklaring worden gegrepen, die weliswaar niet kenmerkend was voor een misbruikstelsel, maar des te meer voor de Nederlandse kartelfilosofic. In ieder geval vergde optreden tegen kartels of tegen economische machtsposities een casuïstisch beleid. Door middel van de pas in de Wem opgenomen bevoegdheid tot generieke onverbindendverklaring werd ten dele afstand gedaan van het misbruiksysteem én casuïstische beleid. Het misbruikkarakter van de Wem ten spijt hadden een strenge interpretatie van het begrip 'algemeen belang' en een ruime aanwending van deze bevoegdheid tot een systeem kunnen leiden dat in praktijk gelijk zou staan met een verbodsysteem. Met instemming kan hier Mok ${ }^{154}$ geciteerd worden:

"Het begrip 'algemeen belang', het centrale toetsingseriterium van de WEM, is elastisch genoeg om tot een zodanige hantering te komen dat kartels, waarvan als vaste regel wordt aangenomen, dat zij niet aan de eisen van art. 85, lid 3, (thans artikel 81 lid 3 EG, HQ) voldoen, in strijd met het algemeen belang geacht worden. Ook dan blijven verschillen bestaan, voortvloeiend uit het onderscheid tussen de Europese verbods-en de Europese (bedoeld is Nederlandse, HQ) misbruikwetgeving, welke echter door een frequenter gebruik van het instrument genericke onverbindendverklaring kunnen worden verkleind. Het resultaat zou een prineipiele gelijke behandeling van EEG-relevante en niet-EEG-relevante (Nederlandse) mededingingsregelingen zijn, op basis van verschillende wetgevingen en door verschillende instanties".

In ieder geval tot 1993 is het zover niet gekomen. Weliswaar gold sinds 1964 een generiek verbod voor collectieve verticale prijsbinding en tot op zekere hoogte voor individuele verticale prijsbinding, maar op de belangrijkste overige terreinen was onverkort het mis-

151 Op grond van het Kartelbesluit is het slechts eenmaal tot een aanwijzing gekomen, namelijk aan een machtspositie van melkstandaardisatic-ondernemingen (Stert. 3 oktober 1957, 192).

152 Stert. 7 augustus 1961, 151 (Sigarenfabrikanten), Stert. 14 juli 1977, 137 (Hoffmann-La Roche), Stert. 28 februari 1996, 43 (Edipress), Stcrt. 23 april 1996, 80 (PNEM), Stert. 17 december 1996, 247 (Kabeltelevisie Amsterdam) en Stert. 17 december 1996, 247 (CAl Alkmaar).

153 Stert. 18 januari 1960, 12 (Bakkers Haarlem), Stert. 5 maart 1968, 447 (Sitos), Stert. 4 april 1974, 67 (Oliemaatschappijen), Stert. I maart 1983, 43 (Sanitaire artikelen), Stert. 27 september 1990, 188 (Dagbladen)en Stert. 10 mei 1994, 89 (Farmaceutischegroothandel).Zie over de Sitos-maatregel Mok (1968), pag. 70-76.

154 Mok (1978), pag. 747. 
bruikstelsel van toepassing. In 1993 en 1994 werden daarnaast in een algemeen streven naar een intensiever kartelbeleid verboden gecreterd voor horizontale kartelafspraken en marktverdelingen. Dit betekende een belangrijke stap in de richting van een verbodstelsel, waarbij moet worden aangetekend dat deze werd gezet op een moment waarop er vergevorderde plannen waren om de Wem te vervangen door een op het verbodstelsel gebaseerde wetgeving. Dus behoudens in de periode waarin een overstap naar een verbodstelsel werd voorbereid, heeft de generieke onverbindendverklaring slechts relatieve betekenis gehad. Een zelfde conclusie kan getrokken worden voor de overige tegen kartels of machtsposities gerichte maatregelen die de Wem kende: in vrijwel veertig jaar Wem werden slechts 26 formele besluiten genomen, daaronder begrepen de maatregelen met een voorlopig karakter; en van deze 26 besluiten werden er 15 in de jaren negentig genomen. Tot een algemeen verbindendverklaring kwam het onder het regime van de Wem zelfs maar twee keer. ${ }^{153}$

Hoewel dus de instrumenten aanwezig waren om met krachtige hand tegen kartels ${ }^{136}$ op te treden, werd van deze instrumenten weinig gebruik gemaakt. ${ }^{157}$ Dit bood zeker een indicatie van een weinig streng en repressief beleid van de Nederlandse overheid in kartelzaken, maar hiermee was nog niet zonder meer gezegd dat van enig rečel Nederlands kartelbeleid nauwelijks sprake was. Het Nederlandse kartelbeleid bestond namelijk niet slechts uit optreden in bedoelde repressieve zin, maar tevens uit het zogenoemde informele beleid. ${ }^{158}$ Hieronder werd verstaan "het van geval tot geval aan een onderzoek onderwerpen van mededingingsregelingen en economische machtsposities, alsmede het toetsen van deze regelingen en machtsposities aan het algemeen belang, zonder dat dit resulteert in een adviesaanvrage aan de Commissie economische mededinging". ${ }^{150}$ Dit informele beleid, dat voor een groot gedeelte bestond uit de behandeling van klachten, maar ook uit ambtshalve onderzoeken, was er op gericht om in overleg tussen overheid, kartellerende ondernemers en eventuele klagers tot een aanvaardbare oplossing te geraken. Waar dus in het formele beleid de overheid eenzijdig en van bovenaf aan ondernemers maatregelen oplegde, daar had in het informele beleid de overheid de rol van bemiddelaar en onderhandelaar, die het algemeen belang en het belang van de klagers beschermde maar tegelijk openstond en begrip had voor de problemen van de kartellerende ondernemers. Dit deel van het Nederlandse kartelbeleid was dan ook niet gericht op het weren van kartelmatig gedrag, maar op het wegnemen van de scherpe kanten ${ }^{160}$ van de gedragingen van het kartel of de machtspositie, waardoor aan de bezwaren (vanuit het algemeen belang) tegemoet werd gekomen zonder het kartel of de machtspositie als zodanig aan

155 Zie voor een bespreking van de beschikkingspraktijk op grond van de Wem in de periode van 1993 tot 1998 (veelal betreffende ontheffingsverzoeken van generieke maatregelen) Wezenbeek-Geuke en Hulsen (1998), pag. 277 e.v.. en Glazener en Janssen (1998), pag. 327 e.v..

156 Kartelbevordering in de vorm van algemeen verbindend verklaring was zelfs vrijwel geheel afwezig. hetgeen echter primair te danken was aan de (gunstige) economische situatie.

157 Van As (1986), pag. 835, concludeert "dat het met het gevoerde mededingingsbeleid in Nederland maar matig gesteld is":

158 Zie hierover ook Uitermark (1990), pag. 312-398.

159 Jaarverslag Wem 1964, TK 1964-1965, 8038, pag. 4 (cursivering HQ).

160 Te denken valt aan een aanpassing van het kartel (bijvoorbeeld versoepeling van een exclusief verkeer. regeling of verlaging van kartelprijzen), een alsnog leveren van producten aan de klager, eventueel het opheffen van (delen van) een mededingingsregeling etc. 
te tasten. Met zoveel woorden is door de Nederlandse overheid in 1961 gesteld dat het informele beleid het zwaartepunt van het kartelbeleid moest vormen; in het jaarverslag over de toepassing van de Wem in 1960 wees toenmalig staatssecretaris van Economische Zaken Veldkamp op "het streven van de overheid het mededingingsbeleid op zodanige wijze te voeren, dat mededingingsbeperkingen, die met het algemeen belang strijdige aspecten vertonen, zoveel mogelijk zonder formele maatregelen worden gecorrigeerd" ${ }^{\text {. }} 6$ Onderling overleg -met noodgedwongen meestal een compromis als uitkomst- had aldus de voorkeur boven het gebruik van de harde hand. Formeel optreden zou pas overwogen dienen te worden indien informeel overleg geen bevredigend resultaat had opgeleverd ${ }^{162}$, waarbij de adviesaanvraag bij de Commissie economische mededinging als stok achter de deur fungeerde. ${ }^{163}$ Het door Veldkamp geuite beleidsvoornemen werd ook in praktijk gebracht. Uit de jaarverslagen van de toepassing van de Wem blijkt dat vanaf haar inwerkingtreding het informele beleid (waarvan de intensiteit in de loop der jaren ook wisselend was) aanmerkelijk intensiever was dan het formele ${ }^{164}$, met deze kanttekening dat er vanaf de eerste concrete beleidsvoornemens tot intensivering van het kartelbeleid medio jaren tachtig tussen formeel en informeel beleid meer evenwicht kwam. ${ }^{165}$ En áls werd gekozen voor het inschakelen van de Commissie economische mededinging -en er dus een formele procedure werd gestart-, dan nog zag de minister meestal af van een maatregel indien de ondernemers zich alsnog bereid verklaarden het kartel conform diens wensen aan te passen. In dit streven om zo min mogelijk met harde hand te ageren, paste ook de praktijk van informele afhandeling van overtredingen van generieke maatregelen. $\mathrm{Bij}$ gebleken overtreding werd veelal niet strafrechtelijk of anderszins opgetreden, maar werd in overleg op aanpassing van de regeling aangedrongen. ${ }^{166}$

161 Jaarverslag Wem 1960, TK 1960-1961, 6348.

162 Uitermark (1987 I), pag. 37 verwoordt het als volgt: "Enigszins gechargeerd gesteld zou men (...) het formele beleid dus kunnen beschouwen als 'mislukt overleg'".

163 Zie jaarverslag Wem 1969, TK 10 642, pag. 2.

164 De tendens naar een toenemend gebruik van informeel beleid was overigens reeds ingezet onder het Kartelbesluit. Vergelijk ook VerLoren van Themaat (1957), pag, 1.

165 Uit de jaarverslagenbleek de overheersing van het informele beleid onmiskenbaar, maar niet steeds werden concrete cijfers genoemd, zeker niet eind jaren zestig en in de jaren zeventig. Begin jaren zestig leidde het informele beleid tot enkele tientallen aanpassingen per jaar. Om enkele voorbeelden uit de jaren negentig te noemen: in 1990/1991 werd in $40 \%$ van de gevallen de reden van de klacht weggenomen; in 1991/1992 werd in $25 \%$ van de klachten (totaal 69 ) na bemiddeling de reden van de klacht weggenomen of werd de klacht aan een andere overheidsinstantie overgedragen; in $52 \%$ van de gevallen werd het kartel opgeheven of aangepast, danwel was er niet van strijd met het algemeen belang gebleken.

166 Zie bijvoorbeeld met betrekking tot verticale prijsbinding de jaarverslagen Wem over de jaren 1967 (TK 1967-1968, 9563) en 1968 (TK 1968-1969, 10117 ) en met betrekking tot disciplinaire kartelrechtspraak het sinds 1975 (jaarverslag Wem 1975, Stcrt. 20 oktober 1976, 204) lange tijd gevoerde beleid. In deze praktijk stond de Wem overigens niet alleen. Dit blijkt bijvoorbeeld Handhaven op niveas (1998), pag. 48: "Naleving wordt bevorderd en ook vaak bewerkstelligd door overreding en in overleg. Demeeste geconstateerdeovertredingen worden in het 'voortraject' beêindigd, dus voor er een sanctic hoeft te worden getroffen. De (mogelijkheid van een) sanetie werkt dan 'slechts' als stok achter de deur. Hierbij moet wel worden opgemerkt dat veel besturursorganen uiteindelijke naleving als belangrijkste, zo niet enige handhavingsdoel zien". 
Door deze voorkeur voor de informele weg, gevoegd bij de omstandigheid dat in de onderhandelingen de kartels niet werden geconfronteerd met al te strenge normen ${ }^{167}$ en dat ook het informele beleid niet overmatig actief was, ontstond het beeld van een tenminste onopvallend kartelbeleid, waarin voor kartellering alle ruimte werd gelaten en slechts in uitzonderlijke gevallen een formele maatregel uit de kast werd gehaald. In dit vaak bekritiseerde beleid -als gezegd sprak VerLoren van Themaat bijvoorbeeld in kritische bewoordingen van "de in gebreke blijvende nationale mededingingspolitiek" en een "al jaren durende impasse in het Nederlandse kartelbeleid" ${ }^{\text {"168 }}$ - vond het stigma van Nederland als kartelparadijs zijn oorsprong.

De vraag die rijst is waarom in Nederland een beleid als bedoeld is gevoerd. Strikt genomen valt deze vraag uiteen in zeker drie deelvragen: waarom was de Nederlandse overheid geen voorstander van een streng anti-kartelbeleid, waarom was nauwelijks sprake van enig actief beleid en waarom werd bij voorkeur de informele weg bewandeld? Hieronder zal blijken dat deze deelvragen (en hun antwoorden) zozeer met elkaar verband houden dat zij samen kunnen worden behandeld. Daar waar specifiek een deelaspect aan de orde is, zal dat worden aangegeven.

De primaire verklaring voor het ontbreken van een streng anti-kartelbeleid was dat in de optiek van de Nederlandse overheid kartellering gunstige (economische) gevolgen kon hebben ${ }^{169}$ Dit was de meest voorname reden om de Ondememersovereenkomstenwet 1935 in het leven te roepen en bedoeld uitgangspunt werd ook bij de totstandkoming van de Wem en in latere beleidsstukken onderstreept. Meer in het algemeen stonden samenwerking en onderling overleg op allerlei terreinen in Nederland hoog in het vaandel, met een overheid die zich afzijdig hield of wellicht bij samenwerking en overleg betrokken was, maar die zo min mogelijk intervenieerde. Hier denke men alleen al aan fenomenen als zelfregulering en de collectieve arbeidsovereenkomst, aan (overige) gebieden met een aanzienlijke rol voor werkgevers- en werknemersorganisaties, maar ook aan kartellering. In dit licht van de Nederlandse overlegeconomie -die ook in het poldermodel nog voortleeft- en een wijdverbreid corporatisme was aanvaarding van kartellering en afzijdigheid van de overheid een vertrouwd verschijnsel. Terecht stelde Braakman in dit verband dat "de Nederlandse traditie van corporatisme (...) geacht (werd) meer in het algemeen belang te zijn dan de toepassing door de Overheid van regels die gericht zijn op de beperking daarvan". ${ }^{170}$ Het voorgaande verklaarde het bestaan van het informele beleid: het algemene beleid dat conflicten primair door middel van overleg tussen betrokkenen moesten worden opgelost, kwam in het informele kartelbeleid volledig tot zijn recht. Ook hier werd in overleg getracht om tot een voor iedereen (overheid, kartelleden en eventuele

167 Zo concludeerden't Gilde en Haank (1985), pag. 11/12, dat de overheid genoegen nam met relatief geringe aanpassingen.

168 VerLoren van Themaat (1978), pag. $191 \mathrm{en} 192$. Mok (1982 II), pag. 248, constateerde dat kartelbeleid "in Nederland nog aitijd niet populair" was, terwijl Geelhoed(1985), pag. 712, verzuchtte: "Kortom. bet blijft tobben".

169 Terwijl de openheid van de Nederiandse economie als garantie tegen al te grote misbruiken werd gezien.

170 Braakman (1997 II), pag. 196. In vergelijkbare zin VerLoren van Themaat (1988 II), pag. 73. De Jong (1986 I), pag. 3, stelde: "Van een overheid die boven de partijen staat en voor de marktwerking garant staat, is vaak weinig te bespeuren". 
klagers) aanvaardbare oplossing te komen ${ }^{17}$; eenzijdig overheidsoptreden -in de vorm van een onverbindendverklaring of aanwijzing- werd pas overwogen nadat overleg was gestrand. Daarbij moet worden bedacht dat kartelbeleid slechts één aspect van het gehele economische beleid vormde, een aspect dat bovendien met belangen op andere beleidsterreinen kon conflicteren. ${ }^{172}$ Niet alleen zouden in de toen heersende visie voor deze conflicten met name via onderling overleg de beste oplossingen gevonden kunnen worden $^{173}$, maar bovendien zou een harde aanpak van marktpartijen die zich in een kartel verenigd hadden, overleg van het ministerie van Economische Zaken met diezelfde partijen op andere beleidsterreinen ongetwijfeld frustreren ${ }^{174}$ : de animo om met het ministerie om de tafel te gaan zitten, zou in dat geval bij de marktpartijen ongetwijfeld zeer gering zijn. ${ }^{175}$

Een tweede reden voor het in Nederland gevoerde kartelbeleid werd wel gezocht in de Wem en het aan haar ten grondslag liggend misbruikstelsel. Zo zou het casuïstische beleid een streng anti-kartelbeleid niet mogelijk maken. Naar mijn mening heeft de naoorlogse praktijk van het Kartelbesluit het tegendeel aangetoond. Dat laat onverlet dat het casuinstische optreden wel enkele problemen kende. Een eerste probleem was de geringe efficiency van dit optreden, met name gelet op de noodzaak van de adviesprocedure bij de Commissie economische mededinging. Dit probleem kon voor een groot gedeelte worden opgevangen door gebruikmaking van de informele procedure, maar deze leidde naar haar aard tot een minder streng optreden. Een tweede probleem was dat het nemen van een maatregel politiek nogal gevoelig lag. Iedere maatregel kon rekenen op de nodige weerstand en onbegrip, voornamelijk bij de betrokkenen, maar ook bij andere ondernemers en zelfs bij de politieke partijen: volslagen natuurlijke gedragingen van ondernemers, die in beginsel zelfs door de overheid werden toegejuicht, werden 'plotseling' door de bewindsman verboden. Deze moest sterk in zijn schoenen staan en zeker van zijn zaak zijn om dan toch van de uitgangspunten van de wet af te stappen en een formele maatregel te nemen, temeer daar met name de groep ondernemers uit het midden- en kleinbedrijf hierdoor werd getroffen, een groep die een niet onbelangrijk deel van het electoraat vertegenwoordigde. ${ }^{176}$ Ook VerLoren van Themaat wees op de politieke gevoeligheid van streng optreden als reden voor het milde, informele kartelbeleid, zij het dat hij dit in

171 Informeel optreden maakte sturing van gedrag door de overheid mogelijk. Mok (1964 I), pag. 157, wees bijvoorbeeld op het Nederlandse prijsstabilisatiebeleid, dat "zich liever bediende van kartels dan dat het zich ertegen verzette".

172 Zie hierover ook 't Gilde en Haank (1985), pag. 17 en Mok (1964 I), pag. 152. Deze schrijver stelde: "Het tegelijkertijd dienen van het belang van de middenstand en van de economische mededinging is een opgave die de kiem van spanningen in zich draagt",

173 Mok (1969 II), pag. 186, stelde terecht: "De constructie dat het kartelbeleideen deel is van het algemeen economisch beleid kan er in de praktijk toe leiden dat het kartelbeleid aan het algemeen economische beleid wordt opgeofferd". In de praktijk is dit inderdaad lange tijd gebeurd, hetgeen ook blijk uit de bevindingen van ' $t$ Gilde en Haank (1985), pag. 23/24.

174 In deze zin eveneens Mok (1969 II), pag. 185 en (1978), pag. 760.

175 Michiels (1994), pag. 16/17, wijst eveneens -zij het in een andere context- op het gevaar dat het eenzijdig opleggen van (bestuurlijke) boetes door een bestuursorgaan kan opleveren voor de bereidheid tot de samenwerking van de zijde van een overtreder.

176 Mok (1964 I), pag. 151, stelde: "dat het uitvoeren van een kartelwet die een misbruikstelsel volgt niet alleen een zaak van politieke keusbepaling maar ook van doorzetten, druk overwinnen en risico's durven nemen is". In vergelijkbare zin dezelfde auteur (1978), pag. 760. 
verband bracht met een ander bezwaar tegen de wettelijke regeling. ${ }^{177}$ Dit derde probleem van het casuistische optreden op grond van de Wem lag in de grote beleidsvrijheid van de minister van Economische Zaken, mede veroorzaakt door vage normen als 'algemeen belang' en 'economische machtspositie'. ${ }^{178}$ Volgens VerLoren van Themaat maakte een beleidsvrijheid die twee volledig tegengestelde maatregelen toeliet een duidelijk en doeltreffend beleid onmogelijk. Toegegeven kan worden dat door opneming van duidelijke en concrete normen in een wettelijke regeling de toepassing ervan eenvoudiger is, met name omdat er in die situatie daadwerkelijk sprake is van toepassing van de wet en niet zoals bij vage normen en grote beleidsvrijheid het geval is- van invulling van de wet (en daarmee de facto van wetgeving zelf). Het ijs is voor de bewindslieden in het tweede geval aanmerkelijk gladder dan in het eerste geval. Toch mag het belang van dit probleem naar mijn mening niet overschat worden. Ten eerste omdat -wellicht met enige inspanningvia beleidslijnen en invulling van vage termen de bevoegdheden geconeretiseerd hadden kunnen worden. Het is bijvoorbeeld niet in te zien waarom het voor het ministerie van Economische Zaken moeilijker zou zijn om het begrip (economische) machtspositie vorm te geven dan voor de Europese Commissie, die hierin wel is geslaagd. Ten tweede geldt dat bij daadwerkelijke onwerkbaarheid van de casüstische aanpak hetzij de Wem als zodanig had kunnen worden aangepast, hetzij generieke maatregelen hadden kunnen worden getroffen. Lange tijd is geen van beide gebeurd, hetgeen mijns inziens eveneens wees op een gebrek aan politieke wil om werk te maken van een streng mededingingsbeleid; was deze politieke wil er wel, zoals bijvoorbeeld bij voormalig staatssecretaris Van Rooy en minister Wijers, dan bleek een streng optreden wel binnen de mogelijkheden van de Wem te liggen. ${ }^{179}$ Een probleem was wel dat de visie dat de Wem 'niet werkte' een eigen leven ging leiden. Opmerkelijk was bijvoorbeeld dat in de jaren zeventig bij de regering wel de politieke wil aanwezig was, getuige enkele voorstellen tot wijziging van de Wem, die overigens geen van alle de eindstreep haalden. ${ }^{180}$ Verwacht zou dan mogen worden dat op beleidsniveau de teugels strakker zouden zijn aangehaald en dat in de praktijk op grond van de bestaande regeling een stringenter beleid zou worden gevoerd. Dit was echter niet het geval, mede omdat de voorbereiding van de voorstellen beslag legde op een groot deel van de capaciteit, maar waarschijnlijk tevens omdat de overtuiging was gegroeid dat de bestaande regeling een strenger beleid in de weg stond.

177 VerLoren van Themaat (1988 1), pag. 4-15 en (1988 II), pag. 60-77.

178 Volgens 't Gilde en Haank (1985), pag. 17 e.v. werd de vaagheid van de normen ook binnen het departement als een belangrijk minpunt van de Wem ervaren.

179 Mok (1969 II), pag. 131, constateerde dat "de persoonlijke invloed van de bewindslieden speurbaar (was), in die zin dat accenten anders gelegd kunnen worden en vooral dat de mate van dynamiek van het beleid nogal uiteen kan lopen. Ik heb de indruk dat dit overigens meer met de persoonlijke instelling van de ministers of staatssecretarissen, dan met hun politicke signatuur, of die van de regering waarvan zij deel uitmaken, samenhangt". Beziet men de historie van het Nederlandse kartelbeleid sindsdien, dan wordt deze indruk alleen maar bevestigd. Vergelijk mede 't Gilde en Haank (1985), pag. 18.

180 Zie onder meer VerLoren van Themaat (1978), pag. 187. Het wetsvoorstel voorzag in de invoering van een vergunningenstelsel voor prijsafspraken en van een mogelijkheid voor de overheid tot vaststelling van minimumprijsafspraken. Volgens VerLoren van Themaat was het met name de bedoeling de kartels te vormen naar de inzichten van de overheid en aldus de kartels te gebruiken ter ondersteuning van het economische beleid van de overheid, de reden waarom deze schrijver sprak van karteldirigisme. 
Als derde reden voor het bescheiden kartelbeleid van de Nederlandse overheid zou het bestaan van het communautaire mededingingsbeleid kunnen worden aangevoerd. Vanuit een houding, die VerLoren van Themaat wel heeft omschreven als 'omgekeerd subsidiariteitsbeginsel $^{181}$, zou elk kartel met communautaire dimensie ter beoordeling aan de Europese Commissie worden overgelaten. Ik betwijfel of dit aspect heeft bijgedragen aan de terughoudendheid om de Wem (streng) toe te passen. Dit gold zeker niet voor het eerste decennium van de Wem, waarin het communautaire kartelrecht nog volop in ontwikkeling was. Maar bovendien bood het bestaan van een streng communautair beleid nog geen verklaring voor het Nederlandse beleid ten aanzien van typisch nationale (dus: niet-communautaire) kartels. Het verband tussen nationaal en communautair beleid leek eerder omgekeerd, zeker sinds de jaren tachtig. Het EG-kartelrecht en de beschikkingen van de Europese Commissie tegen kartels waarbij Nederlandse ondernemingen waren betrokken, deden de roep om aanscherping van de Wem en van het daarop gevoerde beleid toenemen.

Op grond van het voorgaande concludeer ik dat de voornaamste redenen voor het milde en informele Nederlandse kartelbeleid waren gelegen in het corporatisme en de Nederlandse overlegcultuur en -ten dele daarmee samenhangend- in de ontbrekende politicke wil tot een streng beleid. Het systeem van de wet en de open formulering van de bevoegdheden stond weliswaar een ander beleid niet in de weg, maar vormde niet de meest ideale basis voor een anti-kartelbeleid naar Europees voorbeeld. In zoverre kan dan ook worden ingestemd met Duk, waar hij stelde: "Door de moeilijkheden bij de toepassing van de W.E.M. (...) wordt, naar het mij voorkomt, aangetoond dat, hoezeer in theorie mogelijk, een combinatie van misbruikstelsel en intensief mededingingsbeleid in de praktijk uiterst problematisch is"..$^{182}$

Met het bovenstaande zij overigens niet gezegd dat het Nederlandse kartelbeleid tekortschoot. Of hiervan sprake is, hangt af van wat men van beleid verwacht. Indien men een beleid naar communautair voorbeeld wenselijk acht, hetgeen heden ten dage het geval is, dan kan men niet anders dan concluderen dat de Wem en het op basis daarvan gevoerde beleid hebben gefaald. Met evenveel recht kan men tot een andere conclusie komen. Het kartelbeleid is weliswaar niet omvangrijk geweest -dat kan men de Nederlandse overheid zeker tegenwerpen-, maar het paste naadloos in de Nederlandse overlegcultuur en bij het uitgangspunt dat kartellering positieve aspecten heeft en dus in beginsel moet zijn toegestaan. Als de nadruk op dit laatste wordt gelegd, dan is een tekortschieten van het beleid minder duidelijk.

\section{Strafrechtelijke handhaving van de Nederlandse kartelwetgeving}

Hoe men ook over het voorgaande denkt, duidelijk is dat ondernemers op kartelgebied van de Nederlandse overheid weinig hadden te vrezen. Voor zover een kartel niet onder de reikwijdte van een generieke onverbindendverklaring zou vallen, gold voor ondernemers het motto 'vrijheid blijheid'. De Nederlandse overheid was tolerant ten aanzien van kartels en trad de facto slechts op tegen excessen; en zelfs dan werd pas voor een formele maatre-

181 VerLoren van Themaat (1988 I), pag. 4.

182 Duk (1973), pag. 453. Dat ook de Wem in theorie een strenger anti-kartelbeleidmogelijk zou maken. wordt door dezelfde schrijver in 1974 nog eens herhaald: zie Duk (1974), pag. 631 . 
gel geopteerd indien zij in onderling overleg met de ondernemers niet tot een (voor beide partijen) aanvaardbare oplossing was gekomen. Volgde in een zeldzaam geval toch een onverbindendverklaring of een aanwijzing aan een economische machtspositie, dan stond vanzelfsprekend terecht ${ }^{183}$ - tegen deze beslissing beroep open bij de Kamer voor mededingingszaken van het College van Beroep voor het bedrijfsleven. ${ }^{184}$ Hoewel aanvankelijk ${ }^{113}$ de mogelijkheden om bij dit College in beroep te komen, beperkt waren ${ }^{186}$, heeft het zijn waarde voor het Nederlandse mededingingsrecht (en voor de justitiabelen ${ }^{15}$ ) zeker bewezen, hetgeen wordt onderstreept door het gegeven dat het niet alleen de uniformeringsgedachte van de Algemene wet bestuursrecht (centrale rechterijke instantie is de bestuurskamer van de arrondissementsrechtbank), maar zelfs de Wem heeft overleefd: in de Mededingingswet is het College de beroepsinstantic inzake vonnissen van de arrondissementsrechtbank Rotterdam.

183 Toch is de regeling van beroep op een administratieve rechter pas na hardnekkig verzet van de minister van Economische Zaken en onder grote druk van de Tweede Kamer in de Wem opgenomen. De inwerkingtreding van de -goedgekeurde. Wem werd zelfs afhankeljikgesteld van de totstandkoming van bedoelde regeling. Deze werd in 1958 door het parlement goedgekeurd (Stb. 1958, 412). Mulder (1982), pag. 221, wijst er op dat de periode waarin de Wem tot stand kwam meer in het algemeen wend gekenmerkt door een grotere aandacht voor rechtsbescherming.

184 De keuze voor het CBB lag niet geheel voor de hand omdat het geen besluiten van bedrijfslichamen (waartoe de Wet administratieve rechtspraak bedrijfsorganisatie tot dan toe beperkt was) maar besluiten van de centrale overheid betrof. De keuze viel volgens de MvT TK 1956/1957, 4762, toch op het $\mathrm{CBB}$ om redenen van ervaring van het $\mathrm{CBB}$ met zaken die verwantschap met mededingingszaken vertoonden en van 'concentratie van de administratieve rechtspraak, op het terrein van de sociaaleconomische wetgeving, bij één rechter'. Deze concentratiewerd van belang geachtvoor bevordering van eenheid van jurisprudentie op sociaal-economisch gebied, voor vergroting van het gezag van het $\mathrm{CBB}$ en voor stimulering van de bereidwilligheid om hierin zitting te nemen. De keuze voor een aparte mededingingskamer vloeide voort uit twijfels omtrent de deskundigheid inzake de specifieke mededingingsrechtelijke problemen en uit de hoop dat dit een grotere continulteit in de Wem-jurisprudentie zou meebrengen.

185 De rechtsbescherming is in de loop der tijd aanmerkelijk verruimd, onder meer door de erkenning van de mogelijkheid van Kroonberoep (op grond van de Wet beroep administratieve beschikkingen) van beschikkingen houdende voorlopige voorzieningen (zie KB 5 juni 1974, no. 76, SEW (1975), pag. 556 e.v. m.nt. Van Houten) en door de Wet van 2 maart 1989 tot wijziging van de Wet economjsche mededinging en van enige andere wetten (uitbreiding van de mogelijkheden van beroep), Stb. 1989, 57.

186 Mulder en Mok (1962), pag. 170 e.v. geven aan dat aanvankelijk beroep slechts openstond tegen enkele, uitdrukkelijk in de Wem opgenomen beschikkingen, met name betreffende ontheffingen ( $v a n$ de meldingsplicht of een algemeenverbindendverklaring), onverbindendverklaring en aanwijzingen aan machtsposities. Daarenboven kon in grote lijnen beroep slechts worden ingesteld door de teleurgesteide verzoeker van een beschilkking of de direct getroffene van bijvoorbeeld een onverbindendverklaring. Ook de beroepsgronden waren beperkt. Hiervoor werd aangeslotenbij artikel 5 Wet administratieve rechtspraak bedrijfsorganisatie (Stb. 1954, 416): a. strijd met een algemeen verbindend voorschrift; b. détournement de pouvoir; c. onmogelijkheid om bij afweging van de betrokken beiangen tot de betreffende beslissing te komen, en d. strijd met een algemeen beginsel van behoorlijk bestuur. Met de inwerkingtreding van de Awb is aansluiting gezocht bij de aldaar gehanteerde beroepsgronden. In dere regeling is verandering gekomen bij de Wet van 16 december 1993, Stb. 1993, 650 (voltooing eerste fase herziening rechterlijke organisatie). Als gevolg van deze wet werden de hoofdregels van de Awb gevolgd.

187 Voor een voorbeeld van vernietiging van een beschikking op grond van schending van het zorgvul. digheidsbeginsel zie CBB 5 maart 1969, No, 150/01/12, SEW (1969), pag. 300 e.v.. 
Ook vanuit civielrechtelijke hoek hadden kartellerende ondernemers relatief weinig te duchten. $^{188}$ Theoretisch is de gang naar de burgerlijke rechter voor burgers veelal de kortste en meest directe weg om dat te trachten te bereiken waarop zij recht (menen te) hebben: het initiatief tot een civiele actie ligt bij henzelf, zij zijn niet afhankelijk van overheidsoptreden (dat zij bovendien vaak niet kunnen afdwingen) en het civiele geding biedt - bij honorering van de eis- een uitkomst (bijvoorbeeld veroordeling tot schadevergoeding, nietigverklaring van de rechtshandeling, verbintenis tot ongedaanmaking) waarbij de eiser direct gebaat is. ${ }^{189}$ Een wandeling op deze civielrechtelijke weg beloofde echter in het kader van de Wem slechts onder omstandigheden succes, namelijk indien er tegen een kartel of machtspositie óf tegen een soort mededingingsregelingen reeds van overheidswege een formele maatregel was genomen én deze maatregel vervolgens door onder. nemers niet werd nageleefd. Bij ontbreken van een dergelijke maatregel (bedacht moet worden dat de civiele rechter niet bevoegd was tot bijvoorbeeld onverbindendverklaring) leverde het gedrag van ondernemers geen strijd op met de Wem en was het -behoudens strijd met algemene civielrechtelijke regels- rechtens bindend en afdwingbaar. Aantonen dat het gedrag desalniettemin in strijd met het recht en onrechtmatig ten opzichte van benadeelde eisers was, was dan ook niet eenvoudig. ${ }^{190}$ Het, zoals in de vorige paragraaf bleek, beperkte aantal formele maatregelen had zodoende directe repercussies voor de civielrechtelijke handhaving. Dat er toch enige ruimte voor deze handhavingsmodaliteit was, was met name te danken aan de generieke onverbindendverklaring van verticale prijsbinding.

De mogelijkheden voor civielrechtelijke handhaving waren gelet op het voorgaande relatief beperkt. De vraag die hierna aan de orde komt, is in hoeverre het strafrecht enige rol van betekenis heeft kunnen spelen. Vooraleer hierop wordt ingegaan, zal eerst in paragraaf 3.1 worden bezien waarom de wetgever voor de mogelijkheid van strafrechtelijke handha ving heeft gekozen. Paragraaf 3.2 staat in het teken van een bespreking van de strafbare gedragingen, waarna in de paragrafen 3.3 en 3.4 de handhavingsbevoegdheden respectievelijk de mogelijke sancties aan bod komen.

188 Afgezien van een suecesvolle actie tot nakoming van de mededingingsregeling, indien de gedaagde zich niet meer wenste te conformeren aan hetgeen onder meer door hem zelf eerder was overeengekomen.

189 In het kartelrecht kan gedacht worden aan consumenten of (andere) afnemers die schade ondervinden van een door producenten of leveranciers gesloten kartelafspraak inzake minimumprijzen. Of aan ondememers die aan een kartel deelnemen, maar hieruit in strijd met de wil van de overige kartelledes willen terugtreden. Of aan een ondernemer die zich in een bepaald gebied wenst te vestigen, mast geconfronteerd wordt met een gebiedsbeschermende kartelafspraak waardoor het hem niet lukt in de markt te penetreren. In het eerste geval zullen consumenten en afnemers deze schade willen verhalet op de kartelparticipanten, bijvoorbeeld via een actie uit onrechtmatige daad. In de twee laatstgenoemde situaties willen de gelaedeerde ondernemers dat het kartel van het toneel verdwijnt.

$190 \mathrm{Zij}$ het niet onmogelijk. De civiele rechter achtte zich bijvoorbeeld bevoegd de toepassing van de mededingingsregeling te toetsen. Vergelijk bijvoorbeeld HR 11 februari 1972, NJ 1972, $259 \mathrm{~m} . \mathrm{nt}$ G.J.S. 


\section{I De keuze voor strafrechtelijke handhaving}

Het totstandbrengen van een wettelijke regeling impliceert dat er een keuze gemaakt moet worden ten aanzien van de handhaving van de naleving van deze regeling: vormt het burgerlijke recht een voldoende waarborg voor een adequate handhaving of dient deze handhaving (mede) door de overheid zelf ter hand te worden genomen; is dit laatste het geval, dient dan de bestuursrechtelijke of de strafrechtelijke weg bewandeld te worden, waarbij in beginsel geldt dat het strafrecht slechts als uiterste (red)middel (ultimum remedium) zal mogen worden gebruikt? Voor dergelijke vragen met betrekking tot de handhaving zag vanzelfsprekend ook de kartelwetgever zich gesteld. Aanvankelijk werd door de indieners van het wetsvoorstel dat leidde tot de Ondernemersovereenkomstenwet 1935 geoordeeld dat civielrechtelijke handhaving voldeed. In geval een marktpartij een algemeen verbindendverklaring dan wel een onverbindendverklaring zou schenden, zou het aan andere, benadeelde marktpartijen kunnen worden overgelaten om via een civielrechtelijke onrechtmatige daad-actie tegen de overtreder in rechte op te treden. ${ }^{191}$ Deze aanpak borg in zoverre mogelijke complicaties in zich dat geen zekerheid bestond dat marktpartijen inderdaad in geval van overtreding de weg naar de civiele rechter zouden kiezen. Het hierdoor dreigende handhavingstekort klemde met name daar waar het algemeen belang in het geding was. Reeds bij de Nota van Wijzigingen gaf de minister van Economische Zaken $^{192}$, mede naar aanleiding van kritische kanttekeningen in het Voorlopig Verslag. ervan blijk deze complicaties -zij het uitsluitend met betrekking tot de onverbindendverklaring-als reëel te ervaren. Hoge kosten en de dreiging van repercussies zijdens de kartellerende ondernemers zouden volgens Steenberghe benadeelden van een schending van een onverbindendverklaring van een actie uit onrechtmatige daad weerhouden. ${ }^{193}$ Consequentie hiervan was dat onvoldoende heil van het burgerlijke recht werd verwacht en alsnog naar publiekrechtelijke -in casu strafrechtelijke- handhaving werd gegrepen. Ten aanzien van schendingen van algemeen verbindendverklaringen daarentegen werd de minister niet overtuigd van de noodzaak tot strafrechtelijke handhaving. Een dergelijke schending dupeerde primair de concurrenten van de overtreder, die ten opzichte van de overtreder echter relatief sterk stonden. Zoals in $\S 2.3 .1$ is gebleken, kon pas tot algemeen verbindendverklaring worden besloten als de meerderheid van de marktpartijen reeds in de ondernemersovereenkomst participeerden; doel was dan ook de enkeling die niet vrijwillig wenste te coōpereren, alsnog tot medewerking te dwingen. Gevolg hiervan was dat de overtreder in beginsel steeds tegenover een meerderheid in de bedrijfstak stond. Daarbij kwam nog dat het de ondernemers zelf waren van welke het initiatief tot de algemeen verbindendverklaring was uitgegaan. Van ondernemers die deze stap gezet hadden, mocht tevens verwacht worden dat zij -als eenmaal de overeenkomst algemeen verbindend was-zelf juridische stappen ondernamen tegen ondernemers die deze overeenkomst toch trachtten te

191 Aldus minister van Economische Zaken ad interim Colijn, Handelingen 1933-1934, 460, nt. 3. De noodzaak van strafrechtelijke handhaving was volgens de minister a.i. (nog) niet gebleken en mede daarom diende strafbaarstelling achterwege te blijven; een aardig voorbeeld van de ultimum remediumgedachte. Evenmin opteerde de bewindsman voor de instelling van een bijzonder orgaan dat zou zijn belast met het toezicht op de naleving van het algemeen belang.

192 Inmiddels werd dit ambt bekleed door Steenberghe.

193 Handelingen 1934-1935, 64, nrs, 1 en 2. Opgemerkt moet worden dat in dit verband Steenberghe met name een verticale relatie (leverancier-afnemer)voor ogen stond, waarbij de afnemer duidelijk de zwakkere was. 
ontduiken. Civielrechtelijke handhaving werd dan ook -niet onbegrijpelijk- door de minister als adequaat beschouwd als gevolg waarvan het strafrecht niet behoefde te worden ingeschakeld. $^{194}$

Aan de keuze voor het strafrecht als publiekrechtelijk handhavingsmiddel van overtredingen van onverbindendverklaringen ging geen discussie vooraf waarin mogelijkheden, voordelen en beperkingen van het strafrecht tegen die van andere publiekrechtelijke handhavingsvormen, en meer in het bijzonder van het bestuursrecht, werden afgewogen. Dit hoefde om zeker twee redenen niet te verbazen. Ten eerste was de wetgever blijkens de behande. ling van het ontwerp van de Ondernemersovereenkomstenwet 1935 zeer beducht voor toekenning van bevoegdheden aan de executieve: getracht werd zoveel mogelijk waarborgen tegen misbruik aan te brengen; vanuit dit streven lag de toekenning aan het bestuur van een bevoegdheid tot bestraffing niet voor de hand. Ten tweede was de bevoegdheid tot het opleggen van punitieve sancties buiten het (commune) strafrecht om toentertijd geen alledaags gegeven. Bij dit laatste past echter een belangrijke kanttekening, namelijk dat de wetgever -voornamelijk uit doelmatigheidsoverwegingen ${ }^{195}$ - in verschillende (andere) crisiswetten wél zijn toevlucht nam tot handhaving die buiten het commune strafrecht lag. Deze voornamelijk via organisaties van aangesloten ondernemingen lopende handhaving werd aangeduid als tuchtrechtelijk, maar was volgens Mulder ${ }^{196}$ "niet anders dan een bijzondere vorm van strafrechtspraak"; een vorm van handhaving die enige gelijkenis vertoont met de hedendaagse handhaving door middel van bestuurlijke boetes. ${ }^{19}$ ?

194 Zie hieromtrent onder meer ook Kruisheer (1939), pag. 73. Op deze zienswijze werd wel kritiek geuit. Zo was Westerman, Handelingen 1934-1935, pag. 1496, van mening dat het ontduiken van een verbindend verklaring niet alleen eenzaak was tussen de ondernemingen die aan de overeenkomst waren gebonden, maar eerst en vooral een aantasting van het algemeen belang opleverde. En omdat het algemeenbelang in het geding was, zou aan de overheidde mogelijkheid moeten worden geboden om in te grijpen. Deze kritiek werd tegemoet gekomen via de volgende constructie: de Commissie van Toezicht, een centraal overheidsorgaan, werd als belanghebbende aangemerkt bij de nakoming van een verbindend verklaring waardoor deze commissie kon optreden tegen schendingen via het burgerlijke recht. Kritisch hieromtrent Maitland (1946), pag. 54. De wetswijziging van 1939 bracht in deze situatie overigens geen verandering, ondanks de aanwezigheid van voorstanders van een strafrechtelijke sanctie naar analogie van artikel 12 Ontwerp van de "Landbouw-Bedrijfsregelingenwet".

195 Vergelijk Mulder (1959), pag. 5: de "commune strafrechtspraak achtte men onvoldoende repressief. de rechter werd niet genoeg deskundig gevonden, het gewone strafarsenaal leek ontoereikend"; in gelijke zin Schaffmeister (1978), pag. 17.

196 Mulder (1959), pag. 5

197 Zie hierover ook Widdershoven (1995), pag. 205-208. Belangrijke exponent van dit streven naar andere handhavingsmogelijkheden was de tuchtrechtelijke (naast, niet in plaats van, de strafrechtelijke) rechtspraak die de Landbouw-Crisiswet 1933 (in samenhang met het Crisis-Organisaticbesluit) kende. iedere ondememer werkzaam op het gebied van de landbouw moest zijn aangesloten bij een landbouwerisis-centrale en moest zich onderwerpen aan het binnen deze centrale geldende tuchtrecht. Hoewel de term tuchtrecht niet doet vermoeden dat het (quasi-)strafrecht betreft, is een dergelijke kwalificatic wel terecht, met name gelet op de op ondernemingen rustende dwang tot toetreding tot de landbouwcrisis-centrales, op de prominente rol die de overheid in deze vervulde en op het ten dele publiekrechtelijk karaktervan de tuchtrechtelijkte handhaven voorschriften. Daarbij kwamnog dat de 'vervolging' geconcentreerd was bij de Hoofdambtenaar voor de Crisis-tuchtrechtspraak. Zie dienaungaande Schaffmeister (1978), pag. 58 en Wladimiroff en Schreuders (1990), pag. 71 e.v. 
Deze ontwikkeling van tuchtrechtelijke handhaving stond zoals aangestipt in het teken van een doelmatig (overheids)optreden. ${ }^{195}$ De keuze voor een buiten het commune strafrecht liggende handhavingsmodaliteit impliceerde dan ook dat het commune strafrecht als onvoldoende doelmatig instrument voor de handhaving van de desbetreffende wetgevingen werd beschouwd. Interessant is het nu om de afzonderlijke bezwaren tegen dit commune strafrecht -zoals die in de crisis-tijd werden gevoeld-te bezien; interessant niet alleen omdat zij de beweegredenen van de toenmalige wetgever tonen en ook duidelijkheid kunnen verschaffen over de vraag waarom de kartelwetgeving niet tuchtrechtelijk werd gehandhaafd, maar meer nog omdat -zoals nog zal blijken- verschillende argumenten opmerkelijke overeenkomsten vertonen met de argumenten die hebben geleid tot de totstandkoming van de WED ${ }^{199}$ (als bijzondere strafwet) én met de argumenten die (ruim zestig jaar na de crisis-wetgeving) ten grondslag lagen aan de voorkeur van de wetgever voor bestuursrechtelijke (in plaats van strafrechtelijke) handhaving. Mulder ${ }^{200}$ onderscheidde de volgende argumenten die de keuze van de toenmalige wetgever hebben bepaald of tenminste beïnvloed:

- een bestaand wantrouwen tegen de rechterijke macht: de door deze tot dan toe uitgesproken sanctics waren vanuit preventief oogpunt ontoereikend;

het ontbreken van een regeling omtrent strafbaarheid van rechtspersonen en van de sanctie van tijdelijke 'stillegging' van een onderneming:

- de wens van een eenvoudige en snelle behandeling van zaken: het Wetboek van Strafvordering wierp, met name door de bewijaregels en de aan de inhoud van de dagvaarding gestelde eisen, te hoge barrieres op tegen een effectieve handhaving, en

- twijfels over de organisatie van de rechterlijke macht: deze zou zonder uitbreiding ${ }^{\text {sot }}$ de aanzienlijke stroom van zaken niet kunnen verwerken, zou over onvoldoende deskundigheid beschikken en zou problemen ondervinden met de vaststelling van de strafmaat (hetgeen samenhing met het als het eerste genoemde argument) en met een snelle afhandeling van zaken.

Het materieel en formeel strafrecht alsmede de strafrechter waren dus in de visie van de wetgever niet geschikt voor de handhaving van wetten die een bijzondere deskundigheid vergden en waarbij effectiviteit -gelet op het belang dat deze wetten dienden- het welhaast hoogste gebod vormde. Hiermee hing samen dat de tuchtrechtelijke weg werd gereserveerd voor handhaving van (voorschriften in) wetten die "in bijzonder sterke mate werden overtreden ${ }^{\text {"202 }}$, waarbij het bovendien ging om wetten met een tijdelijk karakter. Naast de reeds gememoreerde vrees voor overmatige bestuursbevoegdheden en voor marginalisering van de rol van de rechterlijke macht die het gevolg van tuchtrechtelijke handhaving zou zijn, lagen hier twee verdere redenen voor strafrechtelijke handhaving van de Ondernemersovereenkomstenwet 1935: deze wet was uitdrukkelijk structureel van aard en zou

198 Hetzelfde gold overigens voor de in de crisistijd veel voorkomende toekenning van verstrekkende ordeningsbevoegdheden aan de administratie. Lang niet iedere wet die in de crisis-periode tot stand kwam, kende derhalve een vergelijkbaar grote aandacht voor de limitering van de bevoegdheden van de executieve als de Ondernemersovereenkomstenwet 1935, hoewel ook in deze aanzienlijke ordeningsbevoegdheden waren neergelegd.

199 Wet van 22 juni 1950, Stb. K 258, houdende vaststelling van regelen voor de opsporing, de vervolging en de berechting van economische delicten. Aangepast op grond van (voor zover hier van belang) artikel 49 Wem.

200 Mulder (1950), pag. 109.

201 Die gelet op het beoogd tijdelijke karakter van de wetten in kwestie niet wenselijk werd geacht.

202 Mulder (1950), pag. 157. 
juist niet frequent worden geschonden. Immers de onverbindendverklaring -de enige maatregel waarvan de naleving publiekrechtelijk zou worden gehandhaafd-vormde slechts het sluitstuk van de wettelijke regeling en duidelijk was dat in crisis-tijden van deze maatregel nauwelijks gebruik zou worden gemaakt. Het aantal overtredingen van cen onverbindendverklaring kon dan niet anders dan zeer marginaal zijn. Dit zou in tijden van grotere economische voorspoed wellicht anders zijn (en gelet op het structurele karakter van de wet zou deze ook dan dienen te gelden), maar in die situatie zou een regeling waarin effectiviteit centraal stond en de bescherming van het individu duidelijk op het tweede plan kwam, niet (langer) aanvaardbaar zijn geweest. ${ }^{203}$ Als laatste reden voor strafrechtelijke handhaving van de kartelwetgeving noem ik dat een keuze voor het tuchtrecht een aanzienlijk verdergaande ordening van de markt en de verschillende sectoren zou hebben meegebracht dan door de wetgever voor wenselijk werd gehouden. Omdat ondernemersovereenkomsten in beginsel binnen iedere sector de kop konden opsteken, zou het tuchtrecht immers niet langer beperkt kunnen blijven tot enkele marktsectoren. ${ }^{204}$ De facto zou de overheid dan iedere onderneming hebben moeten verplichten zich aan te sluiten bij een organisatie binnen haar bedrijfstak; en dat voor cen maatregel -de onverbindendverklaring- waarvan de verwachting was dat zij niet in groten getale zou worden toegepast. ${ }^{205}$

Het Kartelbesluit week op dit punt niet af van de Ondernemersovereenkomstenwet 1935 , ondanks een intensivering in bezettingstijd van de tuchtrechtelijke aanpak van andere wetgevingen, met name op het gebied van de voedselvoorziening en de prijsbeheersing. Wel werd de strafrechtelijke handhaving uitgebreid tot inbreuken op algemeen verbindendverklaringen, omdat aldus "In nog sterkere mate (...) een verbindendverklaarde bedrijfsregeling gestempeld (werd) tot een regeling, waarbij het algemeen belang is betrokken". ${ }^{206}$ Voorts werden -in aansluiting bij hetgeen ook in andere wetten gebeurde ${ }^{207}$ - kartelzaken op grond van artikel 17 Kartelbesluit in handen gelegd van een bijzondere, economische strafrechter. Beide (primair uit doelmatigheidsoverwegingen voortvloeiende) tendensen sinds begin jaren dertig -het gebruik van punitieve handhaving buiten het strafrecht om en het creèren van bijzondere regels binnen het strafrecht voor handhaving van ordeningsc.q. economisch recht- hebben hun invloed uitgeoefend op de na-oorlogse regelgeving op handhavingsgebied. De eerste tendens, met name ten gevolge van de overheersende

203 Hier zij nog onderstreept dat de genoemde bezwaren tegen strafrechtelijke afdoening (hoewel aanwezig. als men alleen al de waarschijnlijk geringe deskundigheid van de rechter op dit toentertijd volstrekt nieuwe rechtsgebied in ogenschouw neemt) gelet op de marginale toepassing van de onverbindend verklaring in crisis-tijd voor de Ondernemersovereenkomstenwet 1935 niet veel gewicht in de schaal legden. En voor economische betere tijden zouden de -tegen de achtergrond van vermeend geringe effectiviteit van het strafrecht geuite- bezwaren als zodanig van minder belang zijn.

204 Tot dan toe was deze handhavingsvorm beperkt gebleven tot enkele specifieke bedrijfstakken, waaronder in de cerste plaats de landbouw.

205 Tuchtrechtelijke handhaving was overigens wel mogelijk met betrekking tot algemeen verbindend verklaringen, met dien verstande dat deze handhavingsvorm door ondernemingenzelf in de algemeen verbindend te verklaren ondernemersovereenkomst moest zijn opgenomen. Was dit het geval, dan vormde tuchtrechtelijke handhaving een goed alternatief voor een civiele actie uit onrechtmatige daad, aangerien per definitie alle ondememers in de betreffende bedrijfstak aan de ondememersovereenkomst en dus aan het tuchtrecht waren gebonden.

206 Het Kartelbesluit (1941), pag. 1682.

207 Zie Mulder (1950), pag. 158 e.v.. 
aandacht voor doelmatigheid die ten koste ging van de rechtsbescherming van justitiabe$\mathrm{len}^{204}$, zorgde ervoor dat er een afkeer ontstond tegen 'punitief bestuursrecht ${ }^{209}$ : straffen behoorden volgens de heersende mening tot het terrein van het strafrecht waarin de rechten van burgers en de beperking van overheidsmacht verankerd waren. ${ }^{210} \mathrm{Er}$ bestond dan ook -noch direct na de oorlog, noch bij de totstandkoming van de Wem-geen animo om de strafrechtelijke handhaving van het kartelrecht te heroverwegen en een punitief bestuursrechtelijke handhaving daarvoor in de plaats te zetten. De tweede tendens vond daarentegen -hoewel ook deze regeling tijdens de bezettingstijd, mede ten gevolge van de politieke benoemingen van verschillende rechters en de strenge praktijk waar het de strafoplegging betrof, op weinig sympathie kon rekenen ${ }^{21 !}$ - uiteindelijk wel navolging. De meest voomame reden hiervoor was wederom de te verwachten en -gelet op de cruciale positie van het sociaal-economische recht in de na-oorlogse opbouwfase- noodzakelijk bevonden doelmatigheid van een bijzonder economisch strafrecht; een doelmatigheid die niet aan het commune strafrecht werd toegedicht. Maar tevens een doelmatigheid die de rechten van het individu niet in de verdrukking zou brengen. Aanvankelijk werden bijzondere (materieel- en formeel-) strafrechtelijke regels neergelegd in het Besluit Berechting Economische Delicten, zij het dat dit besluit slechts gelding had voor een zeer beperkt aantal, specifiek genoemde wetten. Het Kartelbesluit behoorde hier niet toe. ${ }^{112} \mathrm{Het} \mathrm{Be}$ sluit Berechting Economische Delicten was bedoeld als tijdelijke regeling die vervangen zou moeten worden door een permanente wet, waarin de handhaving van het sociaal-economisch recht zou worden neergelegd. De voorgestane doelmatigheid diende vorm gegeven te worden door een regeling waarin snel, effectief en streng tegen sociaal-economische criminaliteit kon worden opgetreden, zonder echter zoals gezegd verwaarlozing van de rechten van justitiabelen. ${ }^{213}$ Meer in het bijzonder werd de noodzaak gevoeld van een deskundige rechter en van andere en verdergaande sanctie- en handhavingsmogelijkheden (te denken valt aan de ontneming van wederrechtelijk verkregen voordeel en de strafbaarheid van de rechtspersoon), dan die welke door het commune strafrecht werden

208 Zie ten aanzien van de Landbouw-Crisiswet Schaffmeister (1978), pag. 58 e.v.: de verdachte "durfte die Untersuchung in keiner Hinsicht erschweren, mußte die Wahrheit sagen und durfte keine sachdienlichen Tatsachen verschweigen. Kam er diesen Verpflichtungen nicht nach, konnte Schuld angenommen werden".

209 Dit wordt onderstreept door artikel 5 WED, waarin het uitgangspunt is neergelegd dat ter zake van economische delicten geen punitieve maatregelen buiten de WED mogen worden opgelegd, behoudens wettelijke uitzonderingen. Zie hierover Mulder (1959), pag. 26-27.

210 Overigens werd in het Besluit Berechting Economische Delicten (Besluit van 31 October 1944, houdende vaststelling van het Besluit berechting economische delicten, Stb. 1944, E 135) op belangrijke gebieden als de voedselvoorziening en de prijsbeheersing onverminderd voorzien in een tuchtrechtelijke handhaving, hetgeen te herleiden is tot de nijpende situatie in de eerste jaren na de Tweede Wereldoor$\log$.

211 Mulder (1950), pag. 159 e.v..

212 Hoewel zoals eerder vermeld het Kartelbesluit na de bezetting werd gehandhaafd, werd de behandeling van kartelzaken weer overgedragen aan de commune strafrechter. Dit op grond van het Besluit van 17 september 1944, houdende vaststelling van het Besluit bezettingsmaatregelen, Stb. E93, waarbij het Kartelbesluit voorlopig werd gehandhaafd, maar (naast artikel 25 ) artikel 17 van dit besluit werd geschrapt.

213 Slechts de inachtneming van deze rechtenzou immers leiden tot een aanvaardbareregeling. Het grote punt van kritick van de eerdere bijzondere economische strafwetgeving in de bezettingstijd had juist betrekking op de grove verwaarlozing van deze rechten. 
geboden. Dit streven mondde uit in de totstandkoming van een -zoals Doorenbos ${ }^{214}$ het formuleert- tweede strafvorderlijk traject: de Wet op de Economische Delicten, die bovendien eenheid in de versnipperde regelgeving ten aanzien van handhaving van economische wetgeving moest brengen. ${ }^{215}$ Voor het Nederlandse kartelrecht -als typisch ordeningsrecht- betekende dit dat zowel het Kartelbesluit als later de Wem onder de reikwijdte van de WED werden gebracht.

Deze Wet op de Economische Delicten, met haar gespecialiseerde rechter ${ }^{216}$ en opsporingsambtenaren en met haar -in vergelijking met het commune strafrecht-verstrekkende bevoegdheden heeft op het economische strafrecht ${ }^{217}$ in Nederland een niet te onderschatten invloed gehad. Voor de handhaving van kartelrecht daarentegen heeft zij in de praktijk slechts weinig betekend. Tot strafvorderlijk optreden wegens overtreding van de Wem is uitermate zelden overgegaan; aan de redenen hiervoor zal hierna nog uitgebreid aandacht worden besteed. Het zal weinig verbazing wekken dat met name bij de -sinds medio jaren tachtig steeds luider wordende- roep om verscherping van het Nederlandse kartelbeleid deze vrijwel gehele afwezigheid van strafrechtelijk optreden op de nodige kritiek mocht rekenen. Dit leidde in eerste instantie tot verruiming van de strafrechtelijke mogelijkheden en uiteindelijk-bij de totstandkoming van de Mededingingswet-zelfs tot een keuze voor bestuursrechtelijke handhaving.

\subsection{Strafbare gedragingen}

Nadat hiervoor is vastgesteld waarom de keuze op strafrechtelijke handhaving van het Nederlandse kartelrecht tot 1998 is gevallen, komen in deze paragraaf de strafbaarstelling en de gevolgen daarvan voor strafrechtelijke handhaving aan bod. In de Ondernemersovereenkomstenwet 1935 werd zoals gezegd slechts (afgezien van schending van de geheimhoudingsplicht van met name de Commissie van Toezicht) de overtreding van een onverbindendverklaring strafbaar gesteld. Op grond van artikel $11 \mathrm{j}^{\circ} 6$ Ondernemersovereenkomstenwet 1935 was voor zover hier relevant strafbaar hij die opzettelijk in strijd handelde met de verplichting "zich te onthouden van gedragingen, waardoor hij een ander rechtens of economisch in zijn vrijheid beperkt ten aanzien van datgene, hetwelk naar zijn aard onder een onverbindend verklaarde overeenkomst zou vallen". Met deze niet zeer helder geformuleerde strafbaarstelling werd beoogd te voorkomen dat ondernemers een onverbindendverklaring rechtens of feitelijk voortzetten. Verboden was het sluiten van een nieuwe overeenkomst van dezelfde strekking, het druk zetten op 'naleving' van de kartelafspraak,

214 Doorenbos (1995), pag. 74: "De wetgever creềerde hiertoe als het ware een tweede strafvorderlijk traject, waarlangs de opsporing, vervolging en berechting van economische delicten doeltreffender, sneller en eenvoudiger zou kunnen verlopen dan langs het traditionele traject van de commune strafvordering",

215 Vergelijk ook Hollander (1952), pag. 4 en Schaffmeister (1978), pag. 14.

216 Van Dorst (1985), pag. 1137 e.v., pleitte er overigens voor om de economische strafkamer weer af te schaffen.

217 Maar ook op het commune strafrecht als men bedenkt dat via de WED verschillende leerstukken en sancties in het commune strafrecht terechtzijn gekomen. Wederomzij als belangrijke voorbeelden verwezen naar de rechtspersoon als dader en naar de ontnemingsmaatregel. Hierover uitgebreid Schaffmeister (1978). 
het boycotten van degenen die de onverbindendverklaring wel naleefden etcetera. In tegenstelling tot Kruisheer ${ }^{215}$ meen ik dat ook een gentlemen's agreement die ter vervanging van de onverbindend verklaarde regeling in het leven werd geroepen onder de reikwijdte van het verbod viel. Niet verboden daarentegen was het om vrijwillig dat gedrag te blijven ontplooien dat door de minister in het verband van de ondernemersovereenkomst in strijd met het algemeen belang was geacht. ${ }^{219}$

Het Kartelbesluit kende in artikel 7 lid $3 j^{\circ} 15$ een mutatis mutandis gelijkluidende strafbaarstelling, met dien verstande dat naast de opzettelijke inbreuk op een onverbindendverklaring ook de culpoze inbreuk strafbaar was. Een verder verschil met de Ondernemersovereenkomstenwet 1935 lag in het strafrechtelijk verbod op overtreding van een algemeen verbindendverklaring, waarmee een verdere verruiming van de overheidsbemoeienis in het Kartelbesluit werd gerealiseerd. Laatstbedoeld verbod werd in de Wem niet overgenomen; strafbaarstelling van inbreuken op onverbindendverklaringen, op generieke onverbindendverklaring en op aanwijzingen aan een economische machtspositie daarentegen werd wel noodzakelijk geacht. ${ }^{220}$ Voor zover betrekking hebbend op de onverbindendverklaring (verboden en strafbaar waren gedragingen, welke strekten tot het naleven of doen naleven van een onverbindend verklaarde mededingingsregeling of gedeelte daarvan) was de formulering van het verbod afwijkend van die in de Ondernemersovereenkomstenwet 1935, maar inhoudelijk werd geen wijziging beoogd. ${ }^{221}$ Dus ook onder het regime van de Wem was het strafbaar om onverbindend verklaarde mededingingsregelingen (zelf steeds -tot inwerkingtreding van de maatregel- juridisch bindend) om te zetten in een niet-bindende overeenkomst, zoals een gentlemen's agreement. Een nieuw aspect vormde het strafrechtelijk te handhaven verbod van "gedragingen welke strekken tot het tot stand brengen, naleven of doen naleven van bepalingen in mededingingsregelingen of van richtlijnen van een aard of strekking, aangewezen bij een (generieke) maatregel". Dit verbod kwam in zijn uitwerking in grote lijnen overeen met het verbod betreffende gedragingen die verband hielden met een onverbindend verklaarde mededingingsregeling ${ }^{222}$, zij het dat door de verwijzing naar 'richtlijnen' de strekking hier nog ruimer was. Hieron-

218 Kruisheer (1939) pag. 71: "Door de onverbindendverklaring is niet anders bereikt dan een uitspraak van de Overheid, dat de partijen zich niet meer gebonden behoeven te achten aan de overeenkomst, of m.a.w. dat deze rechtskracht heeft verloren en de naleving dus niet meer in rechte kan worden afgedwongen. Onverbindendverklaring zonder meer verhindert evenwel niet, dat de ondernemers bij onderlinge afspraak, b.v. in den vorm van een gentlemen's agreement, zich toch aan de bepalingen der onverbindend verklaarde ondernemersovereenkomst houden, waardoor de onverbindendverklaring illusoir dreigt te worden".

219 VV TK 1933-1934, 460, nr. 4, pag. 6. De minister (MvA 1933-1934, 64 nr. 1, pag. 3) merkte naar aanleiding van de kritiek op "dat inderdaad den ondernerners niet kan worden belet bij onverbindendverklaring van een minimumprijs, deze toch vrijwillig te handhaven".

220 Hetselfde gold voor de voorlopige maatregelen, te weten de voorlopige aanwijzing aan een economische machtspositic en de schorsing van mededingingstegelingen.

221 Dit viel onder meer af te leiden uit het SER-advies, gevoegd als bijlage bij de MVT TK 1953-1954, 3295, nr. 4.

222 In de memorie van toelichting bij het wetsvoorstel betreffende vergroting van de effectiviteit (TK 1992-1993, 23 306) verwoordde toenmalig staatssecretaris van Economische Zaken Van Rooy de strekking van het verbod als volgt: "De bedoeling van het verbod van artikel 15 is te voorkomen dat de bij of krachtens de wet onverbindend verklaarde mededingingsregelingen worden vervangen door rechtens niet bindende vormen van concurrentiebeperking. Deze kunnen immers even effectief zijn als mededingingsregelingen". 
der konden namelijk in de woorden van $\mathrm{Mok}^{223}$ worden verstaan 'niet-bindendesanbevelingen tot het volgen van een zeker gedrag'. Theoretisch impliceerde dit dusdat zelfs advisering over marktgedrag een strafbare gedraging opleverde, ook indien er geen druk tot naleving van het advies werd uitgeoefend. Al met al was er sprake van een zier ruime categorie van verboden en strafbare gedragingen. Toch werd in het streven naar ntensive. ring van het kartelbeleid op dit punt zowel ten aanzien van de generieke onverbirdendverklaring als ten aanzien van de 'individuele' onverbindendverklaring nog een hiaatgevoeld. Wat namelijk niet onder het verbod viel, maar daar volgens de wetgever van 994 wel hoorde, was onderlinge afstemming met een mededingingsbeperkend karaker: "Een onderlinge afstemming van prijzen, en daarmee een beperking van de prijsconcirrentie, kan het gevolg zijn van bijvoorbeeld geheel vrijblijvende adviezen of aanbevelingen dan wel van uitwisseling, op welke wijze dan ook, van informatie over prijzen". ${ }^{22}$ In deze situaties waarin de mededingingsbeperking niet berustte op een (niet-bindende) ifspraak en waarin geen druk tot naleving van een onverbindende regeling werd uitgeoefeni, diende er volgens de bewindsvrouw onverkort een verbod te gelden. Tegelijk met de intoductie van de mogelijkheid om via een 'onverbindendverklaring' tegen juridisch niet-oindend gedrag op te treden en enkele andere aanpassingen ter vergroting van de effectiviteit van de Wem, werd het verbod van de artikelen 15 en 22 uitgebreid tot een verbod op onderling afgestemde feitelijke gedragingen van dezelfde strekking als de door een maatregd getroffen gedraging. ${ }^{225}$ Onder dit begrip moest blijkens de memorie van toelichting -in de Wem zelf werd de definitie ten onrechte niet ọngenomen- worden vesstaar "een vorm van coördinatie tussen ondernemingen (...) die, zonder dat het tot een eigenlijke overeenkomst komt, de risico's der onderlinge concurrentie welbewust vervangt door een feitelijke samenwerking". Deze aan vaste jurisprudentie van het Hof ontleende definitie -het begrip onderling afgestemde feitelijke gedraging zelf was overgenomen uit artikel 85 EG-Verdrag

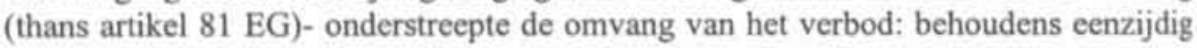
handelen van een ondernemer en parallel gedrag viel vrijwel ieder denkbaar mededingingsbeperkend gedrag hieronder. ${ }^{226}$

Wat kan er nu uit het voorgaande ten aanzien van strafrechtelijke handhaving worden geconcludeerd? Ten eerste dat de verboden omtrent met een (generieke) onverbindendverklaring verband houdend gedrag zeer ruim waren omschreven. Vanaf het begin viel mede juridisch niet-bindend gedrag onder de reikwijdte van het verbod, zij het dat er in beginsel wel sprake diende te zijn van uitgeoefende feitelijke druk of van een niet-bindende afspraak. Door de wet van 1994 werd dit verbod ten dele nog uitgebreid tot elk onderling afgestemd feitelijk gedrag van de strekking van de onder de maatregel vallende gedraging, waardoor in feite slechts individueel gedrag en parallel gedrag niet verboden waren. Een tweede conclusie kan zijn dat zolang de verboden gedraging de vorm had van schriftelijke

223 Mok (1995), pag. 154.

$224 \mathrm{MvT}$ wetsvoorstel betreffende vergroting van de effectiviteit, TK 1992-1993, 23 306. Zie voor een bespreking van dit voorstel Van der Wal (1994 II), pag. 846 e.v..

225 Vergelijk hieromtrent Ottervanger en Nijhuis (1994), pag 485-486.

226 Ten dele werd door de wijziging onbedoeld de reikwijdte van het verbod beperkt. Onderlinge afstemming vereist namelijk ten minste twee partijen die samen tot een bepaald gedrag komen, terwijl voor het in de vervangen tekst gebruikte begrip 'doen naleven' volstond dat én marktpartij druk uitoefende op derden. Aldus was het herziene artikel 22 Wem niet meer van toepassing op gedrag van één partij. vergelijk Mok (1995), pag. 123. 
afspraak of daadwerkelijk uitgeoefende druk of wanneer er sprake was van niet-naleving van een aanwijzing aan een economische machtspositie (men denke bijvoorbeeld aan het niet-nakomen van een opgelegde leveringsverplichting), deze gedraging nog relatief cenvoudig strafrechtelijk te bewijzen was. Dit was echter anders ten aanzien van een gentlemen's agreement, een niet op schrift gestelde richtlijn of een onderling afgestemde feitelijke gedraging. Deze gedragingen werden meestal ontplooid in situaties waarin ondernemers zich ervan bewust waren dat zij in strijd met het recht handelden. Het geheime karakter van die gedragingen en het daarmee gepaard gaande ontbreken van schriftelijk of enig ander in artikel $339 \mathrm{WvSv}$ genoemd bewijsmateriaal, maakte succesvol strafrechtelijk optreden tot een lastige aangelegenheid. Daar kwam nog bij dat de grens tussen ongeoorloofd mededingingsbeperkend gedrag en toelaatbaar marktgedrag -waaronder parallel gedrag-vaak zeer moeilijk te trekken was, waardoor het voor de strafrechter moeilijk was om tot de in artikel $338 \mathrm{WvSv}$ vereiste overtuiging te geraken. Een belangrijk probleem van de (strafrechtelijke) handhaving lag dus op het terrein van het bewijs, zeker bij die gedragingen die niet openlijk werden ontplooid. De derde conclusie is dat -analoog aan hetgeen het geval was bij civielrechtelijke handhaving- strafrechtelijke handhaving afhankelijk was van door de minister of regering genomen maatregelen: zonder cen (generieke) onverbindendverklaring of aanwijzing aan een machtspositie was er voor het strafrecht geen plaats. ${ }^{227}$ Alleen al om deze reden kon strafrechtelijke handhaving een niet meer dan marginale rol in de Wem vervullen. Hiervoor immers bleek dat het aantal onverbindendverklaringen en aanwijzingen welhaast verwaarloosbaar was. Via de generieke maatregelen werd weliswaar tenminste ${ }^{228}$ éen belangrijke categorie gedragingen (te weten de verticale prijsbinding) aangepakt, maar voor het overige werd ook hier -tot 1993- door de Nederlandse overheid nauwelijks gebruik gemaakt van de door de Wem geboden mogelijkheden.

In de regeling zoals het Nederlandse kartelrecht die tot 1998 kende, werd het belang van het strafrecht voor de praktijk van de handhaving bepaald door twee factoren, te weten de bereidheid van de overheid om individuele of generieke verboden of aanwijzingen in het leven te roepen én de bereidheid van de strafrechtelijke organen om deze verboden met inzet van strafrechtelijke middelen te handhaven. Zoals verschillende malen aangehaald werd het Nederlandse beleid met name gekenmerkt door informeel optreden en werden formele maatregelen met terughoudendheid toegepast, hetgeen directe repercussies had voor de mogelijkheid van strafrechtelijk optreden. Maar ook daar waar er wel formele maatregelen waren genomen en het strafrecht dus een rol binnen de handhaving had kunnen spelen, werd nauwelijks de strafrechtelijke weg bewandeld. Dit moge onder meer blijken uit de gang van zaken ten aanzien van overtredingen van de generieke maatregel

227 Denkbaar zou zjin geweest dat misbruik van de vrijheid tot karteliering zonder voorafgaande maatregel strafrechtelijk zou kunnen worden gesanctioneerd. Nog afgezien van de problemen die dit met zich zou brengen voor de formulering van de strafrechtelijkte handhaven norm (men denke aan het legaliteitsbeginsel van artikel I WvSr) zou dit impliceren dat het beleid van de minister van Economische Zaken door de strafrechter doorkruist zou kunnen worden. Immers zou eerstgenoemde cen bepaald kartel intact kunnen laten terwijl de strafrechterde kartellerendeonderneming wegens dezelfde gedra. ging zou kunnen sanctioneren. Dit zou in strijd zijn geweest met de uitgangspunten van de wetgever en de facto ook met die van een misbruikstelsel.

228 Tot op zekere hoogte was ook de generieke onverbindend verklaring van disciplinaire rechtspraak van belang: de mastregel betreffende discriminatie daarentegen had in de praktijk geen enkele betekenis. 
inzake disciplinaire kartelrechtspraak. In 1975 werd een grootscheeps onderzoek gestart naar de naleving van deze maatregel, waarbij bleek dat zij op grote schaal werd geschonden. ${ }^{229}$ Hoewel tegen de overtreders strafrechtelijk had kunnen worden opgetreden, beperkte de overheid zich tot het aandringen op aanpassing van de mededingingsregelingen aan de wettelijke vereisten. ${ }^{230}$ De harde hand was zodoende ook in strafrechtelijk opzicht niet populair. Welke verklaringen kunnen voor dit -met name sinds eind jaren tachtig bekritiseerde ${ }^{23 !}$ - milde optreden worden gegeven? Een eerste verklaring is dat vanuit het ministerie van Economische Zaken weinig mogelijke overtredingen aan het Openbaar Ministerie zijn gemeld. Het ministerie van Economische Zaken was er meer aan gelegen om de mededingingsregelingen in overeenstemming met het recht te laten brengen door ondernemers een tweede kans te geven, dan deze ondernemers te laten sanctioneren voor een begane inbreuk. De heersende overlegcultuur had ook hier prioriteit. Daar kwam als tweede verklaring bij dat verreweg het meeste kartelgedrag naar mijn mening niet als écht strafwaardig gedrag werd gezien, noch door het ministerie van Economische Zaken, noch door een belangrijk deel van het bedrijfsleven, noch door het Openbaar Ministerie. Ondernemers waren in hun economisch handelen wellicht te ver gegaan en moesten weer op het rechte pad geholpen worden, maar het voerde te ver om daarvoor het als stigmatiserend geldend strafrecht aan te wenden: het beeld heerste dat kartelovertreders toch geen criminelen waren en dat zij allerminst over één kam met dieven, helers en dergelijken konden worden geschoren. Het strafrecht zou dan moeten worden bewaard voor de aperte kartelovertredingen. Daarmee hing als derde verklaring samen dat het kartelrecht niet bepaald hoog op de prioriteitenlijst van het Openbaar Ministerie stond. Dit had verschillende redenen, waarvan er één reeds is genoemd: kartelgedrag werd nauwelijks als strafwaardig beschouwd. Een tweede reden hing samen met het milde kartelbeleid op het departement van Economische Zaken: een begripvol en op aanpassing gericht beleid nodigde niet uit om in een volgend traject (i.c. het strafrechtelijke) wel met harde hand op te treden. Zelfs de Economische Controledienst (ECD), de primaire instantie met strafrechtelijke kartelonderzoeken belast, trachtte in eerste instantie de overtreders tot inkeer en tot aanpassing van hun gedrag te brengen. Het opmaken van een procesverbaal geschiedde slechts ten aanzien van de meest ernstige inbreuken en ten aanzien van die gevallen waarin overleg met betrokkenen niet tot gewenste resultaten had geleid. ${ }^{232}$ Als derde reden kan genoemd worden dat de expertise op kartelgebied bij het

229 Zie jaarverslag Wem 1975, Stcrt. 20 oktober 1976, 204.

230 Dat het kartelrecht hierin niet alleen stond, moge wel blijken uit de studie van Huidekoper (1975), pag. 42 e.v. naar de handhaving van het economisch strafrecht.

231 Kritiek op handhaving hoeft echterniet steeds hout te snijden. Vergelijkbijvoorbeeld Mulder (1976), pag. 380 , met betrekking tot het milieurecht: "Het O.M. wordt bij herhaling publiekelijk gekritiseend over gebrek aan aktiviteit bij het vervolgen van schijnbare overtreders. Tot in het parlement toe nemen eritici beweringen van actiegroepenreeds als vaststaande feiten aan. Nader onderzoek leert dan echtet dat het committment van de bestuursdiensten zo ver is gegaan of dat regelingen nog zo weinig volmakt zijn, dat vervolging een daad van willekeur zou zijn geweest."

232 Vergelijk ook Mulder en Engels (1984), pag. 150 e.v. en Spliet (1990), pag. 11. Uit diens opmerkingen blijkt dat dit beleid niet beperkt was tot kartels: "In dit kader moet ook het streven van de ECD worden geplaatst om, waar dat mogelijk is, tot legalisatie over te gaan zonder gebruik te maken van het straftechtelijke apparaat. Centraal in bet ECD-optreden staat dan ook dat de voorschriften worden nageleefd. Veel overtredingen worden opgespoord en beěindigd, zonder dat daarvoor proces-verbaal wordt opgemaakt". In nog breder kader wordt dit onderstreept door Handhaven op niveau (1998). pag. 54-56. 
Openbaar Ministerie niet bijzonder groot was. Weliswaar werd een economisch officier van Justitic op een eventuele zaak gezet, maar het kartelrecht lag niet in de lijn van de overige zaken waarmee deze officier belast was. Aan het opbouwen van expertise kon hij ook nauwelijks toekomen, gelet op de omstandigheid dat ten eerste het aantal zaken dat voor strafrechtelijke afhandeling in aanmerking kwam zeer beperkt was en ten tweede de normale strafrechtelijke relatieve competentieregels gelding hadden. Dat bracht met zich dat karteldelicten niet op één centrale plaats vervolgd werden en dus dat de weinige zaken die in het strafrechtelijke traject kwamen in beginsel werden behandeld door de officier die bevoegd was binnen het arrondissement waar de overtreding was begaan. Het vervolgen van kartellerende ondernemingen betekende dan ook cen grote inspanning voor de betrokken officier die zich immers in de voor hem veelal nieuwe materie moest inwerken. In een dergelijke situatie was het niet vreemd dat liever werd gekozen om de bemoeienissen te concentreren op een terrein dat voor die officier bekender was en meer kans op succes beloofde. De kans op een succesvolle vervolging wegens karteldelicten werd in ieder geval niet overmatig groot geacht: niet alleen de ontbrekende expertise (van de officier van Justitie, maar ook van de economische strafrechter) stond dit in de weg, maar bovendien de reeds gememoreerde strafrechtelijke bewijsproblemen. Deze problemen, die met name voortvloeiden uit het vaak geheime karakter van de kartels, uit de vage grens tussen toelaatbaar marktgedrag en verboden kartelgedrag en uit de ingewikkelde formulering en opbouw van de generieke maatregelen ${ }^{233}$, zorgden ervoor dat een officier van Justitie met niet al te veel enthousiasme de zaak aan de strafrechter zou voorleggen. ${ }^{234}$ Dat de problemen niet illusoir waren, bleek uit twee van de weinige zaken (met betrekking tot de generieke maatregel betreffende verticale prijsbinding) die de strafrechter wél bereikten: beide leidden tot vrijspraak omdat de rechter het niet bewezen achtte dat het gedrag van de verdachten verboden en dus strafbaar was. ${ }^{235}$ Een en ander verklaarde ook de voorkeur binnen het Openbaar Ministerie om indien mogelijk de zaak af te handelen via een transactie: het Openbaar Ministerie was in dat geval verlost van een moeilijke bewijslast en een arbeidsintensieve procedure, terwijl voor de ondernemers in kwestie de risico's van een strafrechtelijke vervolging (in de vorm van hogere

233. De Roos (1984), pag. 145, wijst er op dat ook in andere landen de geringe toepassing van het strafrecht (mede) is te wijten aan "de eisen van mullum crimen-beginsel (vaagheid van de norm, bewijsmoeilijkheden)".

234 Ook het vertrouwensbeginsel kon een succesvolle vervolging in de weg staan. Indien de letter van de wet vervolging zou toelaten, maar door de regering een beperkter en dus afwijkend standpunt was ingenomen en verkondigd, dan kon het Openbaar Ministerie in beginsel niet aan dit standpunt voorbij gaan. In dat geval zou hij dankzij het opportuniteitsbeginsel van artikel $167 \mathrm{WvSv}$ kunnen afzien van vervolging. Zie ook Mok (1969 II), pag. 171/172. In het ontbrekende enthousiasme voor daadwerkelijke vervolgingen stond het kartelrecht overigens niet alleen, gelet op de -door De Savornin Lohman (1988) en Van der Zwan (1988) van kritische kanttekeningen voorziene-constatering van Buruma (1987) dat de bestrijding van economische criminaliteit in het slop was geraakt. Zie tevens het naschrift van Buruma (1988) op de bedoeide kanttekeningen.

235 Arrest van de Hoge Raad van 19 november 1968, No E 64620, SEW (1969), pag. 186-195, m.nt. Mok en arrest van de Hoge Raad van 22 juni 1971, No. E 65921, SEW (1972), pag. 36 e.v., m.nt. Mok. 
boetes dan het transactiebedrag en van dreiging van negatieve publiciteit) werden voorkomen. $^{236}$

\subsection{Dossieronderzoek bij de Economische Controledienst}

Hierboven is betoogd dat op kartelgebied het strafrecht zijn tanden niet of nauwelijks liet zien. Dat beeld wordt bevestigd door een (dossier)onderzoek dat door mij begin jaren negentig van de vorige eeuw bij de ECD is verricht. De opzet van dit onderzoek was er met name op gericht om er achter te komen hoe de ECD in de praktijk met de handhaving van de Wem omging. In overleg met de ECD -naar (goed) goed Nederlands gebruikis besloten om het onderzock te beperken tot zeven recente en representatieve casus, waarin zowel de verschillende soorten onderzoek die de ECD kon verrichten ${ }^{237}$ als verschillende cindresultaten aan bod moesten komen. ${ }^{238}$

\section{Detailhandel schoenen}

In 1990 stelde de Economische Controledienst een onderzoek in wegens verdenking van overtreding van artikel $2 \mathrm{Wem}$. Deze verdenking was gerezen naar aanleiding van een klacht over een leveringsweigering door een Nederlandse leverancier van exclusieve schoenen aan een detailhandelbedrijf (zijnde de klager). De klager was van mening dat de leveringsweigering te maken had met de vrees van zijn plaatselijke concurrent dat de klager zich niet aan de adviesprijzen zou houden en dus in prijsconcurrentie zou treden. De leverancier echter had de klager laten weten dat het betreffende gebied niet groot genoeg was voor twee verkooppunten. Het opsporingsonderzoek, dat zeer 'low profile' werd gehouden en dat bestond uit het voeren van gesprekken met de leverancier en de

236 Zie voor cen opmerkelijke zaak HR 27 juni 1972, SEW 1973, pag. 281 m.nt. Mok. Een verdachte had bezwaar aangetekendtegen de dagvaarding, betreffende overtreding van de generieke maatregel inzake verticale prijsbinding. Nadat de verdachte niet buitenvervolging was gesteld, werd door de officiervan Justitie alsnog een transactie-aanbodgedaan, dat door de verdachte werd aanvaard. Voor verdere transacties: TK 1992-1993, 22800 hoofdstuk XIII, nr. 3 (overtreding Besluit mededingingsregelingen in de bouwsector; transactiebedrag voor 'een aantal' bedrijven totaal $f 2,2$ miljoen) en TK 1993-1994, 23400 hoofdstuk XIII, $\mathrm{nr} .3$ (twee overtredingen Besluit mededingingsregelingen in de bouwsector: transactiebedrag in één zaak ter hoogte van totaal $f 1$ miljoen, aanvaard door vier van de vijf betrokkenen; in de andere zaak ter hoogte van $f 1,3$ miljoen, aangeboden aan en aanvaard door cen stichting en acht ondernemers).

237 Naast het opsporingsonderzoek betrof het hier het enquêterend onderzoek op grond van artikel 16 Wem. De veronderstelling was dat het verschil in uitgangspunt tussen beide consequenties zou kunnen hebben voor de houding en benaderingswijze van de ECD tijdens het onderzoek. De enquête had tot doel om voldoende informatie te verzamelen teneinde de minister in staat te stellen om te beoordelen of een mededingingsregeling of economische machtspositie al dan niet in strijd met het algemeen belang was. Het betrof met andere woorden een controlebevoegdheid, die kon worden toegepast op verzoek van de minister van Economische Zaken.

238 In de administratie van de ECD werd onderscheiden tussen vijf categoriečn onderzoeksresultaten: 'geen overtreding', 'intrekking', 'correctie', 'proces-verbaal' en 'enquêterend'. Geheel zuiver was de term 'onderzoeksresultaten'niet, aangezienhij strikt genomen slechts op de eerste vier categorieên van toepassing was. Meercorrectzou zijn geweesteen onderscheid tussen opsporings- en enquêterend onderzoek enerzijds en de daarbij mogelijke resultaten anderzijds. 
klager's concurrent alsmede uit inzage van enkele schriftelijke bescheiden, toonde aan dat er inderdaad sprake was van een leveringsweigering ${ }^{299}$, maar bij monde van de directeur van de leverancier werd ontkend dat deze weigering iets te maken had met eventuele exclusieve verkoopregels of de al dan niet naleving van de adviesprijzen. ${ }^{240}$ Wel werd bevestigd dat de exclusiviteit van de schoenenwinkel alsmede de spreiding van de winkels een rol speelde bij de keuze van de winkels waaraan zou worden geleverd.

De (aan de klager meegedeelde) eindconclusie van de ECD ten aanzien van de leveringsweigering was dat deze behoorden tot (aanvaardbare) interne verkooppolitiek. Ten aanzien van de hantering van adviesprijzen was de slotsom dat deze inderdaad geen dwingende status hadden, dat er dus op grond van de toen geldende bepalingen geen sprake was van een mededingingsregeling en dat derhalve geen overtreding van de aanmeldingsplicht van artikel 2 Wem had plaatsgehad.

\section{Auto-occasionshow}

Een impliciete klacht van een organisator van een regionale auto-occasionshow was in 1990 aanleiding voor de ECD om binnen de autobranche een opsporingsonderzoek in te stellen. Een merkdealer had namelijk bedoelde organisator met juridische stappen gedreigd indien deze een andere (hetzelfde merk vertegenwoordigende) dealer zou uitnodigen voor deelname aan c.q. zou toelaten tot de auto-occasionshow. ${ }^{241}$ Deze stappen zouden dan zijn gebaseerd op een door de dealer met zijn importeur gesloten overeenkomst, waarin was bepaald dat een dealer zich niet buiten het aan hem toegewezen rayon mocht presenteren als dealer van het betreffende merk. Het opsporingsonderzoek -bestaande in niet meer dan het benaderen van de klager en de autodealer alsmede in het raadplegen van het kartelregister en dat dan ook slechts ongeveer twee maanden in beslag nam-wees snel uit dat het dealercontract door de importeur was aangemeld en dat het ministerie van Economische Zaken de uit het contract voortvloeiende marktverdeling niet in strijd met de Wem achtte. Aan de klager werd derhalve -gelet op de geheimhoudingsplicht van artikel 42 Wem met de nodige omzichtigheid- medegedeeld dat er geen schending was van artikel $2 \mathrm{Wem}$, noch van enige ander artikel, en dat de dealer er derhalve terecht van mocht uitgaan zijn rayon gerespecteerd zou worden. Veel reêle hoop op deelname

239 Ten gevolge van een misverstand werd tussentijds wél kortstondig aan de klager geleverd. Het misverstand was ontstaan doordat de concurrent van de klager op een latertijdstip dan normaal zijn levering plaatste (dit omdat deze vermoedde dat de klager toch -ongeoorloofd- het betreffende merk in zijn collectie voerde), hetgeen voor de leveraneier aanleiding was te veronderstellen dat hij zou afzien van verdere bestellingen. $\mathrm{Bij}$ opheldering van een en ander herleefde de leveringsweigering.

240 Van dwingende adviesprijzen was volgens de leverancier geen sprake. Zij werden uitsluitend op verzoek van de afnemers gehanteerd, welke afnemerseenrichtlijn omtrent eenredelijkeprijs wensten. Vervolgens conformeerden die afnemers zich overigens wel aan de (advies)prijzen, als gevolg waarvan prijsconcurrentieontbrak. Dit zou volgens de leveranciervoortvloeienuit de noodzaakvan eenzekere (verkoop)marge: omdat bij exclusieve schoenenwinkels de kwantiteit van de verkoop niet voorop zou staan, zou met geringere verkoopcijfers toch voldoende omzet gehaald moeten worden en zouden (stunt)aanbiedingen niet wenselijk zijn.

241 Zelf nam deze dealer niet deel aan de show, gelet op de zijns imziens te hoge kosten en te geringe reclameactiviteiten. 
van een dealer van het betreffende merk aan de show resteerde er derhalve niet voor de organisator.

\section{Hengelsport}

Het derde hier te bespreken onderzoek richtte zich op de (vermoedelijke) hantering van gezamenlijkestandaardbetalingsvoorwaarden doorzes hengelsportleveranciers. Ook hier vormde een klacht de aanleiding voor het onderzoek, welke klacht was ingediend door de Vereniging Landelijke Organisatie Divebo. In het kader van het onderzoek werd één van de zes leveranciers bezocht, waarbij de ECD te woord werd gestaan door de directeur. Door deze werd erkend dat de leveranciers waren overeengekomen bepaalde regels (betreffende onder meer het in rekening brengen van vracht- en administratiekosten bij bestellingen beneden de $f 750$, de vaststelling van een minimumbedrag voor doorgevoerde reparaties, de afschaffing van betalingskortingen alsmede het nemen van maatregelen tegen wanbetalers) gezamenlijk na te leven, hetgeen zij via een brief ook aan hun (potentiële) afnemers bekend hadden gemaakt. ${ }^{242}$ Volgens de directeur was de overeenkomst geboren uit noodzaak omdat de leveranciers door de detaillisten tegen elkaar werden uitgespeeld, onder meer op het gebied van kortingen, en zij zich als gevolg daarvan onder meer geconfronteerd zagen met dalende winstmarges. Daarenboven leden zij aanzienlijke schade door aanhoudende wanbetalers die, indien aan hen door een bepaalde leverancier niet of nog slechts onder rembours werd geleverd, hun toevlucht tot een andere leverancier zochten. Aangezien de standaardvoorwaarden de concurrentie belemmerden, concludeerde de ECD tot het bestaan van een mededingingsregeling die op grond van artikel 2 Wem had moeten worden aangemeld, hetgeen echter verzuimd was. Met andere woorden: de leveranciers konden worden aangemerkt als plegers van een economisch delict, dit ondanks de nobele bedoelingen van de leveranciers -namelijk "te trachten om de hengelsport weer goed op de rails te krijgen en te streven naar een gezonde hengelsportbranche"- en hun verweer dat zij niet van de aanmeldingsplicht voor besluiten zoals het onderhavige op de hoogte waren geweest. Mede omdat de betrokken directeur toezegde het aanmeldingsverzuim per ommegaande te zuiveren, werd door de ECD (na een onderzoek van nog geen drie maanden) besloten om de zaak (voorwaardelijk) te seponeren.

\section{Anti-conceptiva}

Op 1 juli 1991 trad het zogenoemde Geneesmiddelen-vergoedingssysteem in werking op grond waarvan vanaf dat moment voor volledige vergoeding slechts in aanmerking kwamen geneesmiddelen die in bepaalde (sub)clusters waren ondergebracht. Voor buiten die (sub)clusters vallende middelen met vergelijkbare werking werd slechts het maximumbedrag uit de betreffende (sub)cluster uitbetaald, hetgeen tot gevolg had dat het meerdere door de patiěnt zelf moest worden gedragen, tenzij hij overstapte naar één van de binnen een (sub)cluster vallende substituten. Per 1 augustus 1991 zouden de geneesmiddelenfabrikanten de prijzen voor onder meer anti-conceptiva verhogen, waardoor er een grote mate van prijsuniformiteit zou ontstaan. Binnen het ministerie van Economische Zaken werd

242 Ontkend werd uitdrukkelijk dat de overeenkomst ook zag op de te rekenen verkoopprijzen. 
niet uitgesloten dat deze prijsontwikkelingen verband hielden met een eventuele economische machtspositie op de anti-conceptivamarkt. Daarom werd door toenmalig staatssecretaris van Economische Zaken Van Rooy aan de ECD verzocht om een op de artikelen 16 en 17 Wem gebaseerd enquêterend onderzoek te starten naar de prijsvorming ten aanzien van anti-conceptiva. Mede gelet op de aard van het onderzoek (een verdenking was hiervoor immers niet vereist) en de noodzaak tot grondigheid, maar mijns inziens toch ook omdat het onderzoek zich richtte op zes invloedrijke multinationals (tezamen goed voor het totale aanbod op de Nederlandse anti-conceptivamarkt) die men niet tegen zich in het harnas wilde jagen, werd de nodige voorzichtigheid betracht door de ECD. Vooraleer de betrokken ondernemingen te benaderen, werd uitvoerig overlegd met de (toenmalige) Directie Mededinging van het ministerie van Economische Zaken almede met de Directie Geneesmiddelenvoorziening van het ministerie van Welzijn, Volksgezondheid en Cultuur en werd (in samenwerking met deze) een vragenlijst samengesteld, die vervolgens nog ter goedkeuring aan het ministerie van Economische Zaken werd voorgelegd.

De zes ondememingen werden door de ECD-controleurs zoveel mogelijk gelijktijdig bezocht teneinde onderlinge afstemming te voorkomen. Bepaald onverwacht kwamen de controleurs echter niet omdat er reeds de nodige publiciteit was geweest en door de staatssecretaris openlijk was aangekondigd 'een en ander' uit te zoeken; éen van de ondernemingen had zelfs reeds zelfstandig een lijst van punten samengesteld, waarvoor zij de meeste interesse verwachtte. ${ }^{243}$ Het onderzoek maakte allereerst duidelijk dat de leveranciers bij de prijsstelling van zijn product uitging van een vaste apothekersinkoopprijs, waarvan derhalve de groothandel niet mocht afwijken. Dit beleid hield verband met het Geneesmiddelen-vergoedingssysteem: de leverancier wilde niet dat de groothandel kon bepalen of de prijs boven of onder het 'systeem-maximum' zou komen te liggen. Daarenboven bleken de verschillende ondernemingen dezelfde prijzen voor hun producten te hanteren; in één sub-cluster bedroeg de prijsuniformiteit zelfs $100 \%$. Met name het prijs'beleid' van één onderneming was uitzonderlijk te noemen. Nadat zij in eerste instantie ter bescherming van haar marktaandeel de prijzen die boven de limiet van het Geneesmiddelen-vergoedingssysteem lagen had verlaagd tot het niveau van de limiet, verhoogde zij korte tijd later de prijzen van al haar anti-conceptiva tot boven de limiet. Als reden hiervoor werd aangegeven dat zij vanwege het gevaar van parallelimport in Belgię de prijs van haar nieuwste (en naar eigen zeggen voor haar concurrentiepositie belangrijke) product niet kon verlagen, terwijl de relatief hoge prijs (met daaraan verbonden een noodzakelijke bijbetaling door de gebruikster) in Nederland het product onaantrekkelijk maakte, hetgeen uiteindelijk naar verwachting haar bedrijfsresultaat negatief zou beinnloeden. Om substitutie wegens financielle redenen tegen te gaan, besloot de onderneming derhalve om al haar producten in prijs te verhogen. Deze stap was niet zonder risico's (substitutie door producten van andere ondernemingen dreigde immers), maar hij pakte goed uit omdat haar concurrenten -volgens de betrokken onderneming zonder voorafgaande afspraken dienaangaande- haar voorbeeld volgden en de prijzen verhoogden ${ }^{244}$, waarna zij op haar beurt op deze prijsontwikkeling inhaakte. Zoals zo vaak in kartelzaken, betoog-

243 Haar inschattingsvermogen bleek meer dan voortreffelijk daar deze lijst vrijwel reeds iedere vraag van de controleurs beantwoordde.

244 Opéénuitzondering na omdat voor de betrokken onderneming de betreffendeproducten commercieel niet belangrijk genoeg waren om tot prijsaanpassing over to gaan. 
de deze onderneming dat uiteindelijk (mede) de gebruiksters bij deze gedragingen gediend waren: artsen zouden nu louter op medische en niet op financiële gronden voor een bepaald product kunnen kiezen. Een andere onderneming voerde aan dat zij genoodzaakt was om haar prijzen aan het gangbare niveau aan te passen, omdat zij anders haar concurrentie onjuiste (kwaliteits)argumenten zou bieden: een lagere prijs zou kunnen worden geïnterpreteerd als behorende bij een kwalitatief minder product.

Hoe begrijpelijk dit beleid vanuit de optiek van de ondernemingen ook moge zijn geweest, voor gebruiksters (en de overheid) betekende het beleid dat zij dieper in de buidel moesten tasten voor de anti-conceptiva dan gelet op de reële prijs noodzakelijk was, temeer daar (prijs)concurrentie grotendeels ontbrak. Een en ander laat onverlet dat hier niet zonder meer van kartelmatig gedrag kon worden gesproken, hoewel er wellicht wel aanwijzingen in die richting waren. Met name problematisch was in hoeverre aan de gedragingen een onderlinge afspraak ten grondslag lag. Hoe dit ook zij, omdat het een enquêterend onderzoek betrof, was het niet aan de ECD om tot een conclusie dienaangaande te komen. Vanwege het ministerie van Economische Zaken werden geen verdere maatregelen genomen; nog afgezien van de vraag of maatregelen in casu tot de mogelijkheden hadden behoord, werd de eventuele noodzaak hiertoe weggenomen door een prijsverlaging voor anti-conceptiva door de betrokken ondernemingen.

\section{Prijsvorming Brandstof}

Naar aanleiding van een klacht van Konsumenten Kontakt ${ }^{245}$ startte de ECD in 1989 op verzoek van de staatssecretaris van Economische Zaken een enquêterend onderzoek ${ }^{246}$ naar de prijsvorming van brandstof (ook toen reeds was er dus bezorgdheid over de rol van oliemaatschappijen bij de totstandkoming van de benzineprijzen). Evenals in het onderzoek in de anti-conceptivabranche het geval was, werd hier gebruik gemaakt van een (door het ministerie van Economische Zaken) opgestelde vragenlijst. ${ }^{247}$ Uit het onderzoek bleek dat niet de kostprijs van benzine (deze kon niet nauwkeurig worden vastgesteld omdat raffinaderijen slechts zicht hebben op de kosten van de gehele productie), maar de zogenoemde Platts als inkoopprijs van de benzine fungeerde. ${ }^{248} \mathrm{Bij}$ de vaststelling van de adviesprijzen voor de pomphouders stond, naast de dollarkoers en de ontwikkeling van deze alsmede van de ruwe olieprijzen, deze notering eveneens centraal. Van deze adviesprijzen werden de pomphouders niet alleen schriftelijk op de hoogte gesteld,

245 Konsumenten Kontakt diende eveneens een gelijkluidende klacht in bij de Europese Commissie.

246 Het onderzoek werd op twee belangrijke punten beperkt: slechts het beleid met betrekking tot 'superbenzine' (de toentertijd meest verkochte benzinesoort in Nederland) werd onder de loep genomen en slechts de twee marktleiders werden in het onderzoek betrokken omdat deze als representatief werden beschouwd voor de in Nederland opererende oliemaatschappijen en omdat deze over voldoende gegevens over het beleid van de concurrentie beschikten. Opmerkelijk was de uitdrukkelijke vermelding in het ECD-dossier van de omstandigheid dat de betrokken ondernemingen hadden toegezegd vrijwillig aan het onderzoek mee te werken; en dat terwijl zij toch op grond van artikel $16 j^{\circ} 18 \mathrm{Wem}$ reeds verplicht waren verlangde inlichtingen te verstrekken.

247 Bovendien werden ten aanzien van de exporteijfers inlichtingen ingewonnen bij de Directie Energie.

248 Voor de vaststelling van deze Platt's Oilgram Price Report (of kortweg Platts) notering werd kort geregd uitgegaan van de transacties die verschillende handelaren de voorafgaande dag hadden gemaakt alsmede van transacties op de termijnmarkt. 
maar er stond tevens een automatische telefonische informatielijn open waarop dezelfde informatie beschikbaar was. Van de informatielijn van de marktleider, die was bedoeld als service voor de eigen pomphouders, bleek ook door anderen (waaronder concurrenten en onafhankelijke grossiers en pompondernemingen) gebruik te worden gemaakt om op de hoogte te blijven van het prijsbeleid van de marktleider (aan welk beleid zij zich overigens bleken te conformeren). Omdat ook de Nederlandse Organisatie van Olie- en Kolenhandelaren, die de adviesprijzen voor de zogenoemde vrije (niet merkgebonden) pomphouders ${ }^{209}$ opstelde, het telefoonnummer van de informatielijn kende, werden dezelfde adviesprijzen aangehouden door de vrije pomphouders. Ontkend werd dat dienaangaande onderlinge afspraken waren gemaakt en dat de pomphouders gehouden waren de adviesprijzen te volgen. Van prijsconcurrentie was echter zelden of nooit sprake.

De interesse van de ECD ging ook uit naar de totstandkoming van de feitelijke verkoopprijs bij de pompen, waarbij met name werd gekeken naar de mate waarin de adviesprijzen door de pomphouders gevolgd werden. De adviesprijzen waren opgebouwd uit de afgifteprijs van de benzine (de inkoopprijs voor de pomphouder) en de theoretische dealermarge. Bij een hogere prijs zou die marge stijgen, maar dreigde omzetverlies; bij een lagere prijs werd ingeteerd op de -toch al niet riante $e^{250}$ - marge. Omdat in sommige gevallen desalniettemin een aanscherping van de prijs noodzakelijk kon zijn ${ }^{25 !}$, werd de pomphouders door de oliemaatschappijen tegemoet gekomen via een zogenoemd margebijdragesysteem (dat overigens per maatschappij verschilde). De essentic hiervan was dat -in gevallen waarin een lagere pompprijs dan de adviesprijs geindiceerd was- de door de pomphouder te geven korting gedeeltelijk door de oliemaatschappij werd gedragen. ${ }^{252}$ De facto werd bovendien aan zelfbedieningspompen een margebijdrage verstrekt omdat de oliemaatschappijen bij deze pompen een lagere prijs wensten dan bij bediende pom$\operatorname{pen}^{253}$, maar de pomphouders niet ten volle wilden laten opdraaien voor deze lagere prijs. Omdat hierdoor omzetverlies voor bediende pompen dreigde, konden deze op hun beurt relatief eenvoudig in aanmerking komen voor een bijdrage van de maatschappijen. Het margebijdragesysteem trad ook in werking in de concurrentiestrijd met vrije pompen. Omdat de consument in de praktijk merkbenzine bleek te prefereren boven merkloze en -volgens studies- bereid was om daarvoor tot 4 cent per liter meer neer te tellen, werd een prijsverschil tot dit bedrag getolereerd. Bij grotere verschillen trad het margebijdragesysteem in werking bij een te geven korting; kortingen bij een lager verschil gingen volledig ten laste van de betreffende pomphouder. Vervolgens concentreerde de ECD zich op het (feitelijke) prijsverloop bij de verschillende ondernemingen. Omdat de adviesprijzen de facto gelijk lagen, werden de pompprijzen bepaald door de kortingen (hogere prijzen kwamen niet voor). Incidentele verschillen per maatschappij uitgezonderd (tot 2,3 cent per liter), bleken deze kortingen nauwelijks van elkaar af te wijken; wel kon een terugloop in de gemiddelde korting worden geconstateerd (gemiddeld 10,9 cent per liter in 1985; in 19897,6 cent per liter). Ook ten aanzien van dit beleid, bedoeld om

249 In 1987 hadden deze $19 \%$ van de totale benzineomzet in Nederiand in handen.

250 Deze lag toentertijd op een vast niveau van 10,65 cent per liter bij bediende pompen (die waren er toen nog) en 8,12 cent per liter bij zelfbedieningspompen.

251 Bijvoorbeeld door een tijdelijke regionale 'prijzenoorlog' of de constante dreiging voor de Nederlandse pomphouders van 'benzine-toerisme' in de grensgebieden met Duitsland en Belgie.

252 De marktleider verstrekte toentertijd een margebijdrage van 13,2 cent bij een korting van 20 cent.

253 De adviesprijs lag voor zelfbedieningspompen 6 cent lager dan voor bediende pompen. 
de dealermarges te verruimen en de margebijdragen terug te dringen, werd enig voorafgaand overleg ontkend. ${ }^{254}$

Uit het voorgaande moge blijken dat het een -zeker voor Nederlandse kartelbegrippengroots opgezet onderzoek betrof. Daaraan was waarschijnlijk mede het voor de consument gevoelige karakter van de zaak (hoge benzineprijzen) debet, temeer daar de zaak was aangekaart door een consumentenorganisatie. De Nederlandse overheid moest tonen dat zij bereid was deze zaak tot op de bodem uit te zoeken. Een onderzoek binnen het ministerie van Economische Zaken zelf zou waarschijnlijk op de nodige scepsis hebben mogen rekenen, met name als de uitkomst voor de oliemaatschappijen positief zou uitvallen. En dit gebeurde uiteindelijk. In de door de ECD overgelegde onderzoeksresultaten zag het ministerie geen aanleiding om verdere stappen te ondernemen: er waren geen aanwijzingen dat er sprake was van een mededingingsregeling en dus van een overtreding van de Wem.

\section{Grof Groen}

Het opsporingsonderzoek -wederom naar aanleiding van een klacht- naar mogelijk vooroverleg en prijsverbetering in de zogenoemde grof groensector, vond plaats tegen de achtergrond van de toen geldende generieke onverbindendverklaring voor de bouwsector. ${ }^{255}$ Grof groenwerk (aanleg en onderhoud van bosplantsoenen, wegbermen, sloten etc.) viel onder de reikwijdte van deze maatregel waardoor mededingingsregelingen ten aanzien van onder meer verhoging van blankcijfers ${ }^{256}$, verboden en van rechtswege nietig waren, tenzij deze waren gebaseerd op een bij het ministerie van Economische Zaken aangemelde en door deze goedgekeurde aanbestedingsregeling. ${ }^{257}$ Voor beplantingswerken gold een dergelijke aanbestedingsregeling (het Uniform Prijsregelend Reglement voor onderhandse prijsaanbieding en voor prijsaanbieding bij openbare aanbesteding UPR- ${ }^{258}$ ), die in casu ten uitvoer werd gelegd door de Vereniging Wegenbouw Aannemers Combinatie Nederland (WAC). Op grond van het UPR was een aannemer gehouden om aan de WAC melding te maken van iedere uitnodiging voor een openbare of onder-

254 DeECD verzameldeook gegevens omtrent eventueleproductiebeperkingendoor de maatschappijen, omdat via dergelijke beperkingen de Platts (en daarmee de advies- en pompprijzen) kunstmatig zou zijn verhoogd. Hiervoor werden door de ECD in het geheel geen aanwijzingen gevonden.

255 Besluit van 29 december 1986 tot onverbindendverklaring van een aantal bepalingen in mededingingsregelingen aangaande het aannemersoverleg in de bouwsector, Stb. 1986,676.

256 Artikel 1 sub d Besluit mededingingsregelingenin de bouwsector definieerde blankeijfer als de prijs die door een aannemer wordt ingediend ten behoeve van het overleg in het kader van de toepassing van een aanbestedingsregeling ter zake van een bepaald werk.

257 Zijnde een mededingingsregeling waarin de procedure voor deelname aan de inschrijving op werken, voor de vaststelling van inschrijfeijfers dan wel voor de vaststelling van de daarin op te nemen vergoedingen wordt geregeld.

258 Dit door de Vereniging Prijsregelende Organisaties in de Bouwnijverheid (SPO) ingediende UPR zou later op communautair niveau gevoelig onderuit worden gehaald. 
handse aanbesteding. ${ }^{299} \mathrm{Bij}$ verschillende meldingen werd een vergadering belegd teneinde de inschrijfeijfers van de afzonderlijke aannemers te bepalen.

Het onderzoek van de ECD was gericht op een aantal aannemers alsmede op een stichting die volgens haar statuten ten doel had 'het bevorderen en behartigen bij ondernemingen, die zich bezighouden met de groenvoorziening in Nederland, van een ordelijke mededinging, het tegengaan van niet-behoorlijke gedragingen bij prijsaanbiedingen en het bevorderen van de totstandkoming van economisch verantwoorde ${ }^{200}$ prijzen'. ledere deelnemer aan deze stichting had zich verplicht om de werken waarop hij wilde inschrijven, aan de stichting te melden. De aannemer was bij aanmelding gehouden om voor een economisch verantwoorde prijs in te schrijven én om -behoudens in geval van vrijstelling-een financiêle bijdrage aan de stichting te leveren. ${ }^{261}$ Daar stond tegenover dat een onderneming op een uitkering van de stichting kon rekenen indien zij door een buitenstaander 'eraf werd geschreven ${ }^{262}$ en (daarom) het werk niet kreeg toegewezen, indien zij opzettelijk laag had moeten inschrijven om een buitenstaander voor te blijven en indien zij na inschrijving onder druk van de opdrachtgever de aanneemsom had moeten verlagen. Dit leverde hen een aanzienlijk concurrentievoordeel tegenover buitenstaanders op aangezien zij zich konden permitteren om tegen niet of nauwelijks rendabele prijzen in te schrijven. De door één van de verdachten gebruikte typering van de stichting 'als een soort verzekering' was dan ook uiterst treffend. ${ }^{263}$ Daarnaast had de stichting zich ook een marktregulerende taak toegemeten. Vanwege heersende overcapaciteit (en in het verlengde daarvan onder druk staande inschrijfcijfers) streefde de stichting ernaar om het aantal toetredingen en uitbreidingen zo veel mogelijk te beperken en het verlaten van de grof groen sector voor aannemers financieel aantrekkelijk te maken. ${ }^{264}$

Niet alleen de stichting stond in de belangstelling van de ECD; ook de gedragingen van verschillende ondernemingen werden onder de loep genomen. De ECD concentreerde zich met name op de deelname aan de stichting alsmede op het beleid van het respecteren van een zittende aannemer (de aannemer die het aanbestede werk in de daaraan voorafgaande periode reeds heeft mogen uitvoeren). Uit het onderzoek bleek inderdaad dat

259 Navraag door de ECD bij Rijkswaterstaat (de klacht betrof door deze aanbestede werken) maakte duidelijk dat werken met geringere geraamde uitvoeringskosten dan $f 500.000$ door een Regionale Directie onderhands mochten worden aanbesteed. Werken met een hogere raming dienden openbaar aanbesteed te worden, waarbij de aannemers aan bepaalde in het bestek van het werk opgenomen geschiktheidseisen en gunningscriteria dienden te voldoen.

260 Onder economisch verantwoorde prijzen werd hier verstaan een vergoeding voor de directe kosten zoals loon- en materiaalkosten, verhoogd met een verantwoorde opslag voor overhead-en afschrijvingskosten, risico en winst.

261 De vereiste bijdrage bedroeg een bepaald percentage van de aanneemsom ( $8,5 \%$ bij openbaar aanbestede werken en $4,5 \%$ bij onderhands aanbestede werken). De bijdragen moesten de financiele mogelijkheid scheppen om aannemers die hun activiteiten wilden staken, uit te kopen (voor dit doel was de stichting ook aanvankelijk opgericht). Aldus werden aardige bedragen bijeengebracht: in het boekjaar 1990 total $f 2.079 .553$; in 1991 total $f 4.530 .480$.

262 Inhoudende dat de concurrent een lager blankcijfer of inschrijfeijfer heeft ingediend.

263 De aannemers kregen daarentegen geen claim op het werk door melding aan de stichting; op dit gebied bleef de concurrentie dus wel intact.

264 Aannemers die van plan waren om hun grof groen activiteiten uit te breiden, werden benaderd om dit niet te doen en om uitsluitend tegen een 'economisch verantwoorde prijs', dus (te) hoge prijs in te schrijven. In nil voot het 'respecteren' van de deelnemers aan de stichten konden de ondernemingen dan vergoedingen van $f 175.000$ tot $f 200.000$ tegemoet zien. 
verschillende malen aannemers voorafgaand aan een WAC-vergadering hun blankcijfer aan hun 'concurrenten' meedeelde, opdat deze hun blankcijfer daarop zouden 'afstemmen'. Ook kwam het voor dat de 'concurrenten' uit eigen beweging duidelijk maakten de zittende aannemer te zullen respecteren. Dit alles gebeurde vanzelfsprekend onder de (stilzwijgende) toezegging dat het respect ook in de omgekeerde richting zou worden betoond. In sommige gevallen ontving de welwillende aannemer (daarenboven) een financiële bonus, met name indien een nieuwkomer of een buitenstaander naar het werk meedong omdat deze veelal bereid waren het werk voor een lager bedrag uit te voeren om hun kansen te vergroten. De financielle bonus kon dan echter een geheel ander licht op de zaak werpen. ${ }^{265}$

De ECD kwam tot de conclusie dat de gemaakte afspraken omtrent respectering. het verlenen van financielle steun en het in rekening brengen van verantwoorde prijzen, mededingingsregelingen vormden die in strijd waren met het Besluit mededingingsregelingen in de bouwsector, aangezien zij niet gebaseerd waren op noch in overeenstemming waren met een goedgekeurde aanbestedingsregeling. Volgens berekeningen van de ECD beliep de schade die voor de opdrachtgevers was ontstaan in 1990 ruim $f 2$ miljoenen en in $1991 f 4,5$ miljoen. Een en ander leidde ertoe dat werd overgegaan tot verbalisering. De verdachten daarentegen bestreden de strijdigheid van hun handelen met de generieke maatregel. Van prijsverhoging was geen sprake geweest en de afspraken garandeerden slechts (handhaving van) de kwaliteit van het te leveren eindproduct, waarvoor inderdaad wel een bepaald prijsniveau noodzakelijk was, gelet op de grote investeringen voor nieuwe hoogwaardige machines, innovatie en het voldoen aan de strenge milieuvoorschriften. Desalniettemin verklaarden zij zich in principe bereid om een schikkingsaanbod van de officier van Justitic te aanvaarden; en inderdaad werd de zaak uiteindelijk afgedaan via een transactie.

\section{Ondergrondse buis- of pijpleidingen}

De aannemersbranche was ook het onderwerp van het laatste hier te bespreken onderzoek, zij het dat hierin aannemers centraal stonden, wier werkzaamheden lagen op het terrein van het aanleggen van ondergrondse buis- of pijpleidingen. Ook hier was de ECD op het spoor van mogelijk ongeoorloofd vooroverleg en daaruit voortvloeiende prijsbeïnvloeding gezet door een aan de Directie Mededinging gerichte klacht. Het juridische kader werd in deze zaak eveneens gevormd door het Besluit mededingingsregelingen in de bouwsector alsmede door het UPR. De tenuitvoerlegging van het UPR in de leidingenbranche lag in handen van het Centraal Bureau Prijsregeling Boringen Kabels en Leidingen (BKL).

In het kader van het onderzoek werd inzage verlangd van de relevante gegevens en werden alle betrokken ondernemingen ter plaatse ondervraagd over hun eventuele betrokkenheid bij voorafspraken. Van een gelijktijdig optreden bij alle betrokkenen was overigens geen sprake. Integendeel: de verschillende ondernemingen werden ruime tijd na elkaar bezocht. Hierin zag de ECD klaarblijkelijk geen probleem: hij beschikte reeds over relevante informatie voordat hij zich rechtstreeks tot de ondernemingen richtte en bovendien werd een van de belangrijkste verdachten als eerste bezocht, waardoor verwacht

265 Was de overtuigingskracht van de bonus niet sterk genoeg, kon de zittende aannenuernog altijd zelf tegen een extreem lage prijs insehrijven, om vervolgens de 'schade' bij de stichting te declareren. 
mocht worden dat voldoende materiaal zou worden verzameld dat ook tegen de overigens kon worden gebruikt. Aan coöperatie van de zijde van de ondernemingen ontbrak het overigens niet: vragen werden (niet verbazend: grotendeels gelijkluidend) beantwoord en opgeèiste gegevens werden verstrekt.

De gedragingen van de betrokken aannemers vertoonden enige gelijkenis met die in de grof groen-zaak. Een onderneming die van een aanbesteder een aanvraag tot prijsopgave kreeg, diende dit bij het BKL te melden. Bij meer interesse voor inschrijving op hetzelfde werk werd door het BKL een vergadering belegd, waarop het uiteindelijke inschrijfcijfer van de aannemers werd bepaald. Hiertegen bestond van overheidszijde geen bezwaar, blijkens de goedkeuring van de aangemelde aanbestedingsregeling. Bedenkingen waren er daarentegen wel tegen de geregelde bijeenkomsten voorafgaand aan de officiële BKL-vergadering, op welke bijeenkomsten afspraken werden gemaakt omtrent prijzen en de verdeling van (toekomstig) werk. Uit het onderzoek bleek namelijk dat de aannemers een claimsysteem hanteerden. In de voorvergaderingen werd in gezamenlijk overleg de aannemer aangewezen die als laagste mocht blanken en die door de anderen gerespecteerd zou worden. In ruil voor de respectering kregen zij een claim op deze aannemer, veelal berekend door het blankcijfer van de laagste blanker te delen door het aantal ondernemingen dat aan de voorvergadering had deelgenomen. Deze claims werd niet uitbetaald, maar werden gebruikt ter bepaling van de ondernemer die bij een volgende aanneming in beginsel ${ }^{266}$ als laagste mocht blanken, waarna weer een nieuwe claimverhouding ontstond. Met dit claimstelsel hing logisch samen dat onderling de prijs werd bepaald waartegen geblankt zou worden door de rechthebbende. Lang niet altijd was deze namelijk bereid te blanken tegen het ramingscijfer van een collega, terwijl zijn eigen ramingscijfer te hoog was om door zijn collega's gehonoreerd te kunnen worden. Over het algemeen werd overeengekomen dat het gemiddelde ramingscijfer het blankcijfer voor de rechthebbende zou worden. Voor de opdrachtgever betekende deze praktijk dat het werk uiteindelijk aanmerkelijk duurder werd dan het geval zou zijn geweest zonder voor(voor)overleg. Door middel van een steekproef raamde de ECD de gemiddelde verhoging van het blankcijfer op 5,4\%, hetgeen voor 1989 gelijk stond met een bedrag van ongeveer $f 4,1$ miljoen. Hierbij zij nog opgemerkt dat de schade voor de opdrachtgevers een nog groter bedrag beliep, aangezien (toegestane) BKL-verhogingen berekend werden over het te hoge blankcijfer.

Ook in deze zaak constateerde de ECD een inbreuk en maakte proces-verbaal po tegen de betrokkenen. Deze achtten het Besluit mededingingsregelingen in de bouwsector niet overtreden omdat het uitgangspunt van onderlinge concurrentie niet zou zijn aangetast en de opdrachtgevers niet zouden zijn werden benadeeld: strikt rekenkundig bezien, werden de prijzen wellicht enigszins verhoogd, maar daar stond dan tegenover dat aannemers zich niet meer op een later tijdstip zouden terugtrekken vanwege een onrendabele prijs. In feite zouden de opdrachtgevers zelfs gebaat zijn bij de gedragingen, omdat zij de continuilteit van de aannemers ten goede kwamen, waardoor deze zich konden blijven inspannen een kwalitatief goed product te leveren voor een verantwoorde prijs. Daarnaast profiteerden hun werknemers van de onderzochte praktijk omdat hun werkgelegenheid behouden bleef. De aannemers waren zozeer ervan overtuigd dat zij niet laakbaar handelden, dat zij ook na aanvang van het onderzoek nog volhardden in het maken van onderlinge afspraken. Desalniettemin werden ook zij gepolst omtrent hun bereidwilligheid om

266 Namelijk tenzij deze slechts voor een exorbitant hoog bedrag wilde blanken. 
een mogelijk transactieaanbod van de officier van Justitie te accepteren. En ook hier werd de zaak inderdaad afgedaan door middel van een schikking.

\section{Conclusie}

Het door mij verrichte onderzoek bij de ECD bevestigen het eerder geschetste beeld van de handhaving van de Wem. Een onderzoek zonder voorafgaande klacht behoorde tot de zeldzaamheden ${ }^{267}$; een onderzoek zonder redelijke verdenking in de zin van artikel 27 WvSv kwam zelfs in het geheel niet voor, uitgezonderd vanzelfsprekend het enquêterend onderzoek. ${ }^{268}$ De sfeer rondom de onderzoeken van de ECD was ronduit mild, coőperatief en in zekere zin begripvol. Dat gold a priori voor de enquêterende onderzoeken, maar ook waar het het opsporingsonderzoek betrof, wees vrijwel niets erop dat het om een strafrechtelijk onderzoek ging. Met name meldingsverzuimen werden 'low profile' afgehandeld en leidden niet tot het opmaken van een proces-verbaal, maar ook bij overtredingen van generieke onverbindendverklaringen werd allerminst het klassieke strafrechtelijke (dwangmiddelen)arsenaal uit de kast gehaald. Zelden werden verschillende bij hetzelfde kartel betrokken ondernemingen (tegelijk) binnengevallen (de FIOD is in dat verband aanmerkelijk drastischer) en in het uitzonderlijke geval dat dit wel gebeurde was er veelal reeds zoveel publiciteit aan de zaak besteed dat de verschijning van de ECD bij de ondernemingen bepaald niet onverwacht kwam. De praktijk was veeleer dat de met het onderzoek belaste ambtenaar telefonisch een afspraak met de betrokkene maakte om ten kantore van de onderneming de zaak te bespreken en tot een oplossing van het gerezen probleem te komen. Aldus werden de goede banden met het bedrijfsleven niet op het spel gezet, terwijl toch kon worden bereikt dat ondernemingen uiteindelijk hun beleid bijstelden In het verlengde hiervan ligt dat de afdoening niet bepaald getuigde van een repressief optreden: overtredingen op de meldingsplicht werden met de mantel der liefde bedekt indien werd toegezegd het kartel alsnog aan te melden ${ }^{269}$; van overtredingen op de generieke maatregelen werd wel proces-verbaal opgemaakt, maar dit leidde doorgaans hooguit tot het treffen van een schikking.

\subsection{Controle- en opsporingsbevoegdheden}

Dat het niet tot een grootschalig strafrechtelijk optreden tegen kartelovertreders kwam, is hiervoor besproken. Als een van de redenen hiervan werden problemen van bewijstechnische aard genoemd. Een gedegen (strafrechtelijk) onderzoek naar overtredingen zou een belangrijk deel van deze problemen hebben kunnen wegnemen. Dit vergde naast de wil en de (financiële) middelen om daadwerkelijk onderzoek te verrichten, tevens de aanwezig.

267 Voor zover de klachten bij het ministerie van Economische Zaken binnenkwamen, werden deze lang niet altijd aan de ECD doorgespeeld. Mede gelet op de beperkte kwantitatieve capaciteit van het Went team gebeurde dit slechts ten aanzien van beduidende zaken die niet door het ministerie zelf afgehandeld konden worden of waarvan een optreden buiten het ministerie zelf de voorkeur verdiende.

268 In feite was toepassing van de artikelen $16 \mathrm{en} 17$ Wem slechts geoorloofd indien vaststond dat ef een mededingingsregeling op de markt aanwezig was. Aan dit vereiste werd echter niet zeer strikt de hand gehouden.

269 Dit wijst er op dat inbreuken op de meldingsplicht niet als 'echte' strafbare feiten werden beschouwd 
heid van adequate bevoegdheden tot strafrechtelijke handhaving. In deze paragraaf zal worden bezien in hoeverre binnen het Nederlandse kartelrecht dergelijke bevoegdheden aanwezig waren.

Geheel in de lijn van de terughoudendheid waarmee in de Ondernemersovereenkomstenwet 1935 gekozen werd voor strafrechtelijke handhaving van onverbindendverklaringen, was de regeling van de handhaving van het strafrechtelijk verbod. Niet aan opsporingsambtenaren, maar aan een Commissie van Toezicht werd de taak opgedragen om 'in eerste instantie' toezicht te houden op de naleving van zowel onverbindendverklaringen als algemeen verbindendverklaringen ${ }^{270}$ : het blootstellen van ondernemers aan justitięle onderzoeken diende tot het uiterste te worden beperkt. ${ }^{271} \mathrm{Het}$ was derhalve de bedoeling dat de Commissie van Toezicht, waarvan de samenstelling bij algemene maatregel van bestuur werd geregeld ${ }^{272}$, het belangrijkste deel van de handhaving voor haar rekening nam, en dat zij zoveel mogelijk de voor een eventuele strafrechtelijke vervolging noodzakelijke gegevens zou verzamelen. De weg van het wetboek van Strafvordering zou pas moeten worden ingeslagen, indien de Commissie op grond van het door haar verzamelde materiaal van mening was dat een strafrechtelijke vervolging geinndiceerd was of indien verdergaande dwangmiddelen noodzakelijk waren (te denken viel aan huiszoeking). ${ }^{273}$ Deze commissie beschikte ter uitoefening van haar taak over enkele bevoegdheden, te weten de bevoegdheid tot het betreden van plaatsen (eventueel af te dwingen door de 'sterke arm') alsmede die tot inzage van boeken en bescheiden. ${ }^{274}$ Aan de opsporingsambtenaren van artikel $141 \mathrm{WvSv}$ stonden de dwangmiddelen van het wetboek van Strafvordering ter beschikking, waarop hierna, bij de bespreking van de handhaving van de Wem, nog zal worden ingegaan. In het Kartelbesluit was de opsporing een zaak van de opsporingsambtenaren van artikel $141 \mathrm{WvSv}$ en enkele andere in artikel 19 Kartelbesluit aangeduide personen: de Commissie van Toezicht was van het toneel verdwenen. Naast de bevoegdheden van het wetboek van Strafvordering (althans voor de in artikel 141 WvSv genoemde personen), kwamen op grond van de artikelen 20 en 21 Kartelbesluit aan de opsporingsambtenaren nog de volgende bevoegdheden toe: inbeslagneming van voorwerpen en het vorderen van uitlevering van deze, het vorderen van inzage van bescheiden en het betreden van plaatsen (zonodig met behulp van de 'sterke arm'). ${ }^{275}$

De introductie van de WED en de opname van het Kartelbesluit en later de Wem in de lijst van artikel 1 WED (meer in het bijzonder artikel 1 sub $3 \mathrm{f}$ ), brachten in de

270 Zoals gezegd kon bij gebleken overtreding van een algemeen verbindend verklaring de Commissie van Toezicht weliswaar niet met strafrechtelijke middelen tegen de overtreder ageren, maar wel met civielrechtelijke middelen, daar zij geacht werd belanghebbende te zijn bij een goede naleving van bedoelde maatregel.

271 MvA TK 1934-1935, 64, nr. 1, pag. 5.

272 Besluit tot uitvoering van artikel 12, tweede en vierde lid, van de Wet op het algemeen verbindend en onverbindend verklaren van ondernemersovereenkomsten 1935, Stb. 1936, 646.

273 Maitland (1946), pag. 58

274 Zie voor deze bevoegdheden artikel 12 Ondememersovereenkomstenwet 1935 alsmede de op dit artikel gebaseerde en hiervoor reeds genoemde AMvB van 1936. De bevoegdheid tot het betreden van woningen tegen de wil van de bewoner was aan verschillende, bij de toenmalige artikelen 120 e.v. WvSv aansluitende voorwaarden gebonden: in bedoelde situatie was vereist dat de commissie hetzij werd vergezeld door de commissaris van politie of de burgemeester, hetzij in het bezit was van een bijzondere schriftelijke last, ondertekend door een van beide genoemde personen.

275 Ten aanzienvan het betreden van woningen tegen de wil van de bewoner gold een regeling, vergelijk. baar met die van de wet van 1935 . 
bovenstaande regeling verandering. Vanaf het moment van de inwerkingtreding van de WED golden de (uniforme ${ }^{276}$ ) materieel- en formeelrechtelijke regels van deze wet mede voor het Nederlandse kartelrecht. ${ }^{277}$ De handhaving van de in de WED genoemde wetten was opgedragen aan de opsporingsambtenaren, zoals bedoeld in de artikelen 141 en $142 \mathrm{WvSv}$. Binnen de laatstbedoelde categorie (de bijzondere opsporingsambtenaren) waren voor het kartelrecht voornamelijk de met opsporing belaste ambtenaren van de Economische Controledienst van belang. In de aard van de bevoegdheden kwam nauwelijks wijziging ten opzichte van de regeling in het Kartelbesluit: de artikelen 18-20 WED regelden de inbeslagneming van goederen, de vordering van inzage van bescheiden en de bevoegdheid tot het betreden van plaatsen, wederom met de bekende beperking voor woningen, in 1994 vervangen door regeling van de Algemene wet op het binnentreden ${ }^{27}$. Daarnaast kende de WED in de artikelen 21-23 nog enkele andere bevoegdheden, die voor het kartelrecht nieuw, maar evenzeer van gering belang waren (en verder buiten beschouwing worden gelaten): monsterneming, vordering tot het openen van verpakkingen en het doen stilstaan en onderzoeken van vervoermiddelen. Beziet men de reikwijdte van de bevoegdheden zoals neergelegd in de artikelen 18-20 WED, dan kan geconcludeerd worden dat (primair) de Economische Controledienst beschikte over redelijk adequate middelen om karteldelicten (betreffende zowel het Kartelbesluit als de Wem) op te sporen. Niet alleen hadden de opsporingsambtenaren de bevoegdheid om relevant materiaal in te zien en in beslag te nemen ${ }^{279}$, maar bovendien waren de ondernemers op straffe van een gevangenisstraf van ten hoogste twee jaar envof een geldboete van $f 25.000$ (in boginsel dezelfde sancties als die welke konden worden opgelegd wegens inbreuk op de kartelbepalingen zelf) verplicht om aan een vordering tot uitlevering of inzage gehoor te geven. ${ }^{280} \mathrm{Er}$ werd aldus een medewerkingsplicht gecreëerd die de taak van de opsporingsambtenaren aanzienlijk kon verlichten. ${ }^{281}$ De bevoegdheid tot het betreden van plaatsen ondersteunde daarenboven het inzagerecht: ter plekke kon beter worden nagegaan van welke gegevens volgens de opsporingsambtenaren inzage gewenst was. Het betredingsrecht machtigde bovendien tot enig zoeken, met dien verstande dat dit zoeken niet een stelselmatig en gericht karakter mocht krijgen aangezien voor een dermate vergaand zoekrecht een bevoegdheid tot huiszoeking (thans: doorzoeking) vereist was. Aldus diende de ECD te blijven binnen de grenzen die aan de hand van drie criteria werden getrokken: de duur van het zoeken, de intensiteit ervan en de privacy-gevoeligheid van de plaatsen waar gezocht werd, waarbij de nadruk -een extreem lang zoeken uitgezonderd- op de laatste twee criteria viel. ${ }^{282}$ De aard van deze criteria bracht een zoekrecht van enige importantie

276 Uniformering van het economische strafrecht was een belangrijke doelstelling van de WED. Dit had evenzeer gegolden voor het Besluit Berechting Economische Delicten, maar dit besluit had slechts voor een zeer beperkt aantal wetten gelding.

277 Zie over de WED in zijn algemeenheid Hollander (1952) en meer recent Mulder en Doorenbos (1995).

278 Wet van 22 juni 1994, Stb. 572, tot vaststelling van de Algemene wet op het binnentreden.

279 Op grond van artikel $94 \mathrm{WvSv}$ waren voor inbeslagneming vatbaar onder meer voorwerpen die konden dienen voor het aan de dag brengen van de waarheid.

280 Artikel $26 j^{\circ}$ artikel 1 sub 4 (later sub 5) $j^{\circ}$ artikel 2 lid 4 (later lid 5) $j^{\circ}$ artikel 6 lid 1 sub 2 WED.

281 Maar die wel in principe zou kunnen indruisen tegen het nemo tenetur-beginsel. In hoeverre dat inderdaad zo was, zal in hoofdstuk 5 worden besproken.

282 Zie omtrent bedoeld onderscheid en de criteria met name HR 28 mei 1985, NJ 1985, 822 (Keukenkastje), HR 17 maart 1987, NJ 1988, 155 m.nt. ThWvV (Cocaïne in linnenkast) en HR 19 decembet 1995, NJ 1996, 249 (Zwolsman). 
met zich, aangezien met name de privacy-gevoeligheid binnen het economische strafrecht, waar het doorgaans betreding van bedrijfsruimten betrof, minder groot was. Wat echter in ieder geval niet geoorloofd was, was het forceren van toegang tot ruimten, kasten en dergelijke. Voor zover dit noodzakelijk was, moest gegrepen worden naar het middel van de huiszoeking, waarmee tevens de belangrijkste bevoegdheid uit het wetboek van Strafvordering voor het kartelrecht is genoemd. Hier was wel sprake van cen binnen de grenzen van proportionaliteit en subsidiariteit alomvattend zoekrecht. Onder het toen geldend recht was de huiszoekingsbevoegdheid op grond van artikel 111 (oud) WvSv voorbehouden aan de rechter-commissaris (in het kader van een gerechtelijk vooronderzoek), die in beginsel slechts kon handelen met verlof van de rechtbank. ${ }^{283}$ Artikel $125 i$ e.v. WvSv machtigde de rechter-commissaris daarenboven tot het onderzocken van geautomatiseerde werken, terwijl hij op grond van artikel $210 \mathrm{WvSv}$ bevoegd was getuigen te verhoren, die op hun beurt verplicht waren te verschijnen en -behoudens verschoningsrecht- te verklaren. Voor het overige bood het wetboek van Strafvordering geen dwangmiddelen van belang: zo konden vrijheidsbenemende dwangmiddelen ten gevolge van de te lage sanctiedreiging voor kartelinbreuken niet worden opgelegd (artikel $67 \mathrm{WvSv}$ ), de reden waarom bijvoorbeeld evenmin een telefoontap kon worden bevolen.

Hoewel dus niet alle mogelijkheden van het wetbock van Strafvordering in cen kartelonderzoek konden worden benut, stonden de opsporingsambtenaren naar mijn mening voldoende adequate middelen voor een doeltreffend anderzack ter beschikking. Desalniettemin werden de onderzoeksmogelijkheden in 1994 uitgebreid, dit met het oog op de vergroting van de effectiviteit van de Wem. Artikel 41 Wem stelde, voor zover hier relevant, het volgende:

3. De aangewezen ambtenaren zijn bevoegd van een ieder de inlichtingen te verlangen die redelijkerwijs voor de vervulling van hun taak nodig zijn

4. Zij zijn te allen tijde bevocgd alle plaatsen, met uitzondering van woningen zonder toestemming van de bewoner, te betreden, voor zover dat redelijkerwijs voor de vervulling van hun taak nodig is

5. Zij zijn bevoegd inzage te vorderen van boeken en andere zakelijke bescheiden en van gegevens die langs geautomatiseerde weg zijn vastgelegd, voor zover zulks redelijkerwijs voor de vervulling van hun taak nodig is. (...)

Artikel 41a Wem legde een strafrechtelijk gesanctioneerde mededwerkingsplicht op de betrokkenen. De hierboven genoemde bevoegdheden verschilden niet wezenlijk van hetgeen reeds op grond van de WED mogelijk was. Waarom werden deze bevoegdheden dan toch geintroduceerd? Dit hing samen met de bij de Nederlandse overheid heersende visie ten aanzien van een verschil tussen opsporingsbevoegdheden enerzijds en toezichthoudende of controlebevoegdheden anderzijds. In de memorie van toelichting bij het wetsvoorstel vergroting effectiviteit stelde staatssecretaris Van Rooy:

283 De spoedhuiszoeking van artikel 97 WvSv was voor het kartelrecht -niet alleen in de praktijk- van geen betekenis: voorlopige hechtenis behoorde voor karteidelicten niet tot de mogelijkheden en ontdekking op heterdaad van deze delicten was een niet meer dan theoretische mogelijkheid. Sindsdien is de huiszoekingsregelingop grond van de Wet van 27 mei 1999 tot partiele wijziging van het Wetboek van Strafvordering (herziening van het gerechtelijk vooronderzoek), Stb. 1999, 243, nogal ingrijpend veranderd. Zie hierover hoofdstuk 2 alsmede Corstens (1999), pag. 445 e.v.. 
"Opsporing impliceert (...) dat er een redelijk vermoeden dient te bestaan dat een strafbaar feit heef plaatsgevonden of nog plaatsvindt". "Op basis van de huidige wet dient optreden van de opsporingsamb. tenaren beperkt te blijven tot die gevallen waarin sprake is van een redelijk vermoeden dat de wet is overtreden. In het geval van de Wet economische mededinging is het echter in de praktijk zeer moeilijk gebleken in voorkomende gevallen zodanig conerete feiten te vinden, dat daarop zonder nader onderzoek een dergelijk redelijk vermoeden gebaseerd kan worden",

De (opsporings)bevoegdheden van de WED konden volgens de staatssecretaris uitsluitend worden toegepast zodra er een verdenking in de zin van artikel $27 \mathrm{WvSv}$ was gerezen. ${ }^{2.55}$ De bewindsvrouw volgde daarmee de visie die sinds begin jaren zeventig bij de centrale Nederlandse overheid de heersende was. Aangezien de verdenkings-eis een effectieve handhaving in de weg stond, dienden er -met de WED-bevoegdheden vergelijkbarecontrolebevoegdheden ${ }^{286}$ te worden geschapen voor de situatie, waarin er nog geen verdenking was. ${ }^{287}$ De woorden van Van Rooy toonden eens te meer aan dat voordien de Nederlandse overheid niet bijzonder geïnteresseerd was in strafrechtelijke handhaving: indien namelijk de WED-bevoegdheden in de praktijk inderdaad nauwelijks konden worden toegepast omdat de voorhanden zijnde gegevens zelden het bestaan van een verdenking rechtvaardigden, dan zou bij een bestaande wil tot intensieve strafrechtelijke handhaving een wetswijziging in een veel eerder stadium voor de hand gelegen hebben. Een tenminste even relevante constatering kon zijn dat de staatssecretaris het juridisch niet bij het rechte eind had. ${ }^{288}$ Voor de uitoefening van de opsporingsbevoegdheden van de WED was namelijk geen verdenking vereist. Het arrest van de Hoge Raad inzake de Heggeveldse stroper $^{289}$ deed reeds vermoeden dat voor de opsporingsbevoegdheden van de WED

284 MvT TK 1992-1993, 23 306, nr. 3, pag. 12/13.

285 Voor de Ondernemersovereenkomstenwet 1935 en het Kartelbesluit gold deze beperking niet. In de wet van 1935 waren uitdrukkelijk toezichthoudende bevoegdheden opgenomen; het Kartelbesluit maakte weliswaar slechts melding van opsporingsbevoegdheden, maar er moet (nog afgezien van het feit dat er toentertijd geen scherp onderscheid werd gemaakt tussen controle en opsporing) vanuit worden gegaan dat het niet de opzet van de toenmalige besluitnemer was om de handhavingsbevoegdheden ten opzichte van die uit de wet van 1935 te beperken. Dus onder opsporing moest in dit verband mede worden verstaan handelen zonder de noodzaak van verdenking.

286 De controle wordt gerekend tot het bestuursrecht, dit in tegenstelling tot de opsporing die als strafrechtelijk wordt aangemerkt. Interessant in dit verband is dat artikel 1:6 Awb bepaalt dat deze wet zich niet uitstrekt over de opsporing en vervolging van strafbare feiten (maar dus wel over het toezicht). Aldus worden het strafrecht en het bestuursrecht strikt gescheiden, hetgeen nauwelijks nog van deze tijd is. Zie daarover onder meer Sackers (1994), pag. 804 e.v. en Jansen (1994 II), pag. 257 e.v.

287 In de artikel 16-18 Wem waren van oudsher ook enkele bevoegdheden opgenomen tot inlichtingenvergaring, tot het verlangen van inzage van boeken en dergelijke en tot het betreden van plaatsen. Deze hadden echter een andere achtergrond. $\mathrm{Zij}$ waren namelijk niet gericht op de controle op de naleving van een getroffen maatregel, maar zij moesten de overheid in de gelegenheid stellen om informatie te vergaren over het al dan niet in strijd met het algemeen belang zijn van bepaald gedrag. De aldus vergaarde informatie maakte het mogelijk om te beslissen over het al dan niet nemen van een maatregel. Zie onder meer Samkalden (1954), pag. 1.

288 Hetgeen haar overigens niet kwalijk genomen kon worden, aangezien zij zoals gezegd slechts de bij de Nederlandse overheid heersende visie volgde.

289 HR 30 oktober 1984, NJ 1985, 275. Zie voor instemmend commentaar op dit vonnis Mulder (1985). pag. 564 e.v.. 
geen verdenking vereist was ${ }^{290}$; aan alle onzekerheid kwam een einde door een arrest van de Hoge Raad in 1993. ${ }^{291}$ Hierin bepaalde de Hoge Raad op wetshistorische gronden ten aanzien van artikel 23 WED:

Aan het middel ligt blijkens de daarop gegeven toelichting de opvatting ten grondslag dat van "opsporing", zoals dat begrip wordt gebezigd in art. 23 eerste lid WED eerst dan sprake kan zjn indien een redelijk vermoeden van schuld in de zin van art. $27 \mathrm{~Sv}$ is gerezen. Deze opvatting kan niet als juist worden aanvaard.

De motivering van dit vonnis was van dien aard dat naar mijn mening als vaststaand moet worden beschouwd dat dezelfde conclusie geldt ten aanzien van de overige artikelen van de WED waarin 'opsporingsbevoegdheden' zijn opgenomen. In tegenstelling tot hetgeen in het wetboek van Strafvordering geldend was ${ }^{292}$, konden de opsporingsbevoegdheden van de WED mede worden gebruikt indien er nog geen verdenking van een strafbaar feit bestond. ${ }^{293}$

In feite impliceert het voorgaande dat de invoering van controlebevoegdheden in de Wem gelet op de motivering van de staatssecretaris- overbodig was. ${ }^{294}$ Probleem was echter

290 Vergelijk naast Mulder in zijn kanttekeningen bij bedoeld arrest tevens Van Buuren (1986), pag. $74 \mathrm{en}$ Moorman (1988), pag. 414, die concludeerde "dat de opsporingsambtenaren waar het om ceonomische delicten gaat, mede een toezichthoudende taak hebben en de bevoegdheden van de artikelen 18 tot en met 23 Wet Economische Delicten als controle-bevoegdheden, dus zonder verdenking van een strafbaar feit, kunnen uitoefenen".

291 HR 9 maart 1993, NJ 1993, 633 m.nt. ThWvV. Zie hierover ook Mulder en Doorenbos (1995), pag. 109-111.

292 Sinds 1 februari 2000 geldt ook voor het wetboek van Strafvordering een ietwat ruimer opsporingsbegrip, en wel op grond van artikel 132a WvSv: "Onder het opsporingsonderzoek wordt verstaan het onderzoek onder leiding van de officier van justitie naar aanleiding van een redelijk vermoeden dat cen strafbaar feit is begaan of dat in georganiseerd verband misdrijven worden beraamd of gepleegd, als omschreven in artikel 67, eerste lid, die gezien hun aard of samenhang met andere misdrijven die in dat georganiseerdeverband worden beraamd of gepleegdeen ernstige inbreuk op de rechtsorde opleveren, met als doel het nemen van strafvorderlijke beslissingen".

293 Of dit tevens, zoals Corstens (1999), pag. 252, stelt, impliceert dat de WED-bevoegdheden tevens controle-bevoegdhedenzijn (Van Veen trok in zijn noot onder het geciteerdearrest een vergelijkbare conclusie), is een vraag van een andere orde. Indien men het onderscheid tussen opsporing en toezicht legt bij de vraag of er al dan niet een verdenking bestaat, dan moet zij bevestigend worden beantwoord. Indien men echter met Buruma (1993), pag. 201, van mening is "dat er sprake is van een opsporingsbevoegdheid als de bevoegdheid wordt toegedeeld aan een opsporingsambtenaar mits daarbij gesteld wordt dat uitoefening ervan noodzakelijk is voor de vervulling van zijn taak -die van opsporingsambtenaar- of als wordt gesproken van 'het belang van de opsporing'" -waarbij het al dan niet bestaan van een verdenking niet relevant is-, dan is er onverminderd sprake van een opsporingsbevoegdheid. Dit is in de visie van Buruma in zoverre relevant dat volgens hem de ratio van opsporing aanmerkelijk verschilt van die van toezicht, waarbij -zeer kort gezegd- toezicht naadloos in een overiegcultuur past, terwijl bij opsporing de partijen tegenover elkaar staan. Jansen (1994 I), pag. 545 pleitte er in ieder geval voor om het opsporingsbegrip ook in de WED te beperken tot de gevallen waarin er sprake is van een redelijk vermoeden van schuld.

294 Later -in de Nota naar aanleiding van het eindverslag. TK 1993-1994, 23 306, nr. 7-gaf de Staatssecretaris blijk van een veranderde visie. Volgens haar waren ondanks het ruime WED-opsporingsbegrip de toezichthoudendebevoegdhedennoodzakelijkomdat deze ook zonder concreteaanwijzingen voor een inbreuk zouden kunnen worden uitgeoefend. Indien het inderdaad haar bedoeling was om de betreffende bevoegdhedente doen uitoefenen zonder enige concrete aanwijzing voor een overtreding 
dat de Economische Controledienst zich had geconformeerd aan de visie van de Nederlandse overheid, waardoor hij in de praktijk geen gebruik maakte van de door de WED geboden mogelijkheid op te treden als er nog geen verdenking was. ${ }^{295}$ In zoverre moest er tegen de achtergrond van de intensivering van het kartelbeleid iets gebeuren. Het zou echter de voorkeur hebben verdiend (boven de introductie van nieuwe wettelijke controle. bevoegdheden) indien de visie omtrent de verdenkingseis conform de jurisprudentie van de Hoge Raad zou zijn herzien. Een dergelijke herziening zou het kartelrecht hebben overstegen, aangezien aldus zou zijn voorkomen dat in bijzondere wetten steeds een afzonderlijke regeling van controlebevoegdheden zou moeten worden opgenomen. ${ }^{2 \%}$

\subsection{Sancties}

Rationeel (markt)gedrag vooronderstelt een afweging van door dit gedrag te verwachten kosten en baten. Een rationele ondernemer zal een dergelijke economische afweging ook aan eventuele economische criminaliteit, waaronder inbreuken op het kartelrecht, doen voorafgaan. ${ }^{297}$ Als er namelijk één vorm van criminaliteit is waarbij verwacht mag worden dat voordelen en risico's bewust tegen elkaar worden afgewogen, dan is het wel de financiële, economische criminaliteit. In het verlengde daarvan kan tevens worden geconcludeerd dat áls het strafrecht ergens generaal preventieve werking heeft, dit het geval is bij economische criminaliteit. Voor de overheid die in het kader van de criminaliteitsbestrijding deze generaal preventieve werking wil benutten, is het dan zaak om overtredingen zo onaantrekkelijk mogelijk te maken, door er tenminste voor te zorgen dat voor de potentiële overtreder de baten de kosten niet overstijgen. De aspecten waarmee bedoelde potentięle overtreder van economische regelgeving rekening moet houden, kunnen verschillend van aard zijn; ik noem enkele. Aan de baten-zijde spelen bijvoorbeeld het behalen van financiële voordelen, het verstevigen of behouden van de positie ten opzichte van concurrenten en het behoud van productie en werkgelegenheid een rol. ${ }^{298}$ Aan de kostenzijde kan met name gedacht worden aan de sancties die de overtreder boven het hoofd hangen, de kans dat een sanctie zal volgen (waarvan de 'pakkans' een belangrijk aspect is) en de negatieve publiciteit (en de daaruit mogelijk volgende economische consequenties) van een publiekrechtelijk optreden. ${ }^{299}$

(controle dus in de meest pure zin van het woord), dan kan men zich niet alleen afvragen of deze bevoegdhedendan niet wat te veel van het goede waren, maar moet bovendien geconcludeerdworden dat zij wel een heel erg drastische wijziging in de handhaving verwachtte of tenminste voorstond.

295 Dat de ECD zich deze 'zelfbeperking' had opgelegd werd uitdrukkelijk erkend door Engels, voormalig directeur van de ECD. Zie Mulder en Engels (1984), pag. 152.

296 Uit HR 26 april 1988, NJ 1989, $390 \mathrm{~m} . \mathrm{nt}$. ThWvV blijkt overigens dat controlebevoegdhedenmede in het kader van de opsporing mogen worden gebruikt, mits de rechten die de verdachte in deze fase tockomen, worden gehonoreerd. Zie hierover Knigge (1988), pag. 773 e.v..

297 Aldus ook Mulder (1959), pag. 30.

298 Vergelijk in deze ook Mulder (1959), pag. 29.

299 Deze aspecten (zowel aan de kosten-als aan de baten-zijde) kunnen elkaar overlappen. De mogelijkheid van openbaarmaking van een strafrechtelijk vonnis als sanctie beìnvloedt de dreiging van negatieve publiciteit. 
Hierna zal ik mij concentreren op de kosten-zijde en meer in het bijzonder de sanctie als een belangrijk aspect daarvan. ${ }^{300}$ De sanctic zal qua aard en omvang een rečel antwoord moeten zijn op de overtreding waarvoor zij wordt opgelegd. Met andere woorden: van de sanctie moet een generaal preventieve werking (kunnen) uitgaan. Eén van de kritiekpunten op de strafrechtelijke handhaving van de voorgangsters van de Mededingingswet richtte zich juist op de omvang van de sancties: deze zou te gering zijn om potentiele kartelovertreders van hun daden te weerhouden. Hieronder zal worden bezien in hoeverre deze kritiek terecht was.

Het oorspronkelijk ontwerp van de Ondernemersovereenkomstenwet 1935 kende, zoals gezien, geen vorm van strafrechtelijke handhaving en dientengevolge evenmin enige strafrechtelijke sanctie. Hierin kwam verandering omdat van civielrechtelijke handhaving van onverbindendverklaringen relatief weinig heil werd verwacht. Het hieruit voortvloeiende gebrek aan generaal preventieve werking van deze handhavingsvorm en de omstandigheid dat het algemeen belang in het geding was (en niet adequaat door civielrechtelijke handhaving zou worden beschermd), noopten tot de keuze voor het strafrecht. De sancties waren relatief mild: de als misdrijf gekwalificeerde opzettelijke overtreding van een onverbindendverklaring kon worden gesanctioneerd met een geldboete van ten hoogste $f 10.000$ en -in theorie niet onbelangrijk- met openbaarmaking van de rechterlijke uitspraak. Vanuit de gedachte van generale preventie en gelet op het beoogde structurele karakter van de Ondernemersovereenkomstenwet 1935 zouden ingrijpendere sancties meer voor de hand gelegen hebben. De betrekkelijke mildheid ${ }^{301}$ van de sancties vloeide ten dele voort uit de niet meer dan secundaire plaats van de onverbindendverklaring, maar meer nog uit de terughoudendheid waarmee men in het kartelrecht van het strafrecht als handhavingsinstrument gebruik wenste te maken. ${ }^{302}$

Het Kartelbesluit zorgde - geheel in de lijn van zowel het streven naar een hardere en meer efficiënte aanpak van (kartel)overtredingen als de daarmee samenhangende uitbreiding van de repressieve overheidsbevoegdheden in de bezettingstijd-voor een aanmerkelij-

$300 \mathrm{De}$ 'pakkans' is zoals gezegd evenzeer van belang. Of deze groot is hangt voornamelijk af van de mate waarin de overtredingen in het geheim platsvinden (dus al dan niet moeilijk zijn op te sporen), van de middelen die de overheid ter beschikking staan om overtredingen op te sporen en van de intensiteit van het opsporingsbeleid. Zoals gezien waren er voldoende middelen voor de overheid om inbreuken op het spoor te komen, ook al vonden veel van deze inbreuken in het geheim plaats. Duidelijk was echter ook dat van de middelen weinig gebruik gemaakt werd. De kans dat er een strafrechtelijke veroordeling volgde als reactic op een overtreding was gering. In zoverre was de pakkans -en de general preventieve werking-gering. Evenmin ging een dergelijke werking uit van het transactiebeleid, omdat ook dit een te incidenteel karakter had. Dit zou bij continuering van het begin jaren negentig ingezette beleid wellicht anders zijn geweest.

301 Betrekkelijk, aangezien $f 10.000$ toentertijd geen gering bedrag was, zekerniet voor een onderneming in financięle moeilijkheden.

302 Deze terughoudendheid blijkt uit tenminste twee omstandigheden. Ten eerste werd niet naar het strafrecht gegrepenvoor de handhaving van algemeenverbindend verklaringenen werd, zoals gezien, het strafrecht als handhavingsinstrument van onverbindend verklaringen pas in tweede instantie (bij de Nota van Wijzigingen) geintroduceerd. Ten tweede werd een afzonderlijke Commissie van Toezicht belast met de handhaving van de naleving van de Ondernemersovereenkomstenwet 1935 met als reden dat ondernemers niet zouden moeten worden blootgesteld aan een overmaat aan justitieel onderzoek. Strafrechtelijk optreden 'met de harde hand' werd met andere woorden niet wenselijk geacht; dientengevolge was er ook geen noodzaak voor zeer hoge geldboetes. 
ke aanscherping van de mogelijke sancties, waarbij niet alleen de hogere boetes, maar ook de introductie van vrijheidsbenemende sancties opvielen. De overtreder ${ }^{303}$ van een algemeen verbindendverklaring of van een onverbindendverklaring kon -als schuldig aan een overtreding- gestraft worden met hechtenis van ten hoogste één jaar of een geldboete van ten hoogste $f 25.000$ en met openbaarmaking van het vonnis. Bij een opzettelijke inbreuk -in dat geval was er sprake van een misdrijf- bedroegen de maximale sancties zelfs gevangenisstraf van ten hoogste twee jaar of een geldboete van $f 50.000$. Deze regeling kwam te vervallen met de inwerkingtreding van de Wet op de Economische Delicten. De wetgever besloot om onder meer het Kartelbesluit in de lijst van de via de WED te handhaven wetten op te nemen (en wel in artikel 1 sub 3 f WED), als gevolg waarvan de sanctiebepalingen uit het Kartelbesluit werden geschrapt en werden vervangen door de algemene bepalingen van de WED. In concreto betekende dit het volgende. Het onderscheid tussen misdrijven en overtredingen bleef bestaan: op grond van het gewijzigde artikel 15 Kartelbesluit werden onverkort opzettelijke inbreuken op het Kartelbesluit als misdrijven en culpoze inbreuken als overtredingen aangemerkt. Het onderscheid tussen misdrijf en overtreding was op grond van artikel $6 j^{\circ}$ artikel 2 lid 3 WED bepalend voor de sancties die konden worden opgelegd wegens schending van het Kartelbesluit. Voor overtredingen bedroeg de maximale sanctie hechtenis van zes maanden en/of een geldboete van $f$ 10.000; degene die -door opzettelijk te handelen- zich schuldig maakte aan een misdrijf moest rekening houden met cen gevangenisstraf van ten hoogste twee jaar en/of een geldboete van maximaal $f 25.000$. De maxima zoals de WED die voor kartelinbreuken kende, waren derhalve lager dan de maxima zoals die tot de inwerkingtreding van de WED in het Kartelbesluit waren opgenomen. ${ }^{304}$ Hiermee is echter nog niet gezegd dat het gehele regime van de WED milder was. Ten eerste valt op dat -in tegenstelling tot hetgeen in het Kartelbesluit het geval was- de vrijheidsbenemende sancties en de geldboete cumulatief konden worden opgelegd. Ten tweede -en belangrijker-voorzag de WED in een aantal vergaande bijkomende straffen ${ }^{305}$ en maatregelen ${ }^{306}$, die weliswaar niet allemaal als een passende reactie op kartelovertredingen konden worden beschouwd (te denken viel bijvoorbeeld aan de ontzetting van rechten en de plaatsing in een rijkswerkinrichting), maar die desalniettemin de conclusie rechtvaardigden dat onder het regime van de WED althans in theorie zeer gevoelige sancties op overtreding van het Kartelbesluit konden volgen. In het bijzonder moet hier worden gewezen op de ontneming van het wederrechtelijk verkregen voordeel, welke maatregel naast de hoofdstraf kon worden

303 Indien de inbreuk door een rechtspersoon werd gepleegd, kon op grond van artikel 15 lid 2 Kartelbesluit de strafvervolging worden ingesteld tegen de opdrachtgever dan wel de feitelijk leidinggevende. De straf kon dientengevolge nog niet tegen de rechtspersoon zelf worden uitgesproken.

304 Opmerking verdient de tweede volzin van artikel 6 WED (oud), op grond waarvan de boete kon oplopen tot een viervoud van de waarde van de zaken waarmee het economische delict was begaan of die door middel van dit delict waren verkregen.

305 Ontzetting van rechten, plaatsing in een rijkswerkinrichting, stillegging van een onderneming, verbeurdverklaring en -de reeds sinds de Ondernemersovereenkomstenwet 1935 in het kartelrecht bekendeopenbaarmaking van de rechterlijke uitspraak.

306 Onderbewindstelling, storting van een waarborgsom, verplichting tot het verrichten van hetgeen wederrechtelijk was nagelaten en de ontneming van het wederrechtelijk verkregen voordeel. 
opgelegd en die ervoor moest zorgdragen dat de overtreder geen voordeel aan zijn gedrag zou overhouden. ${ }^{307}$

De conclusie dat de sancties op overtreding van de kartelregelgeving in theorie ondernemers gevoelig konden treffen, gold in gelijke mate voor de Wem. Deze nam bij haar inwerkingtreding (op grond van artikel 49 Wem) in artikel I sub 3 WED de plaats van het Kartelbesluit over, als gevolg waarvan de strafmaxima voor kartelinbreuken ongewijzigd bleven. Wel bracht de Wem een beperkte verandering in de kwalificatie van de inbreuken als misdrijven respectievelijk overtredingen. Artikel $41 \mathrm{Wem}$ onderscheidde namelijk drie categorieèn gedragingen: het opzettelijk naleven van beslissingen van buitenlandse mogendheden op kartelgebied (gekwalificeerd als misdrijf), verzuim van de aanmeldings- en informatieplicht (gekwalificeerd als overtreding) en inbreuken op een (generieke) onverbindendverklaring of een schorsing. Voor deze laatste categorie was wederom de intentie het onderscheidende criterium: een misdrijf impliceerde opzet, terwijl culpoos gedrag 'slechts' een overtreding betekende. In deze sanctie-regeling veranderde tot 1983 niets. In dat jaar zag de Wet vermogenssancties ${ }^{308}$ het licht, waarin een algehele revisie van de vermogenssancties binnen het strafrecht werd gerealiseerd. Een van de meest voorname punten van deze revisie was ongetwijfeld de introductie van de (overigens op de WED geĭnspireerde) boete-categorieěn in artikel $23 \mathrm{WvSr}{ }^{309}$ Voor de WED betekende dit dat artikel 6 moest worden aangepast aan deze nieuwe situatie: de binnen de WED geldende maxima werden dan ook vervangen door een verwijzing naar de boetecategorieèn van artikel $23 \mathrm{WvSr}$. Deze aanpassing had als zodanig geen consequenties voor het kartelrecht: op misdrijven werd de vierde categorie toepasselijk (hetgeen overeenkwam met een boete van $f 25.000$ ), voor overtredingen gold een boete van de derde categorie (hetgeen overeenkwam met $f 10.000$ ) als maximum. Voor de bestraffing van kartelovertreders was van grotere betekenis de regeling van artikel 23 lid $7 \mathrm{WvSr}$. Hierin werd bepaald dat bij veroordeling van een rechtspersoon -en karteldelicten worden vaak door rechtspersonen gepleegd- een geldboete van de naast hogere categorie kon worden opgelegd, althans voor zover de voor het feit geldende boete-categorie niet als passende sanctie door de rechter werd beschouwd. Concreet: voor rechtspersonen golden onder de genoemde restrictie als maxima respectievelijk $f 100.000$ (voor misdrijven) en $f 25.000$ (voor overtredingen). Meer nog: indien een groot belang in het geding was (het voordeel uit het delict -in casu dus het karteldelict- bedroeg in dat geval meer dan een vierde van de maximum-boete), kon -in cumulatie met de verhoging voor de rechtspersoon als dadernogmaals worden gegrepen naar de naast hogere boete-categorie. Indien van beide mogelijkheden tot verhoging van het sanctie-niveau cumulatief gebruik werd gemaakt, bedroegen de maximale sancties op kartelovertredingen derhalve liefst $f 1.000 .000$ voor misdrijven

307 Van belang was ook de regeling van de strafbaarheid van rechtspersonen, zij het dat aan rechtspersonen nog geen hogere boetes konden worden opgelegd dan aan natuurlijke personen.

308 Wet van 31 maart 1983, houdende berziening van bepalingen van het Wetboek van Strafrecht, het Wetboek van Strafvordering, de Wet op de economische delicten en enkele andere wetten in verband met de oplegging van vermogenssancties, Stb. 1983, 153. Zie over het ontwerp van deze wet kritisch Groenhuijsen en Van Kalmthout (1983), pag. 8 c.v..

309 Voor een bespreking van dit en andere belangwekkendeaspecten van genoemde wet zie men Hustinx (1984), pag. 147-153, 
en $f 100.000$ voor overtredingen. ${ }^{310}$ Het veel gehoorde geluid dat via het strafrecht geen boetes konden worden opgelegd die qua omvang ook op grote ondernemingen indruk konden maken, was dan ook allerminst zuiver, zeker als men in ogenschouw neemt dat de rechter naast de boeteoplegging nog kon besluiten tot het opleggen van een vrijheidsbenemende straf voor de feitelijk leidinggevende of de opdrachtgever en tot ontneming van het wederrechtelijk verkregen voordeel. Waarlijk geen geringe sancties, waarbij moet worden aangetekend -en daar lag meer de pijn dan in de wettelijke regeling- dat deze sanctie-ruimte nooit ook maar bij benadering is uitgeput.

De Nederlandse overheid deelde de -naar mijn mening onterechte- kritiek op de strafrechtelijke sanctiemogelijkheden in het kartelrecht niet. Dat eerder het tegendeel het geval was, moge hieruit blijken dat zij verschillende malen heeft voorgesteld om de wettelijke regeling in die zin te wijzigen dat alle (of bij één wijzigingsvoorstel: het gros van de) kartelinbreuken nog slechts als overtreding zouden worden gekwalificeerd. Twee pogingen hiertoe strandden ${ }^{311}$; de derde daarentegen verwierf in 1990 kracht van wet. ${ }^{312}$ De wijziging bestond hierin dat artikel 41 Wem werd geschrapt en de Wem binnen de WED van artikel 1 sub 3 naar artikel 1 sub 4 werd overgeheveld. Het zij herhaald: doel (en gevolg) hiervan was dat inbreuken op de Wem als overtreding werden aangemerkt. Toenmalig staatssecretaris van Economische Zaken Evenhuis greep in zijn toelichting op deze wijziging met klaarblijkelijke instemming terug op de memorie van toelichting bij het wetsvoorstel-Lubbers (TK 1977/1978, 14 886) door te stellen "dat de opvattingen over strafbedreigingen zich sedert de totstandkoming van de Wet economische mededinging zodanig hebben ontwikkeld, dat het minder wenselijk werd geoordeeld de (...) opzettelijke gedragingen als misdrijf te blijven bestempelen, en dat daaraan in de praktijk ook geen behoefte bleek te bestaan". ${ }^{313}$ Daaraan voegde de bewindsman toe dat vereenvoudiging van de bewijslast van het Openbaar Ministerie één van de aspecten van deze -volgens Evenhuis "ook in de laatste jaren voortgegane"- ontwikkeling van de opvattingen over

310 Uit de memorie van toelichting (TK 1977/1978, 15 012, nr. 3) blijkt overigens dat de zesde categorie van artikel $23 \mathrm{WvSr}$ uitsluitend is toegevoegd om de mogelijkheid te scheppen om ook tot verhoging van de maximum-sanctic over te kunnen gaan in die gevallen waarin een rechtspersoonzich schuldig maakt aan een delict waarop reeds de hoogste categorie (i.e. de vijfde) van toepassing is.

311 In 1977 (TK 1977-1978, 14 886) werd voorgesteld om artikel 41 Wem in die zin aan te passen dat behoudens overtreding van artikel 39 Wem alle kartelinbreuken als overtredingen zouden worden aangemerkt. In 1985 (TK 1985-1986, 19 361) werd het voorstel gelanceend om de Wem over te hevelen naar artikel 1 sub 4 WED, als gevolg waarvan iedere inbreuk op de Wem een overtreding zou zijn. Beide wetsvoorstellen haalden de eindstreep niet, om redenen die geen verband hielden met de voorgestelde wijzigingen op sanctiegebied.

312 Wet van 15 november 1989 tot wijziging van de Wet economische mededinging (voorzieningen met betrekking tot verticale prijsbinding), Stb. 1990, 6 .

313 Voorstel tot wijziging van de Wet economische mededinging (voorzieningen met betrekking tot verticale prijsbinding), TK 1988-1989, 21 105, nr. 3. Deze memorie van toelichting was overigens met betrekking tot onderhavige wijziging van de WED vrijwel gelijkluidend aan de memorie van toelichting bij het voorstel van wet uit 1985 (TK 1985-1986, 19 361). 
strafbedreiging was. ${ }^{314}$ Hoewel deze redengeving niet uitblonk in duidelijkheid, kon naar mijn mening hieruit niets anders geconcludeerd worden dan dat het gevoelen was gegroeid dat de kwalificatie van kartelinbreuken als misdrijf -gelet op de vermeend geringe (ook morele) ernst van deze gedragingen- te streng was. Kartelovertreders mochten klaarblijkelijk niet (langer) over één kam geschoren worden met 'echte' criminelen, dit terwijl naar mijn mening een opzettelijke overtreding van een (generiek) verbod stellig ernstig genoeg was om als misdrijf betiteld te kunnen worden. Hoe dit laatste ook zij, de visie was dat de overheid in het uiterste geval ook strafrechtelijk moest kunnen optreden, maar dat de tik die via het strafrecht werd uitgedeeld -mede vanuit het oogpunt van dreigende stigmatisering van de ondernemer door dit strafrechtelijk optreden- niet al te hard voor de betrokkene mocht aankomen. Dit alles verbaasde tegen de achtergrond van het corporatisme en de Nederlandse overlegeultuur niet, maar paste in het geheel niet in het toenmalige streven naar intensivering van het kartelbeleid. Immers door de transformatie van kartelmisdrijven in kartelovertredingen werd een signaal afgegeven dat haaks stond op dit streven, aangezien zij duidde op een relatief geringe strafwaardigheid van kartelinbreuken en een beeld van geringe prioriteit bij de vervolging van deze inbreuken opriep. Al met al kwam dit -mede gelet op de verlaging van de maximum sancties ${ }^{315}$ - een eventuele generaal-preventieve werking van het strafrecht niet ten goede. De memorie van toelichting gaf echter tegelijk een tegenovergesteld signaal, waar aandacht werd besteed aan de verlichting van de bewijslast voor het Openbaar Ministerie. Deze aandacht zou weinig zin hebben gehad indien niet tevens de hoop werd gekoesterd dat er een intensiever gebruik van het strafrecht zou worden gemaakt. In zoverre was de boodschap van de memorie van toelichting: verhoging van de kans op een strafrechtelijke sanctie, maar bestraffing met mate. Dit alles was weinig consistent en ondanks de bemoeienissen tot intensivering van het beleid voerde de nadruk op de geringe strafwaardigheid van kartelovertredingen onverminderd de boventoon. Maar meer nog: de wijziging was -behoudens die wellicht ten aanzien van artikel $39 \mathrm{Wem}$ - mijns inziens overbodig en zelfs weinig doordacht. $\mathrm{Zij}$ was overbodig omdat er -behalve juist ten aanzien van artikel 39 Wem- geen bewijslastverlichting werd bereikt. Kennelijk werd de uit de kwalificatie als misdrijf voortvloeiende noodzaak tot het bewijs van opzet als een te hoge barrière voor een effectieve toepassing van het strafrecht beschouwd. Als dit inderdaad zo was, dan getuigde dit van weinig

314 Evenhuis noemde als factor die als begunstigend kon worden aangemerkt voor de wetswijziging (de staatssecretaris beperkte zich tot artikel $39 \mathrm{Wem}$, maar zijn redenering fijkt mij ook te gelden voor de overige artikelen) de totstandkoming van de Wet vermogenssancties. De hogere boetes die dankzij deze wet voor overtredingen konden worden opgelegd (Evenhuis had waarschijnlijk bestraffing van rechtspersonen in gedachte aangezien de Wet vermogenssancties geen wijziging bracht in de hoogte van de boetes voor WED-overtredingen) zouden namelijk de noodzaak tot het handhaven van de kwalificatie als misdrijf overbodig maken. Meer dan begunstigend was bedoelde factor overigens niet. Dit blijkt alleen al hienuit dat in het door Lubbers in 1977 gelanceerde (en op dit punt vrijwel gelijkluidende) wetsvoorstel de Wet vermogenssancties nog niet in werking was. Interessant en typerend voor het Nederlandse kartelbeleid is dat Evenhuis geen woorden besteedde aan de gevolgen voor de vrijheidsstraffen. De aanmerkelijk lageremaxima van deze straf vormden klaarblijkelijkgeen punt dat in de overweging een rol had gespeeld. Dit onderstreepte dat binnen het kartelrecht vrijheidsstraffen als niet-passend en disproportioneel werden beschouwd.

315 De maximale vrijheidsbeneming bedroeg zes maanden hechtenis (in plaats van voordien voor misdrijven 2 jaar gevangenisstraf), terwijl de boete werd verlaagd tot cen boete van derde categorie respectievelijk (gelet op artikel $23 \mathrm{WvSr}$ ) vierde categorie (dus -afgezien van artikel 6 lid 1 tweede volzin WED. $f 25.000)$ voor rechtspersonen. 
strafrechtelijk inzicht. Immers lag niet alleen de balk voor het bewijs van opzet sinds het Cicero-arrest ${ }^{16}$ niet zeer hoog, maar bovendien kon de officier van Justitie zich onder de 'oude' regeling, indien hij van mening was dat opzet niet te bewijzen was, beperken tot het ten laste leggen van de overtreding of kon hij deze als subsidiair feit ten laste leggen. De wetswijziging was weinig doordacht omdat de wetgever een belangrijk aspect over het hoofd had gezien (hetgeen wederom duidt op weinig 'feeling' met het strafrecht). Door de transformatie naar overtredingen werd de strafrechtelijke verjaringstermijn aanzienlijk verkort: kon het Openbaar Ministerie voordien op grond van artikel 70 WvSr gedurende zes jaar na het begaan van het feit tot vervolging overgaan, na de wetswijziging restten het Openbaar Ministerie hiervoor nog slechts twee jaar. ${ }^{317}$ Dat dit een gelet op het geheime karakter van de gemiddelde kartelinbreuk alsmede op de ingewikkeldheid van een strafrechtelijk onderzoek naar dergelijke overtredingen, niet al te ruime termijn was, spreekt voor zich. Als het dus de bedoeling van de wetgever was om de strafrechtelijke handhaving te intensiveren -mede door de vermeende verlichting van de bewijslast-, dan was de transformatie in ieder geval contra-productief.

Beziet men het voorgaande, dan ontstaat het beeld dat de Nederlandse overheid zich eigenlijk geen raad wist met strafrechtelijke handhaving binnen het kartelrecht. Enerzijds werd een steviger optreden wenselijk geacht, maar anderzijds werd strafrechtelijke benadering van overtreders toch weer te stevig bevonden. En de wijzigingen die toch het pad voor strafrechtelijke handhaving moesten effenen, werkten juist in tegengestelde richting, hetgeen duidde op weinig kennis van en affiniteit met het strafrecht en de ontwikkelingen daarbinnen. ${ }^{318}$ Dit zou later bij de behandeling van het in 1993 gelanceerde wetsvoorstel ter vergroting van de effectiviteit worden bevestigd. ${ }^{319}$ Hierin werd voorgesteld om op het punt van de strafrechtelijke handhaving de klok min of meer terug te draaien: een duidelijk voorbeeld van hoezeer met het strafrecht binnen het kartelrecht werd geworsteld. ${ }^{320}$ Staatssecretaris Van Rooy wilde -overigens met succes- in het kader van de vergroting van de effectiviteit van de handhaving van de Wem het onderscheid tussen opzet- en schulddelicten en in het verlengde daarvan tussen misdrijven en overtredingen her-introduceren door de Wem over te hevelen van artikel 1 sub 4 WED naar artikel

316 In dit Cicero-arrest (HR 9 november 1954, NJ 1955, 55) werd het voorwaardelijk opzet aanvaard, hetgeen werd omschreven als 'het zich willens en wetens blootstellen aan een geenszins als denkbeeldig te verwaarlozen kans'.

317 Niet noodzakelijk was het dat de vervolging ook binnen deze twee jaar werd afgerond. Op grond van artikel $72 \mathrm{WvSr}$ stuit namelijk iedere daad van vervolging de verjaring, waarna een nieuwe termijn (i.c. van twee jaar) een aanvang neemt. Als daad van vervolging kan worden aangemerkt "elke formele daad uitgaande van $\mathrm{OM}$ of rechter om in de fase voorafgaande aan de tenuitvoerlegging, tot een (uitvoerbare) rechterlijke beslissing te geraken"; zie Hazewinkel-Suringa/Remmelink(1994), pag. 606.

318 Een vergelijkbare conclusie kon reeds getrokken worden bij de bespreking van de invoering van controle-bevoegdheden in de Wem. Deze als uitbreiding bedoelde bevoegdheden kwamen de ECD de facto reeds toe op grond van de WED.

319 TK 1992-1993, 23 306, uiteindelijk leidend tot de Wet van 2 november 1994 tot wijziging van de Wet economische mededinging (vergroting van de effectiviteit), Stb. 1994, 801.

320 Kritisch over deze gang van zaken is ook Mok (1995), pag. 242. 
1 sub 2 WED. ${ }^{321}$ Waarin zag Van Rooy op dit punt de vergroting van de effectiviteit? De staatssecretaris stelde voorop dat intensivering van het mededingingsbeleid hand in hand ging met een goede handhaving. En deze was, aldus Van Rooy in de oorspronkelijke memorie van toelichting, "niet alleen afhankelijk van de mogelijkheden om verboden gedragingen op te sporen en te vervolgen, maar ook van de hoogte van de strafsancties", waarbij de generaal preventieve werking van deze sancties een belangrijke rol werden toegedicht. Verhoging derhalve als belangrijkste reden voor aanpassing. Wat de staatssecretaris echter over het hoofd had gezien, was dat op 10 december 1992, dus ruim voordat de oorspronkelijke memorie van toelichting ter advisering aan de Raad van State werd voorgelegd, een wetsvoorstel tot wijziging van onder meer artikel 6 WED was bekrachtigd. ${ }^{322}$ Deze wet voorzag in een ophoging van het maximum boeteniveau voor overtredingen als bedoeld in lid 1 sub 4 van genoemd artikel ${ }^{323}$ : vanaf de inwerkingtreding van de wet op 1 maart 1993 konden deze overtredingen bestraft worden met een boete van ten hoogste de vierde categorie, dezelfde boete derhalve als conform artikel 6 lid 1 sub 2 WED op een misdrijf was gesteld. Duidelijk was dus in ieder geval -en dit had ook voor de staatssecretaris op het moment van de adviesaanvraag reeds duidelijk moeten zijn- dat de eerdergenoemde overheveling geen verhoging van de boetes zou bewerkstelligen. ${ }^{324}$ Dat dit aanvankelijk niet bij het ministerie van Economische Zaken bekend was, getuigt wederom niet van een overmatige kennis van het strafrecht. Hoe dit ook zij, het voorstel tot overheveling werd ondanks het ontbreken van gevolgen voor het boeteniveau -mijns inziens terecht- gehandhaafd, en wel om twee redenen. De eerste reden betrof de disproportionaliteit tussen de ernst van de inbreuk en de kwalificatie als overtreding: opzettelijke inbreuken op (generieke) onverbindendverklaringen of op aanwijzingen aan economische machtsposities waren dermate ernstig dat zij aldus de bewindsvrouw als misdrijven dienden te worden aangemerkt. ${ }^{325}$ Deze reden staat haaks op de opvattingen van de voorgangers van Van Rooy; kennelijk hadden de gestaag gegroeide opvattingen over strafbedreiging zich in nauwelijks drie jaar tijd in tegengestelde richting ontwikkeld. Zoals verwacht mocht worden werd als tweede reden voor de aanscherping de verruiming van de verjaringstermijn aangevoerd. Een verjaringstermijn van slechts twee jaar en een effectieve (lees: repressieve) handhaving waren niet met elkaar te rijmen.

321 In tegenstelling echter tot eerdere regelingen zou het onderscheid tussen opzet- en culpoze delicten op grond van artikel 1 sub 2 WED voor alle kartelinbreuken gelden, dus ook voor artikel 39 Wem.

322 Wet van 10 december 1992 tot wijziging van het Wetboek van Strafrecht en het Wetboek van Strafvordering en enkele andere wetten ter verruiming van de mogelijkheden tot toepassing van de maatregel van ontneming van wederrechtelijk verkregen voordeel en andere vermogenssancties, Stb. 1993, 11.

323 Als reden hiervoor werd aangevoerd dat een geldboete van $f 10.000$ niet steeds toereikend was.

324 Wel bracht zij met zich dat de maxima van de vrijheidsbenemende sancties toenamen. Zoals gezien had dit voor de praktijk nauwelijks betekenis. Maar ook op beleidsniveau werd niet veel waarde gehecht aan deze sancties op kartelgebied, gelet op de wetswijziging van 1990 (als gevolg waarvande maxima van de vrijheidsbenemende saneties juist werden beperkt) en -zij het enkele jaren later-op de totale afstand van vrijheidsbenemende sancties binnen de Mededingingswet.

325 TK 1992/1993, 23 306, nr. 3. 


\section{Conclusie}

De wortels van de Nederlandse kartelwetgeving liggen in de jaren dertig van de vorige eeuw. De export- en afzetmogelijkheden waren in deze crisisjaren beperkt en de concurrentie had desastreuze vormen aangenomen. De Nederlandse overheid zag in kartels een middel om concurrentie terug te dringen, prijzen te stabiliseren, productie in stand te houden en werkgelegenheid zeker te stellen. De inzet van de wet en het beleid moest dan ook meer gericht zijn op bevordering van (de werking van) kartellering dan op beteugeling ervan. Daarom werd gekozen voor een wet die gebaseerd was op het misbruikstelsel, waarin het uitgangspunt de geldigheid van kartels was en een verbod slechts kon worden uitgesproken bij gebleken strijd met het algemeen belang. Het doel van die wet, de Ondernemersovereenkomstenwet 1935, kwam ook tot uiting in de maatregelen die de overheid ten aanzien van kartels kon nemen: primaire maatregel -ook in de praktijk-was de algemeen verbindendverklaring, waarmee de werking van kartels kon worden uitgestrekt over ondernemers die niet vrijwillig wensten te participeren; de onverbindendverklaring, waarmee kon worden opgetreden tegen kartels die in strijd hadden gehandeld met het algemeen belang, stond op het tweede plan, hetgeen wordt onderstreept door het feit dat zij onder het regime van de wet uit 1935 nooit is toegepast. Het misbruik-uitgangspunt van de Nederlandse kartelwetgeving bleef tot 1998 ongewijzigd, maar de na-oorlogse praktijk toonde wel een duidelijke accentverschuiving. Het neutrale standpunt ten aanzien van kartels vormde weliswaar ook in de praktijk het uitgangspunt, maar als er werd opgetreden tegen kartels dan was dit optreden eerder gericht op kartelbestrijding dan op kartelbevordering. Dit bleek onder meer uit het relatief strenge (anti-)kartelbeleid dat in het eerste decennium na de Tweede Wereldoorlog op grond van het Kartelbesluit ${ }^{326}$ werd gevoerd en uit de introductie van de mogelijkheid van generieke onverbindendverklaring in de Wem. Met deze mogelijkheid om kartels van een bepaalde aard of strekking bij voorbaat onverbindend te verklaren, werd de Nederlandse kartelwetgeving verrijkt met een verbodelement. Lange tijd echter werd van deze mogelijkheid -op één belangrijke uitzondering na, te weten de generieke onverbindendverklaring van verticale prijsafspraken in 1964 geen gebruik van betekenis gemaakt. Pas in 1993 en 1994 werd door de generieke maatregelen ten aanzien van horizontale prijsafspraken en marktverdeling voor de belangrijkste kartelvormen een algemeen verbod gerealiseerd. Ook tot onverbindendverklaringen kwam het op grond van de Wem nauwelijks: tussen 1959 en 1986 is er zelfs geen enkele maatregel van deze strekking genomen. Gesteld kan dan ook worden dat van een krachtig optreden tegen kartels en van een intensief formeel kartelbeleid geen sprake is geweest. Veeleer vormde informeel optreden het zwaartepunt van het beleid, zij het dat ook dit deel van het beleid een wisselende (maar niet overmatig hoge) intensiteit kende. Dit informele optreden was erop gericht om in onderling overleg de scherpe kanten van een kartel weg te nemen; waar mogelijk moest een kartel niet van de markt geweerd worden, maar diende het in overeenstemming te worden gebracht met het algemeen belang.

De redenen voor het milde en informele beleid lagen met name in de Nederlandse traditie van corporatisme en in de Nederlandse overlegcultuur. Op allerlei terreinen hadden samenwerking en onderling overleg voorrang boven interventies van de overheid; het

326 In het Kartelbesluit werd een algemene verplichting voor ondernemingen geschapen om hun kartel aan te melden en werd bovendien de mogelijkheid gecreëerd om maatregelen tegen economische machtsposities te nemen. 
kartelrecht vormde hierop geen uitzondering. In het informele beleid kwam dit goed tot zijn recht: een oplossing voor een conflict tussen overheid, ondernemer en eventuele derden werd primair gezocht via de weg van onderling overleg, teneinde een uitkomst te bereiken waarmee elk van de betrokkenen 'kon leven'. Pas als dergelijk overleg mislukte, werd eenzijdig overheidsoptreden overwogen. ${ }^{327}$ Een andere reden voor het gevoerde beleid ligt mijns inziens hierin dat de politieke wil tot krachtig optreden veelal ontbrak. Een minister die streng tegen kartels ageerde maakte zich niet bijzonder populair bij ondernemingen en daarmee bij een -niet onbelangrijk- deel van de kiezers. Daarnaast is er wel op gewezen dat de Wem een streng beleid welhaast onmogelijk zou maken: de vaagheid van de normen, de noodzaak van een inefficiënt casuistisch optreden en de politieke gevoeligheid die inherent is aan iedere afzonderlijke maatregel zouden in de weg staan aan een anti-kartelbeleid. Hoewel een op cen misbruikstelsel gebaseerde wet inderdaad niet de meest ideale basis vormt voor een dergelijk beleid, is hier mijns inziens sprake van niet meer dan een begunstigende factor. De praktijk van de na-oorlogse jaren en van het recente verleden onder het bewind van staatssecretaris Van Rooy en minister Wijers (beide Economische Zaken) toont namelijk aan dat, zodra de politieke wil aanwezig was, het beleid onder het regime van de Wem wel degelijk kon worden aangescherpt.

Vanaf 1935 tot 1998 is het Nederlandse kartelrecht strafrechtelijk gehandhaafd, althans voorzover het onverbindendverklaringen en (sinds de Wem) generieke onverbindendverklaringen betrof. ${ }^{328}$ De wetgever van 1935 had dus niet gekozen voor tuchtrechtelijke handhaving, hoewel voor deze vorm van handhaving in de jaren dertig in verschillende wetten was geopteerd. De reden voor de opkomst van het tuchtrecht lag met name in zijn doelmatigheid: materieel en formeel strafrecht alsmede de strafrechter werden -ook toen reedsdoor de wetgever niet geschikt geacht voor de handhaving van wetten die een bijzondere deskundigheid vergden en waarbij effectiviteit het hoogste goed was. Mede daarom werd tuchtrechtelijke handhaving gereserveerd voor wetten met een tijdelijk karakter die in bijzonder sterke mate werden overtreden. Dit verklaart mede de keuze voor strafrechtelijke handhaving van de kartelwetgeving: hier betrof het een structurele wet die naar verwachting niet frequent zou worden overtreden. Daarenboven vormde effectiviteit hier uitdrukkelijk niet het hoogste goed, aangezien de wetgever juist zeer beducht was voor misbruik door de overheid en daarom grote waarde hechtte aan een goede rechtsbescherming.

De nadruk die met name ook in de bezettingsjaren werd gelegd op een doelmatige handhaving en de daarmee samenhangende veronachtzaming van rechtswaarborgen leidden tot een afkeer van (publiekrechtelijke) straffen buiten het strafrecht om. Desalniettemin verstomde de kritiek op het (commune) strafrecht niet. De rechter werd onvoldoende deskundig geacht onder meer inzake delicten met een economisch karakter en de handhavings- en sanctiemogelijkheden werden te beperkt geacht; kortom: aan de doelmatigheid van het (commune) strafrecht werd getwijfeld. Daarom werd de WED in het leven geroepen en werden het Kartelbesluit en later de Wem in de lijst van de via de WED te handhaven regelingen opgenomen. Ook onder de WED echter heeft de strafrechtelijke handhaving

327 Een consequente harde aanpak door de overheid zou overigens niet alleen het einde van overieg in kartelaangelegenhedenhebben betekend, maar zou tevens overleg op andere gebieden waarbij het ministerie van Economische Zaken betrokken was, aanmerkelijk hebben bemoeilijkt.

328 Voor algemeen verbindendverklaringen werd -behoudens onder het regime van het Kartelbesluit. privaatrechtelijke handhaving als toereikend beschouwd. 
van het Nederlandse kartelrecht geen bloeiend bestaan gekend. Dit heeft verschillende redenen. De eerste reden is dat strafrechtelijk pas kon worden opgetreden indien een inbreuk was gemaakt op een (generieke) onverbindendverklaring dan wel op een aanwijzing aan een machtspositie. ${ }^{329}$ De strafrechtelijke handhaving was derhalve afhankelijk van een dergelijke formele maatregel, en juist aan dit formeel optreden ontbrak het veelal. De tweede reden is hierin gelegen dat de bereidheid bij de strafrechtelijke organen om de verboden met harde hand te handhaven gering was. Hiervoor kunnen mijns inziens drie verklaringen worden gegeven. De eerste is dat door het ministerie van Economische Zaken nauwelijks eventuele overtredingen bij het Openbaar Ministerie werden gemeld (ook na een overtreding stond binnen het ministerie van Economische Zaken overleg voorop). De tweede verklaring ligt hierin dat kartelovertredingen niet echt als strafrechtelijke delicten werden beschouwd. De derde verklaring voor de geringe bereidheid om strafrechtelijk op te treden, betreft het feit dat het kartelrecht niet hoog op de prioriteitenlijst van het Openbaar Ministerie stond, hetgeen onder meer samenhing met het milde beleid op het ministerie van Economische Zaken (het op overleg gebaseerde beleid van dit ministerie nodigde niet uit om vervolgens strafrechtelijk met de harde hand op te treden) en met de beperkte deskundigheid op kartelgebied binnen het Openbaar Ministerie.

Dat de strafrechtelijke weg doorgaans onbewandeld bleef, impliceert niet dat de bevoegdheden van de strafrechtelijke organen of de strafrechtelijke sancties inadequaat waren. Dit was ook allerminst het geval. Op grond van de WED had de Economische Controledienst de bevoegdheid tot inbeslagneming van voorwerpen, tot vordering van inzage van bescheiden en tot betreding van plaatsen; bovendien bestond voor degenen tot wie een vordering was gericht de verplichting tot medewerking. Daarenboven behoorde onder meer een huiszoeking tot de mogelijkheden, zij het dat daarvoor een gerechtelijk vooronderzoek vereist was. Voor opheldering van kartelovertredingen zijn deze bevoegdheden toereikend, temeer daar zij ook konden worden aangewend voordat er een verdenking was gerezen. Deze mogelijkheid werd echter door de ECD in het geheel niet benut, hetgeen waarschijnlijk mede zijn grond vindt in het feit dat de Nederlandse overheid ten onrechte van mening was dat de opsporingsbevoegdheden van de WED zich niet uitstrekten over de fase voorafgaand aan de verdenking. Om deze reden werden in 1994 aan de WEDbevoegdheden vrijwel identieke controlebevoegdheden in de Wem opgenomen.

Ook de strafrechtelijke sancties waren aanzienlijk: nog afgezien van de mogelijkheid tot ontneming van het wederrechtelijk verkregen voordeel, kon aan rechtspersonen een boete worden opgelegd van $f 100.000$ en onder omstandigheden zelfs van $f 1.000 .000$ per overtreding. Dit was althans de situatie tot 1990. Een wetswijziging in dat jaar bewerkstelligde -dwars tegen de pogingen in om te komen tot een strenger kartelbeleid- dat inbreuken op de Wem nog slechts als overtredingen werden aangemerkt, waardoor niet alleen de strafmaxima aanmerkelijk werden verlaagd, maar ook de verjaringstermijn werd verkort van zes naar twee jaar. Dat de indiener van het voorstel tot bedoelde wetswijziging dit laatste over het hoofd had gezien, doet de aanwezigheid van weinig strafrechtelijk inzicht op het ministerie van Economische Zaken vermoeden. Hoe dit ook zij, de klok werd reeds na zo'n vier jaar teruggedraaid, deels om recht te doen aan de ernst van kartelovertredingen en deels om een verlenging van de verjaringstermijn te realiseren. 
Uit de gang van zaken rondom de strafbaarstelling van karteldelicten sinds eind jaren tachtig bleek, naast een geringe kennis van het strafrecht bij het ministerie van Economische Zaken en een zekere weerzin tegen strafrechtelijke sancties, mede een twijfel omtrent de werking van het strafrecht als instrument bij de handhaving van het kartelrecht. Onder meer deze twijfel heeft geleid tot bestuursrechtelijke handhaving van de Mededingingswet. Een recle kans heeft strafrechtelijke handhaving echter niet gehad en het staat naar mijn mening dan ook allerminst vast dat continuering van deze handhavingsvorm binnen de Mededingingswet tot een handhavingstekort zou hebben geleid. De wetgever heeft echter anders beslist. Hij heeft zoveel mogelijk, ook op het gebied van de handhaving, bij het communautaire kartelrecht aansluiting willen zoeken. In hoeverre dit communautaire recht in een effectievere regeling voorziet, komt in het volgende hoofdstuk aan de orde. 



\section{Het communautaire kartelrecht}

In het vorige hoofdstuk bleek dat de Nederlandse overheid in de eerste helft van de jaren negentig in het kader van het streven naar intensivering en convergentie het Nederlandse kartelbeleid en -recht heeft aangescherpt. Met name de generieke onverbindendverklaringen van 1993 en 1994 hebben eraan bijgedragen dat het Nederlandse kartelrecht zich in de richting van een verbodstelsel naar communautair voorbeeld ontwikkelde. De overgang van de Wem en zijn misbruikstelsel naar de Mededingingswet en zijn volledig naar communautair voorbeeld gemodelleerd verbodstelsel, was derhalve minder groot dan wel is beweerd. Duidelijk is in ieder geval wel dat in het recente Nederlandse kartelbeleid de aandacht voor en het belang van de communautaire kartelregels aanzienlijk is. Maar ook los hiervan heeft het communautaire kartelverbod door zijn rechtstreekse werking grote relevantie, namelijk voor (Nederlandse) ondernemingen die op de gemeenschappelijke markt actief zijn. Vast staat derhalve dat het communautaire recht op mededingingsgebied een cruciale functie vervult. Daarom staat in dit hoofdstuk het communautaire kartelrecht centraal.

In paragraaf 1 wordt het streven naar integratie binnen Europa besproken alsmede de rol die het communautaire kartelrecht daarbij speelt. Paragraaf 2 staat in het teken van de bespreking van de meeste relevante kenmerken van het materiele communautaire kartelrecht, waarbij onder meer wordt ingegaan op de reikwijdte van de verboden van de artikelen 81 en 82 EG. In paragraaf 3 komt de handhaving van de materięle verboden aan de orde. Na een korte schets van het procedureverloop zal aandacht worden besteed aan de bevoegdheid van de Commissie tot het inwinnen van inlichtingen en die tot het verrichten van verificaties. In paragraaf 4 tenslotte zal de Wet uitvoering EG-mededingingsverordeningen worden besproken. In deze wet zijn de bevoegdheden neergelegd tot het verlenen van bijstand door de Nederlandse overheid aan een communautaire verificatie.

\section{Historie en doel ${ }^{1}$}

De wortels van de Europese economische integratie, van de Europese Gemeenschap en ruimer- van de Europese Unie, liggen in de periode volgend op de Tweede Wereldoorlog. Internationale samenwerking was noodzakelijk om verschillende problemen en dreigingen het hoofd te kunnen bieden: samenwerking die voor een belangrijk deel als doel had "(to) keep the Russians out of Europe, the Americans in, and the Germans down". ${ }^{2}$ De positie tegenover de Verenigde Staten vormde het eerste probleem. De Europese landen waren in hoge mate afhankelijk geworden van de Verenigde Staten, die als een wereldmacht uit de Tweede Wereldoorlog waren gekomen. Deze afhankelijkheid bestond niet

1 Zie algemeen Timmermans (1995), Edward en Lane (1995), Lauwaars en Timmermans (1999), Lenaerts en Van Nuffel (1999) en Barents en Brinkhorst (1999).

2 Aldus Lord lsmay, de eerste Secretaris-Generaalvan de NAVO, wijzend op het doel van de NAVO. Zie Hyde-Price (1990), pag. 120. 
alleen op militair gebied (een reden 'to keep the Americans in'), maar minstens evenzeer op economisch terrein: de grootschalige Marshal-hulp, die Europa een economische steun in de rug moest geven, getuigde hiervan. Om meer tegenwicht aan de Verenigde Staten te kunnen bieden, werd de noodzaak gevoeld tot een vergaande coöperatie binnen Europa, met name op politiek en economisch gebied. Teneinde dit te verwezenlijken, werd de Raad van Europa opgericht (die overigens zeker op economisch gebied door de Europese Gemeenschap uiteindelijk is overvleugeld). Groter dan het probleem van de afhankelijke positie tegenover de Verenigde Staten was de dreiging die werd gevoeld van de SovjetUnie. De militaire kracht van de Sovjet-Unie was aanzienlijk in vergelijking met die van de Europese staten. Deze kracht en de opmars van het communisme in het oosten van Europa voedden de vrees voor een oorlog met het communistisch pact. De militaire (over)macht van de Sovjet-Unie maakte bundeling van militaire macht van het Westen noodzakelijk, hetgeen leidde tot de oprichting van de NAVO. Naast de positie van WestEuropa tegenover de Verenigde Staten en de Sovjet-Unie was er nog een derde probleem, dat uiteindelijk de belangrijkste aanzet bleek tot de Europese (economische) integratie: de positie van Duitsland binnen Europa. Met name in Frankrijk leefde de vrees voor een hernieuwde confrontatie met Duitsland. Daarom werd er, in navolging van de na de Eerste Wereldoorlog gevoerde politiek, aanvankelijk naar gestreefd om de Duitse economische en politieke macht zoveel mogelijk te verzwakken ('to keep the Germans down'). Deze politiek had echter in het Interbellum reeds gefaald en leverde ook na de Tweede Wereldoorlog niet het gewenste resultaat. ${ }^{3}$ Een blijvende vrede met Duitsland vergde derhalve een andere aanpak, namelijk een waarbij Duitsland op voet van gelijkwaardigheid zou worden behandeld en waarbij gewaarborgd werd dat Duitsland binnen Europa geen overheersende positie zou gaan innemen. Deze aanpak werd in 1950 in het Schuman-plan, genoemd naar de toenmalige minister van buitenlandse zaken van Frankrijk, gelanceerd. Dit plan voorzag in de samenvoeging van de kolen- en staalproductie van Frankrijk, Duitsland en geïnteresseerde derde Europese landen. ${ }^{4}$ Deze samenvoeging op een beperkt, maar belangrijk terrein moest de verstandhouding tussen Frankrijk en Duitsland verbeteren, een zekere mate van onderlinge afhankelijkheid tussen beide landen creëren en de eerste aanzet zijn tot de tot stand brenging van een verenigd Europa, welke vereniging in de optiek van Schuman de beste garantie was voor een blijvende vrede binnen Europa. Dit Franse initiatief werd door zes landen -naast Frankrijk en Duitsland waren dit Italië en de Beneluxlanden- met enthousiasme ontvangen en leidde in 1952 tot de oprichting van de Europese Gemeenschap voor Kolen en Staal (EGKS). De EGKS met als belangrijke doelstellingen de verbetering van productiviteit en kwaliteit en de verwezenlijking van gelijke leveringsvoorwaarden binnen de Gemeenschap- ontleende haar belang niet alleen aan het feit dat de banden tussen verschillende Europese landen werden aangehaald, maar bovendien aan de wijze waarop de samenwerking gestalte werd gegeven. Er werd namelijk niet gekozen voor de in het internationale verkeer meer gangbare intergouvernementele samenwerking, maar voor een gemeenschap van ten dele supranationale aard, waarin de lidstaten een deel van hun soevereiniteit prijsgaven. ${ }^{5}$ De deelnemen-

\footnotetext{
3 Met name de Verenigde Staten zagen in Duitsland een belangrijke factor in de strijd tegen het communisme en achtten herstel van de Duitse economie van cruciaal belang voor herstel van geheel Europa.

4 Verklaring van Schuman d.d. 9 mei 1950, onder meet opgenomen in het StudiemateriaalElementair Internationaal Recht (T.M.C. Asser Instituut), 1996 pag. 225-226.

5 Hetgeen voor Groot-Brittanniê een belangrijke reden vormde voor niet-participatie.
} 
de landen droegen hun bevoegdheden op het terrein van de kolen- en staalproductie aan de Hoge Autoriteit over die met haar beslissingen de lidstaten kon binden.

Ook op andere terreinen werden -met wisselend succes- pogingen ondernomen tot verdergaande samenwerking binnen Europa. Pogingen om te komen tot een defensiegemeenschap en een politicke gemeenschap strandden; plannen voor een grotere samenwerking volgens EGKS-model op het gebied van de kernenergie en -belangrijker- de economie werden daarentegen wel aanvaard en leidden in 1958 tot de inwerkingtreding van respecticvelijk het verdrag inzake de Europese Gemeenschap voor Atoomenergie (Euratom) en het verdrag inzake de Europese Economische Gemeenschap (EEG). ${ }^{6}$ Dat de (eveneens supranationale) EEG een niet te overschatten belang heeft gehad, behoeft eigenlijk geen betoog meer. Toch noem ik hier een drietal aspecten. Ten eerste is via de EEG sinds 1958 een vergaande mate van economische integratie tussen de Europese staten bereikt. ${ }^{7}$ Vertrokken vanuit een streven naar instelling van een douane-unie (een vrij goederenverkeer, aangevuld met een gemeenschappelijk douanetarief en een gemeenschappelijk handelsverkeer) en een gemeenschappelijke markt (met vrijheid van verkeer van alle productiefactoren, dus goederen, diensten, arbeid en kapitaal), werd bij de Europese Akte $^{8}$ aan het EEG-Verdrag de doelstelling toegevoegd van de bewerkstelliging van een interne markt. Deze Europese Akte gaf bovendien een voorzet (maar niet meer dan dat) tot het creèren van een Economische en Monetaire Unie. In 1993 werd dankzij het Verdrag van Maastricht (of Unie-Verdrag) het streven naar de afronding van het economische integratieproces door middel van een dergelijke Economische en Monetaire Unie concreet, gekenmerkt door een gecoördineerd economisch beleid van de lidstaten en een gemeenschappelijke monetaire politiek, met één gemeenschappelijke munt, de Euro. Naast deze economische integratie heeft zich -en dit betreft het tweede aspect- rondom de Europese Gemeenschappen ook samenwerking op andere gebieden ontwikkeld. Zoals gezien, was één van de belangrijkste motieven om te komen tot de EGKS het streven naar veiligheid en vrede in Europa. Ook met het EEG-Verdrag werd gehoopt dat economische integratie de lidstaten dichter bij elkaar zou brengen en een goede bodem voor verdergaande samenwerking, met name op politiek gebied, zou vormen. Begin jaren zeventig ontstond in dit verband op intergouvernementele basis de Europese Politieke Samenwerking (EPS), die voorzag in een frequent overleg tussen de ministers van Buitenlandse Zaken van de lidstaten. Deze samenwerking werd in 1987 in de reeds genoemde Europese Akte formeel opgenomen. Op justitieel gebied kan op het Akkoord van Schengen ${ }^{10}$ alsmede de Uitvoeringsovereenkomst van Schengen" worden gewezen. Het Unie-verdrag vormde samen met

6 Verdrag van 25 maart 1957, Trb. 1957, 91 (Verdrag van Rome).

7 Zie hierover Barents en Brinkhorst (1999), pag. 282 e.v.

$8 \quad \mathrm{~Pb} 1987$ L 169.

9 Verdrag van 7 februari 1992, Trb. 1992, 74.

10 Akkoord tussen de Regeringen van de staten van de Benelux Economische Unie, van de Bondsrepublick Duitsland en van de Franse Republiek betreffende de geleidelijke afschaffing van de controles aan de gemeenschappelijkegrenzen met proces-verbaal en bijlagen, Schengen 14 juni 1985, Trb. 1985, 102.

11 Overeenkomst ter uitvoering van het tussen de Regeringen van de staten van de Benelux Economische Unie, van de Bondstepubliek Duitsland en van de Franse Republiek op 14 juni 1985 te Schengen gesloten Akkoord betreffendede geleidelijkeafschaffing van de controles aan de gemeenschappelijke grenzen met bijbehorende Slotakte, Protocol en gemeenschappelijke verklaring, Schengen, 19 juni 1990, Trb. 1990, 145. 
het Verdrag van Amsterdam ${ }^{12}$ het -voorlopige- hoogtepunt in het streven naar samenwerking binnen Europa. Centraal bleef staan de Europese Gemeenschap ${ }^{13}$, samen met de EGKS en Euratom de eerste pijler van de Unie vormend. Daarnaast moest de Unie op een tweede en derde pijler steunen: respectievelijk het gemeenschappelijk buitenlands en veiligheidsbeleid (artikel J EU-Verdrag) en de samenwerking op het gebied van justitie en binnenlandse zaken (artikel K EU-Verdrag). ${ }^{14}$ Deze regeling betekende een belangrijke stap in de richting van meer coőperatie tussen de lidstaten op de genoemde gebieden, waarbij deze tweede en derde pijler in tegenstelling tot de eerste niet supranationaal, maar intergouvernementeel zijn. Het Verdrag van Amsterdam breidde in aanvulling op het Unie-Verdrag de aandachtsgebieden van de Unie uit en versterkte de samenwerking, zowel door een deel hiervan (namelijk vrij verkeer van personen) van de derde naar de eerste (en dus supranationale) pijler over te hevelen, als door de aanscherping van de samenwerking in de tweede en derde pijler. ${ }^{13}$ Ten derde heeft -zeker in samenhang met de twee hiervoor genoemde aspecten- ook de territoriale uitbreiding aan het belang van de Europese Gemeenschap in wezenlijke mate bijgedragen. ${ }^{16}$

Uit het voorgaande blijkt dat de aanzet van Schuman in het belang van veiligheid en welvaart om de banden tussen de staten van Europa aan te halen, een vervolg heeft gekregen in de tot stand brenging van de EEG en uiteindelijk van de Europese Unie. ${ }^{17} \mathrm{De}$ Europese integratie heeft zich primair ontwikkeld langs de weg van de economische samenwerking, maar heeft zich, zoals gebleken, uitgebreid over tal van andere (beleids)terreinen. Dit volgt ook uit de doelstellingen van de EG, zoals deze zijn verwoord in artikel 2 EG na de wijziging op grond van het Verdrag van Amsterdam:

De Gemeenschapheeft tot taak, door het instellen van een gemeenschappelijke markt en een economische en monetaire unic en door de uitvoering van het gemeenschappelijk beleid of de gemeenschappelijke activiteiten, bedocld in de artikelen $3 \mathrm{en} 3 \mathrm{~A}$, het bevorderen van een harmonische, evenwichtige en duurzame ontwikkeling van de economische activiteit binnen de gehele Gemeenschap, een hoog niveau van werkgelegenheid en van sociale bescherming, de gelijkheid van mannen en vrouwen, een duurzame en niet-inflatoire groei, een hoge graad van concurrentievermogen en convergentie van economische prestaties, een hoog niveau van bescherming en verbetering van de kwaliteit van het milieu, een verbetering van de levensstandaard en van de kwaliteit van het bestaan, de economische en sociale samenhang en de solidariteit tussen de Lid-Staten.

Dat het EG-Verdrag weliswaar primair, maar niet uitsluitend economische doeleinden nastreeft, blijkt niet alleen uit de doelstellingen van het verdrag, maar tevens uit de in

12 Verdrag van Amsterdam, Trb. 1998, 11, houdende wijziging van het Verdrag betreffendede Europese Unie, de Verdragentot oprichting van de Europese Gemeenschappenen sommige bijbehorendeakten.

13 Het Unie-Verdrag wijzigde de naam van de Europese Economische Gemeenschap in Europese Gemeenschap, waarmee het bredere (niet louter economische) karakter van de Gemeenschap werd onderstreept.

14 Voor het onderwerp van dit boek is overigens uitsluitend de eerste pijler relevant; de tweede en derde pijler blijven dan ook verder onbesproken.

15 Zie over het Verdrag van Amsterdam onder meer Barents (1997).

16 Sedert de inwerkingtreding van het Verdrag zijn tot de EG toegetreden: Groot-Brittanniē, Ierland, Denemarken, Griekenland, Portugal, Spanje, Finland, Oostenrijk en Zweden. Binnen afzienbare tijd zijn met name uit het voormalige Oostblok nieuwe toetredingen te verwachten.

Fierstra (1993), pag. 17, stipt dit ook aan. 
artikel 3 genoemde middelen ter verwezenlijking van deze doelstellingen. ${ }^{18}$ Voor het onderwerp van onderhavige studie is echter wel een van de op het economische vlak liggende middelen van artikel $3 \mathrm{EG}$ relevant. Het betreft artikel 3 sub g EG (het vroegere 3 sub $\mathrm{f}$ EEG-Verdrag) waarin de opdracht is opgenomen tot het creëren van "een regime waardoor wordt verzekerd dat de mededinging binnen de interne markt niet wordt vervalst". Deze opdracht raakt de kern van het kartelrecht en geeft, in samenhang met de in artikel 2 genoemde doelstellingen, het grote belang binnen het communautaire recht ervan aan. Het (economische) fundament van de EG ligt, zoals gezegd, bij de gemeenschappelijke, interne markt, waarin alle belemmeringen" ${ }^{19}$ tegen een vrij verkeer van goederen, personen, diensten en kapitaal worden afgebouwd. Interstatelijke barrières die de totstandkoming danwel de continuering van de interne markt frustreren, moeten derhalve worden geslecht c.q. voorkomen. Dit zou echter zinloos zijn indien door private partijen alsnog (handels)belemmeringen zouden kunnen worden opgeworpen: afspraken tussen ondernemingen over de verdeling van markten, over het weren van concurrenten, over niet-levering aan gegadigden, over de hantering van vaste en vastgestelde prijzen en dergelijke druisen niet minder in tegen de doelstellingen van de EG dan overheidsmaatregelen met een vergelijkbare strekking. ${ }^{20}$ Kortom: kartels zijn in principe strijdig met hetgeen de EG tracht te bewerkstelligen, terwijl vrije mededinging bijdraagt aan de realisering van de EG-doelstellingen. ${ }^{21}$ In feite wordt deze vrije mededinging geacht twee doelen te dienen: ten eerste de tot stand brenging en instandhouding van de interne markt ${ }^{22}$ en ten tweede de bevordering van de economische ontwikkeling en welvaart binnen de EG. De taak van het kartelrecht ligt in het verlengde hiervan: het is erop gericht om "binnen (de) vrijgemaakte markt de mededinging als systeem optimaal te laten functioneren, d.i. haar t.a.v. de economie een integrerende, coördinerende en stimulerende rol te laten vervullen". ${ }^{23}$ Deze voor de economische ontwikkeling stimulerende rol van het communautaire kartelrecht moet voornamelijk in het licht van het economisch liberalisme worden gezien. Zoals Van der Woude terecht stelt berust de "door het EG-Verdrag gewenste markt-ordening $(. .$.$) in hoofdzaak op liberale beginselen: de allocatie van het produktie-$

18 Men vergelijke bijvoorbeeld de gezondheidsbescherming (sub p), de inspanningen met betrekking tot het onderwijs en de ontplooiing van de culturen van de lidstaten (sub q) en de ontwikkelingssamenwerking (sub $r$ ).

19 Om enkele voorbeelden te noemen: heffing van invoerrechten, douaneformaliteiten, staatssteun voor bepaalde bedrijven, discriminerende regelgeving (men denke aan het bekende Bosman-arrest).

20 In deze zin ook VerLoren van Themaat (1981), pag. 4, De Jong (1986 II), pag. 291 en Möschel (1995), pag. 282, die stelt: "Das Ersetzen der fallenden staatlichen Schranken innerhalb des Binnenmarkts durch vertraglich begründete oder als Folge strategischen Verhaltens erzwungene Schranken gilt sozusagen als Todsünde des Wettbewerbsrechts".

21 Men vergelijke Schröter (1999 I), pag. 2/23: "Der Vertrag geht davon aus, daß die vorgenannten Ziele (het creěren van de interne markt, het zorgdragen voor een goed functioneren daarvan alsmede de doelen genoemd in artikel 2, HQ) in aller Regel am schnellsten und sichersten bei freiem, unverfalschtem und wirksamem Wettbewerb erreicht werden".

22 Zie Schrōter(1999 I), pag. 2/22: "Die Verschmelzung der nationalen Mărkte zu einemeinzigen Wirtschaftsgebiet bildet die primăre Aufgabe der Gemeinschaft, in deren Dienst auch der Wettbewerb und die ihn schützenden Wettbewerbsregeln gestellt sind".

23 Van Gerven c.s. (1997), pag. 6. Vergelijk ook Ottervanger, Steenbergen en Van der Voorde (1998), pag. 3: "In addition to the traditional role of competition law, which is to maximise efficiency at all levels of the economic process, to provide a stable economic environment and to protect the interests of the consumer, EC competition law aims to assist the process of European economic integration". 
proces dient zich te voltrekken aan de hand van een regime van onvervalste mededinging". 24

Zowel deze gewenste markt-ordening als het uitgangspunt dat vrije mededinging een integratief doel heeft, leiden onherroepelijk tot de conclusie dat voor kartels binnen de EG geen plaats is: zij druisen immers tegen beide in. Logische consequentie hiervan is dat het de primaire taak van het communautaire kartelrecht is om kartels -voorzover deze belemmeringen opwerpen tegen intra-gemeenschappelijke en inter-lidstatelijke handelvan de gemeenschappelijke markt te weren. Dit vertaalt zich ook in de keuze voor het verbodstelsel. Een verbodstelsel gaat immers uit van de schadelijkheid en ontoelaatbaarheid van kartelgedragingen ${ }^{25}$ en -zoals de naam reeds aanduidt- van een verbod op iedere vorm van kartellering, veelal overigens met een dispensatiemogelijkheid. Kartels kunnen zodoende in een dergelijk stelsel nooit rechtsgeldig tot stand worden gebracht (nogmaals: behoudens dispensatie).

De basis voor dit verbodstelsel is neergelegd in de artikelen 81 en $82 \mathrm{EG}^{26}$, die steeds in samenhang met de artikelen 2 en 3 sub g EG moeten worden gelezen. ${ }^{27}$ Artikel 81 EG ziet op afspraken en gedragingen tussen verschillende economische entiteiten (kartels in strikte zin), terwijl artikel 82 EG betrekking heeft op misbruik van een machtspositie van een of meer entiteiten. Om te onderstrepen hoe verstrekkend beide bepalingen zijn, is het goed deze hier -voorzover van belang- te citeren:

Artikel 81

Onverenigbaar met de gemeenschappelijke markt en verboden zijn alle overeenkomsten tussen ondernemingen, alle bestuiten van ondernemersverenigingen en alle onderling afgestemde feitelijke gedragingen welke de handel tussen Lid-Staten ongunstig kunnen beinnvloeden en ertoe strekken of ten gevolge hebben dat de mededinging binnen de gemeenschappelijke markt wordt verhinderd, beperkt of vervalst.

Artikel 82

Onverenigbaar met de gemeenschappelijke markt en verboden, voor zover de handel tussen Lid-Staten daardoor ongunstig kan worden beinvloed, is het, dat een of meer ondernemingen misbruik maken van een machtspositie op de gemeenschappelijke markt of op een wezenlijk deel daarvan.

24 Van der Woude (1995), pag. 198. Dit impliceert overigens niet dat van het concept van een 'perfect competition' wordt uitgegaan. Uit onder meer HvJ (29/76) Jur. 1977, 1875 (Metro) blijkt dat binnen de EG het concept van de 'workable competition' wordt gehanteerd: van belang was volgens het Hof "de mate van mededinging die noodzakelijk is voor de naleving van de fundamentele vereisten en het bereiken van de doelstellingen van het Verdrag, inzonderheidde totstandkoming van één markt met soortgelijke voorwaarden als een interne markt". Zie ook Schröter (1999 II), pag. 2/171-173, Van der Weijden (1987), pag. 1194 e.v. en over het concurrentie-begrip Uitermark (1987 II), pag. 339 e.v..

25 In feite wordt kartellering als zodanig in strijd geacht met het algemeen belang, in casu het belang van de EG en de door haar nagestreefde doeleinden.

26 Aan de opdracht van artikel 3 sub $g$ EG is meer in het algemeen in de artikelen 81-86 EG invulling gegeven. Tot het kartelrecht in nuime zin zou overigens tevens de Concentratieverordening (Vo 4064/89) gerekend kunnen worden. Deze blijft echter hierna buiten beschouwing.

27 Vergelijk Barents (1995 II), pag. 220: "Alle bevoegdheden die door het EG-Verdrag aan de instellingen zijn geattribueerd hebben uiteindelijk dezelfde functie, te weten de verwezenlijking van de doelstellingen, neergelegd in art. $2^{\prime \prime}$. 
Uit deze definities blijkt onmiskenbaar het verbodkarakter van het communautaire kartelrecht -artikel 1 Vo 17 woegt daaraan nog toe dat de gedragingen verboden zijn "zonder dat daartoc enige voorafgaande beschikking is vereist-en de negatieve visie ten opzichte van kartels (waaronder hier begrepen gedragingen in de zin van artikel 82 EG): zij zijn 'onverenigbaar met de gemeenschappelijke markt'. Deze visie impliceert dat de verboden van de artikelen 81 en 82 EG een ruime reikwijdte moeten hebben. De exacte omvang van de verboden blijkt echter niet zonder meer uit deze artikelen, die de nodige ruimte tot interpretatie hebben gelaten. Deze ruimte is door de Europese Commissie (hiema: de Commissie), het Gerecht van Eerste Aanleg (hiema: het Gerecht) en het Hof van Justitie (hierna: het Hof) nader ingevuld, op welke wijze dit is geschied, komt in paragraaf 2 aan de orde. Hier zij reeds vermeld dat de communautaire instellingen -tegen de achtergrond van met name artikel 2 EG- tot een extensieve interpretatie zijn gekomen.

\section{Kenmerken van het communautair kartelrecht ${ }^{23}$}

\subsection{Het ondernemingsbegrip}

Een onderneming in de zin van de communautaire kartelbepalingen is "elke eenheid (...) die een economische activiteit uitoefent, ongeacht haar rechtsvorm en de wijze waarop zij wordt gefinancierd". ${ }^{29}$ Zodoende is voor de kwalificatie als onderneming (hetzelfde geldt voor de ondernemersvereniging ${ }^{30}$ ) niet de juridische status van rechtspersoon doorslaggevend (dit zou ook ongetwijfeld tot problemen leiden gelet op verschillen in het rechtspersonenrecht in de verschillende lidstaten), maar is van belang of de betreffende entiteit door haar handelen in staat is de mededinging te belemmeren. ${ }^{31}$ In feite betekent dit dat vrijwel iedere marktparticipant als onderneming kan worden aangemerkt. ${ }^{32}$ De meningen zijn verdeeld over de vraag of van het ondernemingsbegrip zijn uitgezonderd entiteiten die geen of nauwelijks economische zelfstandigheid hebben, zoals het geval kan zijn in een moeder-dochterrelatie. ${ }^{33}$ In het Centrafarm/Sterling Drug-arrest overwoog het Hof dienaangaande "dat artikel 85 (thans artikel 81 EG, HQ) (...) niet ziet op overeenkomsten of onderling afgestemde feitelijke gedragingen tussen ondernemingen die als moedermaatschappij en dochteronderneming tot een en hetzelfde concern behoren, indien de ondernemingen een economische eenheid vormen, waarin de dochteronderneming haar optreden op de markt niet werkelijk zelfstandig kan bepalen, en indien die overeenkomsten of onderling afgestemde feitelijke gedragingen een interne taakverdeling tussen de ondernemingen ten doel hebben". ${ }^{34}$ Hieruit wordt wel afgeleid dat entiteiten die tot

\footnotetext{
$28 \mathrm{Zie}$ in het algemeen Lane (2000). Voor de relevante regelgeving en praktijk wordt verwezen naar Van Rijn (1999) alsmede naar Van der Woude en Jones (1999).

29 Hivj (C-41/90), Jur. 1991, I-1979 (Hofner).

30 Vergelijk Van Gerven c.s. (1997), pag. 137.

31 In dezelfde zin Van Gerven c.s. (1997), pag. 67.

32 Vergelijk Van Bael en Bellis (1994), pag. 23, waar zij concluderen dat "from the cases it appears that virtually every natural or legal person participating in the economic process will qualify as an undertaking".

33 Bijvoorbeeld $\mathrm{Pb} 1970 \mathrm{~L} 147 / 25$ (Kodak). Zie over deze problematiek uitgebreid Lipowsky (1987).

$34 \mathrm{HvJ}(15 / 74)$ Jur. 1974, 1167 (Centrafarm/Sterling Drug). In gelijke zin HvJ (30/87) Jur. 1988, 2479 (Bodson).
} 
een economische eenheid behoren niet als afzonderlijke ondernemingen gelden, als gevolg waarvan 'onderlinge' afspraken niet onder de reikwijdte van artikel 81 EG vallen. ${ }^{35}$ Deze visie deel ik niet: entiteiten die deel uitmaken van een economische eenheid blijven onverminderd afzonderlijke ondernemingen in de zin van de communautaire kartelbepalingen $^{36}$ en kunnen derhalve ook overeenkomsten sluiten die worden getroffen door het verbod van artikel 81 EG. Dit laatste zal echter slechts zelden het geval zijn. Ten dele is dit zo omdat de mededinging tussen moeder en dochter veelal ontbreekt (de mededinging zou echter wel ten aanzien van derden kunnen worden beperkt); voorts is, in de woorden van Schröter, van belang: "daß den Begriff der 'Verhinderung, Einschränkung oder Verfalschung des Wettbewerbs' notwendigerweise bei jedem der beteiligten Unternehmen einen durch die Absprache beschränkbaren Freiraum für selbständige wirtschaftliche Entscheidungen und Handlungen voraussetzt". ${ }^{37}$ Deze ruimte voor zelfstandige beslissingen ontberen echter de binnen een economische eenheid afhankelijke (dochter)ondernemingen voor een groot gedeelte. De vraag rest of intra-concern afspraken onder het kartelverbod zouden kunnen vallen, indien bedoelde ruimte wél bestaat. ${ }^{38}$ Het hierboven gecitecrde Centrafarm/Sterling Drug-arrest beantwoordde deze vraag bevestigend, althans voorzover het afspraken betrof die de interne takkverdeling te boven gingen en die dus de mededinging voor derden konden beïnvloeden. ${ }^{39}$ De Viho-arresten ${ }^{40}$ lijken daarentegen in een andere richting te wijzen. In deze arresten werd geoordeeld dat artikel 81 EG niet van toepassing was vanwege het enkele feit dat het in casu een economische eenheid betrof: de bijkomende voorwaarde van interne takverdeling werd uitdrukkelijk

35 Van Gerven c.s. (1997), pag. 80: "voor zover de afspraak tussen moeder en dochter de uiting is van een door de moeder aan de dochter opgelegde regeling die een normale interne taakverdeling op het oog heeft, worden beide entiteiten geacht te behoren tot eenzelfde economische eenheid, m.a.w. één onderneming te vormen; gaat de afspraak tussen beide verder of beïnvloedt zij de mededinging met derden, dan wordt zij wel degelijk geacht een afspraak tussen afzonderlijke entiteiten te zijn, die de mededinging kan beinnvloeden". In vergelijkbare zin ook Advocaat-Generaal Lenz in zijn conclusie bij het Viho-arrest, Jur. 1996, 1-5471. Nog afgezien van de vraag of -zoals Van Gerven c.s. lijken te doen-uit een afspraak betreffende interne takverdeling het bestaan van een economische eenheid mag worden afgeleid (het Hof noemt de interne taakverdeling als bijkomende voorwaarde naast het bestaan van een economische cenheid), heb ik bezwaren tegen de visie van Van Gerven c.s.. Zij maken immers het antwoord op de vraag of er al dan niet sprake is van afzonderlijke ondernemingen afhankelijk van de aard van de afspraak (al dan niet interne takkverdeling). Dit zijn echter twee te (onder)scheiden zaken, waarbij de aard van de afspraak hooguit kan bepalen of deze de mededinging beinvloedt. Zie over het Viho-arrest Wezenbeek-Geuke(1997 I), pag. 12 e.v..

36 Aldus ook Gleiss en Hirsch (1978), pag. 67: "Wirtschaftliche Selbststïndigkeit ist für die Qualifikation als "Unternehmen" nicht nötig. Deswegen ăndert wirtschaftliche Abhängigkeit oder Eingliederung in einen Konzern nichts an der Unternehmenseigenschaft"; Schröter (1999 I), pag. 2/70: "Es bleibt daher festzuhalten, daß die wirtschaftliche Selbstständigkeitkein notwendiges Merkmal eines Unternehmens ist": Braakman (1997 I), pag. 11: "Partij bij een overeenkomst kunnen twee of meer (rechts)personen zijn. Zij moeten juridisch van elkaar kunnen worden onderscheiden, maar hoeven in economische opzicht niet los van elkaar te staan. Zo zijn afspraken tussen tot hetzelfde concem behorende ondernemingen ook overeenkomsten", en Van Rijn (1981), pag. 29.

37 Schrōter (1999 II), pag. 2/189.

38 Volgens Lauwaars (1982), pag. 160, is er in een dergelijke situatic echter geen sprake meer van een economische eenheid.

39 Zie hieromtrent ook Braakman (1997 I), pag. 11.

40 GvEA (T-102/92) Jur. 1995, II-17 (Viho Europe) gesteund door HvJ (C-73/95 P) Jur. 1996, I-5457). 
verworpen. ${ }^{4}$ Op deze uitspraak is kritiek geuit, met name omdat zij ook binnen een economische eenheid gemaakte mededingingsbeperkende afspraken buiten schot zou laten. ${ }^{2}$ Het zou inderdaad een stap in de verkeerde richting zijn, indien de bedoelde bijkomende voorwaarde definitief van het toneel is verdwenen. Tot deze conclusie noodzaken de Viho-arresten mijns inziens echter niet zonder meer. In casu betrof het namelijk $100 \%$-dochterondernemingen ${ }^{43}$, een omstandigheden waarop zowel door het Gerecht als door het Hof (en door advocaat-generaal Lenz in zijn conclusie bij het Viho-arrest van het $\mathrm{Hof}$ ) grote nadruk werd gelegd. In deze situatie bestond er voor de dochters geen enkele ruimte voor het nemen van zelfstandige beslissingen; in feite betrof het ook geen afspraken, maar eenzijdig, door de moeder van bovenaf opgelegde verplichtingen. Dat er onder deze omstandigheden geen inbreuk werd geconstateerd op artikel 81 EG verbaast niet. Wellicht echter dat in geval van een economische eenheid waarin de moeder een minder grote invloed heeft op de dochter (maar wel voldoende om tot de aanwezigheid van een economische eenheid te kunnen concluderen), bepaalde gedragingen binnen deze eenheid wel onder de reikwijdte van het kartelverbod zouden kunnen vallen. De vrijheid voor de dochter-onderneming om een eigen beleid te voeren, zou in die situatie groter zijn en zelfs concurrentie tussen beide zou niet geheel uitgesloten zijn. Voor die situaties zou de 'Centrafarm-doctrine' toch weer van betekenis kunnen blijken te zijn en het zou het belang van het onderscheid tussen afspraken betreffende interne taakverdeling en overige afspraken kunnen blijven bestaan. ${ }^{44}$

\subsection{Beinvloeding van de handel tussen lidstaten}

Hoe ruim het toepassingsgebied van de artikelen 81 en 82 EG ook moge zijn, het ligt niet in de lijn van de Europese Gemeenschap zich te mengen in louter nationale aangelegenheden of zich te bemoeien met gedragingen die zich geheel buiten de Gemeenschap afspelen. In de artikelen 81 lid 1 en 82 EG is deze beperking uitdrukkelijk aangebracht door opname van de voorwaarde van ongunstige beïnvloeding van de handel tussen lidstaten. ${ }^{45}$ Deze interstatelijke beïnvloeding -de vraag in hoeverre de beïnvloeding ongunstig is, blijkt in de praktijk van ondergeschikt belang ${ }^{46}$ - is gegeven zodra twee binnen

41 Wel werd gewezen op de mogelijkheid gedragingen van een economische eenheid op grond van artikel 82 EG aan te pakken.

42 Zie Schröter (1999 II), pag. 2/190.

43 Concurrentie tussen moeder en dochter was dus uitgesloten. Vergelijk de conclusie van advocaatgeneraal Lenz in HvJ (C-73/95 P) Jur. 1996, 1-5477.

44 HvJ (15/74) Jur. 1974, 1167 (Centrafarm/Sterling Drug) en HvJ (30/87) Jur. 1988, 2479 (Bodson). Vergelijk ook Pb 1969 L 165/14 (Christiani \& Nielsen) waarin de Commissie concludeerde dat "de in het contractovereengekomenverdeling dermarktenuiteindelijkslechts cen taakverdelingis binnen eenzelfde economische eenheid; dat men in casu niet kan verwachten dat binnen deze eenheid een deel, zelfs al bezit het rechtspersoonlijkheid, in concurrentie treedt met de moedervennootschap".

45 Waaronder mede begrepen het verkeer van diensten, arbeid en kapitaal: zie onder meer HvJ (155/73) Jur. 1974, 409 (Sacchi) Overigens stelt Van der Woude (1995), pag. 199, terecht dat het belang van deze voorwaarde vermindert naarmate er meer sprake is van een grote Europese interne markt.

46 De ongunstigheid moet worden beoordeeld in het licht van de verwezenlijking van de doelstellingen van de gemeenschappelijke markt, aldus HvJ ( 56 en 58/64) Jur. 1966, 450 (Consten/Grundig). Ongunstige beinvloeding kan volgens het Hof ook plaatsvinden als cen overeenkornst al dan niet in aarizieniljke mate "tot een toeneming van de handel tussen staten leidt", vergelijk de Consten/Grundig-uitspraak 
verschillende lidstaten gevestigde ondernemingen een kartelafspraak maken met betrekking tot bijvoorbeeld de export van producten tussen beide staten. Er doen zich echter situaties voor waarbij het minder voor de hand ligt dat er sprake zal zijn van interstatelijke beinvloeding van de handel. Met name kan daarbij gedacht worden aan twee situaties, te weten die waarin een kartel is opgezet door buiten de Europese Gemeenschap gevestigde ondernemingen, maar waarbij de effecten van een kartel wel op de communautaire markt merkbaar zijn en die waarin ondernemingen binnen (slechts) één lidstaat zijn overgegaan tot kartellering. De eerste situatie stelt de vraag van de territorialiteit aan de orde: kunnen gedragingen die buiten het 'grondgebied' van de Gemeenschap worden ontplooid onder de communautaire regelgeving vallen en op deze inbreuk maken? Het antwoord moet wat artikel $81 \mathrm{EG}$ betreft in ieder geval bevestigend luiden voorzover aan een dergelijke kartelafspraak binnen het grondgebied van de Gemeenschap uitvoering wordt gegeven, in welk geval in feite een deel van de gedraging zelf binnen het gemeenschappelijk territoir plaatsvindt. ${ }^{47}$ Zelfs indien de gedraging binnen de Gemeenschap slechts effect sorteert ${ }^{48}$, kan worden aangenomen dat het communautaire recht van toepassing is. ${ }^{49}$ In het verlengde hiervan ligt de territorialiteit met betrekking tot artikel 82 EG. De machtspositie van een onderneming louter buiten gemeenschappelijk grondgebied heeft geen communautaire relevantie. Hetzelfde geldt voor misbruik dat zich buiten de Gemeenschap afspeelt. Met andere woorden: misbruik én machtspositie moeten binnen communautair territoir bestaan. ${ }^{50}$ In de tweede situatie, waarin bij een kartel slechts ondernemingen van één lidstaat

en $\mathrm{HvJ}$ (56/65) Jur. 1966, 391 (LTM/MBU). Indien enige merkbare -een principe waarop hierna zal worden ingegaan- invloed van een gedraging uitgaat op de interstatelijke handel, dan zal deze als ongunstig kunnen worden gekwalificeerd. Nog verder gingen Commissie (onder meer in Consten/Grundig) en Hof (in enkele artikel 82 EG-zaken) door een ongunstige beïnvloeding van de interstatelijke handel aan te nemen met het argument dat deze zich anders ontwikkelde dankzij het kartelmatig gedrag dan zonder dit het geval zou zijn geweest. Schröter (1999 II), pag. 2/231, stelt in dit verband: "Beeinträchtigung ist nicht etwa gleichbedeutend mit negativer Beeinflussung sondern mit Beeinflussung schlechthin",

47 HvJ $(89,104,114,116,117,125-129 / 85)$ Jur. 1988, 5193 (Ahlström Osakeyhtiō).

48 Deze zogenoemde effectleer kan worden gelijkgesteld met de leer van het gevolg, die één van de leren is die binnen het Nederlandse strafrecht wordt gebnikt ter bepaling van het locus delicti; deze leerheeftoverigensweleenrelatiefzwakkevolkenrechtelijkebasis. VergelijkuitgebreidHazewinkelSuringa/Remmelink (1994), pag. 258.

49 Zie bijvoorbeeld Bekendmaking van de Commissie betreffende de invoer van Japanse produkten in de Gemeenschap, $\mathrm{Pb}$ 1972, C 111/13: "Het feit, dat bepaalde of alle daarbij betrokken ondememingen buiten de Gemeenschap zijn gevestigd staat de toepassing van dit voorschrift niet in de weg als de uitwerking van de overeenkomsten, besluiten of onderling afgestemde feitelijke gedragingen zich tot het grondgebied van de gemeenschappelijke markt uitstrekt". Vergelijkbaar: HvJ (22/71) Jur. 1971. 949 (Béguelin): "wanneer de overeenkomst op het grondgebied van de gemeenschappelijke markt effectsorteert". In HvJ (48/69) Jur. 1972, 619 (Imperial Chemical Industries) werd de vraag opgeworpen of de Commissie bevoegd was op te treden (met name in de vorm van boete-oplegging) tegen buiten de gemeenschappelijke markt gevestigde vennootschappen. Het Hof omzeilde deze materic door de leer van de economische eenheid-zoals hiervoor behandeld-toe te passen. In zijn conclusic ging advocaat-generaalMayras daarentegen wel expliciet op het vraagstuk in, verdedigend dat de leer van het gevolg gelding had, mits aan enkele vereistenzou zijn voldaan. Als voorwaardennoemde Mayras rechtstreekse en onmiddellijke communautaire mededingingsbeperking, voorzienbaarheid van de gevolgen voor de mededinging en aanwezigheid van wezenlijke gevolgen binnen het EG-grondgebied. Uitzondering was -uiteraard- de uitoefening van onderzoeksbevoegdheden: hierbij zou de Commissie beperkt zijn tot ondernemingsvestigingen op communautair grondgebied.

Vergelijk Van Gerven c.s. (1997), pag. 486/487. 
zijn betrokken, ligt het probleem bij de afbakening met het nationale recht. Ook hier blijkt dat de communautaire instanties voldoende ruimte zien voor toepasselijkheid van het gemeenschapsrecht, met name indien het kartelmatig gedrag de toegang tot de nationale markt voor derden bemoeilijkt of onmogelijk maakt. ${ }^{\text {"I }}$

\subsection{Mededingingsbeïnvloeding en merkbaarheid}

De voorwaarde van artikel 81 lid 1 EG dat de mededinging door de afspraak of gedraging moet worden verhinderd, beperkt of vervalst -artikel 82 EG noemt deze voorwaarde niet uitdrukkelijk, maar de facto geldt zij ook hier ${ }^{52}$, raakt de kern van het kartel(recht) zelf. Afspraken en overeenkomsten tussen ondernemingen zijn in het economische verkeer aan de orde van de dag. Sterker nog: het betreft veelal de centrale bezigheid van ondernemingen die allerminst door de Europese Gemeenschap wordt ontmoedigd. Zij stuiten slechts op communautaire bezwaren wanneer de gedragingen van ondernemingen de concurrentie aantasten of tot aantasting van deze strekken. ${ }^{13}$ Slechts in dat geval immers druisen zij in tegen de doelstellingen van de Europese Gemeenschap. ${ }^{34}$ De grens tussen de drie in artikel 81 lid 1 EG genoemde vormen van mededingingsbeînvloeding is vloeiend en voor de praktijk is het maken van een onderscheid niet relevant aangezien de rechtsgevolgen niet verschillen. Cruciaal is derhalve dat het gedrag van de ondernemingen de mededinging beïnvloedt; hoe die beïnvloeding gekwalificeerd kan worden, is van ondergeschikt belang.

Tegen de achtergrond van de communautaire relevantie is door het Hof de -niet in de artikelen 81 en 82 EG voorkomende- voorwaarde van merkbaarheid gesteld. ${ }^{55}$ Het communautaire kartelrecht is bedoeld om mededingingsbeperkingen te voorkomen c.q. te bestrijden die de realisering van de doelstellingen van artikel 2 EG frustreren. Kartels die hetzij de intracommunautaire handel, hetzij de mededinging niet noemenswaardig beînvloeden of kunnen beĭnvloeden, vormen geen risico voor die doelstellingen en dienen derhalve buiten het bereik van de communautaire kartelregels te blijven. Door het stellen van het merkbaarheidsvereiste heeft het Hof dit bewerkstelligd. Onder de verboden vallen zodoende niet kartels die de mededinging kwantitatief (onder meer gelet op het marktaan-

51 Zie bijvoorbeeld HvJ (8/72) Jur. 1972, 991 (Vereniging van Cementhandelaren), Pb 1978 L. 242/15 (CSV), Pb 1986 232/15 (Bitumineuze dakbedekking), Pb 1986 L 348/50 (Meldoc) en Pb $1992 \mathrm{~L}$ $92 / 1$ (Bouwnijverheid in Nederland).

$52 \mathrm{HvJ}(6 / 72)$ Jur. 1973, 245 (Continental Can). Het Hof wees in dit verband op de plaatsing van artikel 82 in hoofdstuk 1 van titel V EG.Verdrag (Regels betreffende de mededinging).

53 Het is dan ook niet noodzakelijk - maar wel voldoende- dat de mededingingbeinvloedende gevolgen daadwerkelijk zijn ingetreden: het volstaat als een afspraak of gedraging dese beinvloeding kan bewerkstelligen. Vergelijk Pb 1997 L 26/23 (Veerdienstmaatschappijen), waarin de Commissie overwoog dat "er niet aan (kan) worden getwijfeld dat de regeling op zijn minst een potentieel ongunstig effect op het handelsverkeer tussen de Lid-Staten had".

54 In het EG-Verdrag wordt dan ook primair de mededingingsstructuur beschermd en slechts secundair de handelingsvrijheid van de individuele onderneming. In deze zin ook Van Gerven c.s. (1997), pag. 144: "Mededinging beeft dus meer te maken met een bepaalde marktvorm dan met de graad van handelingsvrijheid waarover elke onderneming op de bewuste markt beschikt".

55 HvJ (56/65) Jur. 1966, 391 (LTM/MBU) en HvJ (5/69) Jur. 1969, 295 (Volk/Vervaecke). 
deel van de betrokken ondernemingen ${ }^{56}$ ) dan wel kwalitatief (bijvoorbeeld gelet op het product in kwestie) niet wezenlijk beperken noch kartels die geen merkbare invloed op de handel tussen lidstaten uitoefenen. ${ }^{37}$ In dit laatste geval kunnen de kartels overigens onverminderd in strijd zijn met nationale kartelbepalingen.

\subsubsection{Verboden gedragingen van artikel 81 EG}

Aan artikel 81 EG ligt de notie ten grondslag dat ondernemingen zelfstandig en in vrijheid hun marktgedrag moeten kunnen bepalen: horizontaal of verticaal gedrag dat deze zelfstandigheid of handelingsvrijheid beknot is op grond van dit artikel verboden. ${ }^{58}$ In welke vorm dit gedrag wordt gegoten, is met het oog op de realisering van de doelstellingen van het EG-Verdrag de facto van secundair belang. Dit verklaart de ruime formulering van de gedragingen die in strijd kunnen zijn met artikel 81 EG: overeenkomsten, besluiten én onderling afgestemde feitelijke gedragingen vallen onder de reikwijdte van het verbod. Voor de praktijk is dit onderscheid tussen de verschillende gedragingen niet echt relevant: zoals gezegd valt elk van de drie gedragingen gelijkelijk onder het verbod van artikel $81 \mathrm{EG}$, terwijl evenmin enig verschil tussen de verschillende gedragingen wordt gemaakt in de boteregeling met betrekking tot overtreding van dit verbod. ${ }^{59} \mathrm{Om}$ deze reden en omdat de grens tussen de verschillende gedragingen ook door de Commissie en de communautaire rechters niet steeds scherp wordt getrokken, zal hier worden volstaan met een korte karakterschets van bedoelde gedragingen.

De term 'overeenkomst' doet vermoeden dat het -parallel aan artikel 6:213 BW- gaat om een (obligatoire) meerzijdige rechtshandeling. Dat een overeenkomst een meerzijdig karakter heeft, staat buiten discussie, aangezien een wilsovereenstemming tussen ondernemingen steeds vereist is. ${ }^{60}$ Artikel 81 lid 2 EG lijkt bovendien te impliceren dat een overeenkomst in de communautaire betekenis tevens een rechtshandeling is: de nietigheidssanctie op verboden overeenkomsten zou immers een contradictio in terminis zijn voor zover overeenkomsten geen juridische binding zouden hebben. Toch is door de Commissie, daarin gevolgd door de communautaire rechters, de noodzaak van juridische binding

56 Dit kwantitatieve aspect is met betrekking tot artikel 81 EG door de Commissie nader omlijnd in haar bagatel-bekendmakingen, waarop in paragraaf 2.4 .2 kort wordt ingegaan.

57 De merkbaarheidseis geldt zowel ten aanzien van de daadwerkelijk ingetreden als ten aanzien van een voorzienbare beperking van de mededinging respectievelijk interstatelijke handel.

58 Zie voor voorbeelden van mededingingsbeperkendgedrag Swann (1983), pag. 77 e.v. en-zeeruitgebreid- Van Gerven c.s. (1997), pag. 210-454.

59 In gelijke zin Kerse (1998), pag. 9-10.

60 Vergelijk bijvoorbeeld GvE.A (T-41/96) n.n.g. (Bayer): "Het bewijs van een overeenkomst tussen ondernemingen (...) moet berusten op de rechtstreekse of onrechtstreekse vaststelling van het subjectief elementdat de essentie vormt van het begrip overeenkomst, namelijk de wilsovereenstemmingtussen marktdeelnemers over de tenuitvoerlegging van een beleid, het nastreven van een doel of het vastleggen van een bepaalde gedragslijn op de markt, ongeacht de wijze waarop uitdrukking wordt gegeven aan de wil van de partijen om zich op de markt te gedragen overeenkomstig de bewoordingen van de overeenkomst". 
ontkend ${ }^{61}$ en kunnen ook 'gentlemen's agreements' als overeenkomsten worden aangemerkt. ${ }^{.2}$ Als gevolg hiervan is het wezenlijke kenmerk van de overeenkomst de "rechtliche, quasi-rechtliche, moralische oder rein faktische Bindungskraft". "Hetzelfde geldt ten aanzien van het besluit dat door Van Gerven c.s. wordt omschreven als "een beslissing die wordt genomen door een maatschappelijk orgaan (algemene vergadering, raad van beheer, enz.) van een vereniging met rechtspersoonlijkheid of van een zuiver feitelijke vereniging en die voor diens leden een verbindend karakter vertoont" ${ }^{\prime \prime 4}$, waarbij zoals gezegd het verbindend karakter niet noodzakelijk duidt op juridische binding. ${ }^{6}$ Het verschil tussen de overeenkomst en het besluit bestaat dan met name uit de eenzijdigheid van het besluit.

Het gegeven dat ook gedrag zonder (beoogde) juridische binding binnen het overeenkomst- (en besluit)begrip is getrokken, doet de grens met de derde kartelvorm, de onderling afgestemde feitelijke gedraging, vervagen. Deze onderling afgestemde feitelijke gedraging de Engelse tekst spreekt van concerted practice- wordt door het Hof omschreven als "een vorm van coördinatie tussen ondernemingen (...) die, zonder dat het tot een eigenlijke overeenkomst komt, de risico's der onderlinge concurrentie bewust vervangt door een feitelijke samenwerking" ${ }^{66}$ Het Hof hanteert hier een zeer ruime omschrijving van het begrip 'onderling afgestemde feitelijke gedragingen', die niet alleen duidelijk maakt dat dit begrip allerlei vormen van juridisch niet-bindend gedrag omvat (hetgeen zoals gezegd de afbakening met het ruime overeenkomstenbegrip bemoeilijkt) maar bovendien aantoont dat het hier gaat om een 'vangnet-categorie' die ontduiking van het kartelverbod zoveel mogelijk moet tegengaan. ${ }^{67}$ De categorie van de onderling afgestemde feitelijke gedragingen geeft tevens de benedengrens van het kartelverbod aan: coördinatie is niet geoorloofd,

61 Zie PB 1974 L 343/24 (Frans-Japans Kogellagerkartel); hier overwoog de Commissie dat "voor de toepassing van artikel 85 , lid 1, van het EEG-Verdrag (thans 81 EG, HQ) niet onmisbaar is dat deze overeenkomstzich aandient in de vorm van eenjuridisch bindende privaatrechtelijkeconventic, maar dat het volstaat dat één van de partijen zich vrijwillig verbindt zijn handelingsvrijheid tegenover de wederpartij te beperken". In Pb 1986 L 230/1 (Polypropyleen) herhaalde en expliciteerde de Commissie haar standpunt: "Er is sprake van een overeenkomst wanneer de partijen overeenstemming bereiken over een plan dat hun commercięle vrijheid beperkt of naar alle waarschijnlijkheidzal beperken door het vastleggen van de wijze waarop zij zich op de markt tegenover elkaar zullen gedragen of van bepaald gedrag zullen onthouden. Contractuele sancties of procedures om dit af te dwingen zijn niet vereist. Evenmin is het noodzakelijk dat een dergelijke overeenkomst op papier staat". Vergelijk ook $\mathrm{Pb} 1991$ L 152/1 (NatriumcarbonaatSolvay/CFK), Pb 1999 L 24/1 (Voorgelsoleerde buizen) en Pb 1999 L. 76/1 (British Sugar). Men zie Mok (1989), pag. 152.

$62 \mathrm{~Pb} 1989$ L 260/1 (Betonstaalmatten).

63 Schröter (1999 II), pag. 2/152, die overigens kritisch tegenover deze ontwikkeling staat.

64 Van Gerven c.s. (1997), pag. 137.

65 Vergelijk Pb 1996 L 181/28 (FENEX), waarin een ondernemersvereniging naar de letter adviesprijzen hanteerde. In door de ondernemersvereniging verspreide circulaires werd echter met de nodige klem aangeraden om de 'adviesprijzen' te hanteren. Volgens de Commissie was er sprake van een "ondubbelzinnige uitdrukking van de wil van de vereniging om het gedrag van haar leden op de betrokken markt te coồrdineren". De Commissie achtte de adviesprijzen dan ook besluiten in de zin van artikel 81 lid 1 EG.

$66 \mathrm{HvJ}(48 / 69)$ Jur. 1972, 619 (Imperial Chemical Industries).

67 In deze zin ook de Commissie in Pb 1991 L 152/1 (Natriumcarbonaat Solvay/IC1). 
parallel marktgedrag daarentegen valt buiten het verbod van artikel $81 \mathrm{EG} .{ }^{68}$ Waar echter deze grens ligt, is in zijn algemeenheid niet aan te geven en is sterk afhankelijk van de omstandigheden van het geval. Volgens vaste jurisprudentie is echter in ieder geval verboden "enigerlei tussen (...) ondernemers al dan niet rechtstreeks opgenomen contact strekkend hetzij tot beïnvloeding van het marktgedrag van een bestaande of mogelijke concurrent, hetzij tot beduiding aan zulk een concurrent van het aangenomen of voorgenomen marktgedrag". ${ }^{69}$

\subsubsection{Bagatelverklaring}

Hiervoor is besproken dat het Hof in het communautaire kartelrecht een merkbaarheidvereiste heeft geinntroduceerd. De kwantitatieve invulling van dit vereiste voorzover het artikel 81 lid 1 EG betreft, is door de Commissie ter hand genomen in enkele zogenoemde bagatelbekendmakingen (ook wel: de minimis-verklaringen). Deze bekendmakingen, die noch de nationale rechters noch het Gerecht of het Hof binden ${ }^{70}$, bieden voor ondernemingen én voor de Commissie voordelen. Ondernemingen weten (althans meer dan zonder bekendmaking) waar zij aan toe zijn; de vage voorwaarde van merkbaarheid wordt concreet ingevuld, waarmee de rechtszekerheid gediend is. Het voordeel voor de Commissie ligt hierin dat verzoeken om zogenoemde negatieve verklaringen en ontheffingsaanvragen ${ }^{n}$ worden voorkomen, hetgeen een niet onbelangrijke capaciteitsbesparing kan opleveren. In de bekendmaking van $1997^{72}$ is gekozen voor het marktaandeel als relevante kwantitatieve factor ${ }^{73}$ : blijven de marktaandelen van alle betrokken ondernemingen tezamen beneden de grens van $5 \%$ voor horizontale kartels en $10 \%$ voor verticale kartels, dan

68 Het bewijs van de aanwezigheid van louter gecoördineerd gedrag levert-zoals reeds geconstateerd ten aanzien van de introductie van het begrip 'onderling afgestemde feitelijke gedraging' in de Wemechter wel problemen van bewijstechnischeaardop. Deze problemen hebben tot een zekereomkering van de bewijslast geleid, waarbij de Commissie stelt dat de feiten alleen verklaring kunnen vinden in een onderlinge afstemming en ondernemingenalternatieveverklaringenvoor hun parallellegedrag moeten aanvoeren. Al te kort mag de Commissie echter niet door de bocht gaan bij het aannemen van onderlinge afstemming. Zie bijvoorbeeld HvJ (29 en 30/83) Jur. 1984, 1679 (CRAM/Rheinzink) en met name HvJ (C-89, 104, 114, 116, 117 en 125-129/85) Jur. 1993, I-1307 (Ahlstrŏm Osakeyhtiō e.a.).

69 HvJ (40-48, 50, 54-56, 111, 113 en 114/73) Jur. 1975, 1663 (Coöperatieve vereniging "Suiker Unie" e.a.). In gelijke bewoordingen onder meer GvEA (T-7/89) Jur. 1991, Il-1711 (Hercules Chemicals), GvEA (T-8/89) Jur, 1991, II-1833 (DSM) en Pb 1997 L 26/23 (Veerdienstmaatschappijen).

70 Afgezien van de in de bekendmakingen neergelegde voorbehouden, is de Commissie zelf op grond van het vertrouwensbeginsel in principe wel gebonden. Beleidswijzigingen blijven daarentegen mogelijk, zij het dat de Commissie in dat geval in verhoogde mate rekening zal dienen te houden met getroffen ondernemingen. Zo zal zij bij verhoging van de bagatelgrens betrokkenen de mogelijkheid en tijd moeten bieden om hun gedragingen aan te passen.

71 Zie over ontheffingen en negatieve verklaringen paragraaf 2.4.3.

72 Bekendmaking inzake overeenkomsten van geringe betekenis die niet onder artikel 85 , lid 1 , (thans $81 \mathrm{EG}, \mathrm{HQ}$ ) van het Verdrag tot oprichting van de Europese Gemeenschapvallen, Pb 1997 C 372/13.

73 De door de bekendmaking van 1997 vervangen Bekendmaking van 3 september 1986 inzake overeetlkomsten van geringe betekenis die niet onder artikel 85, lid 1, van het Verdrag tot oprichting van de Europese Economische Gemeenschap (thans 81 EG, HQ) vallen, Pb 1986 C 231/2, kende nog twee drempels, namelijk naast het marktaandeel de totale omzet van de betrokken ondernemingen Deze mocht ten hoogste 300 miljoen Ecu (vootheen 200 miljoen Ecu) bedragen. 
is artikel 81 EG op deze kartels niet van toepassing. ${ }^{74}$ Hetzelfde geldt in beginsel voor gedragingen van kleine en middelgrote ondernemingen, zelfs als de marktaandelen van deze ondernemingen meer dan de hiervoor genoemde percentages bedragen. ${ }^{75}$ Twee conclusies zijn gelet op het voorgaande gerechtvaardigd. De eerste is dat uitsluitend kleine en middelgrote ondernemingen alsmede (andere) ondernemingen met een gering marktaandeel profiteren van de bagatelverklaring. ${ }^{76}$ Dit ligt ook voor de hand, gelet op de ratio van de merkbaarheidseis. De tweede conclusie is dat de rechtszekerheid door de bekendmaking vergroot, maar niet volmaakt is. Voor ondernemingen zal het veelal niet eenvoudig zijn om de relevante product- en geografische markt en daarmee hun marktaandeel te bepalen, ook al geeft de bekendmaking daaromtrent enige richtlijnen. Voorts kunnen zowel de nationale als de communautaire rechters aan de inhoud van de bekendmaking voorbij gaan. Bovendien, maar dit strekt ondernemingen tot voordeel, kunnen kartels die niet aan de criteria van de bekendmaking voldoen, om andere merkbaarheidsredenen toch buiten het verbod van artikel $81 \mathrm{EG}$ vallen.

\subsubsection{Ontheffing van het kartelverbod}

Het verbod van artikel 81 EG is, zoveel moge uit het voorgaande blijken, zeer ruim. De reden hiervoor moet gezocht worden in het belang dat het kartelrecht vervult bij de realisering van de doelstellingen van artikel $2 \mathrm{EG}$. Toch is het kartelverbod niet absoluut. Schröter stelt terecht: het EG-Verdrag

"erkennt jedoch an, daß den grundlegenden Erfordernissen der Gemeinsehaft unter Umstànden durch indirekte, fordernde Eingriffe besser gedient sein kann als durch eine strikte Anwendung der Verbote. Dies erklänt und rechtfertigt die Verbotsausnahmen fur bestimmte Kartelle. (...) Mit ihrer Hilfe lassen sich zudem Konflikte zwischen verschiedenen Gemeinschaftszielen oder zwischen Interessen der Gemeinschaft und solchen der Mitgliedstaaten leichter lösen"."

Ook in het kader van de Europese Gemeenschap wordt dus erkend dat in bepaalde -zij het uitzonderlijke- gevallen een positieve werking ${ }^{78}$ van een kartel kan uitgaan. ${ }^{79}$ Dit is tot uitdrukking gebracht in het derde lid van artikel $81 \mathrm{EG}$, waarin in een mogelijkheid

74 Kartels betreffende prijzen, gebiedsbescherming of marktverdeling kunnen overigens niet profiteren van de bekendmaking.

75 Voor een antwoord op de vraag wat kleine en middelgrote ondernemingen zijn, zie $\mathrm{Pb} 1996 \mathrm{~L} \mathrm{107/4}$.

76 Wel is duidelijk dat de voorwaarde van merkbaarheid een duidelijke drempel voor toepassing van artikel 81 EG vorrnt, een drempel die bovendien hoger is dan door Snijders (1971), pag. 521, gesuggereerd.

77 Schröter (1999 I), pag. $2 / 23$.

78 Men denke bijvoorbeeld aan franchising. Zie dienaangaande bijvoorbeeld Janssen (1990), pag. 264 e.v.. Onder omstandigheden kunnen ook crisiskartels positieve effecten hebben; zie over de houding van de Commissie tegenover deze kartels Mok (1982 I), pag. 173. Overigens kunnen de voordelen ook buiten mededingingsgebied liggen, zoals met betrekking tot behoud van werkgelegenheid of bevordering van het leefmilieu.

79 In zoverre kent het EG-recht cen uitgangspunt dat tegengesteld is aan het uitgangspunt dat aan de Nederlandse wetgeving tot 1998 ten grondslag heeft gelegen. 
van ontheffing van het kartelverbod ${ }^{30}$ is voorzien. ${ }^{81}$ Dit impliceert dat een kartel steeds nietig is behoudens expliciete ontheffing. ${ }^{12}$ Deze mogelijkheid is in zoverre beperkt dat de voorwaarden voor ontheffing zeer restrictief zijn geformuleerd en, indachtig de doelstellingen van artikel $2 \mathrm{EG}$, ook streng worden getoetst. De vier cumulatieve voorwaarden waarom het gaat, zijn:

- de kartelafspraak moet "bijdragen tot verbetering van de produktie of van de verdeling der produkten of tot verbetering van de technische of economische vooruitgang" ${ }^{\text {"83 }}$;

- de gebruikers moeten een billijk aandeel krijgen in de voordelen die dankzij de afspraak worden bereikt ${ }^{\mathrm{s}}$;

- de beperkingen die uit de kartelafspraak voortvloeien mogen niet onmisbaar zijn voor het bereiken van de beoogde voordelen, en

- de mededinging mag niet voor een wezenlijk deel van de betrokken produkten worden uitgeschakeld."

Deze criteria onderstrepen nadrukkelijk hoezeer binnen de Europese Gemeenschap belang wordt gehecht aan een goed functionerende mededinging, waarbij maar een zeer beperkte plaats voor kartels is ingeruimd. De ruimte die artikel 81 lid 3 EG biedt voor ontheffing is navenant gering, hetgeen in gelijke mate voor beide in dat artikellid genoemde ontheffingsvarianten geldt: de individuele ontheffing en de groeps- of generieke vrijstelling. $\mathrm{Bij}$ de individuele ontheffing wordt ieder daartoe strekkend verzoek ${ }^{86}$ op zijn merites beoordeeld en aan de ontheffingsvoorwaarden getoetst. Het betreft derhalve een bij uitstek casuïstische bezigheid. Dat geldt niet voor de generieke vrijstelling, die voor kartels van een bepaalde bij de maatregel aangewezen soort geldt. Hier worden ondernemingen die aan de betreffende criteria voldoen, zonder voorafgaande aanmelding van het verbod

80 Een analoge ontheffingsregeling ontbreekt voor het misbruik van een machtspositie ex artikel 82 EG. Dit hangt samen met de aard van de gedraging: van misbruik kan moeilijk (algemeen) voordeel uitgaan.

81 Mok (1981), pag. 46 spreckt van 'Erlaubnisvorbehalt', "d. w.z. een verbod met dispensatiemogelijkheid".

82 De ontheffing ontbeert in zoverre terugwerkende kracht dat zij niet geldt voor de periode voorafgaande aan de aanmelding.

83 Met name dit vereiste is relatief vaag en biedt voor de Commissie de nodige beleidsruimte (zie ook Mok (1981) pag. 47). Er zal in ieder geval wel sprake moeten zijn van een objectieve verbetering. dat wil zeggen een verbetering van de marktsituatie of van de positie van (een groot deel van) de marktparticipanten. Het Hof overwoog in HvJ (56 en 58/64) Jur. 1966, 522 (Consten/Gundig), dat een "subjectieve opvatting echter, waarbij het begrip "verbetering" van de contractueleverhoudingen tussen partijen afhankelijk wordt gesteld, niet met doelstellingen van artikel 85 (thans $81 \mathrm{EG}, \mathrm{HQ}$ ) in overeenstemming is". De formulering van onderhavige voorwaarde weerhoudt de Commissie niet ervan miliet- of werkgelegenheidsbevorderende aspecten mee te wegen bij de ontheffingen en vrijstellingen.

84 Ratio hiervan is dat derden mee-profiteren van het kartel. Het begrip 'gebruikers' dient ruim te worden geinterpreteerd. De Commissie doelt veelal op afnemers; Mok (1981), pag. 49, ziet als gebruikers: "anderen dan de bij de mededingingsregeling betrokken ondernemingen".

85 In deze derde en vierde voorwaarde kunnen aspecten van de vereisten van subsidiariteit en proportionaliteit worden aangetroffen.

86 Artikel 4 Vo 17 vereist voor een succesvol ontheffingsverzoek dat -behoudens de uitzonderingen van het tweede lid- het kartel bij de Commissie wordt aangemeld. Aan dit vereiste wordt door de Commissie strikt de hand gehouden. Er bestaat in het communautaire kartelrecht echter geen algemene registratieplicht, zoals die op grond van het Kartelbesluit en de Wem in Nederland gold. 
vrijgesteld. ${ }^{n}$ Het moge duidelijk zijn dat een veelvuldig gebruik van met name de vrijstellingsmogelijkheid een aanzienlijke afzwakking van het communautaire verbod zou betekenen, maar zover is het in de praktijk in ieder geval niet gekomen, hoewel geregeld ontheffingen worden verleend en inmiddels de nodige vrijstellingen het licht hebben gezien. ${ }^{\text {ss }}$ Zeker zware kartelvormen hoeven derhalve niet op communautaire clementie te rekenen.

De bevoegdheid tot het verlenen van individuele ontheffingen en van vrijstellingen is op basis van artikel 83 lid 2 sub b EG door de Raad exclusief bij de Commissie gelegd: op grond van artikel 9 lid 1 Vo 17 is het dan ook aan nationale autoriteiten (waaronder begrepen de rechterlijke macht) niet toegestaan om artikel 81 lid 3 EG toe te passen. Als het aan de Commissie ligt, behoort deze exclusiviteit echter spoedig tot het verleden. Op dit moment ligt namelijk een door de Commissie ingediend voorstel voor wijziging van onder meer Verordening 17 op de tafel van de Raad dat met name -maar niet uitsluitend, waarover later meer- verstrekkende gevolgen heeft voor de toepassing van artikel 81 lid 3 EG ${ }^{89}$ Dit voorstel, als vervolg op het op 28 april 1999 aangenomen Witboek ${ }^{50}$, is revolutionair te noemen aangezien het in de bedoeling ligt om ook aan het derde lid van artikel 81 EG rechtstreekse werking toe te kennen. De toelichting bij het Witboek stelt:

"Voorgesteld wordt een nieuw handhavingssysteem, een zogenoemd 'systeem van rechtstreeks toepasselijke uitzondering', in te voeten. In het kader van een dergelijk systeem kunnen zowel de verbodsregel van artikei 81 , lid 1 , als de uitzonderingsbepaling van artikel 81 , lid 3, rechtstreeks worden toegepast, niet alleen door de Commissie, maar ook door de nationale rechterlijke instanties en de nationale mededingingsautoriteiten. Overeenkomsten zijn rechtsgeldig of nietig naargelang zij al dan niet aan de voorwaarden

87 Evenals bij de bagatelbekendmakingen snijdt het mes hier dus aan twee kanten. Voor de ondernemingen ontstaat er -zij het slechts ten aanzien van de kartelvorm waarop de generieke maatregel betrekking heeft-meer duidelijkheid over de vraag of zij voldoen aan de criteria van artikel 81 lid 3 EG. Bovendien hoeven zij bij bevestigend antwoord op deze vraag geen verdere stappen te ondernemen om ontheffing van het verbod te verkrijgen. De Commissie aan de andere kant blijft verschoond van tal van ontheffingsverzoeken (die alle getoetst zouden moeten worden), waarvan de positieve uitkomst de facto reeds bij voorbaat vaststaat.

88 Met name $V_{0} 240 / 96 \mathrm{~Pb} 1996 \mathrm{~L} 31 / 2$ (overeenkomsten betreffende technologieoverdracht); Vo 2790/99 $\mathrm{Pb} 1999$ L 336/21 (verticale overeenkomsten en onderling afgestemde feitelijke gedragingen); Vo $2658 / 00 \mathrm{~Pb} 2000 \mathrm{~L} 304 / 3$ (specialisaticovereenkomsten); Vo 2659/00 Pb $2000 \mathrm{~L} 304 / 7$ (onderzoeksen ontwikkelingsovereenkomsten). Met name de communautaire aanpakvan verticalekartels is lange tijd (in ieder geval tot de inwerkingtreding van bedoeldevrijstelling inzakeverticaleovereenkomsten) aan kritiek onderhevig geweest. Zie hierover onder meer Schröter (1997), pag. 15 e.v. en over het Groenboek inzake verticale mededingingsbeperkingen Wezenbeek-Geuke(1997 II), pag. 44 e.v.. Over de vrijstelling zelf zie Whish (2000), pag. 887 c.v..

89 Voorstel voor cen Verordening van de Raad betreffende de uitvoering van de mededingingsregels van de artikelen 81 en 82 van het Verdrag en tot wijziging van Verordening (EEG) nr. 1017/68, Verordening (EEG) nr. 2988/74, Verordening (EEG) nr. 4056/86 en Verordening (EEG) nr. 3975/87 ('uitvoeringsverordening van de artikelen 81 en 82 van het Verdrag'), 27 september 2000, COM (2000) 582 definitief -2000/0243 (CNS); (hiema 'Voorstel uitvoeringsverordening'). Zic over dit voorstel Mok (2000), pag. 448-453 en Mok (2001), pag. 101-103.

90 Witboek betreffende de modernisering van de regels inzake de toepassing van de artikelen 85 en 86 van het EG.Verdrag, Programma van de Commissie mr. 99/027, Pb 1999 C 132/1. Zie voor uitgebreide besprekingen van dit Witboek: Wezenbeek-Geuke(1999), pag. 169-178, Mok (1999), pag. 314-322, Hermans en Noè (1999), Rodger (1999), pag. 653-663, Gustafsson (2000), pag. 159-184 en Ehlermann (2000), pag. 537-590. Zeer kritisch over de voorgestelde wijzigingen is Vogelaar (2000), pag. 12-18. 
van artikel 81 , lid 3, voldoen. Err is geen goedkeuringsbeschikking vereist om overeenkomsten die met artikel 81 in zijn geheel in overeenstemming zijn, te handhaven".

Exit ontheffingen derhalve. Overeenkomsten (voor zover vallend onder artikel 81 lid 1 EG) die aan de voorwaarden van artikel 81 lid 3 EG voldoen, zijn van meet af aan geldig. Een (aanvraag tot) ontheffing is daarvoor niet meer nodig. Het voorstel van de Commissic gaat dan ook verder dan een decentralisering van de ontheffingsbevoegdheid: in de toekomst kan -indien het voorstel wordt gevolgd-artikel 81 lid 3 EG rechtstreeks door de Commissie, de nationale (bestuurlijke) mededingingsautoriteiten alsmede de nationale rechter worden toegepast. ${ }^{91}$ Het doel van deze operatie is gelegen in de verhoging van de doelmatigheid van het communautaire mededingingsbeleid. ${ }^{92}$ Het huidige systeem met zijn ontheffingsmonopolie voor de Commissie slokt teveel van dier tijd op als gevolg waarvan haar onvoldoende capaciteit rest om tegen de zwaardere inbreuken op te treden. Resultaat: een weinig doeltreffende bescherming van de mededinging. Teneinde de efficiëntie op te krikken, is de Commissie met het onderhavige voorstel gekomen. Doordat haar taken op ontheffingsgebied zullen wegvallen, zal de Commissie zich meer kunnen gaan concentreren op de opsporing van de ernstigere inbreuken, terwijl ook voor het overige -aldus nog steeds het voorstel- de mededinging beter zal worden beschermd omdat meer (nationale) instanties bij de handhaving betrokken zullen zijn. ${ }^{93}$ Of de voorstellen van de Commissie bijval verdienen, laat ik hier verder in het midden: voor het Audernep, uandezestudiezjiindeze, vrgeen niet, van wezenjiik belang . Wel is duideliik dat het ingrijpende wijzigingen betreft en dat de Commissie voornemens is om nog meer werk te maken van het opsporen van de zware vormen van kartelgedrag. Voor zover (in welke vorm dan ook) een herziening van Verordening 17 haar hiertoe de ruimte zal bieden, mag verwacht worden dat 'het bedrijfsleven' in Europa vaker zal worden geconfronteerd met kartelonderzoeken en met de in dat kader aan de Commissie ter beschikking staande bevoegdheden. Een logisch gevolg daarvan zou zijn dat het aantal boetebeschikkingen zal toenemen.

Wat van het voorgaande ook zij, vooralsnog geldt het systeem van ontheffingen. Van de ontheffing dienen de negatieve verklaring en de zogenoemde comfort letters uitdrukkelijk te worden onderscheiden. De negatieve verklaring is geregeld in artikel 2 Vo 17 en houdt in dat de Commissie vaststelt dat 'op grond van de gegevens die haar bekend zijn,

91 Mok (1999), pag. 318-319, betwijfelt overigens of artikel 81 EG een systeem zoals voorgesteld, toestaat. Ehlermann (2000), pag. 553-556 is van mening dat dit wel het geval is.

92 Bijkomend voordeel zou zijn dat er een lastenverlichting voor ondememingen zou worden bewerkstelligd. Dit is in zoverre juist dat geen ontheffing meer behoeft te worden aangevraagdom geldigheid van een onder artikel 81 lid 1 EG vallende regeling te bereiken. Daar staat tegenover dat ondernemingen nu steeds zelf dienen na te gaan of aan de voorwaarden van het derde lid is voldaan. Aan het nieuwe systeem is derhalve een zekere mate van rechtsonzekerheid inherent.

93 De decentrale toepassing van artikel 81 lid 3 EG zet de uniformiteit van die toepassing onder druk. Het 'Voorsteluitvoeringsverordening' trachtdezeuniformiteitvia verschillendewegente garanderen. Enkele noem ik hier. Omdat volgens de Commissie gedragingen die de handel tussen de lidstaten (kunnen) beinvloeden bij uitsluiting door het communautaire recht worden geregeerd, staat de prejudiciele weg van artikel 234 EG open. Daarnaast moet er een netwerk komen waarin de verschillende nationale mededingingsautoriteiten en de Commissie participeren en waarbinnen nauw wordt samenge werkt en informatie onderling wordt uitgewisseld. Ook zou er een (nog) nauwere samenwerking mocten zijn tussen de Commissie en nationale rechterlijke instanties. 
voor haar geen aanleiding bestaat tegen een overeenkomst, besluit of gedraging, krachtens artikel 81 , lid 1, of artikel 82 EG op te treden'. 94 Dit betekent dus dat de Commissie im een formele beschikking na een daartoe strekkend verzoek neerlegt dat de betreffende gedraging niet onder artikel 81 lid 1 of 82 EG valt en derhalve niet verboden is ${ }^{25}$; in diat geval komt zij logischerwijze niet meer toe aan de vraag of de gedraging van het verbod kan worden ontheven. ${ }^{96}$ Een negatieve verklaring bindt overigens uitsluitend die Commissie zelf ${ }^{p}$, maar is niet dwingend voor een nationale rechter, die dan ook in een voorkomend geval alsnog kan concluderen dat de gedragingen tegen artikel $\mathbf{8 1}$ of $82 \mathrm{EG}$ indruisen. De comfort letter (of troostbrief) behoort tot het informele beleid van de Commissie en vervangt een formele beschikking inhoudende een negatieve verklariing of ontheffing. Als de Commissie de onderneming in een comfort letter mededeelt dat-naar de stand van zaken-niet tegen de gedragingen zal worden opgetreden, dan heeft dat voor de Commissie het voordeel dat niet de formele procedure doorlopen behoeft te worden. De onderneming is met de beslissing gediend omdat zij -behoudens gewijzigde omstandigheden- geen communautair optreden behoeft te vrezen. ${ }^{98}$ Evenals het geval is bij de negatieve verklaring, is een nadeel van de comfort letter dat een nationale rechter hiieraan voorbij kan gaan; absolute zekerheid biedt deze informele afhandeling dan ook niet aan de ondernemingen. " Uit de praktijk blijkt overigens onmiskenbaar dat de bij de Commissie aanhangige zaken in veruit de meeste gevallen via deze comfort letter wordt afgehandeld. ${ }^{100}$

\subsection{Misbruik van een machtspositie}

Artikel 82 EG verbiedt misbruik door een of meer ondernemingen van hun machtspositie op de Gemeenschappelijke markt of een wezenlijk deel daarvan. ${ }^{101}$ De vraag naar schending van artikel 82 EG valt derhalve uiteen in twee deelvragen: is er sprake van een machtspositie en zo ja, wordt hiervan misbruik gemaakt? Voor de vraag naar de aanwezigheid van een machtspositie zal allereerst de relevante markt moeten worden afgebakend. Het belang van deze afbakening is aanzienlijk: hoe beperkter de markt, des te groter de kans op het bestaan van een machtspositie. Bij deze afbakening moet rekening worden

94 Voor een voorbeeld zie Pb 1980 L $39 / 64$ (Rietsuiker).

95 Bijvoorbeeld omdat de interstatelijke handel niet wordt beïnvloed, de ondememing geen machtspositie inneemt of de overeenkomst de mededinging niet merkbaar beperkt.

96 In het 'Voorstel uitvoeringsverordening' is in een vergelijkbare regeling voorzien: de vaststelling van niet-toepasselijkheid (artikel 10). Zij kan betrekking hebben op de artikelen 81 leden 1 én 3 alsmede 82 EG.

97 En ook deze binding is niet onbeperkt, aangezien de Commissie op grond van nieuwe feiten alsnog kan optreden. Zie hierover De Bronett (1999), pag. 2/989 en Kerse (1998), pag. 247.

98 Zie voor een voorbeeld waarin de Commissie ondanks een eerdere comfort letter gedragingen van een onderneming toch in strijd verklaarde met artikel 81 EG: Pb 1993 L 183/1 (Schöller).

99 HvJ (C-59/96 P) Jur. 1997, 1-4809 (Koelman).

100 Zie als voorbeeld de praktijk in de jaren 1996 (XXVle Verslag over het mededingingsbeleid) en 1997 (XXVIle Verslag over het mededingingsbeleid): in 72 respectievelijk 109 gevallen werd een informele negatieve verklaring gegeven; in 61 respectievelijk 83 gevallen werd informeel een ontheffing verieend.

101 Ten aanzien van de territorialiteit is reeds opgemerkt dat zowel de machtspositie als het misbruik binnen de Europese Gemeenschap moeten platshebben. 
gehouden met de productmarkt én de geografische markt. ${ }^{102}$ Voor deze worden door de Commissie de volgende definities gehanteerd:

Een relevante productmarkt omvat alle producten en/of diensten die op grond van hun kenmerken, hun prijzen en het gebruik waarvoor zij zijn bestemd, door de consument als onderling verwisselbaar of substitueerbaar worden beschouwd.

De relevante geografische markt is het gebied waarbinnen de betrokken ondernemingen een rol speien in de vraag naur en het aunbod van goederen of diensten, waarbinnen de concurrentievoorwaarden voldoende homogeen zijn en dat van aangrenzende gebieden kan worden onderscheiden doordat daar duidelijk afwijkende concurrenticvoorwaarden heersen. ${ }^{\text {to }}$

Van belang is dus met name de substitueerbaarheid, zowel aan de vraagzijde als aan de aanbodzijde. Voor de vraagzijde geldt dat alle producten die door de afnemers c.q. consumenten als vervangingsproducten worden beschouwd tot dezelfde productmarkt worden gerekend. ${ }^{104} \mathrm{Bij}$ de substitueerbaarheid aan de aanbodzijde wordt met name gekeken naar de mogelijkheden van (andere) aanbieders om over te schakelen op de vervaardiging van het product in kwestie. ${ }^{105}$ Geografisch moet onder meer rekening gehouden worden met eventuele toetredingsbarrières voor de betreffende markt, met de omvang van de transportkosten voor het betreffende product en met de kosten van het opzetten van een distributienet. $^{106}$

102 Vergelijk HvJ (27/76) Jur. 1978, 207 (United Brands): "dat bij de toetsing van de concurrentiemogelijkheden aan artikel 86 (thans artikel $82 \mathrm{EG}, \mathrm{HQ}$ ) rekening moet worden gehouden met de bijzondere kenmerken van het betrokken produkt en verband moet worden gelegd met een duidelijk omschreven geografisch gebied waarin het in de handel wordt gebracht en waar de mededingingssituatie voldoende homogeen is om de invloed van de economische macht van de betrokken onderneming te kunnen beoordelen".

103 Bekendmaking van de Commissie inzake de bepaling van de relevante markt voor het gemeenschappelijk mededingingsrecht, $\mathrm{Pb} 1997 \mathrm{C} 372 / 5$.

$104 \mathrm{In} \mathrm{Pb} 1976 \mathrm{~L}$ 95/1 (Chiquita) werd als relevante productmarkt de markt van bananen aangemerkt, omdat andere fruitsoorten geen (volledig) substituut vormden. Hieraan was mede debet dat "de banaan een essentieel component is van de voeding van bepaalde delen van de bevolking, zoals kleine kinderen, de zieken en de bejaarden". In $\mathrm{Pb} 1981$ L $353 / 33$ (Michelin) was de relevante productmarkt de markt 'van nieuwe buitenbandenvoor vrachtwagens, autobussene.d. bestemd voor vervanging'. In $\mathrm{Pb} 1987$ L 286/36 (BBI) wordt als relevante markt aangemerkt de markt voor koperinstrumenten voor 'brass bands'.

105 Vergelijk Pb 1989 L 10/50 (BPB) en Pb 1992 L 72/1 (Tetra Pak II). In zoverre spelen aan de aanbodzijde technische aspecten een belangrijke rol; zie Elderson en VerLoren van Themaat (1997), pag. 16. Terecht stellen Ottervanger, Steenbergen en Van der Voorde (1998), pag. 49 dat de substitueerbaarheid aan de aanbodzijde een grotere rol speelt voor de bepaling van een machtspositie dan voor de bepaling van de relevante productmarkt.

106 Vergelijk de bekendmaking van de Commissie inzake de relevante markt, $\mathrm{Pb} 1997 \mathrm{C} \mathrm{372/9}$, alsmede Van Gerven c.s. (1997), pag. 464. Ottervanger, Steenbergen en Van der Voorde (1998), pag. 49 stellen: "The definition of the relevant geographic market (...) leans more to the supply side than the demand side. The factors relevant to the assessment of the relevant geographic market nevertheless include the nature and characteristics of the products or services concerned, the existence of entry barriers. consumer preferences, appreciable differences in the undertakings' market shares between the area concerned and neighbouring areas or substantial price differences". 
Is eenmaal de relevante markt afgebakend, en is geconcludeerd dat het relevante geografische gebied een wezenlijk deel van de Gemeenschappelijke markt vormt ${ }^{107}$, dan rest de vraag van de machtspositie op die markt. Onder een machtspositie wordt in dit verband verstaan "een economische machtspositie van een onderneming, die deze in staat stelt de instandhouding van een daadwerkelijke mededinging in de relevante markt te verhinderen doordat zij sterk genoeg is zich in belangrijke mate onafhankelijk van haar concurrenten, afnemers en uiteindelijk de consumenten te gedragen". ${ }^{108}$ Het betreft zodoende een positie die het een onderneming mogelijk maakt haar wil aan derden op te leggen, zonder dat zij daarvan economische consequenties -bijvoorbeeld in de vorm van een wezenlijk verlies van afzet- behoeft te vrezen. Een aanzienlijk marktaandeel is hiervoor een noodzakelijke, maar niet zonder meer voldoende voorwaarde. Weliswaar kan een aanzienlijk marktaandeel behoudens uitzonderingen reeds het bewijs van een machtspositie vormen ${ }^{109}$-en dit is volgens het Hof zeker het geval bij een marktaandeel van $50 \%{ }^{110}$-, maar er worden desalniettemin steeds aanvullende voorwaarden gesteld die het bestaan van een machtspositie bevestigen dan wel aantonen." Als aanwijzingen voor een machtspositie zijn door Commissie en Hof onder meer aangemerkt: een in verhouding tot de marktleider gering marktaandeel van de concurrenten en met name de naaste concurrent, de aanwezigheid van een technische voorsprong, de afwezigheid van potentielle concurrentie, het vermogen om eenzijdig de prijs te beïnvloeden en de beschikking over een verkooporganisatie. ${ }^{112}$ Voorts kunnen aan de gedragingen van de onderneming aanwijzingen worden ontleend voor het bestaan van een machtspositie. De redenering komt er dan op neer dat een onderneming zich bepaald gedrag niet zou hebben kunnen permitteren indien zij niet over een machtspositie had beschikt. ${ }^{113}$ Daarmee wordt in feite het misbruik aangehaald als (deel)bewijs voor het bestaan van een machtspositie, waarmee tevens de correlatie tussen de machtspositie en het misbruik zichtbaar wordt. ${ }^{114} \mathrm{De}$

107 Zo werden de Nederlandse en de Belgische markt als wezenlijk deel van het Gemeenschappelijk grondgebied aangemerkt:HvJ (322/81) Jur. 1983, 3461 (NederiandscheBanden-Industrie-Michelin) en Pb 1977 L $117 /$ I (ABG) respectievelijk (ten aanzien van België) Pb 1975 L. 29/14 (General Motors). In Pb 1997 L 258/1 (Irish Sugar) concludeerde de Commissie dat lerland een wezenlijk deel van de gemeenschappelijke markt is, met name gelet op de hoeveelheden suiker (het product waarop de machtspositie betrekking had) die aldaar werden geproduceerd en verbruikt. Zie tevens HvJ (C. 179/90) Jur. 1991, I-5889 (Merci convenzionali porto di Genova), waarin zelfs de haven van Genua als geografisch wezenlijke markt werd betiteld.

$108 \mathrm{HvJ}$ (27/76) Jur. 1978, 207 (United Brands); in vergelijkbare bewoordingen Pb $1977 \mathrm{~L} 117 / 1$ (ABG), HvJ (85/76) Jur. 1979, 461 (Hoffmann-La Roche), HvJ (322/81) Jur. 1983, 3461 (Nederlandsche Banden-Industrie-Michelin), HvJ (C-62/86) Jur. 1991, 1-3359 (AKZO Chemic), GvEA (T-30/89) Jur. 1991, Il-1439 (Hilti) en Pb 1997 L 258/1 (Irish Sugar).

109 HvJ (85/76) Jur. 1979, 461 (Hoffmann-La Roche).

$110 \mathrm{HvJ}$ (C-62/86) Jur. 1991, 1-3359 (AKZO Chemie); in GvEA (T-30/89) Jur. 1991, II-1439 (Hilti) had de onderneming een marktaandeelvan $70-80 \%$. Een marktaandeelvan $40-45 \%$ daarentegenwerd in United Brands als niet voldoende beschouwd.

111 Zie hierover ook Ottervanger, Steenbergen en Van der Voorde (1998), pag. 51.

112 Onder meer HvJ (85/76) Jur, 1979, 461 (Hoffmann-La Roche), Pb 1981 L 353/33 (Michelin), Pb 1987 L 286/36 (BBI), Pb 1988 L. 284/41 (Napier Brown/British Sugar), Pb 1988 L 317/47 (Sabena), $\mathrm{Pb} 1989$ L 10/50 (BPB) en HvJ (C-62/86) Jur. 1991, 1-3359 (AKZO Chemie).

113 GvEA (T-30/89) Jur. 1991, II-1439 (Hilti).

114 Vergelijk ook $\mathrm{Pb} 1981$ L 353/33 (Michelin). De Commissie overwoog in deze beschikking: "Zoals dikwijls het geval is in situaties als de hier onderzochte, steunt de vaststelling van het bestaan van een machtspositie mede op het bewijs van het misbruik ervan". 
praktijk onderscheidt dan ook lang niet altijd de aan het begin van deze paragraaf genoemde deelvragen.

Toch rest hier nog de vraag wat onder misbruik dient te worden verstaan. Evenals het geval was bij het begrip 'misbruik' in de Wem, betreft het hier een waardeneutraal begrip. Misbruik dient -zoals steeds in het communautaire recht- tegen de achtergrond van de doelstellingen van artikel 2 EG te worden gezien. Ieder gedrag dat de mededinging en de ontwikkeling van deze aantast en waarmee consumenten, (andere) afnemers en (potentiēle) concurrenten wezenlijk worden benadeeld, kan als misbruik worden gekwalificeerd. ${ }^{115}$ De marktbeheersende positie van de betreffende onderneming legt op haar een bijzondere zorgplicht. ${ }^{116}$ Wat in een andere (markt)situatie een volledig legitieme gedraging is, kan in geval van een machtspositie misbruik opleveren. ${ }^{117}$

Het voorgaande maakt duidelijk dat de verboden van artikel 81 en 82 EG, dankzij hun belang voor de verwezenlijking van de doelstellingen van het EG-Verdrag, een zeer ruim bereik hebben. Zij staan dan ook in schril contrast met het misbruikuitgangspunt van de Wem. In het vorige hoofdstuk is gesteld dat de materiële norm alsmede de visie omtrent de ernst van de gedraging hun invloed doen gevoelen op de handhaving van die norm. Het beleid op grond van de Wem was primair gericht op aanpassing van kartels in overleg tussen het ministerie van Economische Zaken en de kartellerende ondernemingen (eventueel aangevuld met derden). Een vorm van handhaving met de fluwelen handschoen derhalve. Het ligt in de rede dat de bezwaren die, zowel om integratieve als om economische redenen, op communautair niveau bestaan tegen kartellering, leiden tot een strikte handhaving van de kartelregels. Daarvoor is dan wel een geschikt instrumentarium vereist. Dat dit er inderdaad is en dat de Commissie onder omstandigheden zeer wel bereid is om met harde hand op te treden tegen ondernemingen die het kartelverbod overtreden, zal hieronder worden besproken.

\section{Handhaving van het communautaire kartelverbod}

Overheidsoptreden tegen overtredingen vereist bevoegdheden. Voor de Wem waren deze bevoegdheden neergelegd in de Wet op de Economische Delicten alsmede in de Wem zelf. De bevoegdheden tot handhaving van het communautaire kartelrecht zijn voornamelijk opgenomen in de op artikel 83 EG gefundeerde Verordening 17 (Vo 17), en dan met name de artikelen $11 \mathrm{t} / \mathrm{m} 14 \mathrm{Vo} 17$. Deze verordening geldt voor de meeste sectoren waarbinnen een inbreuk op het materiële kartelrecht kan plaatsvinden, waarbij een uitzondering is gemaakt voor de vervoersector. ${ }^{118}$ Voor deze sector zijn de verordeningen $1017 / 68^{119}$ (vervoer over land), $4056 / 86^{120}$ (vervoer over zee) en $3975 / 87^{121}$ (vervoer

115 Zo werd in $\mathrm{Pb} 1972$ L. 299/51 (Zoja CSCICI) het staken van leveringen aan een gebruiker als misbruik aangemerkt.

116 Vergelijk Pb 1997 L. 258/1 (Irish Sugar).

117 Barents (1995 I), pag. 514, acht 'misbruik' het belangrijkste element in artikel 82 EG.

118 Verordening van de Raad 141/62, betreffende niet-toepassing op de vervoersector van Verordening Raad no. 17, Pb 2751/62.

119 Verordening van de Raad van 19 juli 1968 betreffende de toepassing van mededingingsregels op het gebied van het vervoer per spoor, over de weg en over de binnenwateren, $\mathrm{Pb} 1968$ L 175/1. 
door de lucht) in het leven geroepen. Bevoegdheden ter handhaving van de artikelen 81 en 82 EG zijn opgenomen in de artikelen $18 \mathrm{t} / \mathrm{m} 21$ Vo $1017,16 \mathrm{t} / \mathrm{m} 18 \mathrm{Vo} 4056 / 86$ en $9 \mathrm{t} / \mathrm{m} 11$ Vo $3975 / 87$, welke bevoegdheden corresponderen met die van Verordening 17 , waartoe ik mij in het volgende grotendeels zal beperken.

Artikel 11 Vo 17 regelt de bevoegdheid van de Commissie om (schriftelijk) informatie te verlangen van ondernemingen. De bevoegdheid tot het verrichten van een algemeen onderzoek van bedrijfstakken is neergelegd in artikel 12 Vo 17. De artikelen 13 en 14 Vo 17 tenslotte creëren de bevoegdheid tot het verrichten van zogenoemde verificaties, waarbij het eerstgenoemde artikel betrekking heeft op verificaties door nationale autoriteiten van de lidstaten (doorgevoerd op verzoek van de Commissie), terwijl het laatstgenoemde artikel de verificatiebevoegdheid van de Commissie zelf regelt. Artikel 15 Vo 17 vormt het sluitstuk van de handhaving en bevat de mogelijke boetes voor niet-naleving van het kartelverbod en voor inbreuken op de artikelen $11 \mathrm{~V} / \mathrm{m} 14$ Vo $17 .^{122}$ Voor zover het de niet-naleving van de artikelen 81 en 82 EG betreft, zijn de boetes indrukwekkend te noemen: maximaal 1 miljoen euro of, indien dat meer is, $10 \%$ van de omzet van de onderneming, behaald in het aan de boetebeschikking voorafgaande boekjaar. ${ }^{123}$ Voor overtreding van de formele vereisten is het boeteniveau aanmerkelijk lager, te weten maximaal 5.000 euro. ${ }^{124}$

Hoewel uit het voorgaande nog niet voortvloeit dat de bevoegdheden ter handhaving ruim zijn, blijkt toch dat aan het kartelrecht ook op formeel gebied groot belang tockomt. Als uitzondering op de regel dat het communautaire recht door nationale instanties wordt gehandhaafd, is de handhaving van het kartelrecht sinds de inwerkingtreding van Verordening 17 op 13 maart 1962 aan de Commissie zelf, dus door een communautaire instelling, opgedragen $^{125}$; de rol van nationale autoriteiten is slechts secundair. ${ }^{126}$

120 Verordening van de Raad van 22 december 1986 tot vaststelling van de wijze van toepassing van de artikelen 85 en 86 (thans 81 en 82 EG, HQ) van het Verdrag op het zeevervoer, Pb 1986 L 378/4.

121 Verordening van de Raad van 14 december 1987 tot vaststelling van de wijze van toepassing van de mededingingsregels op ondernemingen in de sector luchtvervoer, $\mathrm{Pb} 1987 \mathrm{~L}$ 374/1.

122 Ook hier geldt dat Vo 1017/62, Vo 4056/86 en Vo 3975/87 in respectievelijk artikel 22, 19 en 12 bepalingen kennen die in grote lijnen overeenstemmenmet de sanctiebepaling van Verordening 17.

123 De bespreking van artikel 15 Vo 17 en een analyse van de beschikkingspraktijk en de jurisprudentie met betrekking tot de bestraffing van ondernemingen zullen uitgebreid in hoofdstuk 4 aan de orde komen.

124 De minimumboete bedraagt hier 100 euro. Voor een inbreuk op het materiele recht is dat 1.000 curo.

125 Men vergelijke hieromtrent Guldenmund (1992), pag. 6/7. Tot aan de inwerkingtreding van deze verordening was de handhaving van het communautaire kartelrecht aan de lidstaten zelf. Hiervoor is in Nederland de Wem de wettelijke basis geweest.

126 De centrale positie van de Commissie blijkt tevens uit artikel 9 Vo 17, waarin is bepaald dat bij uitsluiting de Commissie bevoegd is tot het verlenen van ontheffingen van het kartelverbod en dat zij voorts bevoegd is artikel 81 lid 1 EG toe te passen. Nationale rechters-bijvoorbeeld in een civiele procedure- mogen slechts het eerste lid van artikel 81 EG toepassen. Zie over de toepassing van het EG-recht door de nationale rechter Pb 1993 C $39 / 6$ alsmede Bourgeois (1993), pag. 690 e.v.. Nationale autoriteiten zoals sinds 1998 de Nederlandse Mededingingsautoriteit mogen eveneens de artikelen 81 lid 1 en 82 EG toepassen, mits de Commissie nog geen procedure heeft ingeleid krachtens de artikelen 2, 3 of 6 Vo 17. Zie voor de toepassing van het EG-recht door nationale autoriteiten $\mathrm{Pb}$ 1997 C $313 / 3$. 
De aangehaalde bevoegdheden van de Commissie staan hierna centraal, met uitzondering van de artikelen 12 en 13 Vo 17 omdat deze door de Commissie zelden worden aangewend en zodoende in de praktijk van minder belang zijn ${ }^{127}$ Toch is het goed om ook aandacht te besteden aan enkele civielrechtelijke aspecten van het communautaire kartelverbod. Zoals gezien is iedere gedraging die in strijd is met de artikelen 81 en $82 \mathrm{EG}$ in beginsel verboden, ook zonder een daartoe strekkende beschikking van de Commissie of enig andere instantie. ${ }^{128}$ Deze verboden hebben rechtstreekse werking en kunnen dientengevolge in een nationale procedure worden ingeroepen. Hetzelfde geldt voor de nietigheidssanctie van het tweede lid van artikel $81 \mathrm{EG}$; sterker: deze kan slechts door de nationale rechter worden uitgesproken. ${ }^{129}$ Artikel 82 EG kent formeel geen nietigheidssanctie, maar dat laat onverlet dat wel nietigheid naar nationaal recht kan worden uitgesproken. De nietigheid impliceert dat de overeenkomst of het besluit vanaf het moment waarop zij is gesloten respectievelijk genomen juridisch onverbindend is. ${ }^{130}$ Dit betekent onder meer dat naleving van het kartel niet in rechte kan worden afgedwongen, dat verrichte prestaties als onverschuldigd betaald kunnen worden aangemerkt en dat de rechter een vonnis tot schadevergoeding kan uitspreken, een mogelijkheid waarover de Commissie niet beschikt. ${ }^{131}$ Het communautaire kartelverbod opent gelet op het voorgaande de toegang tot de civiele rechter. Ook op dit punt wijkt het dus principieel af van het Nederlandse kartelrecht zoals dat tot 1998 heeft gegolden. De ruimte voor civiele acties bleek daar zeer gering.

\subsection{Korte schets van de procedure}

Het communautaire onderzoek is bedoeld om bepaalde onduidelijkheden ten aanzien van de artikelen 81 en 82 EG uit de weg te ruimen. Deze onduidelijkheden kunnen zowel bestaan ten aanzien van de vraag of een overeenkomst onder de reikwijdte van de ontheffing van artikel 81 lid 3 EG valt als ook ten aanzien van de vraag of een gedraging inbreuk maakt op artikel 81 lid I EG en op grond daarvan voor beboeting in aanmerking komt.

127 Voor een voorbeeld van een onderzoek op grond van artikel 12 Vo 17 (betreffende de brouwerijsector) zie $\mathrm{Pb} 1971$ L 161/2.

128 Dit laat natuurlijk onverlet dat de Commissie wel bevoegd is een dergelijke verbodbeschikking te nemen. Deze heeft dan slechts een declaratoir karakter maarkan desalniettemin wenselijk zijn indien de beschikking bijdraagt tot verheldering van de artikelen 81 en 82 EG. In een verbodbeschikking kan overigens de verplichting voor ondernemingen worden opgenomen om de inbreuk te beěindigen.

129 Zie voor een voorbeeld van uitgesproken nietigheid een uitspraak van het Hof 's-Hertogenbosch (10 juni 1992), die het vonnis van de rechtbank Breda bekrachtigde. De rechtbank had een exclusieve afname-overeenkomst als strijdig met artikel 85 lid 1 en nietig verklaard. Men zie tevens de opmerkingen van Mok over dit arrest: TVVS 1993, 93/2, pag. 49/50. Eventueel zal de rechter alvorens uitspraak te doen het Hof een prejudiciële vraag van artikel 234 EG moeten voorleggen betreffende de uitleg van het EG-Verdrag. Zie voor enkele voorbeelden: Rb Zutphen 19 augustus 1964, NJ 1965, 110; HR 1 maart 1974, NJ 1974, 329; HR 22 oktober 1993, NJ 1994, 94.

$130 \mathrm{Om}$ deze reden worden in het tweede lid van artikel 81 EG de onderling afgestemde feitelijke gedragingen niet genoemd, aangezien deze naar hun aard rechtskracht ontberen. Helemaal zuiver is de formulering van het tweede lid overigens niet (meer), omdat uit de jurisprudentie van het Hof volgt dat ook juridiseh niet-bindend gedrag onder omstandigheden als overeenkomst kan worden gekwalificeerd.

131 Welke de nationale mogelijkheden in deze zijn en welke procedures moeten worden gevolgd, zijn kwesties van nationaal recht. 
Dit tweede aspect dat in een kartelprocedure onderzocht kan worden, staat hier centraal. Tal van zaken kunnen voor de Commissie aanleiding vormen om een procedure te initieren; ik noem enkele veel voorkomende. Ten eerste leidt aanmelding van een kartel door een onderneming teneinde een ontheffing ex artikel 81 lid 3 EG te verkrijgen, tot het bekend worden van een (al dan niet onder de reikwijdte van artikel 81 lid 1 en lid 3 EG vallende) afspraak of gedraging. Deze aanmelding kan -nog los van het feit dat zij op zich aanleiding kan zijn aanvullend onderzoek te verrichten ten einde te kunnen beoordelen of de gedraging daadwerkelijk voor ontheffing in aanmerking komt- bij de Commissie vragen oproepen omtrent de naleving van de kartelregels, ook door anderen dan de aanmelder. Ten tweede zal een direct tot de Commissie gerichte klacht van een onderneming die nadeel ondervindt van een (vermeend) kartel van zijn concurrenten, leveranciers of afnemers de Commissie kunnen attenderen op het bestaan van een mogelijk verboden gedraging. ${ }^{132}$ Ten derde kan de informatie met betrekking tot omstreden handelwijzen van ondernemingen de Commissie bereiken via nationale (kartel)autoriteiten van de lidstaten. Ten vierde kunnen de media een belangrijke informatiebron over de situatie op de (product)markten vormen. ${ }^{133} \mathrm{Al}$ de informatie die voor de Commissie van belang is in het kader van haar taak als handhaafster van het mededingingsrecht, kan voor haar aanleiding zijn nader onderzoek in te stellen naar bepaald gedrag.

Met het starten van dit nader onderzoek neemt het vooronderzoek een aanvang. Hierin staan instrumentele aspecten voorop die het de Commissie mogelijk moeten maken zo goed, grondig en effectief mogelijk licht in de haar voorliggende kwestie te brengen. In het kader hiervan ligt de nadruk op verreikende bevoegdheden van de Commissie die in vergaande mate zijn gegoten in meewerkingsplichten van de geadresseerden. In deze fase van de procedure is er -zeker in het geschreven communautaire recht- weinig ruimte voor bescherming van de rechten van de justitiabelen, met dien verstande dat in de jurisprudentie van het Hof in de loop der tijd wel steeds meer aandacht voor dit rechtsbeschermingsaspect is gekomen. Het vooronderzoek kan uitmonden in verschillende conclusies. Vanzelfsprekend kan de Commissie ondanks een aanvankelijk vermoeden van overtreding tot de conclusie komen dat de gedraging niet onder de reikwijdte van het verbod van artikel 81 of $82 \mathrm{EG}$ valt. In dat geval eindigt de zaak, eventueel door middel van een negatieve verklaring, waarbij de Commissie verklaart op grond van de bij haar bekende gegevens geen reden te zien op te treden tegen de onderneming of door middel van een 'comfort letter' waarin de Commissie aangeeft de zaak niet verder te behandelen, bijvoorbeeld omdat het -in eerste instantie kartelmatige- gedrag reeds is gewijzigd in een vanuit communautaire optiek positieve zin. Voorts kan aan alle voorwaarden voor een ontheffing zijn voldaan, als gevolg waarvan deze zal worden verleend; ook dan zal de onderneming geen verdere stappen behoeven te vrezen. Het oordeel naar aanleiding van het onderzoek kan ook minder positief voor de onderneming uitvallen. In dat geval beschikt de Commissie over een ruime discretionaire bevoegdheid om al dan niet over te gaan tot een formele beschikking, een communautair opportuniteitsbeginsel derhalve. In de meeste gevallen gaat de voorkeur uit naar een informele regeling, een schikking waarbij de betrokken ondernemingen toezeggen dat hun gedragingen in overeenstemming met het communautaire

132 Dit impliceert overigens nog niet dat de Commissie een klacht ook steeds met een onderzoek en een beschikking moet beantwoorden. Zie onder meer Brouwer (1992), pag. 44 e.v..

133 Zie voor andere mogelijke aanleidingen voor het initiëren van een onderzoek, Van Bael en Bellis, (1994), pag. 724 e.v. 
recht worden gebracht. ${ }^{134}$ Voor een schikking zal de Commissie niet opteren indien hetzij het inbreuken betreft die van zodanig ernstige aard zijn dat zij een officiële reactie (en eventucel zelfs een boete) van de Commissie vergen hetzij een beschikking noodzakelijk wordt geacht om bekendheid te geven aan de opvattingen van de Commissie over een bepaalde, tot dan toe onduidelijke, rechtssituatie.

In geval de Commissie een (boete)beschikking wenst te nemen, dient zij aan de onderneming de zogenoemde punten van bezwaar mede te delen, welke mededeling de fase van het vooronderzoek uit- en de contradictoire fase inluidt. In deze fase op tegenspraak staan -ondanks het gegeven dat het de Commissie, en dus niet een rechterlijke instantie, is en blijft die de beslissingen neemt- de rechtswaarborgen van de justitiabelen meer op de voorgrond, hetgeen met name wordt vorm gegeven in het recht op hoor en wederhoor, zoals vervat in artikel 19 Vo 17 en nader uitgewerkt in Vo 99/63. ${ }^{135}$ Deze mededeling van de punten van bezwaar, die sterke overeenkomsten vertoont met een strafrechtelijke tenlastelegging en met het rapport in de Mededingingswet, is van cruciaal belang omdat zij de omvang van het geding bepaalt: de Commissie mag bij haar eindbeslissing geen punten in aanmerking nemen waarover de getroffen onderneming zich niet heeft kunnen uitspreken en tegen welke zij zich niet heeft kunnen verdedigen. De Commissie dient zodoende aan de onderneming al het relevante materiaal te overhandigen en haar in staat te stellen effectief verweer te voeren onder meer door haar te horen. De voorbereiding van de (niet-openbare) hoorzitting en het voorzitterschap van deze wordt door de zogenoemde raadadviseur-auditeur ('hearing officer') ter hand genomen die ervoor zorg moet dragen dat alle relevante aspecten aan de orde komen. ${ }^{136}$ Indien de Commissie na de hoorzitting de overtuiging heeft over voldoende bewijsmiddelen te beschikken, dan kan zij overgaan tot het nemen van een met redenen omklede eindbeschikking waarin de inbreuk wordt vastgesteld, de onderneming voor zover nodig wordt gesommeerd de inbreuk te staken en eventueel een boete wordt opgelegd. ${ }^{137}$ Het voorgaande onderstreept de centrale positie die de Commissie in de communautaire procedure inneemt: toezicht, opsporing, vervolging én berechting zijn bij haar geconcentreerd. Op deze concentratie valt vanuit het oogpunt van de rechten van de verdediging wel wat af te dingen. ${ }^{138}$ Met name zal een betrokken onderneming vraagtekens kunnen zetten bij de onbevangenheid van de Commissie in het kader van een boeteprocedure: zal de Commissie die het onderzoek heeft doorgevoerd en die van mening was dat gelet op de omstandigheden van het

134 In dezezin ook Ottervanger, Steenbergenen Van der Voorde (1998), pag. 8: "Many casesinvestigated by the Commission do not result in a formal decision. Instead, proceedings may come to an end by an informal settlement, whereby the undertakings involved voluntarily terminate their unlawful conduct, or, in some cases, amend their agreements to conform to the competition rules". Zie voor enkele voorbeelden het XXVIe Verslag over de mededinging 1996, waarin melding wordt gemaakt van 6 schikkingen en het XXVHe Verslag over de mededinging 1997, waarin sprake is van 3 schikkingen.

135 Verordening van de Commissie van 25 juli 1963 betreffende het horen van belanghebbenden en derden overeenkomstig artikel 19, leden 1 en 2, van Verordening Raad no. 17, $\mathrm{Pb} 2269 / 63$.

$136 \mathrm{~Pb} 1982$ C 251 en Pb 1994 L 330/67 (Besluit van de Commissie van 12 december 1994 betreffende het mandaat van de raadadviseur-auditeur in mededingingsprocedures voor de Commissie),

137 Reeds in een eerder stadium kan de Commissie overigens voorlopige maatregelennemen, namelijk indien een inbreuk op het mededingingsrecht waarschijnlijk is en er voor de verzocker van de maatregelen ernstige en onherstelbare schade dreigt. Vergelijk $\mathrm{Pb} 1983$ L 252/13 (ECS/AKZO) en Pb 1987 L. 286/36 (BBI).

138 Zie hierover en over mogelijke alternatieven Steenbergen (1997), pag. 101 e.v. alsmede Hall (1995), pag. 35-38. 
geval een boeteprocedure moest worden ingeleid, nog onbevangen en onpartijdig (kunnen) reageren op door de onderneming opgeworpen verweren $?^{199}$ Dit zal met name klemmen indien de Commissie eerst heeft getracht tot een minnelijke schikking te komen, waarop door de onderneming niet is ingegaan omdat zij van mening was dat haar gedrag geen inbreuk op het kartelverbod maakte. De bedoelde cumulatie verhoogt de noodzaak van de mogelijkheid voor betrokkenen om de beschikking van de Commissie bij een onafhankelijke rechterlijke instantie aan te vechten. Hierin is voorzien in artikel 230 EG: op grond van dit artikel kan iedere natuurlijke persoon of rechtspersoon bij het Hof beroep instellen tegen een tot haar gerichte beschikking wegens onbevoegdheid, schending van wezenlijke vormvoorschriften, schending van het EG-Verdrag of misbruik van bevoegdheid.

Als gezegd wordt in artikel 230 EG-Verdrag de behandeling van beroepszaken aan het Hof opgedragen. ${ }^{140}$ Met de instelling van het Gerecht van Eerste Aanleg eind 1989 is hierin in zoverre verandering gekomen dat verschillende zaken in eerste instantie door dit Gerecht worden behandeld. ${ }^{141}$ Dit geldt onder meer voor kartelzaken, aangezien in artikel 3 Besluit instelling Gerecht van eerste aanleg dit Gerecht mede bevoegd is verklard tot behandeling van beroepen ingesteld door (rechts)personen krachtens artikel $229 \mathrm{EG}$. Het Gerecht is aan het Hof toegevoegd, hetgeen inhoudt dat het Gerecht organisatorisch met het Hof een eenheid vormt en geen afzonderlijke instelling in de zin van artikel 4 Verdrag is. ${ }^{142}$ Deze nauwe relatie met het Hof laat onverlet dat het een geheel onafhankelijke rechterlijke instantie betreft. De bestreden beschikking wordt door het Gerecht volledig getoetst hetgeen wil zeggen dat zowel het rechtsoordeel van de Commissie als ook haar oordeel omtrent de feiten worden getoetst. Wordt een ingesteld beroep (gedeeltelijk) gegrond verklaard, dan moet de beschikking op grond van artikel $231 \mathrm{EG}$ (partieel) worden vernietigd. ${ }^{143}$ Komt het Gerecht op grond van zijn overwegingen tot het inzicht dat de omvang van de boete niet correspondeert met de mate van de schending van het kartelverbod, dan heeft het de bevoegdheid om zelf de boete te wijzigen zowel ten voordele als ten nadele van de insteller van het beroep ${ }^{144}$ : het communautaire

139 In zoverre is mede de presumptio innocentiae in het geding.

140 Zie voor een bundeling van relevante regelgeving Winter en Baas (2001) en voor een bespreking van de procedures en het procesrecht Lenaerts en Arts (1999).

141 De mogelijkheid tot de instelling van het Gerecht vindt haar basis is artikel $225 \mathrm{EG}$ (toen nog: 168A EG.Verdrag): in dit artikel is vastgelegd dat de behandeling in eerste aanleg van bepaalde categoriečn zaken kan worden overgedragen aan een Gerecht dat wordt toegevoegd aan het Hof. Het Gerecht is door de Raad ingesteld bij Besluit van 24 oktober 1988 tot instelling van het Gerecht van eerste aanleg van de Europese Gemeenschappen, Pb 1988 L 319/1; gewijzigd bij besluit van de Raad van 8 juni 1993, Pb 1993 L 144/21. Zie over dit Gerecht onder meer Fierstra (1990), pag. 598 e.v. en Vesterdorf (1992), pag. 897 e.v..

142 Vergelijk Eeckman (1989), pag. 67.

143 Bijvoorbeeld op grond van een onvoldoende motivering van (een deel van) de beschikking, zoals het geval was in HvJ (73/74) Jur. 1975, 1491 (Vereniging der Belgische behangselpapierfabrikanten) ten aamzien van het begrip ongunstige beìnvloeding van de handel tussen lidstaten voor nationale kartels. Dat een dergelijke vernietiging door de Commissie ter harte wordt genomen, blijkt uit het Vijfde verslag over het mededingingsbeleid, waarin wordt opgemerkt dat moet worden onthouden dat een ruimere interpretatie van bedoeld begrip met nauwkeurigheid moet worden gemotiveerd.

144 In deze zin ook Gyselen (1993), pag. 63. 
recht kent in dit verband geen verbod op reformatio in peius. ${ }^{145}$ Voor de geheel of gedeeltelijk door het Gerecht in het ongelijk gestelde partij staat binnen twee maanden na de betekening van de beslissing beroep bij het Hof open. De omvang van het geding is beperkt tot rechtvragen ${ }^{146}$, waarmee het Hof met betrekking tot de beslissingen van het Gerecht als een soort cassatierechter fungeert. ${ }^{147}$ Naast het beroep door de in het ongelijk gestelde partij is in artikel 49 , derde alinea, Statuut van het Hof tevens een (hogere) voorziening gecrelerd bij het Hof voor lidstaten en instellingen die niet in het geding voor het Gerecht zijn tussengekomen; dit beroep is volgens Briët tot op zekere hoogte vergelijkbaar met de 'cassatie in het belang der wet'. ${ }^{148}$ Het Hof kan indien hij het beroep gegrond verklaart en de beslissing van het Gerecht vernietigt hetzij zelf de zaak afdoen "wanneer deze in staat van wijzen is" (artikel 54 Statuut) hetzij de zaak naar het Gerecht verwijzen. ${ }^{149}$

Door de instelling van het Gerecht op mededingingsgebied is de rechtsbescherming voor de ondernemingen toegenomen. De beschikkingen van de Commissie kunnen in eerste aanleg worden voorgelegd aan het Gerecht, dat een volledige toetsing doorvoert ${ }^{150}$, waarna de mogelijkheid bestaat het Hof over rechtsvragen een oordeel te laten vellen. Vergroting van de rechtsbescherming was dan ook één van de belangrijkste redenen om tot de toevoeging van het Gerecht over te gaan. ${ }^{151}$ Een tweede (en aanvankelijk belangrij-

145 Dit in tegenstelling tot hetgeen in het Nederlandse bestuursrecht het geval is. Zie daarover VARwerkgroep Vierde tranche Awb (2000), pag. 50. Het Gerecht heeft op grond van artikel $229 \mathrm{EG} \mathrm{j}^{\circ}$ artikel 17 Vo 17 volledige rechtsmacht ten aanzien van de sancties. Ten onrechte opperde Vesterdorf, GvEA (T-1/89) 1991, II-1019 en 1028 (Polypropyleen) dat het ingrijpen in de boete beperkt zou moeten worden tot de gevallen waarin de Commissie het gelijkheidsbeginsel heeft geschonden doot van een vast boeteniveau af te wijken zonder geldige motivering en de gevallen waarin aan de boete een kennelijke beoordelingsfout van de Commissie ten grondslag heeft gelegen.

146 Artikel 225 EG en artikel 51 Statuut van het Hof.

147 Lenaerts (1990), pag. 529. Daarom overwoog het Hof ook dat het niet aan hem is om "uit billijkheidsoverwegingen zijn oordeel in de plaats te stellen van dat van het Gerecht, dat zich in de uitoefening van zijn volledige rechtsmacht heeft uitgesproken over het bedrag van de geldboeten die ondernemingen wegens schending van het gemeenschapsrechtopgelegd hebben gekregen. Het Hof is echter wel bevoegd om na te gaan, of het Gerecht rechtens genoegzaam antwoord heeft gegeven op alle door de rekwirant aangevoerde argumenten die strekken tot intrekking of verlaging van de geldboete". Zie HvJ (C-283/98 P) n.n.g. (Mo och Domsjö), in navolging van HvJ (C-310/93 P) Jur. 1995, 1-865 (BPB Industries/British Gypsum), HvJ (C-219/95 P) Jur. 1997, I-4411 (Ferriere Nord) en HvJ (C-185/95 P) Jur. 1998, I-8417 (Baustahlgewebe).

148 Briët (1991), pag 146.

149 Voor een uitgebreide bespreking van de procedure voor het Gerecht en het Hof verwijs ik naar Barents (1996).

150 De instelling van het Gerecht blijkt ook in de praktijk positieve gevolgen te hebben. De onderzocken zijn grondig als gevolg waarvan de Commissie wordt gedwongen in de oorspronkelijke beschikking en op de weg naar deze de procedurele vereisten nauwlettend in acht te nemen. Vergelijk hierover Whish (1995), pag. 44 e.v..

151 De Raad overwoog dat "in beroepen die een grondig onderzoek van complexe feiten vergen, de invoering van rechtspraak in twee instanties de rechtsbescherming der justitiabelen kan verbeteren"; Besluit van de Raad van 24 oktober 1988 tot instelling van het Gerecht van eerste aanleg van de Europese Gemeenschappen, Pb 1988 L 319/1 e.v.. 
kere) reden ${ }^{152}$ waarom tot de instelling van het Gerecht werd besloten, was de grote werkdruk van het Hof. ${ }^{153}$ Het overhevelen van bepaalde categorieěn zaken naar het Gerecht moest ertoe leiden dat de werkdruk van het Hof zou afnemen teneinde zo het Hof voldoende mogelijkheid te bieden om de eenheid in de uitleg van het communautaire recht te verzekeren. Dat dit tot de belangrijkste taken van het Hof kan worden gerekend, moge blijken uit het gegeven, dat de behandeling van verzoeken om prejudicięle beslissingen tot de uitsluitende bevoegdheid van het Hof behoort.

Na deze korte schets van het processuele kader waarbinnen de Commissie haar werkzaamheden verricht, zal in het volgende worden ingegaan op de bevoegdheden die Commissie in het vooronderzoek ter beschikking staan ${ }^{144}$; de contradictoire fase blijft, op een enkele verwijzing na, buiten beschouwing.

\subsection{Het inwinnen van inlichtingen ${ }^{15 s}$}

In artikel 11 Vo 17 is door de Raad de bevoegdheid gecreeserd om inlichtingen in te winnen en wel die inlichtingen die "ter vervulling van de taken welke haar (i.e. de Commissie, HQ) zijn opgedragen in artikel $89 \mathrm{en}$ in voorschriften vastgesteld krachtens artikel 87 van het Verdrag" noodzakelijk zijn. Het inwinnen van inlichtingen op grond van dit artikel is een zeer ruime bevoegdheid die de Commissie in het kader van haar taakvervulling toekomt. Dit blijkt allereerst hieruit dat de Commissie niet alleen gemachtigd is tot het vragen van (mondelinge of op schrift gestelde) inlichtingen als zodanig, maar bovendien is zij -hoewel dit niet expliciet uit de tekst van artikel 11 Vo 17 volgt- bevoegd door haar voor het onderzoek relevant geachte en reeds opgestelde documenten op te vragen. Deze mogelijkheid wordt door de communautaire rechter erkend, aangezien het alternatief voor het verkrijgen van de documenten, de verificatie (een -zoals hieronder zal blijken- onderzoek ter plaatse) een grotere belasting voor de onderneming vormt. ${ }^{156}$

De omvang van de bevoegdheid tot inlichtingeninwinning blijkt eveneens uit het doel waarmee zij kan worden aangewend. Artikel 85 EG draagt aan de Commissie de taak op te waken "voor de toepassing van de in de artikelen 81 en 82 neergelegde beginselen" en onderzoek in te stellen naar vermoedelijke inbreuken op deze beginselen. In combinatie met de voorschriften krachtens artikel 83 EG, waaronder Verordening 17, levert deze taakvervulling een ruime reikwijdte van artikel 11 Vo $17 \mathrm{op}$ : als voorbeelden kunnen worden genoemd het verlangen van informatie met het oog op een beslissing op een ontheffingsaanvraag of met het oog op de controle op de naleving van de artikelen

152 Vetgelijk Barents (1996), pag. 29 en 30. Dit blijkt ook reeds uit het uit 1981 daterende Elfde verslag over het mededingingsbeleid. Hierin pleitte de Commissie voor een 'rechtbank van eerste instantie' omdat de "ingewikkeldheid die inherent is aan alle geschillen inzake economische analyses (met zich brengt) dat deze de arbeidslast van het Hof onvermijdelijkerwijze ernstig verzwaart",

153 Briēt (1991), pag. 142-143, alsmede Wissels (1990), pag. 601.

154 Zie algemeen over de onderzocksfase Ritter, Rawlinson en Braun (1991), pag. 624-641.

155 Zie bijvoorbeeld ook Voillemot (1994), pag. 133 e.v..

$156 \mathrm{Zie}$ in verband met cen inlichtingenverzock met betrekking tot het EGKS (artikel 47) HvJ (5-10 en 13-15/62) Jur, 1962, 925/926 (Società Industriale Acciaierie San Michele e.a.), waarin het Hof instemde met het verzoek van de Commissie tot overlegging van de bescheiden, mede omdat dit een 'minder hinderlijke maatregel' vormt dan een verificatie ter plaatse. 
81 en 82 EG. ${ }^{157}$ Deze 'controle op de naleving', die hierna centraal zal staan, kan worden gezien als toezicht van de zijde van de Commissie op de inachtneming van de communautaire mededingingsregels door economische entiteiten. DeCommissie zal over voldoende gegevens moeten kunnen beschikken, wil zij effectief als waakster over de inachtneming van het mededingingsrecht kunnen optreden. Dit impliceert dat zij in een vroegtijdig stadium de noodzakelijke informatie moet kunnen vergaren en dat zij tot op zekere hoogte proactief moet kunnen optreden. $\mathrm{Zij}$ behoeft met andere woorden niet het moment af te wachten waarop een concreet vermoeden van overtreding van het materiële kartelrecht is gerezen, maar kan haar bevoegdheid ex artikel 11 Vo 17 reeds aanwenden bij twijfel omtrent de naleving van het materiêle kartelrecht door ondernemingen die zich op de communautaire markt hebben begeven.

Hiervoor is gesteld dat mede uit het doel van de bevoegdheid van artikel 11 Vo 17 kan worden afgeleid dat het een ruime bevoegdheid betreft. Dit doel vormt echter tegelijk een belangrijke begrenzing van de commissiebevoegdheden: inlichtingen mogen uitsluitend met het oog op het communautaire materiële kartelrecht worden ingewonnen. Een tweede belangrijke begrenzing is gelegen in het evenredigheidsbeginsel: het aanwenden van de bevoegdheid tot inlichtingeninwinning mag niet disproportioneel zijn. Daarom werd hierboven uitdrukkelijk gesteld dat de Commissie kan optreden zodra twijfel bestaat omtrent de naleving van de mededingingsregelgeving: zolang de Commissie over geen aanwijzingen omtrent enige inbreuk' op het materielle reoht beschikt, mag zij artikel 12 Vo 17 niet toepassen. ${ }^{158}$ Het evenredigheidsbeginsel komt ook expliciet tot uiting in de tekst van artikel 11 Vo 17 waar deze bepaling stelt dat de in te winnen inlichtingen noodzakelijk moeten zijn voor de taakvervulling. Noodzakelijk houdt echter niet in onmisbaar. Ook als de Commissie reeds over voldoende informatie beschikt om tot een beslissing te komen, kan zij toch verdere en aanvullende informatie verlangen teneinde een nog beter zicht op het haar voorliggende probleem te kunnen verkrijgen. De noodzaak moet tegen het licht van de (controle)taak van de Commissie worden gezien. ${ }^{159}$ De extensieve uitleg van het noodzaak-vereiste heeft als consequentie dat de Commissie inlichtingen mag verlangen in ieder stadium van het onderzoek, zolang zij maar van mening is dat de gewenste informatie opheldering van zaken kan geven ten aanzien van het door haar gestarte onderzoek. ${ }^{160}$

Zoals reeds uit het voorgaande moge blijken, is het de Commissie zelf die de noodzakelijkheid met het oog op de kartelprocedure bepaalt, hetgeen voor de hand ligt aangezien de Commissie zelf het beste in staat is te bepalen of zij voor haar taakuitoefening voldoende (achtergrond)informatie bezit. De visie van de Commissie kan weliswaar ter toetsing

157 De bevoegdheid tot het inwinnen van inlichtingen kan ook in het kader van een algemeen onderzock van een bedrijfstak (op grond van artikel 12 Vo 17) worden aangewend. Zie bijvoorbeeld $\mathrm{Pb} 1971$ L 161/2 (Brouwerij Espérance).

158 Een toepassing van de bevoegdheden als daadwerkelijk toezicht op de naleving van de materiele kartelbepalingen ligt daarenboven niet voor de hand als men bedenkt dat de Commissie, en meer in het bijzonder het Directoraat-GeneraallV, kampt met capaciteitsproblemenen een daarmeesamenhangende grote werkdruk; vergelijk De Raat (1994), pag. 11.

159 Zie in dit verband Joshua (1982), pag. 180: "the use of the word 'necessary' must simply refer in a broad sense to the Commission's accomplishment of the tasks assigned to it by the Treaty and bears a meaning more akin to 'relevant to the application of competition rules'".

160 Joshua (1986), pag. 415. 
aas het Gerecht ${ }^{161}$ worden voorgelegd (hetzij in het kader van een beroep tegen een inlichtingenbeschikking van de Commissie, hetzij in het kader van een boeteprocedure wegens overtreding van de verplichtingen ex artikel 11 lid 1 en 5 Vo 17 dan wel het materiēle recht), maar de rechterlijke toetsing zal op dit punt slechts marginaal zijn. ${ }^{162}$ Debeperking tot een marginale toetsing hangt samen met de beleidsvrijheid die de Commissie heeft bij de uitoefening van haar taak. De communautaire rechter zal slechts dan ingrijpen, indien de Commissie niet in redelijkheid heeft kunnen overgaan tot het inlichtingenverzoek dan wel inlichtingenbeschikking en de grenzen van de proportionaliteit heeft overschreden. De Commissie zou in het kader van haar inlichtingeninwinning aan de onderneming duidelijk moeten maken waarom volgens haar de gevraagde inlichtingen noodzakelijk zijn. Dit is van belang met het oog op de rechtspositie van de onderneming dieslechts bij een voldoende concretisering van het noodzakelijkheidsvereiste het door has tegenover de Commissie in te nemen standpunt kan bepalen en de kansen van een eventueel beroep (voor zover mogelijk) tegen de Commissiebeslissing kan inschatten. ${ }^{163}$ Hoe ruim overigens de bevoegdheid tot het inwinnen van inlichtingen ook moge zijn, zij gaat de Commissie nog niet ver genoeg. Uit het 'Voorstel uitvoeringsverordening' (meer in het bijzonder artikel 19) blijkt dat zij behoefte heeft aan de bevoegdheid om natuurlijke of rechtspersonen te horen en hun verklaringen op te tekenen teneinde deze eventueel later als bewijs in de betreffende zaak te kunnen gebruiken. In tegenstelling tot het in paragraaf 3.3 .5 te bespreken voorstel tot verruiming van het betredingsrecht van de Commissie, betreft het hier een logische en wenselijke aanvulling op de bevoegdheden van de Commissie in kartelzaken.

Hierboven is gesteld dat aan de Commissie de bevoegdheid toekomt om, voorzover gewenst en noodzakelijk, inlichtingen in te winnen. Deze stelling is in zoverre onvolledig dat artikel 11 Vo 17 in feite twee verschillende, zij het nauw met elkaar verband houdende bevoegdheden ter informatievergaring bevat, te weten het eenvoudige verzoek om inlichtingen aan de ene kant en de beschikking bij welke die inlichtingen worden opgeëist aan de andere. Het belangrijkste verschil tussen beide varianten bestaat hierin dat in het geval van een verzoek de geadresseerde in beginsel niet verplicht is te antwoorden, terwijl de inlichtingen wel moeten worden verstrekt indien zij bij beschikking zijn verlangd. Beide varianten zullen hieronder nader worden besproken. Allereerst zal echter worden bezien wie de geadresseerden zijn van het verzoek respectievelijk de beschikking.

\subsubsection{De geadresseerden}

De groep potentiële geadresseerden van het verzoek respectievelijk de beschikking ex artikel 11 Vo 17 weerspiegelt de ruime reikwijdte van de in dit artikel vervatte bevoegdheid en accentueert het doel dat met deze wordt beoogd. Met name ten aanzien van het

161 Vergelijk de president van het Gerecht in GvEA (T-39/90 R) Jur. 1990, 11-655 (SEP): dat "de beoordeling van deze noodzaak evenwel onderworpen (blijft) aan de toetsing van het Gerecht".

162 Vergelijk Joshua (1982), pag. 180-181. Anders: Gillmeister (1985), pag. 132.

163 Kahlhom (1986), pag. 7. Deze schrijver stelt dat de Commissic onvoldoende te kennen geeft waarom zij de informatie noodzakelijk acht als gevolg waarvan de ondernemingen niet kunnen controleren of het optreden van de Commissie proportionecl is. 
verzoek om inlichtingen is deze groep zeer uitgebreid. De Commissie kan haar verzoek richten zowel tot regeringen en de bevoegde (kartel)autoriteiten van de lidstaten ${ }^{164}$ als ook tot ondernemingen en ondernemersverenigingen. De inlichtingenbeschikking daarentegen kan slechts worden gegeven ten aanzien van ondernemingen en ondernemersverenigingen. Dit onderscheid hangt samen met het dwingende karakter van de beschikking. De Raad achtte het -mede met het oog op de later te bespreken gevolgen- niet wenselijk de overheid van de lidstaten bij beschikking te gelasten informatie te verstrekken. Een verzoek is bovendien in beginsel voldoende als dit gericht is tot regeringen en kartelautoriteiten van de lidstaten: zij moeten hoewel dit niet onmiddellijk uit Verordening 17 volgt aan het verzoek voldoen. Deze verplichting houdt voornamelijk verband met de uit artikel $10 \mathrm{EG}$ voortvlociende verplichting een actieve bijdrage te leveren aan de verwezenlijking van de doelstellingen van het Verdrag. Het Verdrag kent op deze verplichting een uitzondering: artikel 296 lid 1 sub a EG stelt namelijk uitdrukkelijk dat een lidstaat die inlichtingen mag weigeren "waarvan de verbreiding naar zijn mening strijdig zou zijn met de wezenlijke belangen van zijn veiligheid". Het moge duidelijk zijn dat vanuit het oogpunt van 'gemeenschapstrouw' door een lidstaat niet te snel mag worden aangenomen dat informatieverstrekking in strijd komt met de eigen belangen. ${ }^{165}$

De Commissie kan zoals gezegd haar verzoek en de beschikking tevens richten aan ondernemingen en ondernemersverenigingen, en wel iedere economische entiteit waarvan de Commissio vermoodt dat zij relevante informatie kan verstrekken. ${ }^{166}$ Op het moment van de inlichtingenbeslissing is het niet van belang of reeds voldoende vaststaat dat elk der bij het vermoedelijke kartel betrokken partijen als onderneming is aan te merken: relevant is slechts of de geadresseerde de status van onderneming heef. ${ }^{167}$ Voor zover er al cen verdenking is gerezen, hoeft de Commissie zich niet te beperken tot de verdachte onderneming. Zo kan de Commissie een onderneming die een klacht heeft ingediend tegen concurrenten die zich volgens de onderneming schuldig maken aan kartellering, met gebruikmaking van de bevoegdheid ex artikel 11 Vo 17 officieel verzoeken (aanvullende) inlichtingen te verschaffen. Nu de hier centraal staande bevoegdheid ook tegen derde ondernemingen $^{168}$ uitgeoefend kan worden, heeft artikel 11 Vo 17 (nog afgezien van de mogelijkheid een verzoek tot de lidstaten te richten) een ruimer bereik dan artikel

164 Het gegeven dat de bevoegdheid ook kan worden aangewend tegenover de autoriteiten van de lidstaten onderstreept dat artikel 11 Vo 17 voornamelijk is bedoeld om toezicht te houden op de naleving van het materiēle recht. De in Nederland bevoegde autoriteit was tijdens de Wem het ministerie van Economische Zaken en meer in het bijzonder de Direetie Marktwerking; heden ten dage is de Nederlandse Mededingingsautoriteit de instantie tot welke de Commissie zich met een inlichtingenverzoek kan richten.

165 Mocht een lidstaat inderdaad niet coöperatief blijken te zijn, dan staat voor de Commissie op grond van artikel $226 \mathrm{EG}$ de weg open naar het Hof. De lidstaat zal zich dan moeten verantwoorden wegens het niet-nakomen van de op hem rustende verdragsverplichtingen.

166 In dit geval is de Commissie op grond van het tweede respectievelijk zesde lid van artikel II Vo 17 , verplicht een afschrift te zenden aan de nationale autoniteit van de lidstaat waarbinnen de rechtspersoon waaraan het verzoek c.q. de beschikking is gericht, is gevestigd. Daar deze verplichting betrekking heeft op de relatie Commissie/lidstaat, zal verzuim ervan niet door de onderneming kunnen worden aangegrepenom met succes vernietiging van de betreffende Commissiemaatregelte bewerkstelligen.

$167 \mathrm{~Pb} 1978$ L $157 / 39$ (RALUNITEL).

168 En zelfs tegenover ondernemingen die niet in de EG gevestigd zijn. Het probleem is hier echter dat de uiteindelijke effectuering van het verzoek bij een weigerachtige ondememing niet mogelijk is; vergelijk Joshua (1982), pag. 175. 
$81 \mathrm{EG}$, dat zich immers uitsluitend richt tot ondernemingen die zich schuldig maken aan overtreding van de kartelregels. Dit verschil is voor Debruyne aanleiding om te stellen, dat het begrip 'onderneming' in artikel 11 Vo 17 ruimer is dan dit begrip in artikel 81 EG. ${ }^{169}$ Het maken van een dergelijk inhoudelijk onderscheid lijkt mij. gezien de nauwe samenhang tussen de artikelen 11 Vo 17 en 81 EG, niet alleen ongewenst, maar bovendien gezien de teksten en strekking van beide artikelen niet noodzakelijk. ${ }^{170}$ Mijns inziens heeft het begrip 'onderneming' zowel in artikel $81 \mathrm{EG}$ als in artikel 11 Vo 17 betrekking op in beginsel alle economische entiteiten. Op grond van artikel 81 EG dient iedere economische entiteit zich te onthouden van gedrag dat de interstatelijke handel en de conmunautaire mededinging beĭnvloedt of kan beînvloeden en op grond van artikel 11 Vo $17 \mathrm{kan}$ in het kader van handhaving van het kartelverbod van iedere economische entiteit informatie worden verlangd. In zoverre zijn dus de geadresseerden van beide bepalingen identiek. Dit laat onverlet dat bij gebleken overtreding van artikel $81 \mathrm{EG}$ met betrekking tot het kartelverbod als zodanig slechts die economische entiteiten van belang zijn die in het kartel hebben geparticipeerd, terwijl ten aanzien van de bevoegdheid genoemd in artikel 11 Vo 17 gelet op een goede handhaving van het Verdrag een beperking tot die groep van ondernemingen niet alleen niet noodzakelijk maar zelfs contra-productief zouzijn. Een effectieve handhaving en taakvervulling brengt juist mee dat de Commissie bij iedere onderneming waarvan redelijkerwijs verwacht kan worden dat zij over relevante gegevens beschikt, inlichtingen kan inwinnen. ${ }^{171}$

Wordt het verzoek om inlichtingen gericht aan een onderneming, dan geeft het vierde lid van artikel 11 Vo 17 aan welke personen binnen deze onderneming de gevraagde inlichtingen moeten verstrekken; dit zijn "de eigenaren van een onderneming of degenen die hen vertegenwoordigen, en, in het geval van rechtspersonen en van vennootschappen en verenigingen zonder rechtspersoonlijkheid: degenen die volgens de wet of de statuten belast zijn met de vertegenwoordiging". ${ }^{172}$ De ratio van deze bepaling is dat die personen van welke verwacht mag worden dat zij het beste op de hoogte zijn van hetgeen in de onderneming gebeurt en die verantwoordelijk zijn voor de handelingen van de onderneming, de informatie verstrekken; van de aldus verkregen informatie mag worden aangenomen dat zij correct en 'up to date' is en een volledig antwoord vormt op de vragen van de onderneming. Het mes van artikel 11 lid 4 Vo 17 snijdt echter aan twee kanten. Niet alleen de Commissie is bij de geboden regeling gebaat; ook de onderneming kan ervan profiteren. Zij staat immers in voor de juistheid van de verstrekte informatie en draagt de consequenties indien de verklaringen en gegevens niet de ware situatie weergeven. Deze consequenties worden niet alleen gevormd door mogelijke sancties die de onderneming wegens het verstrekken van onjuiste informatie kunnen worden opgelegd, maar

169 Debruyne (1992), pag. 20.

170 Ook Kerse (1998), pag. 114, acht het waarschijnlijk, dat de inhoud van het begrip 'onderneming' in de bedoelde bepalingen overeenstemt.

171 Hetgeen zij in de praktijk ook doet, zoals Joshua reeds in 1982 constateerde: Joshua (1982), pag. 174.

172 Het 'Voorstel uitvoeringsverordening' voegt daarnog aantoe: "Naar behorengemachtigdeadvocaten kunnennamenshun opdrachtgeversdegevraagdeinlichtingenverstrekken. De opdrachtgeversblijven ten volle voor de volledigheid, juistheid en oprechtheid van de verstrekte inlichtingen verantwoordelijk". Ik vraag mij overigens af of 'oprechtheid van de inlichtingen' vanuit Nederlands-technischoogpunt wel zo gelukkig gekozen is. 
bovendien door de mogelijkheid dat de onjuiste informatie de Commissie ten onrechte tot de voorlopige conclusie brengt dat er mogelijk sprake is van schending van artikel 81 EG. In dit geval zou de Commissie kunnen overgaan tot verdere stappen, bijvoorbeeld het gelasten van een verificatie of zelfs het inleiden van een procedure wegens vermeende overtreding van artikel $81 \mathrm{EG}$, terwijl de reële situatie tot deze stappen geen aanleiding geeft. Of de onderneming aan artikel 11 lid 4 Vo 17 voldoet, wordt grotendeels aan haar overgelaten: de Commissie toetst in beginsel niet of de persoon die haar te woord staat of die haar de bescheiden heeft doen toekomen tot de in genoemd artikellid genoemde groep personen behoort. ${ }^{173}$ Van belang is slechts of de informatie correct is; het verstrekken van juiste informatie door een niet bevoegd persoon levert dan ook geen problemen op. Het tegendeel is het geval indien onjuiste informatie wordt verstrekt door personen die niet op de hoogte zijn van alle details van de overeenkomsten of gedragingen waarop het inlichtingenverzoek betrekking heeft: de onderneming zal zich dan niet kunnen disculperen door te wijzen op de ondeskundigheid van de betreffende persoon. ${ }^{174}$

\subsubsection{Het verzoek en de beschikking om inlichtingen}

Artikel 11 Vo 17 maakt, zoals reeds gesteld is, onderscheid tussen het verzoek om inlichtingen en de beschikking waarbij inlichtingen worden opgetist. Het typische van het inlichtingenverzoek ${ }^{175}$ bestaat er in dat de onderneming (waaronder hierna tenzij anders vermeld tevens wordt verstaan de ondernemersvereniging) iedere medewerking kan weigeren zonder bevreesd te hoeven zijn voor directe consequenties in de vorm van boetes. $\mathrm{Zij}$ is niet verplicht tot antwoorden of tot het verstrekken van de opgevraagde documenten. De onderneming zal indien haar een verzoek conform artikel 11 lid 1 Vo 17 bereikt haar positic in het onderzoek moeten bepalen, waarbij zij de keuze heeft tussen twee extremen: aan de ene kant is dit de weigering aan het verzoek te voldoen; aan de andere kant is het de coöperatie in het onderzoek. Zo extreem als deze tegenstelling lijkt, is zij in praktijk ook daadwerkelijk. Cő̈peratie houdt volledige medewerking in: de onderneming zal iedere gewenste informatie moeten verschaffen en zal geen essentiële details mogen achterhouden. ${ }^{176}$ Dit geldt ook indien de onderneming te kennen geeft dat volgens haar de gewenste informatie van geen belang is voor de beantwoording van de bij de Commissie gerezen

173 Vergelijk met betrekking tot cen verificatie $\mathrm{Pb} 1980 \mathrm{~L}$ 75/30 (Fabbricapisana), waarin de Commissie overwoog "dat het geenszins op de weg van de met de verificatic belaste inspecteurs van de Commissie ligt om de bevoegdheid of de omvang van de wetenschap van de vertegenwoordigers van de (ondernemingen) te beoordelen of aan te vechten".

174 Dat het belasten van personen met de beantwoording van commissievragen in de risicosfeer van de onderneming ligt, blijkt ook uit $\mathrm{Pb} 1986$ L 295/19 (Peugeot). Hierin werd het verweer van Peugeot dat de verstrekking van onjuiste inlichtingen te wijten was aan het feit dat de verstrekkende personen niet alle feiten kenden, verworpen met de overweging dat de onderneming ten minste een onvoldoende mate van toezicht "om een valse verklaring te verhinderen" kon worden verweten. De Commissie concludeerde dan ook tot een inbreuk uit onachtzaamheid.

175 De onderneming hoeft niet in de gelegenheid te worden gesteld zich mondeling over de eventueel tegen haar gerezen verdenking uit te laten, alvorens een inlichtingenverzoek tot haar kan worden gericht: het recht gehoord te worden komt de onderneming pas toe nadat de Commissie tegen haar punten van bezwaar heeft opgesteld. Zie ook Kerse (1995 II), pag 860 e.v..

176 Tenzij zij een beroep doet op het legal privilege of het nemo tenetur-beginsel. In hoeverre een dergelijk beroep kans van slagen heeft, zal in hoofdstuk 5 blijken. 
vrag of dat de overeenkomst in de optiek van de ondememing geen communautair karakte heeft. ${ }^{17}$. Evenmin mag zij foutieve of misleidende antwoorden verstrekken. ${ }^{178}$ De ratio hiervan is dat de Commissie ervan moet kunnen uitgaan dat de verklaringen van een onderneming waarheidsgetrouw zijn. De effectiviteit van het onderzoek gebiedt dat niet iedere verklaring in twijfel moet worden getrokken.

Blijkt een onderneming niet bereid medewerking te verlenen of verstrekt zij onvolledige of niet-correcte informatie, dan kan de Commissie overgaan tot het verlangen van de betreffende inlichtingen bij beschikking op grond van het vijfde lid van artikel 11 Vo 17..$^{179}$ Gevolg hiervan voor de onderneming is dat zij verplicht is de informatie te verstrekken. De onderneming die een verzoek om inlichtingen niet (volledig of naar warheid) beantwoordt, kan dus een beschikking verwachten. Minstens zo belangrijk is echter de constatering dat het inlichtingenverzoek het noodzakelijke voorportaal naar de beschikking is. De Commissie mag met andere woorden pas overgaan tot het opeisen van inlichtingen door middel van een beschikking nadat zij de onderneming een adequate gelegenheid heeft geboden de inlichtingen vrijwillig te verstrekken en de onderneming van deze gelegenheid geen gebruik heeft gemaakt: ook hier heeft het evenredigheidsbeginsel zijn stempel op de bevoegdheden gedrukt.

Voor een goed begrip van de bevoegdheid van artikel 11 Vo 17 in het bijzonder en de communautaire handhavingsbevoegdheden op kartelgebied in het algemeen is de constatering van belang dat primair de medewerking van de ondernemingen wordt beoogd. Niet het zelfstandige optreden van de Commissie staat centraal, maar de coöperatie van ondernemingen. De verzoeken en beschikkingen, genoemd in de artikelen 11 en 14 Vo 17, zijn dan ook in de eerste plaats (al dan niet bindende) opdrachten aan de ondernemingen de gewenste medewerking te verlenen. Artikel 11 Vo 17 kent in dat verband de bijkomende bijzonderheid dat de Commissie verplicht is eerst de onderneming op vrijwillige basis te laten meewerken. Is -in geval van een beschikking-een onderneming verplicht mede te werken, dan blijft er voor haar nauwelijks ruimte om gewenste informatie achter te houden. Zo zal zelfs een onderneming, die bij bekendmaking van bepaalde gegevens gevaar loopt door een nationale instantie wegens schending van een openbaarmakingsverbod vervolgd te worden, niet met succes de verstrekking van informatie kunnen weigeren. $^{180}$

177 Aldus uitdrukkelijk de Commissie in Pb 1971 L. 34/13 (CICG-ZVEI/ZPO): Overwegende "dat een ondememing die een verzoekom inlichtingen over een overeenkomstheeft ontvangen het verstrekken van deze inlichtingen niet kan weigeren met een beroep op het feit dat de overeenkomst naar haar oordeel geen invloed op de handel tussen Lid-Staten heeft". In vergelijkbare bewoordingen $\mathrm{Pb} 1978$ L. 157/39 (RAI/UNITEL). In Pb 1983 L 114/26 (DeutscheCastrol) voerde de betrokken ondememing eveneens aan dat haar overeenkomst de interstatelijke handel niet negatief beinvloedde. In deze zaak volstond de Commissie niet met de voornoemde (standaard)motivering, maar ging inhoudelijk in op het (overigens foutieve) standpunt van de onderneming.

$178 \mathrm{Bij}$ de bespreking van de mogelijk op te leggen boetes zal uiteen worden gezet dat het Hof het begrip 'onjuiste informatic' ruim (en zodoende in het nadeel van de onderneming) interpreteert.

179 De noodzank tot het geven van cen inlichtingenbeschikking deed zich het eerst voor in 1971. Vergelijk hieromtrent het Eerste verslag over het mededingingsbeleid, nr. 124. Voor verdere beschikkingen zie onder meer Pb 1971 L 34/13 (CICG-ZVEI/ZPO), Pb 1971 L 254/15 (SIAE), Pb 1976 L 192/27 (Centraal Stikstof Verkoopkantoor) en Pb 1983 L 114/26 (Deutsche Castrol).

$180 \mathrm{~Pb} 1976$ L $192 / 27$ (CSV). 


\subsubsection{De inhoud van het verzoek en de beschikking om inlichtingen}

Het verschil in rechtsgevolg tussen verzoek en beschikking vindt zijn weerslag in de inhoud van het schrijven waarin de Commissie haar 'wensen' formuleert. Het derde lid van artikel 11 Vo 17 heeft betrekking op het eenvoudige verzoek en legt de Commissie op dat deze in haar verzoek -naast vanzelfsprekend de opsomming van de door haar gewenste informatie- aangeeft op welke rechtsgrond haar verzoek is gebaseerd en welk doel het verzoek dient. ${ }^{181}$ De Commissie dient derhalve haar verzoek te motiveren teneinde de geadresseerde niet in onwetendheid te laten omtrent de reden van het verzoek en om hem in de gelegenheid te stellen een afweging te maken omtrent het al dan niet verlenen van medewerking aan het onderzoek. Voorts eist artikel 11 lid 3 Vo 17 dat de Commissie in het schriftelijke verzoek de onderneming attendeert op de potentiële boetes die opgelegd kunnen worden wegens het verstrekken van onjuiste gegevens. Tenslotte kan uit het vijfde lid van bedoeld artikel worden afgeleid dat de Commissie een redelijke termijn voor beantwoording van het verzoek moet stellen.

Voldoet een onderneming binnen de gestelde termijn niet of niet volledig aan het verzoek, dan kan de Commissie overgaan tot het gelasten van verstrekking van de informatie. Gelet op de dwingende volgorde van artikel 11 Vo $17 \mathrm{zal}$ de Commissie in ieder geval bij beschikking geen andere of verdergaande inlichtingen mogen verlangen dan waarom zij in eerste instantie verzocht heeft. Het systeem van artikel 11 Vo 17 met de daaraan inherente mogelijkheid voor de onderneming te opteren voor vrijwillige medewerking zou anders doorbroken worden. Naast deze inlichtingen dient de beschikking het volgende te bevatten: de gevraagde inlichtingen, een redelijke termijn waarbinnen deze verstrekt moeten worden, een verwijzing naar de sancties die de onderneming bij nietmedewerking opgelegd kunnen worden en de vermelding van het recht van de onderneming om tegen de beschikking bij het Hof (in de praktijk het Gerecht van Eerste Aanleg) in beroep te gaan. In tegenstelling tot het derde lid van artikel 11 Vo 17 verplicht lid vijf niet tot het vermelden van de rechtsgrond en het doel van de beschikking. Door het voorafgaande verzoek zal de onderneming in beginsel hiervan op de hoogte zijn; desalniettemin lijkt het raadzaam doel en rechtsgrond ook in de beschikking op te nemen.

Deze inhoudelijke vereisten zijn van belang zowel vanuit het oogpunt van een goede handhaving van het Verdrag als ook vanuit de optiek van de rechtsbescherming van de ondernemingen. De duidelijke vermelding van de gewenste informatie en het aangeven van een termijn moet ertoe leiden dat de Commissie de door haar noodzakelijk geachte gegevens binnen een redelijke tijdspanne verkrijgt opdat zij effectief toezicht kan houden op de naleving van de materięle kartelbepalingen. Voor de betrokken ondernemingen is het van belang te weten welke informatie precies van haar verlangd wordt en welke consequenties een eventuele weigering zou kunnen meebrengen. Voorts is het wezenlijk

181 Hetmet een inlichtingenverzoek beoogde doel kan overigens in zeeralgemene bewoordingen worden vervat. Zo werden in een inlichtingenverzoek, gericht aan The Scottish Football Association, de gestelde vragen door de Commissie van belang geacht teneinde "het onderzoek met volledige kennis van de feiten en in de juiste economische context" te kunnen verrichten; GvE.A (T-46/92) Jur, 1994, II-1044. In eeninlichtingenverzoekaandeSamenwerkendeElektriciteits-produktiebedrijvenNV was de reden voor het stellen van vragen "de verenigbaarheidte (kunnen) beoordelen van (de) overeenkomst(en) met de mededingingsregels van het EEG-Verdrag, in het bijzonder artikel 85 (thans 81 EG, HQ). basis van een volledige kennis van de feiten en hun economische samenhang"; beschikking van de president van het Gerecht, GvEA (T-39/90 R) Jur. 1990, II-649. 
dat de onderneming op haar rechtspositie wordt gewezen, opdat zij weet welke stappen zij kan ondernemen voor het geval dat zij bezwaren heeft tegen de tot haar gerichte beschikking.

\subsubsection{Sancties}

Hiervoor is verschillende malen gewezen op de mogelijkheid van een sanctie als een onderneming niet of niet volledig tot medewerking overgaat. Ook hier geldt dat de boetemogelijkheden afhankelijk zijn van de aard van het optreden van de Commissie. Weigert een onderneming te antwoorden op een inlichtingenverzoek, dan staan de Commissie behoudens de weg van de beschikking-geen (sanctie)mogelijkheden open: het verdraagt zich niet met het niet-dwingende karakter van het verzoek indien een weigering hierop in te gaan een sanctie tot gevolg zou kunnen hebben. Een bescherming tegen sancties ontbreekt daarentegen voor die gevallen waarin een onderneming niet-correcte informatie verschaft. ${ }^{182}$ De boetebevoegdheid in deze gevallen ligt verankerd in artikel 15 lid 1 sub b Vo 17: de onderneming die opzettelijk dan wel uit onachtzaamheid onjuiste inlichtingen verschaft, kan worden veroordeeld tot betaling van een boete variërend van minimaal honderd tot maximaal vijfduizend rekeneenheden. ${ }^{183}$ Deze regeling is voor de hand liggend indien men bedenkt dat een onderneming het verzoek naast zich neer kan leggen zonder enige sanctie te vrezen. Besluit zij echter tot een coöperatieve houding, dan zal zij de Commissie (al dan niet opzettelijk) geen foutieve informatie mogen doen toekomen, aangezien de Commissie hierdoor mogelijk een niet-correct beeld van de situatie krijgt. In dit laatste geval zou zij juist ten gevolge van verklaringen en andere informatie van de zijde van ondernemingen haar taak als toezichthouder niet op een goede wijze kunnen uitoefenen. ${ }^{1 / 4}$ De sanctiedreiging is dan ook met name bedoeld als een aansporing om correcte informatie te verstrekken. Gezien de hoogte van de sancties zal de preventieve werking ervan wellicht niet overschat mogen worden. Men dient echter te bedenken dat deze boete niet het enige middel is om (uiteindelijk) de noodzakelijk geachte en juiste informatie te verkrijgen. Voor zover het beschikkingen betreft, zijn de sanctiemogelijkheden uitgebreider. Dit geldt zowel ten aanzien van de gevallen waarin een sanctie kan worden opgelegd als ten aanzien van de aard van de op te leggen sanctie. Met betrekking tot de gevallen kan worden geconcludeerd dat niet alleen het verstrekken van onjuiste informatie aanleiding kan zijn voor een sanctie, maar bovendien het in het geheel niet voldoen aan de beschikking: weigert de onderneming medewerking dan kunnen haar

182 Ortiz Blanco (1996), pag. 112 wijst erop dat "at this first stage the Commission cannot impose a penalty for total failure to reply or partial failure (incomplete answers)". Dat deze conclusic maar ten dele opgaat, zal blijken bij de bespreking van de term 'onjuiste inlichting'.

183 Het 'Voorstel uitvoeringsverordening' voorziet in een (aanmerkelijke) verhoging van de sanctic, omdat de huidige boetes niet meer afschrikkend zouden zijn. De Commissie staat (blijkens artikel 22) een boete van maximaal $1 \%$ van de omzet, behaald in het voorafgaande boekjaar, voor ogen; het minimum komt dan overigens te vervallen.

184 Het risico dat door verstrekking van onjuiste inlichtingen een incorrect beeld van de werkelijkheid wordt gegeven, wordt door de Commissie als een belangrijke indicatie gerien voor de strafwaardigheid van een de onderneming van welke de inlichtingen afkomstig zijn; zie de overwegingen van de Commissie in Pb 1982 L I13/20 (National Panasonic Belgium) en Pb 1991 L. 35/23 (Secrétama), welke zaak betrekking had op verordening 4056/86. 
sancties worden opgelegd. De mogelijke sancties zijn in dat geval hetzij een boete wegens de begane inbreuk, hetzij een dwangsom teneinde de onderneming alsnog tot volledige coőperatie te dwingen, hetzij een combinatie van beide.

De boete kan worden opgelegd wegens het opzettelijk of uit onachtzaamheid niet of niet tijdig verstrekken van de gewenste inlichtingen of het geven van een onjuist antwoord op de beschikking. De boete is gelijk aan die welke kan worden opgelegd wegens het verschaffen van incorrecte inlichtingen op een verzoek. Uit de beschikkingspraktijk blijkt dat de Commissie veelal overgaat tot oplegging van de maximale sanctie in geval van een onjuiste inlichting ${ }^{135}$, hetgeen niet vreemd is gelet op de relatief geringe hoogte van deze maximumboete en op de mogelijke schade die de onjuiste inlichting kan berokkenen aan het onderzoek naar het kartelmatige gedrag.

Een directere weg de onderneming alsnog te bewegen tot volledige medewerking is die van de dwangsom. In artikel 16 lid 1 sub c is neergelegd dat de Commissie bij beschikking een dwangsom kan opleggen van minimaal vijftig en maximaal duizend rekeneenheden voor iedere dag dat de onderneming in verzuim blijft de gewenste inlichtingen te verstrekken. ${ }^{186}$ De Commissie kan bij oplegging van de dwangsom uit twee opties kiezen. Ten eerste kan zij afwachten of de onderneming binnen de gestelde termijn voldoet aan de uit de inlichtingenbeschikking voortvloeiende verplichtingen. Verzuimt de onderneming

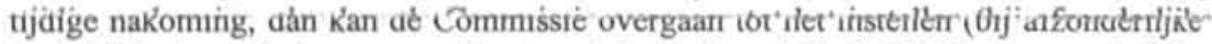
beschikking) van de dwangsom. Ten tweede kan zij onmiddellijk bij de oorspronkelijke inlichtingenbeschikking de dwangsom instellen als gevolg waarvan de dwangsom is verschuldigd vanaf het moment, waarop de termijn waarbinnen aan de verplichtingen moet zijn voldaan, is verstreken. ${ }^{187}$ In beide gevallen zal de Commissie overigens het uiteindelijk verschuldigde bedrag bij beschikking moeten vaststellen, waarbij zij de hoogte nog ten gunste van de onderneming wegens omstandigheden van het geval kan aanpassen. ${ }^{188}$

185 Men vergelijke Pb 1982 L. $27 / 31$ (Comptoir commercial d'importation), Pb 1982 L. 58/19 (Telos), $\mathrm{Pb} 1982$ L. 211/32 (National Panasonic France), Pb 1982 L 113/18 (National Panasonic Belgium) en Pb 1991 L. 35/23 (Secrétama). Slechts 3.000 euro werd opgelegd in $\mathrm{Pb} 2000 \mathrm{~L} 49 / 37$ (AnheuserBusch), en wel omdat het een inbreuk uit onachtzaamheid betrof en de ondememingen voor het overige wel met de Commissie hadden samengewerkt.

186 Ook hier meent de Commissie dat verhoging noodzakelijk is. Artikel 23 'Voorstel uitvoeringsverordening' voorziet in een dwangsom van ten hoogste $5 \%$ van de gemiddelde dagelijkse ormzet in het voorafgaande boekjaar voor iedere dag dat de onderneming in gebreke blijft.

187 Voor de tweede optie werd door de Commissie geopteerd in haar beschikking tegen het Centraal Stikstof Verkoopkantoor, $\mathrm{Pb} 1976$ L 192/27, waarin de Commissie een dwangsom van 1.000 rekencenheden aan niet tijdige nakoming verbond. Zie ook GvEA (T-46/92), 1994, II-1046 (The Scottish Football Association), waaruit blijkt dat de Commissie een dwangsom ter hoogte van 500 rekeneenheden geîndiceerd achtte.

188 In $\mathrm{Pb} 1991$ L. $97 / 16$ (Bacearat) werd het uiteindelijk verschuldigde bedrag aanmerkelijk verlaagd (van 43.000 ecu naar $10.000 \mathrm{ecu}$ ), onder meer omdat de onderneming (op grond van een door hast getroffen schikking met de klaagster) meende niet meer tot antwoorden verplicht te zijn en omdat zij onderstreepte dat zij zich niet aan haar verplichtingen had willen onttrekken. 


\section{3:.5 Onjuiste inlichtingen}

Ht belang van een correct antwoord voor de handhaving van het communautaire recht exrzijs en voor de onderneming -gelet op de sanctiedreiging-anderzijds, werpt de vraag ofwat onder een onjuiste inlichting in de zin van artikel $15 \mathrm{Vo} 17$ moet worden verstaan. D Commissie opteert in deze voor een zeer ruime uitleg van dit begrip en gaat uit van ee mondige onderneming die in staat is het verzoek om c.q de beschikking tot verkrijging va inlichtingen in een brede context te plaatsen en de portee van de vragen van de Commissie juist in te schatten. In Telos omschreef de Commissie bedoeld begrip als "idere inlichting, die van de situatie waarop de vraag betrekking heeft een verwrongen beld geeft, dat op belangrijke punten sterk van de werkelijkheid afwijkt. Wanneer de inormatie derhalve vals of zozeer onvolledig is, dat het antwoord in zijn geheel de Commssie over de werkelijke feiten kan misleiden, is er sprake van een "onjuist antwoord" inie zin van artikel 15 lid 1 , sub b)" ${ }^{159}$ Duidelijk is derhalve dat onder omstandigheden oc het niet-volledig coöpereren in het geval van een verzoek om inlichtingen als het vestrekken van een onjuist antwoord kan worden beschouwd. Hiervoor is noodzakelijk da over het geheel genomen de naar aanleiding van het verzock verstrekte informatie ee incorrect beeld geeft van de daadwerkelijke situatie; de enkele omstandigheid dat beaalde (relevante) informatie niet is verstrekt, kan derhalve niet leiden tot cen boete. .Heruit volgt dat een onderneming de nodige voorzichtigheid zal moeten betrachten bij de beantwoording van een inlichtingenverzoek dan wel beschikking: het welbewust weglaten van antwoorden die voor haar belastend kunnen zijn in combinatie met de accentuering van gunstige informatie, zou een boete wegens het verschaffen van onjuiste informatie kunnen opleveren. De noodzaak tot behoedzaamheid wordt onderstreept door de visie van de Commissie dat "als antwoord op een verzoek om inlichtingen moeten worden beschouwd niet alleen de antwoorden op de concrete door de Commissie gestelde vragen, maar tevens alle verstrekte inlichtingen die buiten het eigenlijke kader van de vragen vallen, alsmede alle gegevens die door de ondememingen ongevraagd werden medegedeeld, die niet in direct verband staan met de specifieke vragen, die door de Commissie werden gesteld". ${ }^{190}$ Alle inlichtingen van de zijde van de onderneming naar aanleiding van een (al dan niet dwingend) verzoek ex artikel 11 Vo 17 zullen dientengevolge correct moeten zijn ongeacht of zij strikt genomen zijn te beschouwen als een antwoord op het betreffende verzoek. ${ }^{191}$ De onderneming zal zich aldus terdege bewust moeten zijn omtrent wat van haar verlangd wordt en zij aan de wensen van de Commissie, voor zover

$189 \mathrm{~Pb} 1982 \mathrm{~L} \mathrm{58/21}$ (Telos). Ook in Pb $1982 \mathrm{~L} 211 / 35$ (National Panasonic France) gaat de Commissic van deze ruime omschrijving uit. Het verweer van de onderneming dat haar antwoord onvolledig maar niet onjuist was, werd niet aanvaard; "Het verstrekte antwoord was bedoeld te worden aanvaard als een volledig antwoord op het verzoek van de Commissie en zou inderdaad als zodanig zijn aanvarud (...) indien er geen bewijzen van het tegendeel voorhanden waren geweest". Met het onvolledige antwoord werd getracht de Commissie op het verkeerde been te zetten, waardoor het antwoord als onjuist kon worden aangemerkt.

$190 \mathrm{~Pb} 1982$ L. $27 / 34$ (Comptoir commercial d'importation). Cath (1987), pag 52, acht deze benadering van de Commissie, die inhoudt dat een onjuist antwoord kan worden gegeven op een niet gestelde vraag, minder juist. Hij opteert voor de in de Telos-beschikking gevolgde weg, waarin verstrekking van niet met de waarheid strokende inlichtingen als (al dan niet opzettelijke) misleiding van de Commissie kan worden aangemerkt.

191 In deze zin ook Ortiz Blanco (1996), pag. 151. 
deze binnen de bevoegdheid ex artikel 11 Vo 17 vallen en voorzover zij redelijk zijn, moeten voldoen. ${ }^{192}$ Aan de andere kant brengt deze regeling voor de Commissie de plicht met zich de door haar gewenste inlichtingen zo nauwkeurig mogelijk te omschrijven teneinde misverstanden aan de zijde van de geadresseerde ondernemingen zoveel mogelijk te voorkomen. ${ }^{193}$

\subsection{Het verrichten van verificaties}

Het verzoek respectievelijk de beschikking om inlichtingen op grond van artikel $11 \mathrm{~V}_{0}$ 17 leveren niet steeds het gewenste resultaat op. Hoewel de onderneming in geval van een beschikking op straffe van een boete of dwangsom verplicht is de gevorderde informatie te verschaffen, staat met deze beschikking nog niet vast dat de onderneming alle informatie ook daadwerkelijk aan de Commissie overdraagt. Noch de boete noch de dwangsom die bij weigering van de onderneming kunnen worden geëffectueerd, zijn van dien aard dat zij een draagkrachtige onderneming ervan afschrikken informatie achter te houden, temeer daar de uiteindelijke consequentie van een veroordeling, een boete ter hoogte van maximaal tien procent van de jaaromzet van de onderneming, vele malen ingrijpender is. Een onderneming die beseft dat informatieverschaffing tot een hoge boete wegens kartelovertreding zal lèdèn, zal wellicht opteren voor een miet-cooperatieve tiouding in het onderzoek, de boetes wegens overtreding van de formele verplichtingen op de koop toe nemend. De Commissie zal dan met het oog op een goede handhaving dienen te beschikken over een meer dwingende bevoegdheid die ook kan worden ingezet als de Commissie vreest dat de betrokken onderneming opzettelijk informatie verduistert zodra zij wordt geconfronteerd met een verzoek ex artikel 11 Vo 17. Deze verdergaande bevoegdheid vindt haar grondslag in artikel 14 Vo 17. Op grond van dit artikel kan de Commissie "ter vervulling van de taken welke haar zijn opgedragen in artikel 89 (thans artikel $85 \mathrm{EG}, \mathrm{HQ}$ ) en in voorschriften vastgesteld krachtens artikel 87 (thans artikel 83 EG, HQ) van het Verdrag" overgaan tot het verrichten van noodzakelijke verificaties. Deze verificatiebevoegdheid heeft een geheel ander en meer ingrijpend karakter dan de bevoegdheid van artikel 11 Vo 17 . De omvang van deze bevoegdheid zal hierna nog uitgebreid aan bod komen, maar hier zij er reeds op gewezen dat het meest in het oog springend onderscheid met de inlichtingenbevoegdheid de omstandigheid is dat verificaties ten kantore van de onderneming plaatsvinden, hetgeen mede impliceert dat de Commissie over een recht op het betreden van plaatsen -en hieraan gekoppeld een zekere mate van zockrecht $^{194}$ - beschikt.

192 Temeer daar het verstrekken van 'aanvullende' informatie die achteraf onjuist blijkt te zijn, door de Commissie wordt beschouwd als een poging van de onderneming haar opzettelijk in de verkeerde richting te leiden, hetgeen in beginsel zal leiden tot oplegging van een (maximum)boete: "Het geven van een antwoord dat verder gaat dan het gevraagde en de aanduiding dat geen onderscheid wordt gemaakt tussen Franse en buitenlandse cliěnten, tonen juist aan dat Telos welbewust en opzettelijk de Commissie heeft misleid"; Pb 1982 L 58/22 (Telos).

193 Dit houdt niet in dat in dit stadium van de procedure alle gewenste informatic precies kan worden benoemden beschrevendoor de Commissie; zoals de Hoge Autoriteit het in het kader van een EGKSprocedure treffend omschreef, is dit niet mogelijk "daar zij niet over voorspellende gaven beschikt". HvJ (31/59) Jur. 1960, 164 (Acciaieria e tubificio di Brescia).

194 De reikwijdte van dit zoekrecht wordt in paragraaf 3.3.6.2 uitgebreid besproken. 


\subsection{De geadresseerden}

Verificaties kunnen worden verricht bij ondernemingen en ondernemersverenigingen. D groep van mogelijke geadresseerden is daarmee beperkter dan het geval is in artikel 1 Vo 17, aangezien verificaties niet kunnen worden doorgevoerd bij lidstaten en bevoegde atoriteiten van de lidstaten. Dit verbaast ook niet gelet op de hiervoor vermelde omstandzheid dat verificaties een betredings- en zoekrecht meebrengen: dergelijke bevoegdheden leen zich niet voor uitoefening tegen overheden of overheidsinstanties. ${ }^{195}$ De groep odememingen en ondernemersverenigingen daarentegen is wel ruim. Verificaties kunnen wrden verricht bij alle ondernemingen en ondernemersverenigingen waar relevante inormatie wordt vermoed aanwezig te zijn, ongeacht de vraag of deze economische etiteiten verdacht worden van overtreding. Daarenboven is niet noodzakelijk dat de oderneming direct betrokken is bij de productie of handel. Voldoende is dat de ondernemng diensten heeft verricht voor andere ondernemingen, welke diensten verband houden $\mathrm{mt}$ het door de Commissie ingestelde kartelonderzoek. ${ }^{196}$ Bedrijfsintern geldt bovendien $\mathrm{d} z$ ondernemingen ervoor zorg moet dragen dat "zij gedurende de verificatiebezoeken wrden vertegenwoordigd door verantwoordelijke en deskundige personen". ${ }^{19}$

\section{3.j.2 De opdracht en de beschikking tot verificatie}

Evenals artikel 11 Vo 17 kent artikel 14 Vo 17 twee verschillende categorieèn verificatie, te weten de verificatie op grond van een schriftelijke opdracht en de verificatie bij beschikking. Het verschil tussen deze beide is -analoog aan de regeling in artikel 11 Vo 17 . gelegen in de gevolgen voor de ondernemingen: de eerstbedoelde verificatie brengt geen directe plichten en daarmee geen duldplicht voor de onderneming mee, terwijl de laatstbedoelde wel bindend is als gevolg waarvan de onderneming deze in beginsel zal dienen te ondergaan en zelfs aan de verificatie tot op zekere hoogte zal moeten meewerken. Logische consequentie hiervan is dat een onderneming slechts sancties opgelegd kunnen worden in geval van gehele of gedeeltelijke weigering tot meewerken aan de verificatie bij beschikking ${ }^{198}$ en -de structuur van artikel 11 Vo 17 wordt ook hier gevolgd- in geval van gedeeltelijke niet-coöperatie bij verificaties op verzoek. ${ }^{199}$ Een algehele weige-

195 De uitsluiting van overheden en bevoegde instanties in artikel 14 Vo 17 als geadresseerden van een verificaticbeslissing brengt met zich dat de Commissie ten aanzien van deze slechts over de bevoegdheid van artikel 11 lid 1 Vo 17, het eenvoudige verzoek om inlichtingen, beschikt. Het is dan ook van het grootste belang dat de geadresseerde overheid(sinstantic) volledig voldoet aan het verzoek.

$196 \mathrm{Zie} \mathrm{Pb} 1979$ L $57 / 33$ (Fides).

197 Aldus de Commissie in haar Negende verslag over het mededingingsbeleid, nr. 138.

198 De plicht tot co-operatic in geval van een beschikking is zeer verstrekkend. Vergelijk de overwegingen van de Cornmissie dienaangaande in $\mathrm{Pb} 1992$ L 305/16 (CSM): "Aan de verplichting van een onderneming zich te onderwerpen aan een verificatie die de Commissie bij een krachtens artikel 14, lid 3 , van Verordening $\mathrm{nr} .17$ gegeven beschikking heeft gelast, wordt zelfs dan niet voldaan indien de ondememing zich slechts tijdelijk verzet tegen de uitoefening van de bevoegdheden van de ambtenaren die de Commissie met de uitvoering van de verificatie heeft belast".

199 Hoe vergaand de verplichtingen voor ondernemingen in het kader van een verificatie bij opdracht volgens de Commissie kunnen zijn, blijkt uit $\mathrm{Pb} 1980$ L 75/35 (Fabbrica Lastre di Vetro Pietro Sciarra). Deze onderneming in de Italiaanse glassector had niet alle opgevraagde gegevens verstrekt. Toch meende zij dat na deze verificatie geen verplichtingen meer op haar rustten. In dezelfde zaak poogde 
ring in laatstbedoeld geval zal niet kunnen worden beboet, maar zal uiteindelijk in de meeste gevallen leiden tot een formele beschikking, waaraan de onderneming zich wel zal dienen te conformeren.

De analogie met artikel 11 Vo 17 houdt echter op bij de vraag of er een dwingende volgorde tussen de twee vormen van verificatie bestaat: deze dwingende volgorde ontbreekt in artikel 14 Vo 17. Dit staat in ieder geval vast sinds de National Panasonic-zaak. ${ }^{200}$ In deze zaak voerde de betrokken onderneming aan, dat ondanks het ontbreken van een twee-stappen procedure in de tekst van artikel 14 Vo 17 , ook bij verificaties zou moeten worden vastgehouden aan een dergelijke procedure. Dit volgde in de visie van de onderneming uit de ratio van de bepaling en was tevens noodzakelijk ter waarborging van de rechten van de onderneming, met name het recht om gehoord te worden. Een voorafgaande 'waarschuwing' door een niet-dwingende verificatie zou de onderneming in staat stellen haar mening te geven over de (reden tot) verificatie, zich voor te bereiden op de verificatie en de beslissing tot verificatie vóór de uitvoering hiervan aan het Hof voor te leggen. Het Hof volgde de onderneming niet en stelde, dat "in artikel 14 (...) de procedure van verificatie bij wege van beschikking van geen enkele (...) voorafgaande maatregel afhankelijk (wordt) gemaakt". ${ }^{201}$ Het verschil tussen de regeling in artikel 11 en artikel $14 \mathrm{Vo}$ 17 hangt volgens het Hof samen met het gegeven, dat ter verkrijging van inlichtingen in beginsel de medewerking van de betrokken onderneming noodzakelijk is, terwijl bij verificaties de Commissie tot op zekere hoogte zelfstandig de gegevens, noodzakelijk ter controle van de juistheid en draagwijdte van de reeds in bezit van de Commissie zijnde inlichtingen, kan vergaren. ${ }^{202}$ Het Hof gaat er derhalve klaarblijkelijk van uit, dat in de gevallen waarin medewerking vereist is, de onderneming in staat moet worden gesteld deze eerst vrijwillig te verstrekken; waar de Commissie zelfstandig de informatie kan verkrijgen, behoeft de onderneming niet de gelegenheid te worden geboden tot vrijwillige coöperatie. Ten aanzien van het verweer van de zijde van de onderneming dat zij het recht had om gehoord te worden, stelde het Hof, dat dit met name past bij procedures waarin een overtreding wordt vastgesteld en niet in procedures die dienen ter bewijsvergaring, zoals de procedure vervat in artikel $14 \mathrm{Vo} 17$.

De overwegingen van het Hof geven goed het karakter van de verificatiebevoegdheid aan. Het betreft een bevoegdheid ter verifiëring van informatie waarover de Commissie (uit welken hoofde dan ook) reeds beschikt. Voor zover die informatie in de richting van overtreding van het materiële kartelrecht wijst, staat de verificatieprocedure in het

de Commissie echter een verificatie te verrichten bij Fides, een onderneming die bepaalde diensten verrichte voor onder meer Fabbrica Sciarra. De weigering van Fides zich aan de verificatie te onderwerpen, had volgens de Commissie voor Fabbrica Sciarra aanleiding moeten zijn om alsnog aanvullende gegevens te verstrekken en zo haar goede trouw te tonen; de onderneming kon namelijk volgens de Commissie niet volhouden dat "zij alle reden had om aan te nemen dat de Commissie tevreden was met de $(. .$.$) verkregenantwoorden, omdat redelijkerwijzekan worden veronderstelddat zij onver-$ wijld door haar gemachtigde FIDES was ingelicht over de weigering van laatstgenoemde zich te onderwerpen aan een verificatie".

$200 \mathrm{HvJ}$ (136/79) Jur. 1980, 2033 (National Panasonic).

201 HvJ (136/79) Jur. 1980, 2033 (National Panasonic).

202 De Commissie stelt dienaangaande in het Tiende verslag over het mededingingsbeleid: "Terwijl artikel 11 de Commissie de middelen verschaft om inlichtingen te verkrijgen welke zij nodig heeft om met volledige kennis van zaken uitspraak te doen over een zaak welke haar is voorgelegd, stelt artikel $14 \mathrm{de}$ Commissie in staat, na te gaan wat de realiteit en de strekking zijn van inlichtingen waarover zij reeds beschikt". 
telen van verdere bewijsvergaring en toont deze procedure overeenkomsten met de opsporirg in strafzaken. Het door middel van verificatie te verkrijgen materiaal moet de Commissie immers in staat stellen een oordeel over de situatie te geven en het bestaand vermoeden van overtreding van de artikelen 81 en 82 EG al dan niet te bevestigen. Cooperatie van de onderneming staat hier nog steeds voorop, maar is in zoverre niet noodzakelijk dat de Commissie zelf -zij het met de nodige, hieronder te bespreken, restricties- gerechtigd is aaar informatie op zoek te gaan. Evenmin als het geval is bij doorzoekingen in het Nederlandse recht (maar ook in andere rechtsstelsels), behoeven verificaties bij de onderneming te worden aangekondigd. Het verrassingseffect moet garanderen dat de verificatie succesvol is, althans dat de informatie die vermoed wordt aanwezig te zijn, ook daadwerkelijk kan worden opgespoord ${ }^{203}$ : aankondiging van het verificatievoornemen zou mogelijk tot gevolg hebben dat ondernemingen die zich schuldig hebben gemaakt aan kartelmatig gedrag, belastend materiaal zullen doen verdwijnen om aldus de Commissie geen bevijzen te bieden voor de gepleegde inbreuk. ${ }^{204}$ Maar ook uit proceseconomische overwegingen is een aan een beschikking voorafgaand verzoek tot verificatie vaak niet wenselijk, met name in die gevallen waarin een onderneming reeds blijk ervan heeft gegeven niet te willen meewerken aan het communautair onderzoek: in dat geval zou eer verzoek volstrekt nutteloos zijn en zou uitsluitend leiden tot tijdverlies. ${ }^{205}$

De conclusie dat verificatie bij beschikking niet behoeft te worden voorafgegaan door enig andere maatregel laat onverlet dat de Commissie niet lukraak mag kiezen voor een verificatie bij beschikking. Het betreft een ingrijpende maatregel die een groot beslag kan leggen op de bedrijfsvoering van de betrokken onderneming. Indien de Commissie de informatie redelijkerwijs via een andere, minder belastende weg -bijvoorbeeld die van artikel 11 Vo 17- kan bemachtigen, zal zij deze weg moeten bewandelen. Welke weg in het concrete geval moet worden ingeslagen, is afhankelijk van de omstandigheden van het geval en is ter beoordeling aan de Commissie. Deze is hiervoor ook de meest aangewezen instantie omdat zij over de relevante informatie beschikt om de noodzakelijke afwegingen te maken. Welke maatstaven de Commissie aan haar beslissing ten grondslag moet leggen, is echter niet zonder meer duidelijk. Deze problematiek werd in de reeds aangehaalde National Panasonic-zaak ${ }^{206}$ aangekaart. De betrokken onderneming voerde aan dat uit het evenredigheidsbeginsel voortvloeit, dat een verificatie bij beschikking zonder voorafgaand informeel verzoek slechts onder bepaalde omstandigheden geoorloofd is en wel als "de toestand zeer ernstig is, indien er een dringende noodzaak bestaat en indien vóór het begin van de verificatie een strikte geheimhouding vereist is". Het Hof

203 Vergelijk ook Jorna (1990), pag. 632.

204 Vergelijk Pb 1994 L. 294/31 (Akzo Chemicals) en Pb 1993 L 20/6 (Mewac): "Wegens de ernst van de vermeende inbreuk en het gevaarvoor verdwijning van eventuele bewijselementenachtte de Commissie het noodzakelijk een beschikking te geven": in casu betrof het overigens een procedure op grond van verordening 4056/86. Om de genoemde redenen behoeft een verificatie, overeenkomstig de regeling in het EGKS-Verdrag, ook niet te worden voorafgegaan door een verzoek en eventueel beschikking tot het verkrijgen van inlichtingen. Zie hieromtrent HvJ (31/59) Jur. 1960, 176/177 (Acciaicria e tubificio di Brescia).

$205 \mathrm{Er}$ bestaat overigens bovendien in het geheel geen dwingende volgorde tussen de bevoegdheden van artikel 11 en artikel 14 Vo 17; beide bevoegdheden kunnen onafhankelijk van elkaar en in willekeurige volgorde worden aangewend.

206 HvJ (136/79) Jur. 1980, 2033 (National Panasonic). 
stelde de onderneming niet in het gelijk en zag geen schending van genoemd beginsel in het concrete geval: "De keuze van de Commissie tussen een verificatie bij enkele schriftelijke opdracht en een verificatie die bij beschikking wordt gelast, hangt niet af van de door verzoekster (i.e. de onderneming, HQ) aangehaalde omstandigheden, maar door de vereisten van een doeltreffend onderzoek, zulks in het licht van de bijzondere omstandigheden van het geval". Het primaat ligt dus bij een doeltreffend onderzoek, waarmee het evenredigheidsbeginsel in belangrijke mate buiten spel lijkt te worden gezet. Toch mag deze conclusie niet zonder meer uit boven weergegeven overweging van het Hof worden getrokken. National Panasonic had zeer nauwe grenzen aan de mogelijkheden van de Commissie verbonden, welke grenzen door het Hof tegen de achtergrond van de handhaving van het communautaire kartelrecht niet geaccepteerd kónden worden. In de verwerping van deze grenzen heeft het $\mathrm{Hof}$ echter in wellicht te stellige bewoordingen de zijde van de doeltreffendheid gekozen. Het is zeer wel denkbaar dat -vergeleken met verificaties bij opdracht- gelijktijdige en onaangekondigde verificaties bij verschillende van kartelmatig gedrag verdachte ondernemingen belangrijke voordelen biedt voor het onderzoek ${ }^{207}$, hoewel het resultaat, te weten vergaring van al het noodzakelijke materiaal, naar verwachting gelijk is. Aankondiging zou bijvoorbeeld tot gevolg kunnen hebben dat ondernemingen met elkaar in overleg treden over de formulering van (niet noodzakelijk misleidende) antwoorden op te verwachten vragen, terwijl het onderzoek gebaat is bij 'spontane' en niet zonder meer in essentie gelijke antwoorden. Het gegeven dat de Commissie om onderzoekstechnische redenen mag opteren voor een verificatiebeschikking zonder aankondiging, zonder dat gesteld kan worden dat een andere vorm van onderzoek tot wezenlijk andere resultaten zou leiden, brengt echter geenszins mee dat het evenredigheidsbeginsel geen rol meer speelt. Ook hier dient onverminderd het aan te wenden middel in een redelijke verhouding tot het beoogde doel te staan en dient voor het minder ingrijpende middel te worden gekozen indien de doelmatigheid hieronder niet wezenlijk lijdt. ${ }^{208}$ De bijzondere omstandigheden van het geval zullen bij de inachtneming van de evenredigheid het belangrijkste gewicht in de schaal leggen. Zo zal de Commissie naar mijn mening onder meer de volgende factoren moeten meewegen: de aard van de gerezen verdenking (welke kartelvorm is in het geding), de (markt)positie van de betreffende onderneming, de houding van deze ten tijde van eventuele eerdere communautaire onderzoeken en het gegeven dat de bevoegdheid zal worden aangewend tegenover een derde, niet bij het vermoedelijk kartelmatige gedrag betrokken onderneming. Dit laatstbedoelde gegeven zal met name doorslaggevend kunnen (maar niet noodzakelijk moeten) zijn indien het een verificatie betreft bij een onderneming die een klacht bij de Commissie heeft ingediend wegens vermeend kartelmatig gedrag van concurrenten of leveranciers. In beginsel zal er immers van uit mogen worden gegaan dat de klager vrijwillig de gewenste en noodzakelijke informatie (voor zover in zijn bezit) zal leveren. Geen van deze

207 In het Negende verslag over bet mededingingsbeleid, $\mathrm{nr}$. 137, noemde de Commissie het gelijktijdig verrichten van verificaties ten kantore van verschillende ondernemingen als één van de motieven om tot onaangekondigde verificaties over te gaan. Verder noemde zij de vrees voor vernietiging van bewijsmateriaal en indicaties voor het bestaan van een ernstige inbreuk.

208 De Commissie dient dan ook in de woorden van Kreis (1981), pag. 284, het "Rechtsprinzip des Interventionsminimums" in acht te nemen. Vergelijk ook Von der Groeben, Thiesing en Ehlermann (1993), pag. 708. Met Cath (1991), pag. 41, kan gesteld worden dat de Commissie gedurende de gehele onderzoeksfase rekening zal moeten houden met het evenredigheidsbeginsel. 
factoren heeft op zich een doorslaggevend gewicht, maar kan een indicatie zijn voor het te opteren onderzoek.

Zeals gesteld, is er voor de Commissie geen noodzaak om voorafgaand aan een verificatie de onderneming te horen. Wel zal de Commissie de bevoegde autoriteiten van een lidstaat ervan tijdig op de hoogte dienen te stellen, indien zij een verificatie op grond van artikel 14 lid 2 Vo 17 wil verrichten: dit is mede van belang gezien het recht van die autoriteiten om bij de verificatie aanwezig te zijn. Indien de Commissie de verificatie bij beschikking wil gelasten, zal zij zelfs de nationale autoriteiten moeten horen. Hoe dit horen dient plaats te hebben, is niet in Vo 17 vastgelegd. In haar antwoord op een schriftelijke vraag van Lady Elles dienaangaande merkte de Commissie op dat horen in dit verband betekent ten eerste dat de nationale autoriteit op de hoogte wordt gebracht van het voornemen een beschikking te geven alsmede van de inhoud van die beschikking; ten tweede dat deze autoriteit in de gelegenheid wordt gesteld opmerkingen te maken en ten derde dat de Commissie op deze opmerkingen acht slaat. ${ }^{209}$ Het Hof heeft in het AKZO-arrest op dit punt beslist, dat het horen ook op informele wijze kan geschieden en dat zelfs een telefonisch contact kan volstaan: gelet op het mogelijke belang van verificatie bij beschikking moet vertraging door het stellen van formele eisen zoveel mogelijk voorkomen worden. ${ }^{210}$

\subsubsection{De inhoud van de verificatiebeslissing}

Het onderscheid tussen de twee vormen verificaties heeft gevolgen voor de inhoud van de verificatiebeslissing. Deze inhoud is van belang voor de ondernemingen tot welke de beslissing is gericht, met name omdat zij aan de schriftelijke beslissing moeten kunnen ontienen op welke gronden de Commissie de verificatie noodzakelijk acht en wat van hen wordt verwacht tijdens de verificatie. ${ }^{211}$ Aangezien de verificatie bij beschikking, gelet op het dwingende karakter, verderstrekkende gevolgen voor de ondernemingen dan de verificatic bij schriftelijke opdracht heeft, dient de beschikking met meer redenen omkleed te zijn dan bedoelde opdracht. Op grond van artikel 14 lid 2 Vo 17 moet de schriftelijke opdracht ter verificatie naast het voorwerp en het doel van de verificatie ook de mogelijke geldboete bij het niet volledig tonen van de gevraagde bescheiden behelzen. ${ }^{212}$ De verificatiebeschikking moet volgens lid 3 van artikel 14 Vo 17 eveneens het voorwerp en het doel van de verificatie bevatten. Daarnaast zal de Commissie de begindatum van de verificatie moeten vermelden alsmede de mogelijkheid van sancties

$209 \mathrm{~Pb} 1979 \mathrm{C} 310 / 30$

$210 \mathrm{HvJ}$ (5/85) Jur. 1986, 2612 (AKZO).

211 Verordening 17 vereist overigens geen nauwkeurige bepaling van de te verifiêren plaatsen. Volgens de Commissie is dat begrijpelijk "omdat met name in het geval van grote ondernerningen met een complexe organisatiestructurur het veelal onmogelijk is van te voren na te gaan waar alle voor de verificatie relevante bedrijfsruimten zich zouden kunnen bevinden"; zie Pb 1994 L 294/31 (Akzo Chemicals). Indien met andere woorden in de beschikking de hoofdzetel van de geadresseerde wordt genoemd, betekent dat nog niet dat de verificatie beperkt moet blijven tot de plaats van hoofdzetel.

212 Voldoende is overigens de ondernemingen te wijzen op de artikelen 14 en 15 Vo 17. Niet noodrakelijk is dat de onderneming vooraf uitdrukkelijk op haar recht de verificatie niet te ondergaan, wordt geattendeerd; zie Pb 1982 L. 319/12 (Fédération Nationale de l'Industrie de la Chaussure de France). 
(zijnde zowel een geldboete als een dwangsom) bij niet- (volledige) medewerking en het recht om beroep bij het Gerecht van Eerste Aanleg in te stellen tegen de beschikking. Dit laatste is van grote waarde voor de onderneming die meent dat ten onrechte tot de verificatie is besloten of die inhoudelijke bezwaren tegen de verificatiebeschikking heeft. Ten overvloede zij hier vermeld dat de opdracht ter verificatie de mogelijkheid van beroep niet bevat en niet kan bevatten vanwege het eenvoudige feit dat geen beroep tegen de opdracht openstaat. Mocht de onderneming de verificatieopdracht disproportioneel achten of mocht zij andere bezwaren hebben die verband houden met het verificatievoornemen van de Commissie, dan zal zij een verificatiebeschikking moeten uitlokken (door niet mee te werken aan een verificatie ex artikel 14 lid 2 Vo 17), welke beschikking wel ter beoordeling aan de communautaire rechter in eerste aanleg kan worden voorgelegd.

De aard van de verificatiebevoegdheid en het principe van de in acht te nemen evenredigheid brengen mee dat de Commissie niet lukraak tot een verificatie mag besluiten. Er dienen steeds min of meer concrete aanwijzingen te zijn dat het materiële recht door (bepaalde) ondernemingen wordt geschonden; de onderhavige bevoegdheid dient er dan toe om de juistheid van het gerezen vermoeden te verifiëren. ${ }^{213}$ Met het oog op een goede procesorde en teneinde het recht op beroep bij het Gerecht van Eerste Aanleg (in geval van een beschikking) niet illusoir te doen zijn, is het essentieel dat de Commissie haar vermoeden en haar informatie waarop zij dit vermoeden baseert aan de onderneming via de schriftelijke beslissing kenbaar maakt. Het gaat er dan om dat de onderneming weet wat haar verweten wordt of (in het geval waarin de verificatie zal worden verricht bij een onderneming die geen 'verdachte' is) waarom zij de geadresseerde van de beslissing is. Niet noodzakelijk is dat de Commissie uitputtend al de haar bekende gegevens aan de onderneming onthult. Ten aanzien van sommige informatie geldt zelfs dat de Commissie deze niet kenbaar mag maken aan de betrokken onderneming, bijvoorbeeld omdat de informatie binnen de reikwijdte van de geheimhoudingsplicht van de Commissie valt. ${ }^{214}$ Evenmin zal de Commissie een nauwkeurige juridische kwalificatie van de vermoede feiten in de beslissing behoeven op te nemen, hetgeen veelal ook nog niet mogelijk zal zijn op grond van de voorhanden zijnde gegevens. ${ }^{215}$ Ook hier geldt dat voldoende is dat de onderneming weet welke gedragingen volgens de Commissie mogelijk in strijd met het communautaire recht zijn. In dit stadium van de procedure zal het de Commissie vaak niet mogelijk zijn om meer nauwkeurig de tegen een onderneming gerezen bezwaren aan te geven, aangezien de verificatie hierover juist uitsluitsel moet geven.

In die situaties waarin de verificatie voor de onderneming niet als een verrassing komt (met name als de Commissie alvorens een beschikking te nemen, heeft getracht een verificatie bij opdracht uit te voeren), kan zij aan de Commissie voorafgaand aan de verificatie haar visie ten aanzien van het onderzoek duidelijk maken. In haar verificatiebeschikking behoeft de Commissie niet inhoudelijk op deze visie in te gaan en is evenmin verplicht aan te geven waarom zij hieraan voorbij gaat. Zou een dergelijke verplichting wel bestaan, dan zou er een striktere motiveringseis gelden voor de beschikking die wordt

213 Bosman (1990), pag. 637, stelt zelfs dat verificatie pas is geoorloofd bij het bestaan van een redelijk vermoeden van een inbreuk.

214 Zie voor deze geheimhoudingsverplichting nader Hoofdstuk 5 paragraaf 6.2.

215 Joshua (1986), pag. 411 , stelt terecht dat "Vague referencesto Article 85 or 86 (thans 81 en 82 EG, HQ) would not be enough", maar dat aan de andere kant niet alle gegevensvermeld hoevente worden: "if the Commission knew all the details, it would not have to carry out an investigation". 
genomen na een daaraan voorafgaande poging tot een 'vrijwillige' verificatie, dan voor de beschikking waarbij onaangekondigd een verificatie wordt gelast. ${ }^{216}$

\subsubsection{Sancties}

Een onderneming (maar niet een lidstaat) die niet of niet geheel aan de haar in artikel 11 Vo 17 opgelegde verplichtingen tot het verschaffen van inlichtingen voldoet, kan -zo bleek hiervoor-financiele sancties verwachten. Eenzelfde lot wacht de onderneming die haar verplichtingen in het kader van verificaties naast zich neerlegt: de analogie met de bestraffing van een overtreding van artikel 11 Vo 17 is duidelijk aanwezig en daarom kan volstaan worden met cen korte bespreking. De Commissie staan als reactie op een overtreding van artikel 14 Vo 17 twee sanctiemodaliteiten ter beschikking, te weten de boete $^{217}$ en de dwangsom. Bij beide modaliteiten is van belang of aan de verificatie een opdracht dan wel een beschikking ten grondslag ligt ${ }^{218}$ : in laatstbedoeld geval zijn de mogelijkheden ruimer, zeker met betrekking tot de dwangsom die in eerstbedoeld geval niet tot de mogelijkheden behoort. Voor de boete geldt dat in geval van verificaties bij opdracht een gehele weigering van een onderneming het onderzoek toe te staan, niet kan leiden tot een boete, gelet op het niet-dwingend karakter van de opdracht. ${ }^{219}$ Artikel 15 lid 1 sub c Vo 17 beperkt de bestraffingsmogelijkheid van de Commissie tot de situatie waarin een onderneming bij een verificatie bij opdracht geen volledige inzage geeft van de gevraagde bescheiden. Ook ten aanzien van artikel 14 Vo 17 geldt dat onderwerping aan een verificatie een volledige (zij het binnen de grenzen van redelijkheid) coŏperaticplicht tot gevolg heeft. Is de verificatie bij beschikking gelast, dan mag de Commissie daarnaast overgaan tot sanctie-oplegging indien de onderneming zich geheel tegen de verificatie verzet; artikel 15 lid 1 sub c Vo 17 voorziet in de mogelijkheid ondernemingen die "zich niet onderwerpen aan verificaties welke de Commissie bij een krachtens artikel 14, lid 3, gegeven beschikking heeft gelast" een boete op te leggen. ${ }^{220}$

De omvang van de boete, die slechts kan worden opgelegd indien de onderneming de bestreden gedraging opzettelijk of uit onachtzaamheid heeft begaan (hetgeen geen

$216 \mathrm{HvJ}$ (5/85) Jur. 1986, 2585 (AKZO).

217 De Tiense Suikerraffinaderij viel in 1971 de twijfelachtige eer te beurt als eerste onderneming te worden beboet wegens het overleggen van een onvolledige documentatie bij een verificatie, zie het Eerste verslag over het mededingingsbeleid, nr. 124.

218 Vergelijk Van Bael en Bellis (1994), pag. 758/759.

219 Een andere mening lijkt Barents (1995 1), pag. 525, toegedaan. Hij stelt dat ook "het zich onderwerpen aan deze verificaties (...) verplicht (is) op straffe van boeteoplegging", waarbij hij niet tussen de verschillende vormen van verificatie onderscheidt.

220 Als weigering om zich aan een verificatie te onderwerpen, kan reeds een tijdelijke weigering worden aangemerkt; zie Pb 1993 L 20/6 (Mewac). Wegens de afwezigheid van de secretaris-generaalen een radsman weigerde een ondernemersvereniging de verificatie op de betreffende dag toe te staan, waarbij werd aangegeven dat de ondernemersvereniging zich niet zou verzetten tegen een verificatie op de daropvolgende dag. De Commissie beoordeelde dit als een gehele weigering omdat secretaris-generaal een andere vertegenwoordiger had kunnen aanwijzen of tenminste nog diezelfde dag zelf naar de plaats van verificatie had kunnen komen, waarbij de Cornmissie-ambtenaren bereid zouden zijn geweest om tot na kantooruren te wachten. 
groot struikelblok vormt ${ }^{221}$ ), varieert van ten minste honderd tot ten hoogste vijfduizend rekeneenheden per overtreding. ${ }^{222}$ Hoewel de sanctie-oplegging een punitief karakter heeft en in die zin een directe reactie van de Commissie is op verboden gedrag van de onderneming, zal de boete weinig ondernemingen ontzag inboezemen ${ }^{223}$ en zal vanuit die optiek van haar een slechts geringe preventieve werking uitgaan. ${ }^{224}$ Wellicht belangrijker en voor de onderneming belastender is de mogelijke publiciteit die met een boetebeschikking gepaard gaat. Maar ook los hiervan dient bedacht te worden dat deze boete slechts één van de middelen is om ondernemingen aan te zetten om mee te werken aan kartelonderzoeken van de Commissie of hen in ieder geval ervan te weerhouden deze onderzoeken te obstrueren.

De dwangsom vormt een dergelijk middel dat bovendien wellicht meer effectief is en in ieder geval een directere weg vormt om ondernemingen tot coöperatie te brengen. Deze in artikel 16 Vo 17 verankerde bevoegdheid van de Commissie kan onder meer worden aangewend indien een onderneming zich niet onderwerpt aan een verificatie bij beschikking. De oplegging van de dwangsom zelf dient eveneens bij beschikking te geschieden; de Commissie kan deze sanctie hetzij in de oorspronkelijke verificatiebeschikking hetzij in een afzonderlijke beschikking (zodra is gebleken dat de onderneming de oorspronkelijke beschikking naast zich neerlegt) opnemen. Vereist is dat de Commissie een (niet in Verordening 17 nader bepaalde) termijn stelt binnen welke de onderneming aan de beschikking moet voldoen. Is deze termijn verstreken zonder onderwerping door de onderneming aan de verificatie, dan wordt de 'dwangsombeschikking' effectief: vanaf dat moment is de onderneming voor iedere dag dat zij in verzuim blijft de in de beschikking opgelegde dwangsom, variërende van minimaal vijftig tot maximaal duizend rekeneenheden per dag (op grond van artikel 23 'Voorstel uitvoeringsverordening' zou dit maximaal $5 \%$ van de gemiddelde dagelijkse omzet in het voorafgaande boekjaar worden), verschuldigd. Bij een langdurig verzuim kan het totaal verschuldigde bedrag aanzienlijk oplopen. Alvorens de totale dwangsom te kunnen innen, dient door de Commissie wel een afzonderlijke beschikking te worden genomen, bij welke het verschuldigde bedrag eventueel gelet op de omstandigheden van het geval nog kan worden gematigd.

221 Met name omdat de onderneming door de Commissie steeds op de hoogte worden gebracht van hum verplichtingen en van de consequenties indien zij niet aan deze verplichtingen voldoet.

222 Vergelijk bijvoorbeeld $\mathrm{Pb} 1992$ L. 121/45 (UKWAL), waarin de maximumboete werd opgelegd omdat de ondernemersvereniging opzettelijk handelde (zij werd bijgestaan door een raadsman) en omdat de doeltreffendheid van de verificatie in gevaar was gebracht (de Commissie wilde bij verschillende ondememingen op hetzelfde tijdstip een verificatie doorvoeren). In Pb 1994 L. 294/31 (Akzo Chemicals) werd eveneens de maximumboete opgelegd, ondanks het feit dat geen opzet was geconstateerd('op zijn minst uit onachtzaambeid'); doorslaggevend was hier de enkele omstandigheid dat de doeltreffendheid van de verificatie in gevaar was gebracht. In Pb 1993 L 20/6 (Mewac), evenals de UKWALbeschikking betrekking hebbend op verordening 4056/86, werd een boete opgelegd van $4.000 \mathrm{ecu}$. Hier werd-ondanks het feit dat er sprake was van opzet- niet voor de maximumboete geopteerdomdat de ondememing zich slechts tijdelijk verzette tegen de verificatic.

223 Tot deze conclusie komt ook Kreis (1981), pag. 295.

224 Daarom ook zou de Commissie graag zien dat de boete wordt verhoogd tot $1 \%$ van de omzet van het voorafgaande boekjaar. Zie artikel 22 'Voorstel uitvocringsverordening', 


\subsubsection{De bevoegdheden in het kader van verificaties}

De verificatie is een communautaire bevoegdheid die diep ingrijpt in de 'privésfeer' van een onderneming. De bevoegdheden van de Commissie die in het kader van een verificatic uitgeoefend kunnen worden, mogen dan ook niet ongelimiteerd zijn. Aan de andere kant vereist een goede handhaving van het mededingingsrecht adequate bevoegdheden. Artikel 14, eerste lid Vo 17 geeft een limitatieve opsomming van de bevoegdheden van de Commissieleden. De Raad heeft door middel van deze opsomming een balans trachten te vinden tussen enerzijds een voldoende instrumentarium ter handhaving van de artikelen 81 e.v. EG en anderzijds een beperking van de mogelijkheden met het oog op een waarborging van de rechten van de onderneming. Zoals echter zal blijken, bestaat er in de praktijk onduidelijkheid over de reikwijdte van zowel de bevoegdheden als de rechtsbescherming.

De bevoegdheden die door de Raad aan de Commissie ter verificatie (zowel bij opdracht als bij beschikking) zijn toegekend, zijn:

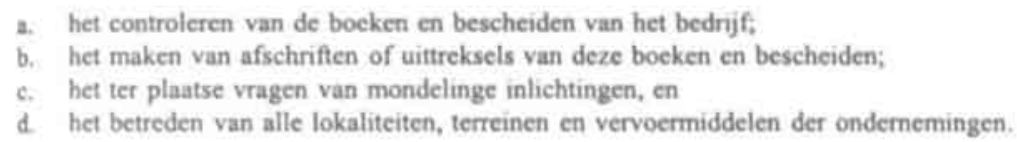

Ad a. De bevoegdheid boeken en bescheiden te controleren is in Verordening 17 niet beperkt tot een bepaalde categorie documenten, met dien verstande dat het niet mag gaan om privé-bescheiden of althans bescheiden die geen bedrijfskarakter hebben. ${ }^{225} \mathrm{Het}$ ligt gezien het belang van de verificatiebevoegdheid en de relatie met artikel 11 Vo 17 voor de hand dat de Raad inderdaad de groep te onderzoeken bescheiden zo min mogelijk heeft willen beperken en zo qua omvang aansluiting heeft gezocht bij artikel 11 Vo 17. Als zodanig omvatten de bescheiden "alle Aufzeichnungen eines Unternehmens zu geschäftlichen Zwecken" ${ }^{1226}$, waaronder mede dienen te worden begrepen computerbestanden, informele aantekeningen en geluidsdragers. ${ }^{227}$ Eén belangrijke grens aan het onderzoek en de te bestuderen documenten is aanwezig en wordt gevormd door het doel van de verificatie, zoals geformuleerd in de opdracht of beschikking. Terecht stelt Kuhlhorn dan ook dat "die EG-Bediensteten im Unternehmen nur thematisch genau beschriebene (mijn cursivering, HQ) Unterlagen zur Vorlage anfordern dürfen". $228 \mathrm{De}$ consequenties die Kühlhorn echter aan deze conclusie verbindt, leiden daarentegen niet alleen tot een dermate restrictieve interpretatie van artikel 14 Vo 17 dat een adequate handhaving van het communautaire kartelrecht welhaast illusoir zou worden, maar zijn bovendien niet in overeenstemming met het formele recht. Zo is het volgens hem aan

225 Of de aangetroffen documenten daadwerkelijk tot de categorie van de bedrijfsbescheiden behoren, kan vanzelfsprekend in het algemeen slechts na (marginale) bestudering ervan worden vastgesteld. Het oordeel over de aard van bet document ligt uitsluitend bij de Commissie; de onderneming zal hooguit kunnen opperen dat in haar visie de documenten niet aan de bedrijfsvoering zijn gerelateerd.

226 Kreis (1981), pag. 289.

227 Om dit te verduidelijkenheeft de Commissie in haar 'Voorstel uitvoeringsverordening' uitdrukkelijk bepaald dat de aard van de drager van de zakelijke documenten (bedoeld zal zijn: de zakelijke gegevens) er niet toe doet.

228 Kühlhorn (1986), pag. 20. 
de ondernemingen om de gevraagde informatie samen te stellen zonder dat de Commissie het recht heeft hierbij aanwezig te zijn. Voorts is de onderneming verplicht slechts die bescheiden te verstrekken die zich ter plekke bevinden en die binnen een redelijke tijd kunnen worden verzameld. ${ }^{229}$ Vanzelfsprekend zijn de commissieambtenaren niet bevoegd om inzage in alle bij de onderneming aanwezige gegevens te verlangen, maar zijn zij gebonden aan het doel van de verificatie en de grenzen getrokken door de proportionaliteit. ${ }^{230}$ Maar dit houdt niet in dat de ambtenaren zich volledig afzijdig moeten houden of dat zij niet ook tot dan toe voor hun onbekende of vooraf niet-geïdentificeerde documenten mogen aanvragen. Voor zover documenten zich binnen de onderneming bevinden en zij redelijkerwijs van belang kunnen zijn voor het bereiken van het doel van de verificatie, zullen zij mogen worden ingezien. Of een bepaald document dat zich bijvoorbeeld in een bepaalde dossierkast bevindt daadwerkelijk van belang is voor het onderzoek, zal veelal pas na inzage vast komen te staan: de redelijkheid van het verzoek om inzage zal in de meeste gevallen gegeven zijn indien het bescheiden betreft die zich op plaatsen bevinden waarop relevante informatie mag worden verwacht. Het recht om documenten in te zien, zal zelfs zo ruim moeten worden opgevat dat de Commissie inzage mag vragen van bescheiden die zich op andere plaatsen bevinden dan die waar de verificatie plaatsheeft. Hiermee correspondeert dan een plicht van de onderneming om (voorzover het een verificatie bij beschikking betreft) ervoor te zorgen dat de documenten in kwestie in het bezit van de commissieambtenaren komen. ${ }^{231}$

Uit het voorgaande kan reeds worden afgeleid dat de onderneming niet tot een passief dulden van de verificatie gehouden is, maar dat zij in tegendeel tot op zekere hoogte mee moet werken aan het onderzoek. Dat deze plicht tot coöpereren ver reikt, zal in verband met de bevoegdheid tot binnentreden hierna onder $\mathrm{d}$. nader worden besproken.

Ad b. De bevoegdheid tot het maken van afschriften hangt nauw samen met de hiervoor beschreven bevoegdheid: van ieder document dat relevant is of redelijkerwijs relevant kan zijn voor de geïnitieerde procedure, mogen door de Commissie kopieën worden gemaakt. Zij heeft daarentegen niet de bevoegdheid de documenten zelf mee te nemen, behoudens het onwaarschijnlijke geval waarin de onderneming dit prefereert en uitdrukkelijk toestaat. In die gevallen waarin de Commissie van deze bevoegdheid gebruik maakt, heeft de onderneming recht op een lijst van gemaakte kopieěn, opdat zij weet welke gegevens voor de Commissie met name van belang zijn, hetgeen in het kader van haar verdediging van belang zal kunnen zijn.

229 Kühlhorn (1986), pag. 20/21.

230 Ook in deze geldt weer dat het de Commissie en niet de onderneming is die de mogelijkheid heeft te bepalen of informatie mag worden opgevraagd; in geval van twijfel zal de onderneming geen informatie mogen achterhouden, maar zal zij zich tot de communautaire rechter moeten wenden. indien noodzakelijk na uitlokking van een beschikking. Vergelijk $\mathrm{Pb} 1982$ L 319/12 (Fédération Nationale de I'Industrie de la Chaussure de France) waarin de Commissie overwoog "dat het in geen enkel opzicht aan de ondernemingen (...) die aan de verificatie zijn onderworpen ter beoordeling staat of het verzoek om overlegging van de documenten gegrond is".

231 Deze visie wordt gedecld door Kerse, die stelt dat "the Commission's power of inspection is not limited to books, etc. located on the business premises" Kerse (1998), pag. 137. Vergelijk tevens Kreis (1981), pag. 289. 
Ad c. De Raad heeft het wenselijk geacht de Commissie de bevoegdheid toe te kennen om ter plaatse mondelinge inlichtingen te vragen. Deze bevoegdheid dient niet op één lijn gebracht te worden met die vervat in artikel 11 Vo 17. Het belangrijkste argument dat zich hiertegen verzet, bestaat erin dat een ruime interpretatie van de bevoegdheid om mondelinge inlichtingen te vragen ex artikel 14 Vo 17 het systeem van artikel 11 Vo 17 zou (dreigen te) doorbreken als gevolg waarvan niet alleen artikel 11 Vo 17 zijn bestaansrecht grotendeels zou verliezen, maar bovendien de bescherming van de rechten van de betrokken ondernemingen duidelijk zou afnemen. De bevoegdheid ex artikel 14 lid 1 sub c Vo 17 kan dan ook slechts restrictief worden geinterpreteerd: het recht om vragen te stellen is beperkt tot die vragen die direct verband houden met de verkregen of nog te verkrijgen (schriftelijke) bescheiden. ${ }^{232} \mathrm{Zo}$ kan de gevraagde uitleg onder meer betrekking hebben op "die Organisation des Unternehmens, die in Rede stehenden Erzeugnisse, Identităt bestimmter Mitarbeiter, Art der Buchhaltung oder der Ablage von Geschäftspapieren"233 of kan opheldering worden gevraagd van bepaalde onduidelijke of onleesbare passages uit de documenten. ${ }^{234}$ De mondelinge uitleg van de zijde van de ondernemingen is met name gewenst om onduidelijkheden die direct verband houden met de bescheiden weg te nemen, teneinde een goede handhaving te bewerkstelligen en te voorkomen dat foutieve conclusies (zowel ten voor- als ten nadele van de onderzochte onderneming) worden getrokken die dan wellicht niet of slechts in een later stadium van het onderzoek gecorrigeerd worden. Wenst de Commissie andere, verdergaande vragen te stellen, dan zal zij een verzoek (of eventueel bij niet-beantwoording van dit verzoek: een beschikking) om informatie conform artikel 11 Vo 17 aan de onderneming moeten richten. Klaarblijkelijk wordt een verdergaand vraagrecht binnen de percelen van de Commissie als een gemis ervaren. ${ }^{235}$ Het 'Voorstel uitvoeringsverordening' voorziet namelijk in een wijziging van de verificatie-bevoegdheid (in de voorgestelde terminologie: bevoegdheid tot inspectie) die ertoe strekt dat 'om het even welke vragen in verband met het voorwerp van de inspectie' kunnen worden gesteld. De antwoorden kunnen worden geverbaliseerd en in een later stadium als bewijs worden gebruikt.

Denkbaar is dat een onderneming geen (aanvullende of verhelderende) uitleg wenst te verschaffen of dat zij weliswaar een mondelinge toelichting geeft, maar dat deze onjuist of onvolledig is. Een dergelijke handelwijze is in beginsel niet voor beboeting vatbaar aangezien in artikel 15 Vo 17 geen voorziening is getroffen voor deze situatie. Weliswaar zou het weigeren van informatieverstrekking door de onderzoekende ambtenaren kunnen worden geduid als een niet-dulden van de verificatie of een niet volledig meewerken aan een dergelijke verificatie, maar dit zal slechts in zeer uitzonderlijke gevallen mogen

232 In die zin de Commissie in haar duplick in HvJ (136/79) Jur. 1980, 2033 (National Panasonic). Verge. lijk hierover tevens Joshua (1986), pag. 413: "the right to ask for oral explanations is only ancillary to the Commission's main powers". Voor cen enge interpretatie van onderhavige bevoegdheid opteren ook Kühlhorn (1986), pag. 22 en Bosman (1990), pag. 638.

233 Kreis (1981), pag. 290.

234 Aldus Kerse (1998), pag. 142, strekt de onderhavige bevoegdheid tot het volgende uit:

"(a) explanations relating to the whereabouts, organisation and maintenance of the undertaking's books and business records (...);

(b) explanations of the books and records under examination or their contents; and

(c) explanations of matters arising from the books and business records under examination and relating

to the subject matter of the investigation as defined by the terms of the Commission's decision".

235 Kritisch was reeds Davidow (1977), pag. 181. 
worden aangenomen. ${ }^{236} \mathrm{De}$ (boete)praktijk wijst uit dat het veel meer voor de hand liggend is dat de Commissie in een eventuele boetebeschikking wegens overtreding van de materiële mededingingsbepalingen (voorzover het tot een dergelijke beschikking komt) bij de bepaling van de strafmaat rekening houdt met de niet-coöperatieve houding van de onderneming. ${ }^{237}$ Indien de procedure niet tot een boete leidt, dan zal een niet-verstrekken van toelichtingen echter geen boetes tot gevolg kunnen hebben.

Ad d. Ten vierde is er een binnentredingsbevoegdheid gecreëerd. Deze bevoegdheid tot binnentreden van "alle lokaliteiten, terreinen en vervoermiddelen" van de onderneming kan worden aangewend ter uitvoering van de overige in artikel 14 genoemde bevoegdheden. ${ }^{238}$ De binnentredingsbevoegdheid geldt zowel in het kader van de verificatie bij schriftelijke opdracht als die bij beschikking, met dien verstande dat de onderneming in geval van de eerstbedoelde verificatie zonder enige consequentie medewerking (en toegang tot de bedoelde plaatsen) kan weigeren. Het moge duidelijk zijn dat de bevoegdheid tot het betreden van plaatsen van groot belang kan zijn voor de effectuering van een goede handhaving van het kartelrecht. Deze communautaire bevoegdheid, die gezien haar aard als het meest ingrijpende dwangmiddel kan worden beschouwd, heeft echter enkele belangrijke vragen opgeworpen. De eerste hierna te behandelen vraag is hoever de bevoegdheid van de Commissie strekt en met name of de Commissieleden (of meer precies de ambtenaren van het Directoraat-Generaal IV) een doorzoeking mogen verrichter. De tweede vraag, die in direct verband staat met de eerste, richt zich op de bescherming van de privésfeer van de onderneming: in hoeverre heeft een onderneming een privésfeer en welke consequenties zijn er verbonden aan de eventuele erkenning van een dergelijke privésfeer. De problematiek die in deze tweede vraag aan de orde komt, raakt de rechtsbescherming van de onderneming en wordt dientengevolge in het hoofdstuk 5 behandeld. Vooraleer op de reikwijdte van het betredingsrecht wordt ingegaan, verdient echter eerst een in het 'Voorstel uitvoeringsverordening' gelanceerde wijziging van de reikwijdte van de verificatie aandacht.

\section{Het betredingsrecht in het 'Voorstel uitvoeringsverordening'}

Volgens de Commissie voldoet de bepaling inzake het recht op het betreden van ondernemersplaatsen niet langer. De Commissie constateert een trend om relevante gegevens niet langer binnen de onderneming, maar op het privé-adres van werknemers te bewaren. Een zeer vergaande vorm van het werk mee naar huis nemen derhalve. De Commissie is dan ook van mening dat haar, om het dwarsbomen van de inspecties te voorkomen, de bevoegdheid moet worden toegekend om ook woning te betreden (in de artikelsgewijze

236 In die zin ook Joshua (1986), pag. 413 en 414.

237 In hoofdstuk 4 zal blijken dat de Commissie een niet-medewerking van de zijde van de onderneming als een strafverzwarende factor aanmerkt. Bij dit beleid van de Commissie kunnen vanuit de optiek van het verbod op gedwongen zelf-incriminatie, dat in hoofdstuk 5 uitvoerig zal worden besproken. overigens kanttekeningen worden geplaatst.

238 Uit Pb 1994 L 294/31 (Akzo Chemicals) blijkt dat kantoren als 'lokaliteiten' kunnen worden aangemerkt "indien en voorzover daarin het bedrijf van de ondememing wordt uitgeoefend". Het is derhalve niet relevant of de ruimten waarin het kantoor is gevestigd aan een andere onderneming dan de geadres. seerde toebehoren. 
toclichting spreekt zij -overigens ten onrechte zoals nog zal blijken-zelfs van 'huiszoekirg'). Daarom stelt zij voor om in het nieuwe artikel 20 lid 2 sub b de volgende bevoegdhed op te nemen:

"het betreden van alle andere lokalen, waaronder de woning van bedrijfshoofden, bestuurders, directeuren en andere personeelsieden van de betrokken ondememingen en ondememersverenigingen, indien kan worden vermoed dat daat documenten van zakelijke aard worden bewaard".

Over uitbreiding van bevoegdheden gesproken. Mok verbaast zich erover dat de Commissie deze bevoegdheid 'met droge ogen' in het leven wil roepen. ${ }^{29} \mathrm{Ik}$ zou zelfs willen stellen dat rillingen van diep Siberische aard zich meester maken van een ieder die tenminste eniz gevoel heeft voor beperking van overheidsoptreden ter bescherming van de individuele rechten. ${ }^{240}$ Een algemeen betredingsrecht, ook geldend voor woningen van alle personeelsleden (en voor woningen van derden?; de voorgestelde tekst sluit dit niet uit), zodra kan worden vermoed (dus niet: redelijkerwijze kan worden vermoed) dat documenten van zakelijke aard (naar mag worden aangenomen toch uitsluitend betrekking hebbend op vermeend kartelgedrag) aldaar worden bewaard. Van privacy-bescherming blijft dan wenig tot niets meer over. Met het oog op artikel 8 EVRM en de strikte uitzonderingsvocrwaarden van het tweede lid van dit artikel is de regeling op zich reeds onaanvaardbaar, zods ook Mok terecht stelt:

\footnotetext{
"Hoezeer men in de heilzame werking van concurrentie mag geloven, het gaat wat ver dat inmenging in het recht op eigen woning van personeelsleden van een onderneming, omdat zich in die woning documenten kunnen bevinden die licht op kartelvorming of misbruik van machtspositie kunnen werpen, noodzakelijk is voor het economisch welzijn. De causaliteitsketen tussen het binnentreden en het economisch welzijn is te lang, zodat het mij duidelijk lijkt dat de geschetste redenering de evenredigheidstoets niet kan doorstaan".2"1
}

Daaraan verandert ook niets dat het voorstel bij iedere voorgenomen betreding van de 'andere lokalen' voorafgaande rechterlijke toestermming eist. Zelfs indien de betredingsbevoegdheid strikter zou worden geformuleerd, levert toetsing door een nationale rechter een slechts beperkte bescherming op, aangezien, zoals hierna nog zal blijken, beschikkingen van de Commissie niet op hun wettigheid, maar slechts op de 'echtheid' en op evenredigheid en willekeur mogen worden getoetst. Deze toetsing lijkt mij hoe dan ook te marginaal waar het een inbreuk op de privé-sfeer die een woning eigen is, betreft. Mede gelet op het voorgaande dient de Commissie mijns inziens in het geheel niet te beschikken over een betredingsbevoegdheid van woningen in de enge zin van het woord. ${ }^{222}$ Een dergelijke bevoegdheid gaat in het (communautaire) kartelrecht te ver en is ook niet strikt noodzakelijk. Nog afgezien van de vraag of het wel echt zo vaak voorkomt dat gegevens zich in de privé-woning van een werknemer bevinden (in de dagelijkse praktijk van een onderneming zal het toch niet goed werkbaar zijn indien belangrijke documenten zich niet

239 Mok (2000), pag. 452.

240 Meer in het algemeen is het opmerkelijk en te betreuren dat in het voorstel geen aandacht wordt besteed aan fundamentele rechten. Het zou heden ten dage toch als welhaast vanzelfsprekendmogen worden beschouwd dat waar aan instrumentele aspectenaandacht wordt besteedt, tevens de rechtsbescherming aan de orde komt.

241 Mok (2000), pag. 453.

242 Mok (2000), pag. 453, ziet hiervoor nog wel enige ruimte. 
bij de onderneming zelf bevinden), heeft de Commissie nog altijd de mogelijkheid om via een boete of dwangsom de afgifte van documenten af te dwingen. Dit geldt temeer indien de sancties wegens het niet-voldoen aan een inlichtingen- of inspectiebeschikking conform het door de Commissie gelanceerde voorstel worden opgehoogd. ${ }^{243}$

\subsubsection{Binnentreden en doorzoeking}

Bij de eerste hierboven geformuleerde vraag staat de reikwijdte van de binnentredingsbevoegdheid centraal en met name de problematiek van de mate van het recht om op zoek te gaan naar relevante informatic. Het recht op binnentreden zou weinig toevoegen aan de overige in artikel 14 Vo 17 geformuleerde bevoegdheden indien het beperkt zou blijven tot het daadwerkelijk verkrijgen van toegang tot de onderneming en de diverse kantoren binnen deze onderneming, zonder enig verder (zoek)recht. Aan de andere kant zou een uitgebreid zoekrecht, waarbinnen tevens de bevoegdheid zou zijn gegeven om kasten en ander meubilair open te breken, een vergaande inbreuk op de rechten van betrokkenen betekenen. Daarbij komt dat een extensieve interpretatie van artikel 14 lid 1 onder $\mathrm{d} V_{0}$ 17 een inbreuk zou kunnen vormen op het gesloten systeem van limitatieve bevoegdheden voor de communautaire autoriteiten en daarmee op gespannen voet zou kunnen staan met het rechtszekerheidsbeginsel.

\subsubsection{Zoekrecht in Nederland}

Alvorens in te gaan op de inhoud van de communautaire binnentredingsbevoegdheid, zal ik eerst de regeling van het binnentredings- en zoekrecht binnen het Nederlandse (commune en bijzondere) strafrecht kort bespreken. De reikwijdte van het Nederlandse strafrechtelijk zoekrecht kan enig licht werpen op de omvang van de communautaire binnentredingsbevoegdheid ex artikel 14 lid 1 sub $\mathrm{d}$ Vo 17. De felheid van dit licht mag echter geenszins overschat worden, aangezien aan de overeenkomst van begrippen in het Nederlandse recht (of meer algemeen: het recht van de lidstaten) en het communautaire recht geen, althans geen doorslaggevende, betekenis mag worden toegekend met betrekking tot de inhoud van deze begrippen. Men zal met andere woorden -gelet op het eigen karakter van de communautaire rechtsorde- niet zonder meer de reikwijdte van de Nederlandse binnentredingsbevoegdheid bepalend mogen achten voor de bevoegdheden van de communautaire ambtenaren bij binnentreden in het kader van een verificatie.

Het Nederlandse formele strafrecht kent een onderscheid tussen de binnentredingsbevoegdheid en de bevoegdheid tot doorzoeking. Binnentredingsbevoegdheden zijn te vinden in verschillende bijzondere wetten (bijvoorbeeld artikel 9 Opiumwet en artikel 20 WED) en in het wetboek van Strafvordering zelf (onder meer artikel $96 \mathrm{WvSv}$ ). Doorzoeking is -behoudens de uitzondering van artikel 49 Wet wapens en munitie- uitsluitend in het wetboek van Strafvordering opgenomen. Ten tijde van de Wem gold dat een (toen nog)

243 De eveneens door de Commissie voorgestelde bevoegdheid tot het verzegelen van bedrijfslokalen of zakelijke documenten tijdens de duur van de inspectic is daarentegen niet meer dan redelijk. De Wet uitvoering EG-mededingingsverordeningen alsmede de Mededingingswet kennen deze bevoegdheid eveneens. Zie daarover paragraaf 4.2 respectievelijk hoofdstuk 3. 
huiszoeking behoudens (voor het mededingingsrecht niet relevante) uitzonderingen uitsluitend door de rechter-commissaris (met -behoudens in geval van dringende noodzakelijkheid- voorafgaand verlof van de rechtbank) kon worden verricht in het kader van een gerechtelijk vooronderzoek. Met de inwerkingtreding van de Wet herziening gerechtelijk vocronderzoek $^{244}$ op 1 februari 2000 is de doorzoekingsregeling tamelijk ingrijpend gevijzigd. Uitgangspunt is op grond van het nieuwe artikel $96 \mathrm{c} \mathrm{WvSv}$ dat de bevoegdheid tot doorzoeking (de voormalige huiszoeking) nu in handen ligt van de officier van Justitie:

"In geval van ontdekking op heterdaad van een strafbaar feit of in geval van verdenking van een misdrijf als omschreven in artikel 67 , eerste lid, kan de officier van justitie ter inbeslagneming elke plaats, met uitzondering van een woning zonder toestemming van de bewoner en cen kantoor van een persoon met bevoegdheid tot verschoning als bedoeld in artikel 218 , doorzoeken".

War aan deze voorwaarden niet is voldaan, kan in beginsel ${ }^{245}$ slechts door de rechterconmissaris tot doorzoeking worden overgegaan (artikel $110 \mathrm{WvSv}$ ). Deze doorzoeking heeft dan nog steeds plaats in het kader van het gerechtelijk vooronderzoek, maar de eis van toestemming van de rechtbank is komen te vervallen. Deze wijzigingen hebben de doorzoeking dus voor een belangrijk deel in het opsporingsonderzoek getrokken, hetgeen de toepassing ervan vereenvoudigt, maar waardoor tevens aan rechtsbescherming -met name in de vorm van (voorafgaande) rechterlijke bemoeienis en toetsing- is ingeboet. Voor het strafrecht als zodanig is dit naar mijn mening een niet bepaald gunstige ontwikkeling; voor het kartelrecht zou dit, indien het in onveranderde vorm nog steeds zou hebben bestaan $^{246}$, geen verandering hebben betekend: aangezien het kartelverbod dan niet onder artikel 67 lid $1 \mathrm{WvSv}$ zou hebben gevallen, zou steeds slechts de rechter-commissaris tot doorzoeking bevoegd zijn geweest.

Het feit dat aan bescherming is ingeboet, klemt te meer omdat doorzoeking een zeer ingrijpend middel is. Doorzoeking -en hier ligt het verschil met binnentreding-impliceert de bevoegdheid tot stelselmatig en gericht ${ }^{247}$ zoeken. Dit betekent dat binnen de grenzen van proportionaliteit ${ }^{248}$ met behulp van de sterke arm (dus met 'geweld') toegang mag worden verschaft tot plaatsen en dat aldaar intensief en wederom zonodig met 'geweld'

244 Wet van 27 mei 1999 tot partiele wijziging van het Wetboek van Strafvordering (herziening van het gerechtelijk vooronderzoek), Stb. 1999, 243.

245 Op grond van artikel $97 \mathrm{WvSv}$ is de officier van Justitie met voorafgaandemachtiging van de rechtercommissaris bevoegd om bij dringende noodzakelijkheid en indien de komst van de rechter-commissaris niet kan worden afgewacht woningen zonder toestemming van de bewoner en kantoren van functioneel verschoningsgerechtigden te doorzoeken. De overige voorwaarden (heterdaad dan wel een misdrijf zoals omschreven in artikel 67 lid $1 \mathrm{WvSv}$ ) gelden wel onverkort. In tegenstelling overigens tot de oude regeling is de officier van justitie dan niet langer gehouden om een vordering tot het openen van een gerechtelijk vooronderzoek te doen.

246 Dit is echter onwaarschijnlijk, omdat de wetgever gelet op de intensivering van de kartelaanpaker ongetwijfeid naar zou hebben gestreefd dat voor een doorzoeking niet de hulp van de rechter-commissaris zou hebben moeten worden ingeroepen.

247 Zie bijvoorbeeld de twee bekende arresten HR 28 mei 1985, NJ 1985, 822 m.nt. ThWvV (Keukenkastje) en HR 17 maart 1987, NJ 1988, 155 m.nt. ThWvV (Cocaìne in linnenkast).

248 Een exponent van dit proportionaliteits- of evenredigheidsbeginsel is door de wetgever neergelegd in artikel 99 lid $1 \mathrm{WvSv}$ : "Tenzij het belang van het onderzoek dit vordert, wordt tot inbeslagneming in eene woning niet overgegaan dan nadat de bewoner of, indien hij afwezig is, een zijner aanwezige huisgenoten is gehoord en vruchteloos uitgenodigd het voorwerp vrijwillig afte geven ter inbeslagneming". Aldus eveneens Jansen (1999), pag. 209. 
mag worden gezocht naar voor inbeslagneming vatbare voorwerpen. Zover mag bij 'gewone' binnentreding niet worden gegaan. De tot binnentreding bevoegde opsporingsambtenaar mag zijn ogen de kost geven en zoekend rondkijken, maar dit zoeken dient beneden de grens van het stelselmatige en gerichte onderzoek te blijven. Waar deze grens precies ligt, is in zijn algemeenheid niet aan te geven. Veel zal afhangen van de concrete omstandigheden van het geval, waarbij onder meer de duur van het onderzoek, de mate van 'privacy-gevoeligheid' van de plaats waar gezocht wordt en de intensiteit van het onderzoek een rol kunnen spelen. ${ }^{249}$ Bij de factor 'intensiteit van het onderzoek' kan gedacht worden aan de wijze waarop het zoeken heeft plaatsgehad: zodra tijdens het onderzoek (dossier)kasten, laden en dergelijke zijn geforceerd teneinde van de inhoud hiervan kennis te kunnen nemen, dan is per definitie sprake van een intensief onderzoek en daarmee van een doorzoeking. Is een dergelijk onderzoek verricht op basis van een binnentredingsbevoegdheid, dan is deze onmiskenbaar overschreden, hetgeen in beginsel zou moeten leiden tot uitsluiting van het bewijs van het aldus vergaarde materiaal.

\subsubsection{Communautair zoekrecht}

Terugkomend op het communautaire kartelrecht, kan het volgende gesteld worden: trekt men bovenbeschreven bevoegdhedenlijn naar de communautaire situatie door, dan zou dit meebrengen dat in ieder geval geen sprake kan zijn van een doorzoekingsbevoegdheid. Artikel 14 Vo 17 maakt immers slechts gewag van de bevoegdheid tot binnentreden, waarbij -analoog aan de Nederlandse situatie- een niet meer dan beperkt zoekrecht zou horen. Hoewel, zoals gezegd, geen al te verstrekkende inhoudelijke consequenties moeten en kunnen worden verbonden aan begripsmatige overeenkomsten, zal blijken dat tot op zekere hoogte daadwerkelijk overeenkomsten bestaan tussen de invulling van het Nederlandse en van het communautaire binnentredingsbegrip, hetgeen onverlet laat dat er tevens enkele belangrijke verschillen zijn.

Beziet men de regeling zoals die in artikel 14 Vo 17 is vervat, dan is er een aantal aspecten die niet in de richting van een grondig en vergaand zoekrecht wijzen. Ten eerste spreekt de tekst van artikel 14 Vo 17 niet van een dergelijk zoekrecht. Gelet op het feit dat met het in handen van de Commissie leggen van de handhaving een geheel nieuwe weg werd ingeslagen en gelet op de 'impact' die een dergelijk zoekrecht zou hebben, zou toch verwacht mogen worden dat dit expliciet in Verordening 17 zou zijn opgenomen. Het tweede aspect ligt in het gegeven dat op de ondernemingen in het kader van verificaties de plicht rust om tot op zekere hoogte mee te werken en met name de verlangde gegevens te verschaffen, hetgeen mede volgt uit het tweede lid van artikel 14 Vo 17 , waarin -onder verwijzing naar artikel $15 \mathrm{Vo} 17$-melding wordt gemaakt van het tonen van de gewenste bescheiden. In feite is een dergelijke medewerkingsplicht -zoals die ook door de Commissie wordt erkend ${ }^{250}$ - overbodig indien de Commissie bevoegd is het gewenste materiaal

249 Wöretshofer (1999 1), pag. 227.

$250 \mathrm{ZiePb} 1980 \mathrm{~L} 75 / 30$ (FabbricaPisana), waarinde Commissie vaststelde dat "de op de ondernemingen rustende verplichting de door de ambtenaren van de Commíssie verzochte bescheiden volledig over te leggen, niet alleen moet worden opgevat als cen mogelijkheid tot al deze documenten toegang te verknijgen, maar juist als de verplichting om in feite de bescheiden te overleggen waarom uitdrukke- 
ook zelfstandig te vergaren. Terecht stelt Kühlhom dan ook: "Wenn hierdurch (i.e. de plieht om gegevens te verstrekken, HQ) ausdrücklich eine aktive Mitwirkungspflicht der Urternehmen bei der Nachprüfung statuiert wird, ist damit auch klargestellt, daß die nachprüfenden EG-Beamten nicht berechtigt sind, selbst Unterlagen aus Aktenschränken oder Schreibtischen zu entnehmen. Die Rechte der nachprüfenden Inspektoren kommen deshalb auch nicht im Ergebnis einem Durchsuchungsrecht nahe". 251 Aldus vormt de vergaande medewerkingsplicht een contra-indicatie voor het afleiden van een doorzoekirgsbevoegdheid uit artikel 14 Vo 17. Desalniettemin is het niet uitgesloten dat de Raad todh een verdergaande bevoegdheid heeft willen creëren, zij het dat hij de Commissie uittrukkelijk heeft willen verplichten om -voorafgaand aan een eventueel zelfstandig onderzoek- de onderneming in de gelegenheid te stellen vrijwillig, zij het onder dwang van een sanctie, volledige medewerking te verlenen. In zoverre zou artikel 14 Vo 17 (op min of meer vergelijkbare wijze als artikel 99 lid 1 WvSv) impliciet verwijzen naar het proportionaliteitsbeginsel.

Het gegeven dat de Raad de mogelijkheid tot het opleggen van dwangsommen in Verordening 17 heeft neergelegd, is een derde aspect dat geen aanleiding geeft om tot deverificatiebevoegdheid de bevoegdheid tot doorzoeking te rekenen. Indien de Commissie een toereikend zoekrecht zou hebben, dan zou zij bij een niet-coöperatieve onderneming zelistandig kunnen optreden en zou niet behoeven te wachten totdat de onderneming zich alsnog onder druk van de dwangsom aan de verificatie onderwerpt en de nodig geachte informatie verstrekt. Zou de dwangsom desalniettemin naast een doorzoekingsbevoegdheid bestaansrecht hebben, dan zou de meerwaarde van eerstbedoeld dwangmiddel beperkt zijn tot die informatie die zich niet binnen de bedrijfsruimten en de (overige) percelen van de onderneming bevinden. Deze gegevens kunnen hoe dan ook niet zelfstandig door de Commissie worden vergaard omdat de betredingsbevoegdheid zich niet over de andere plaatsen (bijvoorbeeld de woning van de directeur van de betrokken onderneming of het kantoor van een externe advocaat) uitstrekt. Denkbaar is ook dat de Raad een extra handhavingsmodaliteit aan de Commissie heeft willen geven, waarvan deze gebruik kan maken als een onderneming niet zonder meer coöpereert, maar waarbij het overgaan tot doorzoeking van de bedrijfsruimten een disproportioneel middel zou zijn.

Een vierde aspect is gelegen in het zesde lid van artikel $14 \mathrm{Vo} 17$ dat de verplichting aan de lidstaten oplegt om desgevraagd bijstand te verlenen in geval een onderneming zich tegen een verificatie verzet. Deze bepaling zou overbodig zijn als de communautaire ambtenaren zelf de bevoegdheden zouden bezitten die doorgaans aan een bevoegdheid tot doorzoeken zijn verbonden. Hiertegen zou kunnen worden ingebracht dat uitsluitend het met harde hand breken van verzet aan de nationale autoriteiten wordt overgelaten en dat alle overige activiteiten die inherent zijn aan een doorzoekingsbevoegdheid wel aan de Commissie toekomen.

Gezien het voorgaande ligt de conclusie dat de verificatiebevoegdheid de Commissie machtigt tot het verrichten van een doorzoeking, niet voor de hand. Het communautaire recht op binnentreden zou veeleer slechts ondergeschikt zijn aan de overige in artikel $14 \mathrm{Vo} 17$ genoemde bevoegdheden of althans een middel vormen ter betere effectuering van deze bevoegdheden. Het speuren naar bewijs zou niet tot de mogelijkheden behoren. Ten aanzien van de verificatiebeschikking stelt Joshua dan ook dat "The decision is essenti-

lijk werd verzocht".

251 Kahlhorn (1986), pag. 20. Vergelijkbaar Gillmeister (1995), pag. 196. 
ally an order addressed to the firm to permit the investigation or face fines and daily penalties. It gives no power to the inspectors to force an entry or break open locked desks and filing cabinets. It is thus very different in nature from a search warrant issued by a court". 252

De vraag is of deze bespiegelingen steun vinden in de rechtspraak van het Hof. Opheldering hieromtrent -althans een aanzet daartoe- kan gevonden worden in de met betrekking tot de reikwijdte van de verificatiebevoegdheid zeer belangrijke uitspraak in de Hoechstzaak. ${ }^{253}$ Hoechst, verdacht van kartelmatig gedrag in de PVC- en polyethyleensector, weigerde zich te onderwerpen aan een verificatie bij beschikking. ${ }^{254}$ Eén van de bezwaren die Hoechst tegen de verificatie aanvoerde, was dat deze materieel zou neerkomen op een doorzoeking, hetgeen volgens haar niet geoorloofd was omdat Verordening 17 niet in een dergelijke bevoegdheid zou voorzien. De Commissie daarentegen was van mening dat haar wel de bevoegdheid tot doorzoeking, als een zwaardere vorm van verificatie, was toegekend en dat zij zodoende het recht had "de gezochte bescheiden op de plaats waar zij worden bewaard te verifiëren, te schiften en uit te kiezen". ${ }^{25 s} \mathrm{Zij}$ stond op het standpunt "dat haar personeelsleden in het kader van verificaties lokalen of meubilair mogen doorzoeken zonder de bijstand van de nationale autoriteiten en zonder de in het nationale recht voorziene procedurele waarborgen te eerbiedigen". Advocaat-Generaal Mischo achtte weliswaar een dergelijk ruime bevoegdheid tot doorzoeken van bedrijfsruimten zoals verwoord door de Commissie niet gelegitimeerd, maar stond wel een extensieve interpretatie van artikel 14 Vo 17 voor. Volgens Mischo hield de bevoegdheid tot binnentreden in dat de communautaire ambtenaren die met het onderzoek zijn belast "alles kunnen bekijken wat zich aldaar bevindt en kunnen vragen dat de voorwerpen die zij aanwijzen hun worden overhandigd". ${ }^{256} \mathrm{De}$ 'voorwerpen' zouden derhalve niet vooraf (dat wil zeggen in de beschikking) behoeven te zijn geïdentificeerd; zelfs het verlangen van inzage in alle documenten uit een bepaalde kast valt in deze lezing binnen de bevoegdheid tot verificatie. Ook de bevoegdheid tot doorzoeking wordt volgens de Advocaat-Generaal door artikel 14 Vo 17 bestreken. Hier ligt de zaak echter genuanceerder omdat bij de verificatie de nadruk op de medewerking van de onderneming ligt waaruit volgt dat de ondememing steeds de mogelijkheid moet worden geboden deze medewerking te verlenen. Voor de bevoegde communautaire ambtenaren brengt dit mee dat zij niet zonder meer een doorzoeking mogen verrichten. Dit geldt ipso facto voor de verificatie die bij opdracht wordt doorgevoerd, omdat hieruit in beginsel geen verplichtingen voor de ondernemingen voortvloeien en de ondermeming dientengevolge zonder consequentie de verificatieopdracht naast zich neer kan leggen. Echter ook in geval de verificatie bij beschikking plaatsheeft en de onderneming het onderzoek heeft te dulden, zullen de ambtenaren, aldus Mischo, niet mogen overgaan tot doorzoeking, dan nadat zij de onderneming in de gelegenheid

252 Joshua (1983), pag. 10. In vergelijkbare zin Joshua (1986), pag. 412: "It is not a licence given to the Commission to do certain acts: rather it is an order addressed to the firm requiring it to submit to an investigation on pain of certain penalties".

$253 \mathrm{HvJ}$ (46/87 en 227/88) Jur, 1989, 2859 (Hoechst); vergelijk tevens HvJ (85/87) Jur. 3137 (Dow Benelux) en HvJ (97/87-99/87) Jur. 3165 (Dow Chemical lbérica e.a.) welke arresten in dezelfde zaak zijn gewezen.

254 Mok (1987 II), pag. 72, vermoedde hier 'Prinzipienreiterei' van Hoechst.

$255 \mathrm{HvJ}$ (46/87 en 227/88) Jur. 1989, 2859 (Hoechst).

256 Conclusie Mischo bij de Hoechst en Dow-zaken, HvJ (46/87 en 227/88) Jur. 1989, 2879. 
hebben gesteld aan haar verplichtingen, voortvloeiend uit de beschikking, te voldoen. Weigert de onderneming te coöpereren, dan zou een gericht zoeken kunnen plaatshebben (waarbij kasten, laden en dergelijke indien nodig kunnen worden opengebroken), maar uitsluitend met bijstand van de nationale autoriteiten op grond van het zesde lid van artikel 14 Vo 17: het openen van meubilair en het hieruit wegnemen van documenten zou dan niet door de communautaire ambtenaren zelf kunnen geschieden. ${ }^{257}$

Het Hof onderstreepte in zijn arrest nogmaals het belang van de materiele kartelregels voor de gemeenschappelijke markt en benadrukte de betekenis van het verificatie- en, meer in het bijzonder, het binnentredingsrecht van de Commissie voor de handhaving van deze kartelregels. Tegen deze achtergrond stond het Hof een ruime interpretatie van artikel 14 Vo 17 voor en sloot nauw aan bij de conclusie van zijn advocaat-generaal. He doel en de betekenis van de binnentredingsbevoegdheid leidden het Hof tot de conclusie dat de bevoegdheid zinloos zou zijn

\begin{abstract}
"indien de personeelsleden van de Commissie zich ertoe zouden moeten beperken, de overlegging te vorderen van documenten of dossiers die zij vooraf nauwkeurig hebben kunnen identificeren. Het recht van toegang impliceert juist de mogelijkheid, allerhande informatic op te sporen die nog niet bekend of geheel geidentificeerd is. Zonder deze mogelijkheid zou de Commissie niet in staat zijn, de voor haur verificatie noodzakelijke inlichtingen in te winnen, wanneer de betrokken ondernemingen hun medewerking weigeren of zich aldus gedragen dat verificatie belemmerd wordt". 23
\end{abstract}

Deze overweging van het Hof getuigt van een wil de bevoegdheden van de Commissie in deze niet te zeer in te perken, maar zij neemt weinig weg van de bestaande onduidelijkheden omtrent de reikwijdte van de binnentredingsbevoegdheid. Dit hangt deels samen met de door het Hof gehanteerde vage term 'opsporen' en deels met de overweging dat de Commissie in staat moet zijn de informatie te verkrijgen indien de onderneming medewerking weigert. Voorshands is niet duidelijk hoever de Commissie bij het opsporen van relevant (bewijs)materiaal mag gaan; de bevoegdheid moet echter ver genoeg reiken, zo kan geconcludeerd worden, om het gewenste materiaal ook bij een weigerachtige onderneming te kunnen bemachtigen. Dit lijkt te impliceren dat de Commissie zelfstandig mag overgaan tot het zoeken van documenten op de daartoe geschikte plaatsen indien de onderneming niet coöperatief is en dat het Hof de vorenvermelde interpretatie van de Commissie zou volgen. Het Hof maakt echter een belangrijke restrictie:

\footnotetext{
"de voorwaseden waaronder de Commissie haar bevoegdheden tot verificatie mag uitoefenen, variêren al naar gelang de door haar gekozen procedure, de houding van de betrokken ondernemingen en het optreden van de nationale autoriteiten".
}

Het is duidelijk dat, zoals hiervoor reeds aangestipt, de mogelijkheden van de Commissie in het kader van een niet dwingende verificatie bij opdracht beduidend geringer zijn dan in het kader van een verificatie bij beschikking. De gekozen procedure alleen is echter

257 Conclusie Mischo bij de Hoechst en Dow-zaken 1989, 2883.

258 De limitering van de bevoegdheid tot binnentreden tot een passieve houding van de Commissie, inhoudende het ter plaatse toezien op het verzamelen door een (werknemer van een) onderneming van de door de Commissie gewenste en precies beschreven en omschreven documenten en het wachten op het moment waarop deze documenten aan haar worden overhandigd, zou inderdaad weinig effectief zijn en de meerwaardevan de verificatie ten opzichte van de bevoegdheid inlichtingen te verlangen ex artikel 11 Vo 17 zou uitermate gering, zo niet non-existent, zijn. 
niet doorslaggevend; van minstens even groot belang is de houding van de onderneming, waarbij het Hof onderscheidt tussen enerzijds de verificatie waaraan de onderneming meewerkt en anderzijds de verificatie waarin dit niet het geval is. In de situatie waarin de onderneming bereid is te voldoen aan de haar bij beschikking opgelegde verplichtingen heeft de Commissie onder meer "de mogelijkheid de overlegging van documenten te vorderen, de lokalen te betreden die zij daartoe aanwijzen, en zich de inhoud van meubilair te laten tonen". In één adem stelt het Hof de restrictie dat de Commissie niet mag overgaan tot het aanwenden van dwang: de personeelsleden van de Commissie

\footnotetext{
"mogen de toegang tot lokalen of meubilair evenwel niet forceren en het personeel van de onderneming niet dwingen, hun die toegang te verlenen, noch mogen zij de lokalen of het meubilair doorzoeken zonder toestemming van de vertegenwoordigers van de onderneming"
}

Met deze overweging heeft het Hof de hierboven weergegeven mening van de Commissie expliciet verworpen. De onderneming die zich niet tegen een verificatie verzet, moet door de Commissie ten volle de gelegenheid worden geboden mee te werken; de Commissie zal dan niet zelfstandig tot enige zoekactie mogen overgaan. Dit wekt weinig verbazing aangezien een handelwijze zoals door het Hof bepaald, voortspruit uit de evenredigheidseis op grond van welke de Commissie steeds zal dienen te kiezen voor het optreden dat de minst ingrijpende inbreuk in de privésfeer van de onderneming oplevert ervan uitgaande dat het eindresultaat van de verschillende modaliteiten van optreden gelijk is. Dit laatste nu is per definitie het geval in die situaties waarin een onderneming bereid is volledige medewerking te verlenen: de Commissie verkrijgt de door haar relevant geachte documenten zowel in het geval zij zelf deze documenten zoekt als in het geval de onderneming deze aan de Commissie overhandigt.

In de situatie waarin een onderneming medewerking weigert en waarin zelfs boetedreiging of oplegging van dwangsommen ${ }^{259}$ de onderneming niet op andere gedachten kan brengen, baat een handelwijze zoals hiervoor ten aanzien van de niet-weigerachtige onderneming beschreven, in het geheel niet. De handhaving van het communautaire recht eist dan ook een verdergaand ingrijpen van de Commissie. De oplossing is door het Hof gevonden in artikel 14 lid 6 Vo 17. Het in dit artikellid bepaalde machtigt de personeelsleden van de Commissie

"om, zonder medewerking van de ondernemingen, alle voor de verificatie noodzakelijke inliehtingen op te sporen met hulp van de nationale autoriteiten, die hun de bijstand moeten verlenen die zij voor de vervulling van hun opdracht nodig hebben"

waarbij de Commissie de "in het nationale recht voorziene procedurele waarborgen" in acht zal dienen te nemen. ${ }^{260}$ Een onderneming die iedere medewerking aan het onderzoek

259 Zie over de in de Hoechst-zaak opgelegde dwangsommen Rudisile (1990), pag. 53-54.

260 In haar Wirboek betreffende de modernisering van de regels inzake de toepassing van de artikelen 85 en 86 van het EG-Verdrag voert de Commissie aan dat de effectiviteit van de verificatiebevoegdheid te lijden heeft onder de omstandigheid dat in de meeste lidstaten (niet in Nederland) voorafgaande rechterlijke toestemming moet worden verkregen, willen de nationale mededingingsautoriteitenhun bijstand aan de verificatie kunnen verlenen. Als zodanig heeft de Commissie hiermee -vanzelfsprekendgeen bezwaren, maar het bemoeilijkt verificaties waarbij in verschillende landen moet worden opgerte den, en dan met name op het punt van de afstemming en de gelijktijdigheid. De Commissie oppert daarom de mogelijkheid om de voorafgaande rechterlijke toetsing te centraliserenop communautair 
van de Commissie weigert of althans in onvoldoende mate hieraan meewerkt, kan een fermer optreden verwachten en moet rekening houden met verdergaande inbreuken in haar privésfeer dan het geval zou zijn geweest indien zij wel bereid was geweest tot coöperatie. Maar ook in deze situatie geldt dat de personeelsleden van de Commissie in het geheel geen dwang mogen uitoefenen. Dit is voorbehouden aan de nationale autoriteiten en zal plaatshebben op grond van de regelgeving van de desbetreffende lidstaat.

De literatuur maakt duidelijk dat, de overwegingen van het Hof ten spijt, het nog steeds niet onomstreden is welke de exacte inhoud en omvang van de bevoegdheden van de Commissie bij toepassing van artikel 14 Vo 17 zijn. Scholz ziet onmiskenbare overeenkomsten tussen de communautaire verificatiebevoegdheid en de Duitse 'Durchsuchung' en acht deze zelfs materieel gelijk ${ }^{261}$, terwijl Schröter en Jakob-Siebert naar aanleiding van het Hoechst-arrest stellen dat weliswaar "sich die Nachprüfungsbefugnisse nach Artikel 14 nicht auf eine passive Nachprüfung seitens der Kommissionsbediensteten beschrïnken, sondern auch die aktive Suche nach noch unbekannten Beweisen umfassen können", maar dat de ambtenaren van de Commissie "aus eigenem Recht keine Durchsuchungen ohne die Einwilligung der Verantwortlichen des Unternehmens" kunnen doorvoeren. ${ }^{262}$ Kerse concludeert dat artikel 14 lid 1 sub d Vo 17 "merely gives a power to enter premises, etc. in order to exercise the other powers contained in Article 14(1)(a), (b) and (c)".

niveau. Omdat dit in haar 'Voorsteluitvoeringsverordening' nietterugkeert, lijkt een dergelijke wijziging -mijns inziens terecht- van de baan.

261 Scholz (1990), pag. 105. Ongeacht het antwoord op de vraag of zijn gevolgtrekking juist is, verbindt Scholz hieraan de te vergaande conclusie dat de waarborgen die het Duitse recht in verband met de huiszoeking kent zonder meer gelding moeten hebben voor het communautaire recht. Hiermee miskent hij echter de bijzondere positie die de communautaire rechtsorde inneemt ten opzichte van de nationale. Pernice stelt dat de Commissie een recht heeft dat in de praktijk verder reikt dan de bevoegdheid tot doorzoeking: "Mit dem in Art. 14 Abs. 1 lit. $\mathrm{d}$ VO nr. 17 verburgten umfassenden Zugangsrecht kommen die Befugnisse der Kommission im Ergebnis dem Durchsuchungsrecht sehr nahe, ja gehen wegen der Mitwirkungspflichten des betroffenenUnternehmens sogar darüber hinaus; freilich sind die Kommissionsbeamten auf die Mitwirkung der Unternehmensvertreter angewiesen und können sich nicht eigenmächtig den tatsächlichen Zugang zu den Geschalftsräumen und Unterlagen verschaffen". Maar ook als de onderneming niet meewerkt, kan er aldus Pernice een doorzoeking plaatshebben: "Durchsuchungen ohne die Einwilligung der Verantwortlichen des Unternehmens sind nur auf der Grundlage des Art. 14 Abs. 6 VO nr. 17 zulässig". Blom en De Doelder (1991), pag. 849-850, zijn van mening 'dat het er naar uitziet' dat het Hof in de binnentredingsbevoegdheid een (soort) huiszoekingsbevoegdheid ziet. Schermerhorn (1994), pag. 27 e.v. acht het recht van de Commissie om op de lokaliteitenvan de coöperatieveonderneming vooraf niet nader geïdentificeerde bescheiden op te kunnen eisen dermate ruim, dat hij tot de slotsom komt dat de verificatiebevoegdheid 'een soort huiszoeking' inhoudt. Een 'echte huiszoeking' behoort ook tot de mogelijkheden maar "alleen in geval van weigering tot medewerking van de onderneming". "Voorwaarde is dat de doorzoeking plaatsvindt in tegenwoordigheid van en bijgestaan door nationale ambtenaren". Hellmann (1988), pag. 611 en Kulka (1989), pag. 2116, lijken er eveneens van uit te gaan dat het een 'Durchsuchung' betreft, terwijl Sauter (1988), pag. 1430, van 'durchsuchungsähnlichen Handlungen' spreekt. Jorna (1990), pag. 632, meent dat de Uitvoeringswet 1968 aldus gelezen diende te worden dat de nationale ambtenaren over een actieve opsporingsbevoegdheid beschikten.

262 Schröter en Jakob-Siebert (1991), pag. 2007. Reeds eerder ontkenden Kreis (1981), pag. 291 en 296, alsmede Rehmann (1987), pag. 3062, het bestaan van de bevoegdheid tot 'Durchsuchung'. In deze zin ook Fierstra (1993), pag. 159, Jorna (1990), pag. 630 en Slotboom (1998), pag. 99. 
Maar "that position becomes entirely different if the undertaking opposes the investigation". 263

Het kan als vaststaand beschouwd worden dat de cesuur die het Hof in de Hoechst-zaak constateert tussen de verificatie waaraan wel en die waaraan niet wordt meegewerkt door de onderneming, voor de toepassing van de bevoegdheden relevant is. De vraag is alleen of het Hof consequenties ten aanzien van de inhoud van de verificatiebevoegdheid heeft willen verbinden aan de verschillende houdingen van een onderneming. De materiële omvang van de bevoegdheid is mijns inziens een vaste waarde die niet afhankelijk is van de opstelling van de betrokkenen; het maakt voor de verificatiebevoegdheid als zodanig geen verschil of een onderneming coőpereert of dat zij dit niet of slechts ten dele doet. De situatie is denkbaar dat een onderneming aan de Commissie toegang tot haar percelen verleent en zelfs inzage gunt in een deel van de relevante documenten, maar sommige bescheiden niet wenst te tonen aan de Commissie; het lijkt op zijn minst zeer onwaarschijnlijk dat door deze weigering de bevoegdheden zoals limitatief opgesomd in artikel 14 Vo 17 'plotseling' een ruimere inhoud verkrijgen. Daarentegen kan de weigering wel tot gevolg hebben dat er een wijziging optreedt in de bevoegdheid tot tenuitvoerlegging van de verificatiebevoegdheid. Deze stelling vergt enige toelichting.

Het Hof heeft in zijn Hoechst-uitspraak geopteerd voor een extensieve interpretatie van artikel 14 Vo 17 en voor een zeer ruime materiële omvang ${ }^{264}$ van de bevoegdheid tot verificatie in het algemeen en de binnentredingsbevoegdheid in het bijzonder. Dit houdt in dat de mogelijkheden die artikel 14 Vo 17 ter opsporing biedt veelvuldig en omvangrijk zijn; hieronder vallen onder meer het verlangen van inzage in alle gewenste documenten (behalve die welke onder het verschoningsrecht' of onder de reikwijdte van het (communautaire) 'nemo tenetur-beginsel' vallen ${ }^{265}$ ), het maken van kopieën, het vragen om toelichting op en uitleg van de opgevraagde of op te vragen bescheiden, het betreden van alle plaatsen van een onderneming en het actief zoeken op deze plaatsen naar voor het onderzoeksonderwerp relevante documenten. Al deze bevoegdheden (dus ook die tot het gericht zoeken) heeft de Commissie steeds als zij besluit tot verificatie over te gaan, niet uitgezonderd de situatie waarin een onderneming volledige medewerking aan de onderzocksactiviteiten van de Commissie verleent. De Commissie zal echter niet in alle gevallen volledig van de haar toekomende bevoegdheden gebruik mogen maken. $\mathrm{Zij}$ is -met name ten aanzien van het zoekrecht- beperkt in haar mogelijkheid tot toepassing en effectuering van haar bevoegdheden: tegenover een ruime 'materiële' omvang staat een meer beperkte 'Vollstreckungszustăndigkeit', ${ }^{266}$ In het geval waarin de onderneming tegen welke de verificatiebeschikking zich richt ${ }^{267}$, bereid is aan de op haar rustende verplichtingen te voldoen, dan zal de Commissie de uitoefening van haar bevoegdheden moeten beperken tot het betreden van alle plaatsen en het aldaar inzage vorderen van

263 Volgens Kerse (1998), pag. 145, is er sprake van een "absence of a forcible power to search",

264 Voor het begrip 'materieller Umfang' zie ook Kamburoglou en Pirrwitz (1990), pag. 268.

265 Zie hiervoor uitgebreid hoofdstuk 5.

266 Vergelijk Kamburoglou en Pirrwitz (1990), pag. 268.

267 De opdracht tot verificatic wordt hierna buiten beschouwing gelaten omdat zij door de onderneming zonder directe gevolgen geweigerd kan worden; dit laat onverlet dat zij wel bijvoorbeeld alle gegevens mag opvragen, maar zij geen mogelijkheden heeft de verstrekking hiervan of in het algemeen het dulden van de verificatic af te dwingen. 
de vereiste documenten (naast het maken van afschriften en verlangen van toelichtingen). ${ }^{208}$ De uitoefening van de bevoegdheden bij een coöperatieve onderneming is derhalve niet gelijk te stellen met -en is mijns inziens ook niet vergelijkbaar met- de bevoegdheid tot doorzoeking ${ }^{269}$, omdat juist het zelfstandig optreden dat karakteristiek voor de doorzoeking is, aan de Commissie ontzegd is. ${ }^{270}$

De weigering van een onderneming om zich aan een verificatie te onderwerpen, heeft een verruiming van de toepassingsmogelijkheid van de bevoegdheden tot gevolg: de Commissie zal meer ingrijpende opsporingsactiviteiten mogen verrichten teneinde zich zo over de passiviteit van de onderneming heen te kunnen zetten. Voorwaarde is wel dat de bevoegde nationale autoriteit aan de commissieambtenaren bijstand verleent. Dit brengt met zich deze ambtenaren voor de uitoefening van hun bevoegdheden steeds afhankelijk zijn van derden, hetzij van ondernemingen (bij coöperatie), hetzij van een bevoegde lidstatelijke autoriteit (bij gebleken niet-medewerking). ${ }^{271}$ Hoever de opsporingsbevoegdheden van de Commissie reiken indien de onderneming weigerachtig is, blijkt niet uit het Hoechst-arrest. Duidelijk is echter dat aan de Commissie meer is toegestaan dan ingeval de onderneming coőperatief is. Mijns inziens mogen de communautaire ambtenaren in die situatie ten kantore van de onderneming gericht zoeken naar materiaal dat antwoord kan geven op de bij de Commissie gerezen vragen; hierbij mogen zij ook alle kasten, bureau's en dergelijke doorzoeken. Een beperktere interpretatie zou een moeilijk werkbare situatie opleveren omdat het gerichte zoeken dan aan derden (de ambtenaren van de bevoegde nationale autoriteit) overgelaten zou moeten worden, terwijl het juist de Commissie is die bij uitstek kan bepalen of een document al dan niet relevant is voor haar onderzoek. Hierbij moet echter een wezenlijke kanttekening worden geplaatst. De commissieambtenaren zijn hoe dan ook, zelfs als zij een nationale collega naast zich weten, niet bevoegd tot het openen van (al dan niet afgesloten) meubilair of tot het wegnemen van documenten uit dit meubilair, noch mogen zij enige (verdergaande) dwang toepassen ${ }^{27}$; uitoefening van deze bevoegdheden is bij uitzondering voorbehouden aan de nationale

268 Dit volgt ook reeds uit het beginsel van evenredigheid.

269 In dezelfdezin ook Debruyne (1992), pag. 69/70. Afwijkend, zoals gezegd, onder meer Schermerhorn (1994), pag. 27 e.v. en Scholz (1990), pag. 105.

270 De ondememing derhalve die weigert om aan de Commissie toestemming tot doorzocking te verlenen, kan niet worden beboet wegens niet-coöperatie, ervan uitgaande dat zij overigens wel bereid is alle noodzakelijk hulp te verlenen. Evenmin kan deze weigering aanleiding vormen voor de inschakeling van de nationale autoriteiten. De praktijk wijst uit dat ondernemingen-om hoe dan ook te voorkomen dat hen een tegenwerking van het onderzoekzou kunnen worden verweten-niet zelden de Commissie wél toestemming tot doorzoeking geven, hetgeen hen overigens niet ontheft van de verplichting om op verzoek van de Commissie gegevens en toelichtingen te verschaffen. Een en ander maakt het echter, zoals Van Bael en Bellis (1994), pag. 737, terecht stellen, wel moeilijk "to prevent an inspector from rummaging through the files, though in principle this ought to be resisted in order to avoid the inspection exceeding its precise scope and degenerating into a fishing expedition".

271 In zijn conclusie bij de Hoechst en Dow-zaken stelt Mischo: "de weigering om de personeelsleden van de Commissie de inhoud van een meubel te overhandigen, is een geval van verzet in de zin van artikel 14, lid 6, waar deze personeelsleden niet zelf overheen kunnen stappen door zich meester te maken van de dossiers; dan is hulp van de vertegenwoordigers van de betrokken Lid-Staat nodig".

272 Vergelijk de Commissie zelf in het kader van de Hoechst-zaakc weigert een onderneming, "dan moeten de personeelsledenvan de bevoegde nationale autoriteit bijstand verlenen, eventueel door toepassing van rechtstreekse dwang, bij voorbeeld door met geweld meubilair te openen en dossiers eruit te nemen, opdat de personeelsleden van de Commissie de gezochte bescheiden kunnen achterhalen". 
ambtenaren. ${ }^{273}$ De procedure dient derhalve als volgt te zijn: indien een onderneming zich verzet, moet de Commissie de hulp inroepen van de bevoegde nationale instantie die zorg moet dragen voor een spoedig en goed verloop van de verificatie. Zodra de (communautaire en nationale) ambtenaren zich gesteld zien tegenover gesloten vertrekken of (af)gesloten kasten, dan zullen slechts de nationale ambtenaren mogen overgaan tot het openen hiervan, waarna de commissieambtenaren in de inhoud van bedoelde kasten mogen zoeken naar (bewijs)materiaal. Wensen zij van bepaalde documenten inhoudelijk kennis te nemen, dan moeten zij, althans theoretisch, het uit de kasten nemen van de documenten aan hun nationale collega's overlaten. Aan deze theoretische letter blijkt in de praktijk vaak niet de hand te worden gehouden. Het is om praktische redenen voor de hand liggend dat de commissieambtenaren niet steeds hun aanwezige nationale collega's te hulp roepen om een document uit een bureau te nemen om vervolgens zelf dit document aan een onderzoek te onderwerpen. Dit heeft geen consequenties voor de geldigheid van de verificatie omdat de rechten van de onderneming mijns inziens door deze -theoretisch niet geheel zuivere- wijze van handelen niet noemenswaardig geschaad zijn. Deze conclusie is overigens uitsluitend geldig voor die gevallen waarin de communautaire ambtenaren afzien van het aanwenden van dwang. Gebeurt dit laatste niet en wordt toegang tot meubilair bereikt door het openbreken hiervan, dan is er sprake van een dermate ingrijpende inbreuk op het communautaire recht en op het algemene beginsel van verbod op détournement de pouvoir, dat de verificatie ongeldig moet worden verklaard en het eventueel tegen de onderneming verkregen bewijsmateriaal moet worden uitgesloten van bewijs.

De constatering dat de Commissie een relatief beperkt recht tot toepassing van haar bevoegdheden ex artikel $14 \mathrm{Vo} 17 \mathrm{heeft,} \mathrm{werpt} \mathrm{de} \mathrm{vraag} \mathrm{op} \mathrm{waarom} \mathrm{het} \mathrm{Hof} \mathrm{een} \mathrm{zeer} \mathrm{exten-}$ sieve uitleg aan de materiële omvang van deze bevoegdheden heeft gegeven. Het antwoord op deze vraag houdt verband met de bijstand die door de autoriteiten van de lidstaten op verzoek van de Commissie moet worden verleend. Met instemming kunnen Kamburoglou en Pirrwitz ${ }^{274}$ worden geciteerd: "Die nationalen Beamten können materiell keine weitergehenden Rechte haben, als die Bediensteten der Kommission, deren Befugnisse sie durchzusetzen verpflichtet sind". ${ }^{275}$ De nationale instanties, die op grond van artikel 14 lid 6 Vo 17 gehouden zijn bijstand te verlenen, hebben aldus ten hoogste de bevoegdheden die in artikel 14, eerste lid Vo 17 zijn neergelegd. Dit volgt reeds uit de bewoordingen van artikel 14 lid 6 Vo 17 waarin wordt gesteld dat de nationale autoriteiten bijstand verlenen aan de Commissie, maar blijkt bovendien uit het uitzonderlijke gegeven dat de handhaving van het EG-Verdrag op kartelgebied bij uitstek een communautaire

273 Aldus eveneens Kamburoglou en Pirrwitz (1990), pag. 268, die echter lijken te opteren voor een nog beperktere bevoegdheid van de Commissie op het gebied van het zoekrecht: "bereits das Betretungsrecht der Bediensteten der Kommission impliziert die Befugnis, nach "noch nicht bekannten oder vollstïndig bezeichneten" Informationsquellen zu "suchen". Allerdings dürfen die Beamten der Kommission diese Befugnis, mangels Zuständigkeit, selbst nicht wahrnehmen. Dem entspricht statt dessen eine Duldungs-und Mitwirkungspflicht derUnternehmen, bzw. Unterstützungspflichtder nationalen Behörden".

274 Kamburoglou en Pirrwitz (1990), pag. 268.

275 In gelijke zin ook de Commissie in HvJ (46/87 en 227/88) Jur. 1989, 2859 (Hoechst): "In het kader van artikel 14 beschikken de Lid-Staten materieel slechts over de bevoegdheden die het gemeenschapsrecht hun verleent. Zou artikel 14, lid 3, dus geen huiszoekingsbevoegdhedenomvatten, dan zouden de nationale personeelsleden niet de noodzakelijke bijstand kunnen verlenen", 
aangelegenheid is, omdat van een communautair optreden meer heil verwacht mag worden dan van verschillende (lid)statelijke acties. In een dergelijke optiek past het niet dat de lidstaten uiteindelijk grotere bevoegdheid ter handhaving hebben of althans kunnen creelren daa de Commissie bij welke het primaat van de handhaving is gelegd. Daarbij komt dat dirergenties in de bevoegdhedenregeling tussen de lidstaten rechtsongelijkheid zou meebrengen voor ondernemingen uit de verschillende staten. Deze ongelijkheid zou met name das aan het licht treden als ondernemingen met zetel in verschillende landen verdacht werden van participatie in één bepaald kartel (hetgeen in de regel het geval is) en daarom aan een onderzoek worden onderworpen: terwijl één onderneming geconfronteerd zou werden met zeer vergaande opsporingsactiviteiten van de autoriteiten, zou een andere onderneming, waartegen dezelfde verdenking bestaat, slechts een minimaal onderzoek meeten dulden, met als wellicht meest extreme gevolg dat eerstbedoelde onderneming wegens overtreding van het materiēle recht wordt veroordeeld en laatstbedoelde onderneming wegens gebrek aan bewijs vrijuit gaat. ${ }^{276}$

Het zou het communautaire kartelbeleid niet ten goede komen als de omvang van de bevoegdheden hoofdzakelijk op nationaal niveau zou worden bepaald. De basis en degrenzen van het nationale optreden dienen derhalve op communautair niveau te zijn geregeld. Nu brengt een effectieve handhaving van het (materielle en formele) kartelrecht mee dat de met de handhaving belaste autoriteiten over voldoende en geschikte bevoegdheden beschikken, waarbij niet in de laatste plaats gedacht kan worden aan de bevoegdheid tot het gericht zoeken. Volgens het Hof ligt deze bevoegdheid dan ook besloten in artikel 14 Vo 17 en geldt voor zowel de communautaire als ook de nationale autoriteiten. Ten aanzien van de Commissie geldt echter dat zij deze bevoegdheid niet (zonder meer) mag aanwenden, met name omdat de Raad het breken van verzet bij de onderneming (behoudens door middel van sanctiedreiging), om soevereiniteitsredenen niet aan de communautaire, maar aan de afzonderlijke lidstatelijke instanties heeft willen overlaten. Hoe deze de hen toekomende (materiële) bevoegdheden toepassen, is afhankelijk van nationale regels. De 'enige' eis dienaangaande is dat de nationale aanpak adequaat is en in het communautaire systeem past.

De voorrang van het communautaire recht tegenover de nationale wetgeving wordt onderstreept door de procedure die wordt ingeleid door een verzoek van de Commissie om bijstand. Bij dit verzoek moeten door de Commissie de relevante gegevens aan de verzochte nationale instantie worden overhandigd opdat deze kan bepalen of zij inderdaad de bijstand zal moeten verlenen. $\mathrm{Zij}$ zal de verificatiebeschikking mogen toetsen, maar deze toetsing is slechts marginaal; het Hof overwoog hieromtrent dat de nationale autoriteit

"niet haar eigen oordeel over de noodzaak van de bevolen verificaties in de plasts mag stellen van dat van de Commissie, wier feitelijke en juridische oordelen alleen door het Hof van Justitie op hun wettigheid kumen worden getoetst. De nationale instantie is echter wel bevoegd om, na de echtheid van de verifieaticbeschikking te hebben vastgesteld, na te gaan of de voorgenomen dwangmaatregelen niet willekeurig zijn of te ver gaan in verhouding tot het voorwerp van de verificatic, en om bij de uitvoering van die maatregelen erop toe te zien dat de regels van haar nationale recht worden gelerbiedigd" .

276 Wel blijft het mogelijk dat tussen de verschillende lidstaten een verschillend niveau van rechtsbescherming optreedt, aangezien het Hoechst-arrest uitdrukkelijk bepaalt dat de nationale procedures, ook op het gebied van de gewaarborgde rechten, moet worden nageleefd.

277 HvJ (46/87 en 227/88) Jur. 1989, 2859 (Hoechst). 
Op grond van deze overweging, die volgens het 'Voorstel uitvoeringverordening' moet worden gecodificeerd ${ }^{278}$, mag de nationale instantie derhalve slechts bijstand weigeren indien zij van mening is dat de Commissie haar bevoegdheden overschrijdt: zij mag niet het communautaire besluit integraal op wenselijkheid en/of noodzakelijkheid toetsen. Verleent zij de bijstand waarom van de zijde van de Commissie verzocht is, dan zal de nationale wetgeving de richtlijn vormen voor het onderzoek. Deze wetgeving bepaalt op welke wijze de verificatie zal plaatshebben, hoever de bevoegdheden in concreto reiken en welke rechten in het kader van de procedure aan de onderneming toekomen ${ }^{279}$; in zoverre is de nationale regelgeving van belang voor de bescherming van de rechten van de onderneming.

\section{De Nederlandse uitvoeringswetgeving}

\section{I Algemeen}

Hiervoor is gebleken dat de Commissie voor de uitoefening van haar bevoegdheden steeds afhankelijk is van de medewerking van de onderneming of, bij gebreke daarvan, van de bijstand van nationale autoriteiten. ${ }^{280}$ Indien een onderneming, ook niet onder druk van mogelijke sancties, in de vorm van boetes of van dwangsommen, niet geheel wenst te coöpereren, ontstaat in het communautaire recht een impasse, die door nationale regelgeving doorbroken moet worden. De Raad heeft in het zesde lid van artikel 14 Vo 17 aan de lidstaten de volgende verplichting opgelegd:

\footnotetext{
"Wanneer een ondememing zich verzet tegen een verificatie waartoe krachtens dit artikel opdracht is gegeven, verieent de betrokken Lid-Staat de nodige bijstand aan de personeelsleden aan wie de Commissie opdracht tot verificatie heeft gegeven, ten einde hun de vervulling van deze opdracht mogelijk te maken. Tot dit doel nemen de Lid-Staten vóór 1 oktober 1962, na raadpleging van de Commissie, de nodige maatregelen".
}

Het Hof overwoog dienaangaande dat "Daarbij (...) de Lid-Staten (zijn) gehouden, de doeltreffendheid van het optreden van de Commissie te waarborgen (...). In zoverre bepaalt derhalve het nationale recht, via welke procedures de rechten van de ondernemingen

278 Artikel 20 lid 8 bepaalt: "Uitsluitend het Hof van Justitie van de Europese Gemeenschappen kan de beschikking van de Commissic op haar wettigheid toetsen. De controle door de nationale rechter boudt slechts in, dat hij de beschikking van de Commissie op haar echtheid toetst en nagaat of de voorgenomen dwangmaatregelenniet willekeurig zijn of te ver gaan in verhouding tot het voorwerp van de inspectie. De nationale rechter kan niet nagaan of de inspectie noodzakelijk is, noch eisen dat hem andere gegevens worden verstrekt dan die welke in de beschikking van de Commissie zijn vermeld". De reden voor deze codificatic is volgens de toelichting bij het voorstel om te waarborgen dat de inspecties (nu nog: de verificaties) in de gehele interne markt aan dezelfderegels onderworpen zijn.

279 Het Hof overwoog ten aanzien hiervan dat de Commissie is gehouden "de dienaangaande in het nationale recht voorziene waarborgen in acht te nemen".

280 Deze afhankelijkheidbrengt zoals gezegd mee dat niet geconcludeerdkan worden dat de Commissie zelf een 'echte huiszoeking' mag uitvoeren. Dit in tegenstelling tot Schermerhom (1994), pag. $33 / 34$ die deze conclusie wel aan het Hoechst-arrest verbindt. 
moeten worden geëerbiedigd". ${ }^{281}$ De opdracht aan de nationale wetgevers is derhalve tweeledig: ten eerste moet ervoor worden gezorgd dat de opsporing van kartelinbreuken effectief kan geschieden en ten tweede moet via de te volgen procedure rekening gehouden worden met de rechten van de betrokken onderneming. Met betrekking tot de effectiviteit is met name van belang of de nationale regeling een gerichte doorzoeking mogelijk maakt of op een andere wijze bewerkstelligt dat de Commissie het relevante materiaal uiteindelijk verkrijgt. Daarbij speelt een voomame rol of in een mogelijkheid tot dwanguitoefening is voorzien; of, in de woorden van Kreis ${ }^{282}$ : "Entscheidend kommt es darauf an, ob und inwieweit die Mitgliedstaaten Voraussetzungen für die Anwendung unmittelbaren Zwanges geschaffen haben, mit dem das Unternehmen zur sofortigen Duldung der von der Kommission angeordneten Nachprüfung veranlaßt werden kann." 283

De in artikel 14 lid 6 Vo 17 neergelegde opdracht resulteerde in Nederland in de Uitvoeringswet Kartelverordening $17^{234}$ die op 7 augustus 1968 in werking trad. De wetgever wilde in de zeven artikelen tellende wet zoveel mogelijk aansluiten bij de communautaire regelgeving en stelde zich, daarmee verband houdend, terughoudend op met betrekking tot het in het leven roepen van afzonderlijke procedures en het creëren van (in aanvulling op de in het communautaire recht voorziene sancties) nationale sanctiedreigingen ${ }^{285}$ : hoofddoel was het scheppen van een bevoegdheid tot dwanguitoefening. Inmiddels is deze wet vervangen door de Wet uitvoering EG-mededingingsverordeningen (Uitvoeringswet). ${ }^{286}$ De Uitvoeringswet richt zich in tegenstelling tot haar voorgangster niet uitsluitend op Verordening 17, maar ook op de mededingingsverordeningen op het gebied van de vervoersector, die eveneens uitvoeringsregelingen vergen. ${ }^{287}$ Voor het overige volgt de huidige wet haar voorgangster in grote lijnen, met dien verstande dat twee nieuwe bevoegdheden zijn geïntroduceerd en dat zij moderner van opzet is.

Doel van de Uitvoeringswet is het creëren van een adequaat bevoegdhedenarsenaal voor nationale ambtenaren teneinde de Commissie bij mededingingsonderzoeken de hulp

$281 \mathrm{HvJ}$ (46/87 en 227/88) Jur. 1989, 2859 (Hoechst).

282 Kreis (1981), pag. 293.

283 Wellicht ten overvloede zij hier vermeld dat het toepassen van dwang door nationale autoriteiten allerminst betekent dat een communautaire boete wegens het verzet tegen de verificatie niet meer opgelegd zou kunnen worden; het tegendeel zal eerder het geval zijn, aangezien de onderneming juist in deze gevallen de onderzoeksactiviteiten van de Commissie frustreert. Daarentegen ligt een dwangsom minder voor de hand aangezien deze een drukmiddel is teneinde de onderneming ertoe te brengen alsnog de verificatic te dulden en hieraan tot op zekere hoogte mee te werken, terwijl in geval van inschakeling van de 'sterke arm' de medewerking van de onderneming niet meer noodzakelijk is,

284 Wet van 10 juli 1968, Stb. 395, tot uitvoering van de Verordening No. 17 van de Raad van de Europese Economische Gemeenschap, gewijzigd bij de Wet van 11 februari 1988, Stb. 77.

285 In de MvT bij de Uitvoeringswet werd met zoveel woorden gesteld dat "het niet wenselijk (lijkt) op het niet nakomen van (de plicht zich aan een verificatiete onderwerpen) een strafsanctie te stellen". De communautaire boete werd als toereikend beschouwd.

286 Enige regels ter uitvoering van een aantal EG-verordeningen op het gebied van de mededinging (Wet uitvoering EG-mededingingsverordeningen), Stb. 1997, 129.

287 De indieners van het wetsvoorstel (de ministers van respectievelijk Economische Zaken, Justitic en Verkeer en Waterstaat) verwachtten geen nieuwe verordeningen meer, die op mededingingsgebied onderzoeksbevoegdhedenzouden bevatten. Derhalve werd gekozen voor één nationale wet die alle bestaande verordeningen zou bestrijken (MvT TK 1995-1996, 24 617, nr. 3). 
te bieden die zij behoeft. Uitgangspunt van de indieners en kenmerk van de wettelijke regeling is dat de nationale autoriteiten over dezelfde bevoegdheden kunnen beschikken als de Commissie, waarmee aansluiting wordt gezocht bij de materiële omvang van de communautaire bevoegdheden. De Memorie van Toelichting noemt als belangrijkste voordeel van een dergelijke nauwe band met het communautaire recht dat de jurisprudentie van het Hof en het Gerecht ten aanzien van de rechten van de verdediging rechtstreekse invloed (blijven) uitoefenen op het nationale uitvoeringsrecht, waarmee een grotere mate van rechtsbescherming wordt beoogd. Consequentie is tevens dat ook de omvang van de bevoegdheid zelf op communautair niveau wordt vastgesteld, hetgeen ook de rechtszekerheid zonder meer ten goede komt.

Een tweede kenmerk van de Uitvoeringswet is de centrale positie van de begrippen beschikking en verzet. ${ }^{288}$ Dit sluit aan bij de regeling van artikel 14 lid 6 Vo 17 (tot welke verordening ik mij hierna zal beperken) die immers slechts verplicht tot een uitvoeringsregeling voor de gevallen waarin ondernemingen zich verzetten tegen een verificatie. De Uitvoeringswet voorziet in de materiële bevoegdheden voor de nationale ambtenaren waarover ook de commissieambtenaren beschikken ongeacht de verificatievorm; bevoegdheden ter effectuering echter ontbreken bij de verificatie bij eenvoudige opdracht. De toegevoegde waarde van de Uitvoeringswet ligt bij de mogelijkheid tot het daadwerkelijk kunnen uitoefenen van de bevoegdheden indien de verificatie bij beschikking is gelast en de onderneming in dat geval niet blijkt mee te werken: de dwang die dan kan worden uitgeoefend door de nationale autoriteiten is het cruciale van de nationale uitvoeringsregelgeving.

De Uitvoeringswet kent uitvoeringsregelingen voor de verschillende vormen van verificatie die Verordening 17 noemt. Artikel 2 richt zich op de verificaties die door de nationale autoriteiten zelf naar aanleiding van een daartoe strekkend verzoek van de Commissie ex artikel 13 lid 1 Vo 17 worden verricht ${ }^{289}$, terwijl artikel 3 in de mogelijkheid voorziet om ambtenaren aan te wijzen die de Commissie behulpzaam zijn bij het uitvoeren van een verificatie. ${ }^{290}$ Voorzover het een verificatie betreft die bij beschikking is gelast, bestaat er zelfs een verplichting ambtenaren aan te wijzen. De aanwijzingsbevoegdheid casu quo aanwijzingsplicht ligt bij de minister van Economische Zaken en eventueel de minister "wie de zaak mede aangaat": zij geven een schriftelijke opdracht aan nationale ambtenaren ${ }^{291}$ voor iedere afzonderlijke communautaire verificatie waaraan Nederland medewerking wenst dan wel dient te verlenen. De bevoegde ministers zijn niet bevoegd

288 In afwijking van de Nederlandse tekst van Verordening 17 is in de Uitvoeringswet expliciet de koppeling van verzet aan de beschikking opgenomen. Hoewel dit implicietuit de regeling van Verordening 17 volgt, is het wenselijk hieromtrent geen enkele onduidelijkheid te laten bestaan.

289 Interessant is dat de MvT bij het wetsvoorstel van 1968, TK 1965-1966, 8668, nadrukkelijk van bet primaat van artikel 13 boven artikel $14 \mathrm{Vo} 17$ uitging. Slechts in uitzonderlijke gevallen om redenen van doelmatigheid of anderszins dringende noodzakelijkheid zou de Commissie de verificaties laten verrichten door eigen functionarissen. De praktijk heeft echter de onjuistheid van deze verwachting aangetoond; vergelijk de MvT Wet uitvoering EG-mededingingsverordeningen, TK 1995-1996, 24 617 , wr. 3 .

290 Aldus de MvT zal van deze bevoegdheid "in beginsel in alle gevallen gebruik worden gemaakt".

291 Onder de 'oude' regeling werd geopteend voor werknemers van het ministerie van Economische Zaken. en voor opsporingsambtenaren van de Economische Controledienst. Onder het huidige regime zijn ambtenaren van de Nederlandse Mededingingsautoriteit aangewezen. 
a algemene opdracht te geven aan een bepaalde groep (opsporings)ambtenaren voor h verlenen van de benodigde hulp in het kader van een communautair kartelonderzoek, varmee niet is geopteerd voor het toekennen van een zelfstandige bevoegdheid aan Nederlidse (kartel)ambtenaren om over te gaan tot het verlenen van bijstand of (in het geval $v$ een verificatie op grond van artikel $13 \mathrm{Vo} \mathrm{17)} \mathrm{het} \mathrm{verrichten} \mathrm{van} \mathrm{een} \mathrm{verificatie.}$ If de ministers 'in elk geval' ambtenaren aanwijzen indien de verificatie bij beschikking izelast, impliceert niet dat zij geen enkele ruimte inzake de aanwijzing van ambtenaren zden hebben. Indien na marginale toetsing van de commissiebeschikking zonder meer ddelijk is dat voor de beschikking geen grond bestaat of dat zij disproportioneel is, dzal nationale medewerking niet hoeven te worden verleend. Wel staat vast dat deze nrge uitermate gering is gezien het communautaire belang dat in het geding is. ${ }^{292}$ [Uitvoeringswet verplicht tot het verlenen van bijstand zodra er een beschikking door dCommissie is gegeven, ongeacht de houding van de onderneming. ${ }^{293}$ Het voordeel brvan is dat bij verzet van de zijde van de onderneming de noodzakelijke hulp (bestaande ieen actief zoeken, vergaring van de gewenste informatic en aanwending van directe dang) onmiddellijk kan worden geboden. ${ }^{294}$

Het voorgaande moge reeds aantonen dat in de Nederlandse uitvoeringsregelgeving gn centrale rol is weggelegd voor een rechterlijke instantie. Het tegendeel is het geval: dbeslissing omtrent het verlenen van bijstand ligt geheel bij de minister ${ }^{295}$ en ook Q eventuele uitoefening van directe dwang is niet aan voorafgaande rechterlijke toetsing onderhevig, met uitzondering van de (naar verwachting uiterst incidenteel toe te passen) bevoegdheid tot doorzoeking, die in handen van de rechter-commissaris is gelegd. Het ontbreken van rechterlijke controle -behoudens in geval van een doorzoeking, waarover hierna nog zal worden gesproken- tijdens een verificatie is mijns inziens te betreuren: ieder onafhankelijk toezicht draagt bij aan de rechtsbescherming van de ondernemingen. Dat voorts voorafgaande rechterlijke controle ontbreekt, acht ik daarentegen weinig problematisch. ${ }^{296}$ Ten eerste blijft een toetsing van het verzoek om bijstand en daarmee samenhangend de toetsing van de verificatiebeschikking beperkt tot een marginale, onafhankelijk van het nationale orgaan dat deze toetsing doorvoert: de toegevoegde waarde van een rechterlijke toetsing is daarmee gering. Ten tweede kan een onderneming op communautair niveau te allen tijde de beschikking aanvechten bij het Gerecht van Eerste Aanleg en om opschorting van de tenuitvoerlegging hiervan verzoeken. Ten derde wordt het ontbreken

292 Hetgeen door het Hof in de Hoechst-zaak is onderstreept.

293 Onder het oude regime was slechts voorzien in bijstand bij gebleken verzet van de zijde van de onderneming. In de praktijk echter werd bijstand ook in andere gevallen verleend.

294 Vergelijk ook MvT bij artikel 3 die de regeling vergelijkt met een voorzorgsmaatregel TK 1995-1996, 24617 , nr. 3.

295 Hetzou in de rede liggen om deze beslissing aan de Directeur-Generaalvan de Nederlandse Mededingingsautoriteit te attribueren. Dit geldt wellicht in mindere mate voor de eerste jaren van de Mededingingswet, aangezien de minister van Economische Zaken voor die periode-zoals in het volgende hoofdstuk zal blijken- duidelijk zelf nog de vinger aan de pols van het mededingingsbeleid wilde houden. Maar vanaf het moment waarop de NMa een grotere zelfstandigheid verkrijgt, lijkt het raadzaam alle beslissingen op mededingingsterrein bij haar te concentreren.

296 Blom en De Doelder (1992), pag. 350-352, pleitten (ten aanzien van de wet van 1968) met het oog op de uit artikel 8 EVRM voortvloeiende privésfeer van ondernemingen voor een regeling, analoog aan de huiszoeking in het Wetboek van Strafvordering. Zoals gezegd meen ik dat een dergelijke regeling de bescherming van de onderneming tijdens de verificatie zou verhogen; voor het overige zou zij echter weinig meer bescherming bieden. 
van voorafgaande rechterlijke controle ten dele $\mathrm{e}^{297}$ gecompenseerd door de mogelijkheid voor de ondernemingen om de eventuele uiteindelijke beschikking van de Commissie ter beoordeling voor te leggen aan de communautaire rechters. Deze zullen bij de behandeling van het beroep tegen de beschikking van de Commissie dan onder meer de handelwijze van de onderzoekende ambtenaren beoordelen en kunnen besluiten tot het uitsluiten van de vergaarde informatie van het bewijs indien is gebleken dat het onderzoek de gestelde grenzen te buiten is gegaan. ${ }^{298}$

\subsection{De bevoegdheden}

De nationale ambtenaren die door de ministers zijn aangewezen, beschikken ten aanzien van elk van de genoemde verificatievormen, zoals hiervoor is aangegeven, over dezelfde bevoegdheden die aan de commissieambtenaren zijn toegekend. ${ }^{299}$ Aldus zijn de ambtenaren op grond van artikel 2 lid 2 Wet uitvoering EG-mededingingsverordeningen bevoegd tot:

a. de inzage van zakelijke gegevens en bescheiden;

b. het maken of verlangen van afschriften of uittreksels van deze zakelijke gegevens en bescheiden;

c. het ter plaatse vragen van mondelinge inlichtingen, en

d. het betreden van alle plaatsen.

De algemene bewoordingen van het voorstel op dit punt geven slechts een indicatie van de inhoud en reikwijdte van de bevoegdheden. Bepalend is niet de tekst van de wet, maar uitsluitend de tekst en interpretatie van de mededingingsverordeningen. Dit open systeem moet een optimale overeenstemming met het communautaire recht garanderen, zowel

297 Dezemogelijkheidbestaatniet indien de ingeleideprocedure nietuitmondt in een(boete)beschikking: bij mogelijke strijdigheid van de beschikking van de Commissie met het communautaire recht, doet de onderneming er derhalve goed aan tegen de verificatiebeschikking zelf beroep in te stellen.

298 Voor het Duitse recht acht Seholz (1990), pag. 106, de inschakeling van een rechter wel noodzakelijk, hoewel de Duitse uitvoeringswet hierin niet voorziet. Hij constateert een strijdigheid met artikel 13 lid 2 Grundgesetz, waarin uitdrukkelijk de inschakeling van een rechter in het kader van doorzoekingen wordt verlangd; zoals hiervoor gesteld, is Scholz van mening dat de verificaties materieel onder de doorzockingen vallen.

299 Op grond van artikel 12 Uitvoeringswet hebben deze ambtenaren voor zover zij in Nederland een verificatie verrichten, tot op zekere hoogte dezelfde status als Nederlandse ambtenaren. Feiten die strafbaar zijn als zij worden begaan tegenover laatstbedoelden, zijn eveneens strafbaar als zij worden begaan tegenover de communautaire ambtenaren. Dat is met name van belang voor toepasselijkheid de artikelen $180 \mathrm{WvSr}$ (wederspannigheid) en $184 \mathrm{WvSr}$ (niet voldoen aan een ambtelijk bevel). Een probleem rijst indien een onderneming als rechtspersoon verantwoordelijk wordt gehouden voor de overtreding van artikel $184 \mathrm{WvSr}$. De weigering om gegevens na een daartoe strekkend bevel ter inzage te geven, vormt namelijk tevens verzet tegen de verificatie, waarvoor op grond van artikel 15 Vo 17 ook een boete kan worden opgelegd. Het gevaar bestaat dat de onderneming wegens hetzelfde feit tweemaal gestraft zou worden, hetgeenmogelijk in strijd zou zijn met het ne bis in idem-beginsel. Het belang van dit beginsel voor het communautaire reeht komt uitgebreid aan bod in hoofdstuk 4. Hier kan erop worden gewezen dat dit door de wetgever waarschijnlijk over het hoofd is gezien en in ieder geval niet is beoogd, aangezien de Memorie van Toelichting bij artikel 2 Uitvoeringswet uitdrukkelijk een nationale straf wegens het niet-voldoen aan de plicht zich te onderwerpen aan de verificatiewordt afgewezenonderverwijzing naarde reedsbestaandemogelijkheiddit plichtsverzuim op communautair niveau te beboeten. 
ten aanzien van de instrumentele omvang van de bevoegdheden als ten aanzien van de voor (de uitoefening van) deze bevoegdheden geldende grenzen. Dit verklaart tevens de minimale aandacht die in het wetsvoorstel wordt besteed aan de rechten van de ondernemingen. Weliswaar wordt aan deze rechten door de indieners van het voorstel een groot gewicht toegekend, maar zij wensen de ontwikkeling hiervan afhankelijk te maken van de communautaire rechtspraak. ${ }^{300}$ Een uitzondering wordt gemaakt voor de onschendbaarheid van de woning. Bescherming van dit recht is beoogd in het derde lid van artikel 2, waarin aan de binnentredingsbevoegdheid van het tweede lid sub d de restrictie wordt aangebracht dat woningen niet zonder toestemming van de bewoner mogen worden betreden. Met deze beperking wordt geen breuk beoogd met de regeling in Verordening 17. Integendeel: uitdrukkelijk wordt overwogen dat artikel 14 Vo 17 zich (ook in de visie van de regering) evenmin uitstrekt tot het binnentreden van woningen tegen de wil van de bewoner. ${ }^{301}$ Het desalniettemin expliciet opnemen van bedoelde beperking is te verklaren vanuit het grondwettelijk belang van de onschendbaarheid van de woning en tevens vanuit wetstechnisch perspectief: de Nederlandse wetgeving kent in tal van andere binnentredingsbepalingen eenzelfde restrictie ten aanzien van woningen. Het weglaten van deze restrictie zou ten onrechte de indruk kunnen wekken dat woningen (en daarmee de privacy van de woonomgeving) in de uitvoeringswetgeving in mindere mate beschermd worden.

De aan de nationale ambtenaren toegekende bevoegdheden, met uitzondering van die tot het vragen van mondelinge inlichtingen, kunnen worden uitgeoefend met behulp van de sterke arm, voorzover de onderneming zich tegen een verificatie bij beschikking verzet en de uitoefening van dwang proportioneel is. Slechts deze voorziening kan een garantie bieden voor een goede handhaving en vormt het in het communautaire kartelrecht ontbrekende formele stukje van de bevoegdhedenpuzzel: pas de mogelijkheid tot het aanwenden van directe dwang door inschakeling van de sterke arm maakt iedere medewerking van de betrokken onderneming overbodig. Concreet houdt het vorenstaande in dat "kasten, laden en andere opbergplaatsen, waarvan het aannemelijk is dat zich daarin zakelijke gegevens en bescheiden bevinden die de aangewezen ambtenaren willen inzien, desnoods opengebroken kunnen worden. Ook kan inzage in computerbestanden worden afgedwongen". ${ }^{302}$ De combinatie van de genoemde bevoegdheden met de mogelijkheid deze met dwang te kunnen uitoefenen brengt met zich dat de nationale ambtenaren de facto een doorzoekingsbevoegdheid hebben. De evenredigheidseis, tot uiting komend in het woord 'nodig', is dan ook niet overbodig, gelet op de ingrijpendheid van het middel voor de bedrijfsvoering van ondernemingen. De inachtneming van de evenredigheid voorkomt dat de hulp van de sterke arm wordt ingeroepen terwijl een onderneming onvoldoende in de gelegenheid is gesteld zich alsnog 'vrijwillig' aan de verificatie te onderwerpen of indien er nog reẽle andere wegen openstaan om het beoogde doel, te weten informatievergaring, te bereiken. De noodzakelijkheid zal overigens vrijwel steeds zijn gegeven

300 Dat volgt ook uit artikel 10 Uitvoeringswet, waarin is vastgelegd dat de rechten van de verdediging zoals die uit de communautaire rechtspraak volgen, dienen te worden gehonoreerd, waarbij als voorbeelden worden genoemd het recht op rechtsbijstand (vergelijk Pb 1993 L 20/6 (Mewac)) en de honorering van de vertrouwelijkheid van de correspondentie tussen advocaat en onderneming.

301 MvT TK 1995-1996, 24 617, nr. 3. Zie reeds MvT Uitvoeringswet 1965-1966, 8668, nr. 3, pag. $3 / 4$

302 MvT bij artikel 4, TK 1995-1996, 24 617, nr.3. 
zodra een onderneming categorisch iedere coöperatie weigert, te meer indien zij in deze weigerachtigheid persisteert ondanks een (dreigende) boete of dwangsom.

Tegen de achtergrond van voorkoming van verduistering van gegevens alsmede de verzekering van de effectiviteit van de verificaties ${ }^{303}$ moet de nieuwe verzegelingsbevoegdheid ex artikel 2 lid 4 worden gezien. Weliswaar moet het uitgangspunt zijn dat een verificatie zoveel mogelijk binnen één dag en tijdens kantooruren moet worden afgerond, maar denkbaar is dat dit niet steeds mogelijk is. Voor die gevallen voorziet de Uitvoeringswet in een bevoegdheid tot verzegeling van bedrijfsruimten en voorwerpen voor de tijdspanne gelegen tussen 18.00 en 8.00 uur. Deze ingrijpende bevoegdheid is geclausuleerd: naast de begrenzing van de tijd tijdens welke de verzegeling is toegestaan, is de beperking gelegen in twee voorwaarden. Ten eerste mag zij slechts worden aangewend indien er sprake is van een verificatie bij beschikking; ten tweede is zij gebonden aan het evenredig. heidsbeginsel. Ten onrechte ontbreekt echter de voorwaarde dat de onderneming zich tegen de verificatie verzet. Zolang de onderneming ten volle medewerking aan het onderzoek verleent, bestaat er geen enkele grond om over te gaan tot dergelijk verstrekkende maatregelen, ook al betreft het een verificatie bij beschikking. Tegengeworpen kan worden dat de nationale autoriteiten de verzegelingsbevoegdheid reeds op grond van het evenredig. heidsbeginsel van het vijfde lid van artikel twee bij coöperatie van de onderneming niet zal mogen aanwenden: in dat geval immers zal verzegeling niet noodzakelijk zijn voor de taakvervulling. Dit kan niet ontkend worden, maar het gegeven dat toepassing van dwangmatregelen pas geoorloofd is als de onderneming voldoende mogelijkheid is geboden om mede te werken, rechtvaardigt het expliciet opnemen van de 'verzetvoorwaarde'. De onderneming zal zo ook eerder beseffen dat coöperatie voordelen kan bieden ten opzichte van het weigeren hiervan. ${ }^{304}$

\subsection{Binnentreden en doorzoeking}

Eveneens nieuw en zonder twijfel de meest opmerkelijke aanvulling is de bevoegdheid van artikel 5 Uitvoeringswet. Hierin is voorzien in de mogelijkheid voor de minister van Economische Zaken om, bij gebleken verzet van de onderneming tegen een verificatie bij beschikking, te vorderen dat de rechter-commissaris onverwijld overgaat tot het doorzoeken van plaatsen waar de gegevens en bescheiden zich waarschijnlijk bevinden. Aldus bestaat onder het regime van de huidige uitvoeringswetgeving een onderscheid tussen het betreden van plaatsen en het doorzoeken van die plaatsen door de rechter-commissaris. Hoe verhouden zich deze twee bevoegdheden tot elkaar? De wet geeft, zoals gezegd, aan dat de nationale ambtenaren over dezelfde bevoegdheden beschikken als hun communautaire collega's, met dien verstande overigens dat eerstbedoelden tevens de mogelijkheid

303 Vergelijk MvT TK 1995-1996, 24 617, nr. 3.

304 Opmerkelijk is dat de verbreking van de verzegeling strafrechtelijk bestraft kan worden en wel op grond van artikel $199 \mathrm{WvSr}$. Overtreding van dit artikel kan leiden tot een gevangenisstraf van ten hoogste twee jaar of een geldboete ter hoogte van maximaal vijfentwintigduizend gulden (of voor rechtspersonen honderdduizend gulden). 
tot effectuering van de bevoegdheden hebben. ${ }^{305}$ Dat betekent dus dat, omdat het Hof een ruime materiēle invulling aan de binnentredingsbevoegdheid heeft gegeven, de nationale ambtenaren de facto een doorzoekingsbevoegdheid hebben. Waarom dan nog een aparte bevoegdheid tot doorzoeken creëren, zo kan men zich met recht afvragen. Omdat, aldus de Memorie van Toelichting, deze aparte doorzoekingsbevoegdheid verder gaat dan die welke uit Verordening 17 voortvloeit: zij ziet namelijk

"op egeheimen bergplaatsen voor die gegevens en bescheiden. Hierbij kan bijvoorbeeld gedacht worden aan het openbreken van vloeren en plafonds indien het vermoeden bestaat dat daar zakelijke gegevens en bescheiden zijn verstopt".

Beslissend voor het onderscheid is dus "de aard van de bergplaats waarop het onderzoek zich richt" ${ }^{306}$ Wordt vermoed dat gegevens zich op plaatsen te bevinden waar bewaring ervan ook normaliter verwacht mag worden, dan kan volstaan worden met het recht van Verordening 17. Waar dit niet het geval is, moet de rechter-commissaris worden ingeschakeld. ${ }^{307}$ De Memorie van Toelichting stelt uitdrukkelijk dat deze bevoegdheid slechts in uitzonderlijke gevallen zal worden toegepast. Hiermee is niets teveel gezegd. Niet alleen is moeilijk voor te stellen welke factoren onderzoekers tot het vermoeden kunnen brengen dat zich gegevens onder -laten we zeggen- de ondernemingsvloer bevinden, maar bovendien zal een ondememing hoogst zelden belangrijke bedrijfsinformatie op een zodanige plaats verbergen. Het betreft veelal immers niet slechts één document waarin de kartelovereenkomst is vastgelegd, maar tal van afzonderlijke geschriften waaruit het kartelmatig gedrag kan worden afgeleid en die niet zelden in de dagelijkse bedrijfsvoering van belang zjjn en dientengevolge niet opgeborgen kunnen worden op nauwelijks te bereiken plaatsen. Anderzijds moet gesteld worden dat in incidentele gevallen het doorzoeken van bedoelde plaatsen wellicht noodzakelijk kan zijn en dat dus de bevoegdheid hiertoe dient te bestaan. ${ }^{308}$ Maar een afzonderlijke regeling is mijns inziens overbodig, omdat die bevoegdheid reeds op grond van Verordening 17 bestaat. In Hoechst- en Dow-arresten wordt van het opsporen van inlichtingen en het doorzoeken van lokalen gesproken, waarbij weliswaar geen melding wordt gemaakt van 'geheime' plaatsen (mede wellicht omdat

305 Zou dit niet zijn beoogd, maar zou zijn geopteerd voor een beperktere omvang van de bevoegdheden, dan zou de Nederlandse wetgever tekort zijn geschoten in de op hem rustende verplichtingen ex artikel 14 lid 6 Vo 17.

306 MvT TK 1995-1996, 24 617, nr. 3.

307 In afwachting van het optreden van de rechter-commissaris kunnen de met de bijstand belaste nationale ambtenarenconservatoire maatregelennemen "die redelijkerwijsnodig zijn om wegmaking, onbruikbaarmaking, onklaarmaking of beschadiging" van de betrokken gegevens te voorkomen, waarbij tevens aanwezige personen in hun bewegingsvrijheid belemmerd kunnen worden. Daarenboven kan de rechtercommissaris tijdens de doorzoeking (orde)maatregelen nemen: artikel 7 lid 3 Uitvoeringswet verklaart de artikelen 124 en 125 WvSv van overeenkomstige toepassing. Artikel 124 WvSv geeft de rechtercommissaris de bevoegdheid om maatregelen te nemen opdat de doorzoeking ongestoord kan plaatsvinden. Bij ordeverstoring of hindering kan de rechter-commissaris de betreffende persoon sommeren te vertrekken of hem zelfs doen verwijderen en in verzekering stellen. Artikel $125 \mathrm{WvSv}$ biedt de mogelijkheid tot het nemen van maatregelentot bewaking of afsluiting en tot het bevelendat niemand zich gedurende de doorzoeking van de plaats in kwestie zal verwijderen. Overtreders kunnen tot de afloop van de doorzoeking worden aangehouden.

308 Slotboom (1998), pag. 100, trekt echter in twijfel of via doorzoeking verkregen informatie wel door de Commissie mag worden gebruikt, aangerien de doorzoeking verder gaat dan de eigen bevoegdheden van de Commissie. 
het zoeken op deze plaatsen niet bepaald voor de hand ligt en omdat dit in de betrokken casus ook niet aan de orde was), maar waarbij evenmin sprake is van een uitsluiting van die plaatsen. Dat rechtvaardigt mijns inziens de conclusie dat ook het zoeken op minder voor de hand liggende plaatsen (voorzover aan te merken als ondernemingsplaatsen) tot de verificatiebevoegdheid behoort. Derhalve moet worden aangenomen dat de Uitvoeringswet in vergelijking tot de wet van 1968 geen uitbreiding van de bevoegdheden heeft bewerkstelligd, maar dat er een verschuiving van bevoegdheden (van de bevoegde ambtenaren naar de rechter-commissaris) heeft plaatsgehad. ${ }^{309}$ Dit past overigens niet echt in de tijdgeest, die, zoals gezegd, juist een tegengestelde tendens laat zien ${ }^{310}$ Het voordeel is wel dat nu een rechter de leiding heeft bij de meest ingrijpende vormen van doorzoeking. ${ }^{311}$ Voor het overige levert de gewijzigde regeling, waar het de rechtsbescherming betreft, echter weinig op. Artikel 5 lid 3 stelt uitdrukkelijk (maar ten overvloede) dat de doorzoeking slechts mag worden geweigerd indien de vordering tot doorzoeking kennelijk ongegrond is. Verder dan het controleren van de echtheid van de verificatiebeschikking en van de evenredigheid van de doorzoeking reikt de bevoegdheid van de rechter-commissaris niet. ${ }^{312}$

\section{Conclusie}

Het communautaire kartelverbod neemt binnen het recht van de Europese Gemeenschap een belangrijke plaats in. Het moet vrije mededinging waarborgen, die op haar beurt geacht wordt twee doelen te verwezenlijken: de tot stand brenging en instandhouding van de gemeenschappelijke, interne markt en de bevordering van de economische ontwikkeling en welvaart binnen de Europese Gemeenschap. Het kartelverbod en het verbod op misbruik van een machtspositie vervullen kortom een centrale rol bij de verwezenlijking van de doelstellingen van het EG-Verdrag, zoals neergelegd in artikel 2 van dit verdrag. Dit verklaart ook de strengheid van de verboden en de extensieve uitleg die daaraan door Commissie, Gerecht en Hof is en wordt gegeven. Zo bijvoorbeeld kan vrijwel iedere marktparticipant als 'onderneming' worden gekwalificeerd, kan hoegenaamd elke de

309 Hiermee is overigens niet uitgesloten dat de indieners van het wetsvoorstel toch een uitbreiding van de huidige bevoegdheden meenden te verwezenlijken. Zou het inderdaad een uitbreiding inhouden, dan is de consequentie dat Nederland sinds de inwerkingtreding van de Uitvoeringswet 1968 niet aan de op haar rustende verplichting ex artikel 14 lid 6 Vo 17 heeft voldaan.

310 Men denke aan de besproken wijziging van de strafrechtelijke doorzoeking.

311 Waarbij overigens in navolging van hetgeen in het straftecht het geval is, de rechter-commissaris niet (de hele tijd) lijfelijk bij de doorzoeking aanwezig boeft te zijn. Voldoende is bereikbaarheid (via telecommunicatie). Zie MvT TK 1995-1996, 24 617, nr. 3.

312 Omdat het officieel de rechter-commissaris is die de gegevens vergaart, moet deze op grond van artikel 8 Uitvoeringswet de verkregen bescheiden aan de nationale en communautaire ambtenaren overhandigen. Aan het einde van de doorzoeking moet hij een proces-verbaslover de gang van zaken tijdens de doorzoeking opmaken, welk proces-verbaal hij aan de minister van Economische Zaken en de onderneming dient te doen toekomen. Daarenboven wordt de onderneming ervan op de hoogte gebracht van welke gegevens afschriften of uittreksels zijn gemaakt. Dit is van groot belang voor de onderneming, omdat zij aldus kan inschatten of en zo ja welke verdere stappen tegen haar zullen worden genomen en omdat zij slechtszo kan (laten) controleren of de doorzoeking binnen de grenzen. getrokken door de commumautaire verordeningen, de nationale uitvoeringsregelgeving en de algemene beginselen, is gebleven. 
mededinging beïnvloedende afstemming als verboden gedraging worden aangemerkt en wordt de voorwaarde van inter-lidstatelijke beïnvloeding van de handel dermate ruim uitgelegd, dat het in de praktijk geen vergaande beperking van de reikwijdte van het kartelverbod meebrengt. Wel is de voorwaarde van merkbaarheid gesteld, waardoor gedragingen die de intracommunautaire handel dan wel de mededinging (kwantitatief dan wel kwalitatief) niet wezenlijk beĭnvloeden niet door het verbod van artikel 81 EG worden geraakt. Kwantitatieve invulling van de voorwaarde van merkbaarheid is door de Commissie in bagatelbekendmakingen gegeven. Opvallend hierbij is dat de Commissie in de loop der tijd de bagatelgrenzen aanmerkelijk heeft verruimd, waardoor eerder en in meer gevallen een succesvol beroep op het ontbreken van merkbaarheid kan worden gedaan. Dat ook het communautaire recht niet uitsluit dat kartelmatig gedrag positieve effecten kan hebben -dit vormde in feite juist het uitgangspunt van de Wem-, blijkt uit het derde lid van artikel $81 \mathrm{EG}$ waarin in een ontheffingsmogelijkheid is voorzien. De generieke of individuele ontheffing is echter aan vrij strenge voorwaarden gebonden, hetgeen nogmaals onderstreept dat dergelijke ontheffingen uitzondering dienen te blijven.

Het belang van het kartelrecht bij de verwezenlijking van de doelen van de Europese Gemeenschap vindt ook zijn vertaling in de regels omtrent handhaving van de artikelen 81 en 82 EG. Met name kan daarbij gewezen worden op het feit dat de handhaving niet in handen is van de afzonderlijke lidstaten, maar een taak van de Commissie zelf is. Teneinde deze taak adequaat te kunnen vervullen, beschikt de Commissie op grond van Verordening 17 over verstrekkende onderzoeks- en boetebevoegdheden. In het kader van een kartelonderzoek is de Commissie meer in het bijzonder bevoegd tot het inwinnen van inlichtingen (artikel 11 Vo 17) en tot het verrichten van verificaties (artikel $14 \mathrm{Vo}$ 17). Ten aanzien van artikel 11 Vo 17 geldt dat alle inlichtingen mogen worden ingewonnen die noodzakelijk zijn voor de vervulling van de karteltaken van de Commissie. Deze bevoegdheid mag in ieder stadium van een kartelonderzoek worden aangewend, mits er tenminste enige aanwijzing van een inbreuk is én mits de Commissie van mening is dat de inlichtingen voor het onderzoek relevantie kunnen hebben. Artikel 11 Vo 17 maakt een onderscheid tussen een inlichtingenverzoek en een inlichtingenbeschikking, waarbij geldt dat de Commissie slechts inlichtingen bij beschikking mag vorderen indien een verzoek vruchteloos is gebleken. Bedoeld onderscheid is om tenminste twee redenen van belang: ten eerste kan de beschikking slechts aan ondernemingen en ondernemersverenigingen (in de zin van de artikelen 81 en 82 EG) worden gegeven ${ }^{313}$, terwijl het verzoek daarnaast ook aan regeringen en kartelautoriteiten van de lidstaten kan worden gericht; ten tweede is een onderneming of ondernemersvereniging in geval van een beschikking op straffe van een boete verplicht volledig mede te werken, terwijl het voldoen aan het verzoek ten volle op vrijwilligheid berust. ${ }^{314}$

De verificatiebevoegdheid van artikel 14 Vo 17 is aanmerkelijk ingrijpender dan de inlichtingenbevoegdheid. Het betreft hier namelijk een onderzoek ten kantore van ondernemingen (verificaties kunnen niet worden doorgevoerd ten aanzien van lidstaten

313 De bevoegdheid is niet beperkt tot ondernemingen of ondernemersverenigingen die ervan worden verdacht van het kartel deel uit te maken.

314 Met dien verstande dat indien is besloten tot coöperatie, dan zal de verstrekte informatie correct en de medewerking in beginsel volledig dienen te zijn. Ieder onjuist antwoord kan in dat geval alsnog tot een boete leiden. 
of kartelautoriteiten) en brengt een betredingsrecht met zich. Ook een verificatie kan zowel op verzoek als bij beschikking worden gedaan, waarbij -analoog aan de regeling van artikel 11 Vo 17- slechts in het laatste geval (wederom op straffe van een boete) medewerking verplicht is. In tegenstelling echter tot hetgeen bij de inlichtingenbevoegdheid het geval is, kan de Commissie onmiddellijk overgaan tot een verificatie bij beschikking. Het verrassingseffect van een onaangekondigde verificatie kan voor het onderzoek ook van groot belang zijn, omdat een onderneming anders eventueel belastend materiaal voorafgaand aan de verificatie zou kunnen verduisteren. De bevoegdheden in het kader van een verificatie zijn verstrekkend en vertonen sterke gelijkenis met de controlebevoegdheden zoals die in de Wem waren opgenomen. De onderzoekende ambtenaren zijn bevoegd tot het controleren van boeken en zakelijke bescheiden -waartoe evenzeer computerbestanden en informele aantekeningen als contracten en jaarrekeningen behoren-, tot het maken van kopieẻn, tot het vragen van mondelinge inlichtingen betreffende de bescheiden, en tot het betreden van alle plaatsen van de onderneming. ${ }^{315}$ De vraag is met name of de Commissie in het kader van een verificatie bevoegd is zelfstandig de ondernemingsplaatsen te doorzocken. Naar mijn mening heeft de Commissie materieel onder meer een uitgebreid zoekrecht, maar is zij bij de uitoefening van deze bevoegdheden steeds aangewezen op hetzij de medewerking van de betrokken onderneming hetzij de bijstand van nationale autoriteiten. Indien de onderneming volledig meewerkt, dan zal de Commissie derhalve niet tot een doarzoeking mogen overgaan. Ontbreekt (volledige) medewerking. dan is een gericht zoeken door de Commissie toegestaan, mits door de nationale autoriteiten bijstand wordt verleend. De Commissie zal echter niet zelf gegevens uit kasten en dergelijke mogen nemen, noch zal zij dit meubilair mogen openen, laat staan dat zij de toegang hiertoe zou mogen forceren: deze handelingen zijn voorbehouden aan de nationale autoriteiten, die in het kader van hun bijstand over dezelfde materiële bevoegdheden beschikken als de Commissie.

Uit het voorgaande blijkt dat bijstand van nationale autoriteiten onontbeerlijk is bij verificaties waaraan ondernemingen niet (vrijwillig of onder de dwang van boetes) wensen mee te werken. Teneinde adequate bijstand te kunnen verlenen, is aan de lidstaten de verplichting opgelegd om dienaangaande de nodige maatregelen te treffen. Met het oog daarop is in Nederland de Wet uitvoering EG-mededingingsverordeningen in het leven geroepen. Op grond van deze wet beschikken de met de bijstand belaste ambtenaren over dezelfde bevoegdheden als de Commissie. De toegevoegde waarde ligt met name in de mogelijkheid de sterke arm in te schakelen, althans voor zover de onderneming zich verzet tegen een bij beschikking gelaste verificatie en toepassing van dwang proportioneel is. Voor de nationale autoriteiten ontstaat er aldus een bevoegdheid die de facto overeenkomt met een doorzoekingsbevoegdheid. Naast een regeling voor de uitoefening van fysieke dwang, kent de Uitvoeringswet voor de gevallen waarin een verificatie niet binnen één dag kan worden afgerond als extra bevoegdheid de verzegeling van plaatsen en voorwerpen voor de periode tussen 18.00 en 8.00. Daarenboven is er nog voorzien in een aparte, aan de rechter-commissaris toegekende bevoegdheid tot doorzoeking van 'geheime' plaatsen zoals vloeren, plafonds en dergelijke. Het ligt niet voor de hand dat van deze bevoegdheid op grote schaal gebruik zal worden gemaakt, onder meer niet omdat zelden voor kartelonderzoeken relevant materiaal op dergelijke 'geheime' plaatsen zal worden bewaard. Het

315 Woningen mogen daarentegen nooit, althans niet zonder toestemming van de bewoner, betreden worden. 
feitdat de bevoegdheid aan de rechter-commissaris is gegeven, doet weliswaar recht aan de ingrijpendheid van de maatregel, maar levert relatief slechts weinig toegevoegde bescherming op (de rechter-commissaris mag een doorzoeking uitsluitend weigeren indien de rordering hiertoe kennelijk ongegrond is), met name indien de rechter-commissaris niet gedurende de gehele doorzoeking aanwezig is. Gelet op de ingrijpendheid van de verficatie is het dan ook geen overbodige luxe dat aan een onderneming het recht op juritische bijstand is toegekend.

In át hoofdstuk is gebleken dat de uitgangspunten van de artikelen 81 en $82 \mathrm{EG}$ en die vande Wem in theorie niet verder uit elkaar konden liggen: een streng, voor de verwezenlijkng van de doelstellingen van de EG noodzakelijk verbodstelsel tegenover het in de Necerlandse overlegcultuur passende misbruikstelsel. De verschillen waren in de praktijk echer minder extreem: het communautaire recht kent de nodige vrijstellingen en ontheffingen en is niet van toepassing op bagatelkartels, terwijl de Wem, met name in de laatste jaren van haar bestaan, door enkele belangrijke generieke onverbindendverklaringen een gedeltelijk verbodkarakter verwierf. Ook het beeld van de steeds met harde hand optredende Commissie en het niet-optreden van het Nederlandse ministerie van Economische Zaken was niet geheel zuiver. Het Nederlandse beleid was weliswaar uiterst zelden streng, maar gepoogd werd toch om excessen in goed overleg te bestrijden. Het communautaire beleid is aanmerkelijk strenger: de Commissie beoogt kartellering zoveel mogelijk aan banden te leggen en de weg van de beboeting van overtreders wordt niet geschuwd. Maar ook hier geldt dat het informele beleid, mede gericht op aanpassing van met het kartelverbod strijdige gedragingen, aanzienlijk omvangrijker is dan het formele beleid en dat in lang niet alle gevallen tot beboeting wordt overgegaan. Geconcludeerd kan worden dat wellicht het belangrijkste verschil tussen het communautaire kartelrecht en het Nederlandse kartelrecht tot 1998 in de bereidheid lag om van de toegekende bevoegdheden daadwerkelijk gebruik te maken.

Of men nu de verschillen tussen communautair en Nederlands kartelrecht groot acht of niet, zij waren in ieder geval aanleiding voor de Nederlandse overheid om in 1998 het Nederlandse recht aan te passen en om een meer Europese koers te gaan varen. In het volgende hoofdstuk zal worden bezien welke redenen aan deze koerswijziging ten grondslag lagen, in welke zin het Nederlandse kartelrecht is gewijzigd en welke consequenties dit heeft voor het Nederlandse (handhavings)beleid. 



\section{Het Nederlandse kartelrecht sinds 1998: de Mededin- gingswet}

Op I januari 1998 is in Nederland de Mededingingswet in werking getreden. ${ }^{2} \mathrm{Zij}$ vormde het hoogtepunt van het eind jaren tachtig ingezette, maar pas begin jaren negentig echt tot ontwikkeling gekomen streven naar intensivering en convergentie van het Nederlandse kartelrecht. Bedoeld streven werd, zoals in hoofdstuk 1 bleek, in eerste instantie inhoud gegeven door drie generieke onverbindend verklaringen en door enkele aanpassingen van de Wem ter verhoging van de effectiviteit. De oude dame kon -zoals Mortelmans het ireffend typeerde ${ }^{2}$ - aan haar tweede jeugd beginnen, een jeugd die zij niet in de vertrouwde misbruikomgeving, maar hoofdzakelijk op het verbodterrein doorbracht. De vervanging van de Wem na zo'n veertig jaar dienst ${ }^{3}$ door de Mededingingswet betekende tenslotte het definitieve einde van het misbruikstelsel en het betreden van het pad van het verbodstelsel naar communautair model. Deze omslag heeft niet in de laatste plaats bij ondernemers voor de nodige beroering gezorgd: het beeld was dat het kartelparadijs werd ingeruild voor de harde realiteit van concurrentic. Dit beeld was in zoverre niet correct dat reeds onder de Wem sinds 1994 kartellering op ruime schaal was verboden (in zoverre had de omslag voor een belangrijk deel dus reeds eerder plaatsgehad) en dat er, zoals zal blijken, ook onder de Mededingingswet nog aanzienlijke mogelijkheden voor kartellering bestaan. ${ }^{4}$ Dus de materiële uitgangspunten van de Mededingingswet verschilden weliswaar fundamenteel met die van de Wem, maar de verschillen in de praktijk waren toch aanmerkelijk minder opvallend.

De totstandkoming van de Mededingingswet en de overstap van misbruik- naar verbodstelsel betekenden wel een duidelijk signaal van de Nederlandse overheid dat haar streven naar convergentie en intensivering serieus moest worden genomen. Hier zal ook een deel van de genoemde beroering aan te danken zijn geweest: de overheid kondigde niet alleen een intensivering van het beleid aan, maar zij ging hiertoe daadwerkelijk over. En waar de overheid spreekt van intensivering van het beleid, daar bedoelt zij over het algemeen het voeren van een strenger beleid. De verwachting was gerechtvaardigd dat aan het verbod strikt de hand zou worden gehouden, dat ontheffingen met terughoudendheid zouden worden verleend, dat de controle op naleving zou worden verscherpt en dat tegen overtreders van het verbod hard zou worden opgetreden. Kortom: op kartelgebied het einde van de overlegcultuur. Dat bij de Nederlandse overheid de noodzaak werd gevoeld de handhaving van de kartelregelgeving aan te scherpen, was overigens reeds in 1994 -dus

Zie over deze wet algemeen: Akyürek-Kievits, Feenstra en Van der Woude II.

Mortelmans (1997), pag. 1472.

Als de ECD inderdaad, zoals Spliet (1990), pag. 9, beweert, het bewijs levert dat het leven bij veertig begint, dan toont de Wem aan dat bij veertig ook de dood kan intreden.

4 Bovendien gold dat de artikelen 85 en 86 EG-Verdrag (thans 81 en 82 EG), dankzij de ruime interpretatie van het vereiste van interstatelijkheid, kartellering door Nederlandse ondernemingen reeds voor een belangrijk deel verboden. Met name voor ondernemingen die de grens van de communautaire de minimis-verklaring overschreden, veranderde er door de inwerkingtreding van de Mededingingswet betrekkelijk weinig. 
nog onder het regime van de Wem- uit de totstandkoming van de Wet vergroting effectiviteit $^{3}$ gebleken. In de Mededingingswet werden in dat verband nog verdergaande stappen gezet die moesten onderstrepen dat het relatief milde klimaat van de Wem definitief tot het verleden behoorde: bestuursrechtelijke handhaving nam de plaats in van de strafrechtelijke handhaving en de bevoegdheden die de Mededingingswet bood, werden geconcentreerd bij één instantie, de Nederlandse Mededingingsautoriteit.

In Nederland moest dus een cultuuromslag plaatsvinden: de tijd voor mededingingsbeperkende afspraken tussen ondernemingen was voorbij, evenals de tijd dat de overheid deze afspraken stimuleerde of tenminste tolereerde. ${ }^{6}$ De Mededingingswet moest aan een succesvolle realisering van die omslag bijdragen; om dit te kunnen bewerkstelligen zorgde zij op haar beurt voor een omslag op zowel materieelrechtelijk (van misbruikstelsel naar verbodstelsel) als formeelrechtelijk gebied (van strafrechtelijke naar bestuursrechtelijke handhaving). Hoe deze omslag gestalte werd gegeven en welke consequenties deze had voor de handhaving van het Nederlandse kartelrecht staat in dit hoofdstuk centraal. In paragraaf 1 zal worden ingegaan op de redenen die aan de omslag van het Nederlandse materiële kartelrecht ten grondslag lagen. Paragraaf 2 staat in het teken van een kritische bespreking van de kenmerken van de Mededingingswet, waarna in paragraaf 3 de handhaving van deze wet aan de orde komt. Daarbij zal met name aandacht worden besteed aan de ratio van de omslag van strafrechtelijke naar bestuursrechtelijke handhaving, aan de (rol en positie van) de Nederlandse Mededingingsautoriteit, aan de regeling van het toezicht en onderzoek en aan de procedure die kan leiden tot het opleggen van een bestuursrechtelijke boete.

\section{De ratio van de omslag}

Primair economische overwegingen lagen ten grondslag aan de omslag van een misbruikstelsel naar een verbodstelsel. Globalisering, technologische ontwikkeling en het verdwijnen van internationale handelsbarrières hebben de concurrentiedruk op de Nederlandse markt en voor Nederlandse bedrijven op de internationale markt, aldus de memorie van toelichting bij de Mededingingswet', doen toenemen. Om deze internationale concurrentie het hoofd te kunnen bieden en om -in het verlengde daarvan- de kansen, die de verruimde toegang tot andere markten biedt, ten volle te kunnen grijpen, werd sterke concurrentic op de nationale markt door de indieners van het wetsvoorstel van essentieel belang geacht: een goede concurrentieverhouding en marktwerking op de nationale markt moesten garanderen dat deze snel en adequaat zou reageren op veranderingen en prikkels van buitenaf.' Maar ook in die sectoren waarin er in mindere mate sprake was van buitenlandse concurrentic, werd binnenlandse competitie van belang geacht voor economische groei, ontwikkeling van werkgelegenheid, het garanderen van een redelijk prijsniveau en innovatie van

\footnotetext{
5 Wet van 2 november 1994, Stb. 801.

6 Vergelijk MvT TK 1995-1996, 24 707, nr. 3.

7 TK 1995-1996, 24 707, nr. 3, pag. 3. Zie hierover ook Ottervanger, Steenbergen en Van der Voorde (1998), pag. 97.

8 Zie hierover ook Van der Geest (1992), pag. 905.
} 
profucten. "Voorts zou interne competitie ondernemingen voorbereiden op tijden waarin ook tot deze sectoren de internationale concurrentie zou doordringen. Het uitgangspunt was kortom dat concurrentie de economische groei zou bevorderen en dat Nederland zeker op de lange termijn- slechts dankzij vrije mededinging op de eigen markt de concurreniestrijd op de internationale markt succesvol zou kunnen aangaan. ${ }^{10}$

In dit economische beeld van vrije concurrentie en marktwerking passen, zoals ook reets bleek bij de bespreking van het communautaire recht, van oudsher kartels niet: karels -als beschermers van de positie van zijn deelnemers en als concurrentiebeperkende matregelen- veroorzaken (volgens de door de memorie van toelichting onderschreven economische theorie) onder meer inefficiënte allocatie van productiemiddelen en het vertwijnen van de prikkel tot innovatie en kwaliteitsverhoging. Kartels ondermijnen in dezz visie de concurrentiepositie van ondernemingen en van de nationale markt als geheel, hetgeen aan de economische ontwikkeling, de welvaarts- en de werkgelegenheidsontwikkelng schade berokkent." Dergelijke schade veroorzaakt door de aanwezigheid van karels op de nationale markt had -aldus constateerde de memorie van toelichting-Nederland daadwerkelijk ondervonden. Economische kansen waren in het verleden niet benut docr wat de memorie van toelichting kwalificeerde als een 'te lankmoedig uitgevoerd metedingingsbeleid'. Intensivering van het kartelbeleid, in de zin van een striktere bestrijding van kartels, werd dan ook noodzakelijk geacht om de concurrentie met het buitenland aante kunnen (blijven) gaan en om in de toekomst de kansen die een goed functionerende marktwerking biedt ten volle te kunnen grijpen. ${ }^{12}$ Van dit streven naar intensivering was de Mededingingswet de vertaling ${ }^{13}$ en was de keuze voor een verbodstelsel de logische -zij het niet dwingende ${ }^{14}$ - consequentie. ${ }^{15}$

9 Hoewel, aldus Gradus en Smulders (1992), pag. 792, voor sommige sectoren kartels juist innovatie kunnen stimuleren.

10 Langer en Sauter (1999), pag. 90: "Minder dan voorheen wordt nadruk gelegd op 'ordelijk economisch verkeer' maar meer belang wordt gehechtaan de algemeneeconomischevoordelen van een werkzame mededinging, die geachtworden ten bate te komen van de groei en de slagkracht van onze economie", Nauwelijks aandacht was er overigens voor de positie van consumenten. Heertje, TK 1996-1997, 24707 , nr. 9, pag. 18, stelde deze positie centraal en was van mening dat de belangen van de consumenten prevaleerden boven de belangen van werkgevers en werknemers. Bij de interpretatie van de Mededingingswet moest het consumentenbelang volgens hem dan ook de leidraad vormen. Bij de visie van de wetgever werd meer ruimte geboden om met de belangen van ondememingen rekening te houden.

11 Maar ook aan de belangen van consumenten brengen kartels schade toe, omdat consumenten verstoken blijven van nieuwe, kwalitatief hoogwaardigere producten en zij tevens veelal een hogere prijs dan noodzakelijk voor de voorhanden producten moeten betalen.

12 Terecht stelde Van der Woude (1995), pag. 200, dat de uitgangspunten van het oude Nederlandse kartelbeleid-met zijn nadruk op de positieve aspecten van kartels- onder invloed van de economische ontwikkelingen zijn gewijzigd. Overigens dient men wel te bedenken dat de intensivering van het beleid ook kosten meebrengt. Zie mede over dit kostenaspect van handhaving Bowles (1982).

13 De Jong, TK 1996-1997, 24 707, nr. 9, wees erop dat wetgeving een (complementair) kader zou kunnen bieden voor een goede mededinging, maar dat zij niet zelf zorg kon dragen voor welvaartsstijging. Het primaat zou aldus bij de marktpartijen liggen; de rol van wetgeving zou in dit verband niet oversehat mogen worden.

14 Zoals bij de bespreking van de Wem reeds bleek, kende deze wet een belangrijk verbodelement dat in theorie nog verderuitgebreid had kunnen worden door een breder scala aan generieke maatregelen. Het lijkt echter niet in de rede te liggen om een verbodstelsel te construeren op grond van een wet die duidelijk is gebaseerd op het misbruikstelsel. Dit zou ook de nodige complicaties met zich brengen, 
In deze economische overwegingen lagen overigens niet de enige motieven voor de kentering in het Nederlandse kartelbeleid. Er waren nog tenminste twee andere redenen, die in meer of mindere mate verband hielden met het communautaire recht. De eerste betreft de omstandigheid dat het kartelvriendelijke beleid van Nederland Brussel al geruime tijd een doorn in het oog was. ${ }^{16}$ Niet alleen werd er door met name DG-IV geregeld kritiek op Nederland geuit, maar bovendien waren Nederlandse kartels regelmatig het lijdend voorwerp van communautaire verbods- en boetebeschikkingen, zelfs als die kartels in feite -zoals het geval was bij het Nederlandse bouwkartel- door de Nederlandse overheid waren goedgekeurd. Tot op zekere hoogte belemmerde het Nederlandse beleid zodoende de realisering van de communautaire doelstellingen. Het optreden van de Europese Commissie op een voor het EG-recht cruciaal gebied als het mededingingsrecht betekende in ieder geval een flinke tik op de Nederlandse vingers, hetgeen voor een land dat de Europese integratic toch een warm hart toedraagt, zeer pijnlijk was. Het op dezelfde (communautaire verbods-) lijn brengen van het Nederlandse kartelrecht, was voor Nederland de beste methode om aan de Commissie zijn goede wil te tonen, de relatie met haar te verbeteren en verdere kritick te voorkomen. ${ }^{17}$ De tweede reden lag in, wat wel genoemd is, de spontane harmonisatie ${ }^{18}$ van het nationale met het communautaire kartelrecht zoals die in verschillende andere lidstaten heeft plaatsgehad. Deze lidstaten hadden dus reeds hun nationale recht naar Europees voorbeeld aangepast en kenden dientengevolge onderling vergelijkbare kartelregelgevingen. Opdeze harmonisatie- en convergentietrein is uiteindelijk ook de Nederlandse overheid gesprongen ${ }^{19}$, hetgeen niet alleen de integratie

zoals de noodzaak van een aanzienlijke hoeveelheid AMvB's, een zwakkere legitimatie van het verbod dan in geval dit door de formele wetgever zou zijn opgesteld en het inboeten van rechtszekerheid voor ondernemingen op grond van versnippering van regelgeving. Kist (1998), pag. 4, staat zelfs op het standpunt dat "een handhaafbaremededingingswet een verbodsstelsel als uitgangspunt heeft".

15 Zoals geregd lag het belang van de principiele breuk met de Wem en het misbruikstelsel -nog afgerien van de problemen die intensivering van het beleid via de Wem met zich zou hebben gebracht-mede in het duidelijke signaal van de Nederlandse overheid dat zij op kartelgebied een wezenlijk andere koers zou gaan varen. Dat dit signaal duidelijk genoeg was, bleek wel uit de vele reacties die de nieuwe wet heeft opgeroepen.

16 Zie hierover ook VerLoren van Themaat (1998), pag. 5.

17 In dezelfde zin Bos (1994), pag. 906. Vergelijk ook Van der Woude (1995), pag. 200, die in dit verband sprak van de 'katalyserende werking' die het communautairerecht en de beschikking inzake het Nederlandse bouwkartel in het bijzonder, op het veranderingsproces van het Nederlandse mededingingsbeleid hebben uitgeoefend.

18 Spontaan, want niet gedwongen door een richtlijn of andere communautaire maatregel. Zie hieromtrent onder meer Van der Woude (1995), pag, 198 en Vogelaar (2000), pag. 10. Mortelmans (1996), pag. 80-81, spreekt in dit verband van symbiose (aansluiting bij het EG-recht en -beleid) en osmose (van nationale rechtsstelsels).

19 Vergelijk ook Biesheuvel, Mok en Sevenster (1996), pag. 1-2, die stelden dat het weinig aantrekkelijk zou zijn als Nederland een van het communautaire kartelrecht en van het kartelrecht van de meeste lidstatenafwijkendsysteemzou handhaven.(Mok (1992 III), pag. 101, betoonde zich overigens reeds lang voorstander van convergentie). Ottervanger (1997), pag. 6, noemde de aansluiting bij het comminnautaire recht mede om deze reden 'onontkoombaar', Van der Woude (1995), pag. 198, wees in dit verband op een ontwikkeling in het Europese integraticproces. Aanvankelijk had dit proces een hoofdra: kelijk negatief karakter: nationale maatregelen die vij verkeer belemmerden, werden terzijde geschoven. Geleidelijk echter kreeg het integratieproces een meer positief karakter in die zin dat er sprake was van een tendens tot harmonisatie van de overgebleven obstakels en tot het ontwikkelen van een geza. menlijk beleid. Dit impliceerdedat nationaal recht het communautair recht beînvloeddeen vice versa. 
bevorderde, maar bovendien voor internationaal opererende ondernemingen het voordeel had dat zij met minder verschillende mededingingsregimes en kartelwetgevingen rekening hoefden te houden. ${ }^{20}$

Gelet op de vanzelfsprekendheid waarmee in de memorie van toelichting de economische nadelen van kartellering worden geponeerd en de voordelen van meer marktwerking worden verdedigd, verbaast het eigenlijk dat het misbruikstelsel en de daarop gebaseerde Wem zo lang in Nederland stand hebben kunnen houden. ${ }^{21}$ Dit toont mijns inziens eens te meer aan hoezeer dit stelsel binnen de Nederlandse cultuur paste en hoe weinig politieke animo er bestond om in de bestaande kartelaanpak verandering te brengen. In ieder geval sinds eind jaren tachtig is tenminste bij de centrale overheid de gedachte gerijpt dat meer marktwerking Nederland en de Nederlandse economie ten goede zou komen. Deze cultuuromslag blijkt niet alleen uit de veranderingen op het kartelgebied, maar onder meer ook uit de privatisering en liberalisering van bijvoorbeeld de energiesector en de telecommunicatiemarkt. ${ }^{22}$

\section{De kenmerken van de Mededingingswet}

De Mededingingswet vormt -ondanks de hiervoor aangebrachte nuancering van het verschil tussen de Mededingingswet en haar voorgangsters- een geheel nieuw hoofdstuk in het Nederlandse kartelrecht. ${ }^{23}$ Kenmerkend voor dit hoofdstuk is zoals gesteld het verbodstelsel. Niet minder kenmerkend is de vergaande harmonisatie en convergentie met het communautaire kartelrecht: de artikelen 85 en 86 EG-Verdrag (thans 81 en 82 EG) en Vo 17 hebben onmiskenbaar model gestaan voor de Mededingingswet. Dit gevoegd bij het

20 Op de nadelenvan verschillendekartelregelgevingenwees reeds VerLoren van Themaat(1953), pag. 295 e.v.. Onder meer noemde hij als nadelen dat door een vreemde mogendheid maatregelenzouden worden genomen in verband met een in Nederland zeer nuttig geachte en eventueel zelfs door de regering algemeenverbindend verklaardekartelregelingen dat bij ondernemers de noodzaak bestond zich bij internationale activiteiten grondig op de hoogte te stellen van de kartelwetgeving in de relevante landen. Hij kwam dan ook tot de conclusie dat "een min of meer uniform kartelbeleid voor het internationaal werkzame bedrijtsleven van groot belang is". Dit belang is door de totstandkoming en ontwikkeling van het EG-Verdrag alleen maar toegenomen, zoals sommige Nederlandse ondernemingen (onder meer in de bouwsector) zullen kunnen bevestigen.

21 Dit geldt te meer daar het inzicht dat kartels de economische ontwikkelingen schade kunnen toebrengen, allerminst nieuw is: de AmerikaanseSherman-actvan 1890 en het Europese verbodstelsel zijn hierop gebaseerd.

22 Verwacht mag worden dat de beoogde cultuuromslag op het niveau van de marktpartijen nog wel wat voeten in aarde zal hebben. Ondernemingen in Nederland-zeker ook in het MKB-zijn sinds jaaren dag gewend aan de vanzelfsprekendheidvan het onderling regelenvan de mededinging (vergelijk Hamburger (1997), pag. 2). Wellicht dat de stelligheid waarmee het nieuwe standpunt van de overheid in de memorie van toelichting wordt verdedigd, mede bedoeld is om duidelijk te maken dat van het nieuwe beleid werk zal worden gemaakt en dat de cultuuromslag bij de marktpartijen spoedig zal moeten plaatsvinden, wil men niet met sancties geconfronteerd worden.

23 Een hoofdstuk waarin voor de algemeen verbindend verklaring geen ruimte is geboden, hoewel in de adviesaanvraag de mogelijkheid hiertoe werd geopperd ten aanzien van bepaalde gedragingen van algemeeneconomisch belang. In de memorie van toelichting, TK 1995-1996, 24707 , nr. 3, pag. 29 , werd terecht het standpunt verdedigd dat een dergelijk ordeningsinstrument niet in een verbodwetgeving past. 
uitgangspunt dat "de mededingingswet niet strenger en niet soepeler zal zijn dan de EGmededingingsregels ${ }^{\prime 24}$ maakt wel duidelijk hoezeer het nationale recht aansluiting zoekt bij het communautaire voorbeeld. Deze link met het communautaire recht blijkt bovendien uit een noviteit binnen het nationale mededingingsrecht, die los staat van het kartelrecht in enge zin: het concentratietoezicht, dat echter in dit boek verder buiten beschouwing blijft. ${ }^{25}$ Als laatste karakteristieke punt van de Mededingingswet noem ik hier nogmaals de op geheel nieuwe leest geschoeide handhaving. De keuze voor bestuurlijke, in plaats van strafrechtelijke, handhaving en de oprichting van de Nederlandse Mededingingsautoriteit (NMa) als handhavende instantie zijn hiervan de meest tekenende aspecten.

\subsection{Het Nederlandse kartelverbod en zijn communautaire mal}

Uitgangspunt van het verbodstelsel van de Mededingingswet ligt in de artikelen 6 en $24 \mathrm{Mw}$, die -voor zover hier van belang- luiden:

Artikel 6

1 Verboden zijn overeenkomsten tussen ondernemingen, besluiten van ondernemersverenigingen en onderling afgestemde feitelijke gedragingen van ondernemingen, die ertoc strekken of ten gevolge hebben dat de mededinging op de Nederlandse markt of een deel daarvan wordt verhinderd, beperkt urfervasil:

2 De krachtens het eerste lid verboden overeenkomsten en besluiten zijn van rechtswege nietig.

Artikel 24

1 Het is ondernemingen verboden misbruik te maken van cen economische machtspositie.

Deze artikelen vertonen een opvallend grote gelijkenis met de artikelen 81 en $82 \mathrm{EG} .^{26}$ Met gevoel voor relativering stelde de memorie van toelichting: "De bepalingen inzake mededingingsafspraken en misbruik van een economische machtspositie in dit wetsvoorstel zijn georiënteerd op die uit het EG-Verdrag, maar zijn geen kopie daarvan". ${ }^{27}$ De facto de enige reden waarom niet tot volledige kopiëring is overgegaan, is gelegen in het feit dat de artikelen 81 en 82 EG verwijzen naar de gemeenschappelijke markt en de handel tussen lidstaten, welke verwijzingen vanzelfsprekend in een voor de Nederlandse markt bedoelde wetgeving niet kunnen worden overgenomen. ${ }^{28} \mathrm{Om}$ deze reden ook refereert artikel $6 \mathrm{Mw}$ aan de Nederlandse markt. De reikwijdte van de convergentie met het EGrecht wordt overigens pas echt duidelijk als men de definiëring van de begrippen overeenkomst, onderneming, ondernemersvereniging en onderling afgestemde feitelijke gedragingen

24 TK 1995-1996, 24 707, nr. 3, pag. 10.

25 Zie over het concentratietoezicht onder meer Brouwer en Gerbrandy (1997), pag. 36-41 en Mok (1998), pag. 230-263.

26 Langer en Sauter (1999), pag. 90, spraken in dit verband van een 'transplantaatwetgeving'.

27 TK 1995-1996, 24 707, nr.3, pag. 10. De term 'mededingingsafspraken' is overigens, zoals Biesheuvel. Mok en Sevenster (1996), pag. 5 terecht stelden, niet correct, aangezien besluiten noch afgestemde gedragingen strikt genomen 'afspraken' zijn.

28 De (niet-limitatieve) opsomming van de artikelen $81 \mathrm{en} 82 \mathrm{EG}$ van onder het verbod vallende gedragingen, is niet overgenomen. Hiertegen bestaan mijns inziens geen bezwaren; het komt de leesbaarheid van de artikelen ten goede, terwijl er aan de inhoud en omvang van het verbod geen concessies worden gedaan. 
in dMededingingswet in ogenschouw neemt. Onder deze begrippen moet op grond van artill $1 \mathrm{Mw}$ worden verstaan: een overeenkomst, onderneming, ondernemersvereniging respctievelijk onderling afgestemde feitelijke gedraging in de zin van artikel 81 , eerste lid $G$-Verdrag. Niet relevant is derhalve wat de -gangbare- inhoud van deze begrippen naaNederlands recht is; doorslaggevend is uitsluitend de communautaire betekenis. ${ }^{29}$ Dit npliceert tevens dat alle inhoudelijke wijzigingen in interpretatie van bedoelde begrippenp communautair niveau rechtstreeks doorwerken in en dus directe repercussies hebben vochet Nederlandse kartelrecht. ${ }^{30}$ Dit is ook de uitdrukkelijke bedoeling van de wetgever"Met het zoveel mogelijk overnemen van de formulering van de artikelen 85 en 86 in het EG-Verdrag (thans 81 en 82 EG, HQ) wordt beoogd, dat de toepassing van de rededingingswet in belangrijke mate wordt beinvloed door de beschikkingenpraktijk vanle Commissie en door de jurisprudentie van het Gerecht van eerste aanleg en van het lof van Justitie van de EG".3" Hierdoor wordt eens te meer duidelijk hoe nauw meheeft willen aansluiten bij het communautaire kartelrecht. Des te meer verbaast het daten aanzien van de economische machtspositie een andere weg wordt bewandeld. ${ }^{32}$ Oner economische machtspositie verstaat artikel 1 sub i Mw:

(de) positie van een of meer ondernemingen die hen in staat stelt de instandhouding van een daadwerkelijke nededinging op de Nederlandse markt of een deel daarvan te verhinderen door hun de mogelijkheid te jeven zich in belangrijke mate onafhankelijk van hun concurrenten, hun leveranciers, hun afnemers of de eindgebruikers te gedragen.

Weliswaar blijkt ook hier nogmaals de band met het communautaire recht ${ }^{33}$, aangezien deze definitie direct is ontleend aan de jurisprudentiële invulling van het communautaire begrip 'machtspositie' door het Gerecht van eerste aanleg en het Hof van Justitie. In dit geval is echter niet volstaan met de enkele verwijzing naar het corresponderende begrip in het EG-Verdrag, maar is de huidige communautaire stand van zaken ten aanzien van het begrip machtspositie in de Mededingingswet verankerd. Wijzigingen in de definitie van bedoeld begrip op communautair niveau oefenen dientengevolge geen invloed uit op artikel $24 \mathrm{Mw}^{34}$; het Europese beleid dat zich binnen deze definitie heeft ontwikkeld

29 Een voor de hand liggend voorbeeld is het begrip overeenkomst. In het Nederlandse recht -zie artikel 6:213 BW- moet hiervoor sprake zijn van juridische binding. Het communautaire recht stelt deze voorwaarde niet, en aldus geldt zij evenmin voor het nationale mededingingsrecht. Mortelmans (1996), pag. 98, stelt terecht dat aldus "de inhoudelijke invulling van enkele kernbegrippen van economisch recht" door de nationale wetgever uit handen wordt gegeven.

30 Terecht spreken Ottervanger, Steenbergen en Van der Voorde (1998), pag. 97, hier van een dynamische invloed van het communautaire kartelbeleid en de communautaire beslissingen op (de uitleg van) de Mededingingswet. Aldus ook I. VerLoren van Themaat (1996), pag. 290.

31 MvT TK 1995-1996, 24 707, nr. 3.

32 De aanduiding economischemachtspositie is overigenseen overblijfsel van de Wem: het EG-Verdrag kent deze toevoeging niet.

33 In de adviesaanvraag was het convergentiestreven op dit punt uit het oog verloren, aangezien werd gekozen voor het handhaven van de definitie van economische machtspositie zoals die in de Wem was gehanteerd. Op advies van de SER is deze definitie aangepast.

34 Onder deze restrictie zal men ook de stelling van de minister van Economische Zaken (MvT, toetichting bij artikel $24 \mathrm{Mw}$ ) moeten zien, dat de communautaire beleidspraktijk en jurisprudentie mede bepalend is voor de interpretatievan artikel $24 \mathrm{Mw}$. Een beleidswijziging die een wezenlijk andere interpretatie van het begrip machtspositie met zich brengt, vergt namelijk een wetswijziging in Nederland, voorzover men de convergentie wil handhaven. In deze zin ook Ottervanger (1997), pag. 8. 
en zal ontwikkelen, blijft wel onverkort relevant voor toepassing van dit artikel. De memorie van toelichting biedt geen verklaring voor deze afwijkende behandeling van de economische machtspositie. Misschien werd de definitie van het communautaire begrip door de minister voldoende uitgekristalliseerd geacht en achtte hij het in het belang van de rechtszekerheid om de definitie in de Mededingingswet zelf op te nemen. Hiervoor zou inderdaad het nodige zijn te zeggen, maar hetzelfde geldt ten aanzien van het opnemen van een definitic van de overige begrippen, waarbij echter volstaan wordt met een enkele verwijzing naar het communautaire recht. Waarschijnlijker is dat de minister de enkele verwijzing niet goed mogelijk achtte, aangezien bij de communautaire invulling van het 'misbruik van een machtspositie' logischerwijze steeds de communautaire markt of een deel daarvan als relevante markt in aanmerking wordt genomen, terwijl voor de Mededingingswet op dit punt slechts de Nederlandse markt of een deel daarvan relevantie heeft. Dit probleem had echter betrekkelijk eenvoudig kunnen worden opgevangen ${ }^{35}$, hetgeen, met het oog op een consequente wetgeving en gelet op het geformuleerde uitgangspunt dat de communautaire beschikkingen en jurisprudentie zo direct mogelijk de Mededingingswet dienen te beīnvloeden, ook de voorkeur zou hebben verdiend.

Ongeacht de voordelen die een dermate vergaande convergentie kunnen meebrengen -het wiel hoeft aldus door de Nederlandse overheid niet voor een tweede maal te worden uitgeyonden, yoor Brusselse kritiek op het Nederlandse kartelrecht en -beleid wordt nauwelijks nog ruimte gelaten en voor ondernemers nemen de rechtszekerheid en duidelijkheid toe en verminderen de administratieve lasten- en ongeacht het feit dat naar mijn mening de keuze van de wetgever terecht is, met name gelet op de voordelen voor de ondernemers, is zij niet dwingend (een nationaal verbodstelsel kan evenzeer op geheel nationale wijze worden vormgegeven) en ligt zij toch minder voor de hand dan de memorie van toelichting wil doen geloven. Ten eerste omdat er op deze wijze weinig ruimte overblijft voor de Nederlandse overheid om voor de Nederlandse markt een eigen kartelbeleid te voeren. ${ }^{36}$ Biesheuvel $^{37}$ stelt weliswaar niet ten onrechte dat door overname van communautaire begrippen strikt genomen slechts een juridische jas wordt overgenomen, die voldoende ruimte laat voor nationale invulling. ${ }^{38}$ Maar het risico blijft bestaan dat ook bij de toepassing van de Mededingingswet nauw wordt aangesloten bij communautair beleid, en de memorie van toelichting leek dit toch ook voor te staan, waar zij stelde dat het Nederlandse recht niet strenger en niet milder dan het communautaire zou mogen zijn. ${ }^{39}$ In ieder

35 Zie bijvoorbeeld de suggestie van Mok (1998), pag. 203: onder economische machtspositie wordt verstaan 'een economische machtspositie in de zin van art. 86 van het EG-verdrag (thans artikel $82 E G, H Q$, met dien verstande dat als relevante markt de relevante Nederlandse markt of een deel daarvan in aanmerking moet worden genomen'.

36 Ottervanger (1997), pag. 7 alsmede Bos en Chatelin (1998), pag. 9, zijn dezelfde mening toegedaan.

37 TK 1996-1997, 24 707, nr. 9.

38 En dat deze nationale invulling tot op zekere hoogte gebeurt, concluderen Langer en Sauter (1999), pag. 98: "Kennelijk houdt de NMa toch terdege rekening met de precedentengesteld door haar hoget beroepsrechter, het CBB, ook wat betreft rechtspraak die dateert uit het stadium van de WEM. Dit dwingt de NMa al meteen tot een eigen uitleg van onze nationale versie van de Europese verbodsregels".

39 Bovendien zou iedere afwijking van de communautaire mal een divergentie tussen het nationale en het communautaire recht opleveren, hetgeen vanuit het oogpunt van nationale belangen geindiceerd kan zijn, maar desalniettemin een inbreuk betekent op het streven van de Nederlandse overheid naar zoveelmogelijk convergentic en naar een grote mate van rechtszekerheidvoor de justitiabelen. Indien 
gell is de kans aanwezig op een situatie waarin typisch nationale problemen onderbelicht blijen en typisch communautaire aspecten hun ingang in het nationale recht vinden. Ditluit aan bij de tweede reden waarom de vanzelfsprekendheid van de vergaande harmonising en convergentie niet geheel terecht is. Het communautaire kartelrecht kan, zoals gezn, niet los gezien worden van de doelstellingen zoals geformuleerd in artikel $2 \mathrm{EG}^{40}$ Datoe behoort weliswaar mede de realisering van een goede economische ontwikkeling (dee economische motieven liggen ook aan de Mededingingswet ten grondslag ${ }^{41}$ ), maar mistens evenzeer heeft het communautaire kartelrecht een cruciale functie ten aanzien varie totstandkoming van de gemeenschappelijke markt. Deze integratiefunctie ontbeert hetvederlandse kartelrecht. ${ }^{42}$ Het is in dat licht niet uit te sluiten dat bij de interpretatie varle overgenomen begrippen door de betrokken EG-instellingen met aspecten rekening wott gehouden die voor het Nederlandse recht niet relevant zijn. Het overnemen van hetommunautaire recht -hoe verdedigbaar ook- zonder aandacht te besteden aan zijn afvikende doelstellingen wekt dan ook bevreemding. ${ }^{43}$

Ho dit ook zij, convergentie is een feit en de inhoud van de belangrijkste begrippen varde Mededingingswet is dan ook gelijk aan de inhoud van de corresponderende EGbeǵppen. Een bespreking van bedoelde begrippen uit de Mededingingswet kan zodoende hitachterwege blijven en kan worden volstaan met een verwijzing naar de bespreking vahet communautaire kartelbegrip in het vorige hoofdstuk. ${ }^{44}$ Een enkele opmerking moet hier wel nog worden gemaakt. Ten aanzien van de territorialiteit geldt dat als relevante markt de Nederlandse markt of een deel daarvan wordt aangemerkt, waardoor plaatselijke of regionale kartels onder het verbod van artikel $6 \mathrm{Mw}$ en ondernemingen met een regionale machtspositie onder het verbod van artikel $24 \mathrm{Mw}$ kunnen vallen. ${ }^{45}$ Cruciaal

er wordt afgeweken van het communautaire recht zal dit in ieder geval duidelijk kenbaar moeten worden gemaakt. Slotboom (1999), pag. 43-44, betoogt dat er ten aanzien van begrippen die 'slechts' naar EG-recht zijn gemodelleerd, uitdrukkelijk ruimte is gelaten voor een eigen invulling door de bevoegde Nederlandse autoriteiten, van welke ruimte zij ook gebruik zouden moeten maken. Dit lijkt mij echter juist niet het uitgangspunt van de wetgever te zijn geweest.

40 De Gemeenschapheeft tot taak, door het instellen van een gemeenschappelijkemarkt en een economische en monetaire unie en door de uitvoering van het gemeenschappelijk beleid of de gemeenschappelijke activiteiten, bedoeld in de artikelen 3 en 4 , het bevorderen van een harmonische, evenwichtige en duurzame ontwikkeling van de economische activiteit binnen de gehele Gemeenschap, een hoog niveau van werkgelegenheid en van sociale bescherming, de gelijkheid van mannen en vrouwen, een duurzame en niet-inflatoire groei, een hoge graad van concurrentievermogen en convergentie van economische prestaties, een hoog niveau van bescherming en verbetering van de kwaliteit van het milieu, een verbetering van de levensstandaard en van de kwaliteit van het bestaan, de economische en sociale samenhang en de solidariteit tussen de lid-staten.

41 Kritisch hieromtrent Van den Bergh (1997), pag. 149 e.v..

42 In deze zin ook Ottervanger, Steenbergen en Van der Voorde (1998), pag. 106: "one should bear in mind that an important aim of EC competition policy is to assist the process of market integration (...), something which as such has no relevance within the Netherlands".

43 Zie over deze problematiek eveneens Biesheuvel, TK 1996-1997, 24 707, nr. 9.

44 Voor een bespreking van de Nederlandse praktijk in dezen zij verwezen naar Van Marissing (2000), pag. 22-69. Hienuit blijkt dat de aansluiting bij het communautaire recht ook in de praktijk zoveel mogelijk wordt gerealiseerd.

45 Aldus bijvoorbeeld ook Braakman (1997 I), pag. 10. Voor de bepaling van het bestaan van een machtspositie geldt overigens dat de relevante geografische markt ook ruimer dan de Nederlandse markt kan zijn; zie hierover Ottervanger, Steenbergen en Van der Voorde (1998), pag. 114. 
in dit verband is -conform het communautaire recht- de plaats waar de kartelgedraging ten uitvoer wordt gelegd: als de mededingingsbeperking zich binnen Nederland voordoet, dan is de Mededingingswet van toepassing. ${ }^{46}$ Voor het verbod van artikel $24 \mathrm{Mw}$ geldt dat niet is gedefinieerd wat onder 'misbruik' verstaan dient te worden. De memorie van toelichting onderscheidt twee relevante vormen: uitbuiting van de positie om voordelen te behalen die bij voldoende concurrentie niet zouden zijn gerealiseerd en versteviging van de eigen positie ten nadele van concurrenten. ${ }^{47}$ Aangesloten wordt dus bij het communautaire misbruikbegrip, als gevolg waarvan ondernemingen met een machtspositie minder speelruimte hebben dan ondernemingen zonder een vergelijkbare positie. ${ }^{48}$

\subsection{Merkbaarheid, vrijstelling en ontheffing}

Evenmin als in artikel $81 \mathrm{EG}$ is in artikel $6 \mathrm{Mw}$ de eis van merkbaarheid van de mededingingsbeperking expliciet opgenomen. Maar evenzeer als het geval is voor het communautaire kartelverbod, geldt deze eis wel impliciet binnen het Nederlandse kartelrecht. Kartels waarvan de (potentiële) invloed op de mededinging om kwantitatieve dan wel kwalitatieve redenen niet meer dan marginaal is, blijven buiten het verbod van artikel $6 \mathrm{Mw}$. In het communautaire recht heeft de Commissie, zoals in het vorige hoofdstuk bleek, in haar Bagatelbekendmakingen een invulling gegeven van het merkbaarheidsvereiste, waarbij de grens is gelegd bij een marktaandeel van $5 \%$ voor horizontale en $10 \%$ voor verticale kartels. Wordt deze grens niet bereikt, dan valt de kartelregeling niet onder het verbod van artikel 81 lid 1 EG. Een vergelijkbare regeling kent de Mededingingswet niet, waardoor de merkbaarheid door de Nederlandse Mededingingsautoriteit per geval moet worden beoordeeld. Hierdoor biedt de merkbaarheidseis voor ondernemers in zoverre weinig bescherming dat zij niet of nauwelijks bij voorbaat zullen kunnen inschatten of zij -kwalitatief dan wel kwantitatief- onder de merkbaarheidsdrempel blijven. De merkbaarheidseis zal in feite slechts soelaas kunnen bieden indien het tot een beoordeling van het gedrag door de Nederlandse Mededingingsautoriteit komt, tenzij deze NMa alsnog door middel van een beleidsregel -vergelijkbaar met de bagatelbekendmaking van de Commissie-een nadere invulling van de merkbaarheid geeft. Dat dit echter niet voor de hand ligt, hangt samen met het feit dat de Mededingingswet zelf reeds in artikel 7 een kwantitatieve bagatelvoorziening kent, maar deze heeft de vorm van een vrijstelling en is -het zij nogmaals onderstreept- geen uitwerking van de eis van merkbaarheid. ${ }^{49}$ Deze tegen de convergentiegedachte indruisende regeling betekent dat gedragingen die aan de criteria van

46 Ten aanzien van artikel $24 \mathrm{Mw}$ stellen Elderson en VerLoren van Themaat (1997), pag. 15, dat "van belang is waar het misbruik zich doet gevoelen". Voor de bestuursrechtelijke handhaving geldt dat de NMa slechts bevoegd is op te treden binnen het Nederlandse territoir. Vergelijk Ottervanger, Steenbergen en Van der Voorde (1998), pag. 99.

47 TK 1995-1996, 24707 , nr. 3, pag. 26.

48 Zie hierover ook Langer en Sauter (1999), pag. 88 e.v..

49 Urlus en Speekenbrink (1997), pag. 32, alsmede Ottervanger, Steenbergenen Van der Voorde (1998), pag. 108 en Mok (1998), pag 122 e.v.. 
de bagatelvoorziening voldoen, onverminderd in strijd zijn met het kartelverbod, maar dat deze gedragingen wel generiek van het verbod ontheven worden. ${ }^{50}$

Om voor de vrijstelling van artikel 7 in aanmerking te komen, moet aan twee cumulatieve voorwaarden zijn voldaan. De eerste ziet op het aantal participanten in het kartel: ten hoogste acht ondernemingen mogen bij het kartel betrokken zijn. De tweede voorwaarde betreft het maximum van de gezamenlijke omzet van de bij het kartel betrokken ondernemingen: tien miljoen gulden voorzover het de levering van goederen betreft en twee miljoen gulden in andere gevallen, waarbij gedacht moet worden aan de dienstverleningssector. Ook hier is afgeweken van de communautaire bagatelvariant: deze gaat uit van een marktaandeelcriterium, terwijl de Nederlandse wet een omzetcriterium hanteert. ${ }^{51}$ Door de minister van Economische Zaken is erkend dat het marktaandeel van ondernemingen een beter criterium vormt voor het bepalen van de (relatieve) macht en daarmee de potentiële schadelijkheid van een kartel dan de omzet. ${ }^{52}$ De reden dat desalniettemin voor het laatste criterium is gekozen, hangt samen met de hanteerbaarheid ervan door ondernemingen. In tegenstelling tot de vaststelling van het marktaandeel -dat overigens onverkort een centrale rol vervult ten aanzien van de bepaling van de economische machtspositie- is de bepaling van de gezamenlijke omzet voor ondernemingen relatief eenvoudig. ${ }^{33}$ Zodoende is het voor hen eveneens relatief eenvoudig na te gaan of zij aanspraak kunnen maken op de door de voorziening geboden bescherming, hetgeen tal van procedures omtrent de toepasselijkheid van de bagatelvoorziening voorkomt. ${ }^{54}$ De afwijking van het communautaire stelsel moet derhalve in het verlengde gezien worden van de ratio van de Nederlandse bagatelvoorziening: doelmatigheid van de uitvoering van de wet aan de ene kant en lastenverlichting voor ondernemers van de andere kant. ${ }^{53}$

Het moge duidelijk zijn dat deze aspecten (doelmatigheid en lastenverlichting) in een verbodstelsel slechts tot niet-toepasselijkheid van het verbod kunnen leiden voorzover de mededinging niet wezenlijk wordt aangetast. Daarom zijn de grenzen van dien aard dat uitsluitend kleine en middelgrote ondernemingen van de bagatelvrijstelling kunnen

50 Deze regeling onderstreept dat de merkbaarheidseis in de praktijk weinig relevantie zal hebben. Dit zal nog meer het geval zijn indien van de mogelijkheid van artikel 7 lid $3 \mathrm{Mw}$ om bepaalde categorieèn van kartelgedragingen -op kwalitatieve gronden- buiten toepassing te verklaren, gebruik wordt gemaakt. Tot een vergelijkbare conclusie komen ook Urlus en Speekenbrink (1997), pag. 32.

51 Voor kritiek op deze keuze zie bijvoorbeeld Koedijk, TK 1996-1997, 24 707, nr. 9.

52 TK 1995-1996, 24707 , nr. 3, pag. 16.

53 Zie echterUrlus en Speekenbrink (1997), pag. 33, die desalniettemintoepassing door ondernemingen relatief complex achten.

54 Volgens De Jong, TK 1995-1996, 24 707, nr. 3r 1996-1997, 24 707, nr. 9, is de relevantie van de keuze voor het omzetcriterium betrekkelijk, omdat bij de beoordeling van kartelgedrag het marktaandeel uiteindelijk toch steeds een rol zal blijven spelen. Op grond van artikel $9 \mathrm{Mw}$ bijvoorbeeid kan de directeur-generaalhet verbod van artikel $6 \mathrm{Mw}$ toch op een kartel van toepassing verklaren, hoewel dit aan de bagatelcriteria voldoet. De directeur-generaal zal met name tot dit middel grijpen indien het marktaandeel van de betrokken ondernemingen zeer aanzienlijk is.

55 Hierover ook Urlus en Speekenbrink (1997), pag. 31-35. De lastenverlichting ligt in het voordeel van de vrijstelling dat ondernemingen geen afzonderlijk ontheffingsverzoek hoeven in te dienen en dus evenmin hun kartel behoeven aan te melden. Voor de uitvoerende instantie, de Nederlandse Mededingingsautoriteit, is de vrijstelling evenmin van belang ontbloot, aangezien de $\mathrm{NMa}$ een minder grote stroom ontheffingsverzoeken krijgt te verwerken. De memorie van toelichting brengt dit in verband met de doelmatigheid van de uitvoering van de Mededingingswet, zie TK 1995-1996, 24 707 , nr. 3, pag. 15. 
genieten. In het aanvankelijk ontwerp van de Mededingingswet was de kring van ondernemingen die een succesvol beroep op de vrijstelling kon doen nog beperkter aangezien was voorzien in bagatel/omzet-grenzen van respectievelijk vijf miljoen en één miljoen gulden. Hierop is een storm van kritiek -met name van ondernemerszijde- losgebarsten die uiteindelijk de minister van Economische Zaken heeft doen besluiten de omzetmaxima te verdubbelen. Maar ook na aanpassing van de bagatelgrenzen bestaat er nog onvrede over de hoogte ervan. ${ }^{56} \mathrm{Zal}$ in de toekomst blijken dat de bagatelvrijstelling haar taken onvoldoende kan vervullen door te lage drempels, kunnen deze op grond van het vierde lid van art $7 \mathrm{Mw}$ bij $\mathrm{AMvB}$ worden aangepast. ${ }^{57}$ Gelet op de doelstelling van de vrijstelling, maar met name ook gelet op de doelstelling van de Mededingingswet zou een verdere verhoging van de drempels naar mijn mening echter geen bijval verdienen. Naarmate de drempels verhoogd worden, zal het kartelverbod steeds meer gereserveerd worden voor grotere ondernemingen. Mededinging tussen kleine en middelgrote ondernemingen zou dan nog steeds niet bevorderd worden en bovendien zou in dat geval de meerwaarde van de nationale Mededingingswet naast het communautaire recht gering dreigen te worden.

Niet alleen bagatelkartels worden vrijgesteld van het verbod van artikel $6 \mathrm{Mw}$. De Mededingingswet kent nog vijf andere vrijstellingsvarianten, die ten dele nogmaals onderstrepen

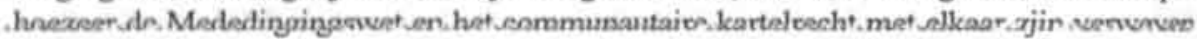
Op grond van de artikelen 12 en $14 \mathrm{Mw}$ zijn vrijgesteld kartelgedragingen waarvoor een communautaire vrijstelling ${ }^{58}$ respectievelijk ontheffing geldt. ${ }^{59}$ Artikel $13 \mathrm{Mw}$ breidt

56 Zie voor kritiek op de lage drempel: Coppens (1997), pag. 2; Urlus en Speekenbrink (1997), pag. 34. Van Wijnbergen, TK 1996-1997, 24 707, nr. 9, ziet meer in lage drempels, terwijl Heertje, TK 1996-1997, 24 707, nr. 9, pag. 19, zelfs voor gehele afschaffing pleit.

57 De NMa zou zelfeen vergelijkbaareffect kunnen bereiken door eenruime interpretatievan het merkbaarheidsvereiste, in die zin dat zij onder omstandigheden kartels waarbij de totale omzet van de ondememingen hoger is dan de genoemde bagatelmaxima, als niet wezenlijk de mededinging beperkend aanmerkt. In dat-niet waarschijnlijke-geval is voor dergelijk kartelgedrag artikel $6 \mathrm{Mw}$ in het geheel niet van toepassing. Mocht hieruit een constant beleid voortvloeien, dan zou aldus het belang van het merkbaarheidsprincipe toenemen.

58 Ook hier gelden volgens de memorie van toelichting, TK 1995-1996, 24 707, nr. 3, pag. 19, weer de voordelen die voor de hele aansluiting bij het communautaire recht worden genoemd: vermindering van bestuurlijke lasten voor de overheid en van administratieve lasten voor ondernemingen alsmede een optimale aansluiting bij het EG-recht met de daarmee gepaard gaande grotere mate van rechtszekerheid en rechtsgelijkheid.

59 De doorwerking in het nationale recht die voor communautaire ontheffingen geldt, geldt niet voor comfort-letters. Hienuit blijkt nogmaals de in het vorige hoofdstuk aangestipte geringe zekerheid die een comfort-letter biedt. Gelet op het uitgangspunt dat de Mededingingswet niet strikter maar ook niet minder strikt mag zijn dan het EG-recht, dient er naar mijn mening door de $\mathrm{NMa}$ (en door rechterlijke instanties) onverkort met deze brieven rekening gehouden te worden, tenzij zij zijn afgegeven om louter communautaireredenen(bijvoorbeeldhetontbrekenvan beînvloeding van de interstatelijke handel. Kritisch op dit punt onder meer ook: Plompen (1996), pag. 161. Ten aanzien van door de Commissie verleende negatieve verklaringen stelt de memorie van toelichting uitdrukkelijk dat zij niet doorwerken in de Mededingingswet, zij het dat deze verklaringen wel invloed uitoefenen op de interpretatievanhetnationalekartelverbod.Automatischedoorwerking vannegatieveverklaringen ligt ook minder voor de hand: de Commissie kan een dergelijke verklaring onder meer afgeven indien een kartel geen grensoverschrijdende invloed heeft of de communautaire mededinging niet beinvloedt, hetgeen onverlet laat dat de mededinging op de Nederlandse markt wel degelijk door dat kartel kan 
de vijstelling van artikel $12 \mathrm{Mw}$ uit in die zin dat eveneens zijn vrijgesteld kartels die welswaar niet de interstatelijke handel of de mededinging binnen de gemeenschappelijke maxt beînvloeden, maar die, als van een dergelijke beïnvloeding wél sprake zou zijn, zoulen profiteren van een communautaire vrijstelling. Ruimte voor eigen beleid biedt artiel $15 \mathrm{Mw}$ waarin de mogelijkheid van een nationale vrijstelling wordt geboden. ${ }^{60}$ BijAMvB kan worden bepaald dat voor bepaalde categorieen kartels het verbod niet gel6. De voorwaarden die voor een dergelijke maatregel gelden zijn vrijwel gelijkluidend aande voorwaarden genoemd in artikel 81 lid 3 EG. ${ }^{61}$

In In met het EG-recht kent de Mededingingswet de mogelijkheid van individucle ontheffing̨van het kartelverbod. In artikel 17 zijn de ontheffingsgronden van het derde lid van artiel 81 EG vrijwel letterlijk overgenomen. Ontheffingen worden -wederom conform conmunautair recht- slechts op aanvraag verleend, hetgeen van de ondernemingen een aannelding van hun kartelgedrag vergt. ${ }^{.2}$ In tegenstelling echter tot het EG-recht levert dez aanmelding geen immuniteit tegen boetes op ${ }^{6}$; mijns inziens ten onrechte aangezien de adernemingen niet de termijn die de NMa voor haar onderzoek nodig heeft aangerekenl kan en mag worden. ${ }^{64}$ Over de aanvraag tot ontheffing beslist bij uitsluiting de direteur-generaal van de Nederlandse Mededingingsautoriteit ( $\mathrm{d}-\mathrm{g} \mathrm{NMa}$ ), nadat er een opebare voorbereidingsprocedure zoals geregeld in afdeling $3.4 \mathrm{Awb}$ is doorlopen. ${ }^{65}$ Artkel $19 \mathrm{Mw}$ kent een beslistermijn voor ontheffingsaanvragen van uiterlijk vier maanden, met dien verstande dat de directeur-generaal de termijn kan verlengen met nog eens vier maanden. Acht maanden kunnen ondernemingen derhalve in onzekerheid blijven omtrent de geldigheid van hun kartel; in ieder geval tot het moment van de beslissing is het kartel nietig. ${ }^{66}$ Voor ondernemingen levert dit een onwenselijke situatie op, die nog versterkt wordt door de genoemde omstandigheid dat een ontheffingsaanvraag geen immuniteit tegen boetes oplevert. Een bijkomend probleem is dat de Mededingingswet geen oplossing biedt voor het geval dat er binnen een termijn van acht maanden geen beslissing is genomen, als gevolg waarvan deze termijn niet 'hard' is. ${ }^{67}$ Bepleit wordt

worden geraakt. Zie hierover ook Biesheuvel, Mok en Sevenster (1996), pag. 30 en Ottervanger, Steenbergen en Van der Voorde (1998), pag. 109.

60 Zie voor Nederlandse groepsvrijstellingen onder meer Brokx (1997), pag. 27-28, en Ottervanger, Steenbergen en Van der Voorde (1998), pag. 110 e.v..

61 De vijfde vrijstellingsmogelijkheid is neergelegd in artikel $16 \mathrm{Mw}$ en regelt de verhouding met (maatregelen op grond van) andere wetten. Het betreft hier een tijdelijke regeling, aangezien artikel $16 \mathrm{Mw}$ na vijf jaar na de inwerkingtreding van de Mededingingswet vervalt.

62 Ook ten aanzien van de individuele ontheffing wordt het voornemen uitgesproken om zoveel mogelijk de beschikkingspraktijk van de Commissie te volgen. Voor zover nodig zal voorafgaand aan een eventuele Nederlandse ontheffing overleg worden gepleegd met de Commissie; vergelijk TK 1995-1996, 24707 , nr. 3, pag. 24.

63 Ten onrechte anders: Janssen (1998), pag. 6.

64 Deze afwijking van het communautaire recht wordt ook betreurd door Ottervanger (1997), pag. 8 .

65 Kritisch over deze openbare voorbereidingsprocedure bij ontheffingsaanvragen is Pijnacker Hordijk (1997), pag. 291.

66 Is de beslissing voor de ondernemers gunstig, dan kan op grond van art $20 \mathrm{Mw}$ aan de beschikking terugwerkende kracht worden verleend tot het moment van de aanvraag.

67 De conclusie van Brokx (1997), pag. 29 dat er "dus geen wettelijke verplichting (is) om een formele beschikking te nemen binnen de termijn van acht maanden", gaat naar mijn mening toch wat ver. Dat de Mededingingswet een overschrijding van de termijn niet sanctioneert, betekent nog niet dat 
wel dat de enkele termijnoverschrijding direct zou moeten leiden tot verlening van de ontheffing van rechtswege. Nadeel van een dergelijke oplossing is echter dat zij de discretionaire vrijheid van het bestuursorgaan (in casu de d-g NMa) in ernstige mate aantast en dat op een gebied waar grote (economische en andersoortige) belangen in het geding zijn en dat een onderdeel vormt van het gehele economische beleid. Aan de andere kant zijn voor ondernemingen grote belangen met de beslissing van de directeur-generaal van de NMa gemoeid en is ondernemingen er dus veel aan gelegen om zo snel mogelijk zekerheid te verkrijgen over al dan niet ontheffing. ${ }^{68}$ De termijn van acht maanden lijkt daarenboven voorshands voor de d-g NMa ruim voldoende om een gedegen ontheffingsbeslissing te kunnen nemen; een sanctie zoals hierboven bedoeld zou eraan kunnen bijdragen om de NMa aan te zetten tot een efficiënte en snelle afhandeling van ontheffingsaanvragen. Gelet hierop zou de van rechtswege verlening van ontheffing door het verstrijken van de termijn van acht maanden mijns inziens inderdaad de voorkeur verdienen. ${ }^{6}$ Een uitzondering zou gemaakt kunnen worden voor procedures waarbij het advies van de Europese Commissie zal worden ingewonnen; de termijn die de Commissie voor haar advies nodig heeft, kan de NMa niet worden aangerekend en zou derhalve buiten beschouwing dienen te blijven.

\section{De handhaving}

Waar de Mededingingswet op materieelrechtelijk gebied convergentie zoekt met het communautaire recht, daar is op formeelrechtelijk gebied de band met het communautair recht aanmerkelijk losser ${ }^{70}$; de band met de handhaving van de Wem is zelfs -zeker op publiekrechtelijk gebied-geheel doorgesneden. In hoofdstuk 1 bleek dat civielrechtelijke handhaving in het misbruikstelsel van de Wem een moeilijke aangelegenheid was, aangezien feitelijk steeds een voorafgaande maatregel van de minister of de regering vereist was. De generieke onverbindend verklaringen boden de beste mogelijkheden, maar hier betrof het dan ook verboden van bepaalde kartelvormen. Bij de bespreking van het commu-

bedoelde verplichting niet bestaat. Een bestuursorgaan dient zich aan de wettelijke regeling én aan de algemene beginselen van behoorlijk bestuur te houden. Het zal zeer goede redenen moeten aanvoeren wil het termijnoverschrijding kunnen rechtvaardigen. Slaagt het bestuursorgaan hierin niet, dan tast dit wellicht niet zijn beslissing inhoudelijk aan, maar dan zou termijnoverschrijding kunnen leiden tot een plicht tot vergoeding van de door de overschrijding veroorzaakte schade.

68 Een spoedig uitsluitsel is om verschillende redenen van belang: gedurende de behandeling van het ontheffingsverzoek is het kartel verboden en nietig, waardoor er -naast door de $\mathrm{NMa}$ op te leggen sancties- civiele acties dreigen. Bovendien -en dit is ook in het algemeen belang-dienen kartels die van het verbod ontheven kunnen worden, zo spoedig mogelijk hun werking te krijgen.

69 Eventueel zou deze regeling pas na een periode van bijvoorbeeld twee jaar in de Mededingingswet kunnen worden vastgelegd. Gebleken is dat in het eerste jaar de NMa geconfronteerd is met een grote stroom ontheffingsaanvragen, maar ook met een aanzienlijke reeks concentratie-aanmeldingendic alle behandeld moeten worden. De werkdruk is in deze beginperiode van de Mededingingswet voor de $\mathrm{NMa}$ aanzienlijk. In dit lieht zijn de consequentiesvan ontheffingen van rechtswegeniet aanvaardbaar. Na de aanloopperiode echter moet de $\mathrm{NMa}$ in staat worden geacht een ontheffingsverzoekmet de nodige spoed en dus zeker binnen acht maanden te kunnen afhandelen.

70 Vergelijk ook Ottervanger (1997), pag. 8: op formeelrechtelijk gebied "vaart Nederland in menig opzicht een eigen koers: ten dele om aansluiting te zoeken bij ons eigen bestuursrecht, ten dele vanuit de wens zo efficiènt mogelijk dossiers te kunnen behandelen". 
nautaire recht werd duidelijk dat een verbodstelsel meer ruimte voor individuen biedt om cirect via de burgerlijke rechter -dus zonder tussenkomst van een overheidsinstantiehun recht te krijgen. ${ }^{71}$ Dit geldt voor het Nederlandse verbodstelsel evenzeer als voor zijn communautaire voorbeeld. Uitzonderingen daargelaten zijn alle kartels verboden (en roor zover het overeenkomsten en besluiten betreft op grond van artikel 6 lid $2 \mathrm{Mw}$ tevens van rechtswege nietig) en is evenmin misbruik van machtspositie toegestaan. ${ }^{72}$ Degene die zich toch aan dergelijk gedrag schuldig maakt, handelt dientengevolge in beginsel in strijd met de wet en begaat -mits aan de overige eisen van artikel 6:162 BW is voldaan- een onrechtmatige daad. Voorts kunnen dankzij de van rechtswege nietigheid prestaties als zijnde onverschuldigd betaald op grond van artikel 6:203 BW worden teruggeverderd en bestaat er geen nakomingsverplichting.

De mogelijkheden voor civielrechtelijke handhaving door individuen zijn dus aanmerkelijk toegenomen, zeker in vergelijking tot de Nederlandse situatie tot 1994 (vanaf welk jaarimmers voor de belangrijkste categoriežn gedragingen generieke onverbindend verklaringen golden). Als gezegd zijn de banden met de Wem op het gebied van de publiekrechtelijke handhaving zelfs geheel doorgesneden. Hierop moet dan ook in dit verband dieper worden ingegaan. ${ }^{73}$

\section{3.) Bestuursrechtelijke handhaving en de Nederlandse Mededingingsautoriteit}

Intensivering van het kartelbeleid is ondenkbaar zonder intensivering van de handhaving. Dit zou in zoverre weinig problemen mogen opleveren dat de handhaving van de Wem geen toonbeeld was van een intensieve handhaving, integendeel. De indiener van het wetsvoorstel, voormalig minister van Economische Zaken Wijers, heeft gemeend dat van een aanscherping van het kartelbeleid zonder wezenlijke wijziging van de onderliggende wettelijke regeling onvoldoende resultaat zou zijn te verwachten. Volgens de minister diende de nieuwe regeling op de volgende uitgangspunten gebaseerd te zijn:

- het absolute primaat van mededingingspolitieke overwegingen in het mededingingsbeleid;

- doorzichtigheid en controleerbaarheid van de besluitvorming:

- concentratie van uitvoeringsbevoegdheden bij één instantie, en

- scheiding van beleid en uitvoering. ${ }^{74}$

De regeling zoals die onder de Wem had gegolden, voldeed in ieder geval niet aan de laatste twee uitgangspunten. Uitvoering voor zover het de toepassing van de maatregelen van de Wem betrof, lag in handen van de minister van Economische Zaken respectievelijk (ten aanzien van de generieke maatregel) de regering; de controle op de naleving geschiedde onder supervisie van eveneens de minister van Economische Zaken, de eventuele opsporing en vervolging was een taak van het Openbaar Ministerie, terwijl slechts de

71 Vergelijk de opmerkingen van Biesheuvel, geuit tijdens een hoorzitting van de vaste commissie voor Economische Zaken, TK 1996-1997, 24 707, nr. 9.

72 Ook hier kan er sprake zijn van nietigheid van rechtswege, voorzover de betrokken gedraging zich daartoe althans leent. De nietigheid is echter niet in de Mededingingswet opgenomen, maar kan worden afgeleid uit artikel 3:40 BW.

73 Zie over de rol van de rechter in de Mededingingswet: Slotboom (1997 II), pag 60 e.v..

74 TK 1996-1997, 24 707, nr. 3, pag. 46-47. 
strafrechter een punitieve sanctie kon opleggen. Van concentratie was hier in het geheel geen sprake. Evenmin was er een scheiding gerealiseerd van beleid en het primaire deel van de uitvoering: de strafrechtelijke handhaving uitgezonderd, waren beide een taak van de minister van Economische Zaken.

Uit het bovenstaande volgt dat de genoemde uitgangspunten tot cen grondige wijziging noopten. Concentratie van bevoegdheden betekende het einde van strafrechtelijke handhaving: behandeling van ontheffingsverzoeken, concentratiecontrole, controle op naleving van het kartelverbod en het verbod op misbruik van machtspositie én bestraffing van overtreders moesten door dezelfde instantie ter hand genomen worden. Het moge duidelijk zijn dat het merendeel van deze taken zich niet leent voor uitvoering van een strafrechtelijke instantic. Wel is het mogelijk deze taken te concentreren bij een bestuursorgaan, hetgeen immers ook is gebeurd in het communautaire recht. Scheiding van beleid en uitvoering bracht met zich dat een min of meer van de minister van Economische Zaken onafhankelijk orgaan met de uitvoering zou moeten worden belast, terwijl de beleidsvoering -uiteraardbij de minister zelf bleef. ${ }^{75} \mathrm{Om}$ deze reden is de Nederlandse Mededingingsautoriteit in het leven geroepen. Op deze aspecten wordt hieronder nader ingegaan.

\subsubsection{De ratio van de bestuursrechtelijke handhaving}

Hiervoor is gesteld dat het streven naar concentratie van bevoegdheden leidde tot het verlaten van het strafrechtelijke handhavingstraject en tot het betreden van het pad van bestuursrechtelijke handhaving en meer in het bijzonder de handhaving via de bestuurlijke boete. ${ }^{76}$ Hierin staat de Mededingingswet niet alleen; punitieve bestuursrechtelijke handhaving is een trend. ${ }^{n}$ Zozeer zelfs dat niet wordt gewacht op de introductie van een regeling van de bestuurlijke boete in de Algemene wet bestuursrecht. ${ }^{78}$ De vraag is waarom deze

75 Dit ondervangt ook het door Michiels (1994), pag. 31, gesignaleerde probleem van bestuurlijke boetes ten opzichtevan strafrechtelijkesancties: "bestuurlijk punitief optreden is minder geschikt in situaties waarin bestuursorgaan en overtreder in een voortdurende en inhoudsvolle relatie tot elkaar staan". In hoofdstuk 1 bleek reeds dat het beschermen van deze relatie onder het regime van de Wem prioriteit had, hetgeen vrijwel gehele afwezigheid van streng en punitief optreden tot gevolg had.

76 Dat betekent onder meer dat de dreiging van vrijheidsstraffen wegens een kartelinbreuk tot het verleden behoort; de boete, door Van Veen (1977), pag. 2, in strafrechtelijke context ooit als 'weinig tot de verbeelding sprekende straf' gekarakteriseerd, is in de Mededingingswet de enige punitieve sanctie.

77 Vergelijk Michiels (1994), Rikmenspoel (1994), pag. 321, Mulder (1994), pag. 220, Corstens (1995 I). Koopmans (1995), pag. 135, Widdershoven (1998), pag. 236 en 237, Jansen (1999), pag. 4, Verheij (1999), pag. 22, Wladimiroff en Van Russen Groen (1999), pag. 89 en Rogier (2001), pag. 8. De nieuwswaarde die volgens Huidekoper (1976), pag. 387 het economisch strafrecht zo'n 25 jaar geleden nog had, ligt nu veeleer bij het bestuurlijke boeterecht.

78 Bezwaren hiertegen heeft de Werkgroep "Handhaving door bestuurlijke boeten" (1995), pag. 9. Positief daarentegen over deze aanpak is Verheij (1999), pag. 29. Een algemeneregeling van de bestuurlijke boete zal naar alle waarschijnlijkheid worden geìntroduceerd in de vierde tranche van de Awb. Zie dienaangaandede Commissie wetgeving algemeneregels van bestuurstecht (Commissie Scheltema), het Voorontwerp Algemene wet bestuursrecht vierde tranche, Den Haag 1999 en het commentaar daarop van VAR-werkgroep Vierde tranche Awb (2000), pag. 35 e.v, en Merkx (2000), pag. 49 e.v.. De keuze valt derhalve niet op een door Hartmann (1995), pag. 318 ev. en (1999), pag, 43, voorgestane afzonderlijke wettelijke regeling. Knigge (2000), pag. 83 e.v., die de voorgestelde boeteregeling in de Awb aanduidt als 'een soort schaduwstrafrecht', betoogt dat de oorspronkelijke verschillentussea strafrecht en bestuursrecht voor een belangrijk deel zijn verdwenen. "Van gescheiden werelden kas 
trend bestaat. Het antwoord is tweeledig: ten eerste zou volgens de Nederlandse overheid de verantwoordelijkheid voor de handhaving van beleidsinstrumentele wetten in eerste instantie bij het bestuur zelf moeten liggen (hetgeen aansluit bij het genoemde streven naar concentratie in de Mededingingswet) ${ }^{x}$; ten tweede zou er een handhavingstekort bestan dat niet door het 'relatief zware, tijdrovende en kostbare ${ }^{\text {} 80}$ strafrecht maar wel door het aanmerkelijk effectiever en efficiënter geachte bestuursrecht zou kunnen worden teruggedrongen. ${ }^{81}$ Bijkomend voordeel zou zijn dat het -nu overbelaste- strafrecht gereserveerd zou worden voor de echt ernstige vergrijpen. Beide deel-antwoorden verdienen enig commentaar. De vraag die naar aanleiding van het eerste deel-antwoord rijst, is welke regeingen voor bestuurlijke handhaving in aanmerking komen. De term 'beleidsinstrumentele wetten' biedt weinig houvast, hoewel hij in de richting wijst van een belangrijk deel van de via de WED gehandhaafde wetten; ook de kartelwetgeving lijkt zeker tot de beleidsinstrumentele wetten te kunnen worden gerekend. Meer inhoudelijke duidelijkheid omtrent de mogelijkheid tot bestuursrechtelijke handhaving biedt het advies van de Commissie voo de toetsing van wetgevingsprojecten. ${ }^{22}$ In haar advies, waarvan de conclusies door de regering in hoofdlijnen zijn onderschreven ${ }^{\mathrm{s}}$, heeft deze toetsingscommissie de volgende primaire criteria voor bestuursrechtelijke handhaving geformuleerd ${ }^{\mathrm{s}}$ :

12. de overtreden norm heeft een geringe normatieve lading;

Db. de overtreding pleegt geen letsel aan personen of schade aan goederen toe te brengen;

II. de norm is zodanig duidelijk in de wet of in de nadere regelgeving omschreven dat het mogelijk is om op grond van de wettelijke normen in de praktijk een vaste gedragslijn te ontwikkelen;

III. de ambtenaar of dienst die belast wordt met de handhaving beschikt over voldoende expertise om aan die handhaving adequaat gestalte te geven, en

geen sprake meer zijn. De opsporing en vervolging van strafbare feiten is bestuursrecht woor zover het daarin gaat om het handelen van bestuursorganen. Omgekeerd is de oplegging van boetes door bestuursorganen strafrecht voor zover het daarbij om bestraffing gaat". Knigge vraagt zich dan ook af waarom het Algemeen Deel van het Wetboekvan Strafrecht in het voorontwerp Awb van overeenkomstige toepassing is verklaard.

79 Handhaving door bestuurlijke boeten (1994), pag. 7 en TK 1993-1994, 23400 VI, nr. 48. Michiels (1994), pag. 14, stelt dat voor de bestuurlijke boete pleit "dat het bestuur de sanctionering geheel in eigen hand heeft en niet voor bepaalde overtredingen afhankelijk is van de vervolgingsbereidheid van het OM". Van Buuren (1995), pag. 43, concludeert "dat het enige argument voor de keuze voor de bestuurlijke boete dat werkelijk telt is, dat op die manier een alternatieve handhavingslijn wordt opgezetnaast die van het dichtgeslibde strafrechtelijkekanaal". Hij wijst in dat verbandop de overbelasting van het strafrechtelijk apparaat en de geringe prioriteit van overtredingen van bestuursrechtelijke regels.

80 'Handhaving door bestuurlijke boeten' (1994), pag. 7. Vergelijk ook Michiels(1994), pag. 2 alsmede Corstens (1995 I), pag. 4-5.

81 Michiels (1994), pag. 5, wijst in meer algemene zin op de prioriteit bij de overheid van het streven naar meer doelmatigheid.

82 Handhaving door bestuurlijke boeten (1994). Zie hierover ook De Koning-De Jong (1994), pag. 173 e.v. en (kritisch) Mulder (1994), pag. 231-234, die concludeert "dat als criterium voor het invoeren van bestuurlijke boeten voorop zou moeten staan, dat alleen die gedragingen in aanmerking komen, die slechts vragen om een beoordeling van de daad, zodat bij de strafoplegging, alleen al, gelet op de hoogte van de boete, de persoonlijke omstandigheden van de dader, slechts in bijzondere gevallen in aanmerking hoeven te worden genomen".

83 TK 1993-1994, 23400 VI, nr. 48.

84 Handhaving door bestuurlijke boeten (1994), pag. 18: "De primaire criteria wegen zwaar en kunnen in het algemeen als voorwaarden voor bestuursrechtelijke handhaving worden beschouwd". 
IV. voor de handhaving van de norm zijn geen vrijheidsbenemende of andere ingrijpende dwangbevoegdheden nodig.

Daarnaast formuleerde de commissie nog drie aanvullende criteria, die extra argumenten zouden kunnen opleveren voor bestuursrechtelijke handhaving. Het betrof:

V. de overtreding leent zich voor vaste afdoeningstarieven;

VI. documentatie in verband met recidive is niet nodig, en

VII. de overtreding wordt niet in belangrijke mate door of ten dienste van criminele organisaties gepleegd."

Of de Mededingingswet aan deze criteria voldoet, zal hierna nog worden besproken. Wel kan hier geconcludeerd worden dat de Commissie bestuurlijke handhaving met name wil reserveren voor inbreuken die de samenleving niet ernstig schokken en waarbij de afhandeling relatief snel en doelmatig kan geschieden.

Het tweede deel-antwoord maakt duidelijk dat het effectiviteits- en efficiëntie-argument binnen het Nederlandse (economisch) ordeningsrecht onverslijtbaar is. In de jaren dertig leidde dit argument tot tuchtrechtelijke in plaats van strafrechtelijke handhaving van verschillende wetten ${ }^{86}$, bij de totstandkoming van de WED werd het argument gebruikt ter onderbouwing van de noodzaak van een bijzondere strafrechtelijke regeling en heden ten dage wordt het argument uit de kast gehaald om het strafrecht ten bate van het be-

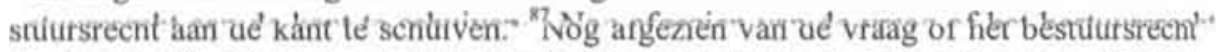
daadwerkelijk efficiënter en effectiever is -hierop zal later nog worden ingegaan-, kunnen vraagtekens gezet worden bij de reden waarom de effectiviteit en efficiëntie verhoogd zouden moeten worden: het bestaan van het handhavingstekort. Zoals Corstens terecht stelt, is er over het algemeen geen sprake van enige empirische onderbouwing van de aanwezigheid van een handhavingstekor ${ }^{88}$, zij het dat daarin wel verandering is gekomen dankzij het rapport van de Commissie Bestuursrechtelijke en Privaatrechtelijke Handhaving (Handhaven op niveau). Daarnaast bestaat het probleem dat het antwoord op de vraag of er een handhavingstekort is, afhankelijk is van de vraag wat men van de handhaving verwacht. Veelal wordt handhavingstekort als synoniem gebruikt voor een te gering aantal wat hiervan ook de normen mogen zijn- succesvolle vervolgingen, te weinig handhaving met de harde hand dus. Ziet men daarentegen handhaving als een ruimer begrip, waaronder mede begrepen het tot inkeer brengen van de overtreder door middel van overleg met deze, dan komt men tot een geheel andere conclusie omtrent het al dan niet bestaan van een handhavingstekort. Om de Wem als concreet voorbeeld te nemen: in de eerste visie

85 Zie voor stevige kritiek op het rapport van de toetsingscommissie: Corstens (1995 I), pag. 13 e.v..

86 Mulder (1950), pag. 109.

87 Interessantin dit verband is de conclusie van Schaffmeister(1978), pag. 168, "daB das WED durehaus vom niederländischenGesetzgeberals bewăhrtes, zur Durchsetzung von strafbewehrten Vorschriften der (...) Wirtschaftsgesetzgebunggeeignetes Instrumentarium angesehen und eingesetzt wurde und wird". In twintig jaar is de tevredenheid van de wetgever klaarblijkelijk aanmerkelijk getaand. Actueel wordt dan ook de vraag of de WED niet zal worden uitgekleed, ten voordele van bestuursrechtelijke handhaving. Het vermelden waard is dat Bos (1976), pag. 387, zich reeds in 1976 afvroeg "of de WED nog een lang leven beschoren dient te zijn". Hij pleitte echter voor overheveling naar het Wetbook van Strafvordering. 
wser absoluut sprake van een schrijnend tekort; in de tweede visie kan men daarover teninste genuanceerder denken. ${ }^{89}$

Het zal niet als een verrassing komen dat de centrale overheid, wanneer zij spreekt vaeen handhavingstekort, dit begrip veelal in de eerste betekenis gebruikt. Daarom wel ook de handhaving van de Wem onvoldoende effectief geacht: het moest strenger. ${ }^{90}$ Emede daarom werd ten aanzien van de Mededingingswet bij de hiervoren genoemde trel aangesloten, hetgeen mede blijkt uit de motivering van de keuze voor bestuursrechtelijk handhaving van deze wet. Uitgangspunt voor de minister van Economische Zaken wadat strafrecht slechts zou mogen worden ingeschakeld indien was gebleken dat andere hathavingssystemen niet voldeden: de 'remonte' van het strafrecht als ultimum remediun ${ }^{11}$ Inderdaad zal men het strafrecht niet onnodig moeten inschakelen, maar tegen dititgangspunt van de minister bestaan ten minste twee bezwaren. Het belangrijkste is at naar mijn mening iedere regeling op grond waarvan punitieve sancties kunnen wden opgelegd slechts als laatste (red)middel mag worden aangewend. ${ }^{92}$ Weliswaar is it strafrecht in verhoogde mate belastend, gelet op zijn monopolie op vrijheidsbenemendeancties (vergelijk artikel 113 lid $3 \mathrm{GW}$ ), maar voor een regeling waarin een justitiabele kaworden getrakteerd op zeer aanzienlijke financięle sancties dient er evenmin plaats te jn indien er andere alternatieven voorhanden zijn. ${ }^{93}$ Een tweede bezwaar tegen dit uilangspunt is dat het geen enkel inhoudelijk aanknopingspunt biedt. Er zal nog steeds muten worden aangetoond dat het bestuursrecht in een -zowel op het gebied van de doelmatigheid als op dat van de rechtmatigheid- goede handhaving voorziet en zodoende een reëel alternatief voor het strafrecht vormt. In dit verband noemde de minister zowel positieve als negatieve argumenten die tot de keuze voor bestuursrechtelijke handhaving hadden geleid. Om met de laatste te beginnen: het vertrouwen in het strafrecht als handhavingsinstrument was niet bijzonder groot, als gevolg waarvan strafrechtelijke handhaving niet als reële en wenselijke optie werd beschouwd. ${ }^{94}$ Getwijfeld werd aan de deskundigheid van Openbaar Ministerie en rechterlijke macht met betrekking tot 'analyse van marktstructuren en van de gevolgen van concurrentiebeperkingen'. ${ }^{95}$ Mede gelet op dit gebrek aan inzicht in de economische aspecten van het mededingingsrecht en de ingewikkeldheid van de materie, maar ook gelet op de capaciteitsproblemen binnen het strafrecht en op 'de relatief geringe verontrusting' die met kartelinbreuken gepaard gaat, vreesde de minister

89 'Handhavenop niveau' (1998), pag 36, spreekt van een handhavingstekort "wanneer bij niet-naleving een tot handhaving bevoegde instantie rechtens moet handhaven doch hetzij wel wil, maar niet kan handhaven, hetzij wel kan, maar niet wil handhaven".

90 De Wet van 2 november 1994, Stb. 801 (vergroting van de effectiviteit) was hiervan een uitvloeisel.

91 TK 1995-1996, 24707 , nr. 3, pag. 42.

92 In deze zin ook Hartmann en Van Russen Groen (1994 III), pag. 78.

93 Hierop wijst ook Rogier (2001), pag. 12.

94 TK 1996-1997, 24707 , nr. 3, pag. 42-43.

95 Te bedenken valt dat bij de totstandkoming van de WED juist op de deskundigheid van de economische rechter werd gewezen. Voorts roep ik de woorden van Mulder (1959), pag. 5, betreffende de LandbouwCrisiswet 1933 in herinnering: "Deze commune strafrechtspraakachtte men onvoldoende repressief: de rechter werd niet genoeg deskundig gevonden (...)". In een meer algemene context stellen Wladimiroff en Van Russen Groen (1999), pag. 90: "Daarnaast speelt het veronderstelde gebrek aan kennis bij het openbaar ministerie van (de normen die gelden in) een specifiek functioneel rechtsgebied, als motief om sanctionering van bepaalde regelovertredingen aan bet bestuur over te laten, zeker als het om economisch strafrecht gaat, een steeds kleinere rol, gezien de verlaagde eisen die in economische strafzaken aan een tenlastelegging worden gesteld". 
dat de handhaving zou verzanden: hij verwachtte dat het Openbaar Ministerie op grond van de genoemde factoren in veel gevallen zijn heil zou zoeken in sepots of transacties.\%

Naast deze negatieve factoren, hebben vier positieve argumenten bijgedragen aan de keuze voor het bestuursrechtelijk traject. Verwezen werd naar het -hiervoren reeds genoemde- standpunt van de regering dat "de primaire verantwoordelijkheid voor de handhaving van beleidsinstrumentele wetgeving behoort te liggen bij het bestuursorgaan dat met de uitvoering van de desbetreffende wet is belast". Het tweede positieve argument vormde het spiegelbeeld van een belangrijk argument dat tegen strafrechtelijke handhaving pleitte: de deskundigheid (op het gebied van mededingingstechnische zaken) die de strafrechtelijke organen ontberen, zou in overvloed aanwezig bij het gespecialiseerde bestuursorgaan dat zich immers uitsluitend met mededingingkwesties zou gaan bezighouden. ${ }^{97}$ Als derde argument noemde de memorie van toelichting dat met behulp van bestuursrechtelijke handhaving sneller en eenvoudiger (en dus doelmatiger) kon worden gereageerd op inbreuken dan met behulp van het strafrecht. Het vierde argument tenslotte dat in het voordeel pleitte van bestuursrechtelijke handhaving was dat de lijnen naar de Commissie in een stelsel met één centraal kartelorgaan kort zijn hetgeen afstemming van het Nederlandse met het communautaire (sanctie- en handhavings)beleid ten goede komt en vereenvoudigt.

Wat nu te denken van de onderbouwing door de minister van de keuze voor bestuursrechtelijke handhaving? Overtuigend is de onderbouwing mijns inziens niet. Mijn eerste bezwaar houdt verband met het hiervoor genoemde advies van de Commissie voor de toetsing van wetgevingsprojecten. De conclusie kan niet anders zijn dan dat de Mededingingswet zich volgens de door deze commissie gestelde -en door de regering aanvaarde-criteria niet voldoet. De mening van de minister dat kartelovertredingen een geringe normatieve lading hebben, kan al in twijfel worden getrokken (hetgeen hierna zal worden toegelicht). Geen twijfel is mogelijk over het tweede criterium van de commissie: hieraan is eenvoudigweg niet voldaan. ${ }^{98}$ Dit blijkt in versterkte mate uit de toelichting van de toetsingscommissie op criterium II: van belang is "dat in de praktijk van de uitvoering weinig of geen verschil van mening (mag) bestaan over de vraag of een bepaalde gedraging al of niet onder de met een bestuurlijke boete gesanctioneerde norm valt". ${ }^{99}$ Beziet men de Brusselse praktijk, die toch gelet op de convergentie als voorbeeld mag dienen, dan blijkt onmiskenbaar dat meningsverschillen over de reikwijdte van het kartelverbod aan de orde van

96 Sceptisch tegenover strafrechtelijke handhaving stond ook Van Wijnbergen, TK 1996-1997, 24 707, nr. 9. "De strafrechter heeft een veel kleinere rol. Dat is het verschil tussen een werkbare en een niet werkbare wet. Als je voor de toepassing van een wet volledig op de strafrechter vertrouwt, dath zal die wet (...) in feite niet functioneren. De strafrechter is een veel te zware sanctie. Administratief is men er niet toe in staat. De expertise is er ook niet. Er is weliswaar een Econornische Kamer. maar men heeft mij vanuit die hoek verzekerd dat de designatie van de Economische Kamer op dat punt over alle kamers roteert. Het heeft niets te maken met specifieke expertise". Knigge (2000). pag. 96, oppert de mogelijkheid om de Nederlandse Mededingingsautoriteit (in plaats van de officier van Justitie) strafrechtelijke vervolgingsbevocgdheid te geven voor inbreuken op de Mededingingswet die een hoge boete rechtvaardigen.

97 Op dit aspect van doelmatigheid wijst ook Michiels (1994), pag. 15/16.

98 Dit lijkt ook de mening van Van Aalst (1997), pag. 556 en van Ham (1994), pag. 506, die in ieder geval gekant is tegen de alles-in-één-hand handhaving. 
de dag zijn. Door onverminderd te kiezen voor bestuursrechtelijke handhaving legde de minister in feite het standpunt van de regering naast zich neer, en dat bij vrijwel de eerste gelegenheid daartoe. De waarde van het advies voor toekomstige keuzes tussen strafrechtelijke en bestuursrechtelijke handhaving wordt daarmee wel zeer twijfelachtig: het lijkt erop dat een bewindspersoon op het moment dat het hem schikt zonder veel problemen van het advies en het regeringsstandpunt kan afwijken. En bij de Mededingingswet schikte het de minister van Economische Zaken. Hij erkende ten volle dat de Mededingingswet niet aan de vaste voorwaarden van de toetsingscommissie voldeed, maar achtte bestuursrechtelijke handhaving toch aanvaardbaar, "onder meer wanneer er een gespecialiseerd opsporingsorgaan is, dat aan de handhaving adequaat gestalte kan geven". ${ }^{100}$ Waarschijnlijk was dit een impliciete verwijzing naar de toelichting van de toetsingscommissie op haar derde criterium, waar zij stelde:

\footnotetext{
"Aan het vereiste dat weinig discussie mogelyk is over de vraag of terecht een boete is opgelegd, kan echter ook worden voldaan, indien de bevoegdheid tot het vaststellen van de overtreding wordt verieend aan een gespecialiseerde dienst en de vaststelling van de boete wordt opgedragen aan een afzonderlijke boete-ambtenaar. Dan kunnen ook wat moeilijker constateerbare feiten met voldoende zekerheid worden vastgesteld en volgens een behoorlijke procedure worden afgedaan".
}

Welnu, indien de minister kartelinbreuken als 'wat moeilijker constateerbare feiten' kwalificeert en van mening is dat er 'weinig discussie' mogelijk zal zijn indien de directeurgeneraal van de Nederlandse Mededingingsautoriteit een boete heeft opgelegd, dan kan men zonder veel risico's stellen dat dit voor het gros van de inbreuken op ordeningsrechtelijke regelgeving zal gelden. Wordt zoveel belang gehecht aan het derde criterium van het advies van de toetsingscommissie, dan is het tweede criterium welhaast van ieder belang ontbloot. Naar mijn mening echter is dit niet de bedoeling van de toetsingscommissie geweest, en is het advies noch het regeringsstandpunt naar aanleiding van dat advies in deze gevolgd. ${ }^{101}$

Er kunnen nog wel meer kanttekeningen bij de motivering van de keuze voor de bestuursrechtelijke handhavingsmodaliteit worden geplaatst. Ten aanzien van het door de minister geschetste negatieve strafrechtelijke scenario kan het volgende gesteld worden. Dit scenario, gekenmerkt door informele afdoening en door dagvaarding in slechts uitzonderlijke gevallen, komt niet uit de lucht vallen: dit is immers het scenario van de handhaving van de Wem geweest. ${ }^{102}$ De dreiging dat dit scenario ook voor de Mededingingswet werkelijkheid wordt, is echter minder groot dan de memorie van toelichting wil doen geloven. ${ }^{103}$ Bedacht moet worden dat ook op het ministerie van Economische Zaken

100 TK 1995-1996, 24 707, nr. 3, pag. 43.

101 In dit verband kan ook gewezen worden op hetgeen wordt gesteld door Michiels (1994), pag. 18: "wanneer er ingewikkelde schuldvragen kunnen rijzen of wanneer de persoon van de dader voor de bestraffing van groot belang is, lijkt de strafrechter gezien zijn ervaring en kennis op deze terreinen de aangewezen sanctic-oplegger".

102 Ook Van der Woude (1995), pag. 200, benadrukt dat het Nederlands kartelbeleid hoofdzakelijk een informeel karakter had.

103 Overigens gaat de memorie van toelichting er zonder meer van uit dat transactie van kartelinbreuken als onwenselijk moet worden beschouwd en dat een repressief optreden voorkeur verdient. Transacties echter kunnen wel degelijk een effectief handhavingsmiddel vormen: gedragingen kunnen via transactievoorwaarden in de gewenste richting worden gestuurd, transactiebedragenkunnen aanzienlijk zijn en kunnen zodoende generaal- en speciaal-preventiefwerken, welke werking versterkt kan worden 
zelf aan de Wem lange tijd weinig aandacht werd geschonken. Mededingingsrecht 'leefde' niet, waardoor het weinig verbaast dat door het Openbaar Ministerie aan de handhaving ervan weinig prioriteit werd toegekend. De Mededingingswet zelf is echter het bewijs ervan dat mededingingsrecht in Nederland nu in ieder geval op beleidsniveau een item is, hetgeen een grotere vervolgingsprioriteit bij het Openbaar Ministerie waarschijnlijker maakt. ${ }^{104}$ Dat de animo tot vervolging te lijden zou hebben onder de 'relatief geringe verontrusting' waarvoor kartelinbreuken zorgen, is evenmin een vast gegeven. Allereerst kan men zich afvragen of de verontrusting inderdaad zo gering is. Toegegeven moet worden dat economische criminaliteit doorgaans voor minder opschudding zorgt dan commune delicten, maar het is niet uitgesloten dat juist door een strengere aanpak deze 'verontrusting' zal gaan groeien. ${ }^{105}$ Bovendien impliceert een geringere normatieve lading van een verbod nog niet dat dit per definitie een negatieve invloed heeft op de mate waarin wordt vervolgd: zo staan fraudezaken -denk bijvoorbeeld aan beursfraudenu toch redelijk hoog op de prioriteitenladder bij het Openbaar Ministerie. ${ }^{106}$ Die prioriteit -het is reeds gezegd- zou ook ten aanzien van karteldelicten hoog kunnen zijn, hetgeen temeer geldt indien enkele leden van het Openbaar Ministerie expliciet zouden worden belast met de handhaving van de kartelregelgeving en voor deze taak voldoende -onder meer in de vorm van een gedegen opleiding en van beschikbaarstelling van voldoende middelen en staf- zouden worden toegerust. ${ }^{107}$ Daarmee wordt tevens het bezwaar ondervangen dat in het Openbasr Ministerie onvoldoende expertise zou zijn. ${ }^{108}$

Uit het voorgaande moge blijken dat mijns inziens de door de minister naar voren gebrachte bezwaren tegen strafrechtelijke handhaving van de Mededingingswet niet doorslaggevend

door openbaarmaking van de transactic. Daar komt bij dat de transactie de facto ook een bestuurlijke sanctie is, die bovendien overeenkomst vertoont met de bestuurlijke boete. Zie daarover Schaffmeister (1974), pag. 332 e.v. die de transactie vergelijkt met het Duitse Ordnungswidrigkeitenrecht.

104 I. VerLoren van Themaat e.a. (1998) wijzen op de meer dan waarschijnlijke weerspiegeling van de politieke consensus op het punt van een strenger kartelbeleid (bij de totstanskoming van de Mededingingswet) in de handhaving. Niet is in te zien waarom dat bij strafrechtelijkehandhaving anders zou zijn geweest. Wel stelt Michiels (1999), pag. 69-71, terecht dat in het kader van terugdringing van 'het handhavingstekort' zich juist die beleidsterreinenkunnen lenen waarop het Openbaar Ministerie wel bevoegd is om te vervolgen, maar dit in de praktijk veelal achterwege laat. Of dit echter voor de Mededingingswet zonder meer opgeld doet, is niet na te gaan, omdat het Openbaar Ministerie nooit de gelegenheid heeft gehad om met een verbodwetgeving te werken. Michiels noemt overigens nog een tweede situatie waarin bestuurlijke handhaving een bijdrage kan leveren aan het verminderen van het handhavingstekort, te weten de situatic waarin een zodanigedoelmatigheidswinstkan worden geboekt, dat daardoor vaker en sneller kan worden opgetreden. Als voorbeeld noemt hij onder meer de Mededingingswet, waarbij hij wijst op de landelijke bevoegdheid van en op de aanwerige gespecialiseerde kennis bij de NMa.

105 Corstens (1995 I), pag. 9, merkt dienaangaande op dat "als men een norm in de tockomst een krachtige normatieve lading wil meegeven, strafrechtelijk reageren aangewezen is". Wladimiroff (1990 II), pag. 194, noemt dit de 'norminprentende functie van het strafrecht'.

106 Het betreft hier een proces dat zichzelf versterkt: door de toename van de aandacht (mede in de vorm van vervolging) voor fraude ontstaat een grotere verontrusting omtrent fraude-delicten, hetgeen dan vervolgens zijn weerslag op het aantal vervolgingen zou kunnen hebben.

107 In deze zin ook Slotboom (1996), pag. 294.

108 Refererend aan de deskundigheid van de ECD in mededingingszaken, komt Rogier (2000 II), pag. 105 tot de conclusie dat het deskundigheidsargument geen argument kon zijn om het strafrecht aan de kant te schuiven. 
zijn voorzover er al problemen liggen, kunnen deze zonder meer worden weggenomes. ${ }^{109}$ Het lijkt er dan ook op dat de minister naar de door hem gewenste eindconclusie toe redeneert: bestuursrechtelijke handhaving geniet de voorkeur, maar is gelet op het advies van de toetsingscommissie in feite niet mogelijk; aangewezen lijkt dan de keuze vocr strafrechtelijke handhaving, maar deze handhavingsmodaliteit wordt op haar beurt als weinig geschikt van de hand gewezen en dus volgt als eindresultaat de keuze voor besuursrechtelijke afdoening. Dat wil overigens nog niet zeggen dat de keuze van de mirister geen juiste was en dat hij dús had moeten kiezen voor strafrechtelijke handhaving. In tet kader van de decriminalisering -en het streven het strafrecht te reserveren voor overtredingen in de commune sfeer en voor overtredingen waarvoor vrijheidsbenemende santies geïndiceerd zijn- is er veel voor te zeggen om de handhaving over to hevelen nar het bestuursrecht. Voorwaarde is wel dat gegarandeerd is dat het bestuursrecht cen adequaat alternatief vormt voor het strafrecht. De doelmatigheid lijkt te zijn gewaarborgd. Deskundigheid is bij een gespecialiseerd bestuursorgaan volop aanwezig, afstemming me de overige uitvoeringshandelingen (te denken is bijvoorbeeld aan invulling van het karelverbod en aan behandeling van ontheffingsverzoeken), met het overige nationale eccnomische beleid én met het communautaire beleid kan, gelet op frequente onderlinge cortacten, soepel verlopen en de sanctiemarges zijn, zoals nog zal blijken, voldoende ruin. Meer problemen liggen op het vlak van de rechtmatigheid. Zoals in hoofdstuk 5 zal worden betoogd, mogen decriminalisering en verhoging van de doelmatigheid -waartegen op zichzelf geen bezwaren bestaan- niet leiden tot minder rechtswaarborgen voor de justitiabelen ${ }^{10}$, laat staan dat de vermindering van rechtswaarborgen de primaire inzet van de decriminalisering is. ${ }^{111}$ Hoewel volgens de memorie van toelichting is "gestreefd naar een evenwicht tussen een doelmatige handhaving van de mededingingswet en voldoende rechtswaarborgen ${ }^{\prime 11}$, ontstaat toch bij lezing van de parlementaire geschiedenis van de Mededingingswet de stellige indruk dat veel rechtswaarborgen die inherent aan het strafrecht zijn, als ballast worden ervaren, die dan ook overboord moet worden gegooid. ${ }^{113}$ Voor zover deze indruk klopt -en of dit zo is, zal in hoofdstuk 5 blijken-,

109 Vermeldenswaardis de opmerking van Mulder (1950), pag. 109-110 ten aanzien van de crisiswetgevingen: "Deze argumenten zijn daarom zo leerzaam, omdat zij illustreren, hoe snel bijzondere omstandigheden kunnen leiden tot het scheppen van een vorm van strafrechtspraak buiten de rechterlijke macht om". En dat terwijl volgens deze schrijver (en niet ten onrechte) een aanpassing van het strafrecht hetzelfde effect zou kunnen bewerkstelligen.

110 In dezelfde zin de Werkgroep "Handhaving door bestuurlijke boeten" (1995), pag. 6.

111 Bedacht moet worden dat het grootste bezwaar tegen de tuchtrechtelijke handhaving uit de crisisen bezettingstijd bestond in de verwaarlozing van de rechten van de justitiabele. Voornamelijk om deze reden werd in de na-oorlogse periode van deze handhavingsvorm afgestapt. Heden ten dage is de voedingsbodem voor bestuursrechtelijke handhaving vruchtbaarder dan toen. Inmiddels is het bewustzijn gerezen, mede dankzij de autonome uitleg van het EVRM, dat ook punitief optreden via het bestuursrecht gebonden is aan de meest fundamentele rechten van de mens. Over de invloed van het EVRM op het bestuursrecht wordt nader in hoofdstuk 5 ingegaan.

112 TK 1995-1996, 24 707, nr. 3, pag. 11.

113 Zie bijvoorbeeld Van Wijnbergen, TK 1996-1997, 24 707, nr. 9. Hij constateerdeeen 'fundamenteel probleem', namelijkdat prijsafsprakenongeoorloofd zijntenzij hettegendeelwordt aangetoond. "Dat gaat niet goed samen met de basis van het strafrecht van 'onschuldig, tot bewezen schuldig'," Dit standpunt miskent volledig dat het ook in het bestuursrecht onverminderd de d-g NMa zal moeten zijn die bewijst dat de ondernemingen -verwijtbaar-inbreuk hebben gemaakt op de verboden. In dezelfdezin Mok, TK 1996-1997, 24 707, nr. 9, die aldaarook kritisch-en volledig terecht-reageerde 
moet in ieder geval de overheveling als negatief worden beoordeeld. ${ }^{114}$ Want, zoals Wladimiroff en Van Russen Groen het terecht verwoorden: "De waarde van een sanctiesysteem wordt niet alleen afgemeten aan het punitieve gehalte daarvan, maar ook aan de kwaliteit van de geboden rechtsbescherming". 11

\subsubsection{De Nederlandse Mededingingsautoriteit ${ }^{116}$}

\section{Reeds in 1969 stelde Mok:}

"Het is een vaststaand feit dat anti-kartelbeleid bij het bedrijfsleven niet populair is. Nu moet men begrijpen dat speciaal de Minister van Economische Zaken op allerlei manieren met het bedrijfsleven te maken heeft. Als hij de medewerking van ondernemingen nodig heeft om nieuwe vestigingen in probleemgebieden te stichten, zal hij zich wellicht nog wel een keer bedenken deze zelfde ondernemingen te ergeren met kartelpolitieke maatregelen en dat kan men hem niet kwalijk nemen ook". ${ }^{117}$

Hierin zag Mok een reden om handhaving van de kartelregelgeving in handen te leggen van een afzonderlijk (bestuurs)orgaan. ${ }^{118}$ Dertig jaar later was het zover: mede uit het oogpunt van concentratie werd de Nederlandse Mededingingsautoriteit in het leven geroepen, die op grond van artikel $3 \mathrm{Mw}$ tot taak heeft "het verrichten van werkzaamheden ten behoeve van de uitvoering van deze wet". Het zij herhaald, de NMa als 'waakhond van de economische democratie ${ }^{1119}$ behandelt dientengevolge onder meer alle ontheffingsverzocken en concentratie-aanmeldingen, verricht onderzoek naar mogelijke inbreuken op de Mededingingswet en sanctioneert overtreders. Daarbij dient op de bijzondere positie van de directeur-generaal van de NMa te worden gewezen: hij staat aan het hoofd van de NMa en neemt (met uitsluiting van de exceptie van artikel $47 \mathrm{Mw}$ met betrekking tot concentraties) alle beschikkingen. Bovendien wijst hij bij besluit de ambtenaren aan die met toezicht en onderzoek zijn belast.

Met de instelling van de Nederlandse Mededingingsautoriteit is niet alleen het uitgangspunt van concentratie van uitvoeringsbevoegdheden verwezenlijkt, maar is tevens een belangrijke bijdrage geleverd aan de realisering van de uitgangspunten dat overwegin-

op het in de nota naar aanleiding van het verslag geformuleerde standpunt dat het nadelig is als ondanks een zorgvuldige voorbereiding van de zaak het toch niet tot een strafrechtelijke veroordeling komt. Als dit bij de centrale overheid als een nadeel beschouwt, dan valt toch wel zeer te vrezen voor de rechten van ondememingen in het kartelrecht.

114 Eveneens kritisch over de rechtsbescherming Mok, TK 1996-1997, 24 707, nr. 9.

115 Wladimiroff en Van Russen Groen (1999), pag. 100.

116 Deze benaming is geintroduceerd bij het amendement Voûte-Droste c.s., TK 1996-1997, 24 707, nr. 33. Aanvankelijk werd nog gesproken van de Dienst voor de mededinging; ook de benaming Nederlandse Kartelautoriteit is enige tijd gebruikt.

117 Mok (1969 II), pag. 185. In hoofdstuk 1 is geconcludeerd dat dit inderdaad een van de redenen van het milde Nederlandse kartelbeleid is geweest.

118 Dit werd nog door het volgende versterkt: "De constructie dat het kartelbeleid een deel is van het algemeen economisch beleid kan er in de praktijk toe leiden dat het kartelbeleid aan het algemeen economische beleid wordt opgeofferd". Mok (1969 II), pag. 186. Dat laat onverlet dat Mok bij de totstandkoming van de Mededingingswet (TK 1996-1997, 24 707, nr. 9) zich wel verzette tegen concentratie van bevoegdheden bij éen instantie, aangezien hij dit in strijd achtte met het beginsel van scheiding der machten.

119 Aldus typeerde Kist, de eerste d-g NMa, de rol van de NMa: zie Kik (1997), pag. 20. 
gen van mededingingspolitieke aard de boventoon moeten voeren (de NMa met haar op het mededingingsterrein gespecialiseerde ambtenaren houdt zich bij uitsluiting bezig met mededingingsaangelegenheden en zal bij de beoordeling van de haar voorliggende zaken dan ook aspecten van mededinging op de voorgrond plaatsen ${ }^{120}$ ) en dat beleid en uitvoering gescheiden dienen te zijn (waarbij de NMa de instantie is die het door de minister van Economische Zaken gemaakte algemene beleid ten uitvoer legt). Wel rijst hier de vraag welke de verhouding tussen de NMa en de minister van Economische Zaken is. Het antwoord op deze vraag hangt samen met de status van de NMa. De status van zelfstandig bestuursorgaan (zbo) zou impliceren dat de interventiemogelijkheden voor de minister gering zijn in dier voege dat hij in beginsel uitsluitend algemene richtlijnen zou kunnen uitvaardigen en niet in concrete gevallen zou kunnen ingrijpen. Interne verzelfstandiging daarentegen zou interventie in concrete gevallen mogelijk maken. ${ }^{121}$ Gekozen is voor de tweede optie: de NMa is een ambtelijke dienst, ressorterend onder de minister van Economische Zaken. En dus kan deze algemene aanwijzingen geven maar tevens in individuele gevallen sturen. ${ }^{122}$ Waarom werd deze keuze gemaakt? Als primaire reden noende de minister dat de beslissingen van de NMa een politiek gevoelig karakter hebben, met name omdat die beslissingen de belangen van een hele sector kunnen raken. Gelet op dit politieke karakter zou het parlement de minister in voorkomende gevallen ter verantwoording willen roepen, ook ten aanzien van individuele gevallen. ${ }^{123}$ Derhalve zou de minister -aldus de redenering- ook in afzonderlijke gevallen moeten kunnen ingrijpen. De mogelijkheid tot ingrijpen in het concrete geval leek de minister bovendien raadzaam om de uitvoering te kunnen sturen in de beginfase van de Mededingingswet. Indien een strenge uitvoering dreigde te verzanden (in 'goede' Wem-traditie), dan zou de minister de kar moeten kunnen trekken; keerzijde was dat overijverig optreden van de NMa zou moeten kunnen worden afgeremd. Na een periode van vijf jaar zou volgens de memorie van toelichting een heroverweging dienen plaats te vinden waarbij de NMa alsnog de status van zbo zou kunnen verkrijgen, een optie die door de minister voor waarschijnlijk werd gehouden. ${ }^{124}$

120 Dat wil echter nog niet zeggen dat de d-g NMa ook alle zaken zal onderzoeken. Van Marissing (2000), pag. 107-109 geeft aan dat de d-g NMa in dezen enkele criteria heeft ontwikkeld, te weten de noodzaak tot prioriteitenstelling, de prima facie aannemelijkheid van een overtreding van de materiēle verboden, de te verwachten baten van het onderzoek en de mogelijkheden die in het betreffende geval een civiele procedure biedt.

121 Voor een nadere uiteenzetting over verzelfstandiging wordt verwezen naar Verantwoord verzelfstandigen en -met betrekking tot toezicht door zelfstandige bestuursorganen- naar het omvangrijke werk van Van Nus (1995).

122 Uit artikel $4 \mathrm{Mw}$ blijkt dat de individuele aanwijzingen schriftelijk moeten zijn. Mok (1998), pag. 267 stelt overigens dat de positie van de $\mathrm{NMa}$ de facto weinig verschilt van de positie van een zbo. Kritisch over deze visie Van der Meulen (2000), pag. 443 (noot 29).

123 Ten aanzien van de decentrale toepassing van het communautaire recht zullen volgens de minister van Economische Zaken hij en zijn opvolgers op het departement in ieder geval ter verantwoording kunnen worden geroepen als de communautaire instellingen van mening zijn dat de toepassing niet correct is geschied.

124 Zie hierover ook Ottervanger, Steenbergen en Van der Voorde (1998), pag. 100. 
Op deze keuze is veel kritiek geuit, zowel zijdens het parlement als zijdens commentatoren van het voorstel. ${ }^{125} \mathrm{Om}$ hierna nog te noemen redenen is naar mijn mening voor een -tot de beginfase van de Mededingingswet beperkte- interventiemogelijkheid van de minister voor het concrete geval veel te zeggen. De opmerkingen van de minister omtrent het politicke karakter van de beslissingen van de NMa vermogen mij echter niet te overtuigen. Correct is dat veelal grote belangen gemoeid zijn met de beslissingen van de $\mathrm{NMa}$ en dat de betrokkenen en hun eventuele belangengroeperingen c.q. politieke vertegenwoordigers hun invloed willen doen gelden. Nog los van de vraag of het reeds om deze reden om politiek gevoelige beslissingen gaat, is de omstandigheid dat grote belangen worden geraakt een reden om de NMa wél vergaand te verzelfstandigen. ${ }^{126}$ Dit houdt verband met één van de uitgangspunten van de uitvoeringsstructuur zoals die door de minister zelf zijn geformuleerd, te weten het primaat van de mededingingspolitieke overwegingen. De mogelijke -politieke- invloed die met de grote belangen gepaard gaat, zou kunnen leiden tot beslissingen die niet primair op gronden van mededinging zijn gebaseerd. De kans hierop neemt toe naarmate het uitvoerend orgaan meer afhankelijk is van de politiek, hier: de minister van Economische Zaken, en via deze onder meer het parlement. Een onafhankelijk orgaan daarentegen biedt een grotere waarborg tegen oneigenlijke, met mededingingsoverwegingen strijdige invloeden op de beslissing van het orgaan. Ruimere interventiemogelijkheden voor de minister vergroten in feite het politieke karakter van beslissingen en druisen in tegen de uitgangspunten zoals door de minister geformuleerd. Daar komt nog bij dat -zoals de praktijk van de Wem heeft aangetoond- niet iedere minister van Economische Zaken in gelijke mate van de voordelen van mededinging overtuigd is als minister Wijers dat was. In dat geval zouden de aanwijzingen van de betreffende bewindspersoon (in strijd met de doelstellingen van de Mededingingswet) de mededinging eerder beperken dan bevorderen. Dat zoals gezegd de keuze voor een tijdelijke grotere afhankelijkheid van de NMa mijns inziens toch geen slechte was, hing samen met de omslag die de Mededingingswet in verhouding tot haar voorgangsters betekende. Op materieel gebied werd het roer omgegooid; op het gebied van de uitvoering moest het roer eveneens om. Vooraf was logischerwijze niet duidelijk hoe de NMa met haar bevoegdheden zou omgaan en of zij haar taak zou uitoefenen conform de wensen van de minister. In die situatie was het verdedigbaar dat de minister een vinger aan de pols hield teneinde zoveel mogelijk te voorkomen dat de Mededingingswet een vergelijkbaar rustig bestaan tegemoet zou gaan als de Wem. De 'eerste jaren NMa' hebben echter aangetoond dat deze dienst een voortvarende aanpak heeft, dat hij 'op eigen benen'

125 Biesheuvel acht onafhankelijkheid van de NMa van groot belang. Volgens hem zou veel zijn gewonnen indien algemene en concrete aanwijzingenvan de minister openbaarzouden worden gemaakt en deel uit zouden maken van het dossier. TK 1996-1997, 24707 , nr. 9. Positiefover de keuze is Mok (1997), pag. 228, met name vanwege de grotere mogelijkheid van democratische controle.

126 In deze zin ook De Jong. TK 1996-1997, 24 707, nr. 9. Hij zag in tegenstelling tot de minister van Economische Zaken in de omstandigheid dat de Mededingingswet noopt tot politick gevoelige beslissingen (beboeting etc.) een reden om geen interventiemogelijkheid aan de minister te geven en om de beslissingsbevoegdheid bij een onafhankelijke instantie te leggen. In vergelijkbare zin Van Wijnbergen, TK 1996-1997, 24 707, nr. 9. Koedijk, TK 1996-1997, 24 707, nr, 9, vreesde een schijn van beìnvlocding door plaatsing van de $\mathrm{NMa}$ binnen het ministerie. 
kan staan en dat hij hard op weg is op de kwalificatie 'autoriteit' te verdienen. ${ }^{127}$ Het is daarom terecht dat minister van Economische Zaken Jorritsma een voorstel van wet heeft ingediend dat ertoe strekt dat de $\mathrm{d}-\mathrm{g} \mathrm{NMa}$ de status van zbo dient te krijgen. ${ }^{12 \mathrm{~s}}$

\subsection{Toezicht en onderzoek $k^{129}$}

Het is reeds hiervoor verschillende malen gesteld: handhaving vergt adequate middelen. Bij de bespreking van het Nederlandse kartelrecht tot 1998 bleek dat de Nederlandse overheid voor de toepassing van de Wem over drie categorieenn bevoegdheden beschikte. De cerste betrof de bevoegdheden van de artikelen 16-18 Wem. Zij moesten de minister van Economische Zaken (en voorzover het artikel 16 betrof: de Commissie economische mededinging) in staat stellen om te beoordelen of er al dan niet sprake was van een met het algemeen belang strijdige gedraging en -in het verlengde daarvan- of hij handelend moest optreden, hetzij op informele wijze (via onderhandeling komen tot een aanpassing van de gedraging) hetzij op formele wijze (door onverbindend verklaring of aanwijzingen aan een economische machtspositie). De bevoegdheden van de tweede categorie waren de opsporingsbevoegdheden zoals in de WED neergelegd. Zij waren gericht op de opsporing van overtredingen van (generieke) onverbindend verklaringen en aanwijzingen aan economische machtsposities. Ten onrechte werd door de overheid ervan uitgegaan dat deze opsporingsbevoegdheden slechts konden worden toegepast in geval van het bestaan van een redelijk vermoeden van schuld zoals bedoeld in artikel 27 WvSv. Deze misvatting -of zo men wil: ten onrechte beperking van de reikwijdte van het opsporingsbegrip van de WED- leidde in 1994 tot de introductie van de derde categorie bevoegdheden: de controlebevoegdheden van de artikelen 41 en 41 a Wem. Deze waren evenals de opsporingsbevoegdheden van de WED gericht op de handhaving van de getroffen (generieke) maatregelen. Hun vermeende meerwaarde ten opzichte van de WED-bevoegdheden lag in de omstandigheid dat voor hun toepassing geen verdenking vereist was; zoals gezegd was deze meerwaarde er niet aangezien de WED de verdenkingseis evenmin stelde.

De Mededingingswet kent een vergelijkbare regeling ten aanzien van de bevoegdheden, met dien verstande dat zij allemaal binnen het bestuursrechtelijke traject liggen. De Mededingingswet maakt een onderscheid tussen toezicht en onderzoek, een onderscheid dat doet denken aan het in het strafrecht gemaakte (en omstreden ${ }^{130}$ ) verschil tussen toezicht

127 Zie voor een analyse van het beleid van de $\mathrm{NMa}$ in de eerste tweeёenhalfjaar van haar bestaan Glazener en Jansen (2000), pag. 20 e.v., Glazener, Jansen en Evans (2000), pag. 362 e.v. en Glazener, Bijleveld en Evans (2001), pag. 62 e.v..

128 TK 2000-2001, 27639 (Wijziging van de Mededingingswet in verband met het omvormen van de Nederlandse mededingingsautoriteit tot zelfstandig bestuursorgaan). In de memorie van toelichting wordt het goede functioneren van de d-g NMa onderstreept en wordt geconstateerd dat hij ook nu reeds zijn taken vervult 'alsof hij een zbo is'. Vanuit die optiek zijn er dus geen obstakels voor de omvorming. De meest voorname reden voor de omvorming ligt blijkens de memorie van toelichting in het 'voorkomen van ongewenste politieke beĭnvloeding'.

129 Zie over toezicht en onderzoek meer algemeen Jansen (1999).

130 Vergelijk onder meer Fransen (1993), pag, 112. 
(of controle) en opsporing. ${ }^{131}$ Onderzoek wordt in artikel 1 sub $\mathrm{k} \mathrm{Mw}$ omschreven als: handelingen die worden verricht met het oog op de vaststelling dat al dan niet een overtreding is begaan. ${ }^{132}$ In de memorie van toelichting voegde de minister van Economische Zaken hier nog aan toe dat het onderzoek niet beperkt was tot de gevallen waarin er reeds een vermoeden van overtreding bestond. Hieruit kan geconcludeerd worden dat de fase van het onderzoek in de Mededingingswet correspondeert met de opsporingsfase van de WED. ${ }^{133}$ Een probleem rijst ten aanzien van de afbakening tussen onderzoek en toezicht. Immers, over het algemeen wordt onder toezicht verstaan het uitoefenen van controle, zonder dat er reeds sprake is van een concreet vermoeden van overtreding. In die zin werd ook toezicht in de Wem gezien (men denke aan de artikelen 16-18 Wem én 41 en 41 a Wem) en ook de Algemene wet bestuursrecht getuigt blijkens de toelichting op hoofdstuk 5 van deze opvatting. Als dit echter zo is, dan overlappen toezicht en onderzoek elkaar gedeeltelijk: beide omvatten dan immers de handelingen die worden verricht met het oog op de vaststelling dat al dan niet een overtreding is begaan, terwijl er nog geen sprake van een verdenking is. De memorie van toelichting bij de Mededingingswet biedt een aanknopingspunt dat deze overlap inderdaad aanwezig is: "Onder toezicht moet worden verstaan controle op de naleving van de wet en de daarop berustende bepalingen zonder dat sprake hoeft te zijn van concrete 'naspeuringen' of al dan niet een overtreding is begaan". ${ }^{134}$ Hieruit volgt dat toezicht wel gericht kan zijn op vaststelling of al dan niet een inbreuk is gemaakt. Van een duidelijk onderscheid tussen onderzoek en toezicht zou dan geen sprake zijn, hetgeen in zoverre een probleem oplevert dat -zoals hierna zal blijken- voor de onderzoeksfase de ambtenaren van de NMa enkele verdergaande bevoegdheden ter beschikking staan: door het ontbreken van een onderscheid als hiervoor bedoeld, kunnen onduidelijkheden met betrekking tot de (rechtmatigheid van de) uitoefening van die extra bevoegdheden ontstaan. Het lijkt er echter -ondanks de hierboven geciteerde omschrijving van het begrip 'toezicht'- op dat de minister van Economische Zaken wel een strikte scheiding tussen onderzoek en toezicht voor ogen heeft gehad. In de nota naar aanleiding van het verslag stelde de minister namelijk dat van toezicht sprake is "indien de controle plaatsvindt zonder dat sprake is van concrete naspeuringen of wellicht een overtreding is begaan", waarna hij vervolgde: "Indien er aanwijzingen zijn dat er sprake is van een overtreding, bijvoorbeeld naar aanleiding van een klacht, zal een onderzoek worden ingesteld". ${ }^{135}$ Hieruit kan worden afgeleid dat onderzoek en toezicht elkaar uitsluiten: handelingen waarmee wordt gepoogd te achterhalen of er al dan niet een inbreuk is gepleegd, behoren tot het onderzoek; alle overige controle-activiteiten in het kader van de Mededingingswet worden tot het toezicht gerekend. In feite

131 Jansen (1997), pag. 44, spreekt van een 'kloon' van het strafrechtelijke onderscheid tussen toezicht en opsporing.

132 Op grond van artikel 1 sub $\mathrm{j} \mathrm{Mw}$ wordt onder een overtreding verstaan: een handeling die in strijd is met het bepaalde bij of krachtens deze wet. Kritiek op de term 'overtreding' uit Jansen (1996), pag. 1251. Hij wijst op de strafrechtelijkelading van dit begrip. Deze kritiek deel ik niet. Weliswaar is bimnen het strafrecht het onderscheid tussen misdrijf en overtreding van grote relevantic, maar buiten het strafrecht is de term 'overtreding' toch ingeburgerd als synoniem voor inbreuk op de wet en de daarin vervatte regels.

133 In deze zin ook Jansen (1997), pag. 45. Otto, De Meijer en De Doelder (1999 II), pag 14, achten het boeteonderzoek nog het best vergelijkbaar met het verkennend onderzoek van artikel $126 \mathrm{gg} \mathrm{WvSv}$.

134 MvT TK 1995-1996, 24 707, nr. 3 (cursivering, HQ).

135 TK 1996-1997, 24 707, nr. 6, pag. 85 (cursivering, HQ). 
betekent dit dat onderzoek de bestuursrechtelijke variant van de WED-opsporing is, terwijl toezicht een vergelijkbaar doel dient als de artikelen $16-18 \mathrm{Wem}$.

In theorie bestaat er dus een principieel verschil tussen toezicht en onderzoek. ${ }^{136}$ In de praktijk zal de grens echter zeer moeilijk kunnen worden getrokken. De minister erkende dit ook door te stellen dat "In de praktijk (...) toezicht en onderzoek vaak vloeiend in elkaar (zullen) overlopen". ${ }^{137}$ De grens vervaagt nog meer doordat toezicht en onderzoek in handen van dezelfde personen ligt. ${ }^{138}$ Als dan toch uitdrukkelijk het onderscheid tussen toezicht en onderzoek in de Mededingingswet wordt geintroduceerd, dan is de vraag wat de reden en de meerwaarde van het bedoelde onderscheid zijn. De reden moet naar mijn mening gezocht worden in de overtuiging van de minister dat niet alle handelingen ter handhaving van de Mededingingswet onder de noemer 'toezicht', zoals reeds geregeld in de $\mathrm{Awb}$, konden worden gebracht. Voor die handelingen die niet tot toezichthandelingen konden worden gerekend, moest derhalve in de optiek van de minister een nieuwe categorie worden gecreelerd. Het antwoord op de vraag wat de meerwaarde van het onderscheid tussen toezicht en onderzoek is, moet mijns inziens luiden dat deze er nauwelijks is. Het onderscheid als zodanig beinvloedt namelijk de rechtspositie van de justitiabelen niet ${ }^{139}$ en de bevoegdheden zijn in beide fasen gelijk, op twee uitzonderingen na: de verzegelingsbevoegdheid en de bevoegdheid om de inzage van bescheiden af te dwingen met behulp van de sterke arm zijn tot de onderzoeksfase beperkt. Deze uitzonderingen impliceren weliswaar een niet onbelangrijk verschil met de toezichtsfase, maar de betekenis hiervan mag toch niet overschat worden. Immers verwacht mag worden dat het overwegende deel van de handhavingsactiviteiten van de $\mathrm{NMa}$ zullen worden verricht met het oog op de vaststelling dat al dan niet een overtreding is begaan. Met andere woorden: voorzover ondernemingen zullen worden geconfronteerd met de bevoegdheden van de NMa ter handhaving, zal deze confrontatie meestal in het kader van het onderzoek plaatsvinden en zullen dus de twee extra bevoegdheden van toepassing zijn.

Uit het voorgaande kan geconcludeerd worden dat het onderscheid tussen toezicht en onderzoek in de praktijk nauwelijks gemaakt kan worden en dat het evenmin veel meerwaarde heeft. Integendeel, het onderscheid kan in de praktijk zelfs aanleiding voor verschillen van mening tussen NMa en ondernemingen geven, met name over de rechtmatigheid van de toepassing van de in de artikelen 54 en $55 \mathrm{Mw}$ genoemde bevoegdheden. ${ }^{140}$ Omdat het onderscheid eerder verwarring schept dan dat het enig reële waarde

136 Terecht wijst Jansen (1999), pag. 174 e.v., op het gevaar van schending van het verbod van détournement de pouvoir, zoals (ten dele) gecodificeerd in artikel 3:3 Awb.

137 TK 1996-1997, 24 707, nr. 6, pag. 85. De stelling van Brouwer en Gerbrandy (1996), pag. 96, dat onderzoek een fase is die op de toezichtsfase volgt, is echter slechts in zoverre juist dat onderzoek een vervolg kan vormen op het toezicht. Noodzakelijk is dit geenszins en bovendien kan onderzoek ook plaatsvinden zonder voorafgaand toezicht.

138 Vergelijk artikel $52 \mathrm{Mw}$ : Met het onderzoekzijn belast de krachtens artikel 50, eerstelid, aangewezen ambtenaren. Artikel 50 lid $1 \mathrm{Mw}$ luidt: Met het toezicht op de naleving van het bepaalde bij of krachtens deze wet zijn belast de bij besluit van de directeur-generaal aangewezen ambtenaren van de mededingingsautoriteit.

139 Met dien verstande dat de justitiabele die 'verdacht' wordt van een overtreding enkele extra rechten toekomen. Dit houdt echter geen verband met het onderscheid tussen toezicht en onderzoek, maar met de vraag of er, in de onderzoeksfase, een vermoeden bestaat dat een overtreding is begaan.

140 Ondernemingen zullen immers aanvoeren dat er 'nog' slechts sprake is van toezicht, terwijl de NMa van mening is dat reeds de onderzoeksfase is gestart. Zie ook Slotboom (1997 I), pag. 324. Hieraan doet niet af dat de NMa het in dat geval veelal bij het rechte eind zal hebben, gelet op het genoemde 


\section{Hoofdstuk 3}

heeft -een verwarring die wordt vergroot doordat in de Mededingingswet een ander toe. zichtbegrip wordt gebezigd (zonder dat dit overigens in de wet gedefinieerd wordt) dan in de Awb het geval is ${ }^{141}$, had de wetgever mijns inziens beter kunnen afzien van de introductie ervan. Voorzover het toezicht van hoofdstuk 5 van de Awb, conform het klaarblijkelijke standpunt van de minister, niet toepasselijk is op handelingen die verricht worden naar aanleiding van een vermoeden van overtreding -en de memorie van toelichting op de Awb lijkt dit standpunt te steunen ${ }^{142}$ - had er beter voor gekozen kunnen worden om de gehele handhaving onder het begrip 'onderzoek' te brengen. In dat geval zou voornamelijk het evenredigheidsbeginsel ${ }^{143}$ (of zo men wil: de beginselen van proportionaliteit en subsidiariteit) beperkingen stellen aan de toepassing van de bevoegdheden, waaronder die tot verzegeling en inschakeling van de sterke arm. Een andere mogelijkheid zou zijn geweest om weliswaar het onderscheid tussen toezicht en onderzoek te handhaven, maar om daarbij het omslagpunt -overeenkomstig het voorstel van de Raad van State ${ }^{144}$. bij de 'verdenking' te leggen. In dat geval zou niet alleen 'toezicht' in de Mededingingswet dezelfde betekenis kunnen krijgen als 'toezicht' in de Awb, maar zou bovendien het verschil tussen toezicht en onderzoek wel waarde verkrijgen, te weten voor de rechtsbescherming. Het begin van de onderzoeksfase zou dan tevens het tijdstip zijn vanaf welk bepaalde rechtswaarborgen, waaronder met name het zwijgrecht, gelding zouden krijgen.

Het bovenstaande moge aantonen dat het huidige onderscheid tussen toezicht en onderzoek een weinig duidelijke situatie schept. Meer duidelijkheid is er ten aanzien van de (toezichtsen handhavings)bevoegdheden. $\mathrm{Zij}$ staan limitatief in de Algemene wet bestuursrecht en de Mededingingswet opgesomd. ${ }^{145}$ Volgens deze wetten staan de NMa in het kader van de handhaving van de Mededingingswet -binnen de grenzen van het evenredigheidsbeginsel van artikel 5:13 Awb- de volgende bevoegdheden ter beschikking:

- het betreden van plaatsen, met uitzondering van een woning zonder toestemming van de bewoner (art. 5:15 lid I Awb);

- het verschaffen van toegang tot die plaatsen met behulp van de sterke arm (artikel 5:15 lid 2 Awb);

- het vorderen van inlichtingen (art. 5:16 Awb);

- het vorderen van inzage van zakelijke gegevens en bescheiden, met inbegrip van de bevoegdheid tot het maken van kopiečn van de gegevens en bescheiden (art. 5:17 Awb), en

feit dat de handelingen meestal gericht zullen zijn op de controle op de naleving van de verboden.

141 Hetgeen temeer klemt daar voor de toezichthoudende bevoegdheden in de Mededingingswet wordt verwezen naar het vijfde hoofdstuk van de Awb. Bovendien wordt de eenheid in het bestuursrecht die met de A wb is en wordt nagestreefd, door regelingenzoals die in de Mededingingswetniet bevorderd.

142 In andere zin Jansen (1996), pag. 1254.

143 Artikel 5:13 Awb: Een toezichthouder maakt van zijn bevoegdheden slechts gebruik voor zover dat redelijkerwijs voor de vervulling van zijn taak nodig is. Dit artikelkan als een concretisering worden gezien van artikel $3: 4$ lid 2 Awb.

144 TK 1995-1996, 24 707, A, pag. 19.

145 Deop grond van artikel $50 \mathrm{Mw}$ aangewezentoezichthouders beschikkendoor de aanwijzing 'automatisch'over de in afdeling 5.2 Awb neergelegdebevoegdheden. Kritisch over dit systeem van bevoegdheidstoedeling is Jansen (1995 D), pag. 463. 
het meenemen van de gegevens en bescheiden teneinde deze te kopiëren, voorzover dit niet ter plaatse kan geschieden (art. 5:17 lid 3 Awb). ${ }^{146}$

\section{Voor de onderzoeksfase gelden daarnaast:}

- de bevoegdheid om voor zover noodzakelijk bedrijfsruimten en voorwerpen te verzegelen gedurende de tijd gelegen tussen 18.00 en 8.00 (art. $54 \mathrm{Mw}$ ), en

- de bevocgdheid om inzage van gegevens en bescheiden af te dwingen met behulp van de sterke arm (art. $55 \mathrm{Mw}$ ).

Van belang is bovendien dat voor de betrokkenen een medewerkingsplicht geldt op grond van artikel 5:20 Awb:

Een ieder is verplicht aan een toezichthouder binnen de door hem gestelde redelijke termijn alle medewerking te verlenen die deze redelijkerwijs kan vorderen bij de uitoefening van zjjn bevoegdheden. ${ }^{14}$

Beziet men deze bevoegdheden dan blijkt dat zij in grote lijnen overeenstemmen met de bevoegdheden van de Europese Commissie, zoals neergelegd in verordening 17, in samenhang met de Wet uitvoering EG-mededingingsverordeningen, én met de bevoegdheden zoals die onder het regime van de Wem en de WED golden. ${ }^{148}$ De centrale bevoegdheid is die tot inzage van zakelijke gegevens en bescheiden (alsmede het maken van afschriften daarvan $)^{149}$ : deze kunnen de NMa de informatie bieden die zij nodig heeft om te beslissen of er sprake is van een kartel of machtspositie en of door deze al dan niet een overtreding is begaan. De toevoeging dat het zakelijke gegevens en bescheiden dient te betreffen, vloeit reeds voort uit het evenredigheidsbeginsel en onderstreept dat slechts inzage van die gegevens en bescheiden mag worden verlangd die redelijkerwijs voor voornoemde beslissing relevant zijn. Binnen de grenzen van het evenredigheidsbegin-

146 In de memorie van toelichting wordt onder impliciete verwijzing naar het evenredigheidsbeginsel gesteld dat bij uitsluiting deze bevoegdheden voor het kartelrecht van belang zijn. In theorie zijn tevens de artikelen 5:18 Awb (monsterneming) en 5:19 Awb (onderzoeken vervoermiddelen, door Jansen (1995 II), pag. 629 aangeduid als doorzoekingsbevoegdheid) van toepassing. Gelet op de aard van deze bevoegdhedenzal hun belang inderdaadniet meer dan theoretischzijn. Vergelijkook artikel 18 van de Wet van 6 november 1997 tot aanpassing van bijzondere wetten aan de derde tranche van de Algemene wet bestuursrecht, Stb. 1997, 510 (Aanpassingswet derde tranche Awb I). Dit artikel voorzag onder meer in een wijziging van artikel 41 Wem: de toezichthouderzou over de in hoofdstuk 5 Awb genoemde bevoegdheden beschikken met uitzondering van de bevoegdheden van 5:18 en 5:19 Awb. De Aanpassingswet derde tranche Awb I kwam echter voor de Wem als mosterd na de maaltijd omdat inmiddels de Mededingingswet de Wem had vervangen.

147 Zoals nog in hoofdstuk 5 zal worden besproken, geldt deze medewerkingsplicht niet voor geheimhouders en -voor zover het een spreekplicht betreft- evenmin voor de onderneming of ondernemersvereniging tegen welke een redelijk vermoeden bestaat dat zij een overtreding hebben begaan. Op de hoofdregel dat op overtreding van de medewerkingsplicht van artikel 5:20 Awb artikel $184 \mathrm{WvSr}$ van toepassing is, is hier een uitzondering gemaakt: de $\mathrm{d}-\mathrm{g}$ NMa kan op grond van artikel $69 \mathrm{Mw}$ wegens overtreding van de medewerkingsplicht een bestuurlijke boete opleggen van ten hoogste $f$ 10.000 ; artikel $184 \mathrm{WvSr}$ is buiten-toepassing verklaard.

148 Zie voor een algemene vergelijking van de (toezichthoudende) bevoegdheden van de Awb met de strafrechtelijke opsporingsbevoegdheden Rogier (1995), pag. 41 e.v..

149 De aan de bevoegdheid tot het maken van kopieën gekoppelde bevoegdheid tot het meenemen van de betreffende gegevens en bescheiden is volgens Jansen (1999), pag. 30, te beschouwen als 'een bestuursrechtelijke (quasi-) inbeslagnemingsbevoegdheid'. 
sel is de inzagebevoegdheid een zeer ruime: opgevraagd mogen onder meer worden officiële (financiële) bedrijfsgegevens, contracten, (informele) notities, vergaderverslagen en computerbestanden. ${ }^{150}$ Uitgezonderd de vordering tot het verschaffen van inlichtingen, die ten dele een zelfstandige betekenis heeft, zijn alle overige bevoegdheden aan de inzagebevoegdheid ondergeschikt. De bevoegdheden tot betreding, tot verzegeling alsmede tot het inroepen van de hulp van de politie staan alle in het teken van de effectuering van het inzagerecht. ${ }^{151}$ De verzegelingsbevoegdheid ziet op de situatie waarin een onderzoek ter plaatse niet in één dag tijdens kantooruren kan worden afgerond en dus de daaropvolgende dag moet worden voortgezet. Teneinde te voorkomen dat relevant materiaal in de nachtelijke uren 'verdwijnt', kunnen plaatsen en voorwerpen worden verzegeld. Het mes snijdt hier aan twee kanten: de kans op belemmering van het onderzoek door de verdwijning van materiaal neemt af -waarbij bedacht moet worden dat het verbreken van zegels op grond van artikel $199 \mathrm{WvSr}$ een strafbaar feit oplevert ${ }^{152}$-, terwijl tevens ten voordele van de ondernemingen (maar zeker ook van de ambtenaren van de NMa) wordt voorkomen dat het onderzoek buiten normale kantooruren plaatsvindt. Gelet op de belasting van de verzegeling voor (de bedrijfsvoering van) ondernemingen, is de bevoegdheid hiertoe beperkt tot de tijdsspanne van 18.00 tot 8.00. Daarna zal de NMa haar onderzoek met de nodige voortvarendheid moeten voortzetten en zal de onderneming, voor zover het onderzoek dit toelaat, in staat moeten worden gesteld om haar dagelijkse bedrijishandelinges te serrichten.

Zoals gezegd staat ook de bevoegdheid tot het betreden van plaatsen in functie van het inzagerecht. Ter plaatse kan door de ambtenaren van de NMa beter dan op afstand beoordeeld worden welke gegevens en bescheiden eventueel relevantie voor het onderzoek hebben. Evenals het geval is bij de begrippen 'gegevens en bescheiden', is de inhoud van de term 'plaats' ruim: betreden mag worden iedere plaats -waaronder ook voertuigen $^{153}$ - voorzover zich daar naar redelijkerwijze mag worden aangenomen materiaal bevindt dat in het kader van het kartelonderzoek relevant kan zijn. Uitzondering vormen echter woningen: deze mogen -behoudens uitdrukkelijke toestemming van de bewoner ${ }^{154}$. in het geheel niet betreden worden. Ook hier is dus convergentie met het communautaire

150 Vergelijk ook Jansen (1999), pag. 20. Over het verschil tussen het recht op inzage en dat tot het inwinnen van inlichtingen stelt hij: "Bij het woord 'gegevens' is niet gedacht aan alle denkbare gegevens, maar uitsluitend aan documenten en gegevensdie in een administratie zijn geordend. (...) Voor het vorderen van losse gegevens is de bevoegdheid om inlichtingen te vorderen geschreven. Het begrip 'inlichtingen' veronderstelt een gerichte vraag, het begrip 'gegevens' is ruimer".

151 De accessoire bevoegdheid tot het inschakelen van de sterke arm maakt de inzagebevoegdheid in het kader van het onderzoek tot een dwangmiddel, aangezien ook buiten de medewerking van de betrokkenen inzage bewerkstelligd kan worden. Aldus ook Jansen (1999), pag. 102.

152 Artikel 199 lid 1 WvSr luidt: Hij die opzettelijk zegels waarmede voorwerpen door of vanwege het bevoegd openbaar gezag verzegeld zijn, verbreekt, opheft of beschadigt, of de door zodanig zegel bewerkte afsluiting op andere wijze verijdelt, wordt gestraft met gevangenisstraf van ten hoogste twee jaren of geldboete van de vierde categorie.

153 TK 1996-1997, 24 707, nx. 6, pag. 99. De reikwijdte van het onderhavige begrip correspondeert dan ook met de in artikel 14 lid 1 sub d Vo 17 gebezigde termen 'lokaliteiten, terreinen en vervoermiddelen'?

154 In dat geval zal onverminderd aan de Algemene wet op het binnentreden voldaan moeten worden. Het begrip 'woning' in de zin van artikel 5:15 Awb heeft overigens een beperktere reikwijdte dan ditzelfde begrip in de zin van artikel 8 EVRM. Dit volgt uit EHRM 16 december 1992 (Niemietz). Hierop zal uitgebreid worden ingegaan in hoofdstuk 5 . 
recit bereikt. Het tijdstip van betreding moet liggen tussen 8.00 en 18.00. Dit volgt niet alleen uit het beginsel van evenredigheid en uit de regels omtrent verzegeling, maar borendien uit de medewerkingsverplichting van de onderneming: op de voorgrond staat de nedewerking van de onderneming en deze is niet mogelijk indien buiten kantooruren wordt binnengetreden. Eenmaal binnengetreden, staat het de ambtenaren van de $\mathrm{NMa}$ vri -ook hier: binnen de grenzen van de evenredigheid- om overlegging van materiaal uiteen bepaalde kast of ruimte te verlangen. Wordt hen de inzage geweigerd, dan levert ditniet alleen een schending van de medewerkingsplicht op die kan leiden tot een bestuurlijk boete, maar dan -en alleen dan- kan bovendien op grond van artikel $55 \mathrm{Mw}$ inzage worden verkregen met behulp van de sterke arm. Toegang tot kasten en dergelijke kan in lat geval worden geforceerd door de politie, waarna de inhoud daarvan kan worden gecontroleerd. Dit betekent niet dat de betredingsbevoegdheid, eventueel in combinatie me inschakeling van de sterke arm, machtigt tot doorzoeking van de betreffende plaatsen. Deambtenaren van de NMa mogen de bedrijfsruimten niet stelselmatig en gericht doorzoeket, maar zullen zich dienen te beperken tot het aanwijzen van meubilair waarin zij relevant materiaal vermoeden en waarvan zij de inhoud willen onderzoeken. Het is dan hetzij aan de onderneming om vrijwillig, hetzij aan de politie -bij gebleken niet-coöperatie var de onderneming- om met gebruikmaking van geweld de inhoud aan de ambtenaren vorr te leggen. Van een stelselmatig en gericht zoeken, is dan ook geen sprake. In zoverre wikt de Mededingingswet af van het EG-recht ${ }^{155}$, en zeker van de regeling zoals die onder het strafrechtelijk regime van de Wem en de WED gold. Voor de praktijk is dit verschil echter in zoverre niet van betekenis dat de huiszoeking (thans: doorzoeking) in het kader van het gerechtelijk vooronderzoek, geen bevoegdheid was die in de handhaving van de Wem een rol speelde. ${ }^{156}$ Toch verbaast het ontbreken van een doorzoekingsbevoegdheid enigszins, omdat zij uitdrukkelijk wel is opgenomen in de Wet uitvoering EG-mededingingsverordeningen. Daar werd het ontbreken van de bedoelde bevoegdheid wel als een gemis beschouwd. Wellicht houdt de keuze van de wetgever in de Mededingingswet hiermee verband dat hij het strafrecht geheel buiten de deur wilde houden en hij een doorzoekingsbevoegdheid in handen van een bestuursorgaan als een te grote inbreuk op de rechten van de ondernemingen beschouwde.

Het voorgaande overziende, kan gesteld worden dat de overheveling van strafrechtelijke naar bestuursrechtelijke handhaving niet heeft geleid tot een afname van de bevoegdheden voor het handhavend orgaan. Dit was ook niet te verwachten op grond van het feit dat de belangrijkste reden voor overheveling was gelegen in een verhoging van de effectiviteit; het toekennen van minder (vergaande) bevoegdheden zou in dat licht contra-productief werken. De aard en de reikwijdte van de (toezichts- en onderzoeks)bevoegdheden van de NMa rechtvaardigen de conclusie dat zij voldoende mogelijkheden heeft voor een

155 Zoals in het vorige hoofdstuk besproken, heeft de Europese Commissie zelf niet de (formele) bevoegdheid om plaatsen te doorzoeken. Deze bevoegdheid kan wel de nationale autoriteiten toekomen, hetgeen mede van de nationale uitvoeringsregeling afhangt. Voor Nederland geldt sinds de inwerkingtreding van de Wet uitvoering EG-mededingingsverordeningen, dat is voorzien zowel in de mogelijkheid van het verschaffen van inzage met behulp van de sterke arm als in een doorzoekingsbevoegdheid voor plaatsen waar bedrijfsgegevens normaliter niet worden opgeborgen. Voor een uitgebreide bespreking verwijs ik naar hoofdstuk 2.

156 Zie voor een korte bespreking van de huidige doorzoekingsregeling hoofdstuk 2 . 
effectieve handhaving, temeer omdat zij ook kan optreden zonder de aanwezigheid van een redelijk vermoeden van overtreding. ${ }^{157}$

\subsection{Het verloop van de boeteprocedure}

Indien er naar aanleiding van het vooronderzoek een redelijk vermoeden is gerezen dat een onderneming het verbod van artikel 6 of van artikel $24 \mathrm{Mw}$ heeft overtreden én de directeur-generaal van mening is dat een boete geindiceerd is, dan moet er op grond van artikel $59 \mathrm{Mw}$ een zogenoemd rapport worden opgemaakt. ${ }^{158}$ Het rapport heeft dezelfde functie als de communautaire mededeling van de punten van bezwaar ${ }^{159}$ en is tevens vergelijkbaar met de strafrechtelijke tenlastelegging. Dit moge blijken uit de inhoud van het rapport:

- de feiten en omstandigheden op grond waarvan is vastgesteld dat een overtreding is begaan;

- waar en wanneer de (...) bedoelde feiten en omstandigheden zich hebben voorgedaan;

- de ondememing of ondernemersvereniging die de overtreding heeft begaan;

- de natuurlijke persoon of rechtspersoon die de overtreding kan worden toegerekend ${ }^{160}$, en

- het overtreden wettelijk voorschrift. ${ }^{161}$

Door dit rapport ${ }^{162}$ eindigt de voorfase en neemt een meer contradictoir deel van de kartelprocedure een aanvang: belanghebbenden worden in de gelegenheid gesteld hun zienswijze naar voren te brengen ${ }^{16} \mathrm{en}$ in artikel $61 \mathrm{Mw}$ is het recht van hoor en wederhoor neergelegd. ${ }^{164}$ Met het horen zijn uitdrukkelijk andere ambtenaren van de $\mathrm{NMa}$

157 Zie in dit verband echter Ottervanger, Steenbergen en Van der Voorde (1998), pag. 101: "Although the Act does not require the existence of a presumption that an infringement has taken place, the investigatory powers will probably be exercisedin cases where such a presumption exists". Dit hangt ten dele samen met het beginsel van evenredigheid, maar ten dele ook met de beperkte capaciteit van de NMa.

158 Hetzelfde geldt op grond van artikel $77 \mathrm{Mw}$ indien de d-g NMa een boeteprocedure start wegens overtreding van de medewerkingsplicht of de concentratieregels.

159 In deze zin ook onder meer Ottervanger, Steenbergen en Van der Voorde (1998), pag. 102 en Mok (1998), pag. 268.

160 Dit is vereist omdat slechts aan deze (rechts)persoon de boete kan worden opgelegd.

161 Het vierde lid van artikel $59 \mathrm{Mw}$ bepaalt dat op verzoekvan de belanghebbendede d-g NMa er zoveel mogelijkzorg voor draagt dat de inhoud van hetrapport de belanghebbendein een voor deze begrijpelijke taal wordt medegedeeld. Gelet op het belang van het rapport is dit een wezenlijke bepaling, waarin echter de woorden 'zoveel mogelijk', althans voor zover betrekking hebbend op de rechten van de 'verdachte' misplaatst zijn.

162 Artikel 60 lid $2 \mathrm{Mw}$ bepaalt bovendien dat het rapport en alle verder op de zaak betrekking hebbende stukken ten minste vier weken voor belanghebbenden ter inzage worden gelegd. In de Memorie van Toelichting (TK 1995-1996, 24 707, n. 3, pag 91) is uitdrukkelijk bepaald dat de uiteindelijke beschikking uitsluitend mag worden gebaseerd op stukken die de belanghebbenden hebben kunnen inzien en waarover zij hun zienswijze hebben kunnen geven. De analogie met het communautaire recht en met het strafrecht is hier onmiskenbaar.

163 Jansen (1999), pag. 184, onderstreept dat de hoorplicht zowel het verdedigingsbelang van de belanghebbende als de zorgvuldigheid van het onderzoek dient.

164 De rapportageverplichting is dan ook zonder meer cruciaal voor de waarborging van het verdedigingsrecht van de onderneming in kwestic. Deze verplichting vloeit mede voort uit artikel 6 lid 3 EVRM en het daarin verankerde beginsel van equality of arms. Aldus ook Jansen (1999), pag. 145. 
belist, dan met het vooronderzoek; zodra het rapport is opgesteld, vindt er namelijk cen verplichte wisseling van de wacht plaats. Op grond van artikel 3 lid 2 Mw mogen ambtenarendie betrokken zijn geweest bij het vooronderzoek en/of het opmaken van het rapport geen rol spelen in het traject volgend op het rapport. Deze scheiding zou een objectieve en onbevooroordeelde beslissing omtrent het al dan niet begaan zijn van een inbreuk en omtrent het al dan niet opleggen van een boete moeten waarborgen ${ }^{165}$ en kan als tegemoetkoming aan de (rechten van de) 'verdachte' worden gezien, nu deze 'verdachte' wordt geconfronteerd met een alles-in-éen-hand handhaving. Zoals Mok terecht stelt, heeft artikel 3 lid $2 \mathrm{Mw}$ echter geen wezenlijke betekenis. ${ }^{166} \mathrm{De} \mathrm{NMa} z \mathrm{zal}$ toch wel steds de schijn tegen hebben, niet in de laatste plaats omdat het de d-g NMa is die zowel een rapport doet opmaken -op het moment waarop hij een redelijk vermoeden van overtreding heeft én van mening is dat een boete een geschikte reactie op de overtreding isals de boete oplegt. ${ }^{167}$ Voor een justitiabele ontstaat dan toch al snel het gevoel dat hetpleit eigenlijk reeds beslecht is zodra een rapport is opgemaakt. Dit zal in versterkte mae zo zijn indien er zich een beleid zou ontwikkelen waarin slechts tot een boeteprocedure wordt besloten bij zeer ernstige overtredingen.

Incien de d-g NMa naar aanleiding van het vooronderzoek en de contradictoire fase het bevezen acht dat de betrokken ondernemingen verwijtbaar of opzettelijk in strijd met het kartelverbod hebben gehandeld, kan hij hen een boete opleggen. ${ }^{168}$ Hierbij dient hij conform het communautaire recht rekening te houden met de ernst en de duur van de inbreuk. ${ }^{169}$ Voor de belanghebbende die zich niet met het standpunt van de $\mathrm{d}$-g NMa kan verenigen, staat beroep op de rechter open. In tegenstelling tot hetgeen in het communautaire recht geldt, maar conform de hoofdregel van artikel 7:1 Awb zal de betrokkene echter eerst bij de d-g NMa een bezwaarschrift moeten indienen. Gelet op het veelal uitgebreide contact tussen gesanctioneerde onderneming en NMa in de procedure voorafgaand aan de boetebeschikking is hiervan weinig heil te verwachten: de standpunten van beide partijen zullen waarschijnlijk voldoende uitgekristalliseerd en duidelijk zijn. ${ }^{170}$ De enige meerwaarde die de bezwaarschriftprocedure heeft en die tot een andere uitkomst in bezwaar zou kunnen leiden, is verplichte advisering door een commissie zoals bedoeld

Zie over het belang van het EVRM voor het mededingingsrecht uitgebreid hoofdstuk 5 .

165 MvT TK 1995-1996, 24 707, nr. 3.

166. Mok (1998), pag. 269. Dat het, zoals Van Veen(1995), pag. 15 het stelt, 'zuiver' is om een dergelijke scheiding aan te brengen, doet daaraan niet af.

167 Van Buuren (1995), pag. 44, noemt dit aspectvan de bestuurlijke boete als zodanig 'burgeronvriendelijk'

168 Volgens artikel 1 sub $1 \mathrm{Mw}$ wordt onder boete verstaan 'de besturlijke sanctie bestaande in de verplichting aan de staat een bepaalde geldsom te betalen'. Artikel 5.4.1.1 VOAwb verstaat onder een bestuurlijke boete 'de bestuurlijke sanctie, inhoudende een onvoorwaardelijke verplichting tot betaling van een geldsom, die is gericht op bestraffing van de overtreder'. Het punitieve aspect wordt in deze definitie dus extra benadrukt. Zie voor commentaar op deze definitie De Raat en Widdershoven (2000), pag. 776-779.

169 Zie voor een analyse van de communautaire boetepraktijk hoofdstuk 4 .

170 Pijnacker Hordijk (1997), pag. 291, pleitte er dan ook -tevergeefs-voor om de bezwaarschriftenprocedure niet in de Mededingingswet op te nemen. Meer algemeen gekant tegen de verplichte bezwaarschriftenprocedure is Biesheuvel (1996 I), pag. 930. Positief daarentegen: Van der Meulen (2000), pag. 441. 
in artikel 7:13 Awb. In deze adviescommissie mogen -omwille van de onafhankelijkheidgeen ambtenaren van het ministerie van Economische Zaken zitting hebben.

Beroep moet op grond van artikel $93 \mathrm{Mw}$ worden ingesteld bij de (bestuurskamer) van de rechtbank Rotterdam. ${ }^{171}$ Daarmee wijkt de Mededingingswet af van de relatieve competentie zoals geregeld in artikel 8:7 lid $2 \mathrm{Awb}$. De reden om niet de bestuursrechter van het rechtsgebied waarbinnen de indiener van het beroepschrift zijn woonplaats heeft, maar slechts de rechtbank Rotterdam bevoegd te verklaren, ligt met name in de deskundig. heid: concentratie van rechtspraak op het moeilijke gebied van de mededinging zou de deskundigheid verhogen. ${ }^{17}$ Erg sterk is dit argument in zoverre niet dat de behandeling van civiele geschillen wel volgens de 'normale' competentieregels van het burgerlijke recht, zoals neergelegd in de artikelen 98 en 126 Wetboek van Burgerlijke Rechtsvordering, verloopt. En de deskundigheid wordt hier niet in twijfel getrokken, hetgeen wellicht mede samenhangt met de verwachting dat er aanmerkelijk meer civiele acties zullen volgen dan beroepsprocedures naar aanleiding van beschikkingen van de d-g NMa. Een afwijking van de gangbare praktijk kan tevens worden aangetroffen in de regeling omtrent het hoger beroep. Oorspronkelijk werd er in het wetsvoorstel geen bijzondere aandacht aan de regeling van het hoger beroep besteed en gold dus de hoofdregel in bestuurszaken, namelijk dat de Afdeling bestuursrechtspraak van de Raad van State belast was met de behandeling van beroepsprocedures. Vanuit het oogpunt van uniformering van het bestuursrecht was dit ook een zeer verdedigbare keuze. Toch werd op deze keuze veel kritiek geuit, omdat zij impliceerde dat voor het College van Beroep voor het bedrijfsleven in mededingingszaken geen plaats meer zou zijn ingeruimd. Dit werd bezwaarlijk geacht omdat deze instantie gedurende ongeveer veertig jaar ${ }^{173}$ een enorme expertise met betrekking tot de mededinging -zij het overigens niet op het gebied van punitieve sancties (dit was immers het terrein van de strafrechter)- had opgebouwd, een expertise waarover de Raad van State in het geheel niet beschikte. Deze expertise zou in de oorspronkelijke regeling -aldus de critici- ten onrechte overboord worden gezet. ${ }^{174}$ De minister van Economische Zaken

171 In tegenstelling tot hetgeen in de Awb is neergelegd en ook voor het communautaire recht geldt, heeft het beroep op grond van artikel $63 \mathrm{Mw}$ wél schorsende werking. Wladimiroff en Van Russen Groen (1999), pag. 98, achten een dergelijke waarborg ook vereist, gelet op artikel 6 EVRM. Van Aalst (1997), pag. 560 wil de schorsende werking beperken tot zware boetes. Afwijzendzijn Michiels (1994), pag. 24 en 38, die de negatieve gevolgen voor de effectiviteit benadrukt, en Jansen (1997), pag. 46. Daarnaast is volgens Widdershoven (1998), pag. 237, het karakter van de toetsing door de rechter verschillend van hetgeen in het bestuursrecht gangbaar is; boetebesluiten van de d-g NMa dienen door de bestuursrechterniet slechts marginaal, maarvolledig getoetstte worden. Daarenboven is de ruimte voor de bestuursrechter om zelf in de zaak te voorzien groter dan overigens in het bestuursrecht. In tegenstelling tot hetgeen in het communautaire recht geldt, kent de Mededingingswet, als deel van het bestuursrecht, voorts het verbod op reformatio in peius.

172 Mok, TK 1996-1997, 24 707, nr. 9 stelde dat de regeling in de Awb juist mede bedoeld was om de deskundigheid te verhogen: "Wij hebben nu de bestuursrechtspraak bij de rechtbank ondergebracht. juist om te proberen coördinerende lijnen te leggen tussen verschillende takken van rechtspraak. waaronder de burgerlijke rechtspraak en de bestuursrechtspraak".

173 Het College van Beroep voor het bedrijfsleven had -toen nog onder het regime van de Wem- ook de uniformeringsoperatie overleefd die bij de inwerkingtreding van de Algemene wet bestuursrecht (Awb) werd doorgevoerd. Aldus werd niet de rechtbank bevoegd verklaard, maar werd de bijzondere rechtsgang bij het $\mathrm{CBB}$ gehandhaafd.

174 Mortelmans (1996), pag, 124. In de literatuur werd dit wel aangeduid als juridische kapitaalvernietiging Biesheuvel (1996 II), pag. 1244. 
zwichtte voor de argumenten, als gevolg waarvan het bestuursrecht een hoger beroepsinstantie -naast de Afdeling bestuursrechtspraak Raad van State en de Centrale Raad van Bercep- rijker is. ${ }^{175}$ Naar mijn mening is er terecht voor deze aanpassing gekozen: het zou inderdaad verspilling zijn geweest indien de aanwezige expertise niet zou worden bent. Wel dient te worden aangetekend dat de expertise met name nuttig zal zijn bij beocrdeling van beslissingen op een ontheffingsverzoek; de expertise op punitief gebied zal zich ook bij het CBB nog moeten ontwikkelen.

\subsection{Sancties}

Hiervoor is behandeld dat de $\mathrm{d}-\mathrm{g} \mathrm{NMa}$ ondernemingen wegens overtreding van de verboden ran artikel 6 en $24 \mathrm{Mw}$ een bestuurlijke boete kan opleggen. Het wellicht belangrijkste kennerk van de Mededingingswet, de vergaande convergentie met het communautaire rech, blijkt ook op dit punt. Op grond van artikel $57 \mathrm{j}^{\circ} 56 \mathrm{Mw}$ kan een boete worden opgelegd van ten hoogste $f 1$ miljoen of -indien dit meer is- van ten hoogste $10 \%$ van de omzet van de onderneming of van de gezamenlijke omzet van de bij een ondernemersvereniging betrokken ondernemingen. ${ }^{176}$ De maximale hoogte van de boete is dus gelijk aan die in het communautaire recht. Aan de convergentie met het communautaire rech is wel een concessie gedaan op het gebied van de minimumsanctie: in aansluiting op de Nederlandse (strafrechtelijke) traditie is niet gekozen voor het opnemen van een minimumboete in artikel $57 \mathrm{Mw}$, als gevolg waarvan de d-g NMa -en in beroep de bestuursrechter- vrij is om een symbolische boete van $f 1$ op te leggen. De vrijheid van de d-g NMa op het punt van de straftoemeting is dan ook zeer aanzienlijk. Zij wordt in zoverre beperkt dat de d-g NMa gehouden is rekening te houden met de ernst en de duur van de overtreding. ${ }^{177}$ Dit uit het communautaire recht overgenomen vereiste biedt noch de directeur-generaal noch ondernemingen veel houvast. Zoals in het volgende hoofdstuk zal blijken, zijn in het communautaire kartelrecht op grond van dit vereiste verschillende meer concrete straftoemetingsfactoren ontwikkeld. Gelet op het streven naar convergentie kunnen en moeten deze factoren -voor zover zij niet betrekking hebben

175 Tweede nota van wijziging, TK 1996-1997, 24 707, nr. 8. In de toelichting bij deze wijziging is uitdrukkelijk de optie naar voren gebracht dat ook voor andere bestuursrechtelijkte handhaven wetten het College van Beroep voor het bedrijfsleven als bevoegde appèlinstantie zal kunnen worden aangewezen. Zie ook De Jong (1997), pag. 42-43. De onduidelijkheid die nog bij Leijten (1993), pag. 117, kon leven over de toekomst van het CBB, lijkt nu dan ook redelijkerwijze niet meer te kunnen bestaan.

176 In artikel 57 lid $3 \mathrm{Mw}$ is vastgelegd dat de berekening van de omzet op de voet van het bepaalde in artikel 6:377 lid 6 BW voor de netto omzet geschiedt. Dit artikel luidt: "Onder de netto-omzet wordt verstaan de opbrengst uit levering van goederen en diensten uit het bedrijf van de rechtspersoon, onder aftrek van kortingen en dergelijke en van over de omzet geheven belastingen". Van der Hulst (2000), pag. 75, lijkt van mening te zijn dat voor het gehele bestuurlijke sanctierecht (dus ook voor het mededingingsrecht) een maximale boete van $f 10.000$ per overtreding aangewezen is. Waar het het mededingingsrecht betreft, hoeft het echter geen betoog dat dergelijke boetes absoluut onvoldoende zijn om ook maar enig effect te sorteren.

177 In artikel 5.4.1.7 lid 2 VOAwb4 is het volgende neergelegd: "Tenzij de hoogte van de bestuurlijke boete bij wettelijk voorschrift is vastgesteld, stemt het bestuursorgaan de bestuurlijke boete af op de ernst van de overtreding en de mate waarin deze aan de overtreder kan worden verweten. Het bestuursorgaan houdt daarbij zo nodig rekening met de omstandigheden waaronder de overtreding is gepleegd". 
op typisch communautaire aspecten- door de d-g NMa ook in het kader van zijn boete. beleid worden gehanteerd. Het is overigens de vraag of de d-g NMa een inbreuk kan constateren zonder oplegging van een boete. Mijns inziens biedt de discretionaire bevoegdheid van artikel $56 \mathrm{Mw}$ hiertoe inderdaad de mogelijkheid. Indien de d-g NMa in afwijking van zijn aanvankelijke oordeel (vergelijk artikel $59 \mathrm{Mw}$ ) tot de conclusie komt dat een boete niet op haar plaats is, dan kan hij afzien van oplegging van deze sanctie, waarbij hij in zijn beschikking de gronden voor zijn beslissing dient neer te leggen. ${ }^{178}$ Een probleem rijst indien de d-g NMa weliswaar een beschikking noodzakelijk acht -bijvoorbeeld ter opheldering van bepaalde onduidelijkheden-, maar bij voorbaat ervan overtuigd is dat geen boete moet worden opgelegd. Daar op die situatie artikel $59 \mathrm{Mw}$ noch enig ander artikel van toepassing is, voorziet de Mededingingswet -in tegenstelling tot artikel 3 Vo 17 - niet in een dergelijke mogelijkheid. ${ }^{179}$ Verwacht mag worden dat de d-g NMa hier analoog aan het communautaire recht zal handelen.

Evenals in het communautaire recht het geval is, kan geen boete worden opgelegd indien de overtreder geen verwijt valt te maken. ${ }^{180}$ Het is aan de betrokken onderneming om dit aannemelijk te maken. De memorie van toelichting noemt dit een disculpatiegrond die zich in de praktijk nauwelijks zal voordoen ${ }^{181}$; Mok stelt echter terecht dat het een onaanvaardbare omkering van de bewijslast betref $\mathrm{t}^{182}$, een onaanvaardbaarheid die voortvloeit uit de presumptio innocentiae, welk beginsel de bewijslast in punitieve procedures op de overheid legt. Als er een boete wordt opgelegd, dan gebeurt dit niet aan de onderneming, maar volgens artikel $56 \mathrm{Mw}$ aan 'de natuurlijke persoon of rechtspersoon aan wie de overtreding kan worden toegerekend', waarmee wordt gedoeld op de eigenaar van een onderneming. ${ }^{183}$ Dit houdt verband met de omstandigheid dat een in belangrijke mate economisch ondernemingsbegrip wordt gehanteerd, terwijl sancties slechts aan (rechts)personen kunnen worden opgelegd. ${ }^{184}$ Uitdrukkelijk van de hand gewezen, is de, in het Nederlandse strafrecht gangbare ${ }^{185}$, optie om ook de opdrachtgever en de feitelijk leidinggevende te kunnen sanctioneren. In dit licht dient ook het vierde lid van

178 Mok (1998), pag. 271, komt tot een zelfde conclusie, zij het via de weg van de analoge toepassing van het rechterlijk pardon van artikel $9 \mathrm{a}$ WvSr.

179 Zou impliciet uit artikel $59 \mathrm{Mw}$ volgen dat een dergelijke mogelijkheid wel is beoogd, dan zou dit meebrengen dat voor beschikkingen waarin een overtreding wordt geconstateerd, maar waarin geen boete wordt opgelegd, geen voorafgaand rapport vereist zou zijn. In het kader van de rechten van de betrokken ondernemingen zou dit echter onaanvaardbaarzijn. Zie hieromtrent tevens Biesheuvel, Mok en Sevenster (1996), pag. 90.

180 Hetzelfde geldt voor het bestuurlijke boeterecht in het algemeen, althans indien artikel 5.4.1.2 VOAwb4 zal worden aangenomen: "Het bestuursorgaan legt geen bestuurlijke boete op voorzover de overtreding niet aan de overtreder kan worden verweten".

181 MvT TK 1995-1996, 24707 , nr. 3, pag. 88. Dat de drempel van de verwijtbaarheid niet hoog ligt, blijkt ook in de communautaire praktijk. In hoofdstuk 4 zal hierop uitgebreid worden ingegaan.

182 Mok (1998), pag. 286. In het mede door deze schrijver opgestelde preadvies uit 1996 wordt nog de visie van de minister gedeeld. Zie Biesheuvel, Mok en Sevenster (1996), pag. 89. De regeling in het Voorontwerp vierde tranche is op dit punt aanmerkelijk beter. Zie hierover Van der Meulen (2000), pag. 442.

183 MvT TK 1995-1996, 24 707, nr. 3, pag. 87.

184 Gritter (1998), pag. 167, stelt dat de eigenaarvan de ondememing als dader kan worden aangemerkt. Dit lijkt mij niet juist: de onderneming is als zodanig dader, de toerekening aan de eigenaargeschiedt voor die gevallen waarin de onderneming zelf geen natuurlijk of rechtspersoon is, omdat slechts aan deze een boete kan worden opgelegd.

185 Vergelijk artikel 51 WvSr. Zie hierover Hazewinkel-Suringa/Remmelink (1994), pag. 153 c.v.. 
artikel $56 \mathrm{Mw}$ te worden gelezen, op grond waarvan de bestuurder van een rechtspersoon niet wordt beschouwd als de natuurlijke of rechtspersoon ${ }^{186}$ aan wie de overtreding kan worden toegerekend en aan wie dus de boete kan worden opgelegd.

\section{Conclusie}

Het streven naar intensivering en convergentie van het Nederlandse kartelrecht en -beleid kende met de inwerkingtreding van de Mededingingswet in 1998 een (voorlopig) hoogtepunt. Er kwam een einde van de op het misbruikstelsel gefundeerde Nederlandse kartelwetgeving (ten gunste van de op het verbodstelsel gebaseerde Mededingingswet) en van de strafrechtelijke handhaving van deze wetgeving (ten faveure van bestuursrechtelijke handhaving). Zowel op materieel- als op formeelrechtelijk gebied betekende de Mededingingswet dan ook een omslag, hoewel de omvang van de materieelrechtelijke omslag door de generieke maatregelen van 1993 en 1994 minder groot was dan de overstap van een misbruikstelsel naar een verbodstelsel doet vermoeden. De redenen die aan deze omslag van het materiële recht ten grondslag lagen, waren primair van economische aard: de gedachte was bij de Nederlandse overheid gerijpt dat ondernemers, consumenten, de economie en -ruimer-het algemeen belang uiteindelijk meer baat hadden bij concurrentic dan bij de continuering van mededingingsbeperkende gedragingen. Naast deze economische motieven bevorderden ook de grote mate van 'Brusselse' kritiek op het Nederlandse kartelrecht en -beleid en de golf van spontane harmonisatie in andere lidstaten de totstandkoming van een op het communautaire recht gestoelde verbodwetgeving.

Dat het communautaire kartelrecht model heeft gestaan voor de Mededingingswet is onmiskenbaar. Niet alleen zijn de verboden van de artikelen 6 en $24 \mathrm{Mw}$ vrijwel letterlijk een kopie van de artikelen 81 en 82 EG (het meest wezenlijke verschil ligt in de verschillende 'markt-begrippen'), maar bovendien wordt voor de definities van de begrippen overeenkomst, onderneming, ondernemersvereniging en onderling afgestemde feitelijke gedraging in de Mededingingswet direct verwezen naar de betekenis van deze begrippen in het communautaire recht. Iedere wijziging van de invulling van deze begrippen door de Commissie of de communautaire rechters heeft dientengevolge directe repercussies voor het Nederlandse recht. Een grotere mate van convergentie is nauwelijks denkbaar. ${ }^{187}$ lets minder vergaand is de convergentie ten aanzien van het begrip 'economische machtspositie': de definitie hiervan is weliswaar ontleend aan de jurisprudentie van het Hof met betrekking tot artikel $82 \mathrm{EG}$, maar zij is in de Mededingingswet zelf opgenomen en wordt dan ook niet direct door eventuele wijzigingen in de definitie van het communautaire begrip 'machtspositie' beïnvloed. Daar de wetgever ten aanzien van eerder genoemde begrippen heeft gekozen voor een enkele verwijzing naar het communautaire recht en

186 Artikel 56 lid $4 \mathrm{Mw}$ noemt hier slechts de natuurlijke persoon. Naar mijn mening geldt hetzelfde voor de rechtspersoon als bestuurder. In dezelfde zin Mok (1998), pag. 285.

187 Gevolg hiervan is dat de ruimte voor eigen Nederlands beleid relatief beperkt is. Dit is overigens niet het enige bezwaarvan een zo vergaande convergentie. De kans bestaat namelijk dat de communautaire instanties bij de bepaling van de inhoud van de onderhavige begrippen, rekening houden met aspectendie voor de Nederlandse situatie geen relevantie hebben. Met name ontbeert het Nederlandse kartelrechtde integratiefunctie, die juist zo kenmerkend is voor het communautairekartelrecht, Dit laat onverlet dat gezien de grotere mate van duidelijkheid die de convergentie voor ondernerningen meebrengt, zij de voorkeur verdient boven een regeling met een geheel nationaal karakter. 
daarmee voor de doorwerking van dit recht in het Nederlandse kartelrecht, had hij ook hier naar mijn mening de lijn moeten doortrekken ${ }^{188}$ Het nu bereikte resultaat is in ieder geval weinig consequent.

Ook uit de regels met betrekking tot ontheffing en vrijstelling blijkt een vergaande aansluiting bij het communautaire recht: de gronden voor ontheffing ${ }^{189}$ en vrijstellingen zijn vrijwel letterlijk ontleend aan artikel 81 lid $3 \mathrm{EG}$, en communautaire vrijstellingen ${ }^{190}$ en ontheffingen zijn expliciet van het Nederlandse verbod vrijgesteld. De Mededingingswet kent bovendien evenals het communautaire recht een bagatelvoorziening, zij het dat tussen de Nederlandse en de communautaire regeling een belangrijk principieel verschil bestaat. De communautaire bagatelregeling is een uitwerking van het merkbaarheidsvereiste, terwijl de Nederlandse voorziening is gegoten in de vorm van een vrijstelling. Daarnaast is de Nederlandse wetgever het communautaire recht inhoudelijk niet gevolgd: ter bepaling van de aanwezigheid van een 'bagatelgedraging' gaat het communautaire recht uit van een marktaandeelcriterium; in de Nederlandse wet wordt -om redenen van hanteerbaarheid door ondernemingen- een omzetcriterium gehanteerd.

Met de overgang van strafrechtelijke naar bestuursrechtelijke handhaving volgt de Mededingingswet cen duidelijk waarneembare trend in het Nederlandse (handhavings)recht. Niet voor niets is aan de Commissie voor de toetsing van wetgevingsprojecten advies gevraagd

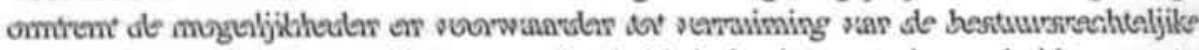
handhaving. Bedoelde trend bestaat omdat de Nederlandse centrale overheid ten eerste de verantwoordelijkheid voor handhaving van beleidsinstrumentele wetgeving meer in handen van het bestuur zelf wil leggen en ten tweede van mening is dat het -overigens cijfermatig niet aangetoonde- handhavingstekort via bestuursrechtelijke weg beter kan worden aangepakt dan via het strafrecht. ${ }^{191}$ Deze argumenten keerden ook terug in toelichting op de keuze voor bestuursrechtelijke handhaving van de Mededingingswet: het strafrecht mocht slechts als ultimum remedium gebruikt worden en zou bovendien niet voldoen als handhavingsinstrument van het kartelrecht (Openbaar Ministerie en de rechterlijke macht zouden onvoldoende deskundig zijn, hetgeen naast de ingewikkeldheid van de materie, de capaciteitsproblemen binnen het strafrecht en de geringe verontrusting die kartelinbreuken teweeg zouden brengen, zou leiden tot -door de overheid niet gewildesepots of transacties), beleidsinstrumentele wetten moesten zoveel mogelijk door het bestuur zelf worden gehandhaafd, het opdragen van de handhaving aan een gespecialiseerd bestuursorgaan zou deskundigheid in mededingingszaken garanderen en zou de afstemming

188 Waarschijnlijklagen aan deze keuze wetstechnischeredenente grondslag. Het communautairebegrip heeft naar zijn aard uitsluitend betrekking op de gemeenschappelijkemarkt, terwijl in de Mededingingswet slechts de Nederlandse markt relevantie heeft. Dit probleem had echter relatief eenvoudig ondervangen kunnen worden door in de verwijzing naar het communautaire recht op te nemen dat als relevante markt niet de communautaire maar de Nederlandse markt in aanmerking moest worden genomen.

189 Ten onrechte heeft de aanmelding in het kader van een ontheffingsaanvraag -in tegenstelling tot hetgeen het geval is in het communautaire recht- geen immuniteit tegen boetes tot gevolg.

190 Vrijgesteld op grond van de Mededingingswet zijn zelfs gedragingen die dils zij de interstatelijke handel of de mededinging binnen de gemeenschappelijke markt zouden beinvloeden, onder de reikwijdte van een communautaire vrijstelling zouden vallen.

191 Het antwoord op de vraag of er een handhavingstekort ten aanzien van een bepaalde regeling geldt, is overigens sterk afhankelijk van de vraag wat men met de handhaving wenst te bereiken. 
methet kartelbeleid van de Europese Commissie vereenvoudigen en -tenslotte- bestuursrechtelijke handhaving werd doelmatiger geacht dan strafrechtelijke. Met name de tegen strarechtelijke handhaving ingebrachte bezwaren overtuigen niet: de ultimum remediumgedichte dient voor iedere vorm van punitief sanctioneren te gelden, eventuele problemen ten sanzien van deskundigheid en capaciteit binnen het strafrecht kunnen worden opgelost en ce prioriteit van mededingingszaken binnen het strafrecht zou waarschijnlijk aanmerkelijkhoger zijn dan ten tijde van de Wem: waar het kartelrecht op beleidsniveau een 'item' is gworden (hetgeen onder de Wem lange tijd allerminst het geval was), zal ook door het Openbaar Ministerie meer werk gemaakt worden van de handhaving. Het was dus geetszins een zekerheid dat met strafrechtelijke handhaving het gewenste resultaat (strenger opteden tegen kartels) niet zou kunnen worden bereikt. Bestuursrechtelijke handhaving lag bovendien niet voor de hand omdat aan een van de meest belangrijke criteria voor besuursrechtelijke handhaving, zoals geformuleerd door de Commissie voor de toetsing vanwetgevingsprojecten, uitdrukkelijk niet was voldaan. Het betrof het criterium dat de torm zodanig duidelijk moet zijn dat het mogelijk is om een vaste gedragslijn te ontvikkelen: de communautaire praktijk toont echter aan dat de norm verre van duidelijk is. Door de minister werd dit probleem weliswaar erkend, maar hij achtte het ontbreken vaneen concrete norm voldoende gecompenseerd door de aanwezigheid van een gespecialiseed orgaan dat met de handhaving was belast; een schoolvoorbeeld van het redeneren naar een gewenst resultaat. Het lijkt erop dat de evidente voorkeur van de minister voor de bestuursrechtelijke handhavingsmodaliteit (naast de voornamelijk politieke reden van het leggen van handhavingsverantwoordelijkheid bij het bestuur) met name door doelmatigheidsoverwegingen is ingegeven. Dit is in zoverre geen probleem indien de grotere doelmatigheid primair gelegen is de concentratie van taken -mits gecompenseerd door een adequate rechtsbescherming- en de eenvoudigere afstemming van nationaal en communautair beleid. Onaanvaardbaar is het echter indien de doelmatigheidsverhoging van de overheveling van straf-naar bestuursrecht hoofdzakelijk is gelegen in een -beoogde- afname van rechtswaarborgen voor de justitiabelen. In hoeverre dit inderdaad het geval is, zal in hoofdstuk 5 worden besproken.

De keuze voor bestuursrechtelijke handhaving, de wens om bevoegdheden in het kader van de uitvoering van de Mededingingswet zoveel mogelijk bij één instantie te concentreren en het voornemen om beleid en uitvoering te splitsen, leidde tot de oprichting van de Nederlandse Mededingingsautoriteit en tot het aan deze autoriteit opdragen van in beginsel alle taken en bevoegdheden in het kader van de Mededingingswet. De voorkeur werd -voor een overgangsperiode van vijf jaar- gegeven aan interne boven externe verzelfstandiging van deze dienst. De primaire reden hiervoor was dat de kartelmaatregelen een politiek karakter droegen, als gevolg waarvan de minister volle ministeriële verantwoordelijkheid voor deze maatregelen moest dragen, hetgeen weer vereiste dat de minister ook zeggenschap had over de individuele gevallen. Daarnaast zou de mogelijkheid om in individuele gevallen aanwijzingen te geven, de minister in staat stellen om bij stagnerend beleid van de NMa handelend op te treden. Het beleid van de NMa in de eerste jaren van haar bestaan, biedt geen aanleiding te vrezen dat dit beleid zal verzanden; aangekondigd is dan ook dat de $\mathrm{NMa}$ binnen afzienbare tijd de status van zbo zal krijgen. ${ }^{192}$

192 De eerstgenoemdereden pleitte naar mijn mening toch al tegen interne verzelfstandiging, aangezien een minister gevoeliger voor politieke druk zal zijn dan een onafhankelijk kartelorgaan. 
De bevoegdheden van de NMa in het kader van de handhaving zijn in grote lijnen gelijk aan de bevoegdheden van de Europese Commissie op grond van Verordening 17 en aan de bevoegdheden zoals die onder het regime van de Wem en de WED golden. Centraal staat het inzagerecht, in dienst waarvan het recht tot betreding, tot verzegeling en tot het inroepen van de hulp van de sterke arm staat. Wat ontbreekt is een doorzoekingsbevoegdheid voor de ambtenaren van de NMa, maar daarvoor in de plaats bestaan er een vergaande plicht tot medewerking voor de ondernemingen en -bij gebrek aan deze coöperatie- het reeds genoemde recht om inzage te verkrijgen met behulp van de sterke arm. Verwacht mag worden dat deze bevoegdheden toereikend zijn voor de gewenste strikte handhaving. Problematisch is echter het juridische kader waarin deze bevoegdheden vallen. De Mededingingswet maakt onderscheid tussen toezicht en onderzoek, waarbij aan 'toezicht' een niet gangbare en van het toezicht-begrip van de Awb afwijkende inhoud is gegeven. Toezicht wordt omschreven als handelingen die worden verricht zonder dat sprake is van concrete naspeuringen of wellicht een overtreding is begaan; onderzoek betreft de handelingen die worden verricht met het oog op de vaststelling dat al dan niet een overtreding is begaan. Van toezicht zal in die visie zelden sprake zijn, aangezien de handelingen van de NMa toch veelal gericht zullen zijn op beantwoording van de vraag of er een overtreding is begaan. Zo moeten bijvoorbeeld de naspeuringen naar aanleiding van een klacht als 'onderzoek' worden gekwalificeerd. Bovendien heeft het

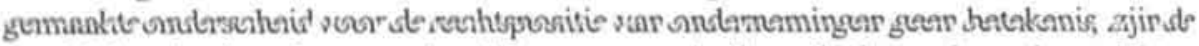
toezichthoudende ambtenaren dezelfde personen als die welke het onderzoek verrichten en beschikken deze ambtenaren in beide fasen over vrijwel dezelfde bevoegdheden. Dat er toch is gekozen voor het onderscheid hangt waarschijnlijk ermee samen dat het begrip 'toezicht' volgens de minister niet alle handelingen ter handhaving dekte. Daar het onderscheid tussen toezicht en onderzoek, zoals gedefinieerd door de minister, echter eerder tot onnodige verwarring leidt dan dat het veel meerwaarde heeft, had de minister mijns inziens van de invoering ervan moeten afzien. De bedoelde bedenkingen van de minister hadden via een minder onduidelijke regeling kunnen worden weggenomen.

De gememoreerde concentratie van taken en bevoegdheden bij de NMa blijkt nadrukkelijk in het kader van de handhaving en de boete-oplegging: toezicht, onderzoek, 'vervolgingsbeslissing' en de beslissing omtrent een eventuele boete en de hoogte daarvan liggen alle in één hand. Weliswaar is er een scheiding gemaakt tussen voorfase en contradictoire fase, in die zin dat in beide fasen verplicht andere ambtenaren zijn betrokken, maar het feit blijft dat alle handelingen onder gezag van de d-g NMa worden uitgevoerd. De interne scheiding die de schijn van partijdigheid moet wegnemen, heeft dan ook geen wezenlijk belang. Gelet op deze alles-in-één-hand handhaving neemt de noodzaak toe van een goede regeling betreffende de toegang tot de rechter. ${ }^{193}$ Hierin is naar mijn mening inderdaad voorzien. Na een verplichte, maar mijns inziens -ondanks de verplichte adviesinwinning. evenzeer overbodige bezwaarfase, kan de onderneming in kwestie beroep aantekenen bij de rechtbank Rotterdam, waarna hoger beroep bij het College van Beroep voor het bedrijfsleven openstaat. De keuze voor de concentratie bij de rechtbank Rotterdam hangt samen met de verwachting van de minister dat er relatief weinig beroepszaken zullen worden gestart: hantering van de 'normale' relatieve competentie zou meebrengen dat

193 Dit wordt ook in het communautaire recht van wezenlijk (zelfs 'grondwettelijk') belang gezien. Zic GvEA (T-348/94) Jur. 1998, II-1875 (Enso Española). 
betuursrechters verspreid over heel Nederland zeer incidenteel met kartelzaken in aanrakirg zouden komen, hetgeen hun deskundigheid en de rechtsgelijkheid niet zou bevorderen. Concentratie van rechtspraak -waarvoor niet in het civiele recht werd gekozen ${ }^{194}$ - daarentegen zou dit wel bewerkstelligen. Niet alleen de keuze voor concentratie van rechtspraak in seroep is opvallend, dit geldt evenzeer voor de aanwijzing van het CBB als hoger beoepsinstantie. Hiervoor is -ondanks de afwijking van de hoofdregel van de Awb, nanelijk dat de Afdeling bestuursrechtspraak van de Raad van State in hoger beroep oodeelt- terecht gekozen omdat geen enkele rechterlijke instantie een vergelijkbare staat va dienst in kartelzaken heeft als het CBB. Daarbij moet wel worden aangetekend dat ophet gebied van de bestuurlijke boete de expertise nog dient te worden opgebouwd. Hezelfde geldt overigens voor de d-g NMa. Immers, hij heeft een zeer ruime vrijheid inake boete-oplegging, aangezien hij bestuurlijke boetes kan opleggen tot maximaal $10 \%$ van de omzet van de bij het kartel betrokken onderneming en de wet hem slechts veplicht bij de bepaling van de hoogte van de boete rekening te houden met de ernst ende duur van de overtreding.

Ui het bovenstaande volgt dat de Mededingingswet een streng anti-kartelbeleid mogelijk met maken. Veel belang wordt daarbij gehecht aan de doelmatigheid van de procedures ende mogelijkheid van het opleggen van een adequate -lees: hoge- boete. Met name an deze redenen is gekozen voor bestuursrechtelijke handhaving, voor een boeteniveau dat gelijk is aan het communautaire en -daarmee samenhangend- voor een zeer ruime discretionaire boetebevoegdheid van de d-g NMa. Wat echter ondergesneeuwd dreigt te raken, zijn de rechtswaarborgen van de ondernemingen, die echter -ongeacht of het strafrechtelijke dan wel bestuursrechtelijke handhaving betreft- in een rechtsstaat van cruciale betekenis zijn. In hoeverre voldoende rekening is gehouden met de rechtspositie van ondernemingen in het kader van de handhaving via de bestuurlijke boete en in hoeverre de rechten in de communautaire en nationale kartelprocedure corresponderen, zal in hoofdstuk 5 worden besproken. In hoofdstuk 4 wordt de communautaire boetepraktijk geanalyseerd, teneinde zicht te krijgen op de verschillende straftoemetingsfactoren (en voorzover na te gaan- hun gewicht) die door Commissie, Gerecht en Hof zijn ontwikkeld. Dit is relevant omdat de Nederlandse en de communautaire regels ten aanzien van beboeting mutatis mutandis gelijk zijn en ook in het beleid convergentie wordt nagestreefd. De communautaire strafmaatfactoren zullen dan ook door de d-g NMa in het kader van een Nederlandse boete-procedure in acht genomen moeten worden, als gevolg waarvan zijn discretionaire bevoegdheid op dit punt wordt ingeperkt en de rechtszekerheid voor de ondernemingen toeneemt.

194 Wellicht omdat het te verwachten aantal civiele zaken aanmerkelijk groter is. 



\section{Deel II De boetepraktijk en rechtsbescherming}

Het doel van mensenrechten is de overheidsmacht aan beperkingen te onderwerpen ten behoeve van de vrijheid van het individu. Als de Gemeenschap overheidsmacht overneemt dan moet zij ook aan dezelfde beperking gebonden zijn. Schermers (1996), pag. 881 



\section{De boetepraktijk}

In het eerste deel is ingegaan op het belang dat aan het kartelrecht op communautair niveau én -betrekkelijk recent- in Nederland wordt toegekend: een strikt kartelbeleid levert een bijdrage aan de bevordering van de economische ontwikkeling en -voorzover het de Europese Gemeenschap betreft- aan de verwezenlijking en instandhouding van de interne markt. Deze waarde van het kartelrecht vindt zijn vertaling in het EG-Verdrag (en de daarop gebaseerde Verordening 17) en de Mededingingswet (in samenhang met de Awb), waarin strenge materiële verbodsnormen zijn neergelegd en waarin is voorzien in verstrekkende en adequate middelen ter handhaving van die normen. De kwalificatie 'streng en adequaat' geldt ook voor het sluitstuk van de handhaving: de strafoplegging. Beide kartelregelgevingen voorzien in de mogelijkheid om een onderneming wegens de overtreding van de kartelverboden een geldboete op te leggen van maximaal $10 \%$ van de omzet van deze onderneming. Om deze geldboete gaat het in dit hoofdstuk. Zowel de Commissie ${ }^{1}$ als de d-g NMa beschikken over een aanzienlijke discretionaire bevoegdheid op sanctiegebied. Dit geldt zowel ten aanzien van de vraag of een boete wordt opgelegd (een onderneming die op het materiële recht een inbreuk heeft gemaakt, kan (maar hoeft dus niet te) worden beboet) als ten aanzien van de vraag welke boete (tot een maximum van $10 \%$ van de omzet van de onderneming) zal worden opgelegd. Noch de communautaire regelgeving noch de Mededingingswet biedt veel houvast bij de invulling van deze vrijheid. Uit beide regelingen blijkt dat een boete slechts kan worden opgelegd indien de betreffende onderneming (tenminste) een verwijt van de overtreding valt te maken. Voor de hoogte van de boete is bepaald dat de Commissie, respectievelijk de $\mathrm{d}-\mathrm{g} \mathrm{NMa}$ rekening moet houden met de ernst en de duur van de overtreding. Verder reiken de voorwaarden die verdrag en wet stellen niet. Wel zullen steeds de algemene beginselen van behoorlijk bestuur -zoals voor het Nederlandse bestuursrecht gedeeltelijk gecodificeerd in de tweede afdeling van hoofdstuk $3 \mathrm{Awb}$ - in acht dienen te worden genomen, waarbij in het bijzonder het evenredigheidsbeginsel relevant is: de boete moet in een redelijke verhouding tot de gepleegde inbreuk staan. ${ }^{2}$

Zoals gezegd bieden deze regels weinig houvast bij de invulling van de discretionaire bevoegdheid. Maar bovendien scheppen zij weinig zekerheid voor ondernemingen. Niet op voorhand duidelijk wordt met name wanneer de Commissie, respectievelijk de $\mathrm{d}-\mathrm{g}$ $\mathrm{NMa}$ tot het opleggen van boetes zullen overgaan en welke strafmaatfactoren onder de vage noemer 'ernst en duur van de overtreding' worden gebracht. Bij de boete-oplegging hangt dus veel af van de Commissie en de d-g NMa. Het is dan ook van groot belang dat de Commissie in een omvangrijke lijst van beschikkingen een boetebeleid heeft ontwikkeld waarin zij haar vrijheid nader heeft ingevuld en waardoor er meer duidelijkheid is ontstaan omtrent de overwegingen die bij de oplegging en de bepaling van de omvang

Opgrond van artikel 15 Vo 17. Hiermee corresponderenvoor de vervoersectorartikel 22 Vo $1017 / 62$, artikel 19 Vo $4056 / 86$ en artikel 12 Vo $3975 / 87$.

2 Zie over de betekenis van de algemene beginselen van behoorlijk bestuur voor de handhaving van het communautaire recht: De Moor-van Vugt (1993), pag. 83 e.v.. 
van de boete een rol spelen. De convergentie van het Nederlandse kartelrecht met het communautaire recht heeft nu als voordeel dat dit boetebeleid ook voor de Nederlandse situatie relevantie heeft. Indien immers het uitgangspunt is dat het Nederlandse kartelrecht niet strenger maar ook niet milder mag zijn dan zijn communautaire voorbeeld, dan zal ook ten aanzien van de sancties dezelfde weg gevolgd moeten worden als die welke door de Commissie wordt bewandeld. De straftoemetingsfactoren die door de Commissie worden gehanteerd, zullen dientengevolge ook door de d-g NMa aan zijn boetebeschikkingen ten grondslag moeten worden gelegd. Daarom zal in paragraaf 4 uitgebreid de communautaire boetepraktijk worden geanalyseerd. Allereerst zal echter inleidend worden ingegaan op de bij de boete-oplegging betrokken instanties en op het rechtskarakter van de boete. De tweede paragraaf bevat een uitwerking van drie voor het (communautaire) mededingingsrecht relevante leerstukken, te weten het schuldvereiste, het verjaringsprincipe en het ne bis in idem-beginsel. In de derde paragraaf wordt aandacht besteed aan het opportuniteitsbeginsel, welk beginsel van belang is aangezien niet iedere overtreding van artikel 81 of 82 EG die aan alle formele voorwaarden voor het opleggen van een boete voldoet, ook daadwerkelijk tot een vervolging behoeft te leiden.

\section{Competentie en het rechtskarakter van de boete}

\subsection{Competentie}

In hoofdstuk 2 is reeds aan de orde gekomen dat het mededingingsrecht binnen het communautaire recht een bijzondere positie inneemt: de handhaving van de materiële verboden van de artikelen 81 en 82 EG is primair een zaak van de communautaire autoriteiten. Beboeting van ondernemingen wegens schending van deze artikelen is dan ook een bevoegdheid die op grond van artikel 15 Vo 17 exclusief aan de Commissie toekomt. ${ }^{3}$ $\mathrm{Zij}$ is het dientengevolge die in eerste instantie bepaalt of aan de voorwaarden voor strafoplegging, zoals in bedoeld artikel geformuleerd, is voldaan en of gezien de omstandigheden van het concrete geval een sanctie op haar plaats is. $\mathrm{Zij}$ is het ook die (binnen bepaalde, hierna te bespreken grenzen) de hoogte van de sanctie bepaalt. Tegen de beschikkingen van de Commissie staat voor belanghebbenden beroep open bij het Gerecht en het Hof. ${ }^{4}$ De boetebeschikkingen van de Commissie en de arresten van het Gerecht en het Hof, vormen op grond van de artikelen 244 en 256 EG een executoriale titel. De tenuitvoerlegging van de beslissingen wordt geregeerd door de wettelijke bepalingen van de staat waar zij plaatsheeft; zij kan derhalve niet door de communautaire organen zelf geschieden. Het recht op inning van de boete binnen de door de Commissie gestelde termijn wordt volgens artikel $242 \mathrm{EG}$ en artikel 53 Statuut niet geschorst door het instellen van beroep bij het Gerecht en het Hof, met dien verstande dat de tenuitvoerlegging wel kan worden opgeschort. Door de expliciete afwijzing van de schorsende werking worden die beroepen voorkomen die als enig doel hebben het verkrijgen van uitstel van betaling van de boete. Eveneens met het oog op de voorkoming van kennelijk ongegronde appèlzaken mag aan

3 Nationale instanties van de lidstaten (waaronder hier mede worden begrepen de nationale rechters) ontberen derhalve een dergelijke bevoegdheid, tenzij eventueeleennationale regeling hierin voorziet.

4 Voor een uitvoerige bespreking van de procedurele gang van zaken bij het Gerecht en het Hof zic Barents (1996). 
de opschorting van de tenuitvoerlegging de voorwaarde worden verbonden dat de ondememing vertragingsrente zal betalen als zij in beroep niet in het gelijk wordt gesteld.

\subsection{Het rechtskarakter van de boete}

De boete van artikel 15 Vo 17 is onmiskenbaar repressief en punitief van aard: reeds uit de hoogte van de maximumboete blijkt dat leedtoevoeging een belangrijk aspect van de boete-oplegging vormt.' De boete heeft voorts een preventief doel: zij moet de beboete, maar ook derde ondernemingen ervan weerhouden het verbod van de artikelen 81 en 82 EG (nogmaals) te overtreden. ${ }^{8}$ Ondanks het feit dat deze aspecten van repressie en preventie inherent zijn aan strafrechtelijke sancties', heeft de boete van artikel 15 Vo 17 op grond van het vierde lid van dit artikel uitdrukkelijk geen strafrechtelijk karakter. ${ }^{10}$ Dereden waarom dit met zoveel woorden in Verordening 17 is opgenomen, moet hierin worden gezocht dat de Raad er geen twijfel over heeft willen laten bestaan dat de soevereiniteit van de lidstaten op strafrechtelijk gebied niet zou worden aangetast: het overdragen van strafrechtelijke competentie naar communautair niveau was zeker toentertijd cen heikel

5 Dezemogelijkheid is, ondanks het ontbreken van eenuitdrukkelijke rechtsgrond, door het Hof erkend in: HvJ (107/82) Jur. 1983, 3151 (Allgemeine Elektricitäts-GesellschaftAEG-Telefunken). Het Hof achtte dezerechtsgrond niet noodzakelijk, aangeziende dreiging van een groot aantalkennelijk ongegronde beroepen niet "met de verdragsbepalingen inzake de rechtsbescherming tegen handelingen van de instellingen" beoogd is, hetgeen het Hof afleidde uit artikel 86 paragraaf 2 van het Reglement voor de procesvoering van het Hof.

6 Zic hierover uitgebreid Winkler (1971).

7 De boete heeft daarentegenalthans in theorie geen stigmatiserend karakter. Terecht stelt Mok (1974), pag. 275 , echter dat het diffamerende karakter van een sanctie veeleer afhangt van de "waardering van het strafbare feit door de rechtsgenoten".

8 Zie voor een uitdrukkelijke erkenning van de preventieve werking HvJ (100-103/80) Jur. 1983, 1882 (Musique Diffusion Française). Vergelijk voorts onder meer Pb 1980 L 377/27 (Johnson \& Johnson) en Pb 1982 L 161/32 (Hasselblad), alsmede Van Gerven c.s. (1997), pag. 699 en Brittan (1993), pag. 12. Tot op zekere hoogte heeft de boete tevens een reparatoir karakter, namelijk voorzover via de boete winsten, verkregenuit kartelovertredingen, worden ontnomen. In hoeverre deze winstontneming, die overigens in belangrijke mate kan bijdragen aan preventic, inderdaad in het communautaire recht een rol speelt, zal in paragraaf 4.4 .2 worden besproken.

9 Zie onder meer Hazewinkel-Suringa/Remmelink(1996), pag. 893 e.v., Van Bemmelenen Van Veen (1998), pag. 14 e.v. en Schermers (1987), pag. 603.

10 'De beschikkingen, gegeven krachtens het eerste of tweede lid, hebben geen strafrechtelijkkarakter'. Vrijwel gelijkluidend artikel 22 Vo 1017/68, artikel 19 lid 4 Vo 4056/86 en artikel 12 lid 4 Vo 3975/87. In GvEA (T-83/91) Jur. 1994, II-755 (Tetra Pak Intemational) ontkende het Gerecht nogmaals uitdrukkelijk de strafrechtelijke aard van de boete. Ook het 'Voorstel uitvoeringsverordening' verandert hieraan niets. Vervaele (1995), pag. 84, vraagt zich af of deze ontkenning nog wel stand kan houden gelet op de Straatsburgse jurisprudentie inzake de 'criminal charge'. In het midden latend of de Europese Gemeenschapdaadwerkelijk gebonden is aan het EVRM (daarop wordt in hoofdstuk 5 uitvoerig ingegaan), moet zijn vraag mijns inziens bevestigend worden beantwoord. De jurisprudentie van het EHRM doet immers niets af aan de kwalificatie die in een bepaalde rechtsorde wordt gehanteerd; indien het EHRM artikel 6 EVRM op een bepaald rechtsgebied van toepassing acht, betekent dit nog niet dat het dus ook 'nationaalrechtelijk' tot het strafrecht moet worden gerekend. 
en waarschijnlijk onbespreekbaar punt. ${ }^{11} \mathrm{Nu}$ met zoveel nadruk is bepaald dat het communautaire sanctierecht niet als strafrecht mag worden aangemerkt, kan de vraag worden gesteld tot welk rechtsgebied het dan wel behoort. Gelet op het feit dat de boete door een administratief orgaan wordt opgelegd, ligt het voor de hand het communautaire sanctierecht tot het bestuursrecht te rekenen. ${ }^{12}$ En aangezien het gaat om de oplegging van punitieve sancties (in tegenstelling tot de reparatoire sancties van het 'klassieke' administratieve recht), zou het gemeenschapsrecht op dit punt als een species van het -in Nederland nog relatief jonge, maar wel zeer in opmars zijnde ${ }^{13}$ - genus 'bestuurlijk boeterecht' kunnen worden gezien. ${ }^{14}$ Het belang van een dergelijke kwalificatie is echter niet meer dan marginaal, aangezien er geen al te vergaande consequenties aan mogen worden verbonden. ${ }^{15}$ Het EG-boeterecht is hoe dan ook communautair recht, dat een autonoom karakter

11 In dezelfde zin Kerse (1998), pag. 287 en 288 en A-G Mayras die in zijn conclusie bij HvJ (7/72) Jur. 1972, 1302 (Boehringer) stelt: "Ongetwijfeld hebben de Lid-Staten op economisch gebied de uitoefening van eenaantal hunner soevereinerechtenaan de instellingender Gemeenschapovergedra. gen, doch anderzijds staat al evenzeer vast dat zj niet van zins waren hun bevoegdheden op strafrechtelijk terrein uit handen te geven". Mulder(1971), pag, 205-206, zoekt de reden erin dat het aanmerken van de communautaire procedure als strafrecht zich niet zou hebben verdragen met de klassieke strafrechtelijkedoctrine, niet in de laatsteplaats omdat daarinstrafrechtelijkeaansprakelijkheidvan rechtspersonen werd afgewezen. A-G Gand wijst in zijn conclusie bij de Kinine-arresten (HvJ (41, 44 en 45/69) Jur. 1970, 686) er overigens op dat ook zonder uitdrukkelijke vermelding het niet-strafrechtelijke karakter van de communautaire boete zou hebben vastgestaan.

12 Mulder (1971), pag. 208, concludeert "dat men te maken heeft met administratieve sanctie-oplegging".

13 Men denke alleen al aan het fiscale recht (artikel 67a-67q AWR), de Wet administratiefrechtelijke handhaving verkeersvoorschriften(Lex Mulder) en de Mededingingswet. Zie over de toch explosieve ontwikkeling van de gebruikmaking van de bestururlijke boete als middel tot handhaving van wetgeving Michiels (1994) en Schaffmeister (1995), pag. 59 e.v..

14 Mok (1974), pag. 269, duidt de bevoegdheid tot het opleggenvan een boete aan als 'kwasi-strafrecht'. Vervaele (1995), pag. 83, spreekt van "een communautair bestuurlijk boetesysteem in de ware zin van het woord", In de Duitse literatuur wordt vaak aansluiting gezocht bij het Ordnungswidrigkeitenrecht; vergelijk bijvoorbeeldWinkler(1971), DanneckerenFischer-Fritsch(1989), pag. 7 en Hamann (1992). Dit recht vertoont, hoewel het tot het strafrecht in ruime zin wordt gerekend, op verschillende punten gelijkenis met het bestuurlijke boeterecht zoals dat in Nederland geldt. Voor een bespreking van het Ordnungswidrigkeitenrecht zie men bijvoorbeeld Rosenkötter (1988). Hier wordt volstaan met een korte karakterschets. Het Ordnungswidrigkeitenrecht onderscheidt zich van het 'Kriminalstrafrecht'. Hoewel de scheidslijn tussen beide niet concreet is aan te geven, omvat het Ordnungswidrigkeitenrechtdelicten met een geringer 'Unrechtsgehalt'. Hiermee samen hangt het kwalitatieve verschil in sanctie-oplegging: een overtreding van een wettelijke bepaling vallende binnen het Kriminalstrafrecht kan onder meer leiden tot de oplegging van een Geldstrafe, terwijl wegens een Ordnungswidrigkeit een niet diffamerende en niet moreel geladen Geldbuße opgelegd kan worden. De boeteoplegging wegens een Ordnungswidrigkeit ligt in handen van een Verwaltungsbehōrde, een administratief orgaan derhalve (Bos (1983), pag. 679, sprak mede daarom van 'pseudo-administratief recht'). Dit orgaan behandelttevens het eventuele bezwaartegen zijn beslissing, in die zin dat het onder meer moet nagaan of de boetebeschikking dient te worden ingetrokken; is dit laatste niet het geval, dan zal het orgaan de zaak aan het openbaar ministerie moeten overdragen, dat de zaak in beginsel aan het Amtsgericht zal voorleggen.

15 Hetzelfdegeldt indien het EG-boeterechttot een anderrechtsgebied, zoals het Ordnungswidrigkeitenrecht, zou worden gerekend. Whish (1995), pag. 51, heeft gelijk waar hij stelt dat er geen duidelijkheid bestaat over het antwoord op de vraag of het EG-boeterecht onder het bestuursreeht dan wel onder het Ordnungswidrigkeitenrecht valt. Het belang van het antwoord is mijns inziens echter van gering belang. 
he:ft. ${ }^{16}$ Dit brengt met zich dat, zoals Van Acker ${ }^{17}$ terecht stelt, 'nationale' kwalificaties nosit bindend kunnen zijn voor de communautaire rechtsorde. Bij de ontwikkeling van he communautaire recht kan het nationale recht dientengevolge wel als bron van inspiratie furgeren, maar het biedt in dat verband geen dwingende antwoorden. ${ }^{18}$ Concreet betekent ditdat als het communautair recht, waar het de strafoplegging betreft, het etiket van 'bestuurlijk boeterecht' wordt opgeplakt, hieruit niet de conclusie mag worden getrokken da nationale normen uit dat rechtsgebied dus (onverkort) voor het communautaire recht geden. ${ }^{19}$ Het betekent evenmin dat indien de Commissie en de communautaire rechters in het kader van hun taakuitoefening aanknopingspunten in het nationale recht zoeken, zijmet handen en voeten gebonden zijn aan (normen of leerstukken van) het bestuurlijk boterecht; voorzover andere rechtsgebieden, zoals bijvoorbeeld het strafrecht, die aanknopirgspunten bevatten, mag daaruit onverminderd geput worden. Gelet op het beperkte beang van een catalogisering als hiervoor bedoeld en gelet op het gevaar ervan (te weten da in weerwil van het autonome karakter van het gemeenschapsrecht een bij die kwalificatiehorend normenstelsel wordt 'meegenomen'), verdient het mijns inziens de voorkeur on het communautair (boete)recht als rechtsgebied sui generis aan te merken ${ }^{20}$; een rechtsgebied dat op tal van punten overeenkomst vertoont met het bestuurlijk boeterecht (et het Ordnungswidrigkeitenrecht) $)^{21}$, maar dat -gelet op zijn autonome karakter en tegen de achtergrond van de doeleinden van het EG-Verdrag- zijn eigen normenstelsel heeft en een eigen, onafhankelijke weg volgt. ${ }^{22}$ Dat in de praktijk deze weg niet zelden

16 HvJ (26/62) Jur. 1963, 3 (Van Gend en Loos), HvJ (6/64) Jur. 1964, 1199 (Costa-ENEL), HvJ (14/68) Jur. 1969, 1 (Walt Wilhelm e.a.), HvJ (11/70) Jur. 1970, 1125 (Internationale Handelsgesellschaft) en HvJ (106/77) Jur. 1978, 629 (Simmenthal). Uit deze jurisprudentie (en uit het autonome karakter zelf) volgt tevens dat het communautaire recht voorrang heeft boven het nationale recht. Zie hierover Barents en Brinkhorst (1999), pag. 34 e.v..

17 Van Acker (1986), pag. 389.

18 Terecht stelt Kühlhorn (1986), pag. 12 dan ook: "Als eigenstăndige Rechtsordnung, die der EuGH zu entwickeln hat, ist das EWG-Recht bei seiner Fortbildung nicht auf den kleinsten gemeinsamen Nenner aller mitgliedstaatlichenRechtsordnungen festgelegt, sondern hat die Lősung zu suchen, die im Rahmen des Integrationszieles sachgerecht ist". Overigens zijn de nationale fundamentele (grond)rechten wel rechtstreeks van belang omdat zij als algemene rechtsbeginselen van gemeenschapsrecht gelden. Hierop wordt later nog ingegaan.

19 In dezelfde zin Van Acker (1986), pag. 390. Daarbij komt overigens nog dat op wezenlijke punten veelal geen sprake zal zijn van een communis opinio binnen de verschillende lidstaten.

20 Aldus ook Van Acker (1986), pag. 393.

21 Dit springt met name in het oog op het gebied van de rechtsbescherming. Zowel het communautair boeterecht, het bestuurlijk boeterecht als het Ordnungswidrigkeitenrecht zijn dan weliswaar geen strafrecht in enge zin, zij zijn alle onverkort punitief van aard. Dit vereist een versterkte aandacht voor de beschermingvan de fundamentelerechtenvan de justitiabele, zoals die onder meerzijn verankerd in het EVRM. In de praktijk blijkt dit EVRM binnen alle drie rechtsgebiedeneen vooraanstaande rol te spelen: in het bestuurlijk boeterecht en het Ordnungswidrigkeitenrecht omdat het EHRM beeft beslist dat het EVRM ook voor deze rechtsgebieden geldt; in het communautaire recht omdat het EVRM, met name op grond van de jurisprudentie van het Hof, een van de belangrijkste bronnen van de algemene rechtsbeginselen van het gemeenschapsrecht is. Zie hierover nader Hoofdstuk 5.

22 Door het communautaire boeterecht als sui generis rechtsgebied te typeren, wordt voorkomen dat onderdelen van het gemeenschapsrecht die vanwege de principiêle afwijkende communautaire belangen en doeleinden niet binnen de grenzen van het strafrecht of bestuursrecht blijken te vallen hetzij verworpen worden als zijnde strijdig met het overeenkomstige rechtsgebied hetzij via een gekunstelde (en daarmee onbevredigende) interpretatic alsnog binnen dit rechtsgebied worden gebracht. 
parallel loopt aan met name de strafrechtelijke weg, moge uit de volgende paragraaf blijken waarin drie van origine strafrechtelijke leerstukken worden behandeld.

\section{Drie (strafrechtelijke) leerstukken}

\subsection{Schuld: opzet en onachtzaamheid ${ }^{23}$}

Het in artikel 15 Vo 17 geformuleerde schuldvereiste vergt afzonderlijke aandacht en tevens enige toelichting. In het gemeenschapsrecht is het uitgangspunt de onwenselijkheid van kartels gelet op hun schadelijke effecten voor de verwezenlijking van de doeistellingen van het EG-Verdrag. Deze effecten van een kartel kunnen optreden ongeacht de vraag of de betrokken ondernemingen een verwijt valt te maken. Het civielrechtelijke verbod dient zich, juist met het oog op de negatieve gevolgen, uit te strekken over iedere gedraging die inbreuk maakt of kan maken op de interstatelijke handel ook als deze gedraging niet aan schuld van de betrokken ondernemingen is te wijten. Dit brengt mee dat schuld geen vereiste kan zijn voor de artikelen 81 lid 1 en 82 EG en evenmin voor de bevoegdheid van de Commissie ex artikel 3 Vo 17 om de ondernemingen te verplichten de inbreuk te beëindigen. De bevoegdheid tot het opleggen van boetes is daarentegen wel afhankelijk

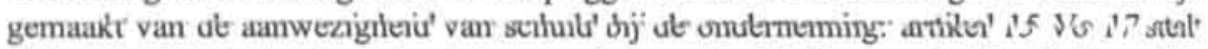
uitdrukkelijk dat slechts een boete kan worden opgelegd indien opzettelijk of uit onachtzaamheid is gehandeld, waarmee het van oorsprong strafrechtelijke principe 'geen straf zonder schuld' in het communautaire recht zijn intrede heeft gedaan. ${ }^{24}$ De inhoud van de begrippen 'opzet' en 'onachtzaamheid' is noch in Verordening 17 noch in enige andere regeling geconcretiseerd. Deze conclusie geldt evenzeer voor de minimaal vereiste mate van onachtzaamheid. Bij de invulling van beide begrippen is er derhalve een grote discretionaire vrijheid van de Commissie, met dien verstande dat de uiteindelijke interpretatie van de rechtsbegrippen door het Hof geschiedt. Aangezien het schuldbegrip een bij uitstek strafrechtelijk gekleurd begrip is, is de verleiding groot bij de interpretatie van deze van de strafrechtelijke inhoud uit te gaan. Nog los van de vraag of er enige (Europese) consensus gevonden zou kunnen worden ten aanzien van de strafrechtelijke betekenis van opzet c.q. Onachtzaamheid, geldt ook hier dat het gemeenschapsrecht, als deel van een eigen communautaire rechtsorde, niet gebonden is aan enige bestaande nationale interpretatie, dus ook niet aan de nationale, strafrechtelijke invulling van het schuldbegrip. Desalniettemin kan hier, vooruitlopend op de bespreking van de communautaire betekenis van de genoemde begrippen, gesteld worden dat zij (inhoudelijk) sterk strafrechtelijk gekleurd zijn.

23 Zie voor literatuur ten aanzien van schuld en opzet in het Nederlandse strafrecht: Peters (1966), Brouns (1988), Hazewinkel-Suringa-Remmelink (1994), Van Bemmelen en Van Veen (1998) en Keulen en Otte (1999). Expliciet op de schuldvraag van artikel 15 Vo 17 gaat Siohl (1986) in.

24 Aldus is er geen sprake van risicoaansprakelijkheid, hetgeen ook op gespannen voet zou staan met artikel 6 EVRM. Op de betekenis van dit artikel voor het communautaire recht wordt in hoofdstuk 5 nader ingegaan. 
Qver het algemeen geeft de Commissie in haar beschikkingen met zoveel woorden aan dit zij schuld aanwezig acht. ${ }^{25}$ In lang niet alle gevallen daarentegen differentieert de Ommissie naar schuld'soort': zij laat dan -door gebruik te maken van de zinsnede 'althans ut onachtzaamheid' (of van woorden van gelijke strekking) ${ }^{26}$-in het midden of er sprake isvan opzet dan wel van onachtzaamheid. Artikel 15 Vo 17 eist een dergelijke differentieing ook niet: ten eerste omdat zij -anders dan in het strafrecht gebruikelijk is- niet van invloed is op de 'strafbaarheid' (met andere woorden: zowel de doleuze als de culpoze irbreuk kan worden beboet); ten tweede omdat volgens de letter van artikel 15 Vo 17 ht verschil tussen opzet en onachtzaamheid geen gevolgen heeft voor de (maximum)sancti. Toch bestaan er mijns inziens bezwaren tegen deze aanpak. De mate van schuld kán inmers wel een factor zijn die bij de strafmaatbepaling wordt meegewogen (en blijkt dt in de praktijk ook te zijn). ${ }^{27}$ Door gebruik te maken van de zinsnede 'althans uit orachtzaamheid ${ }^{28}$ brengt de Commissie weliswaar formeel tot uiting dat er voor opzet ovvoldoende bewijzen zijn ${ }^{29}$, maar de facto laat zij de mogelijkheid open dat hiervan it het voorliggende geval wellicht toch sprake zou kunnen zijn. ${ }^{30}$ In zoverre zou de shijn gewekt kunnen worden dat uiteindelijk de inbreuk de onderneming toch zwaarder wordt aangerekend dan op grond van de bewijzen is geoorloofd. Of dit daadwerkelijk gebeurt, valt uit de beschikking dan niet of nauwelijks af te leiden, hetgeen mede problematisch is met het oog op de toetsing van de beschikking door de communautaire rechters in een eventuele beroepsprocedure. Om bedoelde schijn te voorkomen, zou het derhalve de voorkeur verdienen dat de Commissie, in geval zij opzet niet acht aangetoond, zich

25 Dit is ook noodzakelijk aangezien schuld een constitutief vereiste voor bestraffing vormt. In enkele beschikkingen heeft de Commissie zich echter niet expliciet over de schuldvraag uitgelaten. In die gevallen kan wel uit de overwegingen van de Commissie worden afgeleid dat schuld bewezen wordt geacht. Vergelijk $\mathrm{Pb} 1982$ L 232/1 (SSI), door het Hof op dit punt goedgekeurd in HvJ (240-242, 261, 262, 268 en 269/82) Jur. 1985, 3831, Pb 1992 L 96/34 (British Midland/Aer Lingus), Pb 1992 L 366/47 (verdeling van treinbiljettendoor reisbureaus)en Pb 1992 L 233/27 (Parker Pen). Het betrof in deze zaken gedragingen waarvan de mededingingsbeperkende aard onmiskenbaar was én waaromtrent de negatieve visie van de Commissie buiten twijfel stond.

26 Zo constateerde de Commissie in Pb 1972 L 272/39 (Pittsburgh Corning Europe) -overigens zonder uitdrukkelijk de gronden aan te geven die haar tot deze conclusie leidden- dat de "inbreuk moet worden geacht met opzet of door verzuim te zijn begaan". Vergelijk voorts onder meer $\mathrm{Pb} 1980$ L 39/51 (Floral), Pb 1982 L 379/1 (UGAL/BNIC) en Pb 1984 L 136/9 (Polistil/Arbois).

27 Vergelijk hierover ook Ortiz Blanco (1996), pag. 231. De Raat en Widdershoven (2000), pag. 775 noemen de mate van schuld een belangrijke wegingsfactor bij het bepalenvan de hoogte van de boete. Op de rol van deze factor bij de boeteoplegging wordt hierna nog uitgebreid ingegaan.

28 Voorzover de Commissie twijfelt over een kwalificatieals 'opzet' voorkomt deze aanpak dat de Commissie haar vingers brandt aan een kwalificatie die in beroep wellicht geen stand houdt. Harding (1993), pag. 83, vindt het dan ook begrijpelijk dat de Commissie het zekere voor het onzekere neemt. Een groot probleem zou dit mijns inziens overigens niet opleveren. Indien in beroep de kwalificatie van de Commissie niet zou worden gevolgd, zou het Gerecht de beschikking (partieel) kunnen vernietigen om vervolgens zelf in de zaak te voorzien. In andere zin: A-G Mayras in zijn conclusie bij $\mathrm{HvJ}$ (26/75) Jur. 1975, 1367 (General Motors Continental).

29 Vergelijk Van Acker (1986), pag. 330.

30 Deze aanpak wordt overigens ook wel buiten gevallen van twijfel gevolgd zie bijvoorbeeld $\mathrm{Pb} 1984$ L 136/9 (Polistil/Arbois), waarin het ging om het verbod op nevenimport waarvan de ondernemingen wisten of hadden moeten weten dat dit een beperking van de mededinging meebracht. 
beperkt tot de kwalificatie 'inbreuk uit onachtzaamheid' (vanzelfsprekend voorzover hiervoor wel voldoende bewijs voorhanden is), waarmee zij duidelijk maakt dat zij bij de straftoemeting uitsluitend onachtzaamheid 'in rekening' brengt. Uiterlijk sinds de zaak naar aanleiding van het Nederlandse bouwkartel ${ }^{31}$ staat vast dat het Hof deze bezwaren niet deelt. Het Hof overwoog dat artikel 15 Vo 17 uitdrukkelijk twee van elkaar te onderscheiden vraagstukken behandelt: onder welke voorwaarden kan een boete worden opgelegd, waarbij de schuldvraag speelt, en welke factoren oefenen invloed uit op de omvang van deze boete, waarbij zwaarte en duur van de inbreuk van belang zijn. Het Hof merkt vervolgens op dat

\footnotetext{
"in de tweede alinea van artikel 15, lid 2, in geen enkel opzicht dwingend (overigens ook niet facultatief) wordt verwezen naar de opleggingsvoorwaarde van de eerste alinea, evenmin trouwens als in de rechtspraak van het Hof betreffende de bepaling van de hoogte van de geldboetes. (...) Bovendien zij opgemerkt dat, zoals de Commissie beklemtoont, de uit onachtzaamheid gepleegde inbreuken althans vanuit het oogpunt van de mededinging niet minder emstig zijn dan de opzettelijk gepleegde inbreuken. (...) Zo gezien was het Gerecht niet verplicht, ter bepaling van de zwaarte van de inbreuk te onderzoeken of deze opzettelijk dan wel uit onachtzaamheid was gepleegd en zeker niet om deze beide gevallen te onderscheiden"."
}

Bij de boetebepaling hoeft de mate van schuld derhalve geen rol te spelen hetgeen impliceert dat een inbreuk uit onachtzaamheid even streng kan worden bestraft als een opzettelijke inbreuk. De noodzaak om tussen beide te onderscheiden, vervalt daarmee, behoudens voor die gevallen waarin de Commissie wél uitdrukkelijk met de mate van schuld bij de boetebepaling rekening wenst te houden. ${ }^{33}$ Een en ander heeft repercussies voor de wijze waarop de communautaire autoriteiten omgaan met de schuldvraag. Het dogmatische verschil tussen opzet en schuld dat in het strafrecht een zeer prominente rol vervult, is voor het communautaire recht van vrijwel ieder belang ontbloot. De schuldvraag wordt veeleer pragmatisch benaderd, hetgeen zich mede vertaalt in een normatieve invulling van de schuld. Hoewel het onderscheid tussen opzet en onachtzaamheid derhalve slechts een relatief ondergeschikte rol speelt, wordt hierop toch ingegaan. Dit gebeurt ten eerste omdat in een aantal gevallen de aard van de schuld toch in aanmerking wordt genomen bij de straftoemeting. ${ }^{34}$ Ten tweede ga ik op het verschil tussen opzet en onachtzaamheid in omdat naar mijn mening het verschil steeds een rol zou moeten spelen bij het bepalen van de strafmaat. Het door het Hof gebruikte argument dat een inbreuk uit onachtzaamheid vanuit mededingingsperspectief niet minder ernstig is dan een opzettelijke overtreding is weliswaar correct, maar hetzelfde geldt mutatis mutandis voor veel (strafbare) feiten. Bij deze echter wordt het in het kader van de straftoemeting veelal wel relevant geacht in hoeverre de dader opzettelijk de door de wet beschermde rechtsbelangen aan zijn laars

31 HvJ (C-137/95 P) Jur. 1996, 1-1611 (Vereniging van Samenwerkende Prijsregelende Organisaties in de Bouwnijverheid e.a.). In dezelfde zin HvJ (C-219/95 P) Jur. 1997, 1-4411 (Ferriere Nord).

32 HvJ (C-137/95 P) Jur. 1996, I-1611 (Vereniging van Samenwerkende Prijsregelende Organisaties in de Bouwnijverheid e.a.).

33 Zie over de SPO-zaak ook Kerse (1998), pag. 297.

34 Dit geldt zekerna de in paragraaf 4.5 te behandelen Richtsnoeren voor de berekening van geldboeten. in die zin dat opzet als 'normale situatie' wordt gezien. Vergelijk in dat verband $\mathrm{Pb} 1998 \mathrm{~L} 124 / 60$ (VW), Pb 1998 L 252/47 (Amministrazione Autonoma dei Monopoli đi Stato), Pb 1999 L 76/1 (British Sugar), Pb 1999 L 109/24 (Griekse veerdienstmaatschappijen), Pb 2000 L 268/1 (Far East Trade Tariff Charges and Surcharges Agreement), Pb 2001 L 54/1 (Nathan-Bricolux), Pb 2001 L 59/1 (Opel) en $\mathrm{Pb} 2001$ L 152/24 (Aminozuren). 
heeft gelapt. Naarmate er meer opzet in het spel is, wordt ook de inbreuk van die dader als emstiger beoordeeld en omgekeerd impliceert een geringer verwijt een minder ernstige overtreding. Hetzelfde zou dienen te gelden ten aanzien van het communautaire kartelverbod.

\subsubsection{Opzet}

Bij opzet staan twee vragen centraal die tot op zekere hoogte met elkaar verband houden. De eerste vraag betreft het onderscheid tussen boos opzet en kleurloos opzet: dient de opzet gericht te zijn op de overtreding van de wettelijke of verdragsrechtelijke bepaling of is het voldoende dat de opzet op de gedraging is gericht? De tweede vraag is gericht op de eisen die aan het gedrag zijn gesteld, wil er sprake zijn van opzet; in hoeverre dient de onderneming willens en wetens de overtreding te hebben begaan alvorens tot opzet geconcludeerd kan worden? De connectie tussen beide is gelegen op bewijstechnisch vlak: bewijs van het willens en wetens overtreden van een wettelijke bepaling is immers over het algemeen moeilijk te leveren. ${ }^{35}$

\section{Opzet: boos of kleurloos?}

Opzet is de zwaarste van de twee schuldvarianten die artikel 15 Vo 17 kent. De plaatsing van het begrip 'opzet' in lid 2 van dit artikel doet vermoeden dat deze gericht moet zijn op het overtreden van artikel 81 lid 1 respectievelijk artikel 82 EG en dat de Raad daarmee voor een in de Nederlandse literatuur als 'boos opzet' aangeduide vorm van opzet heeft gekozen: opzettelijk handelt slechts degene die weet dat zijn gedraging (wettelijk) verboden is. ${ }^{36}$ Advocaat-Generaal Mayras ${ }^{37}$, aansluiting zoekend bij het strafrecht van de lidstaten, concludeerde inderdaad dat opzet inhoudt:

\footnotetext{
"dat de betrokkene heeft gehandeld met de wil een bedoelde handeling te verrichten waarvan hij wist dat zij onwettig en in het Verdrag verboden is, en zich daarbij bewust was van de ongeoorloofde gevolgen van zijn gedrag".
}

Het is onduidelijk of de Commissie en het Hof in hun eerste boetebeslissingen zijn uitgegaan van boos opzet. In de Kinine-beschikking ${ }^{38}$ stelde de Commissie dat de ondernemingen wisten dat hun gedragingen inbreuk maakten op artikel $81 \mathrm{EG}$, welke conclusie op grond van de feiten voor de hand lag. Het feit echter dat de Commissie hier de aanwezigheid van wetenschap van het verboden karakter van de gedragingen constateert, houdt als zodanig nog niet in dat zij de wetenschap van de overtreding van het gemeenschaps-

35 Het hanteren van een 'boos opzet' - begrip hoeft echter voor de beboeting als zodanig nog geen fatale gevolgen te hebben, aangezien de onachtzaamheid in deze als vangnet dient.

36 Zie hierover onder meer Hazewinkel-Suringa/Remmelink(1996), pag. 226 en 227, Van Bemmelen en Van Veen (1998), pag. 84, Kelk (1998), pag. 175 en 176, Keulen(1995), pag. 40 e.v. en De Hullu (2000), pag. 208-211.

37 HvJ (26/75) Jur. 1975, 1367 (General Motors Continental),

38. $\mathrm{Pb} 1969 \mathrm{~L} 192 / 5$ (Kinine). 
recht ook als voorwaarde voor opzet heeft gezien. De Kleurstoffenbeschikking ${ }^{39}$ geeft desalniettemin aanleiding om aan te nemen dat de Commissie inderdaad het boos opzet als uitgangspunt heeft genomen, daar zij overwoog

"dat de ondernemingen wisten of er in elk geval niet onbekend mede konden zijn dat (hun) gedragingen inbreuken vormden op artikel 85 (thans 81 EG, HQ)".

Uit het gegeven dat de Commissie concludeerde dat de ondernemingen "althans uit grove onachtzaamheid" hadden gehandeld, zou kunnen worden afgeleid dat zij de wetenschap van de overtreding van artikel 81 EG niet bewezen achtte. De beslissing van de Commissie ten aanzien van het kartelmatig gedrag binnen de suikerindustrie wijst in een andere richting. ${ }^{40}$ De Commissie overwoog hier:

"dat betrokkenen opzettelijk of althans uit grove nalatigheid inbreuken hebben gepleegd aangezien zij niet onwetend waren of althans niet onwetend hadden kumnen zijn van de mededinging beperkende gevolgen van deze gedragingen".

Relevant was hier dus klaarblijkelijk niet of de ondernemingen wisten dat zij inbreuk maakten op het kartelverbod van artikel 81 (en 82 EG); voldoende was dat zij wisten dat het kartelgedrag de mededinging zou kunnen beïnvloeden. Hier lijkt de Commissie te opteren voor het (in het Nederlandse strafrecht geldende) kleurloos opzet: het op straffe verboden zijn van zijn gedraging behoeft de dader niet te hebben geweten. ${ }^{41}$ In de beroepszaak tegen laatstbedoelde beschikking van de Commissie overwoog het Hof dat

"ofschoon verzoekster moet hebben beseft dat het opbouwen van een afzetnet (...) de mededinging kon beperken, de mogelijkheid nochtans niet uitgesloten moet worden geacht dat de bewoordingen der mededeling (van de Commissic, HQ) de opvatting hebben doen postvatten dat zulk een handelwijze toch als met het Verdrag verenigbaar werd beschouwd", ${ }^{2}$

Naar mijn mening heeft het Hof hier in navolging van de Commissie gekozen voor de hantering van kleurloos opzet: voldoende was dat de onderneming willens en wetens de mededinging beînvloedde. Dat het Hof desalniettemin geen boete oplegde, hangt samen met de mededeling van de Commissie: het aldus opgewekte vertrouwen leidde ertoe dat de onderneming geen verwijt kon worden gemaakt. ${ }^{3} \mathrm{De}$ in het Suiker Unie-arrest ingeslagen weg wordt ook -op een enkele uitzondering na ${ }^{44}$ - in latere uitspraken van het Hof

39 In vergelijkbare zin $\mathrm{Pb} 1972$ L 299/51 (Zoja CSC/CI).

$40 \mathrm{~Pb} 1973$ L. 140/17 (Europese Suikerindustrie).

41 Aldus Hazewinkel-Suringa/Remmelink(1996), pag. 226. Vergelijkook Kelk(1998), pag. 175: "voor het aanwezig achten van opzet is het niet nodig dat wordt vastgesteld dat de betrokkene wist dat wat hij deed wederrechtelijkis en ook wettelijk strafbaar is gesteld". In vergelijkbare bewoordingen Van Bemmelen en Van Veen (1998), pag. 84.

42 HvJ $(40-48,50,54-56,111,113$ en 114/73) Jur. 1975, 1663 (Coöperatievevereniging "Suiker Unie" UA c.a.).

43 Anders: Van Acker (1986), pag. 331. Zij stelt dat het Hof hier heeft gekozen voor 'boos opzet'.

44 In HvJ (27/76) Jur. 1978, 207 (United Brands) overwoog het Hof dat de onderneming "maatregelen heef genomen waarvan zij wist of had moeten weten dat zij inbreuk maakten op het verbod van artikel 86 EEG-Verdrag (thans artikel 82 EG, HQ)". Deze conclusiekan echterniet los gezien worden van de eerdere overweging van het Hof dat het een onderneming betrof "die door haar langjarige ervaring in de internationale en nationale handel bijzonder goed bekend is met de wettelijke regelingen 
bewandeld. Zo achtte het Hof het in het Miller-arrest ${ }^{45}$ niet van belang "of verzoekster zich al dan niet ervan bewust was het verbod van artikel 85 (thans $81 \mathrm{EG}, \mathrm{HQ}$ ) te overtreden $^{n+6}$ en stelde het in de beroepszaak tegen de Pioneer-beschikking uitdrukkelijk dat uit het gedrag van Pioneer kon worden afgeleid dat

"deze onderneming zich ten volle bewust moet zijn geweest van het feit dat haar gedrag van dien aard was, dat het beperkingen van de mededinging bevorderde. Een dergelijke kennis volstaat om het handelen van deze onderneming als opzettelijk aan te merken"."t

\section{Aangezien de Commissie deze jurisprudentie volgt ${ }^{48}$-hoewel zij in enkele beschikkingen}

op het gebied van de mededinging, waarvan zij de gestrengheid reeds heeft ondervonden". Wat gesteld is ten aanzien van de Kinine-beschikking, geldt ook hier: dat de onderneming in casu-mede gelet op de aard van de gedragingen- wist of had dienen te weten dat haar gedrag een inbreuk op artikel 82 EG vormde, betekent nog niet dat deze wetenschap ook daadwerkelijk als een vereiste moet worden aangemerkt.

45 HvJ (19/77) Jur. 1978, 131 (Miller International Schallplatten).

46 Een vergelijkbare overweging kan aangetroffen worden in HvJ ( 32 en 36-82/78) Jur. 1979, 2435 (BMW): "niet van belang (is) of (de onderneming) zich al dan niet ervan bewust was, dusdoende tegelijkertijd het verbod van artikel 85, lid 1, EEG-Verdrag (thans artikel 81 EG, HQ) te overtreden". Zie eveneens HvJ (96-102, 104, 105, 108 en 110/82) Jur. 1983, 3369 (LAZ International Belgium e.a.).

47 HvJ (100-103/80) Jur. 1983, 1825 (Musique Diffusion Française). Vergelijk ook HvJ (246/86) Jur. 1989, 2117 (Belasco c.a.): "Het volstaat, dat de onderneming niet onkundig kon zijn van de omstandigheid, dat de gewraakte handelwijze ertoe strekte de mededinging te beperken". In gelijke zin HvJ (C-279/87) Jur. 1990, 1-261 (Tipp-Ex), GvEA (T-15/89) Jur. 1992, II-1275 (Chemie Linz), GvEA (T-61/89) Jur. 1992, II-1931 (Dansk Pelsdyravlerforening), GvEA (T-65/89) Jur. 1993, II-389 (BPB Industries en British Gypsum), GvEA (T-43/92) Jur. 1994, II-441 (Dunlop Slazenger International), GvEA (T-66/92) Jur. 1994, II-531 (Herlitz), GvEA (T-77/92) Jur. 1994, II-549 (Parker Pen), GvEA (T-83/91) Jur. 1994, II-755 (Tetra Pak International), GvEA (T-29/92) Jur. 1995, II-289 (Vereniging van Samenwerkende Prijsregelende Organisaties in de Bouwnijverheid e.a.), GvEA (T-141/89) Jur. 1995, II-791 (Tréfileurope Sales), GvEA (T-142/89) Jur. 1995, II-867 (Usines Gustave Boël), GvEA (T-143/89) Jur. 1995, II-917 (Ferriere Nord), GvEA (T-145/89) Jur. 1995, II-987 (Baustahlgewebe), GvEA (T-150/89) Jur. 1995, II-1165 (Martinelli), GvEA (T-229/94) Jur. 1997, II-1689 (Deutsche Bahn), GvEA (T-213/95 en T-18/96) Jur. 1997, II-1739 (Stichting Certificatie Kraanverhuurbedrijf en Federatie van Nederlandse Kraanverhuurbedrijven), GvEA (T-310/94) Jur. 1998, II-1043 (Gruber+Weber), GvEA (T-347/94) Jur. 1998, II-1751 (Mayr-Melnhof Kartongesellschaft), GvEA (T-348/94) Jur. 1998, II-1875 (Enso Española), GvEA (T-305-307, 313-316, 318, 325, 328, 329 en 335/94) Jur. 1999, II-931 (Limburgse Vinyl Maatschappij e.a.) en GvEA (T-62/98) n.n.g. (Volkswagen).

$48 \mathrm{~Pb} 1987$ L 222/28 (Sandoz): Het kan Sandoz niet "zijn ontgaan dat het uitvoerverbod tot doel had de mededinging te beperken in het handelsverkeer tussen Lid-Staten. Het is dan ook niet van wezenlijk belang na te gaan of Sandoz PF al dan niet wist dat zij het verbod van artikel 85 overtrad". Zie bijvoorbeeld ook Pb 1976 L 95/1 (Chiquita), Pb 1978 L 22/23 (Hugin/Liptons), Pb 1982 L 117/15 (AEGTelefunken), Pb 1983 L 229/1 (Windsurfing International), Pb 1986 L 232/15 (Bitumineuze Dakbedekking), $\mathrm{Pb} 1988 \mathrm{~L} 49 / 19$ (Fisher-Price) en $\mathrm{Pb} 1989$ L 10/50 (BPB). Ook in recente beschikkingen wordt deze lijn gecontinueerd; zie Pb 1995 L 272/16 (BASF Lacke + Farben) waarin het volgens de Commissie volstaat "dat de onderneming niet onkundig kon zijn dat de gewraakte handelswijze ertoe strekte de mededinging te beperken" en met betrekking tot verordening 1017/68, $\mathrm{Pb} 1994 \mathrm{~L}$ 378/34 (Far Eastem Freight Conference). In deze beschikking werd geconcludeerd dat de ondernemingen het oogmerk hadden onderlinge prijsconcurrentie uit te schakelen en dus er niet onkundig van konden zijn dat hun gedraging strekte tot beperking van de mededinging. In Pb $1996 \mathrm{~L}$ 201/1 (ADALAT) overwoog de Commissie: "Bayer wijst erop dat zij van mening is dat de in deze beschikking 
wel uitdrukkelijk ingaat op de kennis bij de onderneming omtrent het communautaire kartelrecht en met name (de strekking van) de artikelen 81 en $82 \mathrm{EG}^{49}$-, kan worden geconcludeerd dat in ieder geval sinds het Suiker Unie-arrest, moet worden uitgegaan van een opzetbegrip dat kan worden aangemerkt als kleurloos. ${ }^{50}$ Met deze conclusie is nog niet de vraag beantwoord wanneer de Commissie en het Hof aannemen dat er sprake is van opzet. Deze problematiek komt hierna aan de orde.

\section{Opzet: willens en wetens}

In de Nederlandse strafrechtstheorie wordt opzet doorgaans vertaald met 'willens en wetens handelen'.51 Dit willens en wetens handelen blijkt ook in de Europese jurisprudentie het uitgangspunt bij de beantwoording van de vraag of een onderneming opzettelijk heeft geageerd. In de Miller-beschikking achtte de Commissie de opzet ten aanzien van een exportverbod bewezen omdat de onderneming "heeft geweten en gewild dat haar afnemers door het exportverbod zouden worden verhinderd met de contractsprodukten in de andere gemeenschapslanden concurrentie te voeren". ${ }^{52} \mathrm{Nu}$ kan het aantonen van opzet problematisch zijn aangezien het 'weten en willen ${ }^{53}$ ' iets interns, iets subjectiefs is. Aangezien zelden door ondernemingen opzettelijk handelen zonder meer wordt erkend ${ }^{54}$, moet

onderzochte aspecten van haar gedrag niet onder de bepalingen van artikel 85 , lid 1 vallen. Een vergissing in de juridische beoordeling door Bayer doet niets af aan het feit dat welbewust voor dit gedrag is gekozen". Vergelijk verder Pb $1998 \mathrm{~L}$ 252/47 (Amministrazione Autonoma dei Monopoli di Stato), Pb 1999 L $76 / 1$ (British Sugar) en Pb 2000 L 39/1 (Nederlandse Federatieve Vereniging voor de Groothandel op Elektrotechnisch Gebied en Technische Unie).

49 Men zie bijvoorbeeld Pb 1976 L $357 / 40$ (Miller Schallplatten)en Pb 1988 L 78/34 (Konica) alsmede $\mathrm{Pb} 1976$ L. 223/27 (Vitaminen) en Pb 1981 L $353 / 33$ (Michelin). Hieruit mag mijns inziens echter niet worden afgeleid dat de Commissie afstand heeft genomen van het kleurloos opzet. In de eerste twee zaken stond onomstotelijk vast dat de betrokken ondernemingen op de hoogte waren van het kartelverbod en dat hun gedragingen dus in versterkte mate als opzettelijk konden worden aangemerkt. In de laatstgenoemdezaken waren de gedragingen van dien aard dat er geen twijfel over kon bestaan dat inbreuk op het EG-Verdrag werd gemaakt. De ondernemingen in kwestie hadden derhalve op de hoogte moeten zijn van de onrechtmatigheid van hun handelen.

50 Vergelijk Emmerich (1994), pag. 518: "Für die Annahme von Vorsatz genügt hierbei schon die Kenntnis der Tatbestandsmerkmale der fraglichen Handlung, während es nicht erforderlich ist, da $B$ der Tăter zusātzlich das BewuBstsein eines Verstoßes gegen die Wettbewerbsregelnhat". Aldus ook Dannecker en Fischer-Fritsch (1989), pag. 283: "Verbotskenntnis, d.h. Kenntnis des generellen Verbotenseins der Handlung, ist nicht erforderlich".

51 Hazewinkel-Suringa/Remmelink(1996), pag. 202, Enschedé (1995), pag. 148, Kelk (1998), pag. 177. Van Bemmelen en Van Veen (1998), pag. 81, Keulen en Otte (1999), pag. 9 e.v. alsmede De Hullu (2000), pag. 205.

$52 \mathrm{~Pb} 1976$ L $357 / 42$ (Miller International Schallplatten). Vergelijk ook Pb 1979 L 16/9 (Kawasaki), waarin de Commissie overwoog dat de ondernemingen "opzettelijk inbreuk gemaakt hebben op artikel 85 , lid 1, doordat zij wisten en beoogden dat de afnemers in andere Gemeenschapslandende toegang tot de markt (...) zou worden ontzegd".

53 Waarbij het op de koop toe nemen van de gevolgen reeds voldoende is, aldus Mayras in zijn conclusic bij het General Motors-arrest. Hier kan een parallel worden getrokken met het in Nederland gehanteerde 'voorwaardelijk opzet', zoals aanvaard in HR 9 november 1954, NJ 1955, 55 m.nt. WP (Cicero).

54 Soms wordt het de Commissie echtergemakkelijkgemaakt, namelijk indien zoals in $\mathrm{Pb} 1969 \mathrm{~L}$. $192 / 5$ (Kinine) in vergadernotulen het weinig verhullende commentaaris opgenomen dat een onderneming ervan op de hoogte is dat "de gehele overeenkomst reeds zo onrechtmatig is als het maar kan" of 
he opzet uit (externe) omstandigheden worden afgeleid. In het communautaire kartelrecht is er dan ook -evenals in het Nederlandse strafrecht $t^{55}$ - sprake van een onmiskenbare objectivering of normativering van schuld. ${ }^{56}$ Daarbij wordt een groot gewicht toegekend aan de eventuele kennis van een onderneming van het communautaire kartelrecht ${ }^{57}$. hergeen bijvoorbeeld het geval is indien zij op een vroeger tijdstip een overeenkomst bij de Commissie heeft aangemeld ${ }^{58}$, er door de Commissie reeds eerder is geïntervenieerd", haar door een (bedrijfs)jurist een advies inzake de Europese kartelregels is verleend ${ }^{60}$ of zij door handelaren of concurrenten op de strijdigheid van een gedraging met het EG-Verdrag is gewezen (en desondanks de overeenkomst uitvoert) ${ }^{61}$ - maar ook aan het 'hebben moeten kennen van het verbod' ${ }^{62}$ De communautaire kartelautoriteiten gan ervan uit dat een onderneming die zich op de EG-markt begeeft, weet welk gedrag ormiskenbaar tot beperking van de mededinging kan leiden en dat zij dit gedrag dan ock zal nalaten. Men zou kunnen spreken van een 'Garantenstellung', waarbij op de ondernemingen -ook op relatief kleine ondememingen ${ }^{63}$ - een vergaande zorgplicht rust dis inhoudt dat zij van de laatste stand van zaken op het gebied van het communautaire

indien zoals in Pb $1998 \mathrm{~L} 124 / 60$ (VW) de onderneming in een interne nota de gedraging als 'sehr bußgeldverdächtig' aanmerkt. Vergelijk voorts $\mathrm{Pb} 1982$ L 167/39 (NAVEWA-ANSEAU).

55 Zie hierover Buruma (1998), pag. 2 e.v. en Kristen, Borgers en Koopmans (1998), pag. 24-27.

56 Zo wordt, aldus ook Gyselen (1993), pag. 64, in de pogingen van een onderneming om systematisch haar gedragingen geheim te houden een aanwijzing gevonden voor de aanwezigheid van opzet. De achterliggende gedachte hierbij is dat er voor degene die zich niet bewust is van zijn ongeoorloofde gedrag, geen noodzaak en geen aanleiding bestaat om dit gedrag voor de Commissie of voor derden te verbergen. Vergelijk Pb 1989 L 74/17 (PVC-I); de ondernemingen hadden "in het geheim een geïnstitutionaliseerd systeem van geregelde bijeenkomsten opgezet", $\mathrm{Pb} 1989$ L 260/41 (Betonstaalmatten); hier werd geconstateerd dat de ondernemingen "hetzij de contacten met de concurrenten hebben ontkend, hetzij het eigenlijke doel van hun contacten, respectievelijk de werkelijke inhoud van hun afspraken hebben verzwegen", $\mathrm{Pb} 1983$ L $317 / 1$ (Gietijzeren en gietstalen walsen) waarin sprake was van een waarschuwingssysteem bij onverwacht 'bezoek' van een autoriteit en Pb 1994 L. 243/1 (Karton), waarin "de ondernemingen in een poging het bestaan van het kartel te verhullen zo ver gingen, dat datum en volgorde van de aankondiging door iedere grote producent van de nieuwe prijsverhogingen vooraf werd gearrangeerd". Zie eveneens Pb 2001 L 152/24 (Aminozuren).

57 Ondanks het feit dat er niet van een boos opzet wordt uitgegaan.

$58 \mathrm{~Pb} 1977$ L 39/19 (Theal/Watts).

$59 \mathrm{~Pb} 1982 \mathrm{~L}$ 94/7 (Moët et Chandon). Dit geldt in versterkte mate indien de betrokken onderneming zelf reeds eerder door de Commissie wegens overtreding van het kartelverbod is veroordeeld. Voor een zeer sprekend voorbeeld zie Pb 1991 L 152/1 (Natriumcarbonaat Solvay/ICI): de betrokken ondernemingen waren voordien reeds drie respectievelijkvier maal veroordeeld wegens overtreding van artikel $81 \mathrm{EG}$.

60 Men vergelijke Pb 1985 L $35 / 58$ (John Deere) en Pb 1988 L $317 / 47$ (Sabena).

61 Vergelijk Pb 1972 L 303/54 (W.E.A.-Filipacchi Music) en Pb 1985 L 374/1 (ECS/AKZO Chemie).

62 In $\mathrm{Pb} 2001$ L 125/27 (Deutsche Post) concludeerde de Commissie zelfs tot het bestaan van opzet uit onder meer de duur van de verboden gedraging. Dit gaat toch wel erg ver. Duur en opzet hebben immers niet noodzakelijk iets met elkaar te maken.

$63 \mathrm{~Pb} 1980 \mathrm{~L} 377 / 16$ (Johnson \& Johnson). Maar bij grote ondernemingen speelt dit punt sterker. In $\mathrm{Pb} 1992 \mathrm{~L}$ 92/1 (Bouwnijverheid in Nederland) zag de Commissie een bijkomende aanduiding voor opzet in de omstandigheid dat het kartel werd gevormd door organisaties die vrijwel de gehele productmarkt bestreken. Dit is met name het geval als de kartelvorm tot de klassieke vormen kan worden gerekend. 
mededingingsrecht op de hoogte zijn. ${ }^{64}$ De beschikkingenpraktijk van de Commissie speelt daarom een cruciale rol. Voorzover ondernemingen gedrag ontplooien waarvan de Commissie reeds in (herhaalde) beschikkingen heeft aangegeven dat het communautairrechtelijk niet door de beugel $\mathrm{kan}^{65}$, is disculpatie in beginsel geen optie meer ${ }^{66}$, en zal die ondernemingen in principe zelfs opzet kunnen worden 'aangerekend', omdat zij bedoelde zorgplicht niet in acht heeft genomen ${ }^{67}$, dan wel -als zij wel op de hoogte was van het verboden karakter van de gedraging- omdat zij de mededingingsbeperking ten minste op de koop toe heeft genomen. In versterkte mate geldt deze conclusie voor afspraken of gedragingen ten aanzien van prijzen ${ }^{68} \mathrm{en} /$ of exportbeperkingen $^{69}$ die door de Commissie consequent als schadelijk worden aangemerkt. ${ }^{70}$

64 Furse (1995), pag. 112, merkt in dit verband op: "Undertakings must now be presumed to be familiar with the Community regime. If they are not, they should be". Dit wordt onderstreept door $\mathrm{Pb} 2000$ L 268/1 (Far East Trade Tariff Charges and Surcharges Agreement): "omdat de partijen onmogelijk onwetend konden zijn van het feit dat een overeenkomstom geen korting aan (te) bieden was bedoeld om (...) de mededinging (...) te beperken".

65 Zie voor de autosector Pb 1984 L 207/11 (BL), waarin door de Commissie werd gewezen op Pb 1975 L. 29/14 (General Motors).

66 Zijn ondememingen desalniettemin van mening dat aan hun gedragingen goede motieven ten grondslag lagen, dan zullen zij hun mening althans tot op zekere hoogte zelf moeten staven met enig bewijs. Dit althans lijkt te volgen uit $\mathrm{Pb} 1990$ L 21/71 (Bayo-n-ox); de betrokken onderneming had geen handelsdocumenten overgelegd die haar visie omtrent het doel van de gedraging konden bevestigen. Wel overwoog de Commissie dat zij zelf evenmin uit andere bron over bevestigende informatie beschikte. De Commissie concludeerde tot opzet hoewel niet kon "worden aangetoond dat dit doel niet echt werd beoogd".

67 Onder meer $\mathrm{Pb} 1978$ L 46/33 (BMW Belgium), $\mathrm{Pb} 1982$ L 354/28 (National Panasonic), Pb 1987 L 222/1 (Tipp-Ex) en Pb 1987 L 222/28 (Sandoz).

$68 \mathrm{~Pb} \mathrm{1978} \mathrm{L} \mathrm{70/54} \mathrm{(Plantaardigperkament);} \mathrm{hier} \mathrm{was} \mathrm{sprake} \mathrm{van} \mathrm{het} \mathrm{hanteren} \mathrm{van} \mathrm{uniforme} \mathrm{percentages}$ ten aanzien van prijsverhogingen waardoor de ondernemingen in het geheel geen concurrentie ondervonden.

$69 \mathrm{~Pb} 1977$ L 39/19 (Theal/Watts), waarin opzet werd aangenomen omdat de betrokken onderneming een exportverbod aan haar (binnenlandse) verdelers had opgelegd teneinde te voorkomen dat deze het betrokken product naar het relatief duurdere buitenland zouden uitvoeren.

70 Commissie, Gerechten Hof lijken hier een duidelijk meer dan globale kennis van het communautaire recht van de ondernemingen te eisen: ondernemingen behoren te weten wat het standpunt van de Commissie en de communautaire rechter is ten aanzien van de meest belangrijke en meest verstrekkende inbreuken op het EG-Verdrag. Zie onder meer $\mathrm{Pb} 1978$ L. 46/33 (BMW Belgium) en Pb $1980 \mathrm{~L}$ $377 / 25$ (Johnson \& Johnson), waarin expliciet wordt verwezen naar het standpunt van Commissie en Hof ten aanzien van exportkartels zoals verwoord in HvJ (56 en 58/64) Jur. 1966, 450 (Consten/Grundig). Zie omtrent prijskartels bijvoorbeeld HvJ (240-242, 261, 262, 268 en 269/82) Jur. 1985, 3831 (Stichting Sigarettenindustric e.a.). Hiermee vervaagt in de praktijk voor de belangrijkste -want potentieel meest schadelijke- kartelvormen het verschil tussen boos en kleurloos opzet. In GvEA (T-3/89) Jur. 1991, II-1177 (Atochem) ging het Gerecht wel heel ver in de normativering van de schuld: "Het Gerecht stelt vast, dat uit de emst van de vastgestelde feiten -met name de vaststel. ling van richtprijzen en verkoopdoelen- blijkt, dat verzockster niet onvoorzichtig of uit onachtzaumheid, doch opzettelijk heeft gehandeld". In die zin ook GvEA (T-10/89) Jur. 1992, II-629 (Hoechst), GvEA (T-11/89) Jur. 1992, II-892 (Shell International Chemical Company), GvEA (T-13/89) Jur. 1992, II-1021 (Imperial Chemical Industries) en GvEA (T-14/89) Jur. 1992, II-1155 (Montedipe). Zie tevens GvEA (T-143/89) Jur. 1995, II-917 (Ferriere Nord): de onderneming kan "gelet op de intrinsieke emst en het flagrante karakter van de inbreuk op artikel 85 , lid 1 , van het Verdrag, in het bijzonder op het bepaalde onder a en c, niet stellen dat zij niet opzettelijk heeft gehandeld". In dezelfde zin GvEA (T-150/89) Jur. 1995, 11-1165 (Martinelli) en -onder verwijzing naar vaste rechtspraak ten 


\subsubsection{Onachtzaamheid}

De tweede in artikel 15 Vo 17 genoemde schuldvariant is de onachtzaamheid. In zijn reeds verschillende malen aangehaalde conclusie bij het General Motors-arrest concludeerde Mayras dat van onachtzaamheid sprake is

"wanneer de betrokkene, zonder de bedoeling onrechtmatig te handelen, de gevolgen van zijn daad niet heeft voorzien, terwijl iemand bij normale zorgvuldigheid en voldoende oplettendheiddie wel zou hebben voorzien".t"

Hier speelt evenals bij opzet het (behoren te) weten een rol. Het verschil tussen opzet en onachtzaamheid is (dogmatisch) gelegen in het al dan niet gewild of op de koop toe genomen hebben van de (redelijkerwijs) voorzienbare gevolgen. Dit verschil komt niet duidelijk in de beschikkingen en jurisprudentie naar voren, hetgeen te wijten is aan de rets gememoreerde niet-dogmatische benadering van de schuldvraag. Het komt in de praktijk nauwelijks voor dat de Commissie 'slechts' onachtzaamheid aanneemt. Een van de schaarse voorbeelden is de Deutsche Philips-beschikking ${ }^{12}$ waarbij het een inbreuk op artikel 81 EG, bestaande in een exportverbod betrof. Deutsche Philips had in een regeling voor elektrische scheerapparaten een algemeen exportverbod opgenomen en gehandhaafd, ondanks uitdrukkelijk verzoek van de moedermaatschappij dit verbod op te heffen. In de algemene leverings- en betalingsvoorwaarden daarentegen was dit uitvoerverbod beperkt tot niet-lidstaten, welke beperking door de onderneming in kwestie aan haar afnemers was medegedeeld; door deze beperking viel de regeling buiten het bereik van het EG-Verdrag aangezien zij slechts betrekking had op derde staten. Bovendien kon Deutsche Philips aantonen dat afnemers daadwerkelijk scheerapparaten naar lidstaten hadden uitgevoerd, waardoor vaststond dat zij de export toestond en dat de betreffende afnemers het verbod in de scheerapparaten-regeling klaarblijkelijk niet bindend achtten. Het verbod in de scheerapparatenregeling was (volgens Deutsche Philips) dan ook per vergissing gehandhaafd en had geen praktische betekenis. De Commissie kwam tot de overtuiging dat de onderneming de inbreuk niet had beoogd, maar dat haar desalniettemin een verwijt gemaakt kon en moest worden: zij had namelijk moeten inzien dat het exportverbod in de scheerapparaten-regeling sommige handelaren van export van deze artikelen zou kunnen weerhouden. De onderneming had haar scheerapparaten-regeling op dit punt moeten wijzigen; door dit niet te doen, had zij onachtzaam gehandeld en kon zij worden beboet. $^{73}$

aanzien van marktafscherming, GvEA (T-62/95) n.n.g. (Volkswagen).

71 Eenformulering die belangrijkeovereenkomstenvertoontmet de in Hazewinkel-Suringa/Remmelink (1996), pag. 231, gebezigde uitleg van het culpa-begrip in het Nederlandse strafrecht: "het niet of onvoldoende werkelijk voorzien hebben van het fatale gevolg van (...) gedrag, hoewel dat gemakkelijk had gekund en derhalve had behoord".

$72 \mathrm{~Pb} 1973$ L 293/40 (Deutsche Philips).

73 In $\mathrm{Pb} 1996 \mathrm{~L}$ 181/28 (FENEX) had een ondernemersvereniging inbreuk gemaakt op artikel 81 EG door quasi-adviesprijzenvast te stellen. Zij stelde dat de inbreukuit onervarenheiden onachtzaamheid had plaatsgehad. De Commissie overwoog dienaangaandeslechts dat dit de ondernemersvereniging niet kon vrijwaren van sancties. Hieruit moet worden afgeleid dat de Commissie in deze zaak opzet niet bewezen achtte. Onachtzaamheidwerd ook aangenomen in Pb 2000 L 5/55 (WK Voetbal 1998), en wel wegens de onduidelijke rechtssituatie. 
Uit het voorgaande moge blijken dat het vereiste van aanwezigheid van schuld geen groot struikelblok vormt voor toepassing van artikel 15 Vo 17. De ruimte voor een onderneming om zich te disculperen en zich met succes op een overmachtsituatie te beroepen, is zeer beperkt ${ }^{74}$ en zal (omdat een zekere kennis van het communautaire recht van de ondernemingen verwacht wordt) afnemen naarmate de communautaire autoriteiten meer kartelvormen in strijd met het EG-Verdrag verklaren. Hoe beperkt deze ruimte is, wordt onderstreept in de Houtslijp-beschikking, waarin de Commissie overwoog dat de door de ondernemingen gepleegde overtreding niet het gevolg was van "een te verontschuldigen en onvermijdelijke vergissing ${ }^{175}$ en dat de ondernemingen derhalve tenminste uit onachtzaamheid de kartelregels hadden overtreden. De eis van onachtzaamheid is, hoewel het voorgaande wellicht anders doet vermoeden, geen dode letter. De Commissie stelde in de Plantaardig perkamentbeschikking dat de gedraging van de ondernemingen,

"welke inhield dat zij elkaar inlichtingen uitwisselden betreffende de hoeveelheden die zij individueel exporteren, alsmede betreffende het peil van hun prijzen, een inbreuk is welke niet noodzakelijkerwijze gepleegd is met opzet of uit nalatigheid; dat trouwens op het ogenblik van de onderhavige feiten, de toepassing van de mededingingsregelen van het EEG-Verdrag nog geen aanleiding had gegeven tot beschikkingen $(. .$.$) welke de draagwijdte ervan op dit gebied voldoende duidelijk hadden gemaakt". "*$

\title{
Een vergelijkbare overweging kan worden aangetroffen in de Decca-beschikking:
}

\begin{abstract}
"Vanwege de complexiteit van de juridische beoordeling in deze zaak en aangezien er geen precedenten zijn, kan niet worden geconcludeerd dat (de ondememing) opzettelijk of uit onachtzaamheid inbreuk heeft gemaakt op artikel 86 (thans artikel 82 EG, HQ)"."
\end{abstract}

In deze zaken was de mededingingsbeperkende strekking van de gedragingen niet zonder meer duidelijk en kon het de ondernemingen niet verweten worden dat zij de strekking niet kenden. Het belang van precedenten treedt wederom op de voorgrond: had de Commissie zich voordien reeds over de onaanvaardbaarheid van de gedragingen uitgelaten, dan zouden de ondernemingen worden geacht het standpunt van de Commissie te kennen en zouden zij derhalve waarschijnlijk wel een sanctie tegemoet hebben kunnen zien, omdat zij dan tenminste uit onachtzaamheid zouden hebben gehandeld. ${ }^{78}$

74 Uit $\mathrm{Pb} 1979$ L 16/9 (Kawasaki) volgt dat zelfs een beroep op door de onderneming ingewonnen juridisch advies haar niet zonder meer baat indien de onjuistheid van het advies relatief eenvoudig was te achterhalen.

$75 \mathrm{~Pb} 1985$ L 85/25 (Houtslijp).

$76 \mathrm{~Pb} 1978$ L. 70/64 (Plantaardig perkament).

$77 \mathrm{~Pb} 1989$ L $43 / 27$ (Decea Navigator System).

78 In HvJ (322/81) Jur. 1983, 3461 (Nederlandsche Banden Industrie Michelin) wordt nogmaals onderstreept hoeveel inzicht in hetgeen al dan niet geoorloofd is van een onderneming wordt verwacht: "Het feit dat noch de Commissie, noch het Hof zich tot nog toe heeft uitgesproken over een kortingsysteem met dezelfde kenmerken als het betrokken systeem, ontheft NBIM niet van haar aansprakelijkheid. Gezien de eerdere beslissingen van de Commissie en de rechtspraak van het Hof, kon NBIM in elk geval verwachten dat dit systeem onder de werkingssfeer van artikel 86 EEG-Verdrag (thans artikel 82 EG, HQ) zou vallen". Vergelijk ook GvEA (T-83/91) Jur. 1994, II-755 (Tetra Pak International), waarin het Gerecht -hoewel er geen precedenten waren en het niet eenvoudig was de werkingssfeer van artikel 82 EG te bepalen- overwoog "dat verzockster niet onkundig kon zijn van de omstandigheid dat de onderhavige feiten door de omvang, de duur en het stelselmatig karakter ervan emstige beperkingen van de mededinging meebrachten, gelet in het bijzonder op haar vrijwel monopolistische positie 
De conclusie ten aanzien van de schuldvraag is op grond van het voorgaande duidelijk: en onderneming die artikel 81 of $82 \mathrm{EG}$ overtreedt, zal slechts in uitzonderlijke gevallen net succes een beroep op overmacht kunnen doen; in veel gevallen -met name bij het ttstandbrengen van export- en prijskartels-zal de onderneming zelfs het plegen van een orzettelijke inbreuk op het EG-recht verweten moeten worden.

\section{Verjaring}

lerjaring is een beginsel dat in het strafrecht van de EG-lidstaten hecht is verankerd, zi het dat de reikwijdte ervan in de verschillende rechtsorden nogal uiteenloopt. ${ }^{79} \mathrm{Het}$ biginsel van verjaring houdt in dat het na verloop van een bepaalde tijd niet meer mogelijk isom tot vervolging en dus uiteindelijk tot strafoplegging over te gaan (vervolgingsverjaring) danwel om een straf ten uitvoer te leggen (executieverjaring). Voor de hantering vin het verjaringsbeginsel kunnen drie argumenten worden aangevoerd. Het eerste houdt hermee verband dat -in de woorden van Remmelink ${ }^{30}$ - "na een lang tijdsverloop de hrinnering aan het gebeurde is verbleekt en daarmee de strafbehoefte verzwakt, zowel ut vergeldingsoogpunt als uit dat van de generale of speciale preventie". ${ }^{81}$ Het tweede (niet voor de executieverjaring geldende) argument ligt op bewijstechnisch vlak: over ht algemeen is het bewijs van daden die zich in een verder verleden hebben afgespeeld, moeilijk te leveren. ${ }^{82}$ Het derde argument houdt rekening met de dader: op een bepaald moment moet ook voor deze de zaak zijn afgedaan en moet aan de dreiging van strafrechtelijke consequenties voor zijn daad een einde komen. Beziet men deze argumenten, dan kan men concluderen dat zij ook binnen het kartelrecht valide zijn. De steeds in beweging zijnde economische markt doet de gevolgen van beëindigd mededingingsbeperkend handelen veelal relatief snel vervagen, mede als gevolg waarvan de behoefte aan sancties ook afneemt. Waar de vergaring van bewijs over het algemeen in kartelzaken al niet eenvoudig is (kartelinbreuken worden door ondernemingen lang niet altijd op schrift gesteld en dragen doorgaans een geheim karakter), daar wordt het bewijsprobleem door tijdsverloop alleen maar groter (onder meer omdat eventuele schriftelijke stukken na beëindiging van de inbreuk naar verwacht mag worden veelal zullen worden vernietigd). Het derde argument speelt wellicht in zoverre een minder prominente rol in het kartelrecht

op de (betrokken) markten. Gelet op haar positie op de relevante markten en op de zwaarte van de inbreuken op de mededinging moest verzoekster zich bovendien wel ervan bewust zijn, dat zij het verbod van artikel 86 (thans artikel 82 , HQ) van het Verdrag overtrad".

79 Zo is in Nederland het verjaringsbeginselop in beginsel alle strafbare feiten van toepassing (uitgezonderd oorlogsmisdaden), terwijl in Engeland slechts lichte delicten kunnen verjaren. Zie HazewinkelSuringa/Remmelink (1996), pag. 611.

80 Hazewinkel-Suringa/Remmelink(1996), pag. 871. Zie voorts Van Bemmelenen Van Veen (1998), pag. 258 e.v..

81 Vergelijk ook HR 26 maart 1985, NJ 1985, 688 m.nt. ThWvV: "Aan de in art. 70 Sr erkende verjaring van het recht tot strafvordering ligt ten grondslag het ervaringsgegeven dat tijdsverloop aan de -door het begaan van een strafbaar feit veroorzaakte-verstoring van de rechtsorde het om vervolging en bestraffing vragende karakter ontneemt".

82 Vergelijk Hazewinkel-Suringa/Remmelink (1996), pag. 611 en De Hullu (2000), pag. 124. De huidige discussie in Nederland omtrent de afschaffing van vervolgingsverjaring voor moord wordt mede tegen de achtergrond gevoerd van de toenemende mogelijkheden (waaronder DNA-profielen) om ook na lange tijd nog bewijzen te kunnen vinden. 
dat van psychische druk in verband met de dreiging van een mogelijke boeteprocedure bij (omvangrijke) rechtspersonen -waarom het toch doorgaans in dit rechtsgebied gaatin beginsel niet gesproken kan worden. Dit laat mijns inziens onverlet dat ook voor rechtspersonen geldt dat zij op een gegeven moment het verleden achter zich moeten kunnen laten en dat de dreiging van een zeer aanzienlijke boete wordt weggenomen. ${ }^{83}$ Kortom: de argumenten voor hantering van het verjaringsbeginsel gelden ook ten aanzien van het kartelrecht. De vraag rest nu of dit beginsel daadwerkelijk ingang heeft gevonden in het (Nederlandse en communautaire) kartelrecht.

\section{Verjaring in het Nederlandse kartelrecht tot 1998}

Dat tot 1998 ten aanzien van kartelinbreuken een verjaringsbeginsel gold, moge vanzelfsprekend zijn: zoals in hoofdstuk 1 bleek, werd de Wem strafrechtelijk, namelijk via de WED, gehandhaafd als gevolg waarvan de algemene verjaringsregeling van de artikelen 70-73 WvSr en -voor de executieverjaring- 76 en 76a WvSr van toepassing was. Mitsdien was er voorzien in de stuiting ${ }^{84}$ én de schorsing ${ }^{85}$ van de verjaring en was de termijn van de vervolgingsverjaring gerelateerd aan de strafbaarstelling: op grond van artikel $70 \mathrm{WvSr}$ verjaren overtredingen na twee jaar, terwijl misdrijven, afhankelijk van de daarop gestelde straf, een verjaringstermijn kennen variërend van zes tot achttien jaar. ${ }^{86}$ In hoofdstuk 1 is reeds aan de orde gekomen dat juist met de strafbaarstelling van karteldelicten in de WED nogal wat is aangerommeld, hetgeen directe consequenties voor de verjaringstermijn heeft gehad. Aanvankelijk werd met betrekking tot een inbreuk op de Wem gedifferentieerd tussen misdrijven en overtredingen, waarbij -althans waar het de overtreding van een (generieke) onverbindend verklaring betrof- het onderscheidende criterium was of de inbreuk al dan niet opzettelijk was begaan. De overtredingen verjaarden in twee jaar, de misdrijven kenden een verjaringstermijn van zes jaar, aangezien op een opzettelijke inbreuk op de Wem een maximumstraf van twee jaar was gesteld. In 1990 verdwenen

83 De mogelijkheid van een hoge boete zou invloed kunnen uitoefenen op de bedrijfsvoering van een onderneming, in die zin dat zij wellicht enige reserves achter de hand houdt teneinde een eventuele boete te kunnen voldoen.

84 Artikel $72 \mathrm{WvSr}$ stelt dat elke daad van vervolging, voorzover bekend of betekend aan de vervolgde, de verjaring stuit. Door de stuiting start een nieuwe verjaringstermijn. Onder 'daden van vervolging' vallen niet de opsporingshandelingen. Doorslaggevend is of het een handeling van de officier van Justitie betreft waarmee hij een rechter in de strafzaak betrekt. Een iets ruimere interpretatie staat Hazewinkel-Suringa/Remmelink(1996), pag. 617, voor. Hij verstaat onder 'daden van vervolging' "elke formele daad uitgaande van $\mathrm{OM}$ of rechter om in de fase voorafgaandeaan de tenuitvoerlegging. tot een (uitvoerbare) rechterlijke beslissing te geraken".

85 De enige reden voor schorsing van de vervolgingsverjaring is blijkens artikel $73 \mathrm{WvSr}$ de schorsing van de strafvervolging ter zake van een prejudicieel geschil.

86 De termijn van de executieverjaring is, aldus is vastgelegd in artikel $76 \mathrm{WvSr}$, een derde langer dan die van de vervolgingsverjaring. De termijn van de executieverjaring start op de dag na die waarop de rechterlijke uitspraak ten uitvoer kan worden gelegd (artikel 76a WvSr). Op grond van artikel 71 WvSr begint de vervolgingsverjaringstermijn -op enkele hier niet relevante uitzonderingen naop de dag na die waarop het feit is gepleegd. Voor voortdurende delieten kan worden aangenomen dat de verjaring een aanvang neemtna het ophouden van de verboden toestand; vergelijk HazewinkelSuringa/Remmelink (1996), pag. 121. Zoals zal blijken, speelt in het communautaire recht de vraag of een inbreuk een al dan niet voortdurend karakter heeft cen belangrijke rol. 
de misdrijven van het Nederlandse karteltoneel: de wetgever achtte het raadzaam om alle inbreuken op de Wem, dus ook de opzettelijke, nog slechts als overtredingen strafbaar te stellen. ${ }^{87}$ Een op dat moment onopgemerkt en onbedoeld neveneffect hiervan was dat alle karteldelicten reeds na twee jaar verjaarden. Dat een dergelijk korte termijn weinig ruimte laat voor een gedegen onderzoek naar doorgaans toch complexe kartelinbreuken, zal geen betoog behoeven. In zoverre had de wetswijziging dan ook een uitwerking die haaks stond op hetgeen toch op zijn minst mede ermee werd beoogd, namelijk intensivering van het kartelbeleid. Een nieuwe wetswijziging kondigde zich dan ook snel aan: reeds in 1993 werd een nieuw wetsvoorstel gelanceerd dat onder meer voorzag in een herintroductie van het onderscheid tussen misdrijven en overtredingen, waarbij voor dit onderscheid wederom bepalend was of er al dan niet opzet in het geding was. Die herintroductie werd in 1995 een feit ${ }^{\text {s8 }}$, waardoor ook de verjaringstermijn van zes jaar voor opzettelijke inbreuken weer in ere werd hersteld.

\section{Verjaring in het communautaire kartelrecht}

In het geschreven communautaire kartelrecht ontbrak aanvankelijk een regeling omtrent verjaring van inbreuken, waarbij met name opvallend was dat Verordening 17 hierin niet voorzag. Reeds snel rees de vraag of daarmee de kous af was of dat verjaring moest worden aangemerkt als een algemeen, ongeschreven beginsel van gemeenschapsrecht. In de Kinine-zaak namelijk hadden de betrokken ondernemingen aangevoerd dat beboeting niet meer mogelijk was aangezien de (vermeende) inbreuken volgens hen verjaard waren. Deze ondernemingen waren van mening dat het ontbreken van een verjaringsregeling in de communautaire mededingingsregels niet van (doorslaggevende) betekenis was aangezien het ging om een door alle nationale rechtsstelsels van de lidstaten erkend principe: een verjaringsbeginsel voor de communautaire sancties zou derhalve niet kunnen ontbreken. Bij het bepalen van de relevante verjaringstermijn werd door de ondernemingen eveneens aansluiting gezocht bij de nationale regelingen aangaande karteldelicten: men kwam uit op een termijn van twee jaar, zijnde de kortste verjaringstermijn voor karteldelicten in de nationale rechtsstelsels. $\mathrm{De}$ (mogelijk gepleegde) delicten dateerden van vroegere tijd, als gevolg waarvan geen sancties opgelegd zouden kunnen worden. De Commissie stond weliswaar stil bij het verweer van de ondernemingen, maar constateerde in de verschillende landen met betrekking tot de toepassing van het verjaringsbeginsel aanzienlijke verschillen en liet in het midden of een algemeen rechtsprincipe als bedoeld daadwerkelijk bestond. Zij constateerde wel dat in de concrete zaak hoe dan ook geen sprake was van verjaring. Volgens de Commissie nam de verjaringstermijn een aanvang op het moment waarop de inbreuk werd beëindigd en eindigde de termijn op het tijdstip waarop de verificaties werden verricht. De totale termijn bedroeg ongeveer twee jaar (en voor sommige delicten slechts één jaar), welke periode "gezien de aard en de zwaarte der inbreuken op artikel 85 (thans $81 \mathrm{EG}, \mathrm{HQ}$ ) en de voor vergelijkbare inbreuken in de rechtsstelsels der LidStaten vastgestelde verjaringstermijnen, niet (volstond) om de vervolging van de inbreuken

87 Wet van 15 november 1989 tot wijziging van de Wet economischemededinging (voorzieningenmet betrekking tot verticale prijsbinding), Stb. 1990, 6 .

88 Wet van 2 november 1994 tot wijziging van de Wet economische mededinging (vergroting van de effectiviteit), Stb. 1994, 801. 
der deelnemers uit te sluiten". 89 De Commissie wenste dus weliswaar geen algemene verjaringsregels te formuleren, maar de bewoordingen van de beschikking geven aan dat de Commissie wel ruimte zag voor een communautair verjaringsbeginsel. In de beroepszaak kwam de vraag omtrent de verjaring eveneens aan de orde. Het Hof bleek evenals de Commissie zeer terughoudend te zijn bij de behandeling van het verjaringsvraagstuk, terughoudender in ieder geval dan Advocaat-Generaal Gand. ${ }^{90}$ Deze was in zijn conclusie van mening dat verjaring een algemeen beginsel was dat door het Hof voor het communautaire kartelrecht erkend moest worden en waarbij het Hof bij ontbreken van een wettelijke regeling zelf de toepassingsmodaliteiten diende te regelen. Gand constateerde wel dat er geen eensluidend en gemeenschappelijk beginsel bestond met betrekking tot de verjaringstermijn, als gevolg waarvan het Hof zelf een (gezien de bijzonderheden van het communautaire mededingingsrecht) redelijke termijn zou moeten vaststellen, waarbij hij een termijn van vijf jaar voorstelde. Het Hof wilde niet zover gaan en stelde

\footnotetext{
"dat een verjaringstermijn om aan zijn doel, de bevordering van de rechtszekerheid, te beantwoorden voorop moet zijn vastgesteld" en "dat de vaststelling van zijn duur en van de voorwaarden voor zijn toepasselijkheid behoort tot de bevoegdheid van de gemeenschapswetgever"."1
}

Volgens het Hof maakte het verjaringsprincipe geen deel uit van de algemene beginselen van gemeenschąnsrecht -hoewel in iedere lidstaat een dergeliik beginsel in het strafrecht was verankerd ${ }^{92}$ - en het Hof verwierp de grieven met betrekking tot de verjaring van de begane overtredingen, ten dele omdat het (geschreven en ongeschreven) communautaire mededingingsrecht geen verjaringsbeginsel kende en ten dele omdat het Hof het niet tot zijn bevoegdheden rekende om een dergelijke regeling te introduceren. ${ }^{93}$ In de arresten naar aanleiding van de kleurstoffen-zaak verwierp het Hof de grieven van de ondernemingen aangaande de verjaring in vergelijkbare bewoordingen als in de Kinine-arresten, waarbij het Hof bovendien te kennen gaf dat áls er al een verjaringsbeginsel zou hebben gegolden, de termijn die in de onderhavige zaak was verstreken in ieder geval niet onaanvaardbaar lang was. ${ }^{94}$

Gelet op het voorgaande werd reeds snel duidelijk dat een verjaringsregeling slechts via de gemeenschapswetgever haar intrede zou kunnen doen. De Raad, overtuigd van de noodzaak van een verjaringsregeling (met name van het oogpunt van de rechtszekerheid),

$89 \mathrm{~Pb} 1969$ L $192 / 5$ (Kinine).

90 Zie zijn conclusie bij de Kinine-arresten, Jur. 1970, 706 e.v..

91 Zie HvJ (41/69), Jur. 1970, 661 (ACF Chemiefarma), HvJ (44/69) Jur. 1970, 733 (Buchler).

92 Dit onderstreept dat de communautaire rechtsorde een geheel eigen dynamiek heeft en dat een in de lidstaten algemeen erkend (strafrechtelijk) beginsel niet zonder meer gelding heeft binnen het communautaire recht.

93 Zie over deze arresten -met instemming op dit punt-Mulder (1971), pag. 211.

$94 \mathrm{HvJ}$ (48/69), Jur. 1972, 619 (Imperial Chemical Industries), HvJ (49/69) Jur, 1972, 713 (BASF), HvJ (51/69), Jur. 1972, 745 (Bayer), HvJ (52/69), Jur. 1972, 787 (Geigy), HvJ (53/69) Jur. 1972. 845 (Sandoz), HvJ (54/69) Jur. 1972, 851 (Francolor), HvJ (55/69) Jur. 1972, 887 (Cassella) en Hv] (56/69) Jur. 1972, 927 (Hoechst). Het Hof overwoog hier "dat $z 0$ (...) de fundamentele eis van rechtsezkerheid zich er al tegen verzet dat de Commissie eindeloos kan wachten met de uitoefening van haar bevoegdheid tot oplegging van geldboeten, de in casu gevolgde gedragslijn toch niet als een beletsel kan worden beschouwd". 
ondernam dan ook spoedig actie en stelde in 1974 een verordening ${ }^{95}$ vast waarin de betaande lacune werd opgevuld.

\section{Veordening $2988 / 74^{96}$}

Evenals het Nederlandse strafrecht maakt Verordening 2988/74 een onderscheid tussen vevolgings- en executieverjaring. ${ }^{97}$ Het recht op tenuitvoerlegging van een boetebeschikking vervalt na een periode van vijf jaar, welke periode begint op de dag waarop de bechikking niet meer kan worden aangevochten. Voor de vervolgingsverjaring geldt da de termijn gerelateerd is aan de aard van de inbreuk: inbreuken op de formele regels vejaren (met name inbreuken op de regels met betrekking tot het inwinnen van inlichtinget en het verrichten van verificaties) na drie jaar; de overige inbreuken (de overtredingen val de verboden van de artikelen 81 en 82 EG) kennen een verjaringstermijn van vijf jar. In tegenstelling tot hetgeen in het Nederlandse strafrecht regel is, begint de verjaringstermijn op de dag waarop de overtreding is gepleegd. Hierop bestaat één uitzondering dirin de praktijk van aanmerkelijk belang is: voor voortdurende en voortgezette inbreuken gedt de dag waarop de inbreuk is beëindigd als beginpunt van de verjaringstermijn. ${ }^{9}$ Nikomt het geregeld voor dat verspreid over een ruime periode door een groep ondernemingen verschillende kartelinitiatieven worden ontplooid. De vraag is dan of deze initiatieven als afzonderlijke inbreuken moeten worden beoordeeld of dat zij deel uitmaken van één voortgezette inbreuk. Het antwoord op deze vraag hangt sterk af van de omstandigheden van het geval, waarbij met name relevant is in hoeverre er tussen de gedragingen een verband bestaat. Illustratief is in dit verband de LdPE-zaak. ${ }^{99}$ Tussen de oorspronkelijke kartelovereenkomst en de eerste onderzoekshandeling van de Commissie lagen ongeveer zeven jaar, gedurende welke tijd door de betrokken ondernemingen verschillende kartelgedragingen waren ontplooid. De Commissie oordeelde dat de overeenkomst en de bedoelde gedragingen gezien "hun gemeenschappelijke doel en de omstandigheid dat de methode waarop het kartel functioneerde juist die was als in het plan (het oorspronkelijke kartelvoornemen, HQ) voorgesteld", onderdeel van dezelfde voortdurende inbreuk vormden. Zo kon de Commissie ook concluderen dat herhaling van een inbreuk na een termijn

95 Verordening van de Raad no. 2988/74/EEG van 26 november 1974 inzake de verjaring van het recht van vervolging en van tenuitvoerlegging op het gebied van het vervoers- en mededingingsrecht van de Europese Economische Gemeenschap, Pb 1974 L 319.

96 Zie over deze verordening ook Van Gerven c.s. (1997), pag. 729-730. Mogelijk geldt deze verjaringsregeling niet meer al te lang voor het kartelrecht. Het 'Voorstel uitvoeringsverordening' voorziet namelijk in een eigen verjaringsregeling, die mutatis mutandis echter gelijk is aan de huidige regeling.

97 Het zij onderstreept dat de Commissie na het verstrijken van de vervolgingsverjaringstermijn niet meer bevoegd is om een boete op te leggen. De termijn heeft als zodanig geen invloed op de onderzoeksbevoegdheden van de Commissie. Dit spreekt ook in zoverre voor zich dat veelal pas na het verrichte onderzoek duidelijk wordt of er sprake is van een gedraging die verjaard is. Evenmin weerhoudt de verjaringstermijn de Commissie ervan om op grond van artikel 81 of 82 EG een (declaratoire) nietigverklaring uit te spreken.

98 Hierdoor kan er sprake zijn van een voor een uitermate lange periode die bij bepaling van de boete in aanmerking genomen kan worden. Zie onder meer $\mathrm{Pb} 1987$ L 222/28 (Sandoz), $\mathrm{Pb} 1992 \mathrm{~L} 131 / 32$ (DSI).

$99 \mathrm{~Pb} 1989$ L 74/21 (LdPE). 


\section{Hoofdstuk 4}

van ruim twee jaar kan duiden op een voortgezette inbreuk ${ }^{100}$, dat maatregelen die gedurende een periode van ongeveer dertien jaar werden getroffen, op één basisovereenkomst berustten $^{101}$ en dat tussen een verder in het verleden liggende bodemprijsregeling en het latere gedrag een zodanig verband bestond dat er sprake was van een voortgezette inbreuk. ${ }^{102}$ In de Dunlop-zaak was de Commissie volgens het Gerecht daarentegen ten onrechte van een voortdurende inbreuk uitgegaan, hetgeen tot gevolg had dat de verder in het verleden liggende inbreuk verjaard was. ${ }^{103}$

Verordening 2988/74 kent evenals het Nederlandse strafrecht de mogelijkheid van stuiting en schorsing van de vervolgingsverjaring. ${ }^{104}$ Stuiting heeft plaats zodra er door de Commissie of door een lidstaat op verzoek van de Commissie een handeling "tot onderzoek of vervolging van de inbreuk" wordt verricht en deze handeling is medegedeeld aan tenminste één van de overtreders. ${ }^{105}$ Tot de categorie handelingen die de verjaring stuiten behoren volgens artikel 2 onder meer het verzoek om en het opeisen bij beschikking van inlichtingen, de opdracht en de beschikking tot verificatie, de inleiding van een procedure en de mededeling van de punten van bezwaar. ${ }^{106}$ Aangezien stuiting -evenals overigens schorsing- dezelfde rechtsgevolgen heeft als in het Nederlandse strafrecht, geldt dat de Commissie door telkens voor het verstrijken van de termijn een onderzoeks- of vervolgingsdaad te verrichten, het verjaren van een inbreuk eindeloos zou kunnen uitstellen. Om dit te voorkomen, heeft de Raad bepaald dat het feit in ieder geval verjaard is na een periode van tweemaal de oorspronkelijke verjaringstermijn, eventueel aangevuld met

$100 \mathrm{~Pb} 1989$ L 260/1 (Betonstaalmatten).

$101 \mathrm{~Pb} 1984$ L 220/27 (Zinc Producer Group).

$102 \mathrm{~Pb} 1986$ L 230/33 (Polypropyleen). Hoe zeer de visies op dit punt uiteen kunnen lopen, blijkt wel uit het vervolg van deze zaak. Vesterdorf stelde in zijn conclusie bij de Polypropyleen-zaken, GvEA (T-1/89), 1991, II-989, dat er geen sprake was van een voortgezette inbreuk omdat de bodemprijsovereenkomst "weliswaar hetzelfde doel als de latere overeenkomsten (had), maar (zij) sproot (...) niet voort uit in hetzelfdekader gevoerde onderhandelingen". Het Gerechtechter benadrukte op zijn beurt het nauwe verband tussen de verschillendeafspraken en steunde zo de Commissie in haar zienswijze. Men zie GvEA (T-7/89) Jur. 1991, II-1711 (Hereules Chemicals), GvEA (T-10/89) Jur. 1992, II-629 (Hoechst), GvEA (T-11/89) Jur. 1992, II-892 (Shell Intemational Chemical Company), GvEA (T-13/89) Jur. 1992, II-1021 (Imperial Chemical Industries), GvEA (T-14/89) Jur. 1992, II-1155 (Montedipe) en GvEA (T-15/89) Jur. 1992, II-1275 (Chemie Linz).

$103 \mathrm{~Pb} 1992$ L. 131/45 (DSI) en GvEA (T-43/92) Jur. 1994, II-441 (Dunlop Slazenger International).

104 Ook de executieverjaring kan worden gestuit en/of geschorst. Stuiting wordt veroorzaakt door de kennisgeving van een beschikking waarin een verzoek tot wijziging van het opgelegde bedrag van de boete of de dwangsom wordt afgewezen of waarin het bedrag wel wordt aangepast of door cen handeling waarmee de inning van de opgelegde boete of dwangsom met dwangmiddelen wordt beoogd. Schorsing is aan de orde zolang betalingsfaciliteitenzijn toegestaan of zolang de tenuitvoerlegging van de beschikking door het Hof is geschorst.

105 Zodra de mededeling aan één der betrokkenen heeft plaatsgevonden, geldt de stuiting voor elk van de aan het kartel participerende ondernemingen. Deze 'horizontale werking' van de stuiting speelde een rol in Pb 1989 L 74/1 (PVC-1).

106 In Pb 1989 L 260/1 (Betonstaalmatten) kan een voorbeeld gevonden worden van stuiting van de verjaringstermijn door een verificatie bij beschikking. Vergelijk ook Pb 1997 L 258/1 (Irish Sugar) en GvEA (T-305-307, 313-316, 318, 325, 328, 329 en 335/94) Jur. 1999, II-931 (Limburgse Vinyl Maatschappij e.a.). 
de periode gedurende welke de verjaring geschorst is. ${ }^{107}$ Concreet (en geabstraheerd van de schorsing) betekent dit dat de mogelijkheid om een boete op te leggen uiterlijk eindigt na zes (ten aanzien van overtredingen van de formele kartelregels) respectievelijk tien jaar (met betrekking tot inbreuken op artikel 81 of $82 \mathrm{EG}$ ) na (beěindiging van) de inbreuk. ${ }^{108}$ Schorsing van de verjaring kan echter bewerkstelligen dat deze periode aanzienlijk wordt verlengd. De verjaring wordt geschorst gedurende de periode waarin een beroepsprocedure bij het Gerecht of het Hof aanhangig is. De ratio van deze bepaling is dat de Commissie in de gelegenheid moet zijn een nieuwe beschikking te nemen in geval haar oorspronkelijke beschikking door het Gerecht of het Hof wordt vernietigd op procedurele gronden. ${ }^{109}$ Dit laatste was het geval in PVC-II. ${ }^{110}$ De oorspronkelijke boetebeschikking van de Commissie in de PVC-sector ${ }^{111}$ werd uiteindelijk door het Hof wegens 'klassieke' vormfouten vernietigd. ${ }^{112}$ De gehele procedure voor het Hof had echter wel liefst vijf jaar en twee maanden in beslag genomen, gedurende welke tijd de verjaring geschorst was. Voor Montedison, één van de betrokken ondernemingen, hield dit in dat zij, na het kartel begin 1983 verlaten te hebben, in 1995 -dus na bijna twaalf jaar- toch nog beboet kon worden. ${ }^{113}$ Immers door een inlichtingenbeschikking (op een tijdstip waarop Montedison bijna vijf jaar geen kartelmatig gedrag meer had vertoond) werd de verjaring gestuit en tijdens de nieuwe periode van vijf jaar werd de zaak aanhangig gemaakt bij het Hof, dat op zijn beurt na ruim vijf jaar de zaak 'casseerde'.

107 Volgens Van Gerven c.s. (1997), pag. 729-730, ligt het doel van deze bepaling enerzijds in het beschermen van de ondernemingen tegen de nadelen van een onredelijk lange vervolging en anderzijds in het aansporen van de Commissie om de procedure binnen een redelijke termijn af te handelen.

108 In Pb 2000 L 268/1 (Far East Trade Tariff Charges and Surcharges Agreement) overwoog de Commissie dat in casu geen sprake was van verjaring omdat deze door de mededeling van de punten van bezwaaren vervolgens door schriftelijke verzoekenom inlichtingen was gestuit, terwijl de maximum termijn nog niet was verstreken. In $\mathrm{Pb} 2001 \mathrm{~L} 152 / 24$ (Aminozuren) constateerde de Commissie dat de verjaring was gestuit door verificaties.

109 Niet op inhoudelijke gronden aangezien dit een nieuwe vervolging wegens hetzelfde feit zou inhouden, hetgeen een inbreuk zou opleveren op het ne bis in idem-beginsel. Zie over de gelding van dit beginsel uitvoerig de volgende paragraaf.

$110 \mathrm{~Pb} 1994$ L 239/14 (PVC-II).

$111 \mathrm{~Pb} 1989$ L 74/1 (PVC-1).

112 GvEA (T-79, 84-86, 89, 91, 92, 94, 96, 98, 102 en 104/89) Jur. 1992, II-315 (BASF e.a.). Het Gerecht had de 'beschikking' van de Commissie non-existent verklaard, vanwege ernstige procedurele gebreken, waaronder schending van het beginsel van onaantastbaarheid van de vastgestelde handeling en van de authentisatieprocedure alsmede onbevoegdheid van de persoon die de 'beschikking' had vastgesteld. Het Hof daarentegen zag 'slechts' gronden voor een vernietiging van de beschikking: zie HvJ (C-137/92 P) Jur. 1994, 1-2555 (BASF e.a.). De LdPE-beschikking kende vrijwel identieke gebreken als de PVC-beschikking en werd door het Gerecht vernietigd; zie GvEA (T-80, 81, 83, 87, 88, 90, 93, 95, 97, 99-101, 103, 105, 107 en 112/89) Jur. 1995, II-729 (BASF e.a.). Voor een vernietiging wegens een schending van de authentisatieprocedurezie tevens GvEA (T-31/91) Jur. 1995, II-1821 (Solvay), GvEA (T-32/91) Jur. 1995, II-1825 (Solvay) en GvEA (T-37/91) Jur. 1995, II-1901 (Imperial Chemical Industries), bevestigd door HvJ (C-287 en 288/95 P) n.n.g. (Commissie/Solvay) en HvJ (C-286/95 P) n.n.g. (Commissie/ICI).

113 Montedison werd inderdaad wederom een sanctie opgelegd en wel exact dezelfde als in eerste instantie door de Commissie noodzakelijk werd geacht. Hier zou mijns inziens, tegen de achtergrond van de lange periode gedurende welke de onderneming in onzekerheidverkeerdeen daarmeetegen de achtergrond van het recht op een berechting binnen redelijke termijn zoals gewaarborgdin artikel 6 EVRM, een aanzienlijke matiging op haar plaats zijn geweest. 
Theoretisch hield dit in dat de Commissie nog tot vijftien jaar na de laatste geconstateerde inbreuk Montedison een boete kon opleggen. ${ }^{114}$

\section{Verjaring in de Mededingingswet}

Met de inwerkingtreding van de Mededingingswet is er binnen het Nederlandse kartelrecht vanzelfsprekend geen plaats meer weggelegd voor de strafrechtelijke verjaringsregels zoals hierboven besproken: de boetes wegens overtreding van het kartelverbod dragen immers een bestuursrechtelijk karakter. Wel kent de Mededingingswet zelf twee bepalingen waarin een verjaringsregeling is opgenomen, te weten de artikelen $64 \mathrm{Mw}$ (met betrekking tot overtredingen van de materiële verboden) en $82 \mathrm{Mw}$ (met betrekking tot de overtredingen van de medewerkingsplicht):

De bevoegdheid tot het opleggen van een boete (...) als bedoeld in artikel 56, eerste lid, vervalt vijf jaren nadat de overtreding is begaan.

en

De bevoegdheid tot het opleggen van een boete als bedoeld in (artikel) 69, eerste lid, (...) vervalt twee jaren nadat de overtreding is begaan."1'

De memorie van toelichting bij deze artikelen is zeer summier. Zo wordt niet expliciet ingegaan op de reden voor de introductie van deze verjaringsregeling. Men kan er echter van uit gaan dat in ieder geval twee redenen hieraan ten grondslag hebben gelegen. De eerste houdt verband met het advies van de Commissie voor de toetsing van wetgevingsprojecten: zij achtte het gewenst om in een punitief bestuursrechtelijk handhavingsmodel een verjaringstermijn op te nemen, en wel vanuit het oogpunt van de rechtszekerheid. ${ }^{116}$ De tweede reden ligt hierin dat -zoals hiervoor uiteengezet- ook het communautaire kartelrecht verjaringsregels kent en dat de minister van Economische Zaken ook op dit punt bij het gemeenschapsrecht heeft willen aansluiten. Dit laatste wordt bevestigd door de keuze voor een (althans voorzover het de inbreuken op de artikelen 6 en $24 \mathrm{Mw}$ betreft) met het communautaire recht overeenstemmende verjaringstermijn van vijf jaar ${ }^{117}$ en

114 In de beroepszaak tegen de tweede PVC-beschikking, GvEA (T-305-307, 313-316, 318, 325, 328, 329 en 335/94) Jur. 1999, II-931 (Limburgse Vinyl Maatschappije.a.), werd door het Gerecht geoordeelddat de bevoegdheid tot het opleggen van boetes -dankzij stuiting en schorsing-na bijna veertien jaar nog niet was verjaard.

115 Artikel 5.4.1.6 VOAwb4 kent dezelfde verjaringstermijnen.

116 Handhaving door bestuurlijke boeten (1994), pag. 66-67.

117 Hiermee is afgeweken van het advies van de Commissie voor de toetsing van wetgevingsprojecten, die een termijn van twee jaar wenselijk achtte. Daarbij zij in herinnering geroepen dat deze commissie niet bestuursrechtelijkehandhaving van overtredingen als onderhavige voor ogen stond. Een termijn van twee jaar was in het advies van de commissie dan ook zeer wel verdedigbaar, maar deze termijn zou, zoals ook reeds gold binnen de strafrechtelijke handhaving, absoluut onvoldoende zijn in het kader cen kartelprocedure. Het advies van de commissie is daarentegen wel gevolgd ten aanzien van de formele inbreuken, waarmee de termijn afwijkt van de communautaire verjaringstermijn, die immers drie jaar bedraagt. De minister. MvT TK 1995-1996, 24 707, nr. 3, achtte "de noodzaak voor afstemming van de verjaringstermijn voor formele overtredingen (...) minder dringend dan die voor overtredingen van het kartelverbod en het verbod van misbruik van een economische machtspositie, waarbij de bepalingen van het verdrag en de nationale verboden elkaar overlappen". Desalniettemin pleit Van der Hulst (2000), pag. 73, -mijns inziens dus ten onrechte-voor een maximale verjaringstermijn 
door de expliciete vermelding in de memorie van toelichting dat bij voortdurende inbreuken de verjaringstermijn pas begint te lopen als de overtreding is beëindigd ${ }^{118}$ Opmerkelijk genoeg ontbreekt een stuitings- en schorsingsregeling. De reden hiervoor is niet duidelijk; zij is waarschijnlijk over het hoofd gezien. ${ }^{119}$ Dit impliceert in ieder geval dat een onderzoeks- of 'vervolgings'daad de verjaring niet stuit noch dat een bezwaarschrift- en beroepsprocedure de verjaring schorst, hetgeen voor de betrokken ondernemingen zeer aantrekkelijk is, maar vanuit handhavingsoptiek problematisch kan zijn. ${ }^{120}$

\section{$2.3 \mathrm{Ne}$ bis in idem en non-cumulatie}

In het strafrecht is vrij algemeen het beginsel aanvaard dat iemand niet tweemaal voor hetzelfde feit mag worden berecht of gestraft. ${ }^{121}$ Dit ne bis in idem-beginsel, dat zijn weg heeft gevonden naar verschillende internationale verdragen ${ }^{122}$, beschermt zowel het algemeen als het individueel belang. De bescherming van het individu ligt erin dat hij niet andermaal ter verantwoording kan worden geroepen voor een feit waarover bij rechterlijke uitspraak onherroepelijk is beslist: door de uitspraak is voor betrokkene de zaak definitief afgedaan. Het algemeen belang is bij het ne bis in idem-beginsel gebaat omdat aldus "de rechter niet wordt genoodzaakt zichzelf te herhalen of tegen te spreken". ${ }^{12}$ Het ne bis idem-beginsel heeft echter ook een keerzijde: aan de vervolgende instantie staan in beginsel geen middelen ter beschikking om een voor de maatschappij niet wenselijk geachte uitkomst van de gevoerde procedure opnieuw ter discussie te stellen. Uit de vrij algemene erkenning van het ne bis in idem-beginsel blijkt echter dat -althans in nationale context- de genoemde voordelen geacht worden te prevaleren.

van drie jaar.

118 MvT TK 1995-1996, 24 707, nr. 3.

119 In het advies van de Commissie voor de toetsing van wetgevingsprojecten wordt op de stuiting wel ingegaan. Gesteld wordt dat het opstellen van een rapport door het bevoegde bestuursorgaan de verjaring stuit. Zou de commissie hiermee hebben willen aangeven dat een stuitingsvoorziening inherent is aan de verjaring, dan moet deze visie worden verworpen. Wil de verjaring gestuit dan wel geschorst kunnen worden, dan moet de wettelijke regeling hierin uitdrukkelijk voorzien.

120 Zie hierover ook Mok in: Biesheuvel, Mok en Sevenster (1996), pag. 98. Het Voorontwerp Awb vierde tranche lost dit probleem deels op. In artikel 5.4.1.6 lid 3 VOAwb4 is namelijk bepaald: "Indien tegen de bestuurlijke boete bezwaarwordt gemaakt of beroep wordt ingesteld, wordt de vervaltermijn opgeschort tot onherroepelijk op het bezwaar of beroep is beslist".

121 Vergelijk Krabbe en Poelman (1985), pag. 126, Schermers (1987), pag. 602 en Hazewinkel-Suringa/Remmelink (1996), pag. 593.

122 Zie bijvoorbeeld artikel 14 lid 7 IVBPR (Verdrag van 19 december 1966, Trb. 1978, 177), de artikelen 54-58 Uitvoeringsovereenkomst van Schengen, de artikelen 35-37 Europees Verdrag betreffende de Overdracht van Strafvervolging (Verdrag van 15 mei 1972, Trb. 1973, 84) en artikel 4 van het Zevende Protocol bij het EVRM (Protocol van 22 november 1984, Trb. 1985, 2).

123 Hazewinkel-Suringa/Remmelink(1996), pag. 594. Franken(1995), pag. 11. Herhaling zou niet van veel proces-economie getuigen; het 'zichzelf tegenspreken' zou de autoriteit van de rechter en het gezagvan de uitspraakaantasten. In dezelfdezin Michiels(1994), pag. 41, ten aanzienvan de bestuurlijke boete: "Het gaat niet aan iemand twee keer te straffen voor hetzelfde feit met hetzelfde doel. Dat is niet alleen uit een oogpunt van rechtszekerheiden rechtvaardigheid ongepast; met de tweede straf zou ook tot uitdrukking worden gebracht dat de eerste niet zinnig of onvoldoende effectief was. Dat lijkt me niet best voor het imago van de boete en van bet orgaan dat haar oplegt". 
Het ne bis in idem-beginsel in het Nederlandse strafrecht ${ }^{124}$

In het Nederlandse strafrecht is het ne bis in idem-beginsel neergelegd in artikel $68 \mathrm{WvSr}$, dat (voorzover hier van belang) luidt:

1. Behoudens de gevallen waarin rechterlijke uitspraken voor herziening vatbaar zijn, kan niemand andermaal worden vervolgd wegens een feit waarover te zijnen aanzien bij gewijsde van de rechter in Nederland (...) onherroepelijk is beslist.

2. Is het gewijsde afkomstig van een andere rechter, dan heeft tegen dezelfde persoon wegens hetzelide feit geen vervolging plaats in geval van:

$1^{\circ}$ vrijspraak of ontslag van rechtsvervolging:

$2^{\circ}$ veroordeling, indien een straf is opgelegd, gevolgd door gehele uitvoering, gratie of verjaring der straf.

Uit artikel 68 lid $1 \mathrm{WvSr}$ blijkt dat voor een justitiabele ten aanzien van een bepaald feit de kous af is zodra door een Nederlandse rechter, waaronder een Nederlandse strafrechter moet worden verstaan ${ }^{125}$, onherroepelijk en inhoudelijk ${ }^{126}$ over dat feit is beslist. De centrale vraag in dit verband is wanneer er sprake is van hetzelfde feit. Sinds de inwerkingtreding van het wetboek van Strafrecht in 1886 is de (jurisprudentiële) invulling van dit feitsbegrip nogal aan wijzigingen onderhevig geweest. ${ }^{127}$ Tot begin jaren dertig van de vorige eeuw werd uitgegaan van een materieel feitsbegrip: één feitelijke gedraging impliceerde het bestaan van één feit in de zin van artikel $68 \mathrm{WvSr}$, ook al viel deze gedraging onder verschillende en andersoortige strafbepalingen. Deze interpretatie van het feitsbegrip leidde tot een zeer ruime en naar bleek voor de praktijk te ruime werking van het ne bis in idem-beginsel. ${ }^{128}$ In 1932 gooide de Hoge Raad het roer dan ook drastisch om: bepalend was niet langer de gedraging als zodanig, maar de (al dan niet gelijksoortige) strekking van de overtreden strafbepalingen. ${ }^{129}$ 'Feit' kon als het ware gelezen worden als 'strafbaar feit'..$^{130} \mathrm{En}$ omdat gelijksoortigheid van strekkingen niet licht werd aangenomen, werd de bescherming van het ne bis in idem-beginsel tot een bedenkelijk niveau beperkt: zolang de officier van Justitie zijn tweede vervolging maar afstemde op een strafbaar feit dat een ander rechtsbelang diende dan het eerder ten laste gelegde feit, stond artikel $68 \mathrm{WvSr}$ aan die tweede vervolging niet in de weg. Deze invulling van het feitsbegrip en de daarmee gepaard gaande uitholling van het ne bis in idembeginsel heeft geruime tijd standgehouden. Begin jaren zestig heeft de Hoge Raad echter

124 Zie hierover De Hullu (2000), pag. 515-531.

125 Vergelijk onder meer HR 9 oktober 1984, NJ 1985, 251 m.nt. 'tH, HR 5 februari 1991, NJ 1991, 402 en HR 21 mei 1991, NJ 1991, 728 m.nt. ThWvV.

126 De strafrechter moet met andere woorden zijn toegekomen aan beoordeling van de materiële vragen van artikel $350 \mathrm{WvSv}$. Een einduitspraak als bedoeld in artikel $349 \mathrm{WvSv}$ staat aan een nieuwe vervolging niet in de weg.

127 Zie over de ontwikkeling van het feitsbegrip onder meer Hazewinkel-Suringa/Remmelink(1996), pag. 596 c.v., Franken (1995), pag. 47 e.v., Van Bemmelen/Van Veen (1998), pag. 253 e.v., Kelk (1998), pag. 59 e.v. en Worretshofer (1999 II), pag. 340 e.v..

128 Voor een wel zeertyperend voorbeeld van de onwenselijke gevolgen van hantering van het materiele feitsbegrip zie Hof Amhem 1 oktober 1931, NJ 1932, 908.

129 HR 15 februari 1932, NJ 1932, 289 m.nt. T (Oude Kijk in ' $t$ Jatstraat)en HR 27 juni 1932, NJ 1932. 1659 m.nt T (Brakelse Kermis).

130 Vergelijk Hazewinkel-Suringa/Remmelink (1996), pag. 599 en Franken (1995), pag. 49. 
zijn koers enigszins bijgesteld en is hij in feite tot een middenweg gekomen. Bij de vraag of er sprake is van hetzelfde feit is beslissend of tussen de feiten

"een zodanig verband bestaat met betrekking tot de gelijktijdigheid van de gedragingen en de wezenlijke samenhang in het handelen en de schuld van de verdachte, dat artikel $68 \mathrm{Sr}$ meebrengt dat deze in de zin van die bepaling als dezelfde feiten zijn aan te merken". ${ }^{131}$

Bij deze beoordeling zijn zowel de wet (het karakter van de strafbepalingen) als het feitelijk gebeuren van belang. ${ }^{132}$ Wélk van beide aspecten doorslaggevend is, is in sterke mate afhankelijk van de omstandigheden van het geval. Duidelijk is wel dat, behoudens wellicht in de gevallen waarin de verschillende strafbepalingen qua karakter zeer ver uiteenlopen ${ }^{133}$, de strekking alléén niet meer beslissend is (in die zin dat een verschil in strekking automatisch het bestaan van meer dan één feit impliceert), maar dat de concrete, feitelijke omstandigheden mede bepalen of er sprake is van hetzelfde feit. ${ }^{134}$

De hier besproken invulling van het feitsbegrip geldt niet alleen ten aanzien van het eerste lid van artikel $68 \mathrm{WvSr}$, maar ook met betrekking tot het tweede lid, waarin het 'internationale' ne bis in idem-beginsel is verankerd ${ }^{135}$ : binnen de daar gestelde grenzen staat ook een gewijsde van (straf)rechters uit een andere rechtsorde aan vervolging in Nederland wegens het betreffende feit in de weg. Met deze erkenning van het zogenoemde 'Erledigungsprinzip' voor buitenlandse gewijsden, gaat Nederland verder dan doorgaans in internationale context gebruikelijk is. ${ }^{136}$ In andere rechtsstelsels blijft de werking van het ne bis in idem-beginsel vaak beperkt tot wat wel wordt aangeduid als het 'Anrechnungsprinzip': een buitenlands rechterlijk gewijsde levert dan geen vervolgingsbeletsel op, maar op de rechter rust wel de plicht om de bij de 'buitenlandse' uitspraak opgelegde sanctie te verdisconteren in de door hem op te leggen straf. ${ }^{137}$ In feite beperkt het ne

131 HR 13 december 1994, NJ 1995, 252 (Spiegelbeeld), aansluitend bij HR 21 november 1961, NJ 1962 , 89 m.nt. BVAR (Emmense bromfietser), HR 5 februari 1963, NJ 1963, 320 m.nt. BVAR (Van der Does de Willeboissingel) en HR 17 december 1963, NJ 1964, 385 m.nt. WP (Joyriding II). Vergelijk ook HR 26 november 1996, NJ 1997, 209. Een eerste aanzet tot de aanpassing van de interpretatie van het feitsbegrip kan overigens reeds in HR 13 april 1954, NJ 1954, 369 m.nt. BVAR gevonden worden.

132 Hazewinkel-Suringa/Remmelink(1996), pag. 600, Franken (1995), pag. 51 en Kelk (1998), pag. 62 .

133 Zie met name HR 18 januari 1972, NJ 1972, 378 m.nt. CB (Joyriding IV) en HR 25 maart 1975, NJ 1975, 296 (Beschonken zondagsrijder), waarin de strekkingen van de in het geding zijnde strafrechtelijke normen dermate van elkaar verschilden dat reeds op grond hiervan tot twee feiten werd geconcludeerd. De feitelijke omstandigheden speelden in die situatie geen rol meer. Zie hierover Franken (1995), pag. 52 en Hazewinkel-Suringa/Remmelink (1996), pag. 602 en 603.

134 Corstens (1995 II), pag. 725, spreekt in dit verband van de corrigerende werking van het door de Hoge Raad in zijn Emmense bromfietser-arrest gelanceerde criterium.

135 Dat volgt reeds uit HR 13 december 1994, NJ 1995, 252 (Spiegelbeeld), waarin het om een grensoverschrijdend drugstransport ging en waarin de verdachte in Nederland werd vervolgd (wegens het vervoeren en naar België exporteren van verdovende middelen), hoewel hij voor dezelfde gedraging reeds in Belgiê was veroordeeld (te weten wegens invoer en doorvoer in België).

136 Zie hierover Krabbe en Poelman (1985), pag. 127 e.v..

137 Voor dit 'internationale' ne bis in idem-beginsel heeft het eerder genoemde artikel 14 lid 7 IVBPR geen betekenis, aangezien het uitsluitend ziet op de erkenning van nationale vonnissen: Communication No. 204/1986, 2 November 1987, U.N. Doc. CCPR/C/OP/1 at 67, 1987 (A.P. v. Italy). Vergelijk 
bis in idem-beginsel zich dan tot een verbod op sanctie-cumulatie. ${ }^{138}$ Dat het 'Erledigung. sprinzip' in internationale context zich slechts in een beperkt enthousiasme mag verheugen, is terug te voeren op drie, tot op zekere hoogte met elkaar samenhangende, aspecten. Ten eerste doen de redenen die aan hantering van het ne bis in idem-beginsel ten grondslag liggen, in internationale context maar ten dele opgeld. Voor het individueel belang verandert het internationale aspect niets: voor de betrokkene blijft het cruciaal dat hij niet een tweede maal van overheidswege wegens hetzelfde feit ter verantwoording wordt geroepen; of de eerdere veroordeling binnen een andere rechtsorde heeft plaatsgevonden, zal hem niet deren en is de facto ook niet relevant. Dat laatste is anders ten aanzien van het algemeen belang dat het ne bis in idem-beginsel beschermt. Voorzover de tweede vervolging zich in een andere rechtsorde afspeelt, ontbreekt immers het gevaar dat een rechter zichzelf' zal herhalen of tegenspreken. Dat hij onvermijdelijk wel een 'andere' rechter (de rechter dus uit een andere rechtsorde) hetzij herhaalt hetzij tegenspreekt, tast zijn eigen autoriteit en het gezag van de rechterlijke uitspraken binnen 'zijn' rechtsorde niet aan. ${ }^{139}$ In zoverre is het fundament voor de hantering van het ne bis in idem-beginsel in internationale context dan ook minder stevig dan in nationale context. ${ }^{140}$ Het tweede argument houdt verband met de soevereiniteit van de staten: over het algemeen ligt het bij staten zeer gevoelig om de soevereiniteit ten aanzien van vervolging en bestraffing prijs te geven. ${ }^{141}$ Dit houdt met name ermee verband dat het gegeven dat over een feit in een andere rechtsorde onherroepelijk is beslist, nog niet inhoudt dat deze beslissing recht doet aan de belangen van de eigen, nationale rechtsorde. Met name zal een staat de vervolging zelf ter hand willen nemen als zijn eigen rechtsorde zeer geschokt is door de overtreding en deze niet afdoende -niet in de laatste plaats met het oog op de hoogte van de in een derde staat opgelegde sanctie- is bestraft. Het derde argument voor de terughoudendheid ten aanzien van het 'Erledigungsprinzip' ligt hierin dat omarming ervan zou impliceren dat ook rechterlijke uitspraken moeten worden geaccepteerd uit staten, ten aanzien waarvan het vertrouwen (in de rechtspraak) gering is. ${ }^{142}$ Dit blijkt voor veel staten -niet geheel onbegrijpelijk- niet aanvaardbaar. ${ }^{143}$ Gelet op deze argumenten verbaast het niet dat niet het 'Erledigungsprinzip', maar het 'Anrechnungsprinzip' in internationale context de boventoon voert. Dit 'Anrechnungsprinzip' kan als een compromis worden gezien, waarin de belangen van de staat worden beschermd (met name blijft de soevereiniteit op vervolgingsgebied in takt en hoeft een staat zich niet neer te leggen bij een gewijsde uit een land waarin het vertrouwen niet al te groot is), maar waarin toch -zij het in mindere

tevens Vermeulen (1994), pag. 217 e.v.. Hetzelfde geldt overigens voor artikel 4 van het Zevende Protocol bij het EVRM, welk Protocol overigens door Nederland(nog) niet is ondertekend, alsmede expliciet voor de Single Convention on Narcotic Drugs, 23 maart 1961, New York.

138 Vergelijk De Doelder en Van der Hulst (1993), pag. 732.

139 Strikt genomen wordt de autoriteit van de rechter binnen de andere rechtsorde evenmin aangetast. Het moge echter duidelijk zijn dat een principieel andere uitkomst een latere 'buitenlandse' procedure afhankelijk van de reden voor deze andere uitkomst- als zeer gevoelig kan worden ervaren.

140 De Doelder en Van der Hulst (1993), pag. 731, stellen derhalve terecht: "Het belang van de staat bij een intemationale werking van het ne bis in idem-beginsel is relatief aangezien verschillende rechters met een verschillende invalshoek over een bepaald feit oordelen. De geloofwaardigheid van de staat is vooral in het geding indien dezelfde organen zich zouden gaan tegenspreken".

141 In deze zin ook Krabbe en Poelman (1985), pag 127.

142 Zie hierover ook Sehermers (1987), pag. 604/605.

143 Nederland heeft hiermee minder moeite, getuige de aanvaarding van het 'Erledigungsprinzip' in het tweede lid van artikel $68 \mathrm{WvSr}$. 
mate dan bij het 'Erledigungsprinzip'- met de belangen van het individu rekening wordt ghouden, namelijk door bij de straftoemeting rekening te houden met de eerder opgelegde staf. Nederland gaat echter voor zover het het strafrecht betreft zoals gezegd tamelijk ver in de erkenning van het ne bis in idem-beginsel. Hieronder komt aan de orde in hoeverre dit ook het geval is binnen de communautaire rechtsorde.

\section{Communautaire sancties en ne bis in idem}

In hoofdstuk 2 bleek reeds dat de eis van interstatelijkheid uit de artikelen 81 en 82 EG zeer ruim wordt geïnterpreteend. Daardoor is het geenszins denkbeeldig dat door ondernemingen ontplooid kartelgedrag zowel inbreuk maakt op het gemeenschapsrecht als op het nationale mededingingsrecht van één der lidstaten. In het verlengde daarvan ligt dat en onderneming tenminste theoretisch wegens dezelfde gedraging zowel door de Commissie als door een nationale autoriteit ter verantwoording kan worden geroepen. Voor zover beide dit daadwerkelijk doen, loopt de onderneming derhalve de kans om tweemaal wegens hetzelfde feit te worden 'vervolgd' en gestraft. De vraag is nu of het ne bis in idembsginsel zich hiertegen verzet. Dit beginsel zou daarnaast soelaas kunnen bieden voor tvee andere situaties, te weten die waarin de Commissie zelf wegens hetzelfde feit andermaal een procedure tegen de onderneming inleidt en die waarin de Commissie een boeteprocedure initieert wegens een inbreuk waarvoor reeds eerder door een autoriteit uit een niet-lidstaat is vervolgd. Voorop gesteld kan worden dat het geschreven gemeenschapsrecht nergens met zoveel woorden het ne bis in idem-beginsel noemt. Maar ook hier geldt dat het beginsel toch, als algemeen beginsel van gemeenschapsrecht, deel zou kunnen uitmaken van het communautaire recht. Tot op zekere hoogte blijkt dit inderdaad het geval te zijn. Het is de Commissie namelijk niet toegestaan om een onderneming wegens een feit, waarover door haar in een beschikking reeds een oordeel is geveld, andermaal te 'vervolgen', tenzij de beschikking op procedurele gronden door het Gerecht of het Hof nietig is verklaard. ${ }^{144}$ Hier geldt dus een ne bis in idem-beginsel dat -analoog aan het beginsel zoals dat in veel rechtstelsels voor de nationale context wordt gehanteerduitgaat van het 'Erledigungsprinzip'. Er zijn mijns inziens ook geen goede gronden aanwezig om tot een ander standpunt te komen: de Commissie heeft de mogelijkheid gehad om over het gedrag te oordelen, waarna de onderneming met rust moet worden gelaten, ook al is de Commissie later om welke reden dan ook minder gelukkig met de uitkomst van de eerdere procedure. ${ }^{145}$

144 GvEA (T-305-307, 313-316, 318, 325, 328, 329 en 335/94) Jur. 1999, II-931 (Limburgse Vinyl Maatschappije.a.). Dit werd -mede naar aanleiding van HvJ (18 en 35/65) Jur. 1967, 74 (Gutmann)reeds eerder aangenomen. Vergelijk Van Acker (1986), pag. 346 en De Moor-Van Vugt (1999), pag. 170. Dat na nietigverklaring wel een nieuwe 'vervolging' mogelijk is, hangt samen met het feit dat in dat geval de communautaire rechter zich nog niet heeft kunnen en hoeven uitspreken over de inhoudelijke aspectenvan de zaak. In zoverre is er een parallelmet het Nederlandse strafrecht waarin immers artikel $68 \mathrm{WvSr}$ slechts opgeld doet indien de rechter aan de (materiële) hoofdvragen van artikel $350 \mathrm{WvSv}$ is toegekomen.

145 De bescherming van de onderneming staat eveneens voorop bij het beleid van de Commissie ten aanzien van samenloop van inbreuken. Indien een gedraging onder verschillende verdragsartikelen valt, dan legt de Commissie, bij ontbreken van een communautaire samenloopregeling, slechts een sanctie op wegens één, zij het de zwaarste, overtreding: zie $\mathrm{Pb} 1989$ L 33/44 (Vlakglas). In gevallen 
In de verhouding lidstaat/Gemeenschap daarentegen is er geen plaats weggelegd voor het 'Erledigungsprinzip'. Dat blijkt uit het gezaghebbende Wilhelm-arrest ${ }^{146}$, waarin het Hof het probleem van de dubbele 'vervolging' in het bredere kader van de verhouding tussen nationaal en communautair recht behandelde. Het Hof oordeelde

"dat (...) de nationale gezagsorganen krachtens het nationale recht naar aanleiding van een ondememers. afspraak mogen optreden, ook wanneer voor de Commissie in onderzoek is in hoeverre bedoelde afspraak zich met de voorschriften van het gemeenschapsrecht verdraagt, met dien verstande dat deze toepassing van het nationale recht aan een volledige en uniforme toepassing van het gemeenschapsrecht -en aan de werking der uitvoeringsbesluiten-geen afbreuk mag doen; (...)

dat de mogelijkheid van cumulatie van sanctiesniet uitsluit, dat twee parallel lopende, ter verwezenlijking van verschillende doelstellingen aanhangig gemaakte procedures mogen worden ingesteld; (...)

dat wanneer de mogelijkheid van tweeèrlei procedure echter tot oplegging van tweeërlei sanctic zou leiden, algemene billijkheidsgronden (...) medebrengen, dat bij bepaling der straf met eerdere beslissingen van repressieve aard rekening dient te worden gehouden."

Tegen de achtergrond van de uiteenlopende doelstellingen van het communautaire en het nationale recht, is het Hof derhalve tot het oordeel gekomen dat een parallelle toepassing van communautair en nationaal recht op één ondernemersafspraak tot de mogelijkheden behoort. Een communautaire procedure betekent derhalve niet dat de nationale autoriteiten moeten terugtreden; een nationale procedure bindt de communautaire instanties niet. Ten aanzien van dit laatste geldt dat een andere opvatting niet alleen het beleid van de Commissie zou doorkruisen (en dus de verwezenlijking van de doelstellingen van het EG-Verdrag zou kunnen frustreren) maar bovendien dat zij ook onverenigbaar zou zijn met de voorrang van het gemeenschapsrecht. ${ }^{147}$ Deze voorrang brengt voorts mee dat de nationale autoriteiten de Commissie bij de verwezenlijking van de communautaire doelstellingen niet in de wielen mogen rijden: parallelle toepassing is slechts toegestaan voorzover daardoor geen conflict met een (nog te nemen of reeds genomen) Commissiebesluit optreedt. Met een verwijzing naar de bevoegdheidsverdeling (ten aanzien van kartelgedragingen) tussen de Gemeenschap en de lidstaten achtte het Hof ook een parallelle boeteprocedure niet uitgesloten, waarmee hij dus het 'Erledigungsprinzip' in de verhouding Gemeenschap/lidstaat niet aanvaardde. ${ }^{148}$ Een onderneming kan derhalve wegens hetzelfde feit zowel op communautair als op nationaal niveau worden 'vervolgd' en gestraft. Wel geldt bij een dubbele 'vervolging' een op algemene billijkheidsgronden berustend 'Anrechnungsprinzip', op grond waarvan in het kader van de tweede boeteprocedure

waarin verschillende inbreuken tegelijk worden 'berecht', draagt de Commissie er zorg voor dat 'dezelfde feiten niet meermaals worden bestraft': zie Pb 1976 L 95/1 (Chiquita).

$146 \mathrm{HvJ}(14 / 68)$ Jur, 1969, 1 (Walt Wilhelm e.a.). Het betrof een prejudiciele beslissing naar aanleiding van vragen van het Duitse Kammergericht in de kleurstoffen-zaak.Zie voor commentaarop dit arrest VerLoren van Themaat (1969), pag. 312 e.v., Mok (1969 I), pag. $24-26$ en Mok (1970), pag. 151 c.v..

$147 \mathrm{HvJ}$ (6/64) Jur. 1964, 1199 (Costa-ENEL). Zie hierover onder meer Barents en Brinkhorst (1999). pag. 34 e.v. en Bekkers e.a. (1993), pag. 91 e.v..

148 Zie hieromtrent Pernice (1979), pag. 40; "Das Verbot der Doppelsanktion als Hindernis für das Nebeneinander von nationalenund europăischemKartellverfahrenanzusehen, verbietetsich nach Auffassung des Gerichtshofs wegen der Autonomie beider Rechtsebenen und weil jede Behörde das Marktverhalten der Unternehmen unter anderen Gesichtspunkten zu beurteilen hat". 
rekening moet worden gehouden met een eventuele eerder opgelegde sanctie wegens hetzelfde feit. In zoverre kan dan ook geconcludeerd worden dat de reikwijdte van het ne bis in idem-beginsel in de verhouding Gemeenschap/lidstaat vergelijkbaar is met de reikwijdte van het 'internationale' ne bis in idem-beginsel zoals dat door veel landen mar zoals gezien niet door Nederland- wordt gehanteerd. ${ }^{149}$

Rest de vraag naar de werking van het ne bis in idem-beginsel in de verhouding nietlidstaat/Gemeenschap. Het moge duidelijk zijn dat daar waar het Hof in een eerdere vervolging door een lidstaat -met zijn toch aan de Gemeenschap parallel lopende rechtsbelangen ${ }^{150}$ - geen beletsel voor de Commissie ziet om een communautaire boeteprocedure te starten, hij het 'Erledigungsprinzip' ten aanzien van gewijsden uit derde staten -waarbij de parallellie van rechtsbelangen allerminst een gegeven is- zeker niet zal aanvaarden. Geldt dit echter ook voor het 'Anrechnungsprinzip'? Vooropgesteld zij dat het voor de onderneming volledig irrelevant is of de voorafgaande boete afkomstig is van een instantic uit cen lidstaat of uit een derde staat: in beide gevallen is voor haar het belang van honorering van het 'Anrechnungsprinzip' (even) groot. Daar staat tegenover dat verrekening van de eerdere boete hier vanuit communautair gezichtspunt wellicht minder voor de hand ligt dan in de situatie waarin het eerdere gewijsde afkomstig is van een lidstatelijke autoriteit: de (ook geografisch) nauwe band tussen lidstaat en Gemeenschap is immers inde verhouding derde staat/Gemeenschap op zijn minst minder prominent aanwezig. ${ }^{151}$

De hierboven gestelde vraag over de gelding van het 'Anrechnungsprinzip' werd reeds in de Kinine-zaak aan de orde gesteld. De onderneming Boehringer had door deelname aan het internationale Kinine-kartel zowel de federale mededingingswetgeving van de Verenigde Staten als artikel 85 EG-Verdrag (thans artikel 81 EG) overtreden. Boehringer werd voor deze deelname eerst door de Amerikaanse autoriteiten en vervolgens door de Commissie beboet. De onderneming was van mening dat de 'Wilhelm-doctrine' ook gold ten aanzien van de verhouding derde staat/Gemeenschap en dat derhalve de in de Verenigde Staten opgelegde sanctie op de communautaire boete in mindering zou moeten worden gebracht. In het eerste Boehringer-arrest ${ }^{152}$ overwoog het Hof dat de 'buitenlandse' sancties

"zijn opgelegd terzake van mededingingsbeperkingen buiten de Gemeenschap; dat derhalve geen termen aanwezig zijn daarmede in dit geding rekening te houden".

149 Slechts enkele maanden na het Wilhelm-arrest zag in dezelfde kleurstoffen-zaak een beschikking van de Commissie (Pb 1969 L 195/11) het licht, waarin zij onder meer aan de Duitse leden van het kleurstoffenkartel boetes oplegde, ondanks een eerdere boete op nationaal niveau. Bij de bepaling van de strafmaat hield de Commissie overigens geen rekening met deze cerdere boetes. De reden hiervoor moet mijns inziens gezocht worden in de omstandigheid dat de Duitse procedure nog niet was afgerond. De ondernemingenhebben overigens de nationale boetesnooit hoeven te betalenomdat het door hen ingestelde -en schorsende werking hebbende- beroep tegen het besluit van het Bundeskartellamt leidde tot vernietiging van dat besluit. Zie HvJ (51/69) Jur. 1972, 713 (Bayer), HvJ (55/69) Jur. 1972, 887 (Cassella) en HvJ (56/69) Jur. 1972, 927 (Hoechst).

I50 Mulder (1989), pag. 476.

151 Daar komt nog bij dat het vertrouwen in de rechtspleging van de lidstaten een gegeven is. Een dergelijk vertrouwen ten aanzien van derde staten is minder vanzelfsprekend.

$152 \mathrm{HvJ}$ (45/69) Jur. 1970, 769 (Boehringer Mannheim). In vergelijkbare bewoordingen HvJ (44/69) Jur. 1970, 733 (Buchler). 
Zonder nadere toelichting wordt aldus tamelijk stellig door het Hof verrekening van de hand gewezen in die gevallen waarin de eerdere veroordeling betrekking had op kartelgedrag dat buiten EG-grenzen is ontplooid. Dit betekent echter nog niet dat het Hof de gelding van het 'Anrechnungsprinzip' in de verhouding derde staat/gemeenschap heeft verworpen: de geciteerde overweging laat de mogelijkheid open dat het Hof verdiscontering wel geinndiceerd achtte indien de in een derde staat opgelegde sanctie betrekking had op een op EG-grondgebied gepleegde overtreding. Al te vergaande conclusies mogen echter op dit punt niet uit het eerste Boehringer-arrest worden getrokken. Het probleem deed zich namelijk voor dat de Commissie geen kans had gehad om in haar oorspronkelijke boetebeschikking aandacht aan deze problematiek te besteden aangezien het verzoek om mindering van de boete haar pas had bereikt nadat zij de beschikking had genomen. Het Hof had bij de behandeling van het beroep tegen deze beschikking dan ook geen aanleiding gezien om wel nader op de bedoelde problematiek in te gaan. ${ }^{153}$ Dit was anders nadat Boehringer tegen een alsnog door de Commissie ten aanzien van dit punt genomen (en voor de onderneming negatieve) beschikking ${ }^{154}$ bij het Hof beroep had ingesteld. $\mathrm{Na}$ bevestiging van de Wilhelm-doctrine voor sancties binnen het grondgebied van de Gemeenschap, overwoog het Hof

"dat de vraag of de Commissic ook kan zijn gehouden een door de gezagsorganen van een derde staat opgelegde straf in mindering te brengen, slechts behoeft te worden beantwoord wanneer de feiten welke aan verzockster enerzijds door de Commissie en anderzijds door de Amerikaanse autoriteiten zijn ten laste gelegd, dezelfde zijn" "Is

Met deze overweging trapte het Hof een tamelijk wijdopenstaande deur in: in ieder geval geen 'Anrechnung' indien het niet dezelfde feiten betreft. Maar juist dit punt vormde voor Boehringer het struikelblok: volgens het Hof konden de in de Verenigde Staten bestrafte inbreuken niet als 'hetzelfde feit' (op dit begrip wordt hierna nog ingegaan) worden aangemerkt. Dientengevolge kwam het Hof niet toe aan de beantwoording van de vraag of sanctiecumulatie geoorloofd is indien wegens een feit reeds in een derde staat een boete is opgelegd. Desalniettemin kan naar mijn mening uit het tweede Boehringer-arrest de conclusie worden getrokken dat het Hof ten aanzien van 'buitenlandse' gewijsden in ieder geval de bevoegdheid van de Commissie tot verrekening heeft aanvaard. Een andere conclusie ligt namelijk niet in de lijn van het arrest: de uitdrukkelijke, inhoudelijke aandacht voor en toetsing van het feitsbegrip is immers volstrekt overbodig, indien het Hof vervolgens de Commissie het recht op verdiscontering zou ontzeggen. ${ }^{156} \mathrm{Het}$ is naar mijn mening aannemelijk dat het Hof daarenboven in zijn tweede Boehringer-arrest ervan is uitgegaan dat op de Commissie tevens een verplichting rust tot het in rekening brengen van een eerdere buiten de EG opgelegde boete; dat, met andere woorden, het Hof het 'Anrechnungsprinzip' ook heeft erkend voor de verhouding derde staat/Gemeenschap. ${ }^{157}$ Mijns inziens is namelijk niet in te zien waarom de algemene billijkheidsgron-

153 Vergelijk ook de opmerkingen hieromtrent van Winkler (1971) in noot 566, pag. 102.

$154 \mathrm{~Pb} 1971$ L 282/46 (Boehringer).

$155 \mathrm{HvJ}(7 / 72)$ Jur. 1972, 1281 (Boehringer).

156 In die zin ook Schrōter (1991), pag. 1391.

157 In de literatuur bestaat hierover nog wel de nodige onenigheid. VerLoren van Themaat (1973), pag. 277, stelt bijvoorbeeld dat deze conclusie niet zonder meer 'a contranio' uit onderhavig arrest mag worden afgeleid. Ook Van Gerven c.s. (1997), pag. 106, stellen dat het nog een open vraag is of 
den, waaraan door het Hof in zijn Wilhelm-arrest ter bescherming van ondernemingen zo'n groot gewicht is toegekend, zich in de verhouding derde staat/Gemeenschap niet zouden verzetten tegen onbeperkte cumulatie van sancties, vooropgesteld althans dat de belangen van de Gemeenschap zijn gewaarborgd. En dit laatste is het geval doordat door het Hof een enge invulling aan het feitsbegrip wordt gegeven, hetgeen overigens weer tot gevolg heeft dat de praktische betekenis van het 'Anrechnungsprinzip' in bedoelde verhouding uiterst marginaal is. Dit moge blijken uit het volgende. A-G Mayras verdedigde in zijn conclusie bij het tweede Boehringer-arrest een visie die raakvlakken vertoont met hetgeen in Nederland in de jaren dertig-jaren zestig van de vorige eeuw heersende leer was:

"de straf moet (..) haar rechtvaardiging vinden in de voor de mededinging binnen de gemeenschappelijke
markt nadelige gevolgen welke deze overeenkomsten, besluiten of gedragingen kunnen hebben -of in
concreto reeds hebben gehad-. De 'daadwerkelijk of potenticel' intredende territoriale gevolgen zijn een
der bestanddelen, ja een noodzakelijk bestanddeel, van de inbreuk. (...) Al zouden dus dezelfde ondernemin-
gen zich ter zake van hetzelfde feitelijk gebeuren voor een Amerikaanse federale rechter en tegelijkertijd
voor de Commissie van de Europese Gemeenschappen moeten verantwoorden, dan nog zouden de bestand-
delen van elk van beide inbreuken noodrakelijkerwijze verschillen. (...) Dat het om dezelfde overeenkomsten
gaat, wil nog niet zeggen dat ook de ten laste gelegde feiten dezelfde zijn".

Niet het feitelijke gebeuren, maar de 'tenlastelegging' bepaalt of er sprake is van een 'idem': 'feit' staat gelijk aan 'ten laste gelegd feit'. Voor het communautaire ne bis in idem-beginsel is derhalve de identiteit van (de strekking van) de ten laste gelegde feiten doorslaggevend. Waar het met andere woorden om draait, is dat de belangen die in de eerdere procedure zijn beschermd, gelijk zijn aan de belangen die bij de tweede 'vervolging' centraal staan. En daar zit het probleem bij de verhouding derde staat/Gemeenschap: hier lopen de belangen welhaast per definitie uiteen. Dat houdt ermee verband dat, zoals Mayras terecht stelt, de territorialiteit van de gevolgen een wezenlijk bestanddeel van een inbreuk op de mededingingsregels vormt: het rechtsbelang dat door het statelijk mededingingsrecht wordt beschermd, is in beginsel de mededinging binnen de eigen grenzen van de betreffende staat; voor het communautaire kartelrecht is dat rechtsbelang per definitie beperkt tot de mededinging binnen de Gemeenschap. Dat impliceert dat

de Commissie verplicht is rekening te houden met een in een derde staat opgelegde sanctic. Kerse (1998), pag. 328, stelt echter mijns inziens terecht dat het Hof "acknowledged, as a matter of Community law, the equity of a set-off to avoid or mitigate such double jeopardy, but did not consider it applicable in the circumstances of the case". Vergelijk ook Ortiz Blanco(1996), pag. 229/230: "there is in principle no reason for penalties imposed under other competition laws of non-member States not to be taken into account for the purpose of reducing a fine, provided that both the conduct constituting the infringement and its geographical scope are the same". De Doelder en Van der Hulst (1993), pag. 732, leiden daarentegen klaarblijkelijk uit het tweede Boehringer-arrest af dat het Hof het 'Anrechnungsprinzip' ten aanzien van 'buitenlandse' gewijsden niet heeft aanvaard. Zij stellen immers dat de verplichting tot verrekening alleen geldt "indien die straffen wegens een op het grondgebied van de EEG gepleegde inbreuk op het kartelrecht van een lidstaat zijn opgelegd. Een buiten de EEG opgelegde boete behoeft derhalve niet in rekening te worden gebracht" (cursiveringen HQ). Hun verwijzing in deze naar Hellingman en Mortelmans (1989), pag. 279, kan deze conclusie mijns inziens niet staven. Hellingman en Mortelmans stellen weliswaar dat het Hof oordeelde dat het beginsel "niet geldt ten opzichte van mededingingsbeperkingen buiten de Gemeenschap", maar baseren die conclusie uitsluitend op het eerste Boehringer-arrest en tweede beschikking van de Commissie en laten het tweede Bochringer-arrest onbesproken. 
in de verhouding derde staat/Gemeenschap van een gelijkheid van te beschermen belangen en dus van een identiteit van op die belangen afgestemde tenlasteleggingen geen sprake kán zijn, behoudens in het waarschijnlijk zeldzame geval dat een derde staat rechtsmacht heeft ten aanzien van gedragingen die zich op EG-grondgebied hebben afgespeeld en hij deze ook heeft uitgeoefend. In dat geval immers is de territorialiteit als bestanddeel van de inbreuk in beide 'vervolgingen' gelijk en heeft de 'buitenlandse' veroordeling wél bijgedragen aan de waarborging van het communautaire belang.

Het Hof volgt klaarblijkelijk de visie van Mayras. Nadat het Hof in zijn tweede Boehringer-arrest geoordeeld had dat de vraag omtrent de gelding van het 'Anrechnungsprinzip' slechts behoeft te worden beantwoord indien de ten laste gelegde feiten dezelfde zijn, overwoog het

"dat de feiten welke tot deze beide veroordelingen hebben geleid, weliswaar hun oorsprong vinden in hetzelfde pakket van overeenkomsten, doch niettemin overwegend een verschillende strekking hebben en niet op dezelfde plaats zijn begaan". ${ }^{38}$

Bepalend is de identiteit van de strekking van de feiten (de wijze waarop de mededinging wordt verstoord, moet gelijk zijn) en van de plaats waar zij zijn begaan; niet relevant is waar de eerdere 'veroordeling' heeft plaatsgehad. ${ }^{159}$ Dit betekent dus dat, wil er vanuit communautaire optiek sprake kunnen zijn van hetzelfde feit en dus van verdiscontering van een eerder opgelegde sanctie, de eerder gevoerde procedure in ieder geval betrekkiking moet hebben gehad op mededingingsbeperkend gedrag dat binnen de Gemeenschap is ontplooid: de rechtsmacht van de Commissie zelf is immers beperkt tot EG-territoir. ${ }^{100}$ En juist omdat, zoals gezegd, ook de statelijke mededingingswetgeving in beginsel niet verder zal reiken dan het eigen grondgebied, is gelijkheid van feiten in de verhouding derde staat/Gemeenschap vrijwel uitgesloten. Dit is anders in de verhouding lidstaat/Gemeenschap. Een veroordeling door een lidstatelijke autoriteit wegens overtreding van het nationale kartelrecht heeft weliswaar in beginsel eveneens slechts betrekking op gedrag dat binnen de eigen grenzen de mededinging heeft aangetast (of zou kunnen aantasten), maar in dat geval heeft die veroordeling wel tevens betrekking op een deel van het EGgrondgebied; de vereiste territoriale identiteit is hier dan ook welhaast een gegeven. En

$158 \mathrm{HvJ}(7 / 72)$ Jur. 1972, 1281. In haar Tweede verslag over het mededingingsbeleid, nr. 26, concludeerde de Commissie dat het Bochringer-arrest erop was gebaseerd dat niet was vastgesteld "dat de uit hoofde van elk der wetgevingen ten laste gelegde feiten identiek zijn". Vergelijk ook Pb 2001 L 152/24 (Aminozuren), waarin de Commissie geen rekening wenste te houden met eerder opgelegde sancties in de Verenigde Staten en Canada: "De Commissie merkt overigens op dat volgens informatie, verstrekt door de autoriteiten van de Verenigde Staten en Canada, de strafrechtelijke geldboeten welke door die autoriteiten zijn opgelegd aan de ondernemingen tot wie deze beschikking gericht is, uitsluitend rekening hielden met de coneurrentieverstorende gevolgen die de in deze beschikking onderzochte geheime afspraken hadden binnen hun rechtsgebied".

159 Niet bepalend was dat de feitenuit hetzelfdepakket van overeenkomstenvoortvloeiden. Dat betekent niet dat dit aspect van ieder belang ontbloot is. Integendeel: indien hieraan niet is voldaan zal zelden of nooit tot hetzelfde feit geconcludeerd kunnen worden.

160 Pas dan zijn ook de rechtsbelangen van de derde staat en die van de Gemeenschapgelijk. Reeds naar aanleidingvan heteerste Bochringer-arreststelde Mulder(1971), pag. 213, ten aanzienvan 'hetzelfde feit': "Bij dit begrip denken wij aan twee kenmerken: gelijktijdigheid van de handeling en schending van identieke rechtsbelangen". 
iddien deze inderdaad een feit is, dan staat verdiscontering van de eerder opgelegde boete ok nauwelijks meer iets in de weg. ${ }^{161}$ Dat toont de beschikkingspraktijk ook aan. In ¿Gietijzeren en gietstalen walsen-zaak werd de Commissie geconfronteerd met sancties de door het Bundeskartellamt waren opgelegd wegens prijsafspraken binnen het Duitse gondgebied. De procedure bij de Commissie betrof prijsafspraken met betrekking tot ofertes voor buitenlandse, niet-Duitse klanten. De Commissie achtte verrekening van d. Duitse boetes geìndiceerd aangezien de inbreuken die door het Bundeskartellamt en dor de Commissie werden beoordeeld in het kader van één organisatie waren gepleegd e gedeeltelijk gedurende dezelfde periode plaatshadden. ${ }^{162} \mathrm{De}$ Commissie verdisconteerd in de Betonstaalmattenbeschikking ${ }^{163}$ door de Franse kartelautoriteiten opgelegde sncties. De Commissie overwoog dat het Franse besluit betrekking had op de gevolgen vn de handelingen voor de binnenlandse markt, terwijl voor de Commissie de algemene gvolgen van de handelingen van belang waren, maar stelde dat verrekening toch geĭndicerd was omdat de inbreuken binnen hetzelfde organisatorische kader waren begaan.

Celet op het voorgaande moet de conclusie luiden dat het ne bis in idem-beginsel welisvaar voor het gehele gemeenschapsrecht van toepassing is (op communautair niveau il de vorm van het 'Erledigungsprinzip'; in de verhouding tot staten slechts als 'Anrechnngsprinzip'), maar dat het door een enge interpretatie van het feitsbegrip voor de verhouding derde staat/Gemeenschap nauwelijks enige betekenis heeft. Naar mijn mening heeft ht Hof aldus een goede invulling gegeven aan het communautaire ne bis in idem-beginsel, waarbij zowel aan de belangen van de ondernemingen als aan de communautaire belangen tegemoet is gekomen. Indien een onderneming reeds door de Commissie is beboet, kan zij op gemeenschapsniveau niet voor dezelfde inbreuk een tweede maal ter verantwoording worden geroepen. Is de boete daarentegen door een nationale kartelautoriteit opgelegd, dan staat dit niet aan een communautaire procedure wegens inbreuk op de artikelen 81 en $82 \mathrm{EG}$ in de weg. Voorzover echter het door het communautaire recht beschermde belang, te weten de mededinging op de gemeenschappelijke markt, door de nationale veroordeling is bewaakt -hetgeen uitsluitend het geval is indien deze betrekking had op kartelgedragingen die zich op EG-grondgebied hebben afgespeeld-, is de Commissie gehouden met de eerder opgelegde boete rekening te huden. ${ }^{164}$ Aldus wordt sanctiecu-

161 Schermers (1987), pag. 610, ziet dit klaarblijkelijk anders. Hij stelt ten aanzien van het Wilhelm-arrest: "The act was the same: the limitation of free competition. The territorial effect of the act was partly the same as well, as in both cases it was mainly the German market which was affected. The infringed rules differed, however". Hieruit concludeert hij dat het Hof de inbreuken niet als hetzelfde feit aanmerkte. Het Hof hoefde zich echter over deze vraag niet uit te laten, aangezien in de prejudiciêle vraaghet bestaanvan één feit was verondersteld. Als er volgens het Hof inderdaadsprake was geweest van twee feiten is bovendien niet in te zien waarom het Hof verrekening van de eerdere sanctie desalniettemin noodzakelijk achtte.

$162 \mathrm{~Pb} 1983$ L $317 / 1$ (Gietijzeren en gietstalen walsen).

$163 \mathrm{~Pb} 1989 \mathrm{~L} 260 / 1$ (Betonstaalmatten), welke handelwijze door het Gerecht in GvEA (T-141/89) Jur. 1995, Il-791 (Tréfileurope Sales), GvEA (T-147/89) Jur. 1995, II-1057 (Société métallurgique de Normandie), GvEA (T-148/89) Jur. 1995, II-1063 (Tréfilunion) en GvEA (T-151/89) Jur. 1995, II-1191 (Société des treillis et panneaux soudés) werd goedgekeurd.

164 In deze zin ook Van Gerven c.s. (1997), pag. 107. Deze schrijver gaat echter van een mijns inziens onjuiste lezing van het feitsbegrip uit. Hij stelt -terecht- "dat een straf die uitzonderlijk door de gezagsorganen van een Lid-Staat zou zijn opgelegd wegens cen buiten de Gemeenschap voorgekomen mededingingsbeperking niet in mindering moet worden gebracht." Hij voegt hieraan echter ten onrechte 
mulatie voorkomen, terwijl de bescherming van het communautaire mededingingsbelang onverminderd tot zijn recht komt. Sanctiecumulatie blijft wel mogelijk indien een ondememing reeds een boete is opgelegd wegens een buiten de Europese Gemeenschap gepleegde inbreuk: de geschonden rechtsbelangen corresponderen in dat geval niet. ${ }^{165}$

\section{Ne bis in idem in het Nederlandse kartelrecht}

Over de gelding van het ne bis in idem-beginsel binnen het Nederlandse kartelrecht tot 1998 hoeft niet veel gezegd te worden: de Wem werd strafrechtelijk gehandhaafd en dus gold de ne bis in idem-regeling van artikel $68 \mathrm{WvSr}$. Voor de praktijk was dit artikel echter van ieder belang ontbloot: vervolging van kartelovertreders stond nauwelijks op de agenda van het Openbaar Ministerie; de animo om een tweede vervolging te starten, was zo mogelijk nog geringer. Datzelfde geldt voor de situatie waarin door de Commissie reeds een boete was opgelegd wegens overtreding van het communautaire recht. Dat laat overigens onverlet dat de wet zich tegen een tweede vervolging in die situatie niet verzette: artikel $68 \mathrm{WvSr}$ verbiedt immers slechts een tweede vervolging indien het eerste gewijsde van een strafrechter afkomstig is, hetgeen bij communautaire boete-oplegging niet het geval is. ${ }^{166}$ In het hypothetische geval van een tweede vervolging zou -aldus volgt uit het Wilhelm-arrest ${ }^{16}$ - de strafrechter overigens gehouden zijn tot verdiscontering van de door de Commissie opgelegde boete. ${ }^{168}$

Met de inwerkingtreding van de Mededingingswet is afscheid genomen van de strafrechtelijke handhaving en daarmee van artikel $68 \mathrm{WvSr}$. Hiervoor is echter geen analoge regeling in de plaats gekomen. Weliswaar geldt de verrekeningseis van het Wilhelm-arrest ook voor de d-g NMa indien deze een boete oplegt wegens een feit dat reeds door de Commis-

toe "altijd in de veronderstelling dat het gaat over dezelfde feiten". In de door hem geschetste situatie kản er naar mijn mening juist nooit sprake zijn van één feit.

165 Zoals Mulder (1971), pag. 213, het naar aanleiding van het eerste Boehringer-arrest verwoordde: "Het Amerikaanse rechtsbelang interesseertde Europese rechtsordeniet". Zie voorts over de uiteenlopende rechtsbelangen Hellingman en Mortelmans (1989), pag. 280 en Mulder (1989), pag. 476.

166 Desondanks zijn De Doelder en Van der Hulst (1993), pag. 733, van mening dat de werking van het ne bis in idem-beginsel met zich brengt dat in situaties zoals deze het Openbaar Ministerie nietontvankelijk verklaard zou moeten worden. Men kan zich overigens afvragen of de tijd niet rijp is voor een verruiming van artikel $68 \mathrm{WvSr}$ op dit punt. Het hanteren van een strikt onderscheid tussen strafrecht en andere rechtsgebieden waarin een repressief overheidsoptreden tot de mogelijkheden behoort, lijkt -zeker met het oog op bescherming van fundamentele waarborgen-achterhaald. Een aanpassing zou tevens kunnen voorkomen dat in afzonderlijke wetten op grond waarvan een dubbele 'vervolging' dreigt cen ne bis in idem-regeling of een daarmee vergelijkbare regeling moet worden opgenomen.

167 In deze zin eveneens Winkler (1971), pag. 103 en Schrŏter en Delsaux (1999) pag. 2/89. De Doelder en Van der Hulst (1993), pag. 732, Mok (1970), pag. 173 en De Moor-Van Vugt (1999), pag. 170. lijken hiervan ook uit te gaan. Anders: Van Gerven c.s. (1997), pag. 106: "of een door de gemeenschapsautoriteiten opgelegde geldboete, ook in mindering moet worden gebracht op een later door de nationale autoriteiten vast te stellen geldboete, is uiteraardeen vraag die op grond van het nationale recht moet worden beslecht".

168 Dit alleen al zou het Openbaar Ministerie ongetwijfeld hebben doen afzien van een vervolging. Het gemiddelde niveau van de communautaire boetes is immers van dien aard dat er voor de Nederlandse rechter geen ruimte meer zou zijn geweest om een boete op te leggen. 
sic is bestraft, maar een verbod op een herhaling van een Nederlandse boeteprocedure een nationaal bestuursrechtelijk ne bis in idem-beginsel voor het kartelrecht- is nergens te vinden. ${ }^{169}$ Ook het internationale recht biedt in deze geen soelaas. Artikel 14 lid 7 IVBPR kent weliswaar een ne bis in idem-verbod ${ }^{170}$, maar dit geldt in ieder geval voor Nederland slechts binnen strikt strafrechtelijke context. ${ }^{171}$ Artikel 4 van het Zevende Protocol bij het EVRM ${ }^{172}$ waarin eveneens een ne bis in idem-bepaling is opgenomen $^{17}$, lijkt deze restrictie (ondanks de bewoordingen van dit artikel) blijkens de jurisprudentie van het Europese Hof ${ }^{174}$ niet te kennen en lijkt zich dientengevolge mede uit te strekken over bestuursrechtelijke punitieve procedures; het Zevende Protocol is echter voor Nederland nog niet in werking getreden. Het ontbreken van een ne bis in idem-regeling in de Mededingingswet vormt mijns inziens een onaanvaardbare lacune. De argumenten die voor de hantering van het ne bis in idem-beginsel binnen het strafrecht worden aangevoerd, gelden onverkort voor bestuursstrafrechtelijke handhaving. Men kan niet zonder meer erop vertrouwen -eventueel onder verwijzing naar de algemene beginselen van behoorlijk bestuur- dat door de d-g NMa geen tweede boeteprocedure wegens hetzelfde feit zal worden gestart. Derhalve dient zo spoedig mogelijk in een wettelijke regeling van het ne bis in idem-beginsel, analoog aan artikel $68 \mathrm{WvSr}$, te worden voorzien, waarbij ik mij ten aanzien van de internationaalrechtelijke component zou kunnen voorstellen dat de reikwijdte beperkt wordt tot het 'Anrechnungsprinzip', en wel niet zozeer omdat dit een convergentie met het communautaire uitgangspunt zou betekenen, maar met name omdat dit de d-g NMa niet in zijn mogelijkheden zou beperken om een (declaratoire verbods)beschikking te geven waarin hij kan aangeven dat dergelijk gedrag ook tegen het Nederlandse mededingingsrecht indruist. ${ }^{175}$ Introductie van het ne bis in idem-begin-

169 Hetzelfde geldt overigens voor een samenloopregeling, en dat terwijl in het communautaire recht alsmede in het strafrecht wel (tot op zekere hoogte) met samenloop rekening wordt gehouden. Ten dele kan dit worden opgevangen door het evenredigheidsbeginsel, maar veel rechtszekerheid biedt dit niet. Met Hartmann (1999), pag. 53-57, ben ik dan ook van mening dat een samenloopregeling geen overbodige luxe is, hoewel de noodzaak hiertoe minder groot is dan in het strafrecht met zijn vrijheidsstraffen. Bedacht moet worden dat voor zover het de meerdaadse samenloop betreft de cumulatiebeperking niet voor boetes geldt.

170 "Niemand mag voor een tweede keer worden berecht of gestraft voor een strafbaar feit waarvoor hij reeds overeenkomstig de wet en het procesrecht van elk land bij onherroepelijke uitspraak is verootdeeld of waarvan hij is vrijgesproken".

171 Nederland heeft namelijk bij artikel 14 lid 7 IVBPR het voorbehoud gemaakt dat 'no obligations arise from it further to those set out in article 68 of the Criminal Code of the Netherlands'. En zoals gezien, is artikel $68 \mathrm{WvSr}$ beperkt tot een verbod op verschillende strafrechtelijke vervolgingen wegens hetzelfde feit.

172 Protocol van 22 november 1984, Trb. 1985, 2.

173 "Niemand wordt opnieuw berecht of gestraft in een strafrechtelijkeprocedure binnen de rechtsmacht vandezelfdeStaat voor een strafbaarfeit waarvoor hij reeds onherroepelijk is vrijgesproken of veroordeeld overeenkomstig de wet en het strafprocesrecht van die Staat".

174 Het betreft de Gradinger-zaak en de Oliviera-zaak. Zie hierover Keulen en Lenos (1999), pag. 233-240 en Krabbe en Van Hattum (2000), pag. 6-20. Interessant is dat het Europese Hof in deze twee zaken een vergelijkbare weg aflegt als de Hoge Raad tot de jaren zestig: in de Gradinger-zaak wordt uitgegaan van een materieel feitsbegrip, terwijl in de Oliviera-zaak een juridische uitleg wordt voorgestaan.

175 Op die wijze kan de d-g NMa de rechtssituatic verduidelijken, zonder gehinderd te worden door een veroordeling door een andere kartelinstantie. Tot boete-oplegging zal het dan zeker in die gevallen waarin de eerdere boete door de Commissie is opgelegd, wellicht zelden (hoeven te) komen. Bij de invulling van het feitsbegrip zou dan in dit verband voornamelijk naar de strekking gekeken moeten 
sel in de Mededingingswet valt echter niet te verwachten. Daar staat tegenover dat het ernaar uitziet dat het beginsel binnen redelijk afzienbare tijd in de Awb zal worden opgenomen. Artikel 5.4.1.4 VOAwb4 luidt namelijk:

Het bestuursorgaan legt geen bestuurlijke boete op indien aan de overtreder wegens dezelfde gedraging reeds cerder cen bestuurlijke boete is opgelegd, dan wel een kennisgeving als bedoeld in artikel 5.4.2.3, tweede lid, is bekendgemaakt. ${ }^{176}$

In het bovenstaande zijn de voorwaarden voor boeteoplegging door de Commissie besproken, waarbij tevens duidelijk werd dat verjaring aan boeteoplegging in de weg kan staan. Als alle voorwaarden zijn vervuld (en de inbreuk niet is verjaard), kan de Commissie beslissen om een sanctie op te leggen. Er bestaat derhalve geen gebondenheid tot het opleggen van een boete, waarmee het communautaire recht -evenals het Nederlandse strafrecht (vergelijk de artikelen 167 en $242 \mathrm{WvSv}$ )- in feite op de leest van het opportuniteitsbeginsel geschoeid is. ${ }^{177}$ Aangezien Verordening 17 niet nader vermeldt op welke gronden de Commissie moet beslissen om al dan niet tot bestraffing over te gaan, is haar discretionaire bevoegdheid in deze zeer ruim. ${ }^{178}$ Aan de hand van welke criteria de Commissie haar beslissing maakt, komt in de volgende paragraaf aan de orde.

\section{Discretionaire bevoegdheid}

Het discretionaire aspect van de boeteoplegging is niet slechts theorie. De praktijk wijst uit dat de Commissie inderdaad in lang niet alle gevallen waarin dat mogelijk is, een

worden, waarbij evenals in het communautaire recht de territorialiteit de doorslaggevende factor zou moeten vormen.

176 In het tweede lid van artikel 5.4.2.3 VOAwb4 is een regeling opgenomen die vergelijkbaar is met de strafrechtelijke kennisgeving van niet verdere vervolging (artikelen $242 \mathrm{j}^{\circ} 246 \mathrm{WvSv}$ ): "Indien het bestuursorgaan nadat de overtreder zijn zienswijze naar voren heeft gebracht, beslist dat:

a. voor de overtreding geen bestuurlijke boete zal worden opgelegd, of

b. de overtreding alsnog aan het openbaar ministerie zal worden voorgelegd,

wordt dit schriftelijk aan de overtreder medegedeeld". Voor het mededingingsrecht is slechts onderdeel a van belang, aangezien het strafrecht geheel buiten de deur is gehouden. In het verlengde van het ne bis in idem-beginsel is in artikel 5.4.1.5 VOAwb4 een -voor de Mededingingswet niet relevanteuna via-regeling neergelegd, waarvan het spiegelbeeld op grond van artikel III VOAwb4, in artikel $243 \mathrm{WvSv}$ zal worden opgenomen. Het una via-beginsel als complement van het ne bis in idem-beginsel is, aldus Wladimiroff en Van Russen Groen (1999), pag. 95, "geen verbod, maar het houdt in een verplichting voor de (vervolgende) overheid om bij het opleggen van cen sanctie te kiezen uit de mogelijkheden daartoe die verschillende rechtsgebieden bieden". Vergelijkbaar: Rogier (2000 II), pag. 91.

177 In die zin eveneens De Bronett (1999), pag. 2/975.

178 Met dien verstande dat de Commissie haar beslissing steeds dient te nemen tegen de achtergrond van de verwezenlijking van de doelstellingen van het EG-Verdrag. Vergelijk dienaangaande GvEA (T-213/95 en T-18/96) Jur. 1997, II-1739 (Stichting Certificatie Kraanverhuurbedrijf en Federatic van Nederlandse Kraanverhuurbedrijven): "De Commissie beslist (...) met inachtneming van de bijzondere omstandigheden van elke concretezaak en in de uitoefening van haar beoordelingsbevoegdheid, of het opportuun is om een geldboete op te leggen teneinde de vastgestelde inbreuk te bestraffen en de doeltreffendheid van het mededingingsrecht te handhaven". 
boete oplegt, hetgeen alleen al voor de hand ligt omdat de Commissie simpelweg over onvoldoende capaciteit beschikt om alle overtredingen te vervolgen en te beboeten. Dat betekent wel dat de Commissie een bepaalde lijn zal moeten volgen bij haar beslissing om bepaalde inbreuken niet te bestraffen. En omdat deze (beleids)lijn transparant en controleerbaar -mede tegen de achtergrond van de algemene beginselen van behoorlijk bestuur c.q. gemeenschapsrecht ${ }^{179}$ - zou moeten zijn, zou de Commissie haar beslissing steeds uitdrukkelijk moeten motiveren. Dit is helaas lang niet altijd het geval. ${ }^{180}$ Soms gaat zij in haar beschikkingen in het geheel niet in op haar overwegingen om geen sanctie op te leggen ${ }^{181}$; in sommige andere gevallen volstaat zij met een verwijzing naar de 'bijzondere omstandigheden van de zaak', zonder deze te concretiseren. Illustratief is in dat verband de beschikking ten aanzien van de beperking van aluminiuminvoer uit Oost-Europa ${ }^{182}$, welke zaak desondanks een aardig inzicht kan bieden in de wijze waarop de Commissie de strafvraag benadert. In deze casus ging het met name om overeenkomsten tussen Oost-Europese organisaties voor buitenlandse handel en een aantal westerse aluminiumproducenten. De overeenkomsten betroffen de exclusieve verkoop van aluminium aan de producenten door de organisaties voor buitenlandse handel in het voormalige Oostblok, waarbij tevens voor alle producenten een vaste koopprijs werd vastgesteld. Het voornaamste doel van de overeenkomsten was het (kunstmatig) hooghouden van de aluminiumprijzen. Ondanks deze aanzienlijke schending van artikel 81 EG zag de Commissie, zoals gezegd, af van oplegging van een boete. Hiervoor voerde zij in haar Veertiende verslag over het mededingingsbeleid een tweetal motieven aan: de niet volledig heldere rechtssituatie (tot dat moment was nog niet duidelijk dat de communautaire kartelregels ook van toepassing waren op handelsorganisaties van landen met staatshandel) en de lange tijdsduur (hoewel onvoldoende voor verjaring) die was verstreken tussen de beëindiging van de inbreuk en het nemen van de beschikking. Daarnaast kan uit de beschikking zelf nog een aantal andere factoren worden gedestilleerd. Ten eerste had het gedrag geen wezenlijke gevolgen: de vastgestelde prijzen verschilden (voorzover dit bepaald kon worden) niet of althans niet aanzienlijk van de prijzen die in een situatie van meer concurrentie waarschijnlijk tot stand zouden zijn gekomen. Ten tweede hadden

179 Te denken valt bijvoorbeeld aan het gelijkheidsbeginsel, dat nogal wordt ingeroepen door ondernemingen die zijn beboet, terwijl andere bij hetzelfde kartel betrokken ondernemingen de boetedans zijn ontsprongen. De kans van slagen van een dergelijk 'verweer' is echter gering, ten dele omdat de situaties van de verschillende ondernemingen zelden gelijk zijn en deels omdat doorgaans de communautaire rechters geen 'vergelijkingsmateriaal' hebben omdat de niet-gesanctioneerde ondernemingen zelden in beroep zullen gaan. Het is dan ook vaste rechtspraak dat "een verzoeker zich niet aan een sanctie die hem wegens inbreuk op artikel 85 van het Verdrag is opgelegd, kan onttrekken met het argument dat de Commissie een andere onderneming die bij een inbreuk betrokken is, geen geldboete oplegt, wanneer de situatie van die andere onderneming zelfs niet het voorwerp van een procedure voor de gerneenschapsrechter is". Zie GvEA (T-43/92) Jur. 1994, II-441 (Dunlop Slazenger Intermational), GvEA (T-77/92) Jur, 1994, II-549 (Parker Pen), GvEA (T-49/95) Jur. 1996, II-1799 (Van Megen Sports Group) en -reeds eerder- HvJ (C-89, 104, 114, 116, 117 en 125-129/85) Jur. 1993, 1-1307 (Ahlström Osakeyhtiō). Zie over het gelijkheidsbeginsel en enkele andere beginselen ook Van der Wal en Prechal (1990), pag. 608-609.

180 Zie over de ondoorzichtigheid van het sepot-beleid van de Commissie reeds Van Bael (1986), pag. 64 e.v..

181 Bijvoorbeeld Pb 1982 L 362/51 (Walserijprodukten en zinklegeringen) en Pb 1982 L 379/27 (ToltecsDorcet).

$182 \mathrm{~Pb} 1985 \mathrm{~L}$ 92/1 (Aluminiuminvoer uit Oost-Europa). 
de overeenkomsten een dreigende afzet tegen dumpprijzen (en dus oneerlijke concurrentie uit Oost-Europa) voorkomen; het daaruit voortvloeiende lage prijsniveau zou voor de (financiēle) positie van de producenten uit de gemeenschap zeer nadelige gevolgen gehad hebben, die het kartel had weten te verhinderen. Ten derde liet de Commissie waarschijnlijk meewegen dat de relevante ministeries van zowel de Bondsrepubliek Duitsland als ook het Verenigd Koninkrijk de overeenkomsten in beginsel hadden geduld. ${ }^{183}$ Ten vierde -en dit was waarschijnlijk het belangrijkste punt- waren bij de overeenkomsten organisaties uit het voormalige oostblok, en dus nauw aan de communistische partij gelieerde organisaties, betrokken, hetgeen een boeteoplegging een ongewenst politiek karakter zou geven. ${ }^{184}$

Uit deze zaak blijkt wel dat de Commissie rekening houdt met tal van factoren bij haar beslissing om al dan niet een boete op te leggen. Een deel van deze factoren keert ook terug in andere beschikkingen. Ten eerste is er het ontbreken van (verstrekkende) gevolgen. Deze factor was reeds doorslaggevend in de Plantaardig perkament-beschikking. ${ }^{185}$ Continentale producenten van plantaardig perkament onthielden zich van directe verkoop aan gebruikers in het Verenigd Koninkrijk, maar leverden uitsluitend aan de op de Britse markt actieve producent. Het betrof een onderling afgestemde feitelijke gedraging die volgens de Commissie echter geen nadelige gevolgen voor de bevoorrading van de gebruikers had: de vraag naar het perkament op de Britse markt was namelijk afgenomen en de import werd (ook zonder kartel) belemmerd als gevolg van een douanerecht van $18 \%$. De kans werd klein geacht dat de continentale producenten een essentiële verruiming van de afzet zouden hebben kunnen bewerkstelligen als zij direct aan de gebruikers hadden willen leveren. Ten tweede speelt een rol de mate van het verwijt dat ondernemingen gemaakt kan worden. ${ }^{186}$ Deze kan -zoals in de Aluminium-zaak- gering zijn vanwege de onduidelijkheid van de rechtssituatie, die zich met name kan voordoen bij relatief recente communautaire regelingen ${ }^{187}$, maar ook nog in een later stadium, waarbij door de Commissie met name belang wordt gehecht aan het eventuele ontbreken van eerdere beschikkingen over de onverenigbaarheid van het betreffende gedrag met het mededingingsrecht of over de toepasselijkheid van dit recht binnen de in het geding zijn sector. ${ }^{188}$

183 Bij de bespreking van de strafmaatfactoren zal blijken dat de Commissie tot op zekere hoogte bij de boete-oplegging rekening houdt met het optreden van nationale autoriteiten.

184 Tot deze conclusie komen ook Dannecker en Fischer-Fritsch (1989), pag. 295.

$185 \mathrm{~Pb} 1978 \mathrm{~L} 70 / 61$ (Plantaardig perkament). Vergelijk ook Pb $1989 \mathrm{~L} \mathrm{10/50}$ (BPB), waarin het ontbreken van verstrekkende rechtstreekse gevolgen eveneens een reden voor niet-bestraffing opleverde.

186 Naast de hierna te bespreken redenen voor geringe verwijtbaarheid, zijn er nog andere denkbaar. In $\mathrm{Pb} 1977 \mathrm{~L} 117 / 1$ (ABG), waarin het om een niet-levering door in Nederland opererende aardolicmaatschappijen ging, waren de oliecrisis en de onzekerheid die deze crisis voor de betreffende onderneming meebracht ten aanzien van verplichtingen tot levering van benzine voor de Commissie reden om geen boete op te leggen. Van verwijtbaar handelen was derhalve in feite nauwelijks sprake.

$187 \mathrm{~Pb} 1992$ L $96 / 34$ (British Midland/Aer Lingus) en Pb 1993 L 34/20 (Cewal e.a.). Hier legde de Commissie geen boete wegens overtreding van artikel 81 EG op omdat zij het de ondememingen niet wenste aan te rekenen dat bij deze onduidelijkheid bestond over de vraag of hun overeenkomst aan de in artikel 3 Vo 4056/86 opgesomde vrijstellingsvoorwaarden voldeed.

$188 \mathrm{~Pb} 1985 \mathrm{~L}$ 35/58 (John Deere); hier betrof het de eerste beschikking in de landbouwmachinesector. $\mathrm{Pb} 1985$ L 376/27 (Sperry New Holland); deze zaak speelde eveneens in de landbouwmachinesector, maarde beschikking in de Deere-casuswasten tijde van de overtreding nog niet gepubliceerd. Tevens $\mathrm{Pb} 1988$ L. 284/41 (Napier Brown/British Sugar) en Pb 1993 L 20/1 (Ford Agricultural) waarin de 
Tenzij de rechtssituatie anderszins duidelijk is ${ }^{15}$, zijn deze omstandigheden voor de Commissie in verschillende gevallen aanleiding om van een boete af te zien. Hetzelfde geldt indien ondernemingen zich slechts onder (economische) druk hebben aangesloten bij of geconformeerd aan een kartel of indien hun verantwoordelijkheid voor de gedragingen anderszins gering zijn, bijvoorbeeld omdat zij niet bij de totstandkoming van het kartel betrokken waren (en zich hierbij dus slechts in een later stadium hebben aangeslo$\left.t_{t e n}\right)^{100}$ en bij het gedrag een zeer geringe rol hebben vervuld. ${ }^{191}$ Het blijkt echter

Commissie ceningrijpende inbreuk constateerde, maar toch geen boete oplegde, mede omdat zij zelfs gedurende de inbreukprocedure aan de onderneming in kwestie niet had te kennen gegeven dat haar gedrag -in tegenstelling tot hetgeen de onderneming meende-niet onder een groepsvrijstelling viel. De onderneming werd hierdoor in haar (onjuiste) mening gesterkt. Terecht stelde de Commissie zich echter in GvEA (T-29/92) Jur. 1995, II-289 (Vereniging van Samenwerkende Prijsregelende Organisaties in de Bouwnijverheid e.a.) op het standpunt dat een eerdere beschikking niet als voorwaarde voor boeteoplegging kan worden beschouwd: "het feit dat het hier haar eerste ingrijpen in de sector van de bouwnijverheid betrof, behoefde voor haar geen reden te zijn om geen geldboete op te leggen, want anders zouden alle ondernemingen die actief zijn in sectoren ten aanzien waarvan nog geen beschikking van de Commissie is gegeven, straffeloos inbreuken op de mededingingsregels kunnen begaan". Uit het voorgaandemag overigensniet geconcludeerdworden dat de Commissie in gevallen waarin het standpunt van de Commissie wel reeds onomstotelijk vaststaat, steeds tot een boete besluit. Vergelijk bijvoorbeeld Pb 1982 L 379/27 (Toltecs-Dorcet), waarin geen boete werd opgelegd hoewel de Commissie "reedsherhaaldelijkuiting gegeven(had) aanhaarbezwarentegengebiedsbescherming via beweerde afbakeningsovereenkomsten inzake merken".

189 GvEA (T-213/95 en T-18/96) Jur. 1997, II-1739 (Stichting Certificatic Kraanverhuurbedrijf en Federatic van Nederlandse Kraanverhuurbedrijven) en GvEA (T-68, 77 en 78/89) Jur. 1992, II-1403 (Società Italiana Vetro e.a.) waarin het Gerecht -een deel van de commissiebeschikking vernietigend-afzag van de gehele opheffing van de door de Commissie opgelegde boetes omdat de ondernemingenreeds eerder met een commissiebeschikking waren geconfronteerd en het een inbreuk betrof op de uitdrukkelijke bewoordingen van de communautaire kartelbepalingen.

$190 \mathrm{~Pb} 1985 \mathrm{~L} 35 / 58$ (John Deere). Hier was sprake van een in een standaardovereenkomstopgenomen exportverbod. De keuze voor de onderneming was in feite beperkt tot het aanvaardenvan de overeenkomst (inclusief de met het EG-Verdrag strijdige exportbeperking) of het in het geheel niet sluiten van een overeenkomst; het maken van een voorbehoud zou er waarschijnlijk toe leiden dat de wederpartij niet met haar in zee zou gaan.

$191 \mathrm{~Pb} 1986$ L 232/30 (Bitumineuze dakbedekking), waarin onderscheid gemaakt tussen de leden van het kartel en ondernemingen die niet aan het kartel zelf deelnamen. Laatstgenoemden hadden zich schuldig gemaakt aan overtreding van artikel 81 lid 1 EG door met de kartelleden overeenkomsten met betrekking tot hantering van gemeenschappelijkekortingstarieven aan te gaan. De Commissie was van mening dat de 'onafhankelijke' ondernemingen niet gesanctioneerd behoefden te worden, onder meer omdat zij niet tot het kartel zelf waren toegetreden, zij bij de bepaling van hun marktbeleid in sterke mate gebonden waren aan het kartel en het niet aangetoond was dat zij de bedoelde overeenkomst hadden nageleefd. In HvJ (246/86) Jur. 1989, 2117 (Belasco e.a.) werd een beroep op schending van het gelijkheidsbeginsel in onderhavige zaak afgewezen. Tevens Pb 1984 L 212/13 (Vlakglas Benelux), Pb 1988 L 49/21 (Fisher Price), Pb 1985 L 376/27 (Sperry New Holland) -waarin de ondergeschiktheiden het geringe verwijtuit het feit bleken dat het handelenvan een van de betrokken ondernemingen in strijd was met haar eigen economisch belang-, Pb 1992 L 134/1 (Frans-Westafrikaanse rederscomités) -waarin de beperkte rol en het geringe marktaandeel van de Westafrikaanse kartelleden een rol speelde-, $\mathrm{Pb} 1994$ L 378/45 (Tretorn), Pb 1996 L 201/1 (ADALAT) -rekening werd gehouden met het aanzienlijkeverlies van omzet, klanten en 'commerciëlegeloofwaardigheid' dat de groothandelaren hadden moeten incasseren door het door hen impliciet aanvaarde, maar door de producent ontwikkelde kartelgedrag, $\mathrm{Pb} 1998 \mathrm{~L} 124 / 60$ (VW), waarin werd overwogen dat bepaalde ondememingen "het slachtoffer van het door de wederpartijen gevoerde restrictieve beleid (zijn), waarmee zij onder druk hebben ingestemd. De (ondernemingen) hebben hieraan niet actief meegewerkt 
zeker geen automatisme dat de Commissie afziet van sancties in gevallen waarin door de betreffende onderneming is toegegeven aan druk of een niet meer dan beperkte rol in het kartel is gespeeld: in de Parker Pen-zaak werd de betrokkenheid van een onderneming die zich slechts naar de wensen van de hoofdverantwoordelijke onderneming had geschikt, te groot geacht ${ }^{192}$, terwijl in de beschikking inzake de Frans-Westafrikaanse rederscomités overwegingen van principiële aard -ondanks een gering verwijt- tot het opleggen van sancties aanleiding gaven. Hier oordeelde de Commissie namelijk "dat een onderneming die bloot staat aan druk om zich aan te sluiten bij met de Verdragsregels strijdige activiteiten, zich tot de Commissie of tot de nationale rechter kan wenden om deze activiteiten te doen stopzetten". ${ }^{193}$ Met name in gevallen waarin de rechtssituatie voldoende vaststaat, kan het ondernemingen worden aangerekend dat zij -in plaats van het aanvechten van het met de mededingingsregels strijdige gedrag via de juridisch juiste weg- voor de (voordeligere) weg van de ogenschijnlijk mindere weerstand kiezen en zich, zij het schoorvoetend, bij een kartel aansluiten. Dit uitgangspunt is zeker verdedigbaar en het geeft mogelijk een extra prikkel aan ondernemingen om bij kartelpraktijken bij de Commissie aan te kloppen. Bovendien heeft deze blijkens genoemde Volkswagenbeschikking -die na de beschikking inzake de redercomités het licht heeft gezien-nog ruimte (zij het wellicht minder dan voorheen) gelaten om haar discretionaire bevoegdheid ten voordele van ondernemingen toe te passen in die situaties waarin de rol verwaarloosbaar of de druk zeer manifest is. ${ }^{194}$ Opgemerkt moet worden dat vanuit het oogpunt van generale preventie de noodzaak om ondernemingen in dergelijke situaties een boete op te leggen niet erg groot is. Deze generale preventie wordt (voor zover mogelijk) reeds bereikt door de bestraffing van de ondernemingen met een prominente en leidende rol bij het verboden gedrag, waarbij gelet op deze rol de boete over het algemeen aanzienlijk zal zijn. ${ }^{195}$

en de Commissie legt hen derhalve geen geldboete op" en Pb 2001 L 59/1 (Opel) waarin vrijwel gelijkluidende motieven werden aangevoerd om van een sanctie af te zien. In GvEA (T-24-26 en 28/93) Jur. 1996, II-1201 (Compagnie maritime belge transports e.a.) stelde het Gerecht dat de Commissie mocht concluderen dat de "reder geen actieve rol heeft gespeeld in de inbreuken en mocht zij. zonder het beginsel van gelijke behandeling te schenden, besluiten om aan deze reder geen geldboete op te leggen".

$192 \mathrm{~Pb} 1992$ L 233/27 (Parker Pen). Het gegeven dat de overeenkomst door de 'afhankelijke' ondememing mede was ondertekend en vervolgens ten uitvoer was gelegd, was voor de Commissie voldoende aanleiding om toch tot het opleggen van een boete over te gaan, zij het dat de omvang van boete enigszins gematigd werd.

$193 \mathrm{~Pb} 1992 \mathrm{~L} 134 / 1$ (Frans-Westafrikaanse rederscomités); aangezien in casu de ondernemingen aan de druk hadden toegegeven, was er geen reden om hen boetes te besparen. In vergelijkbarezin GvEA (T-141/89) Jur. 1995, 11-791 (Tréfileurope Sales) en GvEA (T-152/89) Jur. 1995, II-1197 (ILRO).

194 Hetzelfde geldt voor Pb 1994 L. 104/34 (MCN). In deze binnen de vervoersector -in het kader van Vo 1017/68- genomen beschikking, leken de Nederlandse en Belgische spoorwegen geen andere oplossing te hebben dan het aangaan van een (kartel)overeenkomst met de Deutsche Bahn (die overigens wegens misbruik van haar machtspositie werd veroordeeld en beboet).

195 Dat de generaal preventieve werking van de boete een punt van aandacht van Commissie is, moge ondermeer blijken uit Pb 1994 L 378/34 (Far Eastem Freight Conference). In deze beschikking legde de Commissie een (weliswaar symbolische) boete ter hoogte van 10.000 rekeneenhedenper onderneming op, welk bedrag "duidelijk het bestaan van de inbreuk vaststelt en de noodzaak voor de betrokken ondernemingen en voor andere ondernemingen die gelijkaardige praktijken mochten toepassen, zich voortaan naar de communautaire mededingingsregels te voegen". De boete zet aldus de beschikking kracht bij en vormt -ook wegens overtredingen die voor de eerste maal officieel onder de aandacht 
Naast het ontbreken van vergaande gevolgen van het gedrag of het bestaan van een gering verwijt bij een overtreder, kunnen nog andere factoren -in onderlinge samenhang- tot het afzien van boetes aanleiding geven. Zo kunnen een rol spelen: de zwaarte van de inbreuk, duur ervan ${ }^{196}$, de (zorgwekkende) financiële situatie van de overtreder ${ }^{197}$ alsmede de wijze waarop een onderneming op de communautaire procedure reageert. Bij deze laatste factor kan gedacht worden aan de situatie waarin een onderneming volledige medewerking verleent aan een tegen haar gestart onderzoek en/of in een vroeg stadium van de procedure (of zelfs nog daaraan voorafgaand) het omstreden gedrag beěindigt of aanpast. ${ }^{198}$ Dat ondernemingen in deze gevallen worden ontzien, vindt zijn rechtvaardiging in de uit het gedrag van de ondernemingen voortvloeiende vereenvoudiging van de taak van de Commissie alsmede in de in dat gedrag tot uiting komende wil van de ondernemingen om het kartelrecht voortaan te respecteren. De National Panasonic-beschikking biedt een treffend voorbeeld van een zaak waarin wegens vergaande maatregelen van de onderneming geen boete is opgelegd. ${ }^{199}$ Matsushita Electric Trading Company had in samenwerking met de Commissie haar garantiesysteem ten voordele van de Europese consumenten aangepast en gedragscodes aan de dochterondernemingen opgelegd opdat deze zich conformeerden aan het Europese recht. Het door Matsushita Electric gevoerde beleid moest "worden gezien als een positieve stap, die bijdraagt tot het bewustzijn van de invloed van het mededingingsbeleid op het dagelijks leven op alle echelons binnen de groep. Het zorgt ervoor dat men op directieniveau in staat is het marktgedrag van de gehele groep te controleren, waarbij tevens effectieve interne regels worden neergelegd ten einde te voldoen aan de mededingingsregels van de Europese Gemeenschappen". ${ }^{200}$

van de Commissie komen- een duidelijke waarschuwing voor derden dat het in het geding zijnde gedrag niet getolereerd kan worden.

$196 \mathrm{~Pb} 1986 \mathrm{~L} \mathrm{232/30}$ (Bitumineuze dakbedekking). Of een inbreuk al dan niet van lange duur is, is een kwestie van interpretatie en kan aan veranderingen onderhevig zijn. In onderhavige beschikking werd een inbreuk van omstreeks één jaar en negen maanden als relatief kort aangemerkt. In haar Richtsnoeren voor de berekening van geldboeten die uit hoofde van artikel 15, lid 2, van Verordening nr. 17, respectievelijk artikel 65, lid 5, van het EGKS-Verdrag worden opgelegd, $\mathrm{Pb} 1998 \mathrm{C} \mathrm{9/3,}$ betitelt de Commissie een inbreuk van één tot vijf jaar als 'middellang'.

$197 \mathrm{~Pb} 1992 \mathrm{~L}$ 134/1 (Frans-Westafrikaanse rederscomités) en GvEA (T-24-26 en 28/93) Jur. 1996, II-1201 (Compagnie maritime belge transports e.a.).

198 Vergelijk bijvoorbeeld $\mathrm{Pb} 1973$ L 293/40 (Deutsche Philips), waarin een deel van het omstreden

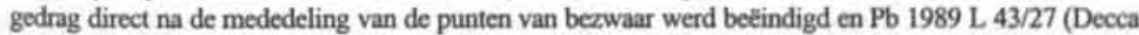
Navigator System): de onderneming heeft "vanafhet eerste begin haar gedragingen onder de aandacht van de Commissie gebracht en heeft medegewerkt om aan de inbreuk een einde te maken". Zie ook $\mathrm{Pb} 1992 \mathrm{~L} \mathrm{134/1}$ (Frans-Westafrikaanserederscomités)waarin van beboeting van bepaalde ondernemingen werd afgezien omdat zij ertoe hadden bijgedragen dat het kartelmatig gedrag bij de Commissie onder de aandacht was gekomen, en $\mathrm{Pb} 1994 \mathrm{~L} 104 / 34$ (MCN), waarin de ondernemingen de overeenkomst hadden opgezegd na de mededeling van de punten van bezwaar. Hoezeer de Commissie cooperatie van een ondememing op prijs stelt, blijkt wel uit haar mededeling betreffende het niet opleggen of verminderen van geldboeten in zaken betreffendemededingingsregelingen, $\mathrm{Pb} 1996 \mathrm{C}$ 207/4. Op deze mededeling wordt hierna nog uitgebreid ingegaan.

$199 \mathrm{~Pb} 1982$ L $354 / 34$ (National Panasonic).

200 Een vergelijkbare situatie deed zich voor in $\mathrm{Pb} 1993 \mathrm{~L} \mathrm{20/1}$ (Ford Agricultural). Hierin liet de Commissie meewegen dat de nieuwe eigenaren van de betrokken onderneming de inbreuk erkenden en "dat zij krachtdadig optreden om iedere herhaling van deze onrechtmatighedente voorkomen". Daarnaast vormde cen belangrijke reden voor het afrien van een boete dat de inbreuken zich geruime tijd voordien hadden voorgedaan. 
In een situatie als deze dwingen aspecten van speciale preventie niet langer tot het opleggen van sancties, aangezien reeds onmiskenbare stappen zijn gezet in de richting van respectering van het communautaire recht in de toekomst. ${ }^{201}$ Maar ook hier geldt weer dat niet kan worden geabstraheerd van de andere omstandigheden van het geval. Zo had in de Miller-zaak ${ }^{202}$ de betrokken onderneming onder meer toegezegd zich in de toekomst van de omstreden gedragingen te onthouden. De Commissie legde toch een boete op omdat er opzet in het spel was geweest en er reeds eerder in de grammofoonplatensector (in de WEA-Filipacchi Music-beschikking) een boete door de Commissie was opgelegd. ${ }^{203}$ Aard van de overtreding en de schuld bij de onderneming wogen hier zwaarder dan de gedane toezeggingen.

Kort samengevat: niet iedere geconstateerde inbreuk heeft een communautaire boete tot gevolg, waarbij een rol spelen de aard en de gevolgen van het kartel, het verwijt dat een onderneming gemaakt kan worden (mede gezien haar positie op de markt en haar eventuele afhankelijkheid van derde ondernemingen), de duur van de inbreuk en de bereidwilligheid van de onderneming om terstond haar beleid aan te passen. Is de Commissie van oordeel dat een boete wel op haar plaats is, dan zal zij overgaan tot het bepalen van de hoogte van de boete. Welke factoren zij bij de strafmaatbepaling meeweegt, zal in de volgende paragraaf worden besproken.

\section{Strafmaatfactoren}

Evenals bij de beantwoording van de vraag of in een concreet geval een boete dient te worden opgelegd, heeft de Commissie bij de straftoemeting een aanzienlijke beleidsmarge. Deze uit zich mede in de grote boeteruimte die artikel 15 Vo 17 biedt: zoals gezien kan wegens een inbreuk op de artikelen 81 lid 1 en 82 EG een boete worden opgelegd ter hoogte van minimaal duizend tot maximaal vele miljoenen rekeneenheden, waarbij de enige kwantitatieve restrictie is dat de boete niet meer mag bedragen dan $10 \%$ van de omzet van de onderneming. ${ }^{204}$ De grote vrijheid van de Commissie inzake straftoemeting wordt tevens weerspiegeld in de niet meer dan algemene en relatief vage aanduiding in Verordening 17 van de factoren waarmee de Commissie bij de bepaling van de omvang van de boete rekening moet houden, te weten de zwaarte van de inbreuk en de duur hiervan. Hoe deze factoren moeten worden ingevuld, is aan de Commissie overgelaten. Dat betekent vanzelfsprekend nog niet dat de Commissie in deze geheel de vrije hand heeft. Zij zal steeds de communautaire belangen moeten behartigen, ook in het kader van de sanctie-oplegging. Daarenboven is zij gebonden aan de algemene beginselen van behoorlijk bestuur c.q. gemeenschapsrecht. Zo moeten op grond van het evenredigheidsbeginsel -waarvan, zoals Van Acker ${ }^{203}$ terecht stelt, de verplichting om met zwaarte

201 Dat speciale preventie één van de aandachtspunten van de Commissie is, wijst $\mathrm{Pb} 1994 \mathrm{~L}$ 343/124 (Cement) uit. In deze beschikking overwoog de Commissie dat sancties voor de betrokken ondernemersverenigingen noodzakelijk waren teneinde "deze te ontmoedigen in de tockomst het initiatief te nemen tot of deel te nemen aan dergelijke mededingingsregelingen".

$202 \mathrm{~Pb} 1976$ L. $357 / 40$ (Miller Schallplatten).

203 Aldus de Commissie in haar Zesde verslag over de mededinging, nr. 152.

204 Voor de omvang van de door de Commissie opgelegde sancties verwijs ik naar bijlage I.

205 Van Acker (1986), pag. 354. 
a duur van de inbreuk rekening te houden een uitwerking is- alle relevante factoren sowel die met betrekking tot de inbreuk zelf als overige omstandigheden) bij de strafmaattpaling in ogenschouw worden genomen, waarbij aan geen van deze factoren een disproprtioneel gewicht mag worden toegekend. ${ }^{206}$ Bovendien rust op de Commissie de plicht m een coherent en consistent straftoemetingsbeleid te voeren, welk beleid haar wederom oor de toekomst bindt in die zin dat zij niet zonder geldige reden en motivering van it beleid mag afwijken. ${ }^{207}$ Aldus spelen het vertrouwensbeginsel, het gelijkheidsbegin$\mathrm{A}^{208}$ alsmede het verbod van willekeur een rol in de communautaire boetepraktijk. liet in de laatste plaats komt ook betekenis toe aan het motiveringsbeginsel:

"Volgens vaste rechtspraak heeft de verplichting tot motivering van een individuele beschikking tot doel, de gemeensehapsrechter in staat te stellen de wettigheid van de beschikking te onderzocken, en de betrokkene voldoende gegevens te versehaffen om na te gaan of de beschikking gegrond is dan wel een gebrek vertoont op grond waarvan de wettigheid kan worden betwist $(. . .)^{n}, 20$

lotivering als voorwaarde voor transparantie en controleerbaarheid van de beschikking $\mathrm{a}$ het beleid derhalve. Het is interessant om te constateren dat het Gerecht met het oog p deze aspecten van individueel én algemeen belang, de motiveringseisen voor commisiebeschikkingen relatief recent aanmerkelijk heeft willen aanscherpen. In 1995 tikte het ierecht de Commissie uitdrukkelijk op de vingers, zij het dat hieraan geen consequenties erbonden werden:

"Ofschoon het wenselijk is dat de ondernemingen -teneinde met volledige kennis van zaken hun standpunt te kunnen bepalen- op een door de Commissic opportuun geachte wijze gedetailleerd kennis kunnen nemen van de wijze van berekening van de hun opgelegde geldboete, zonder daarvoor de beschikking van de

$206 \mathrm{~Pb} 1980$ L $377 / 27$ (Johnson \& Johnson): de Commissie dient "met de beginselen van billijkheid en evenredigheid (...) rekening" te houden. Zie tevens Richardson (1999), pag. 363.

207 Hetzelfde geldt overigens indien de Commissie via andere wegen haar discretionaire vrijheid nader invult, zoals dat is gebeurd in haar Richtsnoeren voor de berekening van geldboeten die uit hoofde van artikel 15, lid 2, van Verordening nr. 17, respectievelijkartikel 65, lid 5, van het EGKS-Verdrag worden opgelegd, $\mathrm{Pb} 1998 \mathrm{C} 9 / 3$.

208 De betekenis van dit gelijkheidsbeginsel is overigens, evenals dit het geval is in het strafrecht of in het bestuursstrafrecht, marginaal omdat twee gevallen slechts zelden op wezenlijke punten gelijk zijn. Wel is dit beginsel in zoverre van belang dat gevallen in de mate dat zij gelijk zijn ook daadwerkelijk gelijk moeten worden behandeld. Zie voor casus waarin zonder sueces een beroep werd gedaan op het gelijkheidsbeginsel GvEA (T-29/92) Jur. 1995, II-289 (Vereniging van Samenwerkende Prijsregelende Organisaties in de Bouwnijverheid e.a.), GvEA (T-143/89) Jur. 1995, II-917 (Ferriere Nord), GvEA (T-150/89) Jur. 1995, II-1165 (Martinelli) en GvEA (T-308/94) Jur. 1998, II-925 (Cascades). In deze zaak alsmede in GvEA (T-327/94) Jur. 1998, II-1373 (SCA Holding) en GvEA (T-347/94) Jur. 1998, II-1751 (Mayr-MelnhofKartongesellschaft), herinnerdehet Gerechteraan"dat de eerbiediging van het beginsel van gelijke behandeling te verenigen moet zijn met de eerbiediging van het legaliteitsbeginsel, dat meebrengt dat niemand zich ten eigen voordele kan beroepen op een onwettigheid waarvan anderen hebben kunnen profiteren". Succesvol was daarentegen het beroep op het gelijkheidsbeginsel in GvEA (T-309/94) Jur. 1998, II-1007 (Koninklijke KNP BT), GvEA (T-310/94) Jur. 1998, II-1043 (Gruber+Weber) en GvEA (T-295/94) Jur. 1998, II-813 (Buchmann). De Commissie had in het laatste geval namelijk zonder geldige reden bij de onderneming voor de bepaling van de boete een andere omzet gekozen dan zij bij de overige bij het Karton-kartel betrokken ondernemingen had gedaan. Voor schendingen van het gelijkheidsbeginsel door het Gerecht zie HvJ (280/98 P) n.n.g. (Moritz J. Weig) en HvJ (C-291/98 P) n.n.g. (Sarrió).

209 GvEA (T-295/94) Jur. 1998, II-813 (Buchmann). 
Commissie in rechte te moeten aanvechten -hetgeen zou indruisen tegen het beginsel van behoorlijk bestuur. is het Gerecht (...) van mening, dat het middel inzake gebrekkige motivering niet kan worden aanvaard" . .

Deze onmiskenbare kritiek op de Commissie werd in de Karton-zaak herhaald, waarna het Gerecht oordeelde:

\begin{abstract}
"Wanneer de Commissie in een beschikking een inbreuk op de mededingingrregels vaststelt en de ondeme. mingen die daaraan hebben deelgenomen een geldboete oplegt, moet zij derhalve, indien zij bepaalde basisfactoren bij de vaststelling van het bedrag van de geldboeten stelselmatig in aanmerking heeft genomen, deze factoren in de beschikking zelf vermelden, om de ondememingen tot wie zij is gericht, in staat te stellen, de juistheid van het niveau van de geidboete te verifietren en na te gaan of er eventueel sprake is van discriminatie. ${ }^{\text {nII }}$
\end{abstract}

\title{
Dit ging het Hof echter te ver. Volgens het Hof wordt
}

"aan de eisen van het wezenlijke vormvoorschrift van de motivering voldaan, wanneer de Commissic in haar beschikking de factoren aangeeft op basis waarvan zij de zwaarte en de duur van de inbreuk heeft beoordeeld", (...) De Commissie kan stellig geen afstand doen van haar beoordelingsbevoegdheid door uitsluitend en mechanisch wiskundige formules toe te passen. Zij mag voor haar beschikking evenwel een motivering geven die verder gaat (dan de zojuist genoemde factoren, HQ), onder meer door de eijfers te vermelden die in het bijzonder voor de nagestreefde preventieve werking de leidraad waren voor de uitoefening van haar beoordelingsbevoegdheid bij de vaststelling van de geldboeten (...). Het kan immers wenselijk zijn, dat de Commissie van die mogelijkheid gebruik maakt opdat de ondernemingen precies kunnen weten, hoe de hun opgeiegde geldboete is berekend. Meer algemeen kan dat de transparantie van het bestuursoptreden ten goede komen en de uitoefening van de volledige rechtsmacht van het Gerecht vergemakkelijken, waardoor het niet alleen de bestreden beschikking op haar wettigheid kan toetsen, maar ook kan beoordelen, of de opgelegde geldboete passend is. Zoals de Cormmissie heeft opgemerkt, kan die mogelijkheid de omvang van de uit de motiveringsplicht voortvloeiende vereisten evenwel niet veranderen". 212

Het is de Commissie derhalve toegestaan om de straftoemeting nader uit de doeken te doen, maar verplicht hiertoe is zij niet. Dat laat onverlet dat de kritiek van het Gerecht duidelijk niet aan dovemansoren is gericht en dat zij de Commissie alleen maar sterkt in het vervolgen van de door haar in 1998 ingeslagen weg om de straftoemeting inzichtelijker te maken; een straftoemeting die qua doorzichtigheid en controleerbaarheid toch

210 Op dit belang werd ook gewezen in GvEA (T-147/89) Jur. 1995, II-1057 (Société métallurgique de Normandie), GvEA (T-148/89) Jur. 1995, II-1063 (Tréfilunion) en GvEA (T-151/89) Jur. 1995, II-1191 (Société des treillis et panneaux soudés).

211 GvEA (T-295/94) Jur. 1998, II-813 (Buchmann), GvEA (T-308/94) Jur. 1998, II-925 (Cascades), GvEA (T-317/94) Jur. 1998, II-1235 (Moritz J. Weig), GvEA (T-319/94) Jur. 1998, II-1331 (Fiskeby Board), GvEA (T-327/94) Jur. 1998, II-1373 (SCA Holding), GvEA (T-334/94) Jur. 1998, II-1439 (Sarrió), GvEA (T-338/94) Jur. 1998, II-1617 (Finnboard), GvEA (T-347/94) Jur. 1998, II-1751 (Mayr-Melnhof Kartongesellschaft), GvEA (T-348/94) Jur. 1998, II-1875 (Enso Española), GvEA (T-352/94) Jur. 1998, II-1989 (Mo och Domsjo) en GvEA (T-354/94) Jur. 1998, II-2111 (Stora Kopparbergs Bergslags). Ook nu had dit motiveringsgebrek nog geen gevolgen voor de beschikkingen, omdat de kritiek op de motiveringspraktijk van de Commissie ten tijde van de beschikkingen nog niet door het Gerecht was geuit en omdat de Commissie later alsnog de relevante informatie bad verstrekt.

212 HvJ (C-248/98 P) n.n.g. (Koninklijke KNP BT), HvJ (280/98 P) n.n.g. (Moritz J. Weig), HvJ (C-28298 P) n.n.g. (Enso Española), HvJ (C-283/98 P) n.n.g. (Mo och Domsjo), HvJ (C-286/98 P)n.n.g. (Stora Kopparbergs Bergslags), HvJ (C-291/98 P) n.n.g. (Sarrió), HvJ (C-297/98 P) n.n.g. (SCA) en HvJ (C-298/98 P) n.n.g. (Metsă-Serla Sales). 
meer dan redelijk was te noemen ${ }^{213}$, zeker als men deze afzet tegen de Nederlandse gafrechtelijke praktijk. ${ }^{24}$ Maar nog steeds is straftoemeting geen wiskunde en zal at ook niet worden op kartelgebied. Veel meer dan een benaderende indicatie -voorafgand aan een beschikking of zelfs aan de inbreuk- kan uit het beleid en uit de door de (ommissie in 1998 gelanceerde Richtsnoeren voor de vaststelling van de boete ${ }^{215}$ niet forden gehaald. ${ }^{216}$ En dan nog kan achteraf blijken dat met die indicatie de plank gevoc$\mathrm{g}$ is misgeslagen. ${ }^{217}$ Exacte voorspelbaarheid van de boete wordt ook niet door de (ommissie nagestreefd omdat dit volgens haar de handhaving van het communautaire (artel)recht uiteindelijk zou kunnen frustreren. Zoals de Commissie het treffend formujerde:

"Als zij (de Commissic, HQ) de elementen ten laste en de elementen à decharge zou dienen te becijferen, gaat de preventieve werking van de geldboeten verloren, want indien de beoordelingsvrijheid van de Commissiewiskundigkan worden getoetst, zullen de ondememingen bij de berekening van de rentabiliteit van hun voorgenomen kartels het bedrag van de eventuele geldboete laten meewegen", ${ }^{21}$

jet voorgaande houdt derhalve in dat de Commissie een evenwicht moet bereiken tussen (e niet tegengestelde waarden van) voldoende openheid en preventieve werking. De fichtsnoeren lijken hieraan in ieder geval ver tegemoet te komen. Maar, zoals gezegd,

.13 Wils (1998), pag. 257, wijst echter op de problemen van de 'oude' aanpak van de Commissie: de beschikkingen "almost invariably only contained in the recitals a list of the factors which the Commission had taken into accountin determining the amount of the fine, described in purely qualitative terms, as well as the final figure in the operative part of the decision. How the Commission had arrived at this final figure on the basis of the listed factors was not explained".

214 Hetstraftoemetingsbeleidbinnen het strafrecht is dan ook al lange tijd een punt van discussie, waarbij in vergelijking met het communautaire recht zich nog de complicerende factor voordoet dat de bevoegdheid tot het opleggen van sancties niet bij éen instantie is geconcentreerd(hetgeen weer wel in het Nederlandse kartelrechthet geval is), maar (in eersteaanleg) in handen is van de verschillendekantonrechters en rechtbanken. Zie kritisch over de straftoemetingspraktijk in het Nederlandse strafrecht reeds het interessante debat uit 1975 over een handbock voor de straftoemeting: Enschede (1975), d' Oliveira-Prakken (1975 I), Franken (1975) en d' Oliveira-Prakken (1975 II).

215 Zie daarover paragraaf 4.5 .

216 Gyselen (1993), pag. 64: "Transparency (...) does not apply to the exact amount of the fine but to the parameters for fixing this amount. In this respect, companies are entitled to a coherent Commission policy".

217 Dit hangt mede samen met het feit dat de Commissie uit preventie-overwegingen de boete in een concreet geval -mits gemotiveerd- op een hoger niveau mag vaststellen dan tot dan toe het geval was.

218 Aldus de Commissie in haar verweerin GvEA (T-15/89) Jur. 1992, II-1275 (Chemie Linz). Vergelijk ook Gyselen (1993), pag 64. Inzicht in de boetesleutel, zoals verzocht door DSM -vergelijk GvEA (T-8/89) Jur. 1991, II-1833 (DSM) zal de Commissie dan ook niet snel geven. Interessant in dit verband is ook GvEA (T-83/91) Jur. 1994, Il-755 (Tetra Pak International): "Het volstaat wanneer de Commissie in de beschikking de criteria preciseert, op basis waarvan zij het algemene niveau van de aan een onderneming opgelegde geldboete heeft vastgesteld. $\mathrm{Zij}$ is niet verplicht specifiek te vermelden, op welke wijze zij met elk van de factoren die als criterium zijn genoemd en die een rol spelen bij de vaststelling van het algemene niveau van de geldboete, rekening heeft gehouden". Wils (1998), pag. 257 (daarin gevolgd door Richardson (1999), pag. 368), stelt weliswaar niet ten onrechte dat "Tarification (...) rather serves deterrence, so long as the tariff is either sufficiently detailed or sufficiently flexible to accommodate relevant differences between individual cases, and the amounts are set or can be set at the right level", maar enige marge bij de beoordeling en de mogelijkheid van 'plotselinge' verhoging van het boeteniveau kan een goede preventieve stok achter de deur betekenen. 
de daaraan voorafgaande beschikkingspraktijk vertoonde eveneens een wezenlijke transparantie, in die zin dat gaandeweg duidelijk werd met welke factoren de Commissie bij de straftoemeting rekening hield. Deze beschikkingspraktijk wordt hieronder uitgebreid geanalyseerd. Maar ook de Richtsnoeren van de Commissie en de daarop gebaseerde beschikkingen zullen aan bod komen. Teneinde de overzichtelijkheid te bevorderen, zijn de door de Commissie in aanmerking genomen factoren door mij in verschillende groepen onderverdeeld. Aangezien de Commissie, zeker tot 1998, in lang niet alle gevallen een dergelijke onderverdeling maakt, is een andere catalogisering ook denkbaar. Bovendien kunnen verschillende factoren binnen meer dan één groep een rol spelen. Om een voorbeeld te noemen: een overheersende positie van een onderneming op een bepaalde productmarkt is veelal een indicatie voor de rol die de onderneming binnen een kartel speelt, maar tevens voor de schade die haar gedrag aan de mededinging op die markt berokkent. Uiteindelijk worden de factoren door de Commissie dan ook veelal slechts in onderlinge samenhang besproken. Toch dient naar mijn mening onderstaande onderverdeling de helderheid van de bespreking van de door de Commissie in aanmerking genomen factoren. Op de (extensieve) interpretatie en invulling van de begrippen zwaarte en duur van de inbreuk zal in de paragrafen 4.2 en 4.3 worden ingegaan. Niet iedere door de Commissic gehanteerde strafmaatbepalende factor is echter onder de noemer van beide begrippen te brengen. Hierboven is reeds melding gemaakt van de toepasselijkheid van het Anrechnungsprinzip: een eerder opgelegde boete wegens hetzelfde feit moet in de latere boete verdisconteerd worden. Aandacht verdienen ook de preventieve doeleinden van de sanctie. Boetedreiging is pas dan effectief, als de te verwachten boete voldoende impact heeft, waarbij in beginsel het uitgangspunt zou moeten zijn dat kartelinbreuken niet lonen. Slechts in dat geval zal een onderneming redelijkerwijs ervan worden weerhouden over te gaan tot kartelmatig gedrag. In hoeverre deze preventieve aspecten in de beschikkingen een rol spelen, zal in paragraaf 4.4 aan de orde komen. Aangezien de Commissie in 1998 wijzigingen in de berekening van de communautaire boete doorvoerde, zal in paragraaf 4.5 uitgebreid aandacht worden besteed aan deze vernieuwde boetepraktijk. Allereerst wordt echter stilgestaan bij het belang van de omzet van de bij een kartel betrokken onderneming.

\subsection{De omzet}

Zeker tot 1998 vormde de omzet van de bij een kartel betrokken ondernemingen ongetwijfeld één van de meest invloedrijke factoren in het kader van de straftoemeting. ${ }^{21}$ Dit is het gevolg van de omstandigheid dat de omzet op verschillende wijzen zijn invloed doet gelden. Primair is de omzet van belang om de maximum toegestane boete vast te stellen: op grond van artikel 15 Vo 17 is iedere boete die meer dan één miljoen Euro bedraagt immers gerelateerd aan de omzet van de onderneming. ${ }^{20}$ Bedoeld is hier de

219 Onbelangrijk is daarmee de omzet nog allerminst. Vergelijk Pb 1999 L. 109/24 (Grickse veerdienstmaatschappijen) waarin werd overwogen: "Bij de vaststelling van het bedrag van de geldboeten kan de Commissie rekening houden met het daadwerkelijkevermogen van de overtredersom aanzienlijk: schade te veroorzaken". De relevantie van de omzet is in dat verband onmiskenbaar.

220 Deze relatie met de omzet geldt klaarblijkelijk niet ten aanzien van ondernemingen met een lagert omzet dan 10 miljoen Euro. In GvEA (T-213/95 en T-18/96) Jur. 1997, II-1739 (Stichting Certificatic Kraanverhuurbedrijf en Federatie van Nederlandse Kraanverhuurbedrijven) deed zich namelijk de 
totale (wereldwijde) omzet ${ }^{221}$ van de onderneming -in het aan de beschikking voorafgaande boekjaar ${ }^{22}$. Dit is niet alleen uitdrukkelijk door de communautaire rechters erkend $^{22}$, maar kan tevens uit de ratio van die bepaling worden afgeleid. Deze is immers gelegen in het creëren van een mogelijkheid om een adequate boete op te leggen aan ondernemingen die cen ruime financiēle basis hebben. Beperking van het omzet-begrip tot de omzet die betrekking heeft op het product ten aanzien waarvan het kartelgedrag werd ontplooid, zou leiden tot een - vanuit het oogpunt van preventie en leedtoevoegingontoereikende boetemarge, met name bij multinationals, die hun omzet mede of in belangrijke mate met andere producten bereiken. ${ }^{224}$ Maar de omzet is ook op andere wijze mede bepalend voor de straftoemeting. Het Hof formuleerde het als volgt:

"Bij de vaststelling van de crnst van een inbreuk moet worden rekening gehouden met een groot aantal factoren die naar aard en belang kunnen verschillen naargelang van de soort inbreuk waarom het gaat, en de bijzondere omstandigheden waaronder zij is begaan. Afhankelijk van de omstandigheden kunnen deze factoren zijn: de hoeveelheid en de waarde van de goederen waarop de inbreuk betrekking had, alsmede de omvang en de economische macht van de ondememing en derhalve de invloed die deze op de markt kon uitoefenen. Daaruit volgt enerzijds dat bij de vaststelling van de boete rekening mag worden gehouden zowel met de totale omzet van de onderneming, die -zij het ook benaderend en onvolkomeneen aanwijzing vormt voor de ornvang en de economische macht van de onderneming. als met het gedeelte van deze omzet, dat betrekking heeft op de goederen in verband waarmee de inbreuk is gepleegd, en dat dus cen aanwijzing kan vormen voor de omvang van de inbreuk. Anderzijds volgt daaruit, dat aan geen van deze omzeteijfers cen belang dient te worden toegekend dat onevenredig is aan dat van de andere

situatie voor dat een onderneming met een omzet van bijna 300.000 ecu een boete werd opgelegd ter hoogte van $300.000 \mathrm{ecu}$, dus meer dan de totale omzet over het relevante jaar. Het Gerecht stelde dat de Commissie onder het maximum van 1 miljoen ecu was gebleven, maar achtte de boete wel onevenredig, waarna de boete werd verlaagd tot $100.000 \mathrm{ecu}$. Het is mijns inziens in strijd met het beginsel van evenredigheiddat aldus ondernemingenmet een geringe omzet relaticfzwaarder kunnen worden gestraft. $\mathrm{Bij}$ ondernemersverenigingen is overigens niet hun eigen omzet relevant, maar de omzet van de bij de vereniging betrokken ondernemingen, althans voor zover deze de ondernemingen kan binden. Vergelijk GvEA (T-338/94) Jur. 1998, II-1617 (Finnboard).

221 Tot deze omzet behoort ook de waarde van ondernemingsinterne leveranties. Zou dit niet zo zijn, "dan zouden onvermijdelijk de verticaal geīntegreerde ondernemingen op ongerechtvaardigde wijze worden bevoordeeld". Aldus GvEA (T-304/94) Jur. 1998, II-869 (Europa Carton).

222 Voorzover de keuze voor het voorafgaande boekjaar tot een ongelijke behandeling zou leiden, moet overigens voor een ander referentiejaarworden gekozen. Dat blijkt uit GvEA (T-142/89) Jur. 1995, II-867 (Usines Gustave BoêI). In deze zaak was 1985 als het relevante boekjaar door de Commissie in aanmerking genomen. Boël had in dat jaar echter een relatief hoge omzet bereikt terwijl andere ondernemingenjuist minder hadden omgezet. Hierdoor werd Boël ten opzichte van de anderen benadeeld, in die zin dat zij een hogere boete kreeg dan de overige ondernemingen. Dit was voor het Gerecht aanleiding om de boete te verlagen.

223 HvJ (100-103/80) Jur. 1983, 1825 (Musique Diffusion Française), GvEA (T-30/89) Jur. 1991, II-1439 (Hilti), GvEA (T-43/92) Jur. 1994, II-441 (Dunlop Slazenger International), GvEA (T-141/89) Jur. 1995, II-791 (Tréfileurope Sales), GvEA (T-145/89) Jur. 1995, II-987 (Baustahlgewebe)en GvEA (T-149/89) Jur. 1995, II-1127 (Sotralentz). Dat er geen territoriale beperking ten aanzien van de omzet bestaat, wordt onderstreept in HvJ (C-279/87) Jur. 1990, 1-261 (Tipp-Ex).

224 In zoverre kan ook een rol spelen of de onderneming deel uitmaakt van een groot concern. Weliswaar zal dan in beginsel niet de totale omzet van het concern als uitgangspunt kunnen worden genomen, maar zal deze omstandigheid wel aanleiding kunnen zijn om een procentueel hogere boete op te leggen. Zo overwoog de Commissie in Pb 1992 L 233/31 (Parker Pen) in het kader van de strafoplegging uitdrukkelijk dat "Parker (...) onderdeel (is) van een groot concern met hoge ormzet". 
factoren, en dat de vaststelling van een passende boete derhalve niet de resultante kan zijn van cen eenvoud. ge berekening. gebascerd op de totale omzet".23

De totale omzet kan kortom een indicatie geven voor het gewicht van de onderneming op de markt; de omzet op de relevante productmarkt zegt iets over de omvang van de inbreuk. Het gaat dan ten dele om de ernst van het kartel als geheel: indien alle kartelleden tezamen een belangrijk deel van (de omzet op) de betreffende productmarkt bestrijken en het kartel daarmee die markt domineert, zijn de gevolgen van dit kartel voor de mededinging navenant groot en vice versa. ${ }^{226}$ Daarnaast is de verhouding tussen de totale omzet van een onderneming en haar deelomzet met betrekking tot het betrokken product van belang. Proportionaliteitsoverwegingen brengen met zich dat het niet redelijk is een boete op te leggen die uitsluitend met de totale omzet van een onderneming rekening houdt indien haar deelomzet hiervan slechts een klein deel uitmaakt ${ }^{227}$, waarmee nogmaals de spilfunctie van het evenredigheidsbeginsel in het communautaire boeterecht wordt onderstreept. ${ }^{228}$

Dat de boete niet meer dan $10 \%$ van de jaaromzet mag bedragen, betekent nog niet dat dus de boete in concrete gevallen steeds aan de omzet zou moeten worden gerelateerd. Toch is het tot 1998 vaste commissiepraktijk geweest om bij zwaardere inbreuken steeds af te stemmen op een bepaald percentage van de 'relevante' omzet. ${ }^{229}$ Wat als relevante omzet werd aangemerkt, was in sterke mate afhankelijk van de omstandigheden van het geval, hetgeen tot een nogal wisselend 'beleid' leidde. ${ }^{230}$ In de Pioneer-zaak bijvoorbeeld was dit de totale omzet, in de Vlakglas Benelux-beschikking ${ }^{23 !}$ de omzet binnen de

225 HvJ (100-103/80) Jur. 1983, 1825 (Musique Diffusion Française); vergelijkbaar GvEA (T-77/92) Jur. 1994, II-549 (Parker Pen), GvEA (T-29/92) Jur. 1995, II-289 (Vereniging van Samenwerkende Prijsregelende Organisaties in de Bouwnijverheide.a.), GvEA (T-143/89) Jur. 1995, II-917 (Ferriere Nord), GvEA (T-24-26 en 28/93) Jur. 1996, Il-1201 (Compagnie maritime belge transports e.a.), GvEA (T-229/94) Jur. 1997, II-1689 (Deutsche Bahn) en HvJ (C-185/95 P) Jur. 1998, 1-8417 (Baustahlgewebe).

226 Vergelijk voor een geval waarin sprake was van een geringe omzet $\mathrm{Pb} 1980$ L $39 / 59$ (Floral).

227 In de Floral-zaak achtte de Commissie blijkens haar Negende verslag over bet mededingingsbeleid. nr. 82, cen geringe boete passend omdat "de betrokken ondemerningen in Duitsland een betrekkelijk geringe omzet realiseerdendie geen wezenlijk deel van hun activiteit in de meststoffensectorvormt". In de Parker Pen-zaak was de Commissie hieraan echter voorbij gegaan. Zie GvEA (T-77/92) Jur. 1994, II-549 (Parker Pen): "Daarentegen blijkt uit de beschikking, dat de Commissie geen rekening heeft gehouden met het feit dat de omzet die is behaald met de produkten waarop de inbreuk betrekking had, betrekkelijk gering was ten opzichte van Parkers omzet uit alle verkopen". Deze omstandigheid was aanleiding voor het Gerecht om de boete te verlagen van 700.000 tot $400.000 \mathrm{ecu}$.

228 Dit blijkt ook bijvoorbeeld uit GvEA (T-13/89) Jur. 1992, II-1021 (Imperial Chemical Industries)

229 Kritisch over deze praktijk: Wils (1998), pag. 254-256.

230 In gevallen waarin het kartel, waaraan de onderneming deelneemt, het gehele productenscala van deze onderneming bestrijkt, was de relevante omzet uit de aard der zaak de totale omzet, warby eventueel nog een territoriale beperking kon worden aangebracht. Voor zover het kartel zich slechts op een (beperkt) deel van de marktactiviteiten van de onderneming richtte, werd veelal aangesloten bij de omzet in het betrokken product. De conclusie van Dannecker en Fischer-Fritsch (1989), pag 317, dat de Commissie vanaf de Pioneer-zaak bij zware inbreuken voor een boete koos van vier tor vijf procent van de 'relevante' omzet, is gelet op het wisselend beleid inzake de relevante omzet weinig verhelderend.

$231 \mathrm{~Pb} 1984$ L. 212/13 (Vlakglas Benelux). 
Benehux (en ten aanzien van enkele ondernemingen bovendien in derde landen) en in de Sperry New Holland-beschikking ${ }^{232}$ de communautaire omzet in landbouwmachines. ${ }^{213}$ De meer recente beschikkingen voorafgaand aan 1998 echter sloten voornamelijk aan bij de omzet op de gemeenschappelijke markt, behaald in het product waarop het kartel betrekking had. ${ }^{234}$ Dit impliceert echter allerminst dat de boetes nominaal geringer zijn. In tegendeel: de boete van 102 miljoen ecu in de Volkswagen-beschikking ${ }^{225}$ toont aan dat de aanvankelijke schroom om nominaal hoge boetes op te leggen, nu -met name vanuit preventie-overwegingen- volledig is verdwenen.

\subsection{De zwaarte van de inbreuk}

Het in artikel 15 Vo 17 genoemde begrip 'zwaarte van de inbreuk' kan de meest uiteenlopende strafmaatfactoren omvatten. De Commissie heeft in de loop der tijd inderdaad een omvangrijk scala aan straftoemetingsfactoren in aanmerking genomen, zij het dat zij -althans tot 1998- niet steeds tot uiting brengt of zij de verschillende aspecten als onderdeel van de zwaarte van de inbreuk ziet of dat zij, nadat de zwaarte van de overtreding is vastgesteld, de bijzondere omstandigheden als afzonderlijke strafverzwarende c.q. strafverlichtende omstandigheden aanmerkt. Toch is het met name deze laatste weg die door de Commissie wordt gevolgd ${ }^{236}$, welke aanpak overigens -zij het in ietwat aangepaste zin- in de reeds gememoreerde mededeling van 1998 is geïnstitutionaliseerd. Allereerst stelt de Commissie de algemene orde van grootte van de geldboete vast ${ }^{237}$, en wel met name aan de hand van de aard, de gevolgen en de duur van het kartelmatig gedrag. Aldus wordt een percentage van de relevante omzet bepaald dat naar boven of naar beneden kan worden bijgesteld indien andere omstandigheden daartoe aanleiding geven. ${ }^{238}$ De omstandigheden die de algemene grootte van de boete bepalen, gelden

$232 \mathrm{~Pb} 1985$ L $376 / 27$ (Sperry New Holland).

233 Instructief is ook Pb 1991 L 152/1 (Natriumcarbonaat Solvay/ICI), waarin naar voren kwam dat ICI een aanmerkelijk lagere omzet in Natriumcarbonaat bereikte dan haar kartelpartner Solvay. Daar stond tegenover dat de totale omzet van ICI beduidend hoger was dan die van Solvay. Mede gelet op deze gegevens en tegen de achtergrond van de omstandigheid dat het in beide gevallen een multinational betrof, oordeelde de Commissie het raadzaam beide een boete van gelijke nominale hoogte op te leggen.

234 Zo werd in $\mathrm{Pb} 1994$ L 243/1 (Karton) voor de zwaarste inbreuken uitgegaan van een 'basisboete' (het bedrag voorafgaand aan strafvermindering) van liefst $9 \%$ van de omzet in het betreffende product, hetgeen uiteindelijk leidde tot verschillende boetes ter hoogte van omstreeks 20 miljoen ecu.

$235 \mathrm{~Pb} 1998$ L 124/60 (VW).

236 Vergelijk bijvoorbeeld Pb 1988 L 316/43 (Dansk Pelsdyravlerforening), Pb 1984 L 212/13 (Vlakglas Benelux) en Pb 1992 L 95/50 (Eurocheque). In deze laatste beschikking worden door de Commissie allereerst de aansprakelijkheid van de participanten en de behaalde winsten bepaald, waarna achtereenvolgens verzwarende en verzachtende factoren worden opgesomd en tegen elkaar worden afgewogen.

237 Pb 1989 L. 74/17 (PVC-I); Pb 1989 L 74/39 (LdPE); Pb 1992 L $92 / 27$ (Bouwnijverheid in Nederland): $\mathrm{Pb} 1994$ L $239 / 31$ (PVC-II) en Pb 1994 L 243/52 (Karton).

238 In deze zin ook Dannecker en Fischer-Fritsch (1989), pag. 315 e.v.. Aldus wordt in het communautaire recht gerealiseerdwat in het (Nederlandse) strafrechtallerminst vanzelfsprekendis: het in het oordeel tot uiting laten komen van strafverzachtende ornstandigheden. Zie Meijers (1989), pag. 211: "De motivering van de straf zal (...) aan duidelijkheid en overtuigingskracht winnen, wanneer de rechter ervan doet blijken ook factoren die ten gunste van de verdachte werken bij de bepaling van de straf te hebben betrokken". 
in beginsel in gelijke mate voor alle betrokkenen en hoeven niet te worden geïndividualiseerd. ${ }^{239}$ De overige omstandigheden, waaronder strafverzwarende c.q. strafverlichtende, hebben veelal betrekking op de afzonderlijke kartelleden, maar kunnen ook gevonden worden in van de kartellerende ondernemingen onafhankelijke factoren. Deze aanpak is dogmatisch de meest correcte, aangezien enkele strafbepalende omstandigheden geheel los van de concrete inbreuk staan en daarmee strikt genomen geen informatie bieden omtrent de zwaarte van de overtreding. Hoewel, zoals gezegd, de Commissie niet in alle gevallen een strikte onderscheiding zoals hiervoor aangegeven hanteer ${ }^{200}$, zal daaraan hierna wel worden vastgehouden. Derhalve komen allereerst de factoren aan de orde die de ernst van het kartel bepalen. Vervolgens worden de omstandigheden besproken die tot strafverzwaring of -vermindering aanleiding kunnen geven. Hierbij kan een onderverdeling worden gemaakt tussen omstandigheden die direct betrekking hebben op de afzonderlijke kartellerende ondernemingen (en die dus een differentiatie van de sancties tussen deze verschillende deelnemers aan één kartel mogelijk maken) en de omstandigheden die buiten de invloedssfeer van de ondernemingen liggen en in beginsel voor iedere onderneming een gelijke werking hebben.

\subsubsection{Kartelgebonden factoren}

\section{De ernst van de gedraging}

Bij de bepaling van de zwaarte van de inbreuk wordt door de Commissie een groot belang gehecht aan de ernst van de gedraging. Deze veelvuldig gebruikte straftoemetingsgrond is tamelijk vaag en kan in principe ieder van de overige door de Commissie aangewende factoren omvatten. Dit laat onverlet dat de Commissie de ernst van de gedraging hoofdzakelijk koppelt aan de aard van het kartelgedrag. ${ }^{241}$ De aard van het kartel is een indicatie voor de potentiële schadelijkheid van een kartelmatige gedraging voor de gemeenschappelijke markt en voor de positie van derden (waaronder consumenten). Bij de beoordeling van de aard van het kartel wordt geabstraheerd van de concrete gevolgen van de inbreuk. Het gaat hierbij om een objectief criterium dat voor alle kartelleden gelijk is. Tot de meest ernstige inbreuken moet worden gerekend kartelgedrag dat beperking van export of vaststelling van prijzen dan wel het verdringen van ondernemingen van de markt beoogt

239 Zie hierover HvJ (45/69) Jur. 1970, 769 (Bochringer Mannheim): "Overwegende dat het vooraf vaststellen van een globale som voor de boete, bepaald naar de mate van het gevaar welke het kartel voor de mededinging en het bandelsverkeer binnen de gemeenschappelijke markt opleverde, met de individuele vaststelling der sanctie niet onverenigbaar is; dat immers de positie en het individueel gedrag van iedere onderneming en de rol welke zij in het kartel heeft gespeeld bij het begroten det boete voor ieder hunner in aanmerking kan worden genomen". Vergelijkbaar HvJ $(96-102,104,105$. 108 en 110/82) Jur. 1983, 3369 (IAZ International Belgium e.a.), GvEA (T-2/89) Jur. 1991, 11-1087 (Petrofina); GvEA (T-4/89) Jur. 1991, II-1523 (BASF); GvEA (T-9/89) Jur. 1992, II-499 (Hüls), GvEA (T-12/89) Jur. 1992, Il-907 (Solvay) en GvEA (T-14/89) Jur. 1992, II-1155 (Montedipe)

240 Vergelijk hierover Van Acker (1986), pag. 359.

241 Het belang van de aard van de mededingingsbeperking werd reeds onderstreept in HvJ (41/69), Jur. 1970, 661 (ACF Chemiefarma)en HvJ (44/69) Jur. 1970, 733 (Buchler), Vergelijk ook GvEA (T-39 en 40/92) Jur. 1994, II-49 (Groupement des cartes bancaires 'CB' en Europay International), GvEA (T-77/92) Jur. 1994, 11-549 (Parker Pen) en GvEA (T-213/95 en T-18/96) Jur. 1997, II-1739 (Stichring Certificatie Kraanverhuurbedrijf en Federatie van Nederlandse Kraanverhuurbedrijven). 
of bewerkstelligt, juist omdat deze naar hun aard tegen de doelstellingen van het EGVerdrag indruisen. ${ }^{242}$ Ondernemingen die dergelijk gedrag ontplooien, kunnen -behoudens contra-indicaties ${ }^{24}$ - rekenen op cen (procentueel) hoge boete. ${ }^{24}$ Ten aanzien van de exportverboden is de afwijzende houding van de Commissie duidelijk sinds de Grundig/Consten-beschikking in $1964^{245}$, naar welke beschikking door de Commissie verschillende malen in haar latere beschikkingen expliciet dan wel impliciet wordt verwezen. ${ }^{246}$ $\mathrm{D} e$ schadelijkheid voor de communautaire mededinging van prijskartels blijkt reeds uit de uitdrukkelijke opname ervan in de artikelen 81 lid 1 sub a en 82 EG. ${ }^{247}$ Als ernstig worden voorts aangemerkt gedragingen waarmee wordt voorkomen dat een onderneming tot een markt toetreedt of die (pogen te) bewerkstelligen dat een onderneming van de markt verdwijnt of dat haar positie hierop aanmerkelijk wordt verzwakt. De mededinging wordt door dergelijk gedrag in ernstige mate aangetast, hetgeen in het bijzonder het geval is indien bedoeld gedrag wordt ontplooid door een onderneming met een machtspositie. ${ }^{245}$ Het moge voor zich spreken dat de ernst van een gedraging toeneemt indien ondernemingen zich schuldig maken aan verschillende vormen van ernstig mededingingsbeperkend gedrag. ${ }^{249}$ Vanuit de optiek van de onderneming is dit vaak noodzakelijk aangezien zonder een combinatie van gedrag haar inspanning geen effect zou sorteren: zo zullen marktverdelingen en prijsafspraken vaak hand in hand gaan, omdat anders alsnog de aankoop door derden dreigt te geschieden in de regio waar lagere prijzen gelden. Deze noodzaak laat vanzelfsprekend onverlet dat de Commissie streng tegen dergelijke gedragingen optreedt. ${ }^{250}$ Tegenover deze ernstige kartelvormen staan die waarvan geen groot nadeel is te verwachten. Dit is bijvoorbeeld het geval bij kartels die beperkt zijn tot

242 Voor exportverbodenzie bijvoorbeeldHvJ (19/77) Jur. 1978, 131 (Miller International Schallplatten) en HvJ (C-89, 104, 114, 116, 117 en 125-129/85) Jur. 1993, I-1307 (Ahlström Osakeyhtió). In Pb 1986 L 232/30 (Bitumineuze dakbedekking) overwoog de Commissie dat "beperkingen inzake de prijzen en de verdeling van de markt alsmede de gezamenlijke tegen concurrenten gerichte maatregelen tot de ernstigste inbreuken die op de vrije mededinging kunnen worden gepleegd" behoren. Voor een marktverdelingskartel zie bijvoorbeeld $\mathrm{Pb} 1994 \mathrm{~L} 343 / 1$ (Cement).

243 Bijvorbeeld $\mathrm{Pb} 1991$ L 185/23 (Martell), waarin een lage boete werd opgelegd ondanks een gehanteerd exportverbod.

244 Eén van de talrijke voorbeelden hiervan is $\mathrm{Pb} 1982 \mathrm{~L}$ 94/7 (Moêt et Chandon).

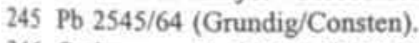

246 Onder meer Pb 1985 L 35/58 (John Deere), Pb 1995 L 272/16 (BASF Lacke + Farben) en Pb 1997 L 47/11 (Novalliance/Systemform). Voor een voorbeeld van belemmering van parallel-export, zie $\mathrm{Pb} 1996$ L 201/1 (ADALAT).

$247 \mathrm{~Pb} 1982 \mathrm{~L}$ 379/1 (UGAL/BNIC) en Pb 1997 L 26/13 (Veerdienstmaatschappijen).Zie tevens GvEA (T-142/89) Jur. 1995, II-867 (Usines Gustave Boel).

$248 \mathrm{~Pb} 1972$ L 299/51 (Zoja CSCICI), waarin door een leveringsstop de uitschakeling van een onderneming dreigde, Pb 1989 L 10/50 (BPB), HvJ (C-62/86) Jur. 1991, I-3359 (AKZOChemie), GvEA (T-30/89) Jur. 1991, Il-1439 (Hilti), Pb 1992 L $72 / 1$ (Tetra Pak II) -bevestigd in GvEA (T-83/91) Jur. 1994, II-755 (Tetra Pak International)-, Pb 1992 L 96/34 (British Midland/Aer Lingus), GvEA (T-24-26 en 28/93) Jur, 1996, II-1201 (Compagnie maritime belge transports c.a.) en Pb 1997 L 258/1 (Irish Sugar).

249 Uit GvEA (T-141/89) Jur. 1995, II-791 (Trefileurope Sales), GvEA (T-144/89) Jur. 1995, II-947 (Cockerill Sambre) en GvEA (T-149/89) Jur. 1995, II-1127 (Sotralentz) blijkt dat voor verschillende inbreuken één geldboete kan worden opgelegd.

$250 \mathrm{~Pb} 1989$ L 74/1 (PVC-1); de ondernemingen stelden niet alleen prijzen vast maar wisselden tevens gegevens uit, verdeelden de markten en hanteerden een quotaregeling. 
informatieuitwisseling ${ }^{251}$; deze brengen in beginsel geen vergaande consequenties met zich, tenzij natuurlijk de verkregen informatie wordt aangewend voor de uitvoering van een andere kartelvorm, zoals prijs- of quotavaststelling en verdeling van markten. ${ }^{28}$

\section{De gevolgen van het kartel}

De hierboven genoemde straftoemetingsfactor 'ernst van de gedraging' ziet op de potenticle negatieve consequenties van een kartel voor de mededinging en de contractspartijen (waar. onder consumenten). Hij zegt echter niets over de daadwerkelijke gevolgen van de mede. dingingsregeling: op papier ernstige inbreuken kunnen (bijvoorbeeld door gebrek aan toepassing) in de praktijk gevolgen ontberen ${ }^{253}$, maar kunnen ook (door strikte toepas. sing) zeer succesvol zijn. Omgekeerd kan een theoretisch minder schadelijk kartel verstrekkende gevolgen teweegbrengen. De zwaarte van de inbreuk hangt dientengevolge mede af van de effectiviteit en de gevolgen van de gedraging. ${ }^{254}$ Welke de concrete consequenties van mededingingsbeperkend gedrag zijn, is vaak niet eenvoudig te bepalen. ${ }^{25}$ Afhankelijk van het geval zou eventueel een vergelijking kunnen worden gemaakt tussen het gedurende de 'kartelperiode' geldende prijsniveau en het prijsniveau zoals dat naar verwachting zou hebben gegolden zonder kartelgedrag. ${ }^{256}$ Maar dit laatste prijsniveau is veelal nauwelijks nauwkeurig te ramen. De Commissie komt derhalve ook via andere wegen tot de conclusie dat de gedraging effectief was, bijvoorbeeld indien blijkt dat "doeltreffend iedere mogelijkheid van daadwerkelijke concurrentie" 257 is uitgeschakeld

$251 \mathrm{~Pb} 1987$ L $3 / 17$ (Vetzuren). In GvEA (T-39 en 40/92) Jur. 1994, II-49 (Groupement des cartes bancaires 'CB' en Europay International) werd overwogen dat de overeenkomst slechts verplichtte tot het in rekening brengen van een commissie, waarbij het bedrag van de commissie niet dwingend was voorgeschreven.

$252 \mathrm{~Pb} 1994$ L 343/1 (Cement).

253 Voor het ontbreken van concrete gevolgen voor de interstatelijke handel zie men $\mathrm{Pb} 1988 \mathrm{~L} 7834$ (Konica). In Pb 1986 L 230/1 (Polypropyleen) treft men een voorbeeld aan van een prijskartel dat niet steeds effectief was. In Pb 1992 L 96/34 (British Midland/Aer Lingus) werd ermee rekening gehouden een vastgesteld misbruik van machtspositie een onderneming schade had berokkend, maat dat deze niet van de markt was verdreven. In Pb 1997 L. 26/23 (Veerdienstmaatschappijen)was het ontbreken van vergaandegevolgen van een onderling afgestemdefeitelijkegedraginginzakegemeenschappelijkeprijsverhogingenreden om eenrelatieflage boete op te leggen. De Commissie overwoog echter wel uitdrukkelijk dat de ernst van de gedraging een slechts symbolische boete niet toeliet.

254 Het Gerecht houdt toezicht op de al dan niet juiste beoordeling van de gevolgen door de Commissie. Vergelijk GvEA (T-308/94) Jur. 1998, II-925 (Cascades), GvEA (T-317/94) Jur. 1998, II-1235 (Moritr J. Weig), GvEA (T-334/94) Jur. 1998, II-1439 (Sarrió), GvEA (T-338/94) Jur. 1998, II-1617 (Finnboard), GvEA (T-347/94) Jur. 1998, II-1751 (Mayr-Melnhof Kartongesellschaft), GvEA (T352/94) Jur, 1998, II-1989 (Mo och Domsjo) en GvEA (T-354/94) Jur. 1998, II-2111 (Stora Kopparbergs Bergslags), waarin echter de onjuiste beoordeling van door Commissie niet tot een verlaging van de boetes leidde.

$255 \mathrm{~Pb} 1982 \mathrm{~L} 117115$ (AEG-Telefunken), waarin de directe gevolgen van selectieve distributieregelias niet nauwkeurig bepaald konden worden, maar waarin invloed op de prijzen werd aangenomen of grond van het gegeven, dat de producten niet daar konden worden aangeschaft, waar het prijsniveas het laagste lag.

256 Voor een voorbeeld zie men Pb $1980 \mathrm{~L} 377 / 16$ (Johnson \& Johnson); hier bedroeg het te verwachten maximale prijsverschil voor dezelfde producten $375 \%$.

$257 \mathrm{~Pb} 1985$ L 35/16 (Peroxyde). 
of dat een onderneming haar machtspositie heeft behouden of zelfs heeft uitgebouwd. ${ }^{28 s}$ Op de praktische gevolgen van een gedraging heeft in ieder geval een aantal factoren direct dan wel indirect invloed. Deze factoren worden hieronder besproken.

a) De aard en het belang van het betrokken product

De Commissie weegt bij de boeteoplegging de aard en het belang van het product mee: gedragingen met betrekking tot een om welke reden dan ook onmisbaar of moeilijk substituecrbaar product, zullen in beginsel verstrekkende gevolgen hebben. ${ }^{299}$ De afnemers zjn in die gevallen afhankelijk van de producenten of leveranciers en kunnen niet hun toevlucht zoeken tot een ander product waarvoor de afspraken niet gelden ${ }^{260}$; derhalve zal iedere productiebeperking of prijsverhoging direct op de markt merkbaar zijn. ${ }^{201}$ Een kartel dat betrekking heeft op een minder belangrijk product zal in beginsel veel minder schade voor de mededinging berokkenen. ${ }^{202}$ In dat verband kan een rol spelen of het een massagoed betreft ${ }^{263}$, maar ook niet-massagoederen kunnen belangrijke producten zijn. Zo oordeelde de Commissie dat kwalitatief hoogwaardige, dure spiegelreflexcamera's een belangrijk product vormen, aangezien ten eerste bij een geringe afzet reeds een grote omzet wordt bereikt, ten tweede beroepsfotografen bij de uitoefening van hun werkzaamheden van deze camera's afhankelijk zijn en ten derde het voor detailhandelaren met het oog op hun bedrijfsvoering en concurrentiepositie essentieel is de toestellen in hun assortiment op te kunnen nemen. ${ }^{264}$

\section{b) Marktdekking}

De effectiviteit van het kartel wordt in belangrijke mate bepaald door de marktdekking ervan. Naarmate de dekking groter is, zal de merkbaarheid van de gedragingen toenemen.

258 Zoals het geval was in Pb 1992 L $72 / 1$ (Tetra Pak II). In Pb 1978 L 22/23 (Hugin/Liptons) ging het om een leveringsweigering door een onderneming met een machtspositie. Gevolg hiervan was dat de 'afnemer' aanzienlijke verliezen leed en als concurrent van de markt dreigde te verdwijnen, waardoor de mededinging danig werd beïnvloed. In HvJ (C-62/86) Jur. 1991, 1-3359 (AKZO Chemie) daarentegenoverwoog het Hof dat een verlaging van de door de Commissie opgelegde boete geǐndiceerd was omdat het mededingingsbeperkend gedrag de marktaandelen van de betrokken ondernemingen nauwelijks had beïnvloed.

259 Vergelijk reeds $\mathrm{Pb} 1969 \mathrm{~L}$ 195/11 (Kleurstoffen). Ook suiker werd als een belangrijk product aangemerkt: zie Pb 1997 L 258/1 (Irish Sugar).

260 Vergelijk bijvoorbeeld Pb 1994 L 343/1 (Cement), waarin de Commissie voor de hoogte van de boete mede bepalend acht dat "de cementmarkt (...) een primaire industriesector (is), die van groot belang is voor de bouwnijverheid en voor de economie in het algemeen".

$261 \mathrm{~Pb} 1969 \mathrm{~L} 192 / 5$ (Kinine); de Commissie overwoog ten aanzien van kinine en kinidine, dat het bij deze stoffen gaat "om produkten die van bijzondere betekenis zijn als geneesmiddel en die niet in ieder opzicht door substitutieprodukten kunnen worden vervangen". Vergelijk ook (Polypropyleen), Pb 1989 L 74/1 (PVC-I) en Pb 1989 L. 74/21 (LdPE) waarin werd gesteld dat deze goederen als belangrijke industrieproducten moesten worden beschouwd.

$262 \mathrm{~Pb} 1977$ L. $39 / 26$ (Theal/Watts); het betrof hier een platenreiniger. Vergelijk ook HvJ (193/83) Jur. 1986, 611 (Windsurfing International).

$263 \mathrm{~Pb} 1976 \mathrm{~L}$ 95/1 (Chiquita). De Commissie overwoog dat "het gaat om een produkt van grootverbruik dat van belang is voor de consument".

$264 \mathrm{~Pb} 1982$ L 161/18 (Hasselblad). 
Daarbij is in eerste instantie niet het aantal ondernemingen doorslaggevend; ook mededin. gingsbeperkend gedrag dat door één onderneming (men denke aan artikel $82 \mathrm{EG}^{\text {tas }}$ ) of door een beperkt aantal, waaronder de marktleider $(\mathrm{s})^{266}$, wordt ontplooid, kan vergaan. de effecten bewerkstelligen. Centraal staat of er buiten het kartel om redelijkerwijs nog voldoende mate van concurrentie resteert. Is dit het geval, dan zullen de gevolgen voor de mededinging, maar ook voor bijvoorbeeld de consumenten beperkt zijn. Daarenboven zal dan het kartel geen lang leven beschoren zijn aangezien het door de (concurrentie)gedragingen van derden zal worden ondermijnd. Niet alleen is van belang welke marktdekking een kartel heeft, maar bovendien op welke (geografische) markt deze dekking betrek. king heeft. Kartels die slechts een beperkt deel van de (product)markt binnen één lidstaat bestrijken, behoren tot de minder schadelijke kartels. ${ }^{267}$ Dit is reeds anders indien de gehele markt binnen één lidstaat door het kartel wordt gedekt: in dat geval is vrije concurrentie -ook door ondernemingen uit derde landen- binnen deze staat niet meer mogelijk. ${ }^{268}$ De nadelige effecten worden nog versterkt indien het nationale kartel tevens een machtspositie op de communautaire markt heeft, hetgeen onder meer het geval was in het Deense bontkwekerskartel. ${ }^{209}$ De in het geding zijnde vereniging had in de contrace ten met haar leden onder meer de verplichting opgenomen uitsluitend via de door haar georganiseerde veiling te verkopen, waardoor zij vrijwel een monopoliepositie innam. Dit was volgens de Commissie des te kwalijker daar Denemarken één van de belangrijkste bontproducenten van de gemeenschap was en dientengevolge de effecten voor de handel binnen de gehele gemeenschap aanzienlijk waren. Daarmee is de stap gemaakt naar een nog ernstigere kartelvorm, te weten die kartelinbreuken die een groot deel van de communautaire markt van het betreffende product bestrijken. Reeds in de Kleurstoffen-zaak blijkt dit een belangrijke graadmeter te zijn voor de zwaarte van de inbreuk. De Commissic oordeelde in dit verband "dat de zwaarte van de gepleegde inbreuken (...) blijkt uit het feit dat deze ondernemingen, die trouwens allen van aanzienlijke omvang zijn, alleen reeds meer dan $80 \%$ van de leveranties aan kleurstoffen binnen de E.E.G. verzorgen". De aanwezigheid van een vergelijkbaar overheersend kartel werd geconstateerd in de Houtslijpcasus: het in deze casus centraal staande kartel had bijna tweederde van de economisch zeer belangrijke Europese markt in gebleekte sulfaathoutslijp in handen. ${ }^{271}$ Ook recente beschikkingen tonen aan dat de Commissie de inbreuk in versterkte mate

265 Onder meer $\mathrm{Pb} 1992$ L 72/1 (Tetra Pak II) en het beroep tegen deze beschikking GvEA (T-83/91) Jur. 1994, II-755 (Tetra Pak International).

$266 \mathrm{~Pb} 1973$ L. 293/40 (Deutsche Philips), Pb 1982 L $94 / 7$ (Moět et Chandon) en Pb 1988 L $316 / 43$ (Danss Pelsdyravlerforening).

267 Bij gebrek van elk communautair belang zijn de artikelen 81 en 82 EG zelfs geheel niet van tocpassing

268 Deze omstandigheid heeft aldus de Commissie in $\mathrm{Pb} 1992$ L $92 / 1$ (Bouwnijverheid in Nederland) "naar haar aard een versterking van de nationale drempelvorming tot gevolg, hetgeen de in het Ventras beoogde economische vervlechting doorknist en de nationale produktie bescherming verschaft". Aldur ook Pb 1991 L 152/1 (Natriumcarbonaat Solvay/CI), waarin werd benadrukt dat afscherming vart de gehele markt binnen een lidstaat tegen concurrentie de eenwording van de markt voorkomt.

$269 \mathrm{~Pb} 1988$ L $316 / 43$ (Dansk Pelsdyravlerforening).

$270 \mathrm{~Pb} 1969$ L 195/15 (Kleurstoffen).

$271 \mathrm{~Pb} 1985$ L. 85/1 (Houtslijp). 
emstig acht indien "de aan de inbreuk deelnemende ondernemingen (de) markt nagenoeg geheel in handen" hebben. ${ }^{272}$

Lijnrecht tegenover de situatie waarin er een zeer overheersend kartel op de markt aanwezig is, staan de gevallen waarin er ondanks het kartel een voldoende mate van concurrentie op de markt bestaat. ${ }^{275}$ Een dergelijke situatie kan zich om verschillende redenen voordoen bijvoorbeeld omdat het totale marktaandeel ${ }^{274}$ van de bij een kartel betrokken ondernemingen of hun omzet ${ }^{275}$ gering is of omdat de ondernemingen zelf de omzet die via het kartel wordt bereikt, beperken. ${ }^{276}$ Een situatie waarin de doeltreffendheid van het kartel gering is, kan ook ontstaan in de loop van de periode waarin het kartel actief is, bijvoorbeeld omdat enkele ondernemingen op een zeker moment het kartel de rug toe keren. ${ }^{2 m}$

\section{c) De naleving van het kartel}

Ondernemingen kunnen een op papier zeer schadelijke kartelovereenkomst sluiten, maar kunnen tevens nalaten deze overeenkomst na te leven of kunnen zelfs op een wijze handelen die direct tegen de gemaakte afspraken indruist. In een dergelijke situatie zullen de gevolgen beperkt zijn of zelfs geheel ontbreken. Dit was onder meer het geval in de zaak die aanleiding vormde tot de reeds eerder besproken Deutsche Philips beschikking. ${ }^{27 n}$ De betrokken onderneming had weliswaar een exportverbod in haar verkoopvoorwaarden opgenomen (en per vergissing gehandhaafd), maar het verbod had in de praktijk geen toepassing gevonden. Aan de andere kant kunnen de ondernemingen alles in het werk stellen om een optimaal functioneren van het kartel te realiseren. Dit is in vergaande mate het geval als "de heimelijke verstandhouding was geïnstitutionaliseerd in een systeem van geregelde kartelbijeenkomsten die tot doel hadden de (betreffende) markt tot in de

$272 \mathrm{~Pb} 1989$ L 74/1 (PVC-I). Vergelijkbaar Pb 1989 L 74/21 (LdPE) waarin een dekking van 90\% door het kartel op de betrokken markt werd geconstateerd, $\mathrm{Pb} 1994$ L 343/1 (Cement) en Pb 1994 L 243/1 (Karton). Als andere factoren daartoe aanleiding geven, kan de Commissie de boete -ondanks een aanzienlijke marktdekking- onverminderd matigen. Vergelijk Pb 1987 L $3 / 17$ (Vetzuren).

$273 \mathrm{~Pb} 1984$ L 136/15 (Polistil/Arbois).

$274 \mathrm{~Pb} 1977$ L $39 / 19$ (Theal/Watts). Zie ook Pb 1988 L 78/34 (Konica): de gevolgen van het verbod van nevenimport naar Duitsland bleven beperkt aangezien het marktaandeel van de betrokken ondememingen op de Duitse markt zeer gering was.

$275 \mathrm{HvJ}$ (86/82) Jur. 1984, 883 (HasselbladGB). In Pb 1976 L 357/40 (Miller International Schallplatten) maakte het in dit verband niet uit dat de onderneming onderdeel was van een groot concern. Dit speelde daarentegen wel een rol in de Betonstaalmatten-zaak, waarin de Commissie inbreuken van ondernemingen die tot een grote economische eenheid behoorden, als zwaarder kwalificeerde gelet op de gevolgen ervan. Het omgekeerde was eveneens het geval. In GvEA (T-142/89) Jur. 1995, II-867 (Usines Gustave Boell) leidde dit ertoe dat de boete door het Gerecht werd verlaagd omdat de Commissie Boell ten onrechte tot een grote economische eenheid had gerekend en dus ten onrechte niet met een strafverlagende omstandigheid rekening had gehouden. In GvEA (T-145/89) Jur. 1995, II-987 (Baustahlgewebe) daarentegen had de Commissie het feit dat de ondememing niet tot cen grote economische eenheidbehoorde, volgens het Gerechtterecht niet als verzachtendeomstandigheidin aanmerking genomen, omdat de ondememing het grootste aandeel van de Duitse markt in handen had.

$276 \mathrm{~Pb} 1980 \mathrm{~L} 39 / 59$ (Floral); de ondernemingenhaddenhier een gemeenschappelijkeverkooporganisatie opgericht, welke organisatie een relatief geringe omzet bereikte.

$277 \mathrm{~Pb} 1989$ L 260/41 (Betonstaalmatten).

278 Pb 1973 L 293/40 (Deutsche Philips). 
kleinste bijzonderheden te ordenen". ${ }^{29}$ De handelwijze van de ondernemingen beïnvioedt aldus het al dan niet intreden van reële gevolgen van het kartel. Op de rol die afzonderlijke ondernemingen spelen binnen een kartel zal in het kader van de niet-kartelgebonden factoren nog nader worden ingegaan.

\section{d) De marktsituatie}

De consequenties van een mededingingsregeling kunnen ook samenhangen met de situatie op de markt of met andere aspecten die niet door de ondernemingen merkbaar kunnen worden beïnvloed. ${ }^{280}$ In de Johnson \& Johnson-zaak bijvoorbeeld had een aan Duitse handelaren opgelegd uitvoerverbod geen enkele reêle betekenis aangezien het prijsniveau in Duitsland hoger lag dan in andere landen; in die situatie lag export ook zonder kartel niet voor de hand, waardoor de gevolgen van het kartel zeer beperkt waren. ${ }^{281}$ Daarnaast kan een verandering van economische omstandigheden (waaronder een wijziging van de situatie van vraag en aanbod tijdens het bestaan van het kartel ${ }^{282}$ ) aanleiding vormen tot matiging van de boete. 283

\subsubsection{Niet-kartelgebonden factoren}

\section{Factoren die verband houden met de ondernemingen}

Boetes moeten geïndividualiseerd worden. Dat brengt met zich dat ondernemingsgebonden factoren bij de bepaling van de aan een onderneming op te leggen boete een prominente plaats innemen. Binnen een kartel waaraan verschillende ondernemingen deelnemen, kan dit dan ook leiden tot aanzienlijk uiteenlopende boetes, ondanks het feit dat iedere ondeme ming dezelfde gedraging valt te 'verwijten'. In de PVC-beschikking verwoordde de Com. missie het typerend (maar wel zeer bondig):

"Bij de vaststelling van de aan iedere ondememing afzonderlijk op te leggen geldbocte heeft de Commisée rekening gehouden met graad van betrokkenheid van elk van hen, met de rol (..) die elk van hen bij de heimelijke afspraken heeft vervuld en met het respectieve belang van elk bedrijf op de PVC-markt". "

Deze en andere in de beschikkingspraktijk naar voren komende ondernemingsgebonden factoren worden hieronder besproken.

$279 \mathrm{~Pb} 1989$ L. 74/17 (PVC-I), Pb 1989 74/21 (LdPE) en Pb 1986 L 230/35 (Polypropyleen) en Pb 1994 L 243/1 (Karton). Vergelijk ook Pb 1994 L 343/123 (Cement): "de heimelijke verstandhouding is geînstitutionaliseerd in het kader van internationale organisaties of vergaderingen en van bilaterale of multilaterale contacten met als doel de cementmarkt te reguleren en te organiseren".

280 in Pb 1996 L 201/1 (ADALAT) was sprake van een exportverbod, maar dankzij overheidsregels ten aanzien van de prijzen voor geneesmiddelen bewerkstelligde het verbod geen discriminatie bij de vaststelling van verbruikersprijzen.

$281 \mathrm{~Pb} 1980 \mathrm{~L} 377 / 26$ (Johnson \& Johnson). In casu baatte dit de kartelleden overigens niet: de Commissie zag de Duitse overeenkomst als een bevestiging van de algemene politiek van de ondernemingee om de mededinging te beperkennu zij ook in het Verenigd Koninkrijk een exportverbod hanteerden.

$282 \mathrm{~Pb} 1989$ L 260/41 (Betonstaalmatten).

283 Zie bijvoorbeeld Pb 1975 L 29/26 (Champignons in blik).

$284 \mathrm{~Pb} 1989$ L $74 / 17$ (PVC-I). 


\section{a) De mate van schuld}

In paragraaf 2.1 is reeds besproken dat het Hof -mijns inziens ten onrechte ${ }^{285}$ - heeft geoordeeld dat de mate van schuld in het kader van de straftoemeting geen rol behoeft tespelen. Dit laat echter onverlet dat dit in de praktijk desalniettemin wel in veel gevallen gebeurt. Kortom: het onderscheid tussen opzettelijke en culpoze gedragingen kan wel degelijk invloed uitoefenen op de hoogte van de sanctie. ${ }^{286}$ Een onderneming die -hoewel varwijtbaar handelend- nauwelijks enige blaam treft ${ }^{267}$, wordt dan ook doorgaans aanmerkelijk milder gestraft dan een onderneming die welbewust de kartelbepalingen overtreedt. ${ }^{28 \pi}$ Dit stuit ook niet op bezwaren bij de communautaire rechters. ${ }^{209}$ De Commissie blijkt in haar beoordeling van de mate van schuld enigszins milder dan bij de beantwoording van de vraag of er schuld is. Waar een onderneming zich niet of nauwelijks kun disculperen in gevallen waarin de visie van de Commissie in voldoende mate vaststaat, duar is de Commissie bij de straftoemeting bereid te aanvaarden -en als strafverlichtende onstandigheid in aanmerking te nemen-dat een onderneming van geringe omvang "zich net volledig van het kartelverbod" bewust is geweest. ${ }^{290}$ Al te veel mildheid hoeft van de Commissie overigens niet verwacht te worden. Indien bijvoorbeeld een onderneming ten onrechte vertrouwt op een door haar ingewonnen (maar onjuist gebleken) juridisch atvies, terwijl de onjuistheid ervan op relatief eenvoudige wijze had kunnen worden vistgesteld ${ }^{29}$, zal zij zich niet met succes op een verminderde verwijtbaarheid kunnen beroepen. ${ }^{2 n}$

285 Advocaat-Generaal Vesterdorf blijkt in zijn conclusie bij de Polypropyleen-zaken, GvEA (T-1/89) Jur. 1991, II-1020, eveneens van mening dat de mate van schuld de boete moet beīnvloeden. Hij acht de mate van opzet zelfs in beginsel van groter belang bij de bepaling van de zwaarte van de inbreuk dan de daadwerkelijke gevolgen van het kartelmatig gedrag.

286 In deze zin ook onder meer Reynolds (1992), pag. 264 en Van Bael (1995), pag. 239.

287 Zoals het geval was in Pb 1973 L 293/40 (Deutsche Philips).

$288 \mathrm{~Pb} 1982$ L 354/28 (National Panasonic), Pb 1986 L 348/64 (Meldoc) en Pb 1992 L 134/1 (FransWestafrikaanse rederscomités).

289 HvJ (41/69), Jur. 1970, 661 (ACF Chemiefarma), HvJ (45/69) Jur. 1970, 769 (Boehringer Mannheim) en HvJ (C-89, 104, 114, 116, 117 en 125-129/85) Jur. 1993, 1-1307 (Ahlström Osakeyhtio). In de laatste zaak ging het Hof bij de vaststelling van de boete ervan uit dat het gedrag enkel een gevolg was van onachtzaamheid.

$290 \mathrm{~Pb} 1986$ L 232/30 (Bitumineuze dakbedekking).

291 Hier wordt dus van de ondernemingenverwacht dat zij de rechtssituatienaar juistheid kunnen inschatten.

$292 \mathrm{~Pb} 1979 \mathrm{~L} 16 / 9$ (Kawasaki). Kawasaki had ten onrechte vertrouwd op cen rechtskundig advies waanuit bleek dat de overeenkomst weliswaar een ongunstige invloed op de handel zou kunnen hebben, maar dat zij binnen de reikwijdte van de bagatelverklaring viel. Kawasaki pleitte voor geen of een slechts 'symbolische' boete. De Commissie was niet onder de indruk van dit verweer. Zij stelde dat Kawasaki wist dat door hantering van het kartel de mededinging beperkt werd en dat Kawasaki niet op het advies had mogen vertrouwen, daar de onjuistheid ervan bij bestudering van de bagatelbekendmaking duidelijk zou blijken. Een beroep op juridisch advies mocht evenmin baten Pb 1984 L 136/14 (Polistil/Arbois). In $\mathrm{Pb} 2001 \mathrm{~L} 59 / 1$ (Opel) had de onderneming in kwestie 'tegenstrijdig juridisch advies' ontvangen. De Commissie veegde dit verweer van tafel door op de overbekende rechtssituatic te wijzen en door op te merken dat de onderneming zich dan maar tot haar had moeten wenden. Een en ander laat overigens onverlet dat inschakeling van een jurist, zelfs als deze een incorrect advies uitbrengt, een anderneming toch tot voordeel kan strekken, omdat deze handelwijze blijk geeft van de wil de communautaire kartelregels te respecteren. Vergelijk Pb 1987 L 222/1 (Tipp-Ex). 
b) De omzet en marktpositie van de onderneming

Het belang van de omzet is reeds in paragraaf 4.1 aan bod gekomen: de omzet bepaalt de maximumboete en kan een indicatie vormen voor de omvang van de inbreuk alsmede voor de invloed van een onderneming op de markt. In feite rust op ondernemingen die cen hoge omzet bereiken en/of die een sterke marktpositie innemen een voorbeeldfunctie voor zover het de naleving van communautaire regels betreft. ${ }^{293}$ Dergelijke ondernemingen moeten zich niet alleen ervan bewust zijn dat hun acties in potentie directe en merkbare repercussies op de betrokken markt hebben ${ }^{294}$, maar bovendien dat hun acties vaak vervolgacties van andere marktpartijen uitlokken. Miskenning van deze voorbeeldfunctie door initietring van, deelname aan of aanzetting tot kartellering leidt dan ook meestal tot een (relatief) hoge boete. ${ }^{205}$ Ondernemingen met een minder prominente marktpositie dragen in dit verband een minder grote verantwoordelijkheid. Dat laat onverlet dat het ook hen niet geoorloofd is om de mededinging merkbaar te beperken. Er zijn echter situaties denkbaar waarin een onderneming welhaast niet anders kan dan te participeren in mededingingsbeperkend gedrag. Dit is met name het geval indien een onderneming ruimte voor het voeren van een zelfstandig beleid ontbeert -omdat er sprake is van een moeder/dochter-relatie of van enige andere juridische of feitelijke binding met de marktbepalende onderneming- of indien zij economisch in een afhankelijke positie verkeert. In dergelijke situaties betracht de Commissie doorgaans coulance. ${ }^{296}$

\section{c) Recidive en strafcumulatie}

Bij de bespreking van het schuldvereiste is op het grote belang van eerdere beschikkingen gewezen: indien de rechtssituatie voldoende duidelijk moet worden geacht, dan kan een onderneming zich welhaast niet disculperen. Een nog groter verwijt kan een kartellerende onderneming worden gemaakt indien zijzelf reeds eerder geadresseerde van een verbods(en eventueel zelfs boete)beschikking is geweest. In een dergelijk geval van recidive, waarin de onderneming toont de belangen van de gemeenschap opzij te zetten ten behoeve van haar eigen (financieel) belang, zal de Commissie vrijwel automatisch tot het bestaan

$293 \mathrm{~Pb} 1991$ L 152/20 (Natriumcarbonaat Solvay/CFK): bij de vaststelling van de hoogte van de boete "neemt de Commissie de machtspositie van Solvay als grootste producent in Duitsland en in de Gemeenschapin aanmerking. Solvay meent dat zij in die hoedanigheid in het bijzonderverantwoordelijk is voor de "stabiliteit" van de markt".

$294 \mathrm{~Pb}$ 1995 L. 272/32 (BASF Lacke + Farben); in deze zaak betrof het een onderneming "met een sterke positie op de markt voor autoreparatielakken in Europa. Haar bedrijfsstrategie heeft daardoor aanzienlifke economische gevolgen"; Pb 1991 L 287/39 (Toshiba): de betrokken onderneming was "een belangrij. ke marktdeelnemerop de markt voor fotokopieerapparatenin de Gemeenschap"en Pb 1992 L 134/23 (Frans- Westafrikaanse rederscomités): de ondememing had "een duidelijk groter deel van het vrachrver voer in handen (...) dan haar partner binnen de rederscomités, zodat haar handelingen een bijzonder gevoelige weerslag op de markt hebben".

$295 \mathrm{~Pb} 1978$ L 46/42 (BMW Belgium), Pb 1991 L 152/16 en Pb 1992 L. 131/45 (DSI): "De Commissic heeft voorts rekening gehouden met de belangrijke positie van DSI op de betrokken markten". Vergelijk ook Pb 1996 L 201/1 (ADALAT).

$296 \mathrm{~Pb} 1978 \mathrm{~L} .46 / 33$ en HvJ (32/78 en 36-82/78) Jur. 1979, 2435 (BMW Belgium), HvJ (100-103/80) Jur. 1983, 1825 (Musique Diffusion Française), Pb 1987 L 222/1 (Tipp-Ex), Pb 1992 L. 233/27 (Parker $\mathrm{Pen}$ ) en $\mathrm{Pb} 1995$ L. 272/16 (BASF Lacke + Farben); in deze laatste beschikking werd de economisch afhankelijke onderneming cen symbolische boete ter hoogte van tienduizend rekencenheden opgelegd 
van opzet concluderen. ${ }^{297}$ Daarenboven blijkt recidive door de Commissie ${ }^{298}$-en daarin gesteund door het Gerecht ${ }^{299}$ - als strafverzwarende omstandigheid in aanmerking te worden genomen, ondanks het feit dat noch het EG-Verdrag noch enige Verordening een regeling hieromtrent kent. ${ }^{300}$

Tegenover dit beleid van de Commissie om recidivisten harder aan te pakken dan 'first offenders', staan haar bemoeienissen om sanctiecumulatie en de gevolgen daarvan in de vorm van een enorme financiële belasting voor ondernemingen te beperken, indien er een samenloop van feiten heeft plaatsgehad. Dit was bijvoorbeeld het geval in de laliaans Vlakglas-beschikking. ${ }^{301}$ De samenloop werd hier gevormd door "gelijktijdige overtreding, door middel van dezelfde gedragingen, van twee artikelen van het Verdrag", te weten de artikelen 81 en 82 EG. Hier opteerde de Commissie voor non-cumulatie en legde uitsluitend een boete op voor de zwaarste overtreding. ${ }^{302}$ In PVC-I was er geen sprake van een overtreding van verschillende artikelen door dezelfde (feitelijke) gedraging. Het ging om een overtreding die betrekking had op een ander product (zij het eveneens in de zogenoemde thermoplasticssector), maar die wel in vrijwel dezelfde tijdspanne had plaatsgehad als de enkele jaren voordien bestrafte overtreding in de Polypropyleensector. ${ }^{103}$ Gezien deze gelijktijdigheid, de omvang van de eerder opgelegde boetes en (waarshijnlijk) de verwantschap van de betreffende producten vond de Commissie enige matiging van de hoogte van de boete voor de gedragingen in de PVC-sector op haar plaats.

297. In Pb 1989 L. 74/1 (PVC-I); Pb 1989 L 74/21 (LdPE) en reeds eerder Pb 1986 L 230/1 (Polypropyleen) werd het recidivisme van enkele ondernemingen die betrokken waren geweest bij het Kleurstoffenkartel in aanmerking genomen en als aanvullend bewijs voor de aanwezigheid van opzet bij de ondernemingen gebezigd.

298 Dit was het geval in $\mathrm{Pb} 1989$ L 33/67 (Italiaans Vlakglas), waarin bij de zwaarte van de inbreuk in aanmerking werd genomen dat de ondernemingen reeds in Pb 1984 L 212/21 (Vlakglas Benelux) waren 'veroordeeld' wegens schending van artikel 81 EG. Recidive speelde ook een rol in $\mathrm{Pb} 1991$ L 151/21 (Natriumcarbonaat Solvay) en Pb 1991 L 152/40 (Natriumcarbonaat ICI). De betrokken ondernemingen waren liefst, zoals eerder aangestipt, drie respectievelijk vier maal cerder 'veroordeeld' wegens overtreding van het communautaire kartelrecht.

299 GvEA (T-6/89) Jur. 1991, II-1623 (Enichem Anic), GvEA (T-7/89) Jur. 1991, II-1711 (Hercules Chemicals) en GvEA (T-11/89) Jur. 1992, II-892 (Shell International Chemical Company). Evenals het geval was in deze zaken, werd in GvEA (T-352/94) Jur. 1998, II-1989 (Mo och Domsjo) onderstreept dat de afwezigheidvan een eerdere inbreuk niet als verzachtendeomstandigheid in aanmerking genomen behoeft te worden. Zie voor een geval waarin de Commissie ten onrechte van recidive was uitgegaan GvEA (T-141/94) Jur. 1999, II-357 (Thyssen Stahl).

300 Zie hierover ook Furse (1995), pag. 112.

$301 \mathrm{~Pb} 1989$ L 33/67 (Vlakglas).

302 Deze handelwijze komt overeen met de regeling van de eendaadse samenloop in het Nederlandse strafrecht. Artikel $55 \mathrm{WvSr}$ stelt dat indien een feit in meer dan één strafbepaling valt, slechts één van die bepalingen wordt toegepast, bij verschil die waarbij de zwaarste hoofdstraf is gesteld.

303 Een identieke overweging hanteert de Commissie in Pb 1989 L 74/21 (LdPE). Deze beschikking trof grotendeels die ondernemingen tegen welke de PVC-beschikking was gericht. De twee bedoelde beschikkingen werden op dezelfde dag gegeven en waren het uitvloeisel van parallelle onderzoeken naargedragingen binnen de plasticfabricagemarkt. Ook de gedragingendie de ondernemingenwerden verweten, waren vergelijkbaar, met dien verstande dat zij andere producten betroffen. 
Dit standpunt van de Commissie is begrijpelijk, aangezien het voldoen van twee ${ }^{\text {mH }}$ hoge boetes binnen korte tijd voor ondernemingen problematisch zou kunnen zijn. Bovendien zou men de gelijktijdige kartelgedragingen kunnen beschouwen als een uiting van een bepaalde politiek binnen de ondernemingen in die periode. Met deze gewraakte politick is door de Commissie reeds bij de eerste boete rekening gehouden; een onverkort meene. men van het beleid van de ondernemingen bij de bestraffing van de tweede overtreding, zou een 'dubbele bestraffing' van de ondernemingen inhouden. Een ander dan het door de Commissie ingenomen standpunt zou temeer geen voorkeur verdienen daar de ondernemingen -ongeacht of zij opzettelijk handelden- niet voor de consequenties gewaarschuwd werden en dus geen kans hadden om hun beleid aan te passen, in tegenstelling tot die gevallen waarin de ondernemingen zich schuldig maken aan recidive. ${ }^{305}$

\section{d) De rol van de ondernemingen}

De rol die een onderneming binnen een kartel vervult, is een duidelijke indicatie voor de ernst van de inbreuk zoals begaan door de onderneming en vormt een goed uitgangspunt voor de differentiatic van aansprakelijkheden van de verschillende kartelparticipanten. Voor de Commissie is het dan ook van belang onderscheid te maken "tussen de volwaardige leden van het kartel en (ondernemingen) die zich in de marge ervan" bewegen. ${ }^{\text {y. }}$ Ondernemingen die initiatieven ontplooien om tot kartellering te komen, die vrijwillig tot een kartel toetreden of dic van de bestaande afspraken 'een succes' willen maken, begaan een ernstigere overtreding tegen het materiële kartelverbod dan de ondernemingen die zich schoorvoetend bij ditzelfde kartel hebben aangesloten of die een goede werking ervan (trachten te) frustreren. De Commissie en de communautaire rechters hechten bij de boete-oplegging aan het enthousiasme waarmee een onderneming in het kartel participeert dan ook grote waarde. ${ }^{307}$ Vaste praktijk is om een in relatie tot de overige kartelleden hoge boete op te leggen aan die ondernemingen die bij de oprichting van het kartel betrokken waren. ${ }^{308}$ Eveneens wordt het een onderneming aangerekend als zij een leiden-

304 Of liever drie gelet op de LdPE-beschikking. Opmerkelijk is overigens dat bij de bepaling van de hoogte van de boete in de PVC-beschikking niet uitdrukkelijk rekening wordt gehouden met de sanctic in de LdPE-beschikking en vice versa.

305 Enige-zij het beperktemate van-gelijkenis kan hier worden ontwaard met de ratio van de meerdaadse samenloop, zoals in het Nederlandse strafrecht gehanteerd. In artikel $57 \mathrm{WvSr} j^{\circ} 63 \mathrm{WvSr}$ is de gedachteneergelegdvan een bepaaldstrafmaximum voor verschillendefeiten die gelijktijdig worden berecht of hadden kunnen worden berecht (in geval van artikel 63). De vergelijking gaat echtermank als men bedenkt dat het Nederlandse strafrecht geen cumulatieverbod ten aanzien van geldstraffen kent. Vergelijk Hazewinkel-Suringa/Remmelink (1996), pag. 845 e.v..

$306 \mathrm{~Pb} 1989$ L. $74 / 17$ (PVC-1).

307 HvJ (41/69), Jur. 1970, 661 (ACF Chemiefarma), HvJ (45/69) Jur. 1970, 769 (Bochringer Mannheim). HvJ (C-89, 104, 114, 116, 117 en 125-129/85) Jur. 1993, I-1307 (Ahlstrōm Osakeyhtio), GvEA (T143/89) Jur. 1995, H-917 (Ferriere Nord), GvEA (T-145/89) Jur. 1995, II-987 (Baustahlgewebe) en GvEA (T-150/89) Jur. 1995, II-1165 (Martinelli). Zie bijvoorbeeld ook Pb 1991 L 152/16 (NatriumcarbonaatSolvay/CFK), waarin de Commissie overwoog dat de onderneming weliswaarrelatiefklein was, maar zich 'een bereidwillige partner' in het kartel toonde.

308 Vergelijk bijvoorbeeld $\mathrm{Pb} 1986$ L 348/64 (Meldoc). In Pb 1991 L. 185/23 (Martell) leidde de initiatiefneming tot kartellering tot oplegging van een (overigens geringe) boete aan de initiatiefnemer, terwil. de medebetrokkene vanwege zijn passieverol geen boete werd opgelegd. Zie tevens $\mathrm{Pb} 1997 \mathrm{~L} .2623$ (Veerdienstmaatschappijen). 
de positie in het kartel bekleedt ${ }^{309}$, als zij een drijvende kracht achter het kartel is en de afspraken strikt naleeft of doet naleven. ${ }^{310}$ Daarom wordt het als zeer zwaarwegend anngemerkt als een onderneming andere kartelleden aanspoort tot het verstrekken van inlichtingen over hun bekende overtredingen van gemaakte kartelafspraken door derde leden" , als zij via andere wegen de identiteit van mogelijke overtreders tracht te achterhalen ${ }^{312}$ of als de onderneming -onder dreiging met of zelfs oplegging van sanctiesderden uitdrukkelijk verzoekt of maant om hun vanuit karteloogpunt gewraakte handelingen te staken. ${ }^{313}$ Hetzelfde geldt ten aanzien van een onderneming met een machtspositie die alles in het werk stelt om een concurrent daadwerkelijk van de markt te weren of te verdrijven. ${ }^{314}$ De omvang van de betrokken onderneming is in dit verband van betrekkelijk geringe importantie ${ }^{315}$ : ook ondernemingen van relatief geringe grootte kunnen door hun bereidwillige coöperatie een wezenlijke bijdrage leveren aan het slagen van het kartel. 316

Waar de Commissie ondernemingen die als stuwende kracht van een kartel kunnen worden aangemerkt, zwaarder straft, daar wordt gedrag waarmee de effectiviteit van het kartelgedrag wordt verminderd, door haar beloond met strafverlaging. Het is aldus van belang indien enig initiatief bij een onderneming ontbreekt ${ }^{317}$, zij niet onverkort de gemaakte afspraken naleeft ${ }^{318}$ of een matigende rol heeft bij de vaststelling van de hoogte van de (kartel)prijzen ${ }^{319}$, zij haar mededingingsbeperkend gedrag ten voordele van afnemers aanpast ${ }^{320}$ of zij geen stappen onderneemt tegen kartelleden die gemaakte afspraken

309 Zie Vesterdorf in zijn conclusie bij de Polypropyleen-zaken, GvEA (T-1/89) Jur, 1991, II-1028.

$310 \mathrm{~Pb} 1985$ L 35/17 (Peroxyde) en Pb 1994 L 243/1 (Karton). In GvEA (T-43/92) Jur. 1994, II-441 (Dunlop Slazenger International) overwoog het Gerecht: "bij de beoordeling van de hoogte van de aan verzoekster op te leggen geldboete moet rekening worden gehouden met de omstandigheid, dat verzoekster niet alleen haar wederpartijen de naleving van een door haar uitgevaardigd, mededingingsverstorend verbod heeft opgelegd, maar ook verschillende uiteenlopende dwangmiddelen heeft gebruikt om bij haar distributeurs en wederverkopers de naleving af te dwingen van een verbod waarvan zij zich bewust was, dat het de mededinging verstoorde".

$311 \mathrm{~Pb} 1979$ L 16/9 (Kawasaki).

$312 \mathrm{~Pb} 1980$ L $377 / 21$ en 22 (Johnson \& Johnson).

$313 \mathrm{~Pb} 1982$ L. $354 / 34$ (National Panasonic); in deze casus werd overtreders van cen exportverbod medegedeeld dat bij voortdurende overtreding de leveringen aan hen zouden worden stopgezet. In $\mathrm{Pb} 1977$ L 39/21 (Theal/Watts) werden geen producten meer geleverd aan een onderneming nadat deze een exportverbod niet had nageleefd.

$314 \mathrm{~Pb} 1985$ L $374 / 1$ (ECS/AKZO Chemie).

315 Dit geldt in beginsel niet ten aanzien van overtredingen van artikel $82 \mathrm{EG}$.

316 Zie bijvoorbeeld $\mathrm{Pb} 1991$ L 152/16 (Natriumcarbonaat Solvay/CFK).

$317 \mathrm{~Pb} 1992$ L 134/23 (Frans- Westafrikaanse rederscomités).

318 Reeds $\mathrm{Pb} 1969$ L 195/11 (Kleurstoffen). Eén onderneming werd een afwijkende (en 20\% geringere) boete opgelegd, omdat zij had geweigerd aan sommige prijsverhogingen deel te nemen. Zie tevens $\mathrm{Pb} 1989$ L 260/41 (Betonstaalmatten) en Pb 1994 L 343/1 (Cement), in welke zaak sommige ondernemingen hadden gepoogd zich aan de overeenkomst te onttrekken en één onderneming geen enkele uitvoeringsmaatregel had geëffectueerd.

319 Vergelijk bijvoorbeeld $\mathrm{Pb} 1978$ L $70 / 54$ (Plantaardig perkament).

$320 \mathrm{~Pb} 1981$ L $353 / 33$ (Michelin). 
niet in acht nemen ${ }^{321}$ en zo de werking van het kartel frustreren. ${ }^{322}$ In versterkte mate worden inspanningen van ondememingen om van een kartel geen succes te maken, gewaardeerd en gehonoreerd indien deze ondernemingen in een van andere kartelleden afhankelij. ke positie verkeren ${ }^{323}$; dan immers ligt dergelijk gedrag niet voor de hand en vormt het voor de betrokken onderneming tot op zekere hoogte een risico. ${ }^{324}$

\section{e) Het behaalde voordeel}

Doorgaans heeft kartelgedrag als oogmerk het handhaven of verstevigen van een marktpositie en/of het bereiken van financiele voordelen. Of deze doelstellingen daadwerkelijk worden bereikt, hangt van tal van factoren af. Is er daadwerkelijk (financieel) succes geboekt, dan houdt de Commissie hiermee bij de straftoemeting rekening. ${ }^{325}$ In de situatie waarin weliswaar het kartel over het algemeen voordelen biedt, maar niet elk der participanten profiteert ${ }^{326}$, zal de Commissie de onderneming die geen wezenlijk voordeel heeft behaald, enigszins kunnen ontzien. ${ }^{327}$ Uit het feit dat het verwezenlijkt voordeel

$321 \mathrm{~Pb} 1976 \mathrm{~L} 357 / 43$ (Miller Schallplatten). Voorwaarde is wel dat de gedragingen tot op zekere hoogte vrijwillig zijn. Vergelijk Pb 1972 L 303/54 (W.E.A.-Filipacchi Music); in dit geval leidde volgens de Commissie tot de welwillende houding van de onderneming de vrees dat de handelareneen klacht bij de Commissie zouden indienen, indien zij wegens niet-inachtneming van de kartelafspraken beboet zouden worden. In Pb 1997 L $47 / 11$ (Novalliance/Systemform) leidde de afwezigheid van daadwerkeli.ke maatregelen om bepaald kartelmatig gedrag af te dwingen tot oplegging van een lagere boetc.

322 Vergelijk echterGvEA (T-327/94) Jur. 1998, I1-1373 (SCA Holding) en GvEA (T-348/94) Jur. 1998, II-1875 (Enso Española): "Het feit dat een onderneming waarvan de deelneming aan een onderlinge afstemming van prijzen met haar concurrenten is aangetoond, zich op de markt niet overeenkomstig de met haar concurrenten overeengekomen wijze heeft gedragen, is niet noodzakelijkerwijze een omstandigheid die bij de vaststelling van het bedrag van de op te leggen geldboete als verzachtende omstandigheid in aanmerking moet worden genomen. Een ondememing die in weerwil van de onderlinge afstemming met haar concurrenteneen min of meerzelfstandigmarktbeleidvoert, kan gewoonweg proberen zich het kartel ten nutte te maken".

$323 \mathrm{~Pb} 1982 \mathrm{~L} 161 / 32$ (Hasselblad) en Pb 1987 L 222/10 (Tipp-Ex) in welke zaak de Commissie overwoog dat een aantal ondernemingen een ondergeschikte rol speelde en "slechts ten dele en tegenstribbelend en alleen onder aanzienlijke druk" in het kartel participeerde.

324 Dat een door een onderneming (in beginsel terecht) opgeworpen strafverminderingsgrond niet altijd positief voor haaruitpakt, moge blijken uit $\mathrm{Pb} 1987$ L 222/28 (Sandoz). SandozProdotti Farmaceutici voerde aan dat de vermelding 'uitvoer verboden' op haar facturen in de praktijk geen betekenis toekwam, hetgeen te meer duidelijk werd daarzij een clausule van gelijke strekking van de verpakkingen van haar geneesmiddelen had verwijderd. De Commissie concludeerde dat de onderneming niet uit louter onachtzaamheid had gehandeld en stelde voorts dat aangezien de gewraakte clausule door de onderneming van haar verpakkingen was verwijderd, er voldoende gelegenheid was geweest om ook de facturen op dit punt aan te passen; het verzuim van deze aanpassing werd als zwaarwegender ervartin dan het schrappen van de omstreden tekst van de verpakkingen.

$325 \mathrm{~Pb} 1991$ L 152/1 (Natriumcarbonaat-I): "Beide fabrikanten hebben uit de inbreuk een aanzienlijk voordeel gehaald". Pb 1994 L. 243/1 (Karton): "het kartel had ruimschoots succes bij het bereiket van zijn doelstellingen". GvEA (T-229/94) Jur. 1997, II-1689 (Deutsche Bahn): De Commissic heeft "terecht rekening gehouden (...) met de commerciēlevoordelen die DB uit haar inbreuk heeft kunnen trekken". Of dit zovergaat dat de Commissie ook daadwerkelijkde financiēle voordelen door middel van de boete ontneemt, zal in paragraaf 4.4 .2 afzonderlijk worden besproken.

$326 \mathrm{~Pb} 1992$ L. 134/23 (Frans-Westafrikaanse rederscomites).

$327 \mathrm{~Pb} 1991$ L. 185/23 (Martell): tot décharge van de ondemerning kon "worden aangevoerd dat de voordelen van zulk een beleid van afscherming der markten niet haar, maar Martell ten goede zijn gekomen". 
een rol speelt bij de straftoemeting, mag overigens niet a contrario worden afgeleid dat bij ontbreken van profijt plaats is voor vergaande strafvermindering. Zoals immers het Gerecht terecht stelde: "Dat uit een inbreuk geen profijt is getrokken, kan overigens de oplegging van aanzienlijke geldboetes niet beletten, omdat deze geldboetes anders hun preventieve werking zouden verliezen". 128

\section{f) De financięle positie van de ondernemingen}

Problematisch is de vraag in hoeverre de financiële positie van een onderneming invloed moet uitoefenen op de hoogte van de boete. Er is veel voor te zeggen dat het beginsel van evenredigheid onder meer met zich brengt dat de boete mede wordt afgestemd op de financiēle situatie van de betrokken onderneming. De koppeling van de boete aan de omzet biedt hierbij geen uitkomst: de omzet zegt immers op zich niets over de financiele situatie van de onderneming; met name is het mogelijk dat ondernemingen in een bedenkelijke financiële situatie verkeren, ondanks het feit dat zij een behoorlijke omzet hebben weten te realiseren. In dat laatste geval lijkt het niet gepast om een onderneming dezelfde boete op te leggen die onder normale omstandigheden geïndiceerd zou zijn. In extreme gevallen zou dat zelfs het voortbestaan van de onderneming kunnen bedreigen. Matiging van de boetes lijkt dan -alleen al vanuit mededingingsperspectief-voor de hand te liggen: het ligt immers niet in de lijn van het EG-Verdrag om ondernemingen in moeilijkheden te brengen of zelfs van de communautaire markt te doen verdwijnen. ${ }^{329}$ Het voorgaande pleit ervoor om binnen het communautaire kartelrecht een draagkrachtbeginsel te hanteren, analoog aan hetgeen geregeld is in bijvoorbeeld artikel $24 \mathrm{WvSr},{ }^{330}$ Deze medaille heeft echter een keerzijde. Een onderneming die, in tegenstelling tot het merendeel van haar concurrenten en mede-kartelleden, een slechte financiële basis bezit, is waarschijnlijk op niet-adequate wijze op de vereisten van een vrije markteconomie ingespeeld. Een dergelijke onderneming is in een open economie onder 'normale' (zijnde niet-kartel) omstandigheden voorbestemd het economische marktspel te verlaten omdat haar activiteiten om welke reden dan ook niet rendabel zijn. Het (wezenlijk) matigen van de boete vanwege de deficitaire situatie van ondernemingen zou, aldus het Hof in zijn arrest in de Navewa/Anseau-zaak, neerkomen "op het verschaffen van een ongerechtvaardigd concurrentievoordeel aan de ondernemingen die het minst zijn aangepast aan de eisen van de markt". ${ }^{331}$ Tot op zekere hoogte heeft het Hof hierin zeker gelijk en een slechte financiéle situatie zal er dan ook niet zonder meer toe moeten leiden dat geen of slechts een symbolische boete dient te worden opgelegd. Maar naar mijn mening dient er wel degelijk rekening te worden gehouden met het vermogen van een onderneming om een opgelegde boete

328 GvEA (T-143/89) Jur. 1995, II-917 (Ferriere Nord).

329 Of in de treffende woorden van de Cormmissie in $\mathrm{Pb} 1983 \mathrm{~L} 317 / 15$ (Gietijzerenen gietstalen walsen): "de doelstellingen van de Gemeenschap (zijn) niet gediend (...) met hoge boetes".

330 Zie hieromtrent eveneens Mok (1984), pag. 142.

$331 \mathrm{HvJ}(96-102,104,105,108$ en 110/82) Jur. 1983, 3369 (LAZ International Belgium e.a.). In gelijke zin GvEA (T-319/94) Jur. 1998, II-1331 (Fiskeby Board), GvEA (T-141/94) Jur. 1999, II-357 (Thyssen Stahl) en Pb 2000 L 268/1 (Far East Trade Tariff Charges and Surcharges Agreement). In deze laatste zaak stelt de Commissie uitdrukkelijk: "De individuele financiēle situatie van een betrokkene bij een inbreuk kan geen aanleiding geven tot een verlaging van het bedrag van de geldboete". 
te dragen. ${ }^{312}$ Inderdaad is het zo dat de onderneming dan tot op zekere hoogte voordeel trekt uit haar situatie, maar de -naar evenredigheid- lagere sanctie heeft voor die ondememing een gelijke of vergelijkbare impact als een -evenredig- hogere boete voor een financieel gezonde onderneming. ${ }^{333}$ Mijns inziens dient kortom de draagkracht wel degelijk bij de straftoemeting te worden betrokken.

De Commissie blijkt over het algemeen minder geneigd te zijn om de wankele financicle positie van een onderneming in aanmerking te nemen indien zij de enige is die niet aan de markteisen voldoet. Geheel ongevoelig voor de financiêle situatie van ondernemingen is de Commissie echter niet: relevant acht zij "in welke mate de ondernemingen door de vastgestelde geldboete getroffen worden" ${ }^{334}$ In het kartel van de FransWestafrikaanse rederscomités bijvoorbeeld werd rekening gehouden met de 'kwetsbare financiele structuur' van een kartellerende onderneming ${ }^{335}$, terwijl in de DSI-beschikking ${ }^{336}$ de financiêle problemen van één der betrokkenen werden aangegrepen om een lagere boete op te leggen. ${ }^{377}$ De Commissie is daarnaast bereid tot een vermindering van de boete voorzover reeds op de financiele middelen van de ondernemingen beslag wordt gelegd omdat deze zich in een noodzakelijk proces van herstructurering en technologische vernieuwing bevinden. Dergelijke inspanningen om zich aan de vereisten van de

332 Mocht voldoening van de opgelegde boete, ondanks de verdiscontering van de draagkracht, toch nog grote problemen opleveren, dan kan aan de Commissie verzocht worden om een betalingsregeling. Dat blijkt uit HvJ (100-103/80) Jur. 1983, 1825 (Musique Diffusion Française): "Het staat aan de Commissie om, in voorkomend geval en de huidige economische situatie van de ondernemingen in aanmerking genomen, te beslissen over de opportuniteit van uitstel van betaling of betaling in termijnen". In gelijke zin GvEA (T-308/94) Jur. 1998, II-925 (Cascades).

333 Twijfels zouden kunnen bestaan over de verenigbaarheid van een beleid waarin met de financiêle armslag van ondernemingen rekening wordt gehouden, met de preventieve doeleinden van de boete: het vooruitzicht van een aanpassing van de boete zal voor ondernemingen met een weinig florissante financiele huishouding geen obstakel vormen voor het overgaan tot kartelmatig gedrag. Ook hierin zit een kern van waarheid, maar de betreffende ondernemingen worden desalnietteminonverminderd naar evenredigheid gestraft. Daarenboven kan men zich met recht vragen of een onderneming die in een uitermate zorgwekkende en welhaast uitzichtloze financiele situatie verkeert, wel door hoge boetes wordt afgeschrikt, omdat kartelmatig gedrag de onderneming wellicht -althans in haar ogende enige uitweg uit haar financiēle impasse biedt.

334 In $\mathrm{Pb} 1978$ L $46 / 42$ (BMW Belgium).

$335 \mathrm{~Pb} 1992 \mathrm{~L}$ 134/1; desondanks resteerde er voor haar overigens nog een aanzienlijke boete.

$336 \mathrm{~Pb} 1992 \mathrm{~L} \mathrm{131/32}$. Ondanks zijn oordeel in zijn LAZ-arrest lijkt het Hof niet geheel ongevoelig voor de mate waarin een boete een onderneming treft. Dit kan worden afgeleid uit HvJ (19/77) Jur. 1978, 131 (Miller International Schallplatten), waarin het Hof in principe bereid bleek het verweer van de onderneming te toetsen dat de boete haar zeer hard zou treffen. Dat het hiertoc uiteindelijk toch niet kwam, was te wijten aan het feit dat de onderneming weigerde haar balans te overleggen.

337 In GvEA (T-145/89) Jur. 1995, II-987 (Baustahlgewebe), steldeeen onderneming dat de boete vrijwel $50 \%$ van het eigen kapitaal bedroeg en dat zij haar in haar bestaan bedreigde. Het Gerecht was hiervoor niet gevoelig: "Met betrekking tot het argument betreffende de verhouding tussen verzocksters mastschappelijk kapitaal en de geldboete moet worden opgemerkt, dat het feit dat verzoekster slechts een gering maatschappelijk kapitaal heeft, haar eigen economische beslissing is, die geen invloed kan hebben op het bedrag van de geldboete, dat wordt gebaseerdop de omzet". In GvEA (T-149/89) Jur. 1995, II-1127 (Sotralentz), eveneens betrekking hebben op het betonstaalmatten-kartel, werd door een ondememing aangevoerd dat de boete in verhouding tot haar totale winst buitensporig hoog was. Het mocht de onderneming in casu niet baten: "Het Gerecht is van oordeel, dat ofschoon de Commissie stellig met een dergelijk element rekening kan houden, dat niet het enige element is dat zij in aanmerking moet nemen". 
markt aan te passen, vergen veelal grote financièle offers die de basis van cen onderneming op korte termijn (verder) aantasten. De Commissie zou de pogingen om de crisis te boven te komen geheel kunnen frustreren als zij hoge boetes, die in een 'normale situatie' gerechtvaardigd zijn, zou opleggen. ${ }^{38}$ Van belang hierbij is dat het daadwerkelijk gaat on herstructurering die door de markt is geïndiceerd en als zodanig verschillende ondernemingen treft. Een bijzondere positie nemen coöperaties in. De leden van coöperaties zijn in beginsel natuurlijke personen die financieel nauw zijn gelieerd aan de coöperatie. Een kenmerk van een coőperatie is dan ook "dat zij het eigendom (is) van boeren die voor hun inkomen rechtstreeks afhankelijk zijn van de commerciële resultaten van hun coöperatie". ${ }^{339}$ Een boete raakt de leden van de coöperatie -anders dan veelal bij ondernemingen het geval is- direct in hun eigen vermogen. Dit gegeven is voor de Commissie aanleiding on de hoogte van de boete ten voordele van de leden aan te passen. Ook hier vervult het draagkrachtbeginsel, tenminste op de achtergrond, een belangrijke functie als strafverzachtende omstandigheid.

\section{g) Geheimhouding}

Kartels hebben in de publieke opinie vaak het imago van geheime afspraken, gemaakt in veraf gelegen motels. ${ }^{340}$ Hoewel op deze visie een en ander valt af te dingen, kan inderdaad beaamd worden dat het veelal niet de bedoeling van ondernemingen is dat hun afspraken algemene bekendheid bereiken. Niet alleen zou dit de effectiviteit van de afspraken kunnen verminderen en de naam van de betrokken ondernemingen niet ten goede komen, maar bovendien is in dat geval de dreiging van overheidsoptreden of acties van gedupeerden groter. Het moge duidelijk zijn dat een gebrek aan openheid van de zijde van ondernemingen de controletaak van de overheden en meer in het bijzonder de Commissie bemoeilijkt. Daarenboven brengen geheime afspraken met zich dat de contractpartijen van kartellerende ondernemingen hun positie tegenover deze niet in voldoende mate kunnen inschatten waardoor zij in de mededinging op dit gebied aanzienlijk worden benadeeld. Tegen de achtergrond van deze nadelen staat de Commissie -daarin gevolgd door het Gerecht ${ }^{341}$ - weinig positief tegenover initiatieven waarmee angstvallig het geheime karakter van de afspraken wordt beoogd en ziet de Commissie in dergelijke initiatieven veelal een aanleiding voor verhoging van de sanctie. Dit was reeds het geval in de Kinine-casus. In deze zaak hadden de betrokken ondernemingen niet alleen bewust afgezien van aanmelding van die afspraken waarvan de ondernemingen wisten dat zij onder het verbod van artikel $81 \mathrm{EG}$ vielen, maar waren zij bovendien niet overgegaan tot aanmelding van afspraken die naar hun mening niet onder het bereik van het verdrag vielen; zij vreesden namelijk informatie prijs te moeten geven die de Commissie op het

$338 \mathrm{~Pb} 1983$ L 317/15 (Gietijzerenen gietstalen walsen); $\mathrm{Pb} 1984$ L 212/22 (Vlakglas Benelux); $\mathrm{Pb} 1985$ L. 35/64 (John Deere).

$339 \mathrm{~Pb} 1986 \mathrm{~L}$ 348/64 (Meldoc); een gelijkluidende overweging treft men ook aan in $\mathrm{Pb} 1988 \mathrm{~L}$ 316/48 (Dansk Pelsdyravlerforening).

340 De Vogel (1992), pag. 11, noemt het voorbeeld van een vroege ontmoeting in een café in een kleine stad.

341 GvEA (T-304/94) Jur. 1998, II-869 (Europa Carton), GvEA (T-334/94) Jur. 1998, II-1439 (Sarrió), GvEA (T-347/94) Jur. 1998, II-1751 (Mayr-Melnhof Kartongesellschaft)en GvEA (T-348/94) Jur. 1998, II-1875 (Enso Española). 
spoor van de verboden afspraak zou zetten. ${ }^{342}$ Maar ook latere beschikkingen tonen aan dat de Commissie weinig gecharmeerd is van geheimhouding van kartelmatig gedrag. ${ }^{343}$ Ook hier geldt dat een medaille twee kanten heeft. De Commissie honoreert namelijk de omstandigheid dat een kartel juist wel bij een breder publiek bekend is en daarmee een geheim karakter ontbeert. Voorbeelden van een positieve invloed van deze omstandigheid op de omvang van de sancties kunnen gevonden worden in Far Eastem Freight Conference, waarin de Commissie expliciet stilstond bij het gegeven dat "het bestaan van de betrokken praktijken ruime bekendheid genoot ${ }^{\text {"34 }}$ en in de beschikking inzake de bouwnijverheid in Nederland, waarin werd overwogen dat "vanwege de publiciteit die aan de onderhavige brancheregelingen is gegeven, (...) de onderlinge afstemming geen klandestien karakter (heeft) gehad". .45 $^{4}$

\section{h) Onderzoek en onderneming}

Geheimhouding en -daar loodrecht op- openheid van kartelpraktijken vormen dus een belangrijke factor waarmee door de Commissie bij de bepaling van de boete rekening wordt gehouden. Een nog groter gewicht komt toe aan de opstelling van een onderneming tijdens een door de Commissie geinnitieerd onderzoek. In hoofdstuk 2 is aangegeven dat de Commissie op grond van artikel 11 en de artikelen 13 en 14 Vo 17 verschillende bevoegdheden heeft om de naleving van de artikelen 81 en 82 EG te controleren en om overtredingen op te sporen. Deze regeling moet de Commissie in staat stellen om alle voor haar taakuitoefening noodzakelijke informatie te vergaren. Tegen deze achtergrond moeten de reeds besproken extensieve interpretatie van de genoemde artikelen, de door aanmelding te bereiken vrijwaring van boetes alsmede de in artikel 15 Vo 17 opgenomen boetes wegens overtreding van deze artikelen worden gezien. Er wordt derhalve zoveel mogelijk in het werk gesteld om het onderzoek en de informatievergaring zo vlekkeloos en voorspoedig mogelijk te laten verlopen. In het verlengde daarvan zijn de communautaire autoriteiten ${ }^{346}$ er zeer gevoelig voor als ondernemingen zich bereid tonen om aan het onderzoek mee te werken dan wel juist een voor een tegenovergestelde opstelling opteren: co-operatie wordt beloond ${ }^{34}$, tegenwerking levert een hogere boete op. ${ }^{348}$ Wanneer er precies sprake is van tegen- dan wel medewerking van de zijde van ondernemingen

$342 \mathrm{~Pb} 1969$ L 192/5 (Kinine).

343 Pb 1986 L 230/1 (Polypropyleen), Pb 1989 L 74/21 (LdPE), Pb 1991 L 152/16 (Natriumcarbonat Solvay/CFK), Pb 1994 L. 343/123 (Cement) en Pb 1994 L. 243/52 (Karton).

$344 \mathrm{~Pb} 1994$ L $378 / 34$.

$345 \mathrm{~Pb} 1992$ L. 92/1 (Bouwnijverheid in Nederland). Het belang van de openbaarheid werd bevestigd in GvEA (T-29/92) Jur. 1995, II-289 (Vereniging van Samenwerkende Prijsregelende Organisaties in de Bouwnijverheid e.a.).

346 Dus ook het Hof, zoals onder meer blijkt uit HvJ (C-277/87) Jur, 1990, 1-45 (Sandoz prodotti farmacevtici): met de houding van een onderneming tijdens de administratieve procedure (in casu blijkend uit de beëindiging van de inbreuk) moet bij de bepaling van de boete rekening gehouden worden

347 Bijvoorbeeld Pb 1994 L. 243/1 (Karton): de Commissie houdt rekening met "eventuele verzachtende omstandigheden met inbegrip van de mate van samenwerking met de Commissie na het onderzock en de mate waarin een dergelijke samenwerking materieel tot de vergemakkelijking of bespoediging van het afsluiten van de huidige procedure kan hebben bijgedragen".

348 Tegenwerkingkan dus leiden tot cenafzonderlijke boete wegensovertreding van formele bepalingen van verordening 17, zoals bijvoorbeeld in Pb 1977 L. 39/19 (Theal/Watts), maar ook tot een verhoging van de boete, opgelegd wegens overtreding van de materiēle verboden. 
is in zijn algemeenheid niet te zeggen. Wel biedt de beschikkingspraktijk een rijke schakering aan gedragingen die als obstructie van respectievelijk co-operatie aan het onderzoek zjn aangemerkt. Een relatief milde vorm van tegenwerking is die waarin een ondememing, anticiperend op de vragen van de Commissie, aan haar afnemers in een brief een standaardatwoord op de verwachte vragen doet toekomen. Bij de waarde van de antwoorden van de afnemers kunnen dan vraagtekens worden geplaatst, aangezien niet of nauwelijks is na te gaan in hoeverre de gegeven antwoorden door de brief zijn beinvloed. ${ }^{39}$ Als obsructie is voorts betiteld de ontkenning van deelname aan kartelmatig gedrag ondanks deaanwezigheid van aanzienlijke bewijzen voor deze deelname. ${ }^{330}$ In de Eurocheque-beshikking ${ }^{311}$ werd een hele reeks van niet-co-operatief gedrag geconstateerd: onvolledige anmelding van de overeenkomst, het pas na herhaald aandringen van de Commissie overhandigen van relevante en opgevraagde informatic en het foutief inlichten van de Commissie door het geven van een foutieve interpretatie van de betrokken overeenkomst. Tegenover deze obstructie van het onderzoek staat een co-operatieve houding, die, zeker als zij in een vroegtijdig stadium van de procedure ten toon wordt gespreid, door de Commissie zeer wordt gewaardeerd. ${ }^{352}$ Zo toont de Commissie zich milder bij de sanctietoemeting indien een onderneming zich vanaf het begin van het onderzoek inspant "actief en vrijwillig alle nodige en nuttige inlichtingen te verschaffen die de Commissie in staat (stellen) de grieven tegen haar (...) op te stellen". ${ }^{33}$ Sommige ondernemingen gaan zeer ver in het winnen van gunsten, zodra zij het nutteloze van hun bemoeienissen om hun gedragingen voor de Commissie verborgen te houden inzien. Als voorbeeld kan de kartonzaak ${ }^{34}$ genoemd worden, waarin één van de betrokken ondernemingen de inbreuk spontaan had toegegeven en gedetailleerd bewijsmateriaal had verschaft. Aldus had zij volgens de Commissie aan de materielle waarheidsvinding bijgedragen, de bewijspositie voor de Commissie aanzienlijk versterkt en andere ondernemingen indirect tot erkenning van het bestaan van en deelname aan de inbreuk aangezet. Strafvermindering derhalve als beloning voor het vrijwillig leveren van bewijsmateriaal dat ook tegen andere ondernemingen kan worden gebruikt. ${ }^{355}$ Deze Karton-zaak toont overigens aan welke relatieve waarde de Commissie toekent aan verschillende vormen van coöperatie en aan medewerking binnen de verschillende stadia van het onderzoek. De medewerking van andere ondernemingen, bestaande in het niet-ontkennen of zelfs erkennen van de inbreuk in hun

349 Men zie $\mathrm{Pb} 1990$ L 21/71 (Bayo-n-ox).

$350 \mathrm{~Pb} 1989$ L $74 / 17$ (PVC-I).

$351 \mathrm{~Pb} 1992$ L $95 / 50$.

352 Bijvoorbeeld Pb 1985 L 85/1 (Houtslijp), Pb 1985 L 376/21 (Sperry New Holland), Pb 1991 L 287/39 (Toshiba) en Pb 1992 L 233/31 (Parker Pen).

$353 \mathrm{~Pb} 1992$ L $92 / 27$ (Bouwnijverheid in Nederland).

$354 \mathrm{~Pb} 1994$ L 243/1 (Karton).

355 Vergelijk tevens GvEA (T-13/89) Jur. 1992, II-1021 (Imperial Chemical Industries): "Daar de aan verzoekster opgelegde geldboete op grond van haar medewerking bij het onderzoek met minder dan $10 \%$ is verlaagd, is het Gerecht van mening dat, gelet op het zeer gedetailleerdekaraktervan verzoeksters antwoord op het verzoek om inlichtingen, dat niet alleen betrekking had op verzoeksters eigen activiteiten, maar ook op die van alle betrokken ondememingen te zamen -zonder welk antwoord het voor de Commissie heel wat moeilijker zou zijn geweest de in de beschikking bedoelde inbreuk vast te stellenen te beetindigen-, voor de bepaling van het bedrag van de aan verzoekster op te leggen boete in ruimere mate rekening moet worden gehouden met die medewerking dan de Commissie heeft gedaan". Dit leverde de onderneming een verlaging van de boete van één miljoen ecu (10\%) op. 
antwoord op de mededeling van de punten van bezwaar, werd door de Commissie eveneens positief gewaardeerd, maar in mindere mate dan de veel verdergaande coöperatie door vorenbedoelde onderneming. ${ }^{356}$ Voorzover de Commissie hier de boete heeft verlaagd wegens coöperatie die niet verder ging dan hetgeen waartoe de ondernemingen reeds op grond van de artikelen 11 e.v. Vo 17 verplicht waren, moet de verlaging overigens worden afgewezen; ruimte voor mitigatie is er slechts dan indien de onderneming meer doet dan waartoe zij is gehouden. ${ }^{357}$

Naast de directe co-operatie in het onderzoek wordt ook waarde gehecht aan het al dan niet aanpassen van de gedraging in reactie op het commissieonderzoek: volhardt een onderneming in haar gedrag tot het moment waarop een definitieve beslissing is genomen, of bečindigt zij in een vroegtijdig stadium al haar mededingingsbeperkend gedrag ${ }^{35 i}$ en neemt zij zelfs -als overtreffende trap van co-operatie- concrete initiatieven ${ }^{359}$ die

356 Zie ook $\mathrm{Pb} 1997$ L 47/11 (Novalliance/Systemform). Niet in alle gevallen leidt co-operatie tot cen boetevermindering. In $\mathrm{Pb} 1997$ L 26/23 (Veerdienstmaatschappijen)werd de boete niet verminderd ondanks een duideliike medewerking "omdat de samenwerking slechts werd verleend nadat de inbreuk door de verificaties van de Commissie aan het licht was gebracht, en omdat (de onderneming) én van de belangrijkste organisatoren van de onderling afgestemde gedraging was".

357 Vergelijk de opmerkingenhieromtrent van Vesterdorf in zijn conclusie bij de Polypropyleenarresten, GvEA (T-1/89) Jur. 1991, II-1025. Zie ook GvEA (T-12/89) Jur. 1992, II-907 (Solvay), waarin het Gerecht overwoog dat de Commissie terecht de medewerking van de onderneming niet als verzachtende omstandigheid had aangemerkt omdat deze medewerking beperkt bleef tot hetgeen waartoe de ondememing reeds op grond van verordening 17 verplicht was. Aldus tevens GvEA (T-143/89) Jur. 1995, II-917 (Ferriere Nord): "dat verzoeksters medewerking aan het onderzoek van de Commissie of aan de herstructurering van de staalindustrie niet verder zijn gegaan dan hetgeen wettelijk verplicht was, zodat een en ander niet als verzachtende omstandigheid in aanmerking behoeft te worden genomen". Zie evencens GvEA (T-308/94) Jur. 1998, II-925 (Cascades), GvEA (T-317/94) Jur. 1998, II-1235 (Moritz J. Weig), GvEA (T-327/94) Jur. 1998, Il-1373 (SCA Holding) en GvEA (T-352/94) Jur. 1998, II-1989 (Mo och Domsjo). Het gegeven dat medewerking boeteverlaging kan bewerkstelligen, legt op de Commissie overigens niet de plicht om een onderneming tot medewerking uit te nodigen. Hier is eigen initiatief van de ondememing geboden. Vergelijk GvEA (T-1/89) Jur. 1991, II-867 (Rhône-Poulenc).

358 "Het beềindigen van een inbreuk in de loop van de administratieve procedure kan bij de vaststelling van de door de Commissie opgelegde geldboete een verzachtende omstandigheid opleveren", aldus het Gerecht in GvEA (T-43/92) Jur. 1994, II-441 (Dunlop Slazenger International). Het beroep op de medewerking mocht de ondememing echter in casu niet baten omdat zij de inbreuk pas verschillende maanden na de mededeling van de punten van bezwaar en ruim drie jaar na de kennisgeving van de ingediende klacht, beěindigde. Overigens kan ook in het voordeel van een onderneming worden meegewogen indien zij een inbreuk betindigt naar aanleiding van een optreden van een andere kartelaptoriteit. Zie hierover $\mathrm{Pb} 2001 \mathrm{~L}$ 152/24 (Aminozuren).

$359 \mathrm{~Pb} 1992$ L. 233/31 (Parker Pen). Parker toonde zich co-operatief door aan het onderzoek mee te werken, de mogelijke inbreuken op het gemeenschapsrecht tijdens het onderzock te betindigen en een juridisch adviseur met de opdracht te belasten ervoor te zorgen dat het gemeenschapsrecht zou worden nageleefl in de verhouding tot aan Parker gelieerde ondernemingen. Zie tevens Pb 1992 L 134/1 (Frans-Westafikaanse rederscomités), waarin door de hooftverantwoordelijke onderneming maatregelen waren genomen om de mededinging te bevorderen. In GvEA (T-327/94) Jur. 1998, II-1373 (SCA Holding) bleck ook van een 'conformeringsprogramma', maar tot een verlaging van de boete leidde dit niet ondat het-zoals de Commissie bondig concludeerde- ondoeltreffend was gebleken. 
rtoe moeten leiden dat het communautaire recht in de toekomst wel wordt gerespeceerd? ${ }^{360}$ Ook hier geldt weer dat het -uiteindelijk-tonen van respect voor de communauaire regelgeving én voor de handelingen en inzichten van de Commissie verlaging van le straf kan bewerkstelligen ${ }^{361}$, terwijl het halsstarrig vasthouden aan eigen principes lie niet stroken met die van de Commissie of -nog ernstiger- het misleiden van de Comnissie $^{362}$ als verzwarende omstandigheid in aanmerking worden genomen. ${ }^{36}$ De bechikkingspraktijk toont bovendien aan dat deze factor een aanzienlijk gewicht in de

;60 Pb 1991 L 287/39 (Toshiba), waurin werd meegewogen dat de onderneming "een verreikend programma voor de naleving van het communautaire mededingingsrecht" had opgesteld en ingevoend. Een vergelijkbaar handelen werd geconstateerd in Pb 1988 L 284/41 (Napier Brown/British Sugar). Zie ook Pb 1985 L 85/1 (Houtslijp), waarin de Commissie als zwaarwegende strafverminderingsfactor in aanmerking nam dat de ondernemingen concrete toezeggingen hadden gedaan die betere concurrentievoorwaarden garandeerdenen de kans op overtredingen terugdrongen. Vergelijk ook Pb 1992 L 131/32 (DSI)

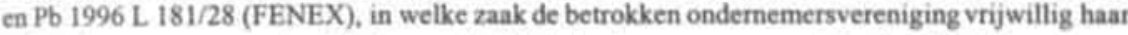
gedrag in overeenstemming bracht met het Nederlandse en communautaire kartelrecht en nieuwe gedragingen bij de Commissie aanmeldde. Deze co-operatieve houding, gevoegd bij een inbreuk uit onachtzaamheid, leverde de ondernemersvereniging een zeer milde boete op; slechts 1.000 ecu. Een wet van Meden en Persen is dat echter niet: GvEA (T-352/94) Jur. 1998, Il-1989 (Mo och Domsjö) en GvEA (T-354/94) Jur. 1998, 11-2111 (Stora Kopparbergs Bergslags): "het enkele feit dat de Commissie in bepaalde gevallen in haar vroegere beschikkingspraktijk de toepassing van een conformeringsprogramma als verzachtende omstandigheid in aanmerking heeft genomen, (betekent) dus niet, dat zij verplicht was om in het onderhavige geval op dezelfde wijze te handelen".

$361 \mathrm{~Pb} 1975$ L 29/14 (General Motors), Pb 1984 L 207/11 (BL), Pb 1985 L 35/63 en 64 (John Deere), Pb 1988 L $316 / 43$ (Dansk Pelsdyravlerforening), Pb 1979 L 16/16 (Kawasaki), Pb 1991 L 185/23 (Martell), Pb 1992 L 366/47 (Verdeling van treinbiljetten door reisbureaus) en HvJ (C-89, 104, 114 , 116, 117 en 125-129/85) Jur. 1993, I-1307 (Ahlström Osakeyhtio). Maar niet steeds leveren dergelijke gedragingen de ondernemingeneen bonus op. Vergelijk GvEA (T-7/89) Jur. 1991, II-1711 (Hercules Chemicals), waarin het Gerecht opmerkte "dat het feit dat de Commissie in een eerdere zaakmeende, in verband met de feitelijke omstandigheden rekening te moeten houden met de maatregelen die de betrokken onderneming had getroffen om nieuwe inbreuken op het communautaire mededingingsrecht te voorkomen, nog niet betekent, dat zij op dezelfde wijze met dergelijke maatregelenrekening moet houden in onderhavig geval, waarbij zij (...) heeft beklemtoond, dat de inbreuk op artikel 85 , lid 1, EEG-Verdrag (thans artikel $81 \mathrm{EG}, \mathrm{HQ}$ ) bijzonder ernstig was en opzettelijk en in het grootste geheim was begaan". Vergelijkbaar GvEA (T-319/94) Jur. 1998, II-1331 (Fiskeby Board).

362 Deze kan onder meer bestaan in de handhaving van een kartel terwijl de onderneming heeft medegedeeld dat het omstreden kartel is opgeheven of in de vervanging van het beetindigde kartel door andere geheime banden tussen de bij het oorspronkelijke kartel betrokken ondernemingen. Vergelijk respectievelijk Pb 1977 L 39/26 (Theal/Watts) en Pb 1984 L 212/21 (Vlakglas Benelux).

$363 \mathrm{~Pb} 1985$ L 374/1 (ECS/AKZO Chemic) waarin AKZO volhardde in haar gedrag ondanks een nationale procedure én een voorlopige maatregel van de Commissie zelf. Vergelijk ook Pb 1994 L 378/17 (Far Eastem Freight Conference)waarin de Commissie het als strafverzwarendefactor in aanmerking nam dat ondernemingen Oostindisch doof waren voor waarschuwingen van de Commissie over het onrechtmatig karakter van hun handelen. Niet-aanpassing en daarmee continuering van gedrag werd eveneens als kwalijk aangemerkt in Pb 1989 L 74/17 (PVC-I), Pb 1992 L $131 / 32$ (DSI) en Pb 1992 L. 134/1 (Frans-Westafrikaanserederscomités). Het hardnekkig ontkennen van strijdigheid met het EG-Verdrag en het voortzetten van de omstreden gedragingen nog tijdens de procedure werd Tetra Pak zeer zwaar aangerekend; vergelijk Pb 1992 L $72 / 1$ (Tetra Pak II). In GvEA (T-24-26 en 28/93) Jur. 1996, II-1201 (Compagnie maritime belge transports e.a.) oordeelde het Gerecht daarentegen dat de Commissie ten onrechte het de ondernemingen had aangerekend dat zij na geconfronteerd te zijn met klachten hun gedragingen niet onmiddellijk hadden gestaakt. Reden hiervoor was dat de klachtente algemeen van aard waren en dat dus niet zonder meer duidelijk was wat het omstreden gedrag was. 
boeteschaal legt, zij het dat -althans tot 1996- andere factoren de balans toch naar de andere kant kunnen doen uitslaan. ${ }^{364}$

Bij de vraag in hoeverre de Commissie het terugtreden op de kartelschreden als strafverminderende factor in aanmerking neemt, speelt niet alleen de aard en reikwijdte van de reactie van de onderneming op het onderzoek een rol, maar tevens het stadium van de procedure waarin de reactie plaatsheeft: hoe eerder een onderneming ingrijpt, des te meer waarde aan de reactie wordt (en moet worden) gehecht. ${ }^{365}$ Het meest lovenswaardig vanuit de optick van de Commissic is vanzelfsprekend de melding van een gedraging waarvan zij nog niet op de hoogte was. Voorzover de procedure reeds een aanvang heeft genomen, geldt ook een onmiddellijke reactie -in de vorm van beëindiging van het (vermeende) kartelgedrag of van een ontheffingsaanmelding-op het onderzoek als uitermate gunstig voor de onderneming. ${ }^{366}$ Bedacht moet namelijk worden dat in die fase nog allerminst (officieel) vaststaat dat het ook daadwerkelijk een inbreuk op het communautaire recht betreft. Een ingrijpen van de onderneming in die fase is dan nog tot op zekere hoogte vrijwillig en toont aan dat de onderneming eventuele fouten zo spoedig mogelijk wil herstellen. Maar eveneens een positieve reactie op het onderzoek in een later stadium van het onderzoek ${ }^{367}$ wordt in vaste boetepraktijk als strafverzachtende omstandigheid aangemerkt. Het betreft dan veelal cen aanpassing van het gedrag als reactie op de mededeling van de punten van bezwaar. ${ }^{368}$ Het staken van het in het geding zijnde gedrag in dat stadium is beduidend minder 'spontaan' dan in een eerdere fase. Hoewel ook op dat moment nog geen definitief oordeel over het gedrag is geveld, staat toch reeds in de meeste gevallen vast dat de Commissie geen ruimte voor de gedraging ziet en dat zij over voldoende bewijzen meent te beschikken om een succesvolle 'vervolging' in te leiden. Met andere woorden: het is tenminste vanaf het moment van de mededeling dat de onderneming moet beseffen dat de (grote) kans bestaat dat zij in strijd met het communautaire mededingingsrecht handelt. De onderneming kan er dan voor kiezen de uiteindelijke beslissing

364 GvEA (T-13/89) Jur. 1992, II-1021 (Imperial Chemical Industries): "Ook hier geldt immers, dat het feit dat de Commissie in een eerdere zaak meende, in verband met de feitelijke omstandigheden rekening te moeten houden met de door de betrokken onderneming getroffen maatregelenom nieuwe inbreuken op het communautaire mededingingsrecht te voorkomen, nog niet betekent, dat zij op dezelifde wijze met dergelijke maatregelen rekening moet houden in onderhavig geval, aangezien (...) de inbreuk op artikel 85, lid 1, EEG-Verdrag (thans artikel 81 EG, HQ) zeer ernstig was en opzettelijk en in het grootste geheim was gepleegd".

365 Voor de Commissie speelt overigens wel een belangrijke rol of de aanpassing van het gedrag direct in verband staat met haar onderzoek dan wel of andere (met name economische) omstandigheden tot de aanpassing nopen.

366 Men vergelijke Pb 1976 L 95/I (Chiquita), Pb 1985 L 376/28 (Sperry New Holland), Pb 1984 L 136/15 (Polistil/Arbois) en Pb 1997 L 47/11 (Novalliance/Systemform).

367 Of bijvoorbeeld een reactie op een rechterlijk bevel. Zie GvEA (T-213/95 en T-18/96) Jur. 1997, II-1739 (Stichting Certificatie Kraanverhuurbedrijfen Federatie van Nederlandse Kraanverhuurbedrijven).

368 De coulance van de Commissie gaat soms zeer ver. In Pb 1992 L 95/50 (Eurocheque) werd de spontane ontbinding van de omstreden kartelovereenkomst als verzachtende omstandigheid in aanmerking genomen, ondanks het feit dat deze ontbinding pas één jaar na de mededeling van de punten van bezwaar geschiedde. Voor de Commissie was doorslaggevend dat de onderneming het (uiteindelijk) niet had laten aankomen op een verbodbeschikking alvorens haar gedraging stop te zetten. Deze amplk werd door het Gerecht goedgekeurd: GvEA (T-39 en 40/92) Jur. 1994, II-49 (Groupement des cartes bancaires 'CB' en Europay International). 
van de Commissie af te wachten en tot die tijd te volharden in haar gedrag, in de al dan siet gerechtvaardigde overtuiging dat aan dit gedrag geen communautaire bezwaren kleven. Zij kan er echter ook voor opteren het gedrag te staken en met de Commissie in overleg te treden over de wijze waarop de onderneming haar doelen kan bereiken met inachtneming van het gemeenschapsrecht. Laatstbedoelde houding levert de onderneming -gezien haar constructieve houding terecht- steevast een verlaging van de boete op. Eerstbedoelde bouding blijkt in sommige gevallen te leiden tot strafverzwaring, hetgeen naar mijn mening wiet terecht is. In feite wordt aldus op de onderneming druk uitgeoefend om haar gedrag. warvan zij (nog slechts) verdacht wordt, aan te passen. Een dergelijke handelwijze druist mijns inziens in tegen de onschuldspresumptie, die tot de eindbeslissing van de Commissie cen dominante positie inneemt en moet innemen.

\section{Het beleid inzake boete-verlaging wegens co-operatie sinds 1996}

Het voorgaande toont aan dat het een vast beleid van de Commissie is om ondernemingen die aan haar onderzoek medewerking verlenen te belonen door hun een lagere boete op te leggen. Met welke mate van 'korting' co-opererende ondernemingen rekening mogen bouden, kan echter niet uit de beschikkingen worden afgeleid. Meer duidelijkheid dienaangaande verschaft een mededeling van de Commissie uit 1996. ${ }^{369}$ In deze mededeling jeeft de Commissie niet alleen aan welke vormen van medewerking tot een boeteverlaging aanleiding geven, maar stelt zij bovendien de omvang van de verlaging vast. Hiermee dient de Commissie niet alleen de rechtszekerheid voor ondernemingen, maar hoopt zij tevens meer ondernemingen aan te zetten tot een vergaande co-operatie. Co-operatie moet bewerkstelligen dat meer zware kartels (de mededeling heeft betrekking op kartels betreffende vaststelling van prijzen, productie- of verkoopquota en betreffende marktverdeling en im- en exportverboden) bij de Commissie bekend worden en dat deze met (groter) succes en geringere belasting van de (naar haar aard beperkte) capaciteit van de Commissie kunnen worden vervolgd en beboet. Co-operatie moet dus leiden tot een betere en efficientere bestrijding van zware kartelvormen en tot een minder lange 'levensduur' van deze. Uit de mededeling blijkt dat de Commissie ervan uitgaat

\footnotetext{
"dat sommige ondernemingen die bij dergelijke overeenkomsten betrokken zijn, hun betrokkenheid wel zouden willen becindigen en bereid zouden zijn de Commissic over het bestan van de mededingingsregeling in te lichten, maar worden afgeschrikt door het risico dat zij een hoge geldboete krijgen opgelegd".
}

Om co-operatie te stimuleren, is de Commissie derhalve bereid om vergaande kortingen toe te passen op de aan een meewerkende onderneming op te leggen boete en zelfs om onder omstandigheden geheel van een boete af te zien. ${ }^{370}$ Zoals de Commissie het stelt:

"Het belang van consumenten en burgers dat genoemde praktijken worden opgespoord en verboden, weegt op tegen de wenselijkheid, ondememingen te beboeten die de Commissie door hun samenwerking in

369 Mededeling van de Commissie betreffende het niet opleggen of verminderenvan geldboeten in zaken betreffende mededingingsregelingen, $\mathrm{Pb} 1996 \mathrm{C} 207 / 4$.

370 In haar XXVle Verslag over het mededingingsbeleid (1996) stelt de Commissie dan ook dat de matiging van de boete bedoeld is als een prikkel "om de muur van stilzwijgen rond geheime kartels te doorbreken', 
staat stellen een mededingingsregeling op te sporen en er een einde aan te maken of die hierbij behulpraan zijn".

Het betreft dus duidelijk een belangenafweging tussen een zware, sterker preventief wer. kende boete aan de ene kant en een grotere 'pakkans' aan de andere kant, waarbij het zwaartepunt bij de laatste ligt. ${ }^{371}$ Dit laat onverlet dat -wil het streven van de Commissie (het terugdringen van ernstige kartelvormen) succesvol zijn- de totale boete onvermindend op een niveau moet blijven waarop van haar een preventieve werking kan uitgaan."3 Beziet men de inhoud van de mededeling én de sinds 1996 opgelegde boetes, dan kan zonder meer geconcludeerd worden dat voor een verlaging van het boeteniveau geen reëel gevaar bestaat.

Inhoudelijk biedt de mededeling -afgezien van de vastlegging van de 'kortingspercentages'- weinig nieuws ten opzichte van het tot 1996 door de Commissie gevoerde beleid. De vormen van co-operatie aan het onderzoek die door de Commissie in haar beschikkingen steeds als strafverminderend of zelfs 'strafuitsluitend' werden aangemerkt, hebben ook hun weg gevonden naar de mededeling. In de zin van de mededeling is het dan ook co-operatief indien de onderneming:

a. het kartel bij de Commissieaanbrengt voordat deze een verificatie bij beschikking heeft verricht en zonder dat deze reeds over voldoende bewijsmateriaal beschikt;

b. als eerste doorslaggevend bewijsmateriaal verstrekt;

c. haar participatic in het kartel uiterlijk op het moment van aungifte betindigt;

d. volledige medewerking blijt verlenen, onder meer door alle gegevens aan de Commissieter beschikking te stellen, en

e. geen andere onderneming tot deelname aan het kartel heeft gedwongen noch het initiatief heeft genomen tot dan wel een bepalende rol heeft gespeeld in het kartel.

Voldoet een onderneming aan al deze voorwaarden, dan ziet de Commissie geheel van een boete af of verlaagt de boete met tenminste $75 \%$. Medewerking die bestaat in bovengenoemd gedrag loont derhalve in hoge mate voor een onderneming, maar tegelijk is duidelijk dat de voorwaarden voor een dermate vergaande mindering zeer streng zijn. Immers zal slechts een onderneming die een ondergeschikte rol in het kartel heeft gespeeld en die als eerste met substanticel en nieuw bewijs komt, aanspraak kunnen maken op deze mate van clementie van de zijde van de Commissie, ${ }^{373}$ Mildere eisen zouden echter contra-productief werken aangezien van de afschrikkende en preventieve werking van de beboeting weinig zou overblijven indien bijvoorbeeld ook de voortrekkers in het kartel of zelfs alle daarbij betrokken ondernemingen een hoge boete zouden kunnen ontlopen

371 De Roos (1987), pag. 78, wijst er op dat "Niet zozeer de strafbaarstelling, maar veeleer de 'pakkans' (...) van doorslaggevend belang (is) wanneer het erom gaat potentiele overtreders af te houden van normschending". Dit gewicht van de pakkans geldt in belangrijke mate ook in de verhouding met de zwaarte van de sanctie als zodanig.

372 Vergelijk Wils (1997), pag. 130: "For the net effect on deterrence to be positive, it is thus crucial that the leniency policy is designed and applied in such a way as to limit the non-imposition $\alpha$ reduction of fines to what is strictly necessary and apt to lead to a (more than proportional) increase in the probability of detection and punishment".

373 Naar verwacht mag worden zal met name in gevallen, waarin een onderneming een kartel aangeeft dat tot dan toe nog niet bij de Commissie bekend was, in het geheel worden afgezien van oplegging van een sanctie aan de betreffende onderneming. 
door hun gedrag aan te melden en vergaande medewerking te verlenen. ${ }^{374}$ Door de beperking van de voordelen van de mededeling tot éen onderneming wordt gegarandeerd dat aan de overige kartelleden -binnen de grenzen van evenredigheid- een boete kan vorden opgelegd waarvan (voorzover mogelijk ${ }^{375}$ ) een voldoende mate van generale preventie uitgaat. Beziet men de voorwaarden voor de $75-100 \%$ matiging van de boete, ean blijkt bovendien dat voorafgaand aan de co-operatie niet met zekerheid door een enderneming kan worden bepaald of zij aan al deze voorwaarden, en meer in het bijzonder de eerste twee, voldoet. Een onderneming zal zelden weten of de Commissie reeds over voldoende bewijsmateriaal beschikt, met name indien de onderneming wordt geconfronteerd met een inlichtingenverzoek of een verificatie bij opdracht. ${ }^{376}$ Evenmin zal zij ervan op de hoogte zijn of zij het eerste kartellid is dat met bewijs naar buiten komt, soch of dit bewijs doorslaggevend is. ${ }^{37}$ In zoverre blijft het voor een onderneming dan ook onvoorspelbaar of haar medewerking het door haar gewenste resultaat -een mindering van minimaal $75 \%$ - oplevert. ${ }^{378}$ Deze onvoorspelbaarheid en de dreiging van een boge sanctie indien het kartel bij de Commissie bekend wordt, zou een onderneming evvan kunnen weerhouden het kartel aan te melden. Uit de mededeling blijkt echter dat cok indien niet aan alle voomoemde voorwaarden is voldaan, een co-opererende ondernening mag rekenen op een lagere boete. Een onderneming namelijk die aan de onder b-e genoemde voorwaarden voldoet, maar die het kartel pas na een verificatie bij beschikking bij de Commissie aanbrengt, terwijl die verificatie nog onvoldoende grond heeft opgeleverd om de contradictoire procedure te starten, wordt beloond met een verlaging van $50-75 \%$.

Daarenboven kan een co-opererende onderneming aanspraak maken op verlaging van de boete met $10-50 \%$ indien zij niet aan alle eerder genoemde voorwaarden voldoet (bijvoorbeeld omdat zij een leidende rol heeft vervuld, omdat zij niet als eerste belangrijk bewijsmateriaal leverde of omdat zij de co-operatie niet voortzette ${ }^{379}$ ). Volgens de mede-

374 In dezelfde zin Wils (1997), pag. 132 en 133.

375 Wils (1997), pag. 139-140, stelt dat het boeteniveauabsoluut ontoereikend is voor een afschrikkende werking. Hij baseert zijn conclusie op Amerikaanse studies, waarin wordt geconcludeerd dat prijskartels een jaarlijkse winst van $10 \%$ opleveren en een gemiddelde levensduur hebben van zes jaar. De kans op een sanctie wordt geraamd op 13-17\%. Wils stelt vervolgens dat, uitgaande van een levensduur van vijf jaar, een winst van vijf procent en een 'pakkans' van $20 \%$, slechts een minimumboete van $125 \%$ van de jaaromzet ondernemingen van kartellering zou kunnen weerhouden. Dit cijfer staat in schril contrast met de maximum-boete van $10 \%$ in het communautaire recht en met de praktijk van de Commissie waarin een boete van $5 \%$ gangbaar is. Hoewel deze cijfers geen rekening houden met schadevergoeding die via civiele procedures kan worden toegekend, noch met de negatieve publiciteit die een 'veroordeling' oplevert, maken zij toch duidelijk de preventieve werking van geldboetes niet overschat mag worden.

376 De uitdrukkelijke verwijzing in de mededeling naar een verificatie bij beschikking brengt mee dat een onderneming toch kan profiteren van de $75-100 \%$ korting indien zij volledig meewerkt aan (en na) een niet-dwingende verificatic, mits natuurlijk aan alle voorwaarden is voldaan.

377 Vergelijk tevens Hornsby en Hunter (1997), pag. 39-40.

378 Nog afgezien van het feit dat veelal niet duidelijk is wat de boetezonder verlaging wegens coöperatie zou zijn geweest. Op dit probleem wijst ook Rijnsbergen (1998), pag. 203.

379 Dit was het geval in Pb 1999 L 76/1 (British Sugar), waarin de onderhavige mededeling analoog werd toegepast op een situatie voorafgaand aan deze mededeling. Eén van de betrokken ondernemingen had de inbreuk bij de Commissie gemeld waardoor deze op de hoogte van de inbreuk raakte. Bovendien leverde de ondememing relevant bewijsmateriaal en trok zich terug uit het kartel. In het verdere verloop van de procedure verleende zij echter geen volledige medewerking meer waardoor zij 'slechts' in anmerking kwam voor een verlaging van $10-50 \%$. Wel was de annvankelijke medewerking van 
deling is dat met name (dus niet uitsluitend) het geval indien de onderneming voordat een mededeling van de punten van bezwaar is verstuurd, inlichtingen of (ander) bewijsmateriaal aan de Commissie verstrekt en indien de onderneming in de contradictoire fase de feiten waarop de Commissie haar beschuldigingen baseert, niet fundamenteel betwist. ${ }^{380}$ De Commissie blijkt in de praktijk bereid om voor deze laatste -en minst vergaande- vorm van co-operatie toch nog een aanzienlijk percentage in mindering te brengen. In de beschikking inzake voorgeïsoleerde buizen ${ }^{381}$ heeft de Commissie voor de enkele niet-betwisting van de mededeling van de punten van bezwaar een mindering toegepast van $20 \%$, terwijl voor het verlenen van belangrijke informatie aan de Commissie een korting van $30 \%$ passend werd geacht. Opmerkelijk en veelzeggend mag worden genoemd dat de Commissie tot -toch aanzienlijke- verlaging van de boetes overging hoewel de ondernemingen de inbreuk gedurende negen maanden na een verificatie hadden gecontinueerd.

Het voorgaande toont aan dat de Commissie een verstevigd offensief heeft ingezet tegen de zwaarste inbreuken op artikel 81 EG. ${ }^{382}$ Weliswaar brengt de mededeling ten aanzien van de vormen van co-operatie geen wijziging in het tot 1996 gevoerde beleid ${ }^{383}$, maar met name de uitdrukkelijke vastlegging van de voorwaarden om aanspraak te (kunnen) maken op een mindering van de boete met $75-100 \%$, moet tot een verhoogde mate van bereidwilligheid bij ondernemingen leiden om kartels onder de aandacht van de Commissie te brengen. ${ }^{204} \mathrm{~A}$ /s zodanig is er mijns inziens weinig op tegen om medewerking te beionen: medewerking bespaart de Commissie onderzoeksinspanningen en duidt er op dat de onderneming bereid is haar 'leven te beteren'. Het is echter de vraag of het de voorkeur verdient om ondernemingen aan te zetten om andere kartelleden te 'verklikken'. ${ }^{35}$ Het gedrag van de 'verklikker' zal hem door de overige leden van het kartel in ieder geval niet in dank worden afgenomen. Bovendien zal de Commissie ervoor dienen te waken dat de onderneming zich niet verplicht voelt de inbreuk te erkennen. Tegen het toekennen van een boeteverlaging in ruil voor een erkenning van de feiten valt relatief weinig in te brengen: de onderneming staat het dan nog altijd vrij om de juridische waarde-

dien aard dat tot een verlaging van $50 \%$ werd besloten.

380 De ondememing zal in dat geval ook niet in de beroepsprocedure bij het Gerecht de feiten mogen betwisten. Doet zij dit toch, dan zal de Commissie blijkens de mededeling het Gerecht verzoeken de boete te verhogen.

$381 \mathrm{~Pb} 1999$ L 24/1.

382 Inbreuken op artikel 82 EG worden door de mededeling niet gedekt. Dit houdt verband met het feit dat dergelijke inbreuken over het algemeen relatief eenvoudig kunnen worden geconstateerd, met name door gedupeerden. In die situatie is een zo vergaande stap van de Commissie om kartelgedrag aan het licht te brengen niet nodig. Vergelijk Wils (1997), pag. 131.

383 Aldus ook Rijnsbergen (1998), pag. 205. Het feit dat de mededeling slechts geldt voor de meest emstige overtredingen van artikel 81 EG laat mijns inziens onverlet dat het beleid waarin met co-operatic van betrokkenen rekening wordt gehouden onverminderd ten aanzien van andere vormen van mededingingsbeperkend gedrag zal worden gecontinueerd. Dit volgt ook uit de door de Commissie bekendgemaakte Richtsnoeren voor de berekening van geldboeten, $\mathrm{Pb} 1998 \mathrm{C}$ 9/3.

384 In dat licht moet mijns inziens ook de visie van de Commissie worden geplaatst dat de behandeling van ondememingen door de mededeling gunstiger is dan voordien; zie Pb 1999 L $76 / 1$ (British Sugar)-

385 De vergelijking dringt zich op met het in het strafrecht zeer omstreden gebruik van kroongetuigen. Wel moet bedacht worden dat in het communautaire recht gegarandeerd is dat de belangrijke overtreders niet buiten schot blijven. 
nng van die feiten te betwisten. $\mathrm{Bij}$ een erkenning van de inbreuk echter wordt tevens begegeven dat het handelen in strijd was met het recht. De positie van de 'verdachte' trengt mijns inziens mee dat een dergelijke erkenning niet mag worden afgedwongen. Het in het vooruitzicht stellen van een aanzienlijke beloning in ruil voor een erkenning saat naar mijn mening gelijk met het uitoefenen van ongeoorloofde druk. ${ }^{386}$ Het lijkt a desalniettemin op dat de Commissie erkenning van de inbreuk eist vooraleer zij tot en verlaging van de sanctie overgaat. Dit kan worden afgeleid uit de beschikking ten anzien van een kartel in voorgeisoleerde buizen. Aan één van de betrokken onderneningen kon geen vermindering van de boete worden toegekend "aangezien haar verweer aubbelzinnig was ten aanzien van de feiten en zij geen expliciete bekentenissen heeft dgelegd". 187

\section{Omstandigheden die niet direct verband houden met de onderneming}

\section{a) De economische situatie op de markt}

Fiervoor is betoogd dat op grond van het draagkrachtbeginsel rekening zou moeten worden gehouden met de financiěle positie van de onderneming ten tijde van de strafoplegging. De Commissie ziet hiervoor wel ruimte, maar is desalniettemin enigszins terughoudend ondat zij niet ondernemingen wil bevoordelen die in feite de minst stevige basis hebben. Meer -zij het niet overmatig veel- begrip toont de Commissie indien de kartelactiviteiten door ondernemingen zijn ontplooid om een conjuncturele teruggang het hoofd te kunnen bieden. Dergelijke kartelactiviteiten kunnen zeker enige positieve gevolgen bewerkstelligen (men denke aan het in stand houden van een onderneming en aan het behoud van werkgelegenheid), hoewel zij desondanks onverminderd in strijd zijn met het communautaire recht. Met name indien alle kartelparticipanten lijden onder een crisissituatie ${ }^{388}$ is de Commissie, ondanks de onrechtmatigheid van het mededingingsbeperkend gedrag, geneigd om in een dergelijke situatie -met inachtneming van de overige omstandigheden van het geval $^{389}$ - de ondernemingen tegemoet te komen door een lagere boete op te leggen. ${ }^{390}$

386 Hier dreigt een conflict met het nemo tenetur-beginsel dat in het volgende hoofdstuk uitgebreid zal worden besproken. Het Gerecht lijkt hier van geen strijd te willen weten, getuige GvEA (T-311/94) Jur. 1998, II-1129 (BPB de Eendracht)en GvEA (T-347/94) Jur. 1998, II-1751 (Mayr-Melnhof Kartongesellschaft).

$387 \mathrm{~Pb} 1999$ L 24/1 (cursivering, HQ).

$388 \mathrm{~Pb} 1985$ L 376/28 (Sperry New Holland); $\mathrm{Pb} 1986$ L 232/30 (Bitumineuze dakbedekking) en $\mathrm{Pb}$ 1984 L 220/27 (Zine Producer Group), In Pb 1989 L 74/17 (PVC-1) werd door de Commissie als verzachtende omstandigheid in aanmerking genomen dat "de betrokken ondernemingen gedurende een groot deel van de door deze beschikking bestreken periode aanzienlijke verliezen leden in de PVC-sector". In mutatis mutandis gelijke zin Pb 1989 L $74 / 39$ (LdPE) en reeds Pb 1986 L 230/1 (Polypropyleen). In Pb 1994 L 343/123 (Cement) woog de Commissie als strafverlichtende omstandigheid mee dat de cementondernemingen "te kampen hebben gekregen met toegenomen, plotse cementinvoerstromen op eenmoment waarop de communautaire bedrijfstak grote moeite had om uit de slechte conjunctuur te geraken". Zie tevens GvEA (T-319/94) Jur. 1998, II-1331 (Fiskeby Board) en Pb 1998 L. 100/55 (Legeringstoeslag).

389 Uit $\mathrm{Pb} 1986 \mathrm{~L}$ 348/50 (Meldoc) kan geconcludeerd worden dat de Commissie bij de boetebepaling bereid is rekening te houden met een slechte marktsituatie, zolang de samenwerking binnen bepaalde grenzen blijft. Bij zelfstandige regulering van de gehele nationale markt, zoals in onderhavige casus 


\section{b) Precedenten}

De invloed van een al dan niet duidelijke rechtssituatie en in het verlengde daarvan van de al dan niet aanwezigheid van precedenten op de omvang van de boete kan welhaast niet onderschat worden. Dat is met name het geval omdat zij een prominente rol vervult bij de beoordeling van de verwijtbaarheid, maar ook daarbuiten is zij relevant. In de praktijk blijkt de Commissie namelijk het enkele feit dat een eerdere beschikking ten aanzien van het in het geding zijnde gedrag of een eerdere boetebeschikking ontbreekt dan wel dat nooit eerder binnen de betreffende sector een verbodbeschikking het licht heeft gezien, mee te wegen bij de bepaling van de boete. ${ }^{391}$ Zo werd in de AEG/Telefunken-beschikking ten voordele van de betrokken onderneming ${ }^{32}$ overwogen dat het de eerste keer was dat de Commissie een uitspraak moest doen over een "met de vrije concurrentie strijdige toepassing van een selectieve distributieregeling waartegen als zodanig door haar geen bezwaar was gemaakt". ${ }^{393}$ In de Eurocheque-beschikking ${ }^{394}$ werd door de Commissie uitdrukkelijk enige 'clementie' betracht omdat het de eerste boetebeschikking in de banksector betrof, ondanks het feit dat het kartel bestond uit een prijsafspraak. In de beschikking inzake de Far Eastern Freight Conference werd als strafverminderings: factor in aanmerking genomen dat de beschikking voor de eerste keer Verordening 1017/68 op leden van een zogenoemde lijnvaartconference werd toegepast. ${ }^{396}$ Het lijkt er echter op dat het ontbreken van precedenten als zelfstandige straftoemetingsfactor weinig toekomst meer heeft. Dit is niet alleen het gevolg van het feit dat voor de meeste gedragingen en het gros van de sectoren onderhand wel precedenten aanwezig zijn, maar hangt bovendien ermee samen dat er klaarblijkelijk een nauwer verband met de verwijtbaarheid wordt

het geval was, worden echter deze grenzen overschreden.

390 Vergelijk hieromtrent Gyselen (1993), pag. 70.

391 Een duidelijke rechtssituatie kan een strafverhogende rol spelen. Vergelijk bijvoorbeeld $\mathrm{Pb} 1978 \mathrm{~L}$ 22/23 (Hugin/Liptons).

392 De discriminatoire en prijsbeinnvloedende uitvoering van de niet door de Commissie verworpen regeling als zodanig kan daarentegen worden aangemerkt als een strafverzwarende factor, men zie HvJ (107/82) Jur. 1983, 3220 (Allgemeine Elektricitäts-Gesellschaft AEG-Telefunken).

$393 \mathrm{~Pb} 1982$ L 117/28. Zie ook Pb 1988 L 284/41 (Napier Brown/British Sugar): De Commissie erkent "dat het recht inzake zulk een misbruik door beschikkingen van de Commissie en arresten van het Hof minder is verduidelijkt dan ten aanzien van de andere (in casu gepleegde) misbruiken (...) en heef daarmee bij het vaststellen van het bedrag van de geldboete rekening gehouden".

$394 \mathrm{~Pb} 1992$ L 95/50. Met instemming het Gerecht: GvEA (T-39 en 40/92) Jur. 1994, II-49 (Groupement des cartes bancaires 'CB' en Europay International).

395 Vergelijk ook Pb 1972 L 95/1 (Chiquita), waarin voor het eerst de prijspolitiek van een ondememing in het licht van artikel 82 EG grondig werd onderzocht, Pb 1987 L $3 / 24$ en 25 (Vetzuren), waarin het ging om een kartel met betrekking tot informatieuitwisseling, Pb 1988 L 233/15 (British Dental Trade Association), met betrekking tot tentoonstellingen, HvJ (C-62/86) Jur. 1991, I-3359 (AKZ0 Chemie), betreffende het aanbieden van onredelijk lage prijzen aan eigen afnemers alsmede ata afhemers van een concurrent en Pb 1992 L $92 / 1$ (Bouwnijverheid in Nederland), waarin de bouwsector de eerste mal werd getroffen door een toepassing van artikel 82 EG.

$396 \mathrm{~Pb} 1994$ L 378/17. Vergelijk ook Pb 1988 L $317 / 47$ (Sabena), waarin de boete mede werd gematigd omdat de Commissie verordening 17 voor het eerst toepaste op de markt voor reservering van vliegtuls: plaatsen per computer. 
gelegd $\mathrm{d}^{m}$; van ondernemingen mag worden verwacht dat zij ook zonder precedenten op het gebied waarop de beschikking direct betrekking heeft, op de hoogte ervan zijn of hun gedrag de toets van het communautaire kartelrecht kan doorstaan, voorzover althans de rechtssituatie van enigszins vergelijkbare gevallen geen vragen oproept. ${ }^{398}$

\section{c) Overheidsmaatregelen en onderzoeksvoortgang}

Kartels zijn soms werkzaam in sectoren waarin door maatregelen van nationale en/of communautaire autoriteiten de vrijheid om eigen beleid te bepalen tot op zekere hoogte is beperkt. Een duidelijk voorbeeld van een dergelijke sector is de landbouwsector: men denke bijvoorbeeld aan de talrijke regels met betrekking tot melkquota of beperking van de veestapel. De van hogerhand opgelegde regulering met haar invloed op de productie, de omzet en het inkomen van de ondernemingen binnen die sector, kan een klimaat scheppen waarin ondernemingen eerder bereid zijn hun heil in onderlinge afspraken te zoeken. De Commissie heeft oog voor de situatie van landbouwondernemingen en is in sommige gevallen bereid tot matiging van de boete. ${ }^{399} \mathrm{De}$ staalsector is een ander voorbeeld van een sector die door nationale en Europese regelgeving wordt beinnvloed. Deze sector was onderwerp van onderzoek in de Betonstaalmatten-zaak. ${ }^{400}$ Op grond van het EGKS-Verdrag had de Commissie voor zogenoemd walsdraad productiequota vastgesteld teneinde de toenmalige structuurcrisis in deze sector te bestrijden. De producenten van betonstaalmatten waren voor de prijsstelling van hun producten voor een groot

$397 \mathrm{~Pb} 1992$ L 134/1 (Frans-Westafrikaanse rederscomités), waarin de Commissie overwoog dat de mogelijkheid bestond dat de ondememingen ten tijde van de inbreuk "niet volledig op de hoogte waren van de verplichtingen die voor hen uit de communautaire mededingingsregels voortvlocien, of de ernst van de door hen begane inbreuken hebben onderschat".

398 GvEA (T-229/94) Jur. 1997, II-1689 (Deutsche Bahn): "In dit verband zij eraan herinnerd, dat de omstandigheid dat voor een beschikking geen precedent bestaat, niet kan worden ingeroepen om een verlaging van de geldboete te bepleiten, wanneer de zwaarte van het misbruik van een machtspositie en van de beperkingen op de mededinging vaststaat". Met klaarblijkelijk instemming stelde het Hof in HvJ (C-333/94 P) Jur. 1996, 1-5951 (Tetra Pak International) dat het Gerecht had geoordeeld dat de onderneming gelet op haar leidende positie op de betrokken markten zich bewust had moeten zijn van de strijdigheid van haar handelen met het EG-Verdrag: "Het Getecht verbond daaraan de conclusie dat wegens het duidelijke karakter en de bijzondere emst van de beperkingen van de mededinging (...) handhaving van het bedrag van de geldboete gerechtvaardigd was, in weerwil van het feit dat voor enige in de bestreden beschikking gegeven juridische beoordelingen geen precedent bestond". In Pb 1992 L 134/1 (Frans-Westafrikaanserederscomités)mocht het feit dat het de eerste beschikking betrof op grond van verordening 4056/86 de ondernemingen-zijnde reders(comites)- niet baten, omdat zij hun rechtspositie kenden. Tot deze conclusie kwam de Commissie omdat de betreffende beschikking in nauw overleg tussen haar en de reders tot stand was gekomen. In GvEA (T-24-26 en 28/93) Jur. 1996, 11-1201 (Compagnie maritime belge transports e.a.) oordeelde het Gerecht dat geen rekening ermee behoefde te worden gehouden dat het een van de eerste beschikkingen was met betrekking tot verordening 4056/86, omdat het ontplooide gedrag (het verdringen van een concurrent van de markt) in het geheel niet nieuw was.

$399 \mathrm{~Pb} 1986 \mathrm{~L}$ 348/50 (Meldoc); deze zaak speelde in de zuivelbranche. In HvJ (40-48, 50, 54-56, 111 , 113 en 114/73) Jur. 1975, 1663 (Suiker Unie e.a.) had de Commissie volgens het Hof onvoldoende rekening gehouden met de situatie op de suikermarkt, die werd gekenmerkt door nationale quota en -voor sommige lidstaten-maximum-consumentenprijzen, als gevolg waarvan slechts geringe ruimte tot mededinging resteerde.

$400 \mathrm{~Pb} 1989$ L 260/1 (Betonstaalmatten). 
deel afhankelijk van de prijs van deze walsdraad en dus was de vrijheid voor de onderne. mingen om hun eigen beleid te bepalen zeer ingeperkt. Daarenboven was voor hen de verhouding tot betonstaafstaal (waarvoor eveneens crisismaatregelen golden) van belang aangezien het staafstaal tot op zekere hoogte een substituut voor de matten is. Er bestond derhalve wel een marge om via prijsafspraken de prijzen voor de betonstaalmatten te verhogen, maar deze was relatief beperkt gezien de prijzen voor het 'concurrerende' staafstaal, Voorts was in deze sector in Duitsland een zowel door het Bundeskartellamt als ook door de Commissie goedgekeurd structuurcrisiskartel werkzaam. Met name dit kartel bracht producenten in andere lidstaten tot het vaststellen van beschermingsmaatregelen ten behoeve van hun eigen positie. Deze handelwijze werd door de Commissie weliswaar allerminst goedgekeurd, omdat het kartelmatig gedrag onverminderd in strijd was met artikel 81 lid 1 EG, maar zij zag in de voor Duitsland genomen maatregel wel een reden om de omvang van de boete te matigen. In de Sandoz-casus ${ }^{401}$ stond de geneesmiddelenmarkt centraal en speelden "maatregelen van de nationale regering op het handelsverkeer" een rol. Deze maatregelen van de Italiaanse regering hielden onder meer in dat een vergunning noodzakelijk was voor het op de markt brengen van een genees. middel; bij deze vergunning werd door een overheidsinstantie tevens de prijs voor het betreffende product vastgesteld, van welke prijs niet mocht worden afgeweken. Dit had tot gevolg dat het prijsniveau op de Italiaanse markt uitermate laag lag en dat export naar andere landen lucratief en derhalve zeer waarschijnlijk was. De betrokken onderneming had teneinde oneerlijke concurrentie zoveel mogelijk te voorkomen een exportverbod opgelegd; zij zou die stap waarschijnlijk niet hebben gezet als de prijzen via de werking van vraag en aanbod tot stand zouden zijn gekomen. Een voorbeeld van een overheids. maatregel waardoor een afspraak verderstrekkende gevolgen krijgt dan door de 'contractanten' is beoogd, biedt de UGAL/BNIC-zaak. ${ }^{402}$ Het bijzondere van deze casus was dat een besluit van een ondernemersvereniging ten aanzien van de vaststelling van minimumprijzen voor cognac door de overheid algemeen verbindend werd verklaard. De werking van het besluit bleef derhalve niet slechts beperkt tot de leden van het BNIC (Bureau National Interprofessionnel du Cognac), maar strekte zich uit over de hele branche, wardoor de mededinging in ernstigere mate werd beperkt dan op grond van het besluit van de ondernemersvereniging verwacht mocht worden. Deze ernstige gevolgen kunnen aanleiding zijn voor een hoge boete; daartegenover staat dat de ondernemingen van deze versterking van het effect van het kartel geen verwijt gemaakt kan worden. In zoverre kan dit aspect bij de strafverminderingsfactoren in aanmerking worden genomen. De SPO-zaak (be)trof de Nederlandse bouwsector en toont treffend de problemen aan die als gevolg van het voormalige Nederlandse kartelbeleid konden rijzen. ${ }^{403} \mathrm{Bij}$ Koninklijk Besluit werd een aantal mededingingsregelingen in de bouwsector generiek onverbindend verklaard en daarmee verboden. ${ }^{404}$ Het gedrag zoals dat in de SPO-beschikking aan de orde kwam. viel echter buiten de reikwijdte van het nationale verbod en was als zodanig vanuit nationale optiek geoorloofd. Het gedrag viel daarentegen onverminderd binnen de werkingssfeer van het communautaire kartelverbod van artikel 81 EG en noopte de Commissie tot optreden. Een boete was gezien de aard van de overtreding geïndiceerd en de handelwijze

$401 \mathrm{~Pb} 1987$ L. 222/28.

$402 \mathrm{~Pb} 1982$ L $379 / 1$.

$403 \mathrm{~Pb} 1992$ L. 92/1.

404 Besluit mededingingsregelingen in de bouwsector, van 29 december 1986, Stb. 1986, 676. 
van de Nederlandse overheid was geen rechtvaardiging voor het gedrag van de ondernemingen vanuit communautair perspectief. ${ }^{405}$ Bedoelde handelwijze was wel aanleiding voor matiging van de boete omdat zij bij de ondernemingen een 'zekere dubbelzinnigheid $^{206}$ deed ontstaan.

Indien er in het kader van het onderzoek fouten worden gemaakt, is de Commissie bereid zelf het boetekleed aan te trekken. In de Eurocheque-beschikking ${ }^{408}$ woog de Commissie mee dat zij zelf had verzuimd een onderzoek naar de reikwijdte van de overeenkomst in kwestie te starten toen haar kort na het sluiten ervan van de zijde van kartelleden informatie had bereikt die een dergelijk onderzoek rechtvaardigde. Dit stilzitten had in ieder geval tot gevolg dat de inbreuk gedurende een langere periode had plaatsgehad dan noodzakelijk; maar daarnaast had de passiviteit van de Commissie door de ondernemingen kunnen worden uitgelegd als een gedogen van de situatie of zelfs als een teken van geen bezwaar. Het lijkt er overigens op dat in deze zaak van groot belang was dat de informatie over het bestaan van het kartel de Commissie uit primaire bron bereikte. Pas dan lijkt er een redelijke mate van zekerheid te bestaan dat inderdaad mogelijk het EG-Verdrag wordt overtreden en worden door niet-optreden bepaalde verwachtingen gewekt bij de betrokken ondernemingen, die dan immers over zekerheid beschikken dat de Commissie van hun handelen afweet. In de SPO-zaak was hieraan in ieder geval niet voldaan, en faalde het beroep op het verzuim om een procedure te starten. ${ }^{40}$

405 Zie hierover ook Van Paridon (1993), pag. 116-117 en 121-123. Een enigszins vergelijkbare situatie deed zich voor in de zaak die uitmondde in GvEA (T-61/89) Jur. 1992, Il-1931 (Dansk Pelsdyravierforening). Hier betrofhet een briefvan de Deensemededingingsautoriteitwaarin-vanuit nationale optiek- geen bezwaar werd gemaakt tegen de gedragingen in kwestie. Het Gerecht stelde dat een dergelijke brief de Commissie op geen enkele wijze kan binden ten aanzien van de toepassing van artikel 15 Vo 17. Zie tevens GvEA (T-148/89) Jur. 1995, II-1063 (Tréfilunion), waarin het Gerecht overwoog dat "de omstandigheid dat de nationale instanties het gedrag van de ondernemingen kenden, toestonden of zelfs aanmoedigden, volgens vaste rechtspraak hoe dan ook geen invloed heeft op de toepasselijkheid van artikel 85 of eventueel van artikel 86 van het Verdrag". Evenmin kan een nationale wet een door het EG-Verdrag verboden gedraging rechtvaardigen, zie GvEA (T-150/89) Jur. 1995, II-1165 (Martinelli).

406 Juist omdat voor bepaalde aanbestedingsregelingenin tegenstelling tot de hoofdregel onder de Wem een verbod bestond, konden de ondernemingen in hun mening worden gesterkt dat hun regeling. die buiten de reikwijdte van de generieke maatregel viel, wél toelaatbaar was. Van een dergelijke dubbelzinnigheid was ook sprake in $\mathrm{Pb} 1999$ L 109/24 (Griekse veerdienstmaatschappijen).

407 Volgens HvJ (44/69) Jur. 1970, 733 (Buchler), is de Commissic overigens niet verplicht rekening te houden met verschillen tussen de nationale wetgevingen op belastinggebied.

$408 \mathrm{~Pb} 1992 \mathrm{~L}$ 95/50. Volgens het Gerecht was dit terecht, zie GvEA (T-39 en 40/92) Jur. 1994, II-49 (Groupement des cartes bancaires 'CB' en Europay International).

409 GvEA (T-29/92) Jur. 1995, II-289 (Vereniging van Samenwerkende Prijsregelende Organisaties in de Bouwnijverheid e.a.). "Verzocksters kunnen de Commissie niet verwijten, dat zij niet vroeger tegen de regelingen is opgetreden. Het feit dat de regelingen openbaar waren en daarover veel commentaren waren verschenen in de vakpers, kan de Commissie zonder formele klacht niet verpliehten, een procedure uit hoofde van artikel 85 , lid 1, van het Verdrag in te leiden. Ook hier komt het betoog van verzoeksters erop neer dat de Commissie wordt verweten dat zij niet vroeger heeft gehandeld, terwijl verzoeksters de mogelijkheid hadden om hun regelingen bij de Commissie aan te melden om voot een ontheffing en de boete-immuniteit in aanmerking te komen". Aan de klacht werd in deze zaak een groot belang gehecht omdat de Commissic aldus "op de hoogte wordt gesteld van de inhoud van de gewraakte gedraging, terwijl de Commissie in casu pas door de aanmelding op de hoogte is gebracht van de objectieve inhoud van de regelingen". 
Naast het eventuele trage optreden van de Commissie bij het starten van een onderzoek, speelt een voorname rol of zij voldoende spoed betracht bij het doorvoeren van het onderzoek. Een vertraging van het onderzoek die aan de Commissie moet worden toegerekend, dient -parallel aan hetgeen het geval is bij schending van de redelijke termijn van artikel $6 \mathrm{EVRM}^{410}$ - (tenminste) gecompenseerd te worden door verlaging van de op te leggen sanctie. ${ }^{411}$ De procedure die uitmondde in de Far Eastern Freight Conference-beschikking $^{412}$ bijvoorbeeld had meer tijd gevergd dan normaliter het geval was, mede omdat het de eerste 'Verordening $1017 / 68$ beschikking' tegen lijnvaartconferences betrof en de Commissie richtsnoeren voor de beoordeling had moeten ontwikkelen. Deze 'extra' periode diende volgens de Commissie niet de ondernemingen te worden aangerekend. ${ }^{41}$ De communautaire rechters oefenen op de voortvarendheid waarmee de procedure wordt gevoerd toezicht uit. Zo nodig wijzen zij de Commissie terecht wegens een te geringe activiteit aan haar kant. In zijn ICI/CSC-arrest overwoog het Hof "dat de zwaarte van de inbreuk weliswaar een hoge boete rechtvaardigt, doch in aanmerking moet worden genomen dat de duur ervan, door de beschikking op meer dan twee jaar gesteld, had kunnen worden bekort, indien de Commissie, gewaarschuwd door Zoja's klacht van 8 april 1971 -dat wil zeggen een half jaar na de eerste weigering van CSC-Istituto-, eerder tussenbeide was gekomen"..$^{14}$ Aangezien echter een (communautair) kartelonderzoek naar zijn aard verre van eenvoudig is, zal het doorgaans de nodige tijd in beslag nemen, waardoor een beroep op een onredelijk lange duur veelal geen succes heeft. ${ }^{415}$

410 Voor een -succesvol- beroep op schending van dit artikel zie HvJ (C-185/95 P) Jur. 1998, 1-8417 (Baustahlgewebe), dat in het volgende hoofdstuk nog uitdrukkelijk zal worden behandeld.

411 Ten dele ligt een vergelijkbare ratio ten grondslag aan de boete-immuniteit die het gevolg is van een aanmelding ter verkrijging van ontheffing.

$412 \mathrm{~Pb} 1994$ L $378 / 17$.

413 Voorzover de omstandigheden buiten de invloedssfeer van de Commissie vallen, bestaat er vanzelfsprekend geen aanleiding om deze bij de boetebepaling in aanmerking te nemen. Zo overwoog het Hof in HvJ (322/81) Jur. 1983, 3461 (Nederlandsche Banden Industrie Michelin): "Ten aanzien van het argument van NBIM dat de Commissie zelf door een sneller optreden de duur van de inbreuk. had kunnen bekorten, moet rekening worden gehouden met de moeilijkheden die het onderzoek van een niet schriftelijk vastgelegd kortingsysteem, dat op een weinig doorzichtige wijze werd toegepast, opleverde". Vergelijk ook GvEA (T-83/91) Jur. 1994, II-755 (Tetra Pak International): "De lange duur van zes jaar voor het door de Commissie verrichte onderzoek en vervolgens van twee jaar voot de administratieve procedure zijn te verklaren door de ingewikkeldheid en de omvang van de onderzoe ken van de Commissie die betrekking hadden op het gehele commerciële beleid van Tetra Pak sedent 1976 in de Gemeenschap".

$414 \mathrm{HvJ}(6 \mathrm{en} 7 / 73)$ Jur. 1974, 223 (Istituto Chemioterapicoltaliano/CommercialSolvents Corporation). Met name om deze reden werd de boete door het Hof gehalveerd. In GvEA (T-305-307, 313-316, 318. 325, 328, 329 en 335/94) Jur. 1999, II-931 (Limburgse Vinyl Maatschappij e.a.) echter oordeclde het Gerecht dat de Commissie wel met de vereiste spoed had opgetreden.

415 GvEA (T-43/92) Jur. 1994, II-441 (Dunlop Slazenger International): "Het Gerecht is van oordeel, dat in bepaalde omstandigheden bij de beoordeling van het bedrag van de aan de betrokken onderneming op te leggen geldboete weliswaar rekening kan worden gehouden met de door de Commissie bij de instructie van de zaak betoonde naarstigheid (...), maar dat de tijd die in casu is verstreket tussen het besluit om de inbreukprocedure in te leiden (...) en de datum waarop de Beschikking is gegeven, in elk geval getuigt van een normale naarstigheid van de administratic. Eveneens staat vast, dat de Commissie vóór het besluit de procedure in te leiden, de noodzakelijke maatregelen voor het onderzoekvan de (...) bij haaringediendeklacht binnen de normale termijnen beeft genomen". Vergelijk tevens GvEA (T-24-26 en 28/93) Jur. 1996, II-1201 (Compagnie maritime belge transports e. 1 ). "Gelet op de ingewikkeldheid van de zaak, het aantal en de verscheidenheid van de inbreuken die 


\subsection{De duar van de inbreuk}

Hierboven is behandeld wat onder de noemer 'zwaarte van de inbreuk' kan worden gebracht. Verordening 17 verplicht de Commissie daarnaast om rekening te houden met de duur van de inbreuk, waarbij ook hier geldt dat de nadere concretisering van deze factor aan de Commissie is overgelaten. De aparte vermelding van de duur van de inbreuk als zelfstandig strafmaatcriterium is in zoverre opmerkelijk -zeker gelet op het feit dat de Raad de 'zwaarte' niet nader heeft willen concretiseren- dat de duur reeds mede bepalend is voor de zwaarte van de inbreuk. ${ }^{416}$ Dat dit criterium toch in artikel 15 Vo 17 is neergelegd, duidt er op dat de Raad de zwaarte en de duur als min of meer gelijkwaardige componenten heeft beschouwd en dat hij heeft willen voorkomen dat dit criterium door andere factoren zou worden ondergesneeuwd. De duur zou dus in de visie van de Rad een grotere rol moeten spelen dan louter als onderdeel van de zwaarte, in welk geval een langdurige inbreuk slechts zou leiden tot een zwaardere inbreuk en vice ver$\mathrm{sa}^{417}$ De Commissie lijkt tot 1998 een minder groot gewicht aan de duur toe te kennen dan waarschijnlijk door de Raad beoogd. Weliswaar toont de beschikkingspraktijk aan dat een inbreuk van (zeer) lange duur tot strafverhoging leidt ${ }^{418}$ en dat een overtreding van (extreem) korte duur aanleiding kan geven tot matiging van de boete ${ }^{419}$, maar in welke mate met deze factor wordt gehouden, kan doorgaans niet uit de beschikkingen worden afgeleid. Het lijkt er op dat de duur in verhouding tot andere straftoemetingsfactoren geen bijzondere positie inneemt. Ter illustratie hiervan kan verwezen worden naar twee beschikkingen waarin de Commissie binnen een periode van minder dan één jaar aan twee ondernemingen wegens overtreding van artikel 81 EG een boete van gelijke omvang heeft opgelegd (namelijk 60.000 rekeneenheden), terwijl het kartelmatig gedrag in het eerste geval minder dan vijf maanden had geduurd ${ }^{420}$ en het kartel in het tweede geval ongeveer vijf jaar had bestaan. ${ }^{421}$ Dat de duur in relatie met andere factoren moet worden bezien, wordt hierdoor onderstreept dat de Commissie enerzijds relatief geringe boetes oplegt voor inbreuken die extreem lang hebben geduurd ${ }^{422}$ en anderzijds er niet

naar aanleiding van algemene klachten moesten worden onderzocht, en het aantal daarbij betrokken lijnvaartconferencesen scheepvaartmaatschappijen,kan de duur van de procedure niet als excessief worden aangemerkt".

416 En volgens Mulder (1989), pag. 473, zelfs ten onrechte. Ook Dannecker en Fischer-Fritsch (1989), pag 325 , zien de duur als een 'geïntegreerd criterium' voor de zwaarte.

417 Overigens kan de emst van een gedraging toenemennaarmate het kartel langer effectief is; na opstartproblemen kan een overeenkomst na verloop van tijd -als haar doeleinden en mogelijkheden meer omlijnd zijn-strikter worden nageleefd. Participatie in de latere fase is in dat geval ernstiger dan deelname in een eerder stadium. Zie Gyselen (1993), pag. 70.

418 Men vergelijke Pb 1980 L 39/51 (Floral), Pb 1987 L 222/28 (Sandoz) en Pb 1992 L 72/1 (Tetra Pak II). De duur van de inbreuken in deze zaken bedroeg ongeveer respectievelijk 10 jaar, 26 jaar en 15 jaar.

$419 \mathrm{~Pb} 1975$ L 29/14 (General Motors), Pb 1988 L $78 / 42$ (Konica) en Pb 1988 L $317 / 47$ (Sabena). In $\mathrm{Pb} 1994$ L 343/1 (Cement) werd in het kader van de boete-oplegging rekening gehouden met de in vergelijking tot andere ondememingen minder langdurige deelname van sommige kartelparticipanten aan de inbreuk.

$420 \mathrm{~Pb} 1972$ L 303/52 (WEA-Filipacchi Music).

421 Po 1973 L. 293/40 (Deutsche Philips).

422 Vergelijk $\mathrm{Pb} 1992$ L $366 / 47$ (verdeling van treinbiljetten door reisbureaus), waarin een boete van bén miljoen rekeneenheden werd opgelegd ondanks cen inbreuk die gedurende veertig jaar had bestaan. 
voor terugschrikt om ook bij overtredingen van zeer korte duur een aanzienlijke boete op te leggen. Aan twee ondernemingen die door middel van een kartel nevenimport verhinderden, werden door de Commissie boetes opgelegd die totaal 900.000 rekeneenheden bedroegen, terwijl de inbreuk slechts negen dagen had geduurd. ${ }^{423}$ In de BMW Belgiumbeschikking constateerde de Commissie eveneens een inbreuk op artikel 81 EG van relatief geringe duur. De onderneming die het initiatief tot de gewraakte overeenkomst had genomen, werd desalniettemin beboet met een bedrag van 150.000 rekeneenheden. De boetes die aan de andere kartelleden werden opgelegd, waren daarentegen zeer laag en varieerden van 1.000 tot 2.000 rekeneenheden per onderneming. ${ }^{424}$ Het MDF-arrest geeft aan dat ook het Hof hoge boetes mogelijk acht bij inbreuken van korte duur. Pioneer immers werd in beroep een boete opgelegd die weliswaar minder dan de helft van de oorspronkelijke boete betrof (met name omdat de Commissie een onjuiste beoordeling van de duur van de onderling afgestemde feitelijke gedragingen had gemaakt), maar die toch twee miljoen rekeneenheden bedroeg ondanks de korte levensduur van het kartel, te weten minder dan één maand. Hoewel de precieze rol van de duur in de straftoemeting tot 1998 moeilijk viel in te schatten, was wel duidelijk dat de Commissie slechts waarde hechtte aan de globale duur van de inbreuk. De benadering van de Commissie in deze wordt goed verwoord in de Kartonbeschikking. De Commissie betrok in haar oordeel de periodes gedurende welke de verschillende deelnemers daadwerkelijk in het kartel hadden geparticipeerd, maar stelde tevens expliciet dat het niet de bedoeling was "bij de berekening van

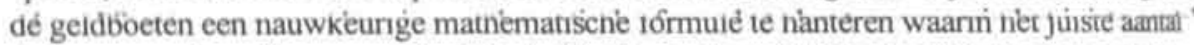
dagen, maanden of jaren waarin de betreffende producent bij het kartel was aangesloten, weerspiegeld wordt". ${ }^{425} \mathrm{Als}$ ondernemingen derhalve alle lang bij een kartel zijn betrokken (bijvoorbeeld minimaal zes jaar), dan is het voor de Commissie in het kader van de straftoemeting vaak niet erg wezenlijk of verschillende ondernemingen enkele jaren langer hierin hebben geparticipeerd. ${ }^{426}$

De bekendmaking ten aanzien van de berekening van de geldboete, die in 1998 het licht heeft gezien, heeft het belang van de duur als straftoemetingsfactor -althans voor inbreuken van een meer dan geringe duur- aanmerkelijk opgewaardeerd. De duur heeft onmiskenbaar een zelfstandige positie naast de zwaarte van de inbreuk gekregen, waarbij bovendien is vastgelegd in welke mate de duur invloed heeft op de omvang van de boete. Daarmee is niet gezegd dat de duur niet langer één van vele factoren is die de omvang van de

$423 \mathrm{~Pb} 1982 \mathrm{~L} 362 / 40$ (Walserijprodukten en zinklegeringen).

$424 \mathrm{~Pb} 1978$ L $46 / 33$.

$425 \mathrm{~Pb} 1994$ L. 243/1 (Karton), In meer algemene zin werd dit door het Gerecht in deze zaak bevestigd. "Bovendien beschikt de Commissie bij de vaststelling van het bedrag van elke geldboete over een beoordelingsmarge en kan zij niet verplicht worden geacht om daartoe een precieze mathematische formule toe te passen", Zie GvEA (T-295/94) Jur. 1998, II-863 (Buchmann).

426 Vergelijk tevens GvEA (T-43/92) Jur. 1994, II-441 (Dunlop Slazenger International): "Het Gerect! is evenwel van oordeel, dat de verlaging van de geldboete niet noodzakelijkerwijs evenredig behoeft te zijn aan de aldus verkorte duur van de inbreuken, zulks gelet op de zwaarte en het cumulatieve karaktervan de door de Commissie vastgestelde inbreuken gedurende de daadwerkelijkeduur ervan". Van evenredigheid van verlaging van de boete was evenmin sprake in GvEA (T-4/89) Jur. 1991. II-1523 (BASF): de boete met $15 \%$ verlaagd terwijl de inbreuk ongeveer 5 jaar in plaats van omstreds 6,5 jaar had geduurd. 
oete bepalen, maar wel dat het gewicht van deze factor is toegenomen. Op welke wijze it is gebeurd, zal in paragraaf 4.5 worden besproken.

\section{Preventie en voordeelsontneming}

Jeelnemers aan kartels hopen door hun deelname voordelen te verkrijgen. Deze voordelen ggen veelal op het gebied van handhaving of verbetering van de (financielle) positie f van de beperking van de verliezen. De drijfveer voor ondernemingen tot kartellering ; met andere woorden gelegen in de vaak aanzienlijke (potentiële) baten. Mededingingsbeerkend gedrag bergt echter ook risico's en dus -potentičle- kosten in zich. Deze bestaan nder meer -en voor zover in dit kader van belang- uit mogelijke boetes wegens inbreuken p het mededingingsrecht, waarbij de 'pakkans' alsmede de hoogte van de boete een il spelen. ${ }^{427}$ Een 'rationele' onderneming zal, alvorens tot bedoeld gedrag over te gaan, en afweging maken tussen de te verwachten kosten en baten. Wil er van het communauire recht een preventieve werking kunnen uitgaan, dan moet die afweging een voor ndernemingen negatieve uitkomst hebben; met andere woorden: de kosten moeten de aten overstijgen. Nu zal dit wellicht zelden het geval zijn ${ }^{428}$, maar de Commissie zal el zoveel mogelijk in het werk moeten stellen om een dergelijke situatie te benaderen. le inspanningen van de Commissie moeten dientengevolge gericht zijn op het voeren in een actief opsporingsbeleid enerzijds, met als doel een hoge pakkans van overtreders van het materiële recht, en het hanteren van een boeteniveau dat van voldoende omvang is om ondernemingen van overtredingen in de toekomst te weerhouden. ${ }^{429}$ Tegen deze achtergrond van generale preventie speelt een rol dat met het recht strijdig gedrag niet lonend zal mogen zijn. Kortom: eventuele winsten zouden (tenminste) aan de overtreder ontnomen moeten worden. Op beide aspecten van preventie wordt hieronder ingegaan.

\subsubsection{Preventieve werking}

De communautaire boete is bedoeld als directe straf en vergelding voor een begane inbreuk op de artikelen 81 en 82 EG. Dit blijkt mede uit het feit dat bij de strafoplegging rekening dient te worden gehouden met de zwaarte en de duur van de inbreuk. Daarnaast heeft zij een preventieve functie: zij moet ondernemingen ervan weerhouden om (nogmaals) een overtreding te begaan. De Commissie onderstreept dan ook

"de noodzaak om onwettige praktijken te doen ophouden en herhaling te voorkomen, waaruit de noodzaak resulteert een boete op te leggen die hoog genoeg is om zo'n onderneming af te schrikken". 40

427 Daarnaast behoren tot de kostenzijde onder meer de negatieve publiciteit die met cen (communautaire) inbreukprocedure gepaard gaat en de dreiging van civiele schadeclaims van gedupeerden.

428 Hetgeen in belangrijke mate ermee samenhangt dat de 'pakkans' over het algemeen relatief laag is. De verwachte kosten zijn dientengevolge eveneens beperkt. Zie over het belang van de pakkans Wils (1996), pag. 17 e.v..

429 Maar dat toch niet geheel voorspelbaar is. Het risico van een plotseling hogere boete dan in voorgaande gevallen, drukt namelijk zwaar op de preventiebalans.

$430 \mathrm{~Pb} 1980$ L $377 / 27$ (Johnson \& Johnson); zie in dit verband ook Pb 1982 L 161/32 (Hasselblad) en GvEA (T-24-26 en 28/93) Jur. 1996, II-1201 (Compagnie maritime belge transports e.a.). 
Dat naast deze speciaal preventieve aspecten ook generale preventie een rol speelt, blijkt uit de voor de boete-oplegging zeer belangrijke Pioneer-zaak. De Commissie was van mening dat het tot dan toe gehanteerde boeteniveau ontoereikend was, aangezien karteis nog steeds tot de dagelijkse realiteit behoorden. Zij besloot dan ook met het oog op de generaal preventieve werking van de sancties tot een drastische verhoging van het boeteniveau voor de meest ingrijpende inbreuken op het mededingingsrecht. ${ }^{431}$ Het Hof gaf hieraan zijn fiat; het stelde dat tot de toezichthoudende taak van de Commissie niet alleen

\begin{abstract}
"de verplichting om individuele inbreuken te onderzoeken en te bestraffen (behoort), maar zij omvat ook de verplichting om een algemeen beleid te voeren dat erop is gericht, op het gebied van de mededinging toepassing te geven aan de door het Verdrag vastgestelde beginselen en het gedrag van de ondernemingen in overeenstemming met deze beginselen te sturen. Daaruit volgt dat de Commissie bij de beoordeling van de ernst van een inbreuk met het oog op de vaststelling van de hoogte van de boete niet enkel de bijzondere omstandigheden van het geval, maar ook de context waarbinnen de inbreuk is gepleegd, in aanmerking moet nemen en ervoor moet zorgen dat haar optreden een preventieve werking heeft. (. ) Voor een doeltreffende toepassing van de communautaire mededingingsregels moet de Commissie het niveau van de geldboetes juist op elk moment aan de eisen van (het mededingingsbeleid) kunnen aanpas$\operatorname{sen}^{\prime \prime},{ }^{3 \prime \prime}$
\end{abstract}

Deze instrumentalistische visie van het Hof onderstreept dat de boete mede een middel is waarmee de realisering van de doeleinden van het EG-Verdrag bevorderd kan worden. ${ }^{43}$ De Commissie zal steeds bij de bepaling van de strafmaat moeten nagaan in hoeverre de op te leggen sanctie van voldoende gewicht is om ondernemingen te weerhouden van mededingingsbeperkingen. ${ }^{434}$ De sanctie die een overtredende onderneming tegemoet kan zien, wordt daarmee niet uitsluitend bepaald door de zwaarte (waarondet hier begrepen de bijzondere omstandigheden van het geval) en duur van de inbreuk maar tevens door beleidsoverwegingen die gericht zijn op een goede werking van het EG-Verdrag. De plicht van de Commissie om rekening te houden met de preventieve functie van de boete kan een relatief hoge boete opleveren, zij het dat de Commissie ook hier de proportionaliteitsgrenzen in acht zal moeten nemen. Omdat de boete steeds in een redelijke verhouding tot de begane overtreding moet staan, dient de Commissie -ook indien er sprake is van een schadelijk kartel waarvoor uit preventief oogpunt een hoge

431 Kritisch over dergelijke stappen Elles (1995), pag. 5-6.

432 HvJ (100-103/80) Jur. 1983, 1882 (Musique Diffusion Française). Op het preventieve doel van de boetes werd door het Hof reeds eerder gewezen: HvJ (41/69), Jur. 1970, 661 (ACF Chemiefarma), HvJ (44/69) Jur. 1970, 733 (Buchler), HvJ (45/69) Jur. 1970, 769 (Boehringer Mannheim) en Hv] (49/69) Jur. 1972, 713 (BASF). Zie tevens GvEA (T-12/89) Jur. 1992, II-907 (Solvay), GvEA (T-13/89) Jur. 1992, II-1021 (Imperial Chemical Industries), GvEA (T-14/89) Jur. 1992, II-11 55 (Montedipe). GvEA (T-29/92) Jur. 1995, II-289 (Vereniging van Samenwerkende Prijsregelende Organisaties in de Bouwnijverheid e.a.) en GvEA (T-143/89) Jur, 1995, II-917 (Ferriere Nord). GvEA (T-304/94) Jur. 1998, II-869 (Europa Carton), GvEA (T-308/94) Jur. 1998, II-925 (Cascades), GvEA (T-311/94) Jur. 1998, II-1129 (BPB de Eendracht), GvEA (T-347/94) Jur. 1998, II-1751 (Mayr-Melnhof Kartongerellschaft), GvEA (T-352/94) Jur. 1998, II-1989 (Mo och Domsjö) en GvEA (T-141/94) Jur. 1999. II-357 (Thyssen Stahl).

433 In GvEA (T-150/89) Jur. 1995, II-1165 (Martinelli) alsmede in GvEA (T-49/95) Jur. 1996, II-1799 (Van Megen Sports Group) en GvEA (T-229/94) Jur. 1997, II-1689 (Deutsche Bahn) benadrubte het Gerecht dat de geldboete "een instrument van het mededingingsbeleid van de Commissic" is.

434 Hierbij is niet in de laatste plaats het nominale bedrag van de boete van belang. 
boete geindiceerd is- de boete te matigen voorzover de bijzondere omstandigheden van het geval hiertoe aanleiding geven.

\subsubsection{Voordeelsontneming}

$\mathrm{D} e$ animo voor ondernemingen om tot kartellering over te gaan, kan zeer groot zijn, angezien kartels vaak lucratieve vooruitzichten bieden. Met het oog op de verwezenlijking van de communautaire doelen is aan de Commissie de taak om dit enthousiasme te temperen. Hieraan zou winstontneming een belangrijke bijdrage kunnen leveren: indien bij veroordeling wegens overtreding van artikel 81 of 82 EG in ieder geval de gehele winst zou moeten worden ingeleverd, dan zou dit bij een 'redelijke onderneming' een prikkel om tot een kartel te komen, wegnemen. ${ }^{435}$ Zeker indien de pakkans aanzienlijk zou zijn, zou van winstontneming (met daarbovenop nog een boete) een aanzienlijke preventieve werking uitgaan. Het communautaire kartelrecht kent echter, in tegenstelling tot het Nederlandse strafrecht ${ }^{436}$, geen afzonderlijke maatregel die ontneming mogelijk maakt. Wil de Commissie desalniettemin de winsten ontnemen ${ }^{437}$, dan zal haar instrument de boete van artikel 15 Vo 17 moeten zijn. De boetemarge vormt in dit kader geen obstakel: zij zal doorgaans toereikend zijn om het behaalde voordeel te ontnemen, aangezien dit voordeel naar verwacht mag worden zelden meer dan $10 \%$ van de totale omzet zal bedragen. ${ }^{48}$ Toch is ontneming langs de weg van de boete minder geschikt door de zij het in het communautaire recht beperkte- werking van het draagkrachtbeginsel. Tenminste voor de gevallen waarin (volledige) ontneming van winsten de financiële positie van een onderneming ernstig zou aantasten, zou die ontneming achterwege moeten blijven. Daar komt nog bij dat deze weg naar mijn mening geen voorkeur verdient. Aldus zou namelijk de winst -voor zover aanwezig- de overheersende strafmaatfactor dreigen te worden. De boete zou dan immers -binnen de grenzen van de draagkracht- in ieder geval een bedrag ter hoogte van het behaalde voordeel moeten belopen, met eventueel een 'toeslag' als reactie en vergelding voor de begane overtreding. Voor toepassing van strafverminderende factoren, bijvoorbeeld omdat een onderneming weinig valt te verwijten, is dan nauwelijks nog ruimte; en de ruimte die resteert, is beperkt tot de berekening van bedoelde 'toeslag'. Op die wijze verkrijgt de behaalde winst een mijns inziens disproportio-

435 Zo ook Gyselen (1993), pag. 69. Overigens ziet Gyselen de aandacht voor het behaalde voordeel in relatie tot de duur van de inbreuk omdat "the companies make their profits as long as their infringement lasts". Hoewel deze relatie evident is (althans voor zover het kartel gericht is op het behalen van financieel voordeel), is het verband tussen duur als straftoemetingsfactor en de behaalde winst mijns inziens cen relatief los verband. Waar het bij de winstontneming primair om gaat, is de bevordering van de preventie; inachtneming van de duur van de inbreuk is met name gericht op repressie.

436 Artikel $36 \mathrm{e}$ WvSr en met betrekking tot economische delicten art 8 sub a WED, welk artikel verwijst naar het Wetboek van Strafrecht.

437 Hetgeen bepaaldniet eenvoudig zal zijn, gelet op de problemen om de onrechtmatige winst te berekenen. De concrete situatie zal dan immers vergeleken moeten worden met een hypothetische, te weten die waarin geen kartel actief zou zijn geweest.

438 Winkler (1971), pag. 61, stelt zelfs in dit verband, "daß der große Strafrahmen des Art. 15 Abs. 2 VO 17 (...) weniger zur Auferlegung eines empfindlichen zusätzlichen Strafubels als vielmehr dazu dient, neben der Schwere des VerstoBes und der Dauer der Zuwiderhandlung (...) den unrechtmă Big clangten Vorteil berücksichtigen zu können, den der Täter aus seiner wettbewerbs- oder sonst marktordnungswidrigen Handlung gezogen hat". 
neel en daarmee onaanvaardbaar gewicht in de boete. Een oplossing hiervoor zou kunnen zijn om een afzonderlijke ontnemingsmaatregel te scheppen, vergelijkbaar met hetgeen in het Nederlandse strafrecht is gebeurd. Daar is in $1983^{439}$ de maatregel ter ontneming van wederrechtelijk verkregen voordeel in het commune strafrecht ${ }^{40}$ geïntroduceerd, welke maatregel in $1993^{4+1}$ aanmerkelijk is uitgebreid. Tot $1983^{442}$ was afroming van winsten in het Nederlandse commune strafrecht eveneens slechts via de boete mogelijk. De wetgever heeft echter aan een aparte ontnemingsmaatregel de voorkeur gegeven, omdat hiermee de mogelijkheden tot winstafroming konden worden verruimd, maar ook omdat dit dogmatisch beter in het Nederlandse strafrechtelijke systeem paste met zijn onderscheid tussen (leedtoevoegende) straf en (de maatschappij beschermende) maatregel. ${ }^{43}$ Daarmee werd tevens bereikt dat het draagkrachtbeginsel -dat immers slechts voor straffen geldtbuiten de deur bleef, hetgeen uit instrumenteel oogpunt wenselijk werd geacht. ${ }^{44} \mathrm{Hoewel}$ het communautaire recht een dergelijk verschil tussen straf en maatregel niet kent, zou, zoals gezegd, indien men echt de ontnemingsmogelijkheden tot op de bodem zou willen benutten, een aparte ontnemingsregeling kunnen worden ingevoerd, die afzonderlijk kan worden opgelegd. Maar ook dit zou mijns inziens geen bijval verdienen, en wel omdat dit tot een disproportionele bestraffing van een onderneming met een wankele financiele basis zou kunnen leiden. Feit blijft dan dat een dergelijke bestraffing niet binnen de communautaire doelstellingen past. De conclusie zou mijns inziens moeten luiden dat weliswaar met de winsten rekening wordt gehouden bij de bepaling van de strafmaat ${ }^{\text {ts }}$ en dat hieraan ook groot gewicht wordt toegekend, maar dat onverminderd andere factoren een proportionele invloed op de boete moeten kunnen blijven uitoefenen. Aldus wordt bereikt dat eventuele winsten een belangrijke, maar geen alles overheersende rol spelen in het kader van de straftoemeting en dat er dus een zekere mate van preventie kan worden gerealiseerd zonder dat aan eventuele strafverminderingsgronden wordt voorbij gegaan.

Het is niet geheel duidelijk welke weg de Commissie in haar beschikkingspraktijk tot 1998 heeft gekozen. In de Kawasaki-beschikking ${ }^{46}$ besteedde de Commissie uitdrukkelijk aandacht aan het behaalde voordeel en ging zij na welke gevolgen het met betrekking tot motoren gehanteerde exportverbod voor consumenten had gehad. Verder dan een raming van de schade voor consumenten (en daarmee de winst van de ondernemingen) kwam zij niet: de Commissie kwam uit op een bedrag van tenminste 100.000 rekeneenheden voor Duitsland en tenminste 500.000 rekeneenheden voor de hele Gemeenschap. Het voordeel kon echter niet worden ontnomen daar de Duitse onderneming die het meest profiteerde van het kartel niet werd beboet; de boete die Kawasaki Motors UK werd

439 Wet vermogenssancties, 31 maart 1983, Stb. 153.

440 Voor het economische strafrecht bestond deze maatregel reeds langer.

441 Wet verruiming vermogenssancties van 10 december 1992, Stb. 1992, 11.

442 Keyser-Ringnalda (1994), pag. 11 en 14 evenals Hazewinkel-Suringa/Remmelink (1996), pag 699, constateren dat winstafroming door middel van de boete ook na bedoelde invoering nog wordt toegepast en dat de huidige regeling deze toepassing ook niet verbiedt.

443 In de optiek van de toenmalige minister van Justitic Hirsch Ballin was ontneming uitsluitend gericht op bescherming van de maatschappij en moest dus als maatregel worden aangemerkt.

444 MvT, TK 1989-1990, 21504, nr.3, pag. 8.

445 Hetgeen zoals bleek ook is geoorloofd; vergelijk HvJ (100-103/80) Jur, 1983, 1882 (Musique Diffirsion Française).

$446 \mathrm{~Pb} 1979$ L. 16/9 (Kawasaki). 
opgelegd bedroeg (ondanks het feit dat het een exportverbod betrof) slechts 100.000 rekeneenheden. In de Eurocheque-beschikking ${ }^{447}$ was het verband tussen voordeel en boete beduidend sterker aanwezig. De Commissie makkte een (overigens zeer ruwe ${ }^{445}$ ) schatting van het uit het kartel behaalde voordeel en kwam uit op een onrechtmatige winst van ongeveer vijf miljoen ecu. Aan de vereniging die dit voordeel had behaald werd een met deze winst corresponderende boete opgelegd. Een hogere boete werd van de hand gewezen met de opmerkelijke overweging dat de verzachtende omstandigheden de verzwarende omstandigheden in het voorliggende geval compenseerden. ${ }^{499}$ Hoewel het erop lijkt dat de Commissie hier heeft aangestuurd op afroming van de winsten, mag deze conclusie blijkens het verweer van de Commissie in het tegen deze beschikking ingestelde beroep niet worden getrokken: de raming van de behaalde voordelen zou slechts een van de strafmaatfactoren zijn geweest, "waarbij de beschikking geen enkel rechtstreeks verband legt tussen deze raming en het bedrag van de geldboete". ${ }^{450}$ Aangezien het Gerecht het deel van de inbreuk waarop de raming van de winst betrekking had niet bewezen achtte, was de raming niet meer relevant en hoefde het Gerecht zich niet uit te laten over in hoeverre de winsten een rol spelen.

De conclusie moet zijn dat de Commissie tot 1998 op zijn minst zeer terughoudend is geweest om artikel 15 Vo 17 mede aan te wenden voor voordeelsontneming: slechts in de Eurocheque-beschikking en in mindere mate in de Kawasaki-beschikking zijn de winsten uitdrukkelijk aan de orde gekomen. Er mag dan ook niet van uit worden gegaan dat voor het overige ontneming van winsten een punt van overweging bij de Commissie is geweest, waarmee niet is gezegd dat met de winsten bij de boetebepaling geen rekening wordt gehouden. Dit is in zoverre verbazend dat binnen DG-IV toch het gevoelen lijkt te bestaan dat het boeteniveau ontoereikend is voor een adequate preventie. ${ }^{451}$ Wellicht dat ook bij de Commissie de bezwaren tegen een onverkorte verrekening van de voordelen op bezwaren stuit.

$447 \mathrm{~Pb} 1992 \mathrm{~L}$ 95/50 (Eurocheque: overeenkomst van Helsinki).

448 De schatting werd gebaseerd op a) het gemiddelde bedrag op eurocheques; b) het jaarlijkse aantal eurocheques; c) de gemiddelde commissie voor banken per eurocheque en d) de duur van de inbreuk. Het totale aldus verkregen bedrag ( 6,5 miljoen ECU) werd aangepast omdat het aantal eurocheques gedurendeeen bepaaldeperiode van de inbreuk "enigszins geringer zal zijn geweest" dan één miljoen. Duidelijk is dat een niet meer dan globale berekening van de winsten door de Commissie wordt doorgevoerd.

449 Het betrof in casu prijsafspraken waarbij aanzienlijke winsten werden behald, hoewel dit niet het primaire doel was van de afspraken. Strafverminderend werkte dat het de eerste boetebeschikking in de banksector betrof en dat de Commissie zelf in een eerder stadium had verzuimd de gemaakte afspraken onder de loep te nemen. In Pb 1992 L 134/1 (Frans-Westafrikaanse rederscomités) kan een bescheidenaanzet worden gevonden om rekening te houden met de voordelen van het kartelmatig gedrag. In deze beschikking vergelijkt de Commissie de prijzen en de omzet die binnen het kartel is bereikt met die welke buiten het kartel om -en dus in een grotere mate van mededinging- werd gerealiseerd. Niet duidelijk is echter of de Commissie hier daadwerkelijkde winsten trachtte te ramen (teneinde deze te ontnemen), hetgeen door Gyselen (1993), pag. 69, wordt betoogd, of slechts de nadruk wilde leggen op de grote effectiviteit van het kartelmatig gedrag. Hoe dit ook zij, door verzachtende omstandigheden werd de boete gematigd.

450 GvEA (T-39 en 40/92) Jur. 1994, II-49 (Groupement des cartes bancaires 'CB' en Europay Interna. tional).

451 Vergelijk De Raat (1994). 


\subsection{Het communautaire boetebeleid sinds 1998}

In 1998 achtte de Commissie de tijd rijp om enige belangrijke wijzigingen in haar boetebe. leid in te voeren. De reden hiervoor was om dit beleid doorzichtiger, objectiever en beter controleerbaar te maken. Daartoe heeft zij in een bekendmaking nieuwe richtsnoeren voor de bepaling van de omvang van de geldboete neergelegd. ${ }^{\$ 2}$ Uitgangspunt is dat het bedrag van de boete bestaat uit een basisbedrag, berekend aan de hand van de zwaarte en de duur van de inbreuk, waarna vervolgens strafverzwarende en strafverzachtende omstandigheden tot aanpassing van het boetebedrag aanleiding kunnen geven. Hiervoor is gebleken dat de Commissie deze methode impliciet reeds voordien heeft toegepast. De bekendmaking draagt er echter zorg voor dat het beleid in de beschikkingen (nog) beter zichtbaar wordt. Bovendien zijn er enkele zeer belangrijke verschillen met het beleid zoals dat tot 1998 werd gevoerd. Ten eerste is de boete niet langer (primair) een aan de omzet van de onderneming gerelateerd cijfer, maar wordt uitgegaan van een absoluut bedrag dat is gekoppeld aan de zwaarte van de inbreuk. Aldus wordt de inbreuk zelf (nog) meer in het centrum van de straftoemeting geplaatst, hetgeen vanuit de gedachte dat de boete een punitieve reactie op de daad is, ook meer voor de hand ligt. Het gevolg is wel dat de omvang van de onderneming meer op de achtergrond raakt en dat ondernemingen die een vergelijkbaar verwijt te maken valt, wellicht absoluut gelijke, maar procentueel toch verschillende boetes kunnen krijgen. Dit hoeft echter geen probleem op te leveren, zolang de grenzen van de evenredigheid maar niet worden overschreden. En mogelijkheden om de evenredigheid in acht te nemen en om per onderneming te differentiěren zijn er volop: de door de Commissie gehanteerde boetemarges per categorie inbreuk laten daarvoor genoeg ruimte evenals de mogelijkheden om een strafverlagende en -verhogende omstandigheid in aanmerking te nemen. ${ }^{453}$ Het is niet te verwachten dat deze aanpassing van de Commissie al te grote praktische veranderingen teweeg zal brengen. ${ }^{454}$ Dat is anders ten aanzien van het tweede verschil met het beleid tot 1998: de verzwaring van de rol van 'de duur van de inbreuk' als straftoemetingsfactor. De Commissie stelt:

"In het algemeen zal de verhoging voor inbreuken van lange duur voortaan aanzienlijk meer bedragen dan tot dusver gebruikelijk was, teneinde beperkingen van de concurrentie die de consument op duurzame wijze schade hebben berokkend, daadwerkelijk te bestraffen".

Waar hierboven reeds is geconstateerd dat de Raad een grotere rol aan de duur was toegedicht dan deze in de praktijk kreeg, daar lijkt de Commissie zich dit -in een poging om de boete nog afschrikkender te maken- nu ook te realiseren. De bijdrage die de duur levert aan de vaststelling van de boete wordt aanmerkelijk opgewaardeerd door deze straftoemetingsfactor een afzonderlijke status naast de zwaarte van de inbreuk toe te kennen.

452 Richtsnoeren voor de berekening van geldboetendie uit hoofde van artikel 15, lid 2, van Verordenin! nr. 17, respectievelijk artikel 65, lid 5, van het EGKS-Verdrag worden opgelegd, $\mathrm{Pb} 1998 \mathrm{C} 9 / 3$

453 Wils (1998), pag. 262, stelt in dit verband dat "fairness may require differentiation according to size or market share in cases of considerable disparity between the different undertakings concemed" Volgens Richardson (1999), pag. 362, "the Commission will look at the different sizes of undertaking committing infringements of the same type in setting the gravity level of the fine".

454 Bchoudens wellicht een verhoging van het algemene boeteniveau, maar dat is een beleidskwestie 
Concreet houdt de nieuwe berekeningswijze van de boete het volgende in. ${ }^{45}$ Allereerst wordt een (voorlopig) boetebedrag bepaald aan de hand van de zwaarte van de inbreuk. Bij de zwaarte spelen de volgende aspecten een rol: de aard van de inbreuk, de weerslag op de markt (dus in feite de gevolgen voor de mededinging) en de omvang van de betrokken geografische markt. Mede aan de hand van deze aspecten heeft de Commissie een onderscheid gemaakt tussen 'niet te ernstige inbreuken', 'zware inbreuken' en 'zeer zware inbreuken'. Tot de categorie 'niet te ernstige inbreuken' worden (voornamelijk verticale) kartels gerekend die beperkte gevolgen hebben op een relatief gering deel van de communautaire markt. Bij deze inbreuken is een boete van 1.000 tot 1 miljoen ecu het uitgangspunt (de 'voorlopige boete'). Zware inbreuken worden gevormd door horizontale of verticale kartels met verdergaande gevolgen op een aanzienlijker deel van de communautaire markt en door schendingen van artikel 82 EG. De 'voorlopige boete' voor deze overtredingen varieert in beginsel van 1 miljoen tot 20 miljoen ecu. De zeer zware inbreuken tenslotte worden gevormd door (met name horizontale) kartels betreffende vaststelling van prijzen, marktverdeling, exportverboden en dergelijke alsmede door misbruik van een machtspositie door ondernemingen met een (vrijwel) monopolistische positie. Het uitgangspunt ten aanzien van deze inbreuken is een 'voorlopige boete' van tenminste 20 miljoen ecu. ${ }^{456}$ Als de voorlopige boete is bepaald, dan hangt het van de duur van de inbreuk af of deze boete nog zal worden verhoogd. Voor schendingen van de mededingingsregels van korte duur (volgens de Commissie in beginsel minder dan één jaar) wordt geen extra bedrag 'in rekening' gebracht. De boete voor inbreuken van middellange duur (én tot vijf jaar) wordt verhoogd met maximaal $50 \%$, terwijl de verhoging voor overtredingen van lange duur (meer dan vijf jaar) $10 \%$ van de 'voorlopige boete' per jaar bedraagt. Het basisbedrag van de boete wordt dan gevormd door de 'voorlopige boete' plus de eventuele verhoging wegens de duur van de inbreuk.

455 De mogelijkheid is overigens uitdrukkelijk open gelaten om symbolische boetes ter hoogte van 1.000 euro op te leggen, waarbij derhalve de hierna te beschrijven berekening niet plaatsvindt. Deze mogelijkheid is in praktijk gebracht in $\mathrm{Pb} 2000 \mathrm{~L}$ 5/55 (WK Voetbal 1998). Bij de kaartverkoop had het organiserende comité misbruik gemaakt van zijn machtspositie. Omdat echter dit comité geen opzet had gehad (de toegepasteverkoopregelingenstemden in grote lijnen overeenmet die welke bij cerdere wereldkampioenschappenvoetbal warengehanteerden het comitéhadniet uit eerderecommunautaire beschikkingen of jurisprudentie kunnen afleiden dat zijn handelen strijdig was met het EG-recht) en omdat het bereid was gebleken zijn gedrag op het recht af te stemmen, achtte de Commissie een boete van slechts 1000 euro passend. Wel voegde zij er uitdrukkelijk aan toe dat dit niet de gedragslijn was die in toekomstige soortgelijke gevallenzou worden gevolgd. Dezelfde symbolische boete werd opgelegd aan een van de betrokken ondernemingen in $\mathrm{Pb} 2001$ L 54/1 (Nathan-Bricolux), en wel met name omdat het een kleine onderneming betrof die zeer coőperatief was.

456 De discretionaire vrijheid die binnen deze drie boetecategorieên overblijft, is zeer aanzienlijk. De 'voorlopige boetes' kunnen dan ook binnen één categoric aanmerkelijk verschillen. Voor de nadere bepaling van de omvang van de 'voorlopige boete' dient blijkens de mededeling onder meer rekening gehouden te worden met de aard van de inbreuk, de daadwerkelijke economische macht van de overtredet en het feit dat omvangrijke ondernemingen op de hoogte moeten zijn van de gevolgen van hun gedrag. Daarenboven meldt de mededeling expliciet dat van de geldboete een voldoende afschrikkende werking moet uitgaan. De bedoelde ruimte biedt voorts de mogelijkheid om te differentiëren naar onderneming: een omvangrijke onderneming zal veelal een groter gewicht in de kartel-schaalleggen en zij verdient dan ook een relatief (en absoluut) hogere boete dan een relatief kleine onderneming. ondanks het feit dat de aard van de gedraging voor beide gelijk is. 
Dit basisbedrag vormt, zoals de term reeds aangeeft, de grondslag van de op te leggen boete. Het uiteindelijke boetebedrag wordt verkregen door het basisbedrag te verhogen respectievelijk te verlagen door het verdisconteren van strafverzwarende respectievelijk strafverzachtende omstandigheden. De bekendmaking van de Commissie noemt -niet limitatief ${ }^{457}$ - in dit verband de volgende omstandigheden. Als verzwarend worden aange. merkt:

- recidive;

- weigering van medewerking of obstructie van het onderzoek;

- een leidinggevende of initiêrende rol:

- retorsiemaatregelen tegen andere ondernemingen teneinde deze het kartelgedrag te doen naleven, en ontneming van onrechtmatige winsten.

Als strafverlichtende omstandigheden noemt de bekendmaking:

- een passieve rol bij de tot stand brenging van de inbreuk;

- het niet in praktijk brengen van de mededingingsbeperkende gedragingen;

beêindiging van de inbreuk in een vroeg stadium van het onderzoek (met name bij verificaties); het bestaan van een redelijke twijfel bij de onderneming omtrent het inbreukmakende karakter vam het mededingingsbeperkend gedrag:

- het begaan van de inbreuk louter uit onachtzaamheid, en

- co-operatic tijdens de procedure.

Met betrekking tot deze factoren is er niets nieuws onder de zon; zij zijn ontleend aan de boetepraktijk tot 1998. Opmerkelijk wellicht is de rol van de mate van verwijtbaarheid. Klaarblijkelijk gaat de Commissie er van uit dat een opzettelijke inbreuk de normalc situatie is en dat het handelen louter uit onachtzaamheid een strafverminderingsfactor oplevert. Het zal dus -misschien nog meer dan voorheen- aan de ondernemingen zijn om met goede argumenten de Commissie ervan te overtuigen dat slechts van verwijtbaarheid sprake was.

In beginsel staat na de verdiscontering van eventuele strafverzwarende of strafverlichtende omstandigheden de boete vast. Conform de praktijk tot 1998 dient de Commissie echter bij de straftoemeting rekening te houden met -in de woorden van de bekendmakingbepaalde objectieve gegevens, waaronder de specifieke economische context, het behaalde economische of financiële voordeel, specifieke kenmerken van de betrokken ondernemingen en hun vermogen om een boete te kunnen betalen (een soort draagkrachtbeginsel derhalve). ${ }^{458}$

Beziet men het voorgaande, dan kan geconcludeerd worden dat de bekendmaking inderdaad een grotere doorzichtigheid en overzichtelijkheid ten aanzien van de berekening van de

457 Omdat de opsomming niet uitputtend is en omdat de genoemde strafverzwarende respectievelijkverzachtendeomstandighedenontleendzijn aan de beschikkingspraktijkvan de Commissie tot 1998 , blijft deze praktijk ook nu nog zijn relevantie behouden voor de in aanmerking te nemen strafvertiogende of strafverlagende omstandigheden.

458 Het behaalde voordeel kan dus in tweeêrlei opzicht een strafverzwarende rol spelen: ten cerste als strafverzwarende omstandigheid als zodanig en ten tweede als factor waarmee aan het einde van de straftoemeting nog rekening kan worden gehouden. Een dergelijke rol voor het voordeel ligt ook in de lijn van hetgeen door mij is bepleit in paragraaf 4.4.2. 
boete heeft gerealiseerd. ${ }^{459}$ Ondernemingen kunnen nog beter dan voorheen inschatten waar zij aan toe zijn, zeker gelet op de indeling naar zwaarte van inbreuk met daaraan gekoppeld de 'voorlopige boetebedragen'. Dit betekent echter geenszins dat de hoogte van de boete met zekerheid kan worden voorspeld. ${ }^{460}$ Tal van aspecten, waaronder het streven naar winstontneming, de eis dat boetes afschrikkend moeten werken alsmede de onzekerheid omtrent het gewicht dat de Commissie aan de verschillende verzwarende en verzachtende omstandigheden toekent, staan hieraan in de weg. Een volledige vastlegging van de boete -indien mogelijk- zou ook geen voorkeur verdienen omdat dan onvoldoende rekening met de bijzondere omstandigheden van het geval zou kunnen worden gehouden en omdat in die situatie het preventieve karakter van de boete mogelijk zou worden aangetast: indien een berekenende onderneming vooraf de kosten van een overtreding exact zou kunnen inschatten, dan zou zij bij hogere te verwachten winsten ongetwijfeld voor het onrechtmatige gedrag kiezen. Enige onzekerheid omtrent de omvang van de boete kan dan ook preventief werken. ${ }^{461}$

De bekendmaking, mede tegen het licht van de eerder besproken mededeling van de Commissie betreffende het niet opleggen of verminderen van boetes, maakt bovendien duidelijk dat het speerpunt van de Commissie ligt bij de opsporing en beboeting van de zwaarste vormen van mededingingsbeperkend gedrag. Hoge boetes liggen dan ook in het verschiet. Mijns inziens mag zelfs voor bedoelde inbreuken redelijkerwijs een stijging van het boete-niveau verwacht worden. Dat houdt niet alleen verband met het feit dat het standpunt van de Commissie ten aanzien van die inbreuken genoegzaam bekend is en dat de Commissie -in de strijd tegen die gedragingen- het 'afschrikkingsaspect' van de boete beter zal willen benutten, maar tevens met de prominentere rol die de duur van de inbreuk bij de bepaling van de boete is gaan spelen.

De boete-beschikkingen na de bekendmaking in 1998 tonen aan dat de voorgaande verwachting inderdaad wordt bewaarheid. Illustratief is in dat verband de Volkswagen-beschik$\mathrm{king}^{462}$, waarin de mededeling inzake de berekening van boetes nauwgezet is toegepast $^{463}$ en waarin uiteindelijk een boete van liefst 102 miljoen ecu aan Volkswagen $A G$ is opgelegd. Het betrof een opzettelijke verhindering van paralleluitvoer van nieuwe motorvoertuigen uit Italie̋ naar met name Duitsland en Oostenrijk. De gedragingen, die

459 Aldus eveneens Wils (1998), pag. 257. Kritisch daarentegen Richardson (1999), pag. 365 e.v. en tot op zekere hoogte eveneens Spink (1999), pag. 108.

460 Het betekent bovendien niet dat de communautaire rechters aan de Richtsnoeren gebonden zouden zijn. Dit wordt nog eens onderstreept door GvEA (T-62/98) n.n.g. (Volkswagen).

461 Anders: Wils (1998), pag. 256. Al te zwaar gewicht moet aan deze preventieve werking overigens niet worden toegekend. De boetes -gekoppeld aan de pakkans) zijn veelal (nog) niet van dien aard dat zij de te verwachten voordelen van kartellering overstijgen. Dat moge reeds blijken uit het feit dat, ondanks zeer aanzienlijke boetes wegens inbreuken op het communautaire mededingingsrecht, dergelijke inbreuken nog zeer frequent voorkomen.

$462 \mathrm{~Pb} 1998 \mathrm{~L}$ 124/60 (VW).

463 Dit is niet steeds het geval. In $\mathrm{Pb} 1999$ L 76/1 (British Sugar) nam de Commissie ten aanzien van de ondernemingen met een geringe invloed op de markt bij de bepaling van het basisbedrag ook in haar overwegingen mee dat deze ondernemingen niet aan een belangrijke bijeenkomst hadden deelgenomen en dat zij slechts enkele maanden na de aanvang van het karteimatig gedrag tot het kartel waren toegetreden. Deze aanpak is de facto niet in overeenstemming met de Richtsnoeren van de Commissie, aangezien het hier strafverzachtende omstandigheden betreft die derhalve na de bepaling van het basisbedrag in aanmerking genomen moeten worden. 
werden ontplooid door de autofabrikant met het grootste marktaandeel in de Europese Gemeenschap, waren zeer succesvol en hadden dus verstrekkende gevolgen voor de mede. dinging. De Commissie kwalificeerde de inbreuk als 'zeer zwaar' en achtte een boete geindiceerd 'die door haar afschrikkende werking herhaling uitsluit'. ${ }^{464} \mathrm{Om}$ dit te realise. ren, werd als uitgangspunt een boete van 50 miljoen ecu gekozen. De duur van de inbreuk had 10 jaar bedragen. Voor zes jaar werd een verhoging van $5 \%$ in rekening gebracht, terwijl voor de vier jaar waarin de intensiteit van de inbreuk groter was $10 \%$ verhoging noodzakelijk werd geacht. Totaal bedroeg de verhoging derhalve $70 \%$ van de 'voorlopige boete', zijnde 35 miljoen ecu. ${ }^{465}$ Het basisbedrag van de boete was dientengevolge 85 miljoen ecu. Daar kwam nog een verhoging van $20 \%$ bovenop wegens strafverzwarende omstandigheden, die in casu bestonden uit enerzijds het voortzetten van de inbreuk door de onderneming nadat zij door de Commissie tot tweemaal toe erop was gewezen dat verhindering van parallel-export tegen het EG-Verdrag indruiste, terwijl de onderneming wel de indruk had gewekt dat de inbreuken waren beëindigd (de Commissie werd met

464 Aldus eveneens $\mathrm{Pb} 2001 \mathrm{~L}$ 59/1 (OpeI), waarin een bedrag van 40 miljoen euro werd aangehouden. Zeer ernstig was ook de inbreuk (prijs- en quotakartel) in $\mathrm{Pb} 2001 \mathrm{~L}$ 152/24 (Aminozuren). In Pb 1999 L. 109/24 (Griekse veerdienstmaatschappijen) was er weliswaar sprake van een prijsafsprak, en dus in beginsel van een zeer ernstige inbreuk, maar de gevolgen waren gering en geografisch was de markt zeer beperkt. Daarom concludeerde de Commissie 'slechts' tot een emstige inbreuk. In $\mathrm{Pb} 1998 \mathrm{~L}$ 252/47 (Amministrazione Autonoma dei Monopoli di Stato) was de gedraging erop gericht om "systematisch ernstige hinderpalen op te werpen voor de toegang van concurrerendeproducenten tot de Italiaanse sigarettenmarkten hun uitbreidingsmogelijkhedenop die markt te beperken". Omdat de gevolgen in de praktijk relatief gering waren (met name ten gevolge van bepaalde overheidsmatre gelen) en de inbreuk beperkt bleef tot één lidstaat, werd tot een 'zware inbreuk' geconcludeerddie een 'voorlopige boete' opleverde van 3 miljoen ecu. Vergelijkbaar Pb 2000 L. 268/1 (Far East Trade Tariff Charges and Surcharges Agreement). In Pb 1999 L 76/1 (British Sugar) was er sprake van een opzettelijke (horizontale) coördinatie van de prijsvaststelling van suiker op de Britse markt door ondememingen die gezamenlijk ongeveer $90 \%$ van de relevante markt in handen hadden. De omstandig heden dat de Commissie de eventuele gevolgen niet in haar beschikking betrok en dat het gedrag beperkt bleef tot het grondgebied van één lidstaat zwakten de ernst van de gedragingen weliswart af, maar de Commissie concludeerde toch tot een zware inbreuk. In Pb 2000 L 30/1 (Virgin/British Airways) was er sprake van een ernstige inbreuk, vormgegeven door een kortingsregeling, waardoor British Airways ondanks deregulering haar marktpositie kon behouden. Daarnaast was van belang dat de kosten van het luchtvervoer zowel voor consumentenals voor het bedrijfsleven een belangrijke factor waren. Pb 2000 L 39/1 (Nederlandse Federatieve Vereniging voor de Groothandel op Elektrotectnisch Gebied en Technische Unie) betrof een collectieve exclusief-verkeersregeling in combinatic met horizontale prijsafspraken, gecoördineerd en gecontroleend door een ondememersvereniging warbig ondernemingen waren aangesloten die tezameneen marktaandeelvan liefst $96 \%$ hadden. Ten aanzien van de zwaarte woog de Commissie mee dat de geografische markt beperkt was tot (regio's binnen) Nederland en dat de betrokken ondernemersvereniging een leidende rol had bij het functioneren van het kartel. In $\mathrm{Pb} 2001$ L 54/1 (Nathan-Bricolux) werd een in beginsel ernstige inbreuk afgezwakt tot 'weinig zwaar' omdat de toepassing ervan niet systematisch geschiedde.

465 In Pb 2001 L. 59/1 (Opel) werd een inbreuk van middellange duur geconstateend, hetgeen een verhoging van 7,5\% tot gevolg had. Middellang was ook de overtreding in Pb 2001 L 54/1 (Nathan-Bricolusx), waarbij de toepassing slechts in é̉n jaar plaatshad, als gevolg waarvan de boete werd verhoogd met $20 \%$ en in Pb $2001 \mathrm{~L} 152 / 24$ (Aminozuren), leidend tot een 30 respectievelijk $40 \%$ hogere basisboete. In Pb 1998 L. 252/47 (Amministrazione Autonoma dei Monopoli di Stato) werd de boete, omdat de overtreding gedurende 'tenminste' 13 jaar had voortgeduurd. In Pb 2001 L 125/27 (Deutsche Post) was sprake van een inbreuk van 26 jaar. Dit werd als 'lang' gekwalificeerden leverde een verhoging met $100 \%$ op. 
andere woorden om de tuin geleid ${ }^{46}$ ) en anderzijds het uitoefenen van druk door Volkswagen teneinde het kartel te doen naleven, waardoor verschillende dealers aanzienlijke verliezen hadden geleden.

Interessant is ook de beschikking inzake een kartel voor voorgeisoleerde buizen ${ }^{467}$ andat de Commissie hier al haar registers kon opentrekken. Het betrof opzettelijke inbreuken op artikel 81 EG die tot de zwaarste categorie gerekend moeten worden: marktverdeling en prijsvaststelling. Het kartel omvatte de markt van de gehele Gemeenschap, leverde uitsluitend voor de participanten voordeel op en werd op zeer krachtige wijze toegepast. Kortom: er was sprake van een extreem zware overtreding van de communautaire mededingingsregels. Aangezien de ondernemingen qua omvang in aanzienlijke mate van elkaar verschilden, stelde de Commissie -zoals steeds het geval- voor iedere onderneming afzonderlijk een boete vast. Voor de onderneming met de grootste marktmacht werd als uitgangspunt een boete van 50 miljoen ecu passend geacht: deze onderneming had doelbewust en op directieniveau alles in het werk gesteld om van het kartel een succes to maken en om het voor de buitenwereld (en met name de Commissie) geheim te houden. ${ }^{46}$ Omdat het kartel een levensduur van vijf jaar had gehad, waarin het echter niet steeds even effectief was, werd de 'voorlopige boete' met $40 \%$ verhoogd, waardoor het basisbedrag 70 miljoen ecu bedroeg. ${ }^{469}$ Als strafverzwarend werd vervolgens aangemerkt dat de onderneming de leidende functie in het kartel bekleedde en andere ondernemingen onder druk zette om tot participatie in het kartel over te gaan, dat zij gerichte maatregelen trof om een onderneming van de markt te verdrijven en dat zij het kartel handhaafde na waarschuwingen en een verificatie van de Commissie. ${ }^{470} \mathrm{Om}$ deze redenen werd de basisboete met $50 \%$ verhoogd. Het feit dat de onderneming reeds schadevergoeding

466 In $\mathrm{Pb} 1999$ L 109/24 (Griekse veerdienstmaatschappijen)werd de boete van een van de betrokken ondernemingen met $10 \%$ verhoogd omdat zij getracht had het onderzoek van de Commissie te belemmeren. In $\mathrm{Pb} 1999$ L 76/1 (British Sugar) werd de boete voor British Sugar met 75\% verhoogd: deze ondememing had niet alleen het kartelinitiatief genomen en was ook daarna de drijvende kracht achter het kartel, maar had bovendien in strijd gehandeld met een zogenoemd nalevingsprogramma, dat zij had opgesteld als reactie op een eerdere communautaire kartelprocedure en waarvoor haar door de Commissie een aanzienlijkevermindering van de boete was toegekend ( $\mathrm{Pb} 1988$ L 284/41 (Napier Brown/British Sugar)). De aanzienlijke verhoging van de boete is dan ook voor een belangrijk deel te verklaren uit het feit dat British Sugar de toezeggingen om haar beleid in overeenstemming met de communautaire regels te brengen, niet gestand heeft gedaan en de Commissie heeft misleid. Het voordeel dat de onderneming had genoten in de eerdere beschikking, heeft zij ongetwijfeld in deze beschikking (met rente) weer terugbetaald.

$467 \mathrm{~Pb} 1999$ L 24/1.

468 De Commissic overwoog ten aanzien van de preventieve werking van de boete: "De bewezen verwikkeling in het kartel op het hoogste directieniveau onderstreept de noodzaak om de boete op een zodanig niveau vast te stellen dat wordt gewaarborgd dat daarvan voldoende afschrikkende werking uitgaat".

469 In $\mathrm{Pb} 2000 \mathrm{~L} 30 / 1$ (Virgin/British Airways) duur de verboden gedraging zeven jaar, hetgeen een verhoging ter hoogte van $70 \%$ tot gevolg had.

$470 \mathrm{In} \mathrm{Pb} 1999 \mathrm{~L}$ 109/24 (Griekse veerdienstmaatschappijen) werd het een onderneming zwaar aangerekend dat zij het initiatief tot het kartel had genomen, dat zij toezicht op de naleving van het kartel hield en dat zij de samenwerking trachtte uit te breiden. Dit gedrag leverde haar een strafverhoging van $25 \%$ op. Daartegenover stond het gedrag van enkele andere ondernemingen die slechts als 'volgers' werden aangemerkt. Hun boete werd om deze reden met $15 \%$ verminderd. Ook in $\mathrm{Pb} 1998 \mathrm{~L}$ 100/55 (Legeringstoeslag)werd de leidende rol van een onderneming 'beloond' met een verhoging van $25 \%$, terwijl in $\mathrm{Pb} 2001 \mathrm{~L}$ 152/24 (Aminozuren) de leidende rol van twee ondernemingenzelfs aanleiding was om de basisboete te verhogen met $50 \%$. 
aan een gedupeerde had betaald, werd als strafverlichtende factor aangemerkt en leverde een reductie van 5 miljoen ecu op. ${ }^{471}$ De passend geachte sanctie wegens de gepleegde inbreuk bedroeg derhalve 100 miljoen ecu. Daar de onderneming echter uiteindelijk op een verzoek om inlichting (op grond van artikel 11 Vo 17) zeer wezenlijke informatie had verschaft, oordeelde de Commissie dat de mededeling betreffende het niet-opleggen of het verminderen van geldboeten moest worden toegepast, waarna de boete met $30 \%$ wegens co-operatie werd gematigd en dus definitief werd vastgesteld op 70 miljoen ecu. ${ }^{4 / 2}$ Voor de overige ondernemingen (met aanzienlijk minder marktmacht) werd een vergelijkbare berekening toegepast, zij het dat de boetes nominaal aanzienlijk lager waren. ${ }^{43}$ Eén aspect verdient echter aandacht. In enkele gevallen leverde de berekening van de boete vóór toepassing van een reductie wegens co-operatie een boete op die meer dan $10 \%$ van de wereldwijde omzet van de betreffende ondernemingen beliep. In die gevallen zag de Commissie zich derhalve genoodzaakt de boete te verlagen tot een bedrag dat de $10 \%$-grens niet overschreed. ${ }^{474}$ Weliswaar werd de uiteindelijke sanctie wegens medewerking nog aanzienlijk verlaagd (met 20 tot $30 \%$ ), maar de aanpak van de Commissie maakt duidelijk dat zij niet (langer) schroomt om een maximum-boete op te leggen indien de vernieuwde berekeningswijze daartoe leidt.

De TACA-beschikking ${ }^{475}$ geeft nogmaals een goed beeld van de aanpak van de Commissie in die gevallen waarin een aantal ondernemingen van uiteenlopende omvang bij mededingingsbeperkend gedrag is betrokken. ${ }^{476} \mathrm{Het}$ betrof in casu twee overtredingen van artikel $82 \mathrm{EG}^{47}$, begaan door 16 ondernemingen. Deze ondernemingen werden

$471 \mathrm{Er}$ zijn echter lang niet altijd strafverlichtende omstandigheden aanwezig. Zie $\mathrm{Pb} 1998$ L 252/47 (Amministrazione Autonoma dei Monopoli di Stato), Pb 2000 L 30/1 (Virgin/British Airways), Pb 2000 L 39/1 (Nederlandse Federatieve Vereniging voor de Groothandel op Elektrotechnisch Gebied en Technische Unie), Pb 2001 L 59/1 (Opel) en Pb 2001 L 125/27 (Deutsche Post).

472 Het verstrekken van documenten voorafgaand aan de mededeling van de punten van bezwaar, waardoor het bestaan van de inbreuk werd bevestigd, leverde (samen met het niet betwisten van de feiten) een onderneming in $\mathrm{Pb} 1999$ L $109 / 24$ (Griekse veerdienstmaatschappijen), een verlaging op van $45 \%$. Ondernemingen die uitsluitend de feiten niet hadden betwist, werd een 'korting' op de boete gegund van 20\%. Dit bracht de Commissie ertoe om de boete met $40 \%$ te matigen. In Pb $1999 \mathrm{~L}$ $76 / 1$ (British Sugar) profiteerde British Sugar -evenals de andere ondernemingen-van het feit dat zij de beschuldigingen in de mededeling van de punten van bezwaarniet wezenlijk betwistte. Omdat het bewijs echter zo dwingend was dat betwisting nauwelijks mogelijk was, leverde dit slechts eet matiging van $10 \%$ op. Ten aanzien van eén van de betrokken ondernemingen echter werd de boete gehalveerd omdat zij in veel verdergaande mate had meegewerkt, onder meer door melding van het kartel aan de Commissie, die pas door deze melding van het bestaan van het kartel op de hoogte raakte. In Pb 2000 L 268/1 (Far East Trade TariffCharges and Surcharges Agreement) werd rekening gehouden (in de vorm van een verlaging van $20 \%$ van het basisbedrag) met het feit dat de ondernemingenna cen schrijven van de Commissie hun gedragingen hadden gestaakt. In Pb 2001 L54/1 (NathanBricolux) verklaarde de onderneming zich na ontvangst van de punten van bezwaar bereid om de inbreuk te bečindigen. Bovendien had zij al eerder belangrijk bewijsmateriaal verstrekt. Zie tevens $\mathrm{Pb} 1998 \mathrm{~L}$ 100/55 (Legeringstoeslag).

473 Hetgeen primair te wijten was aan de geringere marktmacht (en omzet) van die ondernemingen.

474 Dit was ook het geval ten aanzien van een van de betrokken ondernemingen in $\mathrm{Pb} 1999 \mathrm{~L}$ 109/24 (Griekse veerdienstmaatschappijen). Om deze reden werd de boete vastgesteld op 1 miljoen ecu.

$475 \mathrm{~Pb} 1999$ L 95/1 (Trans-Atlantic Conference Agreement).

476 Voor deze aanpak zie ook Pb 2000 L 268/1 (Far East Trade Tariff Charges and Surcharges Agreement) en $\mathrm{Pb} 2001 \mathrm{~L}$ 152/24 (Aminozuren).

477 Er werd eveneens inbreuk gemaakt op artikel 81 EG, maar hiervoor werden geen boetes opgelegd 
in vier groepen onderverdeeld: tussen de groepen verschilde het bedrag van de 'voorlopige boete'; binnen een groep was het bedrag van deze boete gelijk. De duur van twee tot drie jaar zorgde voor een verhoging van deze boete met $25 \%$, terwijl geen bijzondere onstandigheden tot wijziging van de aldus berekende boetes aanleiding gaf. Op deze wijze differentieerde de Commissie naar grootte van de ondernemingen, zonder overigens de boete te relateren aan hun exacte omzet. ${ }^{478}$

\section{De Nederlandse boetepraktijk sinds 1998}

DeMededingingswet kent, zoals eerder besproken, mutatis mutandis dezelfde boetebepalingen als het communautaire recht. Analoog aan hetgeen is neergelegd in artikel 15 lid 2 Vo 17 stelt artikel 57 lid $2 \mathrm{Mw}$ dan ook dat bij de vaststelling van de hoogte van de bocte in ieder geval rekening moet worden gehouden met de ernst (Verordening 17 spreekt van de zwaarte) en de duur van de overtreding. ${ }^{49}$ De memorie van toelichting bij de Mededingingswet voegt daar aan toe:

"Aftankelijk van het geval kunnen ook andere factoren een rol spelen, zoals mogelijke recidive, de bereidheid van de betrokken ondernemers om mee te werken aan het betindigen van de overtreding, het behaalde voordeel en dergelijke. De financiéle positie van de onderneming speelt in beginsel geen rol bij de vaststelling van de hoogte van de boete. Hierdoor zou immers een slecht ondememingsbeleid abeloonds worden door een lagere boete op te leggen dan zou geschieden aan een onderneming die wel floreert (...). Aan de andere kant moet het niet zo zijn dat een boete een faillissement van de onderneming waarschijnlijk zou maken". ${ }^{\text {to }}$

Hoewel de memorie van toelichting hier slechts enkele bijzondere straftoemetingsfactoren noemt, zijn de overeenkomsten met het communautaire recht op dit punt onmiskenbaar en wordt aangestuurd op een vergaande convergentie met het straftoemetingsbeleid van de communautaire instanties. Of en -zo ja- in hoeverre deze convergentie in de praktijk wordt gerealiseerd, ligt in eerste instantie in handen van de $\mathrm{d}-\mathrm{g} \mathrm{NMa}$. Tot op heden zijn drie boetebesluiten genomen, die hieronder -voor zover het het boeteaspect betreft- zullen

478 Interessant is de overweging van de Commissie dat zij het juist achtte "om de wereldwijde omzet (...) als uitgangspunt voor de vergelijking van de relatieve grootte van de ondernemingente hanteren, omdat zij aldus rekening kan houden met de werkelijke middelen en het werkelijke belang van de betrokken ondernemingen".

479 Op grond van artikel $62 \mathrm{Mw}$ dient een boetebeschikking onder meer de opgelegde boete alsmede een toelichting op de hoogte ervan te bevatten. De motiveringsplicht voor de d-g NMa nust ten aarizien van de strafmaatbepaling daarnaast op artikel 3:46 Awb.

480 TK 1995-1996, 24 707, nr. 3. Vergelijk echter Michiels (1994), pag. 36, die stelt: "Wanneer geen tariefstelsel wordt gehanteerd, moet, juist als in het strafrecht, bij het bepalen van de hoogte van de boete met de omstandigheden van de dader, met name zijn draagkracht, volop rekening worden gehouden". In de memorie van toelichting bij artikel 5,4.1.7 lid 2 vOA wb4, dat het bestuursorgaan de verplichting oplegt om rekening te houden met de ernst van de overtreding, met de mate van verwijtbaarheid alsmede 'zo nodig' met de omstandigheden waaronder de overtreding is gepleegd. "In voorkomende gevallen kan daarbij, in lijn met artikel $24 \mathrm{Sr}$, ook de draagkrachtvan de overtreder een rol spelen. Dit betekent niet, dat het bestuursorgaan steeds een onderzoeknaar deze draagkracht moet instellen (...) Maar zeker bij hogere boeten zal het bestuursorgaan zich er van moeten vergewissen dat de boete, mede gelet op de draagkracht van de overtreder, geen onevenredige gevolgen heeft". 
worden besproken. ${ }^{481}$ Vooruitlopend op deze bespreking kan reeds worden gesteld dat bij de strafmaatbepaling weliswaar acht wordt geslagen op de boetepraktijk van de Com. missie, maar dat tevens de duidelijkheid van de Richtsnoeren van de Commissie in het Nederlandse kartelrecht (vooralsnog) ontbreekt.

Het eerste besluit van de d-g NMa waarbij tegen een onderneming een boete wegens een inbreuk op de Mededingingswet werd opgelegd, zag in 1999 het licht en was gericht tegen de Samenwerkende elektriciteits-produktiebedrijven (SEP). ${ }^{42}$ De SEP had van haar machtspositie -de facto was zij monopolist ${ }^{483}$ - misbruik gemaakt door aan een onderneming -Hydro Agri- transportdiensten met betrekking tot elektriciteit te weigeren. ${ }^{484}$ Ten aanzien van de ernst van de overtreding overwoog de d-g NMa, geheel in lijn van de 'communautaire' beoordeling van dit soort gedrag ${ }^{435}$, dat het "een naar haar aard zeer zware overtreding" betrof. Dergelijke overtredingen -de bewoordingen van de d-g NMa duiden erop dat hij hier een algemeen, dus ook buiten de specifieke zaak, geldende regel heeft willen formuleren- brengen volgens de d-g NMa met zich dat 'op zichzelf' een hoge boete geĩndiceerd is. ${ }^{486} \mathrm{Zo}$ ernstig als de inbreuk op de Mededingingswet in casu was, zo kort duurde hij, namelijk minder dan zes maanden. Een dergelijke, als zeer kortdurend betitelde, inbreuk vormt, aldus het besluit, een indicatic voor een lagere boete. Aanleiding tot (verdere) matiging van de boete werd gevonden in de aanwezigheid van twee strafverminderingsfactoren. De eerste had betrekking op

481 De besluiten van de d-g NMa worden gepubliceerd op de website van de Nederlandse mededingingsawtoriteit (www.nma-org.nl).

482 Besluit van 26 augustus 1999, 1999/650 (Hydro Energy t. SEP). Zie over dit besluit ook Mahler (1999), pag. 207 e.v. en De Muynk (1999), pag. 102-103.

483 De relevantemarkt was in casu het transport van elektriciteitmet een vermogen van 25-75 megawatt via hoogspanningsnetten met een voltage van minimaal 220 kilovolt (het zogenoemde koppelnet). SEP was eigenaar van het (enige) koppelnet in Nederland: de (toenmalige) Elektriciteitswet 1989 verbood aan anderen dan de SEP dergelijke netten aan te leggen. Weliswaar waren er enkele andere transportnetten, maar deze vormden met name door hun lagere spanning geen redelijk alternatief voor het koppelnet van SEP.

484 Op grond van de Elektriciteitswet 1989 bestond er voor anderen dan de SEP een verbod op invoet van elektriciteit, behalve indien de elektriciteit was bedoeld voor eigen gebruik van de invoerende grootverbruiker. In dat laatste geval gold echter wel een verbod op doorlevering aan derden. SEP vermoedde dat Hydro laatstbedoeld verbod zou overtreden en eiste dat de onderneming geen electriciteit zou doorleverenaan derden en verlangde concretebewijzen dat dit inderdaadniet zou gebeuren. Deze voorwaarden gingen volgens de d-g NMa verder dan op grond van de Electriciteitswet 1989 geoorloofd was; hij stelde deze handelwijze van de SEP vervolgens gelijk met een weigering tot het verrichten van de gevraagde diensten en achtte misbruik bewezen.

485 Zoals niet alleen uit hiervoor aangehaalde beschikkingen van de Commissie en jurisprudentie van Gerecht en Hof blijkt, maar ook uit de Richtsnoeren van de Commissie waarnaar door de d-g NMa overigens uitdrukkelijk werd verwezen.

486 Overigens gaf de d-g NMa niet aan wanneer in het kader van het Nederlandse kartelrecht een boete hetzij in absolute bedragen, hetzij in relatic tot de omzet-als 'hoog' moet worden aangemerkt. Het besluit op bezwaarin de SEP-zaak (besluit van 27 maart 2000) biedt hieromtrent wel enkele aanknopingspunten. Uitsluitend de emst van de overtreding in aanmerking nemend zou een boete van 'enkele tientallen miljoenen guldens' geindiceerd zijn geweest, dit tegen de achtergrond van een omzet van SEP van 6,9 miljard gulden en gelet op 'het vereiste van afschrikwekkendheid' van de boete. Hoewel absoluut gezien een boete van 'enkele tientallen miljoenen guldens' hoog te noemen is, betreft het slechts een 'voorlopig' boetebedrag van niet meer dan ongeveer $0,5 \%$ van de omzet. Het lijkt ef dan ook op dat de d-g NMa vooralsnog relatief terughoudend is bij de beboeting, in die zin dat hij nog allerminst-ook voor de meesternstige gedragingen-de grenzenvan het boetemaximumbenadert. 
de omstandigheid dat de elektriciteitsmarkt zich in een 'bijzondere overgangssituatie van pablieke naar private sector' bevond. De tweede betrof het ontbreken van recidive: het was de eerste maal dat SEP met een soortgelijke klacht of procedure werd geconfronteerd, waarbij er mijns inziens vanuit moet worden gegaan dat de d-g NMa niet alleen doelde op mogelijk eerdere overtredingen van de Mededingingswet zelf, maar ook waarde hechtte an het gedrag van de onderneming en eventueel daarop betrekking hebbend overheidsoptreden (waaronder hier begrepen rechterlijke uitspraken) ten tijde van de Wem. ${ }^{487}$ Uit het SEP-besluit blijkt voorts dat bij de vaststelling van de omvang van de boete door de d-g NMa rekening wordt gehouden met de eventuele directe financiële schade die een overtreder door zijn verboden gedrag aan derden berokkent; aangezien er in casu echter volgens de d-g NMa geen sprake was van rechtstreekse schade, was er geen reden on de boete te verhogen. ${ }^{458}$ Alle factoren afwegende, kwam de d-g NMa uiteindelijk tot de conclusie dat een 'relatief lage boete' diende te worden opgelegd, te weten een bedrag van $f 14$ miljoen. ${ }^{489}$

Het tweede boetebesluit, gericht tegen Bredase notarissen, volgde minder dan een maand na het SEP-besluit en ging -weinig verbazend gelet op de korte tijdspanne tussen beide besluiten- verder op de in het SEP-besluit ingeslagen weg. ${ }^{490}$ De notarissen hadden itbreuk gemaakt op de Mededingingswet door de markt te verdelen, en wel door opdrachten van de gemeente Breda en haar instellingen bij toerbeurt onderling te verdelen. Deze overtreding van het verbod van artikel $6 \mathrm{Mw}$ werd door de $\mathrm{d}-\mathrm{g} \mathrm{NMa}$-wederom onder

487 Volgens de letter van het besluit zag de $\mathrm{d}-\mathrm{g} \mathrm{NMa}$ in het ontbreken van recidive een reden om de boete niet te verhogen. Uit het besluit op bezwaar in de SEP-zaak (besluit van 27 maart 2000) en het daaraanvoorafgaande advies van de Adviescommissie bezwaarschriftenMededingingswet blijkt echter dat bedoelde omstandigheid in casu tot strafverlaging heeft geleid. De conclusie lijkt gerechtvaardigd dat recidive in beginsel steeds strafverhogend werkt terwijl bij het ontbreken van recidive een onderneming mag rekenen op verlaging van de boete.

488 Mijns inziens suggereert de d-g NMa hier ten onrechte dat de gevolgen voor de mededinging ingrijpender zouden zijn geweest indien Hydro wel financiêle schade had geleden. Door het gedrag van SEP verdween de (ten gevolge van de toenmalige Elektriciteitwet) toch al beperkte mogelijkheid tot concurrentie vrijwel geheel. Eventueel financieel nadeel voor Hydro had deze situatie niet verslechterd. Wel impliceert de aanwezigheid van schade bij een derde dat de gevolgen van de gedraging als zodanig (dus los van de invloed op de mededinging) ernstiger zijn, hetgeen een verhoging van de boete kan rechtvaardigen.

489 Het bezwaar dat door de SEP tegen dit besluit werd aangetekend, werd door de d-g NMa, overeenkomstig het advies van de Adviescommissie bezwaarschriften Mededingingswet, ongegrond verklaard. Daarbij werden onder meer de door SEP aangevoerde bezwaren tegen de sanctiemaat aan de kant geschoven. SEP was van mening dat de boete te hoog was, onder meer omdat de boetes in het buitenland voor soortgelijke gedragingen lager waren, omdat de inbreuk hoogstens als 'zwaar' zou kunnen worden aangemerkt omdat deze slechts een klein deel van het communautaire gebied bestreek en omdathet de eersteNederlandseboetebeschikkingbetrof, terwijl in de eerstecommunautaire boetebeschikkingen de boetes nog zeer laag waren. Dat deze argumenten geen hout sneden, is evident. Ten eerste is het buitenlands boeteniveau voor de toepassing van een Nederlandse wet (en niet alleen de Mededingingswet) in het geheel niet relevant. Ten tweede kunnen de Richtsnoeren van de Commissie hooguit analoog worden toegepast, in die zin dat voor de Mededingingswet slechts de Nederlandse (en dus niet de communautaire) markt van belang is. Ten derde gaat de vergelijking met de situatie van ruim veertig jaar geleden volledig mank: de materiële (communautaire) kartelbepalingen waren toentertijd nieuw; dit geldt allerminst voor de bepalingen van de Mededingingswet die immers mutatis mutandis gelijkluidend zijn aan de EG-bepalingen en dus als bekend mogen worden verondersteld. In die situatie spreekt het voor zich dat het niveau van de boete vanaf het begin hoger ligt.

490 Besluit van 14 september 1999, 1999/952 (Notarissen te Breda). 
verwijzing naar de Richtsnoeren van de Commissie als 'zeer emstig' aangemerkt. ${ }^{\text {"1 }}$ De consequentie was dezelfde als in het SEP-besluit: de ernst van het feit bracht mee dat 'op zichzelf' een hoge boete geĩndiceerd was. De duur van de overtreding -in totaal 15 maanden, welke termijn door de d-g NMa 'niet kort maar evenmin lang' genoemd werd- wees in de richting van een 'gemiddelde boete'. Daarnaast deden zich ook in deze zaak enkele omstandigheden voor die tot verlaging van de boete aanleiding gaven. Ten eerste hadden de notarissen na ontvangst van het rapport van de NMa zelfstandig de marktverdelingsovereenkomst beetindigd. Ten tweede waren de notarissen -evenals SEP in de eerder besproken zaak- wat men in het strafrecht 'first offenders' zou noemen: tegen geen van hen was eerder van overheidswege opgetreden wegens overtreding van een mededingingsrechtelijk voorschrift. Ten derde bestreek de marktverdeling slechts een betrekkelijk gering deel van de werkzaamheden van de notarissen, waaruit niet alleen bleek dat zij niet systematisch in hun gehele 'bedrijfsvoering' onderlinge concurrentie wilden uitbannen, maar waardoor bovendien de concrete gevolgen van het kartel relatief beperkt bleven. Door de notarissen was nog aangevoerd dat zij onbekend waren met de Mededingingswet omdat daaraan in de vakliteratuur nagenoeg geen aandacht zou zijn besteed. Terecht veegde de d-g NMa dit verweer van tafel $^{422}$ : juist van leden van een beroepsgroep als het notariaat mag verwacht worden dat zij op de hoogte zijn van een voor hun ambt zeer wezenlijke -en allerminst in de literatuur onopgemerkt geblevenwet als de Mededingingswet; als zij in dat geval desalniettemin mededingingsbeperkend handelen, dan kan hen zelfs worden tegengeworpen dat hun gedragingen zeer verwijtbaar zijn, hetgeen dan ook door de d-g NMa gebeurde. ${ }^{493}$ De hiervoor genoemde omstandigheden leidden ertoe dat aan alle notarissen afzonderlijk een boete van $f 20.000$ werd opgelegd. ${ }^{494}$

Het derde besluit waarbij een onderneming wegens overtreding van de Mededingingswet werd beboet, trof Secon Group. ${ }^{495}$ Deze (op de markt van hoogwaardige bovenkleding actieve) onderneming had zich schuldig gemaakt aan verdeling van de markt (door hantering van een doorleveringsverbod) alsmede aan het hanteren van vaste prijzen (zij het onder de vlag van 'adviesprijzen'). Vermelding verdient dat de d-g NMa in dit besluit nog voordat hij de concrete boete berekende het gewicht van de generaal- en speciaalpreventieve werking van de boete benadrukte:

491 De emst van de gedraging werd onderstreept door het feit dat marktverdelingen reeds onder het regime van de Wem verboden waren.

492 Overigenszou honorering van het verweervan de notarissen hooguit enige strafvermindering hebben kunnen bewerkstelligen. Zoals de d-g NMa terecht concludeerde, impliceert de aanwezigheidvan rechtsdwaling nog niet dat er geen sprake is van verwijtbaarheid.

493 Het feit dat het kartelgedrag van de notarissen geen financięle gevolgen had in de vorm van hogere prijzen (er golden namelijk uniforme, vaste tarieven), zou nog ten voordele van de notarissen hebben kunnen meewegen. Daar stond echter tegenover dat juist daar waar wél nog concurrentic mogelijk was (onder meer op het gebied van serviceverlening en kwaliteit), deze door de overeenkomst onmoge lijk werd gemaakt, hetgeen de notarissen juist zwaar kon worden aangerekend.

494 De boete was voor ieder der betrokkenen gelijk omdat zij allen dezelfde rol in het kartel vervuldea Een uitzondering werd gemaakt voor drie notarissen die gedurende een kortere periode hadden deelge nomen aan de omstreden overeenkomst, waarbij bovendien twee van hen slechts hadden geparticipeerd in een minder zware inbreuk op de Mededingingswet. Dit leverde voor de betrokkenen een korting op de boete op van $f \mathbf{2 . 5 0 0}$ respectievelijk $f \mathbf{5 . 0 0 0}$.

495 Besluit van 12 januari 2000, 2000/757 (Chilly en Basilicum t. G-Star/Secon Group). 
"De hoogte van de boete dient te worden afgestemd op de concrete omstandigheden van het geval en dient bij te dragen aan een doeltreffende toepassing van de Mededingingswet. Als algemene maatstaf daurbij geldt dat de hoogte van de boete in ieder geval zodanig dient te zijn dat deze de overtreder weerhoudt van nieuwe overtredingen en ook in algemene termen een afschrikkende werking heett" -

Uitgangspunt in de Nederlandse boetepraktijk is derhalve dat de boete van dien aard moet zijn dat foekomstige overtredingen voorkomen worden, welk uitgangspunt een fors boeteniveau doet verwachten. In deze zaak bleef de boete echter ten gevolge van de (overige) strafmaatfactoren relatief beperkt: de uiteindelijke boete beliep $f 500.000 .{ }^{497}$ De aard van de in het geding zijnde gedragingen (marktverdeling en prijsvoorschriften) -de d-g NMakwalificeerde de handelwijze als 'niet geringe overtredingen van de Mededingingswet'- wees nog in de richting van een hoge boete, maar de concrete gevolgen van de gedragingen waren relatief beperkt gebleven "aangezien de beperkingen zich met name manifesteren op bepaalde segmenten van de betrokken markten". ${ }^{498}$ Daar kwam nog bij dat het overtredingen van korte (het doorleveringsverbod was totaal 5,5 maanden van kracht geweest) respectievelijk betrekkelijk korte duur (de 'adviesprijzen' waren gedurende 9,5 maanden gehanteerd) betrof. Voor het overige werd bij de vaststelling van de boete meegewogen dat het omstreden gedrag was beeindigd, zij het dat het ten dele was ingeruild voor ander mededingingsbeperkend gedrag, hetgeen weer in het nadeel van de onderneming pleitte. Het verweer van Secon Group dat de kartelbepalingen niet in praktijk werd gebracht en dat de inbreuken te wijten waren aan administratieve onachtzaamheden werd door de d-g NMa niet aanvaard. ${ }^{49}$

Hoewel de boetepraktijk met betrekking tot overtredingen van de Mededingingswet nog pril is, kan toch een aantal conclusies worden getrokken. Het communautaire boetebeleid vormt onmiskenbaar een bron waaruit de d-g NMa inspiratie voor de uitoefening van zijn boetebevoegdheid put. ${ }^{500}$ De $\mathrm{d}-\mathrm{g}$ NMa volgt immers het communautaire beleid nauw ten aanzien van de aard van de overtreding: gedragingen die door de Commissie als zeer emstig worden aangemerkt, krijgen in het kader van de Mededingingswet -behoudens tot op zekere hoogte in het besluit tegen Secon Group- dezelfde kwalificatie. Ook uit de door de d-g NMa in aanmerking genomen (bijzondere) strafmaatfactoren blijkt dat het communautaire beleid als voorbeeld dient: de al dan niet aanwezigheid van recidive,

496 Vergelijk ook de schriftelijke reactie van de $\mathrm{d}-\mathrm{g}$ NMa in de bezwaarschriftproceduremet betrekking tot de SEP-zaak (besluit van 27 maart 2000).

497 Secon Group had een geconsolideerdeomzet -de omzetten van haar dochterondememingenmeegerekend-van ongeveer $f 250$ miljoen.

498 De aangehaalde, overigens weinigzeggende, kwalificatie doet mijns inziens geen recht aan de aard van de overtreding: de gedragingen in kwestie behoren qua aard tot de meest zware vergrijpen. Dat laat onverlet dat in casu de ernst van de overtreding binnen redelijke perken bleef (en dus niet zwaar maar ook 'niet gering' was), aangezienin de ernst van de gedraging -althans het communautair voorbeeld volgend- mede de gevolgen verdisconteerd moeten worden en deze gevolgen hier niet al te verstrekkend waren.

$499 \mathrm{Bij}$ de verwerping van dit (strafmaat)verweer ging de $\mathrm{d}-\mathrm{g} \mathrm{NMa}$ mijns inziens overigens wel erg kort door de bocht door te volstaan met de stelling dat "de voorliggende feiten en omstandigheden (...) onvoldoende grond (geven) om dit betoog van de Secon Groep te volgen".

500 Dat het communautaire beleid een dergelijke bron voor de $\mathrm{d}-\mathrm{g}$ NMa mág vormen, wordt nog eens uitdrukkelijk bevestigd in het advies van de Adviescommissie bezwaarschriften Mededingingswet inzake de bezwaarprocedure in de SEP-zaak. 
de (vrijwillige) beëindiging van ongeoorloofd gedrag, de omstandigheid dat het gedrag slechts betrekking heeft op een beperkt deel van de bedrijfsvoering, de verhoogde zorg. plicht die op bepaalde ondernemingen rust om op de hoogte te zijn van de materiele mededingingsnormen, maar ook het oogmerk van generale en speciale preventie spelen in het Nederlandse boetebeleid een zelfde rol als in het beleid van de Commissie. Toch wijkt de aanpak van de d-g NMa ook op belangrijke punten af van het Commissiebeleid sinds 1998. De berekening van de omvang van de boete is binnen het Nederlandse recht aanmerkelijk minder duidelijk en doorzichtig dan in het communautaire recht, aangezien de d-g NMa noch een 'voorlopige boete' noch een basisboetebedrag vaststelt. Om als voorbeeld de SEP-zaak te nemen: in plaats van de vaststelling van een 'voorlopige boete' van $f 20$ miljoen of meer (naar communautaire normen het bedrag dat als uitgangspunt dient voor de bepaling van de boete bij een zeer zware inbreuk), volstond de d-g $\mathrm{NMa}$ met de mededeling dat de ernst van de overtreding 'op zichzelf' een hoge boete rechtvaardigde. Ook de rol van de duur van de inbreuk is -mede ten gevolge van het voorgaande- een andere dan in het huidige communautaire beleid. In dit beleid brengt een inbreuk van korte duur, zoals in de SEP- en de Secon Group-zaak ${ }^{502}$, mee dat de 'voorlopige boete' niet wordt verhoogd ${ }^{\text {(0) }}$ en impliceert een inbreuk van middellange duur -zoals het geval in de zaak van de Bredase notarissen- dat de 'voorlopige boete' met maximaal $50 \%$ wordt verhoogd. Uit de Nederlandse praktijk blijkt daarentegen dat de korte duur van een overtreding een indicatic voor een lagere boete vormt, terwijl een overtreding van middellange duur in beginsel een gemiddelde boete met zich brengt, waarbij dient te worden opgemerkt dat in de zaak tegen de Bredase notarissen dit de facto betekende dat de boete lager uitviel dan op grond van de ernst van de overtreding mocht worden verwacht. ${ }^{504}$

Het voorgaande toont mijns inziens aan dat het boetebeleid van de d-g NMa afwijkt van de huidige communautaire aanpak en dat het veeleer verwantschap vertoont met het beleid van de Commissie tot $1998 .^{505}$ Hoewel bedoeld verschil niet noodzakelijk tot

501 Het boetebeleidvan de d-g NMa wekt natuurlijk bepaaldeverwachtingen. Mede tegen de achtergrond van de algemene beginselen van behoorlijk bestuur, en dan met name het verbod van willekeur, het gelijkheidsbeginsel en het vertrouwensbeginsel, moet er dan ook van worden uitgegaan dat de $\mathrm{d}-\mathrm{g}$ $\mathrm{NMa}$ de door hem ingeslagen weg op straftoemetingsgebied zal blijven bewandelen. In ieder geval mogen de ondernemingen derhalve erop vertrouwen dat de huidige strafmaatfactoren ook in tockomstige gevallen bij de bepaling van de boete zullen worden betrokken. Dat wil niet zeggen dat het beleid van de d-g NMa zich niet zal mogen ontwikkelen of dat hiervan niet zal mogen worden afgeweken. Evenmin betekent dit dat de omvang van toekomstige boetes nauwkeurig voorspeld zal kunnen worden: hooguit zal, evenals het geval is op communautair niveau, een grove schatting kunnen worden gemankt.

502 In de optiek van de Commissie is een inbreuk van minder dan één jaar als 'kort' aan te merken. De d-g NMa wijkt van deze terminologie in de Secon Group-zaak enigszins af door een overtreding van 9,5 maanden te kwalificeren als 'betrekkelijk kort'.

503 In geval van een zeer kortdurende inbreuk zijn de 'voorlopige boete' en het basisbedrag van de boete derhalve gelijk. Verlaging kan de beperkte duur van de inbreuk in het communautaire recht echter niet bewerkstelligen.

504 Het is overigens de vraag of de overtreding in deze zaak wel naar communautaire maatstaven als 'zeer ernstig' had mogen worden aangemerkt, gelet op het uiterst beperkte geografische deel van de Nederlandse markt waarop het kartel betrekking had.

505 Een andere mening lijkt Mahler (1999), pag. 212, te zijn toegedaan. Volgens deze schrijver bestast er 'nauwelijks twijfel meer' over de vraag of de d-g NMa de Richtsnoeren van de Commissic hanteert bij zijn eigen boetebeleid. 
een andere uitkomst leidt en hoewel zich geen rechtsregel ertegen verzet dat de d-g NMa een eigen (boete)koers vaart, valt het verschil in aanpak naar mijn mening te betreuren. Dit hangt niet alleen ermee samen dat convergentie met het communautaire recht een van de belangrijkste uitgangspunten van het herziene Nederlandse kartelrecht is en dat door convergentie (Nederlandse) ondernemingen zowel op communautair als op nationaal niveau met dezelfde (rechts)regels zouden worden geconfronteerd, maar bovendien biedt de berekening van de boete volgens de in de Richtsnoeren verwoorde methode verschillende (andere) voordelen, zoals een grotere doorzichtigheid van de strafmaatbepaling, een vermindering van het risico van ongelijke behandeling van ondernemingen bij de beboeting wegens overtreding van de Mededingingswet en vergroting van de controleerbaarheid van de uitspraak waar het de boeteberekening betreft, hetgeen weer de rechtsbescherming ten goede komt. Het verdient mijns inziens dan ook de voorkeur dat de d-g NMa, eventueel door het opstellen van beleidsregels daaromtrent, het beleid van de Commissie op dit punt overneemt. Ten aanzien van de omvang van de boetes is de verwachting gerechtvaardigd dat de d-g NMa niet zal terugschrikken voor, ook in verhouding tot de omzet van de onderneming, aanzienlijke boetebedragen: met cen sanctie van $f 14$ miljoen in het eerste boetebesluit is, hoewel deze boete nog (letterlijk) relatief mild was, toch de toon gezet en de nadruk in de Secon Group-zaak op het belang van de generale en speciale preventie duidt erop dat aan gevoelige sancties in het kader van een goede handhaving van de naleving van de Mededingingswet grote betekenis wordt toegekend.

\section{Conclusie}

De sancties op overtredingen van het Nederlandse en communautaire kartelverbod zijn niet van strafrechtelijke aard: de boetes in de Mededingingswet hebben een bestuursstrafrechtelijk karakter, terwijl de communautairrechtelijke boetes een sui generis-categorie vormen. Het feit dat het om niet-strafrechtelijke sancties gaat, is in zoverre van weinig importantie dat procedures die tot oplegging van een punitieve sanctie kunnen leiden, mede onder de invloed van het EVRM, naar elkaar toegroeien, zeker op het gebied van de vereiste rechtsbescherming. ${ }^{506}$ Bovendien blijken ook buiten het strafrecht wel degelijk aan dit rechtsgebied ontleende leerstukken een rol te spelen. In het communautaire kartelrecht bijvoorbeeld wordt een onderscheid gemaakt tussen schuld en opzet en zijn er voorzieningen getroffen met betrekking tot verjaring en ne bis in idem. Ook de invulling van deze leerstukken sluit nauw aan bij het strafrecht. Het Hof hanteert het (ook in het Nederlandse (economische) strafrecht geldende) kleurloze opzet, hetgeen impliceert dat het willens en wetens handelen gericht moet zijn op de mededingingsbeinvloeding en niet tevens op de overtreding van het verdrag. De drempel voor opzet is overigens relatief laag: hiervan is sprake indien de onderneming redelijkerwijs de onrechtmatigheid van haar handelen had kunnen kennen (hetgeen met name het geval is indien de negatieve visie van de Commissie over de betreffende kartelvorm voldoende vaststaat), maar desalniettemin tot de verboden gedraging is overgegaan. De drempel voor schuld is nog lager: een onderneming kan zich doorgaans slechts disculperen indien het een 'onvermijdelijke vergissing' van haar kant betreft. In feite zal dit slechts door de Commissie worden aange-

\footnotetext{
506 Zie daarover hoofdstuk 5 .
} 
nomen indien haar standpunt over de kartelvorm nog niet bekend kon zijn bij de onderneming.

Ook de verjaringsregeling heeft een strafrechtelijke achtergrond. Aanvankelijk voorzag het communautaire recht niet in een dergelijke regeling, maar dit werd reeds snel als een gemis ervaren, omdat het in alle lidstaten in kartelprocedures werd erkend. De inhoud van de vervolgens in het leven geroepen verjaringsvoorziening doet sterk denken aan de Nederlandse strafrechtelijke verjaringsregeling, zoals neergelegd in de artikelen 70 e.v. WvSr. De termijn van de vervolgingsverjaring inzake overtredingen van de materiele verboden bedraagt vijf jaar (ten tijde van de Wem was dat in Nederland zes jaar ${ }^{50}$, in de Mededingingswet geldt -geheel in de lijn van de convergentiegedachte- een termijn van vijf jaar), de verjaring kan door een onderzoeks- of vervolgingshandeling worden gestuit (waarna de verjaringstermijn opnieuw begint te lopen, met dien verstande dat deze termijn -afgezien van een schorsing-in het totaal niet meer dan tien jaar mag bedragen) en de termijn wordt bovendien nog geschorst gedurende de periode waarin een beroepsprocedure bij Gerecht of Hof aanhangig is. ${ }^{508}$

Als derde beginsel van strafrechtelijk origine kan het ne bis in idem-beginsel worden genoemd. Dit in Nederland in artikel $68 \mathrm{WvSr}$ neergelegde beginsel houdt in dat niemand voor een tweede maal wegens hetzelfde feit mag worden vervolgd, welk beginsel ook binnen bepaalde grenzen geldt ten aanzien buitenlandse rechterlijke gewijsden. Het geschreven communautaire recht kent een dergelijk beginsel niet, maar algemeen wordt aangenomen dat het de Commissie niet is toegestaan om een procedure tegen eer onderneming te starten wegens een overtreding waarvoor zij deze reeds eerder heeft 'vervolgd'. De situatie is anders indien het de verhouding tussen een veroordeling binnen een lidstaat en een communautaire procedure betreft. In zijn Wilhelm-arrest heeft het Hof bepaald dat parallelle procedures mogelijk zijn, met dien verstande dat door de nationale procedure geen afbreuk mag worden gedaan aan het communautaire recht. Dubbele bestraffing is derhalve niet uitgesloten, maar algemene billijkheidsgronden brengen volgens het Hof wel mee dat bij de bepaling van de boete rekening moet worden gehouden met eerdere sancties, waarmee het Hof aansluit bij het zogenoemde Anrechnungsprinzip. Dit beginsel geldt mijns inziens tevens voor de verhouding tussen een veroordeling in een derde-staat (dus een niet-lidstaat) en een communautaire procedure. Wel zal er in deze situatie relatief zelden sprake zijn van 'hetzelfde feit', als gevolg waarvan het ne bis in idem-beginsel in het geheel geen toepassing vindt. Er moet immers van uit worden gegaan dat feiten slechts dan dezelfde zijn voorzover in de nationale beslissing mede een oordeel is gegeven over de effecten van de afspraken binnen de Gemeenschap en voorzover deze effecten invloed hebben gehad op de omvang van de sanctie.

De boetebevoegdheid van de Commissie en de $\mathrm{d}-\mathrm{g} \mathrm{NMa}$ is in grote mate discretionair. Niet iedere inbreuk hoeft dan ook te leiden tot een boete. Of hiertoe desalniettemin wordt overgegaan is -zo blijkt uit de communautaire praktijk- afhankelijk van verschillende factoren. Met name zijn van belang in dit verband welke gevolgen de inbreuk heeft gehad, wat de rol van de betrokken onderneming in het kartel is geweest en in hoeverre de onderneming bereid is gebleken 'haar leven te beteren'. Daarnaast toont de Commissie

507 Afgezienvan eenkorte periode in het begin van de jaren negentig, waarinde verjaringstermijnslechts twee jaar bedroeg.

508 Ten aanzien van executieverjaring bestaat een vergelijkbare regeling. 
bereidheid om ondernemingen te ontzien in die gevallen waarin het een onduidelijke rechtssituatie betreft, hetgeen met name het geval is als de Commissie voordien (in de betreffende bedrijfstak) nog geen oordeel heeft geveld over de in het geding zijnde kartelvorm. Een beschikking is dan noodzakelijk om de visie van de Commissie kenbaar te maken, maar een boete zou in die gevallen te ver gaan.

Besluit de Commissie tot het opleggen van een sanctie, dan zal zij conform artikel 15 tid 2 Vo 17 rekening moeten houden met de zwaarte en de duur van de inbreuk. Meer algemeen zal zij binnen de grenzen van de evenredigheid moeten blijven en zal zij er dus op moeten letten dat de boete in een redelijke verhouding tot de inbreuk staat. In haar over het algemeen zeer goed gemotiveerde boetebeschikkingen heeft de Commissie in de loop der tijd deze factoren aanmerkelijk geconcretiseerd. ${ }^{\text {s10 }}$ In 1998 zag zelfs een bekendmaking van de Commissie het licht aangaande de berekening van de boete. Uitgangspunt is dat aan de hand van de zwaarte en de duur van de inbreuk een basisbedrag voor de boete wordt berekend, waarna strafverzwarende en strafverzachtende omstandigheden tot aanpassing van het boetebedrag aanleiding kunnen geven. Aan de hand van de aard van de inbreuk, de weerslag op de markt en de omvang van de betrokken geografische markt onderscheidt de Commissie tussen 'niet te emstige inbreuken' (met een voorlopige boete van 1.000 tot 1 miljoen ecu), 'zware inbreuken' (met een voorlopige boete van 1 miljoen tot 20 miljoen ecu) en 'zeer zware inbreuken' (met een voorlopige boete' van 20 miljoen ecu of meer). Voor inbreuken van één tot vijf jaar wordt deze boete verhoogd met maximaal $50 \%$; voor inbreuken die vijf jaar overstijgen bedraagt de verhoging $10 \%$ van de 'voorlopige boete' per jaar. Het aldus verkregen basisbedrag wordt verhoogd of verlaagd al naar gelang er zich strafverzwarende dan wel -verlagende omstandigheden voordoen. Als zodanig worden aangemerkt:

- recidive;

- weigering van medewerking of obstructie van het onderzoek;

- een leidinggevende of initiërende rol;

- retorsiemaatregelen tegen andere ondernemingen teneinde deze het kartelgedrag te doen naleven, en

- ontneming van onrechtmatige winsten,

respectievelijk:

- een passieve rol bij de tot stand brenging van de inbreuk;

- het niet in praktijk brengen van de mededingingsbeperkende gedragingen;

- bečindiging van de inbreuk in een vroeg stadium van het onderzoek (met name bij verificaties);

- het bestaan van een redelijke twijfel bij de onderneming omtrent het inbreukmakende karakter van het mededingingsbeperkend gedrag:

- het begaan van de inbreuk louter uit onachtzaamheid, en

- co-operatie tijdens de procedure.

De Commissie heeft met haar beschikkingspraktijk en deze bekendmaking meer doorzichtigheid en voorspelbaarheid bewerkstelligd. Een mogelijkheid tot exacte inschatting van

509 Hetzelfde geldt voor de d-g NMa op grond van artikel 57 lid $2 \mathrm{Mw}$.

510 Grondige motivering is ook van groot belang omdat de Commissie aldus haar standpunt ten aanzien van bepaalde gedragingen openbaart of onderstreept. Uit de beschikkingen kunnen ondernemingen dan afleiden welk gedrag nog binnen de marges van het EG-Verdrag valt en welk gedrag verboden is. Het wordt dan ook van ondernemingen verwacht dat zij zich op de hoogte stellen van de communautaire stand van zaken. Het plegen van een inbreuk waarvan de strijdigheid met de artikelen 81 en/of 82 EG reeds door eerdere beschikkingen vaststaat, leidt meestal tot (aanzienlijke) boetes. 


\section{Hoofdstuk 4}

de hoogte van de boete vooraf levert dat nog steeds niet op (al was het alleen maar omdat de Commissie uit preventieve redenen haar boete-niveau 'plotseling' fors mag verhogen), maar ondernemingen weten nu wel beter waar zij aan toe zijn. En het verhoogt de controleerbaarheid van de straftoemeting in het concrete geval. Het zou de duidelijkheid en de rechtszekerheid ten goede komen indien de $\mathrm{d}-\mathrm{g}$ NMa de door de Commissie ingeslagen weg volgt. De nog prille beschikkingspraktijk van de d-g NMa leidt tot de conclusic dat de d-g NMa vooralsnog meer bij de communautaire praktijk tot 1998 dan bij de praktijk vanaf die tijd aansluit. Het zou beter zijn indien de d-g NMa hier het meest recente beleid van de Commissie zou volgen. 


\section{De rechtswaarborgen in het kartelrecht}

In deel I zijn de bevoegdheden besproken die de Commissie in communautair verband en de Nederlandse Mededingingsautoriteit in het kader van de handhaving van de Mededingingswet ter beschikking staan. Ten aanzien van beide werd geconstateerd dat de bevoegdheden ter handhaving uitermate verstrekkend zijn. Met name kan in dit verband gewezen worden op het inzagerecht, op het daaraan ondergeschikte betredingsrecht en op de -door middel van boetes en dwangsommen afdwingbare- medewerkingsverplichtingen. Met betrekking tot het communautaire recht bleek dat het Hof de reikwijdte van de onderzocksbevoegdheden allerminst restrictief interpreteert: het kartelverbod neemt een belangrijke plaats in het EG-Verdrag in en een ineffectieve handhaving van het verbod zou deze plaats ondergraven. Voor het Nederlandse recht is van belang dat de handhaving van de kartelwetgeving is overgeheveld van het strafrecht naar het bestuurs(straf)recht. Een van de belangrijkste redenen hiervoor was dat de minister van Economische Zaken van strafrechtelijke handhaving onvoldoende effectiviteit verwachtte; effectiviteit die het bestuursrecht wel zou bieden. Uit het voorgaande volgt dat zowel in het communautair recht als in het Nederlandse kartelrecht de effectiviteit als groot goed wordt beschouwd. Op zich is daar niets op tegen: ineffectieve handhaving kan aanleiding geven tot het nietinachtnemen van de materiële norm. Het mag echter naar mijn mening niet zo zijn dat met de nadruk op effectiviteit(sverhoging) de fundamentele rechten van de justitiabele worden veronachtzaamd. 'Dit geldt in versterkte mate voor procedures zoals de communautaire en Nederlandse kartelprocedure, die beide kunnen leiden tot oplegging van aanzienlijke sancties. Zoals in ieder deel van het recht geldt ook hier dat er slechts dan daadwerkelijk sprake is van recht als er een goede balans tussen handhaving en respectering van fundamentele rechten is. ${ }^{2}$ Hoewel noch teveel nadruk op de effectiviteit van de handhaving noch teveel nadruk op de rechtsbescherming tot een aanvaardbare uitkomst leidt, is hiermee overigens niet gezegd dat handhaving en rechtsbescherming elkaars tegenpolen vormen. Zij zijn veeleer onlosmakelijk met elkaar verbonden. Daarom ook kan de toekenning van bepaalde rechten aan justitiabelen een goede handhaving zelfs bevorderen.

In dit hoofdstuk zal worden bezien welke rechtswaarborgen er in het kader van een communautaire en Nederlandse punitieve kartelrechtelijke procedure gelden en in hoeverre deze waarborgen voldoende moeten worden geacht. Dit zal mede worden bekeken tegen de achtergrond van de vraag in hoeverre de overheveling van strafrechtelijke naar bestuurs-

1 Sommigen, waaronder Joshua (1994 II) -sterk bekritiseerd door Lieberknecht (1994), pag. 38 e.v - , leggen mijns inziens in ieder geval duidelijk te veel nadruk op het belang van efficiêntie.

2 Terecht stellen Wladimiroff en Van Russen Groen (1999), pag. 100: "De waarde van een sanctiesysteem wordt niet alleen afgemeten aan het punitieve gehalte daarvan, maar ook aan de kwaliteit van de geboden rechtsbescherming". Zie met betrekking tot het communautairerechthierover in een bredere context Pernice(1979), pag. 16/17: "Die Konstituierung der Gemeinschaftalsautonomer Wirkeinheit impliziert die Zuteilung eigener Gemeinwohlkompetenzund damiteigener-wennauch in den Kontext der mitgliedstaatlichen Verfassungstraditionen integrierter-Ginedrechtskompetenz an die Gemeinschaftsorgane; sie ist zugleich positiver Auftrag und Begrenzung ihrer Befugnisse, auch im Interesse des Individualschutzes". 
rechtelijke handhaving van het Nederlandse kartelrecht een teruggang in de rechtswaarborgen teweeg heeft gebracht. De nadruk zal liggen op de bescherming van ondernemingen ten tijde van het vooronderzoek; de rechten tijdens de contradictoire fase van de procedure zullen grotendeels onbesproken blijven omdat zij buiten het aandachtsveld van het onderhavige onderzoek vallen. Cruciaal voor de vraag naar rechtsbescherming in het kartelrecht zijn -naast de in de 'wettelijke' regelingen expliciet toegekende rechten- enerzijds de aandacht die het Hof heeft voor de fundamentele rechten van de justitiabele en anderzijds de waarborgen die uit het EVRM voortvloeien. ${ }^{3}$ Ten aanzien van de rol van het EVRM in het kartelrecht zijn met name drie vragen relevant: geldt het EVRM ook binnen het communautaire recht, valt de bestuursrechtelijke handhaving van de Mededingingswet onder de reikwijdte van het EVRM en biedt het EVRM -als verdrag inzake de bescherming van de rechten van de mens- ook bescherming aan ondernemingen? Pas als deze vragen bevestigend beantwoord zijn, kan worden bezien of het communautaire en Nederlandse kartelrecht het niveau van rechtsbescherming bieden dat het EVRM eist.

Bovenstaande problematiek zal als volgt worden besproken. Allereerst zal kort de ontwikkeling van de (grond)rechtenjurisprudentie van het Hof worden geschetst. Daarna zal aan de orde komen welke plaats het EVRM in de communautaire rechtsorde inneemt en of de bestuursrechtelijke handhaving van de Mededingingswet wordt bestreken door het EVRM. Vervolgens worden enkele belangrijke waarborgen voor ondernemingen in een kartelprocedure besproken: in paragraaf 3 komt het recht op berechting binnen een redelijke termijn aan de orde, in paragraaf 4 wordt het nemo tenetur-beginsel besproken, paragraaf 5 staat in het teken van een bespreking van het recht op rechtsbijstand en het 'legal privilege', in paragraaf 6 wordt bezien in hoeverre een onderneming toegang heeft tot bestanden en zij recht heeft op geheimhouding van gegevens waarna tenslotte in paragraaf 7 het privacy-recht aan de orde wordt gesteld.

\section{Grondrechten en het Hof van Justitie}

In Verordening 17 ligt het zwaartepunt duidelijk bij de instrumentele zijde van het commissieonderzoek in kartelzaken: centraal staat de toekenning van bevoegdheden die de Commissie in staat moeten stellen een adequate handhaving van het materiële kartelrecht te realiseren. ${ }^{4} \mathrm{De}$ bescherming van het individu (in casu: de onderneming) tegen te vergaand commissieoptreden daarentegen is enigszins stiefmoederlijk behandeld. In artikel $17 \mathrm{~V}_{0}$ 17 is het recht van de communautaire rechter op volle toetsing van commissiebeschikkingen neergelegd; artikel 19 Vo 17 behelst het recht van (belanghebbende) ondernemingen om met betrekking tot een te nemen beschikking te worden gehoord; artikel 20 Vo 17 omvat de geheimhoudingsplicht ten aanzien van in het kader van een onderzoek verkregen

3 Zeker nu het kartelrecht op grond van de Mededingingswet bestuursrechtelijk wordt gehandhasfd, zijn bovendien de algemene beginselen van behoorlijk bestuur, zoals ten dele gecodificeerd in de Awb, van belang. Dit belang strekt zich ook uit tot de toezicht en onderzoeksfase, mede omdat deze beginselen op grond van artikel 3:1 lid 2 Awb tot op zekere hoogte ook gelden voor andere handelingen dan besluiten. Op deze beginselen wordt hierna echter slechts ingegaan voorzover zij bij de doot mij te bespreken rechten in het geding zijn. Voor een uitvoerige bespreking zij verwezennaar Jansen (1999), met name hoofdstuk 7. 
informatie, terwijl artikel 21 Vo 17 zakengeheimen beschermt in geval van bekendmaking van een beschikking. ${ }^{5}$ Hoewel het hier zeer fundamentele en voor ondernemingen onmisbare aspecten van rechtsbescherming betreft, blijft Verordening 17 ver verwijderd van een beschermingsniveau zoals dat bijvoorbeeld in het strafprocesrecht wordt gerealiseerd en zoals dat bij een dermate ingrijpend punitief (overheids)optreden toch verwacht en getist mag worden. Aan deze conclusie verandert ook het noodzakelijkheidsvereiste, zoals dat in de artikelen 11 en 14 Vo 17 is opgenomen, niets. Weliswaar limiteert dit vereiste dat beschouwd kan worden als uiting van het evenredigheidsbeginsel- de bevoegdheden van de Commissie in zoverre dat inlichtingeninwinning en verificatie slechts zijn toegestaan indien en voor zover zij noodzakelijk zijn voor de vervulling van de taken van de Commissic, maar deze beperking is te vaag en te algemeen om een zeer wezenlijke bescherming te kunnen bieden. ${ }^{6} \mathrm{Op}$ het gebied van de rechtsbescherming schiet Verordening 17 naar mijn mening dan ook danig tekort. En het betreft een hiaat dat zeker door het oorspronkelijke overige gemeenschapsrecht niet werd opgevuld. Regels van rechtsbescherming en met name een verankering van klassieke grondrechten en (dus) van fundamentele rechten van de mens ontbraken volledig.' De reden hiervoor moet gezocht worden in de oorspronkelijk heersende gedachte dat rechten van de mens geen of een hooguit marginale rol zouden spelen binnen een gemeenschap wier doeleinden vrijwel uitsluitend op economisch terrein lagen. ${ }^{8}$ De geschiedenis heeft geleerd dat dit een foutieve inschatting was. Alleen al als men het kartelrecht bekijkt met zijn vergaande onderzoeks- en boetebevoegdheden, kan niet anders dan geconcludeerd worden dat de mogelijkheid van inbreuken op fundamentele rechten allerminst illusoir is. Maar ook op andere door de gemeenschap bestreken terreinen is het belang van de rechten van de mens prominent aanwezig. Het gemis van een regeling met betrekking tot fundamentele rechten van de justitiabele, waaronder hier mede wordt verstaan rechten in het kader van een mogelijk tot sancties leidende procedure, werd dientengevolge reeds relatief snel voelbaar. Dit gemis werd alleen maar nijpender naarmate de Europese Gemeenschap zich over meer en andere terreinen dan het strikt economische uitbreidde -waarbij in een breder verband gewezen kan worden op de Europese Unie, met haar doelstellingen onder meer op het gebied van de ontwikkeling van een samenwerking op justitieel gebied-en naarmate de invloed van het EVRM op de nationale

5 De artikelen $19 \mathrm{t} / \mathrm{m} 21$ Vo 17 zullen in dit hoofdstuk nog nader worden besproken.

6 Met dit noodzakelijkheidsvereiste hangt ook het motiveringsbeginsel samen, dat voor het gehele communautaire recht uitdrukkelijk in artikel 253 EG is verwoord. Zoals reeds bij de bespreking van de strafmotivering bleek, is de motivering onmisbaar voor een adequate controle op de naleving van het recht. Vergelijk in dat verband HvJ (24/62) Jur. 1963, 141 (Duitsland t. Commissie) "Overwegende dat artikel 190 (thans artikel 253 EG, HQ) (...) niet slechts op formele gronden berust, doch ten doel heeft partijen in staat te stellen voor hun rechten op te komen, het Hof in staat te stellen zijn taak uit te oefenen en de Lid-Staten en hun eventueel belanghebbende onderdanen in staat te stellen na te gaan, op welke wijze de Commissie het Verdrag heeft toegepast". De beschikking hoeft "slechts de belangrijkstejuridische en feitelijke overwegingen(...) te bevatten, waarop zij berust en die vereist zijn tot begrip van de gedachtengang, die verweerster tot haar beslissing heeft gebracht".

7 Een enkel 'grondrecht' valt wel te ontdekken, zoals artikel $12 \mathrm{EG}$, waarin het verbod van discriminatie op nationaliteit is opgenomen, maar die 'grondrechten' kumnen niet los worden gerien van de doelstellingen van het EG-Verdrag. Wel relevant voor het mededingingsrecht is het reeds genoemde motiveringsbeginsel van artikel $253 \mathrm{EG}$.

8 Vergelijk De Blois (1981), pag. 413, Betten (1985), pag. 4, Van Rijn (1986), pag. 488, 'Toetreding van de EG tot de ECRM' (1991), pag. 699/700, Leenders (1993), pag. 33 en Burkens (1993), pag. 71 . 
rechtsordes van de bij dat verdrag betrokken staten groeide. Het is met name het Hof gebleken dat oog had voor de zich hier voordoende problemen en dat via jurisprudentiele weg het communautaire rechtsbeschermingshiaat voor een belangrijk deel heeft opgevuld. Aanvankelijk was het Hof op dit punt overigens terughoudend. Wegens het ontbreken in het geschreven gemeenschapsrecht van de fundamentele rechten waarop door de betrokken justitiabelen een beroep werd gedaan, achtte het Hof zich niet bevoegd hierover een uitspraak te doen': bij de verzekering van de eerbiediging van het recht (artikel 164 EGVerdrag, thans artikel $220 \mathrm{EG}$ ) beperkte het Hof zich tot het 'geschreven gemeenschapsrecht'. Daar kwam bij dat het Hof als zijn primaire taak zag de ontwikkeling van de Europese Economische Gemeenschap: de gemeenschap stond nog in haar kinderschoenen en moest op de Europese kaart gezet worden. Wilden de communautaire belangen en voorschriften in Europa wortel kunnen schieten, dan moest niet in de laatste plaats het Hof de kar trekken. In de beginjaren lag hier dan ook de prioriteit van het Hof, waarbij met name de ontwikkeling van de gemeenschap als afzonderlijke, supranationale rechtsorde in het oog springt; binnen deze prioriteit paste een (al te) grote nadruk op niet uitdrukkelijk in het gemeenschapsrecht neergelegde rechtsbeginselen, die bovendien niet zonder meer in de lijn van het economische uitgangspunt van het (toen nog) EEG-Verdrag lagen, niet of nauwelijks. Gaandeweg veranderde de houding van het Hof echter en is het zoals gezegd op het terrein van de rechtswaarborgen zelfs een voortrekkersrol gaan vervullen ${ }^{10}$; de restrictieve interpretatie van artikel 164 EG-Verdrag (thans artikel $220 \mathrm{EG}$ ) werd verlaten en ingeruild voor een lezing waarin ook de eerbiediging van ongeschreven recht bij de uitlegging en toepassing van het EG-Verdrag door het Hof moest worden verzekerd." Het is overigens niet zo dat deze omarming van fundamentele rechtswaarborgen door het Hof uit principielle overwegingen van rechtsbescherming voortvloeide; zij had voomamelijk een instrumentele achtergrond. ${ }^{12}$ Het was namelijk al snel duidelijk -en dit werd in 1974 nog eens uitdrukkelijk bevestigd ${ }^{13}$ - dat het voor lidstaten eenvoudigweg niet aanvaardbaar zou kunnen zijn indien de gemeenschap waaraan zij -zij het op een beperkt terrein- hun soevereiniteit en (wetgevende) bevoegdheden hadden overgedragen, de meest fundamentele waarborgen die in hun eigen rechtsordes wél hecht verankerd waren, niet gehonoreerd zouden worden. ${ }^{14}$ Het was immers geenszins de opzet van de lidstaten dat door bedoelde overdracht aan rechtsbescherming zou worden ingeboet. Waarborging van fundamentele rechten was in dat licht een noodzaak om de ontwikkeling en acceptatie

9 De Blois (1981), pag. 414, Betten (1986), pag. 314.

10 Zie over deze rol ook Schermers en Waelbroeck (1992), pag. 37-42.

11 Vergelijk ook Betten (1985), pag. 37.

12 Burkens (1993), pag. 74: "De ontwikkeling van de grondrechtenjurisprudentie van het HvJ EG moet gezien worden in het licht van de aanvankelijkzeer terughoudende reactiesvan de rechterlijkemacht van niet de minste onder de lidstaten. Het Hof voelde zich geroepen de structuur van het gemeenschapsrecht-directewerking en suprematie-te handhaven. Voorkomenmoest echterworden dat deze structuur onder te sterke druk kwam te staan van de zijde van de lidstaten, waardoor de suprematie van het gemeenschapsrechtin gevaar zou komen. Dienovereenkomstig was het zaak om, ondanks het ontbreken van eengrondrechtencatalogusin hetprimaire gemeenschapsrecht, een soort vansubstituut daarvoor te ontwikkelen". In deze zin ook Curtin (1998), pag. 243.

13 Namelijk in het geruchtmakende 'Solange-arrest' van het Bundesverfassungsgericht. Zie voor een samenvatting en bespreking van dit arrest $A A$ 1976, pag. 111 e.v..

14 Aldus tevens Ghandi (1981), pag. 2. Zie voorts Coppel en O'Neill (1992), pag. 672: "It is by now beyond question that the early use of human rights discourse seen from Stauder onward was primarily defensive of the matter of the supremacy of Community law" en Burkens (1993), pag. 72. 
van de gemeenschap niet in gevaar te brengen. ${ }^{15}$ Deze instrumentele benadering door het Hof is ook in zijn latere jurisprudentie niet zonder belang ${ }^{16}$, maar naar mijn stellige overtuiging toont deze jurisprudentie toch vooral dat de rechten van de mens in toenemende mate een zelfstandige plaats worden toegedicht. ${ }^{n}$ Het Hof respecteert deze rechten inmiddels -nogmaals: mede ten gevolge van het toegenomen gewicht van het EVRM in van de uitbreiding van de EG- en EU-terreinen ${ }^{15}$ - primair omwille van hun eigen karakter en belang en vanuit de overtuiging dat in een rechtsorde en een rechtsgemeenschap niet aan deze rechten kan worden voorbijgegaan. ${ }^{19}$ Dit bewustzijn dat de legitimiteit van de Gemeenschap c.q. de Unie op het spel zou staan indien bepaalde minimumrechten niet zouden worden gerespecteerd, is in de loop der tijd eveneens gegroeid bij andere instellingen van de Europese Gemeenschap, hetgeen mede tot uiting is gekomen in de 'codificatie' van de jurisprudentie van het Hof in het Unie-Verdrag alsmede in de meermaals geuite wens van toetreding van de Europese Gemeenschap tot het EVRM en van de opstelling van een eigen, communautaire grondrechtencatalogus. Van toetreding is het tot op heden nog niet gekomen; een grondrechtencatalogus voor de Europese Unie daarentegen is eind 2000 in Nice afgekondigd. Daarmee lijkt de cirkel voor wat betreft de waarborging van de meest fundamentele rechten binnen de Unie en (dus) de Gemeenschap rond te zijn. Dat hierop nog wel wat valt af te dingen, zal hieronder nog worden besproken, maar feit is wel dat de rechten van de mens binnen 'Europa' een belangrijke

15 Het ontbreken van expliciete grondrechten stond haaks op de na de Tweede Wereldoorlog heersende tijdgeestdie juist in hetteken stond van een strikte waarborging van fundamentelerechten;men denke an de verankering van deze rechten in het Duitse Grundgesetz alsmede aan de internationale waarborging van de rechten van de mens via het EVRM. Zoals Burkens (1993), pag. 72, terecht aangeeft: "In deze opzet van de Europese grondrechtenbeschermingpast niet de suprematievan gemeenschapsrecht dat niet door grondrechten wordt beheerst".

16 Hierop doelt Turner (1999), pag. 454, als zij wijst op de noodzaak van bescherming van de rechten van de mens 'to maintain the momentum for economic integration'. Op een ander aspect van de instrumentele benadering wijzen Curtin en Klerk (1997), pag. 204, waar zij stellen dat het Hof het EVRM als bron voor de in de gemeenschap geldende fundamentele rechtsbeginselen heeft aangemerkt teneinde te voorkomen dat de Straatsburgse instanties zich bevoegd zouden achten om zaken die verband houden met het gemeenschapsrecht te toetsen.

17 Anders: Coppel en O'Neill (1992), pag. 692, die het Hof verwijten de mensenrechten voomamelijk instrumenteel te gebruiken: "the high rhetoric of human rights protection can be seen as no more than a vehicle for the Court to extend the scope and impact of European law". Terecht hevig bekritiseerd door: Weiler en Lockhart (1995 I), pag. 51-94 en (1995 II) pag. 579-627. Zij stellen op pag. 70 dat reeds vanaf het begin van de 'grondrechtenjurisprudentie' andere dan instrumentele overwegingen een rol hebben gespeeld: "Even if the protection of the integrity of the legal order gave the Court its primary motive for the change of jurisprudence from Stork to Stauder, this development was an inevitable sequel to Van Gend en Loos and it was coupled with other weighty, if subsidiary, reasons such as protecting the individual in a polity suffering from a deep democracy deficit (accentuated by Supremacy) and a changing historical climate and international consciousness towards human rights".

18 Interessant is in dit verband 'Toetreding van de EG tot de ECRM' (1991), pag. 698: "Met het groeien van de bevoegdheden en het uitbreiden van de werkterreinen van de EG is het belang van een adequate bescherming van menseurechten tocgenomen -overigens niet alleen met het oog op de rechtsbescherming van de burgers, maar ook vanuit de gedachte dat de overdracht van bevoegdheden aan de EG slechts kan worden gelegitimeerd door de aanvaarding van een constitutie, waarin ook grondrechten hecht zijn verankerd".

19 Zie ook 'Toetreding van de EG tot de ECRM' (1991), pag. 706. 
plaats hebben verworven en dat met deze rechten terdege rekening wordt gehouden. De belangrijkste stappen op de weg van een afwezige grondrechtenbescherming naar de huidige situatie zullen nu kort worden aangegeven.

\section{Ontwikkeling van de grondrechtenbescherming}

Reeds in 1959 werd het Hof in een EGKS-zaak geconfronteerd met een beroep op funda. mentele rechten. In het Stork-arrest werd aangevoerd dat door de Hoge Autoriteit inbreuk was gemaakt op de Duitse grondwet. Het Hof overwoog dienaangaande dat het "zich in het algemeen behoort te onthouden van uitspraken omtrent nationale rechtsvoorschriften". ${ }^{21}$ Aldus weigerde het Hof terecht (en doet dit tot op de dag van vandaag) categorisch om het communautaire recht te toetsen aan lidstatelijke grondrechten. Een ander uitgangspunt zou tot gevolg hebben gehad dat een uniforme toepassing van het communautaire recht onder druk zou zijn komen te $\operatorname{staan}^{22}$ en zou onverenigbaar zijn geweest met de latere jurisprudentie van het $\mathrm{Hof}^{23}$ waarin deze de Europese Gemeenschap als eigen, supranationale rechtsorde heeft aangemerkt. ${ }^{24}$ Het feit dat nationale grondrechten niet zonder meer in het communautaire recht gelding hebben, laat onverlet dat zij allerminst van betekenis zijn ontbloot voor de rechtsbescherming binnen de gemeenschap als zodanig. Dat bleck uitdrukkelijk in latere jurisprudentie, waarvan het Stauder-arrest uit 1969 het beginpunt markeert. In dit arrest zette het Hof een voorzichtige stap in de richting van incorporatie van algemene rechtsbeginselen in de communautaire rechtsorde, door te overwegen

"dat (...) de litigieuze bepaling in genen dele in strijd komt met de fundamentele rechten van de mens welke besloten liggen in de algemene beginselen van gemeenschapsrecht, waarvan het Hof de eerbiediging verzekert". 2s

Niet alleen de communautaire geschreven 'wet', maar meer algemeen het communautaire recht zijn derhalve relevant, van welk recht de fundamentele rechten van de mens deel uitmaken. ${ }^{26}$ Met deze officiële erkenning van het belang van rechtswaarborgen binnen het communautaire recht was echter nog niet onmiddellijk duidelijk welke deze rechten waren of waanuit deze konden worden geput. Het Internationale Handelsgesellschaft-arrest

20 Alhoewel de stelling van Ehlermann (1995), pag. 17, dat "The Cornmunity places the respect for human rights as one of its highest, probably the highest, of its priorities" toch enigszins overdreven lijkt, zoals nog zal blijken.

21 HvJ (1/58) Jur. 1959, 43 (Stork).

22 Aldus ook Leenders (1993), pag. 35.

23 Het verdragsrechtkan "op grond van zijn bijzonder karakter niet door enig voorschrift van national. recht opzij (...) worden gezet, zonder zijn gemeenschapsrechtelijk karakter te verliezen en zonder dat de rechtsgrond van de Gemeenschapzelf daardoor wordt aangetast". HvJ (6/64) Jur. 1964, 1199 (Costa-ENEL). Zie voorts HvJ (14/68) Jur. 1969, 1 (Wilhelm) welk arrest in het vorige hoofdstuk aan de orde is gekomen.

24 In die zin tevens Ghandi (1981), pag. 14 en De Blois (1981), pag. 414.

25 HvJ (29/69) Jur. 1969, 419 (Stauder).

26 Betten (1985), pag. 40, meent dat het aannemelijk is dat met 'algemene beginselen van gemeenschaps. recht door het Hof gedoeld wordt op "those principles recognised generally in (inter)national law. which are also applicable in the Community legal order". 
bracht in deze enig licht. Het Hof herhaalde zijn standpunt en uitgangspunt dat het gemeenschapsrecht niet aan het nationale recht en daarin vervatte garanties kan worden getoetst, maar legde tegelijk een link tussen het nationale en het communautaire recht:

"overwegende dat evenwel dient te worden onderzocht of niet enige soortgelijke in het gemeensehapsrecht verankerde garantic is miskend; dat immers de eerbiediging der grondrechten cen bestanddeel uitmaakt van de algemene rechtsbeginselen welker eerbiediging door het Hof van Justitie wordt verzekerd; dat de handhaving dezer rechten, ofschoon uit de gemeenschappelijke constitutionele traditie der Lid-Staten voortvloeiende, in het kader van het communautaire bestel en van de doelstellingen der Gemeensehap moet worden verzekerd".?

Aldus spelen de nationale rechtsstelsels een centrale, zij het indirecte rol bij de ontwikkeling van de rechtsbescherming: nationale stelsels en grondrechten vormen een inspiratiebron voor het Hof -maar niet meer dan dat- ${ }^{28}$ Het Nold-arrest getuigt van een verdere stap voorwaarts in de grondrechtenjurisprudentic. ${ }^{29} \mathrm{Na}$ het belang van de constitutionele tradities opnieuw te hebben onderstreept, overwoog het Hof

"dat aan internationale wilsverklaringen inzake de bescherming van de rechten van de mens waaraan de Lid-Staten hebben medegewerkt of waarbij zij zich hebben aangesloten ook aanwijzingen kunnen worden ontleend waarmede in het raam van het Gemeenschapsrecht rekening dient te worden gehouden". 30

Mensenrechtenverdragen spelen dientengevolge eveneens een rol als inspiratiebron voor het Hof bij de ontwikkeling van de grondrechtenbescherming binnen de communautaire rechtsorde. Voorzover het de klassieke grondrechten betreft, kan met name gedacht worden aan het EVRM alsmede aan het Internationaal verdrag inzake burgerrechten en politicke rechten (IVBPR) ${ }^{31}$, hetgeen door het Hof in een lange reeks arresten is bevestigd. ${ }^{32}$

$27 \mathrm{HvJ}(11 / 70)$ Jur. 1970, 1125 (Internationale Handelsgesellschaft).Bevestigd in onder meerhet Hauerarrest, HvJ (44/79) Jur. 1979, 3727. In dit arrest worden de gemeenschappelijke constitutionele tradities overigens ruim geīnterpreteerd; zo spreekt het Hof van "opvattingen welke aan de constituties der Lid-Staten gemeen zijn", "gegevens, in de constitutionele regelen en praktijken (...) besloten liggende" en "gemeenschappelijke constitutionele opvattingen en vaste legislatieve praktijken".

28 Naarmate het communautaire recht meer vorm krijgt, neemt de relevantie van de nationale rechtsstelsels als inspiratiebronnen voor de ontwikkeling van dit gemeenschapsrechtoverigens af. Over de aanpak van het Hof zie Pernice (1979), pag, 32: "Der Tendenz zur Heranziehung des nationalen Rechts nur mehr als Orientierungshilfe für eine autonome Rechts- (satz-)findung durch den Gerichtshof entspricht einezunehmendeGewichtsverlagerungzugunstender Einpassungmöglicherweiseaus Rechtsvergleichung gewonnener Lösungen win die Struktur und Ziele der Gemeinschaft «und der Rückbesinnung auf individualrechtsschützende Gehalte des Vertragsrechts selbst" en Betten (1985), pag. 26: "the Court has repeatedly drawn inspiration from the written and unwritten law of the Member States, developing a tendency to use national laws, not as a foundation for its judgement, but as an underlying guarantee of its autonomous determination of a rule".

29 HvJ (4/73) Jur. 1974, 491 (Nold).

30 In dezelfde bewoordingen HvJ (44/79) Jur. 1979, 3727 (Hauer). Deze principiêle erkenning van het belang van internationale verdragen in het Nold-arrest werd door het Hof danig beperikt omdat het stelde dat de rechten "normaliter slechts onder voorbehoud van in het openbaar belang voorziene beperkingen worden gewaarborgd" en dat derhalve "bepaalde grenzendie hun rechtvaardigingvinden in de doelstellingen van algemeen belang welke de Gemeenschap nastreeft, moeten worden in acht genomen zolang aan het wezen dier rechten geen afbreuk wordt gedaan".

31 Verdrag van 19 december 1966, Trb. 1969, 99. 
De conclusie kan derhalve luiden dat fundamentele rechten deel uitmaken van het gemeer. schapsrecht; als bronnen van inspiratie voor deze rechten gelden het nationale recht van de lidstaten alsmede de verdragen inzake de rechten van de mens waarbij de lidstaten op de een of andere wijze betrokken zijn. ${ }^{33}$ Dit wordt nog eens onderstreept door artikel 6 lid $2 \mathrm{EU}^{34}$ (het vroegere artikel $\mathrm{F}$ lid 2 van het Verdrag betreffende de Europese Unie):

"De Unie eerbiedigt de grondrechten, zoals die worden gewaarborgd door het op 4 november 1950 te Rome ondertekende Europees Verdrag tot bescherming van de rechten van de mens en de fundamentele vrijheden en zoals zij uit de gemeenschappelijke constitutionele tradities van de Lid-Staten voortvloeien, als algemene beginselen van het Gemeenschapsrecht".

Met deze verdragsrechtelijke erkenning van het belang van de meest fundamentele rechten zoals die -voorzover het het EVRM betreft- ook in alle lidstaten gelden, is een duidelijk (politiek) signaal gegeven dat aan deze rechten ook op communautair niveau niet voorbij mag worden gegaan. Barents stelt dat uit deze formulering in combinatie met het eerste lid van artikel 6 EVRM blijkt dat de "Unie zelf (...) op de beginselen van de rechtsstaat (is) gebaseerd en het is uit dien hoofde dat de Unie het EVRM dient te eerbiedigen","s Inhoudelijk echter heeft het artikel niets toegevoegd aan de jurisprudentie van het Hof." Daarenboven bracht artikel $6 \mathrm{EU}$ geen verandering in het ontbreken van een 'grondrechtencatalogus' binnen het geschreven Gemeenschaps- c.q. Unie-recht. Voornamelijk tegen deze achtergrond moet het Handvest van de grondrechten van de Europese Unie worden gezien: voornaamste doel hiervan is de vergroting van de zichtbaarheid van de geldende rechten. Zoals de Commissie het treffend verwoordde:

"De Europese Raad heeft de met de opstelling van het Handvest belaste Conventie (...) een opdracht gegeven die meer op het gebied van het openbaar maken van bestaande dan van het scheppen van nieuwe rechten, meer op het gebied van compilatie dan van vernieuwing is gelegen". 37

32 Het EVRM werd in dit verband door het Hof voor het eerst genoemd in het Rutili-arrest. Tot de lange lijst van arresten waarin op het EVRM werd ingegaan, behoren onder meer HvJ (85/76) Jut. 1979, 511 (Hoffmann-La Roche), HvJ (136/79) Jur. 1980, 2033 (National Panasonic UK), HvJ (209-215 en 218/78) Jur. 1980, 3125 (Heinz van Landewijck e.a.), HvJ (322/81) Jur. 1983, 3461 (Michelin). HvJ (222/84) Jur. 1986, 1651 (Johnston), HvJ (5/85) Jur. 1986, 2585 (AKZO), HvJ (C-185/95 P) Jur. 1998, 1-8417 (Baustahlgewebe)en HvJ (C-249/96) Jur. 1998, I-621 (L.J. Grant). Het Hof maakt in sommige gevallen onderscheid tussen fundamentele rechtsbeginselen en rechten van de verdediging (waarbij klaarblijkelijk met name typisch communautairrechtelijke rechten bedoeld worden); dit onderscheid is echter nauwelijks te maken temeer daar het belang van het EVRM, en de daarin vervatte fundamentele (verdedigings)rechten voor het communautaire recht toeneemt.

33 Uit GvEA (T-347/94) Jur. 1998, II-1751 (Mayr-MelnhofKartongesellschaft)blijkt uitdrukkelijk dat het Gerecht zich niet bevoegd acht "om een onderzoek op het gebied van het mededingingsrecht te toetsen aan de bepalingen van het EVRM, voor zover deze niet als zodanig deel uitmaken van het gemeenschapsrecht".

34 Verdrag van 7 februari 1992, Trb. 1992, 74, zoals gewijzigd 24 juni 1994, Trb. 1994, $200 \mathrm{j}^{\circ} 1$ januari 1995, Trb. 1995, 64, 2 oktober 1997, Trb. 1998, 11 en 12.

35 Barents (1997), pag. 25.

36 Op het slechts declaratoire karakter van artikel $6 \mathrm{EU}$ wijst ook Burkens (1993), pag. 76.

37 Mededeling van de Commissie betreffende het Handvest van de grondrechten van de Europese Unic ingediend door de heer Vitorino in overeenstemming met de Voorzitter, $\mathrm{COM}(2000) 559$ definitief. 
Dit wordt ten volle bevestigd door de Preambule bij het Handvest:

- Onder eerbiediging van de bevoegdheden en taken van de Gemeenschap en de Unie en van het subsidiariteitsbeginsel, bevestigt dit handvest de rechten die met name voortvloeien uit de gemeenschappelijke constitutionele tradities en internationale verplichtingen van de lidstaten, uit het Verdrag betreffende de Europese Unie en de communautaire verdragen, uit het Europees Verdrag tot bescherming van de rechten van de mens en de fundamentele vrijheden, uit de door de Gemeenschapen de Raad van Europa aangenomen sociale handvesten, alsook uit de jurisprudentie van het Hof van Justitie van de Europese Gemeenschappen en van het Europees Hof voor de Rechten van Mens."

Het Handvest derhalve als codificatie van de (klassieke en sociale grond-) rechten zoals die ook reeds voordien binnen de sfeer van de Unie golden. Ook hier is er dus de facto inhoudelijk niets nieuws onder de zon, althans lijkt dit niet beoogd te zijn. De meerwaarde (voorzover die er al is, waarover hierna nader) ligt dus inderdaad in de grotere kenbaarheid van de rechten en in de daarmee samenhangende verruiming van de rechtszekerheid ${ }^{3 \mathrm{n}}$ alsmede -als voornamelijk politiek 'statement' - in de explicitering dat de Unie ook zelf op grond van geschreven regels gebonden is aan waarden die door alle lidstaten worden onderschreven en waarvan zij van derde staten waarmee zij bepaalde banden onderhoudt, eist dat zij die respecteren. ${ }^{39}$

Hoe moet het bovenstaande nu worden beoordeeld $?^{40}$ In grote lijnen is er zonder meer sprake van een positieve ontwikkeling. De opvatting dat het met schending van fundamentele rechten binnen de Europese Gemeenschap -daartoe beperk ik mij hier gelet op het onderwerp van deze studie- niet zo'n vaart zou lopen, is terecht reeds relatief snel verlaten. Het Hof heeft onderkend en erkend dat fundamentele rechten, zelfs op een zo economisch gebied als het kartelrecht, in het geding kunnen zijn en het heeft ervan blijk gegeven schendingen van deze rechten in de communautaire sfeer niet te zullen tolereren. De Raad en de Commissie lijken op dezelfde lijn te zitten, getuige onder meer de totstandkoming van het Handvest. Al met al kan worden geconcludeerd dat de fundamentele rechten een plaats van belang in het gemeenschapsrecht innemen. Maar daarmee is nog niet gezegd dat 'automatisch' het minimum beschermingsniveau wordt bereikt zoals dat door het EVRM en het Straatsburgse Hof wordt gegarandeerd. Toegegeven: tot op heden zijn er, voor zover mij bekend, geen grote uitschieters in negatieve zin van het Hof geweest en heeft het Hof een doorgaans aanvaardbaar beschermingsniveau gerealiseerd. ${ }^{41}$ Dat

38 Belangrijk punt van kritiek van de jurisprudentiele weg van bescherming van grondrechten was immers dat voorafgaand aan een procedure voor het Hof voor de justitiabele niet zonder meer vaststond of een door hem ingeroepen recht door het Hof ook als communautair grondrecht zou worden erkend, met name niet indien het een recht betrof dat geen deel vormde van de rechten van het EVRM. Op dit aspect van 'legal certainty' wijst ook Turner (1999), pag. 458.

39 Turner (1999), pag. 454, wijst erop dat "most third countries who enter into agreements with the $\mathrm{EC}$ or the $\mathrm{EU}$ are expected to protect human rights as a precondition or as an integral part of the agreement. (...) It would be contradietory, inconsistent and incoherent for the EC to force compliance of such provisions without safeguarding similar rights themselves". Zie hierover ook Bulterman en Lawson (2000), pag. 423 e.v..

40 Zie meer algemeen over algemene rechtsbeginselen en hoe zij de verschillen tussen en binnen verscheidene rechtsordes kunnen terugdringen: Van Gerven (1995).

41 Toch werd in 'Toetreding van de EG tot de ECRM' (1991), pag. 714, nog van een onbevredigende situatie gesproken. Ook Leenders (1993), pag. 67, concludeert: "Alles overziende is de grondrechtenbescherming door het Hof van Justitie niet indrukwekkend. (..) Er is inderdaad een beeld opgebouwd 
laat echter onverlet dat het Hof in ieder geval tot de inwerkingtreding van het Handvest niet steeds de jurisprudentie van het Straatsburgse Hof zonder meer heeft gevolgd. Hieraan is voomamelijk de omstandigheid debet dat de Gemeenschap geen partij is bij het EVRM, als gevolg waarvan het Hof dit verdrag als zodanig als niet-bindend voor de Gemeenschap beschouwt en het EVRM slechts als -zij het een belangrijke-inspiratiebron voor het Hof fungeert. ${ }^{42}$ De consequentie hiervan is door advocaat-generaal Darmon wel zeer duidelijk verwoord:

"Het Hof is niet gebonden, in die zin dat het voor de grondrechten van het gemeenschapsrecht de doot die instanties (namelijk de Straatsburgse instanties, HQ) aan het verdrag gegeven uitlegging niet systematisch behoeft over te nemen"."

In die opvatting bepaalt het Hof dus zelf hoever het bij de bescherming van de rechten gaat. ${ }^{44}$ Het Hof kan dus voorbij gaan aan de interpretatie zoals die door het EHRM aan het EVRM wordt gegeven ${ }^{45}$, zonder het door het Straatsburgse Hof kan worden 'overnuled' ${ }^{46}$ Vanuit beschermingsoptiek is dit op zijn minst bedenkelijk, althans voorzover ten nadele van de justitiabele van het EVRM wordt afgeweken. En dat een dergelijk geval zich daadwerkelijk voordoet, is geenszins denkbeeldig. ${ }^{47}$ Het was namelijk lange tijd vaste praktijk van het Hof om de fundamentele rechten toe te passen en te interpreteren "in het kader van het communautaire bestel en van de doelstellingen der Gemeenschap". " Met andere woorden: (grond)rechten hebben geen hogere status dan het (overige) Gemeen-

als zouden de grondrechten effectiefbeschermd worden door het Hof van Justitie. Maar zoals zojuist geschetst is de 'erelijst' van gevallen waarin grondrechten effectief werden tegengeworpen binnen het kader van gemeenschapsrechtverdacht kort te noemen". Op pag. 68 vervolgt deze schrijver: "Met name op het gebied van het mededingingsrecht is het Hof zeter terughoudend ten aanzien van grondrectten, en soms te kortaf bij verwerping van beroepen op grondrechten. Het Hof bewaakt de effectiviteil van de administratieveprocedure sterk. Zo er al grondrechtelijke of andere rechtsstatelijkeproblemen gesignaleerd worden, wordt duidelijk gemaakt dat zij praktisch niet doorslaggevend kunnen zijn. doordat na toetsing van een besluit de uitvoering ervan niet meer getoetst wordt (Dow Benelux). of doordat geesist wordt dat men aantoont dat het besluit tot een ander resultaat had geleid als het wel rechtmatig genomen zou zijn (Van Landewyck)". Schermers (1996), pag. 881, acht het echter op grond van het strenge toezicht van het Hof op de naleving van mensenrechten onwaarschijnlijk dat met het EVRM strijdige gemeenschapshandelingen de toets van het Hof doorstaan.

42 Cath (1987), pag. 32, spreekt in dit verband van een 'reflexwerking' van het EVRM op het communavtaire recht. Vergelijk ook Ghandi (1981), pag. 3 en Leenders (1993), pag. 37.

43 Conclusie bij HvJ (374/87) Jur. 1989, 3338 (Orkem). Ghandi (1981), pag. 17: "An obligation to follow the Strasbourg Court's interpretation can only exist pursuant to an express provision making it mandatory",

44 Lawson (2000 I), pag. 925.

45 Ghandi (1981), pag. 12 stelt in dit verband: "it is not at all clear that the Strasbourg Institutions would adhere to the same criteria in interpreting the same concepts in proceedings brought under the Conventon",

46 Aldus terecht Tumer (1999), pag. 458, Stessens (1993), pag. 147, alsmede Schermers (1990), pag 257: "As long as the Community is not a party to the European Convention on Human Rights the proceedings of that Convention do not apply to it".

47 De praktijk biedt hiervan ook voorbeelden, zoals hierna nog zal worden besproken.

$48 \mathrm{HvJ}(11 / 70)$ Jur. 1970, 1125 (Internationale Handelsgesellschaft). 
schapsrecht en kunnen in het algemeen (communautair) belang worden beperkt. ${ }^{49} \mathrm{Nu}$ is het weliswaar zo dat een grondrecht zelden absoluut is en er dus doorgaans in het algemeen belang beperkingen op een dergelijk recht geoorloofd zijn, maar de bewoordingen van het $H$ of wijzen erop dat met het oog op het communautaire belang de bereidheid bestond om tamelijk vérgaande beperkingen te aanvaarden, ja zelfs dat het Hof in beginsel niet meer bescherming wilde bieden dan gelet op de realisering van de (primaire) doelstellingen van het EG-Verdrag toelaatbaar kon worden geacht. ${ }^{50}$ De standaard van het EVRM, zoals geinterpreteerd door het Europees Hof in Straatsburg, wordt dan niet (althans niet in alle gevallen) gehaald. Opmerking verdient dat deze aanpak het Hof nauwelijks kwalijk viel -en voorzover deze aanpak zich nog steeds voordoet: valt -te nemen. Het Hof is geen mensenrechtenhof; zijn prioriteiten liggen bij de Europese Gemeenschap, met zijn toch voornamelijk economische doeleinden." Dat fundamentele rechten tegen die achtergrond en prioriteiten worden geinterpreteerd en toegepast, verbaast dan niet. ${ }^{52}$ Daar komt bij dat het Hof vaak de Europese kar heeft moeten trekken en in dat verband ligt het niet voor de hand dat het Hof bijvoorbeeld de -in vergelijking met de nationale bevoegdheden van de uitvoerende macht toch al minder vérstrekkende- bevoegdheden

49 Hetgeen ook volgt uit onder meer HvJ (4/73) Jur. 1974, 491 (Nold). Terecht stelt Clapham (1991). pag. 47/48: "human rights values will have to be interpreted in the light of the demands of European integration. They are not considered the highest law". Coppel/O'Neill (1992), pag. 684: "Where Community actions in pursuit of Community objectives are concerned, claims to fundamental rights are quite clearly not accorded a pre-eminent status". Leenders (1993), pag. 69, wijt dit onder meer aan de 'afwerigheid van een uitdrukkelijke verzekering van grondrechten' en (daarmee samenhangend) aan het feit dat de grondrechten (slechts) worden opgevat als algemene rechtsbeginselen.

50 Coppel en O' Neill (1992), pag. 692 concluderen: "Evidently it is economic integration, to be achieved through the acts of Community institutions, which the Court sees as its fundamental priority". Weiler en Lockhart (1995 II), pag. 589, menen -onder de voorwaarde dat een recht niet wordt uitgeholdterecht dat "whenever a Community measure has to be interpreted or applied one should try, as far as possible, to interpret it in a way which would be respectful of, rather than violative of, the fundamental human rights protected in the legal order of the Community". Maar feit blijft mijns inziens dat de 'communautaire maatregel' onverminderd zal moeten wijken indien zij niet verenigbaar is met het minimum beschermingsniveau van het in het geding zijnde (grond)recht.

51 Turner (1999), pag. 460 overweegt dienaangaande dat "the ECtHR regards human rights protection as the norm and derogation as the exception, whereas the ECJ views respect of the economic provisions of the EC Treaty as the norm providing for limitation, inter alia, in the interests of human rights protection". Toth (1997), pag. 499, wijst eveneens op de mogelijkheid van uiteenlopende interpretaties van het EVRM door respectievelijk het Hof en het EHRM: "Conflicting interpretations are likely to oceur because both Courts follow the same 'teleological' method. (...) The Convention's aim is to protect the individual as a human being, while the Community's aim is to further economic and social integration".

52 Leenders (1993), pag. 35, vat de 'grondrechtenjurisprudentie' als volgt samen: "Het Hof heeft zich bereid getoond, dese (uit artikel 220 EG voortvloeiende, HQ) mogelijkheid tot creatieve rechtsvinding aan te wenden om grondrechten in het gemeenschapsrecht te brengen. Maar het is zeer beducht geweest voor de risico's en de praktische problemen die dat met zich mee kan brengen", Naar aanleiding van de Nold-zaak vervolgt deze schrijver op pag. 38: "De overwegingen van het Hof maken duidelijk dat het economische accentin de communautaire rechtsorde reden is om het te verwachten praktische belang van grondrechten in die rechtsorde vooral niet te overschatten. Het economische karakter van de context waarbinnen grondrechten in de communautaire rechtsorde vooral naar voren komen, brengt een bepaalde invulling van de in het geding zijnde grondrechten met zich mee". 
van de Commissie uit mensenrechtenoverwegingen danig zou inperken. ${ }^{53}$ Hoe legitiem dit vanuit Gemeenschapsoptiek ook moge zijn, op mijn bijval hoeft de jurisprudentic van het Hof op dit punt allerminst te rekenen. ${ }^{34}$ De normen die in het EVRM zijn vervat, moeten, gelet op de aard van die normen en op het belang dat eraan inmiddels algemeen wordt toegekend, toch worden beschouwd als minimumvoorwaarden die in hun volle omvang door iedere rechtsorde, die op die benaming met succes aanspraak wil maken, gerespecteerd zouden dienen te worden. Dit geldt voor de lidstaten (die ook alle lid zijn van het $\mathrm{EVRM}^{55}$ ), en dat is niet anders ten aanzien van de Gemeenschap. De reikwijdte van de communautaire bevoegdheden rechtvaardigt, ja eist zelfs een adequaat niveau van bescherming voor justitiabelen tegen de uitoefening van die bevoegdheden; een niveau van bescherming dat liefst hoger ligt dan het door het EVRM gebodene minimumniveau, maar dat toch in ieder geval niet lager mag liggen. Het karakter van de in het EVRM neergelegde rechten, die gerust als fundamenteel kunnen worden aangemerkt, verzet zich ertegen dat doel-rationele overwegingen aan realisering van die rechten in de weg staan." Door het EVRM slechts als inspiratiebron te gebruiken en niet zonder meer de Straatsburgse jurisprudentie te volgen, wordt bovendien de merkwaardige en door de lidstaten ongetwijfeld niet gewilde situatie gecreěerd dat iedere overheveling van bevoegdheden van lidstatelijk naar communautair niveau het gevaar in zich draagt dat aan bescherming wordt ingeboet. Naast het gegeven dat hiervoor geen goede grond zou kunnen zijn en dat dit vanuit rechtsbeschermingsoogpunt onwenselijk is, zou dit in geval van grove schendingen van het EVRM -die zich echter zoals reeds gezegd tot op heden nog niet hebben voorge. daan- tot grotere terughoudendheid ten aanzien van verruiming van de communautaire bevoegdheden aanleiding kunnen geven. De conclusie dient mijns inziens dan ook te luiden dat, wat er overigens ook zij van de opinie van het Hof dat het EVRM de Gemeenschap rechtens niet bindt ${ }^{57}$, de rechten die in het EVRM zijn verankerd ten volle binnen

53 Aldus ook 'Toetreding van de EG tot de ECRM' (1991), pag. 713, waarin voorts wordt opgemerkt "Het is derhalve zeer wel denkbaar dat het Hof in Luxemburg een geheel ander evenwicht zal nastreven dan de organen van de ECRM, en bereid zal zijn een veel verder gaande beperking van mensenrechten te accepteren". Leenders (1993), pag, 69 zoekt de oorzaak van de "te algemene en vrijblijvende benade ring van grondrechten door het Hof voornamelijk in "de mentale gerichtheid van de rechter die die bescherming moet bieden. En die wordt wat betreft het Hof van Justitie gekenmerkt door een sterke mate van instrumentalisme: het Hof is van Costa/ENEL tot Francovich de architect geweest van de communautaire rechtsorde".

54 Naast de nog te bespreken bezwaren tegen de mogelijke gevolgen van de jurisprudentic, kan hier worden genoemd het reêle gevaar van interpretatieverschillenal naar gelang of het EVRM binnen de communautaire sfeer dan wel daarbuiten toepassing vindt. Vergelijk hierover 'Toetreding van de EG tot de ECRM' (1991), pag. 711 en Turner (1999), pag, 459. Nu kan hiertegen worden ingebrach dat ook nationale rechters hun eigen interpretatie aan het EVRM geven, maar hier geldt dat uiteindelik het laatste woord is aan het EHRM; in het communautaire recht is het echter steeds het Hof zelf dat het laatste woord heeft.

55 Wat nog niet wil zeggen dat het EVRM ook steeds volledig wordt nageleefd.

56 Hoewel ook het EHRM zonder meer oog heeft voor de noodzaak van een adequate handhaving van regelgeving, waakt het ervoor dat uit overwegingen van doel-rationaliteit de rechten niet in den gronde worden aangetast.

57 In de literatuur bestaat hierover onenigheid. Vanuit de gedachte dat niemand meer rechten kan overdra gen dan hij zelf heef, met daaraan gekoppeld de omstandigheid dat de lidstaten op het moment vas oprichting van de Gemeenschap het EVRM hadden ondertekenden op Frankrijk na bovendien reeds hadden geratificeerd, wordt wel verdedigd dat de Gemeenschap-ondanks het feit dat zij zelf gets partij is bij het EVRM- toch rechtens aan dit verdrag is gebonden. Schermers (1996), pag. 881, stell 
het communautaire recht gelerbiedigd dienen te worden, hetgeen met zich brengt dat de jurisprudentie van het Straatsburgse Hof voor het Hof de verplichte maatstaf moet zjn voor zijn eigen 'grondrechtenjurisprudentie'. ${ }^{38}$ Steun voor deze conclusie kan ook worden gevonden in artikel $6 \mathrm{EU}$ alsmede in het Handvest van de grondrechten van de Europese Unie. Zoals besproken benadrukt de Preambule bij dit Handvest met krachtige woorden het belang van het Straatsburgse 'acquis' voor de Unie. Dit belang wordt nog eens bevestigd door de opname in het Handvest van aan het EVRM ontleende, zij het helaas niet integraal overgenomen ${ }^{59}$, klassieke grondrechten. Kroon op het geheel vormen de artikelen 52 derde lid ${ }^{60}$ en $53^{61}$ Handvest waarin is vastgelegd dat de rechten zoals geformuleerd in van het Handvest dezelfde inhoud en reikwijdte hebben als de corres-

dienaangaande: "Omdat de handelingsbevoegdheid van de lid-staten door het EVRM was beperkt wou automatisch ook de handelingsbevoegdheid van de Gemeenschappen aan dezelfde beperking dienen te zijn onderworpen". In gelijke zin deze sehrijver reeds in 1990, pag. 251 en "Toetreding van de EG tot de ECRM' (1991), pag. 700. Pescatore(1988), pag. 450 komt tot cen vergelijkbareconclusie: "ils n'ont pas pu et ils n'ont d'ailleurs pas voulu libérer ces pouvoirs, ni à l'égard d'Etats tiers, ni al l'égard de leurs propres sujets, des contraintes et contrôles résultant de la Convention européenne des Droits de I'Homme". (...) "Si la Cour a appliqué la Convention et si elle continue de I'appliquer, c'est qu'elle est tenue de l'appliquer, c'est son obligation, et non son bon vouloir". Als deze redenering juist is, dan is -in de woorden van Biesheuvel(1996), pag. 669. "het Hof bij de interpretatieen toepassing van het gemeenschapsrechtgehouden (...) daaraan een uitleg te geven die ook met de materiēle bepalingen van de Conventic in overeenstemming is, althans met die bepalingen niet strijdt". Een logisch gevolg hiervan zou zijn dat het Hof zich aan de Straatsburgse interpretatie van het EVRM zou dienen te conformeren. Een mijns inziens zonder meer aantrekkelijkeuitkomst, die echter geen oplossing biedt voor de bestaande onmogelijkheid om communautaire maatregelen voor de Straatsburgse rechter te brengen (voor zover Pescatore's substitutietheorie zover voert dat dit nu reeds mogelijk zou zijn, moet zij overigens worden verworpen). In zijn dissertatie bestrijdt Lawson (1999) echter bedoeldesubstitutietheorie(evenals Vermeulen(1993), pag. 47) en achthij de Gemeenschapevenmin op inhoudelijke gronden gebonden aan het EVRM -hoewel hij de mogelijkheid openlaat dat het EVRM als regionaal ius cogens is te beschouwen- Hij construeert een model waarin de lidstaten aansprakelijk zijn voor eventuele schendingen van het EVRM door de Gemeenschap (positief dienaangaande Van Boven (2000), pag. 641). Aldus zouden-zij het via de omweg van het indienen van een verzoekschrift tegen alle lidstaten-communautaire schendingen van het EVRM alsnog bij het EHRM kunnen worden angekaart. Dit zou enige winst opleveren, maar mijns inziens verdient het de voorkeur dat de Gemeenschap zelf aansprakelijk kan worden gehouden en voor het EHRM 'ter verantwoording kan worden geroepen'.

58 Terechtstelt Clapham(1991), pag. 60, dan ook: "If (...) the Court of Justice is serious about protecting human rights in the Community legal order then it should show more deference to the Strasbourg caselaw".

59 Van Rijn (1986), pag. 491, een voorstander van een afzonderlijk grondrechtenhandvest voor de Europese Gemeenschap, pleitte voor een dergelijk letterlijk ovememen van de grondrechten uit het EVRM en het Europees Sociaal Handvest.

60 "Voorzover dit handvest rechten bevat die corresponderen met rechten die zijn gegarandeerd door het Europees Verdrag tot bescherming van de rechten van de mens en de fundamentele vrijheden, zijn de inhoud en reikwijdte ervan dezelfdeals die welke er door genoemd verdrag aan worden toegekend. Deze bepaling verhindert niet dat het recht van de Unie een ruimere bescherming biedt."

61 "Geen der bepalingen van dit handvest mag worden uitgelegd als zou zij een beperking vormen van of afbreuk doen aan de rechten van de mens en de fundamentele vrijheden welke binnen hun respectieve werkingssferenworden erkend door het rechtvan de Unie, het internationaalrechtende internationale overeenkomstenwaarbij de Unie, de Gemeenschapof alle lidstaten partij zijn, metname het Europees Verdrag tot bescherming van de rechten van de mens en de fundamentele vrijheden, alsmede door de grondwetten van de lidstaten." 
ponderende 'EVRM-rechten' en dat door het Handvest geen afbreuk wordt gedaan aan bestaande fundamentele rechten waaronder die welke in het EVRM worden gewaarborgd. Dit lijkt er toch geen twijfel meer over te laten dat het Hof met betrekking tot het EVRM het steven volledig richting Straatsburg zal moeten wenden. Hierbij past overigens wel de kanttekening dat het Handvest niet alleen slechts een codificatie beoogt van hetgeen reeds via andere wegen was bereikt (hetgeen noopt tot voorzichtigheid bij het trekken van conclusies omtrent een al dan niet noodzakelijke wijziging van de benadering van het Hof), maar ook dat het vooralsnog niet bindend is. ${ }^{62}$ Het kan dan wel in de woorden van de Commissie een 'proclamatorisch politiek effect' hebben, maar juridisch afdwingbar is het daarmee nog allerminst, laat staan dat het een constitutionele status ${ }^{63}$ zou hebben. $^{\text {" }}$ Hoe dit ook zij, een bevestiging van de conclusie dat het Hof zijn koers op Straatsburg zou moeten afstemmen, kan in het Handvest toch wel worden gevonden. Tekenen dat dit ook daadwerkelijk gebeurt, zijn er gelukkig in de jurisprudentie van het Hof ook. Steeds vaker lijkt het Hof daadwerkelijk aan te sluiten bij het EVRM en de Straatsburgse jurisprudentie. Een pregnant voorbeeld daarvan is de betonstaalmattenzaak ${ }^{65}$, waarop in paragraaf 3.2 nader zal worden ingegaan. ${ }^{66}$ Maar ook als het Hof deze koersafstemming daadwerkelijk doorvoert, blijft hoe dan ook een belangrijk probleem bestaan: wie controleert of de interpretatic die het Hof aan het EVRM geeft correct is? Het antwoord moet (vooralsnog ${ }^{67}$ ) luiden: niemand. En dat is mijns inziens zowel vanuit Straatsburgs als vanuit communautair en Unie-oogpunt onbevredigend en onwenselijk. Ten aanzien van

62 Van verschillende kanten wordt er dan ook op aangedrongen dat het Handvest juridisch bindend wordt. Vergelijk Pb 2001 L. 144/42 (Resolutie van het Comité van de Regio's over "De goedkeuring van het handvest van de grondrechten van de Europese Unie").

63 In 'Toetreding van de EG tot de ECRM' (1991), pag. 705 en 706 wordt gewezen op het constitutionele probleem van de Gemeenschap dat via jurisprudentięle weg niet kan worden weggenomen.

64 Meer in het algemeen is het maar zeer de vraag of Europa zat te wachten op een mensenrechtenregeling naast die van het EVRM, die wellicht op materieel gebied identiek is aan het EVRM waar het de klassieke grondrechten betreft, maar waardoor onverminderd twee hoven in hoogste instantic ovet dezelfde normen oordelen. Twijfels over een afzonderlijke catalogus van communautaire grondrechten zijn in het verleden al vaker geuit, onder meer door Ghandi (1981), pag. 27, De Blois (1981), pag. 417 ("Het zou echter boogst onwenselijk zijn wanneer naast de ECRM in Europa nog een mensenrechtenhandvest zou worden ontwikkeld dat betrekking heeft op de terreinen die reeds bestreken worden door de ECRM. (...) Op die wijze zou de ECRM en het daarbij behorende controle mechanisme kunnen worden uitgehold, terwijl er voor de mensenrechtenbescherming een Europa met twee snelheden zou kunnen ontstaan."), Schermers (1990), pag. 252 ("the splitting of human rights protection in Europe over two different bodies may do more harm than good"). Schermers (1996), pag. 882 vreest het uiteengroeien van de jurisprudentie van beide hoven en splitsing van Europa op mensenrechtgebied waarbij niemand gebaat is; Toth (1997), pag. 501 ("In many ways, this would probably be the worst possible scenario"). Voorstanders van een eigen communautaire 'Bill of Rights' betoondenzichonder meer Betten (1986), pag. 320 en Van Rijn (1986), pag. 488.

$65 \mathrm{HvJ}$ (C-185/95 P) Jur. 1998, I-8417 (Baustahlgewebe).

66 Helaas wijst GvEA (T-305-307, 313-316, 318, 325, 328, 329 en 335/94) Jur. 1999, II-931 (Limburgse Vinyl Maatschappij e.a.) in de tegengestelde richting. Zie hierover paragraaf 7.3.

67 Lawson (1999) gaat uit van lidstaatsaansprakelijkheid en meent dat alle lidstaten tezamen aangesproken worden op eventuele schendingen van de rechten van de mens door de Gemeenschap. Nog afgezien van de vraag of het EHRM bereid zal zijn een tegen alle lidstaten gericht verzoek inhoudelijk te behandelen, is de Gemeenschap (c.q. de Unie) in ieder geval niet zelf direct aansprakelijk. Uit de M \& Co beslissing van de ECRM concludeert Turner (1999), pag. 460 dat "Strasbourg will now control whether or not the EC meets the standard of protection and will replace the German control". Vergelijkbaar Vermeulen (1993), pag. 55. 
Straatsburg geldt dat uniforme interpretatie van het EVRM in het gedrang komt doordat het EHRM niet in alle gevallen kan waken over de uitleg van dit verdrag. En gelet op het feit dat de Gemeenschap en de Unie zich over steeds bredere terreinen uitstrekken en zich ook geografisch verder zullen uitbreiden (door toetreding van nieuwe lidstaten), zou dit tenminste theoretisch tot uitholling van het EVRM kunnen leiden. ${ }^{68}$ Voor de Gemeenschap en Unie blijft hoe dan ook het risico bestaan dat de door het Hof gerealiseerde bescherming van de mensenrechten niet het EVRM-niveau bereikt, zelfs al acht het Hof zich gebonden aan (de materiële normen van) het EVRM en tracht het naar eer en geweten zijn jurisprudentie EVRM-conform gestalte te geven. ${ }^{60}$ In dit kader hoeft slechts gewezen te worden op het feit dat menige staat die oprecht van mening was dat zjin handelwijze volledig in overeenstemming was met de vereisten van het EVRM door de Straatsburgse organen op zijn vingers is getikt. ${ }^{70}$ Indien de Gemeenschap onderworpen zou zijn aan de externe controle van het EHRM, zou dit het Hof ook kunnen gebeuren. En gelet op het voorgaande meen ik dat dit ook goed zou zijn: bescherming van de rechten van de mens binnen de Gemeenschap zou in ieder geval op het minimumniveau van het EVRM gegarandeerd zijn en het laatste woord" ten aanzien van dit verdrag zou in alle gevallen aan de instantie zijn waar het ook thuishoort: het Europees Hof voor de Rechten van de Mens. ${ }^{n}$ Om de rechtsbeschermingscirkel daadwerkelijk rond te maken zou de Gerneenschap naar mijn mening dan ook onderworpen moeten zijn aan de externe controle van het EHRM. ${ }^{n}$ De meest gerede weg om dit mogelijk te maken, zou mijns inziens

68 Aldus eveneens Schermers (1996), pag. 881. Volgens deze schrijver zou binding van de Gemeenschap aan het EVRM dan ook voornamelijk aan het EVRM ten goede komen.

69 Zoals in 'Toetreding van de EG tot de ECRM' (1991), pag. 720, terecht naar voren wordt gebracht: "Zelfs cen EG-catalogus die volledig identiek is aan de ECRM (...), kan geen volwaardig alternatief vormen. Het gaat immers niet alleen om de inhoud van de opgenomen normen, maar ook om de vorm van het toezicht op de naleving".

70 In 'Toetreding van de EG tot de ECRM' (1991), pag. 720, wordt onderstreept dat de opzet van het EVRM terug te voeren is op het argument dat mensenrechten niet een interne zaak dienen te zijn, maar dat het een internationaal belang betreft. En zeker voor zover het het kartelrecht betreft, kan de communautaire rechtsorde de vergelijking doorstaan met een interne statelijke rechtsorde.

71 Waarmee de onwenselijke situatie van divergerende uitleg tot het verleden behoren.

72 Juist omdat het EHRM een gespecialiseerd mensenrechtenhof (maar geen hoger rechtscollege dan het $\mathrm{Hof}$ ) is en zich ook met betrekking tot het Gemeenschapsrechtzou beperken tot de vraag of het EVRM is nageleefd, zou men de formele correctie door het EHRM -in tegenstelling tot hetgeen Burkens (1993), pag. 93, meent-niet moeten opvatten als 'onaangenaamgezichtsverlies'voor het Hof. Mocht men dit wel zo voelen, dan moet gevreesd worden dat de hoogste nationale rechterlijke colleges niet meer in de spiegel zullen kunnen kijken.

73 Een bijkomend voordeel van de 'onderwerping' op het gebied van de mensenrechten aan de rechtsmacht van een onafhankelijke rechterlijke instantic zou zijn dat aldus een goed signaal aan derde landen zou worden gegeven. Wel zou men kunnen tegenwerpen dat dit alles misschien wel wat veel van het goede is en dat er een te lange rechtsweg ontstaat, hetgeen de efficientie van de rechtsbescherming wellicht niet ten goede komt (Toth (1997), pag. 505). Zeker op het gebied van de onderhavige studie, waarin de oorspronkelijke beslissing door de Commissie wordt genomen, waarna het Gerecht en het Hof zich nog over de zaak kunnen buigen, valt het met de lengte van de rechtsweg echter wel mee en is hij zeker niet langer (in tegendeel!) dan bijvoorbeeld in het Nederlandse kartelrecht het geval is. Voorzover dit anders zou zijn indien door lidstatelijke instantie het Gemeenschapsrecht wordt toegepast, zou omwille van de genoemde voordelen een langere procedure mijns inziens op de koop toe moeten worden genomen. 
de officiêle toetreding van de Gemeenschap (of breder: de Unie) tot het EVRM zijn." In dat geval zou een formele binding van de Gemeenschap aan de materielle en formele bepalingen van het EVRM worden gerealiseerd, vergelijkbaar met de binding die nu reeds ten aanzien van de staten die partij zijn bij het EVRM bestaat. ${ }^{75}$ Waarschijnlijk is het echter niet dat binnen afzienbare tijd de stap van toetreding wordt gezet. Dit volgt uit het oordeel van het Hof -naar aanleiding van een adviesaanvraag op grond van artikel 228 lid 6 EG-Verdrag (thans artikel 300 EG)- dat toetreding zich niet verdraagt met het EG-Verdrag zoals dat er nu ligt. ${ }^{76}$ De sfeer tijdens de Europese Raad van Nice in december 2000 alsmede de afkondiging aldaar van het Handvest van de grondrechten van de Europese Unie maken deze waarschijnlijkheid alleen maar geringer. ${ }^{n}$

74 Vergelijk ook 'Toetreding van de EG tot de ECRM' (1991), pag. 720: "het cruciale punt aan, dat de EG bereid is zich te onderwerpen aan een extern toezicht op de naleving van de mensenrechten" Door toetreding zou, aldus nog steeds het NJCM-commentaar, bovendien het Straatsburgse mechanisme versterken, terwijl een eigen catalogusdezezou verzwakken. Het zou geen pas hebbenals de Gemeenschap zich van bet EVRM zou afwenden, terwijl de Raad van Europa zich juist uitbreidt. Aan toetroding staan overigens wel enkele (verdragsrechtelijke) barrières in de weg. Het zou te ver voeren hierop in dit kader nader op in te gaan. Daarvoor zij verwezen naar onder meer De Blois (1981), Betten

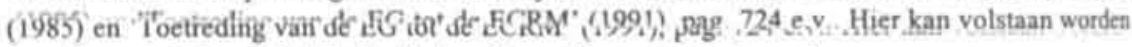
met de constatering dat de bedoelde barrières niet onoverbrugbaar zijn.

$75 \mathrm{Er}$ is meer in het algemeen al vaker getracht om de grondrechten een hechter fundament te geven. Voor een korte weergave van de geschiedenis van deze bemoeienissen zie het Hof in zijn Opinion 2/94 of 28 March 1996, Human Rights Law Journal vol. 17 1996, pag. 53 e.v.. Positief tegenovet toetreding staan ook De Blois (1981), pag. 416, Weiler en Lockhart (1995 I), pag. 81 en Schermers (1990), pag. 258. Deze schrijver wijst -op pagina 256- op twee redenen voor toetreding: "L it would promote the protection of human rights in a uniform way throughout Europe; and II. it would emphasise that the Community legal order is a fully fledged legal order equivalent to those of the Member States: Toth (1997), pag. 511 is van mening dat toetreding door het Hof onverenigbaarmet het EG-Verdrag zou worden verklaard. Daarenboven acht hij het geen ideale oplossing, waarbij hij overigens zeet ruime consequenties van toetreding ziet. Hij stelt voor om de materiēle bepalingen van het EVRM op te nemen in het EU-Verdrag en de lidstaten uit het EVRM te laten stappen, waarna voor deze staten het Hof de hoogste instantic voor de interpretatie van het EVRM zou zijn, op alle gebieden. dus ook die buiten het bereik van de Unie vallen. Turner (1999), pag. 466 e.v. stelt voor om een Mensenrechtenkamerbinnen het Hof op te richten, welke Kamer onder meer in contact zou moeten staan met het EHRM, teneinde aldus interpretatieverschillente voorkomen en de mensenrechtenont. wikkeling mee vorm te kunnen geven.

76 "Accession to the Convention would (...) entail a substantial change in the present Community system for the protection of human rights in that it would entail the entry of the Community into a distinct international institutional system as well as integration of all the provisions of the Convention into the Community legal order. Such a modification of the system for the protection of human rights in the Community, with equally fundamental institutional implications for the Community and for the Member States, would be of constitutional significance and (...) could be brought about only by way of Treaty amendment"; Opinion $2 / 94$ of 28 March 1996, Human Rights Law Journal vol. 17 1996, pag. 51 e.v.. Voor commentaarop dit advies zie onder meer Schermers (1996). Toth (1997), pag. 492, is naar aanleiding van het advies overigens van mening dat het Hof tot op zekere hoogte de grond onder zijn eigen voeten heeft weggeslagen door te overwegen dat mensenrechten buiten het bevoegdheidsgebied van de EG-instellingen liggen.

77 Voor diepergaande uiteenzettingen over de voor-en nadelen van een handvest respectievelijk toetreding tot het EVRM zij onder meer verwezennaarClapham (1991); Burkens (1993), pag. 71 e.v.; Pescatore (1988); Betten (1985), met name hoofdstuk 3 en 'Toetreding van de EG tot de ECRM' (1991). 
Geconcludeerd kan worden dat waar aanvankelijk de fundamentele rechtswaarborgen geen plaats hadden in het Gemeenschapsrecht, het met de rechtsbescherming in de Gemeenschap inmiddels redelijk gesteld is. ${ }^{78}$ Het Hof heeft hierbij de voortrekkersrol op zich genomen en heeft met name aan het EVRM een prominent belang toegekend. De 'Gemeenschapswetgever' is op deze voet verder gegaan, onder meer door de opname in het UnicVerdrag van artikel 6 en door het opstellen van een -vooralsnog-niet bindend Handvest van de grondrechten van de Europese Unie. Het probleem blijft echter bestaan dat er inzake de grondrechten niet in een externe controle is voorzien, zoals het EHRM die uitoefent ten opzichte van de bij het EVRM partij zijnde staten. ${ }^{7}$ Daarom verdient toetreding van de Gemeenschap dan wel de Unie mijns inziens onverminderd aanbeveling. ${ }^{80}$

\section{Mensenrechten, ondernemingen en criminal charge}

Hoe men de positie van het EVRM binnen de Gemeenschap ook ziet, de realiteit is in ieder geval dat het EVRM binnen de communautaire rechtsorde een vooraanstaande rol speelt. Niet is echter ingegaan op de vraag of het kartelrecht een speciale positie in verhouding tot het EVRM inneemt. Hoewel het BVRM een dergelijke uitzonderingspositic behoudens goede gronden in beginsel niet toelaat, zouden twee aspecten het belang van het EVRM voor het kartelrecht kunnen beperken, te weten de omstandigheid dat dit recht zich met uitsluiting richt tot ondernemingen en ondernemersverenigingen en het feit dat de handhaving niet strafrechtelijk in de strikte zin van het woord is. Het eerste aspect doet de vraag rijzen of een verdrag inzake de rechten van de mens op economische entiteiten van toepassing kan zijn. Het tweede aspect heeft betrekking op de vraag of het kartelrecht als 'criminal' in de zin van artikel 6 EVRM kan worden beschouwd. ${ }^{81}$ Voor zover beide vragen negatief beantwoord zouden worden, zou het EVRM alsnog van beperkte waarde voor het kartelrecht zijn. Deze vragen zullen hierna worden behandeld.

78 Ehlermann en Drijber (1996), pag. 383, lijken zelfs op het standpunt te staan dat de communautaire rechters, waar het procedurele garanties betreft, enigszins is doorgeslagen, waardoor niet meer wordt toegekomen aan een inhoudelijke behandeling van de zaak en -zo voeg ik eraan toe- aan de veroordeling van de overtreder. Met dit standpunt kan ik in het geheel niet instemmen. Hoe onaangenaam voor de handhaving van de materięle regels wellicht ook, de procedurele regels zijn er juist om te worden nageleefden komen ten goede aanzowel de individuele onderneming als de faimess van de procedure in zijn geheel. Als overtreding van die regels van dien aard is dat tot een veroordeling niet kan worden gekomen, dan is dat niet meer dan een logisch gevolg van het belang van deze regels.

79 Aldus ook Lawson (2000 II), pag. 939.

80 Voor toetreding pleitte ook reeds Van Outrive (1994), pag. 475.

81 Buiten beschouwing wordt hier gelaten de vraag in hoeverre de toetsing van de reikwijdte van een gedraging of overeenkomst aan het kartelverbod en de daarmee verband houdende vraag naar de nietigheid vande overeenkomst, valt onder 'het vaststellen van burgerlijkerechtenen verplichtingen'. 


\subsection{Mensenrechten en ondernemingen}

Gelden rechten van de mens ook voor ondernemingen? ${ }^{n 2}$ En meer in het bijzonder: geldt het EVRM mede voor ondernemingen? Dat is de vraag die in deze paragraaf centraal staat ${ }^{83}$, omdat bij ontkennende beantwoording ervan het EVRM, ongeacht de betekenis van dit verdrag voor het communautaire recht ${ }^{34}$ (of het Nederlandse recht) als zodanig, alsnog voor het kartelrecht geen (directe) relevantie zou hebben: dit rechtsgebied richt zich immers met uitsluiting tot ondernemingen. ${ }^{\text {ss }}$ Hooguit zou in die situatie het EVRM een bron van inspiratie kunnen vormen, op grond waarvan bepaalde rechten analoog op ondernemingen zouden kunnen worden toegepast, voor zover daar in een concreet geval aanleiding toe zou zijn.

Op het eerste gezicht lijkt echter een ontkennend antwoord op de hierboven geformuleerde vraag voor de hand te liggen. Ondernemingen zijn immers geen mensen 'van vlees en bloed ${ }^{1{ }^{86}}$ Maar dat is slechts één benaderingswijze van de problematiek, en mijns inziens niet de juiste. Mensenrechten bieden bescherming tegen de overheid en dan met name tegen (te ver gaande) machtsuitoefening van de overheid. $\mathrm{Zij}$ doen dit door bepaald overheidsoptreden te verbieden, dan wel door het aan bepaalde procedurele regels te binden. In deze beperking van de machtsuitoefening ligt de kern van de het individu (in een ruime betekenis van het woord) en de maatschappij beschermende functie van de mensenrechten. Vanuit dit uitgangspunt geredeneerd, is het in beginsel niet relevant wie de geadresseerden van deze rechten zijn. Dan is het dus zeer wel mogelijk dat ook ondernemingen, als juridische fictie 'zonder vlees en bloed', door de mensenrechten beschermd worden. Dit lijkt ook de situatie in Nederland te zijn. Bekijkt men namelijk het (grond)rechtenvraagstuk op dit punt vanuit louter Nederlands perspectief (dus abstraherend van het EVRM), dan blijkt dat (grond)rechten zich wel degelijk mede kunnen uitstrekken over ondernemingen. Om het meest voor de hand liggende voorbeeld te geven: de Mededingingswet, een wet die zich bij uitstek richt tot ondernemingen ${ }^{87}$, kent enkele fundamentele rechten, zoals het zwijgrecht (artikel $53 \mathrm{Mw}$ ) en de toegang tot een onafhankelijke rechterlijke instantie (artikel $93 \mathrm{Mw} \mathrm{j}^{\circ}$ hoofdstuk $8 \mathrm{Awb}$ ). ${ }^{85}$ Maar ook meer algemeen geldt deze conclusie: zowel de grondrechten van het eerste hoofdstuk van de Grondwet, als de rechten die in strafvorderlijk verband in acht genomen moeten worden (met name op grond van het wetboek van Strafvordering), bieden mede aan ondernemingen bescherming, zij het met die restrictie dat toepassing op ondernemingen slechts aan de

82 Voor de vraag of ook publiekrechtelijke rechtspersonen aanspraak hebben op grondrechten, verwijs ik naar Finaly (1994), pag. 610 e.v..

83 Hier zullen de begrippen 'onderneming' en 'rechtspersoon' niet worden onderscheiden. Strikt genomen is niet iedere onderneming in de zin van het communautairekartelrechteen rechtspersoon. Van belang is dat de Commissie zelden geconfronteerd wordt met een merkbare overtreding op het kartelrecht door een natuurlijk persoon. Mocht dit toch zo zijn, dan speelt bedoeld probleem niet.

84 Zie hierover de vorige paragraaf.

85 Uitgezonderd vanzelfsprekend de (communautaire) bepalingen die zich richten tot de lidstaten dan wel de bevoegde autoriteiten.

86. Ontleend aan Timmerman (1997), pag. 45.

87 Verwezen zij naar hoofdstuk 3.

88 Ook in de voorstellen voor de vierde tranche van de Awb (onder meer inhoudende de introductic van een algemene regeling ten aanzien van de bestuurlijke boete) zijn verschillende rechten opgenomen waarvan ondernemingen niet worden uitgesloten. 
orde is, voor zover dat 'zinvol' is. Hoewel deze restrictie zeer algemeen is geformuleerd en voor velerlei interpretatie vatbaar is, is het uitgangspunt duidelijk: ondernemingen hebben (grond)rechten. Welke rechten dat zijn, dus ten aanzien van welke rechten geldt dat toepasselijkheid op ondernemingen 'zinvol' is, is niet op voorhand duidelijk en kan onderwerp van discussie zijn. Wel staat vast dat in ieder geval de rechten die onmiskenbaar slechts van toepassing kunnen zijn op natuurlijke personen, buiten deze categorie vallen. Te denken valt dan bijvoorbeeld aan het recht op onaantastbaarheid van het lichaam (artikel $11 \mathrm{GW}$ ), verbod op vrijheidsontneming (artikel $15 \mathrm{GW}$ ), rechten die verband houden met het voorarrest (artikelen 57 e.v. WvSv) en rechten met betrekking tot DNA-onderzoek (artikel 195a e.v. WvSv). Daartegenover staan rechten die, zoals Van Strien ${ }^{\text {s9 }}$ terecht stelt, "dermate essentieel zijn voor de kwaliteit en de eerlijkheid van het proces, dat het voor de hand ligt deze rechten ook aan rechtspersonen toe te kennen". Voor zover derhalve de wettelijke voorziening niet uitdrukkelijk uitsluitsel geeft over de gelding van rechten ten aanzien van ondernemingen, is de aard van het in het geding zijnde recht en daarmee samenhangend het met dit recht te beschermen belang bepalend of er door een onderneming met succes een beroep op kan worden gedaan. Daarmee zijn nog niet alle vragen opgelost, want lang niet altijd is er eenstemmigheid over de aard van een concreet recht (is het 'vlees en bloed'-aspect van een recht dermate dominant dat dit zich slechts tot natuurlijke personen richt, of legt het aspect van bescherming tegen overheidsmacht zoveel gewicht in de schaal dat ook ondernemingen van het recht kunnen profiteren?). Dit zal nog blijken bij de bespreking van het voor deze studie belangrijkste recht uit deze categorie, te weten het privacy-recht.

Hoe is de situatie nu met betrekking tot het EVRM? Bij de totstandkoming van dit verdrag is tenminste primair gedacht aan bescherming van de (rechts)positie van natuurlijke personen. Hierop wijst alleen al de naam van het verdrag. Dit sluit echter nog niet uit dat ook ondernemingen onder de reikwijdte van de door het EVRM geboden bescherming kunnen vallen. De verdragsgeschiedenis alsmede de tekst van het $\mathrm{EVRM}^{\% 0}$ bieden in ieder geval wel enkele aanknopingspunten ervoor dat ondernemingen in beginsel wel de bescherming van het gedrag genieten. Zoals hierna nog zal blijken, is dit in de Straatsburgse jurisprudentie ook aanvaard. Maar deze principiële aanvaarding brengt-evenmin als dat het geval is in de geschetste Nederlandse situatie- nog niet mee dat alle rechten zich lenen voor toepassing op ondernemingen. Om enkele voor de hand liggende voorbeelden te noemen: het folterverbod van artikel 3, het verbod op vrijheidsontneming van artikel 5 en het recht te huwen hebben naar hun aard uitsluitend betrekking op en waarde voor natuurlijke personen. Maar wat als met betrekking tot het door het recht te beschermen belang het 'mens-zijn' niet essentieel is, zoals dat het geval is bij bijvoorbeeld het recht op vrije meningsuiting van artikel 10 en het legaliteitsbeginsel van artikel 7 ? Ook hier dient mijns inziens dan, evenals in het Nederlandse recht het geval is, de aard van het recht en het daarmee te beschermen rechtsbelang het aanknopingspunt te zijn. ${ }^{91} \mathrm{Zo}$ strekt het uit artikel 7 voortvloeiende verbod van terugwerkende kracht van strafbepalingen niet in de eerste plaats tot bescherming van de natuurlijke persoon, maar vormt dit verbod

89 Van Strien (1996 I), pag. 163.

90 Gewezen kan worden op artikel 1 van het eerste Protocol ("ledere natuurlijke of rechtspersoon beeft recht op het ongestoord genot van zijn eigendom") alsmede op artikel 34 EVRM inzake individuele verzockschritten.

91 Wattel (1990) hecht waarde aan de soort van het ingeroepen recht. 
een principiële waarborg (van rechtszekerheid) binnen een rechtstaat, welke waarborg uiteindelijk de faire inrichting van het straf(proces)recht beoogt en aldus de overheidsmacht aan banden legt en de kans op overheidsmisbruik (althans te vergaand optreden van de overheid) beperkt. Gelet hierop mag ondernemingen de bescherming van artikel 7 niet ontzegd worden. Immers: niet is in te zien waarom een onderneming een wezenlijk slechtere positie in een tegen haar van overheidswege gel̈nitieerde strafrechtelijk getinte procedure zou mogen hebben dan een individu dat zich in een vergelijkbare situatie bevindt; in beide gevallen zijn de regels mede bedoeld om overheidsoptreden aan banden te leggen en de, dat wil zeggen iedere, justitiabele tegen de overheid te beschermen. ${ }^{92}$ Om dezelfde reden strekt ook artikel 6 EVRM mede tot bescherming van ondernemingen. Het recht op een behandeling van een zaak binnen redelijke termijn, op een onafhankelijke en onpartijdige rechter, op bijstand van een raadsman alsmede al die andere rechten die in artikel 6 EVRM zijn verankerd en elementen van het 'fair trial-beginsel' vormen, geven aan op welke wijze in een rechtstaat een (punitieve) procedure moet worden vormgegeven. Zij bieden procedurele waarborgen die overheidsoptreden in goede banen moeten leiden, ongeacht de status van degene tegen wie dat optreden zich richt. Voor een eventueel onderscheid tussen natuurlijke personen en ondernemingen is hier naar mijn overtuiging geen redelijke grond aanwezig. ${ }^{93} \mathrm{Na}$ aanvankelijke terughoudendheid bij lagere rechterlijke instanties dienaangaande $e^{94}$, is in de jurisprudentie inderdaad aanvaard dat naast natuurlijke personen ook rechtspersonen onder de reikwijdte van artikel 6 EVRM vallen. Reeds in 1990 oordeelde de Hoge Raad "dat de in artikel 6 EVRM neergelegde waarborgen niet alleen voor natuurlijke personen, doch ook voor rechtspersonen te gelden hebben "9:5, welke visie nadien enkele malen is bevestigd. ${ }^{96}$ Ook de ECRM denkt in deze richting: "a corporate body can claim the protection of Article 6 of the Convention when a "criminal charge" has been made against it".?"

92 Het argument dat een rechtspersoon tegenover de overheid een sterkere positie inneemt dan een individa en om die reden minder bescherming behoeft, snijdt mijns inziens geen hout. Nog afgezien van het feit dat dit argument indruist tegen de ratio van de bescherming, gaat het voorbij aan de omstandigheid dat het verschil tussen een rechtspersoon en een natuurlijk persoon in de praktijk vaak marginal is, waarbij nog allerminst op voorhand vaststaat dat de rechtspersoon de sterkere positic bekleedt.

93 In gelijke zin Scheltens in zijn noot bij HR 17 januari 1990, BNB 1990/193 ("Vrije toegang tot een onafhankelijkerechter, een eerlijkeen openbare behandelingbinneneenredelijketermijn, zijn rechten die naar hun aard ook aan rechtspersonen kunnen worden toegekend") en Swart in zijn noot bij HR 15 december 1992, NJ 1993, 550 (Gelva Holding).

94 Arr.-Rechtb. Leeuwarden 8 februari 1990, NJ 1990, 522 en Arr.-Rechtb. Amsterdam 12 februari 1991, NJ 1991, 488.

95 HR 17 januari 1990, BNB 1990/193 m.nt. Scheltens; ook gepubliceerd in WFR 1990/1112.

96 HR 1 juni 1993, NJ 1994, 52 (Shipping) en HR 12 oktober 1993, NJ 1994, 196 (D. en Co's Handelsmaatschappij), welk arrest de redelijke termijnproblematiek betrof.

97 EHRM 27 februari 1992 (Sociétéstenuitv. Frankrijk). Stessens (1997), pag. HRC/61, is van mening dat "the Strasbourg case law rightly makesno distinction betweennatural persons and legal persons". Het Hof kwam niet tot een inhoudelijk oordeel omdat hij op verzoek van de betrokken onderneming de zaak van de lijst haalde. Ondersteuning voor dit standpunt kan ook gevonden worden in ECRM 10 mei 1994 (Saunders), waarin de ECRM ten aanzien van de faimess van het proces geen onderscheid wenste te maken tussen verschillende categorieênverdachten: "It cannot be compatible with the spirit of the Convention that varying degrees of faimess apply to different categories of accused in criminal trials". Weliswaar volgt na deze opmerking een opsomming variêrend van plegers van fraude tot plegers van terroristische activiteiten, maar de lijn kan naar mijn mening ook worden doorgetrokken naar wetsovertredende rechtspersonen. 
Meer reden tot twijfel kan er bestaan ten aanzien van artikel 8 EVRM, de bescherming van het privéleven, de woning alsmede de correspondentie." Deze begrippen, en zeker de eerste twee, lijken te zijn afgestemd op natuurlijke personen. Finaly ontkent dan ook dat ondernemingen een privésfeer hebben "omdat rechtspersonen abstracties zijn en derhalve geen gevoelens hebben en geen pijn, verdriet of vreugde kennen en derhalve evenmin de geborgenheid, de intimiteit die de privé-sfeer van natuurlijke personen kenmerkt en beschermingswaardig maakt" per definitie niet in haar privé-sfeer (kan) worden geschonden, omdat ze geen privé-sfeer heeft"..$^{100}$ Deze mening deel ik niet. ${ }^{101}$ Vooropgesteld zij dat zonder enige twijfel de band tussen natuurlijk persoon en privacy vele malen hechter, meer precair en fundamenteler is dan de band tussen onderneming en privacy. Voorzover een onderneming een privésfeer heeft, is de privacygevoeligheid van een bedrijfsruimte minder groot dan die van de slaapkamer van een individu. Maar de invalshoek dient naar mijn mening een andere te zijn. Weliswaar vormt in artikel 8 EVRM het 'mens-zijn' een belangrijke factor, maar de limitering van overheidsoptreden neemt in dit artikel een tenminste even hoge status in. Het gaat erom dat een overheid in het kader van een onderzoek of anderszins, niet zonder wettelijke basis, zonder goede reden en zonder te voldoen aan een met waarborgen omklede procedure een justitiabele mag confronteren met onderzoeksmaatregelen die ingrijpen in diens directe omgeving en in diens dagelijkse leven. Dat lijkt mij een fundamenteel uitgangspunt binnen iedere rechtstaat en in het verlengde daarvan van importantie voor het algemeen belang. In dat licht is artikel 8 EVRM, als waarborg tegen ongeclausuleerd overheidsoptreden, van niet minder belang indien het ondernemingen betreft dan indien het gaat om natuurlijke personen. Evenzeer als een individu ervan uit moet kunnen gaan dat zijn woon- en leefomgeving door de overheid (en door anderen) gerespecteerd wordt en dat -behoudens in uitzonderlijke situaties- geen inbreuk zal worden gemaakt op deze persoonlijke leefsfeer waarbinnen hij zich ongestoord kan ontplooien, moet een onderneming erop kunnen rekenen dat haar eigen sfeer waarbinnen zij haar dagelijkse bedrijfsvoering uitoefent (haar 'privacy-sfeer' derhalve) door de overheid ongemoeid wordt gelaten, tenzij deze handelt op wettelijke grondslag met inachtneming van de in de wet voorgeschreven procedure en op grond van redenen die dit optreden kunnen rechtvaardigen. ${ }^{102}$ Ware dit anders, dan zou het functioneren van een onderneming, zoals Timmerman terecht stelt, zeer worden bemoeilijkt en zou de overheidsmacht althans ten aanzien van deze categorie van justitiabelen nauwelijks beperkt zijn. ${ }^{103}$ Een en ander laat echter onverlet dat de bescherming van natuurlijke personen uiteindelijk

98 Het recht op respect voor het familie- en gezinsleven, ook neergelegd in artikel 8 EVRM is in mijn visie in ieder geval beperkt tot natuurlijke personen.

99 Finaly (1991), pag. 109.

100 Finaly (1991), pag. 110. Fokkens in zijn conclusie bij HR 15 december 1992, NJ 1993, 550 m.nt. AHS (Gelva Holding) stelt dat een beperking tot natuurlijke personen voor de hand ligt. In deze zin ook Van Dijck (1999), pag. 614.

101 Hetzelfde geldt voor Krabbe (1996), pag. 141 en 142.

102 Bovens (1998), pag. 657 stelt met betrekking tot de privacy: "Bedrijven kunnen tegenover de overheid recht doen gelden op bescherming van hun bedrijfsgeheimen, niet omdat privacy voor hen cen waarde in zichzelf vertegenwoordigt, maar omdat ontkenning hiervan als consequentie heeft dat hun bedrijfsvoering en daarmee de algemene economische ontwikkeling ernstig kan worden geschaad".

103 Aanknopingspunten hiervoorzijn ook in de Straatsburgse jurisprudentiete vinden. Zie daarovernader paragraaf 6.1. 
groter kan zijn dan die van ondernemingen, hetgeen gelet op het gememoreerde verschil in privacy-gevoeligheid zeer wel wenselijk kan zijn. ${ }^{104}$ Het tweede lid van artikel 8 EVRM opent de deur naar een dergelijke differentiatie: de aldaar genoemde, limitatieve uitzonderingsmogelijkheid op de hoofdregel van het eerste lid kan -zonder het beperkte karakter van die mogelijkheid geweld aan te doen- aldus worden uitgelegd dat inmenging in de sfeer van een onderneming in meer gevallen aanvaardbaar en gerechtvaardigd is dan inmenging in de sfeer van een individu. ${ }^{105}$ Via deze weg kunnen tevens eventuele bedenkingen omtrent een doelmatige handhaving van 'ondernemingsrecht' worden weggenomen.

\subsection{Criminal charge en kartelrecht}

$\mathrm{Er}$ is nog één vraag die (bevestigend) beantwoord moet worden vooraleer de conclusie van Ehlermann dat "The most important question facing us (...) is not whether Article 6 applies to Community competition law procedures, but what actions must be taken in order to ensure its respect" ${ }^{106}$, onderschreven kan worden: valt het kartelrecht onder het begrip 'vervolging' of -meer gangbaar- 'criminal charge', zoals bedoeld in artikel 6 EVRM? Dit begrip wijst in strafrechtelijke richting, terwijl het communautaire maar ook het Nederlandse kartelrecht een bestuursrechtelijk profiel heeft: in beide gevallen ligt het gehele handhavingstrajekt tot en met het opleggen van de boete in handen van het bestuur (de Commissie respectievelijk de NMa). Voor het communautaire kartelrecht is het daarenboven zo dat, zoals in het vorige hoofdstuk bleek, artikel 15 Vo 17 dit recht uitdrukkelijk een strafrechtelijk karakter ontzegt. Tegen deze achtergrond oordeelde Cumming bijvoorbeeld dat het Funke-arrest van het EHRM, handelend over het nemo teneturbeginsel als onderdeel van artikel 6 EVRM, geen betekenis had voor het communautaire kartelrecht omdat dit uitsluitend betrekking zou hebben op 'criminal proceedings' in de enge $\mathrm{zin}$ van het woord. ${ }^{107}$

Het behoeft heden ten dage eigenlijk nauwelijks enig betoog meer dat een dergelijk beperkte lezing verworpen moet worden. Reeds in zijn Engel-arrest ${ }^{108}$ en later in de arresten Oztürk ${ }^{109}$ en Lutz ${ }^{110}$ heeft het EHRM duidelijk gemaakt dat het een autonome

104 Bovens (1998), pag. 656-658 onderscheidt voor toekenning van rechten een deontologische (het beschermde individuele belang is een doel in zich zelf) en een consequentalistische (de bescherming dient eenverder gelegendoel) rechtvaardiging. Ondernemingen kunnen slechts op de laatstgenoemde grond aanspraakmaken op grondrechten, hetgeen volgens Bovens meebrengt dat deze eerder kunnen worden ingeperkt.

105 In deze zin ook Asser in zijn conclusie bij HR 16 oktober 1987, NJ 1988, 850 m.nt. EAA (Driessen Assurantiēn BV): "dat er aanleiding bestaat ook rechtspersonen een beroep op eerbiediging van de persoonlijke levenssfeertoe te kennen. Maar de omvang van dat recht wordt natuurlijk bepaald mede door de omstandigheid dat het een rechtspersoon betreft. Ook rechtspersonen hebben dunkt me aanspraak op eerbiediging van de sfeer waarin zij bijv. geheimen willen bewaren of geen inmenging van buitenaf wensen in het algemeen". Blijkens zijn noot bij HR 23 februari 1990, NJ 1990, 664 ziet ook Verkade raimte voor privacy-bescherming van ondernemingen.

106 Ehlermann (1995), pag. 17.

107 Cumming (1995), pag. 404.

108 EHRM 8 juni 1976.

109 EHRM 21 februari 1984.

110 EHRM 25 augustus 1987. 
interpretatie van het criminal charge-begrip hanteert en aldus voorzover nodig door een (nationale) 'labeling' van een procedure heen prikt. ${ }^{\text {I' }}$ Bij deze autonome uitleg hanteert het EHRM drie criteria: de (nationale) classificatie, de aard van de overtreding (bestaande uit twee deelaspecten, te weten de algemeenheid van het karakter van de norm ${ }^{112}$ en het al dan niet punitieve en afschrikkende karakter van de sanctie) en de aard en gestrengheid van de potentielle sanctie. ${ }^{113}$ Het gewicht rust voornamelijk op de laatste twee criteri$\mathrm{a}$; het eerste criterium is gelet op de ratio van de autonome interpretatie (het onmogelijk maken van omzeiling van het EVRM door een procedure van een niet-strafrechtelijk 'label' te voorzien) van niet meer dan relatieve betekenis. ${ }^{.4}$ Het moge duidelijk zijn dat de bedoelde twee -alternatieve ${ }^{115}$ - criteria slechts tot én conclusie kunnen leiden, namelijk dat het Nederlandse en het communautaire kartelrecht onder de reikwijdte van artikel 6 EVRM vallen: de (verbods)normen hebben een algemeen karakter, de sancties zijn punitief én preventief van aard en kunnen daarenboven als zeer zwaar worden aangemerkt. ${ }^{116}$ Deze conclusie wordt onderstreept door de ECRM. ${ }^{117}$ Aan Société Stenuit was door de Franse minister van Economische Zaken wegens overtreding van de nationale mededingingswetgeving een boete opgelegd. Na vergeefs beroep op de Conseil d' Etat richtte de onderneming zich tot de ECRM omdat zij artikel 6 EVRM geschonden achtte,

111 Deze autonome interpretatie wordt door Cumming (1995), pag. 404, overigens niet bestreden.

112 Waarbij van belang is of de norm zich tot een bepaalde groep of juist tot alle subjecten, eventueel in een bepaalde hoedanigheid, richt.

113 EHRM 21 februari 1984 (Oztürk) en EHRM 25 augustus 1987 (Lutz). Kritisch over de bruikbaarheid van deze criteria uitte zich Riphagen (1994), pag. 17-21.

114 EHRM 22 mei 1990 (Weber).

115 EHRM 25 augustus 1987 (Lutz), bevestigd in EHRM 24 september 1997 (Garyfallou). Zie over dit arrest Viering en Fleuren (1997), pag. 1932-1934. Naar aanleiding van EHRM 24 februari 1994 (Bendenoun) ontstond er over het al dan niet cumulatieve karakter nogal wat discussic. Zie Viering (1994), pag. 1061-1063, Hartmann en Van Russen Groen (1994 I), pag. 1521-1526, Van Dijk (1994), pag. 1526-1527 alsmede Wattel (1994), pag. 1527-1529. Bedoelde discussie ontstond omdat in dit Bendenoun-arrest de criteria door het EHRM wél cumulatief werden gebruikt. Was het EHRM nu 'omgegaan"? Zo ja, dan zou artikel 6 EVRM -in tegenstelling tot hetgeen het geval is bij een 'alternatieve interpretatie'- ten aanzien van normen op de overtreding waarvan een relatief lichte (financiele) sanctic is gesteld, geen rol meer hebben gespeeld, ook al zou de aard van de overtreding in een andere richting wijzen. 'Minor offences' zouden hoe dan ook niet langer onder de reikwijdte van artikel 6 EVRM vallen (en dat terwijl door sommigen, waaronder Bleeker (1993), pag. 1012 en De Raat (1993), pag. 448, tot het Bendenoun-arrest werd betwijfeld of het opleggen van hoge boetes door een bestuursorgaan gelet op het EVRM wel rechtens mogelijk was). Dit zou naar mijn mening een onaanvaardbare beperking van de rechtsbescherming hebben betekend. Hoewel een dergelijke interpretatie mijns inziens allerminst noodzakelijk uit het Bendenoun-arrest volgde, moet het worden toegejuicht dat het EHRM in zijn Garyfallou-arrest uitdrukkelijk de 'alternatieve benadering' heeft bevestigd. Hoewel hierover nog wel het een en ander kan worden gezegd, is een nadere bespreking in het kader van deze studie niet nodig. Want hoe het voorgaande ook zij, voor het kartelrecht als zodanig doet het niet ter zake voor welke interpretatie wordt geopteerd. Immers gaat het zowel in bet Nederlandse als in het communautaire kartelrecht steeds om een zeer aanzienlijke boetedreiging, waardoor aan het derde 'Oztürk-criterium' per definitie is voldaan.

116 Artikel 5.4.1.1 VOAwb4 verstant onder een bestuurlijke boete dan ook "de bestuurlijke sanctie, inhoudende een onvoorwaardelijke verplichting tot betaling van een geldsom, die is gericht op bestraffing van de overtreder" (cursivering, HQ). Terecht stelt Rogier (2001), pag. 10, dat de bestuurlijke boete materieel geen andere sanctie is dan de strafrechtelijke boete.

117 EHRM 27 februari 1992 (Société Stenuit v. Frankrijk). Het Europese Hof kwam niet tot een inhoudelijk oordeel omdat het op verzoek van de betrokken onderneming de zaak van de lijst haalde. 
daar haar geen mogelijkheid was gegeven zich te wenden tot een onafhankelijk gerecht dat de gegrondheid van de tegen haar ingestelde vervolging kon bepalen. De ECRM moest zich derhalve in eerste instantie buigen over de vraag of een boete in het kader van het mededingingsrecht door de minister opgelegd, als vervolging kon worden beschouwd. Het antwoord op die vraag was bevestigend, mede in het licht van de potentiěle (en dus niet de daadwerkelijk opgelegde) sanctie waarin de mededingingswet voorzag: deze was van dien aard dat zij bedoeld was om ondernemingen af te schrikken. ${ }^{118}$

Het bestuursrechtelijk optreden tegen kartelovertredingen op grond van de Mededingings wet alsmede op grond van Verordening 17 vormt dus onmiskenbaar een 'criminal charge' in de zin van artikel 6 EVRM. De bestuurlijke boete vormt een 'bestraffing voor een begane overtreding ${ }^{119}$ en heeft aldus een punitief en leedtoevoegend karakter. In zoverre wijkt het bestuurlijk boeterecht derhalve af van het meer 'klassieke' bestuursrecht dat reparatoir van aard is. In zoverre heeft deze vorm van punitieve handhaving door de overheid zowel bestuursrechtelijke als strafrechtelijke aspecten. Mede in dat licht is er in de literatuur nogal wat discussie ontstaan over de vraag waar men deze handhavings. vorm in het rechtssysteem moet plaatsen (bestuursrecht, strafrecht of een 'sui generis' rechtsgebied ${ }^{120}$ ) en in het verlengde daarvan hoe zij moet worden aangeduid. Het zou het kader van deze studie te buiten gaan om deze discussie en haar achtergronden hier uitgebreid te behandelen. ${ }^{12}$ Naar mijn mening wordt aan het bijzondere karakter van de handhaving via bestuurlijke boetes het meeste recht gedaan door haar in navolging van met name Hartmann en Van Russen Groen aan te merken als bestuursstrafrecht. Wat hieronder wordt verstaan, wordt kort in de volgende paragraaf besproken. ${ }^{122}$

118 De ECRM overwoog: "In the present case the penalty imposed by the Minister was a fine of 50,000 FRF, a sum which, in itself, is not negligible. But it is above all the fact that the maximum fine, i.e. the penalty to which those responsible for infringements made themselves liable, was $5 \%$ of the annual turnover for a firm (...) which shows quite clearly that the penalty in question was intended to be deterrent". Opgemerkt zij dat deze sanctie nog aanmerkelijk lager ligt dan in de Mededingingswet en verordening 17.

119 Michiels (1994), pag. 7. Deze schrijver wijst er (op pagina 10) dan ook op dat de boete in cerste instantie repressief is, maar dat mede preventie beoogd wordt. Vergelijk ook Hartmann (1999), pag42.

120 Riphagen(1994), pag. 49, stelt bijvoorbeeld: "administratievesancties die tevens een criminal charge inhouden, nemen een tussenpositie in tussen administratievesancties in eigenlijkezin en zuiverstrafrechtelijke sancties". Zie voor een bespreking van de verschillen en overeenkomsten tussen het strafiecht en het bestuursrecht Rogier en Hartmann (1994), pag. 1 e.v.. Verschillen tussen strafrechtelijke en bestuursrechtelijke sanctieprocedures worden besproken door De Doelder (1994), pag. 206-207.

121 Daarvoor zij verwezen naar met name Hartmann en Van Russen Groen (1998), met name pag. 105 e.v.

122 Het zij onderstreept dat door mij wordt aangesloten bij de door genoemde schrijvers gebruikte betekenis van bet begrip 'bestuursstraftecht'. Van een eenduidige inhoud van dit begrip is in de Nederlandse literatuur namelijk geen sprake, zoals Hartmann en Van Russen Groen (1994 II), pag. 27-34, reeds bebben aangetoond. 


\subsection{Bestuursstrafrecht}

\section{Hartmann en Van Russen Groen definiëren bestuursstrafrecht als}

"het van het strafrecht en het bestuursrecht te onderscheiden deel van het recht waarin publiekrechtelijke bestuursorganen, zonder tussenkomst van de betrokkene of een onafhankelijke rechter, saneties met een bestraffend karakter kunnen opleggen". 23

Zij zien het bestuursstrafrecht als een afzonderlijk rechtsgebied dat als het ware tussen het bestuursrecht en het strafrecht 'in ligt'. ${ }^{124}$ Omdat het wettelijk gezien bestuursrecht betreft -de sanctie wordt door een bestuursorgaan opgelegd-, hebben het geschreven (en met name de Algemene wet bestuursrecht, behoudens voor zover in de bijzondere wet uitgezonderd) en ongeschreven bestuursrecht in beginsel gelding. Maar dit rechtsgebied is 'van oudsher' reparatoir van aard, en als zodanig -in tegenstelling tot het strafrechtniet afgestemd op punitief optreden. En punitief optreden kent zijn geheel eigen, specifieke normering. Dit betekent weliswaar niet dat dus voldaan moet zijn aan de strafrechtelijke normen zoals onder meer verankerd in het wetboek van Strafrecht -het bestuurlijk boeterecht is immers geen strafrecht. ${ }^{125}$, maar het brengt wel mee dat aan bepaalde -in het strafrecht welhaast vanzelfsprekende- eisen van rechtsstatelijkheid moet zijn voldaan. Meer in het bijzonder zullen, gelet op het 'charge-karakter' van de bestuurlijke boete, tenminste de in artikel 6 EVRM verankerde, strafrechtelijk georienteerde waarborgen moeten worden gerespecteerd. ${ }^{126}$ En dit wezenlijke verschil in normering ten opzichte van het 'klassieke' reparatoire bestuursrecht rechtvaardigt in de optiek van Hartmann en Van Russen Groen dat het bestuursstrafrecht als een afzonderlijk rechtsgebied wordt aangemerkt ${ }^{127}$, waardoor er "een kader waarbinnen vragen met betrekking tot de normering zoals bijvoorbeeld betreffende de bewijsvoering en het soort rechtsbescherming dat moet worden geboden, meer eenduidig kunnen worden beantwoord", ${ }^{128}$ Welke normen binnen dit afzonderlijke rechtsgebied dienen te gelden en (dus) op welk niveau de rechtsbescherming moet liggen, kan nog een punt van discussie zijn, met dien verstande dat, zoals gezegd, in ieder geval de 'artikel 6 EVRM horde' genomen dient te zijn. Maar het staat

123 Hartmann en Van Russen Groen (1998), pag. 74 en reeds eerder Hartmann en Van Russen Groen (1994 II).

124 Vergelijk ook Koopmans (1995), pag. 136. Corstens (1995 I), pag. 36, noemt de term bestuursstrafrecht misleidend.

125 Ook al valt het onder de reikwijdte van artikel 6 EVRM: HR 7 september 1988, BNB 1988/298, HR 11 oktober 1989, BNB 1990/87 en HR 31 januari 1990, BNB 1990/93. Dat laat overigens onverlet dat bijvoorbeeld in het Voorontwerp vierde tranche Awb op verschillende punten aansluiting is gezocht bij het strafrecht.

126 Vergelijk Widdershoven (1998), pag. 236: "Als randvoorwaarde voor (de) overheveling van de sanctionering uit het strafrecht naar het bestuursrecht behoort uiteraard wel te gelden dat dit proces niet mag leiden tot een uitholling van de essentiele rechtsstatelijke waarborgen die eigen zijn aan strafrechtelijke sanctionering." Hierop doelt waarschijnlijk ook Corstens (2000), pag. 1187; "Een bestuurlijke boete is nu eenmaalmaterieeleen strafsanctie, zodat de grondbeginselenvan straf-en strafprocesrecht moeten worden gerespecteerd". Otto, De Meijer en De Doelder (1999), pag 1, spreken van de traditioneel strafrechtelijke waarborgen van de artikelen 6 EVRM en 14 IVBPR waaraan het bestuurlijke punitieve recht zal moeten voldoen.

127 Kritisch hierover is onder meer Sackers (1995), pag. 311.

128 Hartmann en Van Russen Groen (1998), pag. 75 
de wetgever natuurlijk vrij om binnen het bestuursstrafrecht een hogere graad van bescherming toe te kennen aan degenen tegen wie een onderzoek is gestart. Dienaangaande kunnen aard en omvang van de op te leggen sancties belangrijke aanknopingspunten vormen. Naar mijn overtuiging zal, waar het de fundamentele rechten betreft, de bestuursstrafrechtelijke handhaving een beschermingsniveau moeten realiseren dat aansluit bij het in het strafrechtelijke traject geldende niveau, met name daar waar de punitieve sancties zo aanzienlijk zijn als in het mededingingsrecht. Dat maakt de bestuurlijke boete als handhavingssluitstuk wellicht minder aantrekkelijk, maar het fundamentele belang van de bescherming van het individu tegen een (via welke weg dan ook) punitief optredende overheid vergt mijns inziens een dergelijk 'offer'. ${ }^{129}$ Dit wil allerminst zeggen dat ik geen ruimte zie voor bestuursstrafrechtelijke handhaving of dat ik zelfs negatief tegenover deze handhavingsvorm zou staan. Integendeel: de punitieve handhaving door het bestuur biedt tal van voordelen (waaronder deskundigheid, gehele verantwoordelijkheid voot de handhaving bij het bestuursorgaan en eigen opportuniteitsinvulling), maar het mag niet zo zijn dat deze vorm van handhaving tot gevolg (laat staan als oogmerk) heeft dat de justitiabele wezenlijk aan bescherming van zijn fundamentele rechten inboet. Hoe men hierover ook moge denken, op het punt van de rechtsbescherming ligt mijns inziens een van de belangrijkste redenen om te komen tot de erkenning van het bestuursstrafrecht als afzonderlijk rechtsgebied. Op die wijze wordt de rechtsbeschermingscomponent (terecht) in het middelpunt van de discussie geplaatst en wordt vermeden dat hij wordt ondergesneeuwd door een overmatige aandacht voor de instrumentele betekenis van de bestuurlijke boete als handhavingsmiddel.

Op grond van het bovenstaande is duidelijk dat het EVRM, en meer in het bijzonder artikel 6 EVRM, voor het (communautaire) mededingingsrecht van reëel belang is en dat dus tenminste het minimumniveau van bescherming zoals in dat verdrag is neergelegd moet worden gewaarborgd. Betoogd is tevens dat een justitiabele door de overheveling van strafrechtelijke naar bestuursstrafrechtelijke handhaving er in beginsel niet slechter van mag worden. Hierna zullen daarom de voor het mededingingsrecht meest wezenlijke rechten worden besproken, voor zover relevant voor de voorfase. Waar relevant zal worden ingegaan op de stand van zaken in het Nederlandse strafrecht ten aanzien van een bepaald recht. Allereerst komt het recht op een behandeling van de zaak binnen een redelijke termijn aan bod.

\section{De redelijke termijn ${ }^{130}$}

Het recht op behandeling van de zaak binnen een redelijke termijn is een van de rechten die in artikel 6 EVRM verankerd zijn. Het beoogt te voorkomen dat iemand langer dan strikt noodzakelijk in onzekerheid verkeert over de afloop van de tegen hem ingestelde vervolging (in de autonome zin van het woord). ${ }^{131}$ Het belang van het recht op berechting

129 Zie hierover ook Michiels (1999), pag. 72-73.

130 Zie algemeen Jansen (2000)

131 Zie over deze ratio onder meer Swart (1996), pag. 230, Corstens (1999), pag. 490, Van Dijk en Van Hoof (1998), pag. 442 en Mols (1999), pag. 262. Vergelijk tevens onder meer HR 23 september 1980, NJ 1981, 116 m.nt. GEM en HR 3 oktober 2000, NJB 3 november 2000, pag. 1933. In dit 
binnen een redelijke termijn voor de justitiabele is evident indien men het ingrijpende en belastende karakter van een dergelijke vervolging en de daaraan inherente dreiging van vaak zware sancties in ogenschouw neemt. Van vervolging in al haar facetten gaat aldus niet alleen een psychische druk uit, maar kan daarnaast, zoals Corstens ${ }^{132}$ terecht aanstipt, invloed uitoefenen op het functioneren van de justitiabele, ongeacht -zo voeg ik eraan toe- of dit laatste nu een natuurlijk of een rechtspersoon betreft. In dat licht is het ook een voorwaarde voor rechtsstatelijkheid dat de vervolgende overheid met gepaste voortvarendheid te werk gaat, opdat de justitiabele binnen een redelijke termijn weet waar hij aan toe is en opdat -meer algemeen- zo spoedig mogelijk rechtszekerheid wordt verschaft. In deze paragraaf zal worden besproken welke rol dit recht op behandeling van de zaak binnen een redelijke termijn in het kartelrecht speelt.

\section{I Berechting binnen een redelijke termijn: het EHRM en de Hoge Raad}

De eerste vraag die zich opdringt, is welke termijn van het predikaat 'redelijk' kan worden voorzien. Dit is echter in zijn algemeenheid niet aan te geven; daarvoor zijn de omstandigheden van het geval te zeer doorslaggevend. Dat laat onverlet dat door de Hoge Raad een termijn van twee jaar (gerekend vanaf het moment van de aanvang van de vervolging dan wel-voor de appèl c.q. cassatiefase- van het aanwenden van het rechtsmiddel) per procesfase wordt gehanteerd als termijn waarbinnen een einduitspraak door de betreffende strafrechterlijke instantie moet zijn gegeven. ${ }^{133}$ Slechts bijzondere omstandigheden kunnen een langere termijn rechtvaardigen; tot onredelijkheid van een kortere termijn zal in beginsel slechts worden geconcludeerd voorzover bijzondere omstandigheden daartoe aanleiding geven. ${ }^{134}$ Het EHRM heeft niet een dergelijk 'omslagpunt' gefixeerd. Het houdt er een (nog) meer casuïstische benadering op na en beoordeelt het vraagstuk van de redelijke termijn aan de hand van voornamelijk drie criteria: de ingewikkeldheid van de zaak, de houding van de verdachte en (de voortvarendheid van) het handelen van de

laatste arrest wordt nog op enkele 'andere factoren die nopen tot een voortvarende afhandeling' gewezen, te weten de preventieve werking, de belangen van het slachtoffer en de ongunstige invloed van het tijdsverloop op de beoordeling van feiten. In vergelijkbare zin ook Corstens (1999), pag. 490 , die overigens raadsheer bij de Hoge Raad in de betrokken zaak was.

132 Corstens (1999), pag. 490.

133 Voor de beroep- of cassatiefase wordt een termijn van acht maanden (gerekend vanaf het instellen van het rechtsmiddel) gehanteerd waar het het overbrengen van de stukken naar de griffie van de hogere instantie betreft: HR 26 januari 1999, NJ 1999, 326; HR 18 januari 2000, NJ 2000, 568; HR 18 januari 2000, NJ 2000, 569 m.nt. JdH; HR 20 juni 2000, NJ 2000, 720; HR 3 oktober 2000, NJ 2000, 721 m.nt. JdH alsmede de noot van Knigge onder HR 27 januari 1998, NJ 1998, 810.

134 Daarnaast kan de duur van de gehele procedure (dus vanaf het moment waarop de vervolging is gestart tot en met de onherroepelijke einduitspraak) medebepalend zijn voor een eventuele schending van de redelijketermijn. Indien de duur van de procedure in zijn geheel binnen de grenzen van de redelijkheid is gebleven, dan zal een termijnoverschrijding in één of meer fasen van de procedure niet tot het oordeel leiden dat de redelijke termijn is geschonden. Andersom kan het zo zijn dat een cumulatie van onnodige, maar afzonderlijk nog niet onredelijke vertragingen in verschillende fasen van de procedure uiteindelijk betekent dat niet langet van een redelijke termijn kan worden gesproken. 
bevoegde instanties. ${ }^{135}$ Zoals gezegd hangt het in hoofdzaak van deze bijzondere omstandigheden van het geval af of de concrete termijn al dan niet is overschreden. Past men deze criteria op mededingingsrechtelijke zaken toe, dan volgt met name uit het eerste criterium dat een op het eerste gezicht lange termijn (in ieder geval tot het moment van de eerste beslissing) toch veelal door de beugel zal kunnen. Immers: het gaat om complexe economische gedragingen waarvan het bewijs doorgaans niet eenvoudig is op te sporen en die worden ontplooid door evenzeer (niet zelden talrijke en internationaal opererende) complexe en omvangrijke entiteiten. Al met al blijken kartelzaken veelal ingewikkeld van aard te zijn, hetgeen onontkoombaar zijn weerslag heeft op de duur van het onderzock: een relatief lange termijn kan dan toch nog redelijk zijn, althans voorzover niet mede inactiviteit van de autoriteiten debet aan die lengte is.

In het vorenstaande is één aspect van de redelijke termijn-problematiek, dat voor de praktijk van grote betekenis blijkt, in het midden gelaten, te weten vanaf welk moment de relevante termijn begint te lopen. Dit aspect wordt nu besproken. Het antwoord op de gestelde vraag is in zoverre eenvoudig dat artikel 6 EVRM zich slechts uitstrekt over de fase van 'vervolging'. Maar daarmee is nog geen duidelijkheid geschapen: wanneer immers is er sprake van vervolging (of in de Engelse tekst: 'criminal charge')? De jurisprudentie van het EHRM en de Hoge Raad brengt enig licht in deze duisternis. Het EHRM huldigt de volgende interpretatie:

\begin{abstract}
"Whilst 'charge', for the purpose of Article 6 para. 1, may in general be defined as 'the official notification given to an individual by the competent authority of an allegation that he has committed a criminal offence', it may in some instances take the form of other measures which carry the implication of such an allegation and which likewise substantially affeet the situation of the suspect" ${ }^{\text {. }}$
\end{abstract}

De Hoge Raad acht noodzakelijk

"een handeling vanwege de Staat waaraan (de verdachte) in redelijkheid de gevolgtrekking heef kunnen verbinden dat ter zake van overtreding van de evengenoemde wetsbepaling een strafvervolging tegen (hem) zou worden ingesteld". ${ }^{13}$

Vergelijking van deze twee zienswijzen leidt tot de conclusie dat zij niet dezelfde reikwijdte hebben, zij het dat bij beide in ieder geval het bestaan van een verdenking of een bestuursrechtelijk equivalent daarvan als voorwaarde geldt. ${ }^{138}$ De benadering van het

135 Zie bijvoorbeeld EHRM 19 september 2000 (I.J.L., G.M.R. en A.K.P.). Het zijn ook deze criteria die door de Hoge Raad worden gebruikt bij de bepaling van de redelijkheid van de termijn, voor zover die van het genoemde omslagpunt van twee jaar afwijkt. Zie HR 19 februari 1985, NJ 1985, 581 m.nt. ThWvV (Redelijke termijn II).

136 EHRM 10 december 1982 (Foti).

137 HR 26 oktober 1993, NJ 1994, 629 m.nt. C; in vergelijkbare bewoordingen onder meer HR 17 februan 1987, NJ 1987, 951 en Hof Amsterdam 28 april 1994, NJ 1996, 149.

138 Voor de visie van de Hoge Raad hieromtrent zie onder meer HR 23 november 1994, FED 1995/3, m.nt. Feteris en zeer expliciet HR 22 november 1994, NJ 1995, 240 m.nt. Sch., waarin de Hoge Raad de overweging van het Hof dat niet "reeds een redelijk vermoeden van schuld aan een strafbaar feit bestond, laat staan dat reeds sprake was van een criminal charge in de zin van (...) art. 6 EVRM" niet onbegrijpelijk achtte. Vergelijk ook Keulen (1995), pag. 274, die stelt dat het fair trial-beginsel niet kan worden ingeroepen door een verdachte die "(nog) nict 'charged with a criminal offence' is", alsmede Knigge in zijn noot bij EHRM 25 februari 1993 (Funke) en Feteris (1993), pag. 2397. 
EHRM is minder formeel dan die van de Hoge Raad en hecht meer waarde aan de subjectieve perceptie van de verdachte. De Hoge Raad -die de belangrijke materielle aanvulling van het EHRM, bestaande in de zinsnede 'other measures which carry the implication of such an allegation and which likewise substantially affect the situation of the suspect', sterk onderbelicht- legt sterk de nadruk op de bekendheid van de verdachte met de tegen hem gestarte vervolging en op de redelijkheid (en dus de objectiveerbaarheid) van de aan de handelingen van de bevoegde instantie ontleende verwachting van de verdachte dat hem een vervolging boven het hoofd hangt. ${ }^{139}$ Concreet brengt dit met zich dat de verdachte in de Straatsburgse interpretatie beter af is omdat er afhankelijk van de omstandigheden van het geval eerder sprake is van een 'charge'. Met name biedt deze interpretatie meer ruimte om de bescherming van artikel 6 EVRM ook aan een verdachte toe te kennen die er niet van op de hoogte is dat een onderzoek tegen hem gaande is of die nog niet redelijkerwijs uit de overheidshandeling kan afleiden dat vervolging zijn deel zal zijn. Zo is het allerminst denkbeeldig dat het EHRM in tegenstelling tot de Hoge Raad ${ }^{140}$, bijvoorbeeld een verhoor van een verdachte, het geven van de cautic van artikel 29 WvSv alsmede het openen van een gerechtelijk vooronderzoek (zonder dat de verdachte hiervan op de hoogte is), wél zou kwalificeren als handelingen die de positie van de verdachte wezenlijk beïnvloeden. ${ }^{141}$

De aanpak van de Hoge Raad levert nog een tweede probleem (en nadeel) op dat met de Straatsburgse interpretatie wordt vermeden. Dit probleem houdt verband met het gegeven dat het fair trial-beginsel van artikel 6 EVRM geen uniform begrip is, maar dathet wordt vormgegeven door een verzameling van verschillende verdedigingsrechten. Deze verdedigingsrechten hebben ieder een eigen karakter en autonome reikwijdte. Weliswaar hebben zij gemeen dat zij alle tot doel hebben een faire procesvoering voor de justitiabele te garanderen -waarbij over de schending van het recht moet worden geoordeeld tegen de achtergrond van dit doel-, maar zij leveren tevens ieder een geheel eigen bijdrage aan de realisering van een eerlijk proces. Zo beoogt bijvoorbeeld het zwijgrecht te voorko-

Corstens in zijn noot bij HR 26 oktober 1993, NJ 1994, 629, verwoordt die visie als volgt: "Men is eerder verdachte dan "charged with a criminal offence" (...). Wie verdachte is, behoeft nog niet "charged with a criminal offence" te zijn. Die situatie ontstaat pas als een vervolging in het verschiet komt". Blijkens zijn noot staat Corstens zelf echter wel een ruimere interpretatie voor dan welke door de Hoge Raad wordt gehanteerd. Een en ander brengt met zich dat bevoegdhedendie ter controle op de naleving van het (materiele) recht worden aangewend, niet onder het bereik van het fair trialbeginsel vallen, ook al is het allerminst denkbeeldig dat tijdens de controle een vermoeden van overtreding rijst.

139 Zie hierover Corstens (1999), pag. 492 alsmede Schalken in zijn noot bij HR 11 mei 1993, NJ 1994, 142.

140 HR 26 oktober 1993, NJ 1994, 629 m.nt. C. Terecht stelt Corstens in zijn noot dan ook: "Beter verdedigbaar is (...) dat de "situation of the suspect" al eerder "substantially affected" is". Schutte (1994), pag. 623, meent dat er een criminal charge is zodra "de recle mogelijkheid aanwezig is dat er een administratieve boete opgelegd zal worden of een strafrechtelijkevervolging zal plaatsvinden".

141 In EHRM 21 december 2000 (Quinn) was sprake van een ondervraging van een verdachte die niet 'formally charged' was, maar wiens situatie desalniettemin werd aangemerkt als 'substantially affected'. Het betrof weliswaar een intensief verhoor (acht maal in een periode van 48 uur waarin hij van zijn vrijheid was beroofd), maar enige betrokkenheid bij het strafbare feit werd door hem ontkend. 
men dat justitiabelen verplicht zijn aan hun eigen veroordeling mee te werken ${ }^{142}$, terwijl de behandeling van een zaak binnen een redelijke termijn bescherming biedt tegen de onzekerheid die van een vervolging voor de justitiabele uitgaat. Dergelijke verschillen dienen naar mijn mening hun invloed uit te oefenen op het moment vanaf hetwelk zij hun beschermende werking kunnen ontplooien ${ }^{143}$ : het in het geding zijnde (deel)recht bepaalt mede wanneer de situatie van de verdachte 'substantially affected' is. ${ }^{144} \mathrm{Om}$ bij de vorenstaande voorbeelden aan te sluiten: het zwijgrecht zou mijns inziens reeds geactiveerd moeten worden op het moment waarop tegen de betrokkene een redelijk vermoeden van schuld rijst ${ }^{145}$, terwijl het recht op een behandeling binnen een redelijke termijn pas relevant wordt zodra de verdachte kan vrezen dat een vervolging tegen hem zal worden ingesteld, hetgeen niet zonder meer het geval zal zijn door een enkele verdenking tegen hem. Een dergelijke differentiëring, die ook in de lijn van het Imbrioscia-arrest van het EHRM ligt ${ }^{146}$ - wordt door de Hoge Raad echter niet gemaakt; hij houdt star vast aan zijn formele en objectiverende benadering van het beginpunt van de vervolging, onafhankelijk van het (deel)recht van artikel 6 EVRM dat in het geding is. ${ }^{147}$ Hierdoor wordt mijns inziens de reikwijdte van de bescherming van bepaalde in artikel 6 EVRM verankerde rechten onnodig en onterecht beperkt, waarbij niet in de laatste plaats opvalt

142 Of in ieder geval dat zij veroordeeld zouden kunnen worden op grond van bewijsmateriaal waarvan de betrouwbaarheid door een eventuele dwang zou kunnen zijn aangetast. Over het nemo teneturbeginsel en het daarmee samenhangende zwijgrecht zie uitgebreid paragraaf 3 .

143 Aldus ook Wöretshofer (1996), pag. $48-49$ en Keulen (1996), pag. 82, die stelt dat de strekking van het desbetreffende recht bepaalt wanneer het kan worden geschonden.

144 Met instemming kan Schalken in zijn noot bij HR 11 mei 1993, NJ 1994, 142, worden aangehaald waar hij stelt dat de "strekking van het EVRM (...) erop neer (komt) dat honorering van de verdedigingsrechten in het concrete geval dient plaats te vinden met het oog op het doel waarvoor ze in het leven zijn geroepen. Dat doel ligt in elk geval opgesloten in het verdragsrechtelijke vereiste dat het systeem voor de verdachte een faire procesvoering mogelijk moet maken. (...) Het zal dus van de omstandigheden afhangen (en niet alleen van het formele moment van de bekendmaking) of et van een vervolgingsdaad in de zin van het EVRM sprake is".

145 Tegengeworpen zou kunnen worden dat het moeilijk is om in een procedure het exacte tijdstip aan te geven waarop cen redelijk vermoeden van overtreding rijst. Dit is zeker het geval, maar dat laat onverlet dat het hier een objectief(bepaalbaar) criteriumbetreft. Overigens zou ook bij een beperktere interpretatie het verdenkingsbegrip steeds een rol spelen.

146 EHRM 24 november 1993. Het Hof overwoog hier dat het primaire doel van artikel 6 EVRM is gelegen in het verzekeren van een fair trial door een onafhankelijke rechter. Deze nadruk op de contradictoire procedure voor een rechter laat echter onverlet dat artikel 6 EVRM ook op 'pre-trial proceedings' van toepassing kan zijn: de rechten van de verdediging "may also be relevant before a case is sent for trial if and in so far as the faimess of the trial is likely to be seriously prejudiced by an initial failure to comply with them". Terecht concludeert Knigge in zijn noot bij dit arrest, "De vraag naar de mate waarin de verschillende verdedigingsrechten van betekenis zijn voor het vooronderzoek, wordt (...) gekoppeld aan het doel van het verdragsartikel, het verwezenlijken van een fair trial". Van Russen Groen (1998), pag. 90, daarin gevolgd door Jansen (1999), pag. 139, staat op het standpunt dat in de voorfase de waarborgen van artikel 6 EVRM zoveel mogelijk in acht genomen dienen te worden.

147 Ten aanzien van het regeringsstandpunt naar aanleiding van het CTW-advies Handhaving door bestuarlijke boeten dat een verdenking gelet op de jurisprudentic van de Hoge Raad aangaande het "chargemoment' onvoldoende is om het zwijgrecht te activeren, stelt Van Buuren (1995) pag. 49: "lk meen dat die arresten niet betrekking hebben op het zwijgrecht, maar op de vraag wanneer de redelijke termijn voor berechting ingaat, hetgeen wel iets anders is dan de vraag vanaf welk moment het zwijgrecht behoort te gelden". 
dat het de opsporende instantie die het door een daad van haar zijde in de hand heeft het fair trial-beginsel te activeren of -belangrijker- door het achterwege laten van die daad het fair trial principe tijdelijk buiten spel kan zetten, hetgeen moeilijk valt te rijmen met de gedachte achter artikel 6 EVRM.

Concluderend moet worden gesteld dat artikel 6 EVRM geen ruimte laat voor het inroepen van een recht vóór het moment van verdenking: van vervolging kan in dat geval geen sprake zijn. Zodra er echter een verdenking is gerezen, hangt het van het te beschermen recht af wanneer het zijn werking kan ontplooien. Ten aanzien van de redelijke termijn geldt dat de situatie van de verdachte pas wezenlijk is beĩnvloed door een (overheids)maatregel, indien hij van deze op de hoogte is en uit deze kan afleiden dat tegen hem cen vervolging zal worden ingesteld of reeds is ingesteld, waarbij tot op zekere hoogte zijn subjectieve perceptie een rol speelt. Pas op dat moment verkeert de verdachte immers in de onzekerheid over de afloop van het overheidsoptreden, welke onzekerheid zo spoedig mogelijk dient te verdwijnen.

\subsection{Berechting binnen redelijke termijn: het communautaire perspectief}

Zoals reeds in paragraaf 1 werd besproken, schittert het geschreven gemeenschapsrecht niet door aandacht voor fundamentele rechten in het kader van een procedure. In dat licht verbaast het dan ook niet dat in het communautaire kartelrecht algemene regels ontbreken omtrent termijnen waarbinnen een beslissing moet zijn gegeven, met dien verstande dat wel de verjaringstermijnen van Verordening 2988/74 $4^{148}$ in acht genomen moeten worden. Voor zover er dus sprake is van bescherming tegen een onredelijk lange communautaire kartelprocedure, moet deze bescherming (uiteindelijk) van het Hof komen. En het Hof heeft de ondernemingen op dit punt niet in de kou laten staan, zij het dat het lang heeft geduurd vooraleer een zaak bij het Hof aanhangig werd waarin over de redelijke termijn problematiek een specifiek oordeel gegeven kon worden. ${ }^{149}$ In de betonstaalmatten-zaak namelijk klaagde een betrokken onderneming, verwijzend naar artikel 6 EVRM, over de lange duur van de procedure sinds de indiening bij het Gerecht van het verzoekschrift tot nietigverklaring van de beschikking: de procedure voor het Gerecht had liefst ongeveer vijf jaar en zes maanden in beslag genomen. Het Hof merkte hierover met het nodige gevoel voor understatement op

"dat een dergelijke duur op het eerste gezicht erg lang lijkt. De redelijkheid van de termijn moet evenwel worden beoordecld met inachtneming van de specifieke omstandigheden van elke zaak en in het bijzonder

148 Verordening van de Raad no. 2988/74/EEG van 26 november 1974 inzake de verjaring van het recht van vervolging en van tenuitvoerlegging op het gebied van het vervoers-en mededingingsrecht van de Europese Economische Gemeenschap, $\mathrm{Pb} 1974$ L 319. Zie hierover nader hoofdstuk 4, paragraaf 2.2 .

149 Aanzetten om met de verstreken termijn rekening te houden, waren er al eerder. Vergelijk HvJ (6 en 7/73) Jur. 1974, 223 (Istituto Chemioterapico Italiano/Commercial Solvents Corporation) en Pb 1994 L 378/17 (Far Eastern Freight Conference). Op de duur van de procedure werd ook ingegaan in GvEA (T-62/98) n.n.g. (Volkswagen). 
met inachtneming van het belang ervan voor de betrokkene, de ingewikkeldheid van de zaaken het gedrag van de verzocker en de bevoegde autoriteiten". 150

Deze overwegingen tonen allereerst aan dat het Hof met zoveel woorden heeft aanvaard dat het recht op behandeling binnen een redelijke termijn ook binnen de communautaire rechtsorde gelding heeft. Bovendien blijkt -en dat is zeer verheugend- dat het met betrekking tot de voor de beoordeling van de redelijkheid van de termijn in een concreet geval aansluiting zoekt bij de jurisprudentie van het EHRM, waarnaar overigens in het arrest uitdrukkelijk wordt verwezen. Ook de inhoudelijke beoordeling kan de toets der kritiek doorstaan. ${ }^{131}$ Ten aanzien van het belang van de zaak overwoog het Hof dat, hoewel de onderneming door het geschil niet rechtstreeks in haar economische voortbestaan werd bedreigd en zij de door de Commissie opgelegde geldboete nog niet had hoeven te voldoen, dit stellig aanwezig was, mede tegen de achtergrond van de opgelegde boete en de betwisting van de juistheid van het oordeel van de Commissie over de inbreuk op het mededingingsrecht. Dienaangaande moet mijns inziens er overigens van worden uitgegaan dat in kartelzaken een dergelijk belang er per definitie is. Wel zal het zo zijn dat in -zeer uitzonderlijke- situaties waarin de opgelegde boete het voortbestaan van de onderneming wel in gevaar kan brengen en/of waarin de boete -door het ontbreken van de schorsende werking van beroep- wel onmiddellijk wordt geïnd, grotere spoed geboden is en de redelijke termijn dus eerder geschonden zal zijn. Dat de welhaast aan kartelzaken eigen ingewikkeldheid over het algemeen een factor vormt die een langere procedure rechtvaardigt, is hiervoor reeds benadrukt. Het Hof onderstreept in zijn arrest dat het in dit geval zeer zeker een ingewikkelde zaak betrof: veertien producenten hadden artikel $85 \mathrm{EG}-\mathrm{Verdrag}$ (thans artikel $81 \mathrm{EG)}$ overtreden door verschillende gedragingen, het beroep van Baustahlgewebe was één van de elf beroepen in drie verschillende talen en de zaak tegen deze onderneming zelf vergde "een grondig onderzoek van vrij volumineuze documenten en van relatief ingewikkelde feitelijke en rechtsvragen". ${ }^{152}$ Aan de houding van de onderneming in kwestie -het derde criterium- was de lengte van de procedure daarentegen niet te wijten. Weliswaar had zij uitstel verzocht (en gekregen) van het indienen van dupliek (waardoor de procedure met circa één maand werd verlengd), maar voor het overige had zij geen vertragende barrières opgeworpen. ${ }^{133}$ Toch werd er uiteindelijk door het Hof geoordeeld dat de redelijke termijn in deze zaak geschonden was en wel op grond van het vierde criterium: een gebrek aan voortvarendheid door de bevoegde autoriteit, in dit

$150 \mathrm{HvJ}$ (C-185/95 P) Jur. 1998, 1-8417 (Baustahlgewebe), herhaaldin GvEA(T-305-307, 313-316, 318, 325, 328, 329 en 335/94) Jur. 1999, Il-931 (Limburgse Vinyl Maatschappij c.a.).

151 Aldus ook Lawson (2000 III), pag. 177.

152 In GvEA (T-305-307, 313-316, 318, 325, 328, 329 en 335/94) Jur. 1999, II-931 (Limburgse Vinyl Maatschappije.a.) oordeelde het Gerecht dat de redelijketermijn niet was geschonden (het onderzock van de Commissie had totaal 52 maanden in beslag genomen), en wel vanwege de ingewikkeldheid van de zaak (zich onder meer uitend in het aantal verzameide documenten, in de gebleken bewijsmoeilijkheden alsmede in het aantal betrokken ondernemingen).

153 In dit verband is van belang dat het Hof terecht het argument van de Commissie van de hand wees dat de procedure was vertraagd door toedoen van de raadsman, die in de administratieve procedure niet was opgetreden, maar voor het Gerecht zijn pijlen had gericht op de opgelegde geldboete. Het Hof overwoog dienaangaande: "Een onderneming die wordt geraakt door een beschikking van de Commissie waarin schendingen van het mededingingsrecht worden vastgesteld en waarbij haar een geldboete wordt opgeiegd, moet immers met alle middelen die zij geschikt acht, de juistheid van de tegen haar ingebrachte beschuldigingen kunnen betwisten". 
geval het Gerecht. Het Hof erkende weliswaar dat het Gerecht, gelet op zijn rol als feitenrechter, over voldoende tijd moet kunnen beschikken om complexe zaken te onderzoeken en dat het talenregime binnen de communautaire rechtsorde de nodige tijd opslokt, maar dat desalniettemin het Gerecht gehouden was een zaak binnen een redelijke tijd af te ronden. Het Hof concludeerde dat het Gerecht hierin in casu echter niet was geslaagd:

\begin{abstract}
"Met betrekking tot het beginsel van de redelyke termijn zjin in de procedure voor het Gerecht namelijk twee perioden van belang. Tussen het einde van de schriftelijke behandeling en het besluit om tot de mondelinge behandeling over te gaan, zijn ongeveer 32 maanden verstreken. Bij beschikking van 13 oktober 1992 is weliswaar beslist de elf zaken voor de mondelinge behandeling te voegen, maar in die periode is geen enkele andere maatregel tot organisatic van de procesgang of maatregel van instructie getroffen. Bovendien zijn tussen de beeindiging van de mondelinge procedure en het arrest van het Gerecht 22 maanden verstreken".
\end{abstract}

Dergelijk lange termijnen voor instructie en beraadslaging achtte het Hof slechts in uitzonderlijke omstandigheden gerechtvaardigd, waarvan in casu echter geen sprake was. ${ }^{154}$ Het Hof lijkt echter niet bereid om al te vergaande consequenties aan een schending van de redelijke termijn te verbinden. De hem voorgelegde beslissing zal blijkens het Baustahlgewebe-arrest door het Hof alleen nietig worden verklaard indien de lengte van de procedure de uitkomst van het geschil heeft beïnvloed. Een dergelijke beìnvloeding is echter nauwelijks denkbaar. Evenals het geval is in de Nederlandse situatie werd in het onderhavige arrest (en zal naar alle waarschijnlijkheid ook in andere gevallen worden) volstaan met een verlaging van de boete. Al te veel hoop op een aanzienlijke verlaging van de boete lijkt een onderneming overigens toch niet mogen te koesteren: de boete die aan Baustahlgewebe door het Gerecht was opgelegd, werd met welgeteld 50.000 ecu (ofwel $1,7 \%$ ) gematigd. ${ }^{155}$

Het Hof erkent derhalve het recht op behandeling binnen een redelijke termijn. Ook ten aanzien van het tijdstip van aanvang van de criminal charge lijken de communautaire rechters te willen aansluiten bij het $\mathrm{EHRM}^{156}$, hetgeen in mijn optick ook niet meer dan vanzelfsprekend is ${ }^{157}$, maar hetgeen toch gelet op de terughoudendheid van deze rechters ten aanzien van het EVRM tot tevredenheid stemt. Reeds sinds het Hoffmann-La

154 Het Hof wees er op dat in casu geen schorsing van de procedure voor het Gerecht had plaatsgevonden en achtte daarom bijzondere omstandigheden niet aanwezig.

155 In $\mathrm{Pb} 2000 \mathrm{~L} \mathrm{39/1}$ (Nederlandse Federatieve Vereniging voor de Groothandel op Elektrotechnisch Gebied en Technische Unie) werd eveneens de redelijke termijn geschonden geacht. De totale procedure had ongeveer 8 jaar in beslag genomen, welke lange duur 'deels aan de Commissie' was toe te schrijven. Het leverde de betrokken ondernemingen een aftrek van 100.000 euro op, respectievelijk $2,2 \%$ en 4,4\% van de 'oorspronkelijke' boetes. In Pb 2000 L. 268/1 (Far East Trade Tariff Charges and Surcharges Agreement) had de overschrijding van de redelijke termijn cen verlaging van de boete met 100.000 euro tot gevolg.

156 Vergelijk Debruyne (1992), pag. 51: "Wij kunnen ons eens te meer niet van de indruk ontdoen dat het Hof zijn rechtspraak op dezelfde golflengte heeft willen plaatsen als deze van het Europese Hof voor de Rechten van de Mens".

157 Waar het Hof dezelfde ruime materiēle bescherming dient te bieden als het Straatsburgse Hof, daar moet ook worden aangesloten bij de invulling van de formele reikwijdte van artikel 6 EVRM. Zou dit niet gebeuren, dan zou de materiēle bescherming alsnog worden uitgehold. 
Roche-arrest ${ }^{158}$ is duidelijk dat in de contradictoire kartelfase de rechten van de verdediging moeten worden gehonoreerd ook al is deze administratiefrechtelijk van aard. Typerender nog in dit verband is het Hoechst-arrest. ${ }^{159}$ Hierin heeft het Hof uitdrukkelijk bepaald dat rechtsbescherming geen verworvenheid is die slechts in de procedure op tegenspraak een rol speelt, maar dat zij zich tevens uitstrekt tot de voorafgaande (onderzoeks)fase, althans met betrekking tot die rechten die niet naar hun aard gereserveerd zijn voor uitsluitend de contradictoire procedure. Het Hof achtte deze verstrekkende bescherming noodzakelijk, omdat vermeden moet worden dat de rechten van de verdediging "onherstelbare schade lijden in het kader van een voorafgaand onderzoek, met name bij verificaties, daar deze beslissend kunnen zijn voor de totstandkoming van het bewijs van de onrechtmatigheid van gedragingen van ondernemingen, waarvoor deze aansprakelijk zijn". ${ }^{160}$ Een beperktere uitleg ten aanzien van de gelding van de rechten van de verdediging zou de rechtsbescherming van de ondernemingen ondergraven. De overeenkomst in strekking en bewoordingen met de overwegingen van het EHRM in het Imbrioscia-arrest zijn onmiskenbaar.

\section{Nemo tenetur ${ }^{161}$}

In deel I bleek dat in het kader van de handhaving van het communautaire én Nederlandse kartelrecht een belangrijke plaats was en is ingeruimd voor medewerkingsplichten van primair- ondernemingen. Op grond van de artikelen 11 en 14 Vo $17 \mathrm{j}^{\circ}$ artikel $15 \mathrm{Vo}$ 17 zijn ondernemingen in het communautaire recht op straffe van een geldboete van ten hoogste 5.000 euro verplicht om bij beschikking opgeěiste inlichtingen te verschaffen en medewerking te verlenen aan bij beschikking gelaste verificaties. ${ }^{162}$ De Wem kende in samenhang met de WED een medewerkingsplicht zowel voor het opsporingsonderzock (artikel 24a WED, met een maximum strafsanctie van gevangenisstraf van maximaal twee jaar en/of geldboete van $f 25.000$ (voor rechtspersonen: $f 100.000)^{163}$ ) als voor de toezichtsfase (artikel 41a Wem; met een maximale strafrechtelijke sanctie van gevangenisstraf van ten hoogste drie maanden en/of geldboete van $f 5.000 \mathrm{c.q} f 10.000$ voor rechtspersonen). In de Mededingingswet is in samenhang met artikel 5:20 Awb in een medewerkingsverplichting voorzien, op overtreding waarvan in artikel $69 \mathrm{Mw}$ een bestuur-

$158 \mathrm{HvJ}(85 / 76)$ Jur. 1979, 511 (Hoffmann-La Roche): "Eerbiediging van de rechten der verdediging in iedere procedure die tot de oplegging van sancties, met name geldboeten of dwangsommen. kan leiden, is te beschouwen als een grondbeginsel van het gemeenschapsrecht, dat zelfs in een administrat tieve procedure moet worden inachtgenomen". In vergelijkbare bewoordingen HvJ (322/81) Jur. 1983, 3498 (Michelin).

$159 \mathrm{HvJ}$ (46/87 en 227/88) Jur. 1989, 2859; zie tevens de zaken HvJ (85/87) Jur. 1989, 3137 (Dow Benelux) en HvJ (97-99/87) Jur. 1989, 3165 (Dow Chemical Ibérica e.a.).

160 Zie voor het belang van de waarborging van rechten in het vooronderzoek ook Hvj (374/87) Jur 1989. 3283 (Orkem).

161 Zie over dit beginsel algemeen onder meer Berger (1980) en Rogall (1977).

162 Volgens artikel 16 Vo 17 kan deze verplichting voorts kracht worden bijgezet door het opleggen van een dwangsom van ten hoogste 1.000 rekeneenheden per dag.

163 Artikelen $24 a j^{\circ} 26 j^{\circ} 1$ sub $5 j^{\circ} 2$ lid $5 j^{\circ} 6$ lid 1 sub 2 WED. 
lijke boete is gesteld van ten hoogste $f 10.000 .{ }^{164}$ Degenen van wie medewerking wordt gevorderd, zijn kortom op straffe van (soms gevoelige) sancties gehouden inlichtingen te verstrekken en inzage van gegevens en bescheiden te verstrekken. Een dergelijke medewerkingsplicht biedt het voordeel van effectiviteit aangezien de met handhaving belaste autoriteiten niet zelf naar relevante informatie op zoek hoeven. Tot op zekere hoogte biedt zij ook voordelen voor de justitiabelen: bij medewerking is een verdergaand optreden van de overheden niet (meer) noodzakelijk. Maar er is ook een keerzijde. Een medewerkingsplicht komt er namelijk op neer dat een justitiabele zijn eigen graf moet (helpen) graven, in die zin dat hij moet meewerken aan de tegen hem van overheidswegen geinitieerde (strafrechtelijke) procedure. Dit zet zijn positie tegenover de vervolgende overheid onder druk en doet de balans wel zeer merkbaar doorslaan naar instrumentele zijde. Mede daarom kent het wetboek van Strafvordering voor verdachten of degenen die door coöperatic een verdenking op zich zouden laden het recht toe om medewerking te weigeren. ${ }^{165}$ In het bijzondere strafrecht ontbreken vergelijkbare regelingen echter, hetgeen evenzeer voor de Mededingingswet en voor Verordening 17 geldt. ${ }^{166}$ De vraag is nu of deze medewerkingsverplichtingen niet de rechten van de justitiabelen aantasten. Deze vraag spitst zich toe op de vraag naar de gelding en reikwijdte van het zogenoemde nemo tenetur-beginsel.

Nemo tenetur prodere se ipsum: niemand is gehouden aan zijn eigen veroordeling mee te werken. Ruim omschreven is de strekking van dit beginsel dat van overheidswege geen dwang mag worden uitgeoefend tegenover justitiabelen teneinde deze tot het afleggen van een verklaring of het verstrekken van materiaal in eigen zaak te bewegen. De oorsprong van het nemo tenetur-beginsel ligt bij de vrees voor fysieke pressie met als meest vergaande vorm martelpraktijken tegen een justitiabele teneinde bewijs te vergaren. ${ }^{167}$ Dat deze vorm van pressie in een rechtsstaat ontoelaatbaar is, spreekt voor zich. ${ }^{168}$ Maar hoewel ook heden ten dage fysieke dwang en martelingen -ook in Europa- nog niet zijn

164 Conform communautair recht kan daarnaast op grond van artikel $70 \mathrm{Mw}$ een dwangsom worden opgelegd teneinde de betrokkene alsnog te dwingen om inzage van gegevens en bescheiden te verlenen. In tegenstelling tot hetgeen in het gemeenschapsrechthet geval is, is er geen maximum gesteld aan de hoogte van de dwangsom. Het van toepassing verklaarde artikel 5:32 lid $4 \mathrm{Awb}$ stelt slechts dat het bedrag 'in redelijke verhouding tot de zwaarte van het geschonden belang en de beoogde werking van de dwangsomoplegging' staat.

165 Men zie bijvoorbeeld voor de verdachte artikel 29 WvSv (zwijgrecht) en de artikelen 96 a lid 2 en 105 lid $3 \mathrm{WvSv}$ (in verband met een vordering tot uitlevering van voorwerpen ter inbeslagneming) en voor de 'nog niet-verdachte' de artikelen 96a lid 3 en 105 lid 3 WvSv (eveneens verband houdend met de vordering tot uitlevering van voorwerpen) alsmede artikel $219 \mathrm{WvSv}$ (verschoningsrecht). Zie hierover Corstens (1999), pag. 132 e.v., pag. 261 e.v., pag. 445 en pag. 449 e.v..

$166 \mathrm{Wel}$ is in de Mededingingswet een zwijgrecht voor de 'verdachte' opgenomen. Voor het bijzondere strafrecht geldt het algemenezwijgrecht van artikel $29 \mathrm{WvSv}$. In Verordening 17 is daarentegengeen zwijgrecht opgenomen.

167 Vergelijk Van Strien (1996 II), pag. 12. Biesheuvel (1988), pag. 693, ziet in het tortuurverbod het belangrijkste(historische) motief voor hantering van het nemo tenetur-beginsel. Buruma (1993), pag. 243 , nuanceert de band met het folterverbod. Ansmink (1981), pag. 447, ziet slechts het zwijgrecht als reactie op de martelpraktijken.

168 Het verbod van fysieke pressie heeft dan ook ten grondsiag gelegen aan het zwijgrecht van de verdachte, zoals neergelegdin artikel $29 \mathrm{WvSv}$. Zie over het pressieverboden het zwijgrecht Corstens (1999). pag. 264-266. 
uitgeroeid ${ }^{16}$, ligt de nadruk van het nemo tenetur-beginsel nu op andere en minder vergaande vormen van dwang, waaronder dreiging met of oplegging van (vrijheidsbene. mende dan wel financięle) sancties. De vraag is dan waarom ook deze vormen van dwang. uitoefening vanuit rechtsbeschermingsoptiek onaanvaardbaar zijn. De eerste reden hiervoor is van bewijstechnische aard: dwang tast de betrouwbaarheid van de informatie aan (en bij gebruik hiervan: van de uitkomst van de procedure), althans voor zover de dwang invloed kan uitoefenen op (de inhoud van) de informatie. Zoals hierna nog zal blijken, kan dit zich in feite uitsluitend voordoen bij een spreekplicht ${ }^{170}$; bij reeds bestaand materiaal beïnvloedt de dwang de inhoud ervan in ieder geval niet. ${ }^{171}$ Aldus vallen nemo tenetur-beginsel en zwijgrecht samen. Maar er is nog een tweede, verdergaande reden die zich verzet tegen dwang tot medewerking: de erkenning van het recht van justitiabelen om hun eigen procespositie te bepalen in een tegen hen ingestelde strafrechtelijke of daarmee vergelijkbare procedure. ${ }^{172}$ Naast het voorkomen van fysieke pressie ligt hierin mijns inziens de meest voorname grondslag van het nemo tenetur-beginsel. Dwanguitoefening blijft dan een belangrijke factor, maar het antwoord op de vraag waarom dwang niet dient te worden toegepast, is een ander dan bij de andere genoemde grondslagen van het beginsel. De nadruk ligt veel meer op de gedachte dat het, om Reijntjes te citeren ${ }^{13}$, "ethisch verwerpelijk" is om een justitiabele te dwingen aan zijn eigen veroordeling mee te werken. ${ }^{174}$ Met deze eis van ethiek hangt tevens samen dat de justitiabele niet in een "persőnlichen Gewissenskonflikt"175 tussen het voldoen aan een wettelijk voorschrift tot verstrekking van informatie enerzijds en het afleggen van belastende verklaringen tegen zichzelf anderzijds wordt gebracht. ${ }^{176}$ In deze lezing van de grondslag

169 Zo zijn recentelijknog martelingen geconstateerdin landen als Turkije (zie bijvoorbeeld EHRM 18 december 1996 (Aksoy) en EHRM 10 oktober 2000 (Satik e.a.)), Spanje (zie Report CPT, 5 maart 1996, CPT/Inf(96)9) en Frankrijk (EHRM 28 juli 1999 (Selmouni)).

170 Allerminst denkbeeldig is het dat de tot spreken gedwongene, in de hoop onder de dwang uit te komen, een verklaring aflegt die is afgestemd op hetgeen men van hem wil horen.

171 De inhoud van gegevens wijzigt immers niet naargelang deze door de justitiabele vrijwillig zijn verstrekt, de verstrekking onder dwang is gebeurd of de overheid door zelfstandig actief optreden deze gegevens heeft vergaard.

172 In gelijke zin Knigge in zijn noot bij EHRM 25 februari 1993 (Funke) en dezelfde schrijver in zijn noot bij EHRM 17 december 1996 (Saunders). Hartmann (2000), pag. 42, doelt op hetzelfde waar hij het nemo tenetur-beginseleen uitwerking noemt van het uitgangspunt van een accusatoireproces. vorm. Berkhout-van Poelgeest (1999), pag. 256, concludeert uit de Nederlandse geschiedenis van het nemo tenetur-beginsel dat zowel 'humanitaire overwegingen als het mogelijke gebrek aan betrouwbaarheid' argumenten vormden voor hantering van dit beginsel.

173 Reijntjes (1996 II), pag. 18.

174 Ook Schalken in zijn noot bij HR 22 november 1994, NJ 1995, 240, ziet een ethische grondslag van het beginsel waar hij stelt dat het nemo tenetur-beginsel is verankerd in "de (objectiveerbare) eis van publiekrechtelijke ethiek die voorschrijft dat de overheid niet met opzet een situatie moet cretren waarin iemand tegen zijn wil tot een verklaring kan worden gebracht die hij anders zou hebben nagelaten".

175 Dannecker en Fischer-Fritsch (1989), pag. 48.

176 Vergelijk ook Schermers in zijn 'dissenting opinion' bij ECRM 10 mei 1994, nr. 19187/91 FED 1995/2 (Saunders), die stelt dat "the main reason why a fair process should include the right not to incriminate oneself is that one should not put a person in the situation where he must choose between telling the truth which incriminates himself and lying in onder to protect himself". Bal (1996), pag 24, spreekt van het trilemma van het zichzelf belasten, het plegen van meineed of het in gijzeling worden genomen. 
van het nemo tenetur-beginsel legt dit beginsel de verhouding tussen overheid en justitiabelen in een punitieve procedure vast en levert het een wezenlijke bijdrage aan de procedurele gelijkheid tussen overheid en rechtssubject. ${ }^{17}$. Daarbij beperkt het zich niet tot, maar treedt wel in belangrijke mate op de voorgrond bij de bewijsvergaring: de bal ligt geheel en al bij de overheid zelf. ${ }^{17} \mathrm{Zij}$ is het die de 'verdenking' koestert en aan haar is het om de zaak rond te krijgen, dus zonder de 'verdachte' onder druk te zetten om informatie an te dragen die licht in diens zaak moet brengen en zonder in feite de justitiabele te dwingen om bewijs in eigen zaak aan te leveren, aldus zijn latere verdedigingsmogelijkheden en het beginsel van hoor en wederhoor danig aantastend. Als er al sprake is van medewerking van de zijde van de 'verdachte', dan dient deze geheel vrijwillig te worden verleend. Het is tegen deze achtergrond niet relevant om welke informatie (in mondelinge vorm of in de vorm van voorwerpen, documenten etc.) het gaat, als gevolg waarvan het nemo tenetur-beginsel de bescherming van het zwijgrecht naar mijn mening overstijgt. Evenmin is van belang of de verlangde informatie al dan niet belastend is ${ }^{17}$, noch of de justitiabele aan de druk van de overheid toegeeft. Het nemo tenetur-beginsel kan daarentegen geen bescherming bieden tegen een plicht tot dulden van onderzoekshandelingen. ${ }^{100}$ In dat geval blijft immers de justitiabele de passieve partij ${ }^{181}$ (en is het de overheid die de bewijzen vergaart) en speelt de hiervoor genoemde 'persönliche Gewissenskonflikt' niet. ${ }^{182}$ Waar het wel gaat om een plicht tot medewerking, zullen de mate en aard van de dwang van dien aard moeten zijn dat een justitiabele redelijkerwijs in een dergelijke conflictsituatie kan worden gebracht. Dat fysieke dwang en andere dwanguit-

177 Hierop wijst ook Finaly (1996), pag. 112.

178 In zoverre is er ook een band tussen het nemo tenetur-beginsel en de presumptio innocentiae. Zie hierover ook Meijer (1991), pag. 892 en Swart (1993), pag. 676. In zijn 'concurring opinion' bij de uitspraak van de ECRM in de Saunders-zaak(ECRM 10 mei 1994, nr. 19187/91, FED 1995/2) stelde Loucaides zelfs: "The presumption of innocence would in fact be a meaningless protection if an accused person was compelled to give evidence against himself. Therefore the privilege against self-incrimination must be recognised as a sine qua non for the effectiveness of the protection in question".

179 Het stellen van deze eis zou complicaties opleveren aangezien bij voorbaat veelal niet duidelijk zal zijn of materiaal inderdaad belastend is. Daar komt nog bij dat het moeilijk van de betrokkene verwacht kan worden dat deze zich zelf op het belastende karakter beroept indien hij medewerking wil voorkomen. En wie oordeelt dan uiteindelijk over de vraag of er inderdaad sprake is van belastendmateriaal?

180 Men vergelijke bijvoorbeeld ook Rozemond (1992), pag. 129 en Swart (1993), pag. 677.

181 Dit laat overigens onverlet dat de justitiabele in dat geval wel mág meewerken, en dat veelal de beginselen van proportionaliteit en subsidiariteitmeebrengendat de overheid, alvorens het onderzoek te verrichten, de justitiabele uitdrukkelijk in de gelegenheid moet stellen om te coöpereren.

182 Over het algemeen is het onderscheid tussen meewerken en dulden in de praktijk duidelijk; er zijn echter grensgevallen. Het onderscheid tussen beide wordt daarom in de literatuur wel bekritiscerd. Men vergelijkeMeijer (1991), pag. 895 ('erg subtiel'), Feteris (1993) ('niet goed werkbaar'), Wöretshofer (1996), pag. 45 (idem), Reijntjes (1996 II), pag. 12 ('arbitrair karakter') en Van Russen Groen (1998), pag. 267 ('niet scherp en zelfs oneigenlijk'). Meijer komt tot de -mijns inziens te ruimeconclusie dat ook de duldingsplicht onder het nemo tenetur-beginselmoet vallen. Wöretshofer beoordeelt de vraag naar de schending van het beginsel aan de hand van "de relevantie van de betreffende informatie in een (latere) strafzaak jegens de betrokkene, de mate van daadwerkelijke dwang en de mate waarin op (andere) grond- en vrijheidsrechteneen inbreuk wordt gemaakt". Deze criteria maken echter niet duidelijk wat de omvang van het beginsel als zodanig is: zij geven hooguit cen toetssteen aan, aan de hand van welke een eventuele schending kan worden beoordeeld. Bovendien wordt het zelfstandige belang van het nemo tenetur-beginsel zo wel erg uitgekleed. 
oefening, zoals een veroordeling of de oplegging van dwangsommen, hieraan voldoen, spreekt welhaast voor zich. Maar ook dreiging van overheidswege met uitoefening van dwang en zelfs het enkele bestaan van een wettelijke mogelijkheid tot het opleggen van een sanctie wegens het niet-medewerken ${ }^{183}$, volstaan mijns inziens reeds. ${ }^{184}$ Indien de overheid duidelijk laat blijken dat het niet bij een sanctiedreiging blijft, neemt de hierdoor gevormde druk alleen maar toe. Buiten bedoelde dwang valt daarentegen de stok achter de deur van de overheid om bij gebleken niet-coöperatie zelf actief op te treden. Subjectief kan de dreiging van een dergelijk overheidsoptreden zonder twijfel de justitiabele aanzetten tot coöperatie, wanneer hij deze als minder ernstig beschouwt dan het overheidshandelen. Dit optreden kan echter niet als een sanctie worden gezien op de niet-medewerking. Het is slechts een noodzakelijke maatregel die de overheid ter beschikking staat teneinde haar taak adequaat te kunnen uitoefenen. ${ }^{185} \mathrm{Al}$ met al blijkt dat door mij een zeer ruime werking van het nemo tenetur-beginsel wordt voorgestaan. ${ }^{16}$ Wel is er éen belangrijke beperking: het nemo tenetur-beginsel heeft mijns inziens geen directe betekenis voor de controlefase. Voorafgaand aan het moment waarop tegen de justitiabele een redelijk vermoeden bestaat dat hij een inbreuk heeft begaan, is de overheid gerechtigd om medewerking af te dwingen en is de justitiabele verplicht deze medewerking te verlenen. Dit geldt evenzeer indien hij hierdoor een verdenking op zich laadt of indien hij gegevens zou moeten verstrekken die reeds het begaan van een inbreuk zouden bewijzen. De reden hiervoor is gelegen in het feit dat controle niet is gericht op punitief optreden, maar primair op toezicht op de naleving van het recht. Dit toezicht zou onnodig gefrustreerd worden indien ook dan het recht zou bestaan om niet mee te werken. Een probleem ontstaat echter indien de justitiabele in die fase inderdaad belastend materiaal moet verstrekken: in dat geval laadt hij niet alleen een verdenking op zich, maar kan het tevens zo zijn dat hij doorslaggevend bewijs tegen zichzelf levert, waardoor van de bescherming van het nemo tenetur-beginsel en van een adequate verdedigingsmogelijkheid in een eventueel punitief vervolg van de procedure weinig meer overblijft. Het nemo tenetur-beginsel brengt in dat geval met zich dat het door verplichte medewerking verkregen belastende materiaal van het bewijs in de punitieve procedure moet worden uitgesloten. $^{187}$

183 Van belang is wel dat het een reêle mogelijkheid betreft, waarbij een rol kan spelen of de overheid in het algemeen daadwerkelijk in vergelijkbare situaties tot sanctieoplegging overgaat.

184 De artikelen 26 WED, 68 AWR, $69 \mathrm{Mw}$ en 15 Vo 17 vormen aldus voorbeelden van dergelijke dwang. Voor een ruime uitleg van dwang kiest ook Meijer (1991), pag. 895.

185 Laat staan dat de uitnodiging van artikel 99 lid 1 WvSv tot vrijwillige afgifte van een voorwerp als dwang zou kunnen worden aangemerkt. Hier betreft het 'niet meer dan' een concretisering van bet evenredigheidsbeginsel.De opmerking van Jansen (1999), pag. 213, dat dit "op gespannenvoet (lijkt) te kunnen komen met het nemo teneturbeginsel" moet dan ook als onjuist worden verworpen.

186 Anders: Stessens (1997), pag. HRC/54: "the use of compulsion to produce documents can only be held to fall foul of the privilege against self-incrimination when it requires the persons involved to co-operate in their own prosecution by providing the authorities with self-incriminating documents they would otherwise have no access to".

187 Een dergelijke mogelijkheid opperde ook Swart (1996), pag. 231: "De oplossing zou misschien kunnen zijn dat de mogelijkheid dat burgers zichzelf belasten door het verstrekken van informatie hen enerzijds niet ontslaat van de medewerkingsplicht maar dat deze belastende informatie anderzijds niet als bewijs in een latere strafzaak kan dienen". Om een voorbeeld uit het fiscale recht te noemen: op grond van artikel $47 j^{\circ} 68 \mathrm{AWR}$ mogen tot het moment van verdenking gegevens en inlichtingen worden gevorderd. Het aldus verkregenmateriaal kan de aanleiding vormen tot een naheffing of navordering, maar 
Het zij herhaald: het cruciale van het nemo tenetur-beginsel is naar mijn mening de bescherming van de vrijheid van de justitiabele om zijn procespositie te bepalen en dus de bescherming tegen dwang waarmee de overheid poogt medewerking van de justitiabele af te dwingen. ${ }^{138}$ De vraag die hierna aan de orde wordt gesteld, is of deze visie ook in de rechtspraktijk ingang heeft gevonden. Uit de bespreking van de jurisprudentie van het EHRM zal blijken dat dit niet het geval is. Ook uit de nationale en communautaire rechtspraak komt naar voren dat het nemo tenetur-beginsel in beperktere zin wordt opgevat.

\subsection{Het nemo tenetur-beginsel en het EVRM}

De tekst van het EVRM besteedt geen aandacht aan het nemo tenetur-beginsel of het zwijgrecht. Ten aanzien van de historische grondslag van het nemo tenetur-beginsel, het voorkomen van martelpraktijken, biedt artikel 3 EVRM nog uitkomst ${ }^{189}$, maar dit artikel biedt geen soelaas voor minder verstrekkende vormen van overheidsdwang. Uit artikel 14 lid 3 aanhef en sub g IVBPR kan daarentegen wel een bescherming van het zwijgrecht (maar niet van het ruimere nemo tenetur-beginsel ${ }^{190}$ ) worden afgeleid. ${ }^{191}$ Dit artikel luidt (voorzover hier relevant):

Bij het bepalen van de gegrondheid van een tegen hem ingestelde strafvervolging heeft een ieder, in volle gelijkheid, recht op de volgende minimumgaranties: (...) g. niet te worden gedwongen tegen zichzelf te getuigen of een bekentenis af te leggen.

zou mijns inziens niet als bewijs mogen dienen in een bestuurlijke boeteprocedure (vergelijk de artikelen 67d e.v. AWR) noch in een strafrechtelijke procedure (artikel 69 AWR).

188 Hiermee is niet gezegd dat het door de dwanguitoefening bewerkstelligde betrouwbaarheidsdeficit geen rol speelt binnen het nemo tenetur-beginsel. Met name ten aanzien van afgedwongen (mondelinge) verklaringen kan de betrouwbaarheid in twijfel getrokken worden, waarmee de grondslag voor hantering van het beginsel nog sterker wordt. Mede tegen deze achtergrond is verklaarbaar waarom het zwijgrecht, in tegenstelling tot het algemene recht om niet te hoeven bijdragen aan de eigen veroordeling, (zoals hierna nog zal blijken) expliciete ingang heeft gevonden in het Nederlandse strafprocesrecht. Van Strien (1996 II), pag. 12, is van mening dat ondememingen aan het nemo tenetur-beginsel cen aanmerkelijk minder verstrekkende bescherming kunnen ontlenen dan individuen. $\mathrm{Zij}$ komt tot deze conclusie omdat volgens haar ondememingen minder belang hebben bij het verbod op gedwongen zelf-incriminatie; voor ondernemingen betreft het voornamelijk bescherming op het vlak van de verdeling van de bewijslast en speelt het voorkomen van fysieke dwang of het croěren van een persoonlijk gewetensconflict daarnaast in het geheel niet. Van absolute bescherming kan geen sprake zijn volgens Van Strien; zeker, zo stelt zij, "wanneer de activiteiten van de rechtspersoon belangrijke maatschappelijke gevolgen bebben kan het maatschappelijke belang dat de rechtspersoon bepaalde informatie verschaft aan de justitiele autoriteiten zo zwaar wegen, dat de belangen van de rechtspersoon dienen te wijken voor die van de samenleving". Gelet op de ratio van het nemo tenetur-beginsel zoals die door mij wordt gezien, moge het duidelijk zijn dat ik deze visie niet kan delen. Het zal ook ten aanzien van ondernemingen steeds zo dienen te zijn dat in een punitieve procedure de bal bij de overheid ligt, welk uitgangspunt geen uitzondering duldt.

189 Artikel 3 EVRM luidt: Niemand mag worden onderworpen aan folteringen of aan onmenselijke of vernederende behandelingen of bestraffingen.

190 Vergelijk onder meer Feteris (1993) alsmede Schalken in zijn noot bij HR 2 juli 1990, NJ 1990, 751.

191 Een expliciete bescherming van het zwijgrecht levert ook de tekst van dit artikel niet. Vergelijk Buruma (1993), pag. 243 en Van Russen Groen (1998), pag. 261. 
Op grond van de teksten van deze verdragen biedt het IVBPR dus een ruimere bescherming op dit punt dan het EVRM. Toch is ook in het EVRM het nemo tenetur-beginsel verankerd: sinds het Funke-arrest ${ }^{192}$ staat vast dat dit beginsel deel uitmaakt van het recht op een eerlijke behandeling (fair trial), zoals neergelegd in artikel 6 lid 1 EVRM. Aanleding tot de Funke-zaak was een rechterlijke uitspraak waarin Funke een geldboete wetd opgelegd wegens het niet verstrekken van door de douane verlangde schriftelijke gegevens en waarin hem, onder dreiging van een dwangsom, werd opgedragen alsnog inzage van de verlangde documenten te verschaffen. Funke achtte dit een schending van artikel 6 EVRM en diende -na tevergeefs beroep en cassatie te hebben ingesteld bij de nationale (Franse) rechter- een klacht in bij de ECRM, die hem niet in het gelijk stelde. Het EHRM deelde de mening van de Commissie niet en constateerde een inbreuk op het fair trial beginsel van artikel 6 lid 1 EVRM. Het EHRM oordeelde

\begin{abstract}
"that the customs secured Mr Funke's conviction in order to obtain certain documents which they believed must exist, although they were not certain of the fact. Being unable or unwilling to procure them by some other means, they attempted to compel the applicant himself to provide the evidence of offenoss he had allegedly committed. The special features of customs law (...) cannot justify such an infringemeat of the right of anyone "charged with a criminal offence", within the autonomous meaning of this expression in Art. 6, to remain silent and not to contribute to incriminating himself",
\end{abstract}

Door de wel zeer beknopte motivering van het EHRM is er in de literatuur de nodige discussie geweest over de uitleg van het Funke-arrest. Dát het nemo tenetur-beginsel was erkend, stond vast. De vraag was echter: hoe ver reikt de bescherming ervan? Deze discussie speelde zich niet in de laatste plaats af tegen de achtergrond van de gevolgen die een ruime interpretatie zou hebben voor de handhaving van (met name fiscale en ordenings-) wetgeving. Er zijn nogal wat aspecten in het Funke-arrest die op de erkenning van een zeer ruime bescherming duiden. ${ }^{194}$ Zo worden het zwijgrecht en het nemo tenetur-beginsel uitdrukkelijk afzonderlijk genoemd, hetgeen er op duidt dat het twee verschillende, zij het aan elkaar verwante, rechten betreft. ${ }^{195}$ Het nemo tenetur-beginsel heeft dientengevolge een ruimere strekking dan alleen een recht om te zwijgen. Dat wordt nog eens onderstreept door het gegeven dat het in de Funke-zaak om documenten ging. waarbij de vanzelfsprekendheid waarmee het EHRM het nemo tenetur-beginsel ook op documenten ${ }^{196}$ van gelding achtte, veelzeggend is. ${ }^{197}$ De bewoordingen van het arrest

192 EHRM 25 februari 1993.

193 Het feit dat de veroordeling door de Franse rechter tot doel had om Funke tot afgifte van de verlangde bescheiden te dwingen, vormde klaarblijkelijk een belangrijk punt van overweging. Hier zijn duidelijke raakvlakken waarneembaar met het communautaire recht, aangezien ook hier de Commissic een onderneming kan veroordelen wegens het niet-uitleveren van bescheiden en haar tevens een dwangsom kan opleggen: beide sancties hebben (uiteindelijk) tot doel de onderneming te bewegen tot afgifte over te gaan.

194 Zie bijvootbeeld Schutte (1994), pag. 621: "Voor zover er sprake is van bewijsgaring die gericht is op een strafrechtelijke vervolging in ruime zin geldt heel algemeen het beginsel dat de verdachte niet aan zijn eigen veroordeling hoeft mee te werken". Anders: Michiels (1994), pag. 25.

195 Anders: Reijntjes (1996 II), pag, 16.

196 Dit terwijl, zoals nog zal worden besproken, in andere rechtsstelsels de bescherming van documenten niet voor zich spreekt.

197 Dat het nemo tenetur-beginsel ook op documenten van toepassing is, concluderen voorts Schutte (1994), pag. 624, Swart (1993), pag. 677, Wōretshofer(1996), pag. 44 en-zij het met enige aarzeling. Feteris (1993). 
sluiten voorts niet uit dat ook bijvoorbeeld het verplicht uitleveren van voorwerpen of het afgeven van bloed ten behoeve van een DNA-test op grond van het EVRM verboden is. $\mathrm{Er}$ is echter ook een andere, aanmerkelijk beperktere interpretatie mogelijk. Bij deze interpretatie wordt bijzonder gewicht toegekend aan de zinsnede 'documents which they believed must exist, although they were not certain of the fact'. In die lezing, die onder meer door Reijntjes wordt voorgestaan, strekt het nemo tenetur-beginsel zich slechts dan uit tot documenten indien niet zeker is of deze inderdaad bestaan en voor de betrokkene beschikbaar zijn. ${ }^{198}$ Reijntjes concludeert dan ook "dat zowel met straf, als met dwang. als met een dwangsom mag worden opgetreden tegen de weigering om materiaal te verschaffen, ook al kan dat potentieel tegen de verschaffer worden gebruikt, mits voldoende vaststaat dat de betrokkene dat materiaal ook bezit". ${ }^{199}$ Aldus 'verwordt' het nemo tenetur-beginsel tot een zwijgrecht, aangevuld met een verbod van wat wel wordt aangeduid als 'fishing expeditions'. ${ }^{200}$ De ratio van het nemo tenetur-beginsel moet dan primair in de (waarborging van de) betrouwbaarheid van het bewijsmateriaal worden gevonden. ${ }^{20 !}$ Een bezwaar van deze lezing is dat niet in zijn algemeenheid kan worden aangegeven wanneer het als voldoende vaststaand moet worden beschouwd dat de betrokkene de verlangde informatie daadwerkelijk bezit. ${ }^{202}$ Nog afgezien hiervan ben ik er allerminst van overtuigd dat deze interpretatie het toenmalig standpunt van het EHRM juist weergeeft en dat het EHRM op dat moment inderdaad een dergelijk beperkte werking van het nemo tenetur-beginsel voor ogen stond. ${ }^{203}$ Discussies of speculaties daaromtrent hebben echter

198 Hieltjes (1995), pag, 300, lijkt hiervan ook uit te gaan. "Uit het Funke-arrestzou (...) kunnen worden afgeleid dat het EHRM het verbod van zelfincriminatie een werking toekent, die mede de inzageverplichtingen zou kunnen omvatten". Hij zou hiervan echter geen voorstander zijn. Volgens hem zou het nemo tenetur-beginsel aldus moeten worden uitgelegd "dat een verdachte wel verplicht kan worden passief onderzoek te dulden (en inzage te verstrekken), maar niet om daaraan actief mee te werken (inlichtingen te verstrekken)". Waarom hij het verstrekken van inzage als 'dulden' bestempelt, is mij niet duidelijk. Het is ook zeer de vraag of het EHRM een formeel onderscheid tussen het verstrekken van inzage en het verstrekken van inlichtingen, heeft willen maken temeer daar het Hof zich doorgaans niet door formele onderscheiden laat leiden.

199 Reijntjes (1996 II), pag. 18, daarin gevolgd door Otto, De Meijer en De Doelder (1999), pag. 10-11. Reijntjes' interpretatie sluit goed aan bij zijn omlijning van het nemo tenetur-beginsel: "niemand behoort te worden genoopt om bewijsmateriaal, dat tegen hemzelf gebruikt kan worden, aan het licht te brengen - tenzij de belangen van anderen dat nodig maken". Zie Rejintjes (1996 II), pag. 19. In andere zin Wöretshofer (1996), pag. 44.

200 Met name in de vorm van een ruime vordering tot inzage van allerlei bescheiden in de hoop belastend materiaal te vinden, zonder dat er concrete aanwijzingenzijn dat dit materiaal daadwerkelijk bestaat. Van een verklaring zal wel nooit gezegd kunnen worden dat zij materiaal is waarvan voldoende vaststaat dat de betrokkene het bezit. Dit is echter geheel anders met betrekking tot bloed (bijvoorbeeld voor een DNA-onderzoek), jaarrekeningen, boekhoudingen en dergelijke.

201 Hieltjes (1995), pag. 299, lijkt hiervan dan ook uit te gaan: "Bij de inzageverplichtingen bestaat (...) niet het risico dat de verdachte onder druk ten onrechte een bekentenis aflegt. Daardoor is er hoegenaamd geen sprake van een inbreuk op het beginsel van 'fair trial'". Vergelijk ook Schalken in zijn noot bij HR 22 november 1994, NJ 1995, 240, waarin hij voorts (overigens terecht) stelt: "Naarmate de methode van waarheidsvinding minder betrouwbaar is, neemt de betekenis van het nemo tenefurbeginsel toe".

202 Dit criterium zou dan ook ongetwijfeld tot de nodige discussies leiden of aan de vereiste mate van zekerheid is voldaan. Zie ook Wöretshofer (1996), pag. 44 en Knigge in zijn noot bij het Saundersarrest.

203 Kritisch dienaangaande is ook Feteris (1997). 
weinig nut meer aangezien inmiddels duidelijk is dat het huidige standpunt van het EHRM -zoals hierna nog zal worden besproken- in ieder geval deze door Reijntjes geschette lijn volgt. ${ }^{204}$

Op twee aspecten van het Funke-arrest moet hier nog worden ingegaan. Het eente betreft het moment vanaf waarvan een justitiabele de bescherming van het nemo teneturbeginsel geniet. Aangezien dit beginsel een onderdeel vormt van het 'fair-trial-principe' is het weinig verbazend dat het EHRM aansluit bij de 'criminal charge'. ${ }^{205}$ Zou men aansluiten bij de heersende visie ${ }^{206}$-namelijk dat van een vervolging pas sprake is inditn de verdachte aan een handeling van overheidszijde in redelijkheid de verwachting heff kunnen ontlenen dat een punitief optreden zijn deel zal zijn-, dan zou dat niet alleen te positie van de 'verdachte' schade berokkenen, maar bovendien de bescherming van tet beginsel afhankelijk maken van het optreden van de onderzoekende ambtenaren, die door het uitstellen van handelingen waaruit de 'verdachte' redelijkerwijs het bestaan van en vervolging tegen hem zou kunnen afleiden, deze bescherming zouden kunnen beperken. Er dient mijns inziens dan ook een andere invalshoek te worden gekozen, en wel áe welke door mij bij de bespreking van de 'dies a quo' in het kader van de redelijke termin reeds uiteen is gezet. Het in het geding zijnde (deel)recht van artikel 6 EVRM dientte bepalen wanneer de situatie van de verdachte 'substantially affected' is. Bij het neno tenetur-beginsel (evenals bij het beperktere zwijgrecht) is dat het moment waarop de verdenking rijst: iedere poging tot het afdwingen van medewerking beïnvloedt dan wezenlijk de positie van de betrokkene. ${ }^{207}$ Zodra dit het uitgangspunt is, dan is niet relevant of de justitiabele al dan niet ervan op de hoogte is dat hij als verdachte door de overheid wordt aangemerkt. ${ }^{208}$ Evenmin is de werking van het beginsel afhankelijk van de inrocping ervan door de verdachte ${ }^{209}$ : de overheid zal uit eigen beweging iedere dwanguit-

204 EHRM 3 mei 2001 (J.B.).

205 Vergelijk bijvoorbeeld ook Hieltjes (1995), pag. 302.

206 Vergelijk HR 26 oktober 1993, NJ 1994, 629 m.nt. C; Hof Amsterdam 28 april 1994, NJ 1996, 149; HR 29 oktober 1996, NJ 1997, 232 m.nt. Sch en HR 30 september 1997, NJ 1998, 104, gevolgd door onder andere Hieltjes (1995), pag. 302. Zie over deze problematiek onder meer Van Dijk ea Van Hoof (1998), pag. 443 e.v..

207 Met instemming kan Feteris (1993) worden geciteerd waar hij stelt dat het op grond van doel en strekking van het recht om afgifte van belastendmateriaal te weigeren "noodzakelijk (is) dat dit recht al eerder (i.e. voor het moment waarop er een officiele charge bestaat, HQ) ingaat, namelijk zodra de betrokkene geconfronteerd wordt met een onderzock naar een wetsovertreding waarvan hij verdacht wordt. Het zwijgrecht zou voor een belangrijk deel van zijn betekenis worden beroofd wanneer de onderzoeksautoriteiten de verdachte tot medewerking aan de bewijslevering tegen zichzelf zouden kunnen dwingen, waarna pas de 'charge' die op basis daarvan geuit wordt, het beginpunt zou zijn van een zwijgrecht van de verdachte. Op dat moment heeft dit recht geen nut meer". Hij acht deze uitkomst overigens wenselijk, maar staat desalniettemin mijns inziens ten onrechte een beperktere uitleg van het criminal charge begrip voor. Terecht koppelt Schutte (1994), pag. 623, het vervolgingsbegrip aan de reele mogelijkheid dat een boete wordt opgelegd. Deze recle mogelijkheid is niet afhankelijk van een handeling van de overheid, welke handeling bij de justitiabele bekend is. Feteris (1995) benadrukt nog eens dat volgens hem deze uitleg te ruim is.

208 Anders: Corstens in zijn noot bij HR 26 oktober 1993, NJ 1994, 629. Hij stelt dat "van een "charge" pas sprake kan zijn als de verdachte ermee bekend is geraakt dat hij verdachte is".

209 Dezeconstatering is met name van belang voor die gevallen waarin onderzoeksbevoegdhedenworden aangewend die naar de letter van de wet zowel ter controle als ter opsporing c.q. onderzoek in de zin van de Mededingingswet kunnen worden gebruikt. In dat geval is uit de enkele toepassing van de bevoegdheden voor de justitiabele niet af te leiden in welke fase zich het onderzoek bevindt: hij 
oefening achterwege dienen te laten. ${ }^{210}$ Deze visie impliceert dus -in tegenstelling tot de heersende-dat niet meer dan een verdenking vereist is om het nemo tenetur-beginsel te activeren. Maar zij brengt aan de andere kant met zich dat tijdens de controlefase niet met succes een beroep op het fair trial-beginsel (en dus op het nemo tenetur-beginsel) kan worden gedaan ${ }^{211}$, zelfs al rijst door de medewerking een verdenking. ${ }^{212}$ Dit beginsel heeft echter wel enige (indirecte) betekenis voor die fase, in die zin dat, teneinde te voorkomen dat de bescherming van het beginsel illusoir wordt ${ }^{213}$, in die fase vergaarde informatie niet in het punitieve vervolg van de procedure ${ }^{214} \mathrm{zal}$ mogen worden gebruikt. $^{215}$ Uit het hierna nog uitgebreid te bespreken Saunders-arrest ${ }^{216}$ blijkt dat het EHRM over dit laatste hetzelfde denkt.

Het tweede aspect van het Funke-arrest dat aandacht verdient, is de rol van de dwang bij het nemo tenetur-beginsel: slechts gedwongen medewerking is verboden. ${ }^{212}$ Maar

zal dientengevolgeniet kunnen nagaan of hij medewerking zonder meer (dus zonder consequenties in de vorm van sancties) zal kunnen weigeren; de hieruit voortvloeiende onzekerheid strookt niet met de gedachte achter het nemo tenetur-beginsel.

210 Is dit niet het geval, dan zal de verdachte met een beroep op het nemo tenetur-beginsel medewerking zonder vrees voor sancties mogen weigeren; werkt de verdachte desondanks mee aan het onderzoek, dan zal het aldus verkregen materiaal niet voor bewijs mogen worden gebruikt. Schutte (1994), pag. 622 , stelt dat het voor de hand ligt "dat de strafrechter bewijs dat onder enige vorm van dreiging verkregen is van de verdachte zelf, ter zijde moet leggen"

211 Swart (1993), 679 daarentegen staat op het standpunt dat een burger in ieder geval zal mogen weigeren "schriftelijke informatie te verstrekken of documenten uit te leveren als hij daardoor een verdenking op zich laadt of reeds verdachtwordt". Voor zover hij hiermee aangeeftat het criminal charge-begrip zich ook op de fase voorafgaandaan de verdenking uitstrekt, meen ik -en met mij Valkenburg (1993), pag. 206- dat deze uitleg te ver gaat. Het is ook mogelijk dat Swart van mening is dat het Europese Hof het bestaan van een criminal charge niet als voorwaarde voor toepasselijkheid van het nemo tenetur-beginselheeft gesteld. Deze visie zou mijns inziens echter evenmin in overeenstemmingzijn met de uitspraak in de Funke-zaak. Ook 't Hart sluit overigens een beroep op het nemo tenetur-beginsel in gevallen waarin er nog geen verdenking bestaat niet uit: HR 23 november 1994, NJ 1995, 239 m.nt. ' $t$ H. Voor uitzonderlijke gevallen ziet ook Wöretshofer (1996), pag. 48 en 49, ruimte voor bescherming in de fase voorafgaande aan het rijzen van een 'verdenking'.

212 In deze in ook Keulen (1995), pag. 274 en Knigge in zijn noot bij het Funke-arrest. Vergelijk de overweging van het Hof Amsterdam 28 april 1994, NJ 1996, 149, op het gebied van het fiscaal recht: het is volgens het Hof niet in strijd met onder meer artikel 6 EVRM indien afgifte van documenten wordt geelist "in het geval dat jegens degene tot wie die vordering zich richt niet sprake is van een verdenking een in verband met de belastingheffing strafbaar feit te hebben gepleegd, ook niet indien voldoen aan die vordering tot het verschaffenvan gegevenszou leiden die grondslag zouden kunnen vormen voor het ontstaan van zodanige verdenking" (cursivering van mij, HQ).

213 Want hier ligt de reden voor de ruime interpretatie van Swart (1993), pag. 677.

214 Het uitoefenen van controlebevoegdheden (waaronder het opeisen van informatie) in de fase waarin er reeds een verdenking bestaat, behoort overigens onverminderd tot de mogelijkheden. Voorwaarde is wel dat het controleonderzoek geen betrekking heeft op de inbreuk waarvan de betrokkene wordt verdacht. Terecht stelt Keulen (1995), pag. 274 "de bevoegdheid (moet) met een strafvorderlijk doel zijn aangewend; slechts de poging de verdachte te dwingen bewijs van beweerdelijk gepleegde delicten te leveren wordt gewraakt. Het controleren van de verdachte en daartoe aanwenden van controlebevoegdheden ten behoeve van het bestuur is door het EVRM-Hof niet aan banden gelegd".

215 Aldus wordt bereikt dat -in de woorden van Reijntjes (1996 II), pag. 18-19- het beginsel niet aan de nog-niet verdachte voorbij gaat.

216 EHRM 17 december 1996.

217 Schutte (1994), pag. 623 benadrukt dit ook: "Er bestaat tenslotte geen verbod om aan de eigen veroordeling mee te werken, maar alleen het recht om daartoe niet gedwongen te worden". 
de vraag is dan: wanneer is er sprake van dwang? In de Funke-zaak was wel onomstreden dat dwang aanwezig was: Funke werd veroordeeld voor het niet-medewerken én hem werd een dwangsom opgelegd. Maar wat als er sprake is van een lichtere vorm van dwang? Knigge lijkt hier niet al te ver te willen gaan: "Het is het gebruik van de veroordeling als een drukmiddel om Funke te dwingen (...) bewijs tegen zichzelf te leveren, die maakt dat het verdrag geschonden is". ${ }^{218}$ Feteris' opvatting (toegespitst op het fiscale recht) is dienaangaande aanmerkelijk ruimer: dwang is aanwezig "wanneer de belastingplichtige voldoet aan een vordering van de inspecteur op grond van artikel $47 \mathrm{AWR}$, ook al wordt daarbij door de fiscus geen dreigende taal geuit" ${ }^{219}$ Het Funke-arrest geeft over de vereiste dwang echter geen uitsluitsel. Het Murray-arrest ${ }^{220}$ werpt hierop wat meer licht.

In dit Murray-arrest stond de vraag centraal of uit het zwijgen of uit niet-medewerking voor de verdachte negatieve conclusies kunnen worden getrokken. In zoverre betrof het hoofdzakelijk een bewijstechnisch vraagstuk. Murray weigerde enige verklaring af te leggen ondanks het feit dat hij herhaaldelijk op de mogelijkheid werd geattendeerd dat dit zwijgen in zijn nadeel zou kunnen worden uitgelegd. Dit laatste nu zou kunnen worden opgevat als dwang van overheidswege om de verdachte tot verklaren te bewegen. Daarbij kwam dat de rechter bij de beoordeling van de zaak tegen Murray groot gewicht had toegekend aan diens zwijgen. Het EHRM volgde de Funke-lijn:

"Although not specifically mentioned in Article 6 of the Convention, there can be no doubt that the right to remain silent (...) and the privilege against self-inerimination are generally recognised intemational standards which lie at the heart of the notion of a fair procedure under Article 6. By providing the aceused with protection against improper compulsion by the authorities these immunities contribute to avoiding miscarriages of justice and to securing the aims of Article 6".

Het EHRM wenste (helaas, maar gelet op zijn overige jurisprudentie niet verbazend) geen algemeen oordeel te geven over de reikwijdte van de onderhavige beginselen of over de mate van (vanuit bescherming van nemo tenetur) nog toelaatbare dwang. Wel stelde het vast dat er twee extremen in het geding waren:

"On the one hand, it is self-evident that it is incompatible with the immunities under consideration to base a conviction solely or mainly on the accused's silence or on a refusal to answer questions or to give evidence himself. On the other hand, the Court deems it equally obvious that these immunities cannot and should not prevent that the accused's silence, in situations which elearly call for an explanation from him, be taken into account in assessing the persuasiveness of the evidence adduced by the prosecution "

Of het trekken van conclusies uit het zwijgen of de niet medewerking een schending van artikel 6 EVRM oplevert, moest worden beoordeeld in het licht van

"all the cireumstances of the case, having particular regard to the situations where inferences may be drawn, the weight attached to them by the national courts in their assessment of the evidence and the degree of compulsion inherent in the situation:"

218 Knigge in zijn noot bij het Funke-arrest.

219 Feteris (1993). Voor een ruime uitleg van dwang opteren ook Schutte (1994), pag. 622/623 en (nog voor de Funke-zaak) Meijer (1991), pag. 895. Anders wellicht: Wöretshofer (1996), pag. 45.

220 EHRM 8 februari 1996.

221 Cursivering van mij, HQ.

222 Deze Murray-lijn is voortgezet in EHRM 2 mei 2000 (Condron) en EHRM 6 juni 2000 (Averill). 
Zoals Knigge in zijn noot bij dit arrest terecht stelt, spelen twee vragen een rol: was er sprake van ontoelaatbare dwang nu Murray's zwijgen tegen hem kon worden gebruikt en was het in casu 'unfair' om aan het zwijgen gevolgen te verbinden? De eerste vraag. die voor het onderhavige onderwerp het belangrijkste is, werd ontkennend beantwoord. Het EHRM concludeerde dat "his insistence in maintaining silence throughout the proceedings did not amount to a criminal offence or contempt of court". Dit stond volgens het EHRM in schril contrast met de Funke-zaak, waarin er sprake was van een mate van dwang die "destroyed the very essence of the privilege against self-incrimination". De mate van dwang speelt dus een wezenlijke rol. ${ }^{23}$ Knigge concludeert dat deze overweging relevant is voor de interpretatie van het Funke-arrest: "Zij onderstreept dat in dat arrest niet méér is beslist dan dat "such a degree of compulsion" in strijd is met het verdrag. Funke en Murray markeren twee punten op de glijdende schaal van toelaatbare naar ontoelaatbare pressie. Ergens daartussen ligt het omslagpunt, maar waar precies blijft de vraag". ${ }^{24}$ Het gebruik van het zwijgen of de niet-medewerking van de verdachte als bewijs tegen hem, is als zodanig niet ontoelaatbaar. Dit geldt op grond van de overwegingen in de Murray-zaak klaarblijkelijk wel voor die situatie waarin het zwijgen c.q. de niet-coöperatie een strafbaar feit (in de autonome betekenis van het verdrag) oplevert.

De tweede vraag werd eveneens ontkennend beantwoord. Hoewel de bewijzen tegen Murray overweldigend waren, bleef hij in alle toonaarden zwijgen: de gevolgtrekking hieruit dat er -gelet op de feiten-geen redelijke andere verklaring was dan dat het feit door hem was begaan, was 'a matter of commonsense'. ${ }^{225}$ Zwijgen of niet-medewerking mag dus -ervan uitgaande dat de mate van dwang gering is ${ }^{26}$ - als aanvullend bewijs of liever nog als een aspect dat het voorhanden zijnde bewijs of de overtuiging van de rechter versterkt, worden gebruikt. ${ }^{27}$ Een ruimer gebruik zou het zwijgrecht en het nemo tenetur-beginsel volledig ondermijnen. ${ }^{28}$

223 Vergelijk ook Spronken (1996), pag. 23.

224 Knigge in zijn noot bij het Murray-arrest.

225 Een rol speelde ook dat het geen jury-rechtspraak betrof. Van een rechter mag klaarblijkelijk een meer behoedzaam gebruik van conelusies uit zwijgen worden verwacht.

$226 \mathrm{Bij}$ aanzienlijke dwang zijn het nemo tenetur-beginsel en het beginsel van fair trial als zodanig geschonden. Naar mijn mening mogen overigens evenmin vergaande conclusies worden getrokken uit het zwijgen van een 'verdachte' indien er in het geheel geen druk op hem wordt uitgeoefend.

227 In het geval waarin de justitiabele aan milde druk heeft toegegeven en verklaringen heeft afgelegd of documenten ( of ander materiaal) heeft overhandigd, bestaan er naar mijn mening geen bezwaren deze tot bewijs te bezigen: de verklaring en de overhandiging zijn te beschouwen als vrijwillig gedaan, waarbij dient te worden bedacht dat van overheidsoptredentot op zekere hoogte (tenminste subjectief bezien) steeds enige mate van dwang uitgaat.

228 Indien iemand zonder meer kan worden geconfronteerd met conclusies die zijn getrokken uit de omstandigheid dat hij gebruik heeft gemaakt van een hem toekomend recht, in casu het zwijgrecht, dan blijft van de bescherming die het zwijgrecht of meer algemeen het nemo tenetur-beginsel biedt weinig meer over: een verdachte mag te allen tijde zwijgen indien hij dit wenst, maar dit zwijgen kan wel tegen hem worden gebruikt. De keuze tussen zwijgen en coöpereren ligt dan weliswaar ten volle bij de verdachte, maar zij is voor hem wel een keuze tussen lood en oud ijzer. 
Het Murray-arrest toont in ieder geval aan dat het nemo tenetur-beginsel geen absolute werking heeft. ${ }^{229}$ Uit het Saunders-arrest ${ }^{230}$ blijkt dat dit beginsel zoals het uit artikel 6 EVRM voortvloeit aanmerkelijk beperkter is dan sommigen (waaronder schrijver dezes) wel uit het Funke-arrest hebben willen afleiden. Waar het EHRM aansluit bij zijn eerdere overwegingen in zijn Funke- en Murray-arresten lijkt er nog hoop:

"The Court recalls that, although not specifically mentioned in Article 6 of the Convention, the right to silence and the right not to incriminate oneself, are generally recognised international standards which lie at the heart of the notion of a fair procedure under Article 6. Their rationale lies, inter alia, in the protection of the accused against improper compulsion by the authorities thereby contributing to the avoida? ce of miscarriages of justice and to the fulfilment of the aims of Article $6(\ldots)$. The right not to incriminate oneself, in particular, presupposes that the prosecution in a criminal case seek to prove their case against the accused without resort to evidence obtained through methods of coercion or oppression in defiance of the will of the accused. In this sense the right is closely linked to the presumption of innocence contained in Article $6 \$ 2$ of the Convention".

\title{
Deze hoop wordt echter de grond ingeslagen met de overweging dat
}

\begin{abstract}
The right not to incriminate oneself is primarily concerned, however, with respecting the will of an accused person to remain silent. As commonly understood in the legal systems of the Contracting Partics to the Convention and elsewhere, it does not extend to the use in criminal proceedings of material which may be obtained from the accused through the use of compulsory powers but which has an existence independent of the will of the suspect such as, inter alia, documents acquired pursuant to a warrant, breath, blood and urine samples and bodily tissue for the purpose of DNA testing". 2 .
\end{abstract}

Het Saunders-arrest maakt een einde aan veel onduidelijkheden omtrent het nemo teneturbeginsel van artikel 6 lid 1 EVRM, maar tegelijk ook aan een belangrijk deel van zijn (potentiële) bescherming. Het EHRM stelt uitdrukkelijk dat het nemo tenetur-beginsel zoals verankerd in artikel 6 lid 1 EVRM, zich niet uitstrekt over materiaal dat onafhankelijk van de wil van de verdachte bestaat. Daarmee wordt de bescherming de facto beperkt tot het zwijgrecht: slechts (mondelinge of schriftelijke) verklaringen zijn mijns inziens afhankelijk van de wil van de justitiabele. ${ }^{232}$ De reden voor deze beperking ligt in de (primaire) ratio die het EHRM aan het nemo tenetur-beginsel toekent: het voorkomen van 'miscarriages of justice'. De 'fairness' van de 'trial' is dus volgens het EHRM op dit punt niet in het geding indien de dwang niet leidt tot een verhoogde kans op rechterlijke dwalingen. Het EHRM legt hier mijns inziens een directe relatie tussen het nemo teneturbeginsel en de betrouwbaarheid van bewijsmateriaal ${ }^{233}$ : het nemo tenetur-beginsel is

229 Althans voor die situatie waarin er nauwelijks sprake is van dwang en er uit de niet-medewerking conclusies worden getrokken. Dit impliceert nog niet dat het beginsel niet absoluut is, in het geval er well sprake is van aanzienlijke dwang.

230 EHRM 17 december 1996.

231 Herhaald in EHRM 15 juni 1999 (Tirado Ortiz en Lozano Martin) alsmede EHRM 21 december 2000 (Quinn).

232 Tot cen vergelijkbare conclusie komen eveneens Knigge in zijn noot bij het Saunders-arrest, Van Russen Groen (1998), pag. 265 en Hartmann (2000), pag. 45.

233 In dezelfde zin Schalken in zijn noot bij HR 29 oktober 1996, NJ 1997, 232 en Van Russen Groen (1998), pag. 265, die stelt: "De Schutznorm waarop het nemo tenetur-beginsel ziet is de waarheidsvinding: het mag niet zo zijn dat iemand wordt veroordeeld op grond van informatie die mogelijkerwijs onbetrouwbaar is". Knigge in zijn noot onder bet Saunders-arrest daarentegen ziet onverkort de vrijheid om de eigen procesopstelling te bepalen als rechtsgrond van het nemo tenetur-beginsel. 
slechts dan geschonden, indien de dwang tot medewerking de betrouwbaarheid van het bewijs kan beïnvloeden. In dat geval is er een verhoogde kans op een onjuiste uitkomst van de 'strafrechtelijke' procedure. Dat de betrouwbaarheid van een verklaring in het geding is indien deze onder dwang is afgelegd, moge duidelijk zijn. Niet minder duidelijk is dat dit niet het geval is ten aanzien van materiaal dat reeds bestaat en waarvan dientengevolge de inhoud reeds vastligt. Voor de betrouwbaarheid van bijvoorbeeld voorwerpen, bankafschriften, jaarrekeningen of contracten doet het niet ter zake of deze door vrijwillige medewerking van de betrokkene, dankzij op hem uitgeoefende druk dan wel door eigenhandig optreden van de autoriteiten (bijvoorbeeld in het kader van een doorzoeking) zijn verkregen. Hierdoor wordt nogmaals onderstreept dat de bescherming van het nemo tenetur-beginsel niet verder strekt dan een recht om te zwijgen. ${ }^{24}$

Is daarmee ten aanzien van documenten de kous af? De stelligheid waarmee het EHRM -en nog wel de grote kamer's'- materiaal dat onafhankelijk van de wil bestaat (waaronder documenten ${ }^{236}$ ), uitsluit van bescherming door het nemo tenetur-beginsel $\left.\right|^{237}$ alsmede het feit dat het in de Saunders-zaak uitsluitend om verklaringen ging en het EHRM zich dus in het geheel niet had hoeven uit te laten over andere medewerkingsplichten dan de plicht tot spreken, wekken de indruk dat dit inderdaad het geval is en dat het EHRM kennelijk de behoefte voelde om terug te komen op het klaarblijkelijk te ruim uitgevallen Funke-arrest. ${ }^{238}$ Toch blijkt uit een recent arrest van het EHRM dat deze indruk niet geheel juist is. ${ }^{239}$ In de zaak die aan dit arrest ten grondslag lag, rustte op de (van belastingontduiking verdachte) verzoeker de verplichting om aan de bevoegde (Zwitserse) autoriteit alle documenten te overhandigen die betrekking hadden op de ondernemingen waarin hij had geïnvesteerd. Toen de verdachte dit weigerde, werd hij gesommeerd om zijn inkomstenbron aan te geven. Toen hij ook daaraan niet wenste te voldoen, werden hem enkele boetes opgelegd. Het EHRM concludeerde:

"Thus, it appears that the authorities were attempting to compel the applicant to submit documents which would have provided information as to his income in view of the assessment of his taxes."

234 Uit EHRM 20 oktober 1997 (Serves), blijkt dat dit zwijgrecht ruim, maar niet absoluut is. "It is understandable that the applicant should fear that some of the evidence he might have been called upon to give before the investigating judge would have been self-incriminating. It would thus have been admissible for him to have refused to answer any questions from the judge that were likely to steer him in that direction". In zoverre heeft het zwijgrecht slechts betrekking op mogelijk belastende verklaringen. Dat laat onverlet dat -aldus volgt uit Saunders- de verkregen informatic niet op een incriminerende wijze als bewijs mag worden gebruikt. Zie hierover Myjer (1997 I), pag. 314 en Feteris (1997).

235 Dit in tegenstelling tot de Funke-zaak.

236 Aan het feit dat het EHRM als voorbeeld slechts noemt documenten 'acquired pursuant to a warrant' mag mijns inziens geen overwegende betekenis worden toegekend. Artikel 6 EVRM geldt evenmin ten aanzien van documenten die anderszins onder dwang zijn verksegen. In deze zin ook Feteris (1997).

237 Zie hierover ook Myjer (1997 I), pag. 312.

238 Tot dezelfde conclusie komen ook Valkenburg (1997), pag. $578 \mathrm{en}$-zj het voorzichtig- Feteris (1997). Ook Martens, in zijn dissenting opinion bij het Saunders-arrest, acht dit een mogelijkheid, waarbij hij stelt dat het EHRM wellichtmeer heeft willen aansluiten bij het beperkterenemo tenetur-beginsel, zoals erkend door het Hof in de Orkern-zaak. Op deze zaak zal hierna nog uitgebreid worden ingegaan.

239 EHRM 3 mei 2001 (J.B.). 


\title{
Het EHRM vervolgt dat de nationale rechter
}

\begin{abstract}
"referred to various obligations in criminal law obliging a person to act in a particular way in order to be able to obtain his conviction, for instance by means of a tachograph installed in lorries, or by being obliged to submit to a blood or a urine test. In the Court's opinion, however, the present case differs from such material which, as the Court found in the Saunders case, had an existence independent of the person concerned and was not, therefore, obtained by means of coercion and in defiance of the will of that person". ${ }^{300}$
\end{abstract}

De opgeěiste documenten werden aldus aangemerkt als van de wil afhankelijk materiaal, met als logische consequentie dat het nemo tenetur-beginsel op deze documenten wél van toepassing was. De vraag is dan natuurlijk waarom het EHRM aldus oordeelde. De mijns inziens enige redelijke verklaring hiervoor is gelegen in de omstandigheden van het geval en dan met name in de wel zeer ruime verplichting zoals die op de verdachte rustte. Klaarblijkelijk omdat zij onvoldoende bewijs had voor het bestaan van andere inkomstenbronnen (en uiteindelijk dus voor de belastingontduiking), droeg de bevoegde autoriteit de verdachte op om dit bewijs dan maar zelf te leveren, zonder de gewenste informatie ook maar bij benadering te specificeren. ${ }^{241}$ Dit had de facto veel weg van een 'fishing expedition' (hetgeen ook de door de verdachte in kwestie werd aangevoerd, maar -vanzelfsprekend- door de Zwitserse overheid werd ontkend). De raakpunten met de Funke-zaak zijn onmiskenbaar. Daar immers werd van de verdachte gevergd dat hij bescheiden zou verstrekken waarvan het bestaan voor de autoriteiten niet zeker was. ${ }^{36}$ Een en ander leidt tot de conclusie dat geldt wat Reijntjes reeds eerder betoogde: dwanguitoefening is toegestaan, mits maar voldoende vaststaat dat het verlangde materiaal in het bezit van de betrokkene is ${ }^{243}$ Het nemo tenetur-beginsel wordt geschonden indien de gedwongen afgifte van bescheiden neerkomt op de erkenning van het bestaan hiervan. Consequentie is dat het nemo tenetur-beginsel weliswaar primair ziet op de waarborging van het zwijgrecht, maar dat het zich, in gevallen waarin de handhavende autoriteiten over onvoldoende aanwijzingen beschikken dat een persoon 'charged with a criminal offence' in het bezit is van bepaalde bescheiden, tevens over documenten uitstrekt.

De teleurstellende conclusie is dat de bescherming van het nemo tenetur-beginsel niet veel verder rijkt dan een zwijgrecht. Maar de jurisprudentie van het EHRM aangaande

240 Cursivering van mij, HQ.

241 Behoudens dan de 'beperking' dat de informatie de ondernemingen moest betreffen waarin hij had geĭnvesteerd.

242 Schalken stelt in zijn noot bij HR 29 oktober 1996, NJ 1997, 232: "Het is inhumaan om iemand, laat staan een verdachte die een veroordeling boven het hoofd hangt, te verplichten tot iets waarvan niet zeker is dat hij daartoe in staat is".

243 Reijntjes (1996 II), pag. 18. Voor een vergelijkbaar standpunt zie Stessens (1997), pag. HRC/56. Het JB.-arrest lijkt erop te duiden dat het EHRM, ook in zijn Saunders-arrest, nooit van zijn Funke-lin is afgeweken. Naar aanleiding van het Saunders-arrest werd dit reeds betoogd door Schalken in zijn noot bij HR 29 oktober 1996, NJ 1997, 232, Knigge in zijn noot bij het Saunders-arrest, Koopman (1997) en Lenos (1997), pag. 796. Helemaal zeker is dat echter niet. Het is mijns inziens zeer wel mogehijk dat het EHRM in zijn Funke-arrest is uitgegaan van een ruimere invulling, maar dat het hierop, mede naar aanleiding van de kritiek die hierop is geuit, is teruggekomen in zijn Saunders-arrost Met het J.B.-arrest heeft het EHRM de cirkel rond gemaakt door te oordelen dat documenten weliswast onder de bescherming kunnen vallen, maar dat dit slechts in zeer uitzonderlijke omstandigheden het geval is. 
het zwijgrecht biedt ook een lichtpunt. Het volgende was namelijk het geval. Saunders had onder de wettelijke dreiging van een boete en een gevangenisstraf verklaringen afgelegd op cen moment dat er -aldus expliciet het EHRM- nog geen criminal charge was uitgebracht. De aldus verkregen informatie werd in een latere strafzaak tegen Saunders gebruikt 'in a manner which sought to incriminate the applicant'. En tegen dit gebruik was de klacht van Saunders gericht. Het EHRM achtte inderdaad het nemo tenetur-beginsel geschonden: het oordeelde dat het zwijgrecht weliswaar voorafgaand aan de criminal charge nog niet met succes kon worden ingeroepen ${ }^{244}$, maar dat het gebruik van onder dwang verkregen informatie als bewijs in een latere 'strafrechtelijke' procedure wel in strijd met artikel 6 EVRM was. ${ }^{245}$ De conclusie moet dan ook de volgende zijn. Het moment van de criminal charge blijtt van belang voor een justitiabele: zodra hij 'charged' is, heeft hij het recht om te zwijgen (in beginsel niet om in het algemeen niet te hoeven mee te werken); voorafgaand aan dat moment komt hem dit recht niet toe en kan hij dus rechtens verplicht worden om informatie te verschaffen, zelfs al incrimineert hij zichzelf hierdoor of levert hij informatie die in principe de door hem gepleegde inbreuk antoont. Die informatie mag echter niet in een latere punitieve procedure als bewijs tegen hem worden gebruikt. ${ }^{246}$ Dit doet recht aan de achtergrond van het nemo teneturbeginsel, zoals het EHRM deze ziet: voor de betrouwbaarheid van de verklaringen en met het oog op het voorkomen van rechterlijke dwalingen is het niet relevant in welke fase van de procedure de druk op de justitiabele is uitgeoefend. Afgezien van de belangrijke en af te wijzen beperking van de reikwijdte van het nemo tenetur-beginsel tot primair het zwijgrecht, heeft het EHRM hiermee een adequate bescherming voor justitiabelen gerealiseerd, zonder de controle op de naleving van wetgeving wezenlijk te beperken. Tegelijk heeft het EHRM het belang van het beginpunt van de 'criminal charge' voor de bescherming die artikel 6 EVRM biedt, enigszins gerelativeerd. ${ }^{247}$

Er resten nog twee punten van aandacht. Het eerste betreft het probleem van de dwang. In het Funke-arrest werd artikel 6 EVRM mede geschonden geacht omdat Funke was veroordeeld wegens het niet-overhandigen van bankafschriften én hem een dwangsom werd opgelegd; in de Murray-zaak werd de dwang (in de vorm van de mededeling dat zwijgen tegen de betrokkene zou worden gebruikt) onvoldoende geacht. Uit het Saundersarrest blijkt dat de wettelijke dreiging van een boete of gevangenisstraf wél volstaat. ${ }^{248}$

244 Het Europese Hof heeft hier onmiskenbaar oog voor de noodzaak van een adequate uitvoering van wetgeving, aangezien het stelt dat "a requirement that such a preparatory investigation should be subject to the guarantees of a judicial procedure as set forth in Article $6 \S$ I would in practice unduly hamper the effectiveregulation in the public interest of complex financialand commercialactivities".

245 Tot hetzelfde oordeel kwam het Straatsburgse Hof in EHRM 19 september 2000 (I.J.L., G.M.R. en A.K.P.). De verzoekers in deze zaak waren overigens medeverdachten van Saunders in de nationale procedure. Naar aanleiding van het Saunders-rapport van de ECRM kwam De Witt Wijnen (1997), pag. 113 ook reeds tot deze conclusic.

246 Dat geldt voor iedere strafzaak, aangezienhet Europese Hof overwoog "that the general requirements of fairness contained in Article 6, including the right not to incriminate oneself, apply to criminal proceedings in respect of all types of criminal offences without distinction from the most simple to the most complex. The public interest cannot be invoked to justify the use of answers compulsorily obtained in a non-judicial investigation to incriminate the accused during the trial proceedings".

247 In vergelijkbare zin Valkenburg (1997), pag. 578.

248 Vergelijk hierover ook Feteris (1997) en Lenos (1997), pag. 796. De sanctie dient wel uitdrukkelijk bedoeld te zijn om de justitiabele tot verklaren te dwingen. In EHRM 20 oktobet 1997 (Serves) weigerde een verdachte, die 'charged' was, de eed af te leggen en te verklaren. Hij werd hiervoor 
Daarmee staat vast dat bijvoorbeeld de artikelen $68 \mathrm{AWR}^{249}, 184 \mathrm{WvSr}, 69 \mathrm{Mw}$ en 15 Vo 17 een mate van dwang inhouden die in strijd kan komen met artikel 6 EVRM. In die gevallen geldt er dus steeds een zwijgrecht voor degene die 'charged' is. Het verdient in dat licht aanbeveling om het zwijgrecht ook uitdrukkelijk in die regelingen op te nemen, waarin een op deze of vergelijkbare wijze af te dwingen medewerkingsplicht wordt gecreëerd.

Een tweede punt van aandacht is of het gebruik van onder dwang verkregen verklaringen steeds in strijd is met artikel 6 EVRM. De Saunders-zaak geeft hierover niet met zoveel woorden uitsluitsel, hetgeen ook moge blijken uit de verschillende conclusies in de literatuur op dit punt. ${ }^{250}$ Toch kan mijns inziens uit de ratio van het nemo teneturbeginsel zoals die door het EHRM is geformuleerd, worden afgeleid dat het zwijgrecht van artikel 6 lid I EVRM een dergelijke absolute werking niet toekomt. Indien het belang van het zwijgrecht ligt in de voorkoming van rechterlijke dwalingen, waarom zou dan het fair trial-beginsel geschonden zijn als de verklaringen weliswaar onder dwang zijn verkregen, maar aan hun betrouwbaarheid desalniettemin niet behoeft te worden getwijfeld, bijvoorbeeld omdat zij door ander bewijsmateriaal volledig worden gesteund? Indien de procedure als geheel 'fair' is, dan zal het niet-inachtnemen van het zwijgrecht en het gebruik van afgedwongen verklaringen als bewijs, waarschijnlijk geen consequenties hebben. Een aanwijzing hiervoor kan gevonden worden in het rapport van de ECRM in de Abas-zaak. ${ }^{251}$ In deze zaak, die betrekking had op een fiscaal inlichtingenverzoek op grond van artikel 47 AWR, stond de ECRM evenals het EHRM in de Saunders-zaak voor de vraag of het gebruik van verklaringen, afgelegd voorafgaand aan een criminal charge, een schending van artikel 6 EVRM opleverde. ${ }^{252}$ In haar overwegingen betrok de ECRM

"that the answers (...) merely confirmed information already previously submitted voluntarily on the applicant's behalf to the tax authorities in connection with his requests for an exoneration of wage tax" 29

beboet, maar dit leverde geen schending van artikel 6 EVRM op. "Whilst a witness's obligation to take the oath and the penalties imposed for failure to do so involve a degree of coercion, the latter is designed to ensure that any statements made to the judge are truthful, not to force witnesses to give evidence. In other words, the fines imposed (...) did not constitue a measure such as to compel him to incriminate himself as they were imposed before such a risk ever arose". Serves had dus eerst de eed moeten afleggen en vervolgens had hij mogen zwijgen. Voor veel begrip voor de precaire situatie waarin Serves zich bevond, getuigt dit arrest mijns inziens niet.

249 Dit volgt ook uit de nog te bespreken Abas-zank.

250 Feteris (1997) concludeert dat artikel 6 EVRM "zich verzet tegen elk voor de verdachte ongunstig gebruik van informatie die hij onder dwang verstrekt heeft". Anders: Schalken en Rozemond (1997), pag. 808/809, Valkenburg (1997), pag. 579, Koopman (1997) en Jansen (1999), pag. 143.

251 ECRM 26 februari 1997.

252 Deze vraag had althans de ECRM zichzelf gesteld; de klacht was beperkter. Vreemd genoeg beantwoordt de ECRM overigens naar mijn mening deze vraag niet. Zij behandelt slechts de vraag of er -toen de klager verplicht was zijn medewerking te verlenen- sprake was van een criminal charge en constateert, na een ontkennend antwoord hierop te hebben gegeven, dat artikel 6 EVRM dus niet van toepassing was.

253 De ECRM noemde deze omstandigheid in het kader van de beantwoording van de vraag of er sptake was van een criminal charge. Welkerol deze omstandigheid hierin speelt, is mij niet duidelijk. Waarschijnlijk moet bedoelde omstandigheid dan ook los van de vraag naar het al dan niet bestaan van een charge worden gezien. 
In die situatie, waarin de gevraagde informatie reeds eerder vrijwillig is verstrekt, behoeft niet aan de betrouwbaarheid van de inhoud van de afgedwongen verklaringen te worden getwijfeld. $^{254}$

\subsection{Het nemo tenetur-beginsel en communautair recht}

Zoals in hoofdstuk 2 uitgebreid aan de orde kwam, biedt Verordening 17 verschillende voorbeelden van op ondernemingen rustende verplichtingen tot medewerking: zowel in het kader van de bevoegdhedenuitoefening ex artikel 11 Vo 17 als ook in verband met het verrichten van verificaties op grond van artikel 14 Vo 17 wordt van de betrokken ondernemingen een actieve houding verlangd. De plicht tot medewerking kan op grond van artikel 15 Vo 17 worden afgedwongen door dreiging met en oplegging van sancties, in de vorm van hetzij boetes na gebleken niet-coöperatie, hetzij dwangsommen voor de periode gedurende welke de onderneming in verzuim blijft medewerking te verlenen. ${ }^{25 s}$ Bescherming tegen zelf-incriminatie kent de verordening niet. Mede om deze reden en tegen de achtergrond van een effectieve handhaving is door sommige schrijvers de vraag omtrent de gelding van het nemo tenetur-beginsel voor het communautaire recht ontkennend beantwoord ${ }^{256}$; anderen daarentegen opteerden wel voor een bescherming tegen zelfbeschuldiging. ${ }^{257}$ Omdat lange tijd geen verweer dienaangaande werd gevoerd, moesten de Commissie, het Gerecht en het Hof zich in stilzwijgen hullen. Hierin kon pas verandering komen toen aan het Hof de Orkem-zaak werd voorgelegd. ${ }^{258}$

In de zaak die de aanleiding vormde tot dit arrest had de Commissie aan CdF Chimic, het latere Orkem, op grond van artikel 11 Vo 17 een reeks vragen gesteld in het kader van een onderzoek naar kartelafspraken in de polyethyleensector. Beantwoording van deze vragen, die volgden op een verificatie en op een inlichtingenverzoek (en daar op volgende beschikking), leidden er volgens de betrokken onderneming toe dat zij zich zelf zou beschuldigen hetgeen zij in strijd achtte met het algemeen rechtsbeginsel 'nemo tenetur'. De onderneming beriep zich hierbij enerzijds op het IVBPR (artikel 14 lid 3 sub g) en op het EVRM (artikel 6 lid 3) en anderzijds op de afzonderlijke (wettelijke)

254 Zie voor enkele arresten waarin de Hoge Raad de door het EHRM uitgestippelde koers inzake het nemo tenetur-beginsel volgt: HR 26 oktober 1993, NJ 1994, 629 m.nt. C; HR 23 november 1994. BNB 1995/25 m.nt. Wattel en NJ 1995, 239 m.nt. 't H en HR 21 oktober 1997, NJ 1998, 173.

255 Daar komt nog bij dat een niet-coōperatieve houding van een onderneming in het onderzoek een strafverhogende factor is. Zie hierover hoofdstuk 4.

256 Zie bijvoorbeeld Joshua (1982), pag. 179: "Any protection which might result from the application of general principles of law could (...) only apply to the risk of exposure to sanctions other than those provided in the Regulation" en Joshua (1994 II), pag. 34: "It is (...) perfectly normal that in the Commission's system of investigation there should be no specific right to refuse information on the grounds of self-incrimination". Biesheuvel (1988), pag. 693, was van mening "dat een zwijgrecht in mededingingszaken niet zou moeten worden erkend", waarbij hij met 'zwijgrecht' mede doelde op het nemo tenetur-beginsel.

257 Zie onder meer Kamburoglou en Pirrwitz (1990), pag. 268. In hun visie mag de plicht voor een onderneming om aan een verificatie mee te werken niet "zu einer Umkehr der Beweisfuhrungslast fuhren und gewissermaßen auf Umwegen eine Selbstbezichtigungspflicht der Unternehmen mit sich bringen".

$258 \mathrm{HvJ}$ (374/87) Jur 1989, 3283 (Orkem); ook gepubliceerd in NJ 1991, 687. Zie hierover onder meer Mulder (1990), pag. 408-411 en Winter (2000), pag. 114 e.v.. 
regelingen van de lidstaten op dit punt. De Commissie verwierp het standpunt van de onderneming en achtte het bedoelde beginsel voor het communautaire recht niet toepasselijk op grond van de overweging dat de communautaire kartelprocedure een administratief (in tegenstelling tot een strafrechtelijk) karakter heeft en gericht is tegen een rechtspersoon (dus niet tegen een natuurlijk persoon). De Commissie dichtte het nemo tenetur-beginsel aldus een beperkte reikwijdte toe, waarbinnen in haar visie het communautaire kartelrecht niet viel.

Ook de conclusie van advocaat-generaal Darmon viel niet in het voordeel van de onderneming uit. Weliswaar werd door hem erkend dat in de lidstaten een beginsel dat strekt tot bescherming tegen zelf-incriminatie wordt aanvaard, maar hij concludeerde dat slechts een communis opinio op dit punt bestond ten aanzien van (typisch) strafrechtelijke procedures. ${ }^{259}$ Met betrekking tot de reikwijdte van de bescherming van de leden 2 en 3 van artikel 6 van het EVRM was Darmon eveneens terughoudend. Niet alleen trok hij in twijfel of het nemo tenetur-beginsel deel uitmaakte van artikel 6 EVRM (bedacht moet worden dat het Orkem-arrest van eerdere datum was dan de Funke-uitspraak), maar bovendien stond voor hem niet vast dat de communautaire mededingingsprocedure -ook al zou het EVRM de bescherming tegen zelf-incriminatie kennen- zonder meer onder het begrip vervolging (of criminal charge) zou vallen. De vervolging in het communautaire kartelrecht zou, aldus de advocaat-generaal, pas een aanvang nemen op het moment waarop aan de onderneming de punten van bezwaar worden meegedeeld; de fase die voorafgaat aan deze mededeling en waarin de onderzoeksactiviteiten hoofdzakelijk plaatshebben, zou dan niet door het EVRM bestreken worden, als gevolg waarvan het nemo tenetur-beginsel buiten spel zou kunnen blijven.

Het eindoordeel van het Hof pakte voor de onderneming gunstiger uit. Alvorens inhoudelijk op de grieven van Orkem in te gaan, stelde het Hof in navolging van hetgeen het in het National Panasonic-arrest ${ }^{260}$ had bepaald, vast dat de kartelprocedure uit twee van elkaar te onderscheiden onderdelen bestaat, te weten ten eerste de fase van het vooronderzoek en ten tweede de fase van de contradictoire procedure die begint zodra de punten van bezwaar bekend zijn gemaakt. Deze laatstbedoelde procedure op tegenspraak wordt gekenmerkt door tal van belangrijke procedurele rechten voor de onderneming die 'verdacht' wordt van overtreding van de materiële kartelbepalingen. In het vooronderzoek daarentegen ligt de nadruk op de controle op de naleving van het kartelrecht en de opsporing van overtredingen op dit recht. Met het grote belang dat binnen de gemeenschap toekomt aan een correcte naleving van de artikelen 81 e.v. EG corresponderen de ruime onderzoeksbevoegdheden van de Commissie en de medewerkingsplicht van ondernemingen. In deze fase is er volgens het Hof in mindere mate ruimte voor waarborging van de rechten van de onderneming dan in de contradictoire fase, hetgeen mede verklaart dat het nemo tenetur-beginsel niet expliciet in Verordening 17 is opgenomen.

Dit betekende echter nog niet het 'exit' van het nemo tenetur-beginsel voor het communautaire recht, aangezien het nog een exponent kon zijn van de algemene beginselen van gemeenschapsrecht. Dit werd echter door het Hof evenmin erkend. De rechtsvergelijking tussen de rechtsstelsels van de verschillende lidstaten leverde (zoals reeds door Darmon was geconcludeerd) slechts overeenstemming op ten aanzien van de hantering

259 En zelfs bij deze conelusie kunnen vraagtekens worden gezet, alleen al indien men in Nederland de (toenmalige) visie van de Hoge Raad, zoals hiervoor uiteengezet, beziet.

$260 \mathrm{HvJ}$ (13679) Jur. 1980, 2033 (National Panasonic). 
van het beginsel in het kader van een strafvervolging, ingeleid tegen een natuurlijke persoon. ${ }^{261}$ Ook artikel 6 EVRM bood volgens het Hof (nog) geen soelaas: "noch uit de tekst ervan noch uit de rechtspraak van het Europese Hof voor de rechten van de mens valt af te leiden, dat die bepaling het recht erkent om niet tegen zichzelf te getuigen". 20 De voorzichtigheid van het Hof ten aanzien van de interpretatie van het EVRM is opmerkelijk maar verbaast desalniettemin niet. ${ }^{20}$ Inderdaad had het EHRM op het moment van het Orkem-arrest nog geen oordeel hoeven te geven over het nemo tenetur-beginsel in relatie tot artikel 6 EVRM, het beginsel van fair trial. Het Hof wenste zich klaarblijkelijk niet in het vaarwater van de ECRM en het EHRM te begeven door te anticiperen op besluiten van deze instanties op dit gebied. Bovendien heeft het Hof door zijn voorzichtige formulering zichzelf en de Commissie de ruimte geboden om het beleid ten aanzien van het communautaire recht bij te stellen, zodra er wel duidelijkheid van Straatsburgse zijde zou komen. ${ }^{264}$

Noch het geschreven communautaire kartelrecht noch de algemene beginselen van gemeenschapsrecht leidden dus tot een erkenning van het verbod op gedwongen zelfincriminatie in de communautaire procedure. Toch bewerkstelligde het Hof -zij het via een omweg- enige bescherming voor ondernemingen in de fase van het vooronderzock. Het Hof overwoog dat in sommige gevallen de ruime rechtsbescherming tijdens de contradictoire fase pas dan bewerkstelligd en gegarandeerd kan worden indien de rechtsbescherming ook reeds in de fase van het vooronderzoek wordt gehonoreerd. ${ }^{265}$ Zoals reeds eerder aangevoerd, is een op ondernemingen rustende verplichting om in de voorprocedure mee te werken aan de bewijsvergaring moeilijk verenigbaar met de uit het principe van hoor en wederhoor voortvloeiende rechten, waaronder het aanvoeren van tegenbewijs tegen hetgeen de ondernemingen in de punten van bezwaar wordt ten laste gelegd. Al het relevante materiaal, waarop de aanklacht is gebaseerd, is dan immers reeds door de onderneming in de voorfase verstrekt, als gevolg waarvan tegenbewijs nauwelijks nog valt te

261 Van Strien (1996 II), pag.9, concludeertuit de overwegingen van het Hof dat het het nemo teneturbeginsel uitsluitend van toepassing achtte op natuurlijke personen. Deze conclusie is mijns inziens niet juist. Het Hof heeft geen oordeel gegevenover het beginsel als zodanig, maar heeft slechts bezien welke de gemeenschappelijke deler is met betrekking tot het nemo tenetur-beginsel in de verschillende rechtsorden van de lidstaten. Het feit dat deze deler beperkt is tot de categorie van natuurijke personen houdt niet in dat het Hof principieel de toepasselijkheid van het beginsel ten aanzien van rechtspersonen heeft verworpen.

262 Orkem, 3350.

263 Reijntjes (1996 II), pag. 20, stelt dat het Hof "kennelijk terugschrok voor rechtstreekse toepassing van dit (het EVRM, HQ) verdrag". Dit ligt in de lijn van de overige jurisprudentie van het Hof dat het EG-Verdrag en de daarop gebaseerdeverordeningenniet rechtstreeks aan het EVRM toetst, maar aandit laatstewel een belangrijke plaats inruimt binnen de beginselenvan gemeenschapsrecht. Overigens viel er voor het Hof op dat moment weinig toe te passen gezien het feit dat er geen duidelijkheid bestond over het antwoord op de vraag of in artikel 6 EVRM mede het nemotenetur-beginselbesloten lag. In zijn Hoechst-arrestheeft het Hof, zoals nog zal blijken, zijn voorzichtigestellingen ten aanzien van interpretatie van het EVRM verlaten en werd niet veel later door het EHRM getrakteerd op een subtiele maar daarom waarschijnlijk niet minder gevoelige tik op de vingers.

264 Ten aanzien van artikel 14 IVBPR was het Hof stelliger; dit artikel "ziet alleen op personen die in het kader van een strafvervolging worden beschuldigd van een strafbaar feit, en geldt dus niet voor onderzoeken op het gebied van het mededingingsrecht".

265 Deze aanpak vertoont duidelijke parallellen met die van het EHRM, waarbij met name de overeenkomst met -het overigens van latere datum zijnde- EHRM 24 november 1993 (Imbrioscia) in het oog springt. 
leveren. ${ }^{266}$ Ter bescherming van de rechten in de contradictoire fase kwam het Hof tot een middenweg (zij het geen gulden) in het spanningsgebied tussen rechtsbeschering en rechtshandhaving ${ }^{267}$ :

\begin{abstract}
"Ook al kan de Commissie dus ter waarborging van de nuttige werking van artikel 11 (...) de ondern ning verplichten om alle noodzakelijke inlichtingen te verstrekken over feiten waarvan zij eventuecl frnis heeft, en om zo nodig de desbetreffende in haar bezit zijnde documenten over te leggen, ook weneer deze tegen haarzelf of tegen een andere onderneming bewijs kunnen opleveren van een gedragis die in strijd is met de mededingingsregels, toch mag zij, wanneer zij bij beschikking de mededelin van inlichtingen verlangt, geen afbreuk doen aan de rechten van de verdediging van de ondernemir-: $Z_{0}$ kan de Commissie de onderneming niet verplichten antwoorden te geven, waardoor zij het bestaj van de inbreuk zou moeten erkennen, die de Commissic heeft te bewijzen", 2 a
\end{abstract}

Hoewel het Hof dit niet met zoveel woorden zegt, is met deze overwegingen een con ${ }^{\mathrm{nu}-}$ nautaire variant van het nemo tenetur-beginsel aanvaard ${ }^{269}$, zij het dat deze cen slethts beperkte reikwijdte heeft. ${ }^{270}$ Het communautaire zwijgrecht is namelijk een waarorg die -aldus het Hof in zijn prejudiciële beslissing in de zaak Otto t. Postbank ${ }^{271}$ - in eientie als doel heeft "de particulier te beschermen tegen instructiemaatregelen die een cerheidsorgaan heeft gelast om de particulier gedragingen te laten bekennen die hem joot stellen aan strafrechtelijke of administratiefrechtelijke sancties". Van onderneminge,kan derhalve niet worden verlangd dat zij -expliciet dan wel impliciet ${ }^{272}$ - erkennen d zij

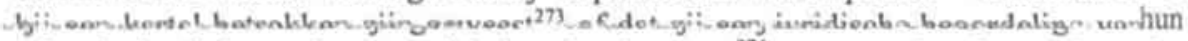
gedrag in het licht van het materiële kartelrecht geven ${ }^{274}$, maar van hen kan wel worden geěist dat zij (feitelijke) informatie over overeenkomsten, vergaderingen en dergelijke

266 Onder omstandighedenzou het aanvoerenvan nog niet bekende gegevens en informatie als antwoord op de punten van bezwaar kunnen leiden tot bestraffing van de onderneming op grond van het niet op juiste wijze voldoen aan de verzoeken respectievelijk beschikkingen van de artikelen 11 en 14 Vo 17.

267 In zoverre is de aanpak van het Hof vergelijkbaar met die van het EHRM. Dit laatste hof houdt immers eveneens rekening met de fase voorafgaand aan de 'criminal charge' omdat bescherming van rechten in deze fase illusoir zou kunnen worden indien zij in een eerdere fase zijn geschonden.

268 Aldus ook GvEA (T-305-307, 313-316, 318, 325, 328, 329 en 335/94) Jur. 1999, II-931 (Limburgse Vinyl Maatschappij e.a.). In de Orkem-zaak oordeelde het Hof enkele door de Commissie gestelde vragen in strijd met het nemo tenetur-beginsel, zoals door hem gehanteerd, en vernietigde de beschikking partieel.

269 Kamburoglou en Pirrwitz (1990), voetnoot 55, pag. 267, constateren hier het ontbreken van een communautaire 'Selbstbezichtigungspflicht'. Finaly (1996), pag. 111, concludeert dat het Hof nemo tenetur voor rechtspersonen heeft erkend, niet omdat artikel 6 EVRM in het geding zou zijn, maar omdat het (op andere gronden) een communautair grondrecht betreft.

270 Clapham (1991), pag. 58, noemt dit arrest echter" an important example of the Court offering a 'high standard ' of protection against the action of Community institutions".

$271 \mathrm{HvJ}$ (C-60/92), Jur. 1993, I-5683 alsmede NJ 1994, 256.

272 Cumming (1995), pag. 403, beperkt de reikwijdte van het communautaire nemo tenetur-beginsel zelfs tot "directly incriminating questions".

273 Te denken valt hierbij aan vragen als 'Welke rol vervulde $U$ in het kartel?', 'Heeft $U$ aan alle prijsverhogende afspraken deelgenomen?', 'Wanneer bent U uit het kartel gestapt?'.

274 Zie Lasok (1990), pag. 91. Hier kan gedacht worden aan vragen als 'Kunt $U$ inlichtingen verschaffen over gedragingen van Uw zijde die in strijd zijn met artikel 81 EG?' of 'Bent $U$ van mening dat het door $\mathrm{U}$ gevolgd prijsbeleid in strijd is met het communautaire recht en waarop baseert $\mathrm{U}$ deze mening?", Beantwoording van deze vragen zou het de onderneming onmogelijk maken om in een later stadium de juridische lezing van de feiten in twijfel te trekken. 
verstrekken, ook al kan daaruit direct door de Commissie een inbreuk worden afgeleid. ${ }^{275}$ Kerse stelt dan ook terecht: "The extent of the privilege is thus narrow and may serve to avoid oppressive behaviour on the part of the Commission. But in practice it is no inhibition on the Commission provided that leading incriminatory questions are avoided". ${ }^{276}$ Van een absoluut zwijgrecht is derhalve geen sprake -ook niet als de ondernemingen in kwestie reeds van een inbreuk op het communautaire mededingingsrecht verdacht worden- en het staat allerminst vast dat de bescherming kan worden ingeroepen ten aanzien van documenten. ${ }^{2 \pi}$ Toch sluiten de bewoordingen van het Hof dit laatste niet uit en kan deze bescherming -zij het binnen de beperkte grenzen van het Orkem-arrestwel worden toegekend. Bestaat er immers een wezenlijk onderscheid tussen de (extreme) vraag "heeft Uw onderneming zich schuldig gemaakt aan kartellering" en de (niet minder vergaande) vraag "overhandig alle documenten waaruit de deelname van de onderneming aan het kartel blijkt"? Beide vragen zullen dan ook niet (op die wijze) gesteld mogen worden. Dit laat onverlet dat het onderhavige principe, zoals door het Hof geìnterpreteerd, een kleinere rol speelt ten aanzien van dwingende verzoeken om overhandiging van schriftelijke gegevens: via deze zal immers in beginsel geen juridisch oordeel over een bepaalde handelwijze kunnen worden afgedwongen, omdat zij veelal slechts feitelijke informatie bevatten. ${ }^{278}$

De ratio van het communautaire nemo tenetur-beginsel ligt ten dele bij de waarborging van de betrouwbaarheid van het materiaal. ${ }^{279}$ Maar mijns inziens belangrijker nog is dat het Hof de presumptio innocentiae (de onderneming mag niet gedwongen worden te erkennen, wat aan de Commissie is om te bewijzen) en het recht van hoor en wederhoor wil beschermen. Beide vormen essentiële waarborgen voor een justitiabele in het kader van een bestuursstrafrechtelijke procedure, die zouden worden geschonden indien hij

275 Vergelijk ook De Moor-Van Vugt (1999), pag. 168: "Het Hof erkent aldus slechts een zwijgrecht als spreken rechtstreeks tot zelfincriminatiezou leiden". Swart (1993), pag. 677, lijkt (mijns inziens ten onrechte) een ruimer toepassingsbereik van het communautaire nemo tenetur-beginsel te zien, daar hij naar aanleiding van het Orkem-arrest stelt dat ondememingen niet door de Commissie verplicht mogen worden "documenten te produceren waaruit zou blijken dat zij inbreuk maakten op regels van gemeenschapsrecht". Reijntjes (1996 II), pag. 20, deelt deze conclusie van Swart evenmin. Jorna (1990), pag. 634, ziet een wel zeer beperkte bescherming, waar hij concludeert "dat het HJEG hier niet meer heeft willen zeggen dan (...) dat de Commissie alvorens gebruik te maken van haar onderzoeksbevoegdheden, een redelijk vermoeden dient te hebben dat bepaalde inbreuken hebben plaatsgevonden".

276 Kerse (1998), pag. 152-153. In dezelfde zin Ortiz Blanco (1996), pag. 109 en 116/117. Het behoeft overigens weinig verbeeldingskracht om te zien dat voor de toelaatbaarheidvan vragen de wijze van formulering ervan in de praktijk vaak doorslaggevend zal zijn.

277 Swart (1993), pag. 677, is van mening dat dit wel het geval is. Cumming (1995), pag. 403, daarentegen stelt dat "The privilege does not apply however to (...) documents". Waarschijnlijk acht ook Kerse (1998), pag. 152, het nemo tenetur-beginsel niet van toepassing op documenten.

$278 \mathrm{De}$ in het vorige hoofdstuk besproken praktijk om een vergaande coöperatieve houding te belonen met verlaging van de boete, levert volgens het Gerecht geen schending van het (communautaire) nemo tenetur-beginsel op, ook niet als de onderneming tijdens de procedure een verlaging van de boete in het vooruitzicht wordt gesteld als zij besluit mee te werken. Vergelijk GvEA (T-311/94) Jur. 1998, II-1129 (BPB de Eendracht) en GvEA (T-347/94) Jur. 1998, II-175I (Mayr-Melnhof Kartongesellschaft).

279 Vergelijk Lasok (1990), pag. 91: "The justification for it is the need to ensure that facts are assessed properly by the investigating authority and that evidence is not distorted or made unreliable by the manner in which it is uncovered". 
zelf het begaan van een overtreding zou moeten bekennen. Daarbij wordt het begnsel door het Hof overigens wel tot het hoogst noodzakelijke beperkt, om vooral een adeduate handhaving zo weinig mogelijk in de weg staan. ${ }^{280}$ Voor een verdergaande bescherting verwijst het Hof uitdrukkelijk naar de contradictoire fase.

Veel verschil in uitkomst met het nemo tenetur-beginsel zoals voortvloeiend uit aikel 6 lid 1 EVRM is er niet: ook het 'Orkem-beginsel' is (primair) beperkt tot een zwijgecht en dit recht is evenmin absoluut. Wel is het zo dat het EHRM eerder dan het Hof aanremt dat informatie zelf-incriminerend is ${ }^{281}$ Dit vergt een aanpassing aan communataire zijde. Aan de andere kant biedt het communautaire recht meer bescherming in die gevllen waarin er nog geen sprake is van een 'criminal charge'. ${ }^{282}$ Ook dan verbiedt het 'Oriembeginsel' vragen die (in)direct aansturen op zelfbeschuldiging. Meer in het algeneen geldt sinds de Saunders- en J.B.-arresten voor het communautaire recht het volgede. Zodra er een 'criminal charge' bestaat, komt de onderneming een recht toe om de bantwoording te weigeren van vragen die waarschijnlijk incriminerend zijn. ${ }^{283}$ Tot datmoment bestaat er slechts een zwijgrecht ten aanzien van 'leading questions'. Voor het ovrige zijn ondernemingen verplicht verklaringen af te leggen. De aldus ingewonnen infoma$\mathrm{tic}^{2 \mathrm{M}}$-voor zover incriminerend of op incriminerende wijze te gebruiken- zal ehter niet als bewijs van het begaan van een inbreuk op artikel 81 of 82 EG mogen weden gebruikt. ${ }^{28 s}$

280 Dannecker en Fischer-Fritsch (1989), pag. 48, wijzen ook op de problemen voor de handhaving indien hier een uitgebreide bescherming zou worden gerealiseerd. In dit licht moet ook de opvatting van Biesheuvel (1988), pag. 693, worden gezien, namelijk dat erkenning van het nemo tenetur-beginsel de verificatiebevoegdheid van de Commissie tot een 'wassen neus' zou maken.

281 Zie EHRM 20 oktober 1997 (Serves).

282 In dezelfde zin De Moor-Van Vugt (1999), pag. 169. Van een criminal charge is naar mijn mening in ieder geval sprake zodra de Commissie gebruik maakt van haar bevoegdheid tot verificatie, althans voorzover deze bij een van overtreding van het kartelverbod verdachte onderneming plaatsvindt. Zoals gezegd, dient mijns inziens ten aanzien van het nemo tenetur-beginsel reeds het bestaan van een verdenking als beginpunt van de 'criminal charge' te worden gezien. Hierdoor zou bij het inwinnen van inlichtingen op grond van artikel 11 Vo 17 het nemo tenetur-beginsel van artikel 6 EVRM in acht genomen moeten worden, althans voor zover artikel 11 Vo 17 niet in het kader van toezicht wordt gebruikt.

283 De Commissie behoeft overigens een ondememing niet op het zwijgrecht te wijzen; een met artikel 29 lid 2 WvSv corresponderende regeling kennen het communautaire recht en het EVRM niet.

284 Een vraag van geheel andere orde is of de Commissie conclusies mag verbinden aan een weigering om een verklaring af te leggen, in die zin dat zij hierin een extra aanwijzing ziet dat de onderneming zich schuldig heeft gemaakt aan overtreding van het materièle recht. Uit het Murray-arrest van het EHRM volgt dat de enkele weigering zo'n conclusies niet rechtvaardigt. Denkbaar is echter dat tijdens een verificatic -of bij de punten van bezwaar- de Commissie de ondememing confronteert met uitermate belastend materiaal. Zwijgen zou in dat geval, bij voldoende ander bewijs en geen of uitermate geringe mate van dwang van de kant van de Commissie, wel een dergelijke aanwijzing vormen.

285 Korte vermelding verdient het volgende: in eivieleprocedureskunnen getuigenverhorenplaatsvinden (zie artikel $214 \mathrm{Rv}$ ), zonder dat de bescherming van het nemo tenetur-beginsel geldt. De informatic die aldus wordt verkregen en die voor nationale en/of communautaire kartelautoriteiten van belang kan zijn, kan aan deze autoriteiten ter ore komen of expliciet worden medegedeeld. Gebruik van deze informatie in een kartelprocedure zou ten dele de bescherming van het nemo tenetur-beginsel teniet doen. Deze problematiek werd als prejudiciēle vraag bij het Hof aangekaart in HvJ (C-60.92). Jur. 1993, I-5683 alsmede NJ 1994, 256 (Otto t. Postbank). Het Hof achtte het niet bezwaarlijk dat de Commissie op de hoogte komt van informatie die zij wellicht onder toepassing van verordening 


\subsection{Het nemo tenetur-beginsel in het Nederlandse recht ${ }^{236}$}

Dat het nemo tenetur-beginsel binnen het Nederlandse recht een prominente positic inneemt, kan niet met recht gezegd worden. Weliswaar kent het wetboek van Strafvordering geen verplichting voor de verdachte ${ }^{257}$ tot medewerking ${ }^{288}$, maar daarmee is nog niet gezegd dat het nemo tenetur-beginsel in Nederland ook daadwerkelijk de status van algemeen beginsel heeft. De Hoge Raad heeft het bestaan van deze status ontkend door te overwegen dat in het Nederlandse recht

"niet is verankerd een onvoorwaardelijk recht of beginsel dat een verdachte op generiei wijze kan worden verplicht tot het verlenen van medewerking aan het verkrijgen van voor hem mogelijk bezwarend bewijsma. teriaal $=2 n$

Het staat de wetgever derhalve vrij om -ook op verdachten rustende- medewerkingsverplichtingen te creèren. ${ }^{290}$ Zoals hiervoor gesteld, heeft de wetgever deze mogelijkheid allerminst onbenut gelaten. Voor verdachten ${ }^{291}$ bestaat in die gevallen geen recht om medewerking te weigeren, tenzij uitdrukkelijk uit de betreffende regeling het tegendeel blijkt. ${ }^{292} \mathrm{Er}$ bestaat hierop één belangrijke uitzondering en die betreft het zwijgrecht van artikel $29 \mathrm{WvSv}^{293}$ : dit recht heeft voorrang boven cen in een bijzondere wet geformuleerde mededelingsplicht. ${ }^{294}$ Hoewel de strekking van het zwijgrecht is "het behoeden

17 niet zou hebben verworven, omdat door de onderneming een beroep op het zwijgrecht wordt gedaan. Het Hof kon tot deze conclusie komen omdat de Commissie "-evenals trouwens een nationale autoriteitdeze inlichtingen noch als bewijs van een inbreuk op mededingingsregels kan gebruiken in het kader van een procedure die tot resultaat kan hebben dat sancties worden opgelegd, noch als aanwijzing die (...) opening van een onderzoek voorafgaand aan een dergelijke procedure wettigt". Hiermee wordt tevens een eventuele rechtsongelijkheid voorkomen, die zou kunnen ontstaan indien een lidstaat zwijgrecht toekent in civiele procedures. Zie over de problematiek uitgebreid Cumming (1995), pag. 402 , die stelt dat de "prohibition on using relevant and available information might be said to constitute a form of secondary privilege".

286 Zie over de historie van het nemo tenetur-beginsel in Nederland Berkhout-van Poelgeest (1999), pag. 249 c.v..

287 Ook aan (nog) niet-verdachten komt een bijzondere positie toe in het Wetboek van Strafvordering, voorzover zij door verklaringen of anderszins zichzelf zouden belasten. Men vergelijke artt. 106 lid 2 sub 3 WvSv, 160 lid 2 WvSv en 219 WvSv.

288 HR 15 februari 1977, NJ 1977, 557 m.nt. GEM; zie hieromtrent ook Rozemond (1992), pag. 127.

289 HR 15 februari 1977, NJ 1977, 557 m.nt. GEM; in gelijke zin onder meer HR 12 juni 1979, NJ 1979. 570; HR 9 oktober 1984, NJ 1985, 176. Meer recent Hof Amsterdam 28 april 1994, NJ 1996, 149; HR 26 oktober 1993, NJ 1994, 629 m.nt C, HR 29 oktober 1996, NJ 1997, 232 m.nt. Sch en HR 22 juni 1999, NJ 1999, 648.

290 Zie hieromtrent onder meer Meijer (1991), pag. 892.

291 Artikel 27 WvSv definieert 'verdachte' als volgt: "Als verdachte wordt vóórdat de vervolging is aangevangen, aangemerkt degene te wiens aanzien uit feiten of omstandigheden een redelijk vermoeden van schuld aan enig strafbaar feit voortvloeit".

292 HR 20 maart 1984, NJ 1984, 547 m.nt. ThWvV.

293 Voor zover hier van belang luidt artikel 29 WvSv:

1. In alle gevallen waarin iemand als verdachte wordt gehoord, onthoudt de verhorende rechter of ambtenaar zich van alles wat de strekking heeft een verklaring te verkrijgen, waarvan niet gezegd kan worden dat zij in vrijheid is afgelegd. De verdachte is niet tot antwoorden verplicht.

2. Voor het verhoor wordt de verdachte medegedeeld dat hij niet verplicht is tot antwoorden. 294 HR 22 juni 1931, NJ 1931, pag. 1602 m.nt. WP en HR 26 oktober 1993, NJ 1994. 629 m.nt. C. 
van de verdachte tegen ongewilde medewerking aan zijn eigen veroordeling ${ }^{\text {"295 }}$, komt de reikwijdte van dit recht niet in de buurt van een ruim nemo tenetur-beginsel: weliswaar is het zwijgrecht niet beperkt tot het afleggen van mondelinge verklaringen ${ }^{29 \%}$; tot bescheiden $^{297}$ strekt het zich echter niet uit. In het strafrecht bestaat er dus geen algemeen recht om niet aan de eigen veroordeling te hoeven mee te werken; het wetboek van Strafvordering neemt hierin een uitzonderingspositie in. Wel bestaat er een algemeen en absoluut zwijgrecht dat prevaleert boven de medewerkingsplichten van de bijzondere strafwetten.

Het bestuursstrafrecht kent zelfs een dergelijk algemeen zwijgrecht niet: artikel $29 \mathrm{WvSv}$ is buiten het strafrecht niet van toepassing ${ }^{298}$ en een algemene regeling omtrent het bestuursstrafrecht met daarin onder meer neergelegd rechtswaarborgen binnen dit deel van het recht, ontbreekt vooralsnog. Hierin komt verandering indien artikel 5.0.11 VOAwb4 in werking treedt. Dit voorgestelde artikel luidt:

1. Degene die aan een handeling van het bestuursorgaan redelijkerwijs de gevolgtrekking kan verbinden dat aan hem een bestuurlijke sanctic, niet zijnde een herstelsanetie, zal worden opgelegd, is niet langer verplicht ten behoeve van deze oplegging inlichtingen omtrent de overtreding te verstrekken.

2. De overtreder wordt hierop gewezen alvorens hem mondeling wordt gevraagd inlichtingen te verstredken, en in ieder geval wanneer hij in de gelegenheid wordt gesteld over het voomemen tot oplegging van de bestuurlijke sanctie zijn zienswijze naar voren te brengen. ${ }^{200}$

Tot die inwerkingtreding echter is de justitiabele voor bescherming van het zwijgrecht (afgezien van de bescherming die artikel 6 EVRM biedt) aangewezen op de bijzondere, bestuursstrafrechtelijk gehandhaafde wet. Dat dit recht ook tot de kern van de bestuursstrafrechtelijke rechtswaarborgen kan worden gerekend, blijkt onder meer uit het advies van de Commissie voor de toetsing van wetgevingsprojecten. Gelet op dit belang is bijvoorbeeld in de Algemene wet inzake rijksbelastingen (artikel 67j AWR ${ }^{300}$ ) en in de

295 HR 2 oktober 1979, NJ 1980, 243 m.nt. GEM. In dezelfde zin HR 13 maart 1979, NJ 1979, 268 m.nt. ThWvV en (zij het betrekking hebbende op het cautievoorschrift van het tweede lid van artikel 29 WvSv); HR 24 mei 1977, NJ 1978, 316; HR 17 januari 1978, NJ 1978, 341 m.nt. ThWvV en HR 26 juni 1979, NJ 1979, 567 m.nt. ThWvV.

296 Hof Amsterdam 28 april 1994, NJ 1996, 149, waarin het Hof overweegt dat "het onderscheid tussen het mondeling of schriftelijk verschaffenvan informatie (...) slechts gradueel van aard" is. Zie tevens HR 29 oktober 1996, NJ 1997, 232 m.nt. Sch, HR 21 oktober 1997, NJ 1998, 173 en HR 22 juni 1999, NJ 1999, 648.

297 HR 9 oktober 1984, NJ 1985, 176; HR 26 april 1988, NJ 1989, 390 m.nt. ThWvV; HR 29 oktober 1996, NJ 1997, 232 m.nt. Sch en HR 21 oktober 1997, NJ 1998, 173. Vergelijk ook Corstens (1999), pag. 266.

298 HR 13 december 1995, NJ 1996, 144.

299 Zoals ook door Knigge (2000), pag. 94, terecht wordt gesteld, spreekt het tweede lid ten onrechte van 'overtreder': aangezien de overtreding in dat stadium van de procedure nog niet is bewezen, dient de betreffendeals 'verdachte 'of 'vermoedelijke overtreder' te worden aangemerkten te worden benaderd. Voor zover, zoals De Raat en Widdershoven (2000), pag. 782 betogen, het zwijgrechthier inderdaad slechts ziet op mondelinge inlichtingen, is de reikwijdte van de in dit artikel geboden bescherming te beperkt. Aldus ook VAR-werkgroep Vierde tranche Awb (2000), pag. 44.

300 "Indien de inspecteur jegens de belastingplichtige of de inhoudingsplichtige een handeling heeft verricht waaraan deze in redelijkheid de gevolgtrekking kan verbinden dat aan hem wegens een bepaalde godraging een boete zal worden opgelegd, is (...) de belastingplichtige onderscheidenlijk de inhoudingsplichtige niet langer verplicht ter zake van die gedraging enige verklaring af te leggen voorzover 
Mededingingswet (artikel $53 \mathrm{Mw}$ ) het zwijgrecht -maar uitdrukkelijk niet het ruime nemo tenetur-beginsel ${ }^{301}$ - expliciet neergelegd. Artikel $53 \mathrm{Mw}$ luidt:

Indien de in artikel 52, eerste lid, bedoelde ambtenaren een redelijk vermoeden hebben dat cen bepaulde onderneming of ondememersvereniging een overtreding heeft begaan, is er geen verplichting aan de zijde van die ondememing of ondememersvereniging ter zake een verklaring af te leggen. De betrokkenen worden hiervan in kennis gesteld voordat hun mondeling ter zake om informatie wordt gevraagd.

Dit zwijgrecht is volgens de memorie van toelichting niet absoluut: het betreft "het recht om geen belastende verklaring tegen zichzelf af te hoeven leggen ter zake van de in onderzoek zijnde overtreding". ${ }^{302}$ Deze beperking correspondeert met het zwijgrecht van artikel 6 EVRM, maar wijkt af van de regeling in artikel 29 WvSv. In tegenstelling tot hetgeen het geval is in de AWR en artikel 5.0.11 VOAwb4, geldt het zwijgrecht in de Mededingingswet overigens wel reeds vanaf het moment waarop er een 'verdenking' rijst. ${ }^{303}$ In de memorie van toelichting wordt overwogen dat het volgen van de 'AWRlijn' en van het kabinetsstandpunt zoals ingenomen naar aanleiding van het CTW-advies Handhaving door bestuurlijke boeten, ertoe zou leiden dat de 'verdachte' pas een recht om te zwijgen zou hebben vanaf het moment waarop aan hem het rapport van artikel $59 \mathrm{Mw}$ bekend zou worden gemaakt. ${ }^{304}$ Het Hof had echter in zijn Orkem-arrest dit recht in een eerdere fase gehonoreerd. De onduidelijkheid die een verschil tussen nationaal en communautair recht voor ondernemingen teweeg zou brengen, noopte volgens de minister van Economische Zaken tot aansluiting bij het communautaire recht. Convergentie met het communautaire recht werd op dit punt dus verkozen boven convergentie met andere nationale bestuursstrafrechtelijke regels. De keuze van de wetgever is alleen al toe te juichen omdat het zwijgrecht mijns inziens steeds vanaf de verdenking dient te gelden. ${ }^{305}$ Dat er echter pas van een 'criminal charge' sprake zou zijn als een onderneming op de hoogte raakt van het bestaan van een rapport, is niet juist. In ieder geval zal een onderzoek ten kantore van een 'verdachte' onderneming als een maatregel "which likewise substantially affect the situation of the suspect" moeten worden beschouwd. Bovendien heeft het Hof de bescherming niet gekoppeld aan het bestaan van een 'verdenking', maar aan de aard van de vragen en aan de gevolgen van de beantwoording daarvan voor realisering van de bescherming in de contradictoire fase. In zoverre is het niet uitgesloten dat het 'Orkem-zwijgrecht' ook vóór een verdenking kan worden ingeroepen.

In tegenstelling tot het EVRM ${ }^{306}$ kent de Mededingingswet -evenals zoals gezien de AWR en artikel 5.0.11 VOAwb4-een cautieplicht. De ondernemingen hoeven slechts

het betreft de boete-oplegging". Voor de cautie zie artikel 671 lid 2 AWR: "Voordat het verhoor aanvangt, deelt de inspecteur de belastingplichtige of de inhoudingsplichtige mede dat hij niet tot antwoorden verplicht is".

301 Zie MvT TK 1995-1996, 24 707, nr. 3, pag. 84; "Dit zwijgrecht geeft overigens geen bevoegdheid om iedere vorm van medewerking aan het verzameien van belastend materiaal te weigeren".

302 MvT TK 1995-1996, 24 707, nr. 3, pag. 84 (cursivering van mij, HQ).

303 Hier blijkt het nadeel van het ontbreken van een algemene bestuursstrafrechtelijkeregeling. Van een uniforme regeling van de rechten van de justitiabelen is zo geen sprake.

304 MvT TK 1995-1996, 24 707, nr. 3, pag. 84/85.

305 In deze zin ook Hartmann (2000), pag. 56. Anders: Verheij (1999), pag. 34.

306 In deze zin ook Jansen (1999), pag. 104. Anders: Hartmann (1998), pag. 85-86, die het onjuist acht om aan het uit artikel 6 EVRM voortvloeiende zwijgrecht niet de cautieplicht te koppelen. De wenselijkheid van de cautie wordt overigens door mij ten volle onderschreven. 
op de hoogte te worden gebracht van hun zwijgrecht zodra hun vragen ter zake wrden gesteld. Daarmee wordt aangesloten bij artikel 29 lid 2 WvSv, waarin hetzelfde tot uitrukking wordt gebracht door de koppeling van de cautieplicht aan het verhoor. Hiernder wordt namelijk verstaan "alle vragen aan een door een opsporingsambtenaar als verochte aangemerkt persoon betreffende diens betrokkenheid bij een geconstateerd strabaar feit" ${ }^{307}$ Ook het reserveren van de cautieplicht voor mondelinge vragen is aan het trafrecht ontleend. ${ }^{308}$ De ratio hiervan is dat door het ontbreken van de rechtstreekse coniontatie met de onderzoekende ambtenaar ook de druk (pressie) om te antwoorden ontbeekt. Deze beperking zou hier -en overigens evenmin in het strafrecht- niet moeten worden aangebracht. ${ }^{309} \mathrm{Bij}$ de cautie gaat het erom dat een verdachte wordt gewezen of zijn recht om te zwijgen. Het niet vermelden van de cautie zou de onterechte indruk kunen wekken dat ten aanzien van schriftelijke vragen dit recht niet zou gelden. De caute zal overigens voor het mededingingsrecht van minder belang zijn dan voor het gros un de strafrechtelijke zaken. Veelal zijn ondernemingen, mede dankzij juridische bijstad (al dan niet in de vorm van een interne juridische afdeling), goed op de hoogte val hun rechtspositie. Dit geldt weliswaar in mindere mate voor 'kleinere' ondernemingen,naar als de NMa net als de Commissie bij onderzoeken ter plaatse -binnen de grenze van redelijkheid- bereid is de komst van juridische bijstand af te wachten, dan word ook hierdoor reeds een bescherming van de rechtswaarborgen bewerkstelligd. Daarbijsomt dat volgens vaste strafrechtelijke jurisprudentie -en niet is in te zien waarom dez niet door het College van Beroep voor het Bedrijfsleven op dit punt zou worden gevolgd ${ }^{310}$. een cautieverzuim geen gevolgen heeft indien de verdachte niet in zijn belang is geschaad $^{311}$; dit is onder meer het geval indien de verdachte op de hoogte is van zijn zwijgrecht (of hiervan op de hoogte moet worden geacht) en indien de verdachte door een raadsman wordt bijgestaan. ${ }^{312}$

Concluderend kan ten aanzien van de Nederlandse situatie gesteld worden dat het Nederlandse recht behoudens in het wetboek van Strafvordering geen recht voor de verdachte kent om in het geheel niet te hoeven meewerken aan zijn eigen veroordeling. Wel geldt er in punitieve procedures een zwijgrecht, waarvan echter het moment van inroepbaarheid en de omvang kunnen verschillen. Voor de Mededingingswet betreft het een recht voor de onderneming om geen belastende verklaringen af te leggen zodra zij van een overtreding wordt verdacht. Tot dat moment bestaat er geen zwijgrecht. Wel is het op grond van artikel 6 lid 1 EVRM verboden om belastende verklaringen, ook al zijn zij afgelegd voor het moment van de 'criminal charge' en (dus) ook voor het ontstaan van een verdenking, als bewijs tegen de onderneming in de boeteprocedure te gebruiken.

307 Zie onder meer HR 2 oktober 1979, NJ 1980, 243 m.nt. GEM; HR 3 juli 1989, NJ 1990, 121 en HR 18 september 1989, NJ 1990, 531 m.nt ThWvV.

308 HR 1 oktober 1985, NJ 1986, 406 m.nt. ThWvV.

309 Met betrekking tot het strafrecht eveneens kritisch: Corstens (1999), pag. 269.

310 Temeer daar de minister in de memorie van toelichting, TK 1995-1996, 24 707, nr. 3, pag. 85, overwoog dat mag worden aangenomen "dat het ten onrechte achterwege laten van de cautie er onder omstandigheden toe kan leiden dat de desbetreffende verklaringen geen rol meer kunnen spelen bij het aantonen van de overtreding" (cursivering van mij, HQ).

311 HR 26 januari 1982, NJ 1982, 353 m.nt. ThWvV.

312 Vergelijk HR 13 september 1988, NJ 1989, 454. 


\section{Rechtsbijstand en verschoningsrecht}

\section{I Rechtsbijstand}

Juridische bijstand, hetzij van een bedrijfsinterne jurist of juridische afdeling, hetzij van een externe advocaat of andere juridisch adviseur, kan voor een onderneming in het kader van haar bedrijfsvoering van groot belang zijn. Het behoeft geen betoog dat cen onderneming zich veelvuldig gesteld ziet voor vragen of problemen van juridische aard die zij aan een specialist wenst voor te leggen. Deze vragen kunnen op tal van gebieden rijzen, niet in de laatste plaats op het gebied van te sluiten overeenkomsten en juridische implicaties van een voorgenomen marktstrategie. Daarbij komen mede de communautaire en nationale (kartel)grenzen in beeld, waarbinnen de onderneming zal dienen te blijven. Voor de effectuering van de mogelijkheid juridisch advies in te winnen, is de bescherming van de correspondentie tussen de onderneming en de juridisch adviseur van groot belang; aan de vraag in hoeverre deze bescherming in het communautaire recht wordt gegarandeerd, wordt de volgende paragraaf besteed. Hier staat centraal de juridische steun waaraan een onderneming in het kader van verificaties behoefte kan hebben. ${ }^{313}$ En gelet op de ingrijpendheid van een verificatie alsmede op de verstrekkendheid van de gevolgen kan deze behoefte groot zijn: de jurist (bijvoorbeeld een advocaat, een bedrijfsjurist of een mededingingsdeskundige) kan erop toezien dat de grenzen van het recht tijdens de verificatie niet worden overschreden, dat documenten die onder het 'legal privilege' vallen of die zakengeheimen bevatten, met de vereiste behoedzaamheid door de Commissie worden behandeld ${ }^{314}$, dat meer in het algemeen de rechten van de onderneming niet worden geschonden en dat deze aan de van haar gevergde medewerking voldoet, teneinde een eventuele sanctie of boete-verhoging wegens niet co-operatie te voorkomen. Daarnaast kan juridische bijstand in het belang van de verificatie en meer algemeen van de handhaving van het communautaire kartelrecht zijn: de jurist die medewerking van de onderneming bevordert en die kennis heeft van de informatie die de Commissie wenst te vergaren en deze derhalve relatief eenvoudig kan verstrekken, bewerkstelligt niet alleen dat een onderneming zo min mogelijk hinder ondervindt van de verificatie, maar vereenvoudigt aldus het werk van de Commissie en draagt bij aan een relatief probleemloze en (voor)spoedige informatievergaring. ${ }^{315}$

Met name gelet op de rechtspositie van de onderneming is het positief te waarderen dat de Commissie het belang van juridische steun heeft erkend, zij het dat van een onvoorwaardelijk recht op rechtsbijstand in deze fase geen sprake is. Uit de door de Commissic gehanteerde toelichting bij de verificatieopdracht ${ }^{316}$ blijkt namelijk dat zij geen bezwaar

313 Bij de inlichtingeninwinning ex artikel 11 Vo 17 speelt een vergelijkbaar probleem niet aangezien een onderneming voldoende tijd wordt gegund om de vragen te beantwoorden en dus te allen tijde de mogelijkheid bestaat om juridische hulp in te roepen.

314 Welke invloed het 'legal privilege' en zakengeheimenin deze hebben, zal worden besproken in de paragrafen 4.2 .3 en 5.2 .4 .

315 Het is natuurlijk ook mogelijk dat de juridisch bijstandverlener de handhaving in de wielen rijdt door allerlei berwaren tegen de verificatie op te werpen en door zoveel mogelijk de co-operatie te beperken. Hoewel de bijstandverlener daarvoor goede gronden kan hebben, is de onderneming daarbij echter uiteindelijk lang niet altijd gediend.

316 Zoals neergelegd in de bijlage bij het Dertiende verslag over het mededingingsbeleid. Zie hierover Schermerhorn (1994), pag. 33. 
maakt tegen juridische bijstand, maar dat tevens de rechtsgeldigheid van de verificatie niet van de inschakeling van een advocaat afhangt. Nu ook zonder juridische bijstand de verificatie doorgang kan vinden, mag de Commissie aan de aanwezigheid van een jurist voorwaarden verbinden. In de bedoelde toelichting heeft zij dienaangaande inderdaad algemene regels opgesteld. Voor zover de onderneming over een eigen juridische dienst beschikt, is de Commissie niet bereid de komst van externe juridische bijstand af te wachten; de positie van de onderneming moet in dat geval reeds als genoegzaam beschermd worden beschouwd. Ontbreekt interne juridische bijstand, dan wordt met de verificatie niet eerder begonnen dan op het moment waarop de advocaat of -waarschijnlijk- een andere externe adviseur arriveert. ${ }^{317}$ Voorwaarde is dan wel dat hierdoor het onderzoek niet onredelijk wordt vertraagd, dat de leiding van de onderneming verzekert dat de bescheiden "ter plaatse en in de toestand blijven waarin zij zich bij de aankomst van de personeelsleden van de Commissie bevonden" en dat de met het onderzoek belaste ambtenaren niet gehinderd mogen worden aan het betreden van en verblijven in door deze aangewezen ondernemingsplaatsen. ${ }^{318}$ De nadruk ligt in deze fase van de procedure -vanzelfsprekend- op de effectiviteit van het onderzoek, ter bescherming van welk belang aan het recht op juridische bijstand grenzen zijn gesteld. Maar dat laat onverlet dat een onderneming in beginsel nooit verstoken hoeft te blijven van rechtsbijstand tijdens de verificatie: of zij heeft haar eigen interne juridische bijstand, of er wordt -althans als hoofdregel- op de externe bijstand gewacht. Aldus heeft de Commissie een mijns inziens goede balans gevonden tussen de doelmatigheid van het onderzoek en de rechten van de onderneming; een balans die bovendien in grote lijnen gelijk is aan die welke met betrekking tot doorzoekingen in het Nederlandse strafrecht is gerealiseerd. Op grond van artikel $99 \mathrm{a}$ WvSr is de verdachte namelijk bevoegd zich tijdens het doorzoeken van plaatsen door zijn raadsman te doen bijstaan, zonder dat de doorzoeking daardoor mag worden opgehouden. $^{319}$

Om het beeld ten aanzien van (effectuering van) juridische bijstand volledig te maken: het recht op juridische bijstand tijdens de contradictoire fase is volledig gegarandeerd. Voorzover deze fase mondeling wordt gevoerd, heeft de onderneming het recht zich te doen vertegenwoordigen door een advocaat. Het overwegend schriftelijke karakter van bedoelde fase waarborgt eveneens het recht op een advocaat.

317 Dit geldt zowel ten aanzien van verificatie bij eenvoudige opdracht als ten aanzien van verificaties bij beschikking. Bij eerstbedoeldeverificatievormzal de Commissie er echter doorgaans weinig voor voelen om de komst van een advocaat af te wachten, althans voor zover zij haar 'bezoek' voonf heeft aangekondigd.

318 Deze voorwaarden zijn bedoeld om te verzekeren dat de onderneming het uitstel niet aangrijpt om relevante gegevens te verduisteren.

319 In het bestuurs(straf)recht is eveneens de bijstand door een raadsman geregeld. Artikel 2:1 Awb garandeert dat een ieder zich ter behartiging van zijn belangen in het verkeer met besturursorganen kan laten bijstaan. Bijstand door een advocaat kan op grond van artikel 2:2 lid 3 Awb niet worden geweigerd. 


\subsection{Verschoningsrecht}

Hiervoor is het belang van advisering door een juridisch geschoolde onderstreept: juridisch advies draagt bij aan de naleving van de wet, is voor de dagelijkse bedrijfsvoering van een onderneming vaak onontbeerlijk en is, mede vanuit de optick van een eerlijk proces, cruciaal in geval van eventuele juridische complicaties en procedures. Ondernemingen moeten zich kortom in vrijheid tot een advocaat of andere jurist kunnen wenden. Van vrijheid kan in deze echter slechts sprake zijn indien het juridisch advies alsmede de daaraan voorafgaande informatieverstrekking en correspondentie tussen adviseur en onderneming niet inhoudelijk bij derden bekend wordt, ook niet indien van overheidswege cen onderzoek naar bepaald gedrag van de onderneming wordt ingesteld. Indien dat immers wel dreigt, zal een onderneming hoogst zelden bereid zijn om volledige openheid van zaken te geven aan degene die de juridische bijstand verleent; zonder een dergelijke openheid echter, is adequate bijstand niet mogelijk. Voor zover het gevoelige interne (bedrijfs)informatie betreft, is de vrees dat een breed publiek (en dan met name concurrenten, leveranciers en (eind)afnemers) hiervan zal kunnen kennisnemen in Verordening 17 tegemoet getreden door een algemene regeling van geheimhouding. Deze regeling komt in de volgende paragraaf aan de orde. Hier staat een andersoortig, maar evenzeer fundamenteel probleem centraal: in hoeverre is de correspondentie tussen juridisch adviseur c.q. bijstandverlener en zijn cliênt (in casu de onderneming) beschermd? Met andere woorden: mag van overheidswege van deze correspondentie kennis worden genomen in het kader van een kartelprocedure? Hier wordt het terrein van het (functioneel) verschoningsrecht betreden: de bijzondere positie die bepaalde geheimhouders toekomt teneinde de vertrouwelijkheid tussen hen en hun cliënt te beschermen. Het verschoningsrecht overstijgt het individuele belang van een cliènt die erbij gebaat is dat zijn informatie niet bij de overheid bekend wordt. De zekerheid dat informatie binnenskamers blijft, dient evenzeer het algemeen belang, te weten dat meer algemeen niemand vanwege de vrees van het bekend worden van de informatie ervan wordt weerhouden om (juridische) bijstand in te roepen. ${ }^{320}$ Voor zover het gaat om het verschoningsrecht van een advocaat komt daar nog bij dat diens beroep een 'bijzonder karakter' heeft, welk karakter erin bestaat dat de advocaat een spilfunctie vervult "in de goede toepassing van het nationale rechtssysteem". ${ }^{321}$ Deze spilfunctie, gekoppeld aan de vertrouwenspositie die een advocaat geniet, brengt mee dat op hem geen verplichting dient te rusten om informatie aangaande zijn cliënt aan overheidsinstanties te verstrekken. De advocaat zal dus informatie voor zich mogen behouden, althans voorzover het verstrekken ervan zich naar zijn overtuiging zou verzetten tegen de genoemde vertrouwenspositie. Hier zij reeds benadrukt dat het dus in deze gaat om de overtuiging van de advocaat; juist gelet op het karakter van het ambt van advocaat, wordt aan zijn mening zo'n groot gewicht toegekend.

Deze korte schets van het (functioneel) verschoningsrecht maakt het belang ervan duidelijk. Alvorens op de vraag zal worden ingegaan of het communautaire recht een (functioneel)

320 Vergelijk Grabandt (1982), pag. 529. Hij stelt dat hoofdzakelijk deze reden aan het Britse verschoningsrecht ten grondslag ligt.

321 Grabandt (1982), pag. 529, die van mening is dat het verschoningsrecht in onder andere Nederland tegen deze achtergrond moet worden gezien. 
verschoningsrecht kent en zo ja, hoever dit reikt, zal eerst de positie van dit recht binnen het Nederlandse strafrecht, worden besproken.

\subsubsection{Verschoningsrecht in het Nederlandse strafrecht}

Het verschoningsrecht is op verschillende plaatsen in het wetboek van Strafvordering neergelegd. Een centrale plaats nemen daarbij de artikelen 217-219 WvSv in, aangezien daar de verschillende categorieën verschoningsgerechtigden zijn genoemd. Het betreft bloedverwanten van de verdachte (artikel $217 \mathrm{WvSv}$ ), getuigen die door beantwoording van bepaalde vragen zich of naasten aan een strafrechtelijke vervolging zouden blootstellen (artikel $219 \mathrm{WvSv}$ ) alsmede, en in dit verband met name van belang, personen die uit hoofde van hun beroep tot geheimhouding verplicht zijn (artikel $218 \mathrm{WvSv}$ ), de functioneel verschoningsgerechtigden. Cruciaal is bij het functioneel verschoningsrecht het beroepsgeheim dat, aldus Spronken, twee grondslagen kent: "de bescherming van de privacy en het belang van vertrouwelijkheid in de hulpverleningsrelatie". ${ }^{322}$ Niet iedere geheimhoudingsplicht brengt echter een verschoningsrecht met zich. Zoals de Hoge Raad het formuleerde:

"De grondslag van dit verschoningsrecht moet worden gezocht in een in Nederland geldend algerseen rechtsbeginsel dat meebrengt dat bij zodanige vertrouwenspersonen het maatschappeijk beiang dat de waarheid in rechte aan het licht komt, moet wijken voor het maatschappelijk belang dat een ieder zich vrijelijk en zonder vrees voor openbaarmaking van het besprokene om bijstand en advies tot hen moet kunnen wenden". 3

Het maatschappelijk, algemeen belang van waarheidsvinding en het algemeen ${ }^{324}$ belang van een adequate hulpverlening staan hier dus op gespannen voet en het is aan de Hoge Raad om de (moeilijke) keuze te maken tussen beide (zeer legitieme) belangen. Het kan gelet op het belang van de waarheidsvinding- dan ook niet anders dan dat het verschoningsrecht wordt gereserveerd voor een relatief gering aantal functies waarbij het hulpverleningsaspect zwaarder weegt, omdat zonder een geheimhoudingsplicht en verschoningsrecht deze functies niet adequaat zouden kunnen worden uitgeoefend. ${ }^{325}$ Daarom is het functio-

322 Spronken (2001), pag. 385. Schending van geheimhouding levert op grond van artikel $272 \mathrm{WvSr}$ een strafbaar feit op.

323 HR 1 maart 1985, NJ 1986, 173. Ten aanzien van de bijstand door een advocaat stellen Van Bavel en Verbunt (1994), pag. 236: "Uit de aard der zaak is het toekennen van een verschoningsrecht de resultante van een afweging van belangen, te weten dat van de waarheidsvinding tegen dat van (de erkenning van) het recht op adequate rechtsbijstand van de justitiabeie en de daaraan inherente vertrovwelijke communicatic. Zonder zekerheid voor de justitiabele dat zijn gesprekken met een advocaat niet zullen worden geopenbaard, zal hij zich immers niet vrijelijk tot hem wenden en kan er van daadwerkelijkerechtsbijstand dan ook geen sprake zijn". In deze zin ook Spronken (2001), pag. 387.

324 Vergelijk HR 19 november 1985, NJ 1986, 533 m.nt. 't H en HR 22 juni 1984, NJ 1985, 188 m.nt. WHH (in een civiele zaak).

325 Zoals gezegd ligt het in de aard van sommige functies, waaronder die van advocaat, dat de 'functionaris' wordt geconfronteerdmet informatie die gelet op haar wezen 'binnenskamers' dient te blijven. Voorzover daaromtrent geen garantic bestaat, zal er redelijkerwijs geen volledige openheid van de hulpzoekende kunnen worden verwacht en kan dus de functie niet naar behoren worden vervuld. 
neel verschoningsrecht hoofdzakelijk gereserveerd voor advocaten ${ }^{326}$, notarissen, artsen en geestelijken die allen op respectievelijk juridisch, medisch en geestelijk terrein maatschappelijk zeer wezenlijke functies vervullen. ${ }^{327} \mathrm{Bij}$ al deze functies is de vertrouwensband met degene die om bijstand verzoekt, en in het verlengde daarvan de plicht tot geheimhouding en het recht op verschoning, cruciaal. Teneinde uitholling van het functioneel verschoningsrecht te voorkomen, wordt wel een afgeleid verschoningsrecht erkend voor directe medewerkers van de functioneel verschoningsgerechtigde, waarbij onder meer gedacht moet worden aan secretarièle medewerkers. ${ }^{328}$ Onduidelijk was geruime tijd of derden-deskundigen die de verschoningsgerechtigde en meer bepaald de advocaat, op diens verzoek adviseerden, zich met succes konden beroepen op een afgeleid verschoningsrecht. Het is zeer wel denkbaar dat in het kader van bijvoorbeeld een verdediging door een advocaat van diens cliënt, advisering door een deskundige van grote relevantic is. Indien de advocaat dan zou moeten vrezen dat door hem aan de deskundige verstrekte vertrouwelijke informatie alsnog bij de bevoegde autoriteiten bekend zou worden omdat de deskundige bijvoorbeeld wél zou moeten getuigen, dan zou hij redelijkerwijs moeten afzien van het inwinnen van het advies, hetgeen zijn cliënt eventueel zou kunnen schaden. Hoewel gelet op het voorgaande een afgeleid verschoningsrecht voor de hand ligt, oordeelde de Hoge Raad in 1990 dat de (vertrouwelijke) correspondentie tussen de adviserende derde en advocaat niet onder het vertrouwelijk verkeer tussen advocaat en eliënt valt. ${ }^{139}$ Terecht is op deze uitspraak kritiek geleverd ${ }^{330}$ : indien immers een advocaat het geĭndiceerd acht een externe specialist te raadplegen, dan gebeurt dit met het oog op een zo goed mogelijke taakuitoefening als advocaat; het ligt dan in de lijn van de ratio van het functionele verschoningsrecht om de correspondentie tussen advocaat en adviseur te beschermen. Klaarblijkelijk heeft de Hoge Raad zich de geuite kritiek aangetrokken, aangezien hij slechts vier jaar later tot een geheel ander oordeel kwam. ${ }^{331}$ De aard en complexiteit van een bepaalde zaak zouden volgens de Hoge Raad kunnen meebrengen dat cen advocaat een advies inwint van een (externe) deskundige:

326 Zie onder meer HR 22 juni 1984, NJ 1985, 188 m.nt. WHH en Hof Arnhem 23 november 1999, NJ 2001, 86. Vergelijk ook De Roos en Serrarens (1993), pag. 128, met verwijzingen naar jurisprudentie. Met het algemeen belang-aspectvan de verlening van bijstand door een advocaathangt ook samen dat-zoals Grabandt (1982), pag. 527 reeds stelde-deze cen belangrijke rol vervult in de goede toepassing van het rechtssysteem en dat op diens objectief oordeel vertrouwd kan worden. Van belang is in dat verband mede dat de advocaat onderworpen is aan het tuchtrecht.

327 De Hoge Raad legt grote terughoudendheid aan de dag waar het gaat om aan andere beroepsgroepen verschoningsrecht toe te kennen. Vergelijk HR 25 oktober 1983, NJ 1984, 132 m.nt. 't H; HR 14 juni 1985, NJ 1986, 175; HR 6 mei 1986, NJ 1986, 813, HR 29 maant 1994, NJ 1994, 552 m.nt. 't H en HR 4 januari 2000, NJ 2000, 537 m.nt. Sch (in al deze arresten werd het verschoningsrecht niet toegekend aan registeraccountants). HR 6 mei 1986, NJ 1986, 815 m.nt. WLH (met betrekking tot belastingadviseurs). Verschoningsrecht werd wel aan een journalist toegekend in verband met artikel 10 EVRM: HR 10 mei 1996 NJ 1996, 578 m.nt. EJD.

328 Vergelijk HR 29 maart 1994, NJ 1994, 552 m.nt. 't H alsmede Corstens (1999), pag. 136.

329 HR 26 juni 1990, NJ 1990, 750; de Rechtbank had overigens een ander (tegengesteld) standpunt ingenomen. In deze zaak betrof het de correspondentie tussen de advocaat en een belastingadviseur.

330 Zie onder meer ' $t$ Hart in zijn noot onder bedoeld arrest.

331 HR 29 maart 1994, NJ 1994, 552 met noot 't Hart, die stelt dat de Hoge Raad op zijn eerder ingenomen standpunt terugkomt. 


\section{Hoofdstuks}

"In aanmerking genomen dat die deskundige in verband met de uitvoering van de hem door de advocaat gegeven opdracht zo nodig kennis moet kunnen nemen van bepaalde gegevens en stukken ten aanzien waarvan de plicht tot geheimhouding voor de advocaat geldt, is ook in zoverre een uitbreiding van diens geheimhoudingsplicht en verschoningsrecht geboden".

Ook op een ander punt is de bescherming van het functionele verschoningsrecht gegroeid. In tegenstelling tot hetgeen Grabandt ${ }^{332}$ in 1982 nog stelde, strekt dit recht zich mede uit over vertrouwelijke informatie die zich in het bezit van de cliënt van de advocaat bevindt. De Hoge Raad overwoog namelijk in 1985 dat het belang, bestaande in een vrije mogelijkheid een advocaat te consulteren, te zeer beperkt zou worden

"wanneer ieder die cen advocaat wil raadplegen niet vrijelijk en niet zonder vrees voor openbaarmaking zou kunnen bewaren afschrift van al hetgeen hij schriftelijk aan zijn advocaat heeft toevertrouwd en hetgeen de advocaat hem heeft geschreven". 3.

Deze terechte verruiming van de reikwijdte van het functionele verschoningsrecht doet echter niets af aan het feit dat de groep verschoningsgerechtigden tamelijk 'overzichtelijk' is gehouden. Zoals gezegd, is dit verklaarbaar tegen de achtergrond dat bij een grotere groep functioneel verschoningsgerechtigden de waarheidsvinding in strafzaken ernstig zou kunnen worden gefrustreerd. ${ }^{334}$ Dit wordt onderstreept door de zeer omvangrijke bescherming die verschoningsgerechtigden genieten:

de verschoningsgerechtigde is niet verplicht een verklaring af te leggen omtrent hetgeen hem in zijn functic is toevertrouwd (artikel 218 WvSv);

hij is niet verplicht aan een bevel tot uitlevering van voot inbeslagneming vatbare voorwerpen te voldoen, voorzover de uitlevering in strijd zou komen met de geheimhoudingsplicht (artikel 96a WvSV);

brieven of andere geschriften tot welke de geheimhoudingsplicht zich uitstrekt, mogen niet in beslag worden genomen, behoudens in geval van toestemming door de verschoningsgerechtigde (artikel 98 WvSv) ${ }^{\mathrm{es}}$;

doorzocking vindt bij een verschoningsgerechtigde alleen plaats voor zover dat kan geschieden zonder schending van zijn geheimhoudingsplicht en mag zich slechts uitstrekken over brieven of andere geschriften die voorwerp van het strafbare feit uitmaken of tot het begaan daarvan hebben gediend (artikel $98 \mathrm{WvSv}$ ). Bovendien is -behoudens spoed (artikel $97 \mathrm{WvSv}$ ) ${ }^{36}$ - tot doorzoeking slechts bevoegd de rechter-commissaris in het kader van een gerechtelijk vooronderzoek (artikel $110 \mathrm{WvSv}$ );

in geautomatiseerde werken (computers en dergelijke) mag geen onderzoek plaatsvinden naar gegevens die door af vanwege een verschoningsgerechtigde zijn ingevoerd, wederom behoudens toestemming van deze (artikel 1251 WvSv); een onderzoek in het geautomatiseerde werk mag slechts plaatsvinden voorzover daarbij geen inbreuk wordt gemaakt op de geheimhoudingsplicht;

332 Grabandt (1982), pag. 527. Deze schrijver stelde ten aanzienvan artikel 98 lid I WvSv dat dit slechts betrekking had "op bij geheimhouders aangetroffen bescheiden" en dat het niet kon voorkomen "dat bij de cliènt van de geheimhouder (-advocaat) aangetroffen adviezen van de advocaat in beslag worden genomen".

333 HR 19 november 1985, NJ 1986, 533 m.nt. ' $t$ H. De vertrouwelijke correspondentie omvat dan ook de gehele communicatie tussen de advocaat en zijn cliênt. En op grond van HR 1 november 1988. NJ 1989, $349 \mathrm{~m} . \mathrm{nt}$. ThWvV zelfs brieven die door de justitiabele nog niet aan zijn advocaat zijn verzonden.

334 Corstens (1999), pag. 135. In vergelijkbare zin Schalken in zijn noot bij HR 4 januari 2000, NJ 2000, 537.

335 Hetzelfde geldt tijdens het strafrechtelijk financieel onderzoek, zie artikel 126d WvSv.

336 In dat geval is de (hulp) officier van Justitie bevoegd, overigens uitsluitend na voorafgaande machtiging van de rechter-commissaris. Vergelijk ook artikel $126 \mathrm{c}$ WvSv. 
een verschoningsgerechtigde hoeft geen gevolg te geven aan een bevel tot het verienen van toegang tot (gegevens die zijn opgeslagen in) een geautomatiseerd werk (artikel $125 \mathrm{~m} \mathrm{j} \mathrm{j}^{\circ} 125 \mathrm{i}$ en $125 \mathrm{k}$ WvSv), en processen verbaal en andere voorwerpen (verkregen door gebruikmaking van de bevoegdheden uit de tutels IV A, V en V A) die mededelingen bevatten, gedaan door of aan een verschoningsgerechtigde, worden vemietigd en derhalve niet bij de processtukken gevoegd.

Mede omdat het verschoningsrecht niet louter het individuele belang dient van degene die zich tot de verschoningsgerechtigde om advies c.q. bijstand heeft gewend, maar daarenboven een maatschappelijk belang heeft, is het van wezenlijk belang dat de beslissing over de uitoefening van dit recht uiteindelijk in handen van de verschoningsgerechtigde en dus niet van bedoelde justitiabele- ligt. ${ }^{337}$ Een andere opvatting zou er volgens de Hoge Raad

\footnotetext{
"toe leiden dat het oordeel omtrent de geloofwaardigheid van hen die zich tot de betreffende vertrouwenspersoon hebben gewend, ongunstig zou kunnen worden beinvloed door hun weigering hem uit zijn geheimhoudingsplicht te ontslaan, zodat de vrees dat zij daardoor naderhand tot een zodanig ontslag zouden worden genoopt hen ervan zou kunnen weerhouden de hulp van die vertrouwenspersoon in te roepen of zich vrijelijk tegenover hem uit te spreken"."."
}

In het verlengde van het voorgaande ligt de vraag aan wie (de verschoningsgerechtigde, de onderzoekende autoriteit of een derde, bijvoorbeeld een onafhankelijke rechter) de bevoegdheid toekomt om te bepalen of het informatie betreft die onder het verschoningsrecht valt. De eventuele vertrouwelijkheid van de informatie staat immers niet steeds op voorhand vast. Ook hier wordt in de Nederlandse rechtspraak een centrale rol aan de verschoningsgerechtigde toegedicht, nu de Hoge Raad in 1985 heeft overwogen

\footnotetext{
"dat door de justitiele autoriteiten van de inhoud van zodanige briefwisseling (tussen advocaat en client. aanwezig bij laatstgenoemde, HQ) geen kennis wordt genomen, anders dan noodzakelijk moet worden geacht om de bewering dat bepaalde brieven het karakter hebben van vorenbedoelde correspondentic op haar aannemelijkheid te toetsen"."
}

Hoe weinig ruimte er voor de autoriteiten rest om aan de woorden van de verschoningsgerechtigde te twijfelen, blijkt wel uit een arrest van de Hoge Raad uit 1991:

"De aard van de hier aan de orde zijnde bevoegdheid tot verschoning brengt (...) mede dat het oordeel
omtrent de vraag of brieven of geschriften object van de bevoegdheid tot verschoning utmaken, in beginsel
toekomt aan de tot verschoning bevoegde persoon. Wanneer deze zich op het standpunt stelt dat het gaat
om brieven of geschriften (...) waarvan kennisneming zou leiden tot schending van het beroepsgeheim,

337 HR 17 februari 1928, NJ 1928, pag. 727 m.nt. EMM alsmede HR 1 maan 1985, NJ 1986, 173. Terecht stelt 't Hart (1992), pag. 106, dan ook dat de verschoningsgerechtigde mag "blijven zwijgen waar de cliènt hem van de zwijgplicht heeft ontslagen". In gelijke zin Corstens (1999), pag 137. Zie voorts 't Hart in zijn noot onder HR 19 november 1985, NJ 1986, 533.

338 HR 1 maart 1985, NJ 1986, 173.

339 HR 19 november 1985, NJ 1986, 533; de Rechtbank had in dezelfde zaak geoordeeld dat voor bedoelde toetsing "het in de regel nodig (zal) zijn om -globaal- kennis te nemen van de inhoud". In HR 26 juni 1990, NJ 1990, $750 \mathrm{~m}$.nt. 'tH, betrof het teruggave van enkele bij een cliênt inbeslaggenomen gegevens die volgens de advocaat 'grensgevallen' betroffen. De rechtbank achtte het wenselijk dat de advocaat de selectie maakte, waarbij de rechter-commissaris (angerien een gerechtelijk vooronderzoek gaande was) bij twijfel zou moeten bemiddelen. 


\section{Hoofdstuk 5}

dient dit standpunt door de organen van politie en justitie te worden geterbiedigd, tenzij redelijkerijze geen twijfel er over kan bestaan dat dit standpunt onjuist is".

Behoudens zeer uitzonderlijke gevallen zal dus steeds op de verschoningsgerechgde vertrouwd moeten worden. ${ }^{341}$ Van de mogelijkheid tot (marginale) toetsing van de iformatie in geval van twijfel -zoals geopend door de Hoge Raad in zijn arrest van 185 zal met de grootst mogelijke terughoudendheid gebruik moeten worden gemaakt. Welisaar zal, indien bij nadere bestudering is gebleken dat het om vertrouwelijke informatie ant, van deze informatie op geen enkele wijze gebruik mogen worden gemaakt (dus oolniet als aanknopingspunt voor een verdenking ex artikel $27 \mathrm{WvSv}^{342}$ ), maar het belangvan het verschoningsrecht ligt er nu juist in dat in het geheel geen kennis wordt genenen van de inhoud van het betreffende materiaal. Immers kan het redelijkerwijs niet va de bevoegde autoriteiten, bijvoorbeeld opsporingsambtenaren, worden gevergd dat $\mathrm{z}$ die inhoud geheel uit hun geheugen bannen. ${ }^{343}$

340 HR 22 november 1991, NJ 1992, 315 m.nt. ThWvV en EAAL. Zie eveneens HR 29 maart 994 , NJ 1994, 537. In vergelijkbare zin oordeelde de Hoge Raadmet betrekking tot de afgeleidevershoningsbevoegdheid van een registeraccountant: "dat het oordeel omtrent de vraag of brieven of stcken object van de afgeleide bevoegdheid tot verschoning uitmaken, in beginsel toekomt aan de peoon

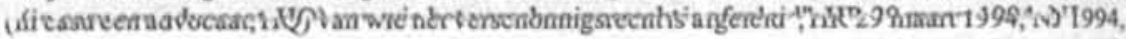
552 m.nt. ' $t H$. De striktere bewoordingen van het geciteerde arrest ten opzichte van het arrest uit 1985 zijn mijns inziens mede verklaarbaaruit de omstandigheid dat het in casu een huiszoeking ten kantore van een verschoningsgerechtigde betrof, dit in tegenstelling tot hetgeen hetgeen het geval was in de zaak die leidde tot het arrest van 1985. Hier werd deze bevoegdheid uitgeoefend bij de cliènt van de verschoningsgerechtigde. Dat een cliēnt erbij gebaat is dat informatie onder het verschoningsrecht valt en dus dat hij dit recht graagzal willen inroepen, is duidelijk. In deze situatie is twijfel omtrent het vertrouwelijke karakter eerder gerechtvaardigd dan in het geval waarin een verschoningsgerechtigde zich op bedoeld recht beroept. Dat laat echter onveriet dat, gelet op het belang van het verschoningsrecht en op het feit dat het primair de verschoningsgerechtigde is die een uitspraak over het karakter van de informatie toekomt, de autoriteiten bij twijfel eerst en vooral de mening van de verschoningsgerechtigde moeten inwinnen.

341 Dit vertrouwen dat aan de verschoningsgerechtigde wordt toegekend, brengt voor deze de opdracht mee alles in het werk te stellen om dit vertrouwen niet te schenden. Hij zal ervoor zorg moeten dragen dat het contact tussen hem en zijn eliënt binnen de geldende grenzen blijft. In dit verband stelt $\mathrm{De}$ Waard (1994), pag. 1444, dat van een advocaat "extra waakzaamheid(zal mogen) worden verwacht zodat hij het verschoningsrecht waardig blijft". Zie tevens van dezelfde schrijver (1995 I), pag. 323 en (1995 II), pag. 880/881 en Quant (1995), pag. 63.

342 Zie bijvoorbeeld HR I november 1988, NJ 1989, 349 m.nt. ThWvV.

343 Het voorgaande schetst een beeld van een ruime en in de afgelopen tijd gegroeide bescherming van het verschoningsrecht voor die beroepsgroepen waaraan het verschoningsrecht is toegekend. Een tegengestelde ontwikkeling is echter ook waarneembaar. Dit hangt samen met de inwerkingtreding van de Wet van 27 mei 1999 tot partiéle wijziging van het Wetboek van Strafvordering (herziening gerechtelijk vooronderzoek), Stb. 1999, 243 en de Wet van 27 mei 1999 tot wijziging van het Wetbock van Strafvordering in verband met de regeling van enige bijzondere bevoegdheden tot opsporing en wijziging van enige andere bepalingen (bijzondere opsporingsbevoegdheden), Stb. 1999, 245. Vergelijk hierover Spronken (2001), pag. 434: "Dit komt omdat bij de toepassing van deze (bijzondere, HQ) opsporingsbevoegdhedenniet altijd kan worden voorkomendat vertrouwelijke informatie wordt onderschept en omdat de uitoefening van deze bevoegdhedenna de invoering van de Wet bijzondere opsporingsbevoegdheden in veel gevallen niet meer verbonden is aan de status van verdachteen dus ook advocaten bij deze opsporingsbevoegdheden betrokken kunnen raken. (...) De enige waarborg die wordt geboden tegen de schending van het beroepsgeheim is dat gegevens (...) op grond van artikel $126 a \mathrm{~S}$ Sv onmiddellijk moeten worden vernietigden niet in het procesdossierterechtmogen komen. 


\subsubsection{Verschoningsrecht in de Mededingingswet}

Uit de Mededingingswet, in samenhang met de Algemene wet bestuursrecht, blijkt dat ook in het kader van het toezicht op de naleving van de nationale mededingingsregels door de $\mathrm{NMa}$ alsmede tijdens de onderzoeksfase het recht op verschoning kan worden ingeroepen. Op grond van artikel 5:20 Awb (j 50 en $52 \mathrm{Mw})$ geldt namelijk de in beginsel op een ieder rustende medewerkingsplicht, niet voor hen die 'uit hoofde van ambt, beroep of wettelijk voorschrift verplicht zijn tot geheimhouding, ${ }^{344}$ Daarenboven bepaalt artikel $51 \mathrm{Mw}$ :

Artikel 5:17 van de Algemene wet bestuursrecht (de bevoegdheid tot het vorderen van inzage van zakelijke gegevens en bescheiden, $\mathrm{HQ}$ ) is niet van toepassing op geschriften met betrekking tot de toepassing van de mededingingsregels, gewisseld tussen een ondememing en een advocaat die is toegelaten tot de balie, die zich bij de ondememing bevinden, doch waarop, indien zij zich zouden bevinden bij die advocaat, artikel 5:20, tweede lid, van de Algemene wet bestuursrecht van toepassing zou zijn.

Aldus wordt ten aanzien van advocaten het verschoningsrecht op strafrechtelijk niveau gebracht. Dit verdient als zodanig bijval, maar de expliciete opname in de Mededingingswet van hetgeen in artikel 51 is neergelegd, blijkt wel op een misvatting te berusten. De toenmalig minister van Economische Zaken stelde in de memorie van toelichting bij dit artikel vast dat in "het Nederiandse recht -zowel het bestuursrecht als het strafrecht(...) de geheimhoudingsplicht uitsluitend (geldt) voor documenten, die zich onder de geheimhouder bevinden". Uit hetgeen in de vorige paragraaf is besproken, moge blijken dat dit een onjuiste weergave is van hetgeen in het Nederlandse strafrecht als geldend is aangenomen. Dat er -ondanks deze foutieve veronderstelling- uitdrukkelijk voor is gekozen om zich bij de onderneming bevindend materiaal te beschermen, hangt samen met het streven naar convergentie met het communautaire recht op dit punt. ${ }^{345}$ Over het communautair verschoningsrecht gaat de volgende paragraaf.

\subsubsection{Communautair verschoningsrecht}

Het geschreven communautaire recht kent geen recht op verschoning. Ook hier geldt derhalve weer de vraag of dit recht via jurisprudentiele weg toegang tot het gemeenschapsrecht heeft gevonden. ${ }^{346}$ In haar antwoord op een schriftelijke vraag van het parlementslid

Hiermee wordt echter niet voorkomen dat deze gegevens wel ter kennis van de opsporende instanties komen. Daarbij komt, dat het oordeel over datgene wat geacht wordt onder het verschoningsrecht te vallen in eerste instantie toekomt aan de officier van justitic en niet aan de advocaat zelf of de rechter-commissaris, eenregeling die uit oogpunt van rechtsbeschermingniet evenwichtigis en (daarorn) weinig vertrouwen wekt".

344 Jansen (1999), pag. 38, is van mening dat bij de exceptie op de medewerkingsplicht de kring van geheimhouders groter is dan het geval is bij het verschoningsrecht dat-bijvoorbeeld op grond van artikel 218 WvSv of 8:33 lid 3 Awb-tegenover een rechter mag worden ingeroepen. De reden hiervoot ligt volgens hem in het grotere gewicht van het belang van de waarheidsvinding door een rechter.

345 Volgens De Raat en Widdershoven (2000), pag. 781 zou een zelfde regeling ook haar weg moeten vinden naar de (Vierde Tranche) Awb.

346 Een overbodige luxe zou dit niet zijn, gelet op de verstrekkende bevoegdheid van de Commissic om in beginsel iedere noodzakelijke informatie op te eisen. 
Cousté gaf de Commissie in 1978 te kennen tot op zekere hoogte een verschoningsrecht te erkennen. Na te hebben geconcludeerd dat er geen geschreven bescherming van juridische 'beroepsdocumenten' bestond, verklaarde zij zich bereid

\begin{abstract}
"orn als bewijs van eventuele schendingen van de concurrentieregels van de Gemeenschap geen gebruik te maken van de documenten die een strikt juridisch karakter dragen en zijn opgesteld ten einde rechtshundig advies te verkrijgen of te geven over de vigerende rechtsregeis of die betrekking hebben op de voorbertiding en de organisatie van de verdediging van de betrokken onderneming (....). Treft de Commissie dergelijke documenten aan, dan neemt zij daarvan geen afschrift". 3 "
\end{abstract}

Het standpunt van de Commissie was derhalve dat zij in beginsel kennis mag nemen van informatie die onder de geheimhoudingsplicht van een jurist valt, maar dat zij deze informatie niet tot bewijs van een inbreuk mag gebruiken. Een aanmerkelijk beperktere acceptatie van het verschoningsrecht dan in Nederland het geval is derhalve. Met dit standpunt van de Commissie werd door $\mathrm{AM} \& \mathrm{~S}$ echter geen genoegen genomen toen zij werd geconfronteerd met een communautair kartelonderzoek. ${ }^{348}$ Deze onderneming beriep zich op het verschoningsrecht en bleek niet bereid om documenten die volgens haar onder de reikwijdte van dit recht vielen, in hun geheel aan de commissieambtenaren te tonen. Volgens haar zou de van dit recht uitgaande bescherming te zeer worden aangetast indien de Commissie inzage zou mogen verkrijgen van documenten, waarvan uitendelijk wellicht zou blijken dat zij door het verschoningsrecht beschermd werden. Dat deze documenten dan uiteindelijk niet tot bewijs zouden mogen worden gebezigd, deed volgens de onderneming hieraan niet af, omdat niet van de Commissie verwacht kon worden dat zij die informatie geheel en al buiten beschouwing zou laten bij haar uiteindelijke beslissing omtrent de al dan niet naleving van de communautaire materiële mededingingsregels. De onderneming kwam daarom met een soort compromis, dat haar rechten zou waarborgen en de onderzoeksmogelijkheden van de Commissie niet al te zeer zou frustreren. Dit voorstel kwam er in het kort op neer dat de Commissie werd toegestaan om delen van de documenten in te zien ${ }^{349}$, teneinde te kunnen bepalen of er al dan niet sprake was van vertrouwelijke informatie. Mocht een dergelijke conclusie niet uit de ter inzage gegeven delen kunnen worden getrokken, dan zou de beslissing hieromtrent aan een onafhankelijk persoon moeten worden overgelaten. De Commissie was niet echt enthousiast en verwierp het voorstel, onder meer omdat zij te zeer afhankelijk zou worden van de selectie van de informatie door de onderneming.

Het Hof stelde in zijn arrest expliciet voorop dat de artikelen 11 en 14 Vo 17 zich ook uitstrekken over de correspondentie tussen advocaat en onderneming en dat deze dus onverminderd door de Commissie kan worden opgevraagd. Het Hof voegde hieraan toe dat bij uitsluiting de Commissie bepaalt of en zo ja welke bescheiden aan haar moeten worden overgelegd. Toch zag het Hof ruimte voor het verschoningsrecht, wijzend op

"het in alle Lid-Staten als belangrijk erkende vereiste, dat elke justitiabele de mogelijkheid moet hebben, (in) alle vrijheid een advocaat te raadplegen, wiens beroep het is, onafhankelijk juridisch advies te geven aan eenieder die het behoeft".

$347 \mathrm{~Pb} 1978 \mathrm{C} 188 / 30$.

348 HvJ (155/79) Jur. 1982, 1575 (AM\&S Europe). Zie over dit arrest Brulard en Demolin (1994), pag. 64 e.v..

349 Vanzelfsprekend slechts zover als met het (vermeend) vertrouwelijke karakter verenigbaar zou zijn. 
Zoals zo vaak ging het Hof voor de bepaling van de reikwijdte van het recht ook hier te rade bij de verschoningsregelingen van de afzonderlijke lidstaten en vond als gemeenschappelijke deler een recht op bescherming van de briefwisseling tussen advocaat en onderneming voor zover de

"briefwisseling enerzijds heeft plaatsgevonden in het kader en ten behoeve van de verdediging van de client, en zij anderzijds afkomstig is van een onafhankelijke advocaat, dat wil zeggen een advocaat die niet in dienstbetrekking is bij zijn cliènt". 350

Het communautaire verschoningsrecht ${ }^{351}$, dat werd gekoppeld aan de eerbiediging van de rechten van de verdediging en in mindere mate aan de aard van het beroep van advocaat, biedt bescherming op het niveau van deze gemeenschappelijke deler. Ten aanzien van de eerste voorwaarde, dus dat de briefwisseling betrekking moet hebben op de verdediging van de onderneming, overwoog het Hof nader dat een effectieve bescherming mee moet brengen dat de gehele correspondentie vanaf het begin van de (administratieve) procedure op grond van Verordening 17 onder de bescherming valt. De mogelijkheid werd zelfs geopend om aan die procedure voorafgaande correspondentie onder de reikwijdte van het legal privilege te doen vallen, voor zover deze correspondentie betrekking heeft op het voorwerp van de latere procedure. ${ }^{352}$ Het begrip 'correspondentie' dient niet te restrictief te worden uitgelegd; ook bedrijfsinterne stukken kunnen, voorzover direct verband houdend met de correspondentie van de advocaat, hieronder vallen. ${ }^{35}$ Meer concreet houdt dit in dat de Commissie geen recht van inzage heeft in die documenten die bijvoorbeeld een samenvatting vormen van door of vanwege de advocaat opgestelde brieven of die (met oog op een vergadering binnen de onderneming) een uitwerking of interpretatie van deze inhouden, steeds onder de voorwaarde dat van een nauwe band met de correspondentie van de advocaat blijkt. Niet beschermd daarentegen zijn documenten die bij een grote groep personen binnen of buiten de onderneming bekend zijn, ook al bestaan die documenten onmiskenbaar uit correspondentie tussen een advocaat en een onderneming. In feite heeft de onderneming in die situatie de vertrouwelijkheid zelf prijsgegeven en is er rechtens geen te beschermen belang meer. Gelet echter op de waarde van het verschoningsrecht mag niet te snel worden aangenomen dat deze situatie zich voordoet.

De tweede voorwaarde voor de toepasselijkheid van het verschoningsrecht (de eis van onafhankelijkheid van de advocaat) sluit uit dat adviezen van een intern juridisch adviseur ten aanzien van het communautaire kartelrecht bescherming kunnen genieten. Zoals ook wel in Nederland het geval is, werd als reden hiervoor opgegeven de bijzondere positie van de advocaat als "medewerker bij de rechtspleging, die geheel onafhankelijk

350 Zie in gelijke zin $\mathrm{Pb} 1998 \mathrm{~L}$ 124/60 (VW).

351 Waarbij niet relevant is of de juridische basis voor het vragen dan wel opeisen van de bescheiden die mogelijk onder het 'legal privilege' vallen, gelegen is in artikel 11 of $14 \mathrm{Vo} 17$. In deze zin ook Kerse (1998), pag. 358.

352 Vergelijk ook Kerse (1998), pag. 355: "The existence of the protection is not dependent on there being an investigation under Article 14, nor is the extent of the protection necessarily limited to the scope of any such investigation. A Commission procedure under Regulation 17 or the likelihood of such a procedure is the key factor".

353 GvEA (T-30/89) Jur. 1990, II-163 (Hilti). Zie hierover Fierstra (1991), pag. 701 e.v. en Winckler (1994), pag. 60-63. 
en in het overwegend belang van deze rechtspleging de door zijn cliënt benodigde rechtskundige bijstand moet verlenen" ${ }^{\text {354 }}$, waarbij door het Hof waarde werd gehecht aan de beroepstucht die het ambt van advocaat kent. De advocaat dient overigens te zijn ingeschreven bij de balie van één van de lidstaten. Niet noodzakelijk daarentegen is dat de advocaat zijn beroep uitoefent in hetzelfde land als waar de onderneming gevestigd is: het Hof wilde natuurlijk niet het vrij verkeer van diensten binnen de gemeenschap frustre. ren.

\subsubsection{De procedure}

$\mathrm{Nu}$ het Hof heeft bepaald dat het verschoningsrecht deel uit maakt van het communautaire recht, mag een onderneming inzage weigeren van documenten die aan de genoemde criteria voldoen. De vraag is dan natuurlijk wie bepaalt of het om door het verschoningstecht beschermde informatie gaat. Dat dit niet de onderneming is, hoeft niet te verbazen; een eenvoudig beroep door de onderneming op de vertrouwelijkheid volstaat derhalve niet. ${ }^{355}$ Maar ook de betrokken advocaat heeft in deze niet het laatste woord: het verschoningsrecht komt namelijk -in tegenstelling tot hetgeen het geval is in Nederland- niet hem, maar de onderneming toe. ${ }^{366}$ Het antwoord op de hiervoor gestelde vraag moet dan ook zijn dat steeds op communautair niveau over de vertrouwelijkheid van de informatie wordt beslist. Dienaangaande heeft het Hof in het AM\&S-arrest belangrijke procedureregels bepaald. Indien een onderneming zich op de vertrouwelijkheid van opgeëiste bescheiden beroept, zal zij (zonder de inhoud van deze bescheiden te openbaren) aan de commissieambtenaren gegevens dienen te verstrekken op grond waarvan deze zich over het al dan niet vertrouwelijke karakter van de bescheiden een oordeel kan vormen. ${ }^{357}$ Weigert de onderneming dit, dan mag van commissiewege worden overgaan tot inzage van het betreffende bescheid. Slaagt de onderneming er aan de andere kant in om aan te tonen dat het materiaal vertrouwelijk is, dan vervalt vanzelfsprekend het recht op inzage. Wordt het beroep op de vertrouwelijkheid echter verworpen omdat de overhandigde gegevens de conclusie dat het vertrouwelijk materiaal betreft niet rechtvaardigen, dan betekent dit allerminst een vrijbrief tot het inzien van het materiaal. Er zal dan van de zijde van de Commissie om aanvullend bewijs verzocht moeten worden; voldoet de onderneming niet aan dit verzoek, dan kan haar bij beschikking een boete worden opgelegd. ${ }^{358}$ Wil

354 Van een ondememingsinteme jurist kan klaarblijkelijk een geheel onafhankelijke en objectieve positie niet zonder meer verwacht worden.

355 Vergelijk ook Lasok (1982), pag. 105.

356 Dit houdt verband met het reeds geconstateerde feit dat het communautaire verschoningsrecht niet primair aan het beroep als advocaat, maar aan de eerbiediging van de rechten van de verdediging is gekoppeld. Vergelijk ook Cath (1987), pag. 38. Een en ander brengt mijns inziens met zich dat het niet de advocaat, maar de onderneming is die in het communautaire kartelrecht de bescherming van het verschoningsrecht kan prijsgeven.

357 Als bewijs of althans aanwijzing voor vertrouwelijkheid kan dienen de omstandigheid dat het document bestaat uit een schrijven op officiecl briefpapier van een advocaat. Maar ook in dat geval zou aanvullend het tonen van enig inhoudelijk deel van het schrijven vereist kunnen zijn.

358 De Commissie kan waarschijnlijk de onderneming geen boete opleggen uitsluitend vanwege het feit dat deze een bepaald document achterhoudt met een (gemotiveerd) beroep op het legal privilege. Pas zodra de onderneming is aangezetaanvullend bewijs te leverenen zij dit weigert, behoort bestraffing tot de mogelijkheden. 
de Commissie vervolgens alsnog inzage van de bescheiden bewerkstelligen, dan zal zij deze moeten opeisen via een afzonderlijke beschikking. ${ }^{359}$ De reden voor deze omweg ligt in de bescherming die daaruit voor de onderneming voortvloeit. Deze heeft dan namelijk op grond van artikel 230 EG het recht om tegen de beslissing van de Commissie beroep in te stellen bij het Gerecht. ${ }^{360}$ Dit beslist dan over de vertrouwelijkheid van het opgeěiste materiaal, waarvoor in beginsel noodzakelijk is dat het Gerecht wél op de hoogte wordt gebracht van de inhoud ervan. ${ }^{361}$ Het recht van inzage vervalt indien het Gerecht de mening van de onderneming deelt; is dit niet het geval, dan zullen de gegevens alsnog -op straffe van een boete- overlegd moeten worden. ${ }^{362}$

Evaluerend moet gesteld worden dat het Hof in die zin een adequate bescherming van het verschoningsrecht heeft bewerkstelligd, dat ondernemingen niet gehouden zijn om informatie waarvan zij menen dat zij beschermd wordt door het verschoningsrecht, inhoudelijk aan de Commissie te openbaren, tenzij het Gerecht uiteindelijk beslist dat het verschoningsrecht niet in het geding is. De rol van de advocaat in deze is echter fundamenteel verschillend. In Nederland is in beginsel hij de 'heer van het verschoningsrecht'; aldus wordt zijn oordeel over de al dan niet vertrouwelijkheid gehonoreerd en is het aan hem (en niet aan zijn cliënt) om eventueel het geheime karakter van de informatie prijs te geven. In het communautaire recht beslist over dit laatste de onderneming (dus de 'client') $^{363}$, terwijl over de al dan niet vertrouwelijkheid steeds door hetzij de Commissie hetzij het Gerecht wordt geoordeeld. De nadruk ligt hier in het communautaire recht dan ook meer dan in het Nederlandse recht op bewaking van de doelmatigheid van het onderzoek, waarmee overigens niet gezegd is dat de door het Hof geboden bescherming ontoereikend zou zijn.

359 Voldoende is dat de Commissie inhoudelijk verwijst naar de reeds eerder gegeven (inlichtingen- of verificatie)beschikking, voorzover aanwezig. Ontbreekt deze, dan zal zij in de beschikking nauwkeurig moeten aangeven van welk document zij inzage wenst.

360 Op grond van de artikelen 242 en 243 EG heeft dit beroep geen schorsende werking. De ratio van de door het Hof geïntroduceerde procedure brengt echter met zich dat een verzock van de onderneming om een voorlopige voorziening, door het Gerecht gehonoreerd zal moeten worden, als gevolg waarvan het de Commissie in ieder geval tot de definitieveuitspraakvan het Gerechtomtrent de vertrouwelijkheid van het materiaal, verboden zal zijn om deze in te zien.

361 In deze zin ook Lasok (1982), pag. 107.

362 Het AM\&S-arrest biedt geen duidelijkheid omtrent de vraag wat de Commissie moet doen met informatie die naar haar aard onder het verschoningsrecht valt, maar waarvan zij reeds inhoudelijk kennis heeft genomen. Dit geval kan zich voordoen indien een ondernerning meewerkt aan de infomatieverlening. maar uit onachtzaamheid ook vertrouwelijk materiaal verstrekt. Gezien het belang en de strekking van het verschoningsrecht, zoals dat door het Hof in dit arrest is aanvaard, moet ervan worden uitgegaan dat de Commissie dan die bescheiden niet als bewijs zal mogen gebruiken, ervan uitgaande dat de onderneming inderdaad de vertrouwelijkheid niet heeft willen prijsgeven.

Vergelijk ook Fierstra (1991), pag. 704. 


\section{Kennisneming van stukken en geheimhouding}

"Het recht op stukken is onderdeel van de rechten van de verdediging, met name van het recht op 'fair trial'" ${ }^{364}$ Zonder een volledige interne openbaarheid van (proces)stuk. ken voor degene tegen wie een (bestuurs)strafrechtelijke procedure is gestart, is het recht van verdediging tegen de beschuldigingen niet meer dan een lege huls: wie van een inbreuk wordt 'verdacht', zal (en liefst zo vroeg mogelijk) kennis moeten kunnen nemen van de informatie die in zijn zaak boven water is gekomen en die dus bij de beoordeling van die zaak een rol speelt. Gebeurt dit niet, dan zal van een serieuze mogelijkheid tot verweer tegen de beschuldiging geen sprake kunnen zijn. Het raakt aldus de kern van de notie van een eerlijk proces indien een veroordeling zou volgen op grond van stukken waarvan de 'verdachte' geen kennis heeft kunnen nemen en dus zijn licht niet over heeft kunnen laten schijnen. De vraag die in deze paragraaf centraal staat, is in hoeverre dit recht op interne openbaarheid -mede tegen de achtergrond van het EVRM- in het Nederlandse en communautaire (kartel)recht is gegarandeerd.

\section{I Interne openbaarheid: het Nederlandse recht en het EVRM}

Uit het hierboven weergegeven citaat van Prakken blijkt reeds dat interne openbaarheid een facet van het recht op een 'fair trial' is. Dat blijkt ook uit de Straatsburgse jurisprudentie ten aanzien van artikel 6 EVRM. In de Edwards-zaak overwoog het EHRM:

\footnotetext{
"that it is a requirement of faimess under paragraph 1 of Article $6(\ldots)$ that the prosecution authorities disclose to the defence all material evidence for or against the accused". ${ }^{\text {.6. }}$
}

De verdediging heeft derhalve recht op kennisneming van de volledige (proces)stukken, of dit materiaal nu belastend of ontlastend is. Een vergelijkbaar standpunt heeft ook de ECRM ingenomen in de Mulders-zaak:

\footnotetext{
"The case-files of the co-suspects and the tapes and the recorded telephone conversations that were not selected by the investigating judge, were not a part of the applicant's case-file that was subsequently submitted by the prosecution to the trial judge. The documents submitted by the applicant disclose no appearance of a violation of the principle of equality of arms. It has not been alleged that the prosecution has used material which the applicant was unaware of, nor that the applicant's conviction was based on evidence that he could not challenge". 300
}

Het gaat er dus om dat de 'verdachte' al het voor zijn verdediging redelijkerwijs relevant materiaal ter beschikking heeft gekregen en dat hij niet wordt veroordeeld mede op grond van stukken die aan hem zijn onthouden. Dit is ook het uitgangspunt van het Nederlandse strafrecht, getuige de artikelen 30-34 WvSv, waarin een recht op kennisneming van processtukken is geregeld. De rechter-commissaris (in het gerechtelijk vooronderzoek) en het openbaar ministerie (tijdens het opsporingsonderzoek) kunnen weliswaar op grond van

364 Prakken (1995), pag. 1458.

365 EHRM 16 december 1992 (cursivering HQ). Vergelijk eveneens EHRM 18 maart 1997 (Foucher).

366 ECRM 6 april 1995, NJCM-Bulletin (1995), pag. 830 e.v. (Mulders). 
artikel 30 lid $2 \mathrm{WvSv}$ in het belang van het onderzoek ${ }^{367}$ de kennisneming van bepaalde stukken aan de verdachte en diens raadsman (vergelijk artikel 51 WvSv) onthouden ${ }^{368}$, maar dit is gelet op artikel $33 \mathrm{WvSv}$ slechts een tijdelijke maatregel:

"De kennisneming van alle processtukken in het oorspronkelijk of in afsehrift mag de verdachte niet worden onthouden zodra het gerechtelijk vooronderzoek is gesioten of geèindigd of, indien een gerechtelijk vooronderzoek niet heeft plaatsgehad, zodra de kennisgeving van verdere vervolging of de dagvaarding ter terechtzitting in eerste aanleg aan hem is betekend".

Uiterlijk derhalve vanaf het moment van betekening van de dagvaarding geldt in het Nederlandse strafrecht een recht op (volledige) interne openbaarheid, althans voor zover het de processtukken betreft. ${ }^{369}$ En daar vertoont de wet een leemte, in die zin dat niet is vastgelegd wat onder processtukken moet worden verstaan. De praktijk wijst uit dat dienaangaande moet worden gerelateerd aan het dossier. Gelet op artikel 6 EVRM alsmede op de ratio van de interne openbaarheid moet -in de woorden van Corstens- als processtukken worden aangemerkt: "Alles wat zich in het dossier bevindt en wat zich daarin zou behoren te bevinden" ${ }^{370}$. Terecht overwoog de Hoge Raad dan ook:

"In het dossier dienen te worden gevoegd stukken die redelijkerwijze van belang kunnen zijn hetzij in voor de verdachte belastende hetzij in voor hem ontlastende zin".

Aldus kent het antwoord op de vraag naar de inhoud van processtukken niet alleen een feitelijke maar ook een normatieve $\mathrm{kant}^{372}$, waardoor wordt voorkomen dat het uiteindelijk van het openbaar ministerie respectievelijk de rechter-commissaris afhangt wat als processtuk wordt aangemerkt en dus over welke informatie(dragers) het inzagerecht zich

367 Prakken (1995), pag. 1452, leidt uit het EVRM af dat het belang van het onderzoek geen weigeringvan het verlenen van inzage kan rechtvaardigen van 'die minimale stukken waaruit de aard en reden van de beschuldiging blijken'.

368 Daaronder vallen blijkens artikel 31 WvSv niet de processen-verbaal van de verhoren van de verdachte zelf, van proceshandelingen waarbij de verdachte of diens raadsman aanwezig heeft mogen zijn alsmede van verhoren waarvan de inhoud aan de verdachte reeds volledig is medegedeeld. Voor zover de verdachte inzage in andere stukken is ontzegd, kan deze tegen de daartoe strekkende beslissing op grond van artikel $32 \mathrm{WvSv}$ een bezwaarschrift indienen.

369 Dat er wel onenigheid kan bestaan over de vraag of een processtuk is onthouden, moge bijvoorbeeld blijken uit HR 7 december 1999, NJ 2000, 263 m.nt. JdH. Als er sprake is van een processtuk, dan impliceert dit niet dat aan de verdediging ook in alle gevallen kopielln moeten worden verstrekt van die stukken. Dit zal bijvoorbeeld achterwege kunnen blijven indien de privacy van derden in het geding is. Vergelijk HR 8 februari 1994, NJ 1994, 295, waarin het om video-en geluidsbanden ging waarvan de verdediging wel kennis had kunnen nemen.

370 Corstens (1999), pag. 84. Zie ook Spronken (1999), art. 30, aant. 2 alsmede Prakken (1995), pag. 1454. Deze concludeert naar aanleiding van Straatsburgse jurisprudentie ten aanzien van de inhoud van een strafdossier: "alles wat er is en wat redelijkerwijs een bijdrage kan leveren tot de beantwoording van een van de vragen als bedoeld in de artikelen 348 en 350 Sv",

371 HR 7 mei 1996, NJ 1996, 687 m.nt Sch; HR 21 januari 1997, NJ 1997, 321; HR 21 oktober 1997, NJ 1998, 133 m.nt. 'tH. Vergelijk tevens Arr.-Rb Rotterdam 13 september 1995, NJ 1996, 343 en Arr.-Rb Breda 6 augustus 1997, NJ 1998, 61, waarin niet de inhoud van het dossier doorslaggevend werd geacht, maar nadruk werd gelegd op het belang van de informatie voor de beantwoording van een van de vragen van artikel 348 en 350 WvSv.

372 Zie hierover ook Schalken in zijn noot bij HR 7 mei 1996, NJ 1996, 687. 
in cen concrete zaak uitstrekt. ${ }^{373}$ Bovendien staat de Hoge Raad in feite geen belangenafweging toe waar het de voeging van processtukken in het dossier betreft: alles wat van belang voor de verdediging kan zijn, moet in het dossier worden opgenomen. ${ }^{37} \mathrm{De}$ conclusie moet dan ook zijn dat, ondanks het feit dat de samenstelling van het dossier in de praktijk nog wel eens punt van discussie is ${ }^{375}$, de door de Hoge Raad geformuleerde uitgangspunten recht doen aan het belang dat met interne openbaarheid voor de verdachte is gemoeid.

Dat de Mededingingswet eveneens een regeling omtrent de kennisneming van stukken kent, moge niet verbazen, gelet op artikel 6 EVRM. Artikel $60 \mathrm{Mw}$ eist dat belanghebbenden schriftelijk worden opgeroepen om hun zienswijze naar voren te brengen over het rapport. Aan deze hoorplicht is in het tweede lid de interne openbaarheid gekoppeld:

"Het rapport en alle verder op de zaak betrekking hebbende stukken worden gedurende een periode van ten minste vier weken voor belanghebbenden ter inzage gelegd".

Uit de memorie van toelichting blijkt dat de boetebeschikking uitsluitend gebaseerd mag worden "op stukken die de belanghebbenden hebben kunnen inzien en waarover zijhun zienswijze hebben kunnen geven" ${ }^{376}$ Aldus lijkt de interne openbaarheid gewaarborgd te zijn: van alle stukken die mogelijk relevant zijn voor de (boete)beschikking moet de 'verdachte' onderneming kennis hebben kunnen nemen, als gevolg waarvan hij bij de uiteindelijke boetebeschikking niet voor verrassingen kan komen te staan. Volledige inteme openbaarheid is echter niet gerealiseerd. Dit volgt uit het van toepassing verklaarde artikel 3:11 lid 2 Awb in samenhang met artikel 10 WOB: onder meer bedrijfs- en fabricagegege-

373 Het oordeel van de rechtbank Rotterdam 24 mei 1983, NJ 1983, 577, moet dan ook worden verworpen, aangezienzij stelde dat uit het systeem der wet volgt "dat in het kader van een gerechtelijkvooronderzoek in beslaggenomen c.q. uitgeleverde bescheiden allereerst aan een onderzoek dienen te worden onderworpen, waarna de R-C op grond van de bevindingen van dat onderzoek bepaalt of die bescheiden dienen te worden toegevoegdaan het procesdossier en aldus tot de processtukken gaan behoren. Eerst indien die bescheidenaan het procesdossierzijn toegevoegd, zijn de art. 30 e.v. Sv, daaropvan toepassing".

374 Zie hieromtrent ook Schalken in zijn noot bij HR 7 mei 1996, NJ 1996, 687. Afweging van belangen is wel toegestaan ten aanzien van documenten, niet zijnde processtukken, die bijvoorbeeld voor de behandeling van een verweer relevant zijn. De Hoge Raad heeft overigens geaceepteerddat dossiens niet volledig zijn. In HR 19 december 1995, NJ 1996, 249 m.nt. Sch (Zwolsman) overwoog de Hoge Raad ten aanzien van artikel 152 WvSv dat het achterwege laten van het opmaken van een procesverbaal (dat vervolgens in het dossier moet worden opgenomen) slechts geoorloofd is "ingeval hetgeen door hen (de opsporingsambtenaren, HQ) is verricht of bevonden naar hun, aan toetsing door de officier van justitie onderworpen, oordeel redelijkerwijs niet van belang kan zijn voor enige door de rechter in het eindonderzoek te nemen beshissing". In dat geval zal er wel voorzien moeten zijp in cen adequate verslaglegging die rechterlijke controle mogelijk maakt.

375 Niet alleen omdat de verdediging bijvootbeeld van mening is dat bepaalde stukken ten onrechte buiten het dossier zijn gehouden, maar ook omdat de stukken, en met name dan de processen-verbaal, die wel in het dossier zijn opgenomen, soms onvolledig of onjuist blijken te zijn. Zie hierover Myjer (1997 II), pag. 738-739.

376 TK 1995-1996, 24 707, nr. 3. 
vens die vertrouwelijk aan de overheid zijn meegedeeld, worden niet openbaar gemakkt. $^{3 n}$ Als vertrouwelijke bedrijfs- en fabricagegegevens worden aangemerkt

"gegevens waaruit wetenswaardigheden kunnen worden gelezen of afgeleid over de bedrijfsvoering of het productieproces dan wel over de afzet van producten of de kring van afnemers en leveraneiers", mi

Het lijkt er derhalve op dat een geheim karakter slechts zeer terughoudend aan informatie wordt toegekend. Zolang inderdaad alleen bedrijfsgegevens in de meest strikte zin van het woord niet bekend worden gemaakt, bestaat hiertegen nauwelijks bezwaar, zeker gelet op de gerechtvaardigde belangen van degene op wie de informatie betrekking heeft. Dergelijke gegevens zijn doorgaans niet voor het beoordelen van de (ernst van de) eventuele inbreuk en (dus) voor de verdediging van belang. Waar dit wel het geval zou zijn, mag de informatie niet aan de beschikking ten grondslag worden gelegd. Maar terughoudendheid blijft desalniettemin onverkort geboden; en voor de onderneming ontlastende stukken zullen in geen geval om redenen van geheimhouding buiten beschouwing mogen worden gelaten.

\subsection{Interne openbaarheid: het communautaire kartelrecht $t^{379}$}

In hoofdstuk 2 bleek dat de Commissie in het kader van een communautaire kartelprocedure nauwelijks wordt beperkt ten aanzien van de aard van de door haar te vragen, op te eisen of te verifiëren informatie: in beginsel iedere informatie mag worden verlangd voorzover deze redelijkerwijze noodzakelijk is, althans door de Commissie zodanig wordt geacht te zijn. Een belangrijke uitzondering hierop is in paragraaf 4 besproken: de bescherming van informatie die onder het verschoningsrecht valt. Daarnaast beperkt het nemo tenetur-beginsel de mogelijkheden van de Commissie tot op zekere hoogte, namelijk voor zover het het opeisen van mondelinge informatie betreft. ${ }^{380}$ Dát de Commissie over dermate vergaande bevoegdheden tot gegevensverzameling beschikt, is begrijpelijk én noodzakelijk aangezien zonder voldoende informatie van een adequate taakvervulling door de Commissie op kartelgebied weinig terecht zou komen; en in dat geval zou de verwezenlijking van de doelstellingen van het EG-Verdrag in de verdrukking kunnen komen. Maar keerzijde van deze vérstrekkendheid is dat informatie van ondernemingen die niet voor de 'buitenwereld' bedoeld is, in handen van derden kan geraken. Voorzover deze derden behoren tot de communautaire of nationale kartelautoriteit zal het probleem niet zo groot zijn (en zal het zeker tegen het algemeen belang van handhaving van recht en waarheidsvinding kunnen opwegen), hoewel een onderneming met het oog op de mogelijke consequenties (onder meer in de vorm van boetes) vanzelfsprekend de informatie ook voor deze liefst verborgen zou willen houden. Het probleem treedt meer op de voorgrond ten aanzien van derden die niet tot bovenbedoelde categorie behoren; te denken

377 Hetzelfdegeldt-voorzover in hetmededingingsrechtmogelijkrelevant-indiendoor openbaarmaking de persoonlijke levenssfeer in het gedrang zou komen of onevenredige bevoordeling of benadeling van de betrokkenen of derden dreigt. Over de wijze waarop de NMa met de openbaarheid tot medio 1999 is omgegaan, zie Glazener en Jansen (2000), pag. 22.

378 Besluit d-g NMa 27 september 1999, 1439 (Duni-De Ster).

379 Zie hierover onder meer ook Doherty (1994), pag. 8 e.v..

$380 \mathrm{Zie}$ voor het communautaire nemo tenetur-beginsel paragraaf 3.2. 
valt aan concurrenten, leveranciers of (eind)afnemers, waaronder consumenten. ${ }^{3 i 1} \mathrm{Het}$ kan in beginsel niet zo zijn dat de door ondernemingen -al dan niet vrijwillig-versrekte of anderszins in het kader van een communautaire kartelprocedure in het bezit van de Commissie (of van de nationale kartelautoriteiten, bijvoorbeeld op grond van artifel 10 Vo $17^{362}$ ) gekomen gegevens via de Commissie bij dergelijke die bekend word. Het lijkt dan ook voor de hand te liggen dat de Commissie deze informatie niet 'naar bitten' mag brengen. Maar zo eenvoudig ligt het niet. Er zijn namelijk nog andere belingen in het spel die de openbaarmaking van bepaalde gegevens wél eisen. Te denken vat dan met name aan het belang van een van overtreding van het kartelrecht verdachte onderneming op kennisneming van de tijdens het onderzoek verzamelde stukken, alsmedz aan het belang van een sluitende motivering en van openbaarheid van de procedure. Met tame waar het het eerste belang betreft, kan het niet zo zijn dat in het kader van de boeteprocedure tegen de onderneming materiaal wordt gebruikt waarover zij haar mening niet heeft kunnen geven. Dit zou immers indruisen tegen tal van fundamentele beginselen, waar)nder met name de beginselen van zorgvuldigheid, van hoor en wederhoor, van 'equalty of arms' alsmede -meer algemeen- van fair trial. Dit 'belangenconflict' is door de Raad onder ogen gezien, gelet op de regeling van de artikelen 19-21 Vo 17, waarin ;owel het recht op kennisneming van gegevens als de bescherming tegen openbaarmaking (vaaronder begrepen de bekendmaking aan derden) zijn geconstitueerd. Alvorens op deze artikelen wordt ingegaan, zal eerst aandacht worden besteed aan het helang van geheinhouding binnen de communautaire context.

\subsubsection{Het belang van geheimhouding}

Tenminste drie redenen liggen ten grondslag aan het communautaire verbod op openbaarmaking van gevoelige gegevens. De eerste reden houdt verband met het algemene kartelbeleid. Het is de taak van de Commissie om de doelstellingen van het EG-Verdrag te realiseren en om in dat licht de vrijheid van mededinging en de verdragsconformiteit van het handelen van ondernemers te bewaken. Hiervoor zijn een goed overzicht over de situatie op de communautaire markt en daarmee samenhangend transparantie van deze markt essentieel. Daarom zal een sfeer moeten worden gecreëerd die ondernemingen aanzet tot een zekere mate van openheid en hen stimuleert om -bijvoorbeeld met het

381 En onder omstandigheden lidstaten zelf. Dergelijke omstandigheden deden zich voor in GvEA (T-39/90) Jur. 1991, II-1497 (SEP). De Nederlandse naamloze vennootschap Samenwerkende Elektriciteitsprodukticbedrijvenwerd geconfronteerdmeteen inlichtingenverzoekvan de Commissie waarbijdeze overhandiging van een overeenkomst van SEP met het Noorse Statoil verlangde. Indien de Nederlandse staat als belangrijkste aandeelhouder in de Gasunie, een andere belangrijke contractant van SEP, kennis zou nemen van de inhoud van bedoeld contract, zou dit de toekomstige onderhandelingspositie van SEP met de Gasunie in ernstige mate kunnen beìnvloeden, omdat de Gasunie dan van door SEP ten opzichte van derden gehanteerde leveringsvoorwaarden op de hoogte zou raken.

382 Dit artikel verplicht de Commissie om onverwijld aan de bevoegde lidstatelijke autoriteiten een afschrit te doen toekomen van onder meer de belangrijkste documenten die haar hebben bereikt met het oog op de vaststelling van inbreuken op het communautaire materiele kartelrecht, het geven van een negatieve verklaring of van een beschilkking met betrekking tot een ontheffingsverzock. Onder 'belang: rijkste documenten' moet blijkens de president van het Gerecht in GvEA (T-39/90 R), Jur. 1990, II-649 (SEP) worden verstaan ieder document dat "relevante gegevens bevat in het kader van een onderzoek om een inbreuk op de mededingingsregels vast te stellen". 
oog op het verkrijgen van een ontheffing of in het kader van het aangeven van eigen of andermans kartelgedrag-(hun) gedragingen bij de Commissie te melden. Het is niet bepaald sfeerbevorderend indien potentiële melders moeten vrezen dat de door hen verstrekte informatie door de Commissie openbaar wordt gemaakt en op die wijze ter ore van derden komt, hetgeen te meer bezwarend is indien de informatie een bedrijfsintern en (financieel en economisch) gevoelig karakter heeft. Het verbod op openbaarmaking maakt dat deze vrees ongegrond wordt en dat dus althans op dat punt medewerking van ondernemingen niet in de weg staat. De tweede reden hangt samen met de idee dat openbaarmaking van (bedrijfsgevoelige) informatie met een sanctie voor ondememingen gelijkgesteld kan worden, met name indien derden daardoor inhoudelijk op de hoogte raken van informatie omtrent de marktstrategie, de financiêle positie of de totale casu quo de op de betreffende productenmarkt gerealiseerde omzet van de ondernemingen. Openheid van deze informatie kan aan de ondernemingen ernstige (concurrentiële) schade berokkenen, hetgeen natuurlijk nooit de bedoeling kan zijn. Daarom zal informatie in beginsel geheim dienen te blijven, ook al komt openbaarheid de kartelprocedure ten goede en is het meer in het algemeen van belang dat beschikkingen zo veel mogelijk de gronden vermelden waarop zij berusten. Het systeem van de communautaire controle- en opsporingsbevoegdheden biedt de derde reden voor niet-openbaarmaking. Deze bevoegdheden en zeker die tot inlichtingeninwinning ex artikel 11 Vo 17 vergen van de onderneming een zekere mate van medewerking aan het onderzoek, in die zin dat op ondernemingen een plicht rust tot het verstrekken opgetiste gegevens. Een garantie dat deze gegevens binnen de percelen van de bevoegde autoriteit blijft, zal de animo van ondernemingen om aan deze plicht te voldoen, aanmerkelijk verhogen. Belangrijker nog dan het wegnemen van dit mogelijke obstakel tegen medewerking is dat ondernemingen niet met een beroep op het gevoelige karakter van gegevens verstrekking hiervan rechtens kunnen weigeren: juist omdat informatie -voorzover gevoelig en geheim van aard-niet aan derden bekend zal worden, is de onderneming verplicht ook deze ten volle aan de Commissie ter inzage te geven. De Commissie mag dan ook "in zo ruim mogelijk mate en zonder dat de ondernemingen hun medewerking mogen weigeren, de (noodzakelijke) gegevens" inwinnen. ${ }^{383}$ In die zin levert het verbod op openbaarmaking een belangrijke bijdrage aan het onder$z^{20 e k}{ }^{384}$ en wordt eens te meer aangetoond dat een grotere rechtsbescherming allerminst automatisch de doelmatigheid van de handhaving aantast. Het tegendeel is hier eerder het geval.

Geheimhouding is dus zonder meer van grote importantie. Hieraan wordt in Verordening 17 recht gedaan doordat een verbod op openbaarmaking geldt en wel ten aanzien van twee verschillende categorieěn gegevens: gegevens die 'naar hun aard onder de geheimhoudingsplicht' vallen (artikel 20) en gegevens die gerekend moeten worden tot de zakengeheimen (expliciet genoemd in de artikelen 19 en 21). Deze artikelen en de reikwijdte van de bescherming die zij bieden, komen in de volgende paragrafen aan de orde. Allereerst zal op artikel 20 Vo 17 worden ingegaan.

$383 \mathrm{HvJ}$ (85/76) Jur. 1979, 512 (Hoffmann-La Roche). Het Hof spreckt hier overigens van de waarborging van de "met eerbiediging van het zakengeheimsamenhangendebelangen"; aangenomenmag worden dat artikel 20 door het Hof niet beperkt wordt tot de categorie 'zakengeheimen'.

384 In dezelfde zin Joshua (1994 I), pag. 69. 


\subsubsection{Informatie die naar haar aard onder de geheimhoudingsplicht valt}

'Onverminderd hetgeen in de artikelen 19 en 21 is bepaald' mag informatie die naar haar aard onder de geheimhoudingsplicht valt niet openbaar worden gemaakt. Dit blijkt met zoveel woorden uit artikel 20 lid 2 Vo 17, dat zich tot de Commissie, tot de autoriteiten van de lidstaten ${ }^{385}$ alsmede tot hun personeelsleden en functionarissen richt. Het doet niet ter zake van wie die informatie afkomstig is: iedere onderneming, of zij nu verdacht wordt van overtreding van de artikelen 81 of $82 \mathrm{EG}$, om ontheffing van het kartelverbod heeft verzocht of een klacht wegens vermeend kartelgedrag heeft ingediend, wordt tegen de openbaarmaking van de door haar verstrekte informatie beschermd. Dit wijst op een ruime geheimhoudingsplicht, hetgeen ook recht zou doen aan bovengenoemde belangen. Met name de vaagheid van de zinsnede 'informatie die naar haar aard onder de geheimhoudingsplicht valt' voorkomt echter dat enkel aan de hand van de tekst van artikel 20 Vo 17 met zekerheid de exacte omvang van de reikwijdte kan worden bepaald. Enig houvast bij de beantwoording van de vraag welke informatie naar haar aard moet worden geheimgehouden, biedt artikel $287 \mathrm{EG}$, dat de algemene geheimhoudingsplicht voor gemeenschapsfunctionarissen regelt. Op grond van dit artikel is het onder meer de (voormalig) ambtenaren en personeelsleden van de Gemeenschap verboden 'de inlichtingen die naar hun aard vallen onder de geheimhoudingsplicht en met name de inlichtingen betreffende de ondernemingen en hun handelsbetrekkingen of de bestanddelen van hun kostprijzen' openbaar te maken. ${ }^{386}$ Deze opsomming is verre van limitatief en de groep van inlichtingen die naar hun aard onder de geheimhoudingsplicht vallen, wordt niet wezenlijk geconcretiseerd. Veel wijzer worden wij hiervan dan ook niet. Wel biedt de aard van de geheimhoudingsplicht enige helderheid, in die zin dat hieruit voortvloeit dat zij in ieder geval niet algemeen bekende, althans eenvoudig te achterhalen gegevens of gegevens met betrekking tot welke het geheime karakter reeds door de onderneming zelf is prijsgegeven, bestrijkt. ${ }^{387}$ Maar ook deze negatieve benadering maakt nog steeds niet duidelijk om welke informatie het wél gaat. Om deze vraag te kunnen beantwoorden, moet naar mijn mening worden teruggegrepen naar de ratio van artikel 20 lid 2 Vo 17. Zoals gezegd houdt de geheimhouding voor cen belangrijk deel verband met de ruime

385 Aldus de president van het Gerecht in zijn SEP-beschikking volgt uit het tweede lid van artikel 20 Vo 17 dat de autoriteit een document dat 'zakengeheimen' bevat "niet aan een andere nationale instantic (mag) doen toekomen, noch (...) het voor een ander doel (mag) gebruiken dan voor het onderzock dat $(.$.$) is ingesteld". Over zakengeheimen zie nader paragraaf 5.2.4.$

386 Uit GvEA (T-62/98) n.n.g. (Volkswagen) blijkt dat het 'lekken' van informatic aan de pers over een nog te nemen en aan de onderneming bekend te maken beschikking een schending van dit artikel oplevert. Volkswagen had bij deze conclusie echter geen baat (behalve dan wellicht de genoegdoening) omdat het Gerecht aansloot bij de vaste jurisprudentie op grond waarvan een dergelijke schending slechts nietigverklaring kan meebrengen indien zij invloed had op de inhoud van de beschikking. Aangezien dat hier niet zo was (en dat zal in zijn algemeenheid niet snel het geval zijn), werd het door de onderneming aangevoerde middel alsnog afgewezen.

387 Debruyne (1992), pag. 62/63. Dit kan het geval zijn indien een aanzienlijk aantal personen binnen de onderneming op de hoogte van de gegevens is of de onderneming de gegevens zelf aan externe derden. Tot deze derden mogen overigens niet gerekend worden die personen of instellingen die de onderneming juridische bijstand verlenen of die op financieel gebied de onderneming bijstaan (men denke aan banken, accountants en dergelijke). Evenmin wordt het geheime karakter en daarmee de bescherming opgegeven indien een onderneming gegevens aan haar beroepsvereniging meedeelt: zie HvJ (209-215 en 218/78) Jur. 1980, 3239 (Heintz van Landewyck e.a.). 
bevoegdheden tot het inwinnen van inlichtingen: het in artikel 20 lid 2 Vo 17 bepaalde kan in dit licht worden aangemerkt als een compensatie voor de ruime inlichtingenverplichtingen die in Verordening 17 zijn neergelegd. ${ }^{3 i s}$ Vanuit deze invalshoek benaderd, is niet zozeer de aard van de gegevens die bij de Commissie bekend zijn, bepalend voor de omvang van de geheimhoudingsverplichting, als wel de wijze waarop en het kader waarin de gegevens zijn verkregen. Het enkele feit dat de informatie in het kader van een kartelprocedure is verkregen, is voldoende om deze informatie tegen mededeling aan derden en openbaarmaking te beschermen, waarbij van geen importantie is of de informatie objectief beschouwd als 'geheim' moet worden aangemerkt. ${ }^{389} \mathrm{De}$ conclusie moet dan ook luiden dat onder de geheimhoudingsplicht van artikel 20 lid 2 Vo 17 valt: alle informatie die is verkregen in het kader van een communautaire kartelprocedure, met uitzondering van die welke reeds bekend is bij of (eenvoudig) beschikbaar is voor een breder publiek. ${ }^{390}$

Het belang dat aan de geheimhoudingsplicht -klaarblijkelijk ook door de Nederlandse overheid- wordt toegedicht, wordt onderstreept door de reeds in hoofdstuk 2 besproken Wet Uitvoering EG-mededingingsverordeningen. Artikel 11 van deze wet luidt:

I. Artikel 272 van het Wetboek van Strafrecht is mede van toepassing op een ieder, die betrokken is bij de uitvocring van een van de EG-mededingingsverordeningen, voor zover het gegevens betreft, die betrekking hebben op een of meer in Nederland gevestigde ondememingen of ondernemersverenigingen en ten aanzien waarvan voor hem een verplichting tot geheimhouding voortvloeit uit die verordening en voor zover de toepasselijkheid van voornoemd artikel niet reeds uit cen andere wettelijke bepaling voortvloeit.

2. De Nederlandse strafwet is ook toepasselijk op een ieder die zich buiten Nederiand schuldig maakt aan overtreding van artikel 272 van het Wetboek van Strafrecht en ten aanzien van wie niet reeds artikel 5 , eerste lid, onder $1^{\circ}$, van dat wetboek geldt, voor zover deze overtreding bestaat uit het handelen in strijd met de in het eerste lid bedoelde verplichting.

Opzettelijke schending van de geheimhoudingsplicht van artikel $20 \mathrm{Vo} 17$ is (voor zover het althans gegevens betreft die betrekking hebben op een in Nederland gevestigde onderneming) in Nederland strafbaar gesteld als misdrijf waarop een maximumstraf staat van én jaar gevangenisstraf of een geldboete van de vierde categorie (vijfentwintigduizend gulden). ${ }^{391}$ Het belang van het tweede lid ligt met name erin dat Nederland ook rechtsmacht heeft ten aanzien van degene die zich als niet-Nederlander buiten Nederland schuldig maakt aan een inbreuk op artikel $272 \mathrm{WvSr}$ voorzover de verplichting tot geheimhouding uit het communautaire mededingingsrecht volgt. Deze uitbreiding, die impliceert dat ook 'buitenlandse' commissieambtenaren strafrechtelijk kunnen worden vervolgd wegens

388 Vergelijk de conclusie van Advocaat-Generaal Lenz bij HvJ (53/85) Jur. 1986, 1977 (AKZO Chemie).

389 Ehlermann (1995), pag. 20, stelt terecht dat in beginsel "all documents received by the Commission pursuant to its powers under Regulation No. 17 should be treated as confidential".

390 Joshua (1994 I), pag. 70: "All that is required for Article 20(2) is that (1) the information is within the scope of the Regulation so that there is a link between it and the Commission's functions and (2) it is not in the public domain". In vergelijkbare zin Kerse (1998), pag. 360.

391 De Uitvoeringswet Kartelverordening 17 kende cen eigen strafbepaling voor de opzettelijke schending van de geheimhoudingsplicht voor zover de informatie betrekking had op een in Nederland gevestigde onderneming. Een inbreuk, gekwalificeerdals misdrijf, kon worden bestraft met een gevangenisstraf van ten hoogste één jaar of een maximale geldboete van zesduizend gulden. 
schending van de geheimhoudingsplicht ${ }^{392}$, werd nodig geacht gelet op het ontbreken in het communautaire recht van directe consequenties aan inbreuken op artikel $20 \mathrm{~V}_{0}$ $17 .{ }^{393}$ Van een onbeperkt vertrouwen in de 'Brusselse' ambtenaren getuigt deze strafbaarstelling niet.

De ruime geheimhoudingsplicht komt, zoals gezegd, tegemoet aan zowel het recht van ondernemingen op niet-openbaarmaking van materiaal als de doelmatigheid van het onderzoek (omdat ondernemingen die zich op het gevoelige karakter van de informatie willen beroepen, de wind uit de zeilen wordt genomen). Er is echter ook een voor de hand liggende keerzijde aan deze plicht. Het moge duidelijk zijn dat zij de doelmatigheid van het onderzoek ook kan aantasten, daar zij er in beginsel aan in de weg staat dat de vergaarde informatie -bijvoorbeeld ter verifiëring - in het kader van een onderzoek aan derden wordt voorgelegd. ${ }^{394}$ Bovendien brengt nakoming van deze plicht de positie van de van overtreding van het kartelrecht verdachte onderneming in het gedrang, namelijk indien zij ertoe leidt dat niet al het door de Commissie verzamelde relevante materiaal, de onderneming onder ogen komt.

Geheimhouding tegenover interne openbaarheid derhalve, waarbij laatstgenoemd belang per definitie moet wijken? Het tweede lid van artikel 20 Vo 17 zorgt ervoor dat het zo'n vaart niet loopt, omdat wel steeds de artikelen 19 en 21 Vo 17 moeten worden gerespecteerd. Wat deze artikelen inhouden wordt hierna besproken.

\subsubsection{Hoorplicht en bekendmaking}

Artikel 19 Vo 17, in samenhang met Verordening $99 / 63^{395}$, bevat het recht van hoor en wederhoor: alvorens een (boete)beschikking ${ }^{3 \%}$ te geven, moet de Commissie de ondernemingen ${ }^{397}$ in de gelegenheid stellen hun standpunt kenbaar te maken 'ter zake van de punten van bezwaar welke de Commissie in aanmerking heeft genomen'. ${ }^{398}$ Dit voor

$392 \mathrm{Zij}$ het dat de commissieambtenaren in beginsel onschendbaar zijn.

393 MvT TK 1995-1996, 24 617, nr. 3.

394 Men denke bijvoorbeeld aan confrontatie van de 'verdachte' met de door derden verstrekte gegevens, aan het voorleggen van informatie aan derden ter verifiēring ervan en dergelijke. Bedoeld belang geldt zowel voor een onderzoek naar een eventuele inbreuk als voor een behandeling van een ontheffingsaanvraag.

395 Verordening van de Commissie 99/63 van 25 juli 1963 betreffende het horen van belanghebbenden en derden overeenkomstig artikel 19, leden 1 en 2, van Verordening Raad no. 17, $\mathrm{Pb} 2269 / 63$.

396 Hetzelfde geldt met betrekking tot beschikkingen inhoudende onder meer een negatieve verklaring of een ontheffing ex artikel 81 lid 3 EG.

397 Ten aanzienvan derden is bepaald dat zij gehoord kunnen of -in geval zij hierom verzoeken en hierbij een redelijk belang hebben- moeten worden. Op grond van het derde lid is de Commissie gehouden om, indien zij voornemens is om een verzoek om een negatieveverklaring of tot ontheffing te honoreren, voorafgaand aan een beschikking het essentiele gedeelte van het verzock bekend te maken teneinde derde-belanghebbenden de gelegenheid te bieden om te reageren.

398 Dat impliceert tevens dat de onderneming genoeg tijd moet worden gegund om haar verdediging voor te bereiden. Zie daarover GvEA (T-62/98) n.n.g. (Volkswagen). Interessant is ook dat de Cormmissie in de punten van bezwaar duidelijk moet aangeven aan wie zij voornemens is een boete op ts leggen. In HvJ (C-395 en 396/96 P) n.n.g. (Compagnie maritime belge transports e.a.) vernietigde 
een eerlijk proces en voor een zorgvuldige voorbereiding van beslissingen onmisbare recht om gehoord te worden en om zich tegen een 'aanklacht' te kunnen verdedigen, heeft slechts dan enige reële waarde indien de onderneming $a l$ het relevante materiaal (belastend én ontlastend) dat door de Commissie is verzameld en waarop de aanklacht is gebaseerd, inhoudelijk kent. ${ }^{399}$ Het Gerecht overwoog dan ook terecht dat

\begin{abstract}
"de procedure inzake toegang tot het dossier in mededingingszaken bedoeid (is) om degenen tot wie de PvB is gericht, in staatte stellen kennis te nemen van de bewijselementen in het dossier van de Commissie, opdat zij op basis van deze elementen een dienstig antwoord kunnen geven op de conclusies waartoe de Commissie in de PvB is gekomen. De toegang tot het dossier is dus èen van de procedurele waarborgen ter bescherming van de rechten van de verdediging, in het bijzonder ter verzekering van de daadwerkelijke uitoefening van het recht te worden gehoord" ${ }^{*}$
\end{abstract}

Deze noodzaak van openbaarheid geldt dus mede voor informatie die onder de geheimhoudingsplicht valt. Artikel 20 Vo 17 gaat er dan ook van uit dat de geheimhoudingsplicht, hoe ruim ook, opzij kan worden gezet ten gunste van het recht op hoor en wederhoor: "The public interest in proper enforcement and its concomitant right to be heard obviously takes precedence (...) over any possible interest in maintaining confidentiality" ${ }^{401}$ Dit gaat echter niet zo ver dat geheimhouding steeds in volle omvang voor het recht om gehoord te worden, moet wijken. Er zal steeds een afweging tussen beide zeer legitieme belangen moeten worden gemaakt, waarbij de uitkomst in het voordecl van de plicht tot geheimhouding kan uitvallen. ${ }^{402}$ Waar het boeteprocedures betreft, zal dit echter eerder uitzondering dan regel (mogen) zijn. Daarvoor zijn het recht op een adequate verdediging, op hoor en wederhoor en op interne openbaarheid te precair. Naar mijn mening zal hooguit materiaal dat voor de verdediging redelijkerwijs van geen belang is en dat dus geen andere licht op (aspecten van) de aanklacht kan werpen, aan ondernemingen mogen worden onthouden.

Tot op zekere hoogte speelt een vergelijkbaar probleem bij de bekendmaking van beschikkingen zoals die in artikel 21 Vo 17 is geregeld, zij het dat deze verplichting niet geldt voor boetebeschikkingen. ${ }^{403}$ Dit is wel het geval ten aanzien van beschikkingen ex artikel 2 Vo 17 (verlenen negatieve verklaring), artikel 3 Vo 17 (verplichting tot beëindiging

het Hof een arrest van het Gerecht waar het de boetes betrof omdat het Gerecht had gedwaald "ten aanzien van het recht door te oordelen, dat de Commissie gerechtigd was, aan de leden van Cewal individuele geldboeten op te leggen waarvan het bedrag was bepaald aan de hand van de mate van hun betrokkenheid bij de litigieuze gedraging, terwijl de mededeling van de punten van bezwaat enkel tot Cewal was gericht" (cursivering HQ).

399 Ottervanger, Steenbergen en Van der Voorde (1998), pag. 14: "Access to the Commission's files is a procedural safeguard to ensure that the right to be heard can be exereised effectively". Ook dan pas is er voldaan aan het beginsel van equality of arms.

400 GvEA (T-10-12, 14 en 15/92) Jur. 1992, Il-2667 (Cimenteries CBR), herhaald in GvEA (T-30/91) Jur. 1995, II-1775 (Solvay).

401 Joshua (1994 1), pag. 70.

402 Vergelijk Kerse (1998), pag. 365: "Even where disclosure of confidential information is permissible, the Commission will have to determine whether the public interest is best served by enforcing the competition rules at the expense of the disclosure of such material". Dit kan ook worden afgeleid uit HvJ (85/76) Jur. 1979, 512 (Hoffmann-La Roche).

403 Dat laat onverlet dat deze-alleen al vanwege de generaal-preventieve werking-wel gepubliceerd plegen te worden. Het belang van publiciteit wordt ook door De Roos (1975), pag. 23, benadrukt. 
kartelinbreuk), artikel $6 \mathrm{Vo} 17$ (verlenen ontheffing van het kartelverbod), artikel $7 \mathrm{~V}_{0}$ 17 (termijnbepaling toepasselijkheid verbod artikel 81 lid 1 EG ten aanzien van ten ijde van het inwerkingtreden van Vo 17 bestaande overeenkomsten) en artikel 8 Vo 17 (velenging termijn ontheffing of intrekking respectievelijk wijziging ontheffingsbeschikking). Ook hier kan geheimhouding conflicteren met andere belangen zoals openheid vas de procedure en controleerbaarheid van het optreden van de Commissie, zodat zij in een concrete situatie voorrang zal moeten verlenen aan een van beide.

\subsubsection{Zakengeheimen}

Zakengeheimen, als species van het genus 'gegevens die naar hun aard onder de geheimhoudingsplicht vallen', nemen in Verordening 17 een bijzondere positie in: zij vornen als het ware de uitzondering op de uitzondering. Artikel 19 lid 3 Vo 17 alsmede arikel 21 lid 2 Vo 17 verplichten de Commissie om bij de bekendmaking van het verzoek tot verkrijging van ontheffing of een negatieve verklaring respectievelijk bij de bekendmating van de in artikel 21 lid 1 Vo 17 genoemde beschikkingen rekening te houden "met het rechtmatige belang van de ondernemingen dat hun zakengeheimen niet aan de openbaar reid worden prijsgegeven". De boetebeschikking wordt hier niet genoemd. Hieraan mott in

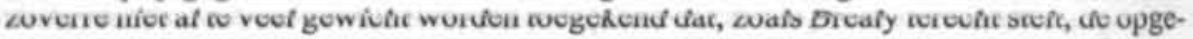
somde beschikkingen "merely examples of a general principle of Community law to protect confidential information" vormen. ${ }^{404}$ Dit impliceert dat ook in het kader van een boeteprocedure bijzondere voorzichtigheid moet worden betracht ten aanzien van gegevens die als zakengeheim gelden. Er kan echter niet aan voorbij worden gegaan dat Verordening 17 dit niet met zoveel woorden eist. Hieruit moet mijns inziens worden afgeleid dat de Raad de interne openbaarheid in de contradictoire procedure in beginsel niet heeft willen 'opofferen' voor bescherming van zakengeheimen. Voor zover zakengeheimen geen relevante informatie voor de verdediging bevat, kan de Commissie er dan ook voor opteren om de gegevens niet bekend te maken; waar dat wel het geval is, zou de Commissie de openbaarheid voorrang moeten geven. ${ }^{405}$ Vanuit de optiek van bescherming van zakengeheimen hoeft dit niet voor veel problemen te zorgen, althans voor zover het predicaat 'zakengeheim' wordt gereserveerd voor de beperkte groep gegevens waarvoor het ook oorspronkelijk is bedoeld ${ }^{406}$ : gegevens die gelet op hun strikt zakelijke aard en inhoud -dit in tegenstelling tot hetgeen het geval is ten aanzien van informatie die

404 Brealy (1995), pag. 68. Dit is door het Hof bevestigd in het later nog te bespreken HvJ (53/85) Jur. 1986, 1965 (AKZO Chemie en AKZO Chemie UK).

405 De mogelijkheid hiertoe wordt ook door Verordening 17 geboden, aangezien de bescherming van zakengeheimenmeer in het algemeenniet absoluut is. Dat blijkt reeds uit de zinsnede "wordt rekening gehouden met het rechtmatigebelang", en wordt bevestigd in de hierna nog te bespreken Mededeling van de Commissie over de toegang tot het dossier. Anders: Brealy(1995), pag. 75: "Under no circumstance can business secrets be disclosed".

406 Dit moge alleen al blijken uit het feit dat het belang van geheimhouding van zakengeheimen behoudens uitzonderlijke omstandigheden niet hoeft te wijken voor andere (conflicterende) fundamentele belangen. Het kan dan niet anders zijn dan dat deze groep klein is en in ieder geval aanmerkelijk kleiner dan de groep gegevens die naar hun aard onder de geheimhoudingsplicht vallen. 
onder de geheimhouding valt- bescherming verdienen. ${ }^{407}$ Dan immers conflicteert geheimhouding in beginsel niet met de interne openbaarheid omdat het gegevens betreft die over het algemeen voor de verdediging (zoals ook reeds is gesteld naar aanleiding van de bescherming van bedrijfs- en fabricagegegevens in het kader van een procedure wegens vermeende overtreding van de Mededingingswet), redelijkerwijs van geen waarde zijn. ${ }^{408}$ Mocht door geheimhouding toch schade voor de interne openbaarheid dreigen, dan ontstaat een probleem dat, zoals gezegd, mijns inziens in ieder geval niet ten koste van de verdediging zou mogen worden opgelost. Maar omdat het communautaire recht een belangenafweging toestaat en de facto hiertoe zelfs verplicht, rust op de Commissie in dezen geen eenvoudige taak. Hoe zij en de communautaire rechters hiermee omgaan, wordt in de volgende paragraaf beschreven.

\subsubsection{Interne openbaarheid: de communautaire praktijk}

De communautaire praktijk toont aan dat de moeilijke verhouding tussen geheimhouding en openheid niet louter een studeerkamerprobleem is. Er worden door ondernemingen regelmatig vraagtekens gezet bij de wijze waarop de Commissic dit probleem oplost en zeker niet steeds zonder succes. Mede daarom heeft de Commissie een Mededeling over de toegang tot het dossier ${ }^{409}$ het licht doen zien, waarin zij aangeeft hoe zij 'de verplichting tot eerbiediging van de rechten van de verdediging en die van de bescherming van de vertrouwelijke gegevens van de ondernemingen' met elkaar poogt te verzoenen. ${ }^{410}$ Uitgangspunt is dat de Commissie ondernemingen toegang moet verlenen tot alle documenten van het dossier 'met uitzondering van de documenten die zakengeheimen van andere ondernemingen bevatten, de interne documenten van de Commissie en andere vertrouwelijke informatie'. ${ }^{411}$ Dat wil echter nog niet zeggen dat zakengeheimen ${ }^{412}$

407 Kerse (1998), pag. 364: "It is protected by virtue of its very nature, not just the circumstances in which it is obtained by the Commission", Joshua (1994 I), pag. 75, voert drie voorwaarden aan waaraan volgens hem moet zijn voldaan, wil de informatie kunnen worden bescherma 'by virtue of its very nature': "(1) it must be guarded as a secret by the holder (...); (2) the holder must have a legitimate interest in its being kept secret in the proceedings; (3) serious competitive injury is likely to result from disclosure to a competitor".

408 Voor alle duidelijkheid zij er hier nogmaals op gewezen dat het geheime karaktervan een document, zelfs al bevat dit onmiskenbaar zakengeheimen, geen legitieme reden voor de onderneming kan zijn om aan de Commissie te weigeren kennis te nemen van de inhoud van dat document; de geheimhouding en de bescherming van het zakengeheim ziet slechts op de bekendmaking (of liever het verbod daarop) door de Cormmissie of nationale kartelautoriteiten en impliceent juist dat kennisneming niet kan worden geweigerd.

$409 \mathrm{~Pb} 1997$ C 23/3 (Mededeling van de Commissie inzake de interne procedureregels voor de behandeling van verzoeken om toegang tot een dossier bij de toepassing van de artikeien 85 en 86 van het EG. Verdrag, van de artikelen 65 en 66 van het EGKS.Verdrag en van Verordening nr. 4064/89 van de Raad).

410 Deze Mededeling scherpt haar tot dan toe gevoerde en in het Twaalfde verslag over het mededingingsbeleid bekend gemaakte beleid an en brengt dit beleid in overeenstemming met de jurisprudentie van het Hof en het Gerecht.

411 GvEA (T-7/89) Jur. 1991, II-1711 (Hercules Chemicals), bij welk arrest de Commissie uitdrukkelijk aansluit. 
en andere vertrouwelijke informatie ${ }^{413}$ dus niet openbaar worden gebracht. ${ }^{414}$ De Commissie stelt in haar Mededeling namelijk:

"Wanneer in zakengeheimen het bewijs van een inbreuk besloten ligt of wanneer deze cen onderneming daarvan kunnen vrijpleiten, moet de Commissie het belang van de bescherming van vertrouwelijke gegevens en het openbaar belang, dat erin bestaat dat aan inbreuken op de mededingingsregels een einde wordt gesteld, verzoenen met de rechten van de verdediging"."1s

Op de Commissie rust derhalve een plicht tot belangenafweging. Hierbij zal zij zich ervan bewust moeten zijn dat geheimhouding voor de handhaving repercussies kan (maar niet noodzakelijk hoeft te) hebben. ${ }^{416}$ Reeds lang staat het Hof namelijk op het standpunt dat het de Commissie niet is toegestaan

"ten laste van de betrokken onderneming omstandigheden of stukken in aanmerking (te nemen) welke zij meent niet te mogen openbaar maken, wanneer het de ondememing door de weigering van zodanige openbaarmaking moeilijk kan worden gemaakt haar standpunt kenbaur te maken met betrekking tot de toedracht en het belang der omstandigheden, de stukken of de conclusies welke de Commissic eraan verbindt". "11?

Het niet ter inzage geven van stukken leidt derhalve -evenals in Nederland- tot bewijsuitsluiting. ${ }^{41 \mathrm{~K}}$ Informatie waarvan de verdediging geen kennis heeft kunnen nemen, mag niet tegen haar gebruikt worden, hetgeen onder omstandigheden de Commissie voor bewijs-

412 De omschrijving die de Commissie van zakengeheimengeeft, is helaas nietszeggend: 'gegevens ten aanzien waarvan een onderneming om bescherming als 'zakengeheim' heeft gevraagd en welke door de Commissie als dusdanig worden erkend'. Wel geeft zij enige voorbeelden (zoals fabricagegeheimen en -procédés, leverantiebronnen, marktaandelen, commercieel beleid), waaruit blijkt dat het een relatief beperkte groep informatie betreft.

413 Zoals "gegevens die de identiteit kunnen onthullen van degenen die informatic hebben verstrekt en ten aanzienvan de partijen anoniem wensen te blijven, alsook bepaaldetypen van aan de Commissie medegedeelde inlichtingen waarbij het voorbehoud werd gemaakt dat de vertrouwelijke aard ervan dient te worden gečerbiedigd".

414 Dat geldt wel voor de interne documenten van de Commissic, die volgens haar gelet op hun aard per definitie geen relevantie voor de verdediging hebben. Gedacht moet bijvoorbeeld worden aan raadplegingen van andere diensten van de Commissie over de zaak, werkdocumenten en contracten inzake technische bijstand.

415 Hetzelfde geldt met betrekking tot andere vertrouwelijke documenten.

416 De Commissie noemt in haar Mededeling aspecten die zij bij haar afweging moet beoordelen. Het betreft 1 . de relevantievan de gegevens voor het al dan niet bestaan van de inbreuk; 2 . de bewijskracht ervan; 3. de onontbeerlijke aard ervan; 4. de graad van gevoeligheid ervan en 5. de ernst van de inbreuk.

417 In vergelijkbare zin reeds HvJ (322/81), Jur. 1983, 3499 (Michelin); de Commissie mocht de gegevens die zij op grond van artikel 20 lid 2 niet bekend had gemaakt "niet aan haar beschikking ten grondslag leggen, in zover de niet-openbaarmaking ervan (de onderneming) in de mogelijkheid beknotte haar standpunt kenbaar te maken inzake de juistheid of de draagwijdte van deze inlichtingen of de door de Commissie eraan verbonden conclusies". Zie hierover Kerse (1995 I), pag. 61-62.

418 Bedacht moet dienaangaande worden dat veelal volstaan zal kunnen worden met het schrappen van bepaalde gevoelige gegevens in de bescheiden. Aan de noodraak tot bewijsuitsluiting van de geschrapte delen doet dat echter niets af. 
problemen kan plaatsen. ${ }^{419}$ Dit laat echter onverlet dat de meest fundamentele rechten van de verdediging dwingend tot dit standpunt van het Hof hebben geleid. Deze rechten eisen tevens dat nooit mogelijk ontlastend materiaal wordt achtergehouden. ${ }^{420}$ Alleen al tegen de achtergrond van het beginsel van 'equality of arms' moet in dat verband worden benadrukt dat het niet zo kan zijn dat de 'vervolgende instantie' (in casu dus de Commissie) bij uitsluiting kan beslissen over de vraag wat wel en wat niet mogelijk ontlastend voor de verdediging is. Daarom overwoog het Gerecht ook terecht:

"In het kader van de in verordening $\mathrm{nr} .17$ geregelde procedure op tegenspraak is het (...) niet alleen aan de Commissie om uit te maken, welke documenten voor de verdediging dienstig zijn. Wanneer het immers (...) gaat om moeilijke en ingewikkelde economische beoordelingen, moet de Commissie de raadslieden van de betrokken onderneming de mogelijkheid geven, de eventueel relevante stukken te onderzoeken teneinde de bewijskracht ervan voor de verdediging te beoordelen", 21

Zou dat anders zijn, dan

"zouden de rechten van de verdediging waarover verzoekster tijdens de administratieve procedure beschikt, te zeer worden beperkt ten opzichte van de bevoegdheden van de Commissie, die de functie van autoriteit die kennis geeft van de bezwaren, dan zou cumuleren met die van beslissende autoriteit, met een verdergaande kennis van het dossier dan de verdediging". ${ }^{22}$

Het is derhalve cruciaal dat de Commissie in dezen een -voor zover redelijkerwijs verenigbaar met de geheimhoudingsplicht- open en controleerbaar beleid voert, teneinde het de betrokken onderneming mogelijk te maken om te bepalen of het materiaal voor haar verdediging mogelijk relevant is en teneinde de communautaire rechter in staat te stellen om het oordeel van de Commissie te toetsen. Het bovengeciteerde oordeel van het Gerecht is voor de Commissie aanleiding geweest om haar beleid in dezen aan te scherpen. In haar Mededeling geeft zij aan steeds een limitatieve lijst van documenten op te stellen die het gehele onderzoeksdossier omvat en waarop is aangegeven in hoeverre de Commis-

419 Noodzakelijk is dat niet. Over het algemeen zal de Commissie immers over meer bewijzen beschikken. Maar dat laat onverlet dat het zeer wel mogelijk is dat (delen van) een inbreuk niet bewezen kunnen worden, waardoor ook de straf lager zal uitvallen.

420 Het kan immers nooit zo zijn dat met een beroep op de geheimhoudingsplicht (of om welke reden dan ook) dergelijke informatie geheel of ten dele buiten beschouwing wordt gelaten. Hier rust op het Gerecht en het Hof een belangrijke controlerende taak ter bescherming van de positie van de van overtreding van het kartelrecht 'verdachte' onderneming. Zie voor een zaak waarin het Gerecht de Commissie, wegens -daar had het althans veel van weg- 'selecief gebruik' van voorhanden bescheiden als bewijs, gevoelig terecht wees: GvEA (T-68, 77 en 78/89) Jur. 1992, II-1403 (Societal Italiana Vetro).

421 Vergelijkbaar: GvEA (T-305-307, 313-316, 318, 325, 328, 329 en 335/94) Jur. 1999, 11-931 (Limburgse Vinyl Maatschappij e.a.).

422 GvEA (T-30/91) Jur. 1995, II-1775 (Solvay). Zie hierover Ehlermann en Drijber (1996), pag. 375 e.v.. In GvEA (T-305-307, 313-316, 318, 325, 328, 329 en 335/94) Jur. 1999, II-931 (Limburgse Vinyl Maatschappije.a.) was volgens het Gerecht het recht op toegang tot het dossier daadwerkelijk geschonden. Het mocht de ondernemingen echter uiteindelijk niet baten omdat het Gerecht tot het oordeel kwam dat door het verzuim van de Commissie de verdedigingsmogelijkhoden van de betrokke. nen niet nadelig waren beĩnvloed. 
sie bereid is toegang tot een bepaald document te verlenen. ${ }^{423}$ Voor zover het de niettoegankelijke documenten betreft, bevat de lijst een beknopte aanwijzing

"aan de hand waarvan de inhoud en het voorwerp ervan op een zodanige wijze kunnen worden vastgesteld dat elke onderneming die toegang tot het dossier heeft gevraagd, in staat is met kennis van zakee vast te stellen of deze documenten voor haar verdediging relevant kunnen zijn, en de opportuniteit te beoordelen om ondanks deze classificatie toegang daartoe te verzocken".

Dit is bij beperkt toegankelijke documenten overbodig omdat daarvan wel inzage kan worden genomen, met dien verstande dat bepaalde informatie (de Mededeling noemt als voorbeeld omzetcijfers) is 'geanonimiseerd'. Voor zover de 'verdachte' onderneming toch met het oog op haar verdediging inzage wil nemen van de geheel of gedeeltelijk niet-toegankelijke informatie, dient zij zich met een daartoe strekkend gemotiveerd beroep tot de raadadviseur-auditeur te wenden ${ }^{424}$, die dan over de al dan niet openbaarmaking van het betreffende materiaal beslist. ${ }^{425}$ Aldus is in een procedure voorzien die kan worden gevolgd indien de 'verdachte' onderneming en de Commissie van mening verschillen over de noodzaak van openbaarheid van bepaalde stukken. Hiermee wordt mijns inziens recht gedaan aan zowel het belang op geheimhouding als het belang van interne opentaarheid, ${ }^{426} \mathrm{er}$ althans van uitgaande dat ook door de raadadviseur-auditeur terughoudend gebruik wordt gemaakt van de mogelijkheid om informatie niet bekend te maken aan ondernemingen die als verdachte betrokken zijn bij een communautaire kartelprocedure.

\subsubsection{Zakengeheimen en derde-klagers}

In verband met de geheimhouding biedt artikel 19 lid 2 Vo 17 in samenhang met artikel 20 lid 2 Vo 17 nog een interessant probleem. Omdat artikel 19 lid 2 Vo 17 naar de letter geen aparte bescherming tegen openbaarmaking van zakengeheimen biedt, mag de Commissie, in het kader van het horen van derden, in beginsel alle gegevens die naar hun aard onder de geheimhoudingsplicht vallen (waaronder dus in principe ook zakengeheimen) aan die derden openbaren, voor zover zij dat althans noodzakelijk acht met het oog op de betrokken procedure. Vanzelfsprekend houdt dit niet in dat derden dus een recht op inzage van vertrouwelijke informatie hebben. Dit blijkt ook uit het Van Landewijck-arrest waarin het Hof oordeelde dat de Commissie ten aanzien van gegevens die onder de geheimhoudingsplicht vallen

423 Levitt (1997), pag. 189, stelt terecht dat "the 'file' to which the undertaking must be granted access must comprise all of the relevant documents in the possession of the Commission as a whole".

424 De Mededeling beperktzich tot niet-toegankelijkedocumenten. Hoewel dit wellicht zeldenhet geval zal zijn, dient deze weg mijns inziens ook open te staan met betrekking tot deels geanonimiseende informatic.

425 Op grond van artikel 5 Pb 1994 L 330/67 (Besluit van de Commissie van 12 december 1994 betreffende het mandaat van de raadadviseur-auditeur in mededingingsprocedures voor de Commissie). De radsadviseur-auditeur beslist eveneens over geschillen tussen de Commissie en de ondememing die meent recht te hebben op bescherming van door haar verstrekte informatie. De Commissie zal dan moeten trachtenom eenniet-vertrouwelijke(dus 'geanonimiseerde') versievan de documentente verkrijgen. Wil de onderneming in kwestie hieraan niet meewerken, dan wordt door de Commissie de zaak aan de raadadviseur-auditeur voorgelegd.

426 In grote lijnen positief is ook Levitt (1997), pag. 188. 
"zich niet op de artikelen $19 \mathrm{en} 20$ van deze verordening (mag) beroepen om de mededeling van deze gegevens aan klagende derden te rechtvaardigen. Artikel 19, lid 2, kent hun immers slechts een recht toe om te worden gehoord en niet het recht om vertrouwelijke gegevens te ontvangen". 2 t

Hier geldt de hoofdregel dat de Commissie het belang van bekendmaking tegen dat van geheimhouding moet afwegen, waarbij zij tevens, tegen de achtergrond van het proportionaliteitsvereiste, zal dienen te bepalen hoever zij bij de eventuele openbaarmaking mag gaan. ${ }^{48}$ In de AKZO-zaak ${ }^{49}$ werd de vraag aan de orde gesteld of deze afweging ook dient te worden gemaakt indien het om zakengeheimen gaat. Met andere woorden: brengt het feit dat artikel 19 lid 2 Vo 17 geen bijzondere bescherming aan zakengeheimen biedt, met zich dat deze bijzondere bescherming inderdaad ontbreekt? Zoals reeds hierboven gesteld, zou deze vraag naar mijn mening ontkennend moeten worden beantwoord. De Commissie echter had in deze zaak -zij het met de nodige zorgvuldigheid- aan een derde informatie bekend gemaakt die volgens AKZO tot haar zakengeheimen gerekend moesten worden. Advocaat-Generaal Lenz concludeerde dat als uitgangspunt moet gelden dat openbaarmaking van zakengeheimen niet is toegestaan, ook niet in het kader van een hoorprocedure ex artikel 19 lid 2 Vo $17 .{ }^{40}$ De enige uitzondering die hij op deze hoofdregel van toepassing achtte, bestaat uit die gevallen waarin zonder openbaarmaking handhaving van het materiele kartelrecht in het geheel niet mogelijk zou blijken te zijn; deze uitzondering zou echter volgens Lenz uiterst zelden een rol kunnen spelen. Aldus stond Lenz een zeer vergaande bescherming van zakengeheimen voor, ook buiten de situaties die uitdrukkelijk in Verordening 17 worden genoemd. Gelet op het voorgaande moge duidelijk zijn dat ik deze visie kan onderschrijven. Het Hof deed dat in grote lijnen eveneens, maar ging zelfs nog verder. Het Hof merkte de artikelen 19 lid 3 en 21 lid 2 Vo 17 aan als "de uitdrukking van een algemeen beginsel dat gedurende de gehele administratieve procedure van toepassing is" en achtte dientengevolge zakengeheimen mede beschermd in de in artikel 19 lid 2 Vo 17 genoemde situatie. Tot zover volgde het Hof dan ook zijn Advocaat-Generaal en gelet op de belangen die met de waarborging van het geheime karakter van zakengeheimen gemoeid zijn -zeker ten aanzien van derdeklagers- zoals gezegd volledig terecht. Opmerkelijk is echter het vervolg van de overwegingen van het Hof. Het concludeerde "dat aan de derde klager in geen geval documenten mogen worden meegedeeld die zakengeheimen bevatten". ${ }^{431}$ Een absolute bescherming van zakengeheimen derhalve tegenover derde klagers. Deze stap werd mede ingegeven door de vrees dat ondernemingen een (ongegronde) klacht zouden indienen met de uitsluitende reden om via deze weg zakengeheimen van hun concurrenten, leveranciers of afnemers te verkrijgen. Wat er ook zij van de gegrondheid van deze vrees ${ }^{42}$, het oordeel

427 HvJ (209-215 en 218/78) Jur. 1980, 3125 (Heinz van Landewijck).

428 In gelijke zin Advocaat-Generaal Reischl in zijn conclusic bij HvJ (209-215 en 218/78) Jur. 1980, 3298/3299 (Heinz van Landewijck).

429 HvJ (53/85) Jur. 1986, 1965 (AKZO Chemie en AKZO Chemie UK).

430 Conclusie A-G Lenz bij het AKZO-arrest, 1977 e.v.. Hij stoelde zijn mening op dit punt met name op het Van Landewijck-arrest, waaraan hij mijns inziens te vergaande conclusies verbindt. Het oordeel van het Hof dat een klagende onderneming geen recht heeft op vertrouwelijke informatie, brengt immers nog niet mee dat openbaarmaking van zakengeheimen zonder meer ongeoorloofd is.

431 HvJ (53/85) Jur. 1986, 1965 (AKZO Chemie en AKZO Chemie UK) (cursivering van mij, HQ).

432 Op grond van de Van Landewijck-jurisprudentie kende artikel 19 lid 2 Vo 17 klagende derden "slechts een recht toe om te worden gehoord en niet het recht om vertrouwelijke gegevens te ontvangen"; dit laat de mogelijkheid voor de Commissie open om per geval te beoordelen of openbaarmaking 
van het Hof betekent dat er voor zakengeheimen in relatie tot derde klagers een verderstrekkende bescherming is gecreëerd dan de bescherming van de artikelen 19 lid $3 \mathrm{en}$ 21 lid 2 Vo 17. Waar deze artikelen de Commissie immers de ruimte bieden om af te wegen tussen het belang van geheimhouding en het belang van een openbare en faire procedure, waarin ook aan derden een adequate gelegenheid moet worden geboden om gehoord te worden, daar wordt in het kader van het horen van derde klagers een absoluut verbod aan de Commissie opgelegd om zakengeheimen te openbaren. ${ }^{43}$ Een belangenafweging door de Commissie zit er dus op dit punt niet meer in. Dit kan met name een probleem opleveren in zaken waarin voor een goede handhaving van het kartelrecht het horen van derde klagers en het verlenen van inzage aan deze door de Commissie van belang wordt geacht. Hoewel buiten discussie staat dat de vertrouwelijkheid van zakengeheimen voor ondernemingen van eminent belang is en dientengevolge in beginsel niet dient te worden prijsgegeven, kan men zich afvragen of het Hof aan de bescherming van die vertrouwelijkheid niet een te groot gewicht heeft toegekend. De Commissie, onder toezicht van de communautaire rechters, is zeer wel in staat om het belang van geheimhouding tegen andere belangen af te wegen; in het kader van de artikelen 19 lid 3 en 21 lid 2 Vo 17 doet zij dit ook reeds. Indien -hoe incidenteel dan ook- deze belangen bekendmaking aan derden vergen, moet de Commissie mijns inziens de mogelijkheid hebben om deze te laten prevaleren. ${ }^{34}$ De absolute bescherming die het Hof hier aan zakengeheimen heeft geboden, maakt dit onmogelijk en is derhalve niet op haar plaats. ${ }^{\text {as }}$ Dat deze regeling in beginsel in het voordeel van ondernemingen werkt, verandert daaraan niets. Temeer daar het gevaar bestaat dat in dit opzicht het schot naar achter afgaat. De ruime bescherming kan namelijk een wissel trekken op de taakvervulling van de Commissie, hetgeen voor haar aanleiding zou kunnen zijn om het begrip 'zakengeheimen' restrictief te gaan interpreteren; de interpretatiemogelijkheid rest haar immers, ook na het AKZOarrest, nog wel. Zou een dergelijk scenario zich voordoen, dan zou ook in andere situaties (waaronder die van de artikelen 19 lid 3 en 21 lid 2 Vo) aan (rechts)bescherming worden ingeboet. ${ }^{436}$

gelet op de te waarborgen belangen dient plaats te hebben. Prevaleert het geheimhoudingsbelang, dan kan en moet de Commissie de inzage weigeren.

433 Onderstreept dient hier te worden dat het Hof alleen de absolute bescherming van zakengeheimen uitdrukkelijk heeft aanvaard in relatie tot derde-klagers. Aangenomen mag worden dat de bekendmaking aan anderen (bijvoorbeeld aan mede-kartelleden) onder omstandigheden en met inachtneming van het proportionaliteitsbeginsel wel mogelijk blijtt.

434 Terecht stelt Joshua (1994 1), pag. 77, dat "trade secret claims must be reconciled with the achievement of the essential purposes of the Regulation".

435 Ook Joshua (1994 I), pag. 79, is van mening dat het Hof te ver is doorgeschoten naar de kant van de bescherming van het zakengeheim en opteent voot het handhaven van de bevoegdheid van de Commissie tot belangenafweging:"The real point (...) is not so much whether the materialin question fits into this or that category but whether in the particular circumstances the Commission considers that its objectivecannot properly be achieved without disclosure, perhaps with appropriateprotection or in some limited form".

436 In het AKZO-arrest heeft het Hof voorts zijn jurisprudentie-vergelijk HvJ (155/79) Jur. 1982, 1575 (AM\&S Europe)- bevestigd dat het in eerste instantie aan de Commissie is om over het karakter vangegevenste oordelen. Er geldt een vergelijkbareprocedureals ten aanzienvan het communautaire verschoningsrecht: alvorens gegevens aan derden bekend te maken, dient de Commissie bij beschilking over het karaktervan de gegevenste beslissen, teneinde de onderneming in kwestie in de gelegenheid te stellen om de zaak bij het Gerecht aan te kaarten. Ook hier moet ervan worden uitgegaan dat een 


\section{Bescherming van de privésfeer van ondernemingen}

In paragraaf 2.1 heb ik uiteengezet dat naar mijn mening artikel 8 EVRM ook bescherming biedt aan ondernemingen. Gelet echter op het feit dat de privacy van ondernemingen minder precair is dan de privacy van natuurlijke personen, is het verdedigbaar dat de uitzonderingen die op grond van het tweede lid van artikel 8 EVRM zijn toegestaan, eerder toepassing vinden dan bij natuurlijke personen het geval is. De reden voor deze interpretatie ligt in de ratio van artikel 8 EVRM zoals ik die zie: naast de protectie van de mogelijkheid tot zelf-ontplooiing van een mens (dus cen natuurlijk persoon), ligt deze in het aan banden leggen van overheidsoptreden. In deze paragraaf zal worden bekeken in hoeverre de praktijk aanknopingspunten biedt voor een dermate vergaande lezing van artikel 8 EVRM en voor een uitgebreide bescherming van ondernemingen op het gebied van de privésfeer.

\subsection{De Straatsburgse visie op artikel 8 EVRM}

In 'Straatsburg' lijkt er wel gevoeld te worden voor een ruime bescherming van artikel 8 EVRM. Hoewel niet eenduidig, wijst de Chappell-uitspraak in deze richting. ${ }^{47}$ Het ging in deze zaak om betreding van een pand waar Chappell zijn (video)bedrijf uitoefende en waar hij tevens woonde; geînteresseerd waren de betreders de facto slechts in de ondernemersactiviteiten van Chappell. Het EHRM overwoog:

"Before the Court, the Government accepted that there had been an "interference" with the exereise of the applicant's right to respect for his "private life" and "home". Mr. Chappell, for his part, conceded that the interference had the aim, which was legitimate under paragraph 2 of Article 8 , of protecting "the rights of others", in that it served to defend the Plaintiffs' copyright against unauthorised infringement. The Court sees no reason to differ on either of these points".

Volgens het EHRM was er kortom sprake van een inmenging in de privésfeer alsmede de 'woning' en was dus het eerste lid van artikel 8 EVRM in het geding. Mag men vervolgens hieraan de conclusie verbinden dat het EHRM artikel 8 EVRM mede van toepassing acht op ondernemingen? Nee, meent Finaly ${ }^{438}$ en wijst daarbij op het feit dat Chappell als natuurlijk persoon (en dus niet als of namens de rechtspersoon) de zaak in Straatsburg aanhangig had gemaakt: "de uitspraak gaat gewoon niet over grondrechten voor rechtspersonen", aldus Finaly. Ik ben het in zoverre met hem eens dat terughoudendheid moet worden betracht bij het trekken van al te vergaande conclusies op grond van het Chappellarrest: het was inderdaad een natuurlijk persoon die de klacht had ingediend en de plaats die was betreden, was mede aan te merken als woning van die natuurlijke persoon. Maar dit laat onverlet dat de ondernemingsaspecten in deze zaak wel zeer op de voorgrond stonden: het ging juist voornamelijk om de activiteiten als ondernemer, uitgeoefend in het bedrijfsgedeelte van het betreffende pand. Men zou toch wel aandacht daaromtrent van de zijde van het EHRM hebben mogen verwachten, indien het van mening was ge-

verzoek om opschorting van de tenuitvoerlegging van de beschikking door het Gerecht zal moeten worden gehonoreerd.

437 EHRM 30 maart 1989.

438 Finaly (1998), pag. 562. Mok (1990), pag. 396 is kennelijk dezelfde mening toegedaan. 
weest dat voor die ondernemersaspecten de bescherming van artikel 8 EVRM niet zou zijn bedoeld. In dat geval immers zou ook het tweede lid van artikel 8 EVRM geen relevantie hebben. In afwijking van Finaly ben ik dan ook van mening dat het EHRM in ieder geval voor een situatie zoals onderhavige, waarin de privésfeer van de natuurlijke persoon en die van de rechtspersoon nauwelijks zijn te (onder)scheiden, artikel 8 EVRM ook van toepassing heeft geacht op ondernemingen. Of hetzelfde geldt voor andere situaties, met name die waarin sprake is van 'grote' NV's en dergelijke, is mijns inziens op grond van het Chappell-arrest niet uitgesloten, maar zekerheid daarover bestaat niet. ${ }^{30}$ Enigszins meer licht in deze materie brengt het Niemietz-arrest ${ }^{40}$, hoewel ook dit de bedoelde zekerheid niet vermag te brengen en wel om goeddeels vergelijkbare redenen als die welke ten aanzien van de Chappell-uitspraak gelden. Aanleiding tot de Niemietzzaak was een doorzoeking van het kantoor van de klager, advocaat van beroep, welke doorzoeking volgens deze in strijd was met artikel 8 EVRM. Het EHRM besteedt aan de vraag of er van een inmenging in de privésfeer sprake was, vrij uitgebreid aandacht:

\footnotetext{
"The Court does not consider it possible or necessary to attempt an exhaustive definition of the netion of 'private life'. However, it would be too restrictive to limit the notion to an 'inner circle' in which the individual may live his own personal life as he chooses and to exclude therefrom entirely the outside world not encompassed within that eircle. Respect for private life must also comprise to a certain degree the right to establish and develop relationships with other human beings. There appears, furthennore, to be no reason of principle why this understanding of the notion of 'private life' should be taken to exclude activities of a professional or business nature since it is, after all, in the course of their working lives that the majority of people have a significant, if not the greatest, opportunity of developing relationships with the outside world. This view is supported by the fact that $(. .$.$) it is not always possible to distin-$ guish elearly which of an individual's activities form part of his professional or business life and which do not. Thus, especially in the case of a person exereising a liberal profession, his work in that context may form part and pareel of his life to such a degree that it becomes impossible to know in what capacity he is acting at a given moment of time. To deny the protection of Art. 8 on the ground that the measure complained of related only to professional activities (...) could moreover lead to an inequality of treatment, in that such protection would remain available to a person whose professional and nonprofessional activities were so intermingled that there was no means of distinguishing between them. (...) As regards the word 'home', ( $\ldots$ ) it may not always be possible to draw precise distinctions, since activities which are related to a profession or business may well be conducted from a person's private residence and activities which are not so related may well be carried on in an office or commercial premises. A narrow interpretation of the words 'home' and 'domicile' could therefore give rise to the same risk of inequality of treatment as a narrow interpretation of the notion of 'private life'. More generally, to interpret the words "private life" and "home" as including certain professional or business activities or premises would be consonant with the essential object and purpose of Art. 8, namely to protect the individual against arbitrary interference by the public authorities".til
}

Een antwoord op de vraag of ondernemingen als zodanig aanspraak kunnen maken op de bescherming van hun eigen sfeer, geven deze overwegingen niet met zoveel woorden. Het EHRM redeneert vanuit het individu en komt aldus tot een ruime interpretatie van artikel 8 EVRM: het privéleven omvat mede beroepsactiviteiten, omdat binnen de beroepsuitoefening bij uitstek contacten met anderen plegen te worden aangeknoopt en onderhou-

439 Cath (1991), pag. 37, alsmede Dommering in zijn noot onder het Chappell-arrest, gaan ervan uit dat dit inderdaad het geval is. Een andere mening is Fokkens toegedaan blijkens zijn conclusie bij HR 15 december 1992, NJ 1993, 550 m.nt. AHJS (Gelva Holding).

440 EHRM 16 december 1992.

441 Bevestigd in EHRM 25 juni 1997 (Halford). 
den; daarbij komt dat onderscheid tussen strikt privé- en zakelijke activiteiten vaak nauwelijks valt te maken, hetgeen in het bijzonder het geval is bij beoefenaren van vrije beroepen. Hetzelfde geldt mutatis mutandis ten aanzien van de uitleg van het begrip woning: ook hier doet een strikt onderscheid tussen woning in enge zin en werkplek volgens het EHRM meer dan gekunsteld aan en zou tot onwenselijke ongelijkheid in behandeling kunnen leiden tussen personen wier werk- en leefomgeving vrijwel identiek is (men denke an de bakker die boven zijn zaak woont) en die waarbij een duidelijke scheiding tussen beide omgevingen bestaat (de werknemer die trouw iedere ochtend naar DSM vertrekt). Al met al komt het EHRM tegen de achtergrond van de ratio van artikel 8 EVRM -bescherming van het individu tegen overheidsoptreden- tot een autonome en extensieve interpretatie van de begrippen 'privéleven' en 'woning', binnen welke interpretatie ruimte is voor bescherming van de zakelijke sfeer. ${ }^{42}$ Maar zoals gezegd, redeneert het EHRM in zijn Niemietz-arrest te zeer vanuit het individu om zonder meer te kunnen concluderen dat ondernemingen zelf onder de reikwijdte van artikel 8 EVRM vallen. Myjer ${ }^{43}$ en Finaly ${ }^{44}$ menen dat deze conclusie in het geheel niet mag worden getrokken; Dommering daarentegen ziet de zaken voor ondernemingen iets rooskleuriger. ${ }^{\text {ts }}$ Ook ik ben geneigd een positievere conclusie te trekken, en wel om de volgende redenen. Allereerst en wellicht ten overvloede zij opgemerkt dat het EHRM in ieder geval niet uitdrukkelijk bescherming voor ondernemingen heeft afgewezen; mocht die in de arresten Chappell en Niemietz nog niet zijn erkend, dan kan dit in een later stadium alsnog gebeuren. En deze erkenning zou zich zeer wel verdragen met genoemde arresten. In het Niemietz-arrest kent het EHRM een belangrijk gewicht toe aan de ratio van artikel 8 EVRM: bescherming van het individu tegen (te vérgaand) overheidsoptreden. Weliswaar wordt hier uitdrukkelijk gesproken van 'the individual', hetgeen lijkt te duiden op een natuurlijk persoon, maar ik zie niet in waarom deze ratio voor ondernemingen als zodanig niet zou gelden: waarom zouden deze wél mogen blootstaan aan 'onredelijke' uitoefening van overheidsmacht? Het ant-

442 Een dergelijke autonome interpretatie van een begrip tegen de achtergrond van de ratio van het in het geding zijnde recht ligt ook in de lijn van de overige jurisprudentie van het EHRM. Te denken valt bijvoorbeeld aan de autonome interpretatievan het begrip criminal charge, waarop in paragraaf 2.2 is ingegaan.

443 Myjer (1993), pag. 327.

444 Finaly (1998), pag. 563: het EHRM overweegt uitdrukkelijk "dat de ratio van privacy-bescherming gelegen is in bescherming van het individu. Ik meen dan ook dat uit het gegeven dat het EHRM bepaalde (gedeeltelijk) commerciele activiteiten van natuurlijke personen onder grondrechtelijke privacybescherming laat vallen, niet is af te leiden dat rechtspersonen ook privacy-bescherming toekomt". Ook Knigge lijkt blijkens zijn noot bij HR 3 oktober 1995, NJ 1996, 219 een beperkte strekking aan het Niemietz-arrest te willen geven: Het EHRM "oordeelde dat de huiszoeking in het kantoor van de advocaat Niemietz een inbreuk vormde op diens home-recht. Daarmee is niet gezegd dat een bedrijfsnimte steeds als een 'home' moet worden aangemerkt. Het arrest kan zo worden gelezen dat dit alleen onder omstandigheden het geval is. Van die beperkte lezing gaat de Hoge Raad, mijns inziens terecht, in het onderhavige arrest uit".

445 In zijn noot onder het Niemietz-arrest: "dat het huisrecht ook geldt voor ondememingen-rechtspersonen. De ratio voor die bescherming is daar evenzeer van toepassing als bij natuurlijke personen, terwij! ook het verschil tussen de "grote" en "kleine" rechtspersonen tot een willekeurige ongelijke behandeling zou leiden". Ook Swart, blijkens zijn noot bij HR 15 december 1992, NJ 1993, 550, en Van der Wal (1995), pag. 736 lijken aan het Niemietz-arrest een ruime reikwijdte toe te kennen, Jansen (1999), pag. 122, concludeert dat "ook niet-huiselijke plaatsen, zoals kantoor- of bedrijfsruimten onder het EVRM als 'home' kunnen worden beschouwd". Geen twijfel heeft Lawson (2000 IV), pag. 181. 
woord op deze vraag zou naar mijn overtuiging moeten zijn: dat mogen zij niet. Dit artikel 8 EVRM in relatie tot een natuurlijk persoon precairder is, doet daaraan niet af. Een tweede reden kan gevonden worden in de overweging van het EHRM dat de inmengingsbevoegdheid van de overheid

"might well be more far-reaching where professional or business activities or premises were involved than would otherwise be the case".

Met andere woorden: indien de privésfeer in de meest strikte zin van het woord in hat geding is, dan moeten de grenzen nauwer getrokken worden dan het geval is indien hat de meer 'bedrijfsmatige' kant van het leven betreft. Een dergelijk uitgangspunt-dat door het EHRM wordt geplaatst in het kader van een effectieve handhaving ${ }^{466}$ - is, zoals $i k$ reeds eerder onderstreepte, bij uitstek geschikt voor toepassing op ondernemingen zelf. Een derde, enigszins van andere orde zijnde, reden ligt in de toch opmerkelijke citering in het Niemietz-arrest van enkele overwegingen van het Hof ten aanzien van de reikwijde van artikel 8 EVRM. Het betreft overwegingen uit het Hoechst-arrest ${ }^{47}$ waarin het Hof een zeer beperkte inhoud gaf aan artikel 8 EVRM en waarin het -ondanks de an het Hoechst-arrest voorafgaande uitspraak inzake Chappell- stelde dat over de verhoudirg artikel $8 \mathrm{EVRM} /$ ondernemingen geen Straatsburgse jurisprudentie voorhanden was. Enig commentaar van de zijde van het EHRM ontbreekt, maar deze citering kan naar min meming nawwelijks amders worulen gezien dan een beleerfle attenderring erop dat het Hof het toch niet helemaal juist gezien had. ${ }^{48}$ De laatste reden voor de conclusie dat het EHRM ruimte ziet voor bescherming van ondernemingen op grond van artikel 8 EVRM houdt verband met de jurisprudentie van dit hof ten aanzien van andere artikelen, en dan met name artikel $10 \mathrm{EVRM}$. In het algemeen lijkt het EHRM er namelijk weinig voor te voelen om al te veel te differentiëren naar categorieën geadresseerden van de artikelen van het EVRM. Dat bleek reeds bij de bespreking van artikel 6 EVRM; dat blijkt ook ten aanzien van artikel 10 EVRM, de vrijheid van meningsuiting:

\footnotetext{
"In the Court's view, neither Autronic AG's legal status as a limited company nor the fact that its activities were commercial nor the intrinsic nature of freedom of expression can deprive Autronic AG of the protection of Article 10. The Article applies to 'everyone', whether natural or legal persons". "60
}

Of het nu een natuurlijk persoon of een onderneming betreft, is niet relevant: de bescherming van artikel 10 EVRM geldt voor 'een ieder'. Ook artikel 8 EVRM richt zich uitdrukkelijk tot 'een ieder'. Dan ligt het toch niet echt voor de hand dat het EHRM hier wel een andere koers zou varen en een strikt onderscheid zou introduceren tussen natuurlijke personen en rechtspersonen, temeer niet daar het reeds de deur heeft geopend naar een voor een effectieve handhaving ruimhartige uitleg van de uitzonderingen van het tweede lid van artikel 8 EVRM waar het niet de directe privésfeer in enge zin betreft.

446 Een ruime interpretatie van de begrippen 'priveleven' en 'woning' "would not unduly hamper the Contracting States, for they would retain their entitlement to 'interfere' to the extent permitted by para. 2 of Art. 8."

447 Zie over het Hoechst-arrest uitgebreid paragraaf 6.3.

448 In dezelfde zin Dommering in zijn noot bij het Niemietz-arrest.

449 EHRM 22 mei 1990 (Autronic). 
De conclusie moet mijns inziens zijn dat weliswaar het EHRM (nog) niet met zoveel woorden heeft erkend dat ondernemingen zelf worden beschermd door het recht op privacy van artikel 8 EVRM, maar dat uit de jurisprudentie desalniettemin kan worden afgeleid dat het wel bereid is ondernemingen die bescherming te bieden.

\subsection{Privacy-bescherming in Nederland}

Erg scheutig met het toekennen van het recht op privacy aan ondernemingen op grond van artikel 8 EVRM is de Nederlandse rechter niet bepaald. In 1975 overwoog de Hoge Raad in een zaak tegen verzekeringsmaatschappij Stad Rotterdam

"dat, aangenomen dat aan req. in deze zaak een beroep op lid I van art. 8 Europees Verdrag tot bescheming van de rechten van de mens en de fundamentele vrijheden zou toekomen, dit beroep reeds moet stranden op hetgeen in lid 2 van dat artikel is bepaald". .

De Hoge Raad liet aldus in het midden of een onderneming een (succesvol) beroep op artikel 8 lid 1 EVRM toekomt. Hij wilde aan deze vraag kennelijk zijn vingers niet branden en koos voor de eenvoudigere weg van toetsing aan lid twee van artikel 8 EVRM: de inmenging in de eventuele privésfeer kon de toets der kritiek ruimschoots doorstaan. ${ }^{451}$ Het Hof Den Bosch daarentegen wilde in 1991 niet weten van bescherming van ondernemingen door artikel 8 EVRM:

"Overwegende, dat van de regel, dat het EVRM rechtstreeks van toepassing is op rechtspersonen, die bepalingen dienen te worden uitgezonderd, die naar hun aard slechts betrekking kunnen hebben op natuurlijke personen; Overwegende, dat tot die bepalingen het voorschrift behoort van art. 8 lid 1, dat een ieder het recht geeft op eerbiediging van zijn 'private and family life and his home'" 452

In dezelfde zaak gooit de Hoge Raad het echter over een andere, reeds eerder door hem beproefde, boeg ${ }^{433}$ :

"In 's hofs overwegingen ligt het oordeel besloten dat de in art. 2:394 BW vervatte plicht van de daar bedoelde rechtspersonen tot openbaarmaking van de jaarrekening zich slechts uitstrekt tot niet onder de

450 HR 10 december 1974, NJ 1975, 178 (Stad Rotterdam)

451 In HR 14 april 1989, NJ 1990, 712 m.nt CJHB en JCS (Benckiser) ging de Hoge Raad evenmin expliciet in op de vraag of de onderneming in kwestie door artikel 8 lid 1 EVRM beschermd werd. De Hoge Raad volstond met de overweging dat de onderneming "geen feiten heeft gesteld die een inmenging in enig in dat artikel bedoeld, haar toekomend recht opleveren". De facto is deze overweging alleen maar relevant indien de Hoge Raad artikel 8 lid 1 EVRM in beginsel van toepassing acht op ondernemingen, maar al te stellige conclusies in die richting mogen toch niet aan de aanpak van de Hoge Raad worden verbonden.

452 Overwegingen van het Hof zoals opgenomen in HR 15 december 1992, NJ 1993, 550 m.nt. AHJS (Gelva Holding).

453 In HR 16 oktober 1987, NJ 1988, 850 m.nt. EAA (Driessen Assurantilen) weet de Hoge Raad de centrale vraag van gelding van artikel 8 EVRM te omzeilen door de nadruk erop te leggen dat het "een in het zakelijk verkeer tussen twee directeuren van bedrijven gevoerd telefoongesprek met een geheel zakelijke inhoud" betrof. Hoewel dit gesprek op band was vastgelegd (zonder toestemming van de ander), was de privacy derhalve volgens de Hoge Raad niet in het geding. De 'aard en de mate van intimiteit' van de informatie speelden hier een cruciale rol. 
bescherming van art. 8, eerste lid, EVRM vallende gegevens met betrekking tot de door de rechtsperroon gedreven onderneming. Dit oordeel is juist".

Artikel 8 EVRM was volgens de Hoge Raad niet in het geding omdat de informatie in kwestie niet privacy-gevoelig was. Deze interpretatie van de overwegingen van het Hof wijkt echter aanmerkelijk af van hetgeen dit klaarblijkelijk bedoelde: het Hof zag in het geheel geen ruimte voor bescherming van ondernemingen door artikel 8 EVRM, terwijl de Hoge Raad, zoals Swart in zijn noot bij dit arrest terecht stelt, nog steeds de mogelijkheid open laat dat artikel 8 EVRM wel in andere opzichten voor ondernemingen van belang kan zijn. Groot lijkt de hier geboden ruimte echter niet, gelet op de nadruk die op de 'aard en de mate van intimiteit' wordt gelegd. ${ }^{454}$ Als men derhalve van de Nederlandse rechtspraak uitgaat, heeft artikel 8 EVRM -zoals gezegd: naar mijn mening ten onrechte én betreurenswaardig- ondernemingen weinig te bieden. Helemaal onbegrijpelijk zijn de onmiskenbare voorzichtigheid en terughoudendheid die ook de Hoge Raad in deze aan de dag legt, niet, gelet op de schaarse en niet door duidelijkheid uitblinkende jurisprudentie van het EHRM in deze. Waar deze duidelijkheid er wel is, dat wil zeggen waar zich in meer of mindere mate een 'Niemietz-geval voordoet, volgt de Hoge Raad het EHRM (vanzelfsprekend) wel op de voet:

\footnotetext{
"Ant. 8 EVRM biedt bescherming tegen willekeurige inbreuken door enig openbaar gezag op de in het eerste lid bedoelde rechten. Het begrip 'home'/ domilice' zoals dit voorkomt in onderscheidenlijk de Engelse en de Franse tekst van art. 8, eerste lid, EVRM beperkt zich niet tot woningen maar kan onder omstandigheden ook bedrijfs- of beroepsruimten omvatten". ${ }^{\text {ss }}$
}

De conclusie moet zijn dat de Nederlandse rechters vooralsnog in zeer beperkte mate bereid blijken om artikel 8 EVRM van toepassing te achten op ondernemingen. De Nederlandse Grondwet heeft ondernemingen helaas niet meer te bieden. Artikel $10 \mathrm{GW}$ (eerbiediging van de persoonlijke levenssfeer) en artikel $13 \mathrm{GW}$ (briefgeheim) lijken gelet op hun bewoordingen de bescherming te beperken tot natuurlijke personen, hoewel ook hier, analoog aan artikel 8 EVRM, de ratio van eerbiediging van de privésfeer alsmede van de correspondentie tot de conclusie kan leiden dat bedoelde artikelen mede ten aanzien van ondernemingen kunnen gelden, temeer daar de wetgever nergens met zoveel woorden de toepasselijkheid ervan heeft beperkt tot natuurlijke personen. Ten aanzien van artikel $12 \mathrm{GW}$ (huisrecht) liggen de zaken echter anders. Dit artikel verleent aan de woning grondwettelijke bescherming in die zin dat het onder meer een wettelijke grondslag vereist voor de gevallen waarin een woning tegen de wil van de bewoner wordt betreden. In tegenstelling tot hetgeen het geval is met betrekking tot artikel $8 \mathrm{EVRM}$, wordt het begrip 'woning' in artikel $12 \mathrm{GW}$ echter beperkt uitgelegd. Dat blijkt bijvoorbeeld uit de memorie

454 Men denke in dit verband aan de bevoegdheid tot het vorderen van inlichtingen en van inzage van gegevens. Waar het ondernemingen betreft, zal het toch in beginsel steeds gaan om niet-privacygevoelige informatic. Dat zou dan impliceren dat artikel 8 EVRM in het geheel geen normerende werking op dit punt voor ondernemingen zou hebben. Zie hierover ook Jansen (1999), pag, 116, die stelt dat met betrekking tot bedrijfsgegevens de persoonlijke levenssfeer meestal niet in het geding is.

455 HR 3 oktober 1995, NJ 1996, 219 m.nt. Kn. In letterlijk gelijke bewoordingen HR 29 april 1997. NJ 1997, 665. Vergelijk ook de conclusie van advocaat-general Van Dorst bij HR 23 april 1996, NJ 1997,370 . 
van toelichting bij de Algemene wet op het binnentreden, welke wet regels stelt omtrent het binnentreden van woningen ${ }^{456}$ :

"Het grondrecht van de onschendbaarheid van de woning beschermt de huisvrede, dat wil zeggen het ongestoord verblijf in een ruimte die tot exclusief verblijf voor een persoon of voor een beperkt aantal in een gemeenschappelijke huishouding levende personen ingericht en bestemd is". "In het licht van de strekking van de grondwettelijke bescherming van het huisrecht is er geen aanleiding deze bescherming ook te doen uitstrekken tot met een woning verbonden ruimten die in het geheel niet voor bewoning zijn bestemd en die van buitenaf via een eigen ingang kunnen worden betreden", 47

Laat staan dat een bedrijfspand onder het begrip 'woning' valt. ${ }^{458}$ Meer in het algemeen geldt dat voorzover de genoemde andere bepalingen van de Nederlandse Grondwet zich mede over ondernemingen uitstrekken, zij deze niet meer bescherming geven dan artikel 8 EVRM. Veel hangt dan ook af van de concrete wettelijke regels die bevoegdheden in het leven roepen die inmenging in de eigen sfeer van een onderneming mogelijk maken. Dat deze lang niet altijd uitblinken in het creëren van vergaande waarborgen, moge alleen al blijken uit de betredingsbevoegdheid zoals die in de Mededingingswet, in samenhang met artikel 5:15 Awb geldt:

"Een toezichthouder is bevoegd, met medeneming van de benodigde apparatuur, elke plaats te betreden met uitzondering van een woning zonder toestemming van de bewoner".

Weliswaar mag op grond van artikel 5:14 Awb de toezichthouder -en de onderzoekerslechts van zijn bevoegdheden gebruik maken voor zover dat redelijkerwijs voor de vervulling van zijn taak nodig is, maar een concrete beperking vormt dit toch nauwelijks. De conclusie moet dan ook zijn dat in het Nederlandse recht de positie van ondernemingen op het gebied van de privésfeer in ruime zin aanmerkelijk zwakker is dan die van een natuurlijk persoon. De vraag die nu rest, is hoe het er in het communautaire recht voorstaat.

\subsection{Privacy in het communautaire recht}

Het kwam al eerder aan de orde: het communautaire recht heeft het lang zonder een geschreven grondrechtencatalogus moeten stellen. ${ }^{459}$ Het Handvest zoals dat er nu ligt, heeft geen bindende werking en is in zoverre van beperkt belang. Wel benadrukt dit Handvest, evenals artikel $6 \mathrm{EU}$, het belang van het EVRM voor de communautaire rechtsorde. Zoals gezegd, impliceert dit mijns inziens dat het Hof de jurisprudentie van het Europees Hof uit Straatsburg volledig dient te volgen. Of dit tot op heden op het punt

456 Wet van 22 juni 1994, Stb. 572. De vereisten betreffen met name een legitimatieplichten een plicht tot het mededelenvan het doel van het binnentreden. Niet minder belangrijkezijn de eisen ten aanzien van het binnentreden van woningen zonder toestemming van de bewoner. In dat geval is in beginsel een machtiging vereist die aan bepaalde voorwaarden moet voldoen en zal van de binnentreding een schriftelijk verslag moeten worden gemaakt dat aan de bewoner moet worden toegezonden.

457 MvT TK 1984-1985, 19 073, nr. 3, pag. 20.

458 De beperktheid van de invulling van het begrip 'woning' wordt nog eens ten volle onderstreept in HR 29 april 1997, NJ 1997, 665.

459 Zie paragraaf 1. 
van de privacy ook daadwerkelijk is gebeurd, mag worden betwijfeld, maar het antwoord op deze vraag is wel mede afhankelijk van de reikwijdte die men aan de arresten Chappel en Niemietz toedicht. In het communautaire kartelrecht is in ieder geval enkele malen de privacy van rechtspersonen aan de orde gesteld. In de eerste zaak waarin een onderneming zich op artikel 8 EVRM beriep, herhaalde het Hof allereerst zijn vaste jurisprudentie dat de in het EVRM vervatte rechten deel uitmaken van de algemene communautaire rechtsbeginselen, om vervolgens te overwegen:

\begin{abstract}
"Te deze moet worden opgemerkt dat, voorzover art. 8 Europees Verdrag van toepassing zou zijn op rechtspersonen, daarin weliswaar het beginsel is neergelegd dat geen inmenging van het openbaar gezag is toegestaan in de uitoefening van de in het eerste lid bedoelde rechten, doch dat in het tweede lid worth erkend dat een dergelijke inmenging mogelijk is mits zij "bij de wet is voorzien en in een democratische samenleving nodig is in het belang van 's lands veiligheid, de openbare veiligheid, of het economisch welzijn van het land, de bescherming van de openbare orde en het voorkomen van strafbare feiten, de bescherming van de gezondheid of de goede zeden, of voor de bescherming van de reehten en vrijheden van anderen'".t.
\end{abstract}

En aan deze voorwaarden van het tweede lid van artikel 8 EVRM was volgens het Hof voldaan, waarbij het refereerde aan het grote belang van artikel 14 Vo 17 -de 'wettelijke' grondslag voor de inmenging- voor de controle op de naleving van de mededingingsregels en aldus uiteindelijk voor de verwezenlijking en bescherming van de doelstellingen van het EG-Verdrag. ${ }^{461}$ Op vergelijkbare wijze als de Hoge Raad in het arrest inzake Stad Rotterdam ${ }^{462}$, ging het Hof hier aldus voorbij aan de fundamentele vraag of artikel 8 EVRM gelding heeft voor ondernemingen. Dit heeft mijns inziens te maken met een zekere mate van schroom en voorzichtigheid om een interpretatie te geven van artikelen c.q. begrippen waaromtrent het Straatsburgse Hof nog geen duidelijkheid heeft kunnen geven. Maar het Hof moet toch wel enige ruimte hebben gezien voor bescherming van ondernemingen op grond van artikel $8 \mathrm{EVRM}$, omdat het anders de knoop reeds op grond van het eerste lid van artikel 8 EVRM zou hebben doorgehakt en niet nader aan het tweede lid van dit artikel zou hebben getoetst. In ieder geval volgde het Hof dezelfde aanpak in zijn Akzo-arrest. ${ }^{463}$ In deze zaak werd eveneens een beroep gedaan op artikel 8 EVRM: de in het geding zijnde beschikking zou hiermee in strijd zijn omdat zij was vastgesteld zonder inachtneming van de procedure van artikel 14 lid 3 Vo 17. Het Hof overwoog dienaangaande:

\footnotetext{
"Verzoeksters geven zelf toe, dat een beschikking waarbij een onderneming wordt gelast zich aan een verificatie te onderwerpen, niet in strijd ismet de fundamentele beginselen, neergelegd in artikel 8 EVRM. indien aan de voorwaarden van artikel 14, lid 3, van verordening $\mathrm{nr}, 17$ is voldaan. Bij onderzoek van de eerste twee middelen is gebleken dat zulks i.c. het geval is".
}

$460 \mathrm{HvJ}(136 / 79)$ Jur. 1980, 2033 (National Panasonic). Ook gepubliceerd in HvJ 26 juni 1980, NJ 1981, 425 m.nt. EAA.

461 DeCommissie stelde in haar Tiendeverslag over het mededingingsbeleid, nr. 43, dat artikel 8 EVRM interventie in de in lid 1 van dat artikel genoemde rechten toestaat "in het geval waarin zulk een interventie bij de wet is voorgeschreven en noodzakelijk is voor de verdediging van het algemeen belang. De krachtens verordening 17 genomen maatregelen, die ten doel hebben de door het verdrag gewenste concurrentie te handhaven beantwoorden precies aan dit eriterium".

462 HR 10 december 1974, NJ 1975, 178 (Stad Rotterdam)

$463 \mathrm{HvJ}(5 / 85)$ Jur. 1986, 2585. 
Inmenging in de eigen sfeer van de onderneming levert met andere woorden geen probleem op tegen de achtergrond van artikel 8 EVRM, mits aan de vereisten van artikel 14 Vo 17 is voldaan. Daarvoor is inderdaad veel te zeggen: de (mededingings) belangen die met de verificaties zijn gemoeid, rechtvaardigen mijns inziens een inmenging in de privésfeer van de onderneming en artikel 14 Vo 17 vormt daarvoor een voldoende concrete en kenbare basis. Deze benadering van het Hof in zjjn arresten National Panasonic en AKZO toont tevens aan dat een erkenning van de privésfeer van ondernemingen geen negatieve invloed op de handhaving hoeft te hebben, terwijl wel de meest fundamentele waarborgen die men bij een inmenging als bedoeld mag verwachten, in acht worden genomen. Via deze weg wordt derhalve tegemoet gekomen aan al de in het geding zijnde belangen. Toch week het Hof in zijn Hoechst-arrest ${ }^{464}$ van zijn eerdere lijn af en zette het de voorzichtigheid ten aanzien van de interpretatie van artikel 8 EVRM aan de kant. Ten aanzien van het, door Hoechst AG ingeroepen ${ }^{465}$, recht op onschendbaarheid van de woning overwoog het dat dit recht:

\footnotetext{
"in de communautaire rechtsorde voor de privó-woning van natuurlijke personen moet worden erkend als een beginsel dat de rechtsstelsels van de Lid-Staten gemeen hebben, maar dat dit niet geldt voor ondernemingen, daar genoemde rechtsstelsels onderling sterk verschillen met betrekking tot de aard en de mate van bescherming van bedrijfslokalen tegen het optreden van het openbaar gezag. Artikel 8 van het Europees Verdrag tot bescherming van de rechten van de mens en de fundamentele vrijheden, waarvan lid I bepaalt "dat een ieder recht heeft op eerbiediging van zjjn privé leven, zijn gezinsleven, zijn huis en zjjn briefwisseling", wijst niet in een andere richting. De bij dit artikel geboden bescherming is gericht op de ontplooiing van de persoonlijke vrijheid van de mens en kan zich derhalve niet uitstrekken tot bedrijfslokalen. Voor het overige moet worden vastgesteld, dat er dienaangaande geen rechtspraak van het Europees Hof voor de rechten van de mens bestaat", 406
}

De stelligheid van het Hof is opmerkelijk, zeker gezien zijn eerdere terughoudende benadering van deze materie. ${ }^{467}$ Helaas voor het Hof was echter een slippartij het gevolg van deze expeditie op glad ijs. ${ }^{468}$ Eerdere rechtspraak van Straatsburgse zijde was er namelijk wel, te weten het (een half jaar voordien gewezen) Chappell-arrest. Hoewel de reikwijdte van dit arrest omstreden is, geeft het toch op zijn minst aanleiding om twijfels te koesteren omtrent uitsluiting van ondernemingen van de bescherming van artikel 8 EVRM. Het moet er dus voor gehouden worden dat het Hof dit arrest over het hoofd heeft gezien of althans het (potentiele) belang ervan voor deze materie niet ten volle heeft onderkend. ${ }^{469}$ Hoe dit ook zij: het Niemietz-arrest zal hem niet zijn ontgaan. Niet alleen omdat

464 HvJ (46/87 en 227/88) Jur. 1989, 2868 en 2670 (Hoechst).

465 Hoechst AG stond op het standpunt dat dit recht zich mede uitstrekte over ondernemingen. Het werd in deze opvatting gesteund door de Commissie.

466 Wattel (1990) concludeert: "Of een rechtspersoon aanspraak kan maken op een grondrecht, hangt dus ook volgens het HvJ EG (mede) af van het karakter van dat grondrecht: gaat het om typisch 'menselijke' waarden, zoals leven, gezondheid, privacy en godsdienst, danzal eenrechtspersoongeen aanspraak op bescherming kunnen maken, tenzij het niet toekennen van die bescherming ertoe zou leiden dat grondrechten van de zich achter de rechtspersoon bevindende natuurlijke personen beschadigd zouden worden".

467 Hoewel het een goede zaak is dat het Hof bereid lijkt te zijn om voorafgaande Straatsburgse jurisprudentie (voor zover aanwezig) te volgen.

468 Kritisch zijn ook Ress en Ukrow (1990), pag. 503-504.

469 Hetgeen overigens niet denkbeeldig is aangezien over de strekking van bedoelde uitspraak zoals besproken de meningen uiteen liepen en nog steeds lopen. 
deze uitspraak naar mijn mening toch belangrijke aanknopingspunten biedt voor een ruime uitleg van artikel 8 EVRM (alhoewel ook hier de reikwijdte omstreden is), maar bovendien omdat de overwegingen ten aanzien van artikel 8 EVRM van het Hof in zijn Hoechst-arrest letterlijk in Niemietz worden aangehaald. Zoals in paragraaf 6.1 betoogd, kan dit niet anders worden gezien dan een -zij het collegiale en beleefde- tik op de vingers van het Hof, die duidelijk moet maken dat het EHRM de zaken ten aanzien van artikel 8 EVRM toch anders ziet dan het Hof. Het Gerecht blijkt zich in een recent arrest in de PVC. zaak $^{470}$ hiervan en van de Straatsburgse ontwikkelingen meer in het algemeen echter opmerkelijk weinig aan te trekken. Het overwoog namelijk dat de Hoechst-rechtspraak gebaseerd is

\footnotetext{
"op een algemeen beginsel van gemeenschapsrecht dat van toepassing is op rechtspersonen. Dat de rechtspraak van het Europees Hof voor de rechten van de mens betreffende de vraag, of artikel 8 EVRM var toepassing is op rechtspersonen, sedert de arresten Hoechst/Commissie, Dow Benelux/Commissieen Dow Chemical tbérica e.a./Commissie, (...) is geêvolueerd, heeft derhalve geen rechtstreekse gevolgen voor de gegrondheid van de oplossingen die in die arresten zijn gegeven".
}

Dit oordeel is meer dan teleurstellend. Niet alleen valt te betreuren dat de Hoechst-lijn wordt gecontinueerd, maar bovendien -en dit is aanmerkelijk bedenkelijker- moet zonder meer worden afgewezen dat het Gerecht de Straatsburgse opvattingen (in dit geval aan-

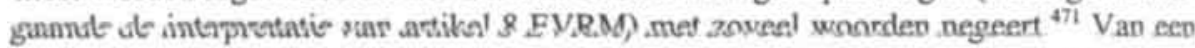
aansluiting van de communautaire grondrechtenjurisprudentie bij de rechtspraak van het EHRM zijn we dan plotseling weer mijlenver verwijderd. Dit toont eens te meer het belang en de noodzaak aan van een mogelijkheid om op het gebied van de mensenrechten communautaire uitspraken aan het EHRM voor te leggen: waar het het EVRM betreft, moet dit Straatsburgse Hof in alle gevallen het laatste woord hebben.

Helemaal ongevoelig voor privacy-argumenten van ondernemingen blijkt de communautaire rechter ondanks het voorgaande overigens niet. Zich kennelijk realiserend dat de uitkomst van zijn visie ten aanzien van artikel 8 EVRM tot onwenselijke en onaanvaardbare gevolgen zou kunnen leiden, overwoog het Hof in zijn Hoechst-arrest namelijk dat

\footnotetext{
"in de rechtsstelsels van alle Lid-Staten, ingrepen van het openbaar gezag in de privé-sfeer van iedere persoon, of het nu gaat om een natuurlijke of rechtspersoon, cen wettelijke grondslag moeten hebben en gerechtvaardigd moeten zijn om redenen bij de wet voorzien, en dat die rechtsstelsels derhalve, zij het volgens verschillende modaliteiten, bescherming bieden tegen ingrepen die willekeurig of onredelijk zouden zijn. Zulk een bescherming moet dan ook worden aangemerkt als een algemeen beginsel van gemeenschapsrecht", th
}

Wat het Hof de ondernemingen met de ene hand heeft ontnomen, reikt het deze via de omweg van de algemene beginselen van gemeenschapsrecht, gedestilleerd uit de gemeenschappelijke tradities van de lidstaten, met de andere hand weer aan: bescherming tegen te vérgaand en willekeurig overheidsoptreden voor zover het de privé-sfeer (!) van ondernemingen betreft. Op de keper beschouwd, bereikt het Hof aldus een resultaat dat vergelijk-

470 GvEA (T-305-307, 313-316, 318, 325, 328, 329 en 335/94) Jur. 1999, H1-931 (Limburgse Vinyl Maatschappij e.a.).

471 Lawson (2000 IV), pag. 182.

472 Cursivering HQ. 
baar is met hetgeen artikel 8 EVRM vereist; helemaal gelijk lijkt de bescherming echter niet te zijn aangezien de uitzonderingen die artikel 8 EVRM limitatief opsomt, concreter zijn geformuleerd en in verdere mate zijn uitgekristalliseerd dan de door het Hof genoemde regels.

\section{Conclusie}

Fundamentele rechten moeten ook in het kartelrecht worden gewaarborgd, hoe groot het belang van een gestroomlijnde handhaving gelet op de potentielle nadelen van kartellering ook moge zijn. Veronachtzaming van dit uitgangspunt zou in een rechtsgemeenschap tot een onaanvaardbare situatie leiden. Het Hof heeft dit met betrekking tot het communautair recht erkend. In het kader van zijn taak om de eerbiediging van het recht bij de uitlegging en toepassing van het EG-Verdrag te verzekeren, heeft het Hof -na een aanvankelijke terughoudende opstelling teneinde de ontwikkeling van het gemeenschapsrecht te verzekeren- een vaste jurisprudentie ontwikkeld waarin rekening wordt gehouden met de fundamentele rechten van de mens. ${ }^{473}$ Weliswaar wordt het gemeenschapsrecht niet aan het nationale recht en de daarin verankerde waarborgen getoetst (dit zou ook indruisen tegen het supranationale karakter van het communautaire recht), maar de nationale rechtsstelsels vormen wel een bron waaruit rechten binnen het sommunautaice sochly wostaw geput: grondrechten die in de lidstaten worden gehonoreerd, maken in beginsel ook deel uit van het gemeenschapsrecht. Sinds het Nold-arrest staat vast dat ook aan internationale verdragen zoals het EVRM en het IVBPR 'aanwijzingen kunnen worden ontleend waarmede in het raam van het Gemeenschapsrecht rekening dient te worden gehouden'. Bescherming van de rechten van justitiabelen is dus een grondbeginsel van gemeenschapsrecht, hetgeen wordt onderstreept door artikel $6 \mathrm{EU}$. Lange tijd heeft het Hof bij de uitleg van deze rechten onmiskenbaar rekening gehouden met communautaire belangen: aan de ene kant mocht het wezen van de rechten weliswaar niet worden aangetast, maar aan de andere kant dienden de rechten de verwezenlijking van de doelstellingen van de Gemeenschap zo min mogelijk in de weg staan. Dat rechten van de mens kunnen worden beperkt, is geen nieuw gegeven (het EVRM staat dit ook tot op zekere hoogte toe), maar de bewoordingen van het Hof duidden erop dat aan het 'algemeen communautair belang' een onevenredig grote betekenis werd gehecht. Hoewel dus rekening werd gehouden met onder meer de in het EVRM vervatte rechten, werd niet noodzakelijkerwijs dezelfde bescherming bereikt als die waarin het EHRM voorziet. De meer recente praktijk wijst erop dat het Hof bereid is om een verdere stap in de goede richting te zetten door aan te sluiten bij (de Straatsburgse interpretatie van) het EVRM en om aldus het beschermingsniveau te garanderen dat het EVRM biedt. De relatief recente uitspraak van het Gerecht in de PVCzaak echter lijkt de klok weer terug te draaien. Hoe dan ook: het probleem blijft dat het Hof op dit punt niet door het EHRM kan worden getoetst. De Europese Gemeenschap is geen partij bij het EVRM -noch kan zij dit vooriopig zijn- en dus bestaat er geen mogelijkheid voor justitiabelen om de gang van zaken binnen de Europese Gemeenschap aan het EHRM voor te leggen.

473 Dit overigens, zoals Pescatore terecht stelt, niet uitsluitend uit goede wil van het Hof, maar omdat het hiertoe gehouden was. 
Waar het Hof rekening houdt met het EVRM, daar valt de bestuursrechtelijke handhavg van de Mededingingswet geheel binnen dit verdrag. Dit geldt ook voor artikel 6 EVRA, hoewel daar sprake is van een 'criminal charge'. Volgens vaste rechtspraak van het EHM dient dit begrip echter autonoom te worden uitgelegd, waarbij met name acht moet woren geslagen op de aard van de overtreding en de aard en zwaarte van de mogelijke stf. Mede gelet op de aanzienlijke sancties die wegens een kartelovertreding kunnen woren opgelegd (tot $10 \%$ van de jaaromzet) staat vast dat het in de Mededingingswet om en 'criminal procedure' gaat. Op dit punt heeft derhalve de overheveling van strafrechtelike naar bestuursrechtelijke handhaving binnen het nationale kartelrecht de rechtsbeschernmg niet aangetast. Voor de toepasselijkheid van het EVRM is het niet relevant dat de rectssubjecten in het kartelrecht doorgaans rechtspersonen zijn. Weliswaar beschermt het EVM in de eerste plaats natuurlijke personen, maar verschillende rechten gelden naar hun ard evenzeer voor rechtspersonen. Dit geldt zonder meer voor artikel 6 EVRM aangezen daarin rechten zijn opgenomen die moeten garanderen dat een procedure die kan leien tot oplegging van cen punitieve sanctie, op een faire, eerlijke wijze wordt gevoerd. let betreft dus een beginsel dat aangeeft hoe een rechtsstaat zijn procedures moet inklecn. Tegen die achtergrond is niet in te zien waarom aan een rechtspersoon een eerlijk procs bestaande onder meer in de behandeling van de zaak door een onafhankelijke recter, berechting binnen redelijke termijn en waarborging van de presumptio innocentiae- ou

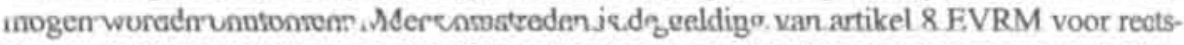
personen. Deze zouden geen privé-leven hebben en zouden dus geen bescherming behoeven. Naar mijn mening echter vormt artikel 8 EVRM primair een waarborg tegen onevenredig en willekeurig overheidsoptreden. Indien de overheid inmenging in het dagelijkse leven noodzakelijk acht, dan zal zij dit slechts mogen doen onder de strikte voorwaarden van het tweede lid van artikel 8 EVRM. Daaronder valt onder meer de eis van een voorafgaande, concrete en kenbare wettelijke regeling. Het lijkt mij in een rechtsstaat toch moeilijk te verdedigen dat aan een onderneming deze bescherming zou moeten worden ontzegd en dat dus de overheid zonder enige wettelijke basis de bedrijfsruimten van de onderneming zou mogen betreden en de gehele boekhouding en dergelijke in beslag zou mogen nemen. Dat laat onverlet dat de eisen die aan dit overheidsoptreden zouden moeten worden gesteld, minder hoog kunnen zijn wanneer het een woning van een natuurlijk persoon betreft. Hier speelt de privacy een grotere rol en mag dientengevolge geèist worden dat overheidsoptreden strenger genormeerd wordt.

Het kartelrecht moet dus voldoen aan de normen die het EVRM in de artikelen 6 en 8 stellen. Dat betekent in de eerste plaats dat de redelijke termijn in acht genomen moet worden. Drie criteria spelen dienaangaande een rol: de ingewikkeldheid van de zaak, de houding van de verdachte en de voortvarendheid waarmee van overheidszijde handha. ving ter hand wordt genomen. De ingewikkeldheid van de zaak is in het kartelrecht welhaast een gegeven. Het zal dus met name van de andere twee factoren afhangen of een termijn als al dan niet redelijk moet worden beoordeeld. Een tweede beginsel dat gerespecteerd moet worden, is het nemo tenetur-beginsel dat eveneens onderdeel uitmaakt van artikel 6 EVRM. De kern van dit beginsel moet hierin worden gevonden dat iedereen het recht heeft zijn eigen procespositie te bepalen in een tegen hem gevoerde 'strafrechtelijke' procedure. Het EHRM staat blijkens de Saunders en J.B.-arresten een aanmerkelijk minder ruime uitleg voor. Het ziet de ratio van het beginsel in het voorkomen van rechterlijke dwalingen en legt daarmee een link met de betrouwbaarheid van het bewijsmateriaal: 
indien dwang de betrouwbaarheid van het materiaal kan aantasten, neemt de kans op rechterlijke dwalingen toe. In feite heeft het EHRM daardoor het nemo tenetur-beginsel beperkt tot een zwijgrecht voor de fase waarin er sprake is van een 'criminal charge': niemand (voor zover 'charged') mag gedwongen ${ }^{474}$ worden om een mogelijk belasten$\mathrm{de}^{475}$ verklaring tegen zichzelf af te leggen. ${ }^{476}$ Tot het moment van de 'charge' kan het zwijgrecht niet met succes worden ingeroepen. Een afgedwongen verklaring mag echter -ook als zij vóór de 'charge' is afgelegd- niet tot bewijs worden gebruikt in een latere 'straf zaak: ook in die situatie staat immers de betrouwbaarheid van de uitkomst van de procedure op de tocht. ${ }^{477}$ Het Hof heeft in zijn Orkem-arrest, nog voordat het Funke-arrest was gewezen, ook een communautair zwijgrecht erkend. Dit recht, dat geen onderdeel vormt van de algemene beginselen van gemeenschapsrecht, werd noodzakelijk geacht om de rechten van de ondernemingen in de contradictoire fase (volgend op de mededeling van de punten van bezwaar) te waarborgen. Met name het recht van hoor en wederhoor en de onschuldspresumptie zouden worden aangetast indien een onderneming -direct of indirect- incriminerende vragen zou dienen te beantwoorden. De reikwijdte van dit zwijgrecht is echter relatief beperkt aangezien feitelijke informatie onverminderd door de Commissie mag worden opgeeist (ook al is deze belastend voor de onderneming in kwestie) en de facto slechts 'leading questions' verboden zijn. De Mededingingswet kent in artikel $53 \mathrm{Mw}$ een zwijgrecht dat sterke gelijkenis vertoont met de communautaire variant.

Het recht op rechtsbijstand is in het communautaire recht niet beperkt tot de contradictoire fase. De Commissie is -tenzij de onderneming beschikt over een interne juridische adviseur- onder omstandigheden bereid in het kader van een verificatie ex artikel 14 Vo 17 de komst van een externe jurist af te wachten. Het onderzoek mag hierdoor echter niet onredelijk vertraagd worden en de onderneming moet de onderzoekende ambtenaren desgewenst volledige toegang tot alle plaatsen bieden en moet verzekeren dat de bescheiden niet worden verplaatst. In zoverre is in een regeling voorzien die ten aanzien van de Nederlandse doorzoeking ontbreekt. Dit komt overigens niet alleen de ondernemingen ten goede, maar kan ook een goed verioop van de verificatie bevorderen. Een jurist kent beter dan de onderneming de rechten maar ook de plichten van deze, hij heeft er beter zicht op welke bescheiden voor de Commissie van belang kunnen zijn en kan bovendien ter plaatse eventuele onduidelijkheden ophelderen. In het bestuurs(straf)recht en dus voor de Mededingingswet is geldt er een recht op bijstand door een raadsman op grond van artikel 2:1 Awb. Bijstand door een advocaat kan op grond van artikel 2:2 lid 3 Awb zelfs niet worden geweigerd.

Beschermd wordt tevens het verschoningsrecht dat correspondentie tussen een advocaat en zijn cliënt (in casu de onderneming) beschermt. Het algemeen belang vergt dat justitiabelen voldoende mogelijkheden hebben om juridisch advies in te winnen; het verschonings-

\footnotetext{
474 Als dwang kan ook worden aangemerkt een wettelijke verplichting, kracht bijgezet door een boete of dwangsom.

475 Het zwijgrecht van artikel 6 EVRM is derhalve niet absoluut.

476 Documenten wordt slechts in zeer uitzonderlijke gevallen beschermd.

477 Warschijnlijkachthet Europese Hof het gebruik van een afgedwongenverklaring voor bewijs echter niet ontoelaatbaar als de procedure in zijn geheel toch als 'fair' kan worden aangemerkt. Dit is met name zo indien ander (betrouwbaar) materiaal de verklaring staaft.
} 
recht ondersteunt deze mogelijkheid. Mede daarom kent het Nederlandse strafrecht een uitgebreid functioneel verschoningsrecht, met dien verstande dat de groep verschoningsg : rechtigden beperkt is: naast de advocaat betreft het de arts, de notaris en de geestelijks, maar bijvoorbeeld niet de registeraccountant. Wel hebben derde-deskundigen die in hit belang van adequate advisering door een advocaat worden ingeschakeld, een van ce advocaat afgeleid verschoningsrecht voorzover het gegevens betreft waarover de geheinhoudingsplicht van de advocaat zich uitstrekt. De bescherming van het verschoningsrecit geldt onverkort ten aanzien van onder dit recht vallend materiaal dat zich bij de cliêt bevindt. Het belang dat het verschoningsrecht in Nederland dient, brengt mee dat ht de advocaat is die beslist over het al dan niet prijs geven van deze bescherming én dut het oordeel omtrent de vraag of materiaal onder het verschoningsrecht valt, toekomt an de advocaat en -behoudens zeer uitzonderlijke gevallen- niet aan de onderzoekende ambt. naren. Dit dient mijns inziens ook ten aanzien van het in de Mededingingswet geregele verschoningsrecht te gelden. De bescherming van het verschoningsrecht in het communataire recht is beperkter. Als uitgangspunt geldt dat ook correspondentie tussen advocat en cliënt opgeetist kan worden. Beschermd is wel de briefwisseling in het kader van ie verdediging van de onderneming (hetgeen mede een briefwisseling voorafgaand aan een communautair onderzoek kan omvatten) die afkomstig is van een onafhankelijke advocat, gevestigd in een lidstaat. Daarbij is het in beginsel de Commissie die bepaalt of het en

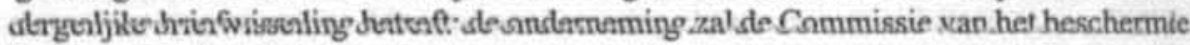
karakter van de briefwisseling moeten overtuigen. Lukt dit uiteindelijk niet, dan moet de Commissie bij afzonderlijke beschikking de betreffende informatie opeisen, hetgeen de onderneming in de gelegenheid stelt om de zaak aan het Gerecht voor te leggen. ${ }^{4 m}$ Beslist het Gerecht ten voordele van de onderneming, dan zal deze de informatie niet aan de Commissie hoeven te overhandigen. Bij een negatief oordeel heeft de onderneming geen recht meer de informatie achter te houden. Het problematische van deze procedure ligt hierin dat de Commissie in eerste instantie overtuigd moet worden, waardoor het verlenen van tenminste enige inzage van de bescheiden onontkoombaar is. De informatie die aldus door de Commissie wordt verkregen, mag dan weliswaar -voor zover vallend onder het verschoningsrecht- niet tot bewijs worden gebruikt, maar het mag niet verwacht worden dat de onderzoekende ambtenaren deze informatie volledig uit hun geheugen bannen; hierdoor kan deze informatie tijdens het onderzock toch een rol blijven spelen.

Dat rechtsbescherming een goede handhaving kan bevorderen, blijkt uit de communautaire regels ten aanzien van geheimhouding. Een onderneming die ervan verzekerd is dat gevoclige informatic derden niet ter ore zal komen, zal sneller geneigd zijn om informatie te verstrekken dan in het geval dat haar deze bescherming niet tockomt. De ruime geheimhoudingsverplichting biedt voorts een tegenwicht tegen de extensieve medewerkingsplicht van Verordening 17: ondernemingen zijn verplicht mede te werken, maar behoeven niet (als quasi-sanctie) openbaarmaking van zeer gevoelige gegevens te vrezen. Het spiegelbeeld hiervan vormt overigens dat een onderneming niet de verstrekking van gegevens mag weigeren die een gevoelige inhoud hebben en dus niet algemeen bekend mogen worden; als de gegevens deze inhoud daadwerkelijk hebben, dan mogen zij immers niet naar buiten

478 Het beroep heett weliswaar geen schorsende werking, maar de onderneming kan wel om een voorlopige voorziening vragen die voorkomt dat de Commissie voor de uitspraak van het Gerecht toch inzage verkrijgt. 
gebracht worden. Dit volgt in eerste instantie uit artikel 20 lid 2 Vo 17: gegevens die naar hun aard onder de geheimhoudingsplicht vallen, mogen niet openbaar worden gemaakt. Het betreft hier alle gegevens die in het kader van de kartelprocedure zijn vergaard, met uitzondering van die informatie die bij een breder publiek bekend is of relatief eenvoudig zou kunnen worden achterhaald. ${ }^{49}$ De geheimhouding geldt echter niet onbeperkt. Gegevens die naar hun aard onder de geheimhoudingsplicht vallen kunnen en moeten onder omstandigheden openbaar worden gemaakt in het kader van de hoorplicht van artikel 19 Vo 17 of van de bekendmaking van een beschikking op grond van artikel 21 Vo 17 . Met name waar het de hoorplicht betreft, kan gesteld worden dat in beginsel de geheimhouding zal dienen te wijken voor het recht op interne openbaarheid: zonder kennisneming van alle relevante stukken, is een onderneming niet in staat om zich adequaat te verdedigen. Mede tegen de achtergrond van het beginsel van 'equality of arms' moet ondernemingen die van een kartelinbreuk worden verdacht, volledige inzage van hun dossier worden verleend. Dit geldt ook ten aanzien van zakengeheimen (die communautairrechtelijk, maar ook op grond van de Mededingingswet, extra bescherming tegen openbaarmaking genieten), zij het dat het probleem zich hier, gelet op het karakter van de informatie die als zakengeheim is aan te merken, nauwelijks voordoet. Of informatie bekend wordt gemaakt, is in eerste instantie aan de Commissie om te beslissen. Wenst een 'verdachte' onderneming echter kennis te nemen van achtergehouden informatic, dan kan zij inzage trachten te bereiken door een daartoe strekkend verzoek bij de raadadviseur-auditeur in te dienen. Wordt om welke reden dan ook aan de onderneming van bepaalde documenten geen inzage verleend, dan mag het betreffende materiaal niet tegen die onderneming gebruikt worden. Ook hier blijkt weer onmiskenbaar een afweging tussen de belangen van de verdediging en de belangen van derden. Des te opmerkelijker is het dat bekendmaking van zakengeheimen aan derde-klagers op grond van het Akzo-arrest van het Hof in het geheel is verboden. Daar ontbeert dus de Commissie -mijns inziens ten onrechteiedere vrijheid van belangenafweging.

Op het gebied van de privacy-bescherming gaat het Hof minder ver dan het EHRM lijkt te gaan. Het EHRM heeft tot op zekere hoogte erkend dat ook rechtspersonen kunnen profiteren van de bescherming van artikel 8 EVRM. Dit is met name het geval indien woning en kantoor nauw met elkaar zijn verweven. Weliswaar koppelt het EHRM de bescherming van de privé-sfeer van ondernemingen sterk aan de persoonlijke ontplooiing van het individu, maar het laat mijns inziens ruimte open voor een toepassing van artikel 8 EVRM op grotere economische entiteiten. Aanvankelijk leek het Hof deze weg ook te kiezen, aangezien werd overwogen dat Verordening 17 en de belangen die met het communautaire betredingsrecht zijn gemoeid, de toets van artikel 8 lid 2 EVRM konden doorstaan. Daarmee is impliciet de optie open gelaten dat artikel 8 EVRM op ondernemingen van toepassing was. In zijn Hoechst-arrest daarentegen overwoog het Hof uitdrukkelijk dat artikel 8 EVRM in het geheel niet van toepassing was op ondernemingen, een overweging die op gespannen voet staat met de Straatsburgse jurisprudentic. Desalniettemin erkende het Hof het bestaan van een algemeen beginsel van gemeenschapsrecht dat slechts mag worden ingegrepen in de privé-sfeer van een rechtspersoon als hiervoor een wettelijke grondslag bestaat die de redenen van ingrijpen bepaalt. Via een zijdeur wordt aldus toch

479 Opzettelijke schending van de geheimhoudingsplicht is artikel 11 Wet Uitvoering EG-modedingingsverordeningen $j^{\circ}$ artikel 272 WvSr strafbaar gesteld. 


\section{Hoofdstuk S}

een bij artikel 8 EVRM aansluitende en aanvaardbare bescherming geboden tegen te vergaand overheidsoptreden. 


\section{Conclusie}

Een sprekender voorbeeld van intensivering en convergentie dan de omslag van het Nederlandse kartelrecht en -beleid in het afgelopen decennium, is maar moeilijk denkbaar. De tot dan toe geldende informele en door overleg gekenmerkte aanpak van kartels maakte plaats voor een hardere en meer formele benadering, het misbruikstelsel werd ingeruild voor een verbodstelsel met als blauwdruk de EG-mededingingsregels, de -in de praktijk vrijwel afwezige- strafrechtelijke handhaving werd (voornamelijk om redenen van effectiviteit) vervangen door een alles-in-één-hand handhaving door middel van bestuurlijke boetes. Kortom: de wens om van het imago van 'Nederland: kartelland' af te komen, werd in daden omgezet, in eerste instantie door het beleid op grond van de Wem aan te scherpen; uiteindelijk door de Wem te vervangen door de Mededingingswet, met de Nederlandse Mededingingsautoriteit, een -voorlopig-intern verzelfstandigde dienst van het ministeric van Economische Zaken, als handhavende instantie. Aan deze omslag lagen verschillende, met elkaar verband houdende, redenen ten grondslag. De eerste was van economische aard: de overtuiging was gegroeid dat kartels tot verstarring van de economie leidden, prikkels tot innovatie en efficiěntievergroting wegnamen en consumenten door hantering van onnodig hoge prijzen benadeelden. De tweede reden voor de (aanzet tot de) omslag lag in de totstandkoming van de Interne markt, met als 'magisch jaartal' 1992. De idee was dat Nederlandse bedrijven in een tijd van globalisering van de economie pas ten volle zouden kunnen profiteren van het verdwijnen van de handelsbarrières indien er ook op de thuismarkt een concurrentiele sfeer heerste; zonder deze dreigden Nederlandse ondernemingen niet te zijn opgewassen tegen ondernemingen die wel van een competitieve thuismarkt profiteerden. Nederland -en hierin lag de derde reden- werd met zijn op het misbruikstelsel geënte mededingingsregime in toenemende mate een vreemde eend in de Europese kartelbijt. Integratie en Europese solidariteit maakten convergentie wenselijk te meer daar het niet passend werd bevonden dat Nederland -zelf in hoge mate afhankelijk van export en buitenlandse handel- zou profiteren van de slechting van de handelsbarrières in Europa, terwijl het voor buitenlandse ondernemingen door het bestaan van kartels moeilijk zou blijven om op de Nederlandse markt door te dringen. De vierde reden hing hiermee samen en was politiek van aard. Het als te mild te boek staande Nederlandse kartelbeleid werd gaandeweg steeds meer onderwerp van communautaire kritiek. Pijnlijk was met name de zaak van het Nederlandse bouwkartel, aan welk kartel Nederland zijn fiat had gegeven, maar dat op communautair niveau onderuit werd gehaald en zwaar werd beboet. Het imago van Nederland binnen de Europese Gemeenschap had hieronder te lijden, hetgeen voor een land dat binnen deze Europese Gemeenschap een voortrekkersrol wil vervullen (men denke aan de inspanningen die leidden tot de Verdragen van Maastricht en Amsterdam) (politiek) zeer gevoelig lag.

Het gevoelen was derhalve dat de Wem en het op grond van die wet gevoerde beleid niet langer adequaat waren. Hieruit mag echter niet worden geconcludeerd dat dus dit beleid ook voordien niet voldeed. Het tegendeel was eerder het geval. Het informeel en zelden met harde hand gevoerde beleid, met als voornaamste doel het vinden van een voor iedereen aanvaardbare oplossing, paste uitstekend bij de toenmalige Nederlandse kartelfilosofie (en dus bij de neutrale houding die tegenover kartels werd ingenomen) 
alsmede bij het corporatistisch denken en de Nederlandse overlegcultuur. Het weren ran een kartel zou in die filosofie hebben betekend dat met het badwater tevens het knd zou worden weggegooid: weliswaar werd aldus de strijd met het algemeen belang dan opgeheven, maar zou geen gebruik gemaakt worden van de positieve aspecten die aan een minder vergaande afspraak werden toegedicht. Vanuit corporatistisch denken moest bovendien aan marktpartijen de vrijheid worden gelaten om hun zaken onderling te regelen; de overheid moest zich zo veel mogelijk afzijdig houden. Was optreden toch geboden, dan moest de oplossing voor het conflict zoveel mogelijk via onderling overleg worlen gevonden. Voor een optreden met harde hand was hierbij geen plaats -hooguit als daadverkelijk 'ultimum remedium'-; een dergelijk optreden zou voorts een negatieve invloed kunnen hebben op de bereidheid van de betrokkenen om op andere terreinen wél om de overlegtafel te gaan zitten. Een en ander laat onverlet dat de wijziging in de houdng van de Nederlandse overheid tegenover kartels een ander en strikter beleid noodzakeijk makte. Dat de Wem voor een dergelijk beleid geen basis had kunnen vormen, is overigens niet juist. Dit bewijzen het -weliswaar niet op zeer ruime schaal gevoerde- relatief stikt informeel én formeel anti-kartelbeleid in de jaren volgend op de Tweede Wereldooriog alsmede het feit dat ook in de jaren negentig de teugels zijn aangehaald door de mrest ernstige vormen van kartelgedrag generiek onverbindend te verklaren. Dat een blijvend strikt en formeel beleid nooit van de grond is gekomen, ligt dan ook meer aan de Necerlandse houding tegenover kartels on aan het ontbreken van de politieke wil am met ferme hand op te treden, dan aan de Wem zelf. Hiermee is overigens niet gezegd dat de Wem inderdaad gehandhaafd had moeten blijven. Waar de overheid een beleid voor ogen staat waarin wordt uitgegaan van het verbod op kartels, verdient het, zowel vanuit de optiek van wettelijke legitimatie van het beleid als gelet op de werkbaarheid van een dergelijk beleid, inderdaad de voorkeur om een verbodwetgeving in het leven te roepen.

Met de inwerkingtreding van de Mededingingswet verdween de strafrechtelijke handhaving ook officieel' van het toneel. De tijd was volgens de overheid rijp voor handhaving via de bestuurlijke boete, die ook -en in toenemende mate- op andere gebieden wordt ingezet. Als redenen voor bestuursrechtelijke handhaving van de Mededingingswet werden aangevoerd: het 'ultimum remedium-karakter' van het strafrecht, de voorkeur voor handhaving van beleidsinstrumentele wetgeving door het met de uitvoering belaste bestuursorgaan, de deskundigheid en effectiviteit die met bestuursrechtelijke handhaving gegarandeerd zou zijn, de bevordering van een goede afstemming met het communautaire recht alsmede als negatieve indicatie voor het strafrecht- de twijfels omtrent de geschiktheid van het strafrecht als handhavingsinstrument van de Mededingingswet, waarbij met name het gebrek aan deskundigheid van het Openbaar Ministerie en de strafrechter, de ingewikkeldheid van de materie, de capaciteitsproblemen binnen het strafrechtelijke systeem en de geringe normatieve lading van de kartelinbreuken twijfels opriepen over het strafrecht als middel tot handhaving van de op nieuwe leest geschoeide Nederlandse mededingingsregels. ${ }^{2}$ Veel indruk maken deze redenen om van het strafrecht af te stappen niet. Nog

1 Van daadwerkelijkestrafrechtelijkehandhaving was in de praktijk immers al nauwelijks sprake. Veel meer dan een stok achter de deur tijdens de onderhandelingen over aanpassing van kartels was bet strafrecht niet.

2 Met name het spookbeeld van informele afhandeling via sepots of transacties doemde bij de minister op. 
afgezien van het feit dat het ontbreken van normatieve lading niet noodzakelijkerwijs hoeft te leiden tot een geringe (vervolgings)prioriteit, hangt de normatieve lading van een inbreuk mede af van de strengheid van het optreden tegen de betreffende inbreuk: een consequente handhaving, kracht bijgezet door sancties, kan normatieve lading 'kweken'. Aan het feit dat het strafrecht onder het regime van de Wem en de WED nauwelijks enige betekenis heeft gehad, kunnen in ieder geval geen aanwijzingen worden ontleend voor de juistheid van het door de minister geschetste negatieve scenario van strafrechtelijke handhaving. Het strafrecht was afhankelijk van voorafgaande maatregelen zoals (generieke) onverbindendverklaringen. Aangezien deze veelal uitbleven, kón het strafrecht geen rol van betekenis spelen. Dat de prioriteit voor die gevallen waarin dat wel mogelijk was niet hoog was, moge niet verbazen aangezien men op het ministerie van Economische Zaken zelf niet geporteerd was van hard optreden: er kan dan moeilijk verwacht worden dat het Openbaar Ministerie in bedoelde gevallen wél steeds krachtig optreedt. Ten aanzien van eventuele problemen op het gebied van deskundigheid, capaciteit en afstemming met het communautaire beleid geldt dat deze kunnen worden opgelost.' Dat van het strafrecht slechts als 'ultimum remedium' gebruik mag worden gemaakt, is op zichzelf genomen zeker juist, maar dit geldt naar mijn mening voor iedere vorm van punitief overheidsoptreden, dus ook voor de handhaving via de bestuurlijke boete. Of bestuursorganen zelf de verantwoordelijkheid moeten dragen voor de handhaving van beleidsinstrumentele wetgeving, is een politieke keuze, die overigens mede wordt bepaald door de grotere doelmatigheid die handhaving door bestuursorganen wordt toegedicht.

De keuze voor bestuursrechtelijke handhaving van de Mededingingswet volgt derhalve niet dwingend uit de door de minister genoemde redenen. Men kan het de minister echter moeilijk verwijten dat hij, gelet op de ervaringen met de strafrechtelijke 'handhaving' van de Wem, het risico van continuering van de oude situatie heeft willen vermijden, te meer daar er zich een in de ogen van de minister geschikt alternatief in de vorm van de bestuurlijke boete aandiende. Daarbij moet echter wel bedacht worden dat ook de keuze voor de bestuursrechtelijke handhaving, ook waar het de effectiviteit van de handhaving betreft, geen volledige zekerheid bood op een 'verbetering' (in de zin van meer, gerichter, en strenger optreden tegen normschendingen) ten opzichte van het strafrecht, aangezien er met de handhaving via bestuurlijke boetes in Nederland nog nauwelijks enige ervaring was opgedaan, zeker niet waar het gaat om boetes met een hoogte zoals de Mededingingswet die kent. Maar de verwachting van een grotere effectiviteit van deze handhavingsvorm was natuurlijk niet geheel uit de lucht gegrepen -mede gelet op de concentratie van de gehele toepassing van de Mededinging bij één instantie- en wordt meer algemeen als voordeel ten opzichte van het strafrecht gezien. Vanuit die optiek is de keuze voor het bestuursrecht een logische stap, waarop in beginsel ook niets tegen is aangezien een effectieve handhaving (in bedoelde zin) een groot goed kan zijn. Maar effectiviteit staat niet op zich. $\mathrm{Er}$ is nog een andere zijde aan de handhavingsmedaille: derechtmatigheid. Het is niet ongebruikelijk dat waar van 'effectiviteitsverhoging' wordt gesproken, het doelmatigheidsaspect van een regeling (meer en makkelijker hanteerbare onderzoeksbevoegdheden, een meer gestroomlijnde handhaving zonder al te veel obstakels in de vorm van de burger beschermende normen, hogere straffen etc.) wordt overbelicht en de rechtmatigheid (beperking van overheidsbevoegdheden, verdedigingsrechten, rechter-

3 Men bedenke dat de NMa ook capaciteit vergt. De middelen die hiervoor zijn vrijgemaakt, hadden ook in de richting van het Openbaar Ministerie en het opsporingsapparaat kunnen vloeien. 
lijke controle etc.) dientengevolge onderbelicht blijft. En zoals bekend, levert over-noch onderbelichting goede resulaten op. Daarom heb $\mathrm{ik}$ mij in dit onderzoek op beide aspecten gericht. Dat de probleemstelling is toegespitst op de rechtmatigheidszijde doet daaraan niet af: zij vormt een tegenwicht tegen de nadruk die van overheidszijde op de doelmatigheidskant van de handhaving wordt gelegd.

Waar het de doelmatigheidszijde betreft, moet de conclusie zijn dat in zowel het communautaire als het Nederlandse kartelrecht de randvoorwaarden voor een effectieve handhaving aanwezig zijn. De concentratie van de gehele toepassing van het communautaire respectievelijk het Nederlandse kartelrecht (van beoordeling van ontheffingsaanvragen, via toezicht en 'opsporing', naar boete-oplegging) bij één gespecialiseerde instantie (de NMa respectievelijk de Commissie) verzekert de aanwezigheid van de benodigde expertise, garandeert dat de onderlinge 'lijnen' kort zijn, dat beleid en handhaving goed op elkaar kunnen worden afgestemd en dat de prioriteit volledig bij kartelzaken (waaronder hier mede begrepen concentratiezaken) kan worden gelegd.

Ook aan adequate bevoegdheden tot handhaving is geen gebrek. De Commissie beschikt over een zeer ruime inlichtingen- en verificatiebevoegdheid, die beide kracht worden bijgezet door een op ondernemingen rustende medewerkingsverplichting. Daarenboven groeit de verificatiebevoegdheid, in geval van niet-coöperatie van ondernemingen, uit tot een bevoegdheid die nauwelijks voor een bevoegdheid tot doorzoeking van ondernemersplaatsen onderdoet, althans voorzover door nationale autoriteiten bijstand wordt verleend. Daar komt voor Nederland op grond van de Uitvoeringswet nog bij dat de rechter-commissaris daadwerkelijk tot doorzoeking van 'geheime plaatsen' kan overgaan. Veel toepassing zal deze doorzoeking in de praktijk echter waarschijnlijk niet vinden. Tot op heden hebben deze bevoegdheden zeer bevredigend gefunctioneerd en er is mijns inziens dan ook geen enkele reden voor een eventuele uitbreiding. De Commissie lijkt het hiermee overigens niet geheel eens te zijn. In haar 'Voorstel Uitvoeringsverordening' geeft zij aan te willen beschikken over een betredingsrecht van woningen (zij het 'slechts' met voorafgaande goedkeuring van een nationale rechter) en wel omdat de praktijk zou uitwijzen dat 'steeds vaker' relevant materiaal in woningen van personeelsleden wordt bewaard, hetgeen de verificatie zou frustreren. Ik kan niet anders dan concluderen dat de Commissie hier wel erg ver doorschiet. Aldus zouden de grenzen van de verificatiebevoegdheid in een onredelijke mate worden uitgerekt. Wanneer immers moet worden aangenomen dat relevant materiaal zich bij een personeelslid thuis bevindt? En bij welk personeelslid of welke personeelsleden dan? Mogelijk alle? En hoe ver mag de toetsing door de nationale rechter gaan? Nog afgezien van het feit dat de Commissie kwaadwillende ondernemingen wel erg onderschat indien zij van mening is dat zij het deze aldus (vrijwel) onmogelijk zou maken om het vergaren van informatie te frustreren, overschrijdt een dergelijke betredingsbevoegdheid alle grenzen van het redelijke. Bovendien is zij niet werkelijk nodig indien men bedenkt dat de Commissie een onderneming wegens nietmedewerking kan beboeten of haar een dwangsom kan opleggen teneinde overhandiging van de informatie alsnog te bewerkstelligen.

De bevoegdheden van de NMa zijn niet minder verstrekkend dan die van de Commissie en verschillen bovendien nauwelijks met de bevoegdheden die het opsporingsapparaat bij een strafrechtelijke handhaving van de Mededingingswet ter beschikking zouden hebben gestaan: 
- het betreden van plaatsen, met uitzondering van een woning zonder toestemming van de bewoner (art. 5:15 lid I Awb);

het verschaffen van tocgang tot die plaatsen met behulp van de sterke arm (artikel 5:15 lid 2 Awb); het vorderen van inlichtingen (art. 5:16 Awb);

het vorderen van inzage van zakelijke gegevens en bescheiden, met inbegrip van de bevoegdheid tot het maken van kopieťn van de gegevens en bescheiden (art. 5:17 Awb);

- het meenemen van de gegevens en bescheiden teneinde deze te kopièren, voorzover dit niet ter plaatse kan geschieden (art. 5:17 lid 3 Awb), alsmede (in het kader van het onderzoek)

- de bevoegdheid om voor zover noodzakelijk bedrijfsruimten en voorwerpen te verzegelen gedurende de tijd gelegen tussen 18.00 en 8.00 (art. $54 \mathrm{Mw}$ ), en

- de bevoegdheid om inzage van gegevens en bescheiden af te dwingen met behulp van de sterke arm (art. $55 \mathrm{Mw}$ ).

Ook hier geldt dat op de ondernemingen een verplichting tot medewerking rust en dat de NMa bij niet-coöperatie haar toevlucht kan nemen tot boetes en dwangsommen alsmede dat zij de hulp van de sterke arm kan inroepen. Daarom is het ontbreken van een doorzoekingsbevoegdheid ook hier geen gemis. ${ }^{4}$

De sancties die wegens een inbreuk op het kartelrecht kunnen worden opgelegd, zouden ook geen hindernis voor een effectieve handhaving mogen vormen. ${ }^{5}$ In tegendeel: een boete van ten hoogste $10 \%$ van de wereldwijde omzet van het aan de boete-oplegging voorafgaande jaar is zowel vanuit het oogpunt van repressie als van preventie meer dan adequaat te noemen. Door de grote discretionaire vrijheid die aan zowel de Commissie als de NMa bij de straftoemeting is gelaten, zijn deze autoriteiten bovendien in staat gesteld om iedere overtreding te beantwoorden met een passende sanctie.

De doelmatigheid lijkt kortom weinig in de weg gelegd. Maar hoe zit het met de rechtmatigheid? De alles-in-één-hand handhaving roept in zoverre bedenkingen op dat zij -hoe objectief de autoriteiten de zaak ook mogen beoordelen- de schijn van partijdigheid tegen zich heeft. Waar in het strafrecht vervolging (alsmede de daaraan voorafgaande opsporing) en berechting bij twee van elkaar onafhankelijke organen (respectievelijk het Openbaar Ministerie en de strafrechter) berusten, daar vinden deze in de bestuursrechtelijke handhaving van de kartelregelgeving door c.q. onder verantwoordelijkheid van een en dezelfde instantie plaats, te weten de Commissie respectievelijk de d-g NMa. Het lijkt op zijn minst zeer onwaarschijnlijk dat de Commissie of de d-g NMa, vanaf het moment waarop de punten van bezwaar respectievelijk het rapport zijn opgesteld, nog gevoelig zal zijn voor argumenten van de verdediging dat vormen zijn geschonden, haar rechten niet in acht zijn genomen, geen schuld kan worden aangetoond etc.. Met het opmaken van de punten van bezwaar en het rapport geeft de betreffende autoriteit immers reeds aan dat zij tot het oordeel is gekomen dat er voldoende aanwijzingen voor een regelovertreding zijn en dat een boete op zijn plaats is. En dezelfde autoriteit die tot deze conclusie is gekomen, oordeelt vervolgens over de bedoelde argumenten. Erg veel vertrouwen in een

4 Het onderstreept mijns inziens wel hoezeer de wetgever het strafrecht buiten de deur van de Mededingingswet heeft willen houden. De Wet uitvoering EG-mededingingsverordeningenkent daarentegen wel een doorzoekingsbevoegdheid.

5 De sancties wegens overtreding van onder meer de medewerkingsplicht zijn, zeker voor 'grote' ondernemingen daarentegenniet echt indrukwekkend. Veel problemen lijkt dat in het communautaire recht niet te hebben opgeleverd. Toch zou de Commissie graag een verhoging van die sancties zien, waar mijns inziens wel wat voor valt te zeggen. 
onvooringenomen en onafhankelijke kijk op de zaak en op een goede afloop kan dan van ondernemingen niet verwacht worden. Daaraan verandert ook het feit niets dat de Mededingingswet vergt dat de onderzoeksfase en de contradictoire fase ook op personeel vlak van elkaar worden gescheiden: een ambtenaar van de NMa mag niet in dezelfde zaak betrokken zijn bij toezicht en onderzoek aan de ene en de uiteindelijke beschikking aan de andere kant. Het probleem blijft hierdoor onveranderd: alle handelingen worden onverkort onder de verantwoordelijkheid van de d-g NMa verricht. Toch is deze concentratie van bevoegdheden mijns inziens niet onaanvaardbaar, ook niet tegen de achtergrond van artikel 6 EVRM. De reden hiervoor ligt erin dat de onderneming, in die gevallen waarin zij inderdaad van mening is dat niet of in onvoldoende mate met haar argumenten rekening is gehouden (en dit zal lang niet altijd redelijkerwijs het geval zijn), zowel in het communautaire als in het Nederlandse recht een adequate mogelijkheid heeft om tegen de betreffende beslissing in beroep te gaan. In het EG-recht staat de weg naar het Gerecht en het Hof open (die beide er reeds blijk van hebben gegeven dat zij de beschikkingen van de Commissie grondig toetsen); het Nederlandse mededingingsrecht kent de mogelijkheid van bezwaar bij de d-g NMa en daaropvolgend beroep bij de rechtbank Rotterdam en -voor hoger beroep- bij het College van Beroep voor het bedrijfsleven. Daarbij is van bijkomend belang dat bezwaar en beroep op grond van de Mededingingswet -en, gelet op de belangen die in het geding zijn, terecht ${ }^{7}$ - schorsende werking hebben, dit in tegenstelling tot hetgeen in het besturursrecht gebruikelijk is, ${ }^{8}$

Het feit dat noch het communautaire recht noch de Mededingingswet strafrechtelijk van aard zijn, werpt ook op andere en voor dit onderzoek belangrijkere punten van rechtsbescherming vragen op. Immers: de waarborgen die eigen zijn aan het strafrecht, gelden niet automatisch voor deze rechtsgebieden. En een van de functies van het (formele) strafrecht is juist de bescherming van de positie van de justitiabele. Daarom kent het straf(proces)recht ook zo'n uitgebreide regeling betreffende de beperkingen van overheidsbevoegdheden en (procedurele) rechten voor de verdachte. Dat kan niet met recht worden gezegd van het geschreven EG-recht. Het geschreven EG/EU-recht blinkt niet bepaald uit in rechtsbescherming; uitzonderingen hierop vormen artikel $6 \mathrm{EU}$ en het -echter vooralsnog niet bindende- Handvest van de grondrechten van de Europese Unie. Op dat gebied is het met de Mededingingswet beter gesteld. Deze wet kent enkele belangrijke rechten en waarborgen die in belangrijke mate zijn ontleend aan het (formeel) strafrecht én aan

Deze bezwaarprocedure kan mijns inziens beter worden afgeschaft. Het past niet in een punitieve procedure waarin de ondernemingen reeds voorafgaand ruimschoots de mogelijkheid hebben gehad om hun visie te geven. De enige meerwaarde ligt in het advies van een onafhankelijke commissic dat door de $\mathrm{d}-\mathrm{g} \mathrm{NMa}$ moet worden ingewonnen. Hoewel verwacht mag worden dat dit advies doorgaans door de d-g NMa zal worden opgevolgd, lijkt dit toch allemaal wat veel van het goede. Een mogelijkheid van beroep bij twee rechterlijke (en gespecialiseerde) instanties lijkt mij voldoende.

7 Ook al wordt daardoor aan doelmatigheid ingeboet. De doelmatigheid zou kunnen worden aangetast door een toename van het aantal bezwaar-en beroepprocedures. Het enkele feit dat bezwaaren beroep schorsende werking hebben, zou immers reeds voor ondernemingen een reden kunnen zijn om een bezwaar en/of beroep in te stellen. Het is echter zeer de vraag of het risico van een toename om deze reden zo groot zal zijn. Gelet op de omvang van de boetes, zal een onderneming hoe dan ook relatief snel geneigd zijn het besluit aan te vechten.

8 Het communautaire recht kent geen schorsende werking, max er kan wel opschorting worden gevraagd. In de praktijk gaat de Commissie niet tot tenuitvoerlegging over indien de zaak nog niet in gewijsde is. 
het EVRM. Dit laatste is niet verbazend omdat op grond van de jurisprudentie van het EHRM ieder overheidsoptreden met een punitief karakter (ongeacht de kwalificatie die in de nationale rechtsorde aan dat optreden wordt gegeven), aan de normen van het EVRM zal moeten voldoen, voor zover natuurlijk de betreffende staat partij bij het EVRM is. Dit geldt mijns inziens eveneens indien, zoals in het kartelrecht, een procedure betrekking heeft op gedragingen van ondernemingen, dus in beginsel van rechtspersonen. Het primaire belang van het EVRM ligt in de beperking van de overheidsmacht die ten opzichte van justitiabelen kan worden uitgeoefend. Het is niet in te zien waarom deze in een rechtsstaat fundamentele waarborgen niet voor ondernemingen zou hoeven te gelden. Het voorgaande betekent dat het Nederlandse kartelrecht gebonden is het EVRM en dat de daaruit voortvloeiende normen in acht moeten worden genomen ook als het geschreven Nederlandse kartelrecht het Straatsburgse beschermingsniveau niet zou bereiken. Dat is echter niet zonder meer het geval voor het communautaire recht: de Europese Gemeenschap is immers -helaas- geen partij bij het EVRM. Hier heeft echter het Hof een belangrijke voortrekkersrol vervuld. Aan de hand van zijn jurisprudentie aangaande de algemene beginselen van gemeenschapsrecht die geěerbiedigd moeten worden (de normen die voortvloeien uit het EVRM alsmede uit de gemeenschappelijke constitutionele tradities van de lidstaten), heeft het een zeer aanvaardbaar niveau van rechtsbescherming gerealiseerd. Door het EVRM als bron voor zijn rechten-jurisprudentie te gebruiken, benadert het Hof in ieder geval het minimum-beschermingsniveau van dit verdrag. Een probleem is echter dat het Hof de rechten van de verdediging niet als het hoogste recht ziet, hetgeen ertoe kan leiden dat communautaire (doelmatigheids)belangen een volledige realisering van de vereiste rechtsbescherming in een concreet geval in de weg staan. Het zou daarom naar mijn mening positief zijn te waarderen indien het communautaire recht onder de competentie van het EHRM zou komen te vallen.

Samenvattend: noch het communautaire recht noch het Nederlandse kartelrecht kennen als zodanig de bescherming die het strafrecht biedt, maar dat betekent niet dat ondernemingen vogelvrij zijn. Dat blijkt ook wel uit de waarborgen die in het mededingingsrecht gelden. Zo geldt in het communautaire recht het ne bis in idem-beginsel, voor interne kwesties in de vorm van het 'Erledigungsprinzip'; voor de verhouding gemeenschap/(derde) staat in de hoedanigheid van het 'Anrechnungsprinzip'. Opmerkelijk genoeg ontbreekt een bescherming tegen een tweede vervolging wegens hetzelfde feit in de Mededingingswet. Weliswaar kunnen in de kamerstukken van deze wet geruststellende woorden van de minister worden gevonden en zal dubbele bestraffing in beginsel steeds in strijd zijn met de algemene beginselen van behoorlijk bestuur, maar dat vergoedt allerminst het ontbreken van wettelijke regels. Op dit punt schiet de Mededingingswet dus onmiskenbaar tekort. ${ }^{9}$ Voor de verjaringsregeling geldt dit niet. Evenals in het communautaire recht en het strafrecht het geval is, kent de Mededingingswet een verjaringstermijn, waardoor na verloop van tijd 'een streep onder de zaak kan worden gezet'. ${ }^{10}$ Een doelmatigheids-

\footnotetext{
9 Bedachtmoet worden dat het EVRM in deze geen soelaas biedt. Het Zevende Protocolkent weliswaar het ne bis in idem-beginsel, mas dit is voor Nederland nog niet in werking getreden. Wel zal in de Vierde tranche Awb algemeen een ne bis in idem-beginsel voor de bestuurlijke boete worden opgenomen. Tot die tijd moet maar gehoopt worden dat de d-g NMa ook zonder wettelijke regeling niet tot een tweede 'vervolging' overgaat.

10 Hazewinkel-Suringa/Remmelink (1994), pag. 601.
} 
probleem ligt echter mogelijk in het ontbreken van een stuitings- en schorsingsregeling ${ }^{\mathrm{E}}$, waardoor binnen vijf jaar (de verjaringstermijn, die overeenkomt met de communautaine termijn en slechts marginaal afwijkt van de strafrechtelijke termijn zoals die voor Wendelicten gold) de zaak rond moet zijn, hetgeen in moeilijk bewijsbare zaken wel eers onvoldoende zou kunnen blijken te zijn.

Andere waarborgen die het Nederlandse en communautaire kartelrecht kent, zin voornamelijk op het EVRM gebaseerd of zijn vergelijkbaar met de daaruit voortvloeience normen. Dit is bijvoorbeeld het geval ten aanzien van de eis van berechting binnen een redelijke termijn, die uit artikel 6 EVRM voortvloeit. De wijze waarop deze eis in hat Nederlandse en in het communautaire recht wordt toegepast, is vergelijkbaar. In navolgirg van het EHRM wordt de redelijkheid van de termijn aan de hand van drie criteria beoodeeld: de ingewikkeldheid van de zaak, de houding van de 'verdachte' en de voortvarentheid van de bevoegde instanties. Aangezien kartelzaken zelden eenvoudig zijn, mag vewacht worden dat met name de laatste twee criteria in de praktijk een rol zullen spelen. Het ziet er echter niet naar uit dat een overschrijding van de redelijke termijn al te groe consequenties heeft. Tot meer dan een verlaging van de (zonder overschrijding gerechtvaadigde) boete zal -behoudens zeer uitzonderlijke gevallen- niet worden besloten.

Een andere waarborg vormt het nemo tenetur-beginsel. Dit recht om niet aan de eigen veroordeling te hoeven mee te werken, is er (tenminste) in een ruime en beperkte variart. De ruime -en te verkiezen- variant biedt de verdachte het recht om iedere medewerking te weigeren. Cruciaal hierbij is de vrijheid van een verdachte om zijn eigen procespositie te bepalen. De beperkte variant ziet de ratio in de voorkoming van rechterlijke dwalingen en, daarmee samenhangend, in de betrouwbaarheid van de te vergaren informatie. En aangezien de betrouwbaarheid slechts in het geding is indien er dwang wordt uitgeoefend ten einde mondelinge verklaringen te verkrijgen, is in die lezing het nemo tenetur-beginsel beperkt tot een zwijgrecht. Dit is de lijn waarop het EHRM helaas in ieder geval sinds het Saunders-arrest zit: vanaf het moment waarop een verdachte 'charged with a criminal offence' is, dus vanaf het moment waarop er van overheidswege een maatregel is genomen die de positie van de verdachte wezenlijk beïnvloedt, geldt een -niet absoluut- zwijgrecht; documenten genieten slechts in zeer uitzonderlijke gevallen bescherming van het nemo tenetur-beginsel. Tot het moment van de 'charge' is dit recht er niet, zij het dat in die fase afgelegde verklaringen in beginsel niet als bewijs in een latere punitieve procedure mogen worden gebruikt. De door het Luxemburgse Hof geboden bescherming wijkt hier niet al te veel van af: de Commissie mag een onderneming niet verplichten antwoorden te geven waardoor zij het bestaan van een inbreuk zou moeten erkennen, die de Commissie moet bewijzen. Deze bescherming geldt ook reeds voorafgaand aan een 'criminal charge', hetgeen ook in de Mededingingswet -om redenen van convergentie- is gerealiseerd door het zwijgrecht te koppelen aan het moment waarop een redelijk vermoeden van overtreding is gerezen. ${ }^{12}$ Andere vormen van medewerking -bijvoorbeeld het overhandigen van be-

11 Zowel het strafrecht als het communautaire recht voorzien wel in een dergelijke regeling.

12 Daarnaast is er analoog aan het strafrecht in een cautieplicht voorzien. De betrokkenen mocten voor een 'verhoor' op de hoogte van hun zwijgrecht worden gebracht. Cautieverzuim heeft echter geen gevolgen indien de onderneming niet in haar belangen is geschaad, hetgeen met name het geval is als zij juridische bijstand heeft gehad. Daar een onderneming in veel gevallen over deze bijstand zal beschikken, biedt de cautieplicht weinig extra bescherming. 
paalde documenten- mogen daarentegen niet geweigerd worden. ${ }^{13}$ Het is te betreuren dat het nemo tenetur-beginsel in de jurisprudentie zo restrictief wordt geinterpreteerd. Feit is wel dat de Mededingingswet en in grote lijnen ook het communautaire recht aan artikel 6 EVRM voldoen.

Een volgend recht is het recht op privacy, zoals dat ook in artikel 8 EVRM wordt beschermd. Dit recht kan ook in het kartelrecht in het geding zijn: ook ondernemingen hebben recht op een 'overheidsvrije' sfeer (alhoewel het Hof mijns inziens ten onrechte oordeelde dat artikel 8 EVRM geen bescherming aan ondernemingen biedt). Wil er derhalve sprake kunnen zijn van een rechtens geoorloofde inbreuk op dit recht, moet er onverminderd aan de voorwaarden van het tweede lid van artikel 8 EVRM worden voldaan. Dat blijkt ook wel het geval te zijn. Woningen mogen -zonder toestemming van de bewoner- (vooralsnog ? $^{14}$ ) niet worden betreden. Voor bedrijfsruimten geldt een dergelijke bevoegdheid zowel in het communautaire als in het Nederlandse kartelrecht wel, maar de grondslag voor deze bevoegdheid (voor het communautaire recht: artikel 14 Vo 17; voor het Nederlandse kartelrecht: artikel 5:15 Awb) is voldoende concreet en de inmenging kan zeer wel als noodzakelijk in een democratische samenleving in het belang van het economisch welzijn worden beschouwd. In een (voorafgaande) rechterlijke toetsing is niet voorzien. Het EVRM eist dit ook niet, waardoor het ook mogelijk was om de doorzoeking in het Nederiandse strafrecht voor een belangrijk deel uit het gerechtelijk vooronderzock te halen en over te hevelen naar het opsporingsonderzoek. Of dit echter een gelukkige keuze is, is een tweede. De privacy bij met name grote ondernemingen is zonder twijfel minder precair dan bijvoorbeeld het geval is bij de woning van natuurlijke personen, waardoor voorafgaande rechterlijke toetsing misschien wat veel van het goede zou zijn. Maar bedacht moet worden dat een doorzoeking, waarmee het betredingsrecht zoals dat uit het communautaire recht en de Mededingingswet volgt vergelijkbaar is, een zeer ingrijpend middel is. Voorafgaande rechterlijke toetsing zou mijns inziens dan ook geen overbodige luxe zijn.

Het recht op rechtsbijstand, ook een in artikel 6 EVRM verankerd recht, alsmede het verschoningsrecht zijn in het communautaire recht goed geregeld, zij het voor zover het het verschoningsrecht betreft minder goed dan in het Nederlandse strafrecht het geval is. ${ }^{15}$ Het is vast beleid van de Commissie dat zij -binnen redelijke grenzen- de komst van een externe juridische adviseur afwacht alvorens met een verificatie te beginnen. Dit is slechts anders indien de onderneming beschikt over een bedrijfsinterne juridisch adviseur of indien zij de ambtenaren van de Commissie geen volledige toegang verleent. Een dergelijke regeling kent de Mededingingswet niet, hetgeen betreurd moet worden. Wel kunnen de artikelen 2:1 en 2:2 Awb uitkomst bieden, waar deze 'in het verkeer met

13 Op dit punt levert de Mededingingswet aan de 'verdachte' dus aanmerkelijk minder bescherming dan het wetboek van Strafvordering. Hierin is immers geen enkele verplichting voor een verdachte opgenomen om op welke wijze dan ook medewerking te verlenen. Deze ruime bescherming biedt de WED echter niet, zodat ondernemingen door de overgang naar bestuursrechtelijke handhaving hier geen rechtsbescherming inleveren.

14 De Commissie wil immers blijkens haar 'Voorstel Uitvoeringsverordening' ook beschikken over een betredingsrecht voor woningen van personeelsleden. Het is te hopen dat deze wens het wetgevingsproces niet overleeft.

15 Met uitzondering overigens van een regeling van kostenloze rechtsbijstand. Hoewel de noodzaak hiervan voor ondernemingen doorgaans afwezig zal zijn, verdient het toch de voorkeur om in een dergelijke regeling te voorzien. 
bestuursorganen' aan een ieder het recht op bijstand toekennen. Een bij het communautaire recht aansluitende en meer op de boeteprocedure toegespitste regeling zou echter de voorkeur verdienen. Communautairrechtelijk is de op de verdediging van de onderneming betrekking hebbende correspondentie tussen (bedrijfsexterne) advocaat en onderneming beschermd: ook indien deze zich ten kantore van de onderneming bevindt, zal de Commissie daarvan geen kennis mogen nemen of, indien dit toch is gebeurd, deze briefwisseling niet als bewijs mogen gebruiken. Wel zal de onderneming de Commissie van het beschermde karakter van de briefwisseling moeten overtuigen, hetgeen doorgaans betekent dat tenminste een globale inzage moet worden verleend. Overtuigt de onderneming de Commissie niet, dan zal deze laatste bij afzonderlijke beschikking de geschriften moeten opeisen, tegen welke beschikking beroep bij het Gerecht open staat. Het hangt dan van het Gerecht af of de informatie uiteindelijk toch in zijn geheel aan de Commissie moet worden overgedragen. De Mededingingswet sluit bij deze communautaire regeling aan en biedt aldus minder waarborgen dan het Nederlandse strafrecht. Het uitgangspunt daar is namelijk dat het de verschoningsgerechtigde is die over het geheime karakter van de informatie oordeelt; is van een dergelijk geheim karakter sprake dan mogen de opsporingsambtenaren in het geheel geen kennis nemen van de gegevens.

Het laatste hier te noemen recht betreft het recht op geheimhouding van informatie die in de loop van een kartelprocedure is vergaard. Het Hof heeft hier onmiskenbaar een balans trachten te vinden tussen enerzijds het belang van ondernemingen en derden om inzage van gegevens te verkrijgen en anderzijds het belang van partijen op geheimhouding van deze informatie. De plicht tot geheimhouding strekt zich in beginsel uit tot alle gegevens die in een kartelprocedure aan het licht zijn gekomen, met dien verstande dat de Commissie in het kader van haar hoorplicht of bij de bekendmaking van een beschikking het recht op geheimhouding terzijde kan schuiven ten faveure van het recht op inzage. In dat geval zal zij dus een belangenafweging moeten maken. Daarbij zal zij echter in bijzondere mate rekening moeten houden met zakengeheimen: openbaarmaking van deze zal slechts in zeer uitzonderlijke gevallen gerechtvaardigd zijn. ${ }^{16}$ Voor de Mededingingswet-evenals trouwens voor het communautaire recht- geldt dat een uiteindelijke beschikking uitsluitend gebaseerd mag worden op "stukken die de belanghebbenden hebben kunnen inzien en waarover zij hun zienswijze hebben kunnen geven". ${ }^{17}$ Dit brengt echter nog geen volledige interne openbaarheid met zich, aangezien onder meer bedrijfs- en fabricagegegevens die vertrouwelijk aan de overheid zijn meegedeeld, niet openbaar worden gemaakt. Voor zover dergelijke gegevens niet van belang zijn voor de beoordeling van de (ernst van de) eventuele inbreuk levert dit geen problemen op. Waar dat belang er wel is, mag de informatie niet aan de beschikking ten grondslag worden gelegd. En steeds zal moeten gelden dat voor de ondememing ontlastende stukken in geen geval om redenen van geheimhouding buiten beschouwing worden gelaten.

Waar het de boete betreft, is de convergentie tussen EG-recht en Mededingingswet maximaal. Zowel de $\mathrm{NMa}$ als de Commissie hebben een extreem ruime discretionaire vrijheid op het straftoemetingsgebied. In feite zijn zij uitsluitend gebonden aan het evenre-

16 Uit de rechtspraak van het Hof blijkt overigens dat openbaarmaking van zakengeheimenaan klagers in het geheel niet geoorloofd is. Dit gaatnaar mijn mening echter te ver: ook hier moet de Commissie de mogelijkheid hebben om de in het geding zijnde belangen af te wegen.

TK 1995-1996, $24707, \mathrm{nr} .3$. 
digheidsbeginsel (waarvan de zwaarte en de duur van de overtreding een -onvolledigeconcretisering zijn) en aan hun eigen beleid. Voor ondernemingen brengt dit nogal wat onzekerheden mee, die echter dankzij een aanzienlijke lijst van veelal opmerkelijk goed gemotiveerde boetebeschikkingen én dankzij de bekendmaking van de Richtsnoeren voor de berekening van geldboeten in belangrijke mate zijn verdwenen. Deze voorzetten op maat kan en moet de d-g NMa verzilveren: hij zal met andere woorden, om redenen van convergentie en duidelijkheid voor ondernemingen, dienen aan te sluiten bij dit communautaire beleid. Dat betekent dat hij rekening dient te houden met alle factoren en -voorzover verifieerbaar-het gewicht daarvan zoals die door de Commissie in haar overwegingen worden betrokken. Dat wil nog niet zeggen dat de boetes ook nominaal gelijk moeten zjn. De markt waarop de schade wordt berokkend is voor het communautaire recht immers doorgaans aanmerkelijk groter, hetgeen zijn vertaling vindt in de hoogte van de boete. De eerste boetebeschikkingen van de $\mathrm{d}-\mathrm{g} \mathrm{NMa}$ laten zien dat deze tot op zekere hoogte inderdaad bereid is het communautaire strafbeleid te volgen. Maar vooralsnog richt hij zich op het beleid zoals dat tot 1998 door de Commissie is gevoerd. Het ware beter indien hij aansluiting zou zoeken bij het meest recente beleid op straftoemetingsgebied.

In hoeverre bieden het Nederlandse en het communautaire recht voldoende rechtsbescherming aan ondernemingen die verdacht worden van een inbreuk op het materiele kartelrecht? Deze vraag stond in dit onderzoek centraal. De conclusie moet zijn dat het niet echt tegenvalt met de geboden bescherming. Zowel in de Mededingingswet als in het communautaire kartelrecht is en wordt getracht te voldoen aan de eisen die het EVRM stelt. Dit stelt in zoverre gerust dat van al te felle overbelichting van de doelmatigheid in ieder geval geen sprake is. Op sommige punten gaan beide zelfs verder dan wat op grond van dit verdrag noodzakelijk is, maar dit is duidelijk meer uitzondering dan regel. Dit is te betreuren omdat het EVRM niet meer dan minimumvoorwaarden stelt. De Nederlandse wetgever is niet bereid gebleken om in de Mededingingswet veel verder te gaan: de doelmatigheid moest toch zo min mogelijk in de weg worden gelegd. Een zelfde conclusie geldt mutatis mutandis voor het Hof. In vergelijking tot het commune strafrecht schieten beide rechtsgebieden nogal wat tekort. Een medewerkingsplicht kent het wetboek van Strafvordering voor de verdachte niet, het zwijgrecht voor de verdachte is op grond van artikel $29 \mathrm{WvSv}$ absoluut, in artikel $68 \mathrm{WvSr}$ is een zeer vergaande ne bis in idemregeling neergelegd, het inzagerecht van stukken is strikter geformuleerd en met het draagkrachtbeginsel moet steeds rekening worden gehouden. Op veel van deze punten kent het communautaire recht weliswaar bescherming, maar deze strekt dan toch minder ver. Het wellicht belangrijkste verschil ligt in de medewerkingsplicht. Maar juist op dat punt is het niet eerlijk om met het commune strafrecht te vergelijken. Immers: het ordeningsstrafrecht, zoals dat met name is geregeld in de WED, en waartoe het kartelrecht toch ook gerekend kan worden, kent een dergelijke medewerkingsplicht eveneens. In feite kan geconcludeerd worden dat het bestuursstrafrecht en het economische strafrecht niet echt veel van elkaar verschillen. Op een enkel punt gaat de communautaire handhaving (en naar mag worden gehoopt ook de bestuursstrafrechtelijke handhaving) zelfs verder in de bescherming van de justitiabele. Dit is met name het geval waar het de boetemotivering betreft. Hier kan de Nederlandse strafrechter veel van leren. Standaardmotiveringen komen weliswaar voor, maar doorgaans wordt door de Commissie duidelijk aangegeven met welke factoren zij rekening heeft gehouden en welke rol deze factoren hebben gespeeld, ook ten aanzien van de verschillende betrokkenen bij de inbreuk. Zonder aldus 
een weinig flexibel en voorspelbaar boetebeleid te creëren, voert zij wel een controleerbaar en relatief doorzichtig beleid. Dat is in het strafrecht nog wel eens anders. Mede om ook in het Nederlandse kartelrecht controleerbaarheid en doorzichtigheid te realiseren, maar ook om redenen van convergentie en rechtszekerheid voor ondernemingen verdient het voorkeur dat de d-g NMa de weg bewandelt die reeds door de Commissie is geplaveid.

De rechtspositie van de onderneming in het kartelrecht is niet wezenlijk verslechterd door de 'omslag' in de handhaving van het Nederlandse kartelrecht. Ook in het bestuurs. strafrecht en het communautaire recht worden de meest cruciale waarborgen gerespecteerd. Dat wil niet zeggen dat het niet beter kan. Met name waar het de medewerkingsplicht betreft, acht ik de geboden bescherming onvoldoende. Dat ligt echter minder aan de bestuursstrafrechtelijke handhaving dan aan de te restrictieve interpretatie van het nemo tenetur-beginsel. De rechtspositie moge dan niet wezenlijk verslechterd zijn, de nog prille geschiedenis van de Mededingingswet laat wel zien dat al met al de positie van de ondernemingen een geheel andere is dan onder het Wem-regime. De bereidheid en de wil om van de geboden mogelijkheden ook daadwerkelijk gebruik te maken, lijkt nu wel aanwezig. Ondernemingen moeten zich derhalve terdege realiseren dat zij niet alleen meer te maken kunnen krijgen met de Commissie, maar ook met de NMa: twee ondernemende autoriteiten. 


\section{Summary}

The Netherlands and cartels: for a long time they seemed an inextricable two-some. In the past decade, however, this has changed. The Dutch government became aware of the fact that from an economic perspective cartels were to be looked upon less favourably than in the past. In addition, it was increasingly felt undesirable that Dutch competition law differed fundamentally from Community competition law and the competition law of other member states. The informal approach to cartels characterised by consultation and consensus, a system premised on corporate abuse, was replaced by a more formal system of prohibitions based on EC competition rules. Enforcement through criminal law, virtually absent in practice, was (for reasons of effectiveness mainly) exchanged for concentrated enforcement through administrative sanctions. In short: the desire to get rid of the image of 'Holland cartelland' was translated into action: initially by tightening policy pursuant to the Economic CompetitionAct (Wet economische mededinging) and ultimately by replacing the Act by the Competition Act (Mededingingswet) which provided for an enforcement agency, the National Competition Authority (NMa). Excnanging entôrcement through criminal law for enforcement through administrative sanctions is in line with the administration's present policy, which is increasingly characterized by this type of enforcement. Nevertheless, the reasons put forward by the Secretary of Economic Affairs for administrative enforcement of the Competition Act are not convincing. This is the case, for instance, where he stresses the 'last resort' character of the criminal law. This should be borne in mind, of course. However, the argument also holds true for other forms of punitive administrative action and, consequently, for enforcement through administrative sanctions. It also applies to doubts expressed as to the suitability of the criminal law as an enforcement tool for the Competition Act. In spite of the anticipated high prioritisation at the Public Prosecution Department, the existing situation continued under the regime of the Competition Act as a result of, among other things, a lack of expertise at the Dutch Department of Justice and the criminal courts, the complexity of the matter and staffing problems within the criminal system. This does not mean that the choice for administrative sanctioning should be rejected. Anticipated greater effectiveness, in particular, is an advantage of this type of enforcement. Concentration of the entire application of the Competition Act within one authority contributes greatly to effectiveness. However, effectiveness does not exist in a vacuum. There is the other side of the enforcement coin: lawfulness. When improving effectiveness is at issue, overexposure of the effectiveness of a regulation -such as more and more readily manageable investigative powers, more streamlined enforcement without too many obstacles in the form of norms for the protection of citizens and more severe punishment- is not unusual. As a result, the lawfulness aspect- such as the restriction of administrative powers, rights of defence and judicial control- are underexposed. This dissertation examines both aspects. Not only is Dutch law scrutinized, but Community law is also examined because of the close link between the two as a result of the 'spontaneous harmonisation' effort of the Dutch government. The core question of the study reads as follows: 
Do Dutch and Community law provide sufficient legal protection for companies suspected of violating substantive competition law?

The enforcement powers created for this purpose are also discussed, since the above question must be seen in conjunction with these.

Where effectiveness is concerned, the author concludes that both Community and Dutch competition law provide the preconditions for effective enforcement. Concentrating application of Community and Dutch competition law, running from applications for exemption, via supervision and 'detection', to imposing penalties, within a single agency, the Commission and the NMa respectively, ensures the necessary expertise, guarantees the efficiency of internal communication, that policy and enforcement are properly matched and that competition cases have first priority. There is no shortage of sufficient powers. The Commission has very broad powers of information gathering and verification, backed up by the duty to co-operate imposed on companies. Moreover, in the event of companies not co-operating, the verification power will transform into a power approximating the power to search business premises, in any case where assistance is rendered by national authorities. In addition, pursuant to relevant Dutch implementation legislation, the Wet Uitvoering EG Mededingingsverordeningen, Dutch examining magistrates are empowered to effectively order the search of 'concealed spaces'. The latter power will probably not be much exercised in practice. Thus far, the above powers have served very satisfactorily and, in the author's view, there is no cause for extending them. The Commission does not seem to agree. In its proposed Execution Regulation, it expresses the desire to have a right to enter private homes, be it upon the approval of the national court 'only'. The reason for this is allegedly that in practice increasingly relevant materials are present in the homes of employees, thus frustrating verification. The conclusion must be that, if implemented, the limits of the power of verification would be stretched unreasonably. When is there reason to assume that relevant materials are to be found at the home of an employee? And at the home or homes of which employee or employees? And what is the extent of control by the national courts? Apart from the fact that the Commission rather underestimates ill-willing companies if it is of the opinion that it would make it (virtually) impossible to frustrate the gathering of information, such a power to enter private homes exceeds the limits of what is reasonable. Furthermore, it is not necessary in effect, seeing that the Commission may fine a company for failure to co-operate or impose an astreinte, a fine for each day it continues to be in breach of its duty, to effect that ultimately the information is surrendered.

The powers of the NMa are as far-reaching as those of the Commission and hardly differ from the powers that would be available to a detection agency if the Competition Act were to be enforced through the criminal law:

- entering places, with the exception of a dwelling, without the permission of the occupant (Art. 5:15, par. 1 General Administrative Law Act (Awb);

- providing access to these places with the aid of the police (Art. 5:15, par. 2 Awb);

- summoning information (Art. 5:16 Awb);

- summoning the examination of business data and documents, with the inclusion of the power to make copies of the data and documents;

- removing data and documents for the purpose of copying these, where this cannot be done on site (Art. 5:17 Awb); 
as well as, for investigative purposes:

- the power to seal off, where necessary, business premises and objects from 6 p.m. to 8.00 a.m. (Art. 54 Competition Act); and

- the power to enforce examination of data and documents with the aid of the police (Art. 55 Competition Act).

Companies have also a duty to co-operate in these circumstances, while the $\mathrm{NMa}$ is empowered to resort to imposing fines and astreintes and call on the police force in cases of non-co-operation. For this reason, the absence of a power to search is not missed.

Nor should the sanctions that may be imposed for breach of competition law, form an impediment to effective enforcement. On the contrary: from the perspective of both repression and prevention a fine of not more than $10 \%$ of the turnover world-wide in the year preceding the imposition of the fine would be more than sufficient. The broad discretionary freedom afforded to the Commission and the NMa in meting out punishment, also enables them to respond to any breach by imposing a suitable sanction.

There are therefore few obstacles to effectiveness. But what about lawfulness? Concentrated enforcement has its drawbacks in that, no matter how objectively the authorities deal with the case, there is always a semblance of partiality. Under the criminal law, prosecution (and the investigation preceding it) and adjudication are vested in two separate institutions which are independent from one another: the Public Prosecution Department and the criminal judge. In administrative enforcement of competition law these are pursued by or under the auspices of one and the same institution, namely the Commission or the Director-General of the NMa. It seems hardly likely in any case that, from the moment the 'statement of objections' or, as the case may be, the report has been drawn up, the Commission or the Director-General of the NMa will be susceptive to arguments by the accused or counsel that rules of procedure have been breached; the rights of the accused and counsel have not been respected; guilt cannot be established; and so on. By drawing up the 'statement of objections' and the report, the authority in question already indicates that that there is sufficient evidence of a violation and that a fine is called for. The very authority drawing the above conclusion subsequently assesses the arguments put forward. One cannot expect a company to have much faith that the case will be examined without prejudice, in an independent way, and reach a satisfactory conclusion. This is not altered by the fact that the Competition Act prescribes that the investigative phase and the adversarial phase must be separated at the personal level: a public servant working for the $\mathrm{NMa}$ may not be involved in the same case in both the supervision and investigative phase and the final decision phase. The problem remains therefore the same: all acts undertaken fall within the responsibility of the Director-General of the NMa. Nevertheless, concentration of powers is not unacceptable in the author's view, even in the light of Article 6 of the European Convention for the Protection of Human Rights and Fundamental Freedoms (the 'European Convention'). The reason for this is that, where the company is of the view that its arguments have not or not sufficiently been considered (which in all fairness will not always be the case), it may lodge an appeal against the decision under both Community and Dutch law. Under EC law, the appeal can be lodged with the Court of First Instance and the European Court of Justice (the 'Luxembourg court'), which have been seen to test the Commission's decisions thoroughly. Dutch competition law provides for the possibility of submitting an objection to the Director-General of the NMa and 
subsequently lodge an appeal with the District Court of Rotterdam. Final appeal lies to the Companies Tribunal (College van Beroep voor het Bedrijfsleven). Objection and appeal pursuant to the Competition Act have suspensive effect. And rightly so, in view of the interests at issue, in contradistinction to what is customary in administrative law and operative Community law.

The fact that neither Community law nor the Dutch Competition Act are criminal provisions also raises questions with regard to other issues of legal protection relevant to this study. The guarantees inherent in criminal law do not automatically apply to these areas of law. One of the functions of the law of criminal procedure is precisely protection of the position of the justiciable. For this reason, criminal procedure offers a comprehensive set of rules governing the restrictions on public powers and the (procedural) rights of the accused. This cannot be rightly said of written EC/EU law. It hardly excels in legal protection, with the exception of Article $6 \mathrm{EU}$ and the EU Charter of Fundamental Rights, which has yet to become binding. The Dutch Competition Act does better in this respect. It affords a number of important rights and guarantees derived, to a large extent, from the law on criminal procedure and the European Convention. This is not surprising, since, pursuant to Strasbourg case law, any administrative action of a punitive nature, irrespective of the characterisation given in the national legal order, must meet the standards of the European Convention, providing the state in question is party to the Convention. In the author's opinion, this also applies in principle, when, as in competition law, proceedings are brought in relation to acts by companies, i.e. juristic persons. The primary importance of the European Convention lies in the restriction of the administrative power which may be exercised against justiciables. It is difficult to see why these guarantees, so fundamental to a state governed by the rule of law, should not apply to companies. It follows that Dutch competition law is subject to the European Convention. The norms ensuing from it must be met, even where codified Dutch competition law does not achieve the Strasbourg level of protection. This does not automatically apply to Community law. Unfortunately, the European Community is not party to the European Convention. The European Court of Justice, however, has played a pioneering role in this respect. As a result of its case law on the general principles of Community law to be observed, i.e. the norms ensuing from the European Convention and the common constitutional traditions of the member states, the European Court of Justice has achieved quite an acceptable level of legal protection. By using the European Convention as a legal source for its case law on rights, the Luxembourg court approximates the minimum standards of legal protection provided for in the Convention. One problem, however, is that the Luxembourg court does not consider the rights of the accused and counsel as the prevailing right, which may result in Community objectives (of effectiveness) thwarting the full realisation in a concrete case of the legal protection required. The author would therefore welcome a development in which Community law fell within the jurisdiction of the European Court of Human Rights.

The guarantees offered prove that companies do not fall outside the law where competition law is concerned. In Community law, for instance, the prohibition against being prosecuted and tried twice for the same offence, the ne-bis-in-idem principle, applies in the form of the disposition principle (Erledigungsprinzip) for internal questions and in the form of the 'Anrechnungsprinzip', by which a previous conviction is taken into account in sentencing, for the relation Community/third state. Curiously enough, protection 
against double jeopardy does not exist under the Dutch Competition Act. Although the parliamentary history pertaining to the Act contains reassuring words from the minister and generally speaking dual punishment is contrary to the general principles of proper administration, this does not justify the absence of legal rules on the subject. The Competition Act is clearly lacking in this respect. Not so the rules on expiration. As in Community law and criminal law, the Competition Act contains rules on expiration, which allows the case to be discontinued after a certain period of time. There may be a problem of effectiveness in the absence of rules on interruption by any act of prosecution and suspension, which Dutch criminal law and Community competition law do provide. As a result of this, the case must have been dealt with within a period of five years. This is the term of expiration which conforms to the term in Community law and only slightly departs from the term in criminal law as applied to cartels until 1998. This five-year term may prove to be insufficient for cases that are difficult to prove.

Other guarantees of Dutch and Community competition law are mainly based on the European Convention or are similar to the norms ensuing from the Convention. A case in point is the requirement contained in Article 6 ECHR to adjudge the case 'within a reasonable time'. Application of this requirement is similar in Dutch and Community law. In following the European Convention, the reasonableness of the term is assessed on the basis of the following three criteria: the complexity of the case, the defendant's conduct and the conduct of the competent authorities. Inasmuch as cartel cases are seldom open and shut cases, it is to be expected that in particular the last two criteria will come into play in practice. Transgression of the reasonable period of time does not seem to have too serious a consequence. Safe for very exceptional cases, the fine that would have been appropriate if the reasonable period had been observed, will be reduced. A second guarantee is the principle of the right to silence (nemo tenetur). This right not to have to co-operate in one's own prosecution and trial comes in two varieties: a broad and a limited right. The broad version, which is to be preferred, offers the accused the right to refuse all co-operation. Crucial here is the freedom of the accused to determine his own trial strategy. The limited variety concerns preventing errors of justice and, in conjunction with this, the reliability of the information (to be) gathered. Inasmuch as reliability is only an issue if the accused is compelled to give an oral statement, the nemo-tenetur principle in this sense is limited to a right to silence. Unfortunately, this has been the Strasbourg court's approach, in any case since Saunders. From the moment at which the suspect is charged with a criminal offence, the -not absolute- right to silence applies; documents enjoy protection under the nemo-tenetur principle in exceptional cases only. Until the moment of charge there is no such right, be it that a statement made by the suspect during this phase may not be used in evidence in subsequent criminal proceedings. The protection offered by the Luxembourg court is not much different: the Commission may not oblige a company to give answers which would constitute an acknowledgement of the very violation that it has to prove. The protection also applies prior to the moment of charge. For reasons of harmonisation, this is also provided for in the Dutch Competition Act: the right to silence is linked to the moment at which a reasonable suspicion of guilt has arisen. Other forms of co-operation, for instance the surrender of documents, may not be refused, however. It is unfortunate that the nemo-tenetur principle is construed so narrowly in case law. However, the Competition Act and, broadly speaking, Community law do comply with Article 6 ECHR. 
Another right discussed is the right to privacy, as protected by the provisions of Article 8 ECHR. This right may also be involved in competition cases: companies are also entitled to non-interference by the administration, although, in the author's view, the European Court has wrongly concluded that Article 8 ECHR did not protect companies. The requirements of the second paragraph of Article 8 must be met for the interference to be lawful. This is nearly always the case: private homes may not -for now?- be entered without the permission of the occupant. In the case of business premises, both Community law and Dutch competition law provide for such a power. However, the legal basis for this power, Article 14 Regulation 17 for Community law and Article 5:15 Awb for Dutch competition law, is sufficiently concrete and interference may very well be deemed 'neces. sary in a democratic society' in the interest of economic well-being. Prior judicial control has not been provided for in Community and Dutch competition law. The European Convention does not so prescribe. This made it possible for the legislature to take search of premises governed by criminal law in large part out of the preliminary judicial criminal investigation and place it within the police investigation phase. Whether this is a happy choice is debatable. The privacy of large companies in particular is without a doubt less sensitive than the privacy of the homes of natural persons, rendering prior judicial control perhaps too much of a good thing. It has to be borne in mind, however, that the measure of search, which is similar to the right to enter ensuing from Community law and Dutch competition law, is a very drastic measure. Prior judicial control may therefore not be too much of a good thing.

Both the right to legal assistance, which right is also laid down in Article 6 ECHR, and legal privilege have been well regulated in Community law, although legal privilege is better regulated in Dutch criminal law. Unless the company has an in-house legal advisor or if it refuses full access to Commission officers, the Commission may await -within reason- the arrival of an external legal advisor before verification is started. Regretfully, the Competition Act lacks such a regulation. Here Articles 2:1 and 2:2 Awb may bring relief, because they afford legal assistance to all 'in dealing with administrative organs'. A regime more based on Community law and more focused on punitive proceedings were to be preferred. Under Community law, correspondence related to the company's defence between the (external) attorney and the company is protected: if the correspondence is at the offices of the company, the Commission is not empowered to take cognisance of it, or, if this nevertheless occurs, it is barred from being used in evidence. The company must, however, convince the Commission of the protected nature of the correspondence. This usually means that it must allow cursory inspection thereof. If the company fails to convince the Commission, the latter must order the handing over of the documents by separate decision. Against this decision an appeal may be lodged with the Court of First Instance. It is up to this court in that case to decide whether the information must be surrendered to the Commission in full. The Dutch Competition Act is in line with Community rules on the subject. In consequence, it offers less guarantees than Dutch criminal law. The assumption in Dutch criminal law is that it is the privileged party that assesses the confidentiality of the information. Where the information is felt to be a confidential nature, the investigative officers may not take cognisance of the data.

The final right discussed in this study is the right to non-disclosure of the information gathered in the course of the cartel proceedings. The European Court has unmistakably attempted to find a balance between the interests of the company and third parties to examine the data and their interests in having the information kept confidential. In princi- 
ple, the duty of non-disclosure covers all data which has come to light during cartel proceedings, be it that the Commission is empowered to put aside the right to non-disclosure in the context of its duty to hear the parties at their request, or in disclosing its decision, in favour of the right to examine the data. In that ease, it will have to weigh the interests involved against one another. In particular, it will have to take into account business secrets: disclosure is only justified under very specific circumstances. Under the Competition Act -and for that matter under Community law- final administrative decisions may be based only on documents which the interested parties have been able to examine and about which they had been given the opportunity to express their opinion. This does not entail full internal disclosure, since commercial and industrial data which has been communicated to the administration in confidence, cannot be disclosed. Insofar as such data is not relevant to the assessment of the (seriousness of) the violation, this does not constitute a problem. If relevant, the information may not be used to underpin the administrative decision. In all instances should documents discharging the company not be left out for reasons of confidentiality.

Where punishment is concerned, there is maximum correspondence between EC law and the Competition Act. Both the $\mathrm{NMa}$ and the Commission possess extremely broad discretionary powers in this area. In effect, they need only observe the principle of proportionality -in this case the seriousness and the length of the violation- and go by their own policy. This creates quite a few uncertainties for companies. This effect has been considerably counteracted by an extensive list of, often remarkably well-reasoned, punitive decisions and by the publication of the Guidelines on the method of setting fines imposed pursuant to Article 15 (2) of Regulation 17. The Director-General of the NMa can and must take advantage of this tailor-made first move by the European Commission. In other words, he must conform to Community policy for reasons of harmonisation and clarity towards companies. This means that he must consider all factors and, where verifiable, their weight as taken into account by the Commission in its decision. This is not to say that fines must be nominally equal. In Community law, the affected market is usually considerably larger. This is reflected in the amount of the fine. The first punitive decisions by the Director-General of the NMa show that he is prepared to follow Community sanctioning policy to a certain degree. However, for the moment, he pursues the policy conducted by the Commission up to 1998. It is to be preferred if he conformed to the most recent Community sanctioning policy.

It must be concluded that the protection offered in competition law is adequate. In both the Competition Act and Community competition law, an attempt has been made and is being made to meet the requirements set by the European Convention. This is reassuring insofar as there is no serious overexposure of the effectiveness aspect. In some respects, the two legal areas offer more than is required by the Convention, although this is clearly more the exception than the rule. This is to be regretted, because the European Convention sets only minimum standards. The fact that neither the Dutch legislature nor the Luxembourg court is seen to be prepared to take the matter further, comes about as a result of the view that effectiveness must not be hampered by too many obstacles. In comparison to criminal law, the two legal areas show deficiencies. The Dutch Code of Criminal Procedure (DCCP) does not contain a duty for the defendant to co-operate; pursuant to Article 29 DCCP his right to silence is absolute; a far-reaching ne-bis-in-idem rule has 
been laid down in Article 68 Dutch Penal Code; the right to examine documents is formulated stricter and there must be a means test on each occasion. In many of these areas, Community law offers some degree of protection. The most important difference lies in the duty to co-operate. However, it is not fair to compare Community law with ordinary codified Dutch criminal law, since the punitive provisions in Dutch economic law also provide for a duty of co-operation. In effect, it may be concluded that there is little difference between Dutch administrative and economic punitive law. In a few areas, Community enforcement offers even more protection to the justiciable, and, one should hope, so does administrative enforcement. This is particularly the case where the reasons for the sanction are given, which should be edifying to the Dutch criminal courts. Standardised statements of reasons are still used, but usually the Commission clearly points out the factors taken into account and the role they played, also with regard to the various parties involved in the violation. Rather than creating a less flexible and predictable sanctioning policy, it pursues a policy that is controllable and relatively transparent. This is not always the case in Dutch criminal law. In order to realise controllability and transparency in Dutch competition law, but also for reasons of harmonisation and legal certainty for companies, it is to be preferred that the Director-General of the NMa takes the course outlined by the Commission.

In essence, the legal position of companies has not deteriorated as a result of the $\mathrm{C}$-change in enforcing Dutch competition law. The most crucial guarantees are also observed in administrative punitive law and Community law. There is, however, room for improvement. In particular with regard to the duty of co-operation, the protection offered is insufficient in the author's view. This is not so much caused by administrative enforcement as by the restrictive interpretation of the nemo-tenetur principle.

That the protection provided for in competition law has turned out relatively well is particularly significant in view of the preparedness and resolve to make competition law really work. Companies must therefore be well aware of the fact that they may not only have to deal with the Commission, but with the $\mathrm{NMa}$ as well: two enterprising authorities.

Translated by L. Rayar 


\section{Bijlage}

\begin{tabular}{|c|c|c|c|c|}
\hline Beschikking & Boete $^{1}$ & Boete $^{2}$ & Gerecht ${ }^{3}$ & Hof \\
\hline Kinine & 0,5 & $0,21 / 0,01$ & - & 0,03 \\
\hline Kleurstoffen & 0,49 & $0,05 / 0,04$ & - & 0,01 \\
\hline Pittsburgh Corning Europe & 0,1 & 0,1 & - & - \\
\hline $\mathrm{CsClCI}$ & 0,2 & 0,2 & - & 0,1 \\
\hline W.E.A.-Filipacchi Music & 0,06 & 0,06 & - & $\cdot$ \\
\hline Suikerunie & 9 & $1,5 / 0,1$ & - & 7,41 \\
\hline Deutsche Philips & 0,06 & 0,06 & - & - \\
\hline Behangselpapier & 0,3585 & $0,135 / 0,036$ & - & $v$ \\
\hline General Motors & 0,1 & 0,1 & - & $v$ \\
\hline Champignons in blik & 0,1 & $0,032 / 0,002$ & - & - \\
\hline Chiquita & 1 & 1 & - & 0,15 \\
\hline Vitaminen & 0,3 & 0,3 & - & 0,1 \\
\hline Miller Schallplatten & 0,07 & 0,07 & - & 0 \\
\hline Theal/Watts & 0,02 & $0,01 / 0,01$ & - & $o$ \\
\hline Hugin/Liptons & 0,05 & 0,05 & - & $v$ \\
\hline BMW Belgium & 0,2035 & $0,15 / 0,001$ & - & $o$ \\
\hline Plantaardig perkament & 0,115 & $0,025 / 0,015$ & - & - \\
\hline Kawasaki & 0,1 & 0,1 & - & - \\
\hline Floral & 0,255 & $0,085 / 0,085$ & - & - \\
\hline Pioneer & 6,95 & $4,35 / 0,3$ & - & 3,75 \\
\hline Johnson \& Johnson & 0,2 & 0,2 & - & - \\
\hline Michelin & 0,68 & 0,68 & - & 0,38 \\
\hline Moët et Chandon & 1,1 & 1,1 & - & - \\
\hline AEG-Telefunken & 1 & 1 & - & $o$ \\
\hline Hasselblad & 0,755 & $0,56 / 0,01$ & $\cdot$ & 0,85 \\
\hline NAVEWA-ANSEAU & 1,0205 & $0,0765 / 0,005$ & - & 0 \\
\hline SSI & 1,475 & $0,425 / 0,1$ & - & 0,050 \\
\hline National Panasonic & 0,45 & 0,45 & - & - \\
\hline Walserijprodukten & 0,9 & $0,5 / 0,4$ & - & $v$ \\
\hline UGAL/BNIC & 0,16 & 0,16 & - & - \\
\hline Toltecs-Dorcet & 0,05 & 0,05 & $\cdot$ & $v$ \\
\hline Windsurfing International & 0,095 & $0,05 / 0,005$ & - & 0,025 \\
\hline ECS/AKZO & 10 & 10 & - & 2,5 \\
\hline Gietijzeren walsen & 1,25 & $0,111 / 0,008$ & - & - \\
\hline Polistil/Arbois & 0,06 & $0,030 / 0,030$ & - & - \\
\hline $\mathrm{BL}$ & 0,35 & 0,35 & $o$ & - \\
\hline Vlakglas Benelux & 4 & $1,45 / 0,765$ & - & - \\
\hline Zinc Producer Group & 3,3 & $0,95 / 0,35$ & - & - \\
\hline Peroxyde & 9 & $3 / 0,5$ & - & - \\
\hline
\end{tabular}


John Deere 2

Houtslijp

2
4,125

2

Sperry New Holland

0,75

Siemens

2

Polypropyleen

57,85

Bitumineuze dakbedekking 1,015

Hilti

6

Meldoc

6,555

Vetzuren

0,15

Tipp-Ex

0,41

Sandoz

Fisher-Price

0,8

Konica

0,3

BDTA

0,15

0,1

Napier Brown/British Sugar 3

Dansk Pelsdyravlerforening 0,5

Sabena

0,1

BPB

Vlakglas

3,15

PVC-I

13,4

LdPE

23,5

Betonstaalmatten

36,1

Bayo-n-ox

Solvay/ICI

Solvay/CFK

Solvay

9,501

0,5

14

4

ICI

20

Martell

Tetra Pak II

10

Bouwnijverheid (SPO)

0,35

75

Eurocheque

British Midland/Aer Lingus

Viho/Toshiba

DSI

Rederscomités

21,4308

6

0,75

2

Parker Pen

Treinbiljetten

Cewal

$\mathrm{MCN}$

PVC-II

SCK/FNK

Karton

5,15

48,0734

0,74

1

10,1

11

19,25

11,8

Cement

131,75

242,42

FEFC

0,13

Tretorn

0,64

BASF Lacke + Farben

2,71

$0,5 / 0,05$

0,75

$1 / 1$

$11 / 0,5$

$0,42 / 0,015$

6

$1,36 / 0,425$

$0,05 / 0,05$

$0,4 / 0,01$

0,8

0,3

$0,075 / 0,075$

0,1

3

0,5

0,1

$3 / 0,15$

$7 / 1,7$

$3,5 / 0,4$

$5,5 / 0,15$

$4,5 / 0,013$

0,5

$7 / 7$

$3 / 1$

20

10

$0,3 / 0,05$

75

$4,7925 / 0,03825$

$5 / 1$

0,75

2

$5 / 0,15$

$11,628 / 0,0024$

$0,7 / 0,04$

1

$9,6 / 0,1$

11

$3,2 / 0,4$

$11,5 / 0,3$

$22,75 / 0,2$

$32,492 / 0,1$

$0,01 / 0,01$

$0,6 / 0,01$

$2,7 / 0,01$
2,895

3,2875 -

- $o$

o $a$

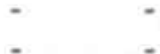

- $\quad 0$

- $\quad 0,3$

-

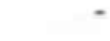

0,2

11,729

ne -

$v$

$1,984 \quad 0,05$

o

\section{v}

\section{$v$}

$v$

$v \quad a$

- $\quad$

o $a$

o

4

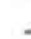

2

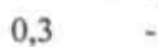

v $a$

$1,01 \quad o$

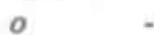

0,1 -

$11,42 \quad 0,95$ 


\begin{tabular}{|c|c|c|c|}
\hline \multicolumn{2}{|c|}{ FENEX } & 0,001 & 0,001 \\
\hline \multicolumn{2}{|c|}{ ADALAT } & 3 & 3 \\
\hline & dienstmaatschappijen & 0,645 & $0,4 / 0,025$ \\
\hline \multicolumn{2}{|c|}{ Novalliance/Systemform } & 0,1 & 0,1 \\
\hline \multicolumn{2}{|c|}{ Irish Sugar } & 8,8 & 8,8 \\
\hline \multicolumn{2}{|c|}{ Legeringstoeslag } & 27,38 & $8,1 / 2,81$ \\
\hline \multicolumn{2}{|c|}{ VW } & 102 & 102 \\
\hline \multicolumn{2}{|c|}{ AAMS } & 6 & 6 \\
\hline \multicolumn{2}{|c|}{ Voorgeissoleerde buizen } & 92,21 & $70 / 0,36$ \\
\hline \multicolumn{2}{|c|}{ British Sugar } & 50,2 & $39,6 / 1,8$ \\
\hline \multicolumn{2}{|c|}{ TACA } & 272,98 & $41,26 / 6,88$ \\
\hline \multicolumn{2}{|c|}{ Griekse veerdienst } & 8,238 & $3,26 / 0,098$ \\
\hline \multicolumn{2}{|c|}{ WK Voetbal 1998} & 0,001 & 0,001 \\
\hline \multicolumn{2}{|c|}{ Virgin/British Airways } & 6,8 & 6,8 \\
\hline \multicolumn{2}{|c|}{$\mathrm{FEG} / \mathrm{TU}$} & 6,55 & $4,4 / 2,15$ \\
\hline \multicolumn{2}{|c|}{ FETTCSA } & 6,932 & $1,24 / 0,134$ \\
\hline \multicolumn{2}{|c|}{ Nathan-Bricolux } & 0,061 & $0,06 / 0,001$ \\
\hline \multicolumn{2}{|c|}{ Opel } & 43 & 43 \\
\hline \multicolumn{2}{|c|}{ Deutsche Post } & 24 & 24 \\
\hline \multicolumn{2}{|c|}{ Aminozuren } & 109,9 & $47,3 / 8,9$ \\
\hline 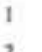 & \multicolumn{3}{|c|}{ Totale boete in miljoenen rekeneenheden } \\
\hline 2 & \multicolumn{3}{|c|}{ Hoogste/laagste boete in miljoenen rekeneenheden } \\
\hline 3 & \multicolumn{3}{|c|}{ Omvang eventuele verlaging van de boete door Gerech//Hof } \\
\hline$o$ & \multicolumn{3}{|l|}{ boete ongewijzigd } \\
\hline$a$ & \multicolumn{3}{|l|}{ beroep afgewezen } \\
\hline$v$ & \multicolumn{3}{|l|}{ vemietigd } \\
\hline$n e$ & \multicolumn{3}{|l|}{ non-existent verklaring } \\
\hline
\end{tabular}





\section{Literatuur}

Van Aalst (1997): E. van Aalst, Handhaving van de nieuwe Mededingingswet. De boeteprocedure in het licht van enige rechtsbeginselen, $A A$ 1997, pag. 555-564.

Aarts (1980): J.W. Aarts, Mededingingspolitiek en economische crisis, $S E W$ 1980, pag. 16-31.

Van Acker (1986): C. van Acker, Communautaire sanctionering van ondernemingen, Kluwer, Deventer 1986.

Akyürek-Kievits, Feenstra en Van der Woude I: H.E. Akylirek-Kievits, J.J. Feenstra en M.H. van der Woude (red.), Praktijkboek Wet economische mededinging, Vuga, 'sGravenhage (losbl.).

Akyürek-Kievits, Feenstra en Van der Woude II: H.E. Akyürek-Kievits, J.J. Feenstra en M.H. van der Woude (red.), Praktijkboek Mededingingswet, Vuga, 's-Gravenhage (losbl.).

Van Alphen (1993): F. van Alphen, Ministerie geeft voortzetting van prijskartels weinig kans, NRC Handelsblad 4 augustus 1993.

Ansmink (1981): A.A. Ansmink, Het meewerken van de verdachte aan zijn veroordeling en art. $29 \mathrm{~Sv}$, RM Themis 1981, pag. 426-448.

Van As (1986): A.A. van As, Het mededingingsbeleid, ESB 1986, pag. 834-837.

Asser Instituut (1993): T.M.C. Asser Instituut, De BV Nederland op de interne markt, 's-Gravenhage 1993.

Association Européenne des Avocats (1994), Droits de la défense et droits de la Commission dans le droit communautaire de la concurrence, Bruylant, Bruxelles 1994.

Van Bael (1986): I. van Bael, The antitrust settlement practice of the EC Commission, CMLRev 1986, pag. 61-90.

Van Bael (1995): I. van Bael, Fining à la Carte: The Lottery of EU Competition Law, ECLR 1995, pag. 237-243.

Van Bael en Bellis (1994): I. van Bael en J-F. Bellis, Competition Law of the European Community, CCH Editions, 1994.

Bal (1996): P. Bal, Murphy's law? Over de uitholling van het nemo tenetur beginsel in Amerika, in: Reijntjes (1996 I), pag. 23-40.

Balkema e.a. (1995): J.P. Balkema e.a. (red.), Dynamisch strafrecht: opstellen ter gelegenheid van het afscheid van prof.mr. G.M.J. Corstens van de Katholieke Universiteit Nijmegen, Gouda Quint, Arnhem 1995.

Barents (1982): R. Barents (red.), In orde. Liber Amiconam Pieter VerLoren van Themaat, Kluwer, Deventer 1982.

Barents (1995 I): R. Barents, Het mededingingsbeleid van de EG, in: P.J.G. Kapteyn en P. VerLoren van Themaat (1995), pag. 449-465 en 485-540.

Barents (1995 II): R. Barents, De communautaire rechter tegenover burocratic en politiek, RM Themis 1995, pag. 219-226.

Barents (1996): R. Barents, Procedures en procesvoering voor het Hof van Justitie en het Gerecht van eerste aanleg van de EG, Kluwer, Deventer 1996.

Barents (1997): R. Barents, Het verdrag van Amsterdam, Kluwer, Deventer 1997. 
Barents en Brinkhorst (1996): R. Barents en L.J. Brinkhorst, Grondlijnen van Europee: recht, Kluwer, Deventer 1999.

Van Bavel en Verbunt (1994): C.J. van Bavel en R.P.G.L.M. Verbunt, Advocaat en telefoontap: schending van de onschendbaarheid, $D D$ 1994, pag. 228-247.

Bekkers e.a. (1993): V.J.J.M. Bekkers e.a., Brussel en Nederland: tegenliggers, spookrijders of reisgenoten? Implementatie van EG-regelingen in de Nederlandse rechtsorde. W.E.J. Tjeenk Willink, Zwolle 1993.

Bellamy en Child (1993): C. Bellamy en G.D. Child, Common Market Law of Competiti. on, Sweet \& Maxwell, London 1993.

Bellamy en Child (1996): C. Bellamy en G.D. Child, Common Market Law of Competition. First supplement to the fourth edition, Sweet \& Maxwell, London 1996.

Van Bemmelen en Van Veen (1998): J.M. van Bemmelen en Th.W. van Veen. Bewerk door D.H. de Jong en G. Knigge, Het materiële strafrecht. Algemeen Deel, Gouda Quint Deventer 1998.

Berger (1980): M. Berger, Taking the Fifth, D.C. Heath and Company, Lexington Massa chusetts 1980.

Van den Bergh (1997): R.J. van den Bergh, Van Nederlands kartelparadijs naar Europee: kartelparadijs, NJB 1997, pag. 149-153.

Berkhout-van Poelgeest (1999): A.M. Berkhout-van Poelgeest, Dwangmiddelen en he nemo tenetur-beginsel: is een andere grens wenselijk?, in: M. Moerings, C.M. Pelse en C.H. Prante, Marale husacties in het strugfreales, Gouda Cuint, Deventer 1009, pag. 247-263.

Betten (1985): L. Betten, The right to strike in community law, Elsevier Science Publishers, Amsterdam 1985.

Betten (1986): L. Betten, Toetreding van de Europese Gemeenschappen tot de Europese mensenrechten-conventie: tweestrooksweg of doodlopende straat, NJCM-Bulletin 1986, pag. 314-321.

Biesheuvel (1988): M.B.W. Biesheuvel, Artikel 6 van de Europese Conventie voor de Rechten van de Mens en het gemeenschapsrecht, SEW 1988, pag. 659-705.

Biesheuvel(1993): M.B.W. Biesheuvel, Het besluit horizontale prijsbinding: Nederlands mededingingsrecht in opmars, NJB 1993, pag. 845-849.

Biesheuvel (1996 I): M.B.W. Biesheuvel, Weg met de bezwaarschriftenprocedure, NJB 1996, pag. 930.

Biesheuvel (1996 II): M.B.W. Biesheuvel, Juridische kapitaalvernietiging, NJB 1996, pag. 1244.

Biesheuvel, Mok en Sevenster (1996): M.B.W. Biesheuvel, M.R. Mok en H.G. Sevenster, Van Ordening naar Marktwerking. Kanttekeningen bij het ontwerp-mededingingswet, SDU Uitgevers, Den Haag 1996.

Bleeker (1993): K.A.M. Bleeker, Verantwoorde communautaire sanctionering van het gemeenschapsrecht?, NJB 1993, pag. 1009-1013.

De Blois (1981): M. de Blois, De Europese Gemeenschappen (EG) en de Europese Conventie voor de rechten van de mens (ECRM), AA 1981, pag, 413-417.

Blom en De Doelder (1991): T. Blom en H. de Doelder, Het in beslag nemen van geschriften, $D D$ 1991, pag. 842-858.

Blom en De Doelder (1992): T. Blom en H. de Doelder, Meer over: Europees beslag op geschriften bij bedrijven, DD 1992, pag. 350-352

Borst (1954): P. Borst, Kartelcontrôle. Administratie of rechter, H.D. Tjeenk Willink \& zoon, Haarlem 1954. 
Bos (1976): P.A.H. Bos, Osmose tussen het economische en commune strafrecht, SEW 1976, pag. 381-387.

Bos (1983): P.A.H. Bos, Economisch strafrecht en ondernemingsstrafrecht, DD 1983, pag. 674-680.

Bos (1994): P.V.F. Bos, Van ontvoogding naar ontgoocheling of van interstatelijkheid naar communautaire dimensie?, NJB 1994, pag. 906-911.

Bos en Chatelin (1998): P.V.F. Bos en M. Chatelin, De nieuwe Nederlandse Mededingingswet en zijn Europese context: 'Even Brussel bellen?', Tyjdschrift Priwatisering 1998, pag. 7-10.

Bosman (1990): A.R. Bosman, De onderzoeksprocedure in het Europese mededingingsrecht, Advocatenblad 1990, pag. 636-641.

Bourgeois (1993): J.H.J. Bourgeois, De nationale rechter en de EG-Mededingingsregelsbekendmaking van de EG-Commissie, SEW 1993, pag. 690-697.

Van Boven (2000): Th.C. van Boven, De rechten van de mens en staatsaansprakelijkheid, Internationale Spectator 2000, pag. 639-641.

Bovens (1998): M. Bovens, Hebben rechtspersonen morele plichten en fundamentele rechten?, AAe 1998, pag. 651-659.

Bowles (1982): R. Bowles, Law and the economy, Martin Robertson, Oxford 1982. Braakman (1997 I): A.J. Braakman, Het kartelverbod in de Mw, Dossier ondernemingszaken 1997, pag. 10-14.

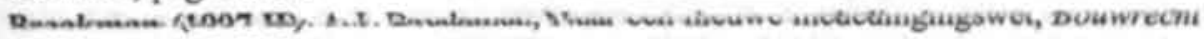
1997, pag. 196-205.

Brealey (1995): M. Brealey, Business Secrecy and Confidentiality, in: Lord Slynn of Hadley en S.A. Pappas (1995), pag. 67-76.

Briēt (1991): C.P. Briět, Het gerecht van eerste aanleg van de EG, Trema 1991, pag. 142-148.

Brittan (1993): L. Brittan, The case against cartels, in: Asser Instituut (1993), pag. 9-15. Brokx (1997): L.M.M. Brokx, Vrijstellingen en ontheffingen, Dossier Ondernemingszaken 1997, pag. 25-30.

De Bronett (1999): G-K. de Bronett, Artikel 87 - Zweiter Teil. Verordnung Nr. 17, in: Von der Groeben, Thiesing en Ehlermann (1999), pag. 2/933-2/990.

Brouns (1988): P.J.H.M. Brouns, Opzet in het wetboek van strafrecht (diss. Groningen), Gouda Quint, Arnhem 1988.

Brouwer (1992): O.W. Brouwer, Europees kartelrecht: klager en aanmelden. Brussel voorbij?, Just 1992, pag. 44-48.

Brouwer en Gerbrandy (1996): O.W. Brouwer en A.M. Gerbrandy, Het voorstel van een nieuwe Mededingingswet, V\&O 1996, pag. 95-97.

Brouwer en Gerbrandy (1997): O.W. Brouwer en A. Gerbrandy, Nationaal concentratictoezicht in de Mw, Dossier ondernemingszaken 1997, pag. 36-42.

Brulard en Demolin: Y. Brulard en P. Demolin (1994), Legal privilege, in: Association Européenne des Avocats (1994), pag. 64-112.

Bulterman en Lawson (2000): M. Bulterman en R. Lawson, Het EU-Grondrechtenhandvest: méér dan cen festijn voor juristen, Internationale Spectator 2000, pag. 423-429. Burkens (1993): M.C. Burkens, Gemeenschapsrecht en het EVRM, in: Burkens en Kummeling (1993), pag. 71-96.

Burkens en Kummeling (1993): M.C. Burkens en H.R.B.M. Kummeling (red.), EG en grondrechten. Gevolgen van de Europese integratie voor de nationale grondrechtenbescherming, W.E.J. Tjeenk Willink, Zwolle 1993. 
Buruma (1987): Y. Buruma, Bestrijding economische criminaliteit in het slop, NJB 1987 , pag. 1322.

Buruma (1988): Y. Buruma, Naschrift, NJB 1988, pag. 332.

Buruma (1993): Y. Buruma, De strafrechtelijke handhaving van bestuurswetten, Gouda Quint, Arnhem 1993.

Buruma (1998): Y. Buruma, Het schuldig subject, in: M.J. Borgers, I.M. Koopmans en F.G.H. Kristen (red.), Verwijtbare uitholling van schuld?, Ars Aequi Libri, Nijmegen 1998, pag. 1-9.

Van Buuren (1986): P.J.J. van Buuren, Toezicht en opsporing, in: J.P. Balkema en C.J.C.F. Fijnaut (red.), De politiële handhaving van strafwetgeving, Van den Brink, Lochem 1986, pag. 66-76.

Van Buuren (1995): P.J.J. van Buuren, De bestuurlijke boete geregeld?, in: Hazewindus en Jansen (1995), pag. 41-51.

Cath (1987): L.G.F. Cath, De onderzoeksbevoegdheden van de commissie in mededingingszaken -overzicht en recente ontwikkelingen, in: Ex lure, Gouda Quint, Arnhem 1987, pag. 17-62.

Cath (1991): I.G.F. Cath, Hebben ondernemingen recht op bescherming van de privésfeer? NJCM-Bulletin 1991, pag. 28-54.

Clapham (1991): A. Clapham, Human rights and the European Community: a critical overview, Nomos Verlag, Baden-Baden 1991.

Coppel en O'Neill (1992): J. Coppel en A. O'Neill, The European Court of Justice: taking rights seriously?, CMLRev 1992, pag. 669-692.

Coppens (1997): H. Coppens, De nieuwe Mededingingswet: ook voor het MKB gaat nu de deur op slot, Ondernemersbrief 1997, pag. 1-2.

Corstens (1995 I): G.J.M. Corstens, Een stille revolutie in het strafrecht, Gouda Quint, Arnhem 1995.

Corstens (1995 II): G.J.M. Corstens, Drugs naar België, AA 1995, pag. 720-726.

Corstens (1999): G.J.M. Corstens, Het Nederlands strafprocesrecht, Gouda Quint, Deventer 1999.

Corstens (2000): G.J.M. Corstens, Bestuurlijke boeten in de vierde tranche Awb, NJB 2000, pag. 1185-1190,

Cras (1996): S.P. Cras, Zes jaar Gerecht van eerste aanleg, NJB 1996, pag. 477-485. Cumming (1995): G. Cumming, Otto v Post Bank and the Privilege against Self-incrimination in Enforcement Proceedings of EC Articles 85 and 86 before the English Courts, ECLR 1995, pag. 400-409.

Curtin en Klerk (1997): D. Curtin en Y. Klerk, De Europese Unie en het Europees Verdrag voor de Rechten van de Mens, NJB 1997, pag. 202-210.

Curtin (1998): D. Curtin, EU police cooperation and human rights protection: building the trellis and training the vine, in: Scritti in onore di Guiseppe Federico Mancini, vol. II, Bologna 1998, pag. 227-256.

Dankert (1993): P. Dankert, De BV Nederland en de concurrentieverhoudingen op de interne markt, in: Asser Instituut (1993), pag. 1-7.

Dannecker en Fischer-Fritsch (1989): G. Dannecker en J. Fischer-Fritsch, Das EGKartellrecht in der Bußgeldpraxis, Carl Heymanns Verlag, Köln 1989.

Davidow (1977): J. Davidow, EEC fact-finding procedures in competition cases: an American critique, CMLRev. 1977, pag. 175-189.

Debruyne (1992): D. Debruyne, De grenzen van de onderzoeksbevoegdheden van de Europese Commissie in mededingingszaken, Maklu Uitgevers, Apeldoorn 1992. 
Deringer (1968): A. Deringer, The competition law of the European Economic Community, Commerce Clearing House, Chicago 1968.

Van Dijek (1999): J.E.A.M. van Dijck, Een rechtspersoonlijke levenssfeer, Weekblad 1999, pag. 613-619.

Van Dijk (1994): P. van Dijk, Bendenoun binnen proporties, NJB 1994, pag. 1526-1527. Van Dijk en Van Hoof (1998): P. van Dijk en G.J.H. van Hoof, Theory and Practice of the European Convention on Human Rights, Kluwer Law International, The Hague 1998.

De Doelder (1994): H. de Doelder, Handhaving van economische regelgeving. Is door de bestuurlijke handhaving het primaat van de strafrechtelijke handhaving doorbroken of geldt het strafrecht als ultimum remedium?, in: De Doelder en Rogier (1994), pag. 205-215.

De Doelder en Van der Hulst (1993): H. de Doelder en J.W. van der Hulst, EEG-sancties en ne bis in idem, $S E W$ 1993, pag. 722-733.

De Doelder, De Meijer en Otto (1999): H. de Doelder, M.E. de Meijer en D. Otto (red.), De bestuurlijke boete in perspectief, Gouda Quint, Rotterdam 1999.

De Doelder en Rogier (1994): H. de Doelder en L.J.J. Rogier, (red.), Opstellen over bestuursstrafrecht, Gouda Quint, Arnhem 1994.

Doherty (1994): B. Doherty, Playing Poker with the Commission: Rights of Acces to the Commission's File in Competition Cases, ECLR 1994, pag. 8-15.

Doorenbos (1995): D.R. Doorenbos, De WED als bron van strafprocesrecht, in: Balkema e.a. (1995), pag. 69-83.

Van Dorst (1985): A.J.A. van Dorst, De competentie van de economische strafrechter, NJB 1985, pag. 1137-1139.

Duk (1973): R.A.A. Duk, Het S.E.R.-advies van 15 juni 1973 inzake herziening van de Wet economische mededinging en versterking van het mededingingsbeleid, SEW 1973, pag. 447-458.

Duk (1974): R.A.A. Duk, De SER en de grondslagen van het Nederlandse mededingingsrecht, SEW 1974, pag. 631-637.

Duk en Limperg (1985): R.A.A. Duk en K. Limperg, Ongeoorloofde mededinging en Europees recht, Bijblad Industriële Eigendom 1985, pag. 176-183.

Edward en Lane (1995): D.A.O. Edward en R.C. Lane, European Community Law. An Introduction, Butterworths, Edinburgh 1995.

Eeckman (1989): P. Eeckman, Het Gerecht van eerste aanleg van de Europese Gemeenschappen, $R W$ 1989-1990, pag. 65-69.

Ehlermann (1995): C.D. Ehlermann, Community Competition Law Procedures, in: Lord Slynn of Hadley en S.A. Pappas (1995), pag. 9-22.

Ehlermann (2000): C.D. Ehlermann, The modernization of EC antitrust policy: a legal and cultural revolution, CMLR 2000, pag. 537-590.

Ehlermann en Drijber (1996): C.D. Ehlermann en B.J. Drijber, Legal Protection of Enterprises: Administrative Procedure, in particular Access to Files and Confidentiality, ECLR 1996, pag. 375-383.

Van Eijkern (1964): W.J. van Eijkern, Wetgevingskroniek Nederland, SEW 1964, pag. 194-201.

Elderson en VerLoren van Themaat (1997): F. Elderson en I.W. VerLoren van Themaat, Misbruik van economische machtspositie, Dossier Ondernemingszaken 1997, pag. 15-19. Elles (1995): D. Elles, Introduction to the Report on Enforcement of Community Competition Rules, in: Lord Slynn of Hadley en S.A. Pappas (1995), pag. 1-8.

Emmerich (1994): V. Emmerich, Kartellrecht, Beck Verlag, München 1994. 
Enschedé (1975): Ch.J. Enschedé, Een nieuw handboek, DD 1975, pag. 1-6.

Enschedé (1995): Ch.J. Enschedé, Beginselen van strafrecht, Kluwer, Deventer 1995. Feteris (1993): M.W.C. Feteris, Aantekening bij EHRM 25 februari 1993 (Funke), FED 1993/628.

Feteris (1995): M.W.C. Feteris, Aantekening bij ECRM 10 mei 1994 (Saunders), FED 1995/3.

Feteris (1997): M.W.C. Feteris, noot bij EHRM 17 december 1996 (Saunders), BNB $1997 / 254$.

Fierstra (1990): M.A. Fierstra, Het Gerecht van Eerste Aanleg van de Europese Gemeenschappen, Advocatenblad 1990, pag. 598-600.

Fierstra (1991): M. Fierstra, Het legal privilege opnieuw beschouwd, SEW 1991, pag. 699-709.

Fierstra (1993): M.A. Fierstra, Europees mededingingsrecht, Kluwer, Deventer 1993. Finaly (1991): R.A.R.S. Finaly, Grondrechtsbescherming van rechtspersonen, NJCMBulletin 1991, pag. 105-120.

Finaly (1994): R.A.R.S. Finaly, Grondrechten voor publiekrechtelijke rechtspersonen; een beschouwing naar aanleiding van het arrest Rost van Tonningen, NJCM-Bulletin 1994, pag. 610-622.

Finaly (1996): R.A.R.S. Finaly, Nemo tenetur...niet voor rechtspersonen?, De Naamloze Vennootschap 1996, pag. 109-114.

Finaly (1998): R.A.R.S. Finaly, Privacy van rechtspersonen, NCJM-Bulletin 1998, pag. 554-570.

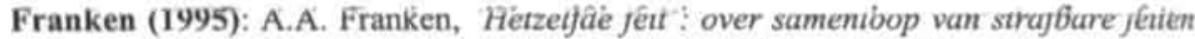
en het non bis in idem-beginsel, Ars Aequi Libri, Nijmegen 1995.

Franken (1975): H. Franken, De prikkel van een editorial, DD 1975, pag. 325-326. Fransen (1993): A.M. Fransen, Toezicht en opsporing, het onduidelijke voortraject bij de publieke rechtshandhaving, DD 1993, pag. 99-112.

Furse (1995): M. Furse, Article 15(2) of Regulation 17: Fines and the Commission's Discretion, ECLR 1995, pag. 110-115.

Geelhoed (1985): L.A. Geelhoed, De Rijksbegroting 1986 en de economische wetgeving, SEW 1985, pag. 708-717.

Van der Geest (1992): L. van der Geest, Kartels onder vuur, ESB 1992, pag. 905. Van Gerven c.s. (1997): W. van Gerven, L. Gyselen, M. Maresceau, J. Stuyck, Kartelrecht II. Europese Gemeenschap, W.E.J. Tjeenk Willink, Zwolle 1997.

Van Gerven (1995): W. van Gerven, Naar een Europees gemeen recht van algemene rechtsbeginselen?, RM Themis 1995, pag. 233-243.

Ghandi (1981): S. Ghandi, Interaction between the protection of fundamental rights in the European Economic Community and under the European Convention on Human Rights, LIEI 1981, pag. 1-33

't Gilde en Haank (1985): A.P.J. 't Gilde en D.J. Haank, De praktijk van de Wet economische mededinging, Onderzoeksrapport nr. 37 Stichting Wetenschappelijk Onderzock Konsumentenaangelegenheden, 's-Gravenhage 1985.

Gillmeister (1985): F. Gillmeister, Ermittlungsrechte im deutschen und europäischen Kartellordnungswidrigkeitenverfahren, Nomos Verlagsgesellschaft, Baden-Baden 1985. Glazener en Janssen (1998): P. Glazener en J.E. Janssen, De beschikkingspraktijk op grond van de Wet economische mededinging in de periode 1 juli 1995 tot 1 januari 1998, SEW 1998, pag. 327-350.

Glazener en Jansen (2000): P. Glazener en T.S. Jansen, Kroniek Mededingingsrecht; anderhalf jaar NMa, SEW 2000, pag. 20-31. 
Glazener, Jansen en Evans (2000): P. Glazener, T.S. Jansen en S.J.H. Evans, Kroniek mededingingsrecht; beschikkingspraktijk van de NMa in het tweede halfjaar 1999, SEW 2000, pag. 362-376.

Glazener, Bijleveld en Evans (2001): P. Glazener, A.S. Bijleveld en S.J.H. Evans, Kroniek mededingingsrecht; beschikkingspraktijk van de $\mathrm{NMa}$ in het eerste halfjaar 2000 , SEW 2001, pag. 62-72.

Gleiss en Hirsch (1978): A. Gleiss en M. Hirsch, Kommentar zur EWG-Kartellrecht, Heidelberg, 1978.

Gormley (1997): L. Gormley (ed.), Current and Future Perspectives on EC Competition Law, Kluwer Law International, The Hague 1997.

Goyder (1998): D.G. Goyder, EC Competition Law, Clarendon Press, Oxford 1998. Grabandt (1982): E. Grabandt, Legal professional privilege en beroepsgeheim van de advocaat tegenover opsporingsbevoegdheid van de overheid, Advocatenblad 1982, pag. 525-531.

Gradus en Smulders (1992): R.H.J.M. Gradus en J.A. Smulders, Kartels: lust of last?, ESB 1992, pag. 788-792.

Gritter (1998): E. Gritter, De nieuwe Mededingingswet: scherpe tanden?, TVVS 1998, pag. 166-170.

Von der Groeben, Thiesing en Ehlermann (1991): H. von der Groeben, J. Thiesing en C.D. Ehlermann, Kommentar zum EWG-Vertrag, Nomos Verlagsgesellschaft, BadenBaden 1991.

Von der Groeben, Thiesing en Ehlermann (1993): H. von der Groeben, J. Thiesing en C.D. Ehlermann, Handbuch des Europäischen Rechts, Nomos Verlagsgesellschaft, Baden-Baden 1993.

Von der Groeben, Thiesing en Ehlermann (1999): H. von der Groeben, J. Thiesing en C.D. Ehlermann (Hrsg), Kommentar zum EU-/EG-Vertrag, Nomos Verlagsgesellschaft, Baden-Baden 1999.

Groenhuijsen en Van Kalmthout (1983): M.S. Groenhuijsen en A.M. van Kalmthout, De wet vermogenssancties en de kwaliteit van de rechtsbedeling, $D D$ 1983, pag. 8-31. Guldenmund (1992): R.M.A. Guldenmund, Strafrechtelijke handhaving van gemeenschapsrecht, Gouda Quint, Arnhem 1992.

Gustafsson (2000): M. Gustafsson, Some Legal Implications Facing the Realisation of the Commission White Paper on Modernisation of EC Antitrust Procedure and the Role of National Courts in a Post-White Paper Era, LIEI 2000, pag. 159-184.

Gyselen (1993): L. Gyselen, The Commission's fining policy in competition cases -"Questo è il catalogo", in: P.J. Slot en A. McDonnell (eds)., Procedure and enforcement in E.C. and U.S. competition law. Proceedings of the Leiden Europa Instituut Seminar on Userfriendly Competition Law, Sweet \& Maxwell, London 1993, pag. 63-75.

Hall (1995): D.F. Hall, Rights of Defence, in: Lord Slynn of Hadley en S.A. Pappas (1995), pag. 33-42.

Ham (1992 I): A.D. Ham, Mediterrane wetgeving op het gebied van de economische mededinging, SEW 1992, pag. 611-622.

Ham (1992 II): A.D. Ham, Ommekeer in de Belgische mededingingswetgeving, SEW 1992, pag. 803-809.

Ham (1993): A.D. Ham, Horizontale prijsbinding onder het mes, SEW 1993, pag. 626-640. Ham (1994): A.D. Ham, Op weg naar een nieuwe Wet economische mededinging, SEW 1994, pag. 492-508.

Hamann (1992): H. Hamann, Das Unternehmen als Täter im europäischen Wettbewerbsrecht, Centaurus-Verlagsgesellschaft, Pfaffenweiler 1992. 
Hamburger (1997): C. Hamburger, De nieuwe Mededingingswet vergeleken met de oude WEM, Dossier ondernemingszaken 1997, pag. 2-5.

Handhaving door bestuurlijke boeten (1994): Advies van de Commissie voor de toetsing van wetgevingsprojecten inzake Handhaving door bestuurlijke boeten, CTW 94/1, 12 januari 1994.

Handhaven op niveau (1998): Commissie Bestuursrechtelijke en Privaatrechtelijke Handhaving, Handhaven op niveau, W.E.J. Tjeenk Willink, Deventer 1998.

Harding (1993): C. Harding, European Community Investigations and Sanctions, Leicester University Press, Leicester 1993.

't Hart (1992): A.C. 't Hart, Perikelen van zwijgplicht en verschoningsrecht, DD 1992, pag. 105-110.

Harteveld, Keulen en Krabbe (1996): A.E. Harteveld, B.F. Keulen en H.G.M. Krabbe, Het EVRM en het Nederlandse strafprocesrecht, Wolters-Noordhoff, Groningen 1996. Hartmann (1995): A.R. Hartmann, De bestuurlijke boete. Naar een zelfstandige wettelijke regeling, Trema 1995, pag. 318-322.

Hartmann (1998): A.R. Hartmann, Bewijs in het bestuursstrafrecht (diss. Rotterdam), Gouda Quint 1998.

Hartmann (1999): A.R. Hartmann, De wettelijke regeling van de bestuurlijke boete naar vorm en inhoud, in: De Doelder, De Meijer en Otto (1999), pag. 39-62.

Hartmann (2000): A.R. Hartmann, Het zwijgrecht en de cautieverplichting, in: Rogier (2000 I), pag. 37-63.

Hartmann en Van Russen Groen (1994 I): A.R. Hartmann en P.M. van Russen Groen, 'Criminal charge' uitgekleed?, NJB 1994, pag. 1521-1526.

Hartmann en Van Russen Groen (1994 II): A.R. Hartmann en P.M. van Russen Groen, Bestuursstrafrecht, in: De Doelder en Rogier (1994), pag. 21-59.

Hartmann en Van Russen Groen (1994 III): A.R. Hartmann en P.M. van Russen Groen, Van strafrecht naar bestuursstrafrecht: de derde decriminaliseringsgolf?, in: De Doelder en Rogier (1994), pag. 61-78 (eerder gepubliceerd in: M. Moerings (eindred.), Hoe punitief is Nederland?, Gouda Quint, Arnhem 1994, pag. 145-163).

Hartmann en Van Russen Groen (1998): A.R. Hartmann en P.M. van Russen Groen, Contouren van het bestuursstrafrecht (diss. Rotterdam), Gouda Quint 1998.

Hazewindus en Jansen (1995), W.G.A. Hazewindus en O.J.D.M.L. Jansen (red.), Van boeteatelier tot boetefabriek, Kluwer, Deventer 1995.

Hazewinkel-Suringa/Remmelink (1994): D. Hazewinkel-Suringa, J, Remmelink, Inleiding tot de studie van het Nederlandse strafrecht, Gouda Quint, 1994.

Hellingman en Mortelmans (1989): K. Hellingman en K.J.M. Mortelmans, Economisch publiekrecht, Kluwer, Deventer 1989.

Hellman (1988): H. Hellmann, Noch einmal: Zur Vollstreckung einer Nachprüfungsentscheidung der Kommission der EG, NJW 1988, pag. 611.

Hendriks e.a (1999): L.E.M. Hendriks e.a., Hoofdstukken strafprocesnecht, Gouda Quint, Deventer 1999.

Hermans en Noë (1999): R.M. Hermans en S.B. Noë, De herziening van Verordening 17 vanuit advocatuurlijk perspectief: een boeiende accentverschuiving, $M \& M 1999$, pag. 144-148.

Van den Heuvel (1994): G.A.A.J. van den Heuvel, Convenanten in de Nederlandse overlegeconomie, $J V 1994$, pag. 9-26.

Hieltjes (1995): H.B. Hieltjes, Spreken blijft plicht; zwijgen niet gauw (te)recht, WFR 1995, pag. 294-302. 
Hollander (1952): F. Hollander, Wet op de economische delicten, Gouda Quint, Arnhem 1952.

Hornsby en Hunter (1997): S. Hornsby en J. Hunter, New Incentives for "Whistle-blowing": will the E.C. Commission's Notice Bear Fruit?, ECLR 1997, pag. 38-41. Huidekoper (1975): P.A. Huidekoper, Hantering van het economisch strafrecht in Nederland, Kluwer, Deventer 1975.

Huidekoper (1976): P.A. Huidekoper, Verslag van het jubileumcongres 25 jaar Wet op de Economische Delicten, SEW 1976, pag. 387-400.

De Hullu (2000): J. de Hullu, Materieel strafrecht. Over algemene leerstukken van strafrechtelijke aansprakelijkheid naar Nederlands recht, Gouda Quint, Deventer 2000. Van der Hulst (2000): J.W. van der Hulst, Enige bepalingen over de bestuurlijke boete belicht vanuit strafrechtelijk perspectief, in: Rogier (2000 I), pag. 65-76.

Hustinx (1984): P.J. Hustinx, De Wet vermogenssancties, $A A$ 1984, pag. 147-153. Hyde-Price (1990): A. Hyde-Price, European security beyond the Cold War, London 1990, pag. 120.

Jansen (2000): A.M.L. Jansen, De redelijke termijn met name in het bestuursrecht (diss. Tilburg), Boom Juridische Uitgevers, 2000.

Jansen (1994 I): O.J.D.M.L. Jansen, Toezicht, opsporing en de Algemene wet bestuursrecht, $D D$ 1994, pag. 534-552.

Jansen (1994 II): O.J.D.M.L. Jansen, Bestuursrecht en strafprocesrecht: doorwerken of afgrenzen, in: T. Hoogenboom en L.J.A. Damen, In de sfeer van administratief recht. Opstellen aangeboden aan Willem Konijnenbelt, Lemma, Utrecht 1994, pag. 257-283. Jansen (1995 I): O.J.D.M.L. Jansen, Handhavingstoezicht in de Algemene wet bestuursrecht: nog steeds onvoldoende!, De Gemeentestem 1995, pag. 461-468.

Jansen (1995 II): O.J.D.M.L. Jansen, (Onder)zoeken in afdeling 5.1 Awb: enkele belangrijke tekortkomingen, De Gemeentestem 1995, pag. 627-629.

Jansen (1996): O.J.D.M.L. Jansen, De bestuurlijke boete in het wetsvoorstel Mededingingswet, NJB 1996, pag. 1250-1254.

Jansen (1997): O.J.D.M.L. Jansen, De bestuurlijke boete in de Mededingingswet, Dossier ondernemingszaken 1997, pag. 43-46.

Jansen (1999): O.J.D.M.L Jansen, Het Handhavingsonderzoek (diss.), Ars Aequi Libri, 1999.

Jansen (2001): O.J.D.M.L. Jansen, Toezicht en onderzoek -een beperkt transnationale benadering, in: Jansen, Van der Meulen en Widdershoven (2001), pag. 146-165.

Jansen en Hazewindus (1995): O.J.D.M.L. Jansen en W.G.A. Hazewindus, Inleiding: de bestuurlijke boete in de derde tranche!, in: Hazewindus en Jansen (1995), pag. 1-14. Jansen, Van der Meulen en Widdershoven (2001): O.J.D.M.L. Jansen, B.M.J. van der Meulen en R.J.G.M. Widdershoven (eindred.), Handhaving van de Mededingingswet, Kluwer, Deventer 2001.

Janssen (1990): H.G.A.J. Janssen, Franchising en het kartel-verbod van artikel 85 EEGVerdrag, Advocatenblad 1990, pag. 264-268.

Janssen (1998): J.E. Janssen, Mededingingswet in werking, Tijdschrift Privatisering 1998, pag. 6-7.

De Jong (1986 I): H.W. de Jong, Mededingingspolitiek: ficties en feiten, ESB 1986, pag. 3.

De Jong (1986 II): H.W. de Jong, De Europese mededingingspolitiek, ESB 1986, pag. 291.

De Jong (1997): J.P. de Jong, Hoger beroep bij het College van Beroep voor het bedrijfsleven, NTB 1997, pag. 42-43. 
Jorna (1990): M.J.Th. Jorna, De onderzoeksprocedure in het Europese mededingingsrecht, Advocatenblad 1990, pag. 630-635.

Joshua (1982): J.M. Joshua, Requests for Information in EEC Factfinding Procedures, ECLR 1982, pag. 173-184.

Joshua (1983): J.M. Joshua, The Element of Surprise: EEC Competition Investigations under Article 14 (3) of Regulation 17, ELRev. 1983, pag. 3-23.

Joshua (1986): J.M. Joshua, Information in EEC Competition Law Procedures, ELRev. 1986, pag. 409-429.

Joshua (1994 I): J.M. Joshua, Balancing the Public Interests: Confidentiality, Trade Secret and Disclosure of Evidence in EC Competition Procedures, ECLR 1994, pag. 68-80. Joshua (1994 II): J.M. Joshua, The powers of the Commission: efficiency and swiftness in investigative procedures, in: Association Européenne des Avocats (1994), pag. 9-37.

Kamburoglou en Pirrwitz (1990): P. Kamburoglou en B.J. Pirrwitz, Reichweite und Vollstreckung von Nachprüfungsentscheidungen der EG-Kommission, $R I W 1990$, pag. 263-272.

Kapteyn en VerLoren van Themaat (1995): P.J.G. Kapteyn en P. VerLoren van Themaat (hoofdred.), Inleiding tot het recht van de Europese Gemeenschappen. Na Maastricht, Kluwer, Deventer 1995.

Het Kartelbesluit (1941): Het Kartelbesluit, Economische Voorlichting, 14 november 1941, pag. 1679-1682.

Kauffmann (1939): A.E. Kauffmann, Het Algemeen Verbindend Verklaren van Ondernemersovereenkomsten, NJB 1939, pag. 104-109.

Kelk (1998): C. Kelk, Studieboek materieel strafrecht, Gouda Quint 1998.

Kerse (1995 I): C.S. Kerse, Access to the File, in: Lord Slynn of Hadley en S.A. Pappas (1995), pag. 55-66.

Kerse (1995 II): C.S. Kerse, Annotatie bij SEP-arrest, CMLRev. 1995, pag. 857-869. Keulen (1995): B.F. Keulen, Economisch strafrecht, Gouda Quint, Arnhem 1995.

Kerse (1998): C.S. Kerse, E.C. Antitrust Procedure, Sweet \& Maxwell, London 1998. Keulen (1996): B.F. Keulen, Artikel 6: een eerlijk proces, in: Harteveld, Keulen en Krabbe (1996), pag. 79-140.

Keulen en Lenos (1999): B.F. Keulen en E.E.V. Lenos, Geen bis in idem bij de uitleg van ne bis in idem, NJCM-Bulletin 1999, pag. 233-240.

Keulen en Otte (1999): B.F. Keulen en M. Otte, Opzet en schuld, Ars Aequi Libri, Nijmegen 1999.

Keyser-Ringnalda (1994): L.F. Keyser-Ringnalda, Boefen buit, Gouda Quint, Amhem 1994.

Kik (1997): L.C.A. Kik, Gesprek met mr A.W. Kist, directeur-generaal NMa, Dossier ondernemingszaken 1997, pag. 20-24.

Kist (1998): A.W. Kist, Mededingingsrecht: een economische discipline?, Tijdschrift Privatisering 1998, pag. 4-5.

Kleijs-Wijnnobel (1994): C.J. Kleijs-Wijnnobel, Handhaving van bestuursrecht, NTB 1994, pag. 94-103.

Knigge (1988): G. Knigge, Controle door de FIOD, AA 1988, pag. 772-775.

Knigge (2000): G. Knigge, De verkalking voorbij. Over de verhouding van het strafrecht tot het bestuursrecht, RM Themis 2000, pag. 83-96.

Koning (2001): P.J.M. Koning, Toezicht en onderzoek in mededingingszaken, in: Jansen, Van der Meulen en Widdershoven (2001), pag. 119-130. 
De Koning-De Jong (1994): B.M. de Koning-de Jong, Het rapport: 'Handhaving door Bestuurlijke Boeten' op de keper beschouwd, in: De Doelder en Rogier (1994), pag. 173 189.

Koopman (1997): R.J. Koopman, Saunders en het nieuwe boeteregime, FED 1997/452. Koopmans (1995): I.M. Koopmans, Strafrecht of administratief recht? Kanttekeningen bij de invoering van de bestuurlijke boete: decriminalisering of juist criminalisering, in: A.J.H.W. Coppelmans, W.E.C.A. Valkenburg, R.D. Vriesendorp en W.J. Witteveen, Het actuele recht 2. Tilburgse commentaren, Koninklijke Vermande, Lelystad 1995.

Korah (2000): V. Korah, An Introductory Guide to EC Competition Law and Practice, Hart Publishing, Oxford 2000.

Krabbe (1996): H.G.M. Krabbe, Artikel 8: de eerbiediging van het privé-leven, in: Harteveld, Keulen en Krabbe (1996), pag. 141-177.

Krabbe en Van Hattum (2000): H.G.M. Krabbe en W.F, van Hattum, De ne bis in idem-regel in de rechtspraak van het EHRM, DD 2000, pag. 6-20.

Krabbe en Poelman (1985): H.G.M. Krabbe en H.M. Poelman, Enkele aspecten van het ne bis in idem-beginsel in internationaal verband, in: J.P. Balkema e.a. (red.), Liber amicorum Th.W. van Veen: opstellen aangeboden aan Th.W, van Veen ter gelegenheid van zijn vijfenzestigste verjaardag, Amhem 1985, pag. 123-145.

Kreis (1981): H.W. Kreis, Ermittlungsverfahren der EG-Kommission in Kartellsachen, RIW/AWD 1981, pag. 281-297.

Kristen, Borgers en Koopmans (1998): F.G.H. Kristen, M.J. Borgers en I.M. Koopmans, Schuld in het strafrecht, in: M.J. Borgers, I.M. Koopmans en F.G.H. Kristen (red.), Verwijtbare uitholling van schuld?, Ars Aequi Libri, Nijmegen 1998, pag. 11-28.

Kruisheer (1939): J.C. Kruisheer, De praktijk der ordening, De Nederlandsche ordeningswetgeving voor het industrieele bedrijfsleven en haar toepassing, Paris, Amsterdam 1939. Kühlhorn (1986): T. Kühlhorn, Ermittlungen der EG-Kommission nach Art. 11 und 14 der VO 17/62, WuW 1986, pag. 7-25.

Kulka (1989): M. Kulka, Art und Umfang der Nachprüfungsbefugnisse der EG-Kommission bei Verdacht von Zuwiderhandlungen gegen Wettbewerbsregeln, Der Betrieb 1989, pag. 2112-2117.

Lane (2000): R. Lane, EC Competition Law, Pearson Education, Harlow 2000.

Langer en Sauter (1999): J. Langer en W. Sauter, Recht in zicht - Misbruik van economische machtspositie onder de nieuwe Mededingingswet, AA 1999, pag. 88-98.

Lasok (1982): K.P.E. Lasok, AM\&S - The Court decides, editorial ECLR 1982, pag. 99-108.

Lasok (1990): K.P.E. Lasok, The Privilege against Self-incrimination in Competition Cases, ECLR 1990, pag. 90-91.

Lauwaars (1982): R.H. Lauwaars, De toepasselijkheid van het Europees Kartelrecht op intraconcern relaties, in: Barents (1982), pag. 155-165.

Lauwaars en Timmermans (1999): R.H. Lauwaars en C.W.A. Timmermans, Europees recht in kort bestek, W.E.J. Tjeenk Willink, Deventer 1999.

Lawson (1999): R.A. Lawson, Het EVRM en de Europese Gemeenschappen (diss, Leiden), Kluwer, Deventer 1999.

Lawson (2000 I): R.A. Lawson, Het EU-grondrechtenhandvest, NJCM-Bulletin 2000, pag. 925-935.

Lawson (2000 II): R.A. Lawson, Ululare vel iubilare? Het EU-handvest als verwarrend verjaardagscadeau voor het EVRM, NJCM-Bulletin 2000, pag. 938-946.

Lawson (2000 III): R.A. Lawson, Noot bij het Baustahlgewebe-arrest, SEW 2000, pag. 175-178. 
Lawson (2000 IV): R.A. Lawson, Noot bij het Limburgse Vinyl Maatschappij-arrest, SEW 2000, pag. 178-182.

Leenders (1993): M.A.J. Leenders, Grondrechten als algemene beginselen van gemeenschapsrecht, in: Burkens en Kummeling (1993), pag. 33-70.

Leijten (1993): M.J.C. Leijten, CBB geen onafhankelijke rechter? Van de Hurk versus Nederland: consequenties van art. 6 EVRM, in: R.D. Vriesendorp, M.L.W. Weerts en W.J. Witteveen (red.), Het actuele recht. Rechtspraak anno 1993 in 67 Tilburgse bijdragen, Koninklijke Vermande, Lelystad 1993, pag. 203-206.

Lenaerts (1990): K. Lenaerts, Het Gerecht van eerste aanleg van de Europese Gemeenschappen, SEW 1990, pag. 527-548.

Lenaerts en Arts (1999): K. Lenaerts en D. Arts, Europees Procesrecht, Maklu, Apeldoorn 1999.

Lenaerts en Van Nuffel (1999): K. Lenaerts en P. van Nuffel, Europees Recht in hoofdlijnen, Maklu, Apeldoorn 1999.

Lenos (1997): E.E.V. Lenos, De sociale en fiscale inlichtingenplicht en het zwijgrecht sinds Saunders, NJB 1997, pag. 795-800.

Levitt (1997): M. Levitt, Commission Notice on Internal Rules of Procedure for Access to the file, ECLR 1997, pag. 187-190.

Lieberknecht (1994): O. Lieberknecht, The request for information and the tights of defence, in: Association Européenne des Avocats (1994), pag. 38-48.

Lipowsky (1987): D. Lipowsky, Die Zurechnung von Wettbewerbsverstößen zwischen verbundenen Unternehmen im EWG-Wettbewerbsrecht, Florentz, München 1987.

Mahler (1999): R. Mahler, Eerste boetebesluit NMa, Bb 1999, pag. 207-212.

Maitland (1946): W.F. Maitland, Kartelwetgeving in Nederland, Boek- en kunstdrukkerij, Den Haag 1946.

Van Marissing (2000): J.P.L. van Marissing, De NMa in actie, Sdu Uitgevers, Den Haag 2000 .

Van der Meer Mohr-Soons (1996): M.H.A. van der Meer Mohr-Soons, Wet economische mededinging, Editie Schuurman \& Jordens, W.E.J. Tjeenk Willink, Zwolle 1996.

Meijer (1991): A. Meijer, De werking van het nemo tenetur-beginsel in het Nederlandse strafrecht, $A A$ 1991, pag. 174-180.

Meijers (1989): L.C.M. Meijers, Strafmotivering; een controlelijst, in: G.A.M. Strijards e.a., De derde rechtsingang nader bekeken. Opstellen aangeboden aan C. Bronkhorst, Gouda Quint, Arnhem 1989, pag. 209-221.

Merkx (2000): C.A.J.M. Merkx, Bestuurlijke handhaving, in het bijzonder de bestuurlijke boete, in: Van der Meulen en Voermans (2000), pag. 49-94

Van der Meulen (2000): B.M.J. van der Meulen, De vierde tranche. Relevantie voor het mededingingsrecht van aanhangige en voorgestelde wijzigingen in de Algemene wet bestuursrecht, SEW 2000, pag. 439-444.

Van der Meulen en Voermans (2000): B.M.J, van der Meulen en W.J.M. Voermans (red.), Info Vierde tranche Algemene wet bestuursrecht, Elsevier, Den Haag 2000. Michiels (1994): F.C.M.A. Michiels, De boete in opmars?, W.E.J. Tjeenk Willink, Zwolle 1994.

Michiels (1999): F.C.M.A. Michiels, Het handhavingstekort en de bestuurlijke boete, in: De Doelder, De Meijer en Otto (1999), pag. 63-75.

Mok (1964): M.R. Mok, Het kartelbeleid tijdens het bewind van het kabinet De Quay, SEW 1964, pag. 117-157.

Mok (1968): M.R. Mok, Toepassing van de Wet economische mededinging (noot bij de Sitos-beschikking), SEW 1968, pag. 70-76. 
Mok (1969 I): M.R. Mok, 'Zweischranken'-leer aanvaard -of toch niet?, SEW 1969. pag. 24-26.

Mok (1969 II): M.R. Mok, Het Nederlands kartelbeleid, SEW 1969, pag. 130-186 Mok (1970): M.R. Mok, Noot bij HvJ (14/68) Jur. 1969, 1 (Walt Wilhelm e.a.), SEW 1970, pag. 151-182.

Mok (1974): M.R. Mok, Europees ekonomisch strafrecht, DD 1974, pag. 268-279.

Mok (1975): M.R. Mok, Conflicterende vrijheden in het kartelrecht, in: Vrijheid en recht. Opstellen aangeboden aan Prof. mr. E.H. s'Jacob, W.E.J. Tjeenk Willink, Zwolle 1975. pag. 153-163.

Mok (1978): M.R. Mok, 20 jaar WEM, SEW 1978, pag. 737-760.

Mok (1980): M.R. Mok, Noot bij Coll. 24 juli 1979 (Hoffmann La Roche B.V.), SEW 1980, pag. 125-140.

Mok (1981): M.R. Mok, De toepassing van artikel 85, lid 3, EEG en de echte kartels, in: VerLoren van Themaat e.a. (1981), pag. 43-70.

Mok (1982 I): M.R. Mok, Europees kartelrecht, TVVS 1982, pag. 173-175.

Mok (1982 II): M.R. Mok, Naar een ander prijsbeleid?, TVVS 1982, pag. 248.

Mok (1982 III): M.R. Mok, Regulering en deregulering; alternatieven voor kartel- en prijsbeleid, TVVS 1982, pag. 248-250.

Mok (1983): M.R. Mok, Het paard achter de wagen, SEW 1983, pag. 666-678.

Mok (1984): M.R. Mok, Geldt het draagkrachtbeginsel niet voor boetes wegens overtreding van Europees kartelrecht?, SEW 1984, pag. 137-143.

Mok (1986 I): M.R. Mok, Naschrift, TVVS 1986, pag. 115-116.

Mok (1986 II): M.R. Mok, Toepassing WEM (II), TVVS 1986, pag. 307.

Mok (1986 III): M.R. Mok, Bank over boekenvak, TVVS 1986, pag. 307-308.

Mok (1987 I): M.R. Mok, Toepassing WEM, TVVS 1987, pag. 46-49.

Mok (1987 II): M.R. Mok, Europees kartelrecht, TVVS 1987, pag. 71-72.

Mok (1987 III): M.R. Mok, Vooralsnog geen openbaar kartelregister, TVVS 1987, pag. $72-73$.

Mok (1988) M.R. Mok, Verband tussen kartelrecht en "vijandige overnemingen" van ondernemingen?, TVVS 1988, pag. 155-156.

Mok (1989): M.R. Mok, Europees kartelrecht, TVVS 1989, pag. 151-153.

Mok (1990): M.R. Mok, Noot bij Hoechst-arrest en Dow-arresten, SEW 1990, pag. 381 397.

Mok (1992 I): M.R. Mok, (Uitvoering WEM) TVVS 1992, pag. 44-46.

Mok (1992 II): M.R. Mok, Toepassing WEM, TVVS 1992, pag. 67-69.

Mok (1992 III): M.R. Mok, (Toepassing WEM) TVVS 1992, pag. 98-101.

Mok (1992 IV): M.R. Mok, Bouwnijverheid in Nederland, TVVS 1992, pag. 125-129.

Mok (1992 V): M.R. Mok, Van Rooy en het einde van het kartelparadijs, TVVS 1992, pag. 266-267.

Mok (1993 I): M.R. Mok, Nederland kartelland? Plaats en toekomst van het nationaal kartelrecht naast het Europese recht, RM Themis 1993, pag. 116-126.

Mok (1993 II): M.R. Mok, Schorsing op grond van WEM, TVVS 1993, pag. 24-25.

Mok (1994 I): M.R. Mok, Voortgaande verscherping nationaal kartelbeleid in Nederland: twee nieuwe generieke maatregelen, $S E W$ 1994, pag. 467-480.

Mok (1994 II): M.R. Mok, Toepassing WEM: generieke maatregelen 'marktverdelings-' en aanbestedingskartels, TVVS 1994, pag. 74-75.

Mok (1995): M.R. Mok, Kartelrecht I. Nederland, W.E.J. Tjeenk Willink, Zwolle 1995. Mok (1997): M.R. Mok, Voorstel-Mededingingswet door Tweede Kamer aanvaard, SEW 1997, pag. 225-229. 
Mok (1998): M.R. Mok, Kartelrecht I. Nederland, De Mededingingswet, W.E.J. Tjeenk Willink, Zwolle 1998.

Mok (1999): M.R. Mok, Naar 'modernisering' van het Europees kartelbeleid. Witboek Europese Commissie mei 1999, SEW 1999, pag. 314-322.

Mok (2000): M.R. Mok, De toekomst van het Europees kartelrecht, Ondernemingsrecht 2000, pag. 448-453.

Mok (2001): M.R. Mok, Europees Kartelrecht. Voorstel nieuwe kartelverordening; samenwerking bestuurlijke en rechterlijke instanties, Ondernemingsrecht 2001, pag. 101-103. Mols (1999): G.P.M.F. Mols, Aantasting van het vervolgingsrecht, in: Hendriks e.a (1999), pag. 253-271.

De Moor-Van Vugt (1991): A.J.C. de Moor-van Vugt, Europees Bestuursrecht, NTB 1991, pag. 144-155.

De Moor-Van Vugt (1993): A.J.C. de Moor-van Vugt, Hobbels bij de rechtshandhaving. De rol van de algemene beginselen van behoorlijk bestuur bij de handhaving van het gemeenschapsrecht, in: Vervaele (1993), pag. 83-105.

De Moor-Van Vugt (1999): A.J.C. de Moor-van Vugt, Bestuurlijke boete en EG-recht, in: De Doelder, De Meijer en Otto (1999), pag. 163-173.

Moorman (1988): H.C. Moorman, Toezichthoudende bevoegdheid van opsporingsambtenaren ingevolge de Wet op de Economische Delicten, Milieu en Recht 1988, pag. 414-423. Mortelmans (1996): K.J.M. Mortelmans, De aansluiting van de ontwerp-mededingingswet bij het EG-mededingingsrecht: symbiose en osmose, in: R.A.J. van Gestel en Ph. Eijlander e.a. (red.), Markt en wet, W.E.J. Tjeenk Willink, Deventer 1996.

Mortelmans (1997): K.J.M. Mortelmans, Kroniek van het economisch publiekrecht, NJB 1997, pag. 1467-1475.

Mőschel (1995): W. Möschel, Subsidiaritätsprinzip und europäisches Kartellrecht, NJW 1995, pag. 281-285.

Mulder (1950): A. Mulder, De handhaving der sociaal-economische wetgeving. Naast strafrechtspraak bedrijfrechtspraak?, D.A. Daamen's uitgeversmaatschappij, 's-Gravenhage 1950.

Mulder (1959): A. Mulder, Wet op de economische delicten, Uitgevers-maatschappij Tjeenk Willink, Zwolle 1959.

Mulder (1971): A. Mulder, Noot bij de Kinine-arresten, SEW 1971, pag. 192-214. Mulder (1976): A. Mulder, Economisch strafrecht en bestuur, SEW 1976, pag. 372-380. Mulder (1982): A. Mulder, De cyclische ontwikkeling van het sociaal-economisch recht en van de economische politiek, in: Barents (1982), pag. 215-232.

Mulder (1985): A. Mulder, Controlebevoegdheden ter opsporing, kanttekeningen bij arrest HR 30 okt. 1984, NJ 1985, 275, SEW 1985, pag. 564-566.

Mulder (1989): A. Mulder, Geldboete, een eigen middel van de Europese Gemeenschappen, SEW 1989, pag. 459-478.

Mulder (1990): A. Mulder, noot bij Orkem-arrest en Solvay-arrest, SEW1990, pag. 397 412.

Mulder (1994): A. Mulder, De bestuurlijke boete als middel tot bestrijding van economische delicten, SEW 1994, pag. 219-235.

Mulder en Doorenbos (1995): A. Mulder en D.R. Doorenbos, Schets van het economisch strafrecht, W.E.J. Tjeenk Willink, Zwolle 1995.

Mulder en Engels (1984): A. Mulder en J.A. Engels, De positie van de bijzondere opsporingsdiensten, in: Recht op scherp, W.E.J. Tjeenk Willink, Zwolle 1984, pag. 137-154. Mulder en Mok (1962): A. Mulder en M.R. Mok, Kartelrecht, Samsom, Alphen aan den Rijn 1962. 
De Muynk (1999): Y. de Muynk, De eerste boete ex art. $62 \mathrm{Mw}$, Nieuwsbrief mededingingsrecht 1999, pag. 102-103.

Myjer (1993): E. Myjer, De getergde rechter en het advocatenkantoor, NJCM-Bulletin 1993, pag. 320-329.

Myjer (1997 I): E. Myjer, Spreekplicht versus zwijgrecht: Guiness is good for you-risprudentie, NJCM-Bulletin 1997, pag. 298-314.

Myjer (1997 II): E. Myjer, De verdachte jager zonder stukken, NJCM-Bulletin 1997 , pag. 734-742.

Myjer (1997 III): E. Myjer, Over stuk recht en recht op stukken, Trema 1997, pag. 179 184.

Noordhoff (1993): I. Noordhoff, Bijna vijftig kartels willen ontheffing verbod, Volkskrant 10 juli 1993.

Van Nus (1995): J.G.L. van Nus, Overheidstoezicht op afstand. Verzelfstandiging van toezichthoudende taken naar zelfstandige bestuursorganen verkend (diss. Maastricht), Maklu 1995.

d'Oliveira-Prakken (1975 I): E. d'Oliveira-Prakken, Het Hoger Handboek, DD 1975 , pag. 128-132.

d'Oliveira-Prakken (1975 II): E. d'Oliveira-Prakken, Handboek (supplement), DD 1975, pag. 469-474.

Van den Oosterkamp (1995): M.J.S. van den Oosterkamp, Een nieuwe mededingingswet: de adviezen van de Sociaal-Economische Raad en de Commissie economische mededinging, SEW 1995, pag. 336-356.

Ortiz Blanco (1996): L. Ortiz Blanco, European Community Competition Procedure, Clarendon Press, Oxford 1996.

Ottervanger (1994): T.R. Ottervanger, De toepassing van het mededingingsrecht in de verzekeringssector, TVVS 1994, pag. 235-239.

Ottervanger (1997): T.R. Ottervanger, Het Nederlandse mededingingsbeleid in Europees perspectief, Dossier ondernemingszaken 1997, pag. 6-9.

Ottervanger en Nijhuis (1994): T.R. Ottervanger en M.T. Nijhuis, Wijziging Wet economische mededinging ter vergroting van de effectiviteit, SEW 1994, pag. 481-491. Ottervanger, Steenbergen en Van der Voorde (1998): T.R. Ottervanger, J. Steenbergen en S.J. van der Voorde, Competition Law of the European Community, the Netherlands and Belgium, Kluwer Law International, The Hague 1998.

Otto, De Meijer en De Doelder (1999): D. Otto, M.E. de Meijer en H. de Doelder, De bestuurlijke boete in perspectief, in: De Doelder, De Meijer en Otto (1999), pag. 1-20. Van Outrive (1994): L. van Outrive, Is een Europees strafrecht mogelijk en noodzakelijk?, Panopticon 1994, pag. 471-475.

Van Oven (1934): van Oven, Ondernemersovereenkomsten, NJB 1934, pag. 533-541. Van Paridon (1993): M.J. van Paridon, Europees mededingingsrecht en convenanten, in: F.J. van Ommeren en H.J. de Ru, Convenanten tussen Overheid en maatschappelijke organisaties, Sdu, Den Haag 1993.

Patijn (1942): C.L. Patijn, Bij het einde van de Ondernemersovereenkomstenwet 1935, ESB 1942, pag. 13-16.

Pernice (1979): L. Pernice, Grundrechtsgehalte im europaischen Gemeinschaftsrecht, Nomos Verlagsgesellschaft, Baden-Baden 1979.

Pernice (1984): I. Pernice, Nach Art. 87, in: E. Grabitz, Kommentar zum EWG-Vertrag, C.H. Beck 1984. 
Pescatore (1988): P. Pescatore, La Cour de justice des Commanautés européennes et la Convention européenne des Droits de l'Homme, in: F. Matscher en H. Petzold, Protecting Human Rights: The European Dimension - studies in honour of Gérard J. Wiarda, Carl Heymanns Verlag, Köln 1988, pag. 441-456.

Peters (1966): A.A.G. Peters, Opzet en schuld in het strafrecht (diss. Leiden), Kluwer, Deventer 1966.

Pijnacker Hordijk (1997): B.H. Pijnacker Hordijk, Procedurevoorschriften in de ontwerpmededingingswet behoeven aanpassing, NJB 1997, pag. 291.

Plompen (1996): P.M.A.L. Plompen, Het ontwerp-mededingingswet, De Naamloze Vennootschap 1996, pag. 158-167.

Prakken (1995): T. Prakken, Interne openbaarheid in het strafproces: een bedreigd goed, NJB 1995, pag. 1451-1458.

Quant (1995): L.H.A.J.M. Quant, Over zwijgen gesproken, Advocatenblad 1995, pag. 61-63.

De Raat (1994): F. de Raat, Brussel deelt harde klappen uit aan kartels, NRC Handelsblad 28 juli 1994.

De Raat (1993): I.Y. de Raat, De bestuurlijke boete in het milieurecht, $A A$ 1993, pag. 443-450.

De Raat en Widdershoven (2000): I. de Raat en R. Widdershoven, De bestuurlijke boete in de algemene wet bestuursrecht, NJCM-Bulletin 2000, pag. 771-788.

Rehmann (1987): W.A. Rehmann, Zur Vollstreckung einer Nachprüfungsentscheidung der Kommission der EG, NJW 1987, pag. 3061-3062.

Reijntjes (1996 I): J.M. Reijntjes (red.), Nemo tenetur, Gouda Quint, Arnhem 1996.

Reijntjes (1996 II): J.M. Reijntjes, Nemo tenetur: een holle leus? in: Reijntjes (1996 I), pag. 9-21.

Ress en Ukrow (1990): G. Ress en J. Ukrow, Neue Aspekte des Grundrechtsschutzes in der Europäischen Gemeinschaft, EuZW 1990, pag. 499-502.

Reynolds (1992): M. Reynolds, EC Commission Policy on Fines, EBLR 1992, pag. 263 265.

Richardson (1999): R. Richardson, Guidance Without Guidance - A European Revolution in Fining Policy? The Commission's New Guidelines on Fines, ECLR 1999, pag. 360-371. Van Rij (1956): P.H. van Rij, Toepassing van de kartelwetgeving, SEW 1956, pag. 161176.

Van Rijn (1986): A. van Rijn, Boekbespreking L. Betten, The incorporation of fundamental rights in the legal order of the European Communities, NJCM-Bulletin 1986, pag. 488-492.

Van Rijn (1981): T.P.J.N. van Rijn, Artikel 85, lid 1, EEG. -Analyse van de toepassingsvoorwaarden, in: VerLoren van Themaat e.a. (1981), pag. 19-42.

Van Rijn (1999): T.P.J.N. van Rijn, Europese mededingingsregels, Editie Schuurman \& Jordens, W.E.J. Tjeenk Willink, Zwolle 1999.

Rijnsbergen (1993): F. Rijnsbergen, Nieuwe kartelwet in Ierland, $S E W$ 1993, pag. 641659.

Rijnsbergen (1998): F. Rijnsbergen, De Clementieregeling: boetevermindering door samen te werken met de Commissie, SEW 1998, pag. 202-206.

Rikmenspoel (1994): M.J.H.T. Rikmenspoel, De bestuursrechtelijke boete: traditie, trend en toekomst, De Gemeentestem 1994, pag. 321-325.

Riphagen (1994): J. Riphagen, Sancties in de sociale zekerheid: bestuursstrafrecht of strafrechtelijk bestuursrecht?, Kluwer, Deventer 1994. 
Ritter, Rawlinson en Braun (1991): L. Ritter, F. Rawlinson en W.D. Braun, EEC Competition Law: A Practitioners Guide, Kluwer, Deventer 1991.

Rodger (1999): B.J. Rodger, The Commission White Paper on modernisation of the rules implementing Articles 81 and 82 of the E.C. Treaty, ELRev 1999, pag. 653-663.

Rogall (1977): K. Rogall, Der Beschuldigte als Beweismittel gegen sich selbst, Duncker \& Humblot, Berlin 1977.

Rogier (1995): L.J.J. Rogier, De Algemene wet bestuursrecht en strafrecht, Kluwer, Deventer 1995.

Rogier (2000 I): L.J.J. Rogier (red.), Commentaren op het Voorontwerp Algemene wet bestuursrecht Vierde tranche, Gouda Quint, Rotterdam 2000.

Rogier (2000 II): L.J.J. Rogier, Una Via, in: Rogier (2000 I), pag. 91-109.

Rogier (2001): L.J.J. Rogier, Straffend bestuur, Gouda Quint, Rotterdam 2001.

Rogier en Hartmann (1994): L.J.J. Rogier en A.R. Hartmann, Verschillen en overeenkomsten tussen strafrecht en bestuursrecht, in: De Doelder en Rogier (1994), pag. 1-20.

De Roos (1975): Th. de Roos, Ekonomiese macht en kartelverbod, Recht en kritiek 1975. pag. 5-23.

De Roos (1984): Th. de Roos, Economische mededinging en witteboordencriminaliteit, enkele opmerkingen over de criminalisering van antitrust- en karteldelicten, in: A.C. Berghuis e.a., Witteboordencriminaliteit, Ars Aequi Libri, Nijmegen 1984, pag. 129-149. De Roos (1987): Th.A. de Roos, Strafbaarstelling van economische delicten (diss. Utrecht), Gouda Quint, Amhem 1987.

De Roos en Serrarens (1993): Th.A. de Roos en J. Serrarens, Advocaten in strafzaken en criminele gelden, in: P.C. van Duyne, J.M. Reijntjes en C.D. Schaap (red.), Misdaadgeld, Gouda Quint, Arnhem 1993, pag. 125-145.

De Rooy (1952 I): C.E. de Rooy, Kartelbeleid sinds de bevrijding, SEW 1952, pag. 201205.

De Rooy (1952 II): C.E. de Rooy, Nogmaals kartelbeleid sinds de bevrijding, SEW 1952 , pag. 241-242.

Van Rooy (1992): Y, van Rooy, Bij scherper mededingingsbeleid kind niet met badwater weggooien, Staatscourant 28 september 1992, pag. 5-6.

Rosenkőtter (1988): G. Rosenkötter, Das Recht der Ordnungswidrigkeiten, Boorberg Verlag, Stuttgart 1988.

Rozemond (1992): K. Rozemond, Het DNA-onderzoek in strafzaken en het nemo teneturbeginsel, $N J B$ 1992, pag. 125-132.

Rudisile (1990): R. Rudisile, Zur Zwangsgeldentscheidung des EuGH im Hoechst-Urteil, EuZW 1990, pag. 53-54.

Van Russen Groen (1998): P.M. van Russen Groen, Rechtsbescherming in het bestruursstrafrecht (diss. Rotterdam), Gouda Quint, 1998.

Sackers (1994): H.J.B. Sackers, De Algemene wet bestuursrecht in straf(proces)rechtelijk perspectief, $D D$ 1994, pag. 802-813.

Sackers (1995): H.J.B. Sackers, Schuld en boete: over verdere convergentie van strafrecht en bestuursrecht, in: Balkema e.a. (1995), pag. 307-320.

Samkalden (1953): I. Samkalden, Het wetsontwerp economische mededinging, $S E W$ 1953, pag. 641-650.

Samkalden (1954 I): I. Samkalden, Het wetsontwerp economische mededinging, SEW 1954, pag. 1-10.

Samkalden (1954 II): 1. Samkalden, Kartelcontrôle, SEW 1954, pag. 273-284. Sauter (1988): H. Sauter, Noch einmal: Zur Vollstreckung einer Nachprüfungsentscheidung der Kommission der EG, NJW 1988, pag. 1429-1431. 
De Savornin Lohman (1988): A.F. de Savornin Lohman, Bestrijding economische criminaliteit in het slop?, NJB 1988, pag. 330-331.

Schaffmeister (1974): D. Schaffmeister, Het afdoen buiten geding van economische delikten in het Duitse en Nederlandse recht, DD 1974, pag. 332-342.

Schaffmeister (1978): D. Schaffmeister, Entwicklung und Begriff des niederländischen Wirtschaftsstrafrechts, W.E.J. Tjeenk Willink, Zwolle 1978.

Schaffmeister (1995): D. Schaffmeister, Handhaving van bestuursrecht door boete of straf?, in: Hazewindus en Jansen (1995), pag. 59-80.

Schalken en Rozemond (1997): T. Schalken en K. Rozemond, Straatsburgse duidelijkheid over nemo tenetur, NJB 1997, pag. 808-809.

Schermerhorn (1994): M.E. Schermerhorn, Verificatie-bevoegdheid EG-Commissie: na Hoechst en Dow meer duidelijkheid?, $S E W$ 1994, pag. 27-44.

Schermers (1987): H.G. Schermers, Non bis in idem, in: Capotorti, F. e.a. (Hrsg.), Du droit international au droit de l'intégration: Liber Amicorum Pierre Pescatore, Nomos Verlagsgesellschaft, Baden-Baden 1987, pag. 601-612.

Schermers (1990): H.G. Schermers, The European Communities bound by fundamental human rights, CMLRev. 1990, pag. 249-258.

Schermers (1996): H.G. Schermers, Toetreding van de EG tot het EVRM: het Hof van Justitic adviseert, NJCM-Bulletin 1996, pag. 874-883.

Schermers en Waelbroeck (1992): H.G. Schermers en D.F. Waelbroeck, Judicial protection in the European Communities, Kluwer, Deventer 1992.

Van Schilfgaarde e.a. (1997): P. van Schilfgaarde e.a., Rechtspleging in het ondernemingsrecht, Kluwer, Deventer 1997.

Scholz (1990): R. Scholz, Grundrechtsprobleme im europäischen Kartellrecht -Zur Hoechst-Entscheidung des EuGH, WuW 1990, pag. 99-108.

Schouten (1960): C.H. Schouten, Enkele opmerkingen over de generieke onverbindendverklaring, SEW 1960, pag. 161-167.

Schouten (1970): C.H. Schouten, Opstellen over economisch ordeningsrecht, deel 1, Universitaire Pers, Rotterdam 1970.

Schouten (1973): C.H. Schouten, Grondslagen van het mededingingsrecht. Opstellen over economische ordeningsrecht, deel 2, Universitaire Pers, Rotterdam 1973.

Schouten (1976): C.H. Schouten, De praktijk van het mededingingsrecht, Opstellen over economisch ordeningsrecht, deel 3, Universitaire Pers, Rotterdam 1976.

Schröter (1991): H. Schröter, Vorbemerkung zu den Artikeln 85 bis 89, in: Von der Groeben, Thiesing en Ehlermann (1991), pag. 1380-1394.

Schröter (1997): H. Schröter, Vertical Restrictions under Article 85 EC: Towards a Moderate Reform of Current Competition Policy, in: Gormley (1997), pag. 15-30.

Schröter (1999 I): H. Schröter, Vorbemerkung zu den Artikeln 85 bis 94, in: Von der Groeben, Thiesing en Ehlermann (1999), pag. 2/15-83.

Schröter (1999 II): H. Schröter, Artikel 85 Absatz 1, in: Von der Groeben, Thiesing en Ehlermann (1999), pag. 2/148-249.

Schröter en Delsaux (1999): H. Schröter en P. Delsaux, Vorbemerkung zu den Artikeln 85 bis 89, in: Von der Groeben, Thiesing en Ehlermann (1999), pag. 2/84-105.

Schröter en Jakob-Siebert (1991): H. Schröter en Th. Jakob-Siebert, Artikel 87 -Zeiter Teil, in: Von der Groeben, Thiesing en Ehlermann (1991), pag. 1971-2023.

Schutte (1994): N.J. Schutte, Funke en verder, de toekomst van art. 47 AWR, WFR 1994, pag. 620-626.

Simons (2001): Th.G.M. Simons, Openingsrede, in: Jansen, Van der Meulen en Widdershoven (2001), pag. 1-10. 
Siohl (1986): U. Siohl, Die Schuldfeststellung bei Unternehmen oder Unternehmensvereinigungen im Rahmen des Art. 15 VO 17 zum EWG-Vertrag, Peter Lang, Frankfurt am Main 1986.

Slot en McDonnell (1993): J.P. Slot en A. McDonnell, (red.), Procedure and enforcement in E.C. and U.S. competition law, Sweet \& Maxwell, London 1993.

Slotboom (1996): M.M. Slotboom, Ten dienste van de mededinging? Procedurele apecten van het voorstel-Mededingingswet, SEW 1996, pag. 291-297.

Slotboom (1997 I): M.M. Slotboom, De NMa staat voor de deur. Toezicht en onderzoek in het kader van de Mededingingswet, TVVS 1997, pag. 323-328.

Slotboom (1997 II): M.M. Slotboom, De rechter in mededingingszaken, Dossier ondernemingszaken 1997, pag. 60-65.

Slotboom (1998): M.M. Slotboom, De Wet uitvoering EG-mededingingsverordeningen, SEW 1998, pag. 96-100.

Slotboom (1999): M.M. Slotboom, De Mededingingswet: niet met handen en voeten gebonden aan het EG-recht, $S E W$ 1999, pag. 42-48.

Slotboom (2001): M.M. Slotboom, De bescherming tegen zelfbeschuldiging in het Nederlandse Mededingingsrecht: te beperkt in het licht van artikel 6 EVRM?, in: Jansen, Van der Meulen en Widdershoven (2001), pag. 131-143.

Lord Slynn of Hadley en S.A. Pappas (1995): Lord Slynn of Hadley en S.A. Pappas (eds), Procedural aspects of EC competition law, European Institute of Public Administration, Maastricht 1995.

Smits (1997): M. Smits, Detaillisten: nieuwe mededingingswet ontaardt in oligopolie, Het Financieele Dagblad, 18 januari 1997.

Snijders (1960): W.L. Snijders, Algemeenverbindendverklaring van ondernemersovereenkomsten, Maandschrift Economie 1960, pag. 435-456 en 577-595.

Snijders (1971): W.L. Snijders, Kartelrecht in Nederland, SEW 1971, pag. 517-538. Snijders (1982): W.L. Snijders, Het optreden tegen economische machtsposities op grond van de Wet Economische Mededinging, in: Barents (1982), pag. 267-293.

Spink (1999): P.M. Spink, Recent Guidance on Fining Policy, ECLR 1999, pag. 101-108. Spliet (1990): J. Spliet, ECD levert het bewijs: het leven begint bij 40, in: C.J.C.F. Fijnaut en F.G.A. Lely (red.), Economisch strafrecht en justitieel politie-optreden, Van den Brink \& Co., Lochem 1990, pag. 9-13.

Spronken (1996): T. Spronken, Nemo tenetur, zwijgrecht en advocatenbijstand bij het politieverhoor: de zaak Murray, Advocatenblad 1996, pag. 420-424.

Spronken (1999): T. Spronken, T\&C Sv, artt. 30-34, Kluwer, Deventer 1999.

Spronken (2001): T. Spronken, Verdediging. Een onderzoek naar de normering van het optreden van advocaten in strafzaken (diss. Maastricht), Gouda Quint, Maastricht 2001.

Steenbergen (1996): J. Steenbergen, Drie Jaar Belgische Wet Mededinging, SEW 1996, pag. 324-332.

Steenbergen (1997): J. Steenbergen, Decision-making in Competition Cases: The Investigator, the Prosecutor and the Judge, in: Gormley (1997), pag. 101-108.

Steenbergen (1999): J. Steenbergen, De wijzigingen van de Belgische Wet Mededinging, SEW 1999, pag. 358-364.

Steenbergen en Barents (1986): J. Steenbergen en R. Barents, Inleiding tot het mededingingsrecht, Kluwer, Antwerpen 1986.

Stessens (1993): G. Stessens, De bevoegdheid van de Europese Gemeenschap tot het vaststellen van sancties: op weg naar een communautair strafrecht?, $R W 1993-1994,137$ 153. 
Stessens (1997): G. Stessens, The Obligation to Produce Documents Versus the Privilege Against Self-incrimination: Human Rights Protection Extended Too Far?, ELRev. 1997, pag. HRC/45-HRC/62.

Van Strien (1996 I): A.L.J. van Strien, De rechtspersoon in het strafproces, Een onderzoek naar de procesrechtelijke aspecten van de strafbaarheid van rechtspersonen (diss.), Sdu Juridische \& Fiscale Uitgeverij, Den Haag 1996.

Van Strien (1996 II): A.L.J. van Strien, Rechtspersonen en mensenrechten, De gelding van mensenrechten voor rechtspersonen in het strafproces, RM Themis 1996, pag. 3-19. Swann (1983): D. Swann, Competition and Industrial Policy in the European Community, Methuen, London 1983.

Swart (1993): A.H.J. Swart, Bewijs leveren tegen zichzelf. Huiszoeking; noot bij het Funke-arrest, $A A$ 1993, pag. 672-680.

Swart (1996): A.H.J. Swart, Vooronderzoek en criminal charge, in: J. Remmelink e.a., Mens en recht. Kanttekeningen bij conclusies van Leo Meijers, Tjeenk Willink, Deventer 1996, pag. 226-232.

Swennen (1993): H. Swennen, Een paar opmerkingen i.v.m. de Belgische Wet tot bescherming van de economische mededinging, SEW 1993, pag. 510-521.

Tabingh Suermondt (1937): F. Tabingh Suermondt, Algemeen verbindend verklaren en onverbindend verklaren van overeenkomsten, NJB 1937, pag. 230-237.

Timmerman (1997): L. Timmerman, Hebben rechtspersonen mensenrechten?, in: Van Schilfgaarde e.a. (1997), pag. 43-55.

Timmermans (1995): C.W.A. Timmermans, Het ontstaan van de Europese Gemeenschappen en hun ontwikkeling, in: Kapteyn en VerLoren van Themaat (1995), pag. 1-29.

'Toetreding van de EG tot de ECRM' (1991): NJCM-commentaar "Toetreding van de EG tot de ECRM", NJCM-Bulletin 1991, pag. 697-735.

Toth (1997): A.G. Toth, The European Union and human rights: the way forward, CMLRev. 1997, pag. 491-529.

Turner (1999): C. Turner, Human Rights Protection in the European Community: Resolving Conflict and Overlap Between the European Court of Justice and the European Court of Human Rights, European Public Law 1999, pag. 453-470.

Uitermark (1986 I): P.J. Uitermark, Het Nederlandse mededingingspolitieke regime. Over de verhouding tussen verbod, misbruik, misstand en casuïstisch beleid, TVVS 1986, pag. 108-116.

Uitermark (1986 II): P.J. Uitermark, Marktwerking en cultuur, SEW 1986, pag. 3-31. Uitermark (1987 I): P.J. Uitermark, Over informeel mededingingsbeleid, Recht der werkelijkheid 1987, pag. 30-53.

Uitermark (1987 II): P.J. Uitermark, Over economische mededinging, SEW 1987, pag. 339-372.

Uitermark (1990): P.J. Uitermark, Economische Mededinging en Algemeen Belang. Een ondezoek naar de economisch-theoretische findering van de mededingingspolitiek, WoltersNoordhoff, Groningen 1990.

Urlus (1997): H.E. Urlus, Meer werk aan de winkel, Nederland verrijkt met een (nieuwe) Mededingingswet, Advocatenblad 1997, pag. 341-347.

Urlus en Speekenbrink (1997): H.E. Urlus en D.A.C. Speekenbrink, De Mw en de bagatelregeling, Dossier ondernemingszaken 1997, pag. 31-35.

Valkenburg (1993): W.E.C.A. Valkenburg, Uw medewerking gevraagd? Medewerkingsplichten en art. 6 EVRM, in: R.D. Vriesendorp, M.L.W. Weerts en W.J. Witteveen (red.), Het actuele recht, Rechtspraak anno 1993 in 67 Tilburgse bijdragen, Koninklijke Vermande, Lelystad 1993, pag. 203-206. 
Valkenburg (1997): W.E.C.A. Valkenburg, De zaak Saunders en de consequenties voor fiscale 'strafachtige' onderzoeken, Weekblad 1997, pag. 573-581.

Vandermeersch (1994): D. Vandermeersch, De Mededingingswet. Een praktisch commentaar bij de wet van 5 augustus 1991 tot bescherming van de economische mededinging, Kluwer Rechtswetenschappen België, Deurne 1994.

VAR-werkgroep Vierde tranche Awb (2000): VAR-werkgroep Vierde tranche Awb, De Vierde tranche Awb. Commentaar en vraagpunten, Boom Juridische uitgevers, Den Haag 2000.

Van Veen (1995): P. van Veen, Naar een nieuwe Mededingingswet (afscheidscollege aan de Erasmus Universiteit Rotterdam), Universiteitsdrukkerij Erasmus, Rotterdam 1995. Van Veen (1977): Th.W. van Veen, Grenzen van de geldboete, RM Themis 1977, pag. $1-4$.

'Verantwoord verzelfstandigen': Verantwoord verzelfstandigen, Rapportage van de commissie-Sint, De Brink, Leiden 1995.

Verheij (1999): N. Verheij, Het wetgevingsbeleid inzake bestuurlijke boeten, in: De Doelder, De Meijer en Otto (1999), pag. 21-37.

I. VerLoren van Themaat (1996): I.W. VerLoren van Themaat, Het voorstel voor de nieuwe mededingingswet: 'mededingingsafspraken' en misbruik van economischemacht (artikel 85/86-complex), SEW 1996, pag. 284-290.

I. VerLoren van Themaat e.a. (1998): I.W. VerLoren van Themaat e.a., National application of Community Competition Law, SEW 1998, pag. 137-145.

VerLoren van Themaat (1952 I): P. VerLoren van Themaat, Het Kartelbeleid sinds de bevrijding, SEW 1952, pag. 129-153.

VerLoren van Themaat (1952 II): P. VerLoren van Themaat, Naschrift, SEW 1952, pag. 204-205.

VerLoren van Themaat (1953): P. VerLoren van Themaat, Documenten over enkele buitenlandse kartelpolitieke invloeden, SEW 1953, pag. 289-296.

VerLoren van Themaat (1957): P. VerLoren van Themaat, Het kartelbeleid in de eerste ambtsperiode van minister Zijlstra, SEW 1957, pag. 1-24.

VerLoren van Themaat (1969): P. VerLoren van Themaat, Noot bij HvJ (14/68) Jur. 1969, 1 (Walt Wilhelm), AA 1969, pag. 312-321.

VerLoren van Themaat (1973): P. VerLoren van Themaat, Noot bij het tweede Boehringer-arrest, SEW 1973, 273-277.

VerLoren van Themaat (1978): P. VerLoren van Themaat, Het wetsontwerp Lubbers tot wijziging van de Wet Economische Mededinging, SEW 1978, pag. 178-192.

VerLoren van Themaat (1981): P. VerLoren van Themaat, Inleiding tot het Europees mededingingsrecht, in: VerLoren van Themaat e.a. (1981), pag. 1-18.

VerLoren van Themaat (1988 I): P. VerLoren van Themaat, Nieuw leven in de Wet Economische Mededinging of terug naar de Abtsweg? Deel 1, SEW 1988, pag. 4-15. VerLoren van Themaat (1988 II): P. VerLoren van Themaat, Nieuw leven in de Wet Economische Mededinging of terug naar de Abtsweg? Deel 2, SEW 1988, pag. 60-77. VerLoren van Themaat (1998): P. VerLoren van Themaat, Het wonderbaarlijke convergentieproces tussen Nederlands en Europees mededingingsrecht, $M \& M$ 1998, pag. 3-6. VerLoren van Themaat e.a. (1981): P. VerLoren van Themaat e.a., Europees kartelrecht anno 1980, Kluwer, Deventer 1981.

Vermeulen (1993): B.P. Vermeulen, De grondrechtenproblematiek bij de bestuursrechtelijke toepassing en handhaving van het gemeenschapsrecht, in: Vervaele (1993), pag. 39-81. Vermeulen (1994): G. Vermeulen, Het beginsel ne bis in idem in het internationaal strafrecht, Panopticon 1994, pag. 217-235. 
Vervaele (1993): J.A.E. Vervaele (red.), Bestuursrechtelijke toepassing en handhaving van gemeenschapsrecht in Nederland, Kluwer, Deventer 1993.

Vervaele (1995): J.A.E. Vervaele, Het gemeenschapsrecht en de bestuurlijke boete in de nationale handhavingsstelsels, in: Hazewindus en Jansen (1995), pag. 83-125.

Vesterdorf (1992): B. Vesterdorf, The Court of First Instance of the European Communities after two full years in operation, CMLRev. 1992, pag. 897-915.

Viering (1994): M.L.W.M. Viering, Het arrest Bendenoun: een stap terug? NJB 1994, pag. 1061-1063.

Viering en Fleuren (1997): M.L.W.M. Viering en J.W.A. Fleuren, Bendenoun revisited, NJB 1997, pag. 1932-1934.

De Vogel (1992): S. de Vogel, Wegen bouwen is in Limburg vooral wegen vinden. Baars als ijsbergtopje, Vrij Nederland 30 mei 1992.

Vogelaar (2000): F.O.W. Vogelaar, Marktwerking moet!, Vossiuspers AUP, Amsterdam 2000.

Voillemot (1994): D. Voillemot, Droit de la défense et droit de la Commission lors des enquêtes préalables en vue de l'application des articles 85 et 86 du Traité de Rome, in: Association Européenne des Avocats (1994), pag. 133-192.

De Waard (1994): T. de Waard, Richtlijnen ter voorkoming van betrokkenheid van de advocaat bij criminele handelingen, NJB 1994, pag. 1441-1444

De Waard (1995 I): T. de Waard, Samenwerkingsrichtlijnen, Advocatenblad 1995, pag. 323.

De Waard (1995 II): T. de Waard, Eén Orde, Advocatenblad 1995, pag. 879-883. Van der Wal en Prechal (1990): G. van der Wal en S. Prechal, Aspecten van Europese rechtsbescherming, Advocatenblad 1990, pag. 604-612.

Van der Wal (1994 I): G. van der Wal, Het bamboe bloeit, Advocatenblad 1994, pag. 702-705.

Van der Wal (1994 II): G. van der Wal, Vergroting van de effectiviteit of de activiteit, Advocatenblad 1994, pag. 846-848.

Van der Wal (1995): G. van der Wal, De positie van partijen in de WEM: rechten en beperkingen, Advocatenblad 1995, pag. 732-736.

Wattel (1990): P.J. Wattel, Heimelijke onttrekkingen, negatieve uitdelingen en grondrechten van rechtspersonen, WFR 1990/1112.

Wattel (1994): P.J. Wattel, Bendenoun, boeten en belastingen, NJB 1994, pag. 1527-1529. Van der Weijden (1987): C.J. van der Weijden, Werkzame mededinging, ESB 1987, pag. 1194-1199.

Weiler en Lockhart (1995 I): J.H.H. Weiler en N.J.S. Lockhart, "Taking rights seriously" seriously: the European Court and its fundamental rights jurisprudence -part I, CMLRev. 1995, pag. 51-94.

Weiler en Lockhart (1995 II): J.H.H. Weiler en N.J.S. Lockhart, "Taking rights seriously" seriously: the European Court and its fundamental rights jurisprudence-part II, CMLRev. 1995, pag. 579-627.

Werkgroep "Handhaving door bestuurlijke boeten" (1995): Met straffe(nde) hand, Rapport van de werkgroep "Handhaving door bestuurlijke boeten" van de Nederlandse Vereniging voor Rechtspraak, mei 1995.

Wessels (1996): P. Wessels, Kartelwet onaanvaardbaar. Hevig verzet detailhandel tegen Wijers, NRC Handelsblad, 21 mei 1996.

Wezenbeek-Geuke (1997 1): M.G. Wezenbeek-Geuke, Viho/Commissie; toepasselijkheid kartelverbod op verhoudingen binnen concern, NTER 1997, pag. 10-13. 
Wezenbeek-Geuke (1997 II): M.G. Wezenbeek-Geuke, Groenboek inzake verticale mededingingsbeperkingen, Nederlands tijdschrift voor Europees recht 1997, pag. 44-48. Wezenbeek-Geuke (1999): M.G. Wezenbeek-Geuke, Het Witbock inzake de modemisering van de regels met betrekking tot de toepassing van de artikelen 81 en 82 EG-Verdrag. NTER 1999, pag. 169-178.

Wezenbeek-Geuze en Hulsen (1998): M.G. Wezenbeek-Geuke en S.H.M. Hulsen, De toepassingspraktijk van de Wet economische mededinging ('WEM') in de periode 1 januari 1993-1 juli 1995, SEW 1998, pag. 277-296.

Whish (1995): R. Whish, The Court of First Instance and the Rights of the Defence, in: Lord Slynn of Hadley en S.A. Pappas (1995), pag. 43-54.

Whish (2000): R. Whish, Regulation 2790/99: The Commission's 'new style' block exemption for vertical agreements, CMLR 2000, pag, 887-924.

Widdershoven (1995): R.J.G.M. Widdershoven, Handhaving van sociaal-economisch recht in Nederland: terugblik en perspectief, RM Themis 1995, pag. 205-218.

Widdershoven (1998): R.J.G.M. Widdershoven, De bestuurlijke boete in de Grondwet, NJB 1998, pag. 236-237.

Willems (1997): J.H.M. Willems, Recht op stukken, juridische semantiek voor gevecht?, Trema 1997, pag. 185-188.

Wils (1996): W.P.J. Wils, E.C. Competition Fines: To Deter or Not to Deter, Yearbook of European Law 1995, Clarendon Press, Oxford 1996, pag. 17-46.

Wils (1997): W.P.J. Wils, The Commission Notice on the Non-Imposition or Reduction of Fines in Cartel Cases: A Legal and Economic Analysis, ELRev. 1997, pag. 125-140. Wils (1998): W.P.J. Wils, The Commission's New Method for Calculating Fines in Antitrust Cases, ELRev. 1998, pag. 252-263.

Winckler (1994): A. Winckler, 'Legal privilege' et droit communautaire de la concurrence, Association Européenne des Avocats (1994), pag. 55-63.

Winkler (1971): R. Winkler, Die Rechtsnatur der Geldbuße im Wettbewerbsrecht der Europäischen Wirtschaftsgemeinschaft, J.C.B. Mohr (Paul Siebeck), Tübingen 1971. Winter (2000): J.A. Winter, Zwijgrecht in het Europees kartelrecht, in: H.J.R. Kaptein, Onrechtmatig verkregen bewijs, Ars Aequi Libri, Nijmegen 2000, pag. 109-122.

Winter en Baas (2001): J.A. Winter en A. Baas, Europees proces- en conflictenrecht, Editie Schuurman \& Jordens, W.E.J. Tjeenk Willink, Deventer 2001.

Wissels (1990): C.M. Wissels, Gerecht van Eerste Aanleg, Advocatenblad 1990, pag. 601-603.

De Witt Wijnen (1997): O.L.O. de Witt Wijnen, Bewijsvoering in vennootschappelijke procedures, in: Van Schilfgaarde e.a. (1997), pag. 93-115.

Wladimiroff (1990 I): M. Wladimiroff (red.), Facetten van economisch strafrecht, Gouda Quint, Arnhem 1990.

Wladimiroff (1990 II): M. Wladimiroff, Hoe apart is economisch strafrecht, een evaluatic, in: Wladimiroff (1990 I), pag. 183-196.

Wladimiroff en Schreuders (1990): M. Wladimiroff en D.S. Schreuders, Tuchtmaatregel of straf bij economische delicten, in: Wladimiroff (1990 I), pag. 67-84.

Wladimiroff en Van Russen Groen (1999): M. Wladimiroff en P.M. van Russen Groen, Enkele opmerkingen over rechtswaarborgen en het bestuursstrafrecht, in: De Doelder, De Meijer en Otto (1999), pag. 89-100.

Wöretshofer (1996): J. Wöretshofer, De meldingsprocedure levensbeëindiging: ongeoorloofd?, in: Reijntjes (1996 I), pag, 41-56.

Wöretshofer (1999 I): J. Wöretshofer, Huiszoeking - Doorzoeking, in: Hendriks e.a. (1999), pag. 219-232. 
Wöretshofer (1999 II): J. Wöretshofer, Ne bis in idem, samenloop en wetsconcursus, in: Hendriks e.a. (1999), pag. 335-350.

Van der Woude (1995): M.H. van der Woude, Nederlands en Europees Kartelrecht, RM Themis 1995, pag. 198-204.

Van der Woude en Jones (1999): M.H. van der Woude en C. Jones, E.C. Competition Law Handbook, Sweet \& Maxwell, London (1999).

Zäch (1994): R. Zäch, Wettbewerbsrecht der Europäischen Union: Praxis von Kommission und Gerichtshof, C.H. Beck'sche Verlagsbuchhandlung, München 1994.

Van der Zwan (1988): W. van der Zwan, Economisch strafrecht nooit in het slop gezeten, NJB 1988, pag. 331-332.

\section{Jurisprudentie en beschikkingen}

\section{Nederland}

HR 17 februari 1928, NJ 1928, 727 m.nt. EMM HR 22 juni 1931, NJ 1931, pag. 1602 m.nt. WP Hof Arnhem 1931, NJ 1932, 908

HR 15 februari 1932, NJ 1932, 289 m.nt. T (Oude Kijk in 't Jatstraat)

HR 37 juni 1033, NJ 1023, 1650, m.nt. T (Drakcolas Kormia)

HR 11 november 1938, NJ 1938, 1116

HR 2 juni 1953, SEW 1953, pag. 465 m.nt. AM

HR 13 april 1954, NJ 1954, 369, m.nt. BVAR

HR 9 november 1954, NJ 1955, 55 (Cicero)

HR 21 november 1961, NJ 1962, 89 m.nt. BVAR (Emmense bromfietser)

HR 5 februari 1963, NJ 1963, 320 m.nt. BVAR (Van der Does de Willeboissingel)

HR 17 december 1963, NJ 1964, 385 m.nt. WP (Joyriding II)

Rb Zutphen 19 augustus 1964, NJ 1965, 110

HR 19 november 1968, No. E 64620, SEW 1969, pag. 186-195, m.nt. Mok

HR 22 juni 1971, No. E 65921, SEW 1972, pag. 36 m.nt. Mok

HR 18 januari 1972, NJ 1972, 378 m.nt. CB (Joyriding IV)

HR 11 februari 1972, NJ 1972, 259 m.nt. GJS

HR 27 juni 1972, SEW 1973, pag. 281 m.nt. Mok

HR 1 maart 1974, NJ 1974, 329

KB 5 juni 1974, no. 76, SEW, pag. 556 m.nt. Van Houten

HR 10 december 1974, NJ 1975, 178 (Stad Rotterdam)

HR 25 maart 1975, NJ 1975, 296 (Beschonken zondagsrijder)

HR 15 februari 1977 , NJ 1977, 557 m.nt. GEM

HR 24 mei 1977, NJ 1978, 316

HR 17 januari 1978, NJ 1978, 341 m.nt. ThWvV

HR 13 maart 1979, NJ 1979, 268 m.nt. ThWvV

HR 12 juni 1979, NJ 1979, 570

HR 26 juni 1979, NJ 1979, 567 m.nt. ThWvV

HR 2 oktober 1979, NJ 1980, 243 m.nt. GEM

HR 23 september 1980, NJ 1981, 116 m.nt. GEM

HR 26 januari 1982, NJ 1982, 353 m.nt. ThWvV

Arr.-Rb Rotterdam 24 mei 1983, NJ 1983, 577 
HR 25 oktober 1983, NJ 1984, 132 m.nt. 't H HR 20 maart 1984, NJ 1984, 547 m.nt. ThWvV

HR 22 juni 1984, NJ 1985, 188 m.nt. WHH

HR 9 oktober 1984, NJ 1985, 176

HR 9 oktober 1984, NJ 1985, 251, m.nt. 't H

HR 30 oktober 1984, NJ 1985, 275

HR 19 februari 1985, NJ 1985, 581 m.nt. ThWvV (Redelijke termijn II)

HR 1 maart 1985, NJ 1986, 173

HR 14 juni 1985 , NJ 1986, 175

HR 26 maart 1985, NJ 1985, 688 m.nt. ThWvV

HR 28 mei 1985, NJ 1985, 822 m.nt ThWvV (Keukenkastje)

HR 18 september 1985, NJ 1986, 406 m.nt. ThWvV

HR 1 oktober 1985, NJ 1986, 406 m.nt. ThWvV

HR 19 november 1985, NJ 1986, 533 m.nt. 't H

HR 6 mei 1986, NJ 1986, 813

HR 6 mei 1986, NJ 1986, 815 m.nt. WLH

HR 17 februari 1987, NJ 1987, 951

HR 17 maart 1987, NJ 1988, 155 m.nt. ThWvV (Cocaine in linnenkast)

HR 16 oktober 1987, NJ 1988, 850 m.nt. EAA (Driessen Assurantiën)

HR 26 april 1988, NJ 1989, 390 m.nt. ThWvV

HR 7 september 1988, BNB 1988, 298

HR 13 september 1988, NJ 1989, 454

HR 1 november 1988, NJ 1989, 349 m.nt. ThWvV

HR 14 april 1989, NJ 1990, 72, m.nt. CJHB en JSC (Benckiser)

HR 18 september 1989, NJ 1990, 531 m.nt. ThWvV

HR 11 oktober 1989, BNB 1990/87

HR 3 juli 1989, NJ 1990, 121

HR 17 januari 1990, BNB 1990/193 m.nt. Scheltens

HR 31 januari 1990, BNB 1990/93

Arr.-Rb. Leeuwarden 8 februari 1990, NJ 1990, 522

HR 23 februari 1990, NJ 1990, 664

HR 26 juni 1990, NJ 1990, 750 m.nt. 't H.

HR 2 juli 1990, NJ 1990, 751 m.nt. Schalken

HR 5 februari 1991, NJ 1991, 402

Arr.-Rechtb. Amsterdam 12 februari 1991, NJ 1991, 488

HR 21 mei 1991, NJ 1991, 728 m.nt. ThWvV

HR 22 november 1991, NJ 1992, 315 m.nt ThWvV

Hof 's Hertogenbosch 10 juni 1992, TVVS, pag. 49 m.nt. Mok

HR 15 december 1992, NJ 1993, 550 m.nt Swart (Gelva Holding)

HR 9 maart 1993, NJ 1993, 633 m.nt. ThWvV

HR 11 mei 1993, NJ 1994, 142 m.nt. Sch.

HR 1 juni 1993, NJ 1994, 52 (Shipping)

HR 12 oktober 1993, NJ 1994, 196 (D. en Co's Handelsmaatschappij)

HR 22 oktober 1993, NJ 1994, 94

HR 26 oktober 1993, NJ 1994629 m.nt. C.

HR 8 februari 1994, NJ 1994, 295

HR 29 maart 1994, NJ 1994, 537

HR 29 maart 1994, NJ 1994, 552 m.nt. 't H

Hof Amsterdam 28 april 1994, NJ 1996, 149 
HR 22 november 1994, NJ 1995, 240 m.nt. Schalken

HR 23 november 1994, NJ 1995, 239 m.nt. 't H; BNB 1995/25 m.nt. Wattel

HR 23 november 1994, FED 1995/3, m.nt. Feteris

HR 13 december 1994, NJ 1995, 252 (Spiegelbeeld)

HR 3 oktober 1995, NJ 1996, 219 m.nt. Kn

Arr.-Rb Rotterdam 13 september 1995, NJ 1996, 343

HR 13 december 1995, NJ 1996, 144

HR 19 december 1995, NJ 1996, 249 (Zwolsman)

HR 23 april 1996, NJ 1997, 307

HR 7 mei 1996, NJ 1996, 687 m.nt Sch

HR 10 mei 1996, NJ 1996, 578 m.nt. EJD

HR 29 oktober 1996, NJ 1997, 232 m.nt. Sch

HR 26 november 1996, NJ 1997, 209

HR 21 januari 1997, NJ 1997, 321

HR 29 april 1997, NJ 1997, 665

Arr.-Rb Breda 6 augustus 1997, NJ 1998, 61

HR 30 september 1997, NJ 1998, 104

HR 21 oktober 1997, NJ 1998, 133 m.nt. 'tH

HR 21 oktober 1997, NJ 1998, 173

HR 27 januari 1998, NJ 1998, 810 m.nt. Kn

HR 26 januari 1999, NJ 1999, 326

HR 22 juni 1999, NJ 1999, 648

Hof Arnhem 23 november 1999, NJ 2001, 86

HR 4 januari 2000, NJ 2000, 537 m.nt. Sch

HR 18 januari 2000, NJ 2000, 568

HR 18 januari 2000, NJ 2000, 569 m.nt. JdH

HR 26 januari 1999, NJB 1999 (Soliano)

HR 7 december 1999, NJ 2000, 263 m.nt. JdH

HR 20 juni 2000, NJ 2000, 720

HR 3 oktober 2000, NJ 2000, 721 m.nt. JdH

HR 3 oktober 2000, NJB 3 november 2000 afl. 39, pag. 1933

\section{Europees Hof voor de Rechten van de Mens}

EHRM 8 juni 1976, Series A, vol. 22, NJ 1978, 223 (Engel)

EHRM 10 december 1982, Series A, vol. 56, NJ 1987, 828 m.nt. P. van Dijk (Foti)

EHRM 21 februari 1984, Series A, vol. 73, NJ 1988, 937 (Oztürk)

EHRM 25 augustus 1987, Series A, vol. 123, NJ 1988, 938 (Lutz)

EHRM 30 maart 1989, Series A, vol. 152, NJ 1991, 522 m.nt. EJD (Chappell)

EHRM 22 mei 1990, Series A, vol. 177, NJ 1992, 454, m.nt. EJD (Weber)

EHRM 22 mei 1990, Series A, vol. 178, NJ 1991, 740, m.nt. EAA (Autronic)

EHRM 27 februari 1992, Series A, vol. 232-A (Société Stenuit v. Frankrijk)

EHRM 16 december 1992, Series A, vol. 251-B, NJ 1993, 400 m.nt. EJD (Niemietz)

EHRM 16 december 1992, NJCM-Bulletin 1993, pag. 449 (Edwards).

EHRM 25 februari 1993, Series A, vol. 256-A, NJ 1993, 485 m.nt. Kn (Funke)

EHRM 24 november 1993, Series A, vol. 274, NJ 1994, 459 m.nt. Kn (Imbrioscia)

EHRM 24 februari 1994, Series A, vol. 284 , NJ 1994, 496 (Bendenoun)

EHRM 8 februari 1996, Series A, vol., NJ 1996, 725 m.nt. Kn (Murray) 
EHRM 17 december 1996, Series A, vol, NJ 1997, 699 (Saunders); NJCM-Bulletin 1997, pag. 298 m.nt. Myjer; BNB 1997/254 m.nt. Feteris

EHRM 18 december 1996, Series A, vol., NJCM-Bulletin 1997, pag. 167-188 (Aksoy) EHRM 18 maart 1997, NJCM-Bulletin (1997), pag. 734 (Foucher)

EHRM 25 juni 1997, ECHR Reports 1997- III, pag. 1004, NJ 1998, 506, m.nt. PJB (Halford)

EHRM 24 september 1997, Reports 1997-V (Garyfallou)

EHRM 20 oktober 1997, Series A, vol., NJ 1998, 758 m.nt. Kn (Serves)

EHRM 15 juni 1999, 43486/98 hudoc (Tirado Ortiz en Lozano Martin)

EHRM 28 juli 1999, 25803/94 hudoc (Selmouni)

EHRM 2 mei 2000, 35718/97 hudoc (Condron)

EHRM 6 juni 2000, 36408/97 hudoc (Averill)

EHRM 19 september 2000, 29522/95. 30056/96 en 30574/96 hudoc (1.J.L, G.M.R. en A.K.P.)

EHRM 10 oktober 2000, 31866/96 hudoc (Satik e.a.)

EHRM 21 december 2000, 36887/97 hudoc (Quinn)

EHRM 3 mei 2001, 31827/96 hudoc (J.B.)

ECRM 10 mei 1994, nr. 19187/91 FED 1995/2 (Saunders)

ECRM 6 april 1995, NJCM-Bulletin (1995), pag. 830 (Mulders)

ECRM 26 februari 1997, nr. 27 943/95 FED 1998/80 met aantekening Feteris (Abas)

\section{Hof van Justitie}

HvJ (1/58) Jur. 1959, 43 (Stork)

HvJ (31/59) Jur. 1960, 164 (Acciaieria e tubificio di Brescia)

HvJ (5-10 en 13-15/62) Jur. 1962, 925/926 (Società Industriale Acciaerie San Michele e.a.)

HvJ (24/62) Jur. 1963, 141 (Duitsland t. Commissie)

HvJ (26/62) Jur. 1963, 3 (Van Gend en Loos)

HvJ (6/64) Jur. 1964, 1199 (Costa-ENEL)

HvJ (56 en 58/64) Jur. 1966, 450 (Consten/Grundig)

HvJ (56/65) Jur. 1966, 391 (LTM/MBU)

HvJ (18 en 35/65) Jur. 1967, 74 (Gutmann)

HvJ (14/68) Jur. 1969, 1 (Walt Wilhelm e.a.)

HvJ (5/69) Jur. 1969, 295 (Völk/Vervaecke)

HvJ (29/69) Jur. 1969, 419 (Stauder)

HvJ (41/69) Jur. 1970, 686 (ACF Chemiefarma)

HvJ (44/69) Jur. 1970, 733 (Buchler)

HvJ (45/69) Jur. 1970, 769 (Boehringer Mannheim)

HvJ (11/70) Jur. 1970, 1125 (Internationale Handelsgesellschaft) 
HvJ (48/69) Jur. 1972, 619 (Imperial Chemical Industries)

HvJ (49/69) Jur. 1972, 713 (BASF)

HvJ (51/69), Jur. 1972, 745 (Bayer)

HvJ (52/69), Jur. 1972, 787 (Geigy)

HvJ (53/69) Jur. 1972, 845 (Sandoz)

HvJ (54/69) Jur. 1972, 851 (Francolor)

HvJ (55/69) Jur. 1972, 887 (Cassella)

HvJ (56/69) Jur. 1972, 927 (Hoechst)

HvJ (8/72) Jur. 1972, 991 (Vereniging van Cementhandelaren)

HvJ (7/72) Jur. 1972, 1281 (Boehringer)

HvJ (6/72) Jur. 1973, 245 (Continental Can)

HvJ (155/73) Jur. 1974, 409 (Sacchi)

HvJ (4/73) Jur. 1974, 491 (Nold)

HvJ (6 en 7/73) Jur. 1974, 223 (Istituto Chemioterapico Italiano/Commercial Solvents Corporation)

HvJ (15/74) Jur. 1974, 1167 (Centrafarm/Sterling Drug)

HvJ (26/75) Jur. 1975, 1367 (General Motors Continental)

HvJ (73/74) Jur. 1975, 1491 (Vereniging der Belgische behangselpapierfabrikanten) HvJ (40-48, 50, 54-56, 111, 113 en 114/73) Jur. 1975, 1663 (Coöperatieve vereniging "Suiker Unie" UA e.a.)

HvJ (29/76) Jur. 1977, 1875 (Metro)

HvJ (19/77) Jur. 1978, 131 (Miller International Schallplatten)

HvJ (27/76) Jur. 1978, 207 (United Brands)

HvJ (106/77) Jur. 1978, 629 (Simmenthal)

HvJ (85/76). Jur. 1979, 461 (Hoffmann-La Roche)

HvJ (32 en 36-82/78) Jur. 1979, 2435 (BMW)

HvJ (44/79) Jur. 1979, 3727 (Hauer)

HvJ (136/79) Jur. 1980, 2033 (National Panasonic)

HvJ (209-215 en 218/78) Jur. 1980, 3239 (Heintz van Landewyck e.a.)

HvJ (155/79) Jur. 1982, 1575 (AM\&S Europe)

HvJ (100-103/80) Jur. 1983, 1825 (Musique Diffusion Française)

HvJ (107/82) Jur. 1983, 3151 (Allgemeine Elektricitäts-Gesellschaft AEG-Telefunken) HvJ (96-102, 104, 105, 108 en 110/82) Jur. 1983, 3369 (IAZ International Belgium e.a.) HvJ (322/81) Jur. 1983, 3461 (Nederlandsche Banden-Industrie-Michelin)

HvJ (86/82) Jur. 1984, 833 (Hasselblad GB)

HvJ (29 en 30/83) Jur. 1984, 1679 (CRAM/Rheinzink) 
HvJ (240-242, 261, 262, 268 en 269/82) Jur. 1985, 3831 (Stichting Sigarettenindustrie e.a.)

HvJ (193/83) Jur. 1986, 611 (Windsurfing International)

HvJ (222/84) Jur. 1986, 1651 (Johnston)

HvJ (53/85) Jur. 1986, 1965 (AKZO Chemie en AKZO Chemie UK)

HvJ (5/85) Jur. 1986, 2585 (AKZO)

HvJ (30/87) Jur. 1988, 2479 (Bodson)

HvJ (89, 104, 114, 116, 117, 125-129/85) Jur. 1988, 5193 (Ahlström Osakeyhtiö)

HvJ (246/86) Jur. 1989, 2117 (Belasco e.a.)

HvJ (46/87 en 227/88) Jur. 1989, 2859 (Hoechst)

HvJ (85/87) Jur. 1989, 3137 (Dow Benelux)

HvJ (97/87-99/87) Jur. 1989, 3165 (Dow Chemical Ibérica e.a.)

HvJ (347/87) Jur. 1989, 3283 (Orkem)

HvJ (C-277/87) Jur. 1990, I-45 (Sandoz prodotti farmaceutici)

HvJ (C-279/87) Jur. 1990, 1-261 (Tipp-Ex)

HvJ (C-41/90), Jur. 1991, I-1979 (Höfner)

HvJ (C-62/86) Jur. 1991, I-3359 (AKZO Chemie)

HvJ (C-179/90) Jur. 1991, I-5889 (Merci convenzionali porto di Genova)

HvJ (C-89, 104, 114, 116, 117 en 125-129/85) Jur. 1993, I-1307 (Ahlström Osakeyhtió e.a.)

HvJ (C-60/92), Jur. 1993, I-5683

HvJ (C-137/92 P) Jur. 1994, I-2555 (BASF e.a.)

HvJ (C-310/93 P) Jur. 1995, I-865 (BPB Industries/British Gypsum)

HvJ (C-137/95 P) Jur. 1996, I-1611 (Vereniging van Samenwerkende Prijsregelende Organisaties in de Bouwnijverheid e.a.)

HvJ (C-73/95 P) Jur. 1996, I-5457 (Viho)

HvJ (C-333/94 P) Jur. 1996, I-5951 (Tetra Pak International)

HvJ (C-264/95 P) Jur. 1997, I-1287 (Union internationale des chemins de fer)

HvJ (C-219/95 P) Jur. 1997, I-4411 (Ferriere Nord)

HvJ (C-59/96 P) Jur. 1997, I-4809 (Koelman)

HvJ (C-249/96) Jur. 1998, I-621 (L.J. Grant)

HvJ (C-185/95 P) Jur. 1998, I-8417 (Baustahlgewebe)

HvJ (C-286/95 P) n.n.g. (Commissie/ICI)

HvJ (C-287 en 288/95 P) n.n.g. (Commissie/Solvay)

HvJ (C-395 en 396/96 P) n.n.g. (Compagnie maritime belge transports e.a.)

HvJ (C-248/98 P) n.n.g. (Koninklijke KNP BT)

HvJ (C-280/98 P) n.n.g. (Moritz J. Weig) 
HvJ (C-282/98 P) n.n.g. (Enso Española)

HvJ (C-283/98 P) n.n.g. (Mo och Domsjö)

HvJ (C-286/98 P) n.n.g. (Stora Kopparbergs Bergslags)

HvJ (C-291/98 P) n.n.g. (Sarrió)

HvJ (C-294/98 P) n.n.g. (Metsä-Serla)

HvJ (C-297/98 P) n.n.g. (SCA)

HvJ (C-298/98 P) n.n.g. (Metsä-Serla Sales)

\section{Gerecht van eerste aanleg}

GvEA (T-30/89) Jur. 1990, II-163 (Hilti)

GvEA (T-39/90R) Jur. 1990, II-649 (SEP)

GvEA (T-1/89) Jur. 1991, II-867 (Rhône-Poulenc)

GvEA (T-2/89) Jur. 1991, II-1087 (Petrofina)

GvEA (T-3/89) Jur. 1991, II-1177 (Atochem)

GvEA (T-30/89) Jur. 1991, II-1439 (Hilti)

GvEA (T-39/90) Jur. 1991, II-1497 (SEP)

GvEA (T-4/89) Jur. 1991, II-1523 (BASF)

GvEA (T-6/89) Jur. 1991, II-1623 (Enichem Anic)

GvEA (T-7/89) Jur. 1991, II-1711 (Hercules Chemicals)

GvEA (T-8/89) Jur. 1991, II-1833 (DSM)

GvEA (T-79, 84-86, 89, 91, 92, 94, 96, 98, 102 en 104/89) Jur. 1992, II-315 (BASF e.a.)

GvEA (T-9/89) Jur. 1992, II-499 (Hüls)

GvEA (T-10/89) Jur. 1992, II-629 (Hoechst)

GvEA (T-11/89) Jur. 1992, II-892 (Shell International Chemical Company)

GvEA (T-12/89) Jur, 1992, II-907 (Solvay)

GvEA (T-13/89) Jur. 1992, II-1021 (Imperial Chemical Industries)

GvEA (T-14/89) Jur. 1992, Il-1155 (Montedipe)

GvEA (T-15/89) Jur. 1992, II-1275 (Chemie Linz)

GvEA (T-68, 77 en 78/89) Jur. 1992, Il-1403 (Società Italiana Vetro e.a.)

GvEA (T-61/89) Jur. 1992, II-1931 (Dansk Pelsdyravlerforening)

GvEA (T-10-12, 14 en 15/92) Jur. 1992, II-2667 (Cimenteries CBR)

GvEA (T-65/89) Jur. 1993, II-389 (BPB Industries en British Gypsum)

GvEA (T-39 en 40/92) Jur. 1994, II-49 (Groupement des cartes bancaires 'CB' en Europay International)

GvEA (T-43/92) Jur. 1994, II-441 (Dunlop Slazenger International)

GvEA (T-66/92) Jur. 1994, II-531 (Herlitz)

GvEA (T-77/92) Jur. 1994, Il-549 (Parker Pen)

GvEA (T-83/91) Jur. 1994, II-755 (Tetra Pak International)

GvEA (T-46/92) Jur. 1994, II-1044 (The Scottish Football Association)

GvEA (T-102/92) Jur. 1995, 11-17 (Viho Europe)

GvEA (T-29/92) Jur. 1995, II-289 (Vereniging van Samenwerkende Prijsregelende Organisaties in de Bouwnijverheid e.a.) 
GvEA (T-80, 81, 83, 87, 88, 90, 93, 95, 97, 99-101, 103, 105, 107 en 112/89) Jur. 1995, II-729 (BASF e.a.)

GvEA (T-141/89) Jur. 1995, II-791 (Tréfileurope Sales)

GvEA (T-142/89) Jur. 1995, II-867 (Usines Gustave Boel)

GvEA (T-143/89) Jur. 1995, II-917 (Ferriere Nord)

GvEA (T-144/89) Jur. 1995, II-947 (Cockerill Sambre)

GvEA (T-145/89) Jur. 1995, II-987 (Baustahlgewebe)

GvEA (T-147/89) Jur. 1995, II-1057 (Société métallurgique de Normandie)

GvEA (T-148/89) Jur. 1995, II-1063 (Tréfilunion)

GvEA (T-149/89) Jur. 1995, II-1127 (Sotralentz)

GvEA (T-150/89) Jur. 1995, II-1165 (Martinelli)

GvEA (T-151/89) Jur. 1995, II-1191 (Société des treillis et panneaux soudés)

GvEA (T-152/89) Jur. 1995, II-1197 (ILRO)

GvEA (T-30/91) Jur. 1995, II-1775 (Solvay)

GvEA (T-31/91) Jur. 1995, II-1821 (Solvay)

GvEA (T-32/91) Jur. 1995, II-1825 (Solvay)

GvEA (T-37/91) Jur. 1995, II-1901 (Imperial Chemical Industries)

GvEA (T-24-26 en 28/93) Jur. 1996, II-1201 (Compagnie maritime belge transports e.a.) GvEA (T-49/95) Jur. 1996, II-1799 (Van Megen Sports Group)

GvEA (T-229/94) Jur. 1997, II-1689 (Deutsche Bahn) GvEA (T-213/95 en T-18/96) Jur. 1997, II-1739 (Stichting Certificatie Kraanverhuurbedrijf en Federatie van Nederlandse Kraanverhuurbedrijven)

GvEA (T-295/94) Jur. 1998, II-813 (Buchmann)

GvEA (T-304/94) Jur. 1998, II-869 (Europa Carton)

GvEA (T-308/94) Jur. 1998, II-925 (Cascades)

GvEA (T-309/94) Jur. 1998, II-1007 (Koninklijke KNP BT)

GvEA (T-310/94) Jur. 1998, II-1043 (Gruber+Weber)

GvEA (T-311/94) Jur. 1998, II-1129 (BPB de Eendracht)

GvEA (T-317/94) Jur. 1998, II-1235 (Moritz J. Weig)

GvEA (T-319/94) Jur. 1998, II-1331 (Fiskeby Board)

GvEA (T-327/94) Jur. 1998, II-1373 (SCA Holding)

GvEA (T-334/94) Jur. 1998, II-1439 (Sarrió)

GvEA (T-337/94) Jur. 1998, II-1571 (Enso-Gutzeit)

GvEA (T-338/94) Jur. 1998, II-1617 (Finnboard)

GvEA (T-339-342/94) Jur. 1998, II-1727 (Metsä-Serla e.a.)

GvEA (T-347/94) Jur. 1998, II-1751 (Mayr-Melnhof Kartongesellschaft)

GvEA (T-348/94) Jur. 1998, II-1875 (Enso Española)

GvEA (T-352/94) Jur. 1998, II-1989 (Mo och Domsjö)

GvEA (T-354/94) Jur. 1998, II-2111 (Stora Kopparbergs Bergslags)

GvEA (T-141/94) Jur. 1999, II-357 (Thyssen Stahl)

GvEA (T-305-307, 313-316, 318, 325, 328, 329 en 335/94) Jur. 1999, II-931 (Limburgse

Vinyl Maatschappij e.a.)

GvEA (T-62/98) n.n.g. (Volkswagen)

GvEA (T-41/96) n.n.g. (Bayer) 
Europese Commissie

$\mathrm{Pb}$ 2545/64 (Grundig/Consten)

$\mathrm{Pb} 1969$ L 165/14 (Christiani \& Nielsen)

$\mathrm{Pb} 1969$ L 192/5 (Kinine)

$\mathrm{Pb} 1969$ L 195/11 (Kleurstoffen)

$\mathrm{Pb} 1970 \mathrm{~L}$ 147/25 (Kodak)

$\mathrm{Pb} 1971$ L 34/13 (CICG-ZVEI/ZPÜ)

$\mathrm{Pb} 1971$ L 161/2 (Brouwerij Espérance)

$\mathrm{Pb} 1971$ L 254/15 (SIAE)

$\mathrm{Pb} 1971$ L 282/46 (Bochringer)

$\mathrm{Pb} 1972$ L 272/39 (Pittsburgh Corning Europe)

Pb 1972 L 299/51 (Zoja CSC/ICI)

$\mathrm{Pb} 1972$ L $303 / 52$ (W.E.A.-Filipacchi Music)

$\mathrm{Pb} 1973$ L 140/17 (Europese Suikerindustrie)

$\mathrm{Pb} 1973$ L 293/40 (Deutsche Philips)

Pb 1974 L 343/24 (Frans-Japans kogellagerkartel)

Pb 1975 L 29/14 (General Motors)

$\mathrm{Pb} 1975$ L 29/26 (Champignons in blik)

Pb 1976 L 95/1 (Chiquita)

Pb 1976 L 192/27 (Centraal Stikstof Verkoopkantoor)

Pb 1976 L 223/27 (Vitaminen)

Pb 1976 L 357/40 (Miller Schallplatten)

$\mathrm{Pb} 1977$ L 39/19 (Theal/Watts)

$\mathrm{Pb} 1977$ L 117/1 (ABG)

$\mathrm{Pb} 1978$ L 22/23 (Hugin/Liptons)

$\mathrm{Pb} 1978$ L 46/33 (BMW Belgium)

$\mathrm{Pb} 1978$ L $70 / 54$ (Plantaardig perkament)

$\mathrm{Pb} 1978$ L 157/39 (RAI/UNITEL)

$\mathrm{Pb} 1978$ L 242/15 (CSV)

$\mathrm{Pb} 1979$ L 16/9 (Kawasaki)

$\mathrm{Pb} 1979$ L 57/33 (Fides)

$\mathrm{Pb} 1980$ L $39 / 51$ (Floral)

$\mathrm{Pb} 1980$ L 39/64 (Rietsuiker)

$\mathrm{Pb} 1980$ L 75/30 (Fabbrica pisana)

$\mathrm{Pb} 1980$ L 75/35 (Fabbrica Lastre di Vetro Pietro Sciarra)

$\mathrm{Pb} 1980$ L $377 / 16$ (Johnson \& Johnson) 
$\mathrm{Pb} 1981$ L 353/33 (Michelin)

$\mathrm{Pb} 1981$ L 370/49 (GVL)

$\mathrm{Pb} 1982$ L $27 / 31$ (Comptoir commercial d'importation)

$\mathrm{Pb} 1982$ L 58/19 (Telos)

$\mathrm{Pb} 1982 \mathrm{~L}$ 94/7 (Moët et Chandon)

$\mathrm{Pb} 1982$ L 113/18 (National Panasonic Belgium)

$\mathrm{Pb} 1982$ L 117/15 (AEG-Telefunken)

$\mathrm{Pb} 1982$ L 161/18 (Hasselblad)

$\mathrm{Pb} 1982$ L $167 / 39$ (NAVEWA-ANSEAU)

$\mathrm{Pb} 1982$ L 211/32 (National Panasonic France)

$\mathrm{Pb} 1982$ L 232/1 (SSI)

$\mathrm{Pb} 1982$ L $319 / 12$ (Fédération Nationale de l'Industrie de la Chaussure de France)

$\mathrm{Pb} 1982$ L 354/28 (National Panasonic)

$\mathrm{Pb} 1982$ L 362/40 (Walserijproducten en zinklegeringen)

$\mathrm{Pb} 1982$ L 379/1 (UGAL/BNIC)

$\mathrm{Pb} 1982$ L $379 / 27$ (Toltecs-Dorcet)

$\mathrm{Pb}$ 1983 L 114/26 (Deutsche Castrol)

$\mathrm{Pb} 1983$ L 229/1 (Windsurfing International)

$\mathrm{Pb} 1983$ L 252/13 (ECS/AKZO)

$\mathrm{Pb} 1983$ L $317 / 1$ (Gietijzeren en gietstalen walsen)

Pb 1984 L 136/9 (Polistil/Arbois)

$\mathrm{Pb} 1984$ L 207/11 (BL)

$\mathrm{Pb} 1984$ L 212/13 (Vlakglas Benelux)

$\mathrm{Pb} 1984$ L 220/27 (Zinc Producer Group)

$\mathrm{Pb} 1985$ L 35/16 (Peroxyde)

$\mathrm{Pb} 1985$ L 35/58 (John Deere)

$\mathrm{Pb} 1985$ L 85/1 (Houtslijp)

$\mathrm{Pb} 1985$ L 92/1 (Aluminiuminvoer uit Oost-Europa).

Pb 1985 L 376/21 (Sperry New Holland)

$\mathrm{Pb} 1986$ L 230/1 (Polypropyleen)

$\mathrm{Pb} 1986$ L 232/15 (Bitumineuze dakbedekking)

$\mathrm{Pb} 1986$ L 295/19 (Peugeot)

$\mathrm{Pb} 1986$ L 348/50 (Meldoc)

$\mathrm{Pb} 1987$ L $3 / 17$ (Vetzuren)

$\mathrm{Pb} 1987$ L 222/1 (Tipp-Ex)

$\mathrm{Pb} 1987$ L 222/28 (Sandoz)

$\mathrm{Pb} 1987$ L 286/36 (BBI)

$\mathrm{Pb} 1988 \mathrm{~L}$ 49/19 (Fisher-Price)

$\mathrm{Pb} 1988$ L 78/34 (Konica)

Pb 1988 L 233/15 (British Dental Trade Association)

$\mathrm{Pb} 1988$ L 284/41 (Napier Brown/British Sugar)

$\mathrm{Pb} 1988$ L 316/43 (Dansk Pelsdyravlerforening) 
$\mathrm{Pb} 1988$ L $317 / 47$ (Sabena)

$\mathrm{Pb} 1989$ L 10/50 (BPB)

$\mathrm{Pb} 1989$ L 33/44 (Vlakglas)

Pb 1989 L 43/27 (Decca Navigator System)

$\mathrm{Pb} 1989$ L 74/1 (PVC-1)

$\mathrm{Pb} 1989$ L 74/21 (LdPE)

$\mathrm{Pb} 1989$ L 260/1 (Betonstaalmatten)

Pb 1990 L 21/71 (Bayo-n-ox)

$\mathrm{Pb} 1991$ L 35/23 (Secrétama)

$\mathrm{Pb} 1991$ L 97/16 (Baccarat)

$\mathrm{Pb} 1991$ L 152/1 (Natriumcarbonaat Solvay/ICI)

$\mathrm{Pb} 1991$ L 185/23 (Martell)

Pb 1991 L 287/39 (Toshiba)

Pb 1992 L 72/1 (Tetra Pak II)

$\mathrm{Pb} 1992$ L 92/1 (Bouwnijverheid in Nederland)

$\mathrm{Pb} 1992 \mathrm{~L}$ 95/50 (Eurocheque)

$\mathrm{Pb} 1992$ L 96/34 (British Midland/Aer Lingus)

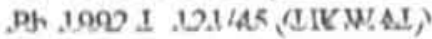

$\mathrm{Pb} 1992$ L 131/32 (DSI)

$\mathrm{Pb} 1992$ L 134/1 (Frans-Westafrikaanse rederscomités)

$\mathrm{Pb} 1992$ L 233/27 (Parker Pen)

$\mathrm{Pb} 1992$ L 305/16 (CSM)

$\mathrm{Pb} 1992$ L 366/47 (Verdeling van treinbiljetten door reisbureaus)

$\mathrm{Pb} 1993$ L 20/1 (Ford Agricultural)

$\mathrm{Pb} 1993$ L 20/6 (Mewac)

$\mathrm{Pb} 1993$ L 34/20 (Cewal e.a.)

Pb 1993 L 183/1 (Schöller)

$\mathrm{Pb} 1994$ L 104/34 (MCN)

$\mathrm{Pb} 1994$ L 239/14 (PVC-II)

$\mathrm{Pb} 1994$ L 243/1 (Karton)

$\mathrm{Pb} 1994$ L 294/31 (Akzo Chemicals)

$\mathrm{Pb} 1994$ L 343/1 (Cement)

$\mathrm{Pb} 1994$ L 378/17 (Far Eastern Freight Conference)

$\mathrm{Pb} 1994$ L 378/45 (Tretorn)

$\mathrm{Pb} 1995$ L 272/16 (BASF Lacke + Farben)

$\mathrm{Pb} 1996$ L. 181/28 (FENEX)

$\mathrm{Pb} 1996$ L 201/1 (ADALAT)

$\mathrm{Pb} 1997$ L 26/23 (Veerdienstmaatschappijen)

$\mathrm{Pb} 1997$ L 47/11 (Novalliance/Systemform)

$\mathrm{Pb} 1997$ L 258/1 (Irish Sugar) 
$\mathrm{Pb} 1998$ L 100/55 (Legeringstoeslag)

$\mathrm{Pb} 1998$ L 124/60 (VW)

$\mathrm{Pb} 1998$ L 252/47 (Amministrazione Autonoma dei Monopoli di Stato)

$\mathrm{Pb} 1999$ L 24/1 (Voorgeïsoleerde buizen)

$\mathrm{Pb} 1999$ L $76 / 1$ (British Sugar)

$\mathrm{Pb} 1999$ L 95/1 (Trans-Atlantic Conference Agreement)

Pb 1999 L 109/24 (Griekse veerdienstmaatschappijen)

$\mathrm{Pb} 2000$ L 5/55 (WK Voetbal 1998)

$\mathrm{Pb} 2000$ L 30/1 (Virgin/British Airways)

$\mathrm{Pb} 2000$ L 39/1 (Nederlandse Federatieve Vereniging voor de Groothandel op Elektrotechnisch Gebied en Technische Unie)

$\mathrm{Pb} 2000$ L $49 / 37$ (Anheuser-Busch)

$\mathrm{Pb} 2000 \mathrm{~L}$ 268/1 (Far East Trade Tariff Charges and Surcharges Agreement)

$\mathrm{Pb} 2001 \mathrm{~L}$ 54/1 (Nathan-Bricolux)

$\mathrm{Pb} 2001 \mathrm{~L} 59 / 1$ (Opel)

$\mathrm{Pb} 2001$ L 125/27 (Deutsche Post)

$\mathrm{Pb} 2001 \mathrm{~L}$ 152/24 (Aminozuren) 



\section{Curriculum Vitae}

Harald Quaedvlieg is geboren op 7 oktober 1968 te Valkenburg/Houthem. In 1987 haalde hij het diploma gymnasium alpha (cum laude) aan het Bernardinuscollege te Heerlen. Hij studeerde Nederlands recht aan de Rijksuniversiteit Leiden. Het doctoraalexamen behaalde hij (met genoegen) in februari 1992. Sedert die tijd is hij verbonden aan de capaciteitsgroep Strafrecht en criminologie van de Universiteit Maastricht, op dit moment als universitair docent Straf- en strafprocesrecht. Tevens is hij sinds maart 2001 honorair rechter-plaatsvervanger bij de arrondissementsrechtbank te Maastricht. 
